\title{
Panel Survey of Young People in Egypt (SYPE) 2014: Generating evidence for policy, programs, and research [Arabic]
}

Rania Roushdy

Population Council

Maia Sieverding

Follow this and additional works at: https://knowledgecommons.popcouncil.org/departments_sbsr-pgy

Part of the Demography, Population, and Ecology Commons, Family, Life Course, and Society Commons, and the International Public Health Commons How does access to this work benefit you? Let us know!

\section{Recommended Citation}

Roushdy, Rania and Maia Sieverding. 2015. "Panel Survey of Young People in Egypt (SYPE) 2014: Generating evidence for policy, programs, and research [in Arabic]" Cairo: Population Council. 




$$
\begin{aligned}
& \text { المسح التتبعي للنشع والثباب }
\end{aligned}
$$

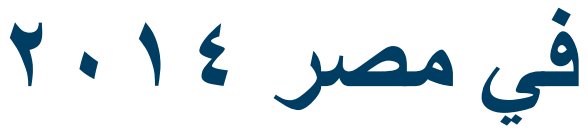

$$
\begin{aligned}
& \text { نحو بناء أدلة للسياسات و البر امج } \\
& \text { تحرير : رانيه رشدي • مايا سفيردنج }
\end{aligned}
$$




\section{POPULATION councli}

Ideas. Evidence. Impact.

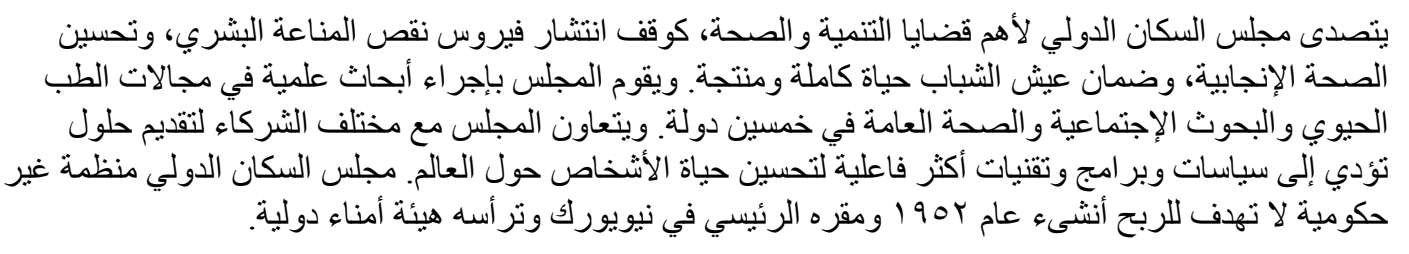

Population Council

One Dag Hammarskjold Plaza

New York, NY 10017

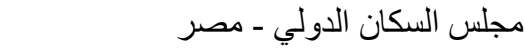

$$
\begin{aligned}
& 59 \text { طريق مصر حلو الن الزئ الزر اعي ـ المعادي }
\end{aligned}
$$

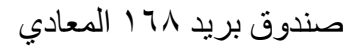

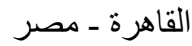

الموقع الالكتروني: Www.popcouncil.org

مجلس الإستشاد المقترح الدولى: رانيه رشدى و مايا سيفردينج. 0 ـ ـ ب. "المسح التتبعي للنشء و الثباب المصري: نحو بناء أدلة

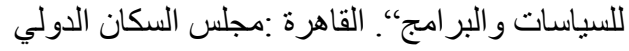

التقرير النهائي لمسح النشء و الثباب في مصر ع ا ـ ب. المادة ومحتويات هذا التقرير هي مسئولية المؤلفين، و لاتعكس

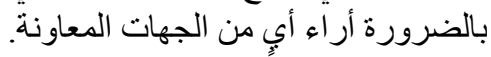

تصميم غلاف: فولف جانج شترنك / سلمى ابو حسين

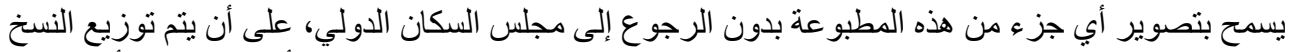

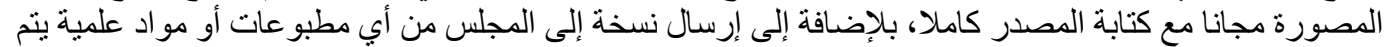
إستخدام هذا التقرير بها.

$$
\text { C } 10
$$




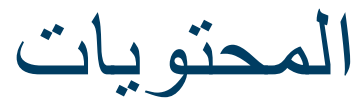

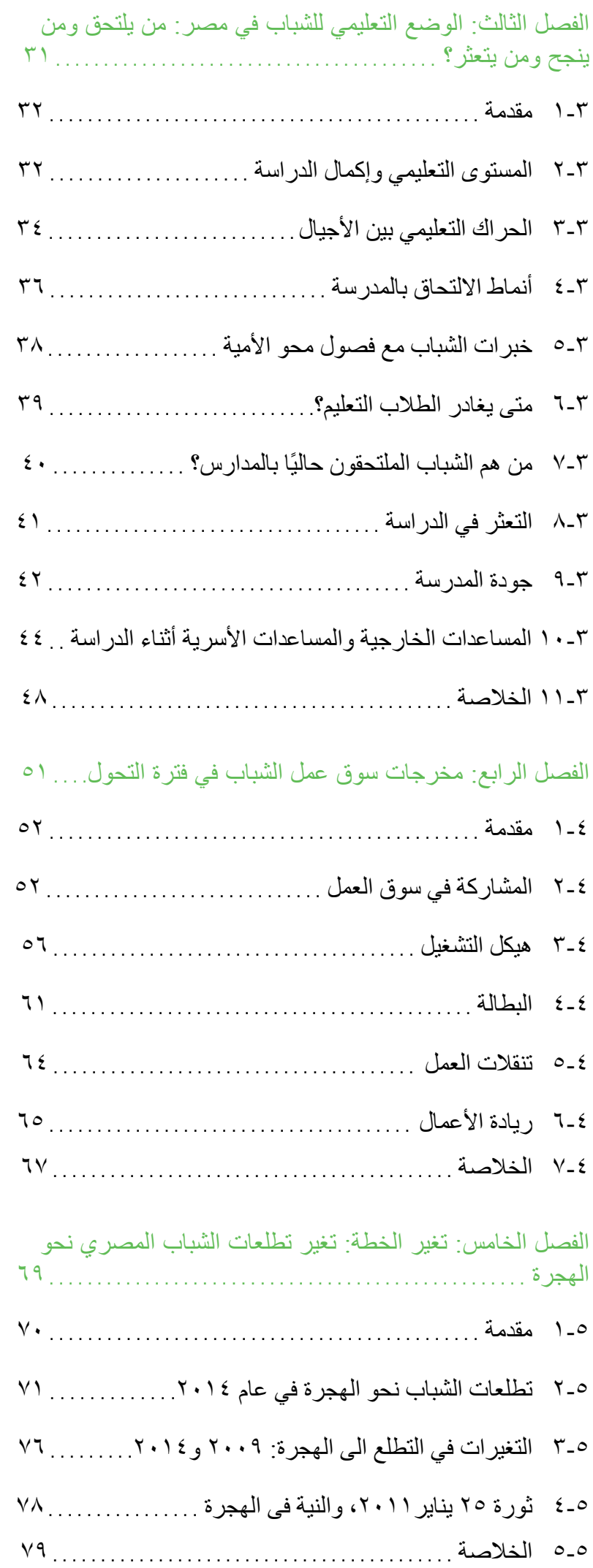

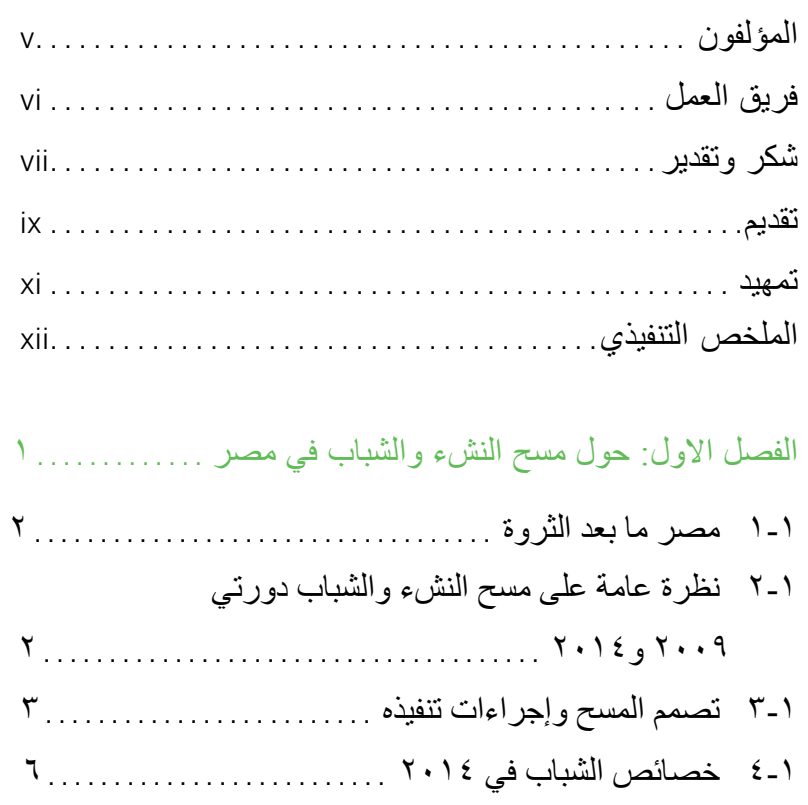

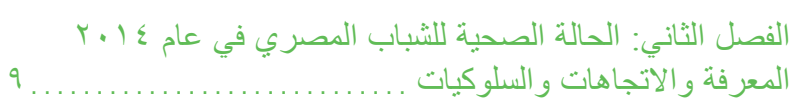

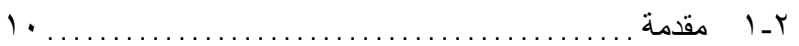

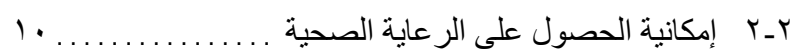
r-r التقييم الذاتي للصحة و التقارير الخاصة بالأمر اض المزمنة و الإعاقة ل............................................ rY

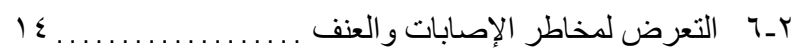

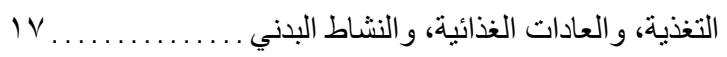

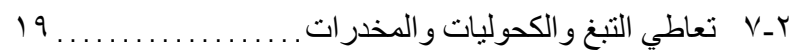

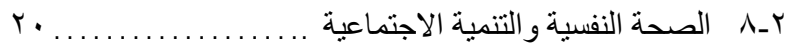
r r 


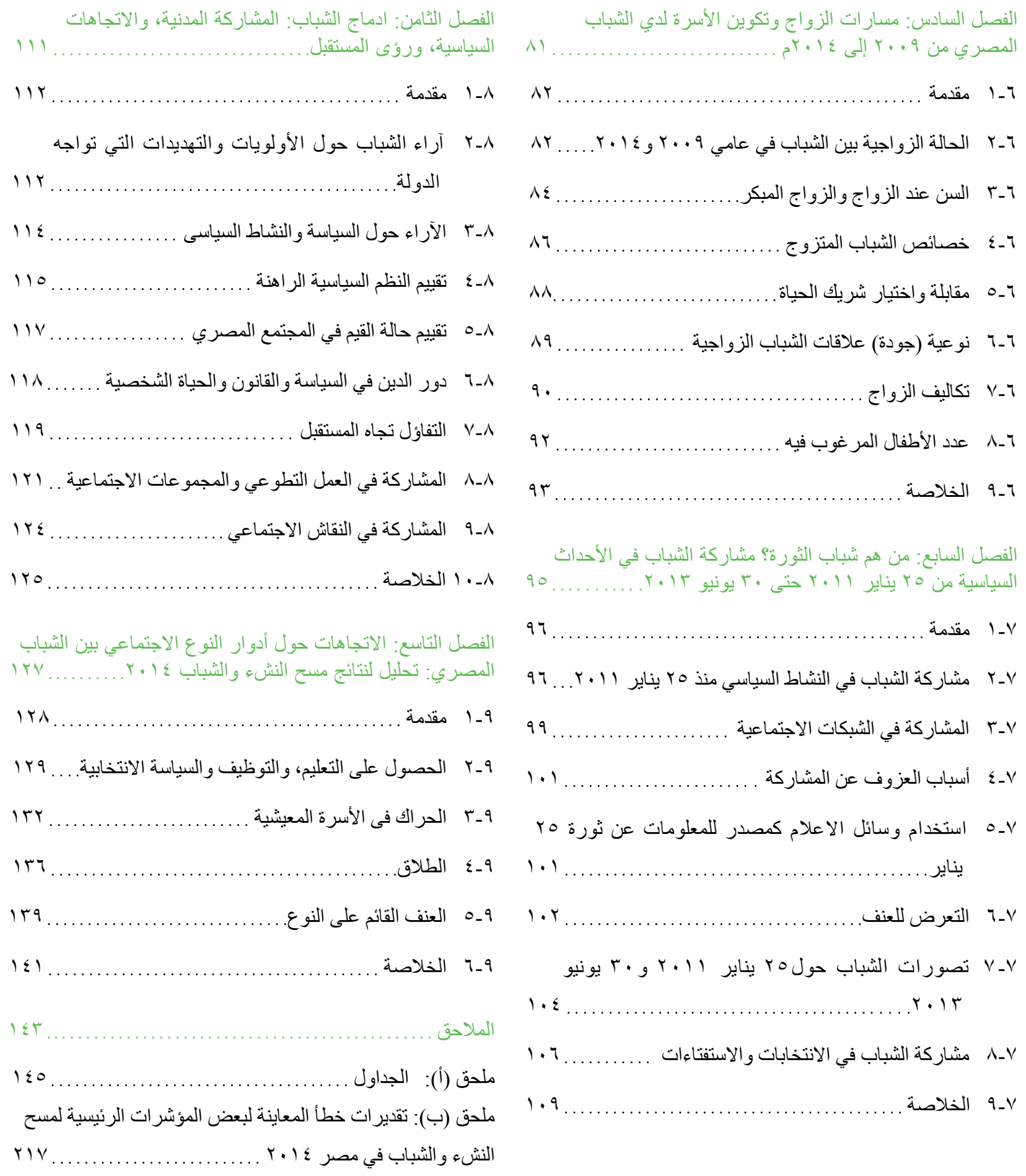




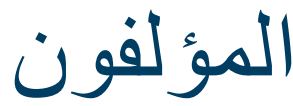

$$
\text { نهلة عبد التواب ممثل مجلس السكان الدولى مصر }
$$

استاذ الاحصاء و رئيس القسم، كلية الاقتصاد و العلوم السياسية، جامعة القاهرة، مصر

محمد اسماعيل

باحثّة، شركاء فى تعميم الحصول على الخدمة الصحية وجودتها، الولايات المتحدة

سارة اسماعيل

الأمريكية

مدرس الاقتصاد، جامعة سانت كاترين، الولايات المتحدة الأمريكية

كارولين كر افت

قائم بالتدريس قسم الاقتصاد، جامعة ساوث هامبتن، المملكة المتحدة

دافنى بابوتساكى

مدرس مساعد قسم الاقتصاد، كلية الاقتصاد و العلوم السياسية، جامعة القاهرة، مصر

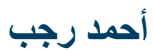
طالبة دكتور اه، قسم علم الاجتماع، جامعة كاليفورنيا لوس انجلوس و باحثة سابقا فى

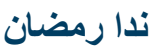

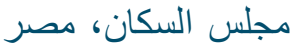
باحث ومحلل بيانات على راشد مدير برنامج الفقر و النوع و الثباب رانيه رشدى استشارى فى مجلس السكان، مصر كوليت ساليمى مدرس اقتصاد، كلية الاقتصاد و العلوم السياسية، جامعة القاهرة، مصر ايرين سلوانس استشارى فى مجلس السكان، مصر ليلى شيرا استشارى ومسئول أبحاث سابقا فى مجلس السكان، مصر أستاذ اقتصاد، قسم الاقتصاد، جامعة ساوث هامبتن، المملكة المتحدة مايا سفيردنج

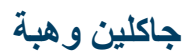


أ. أحمد رجب باحث

أ. ندا رمضان

باحث (سابقا)

\section{فريق الاتصال و التنسيق و التمويل \\ أ. عمرو قطب

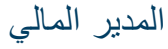

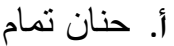 \\ مسئول أول الإتصالات \\ أ. جيهان حسني \\ إداري بر امج أول \\ أ. آية الدفراوي بري

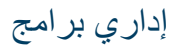

$$
\begin{aligned}
& \text { متدربين ومساعدو الباحثين } \\
& \text { أ. هنار الثيمي }
\end{aligned}
$$

الإخر اج الفني للتثرير

أ. نشوى بهجت

أ. جيهان حسني بهي

أ. أ. روبرت هيديل هينيل

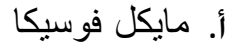

مر اجعة ترجمة اللغنة العربية

أ.د. أحمد ز ايد

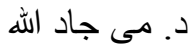

التز جمة للغة العربية

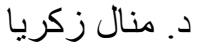

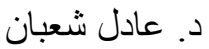

د. سهير محفوظ

تصنيم الغلاف

أ. سلمى أبو حسين

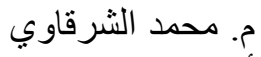

أ. جيهان حسني
الجهاز المركزي للتعبئة العامة و الإحصاء

اللواء أبو بكر الجندي

رئيس الجهاز المركزي للتعبئة العامة و الإحصاء الجناء

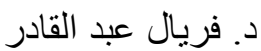

مستثنار ديموجر افي

أ. أمال على نور الدين

رئيسة قطاع الإحصائات و تعداد السكان

أ. أميرة جمال الدين

وكيل وزارة - رئيس الإدارة المركزية للارسات السكانية

و البحث الإجتماعي - وني

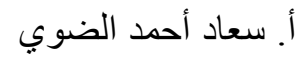

الددير العام لمركز التدريب والتحليل الإحصائي (سابقا)

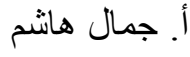

كبير باحثين - مسئول التدريب و التنفيذ الميداني

أ. عصام فتح الله

أخصائي تكنولوجيا المعلومات لهـ

مجلس السكان الاولي فريق البحث

د. نهلة عبد التواب

ممثل مجلس السكان الدولي - مصر

د. دانيه رشدي

المسئول الرئيسى عن المشروع

أ. أ. على راشد

باحث أول ومحلل بيانات

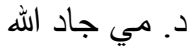

مسئول أبحاث أول مان ماله

د. - إيرين سيلو انيس

باحث بعد الدكتور اة (سابقا)

د. مايا سيفيردينج

مسئول أبحاث (سابقا)

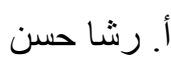


در اسات الثباب و النزاع السياسي بجامعة تينيسي وفريقه

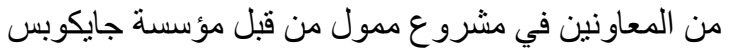

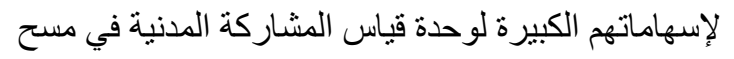

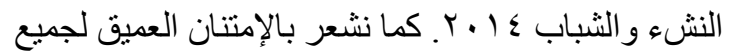

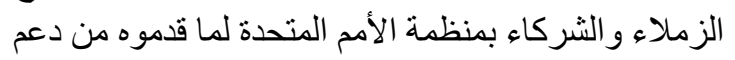
فني لهذا المسح. وقد تم إجر اء هذا المسح تحت إنثر اف برنامج الفقر و النوع

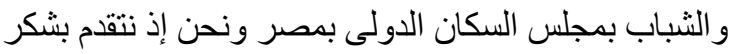

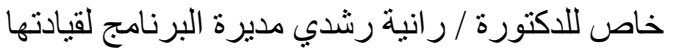

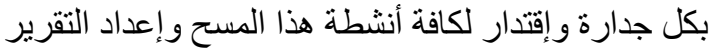

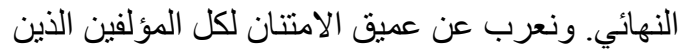

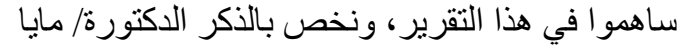

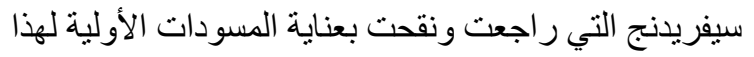

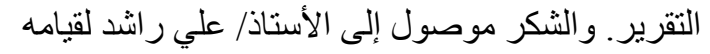

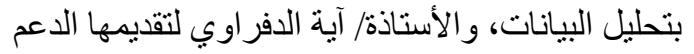
اللوجيستي و الإداري لهذا المشروع.

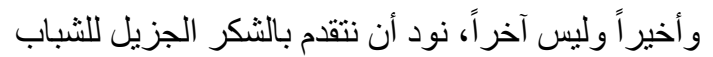

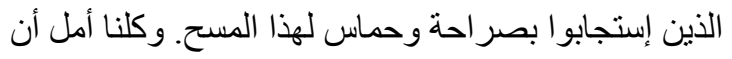

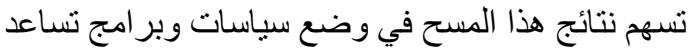
الثباب في مصر على تحقيق أحلامهم وطموحاتهم فى في فئي

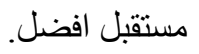

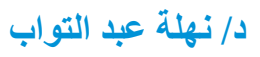

ممثل مجلس السكان الاولي ـ مصر

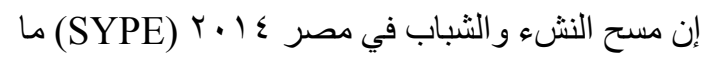

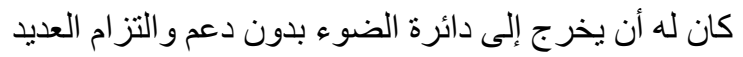

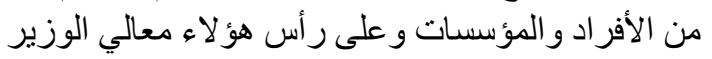

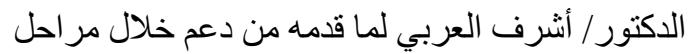

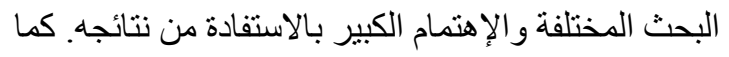

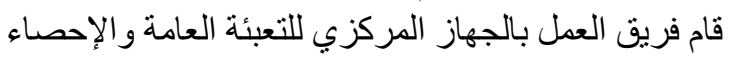

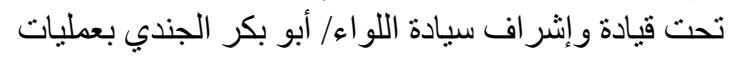

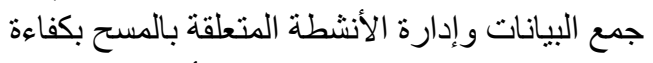

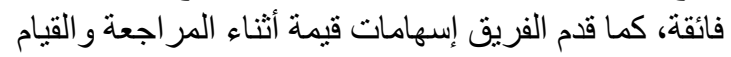
بالإختبار القبلي لاستبيان المسح، فلهم جميعا منا كل الثنكر و التقدير.

كما نتقدم بخالص الثكر و التقدير للعديد من المنظمات

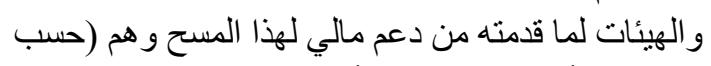

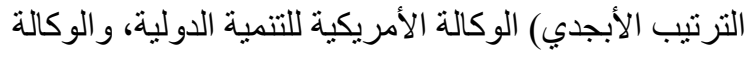

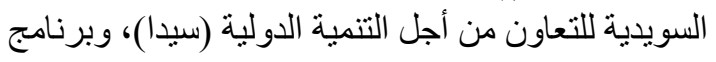

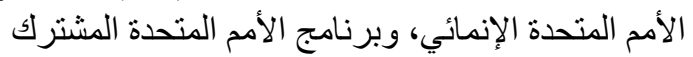

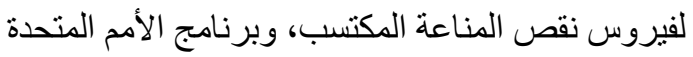

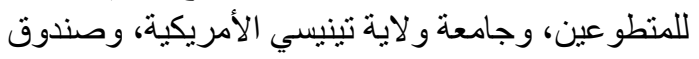

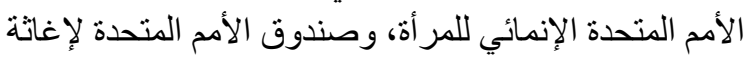

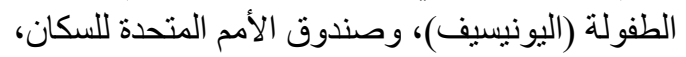

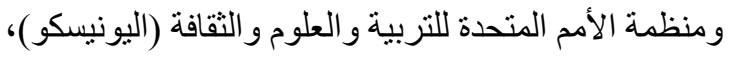

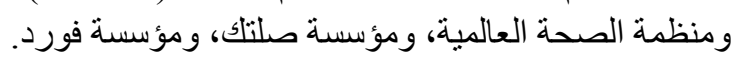

و لا يفوتنا في هذا السياق أن نتقدم بعميق الإمتنان للمسئولين

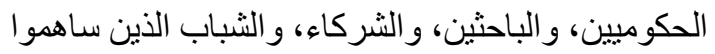

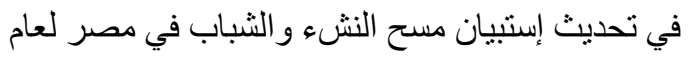

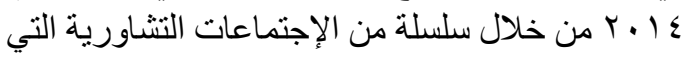

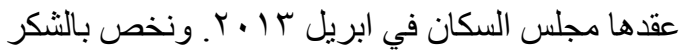

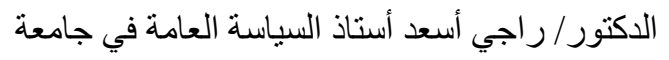
مينسوتا والمدير الإقليمي السابق لمكتب مجلس الست السكان السبان

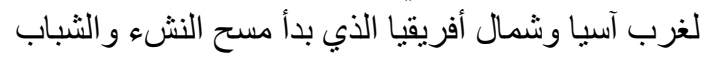

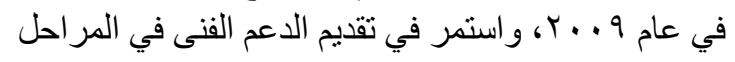

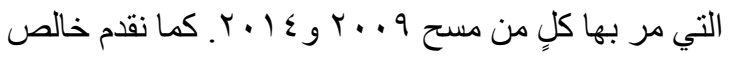
الثكر و التقدير لما أسهم به الدكتور / بر ايان باربر في مركز 

ويعد المجتمع المصري مجتمع فتيّ، حيث تمثل الفئة

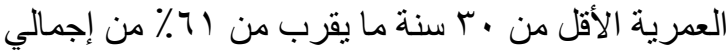

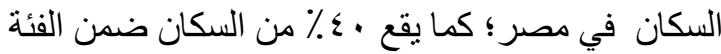

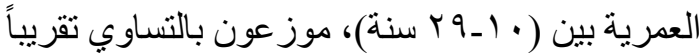

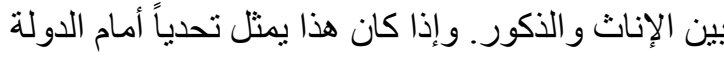

المصرية في توفير خدمات تعليمية وصحية ومسكن مناسب وفرص عمل لهذه الكتلة الكبيرة من النشء

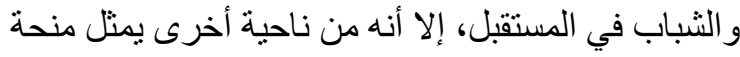
وهبة ديموجر افية يمكن أن يكون لها دور كبير في تحقيق التاني نهضة تنموية حقيقية إذا ما تم تعظيم الاستفادة من هذه انه الطاقات البشرية الهائلة وتوجيههم نحو العمل والإنتاج و المشاركة الفعالة في بناء هذا الوطن.

ومن هذا المنطلق تأتي أهمية مسح النشء و الثباب في

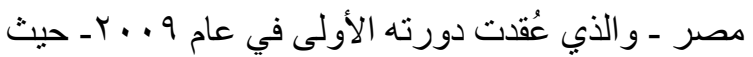
يعتبر أول مسح ميداني في مصر يستهدف الفئة العمرية

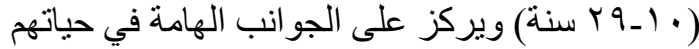

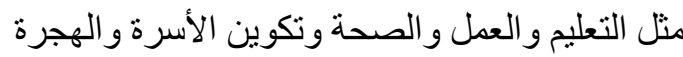
و الصحة الإنجابية و القضايا الاجتماعية و المشاركة المدنية

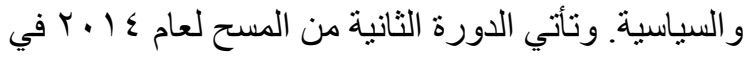

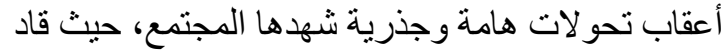
الثباب المصري المجتمع بأسره، في ثورتين عظيمنين

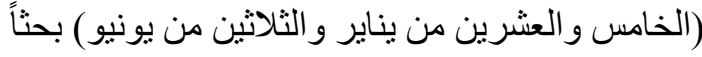

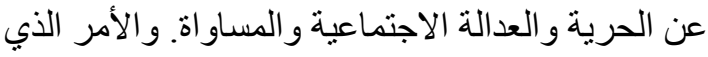

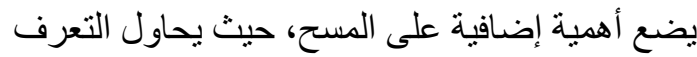
على التغيرات التي حدثت للثباب المصري خلال الفترة

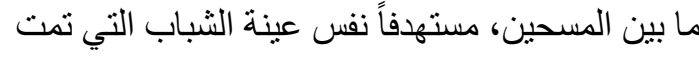

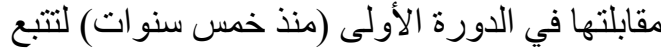
التغير ات و التطورات التي طر أت على أوضاع هؤ لاء

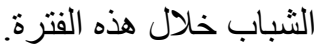

تعتبر مرحلة الثباب من أهم مر احل حياة الإنسان، حيث

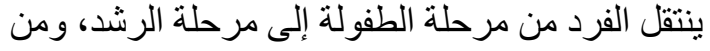

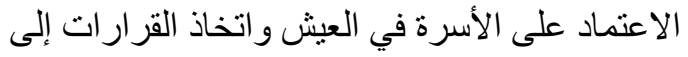

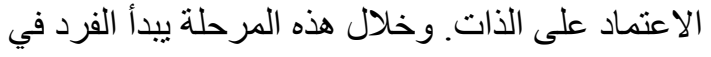

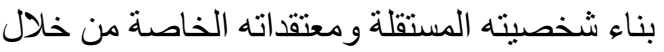

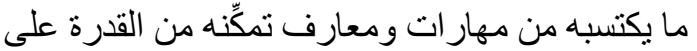

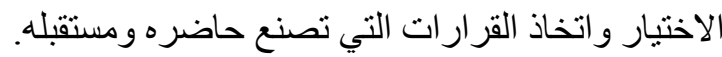

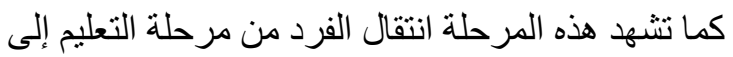
سوق العمل وما يحمله من تحديات وتطلعات للمستقبل بطموحات كبيرة وآمال غير محدودة.

ويمثل الثباب في أي مجتمع ثروة بشرية ومصدر للقوة

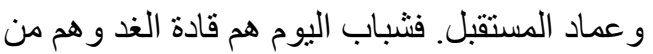
يصنعون مستقبل الأمم، ويحملون على عاتِ هاتقهم مسئولية

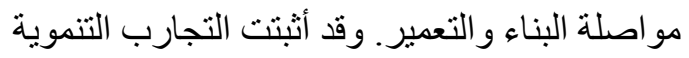

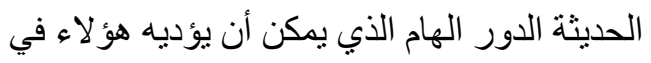

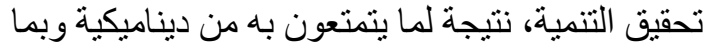

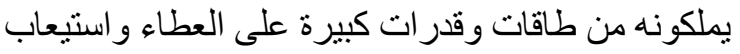

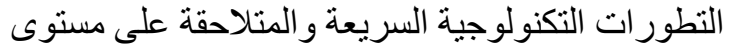

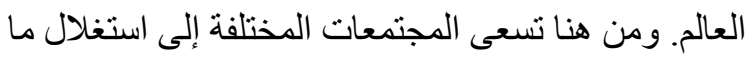

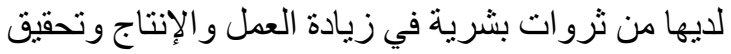

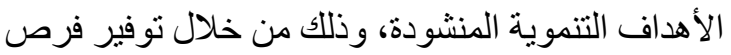

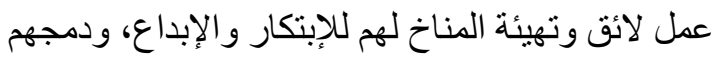

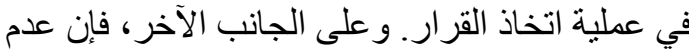

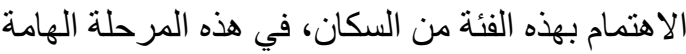

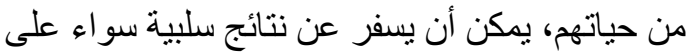
حياتهم الخاصة أو على المجتمع ككل. فالبطالة والإندان الإدان

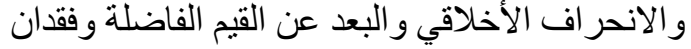
الإحساس بالإنتماء و المواطنة تعد من أهم المخاطر التحني

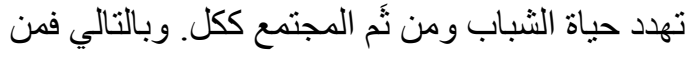

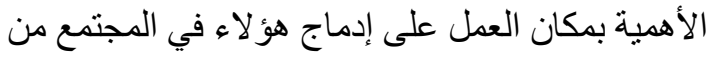

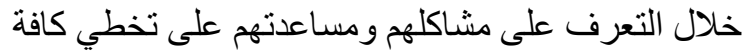
العقبات بنجاح. 
الملائمة لتنمية مهار اتهم و إدماجهم في الحياة السياسية مما ينطلب استمر ار الحكومة المصرية في جهودها نحو التحو

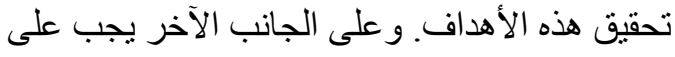
هؤ لاء الثباب العمل على تتمية مهار اتهم ورفع قدر اتهم

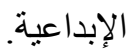

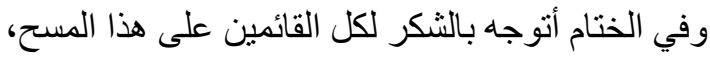

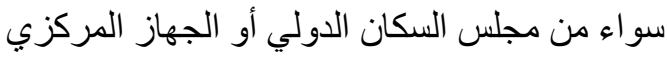

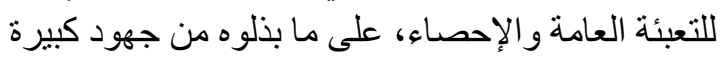
من أجل إتمام هذا العمل. ونأمل أن تسهم نتائج هذا

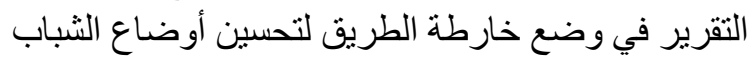
المصري وتحقيق آمالهم وتطلعاتهم في المستقبل. ويحدونا الأمل في أن يكون للثباب المصري الماتي دور أكبر في عملية التنمية في مصر خلال الفترة القادمة.

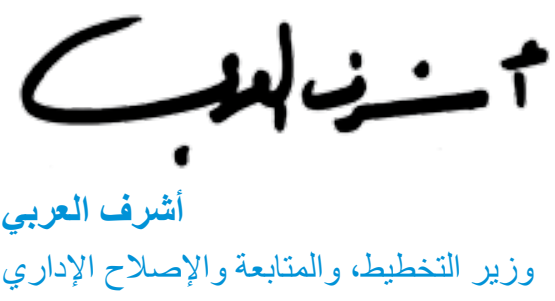

وفي هذا السياق، أشنارت النتائج الأولية للمسح إلى الى الإن

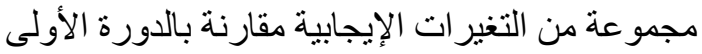
منه. فقد شهدت معدلات البطالة بين الشباب في هذه الفئ الفئة

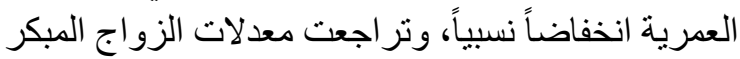

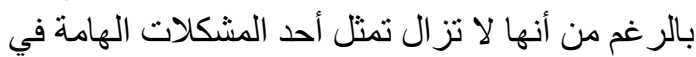
المجتمع. كما أن الفجوة بين الجنسين في إستكمال مر احلى الحل

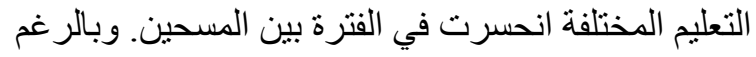

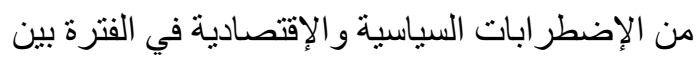

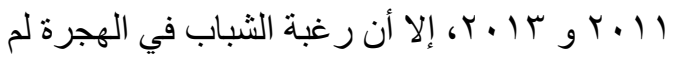

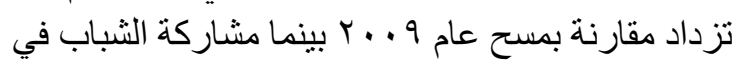

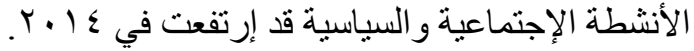

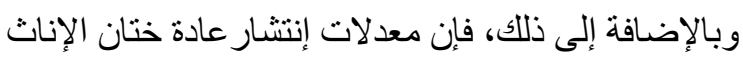

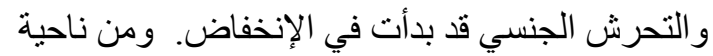

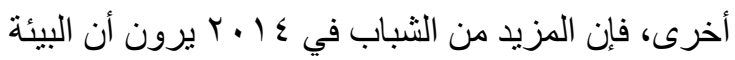

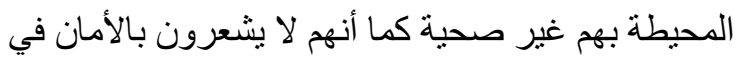

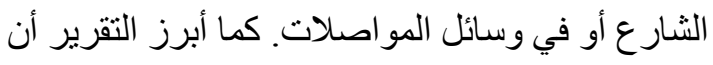

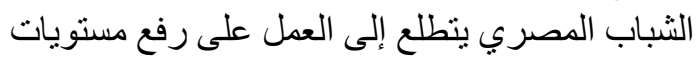
المعيشة ومحاربة الفساد وتحقيق الحرية و الديموقر اطية.

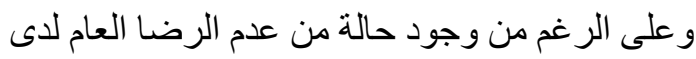

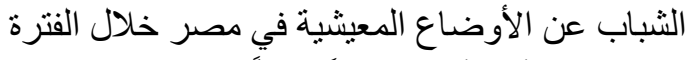

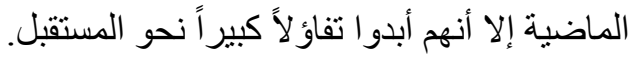

لقد أثبت الثباب المصري وبلا أدنى شك أن لديه قدرات

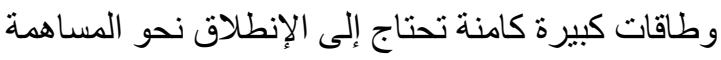

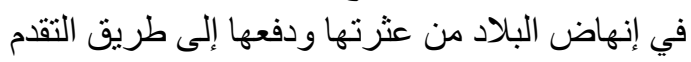
و النمو والرخاء، و هو ما يتطلب العمل على توفير البيئة 
ومن المعروف ان الحكومات و الهيئات تكون دائما في

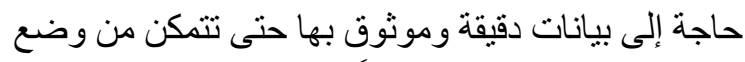

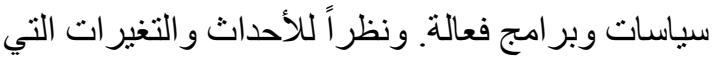

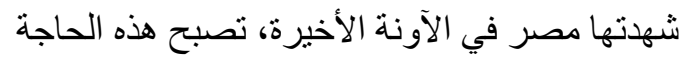

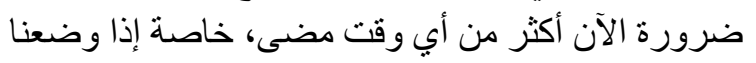
في الإعتبار ما تمثله شريحة الثباب من جملة ألة عدد سكان فيكان

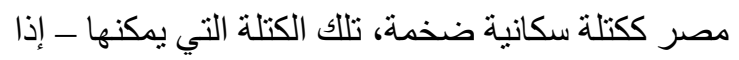

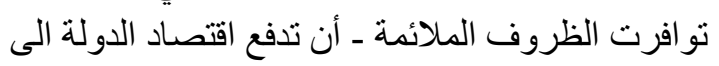

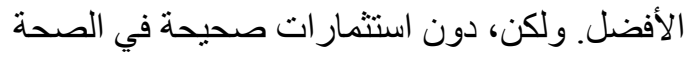

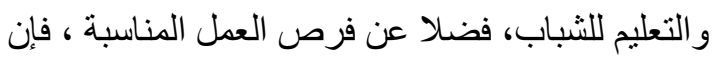

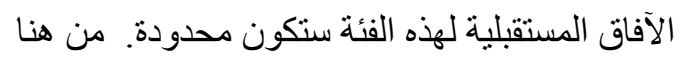

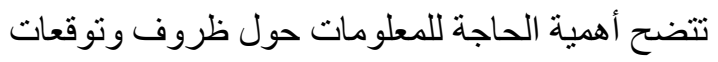
الثباب المصري. في هذا التقرير سنتعرف على أهم أهم

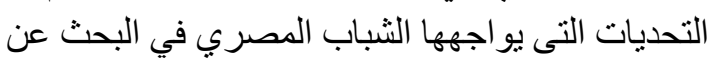

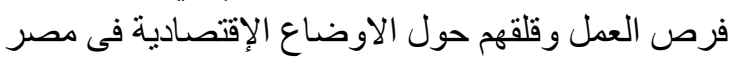
كما نتعرف على تفاؤلهم تجاه المستقبل.

نحن نفتخر بالتاريخ الطويل لمجلس السكان الدولى في الدي مصر ، ونتطلع لمو اصلة العمل و الثر اكة من أجل تحسين الطين حياة ورفاهة الثعب المصري.<smiles>C=CC(C)CC</smiles>

جوليا بونتينج

رئيس مجلس السكان / نيويورك بوني
على مدى العقود الماضية، قدم مجلس السكان الدولى

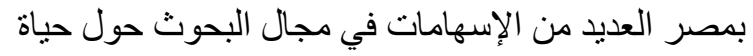

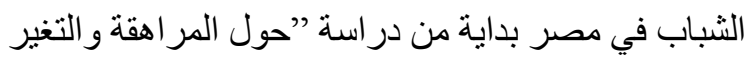

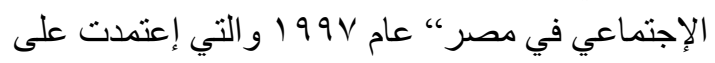

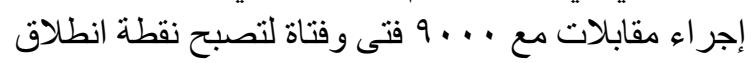

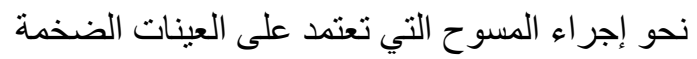

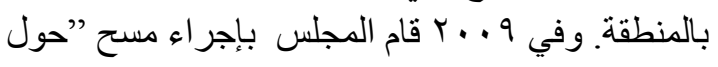
النشء و الثباب في مصر، ، حيث عقد مقابلات مع عينة

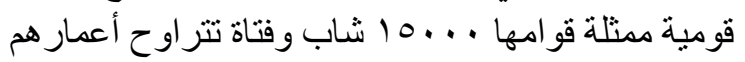

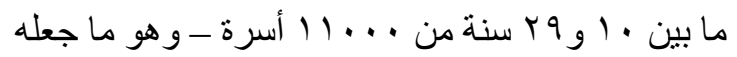

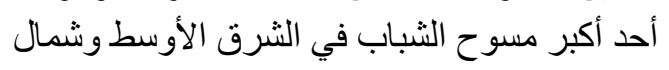
أفريقيا.

وقد تم الإستفادة من نتائج هذه المسوح - بما تضمنته

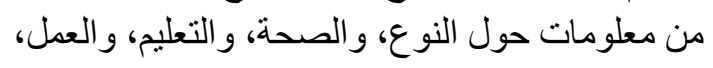

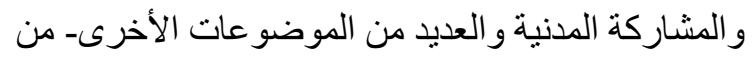

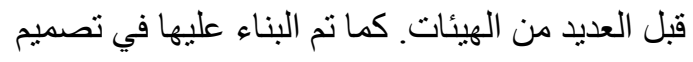

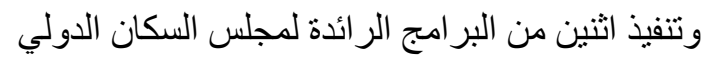

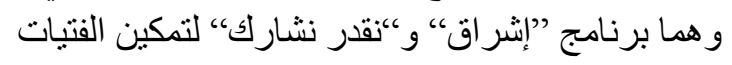
و الثابات في ريف صعيد مصر.

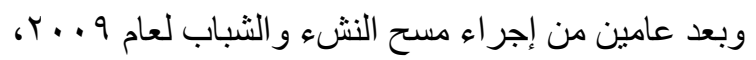

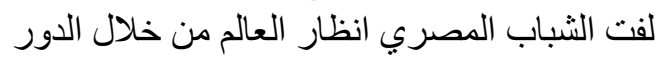

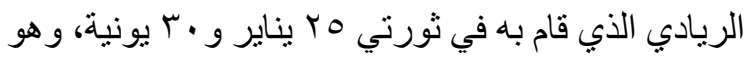

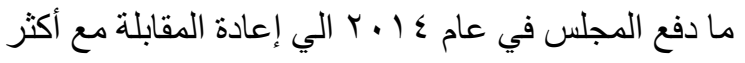

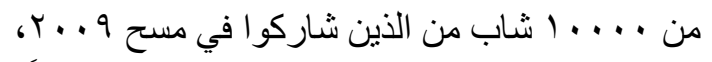

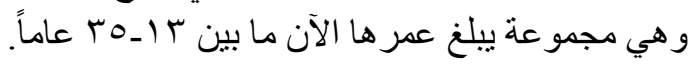

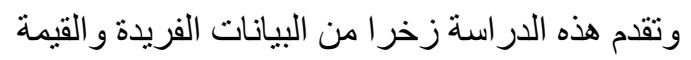

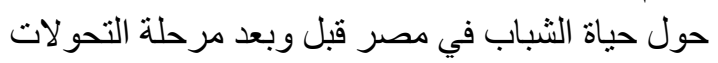
السياسية. 


\section{الخصائص الرئيسية للنشء والثباب في \\ $r+1 \varepsilon$}

نظر الارتفاع معدلات الخصوبة التي شهدتها فترة الثمانينيات

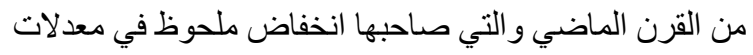
وفيات الأطفال، فان مصر تمر الآن بمرحلة تحول سكاني

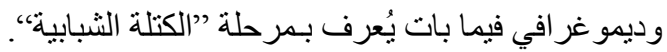

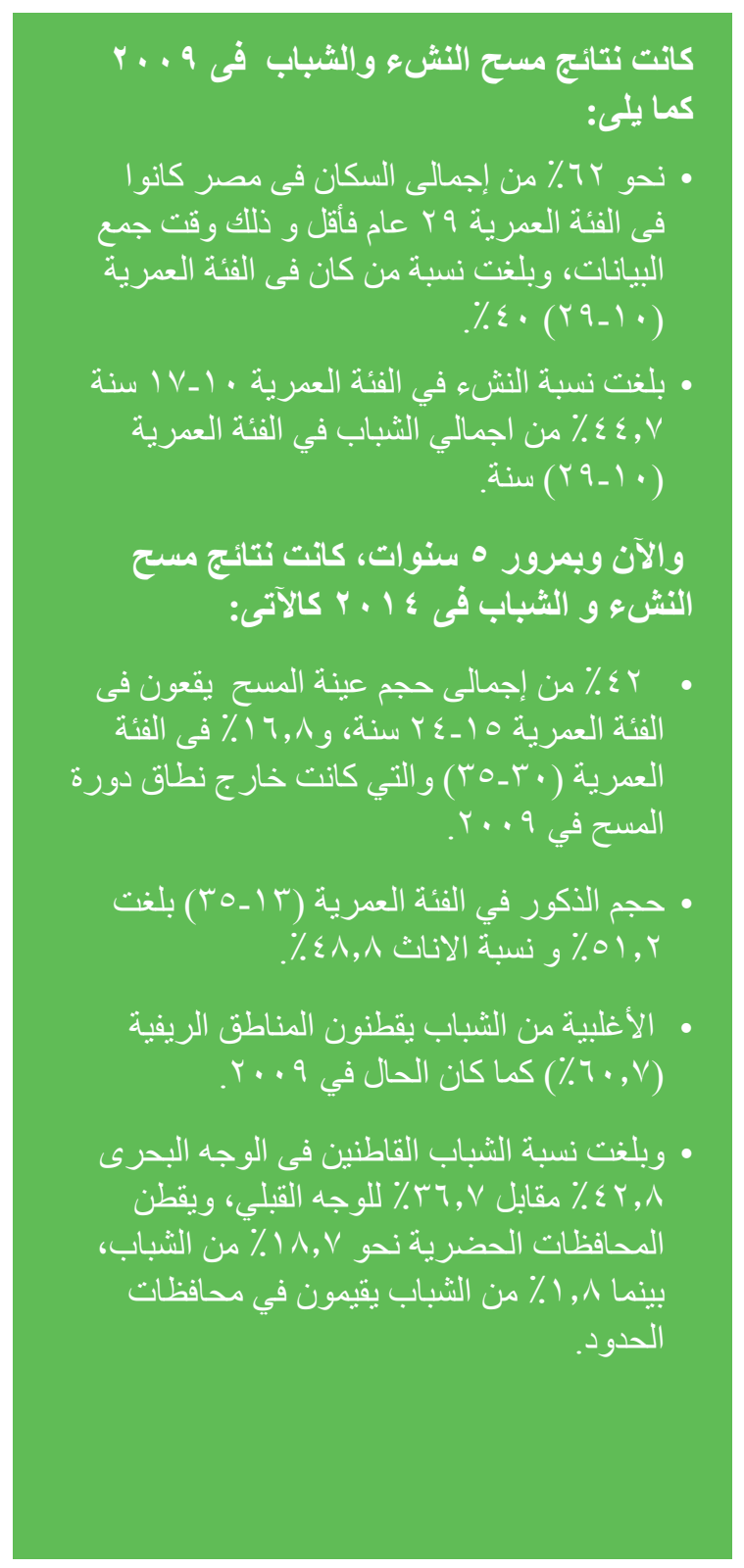

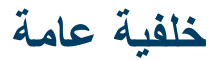

وفر مسح النشء و الثباب لعام 9 . . ب مصدر ا فريداً للبيانات

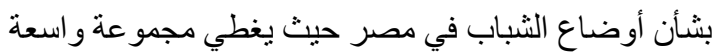

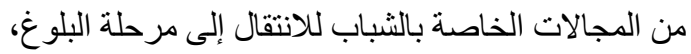

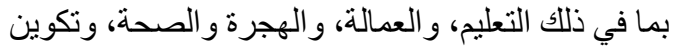
الأسرة، و القضايا الاجتماعية، و المشاركة المدنية و السياسية.

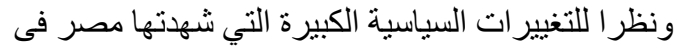
الفترة الإنتقالية، فقد صمم مجلس السكان ونفذ الدورة الثانية

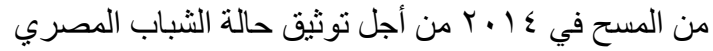

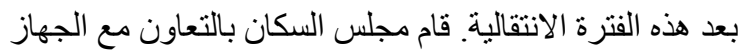

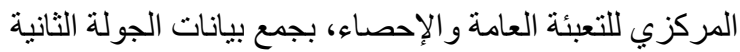

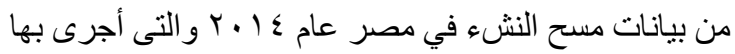
مقابلات مع نفس العينة من الثباب الذين أجريت معهم مقابلات

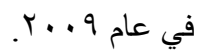

في عام 9 . . r تم مقابلة عينة مدثلة حبمها

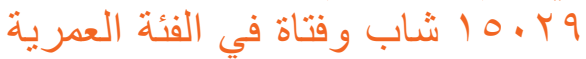

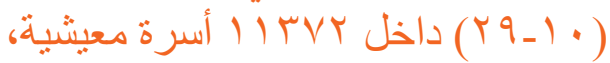

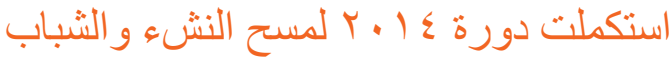

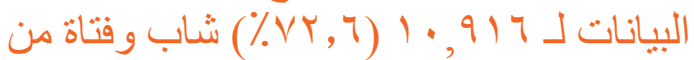

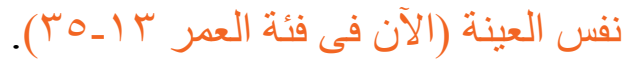

نتج عن ذللك قاعدة بيانات تتبعية ممثلة على المستوى القومي لفترتي المسح. استخدم التقرير كلٍ دورتي مسح النشء و

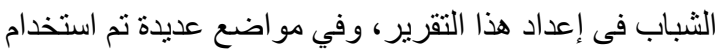

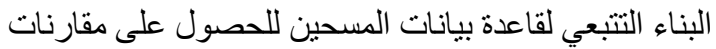

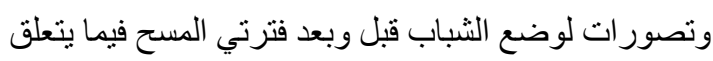
بالموقف الاقتصادي و الاجتماعي و السياسي، وكذلك الحالة

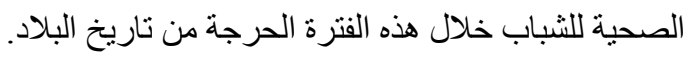

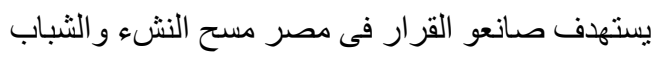
ليساعدهم فى وضع سياسات مبنية على ادلة تعمل على تعزيز قدرة الثباب المصرى ورفاهيته وفيتهر.

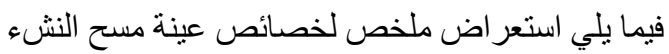
و الثباب في ع ا ـ r، و أهم المؤشرات الرئيسية، وكذلك السياسات المقترحة ذات الصلة. 
ستة من كل عشرة شباب يعرفون عن وسائل تنظيم الأسرة أهم النتائج المختلفة، وكانت النسبة أقل بصورة ملحوظة بين الذكور

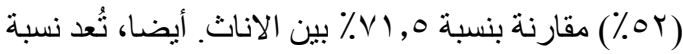

استخدام وسائل منع الحمل بين الثباب المنزوجين حاليا منخفضة بالمقارنة للمتوسط القومي لإستخدام وسائل تنظيم الأسرة وهو 010 \% حسب مسح السكان الصحي بمصر

(EDHS).

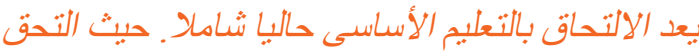

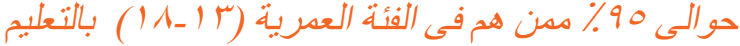

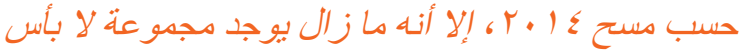

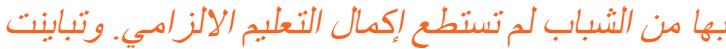

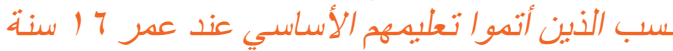

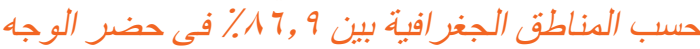

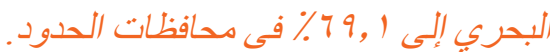

على الرغم من أن الشباب يحظون بمستويات تعليمية أفضل من و الديهم، إلا أن هنالك علاقة وثثيقة بين مستوى تعليم الأباء

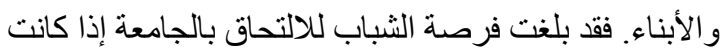

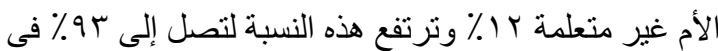

$$
\text { حالة حصول الأم على تعليم جامعي. }
$$

ماز ال أمام مصر تحدى حقيقى لضمان جودة التعليم لجميع الطلاب. يتميز التعليم - حسب وجهة نظر الطلاب ـ بأسلوب

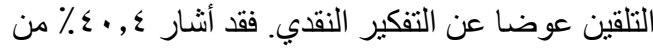

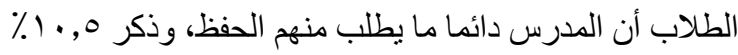
أنه ينم تشجيعهم من قبل المدرسين لتكوين وجهة نظر خاصة بهم، بينما ذكرت نسبة ه,9٪ فقط من الثباب أن المدرسين

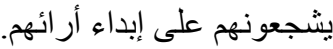

تزداد معدلات الاعتماد على الدروس الخصوصية ومجمو عات

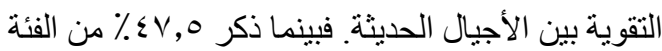

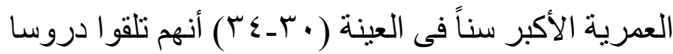

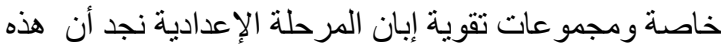

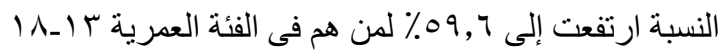

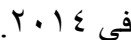

الصحة والأمان

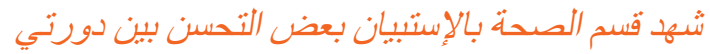

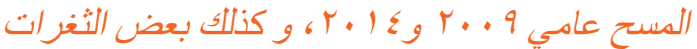

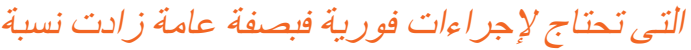

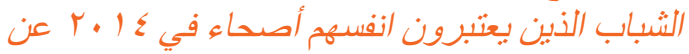

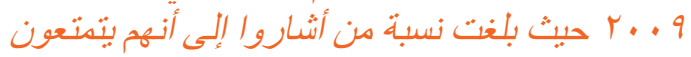

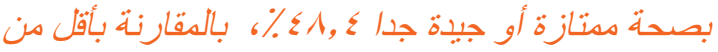

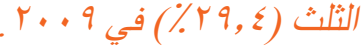

انخفضت نسبة الفتيات اللاتي تعرضن للتحرش في الفئة

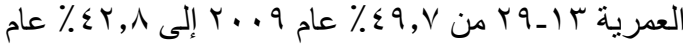

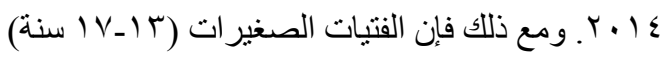
شهدن زيادة طفيفة في التعرض للتحرش الجنسي من ؟ , ؟ ؟ ٪

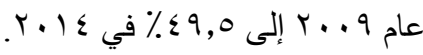

العادات الغذائية للشباب إلى جانب السلوكيات الضارة مثل

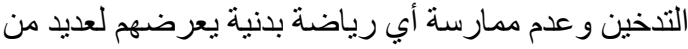

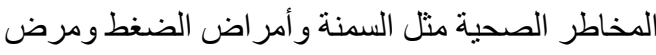

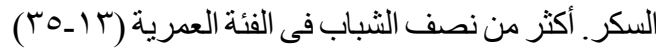

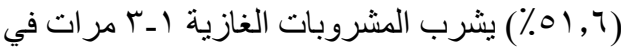

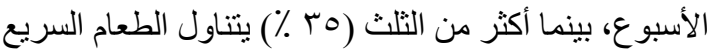

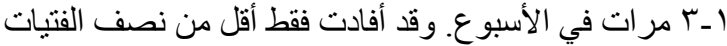

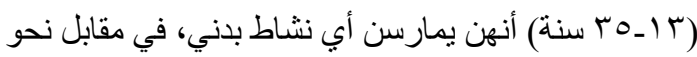

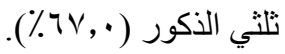

أظهرت النتائج أن الثباب محدود المعرفة بشأن فيروس نقص الثقال الثروي المناعة البشري (HIV/AIDS) أو طرق انتقال العدوى. حيث اشارت نسبة أقل بقليل من ثلاثة أرباع المستجييين أنها

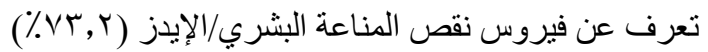

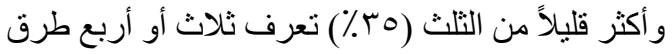

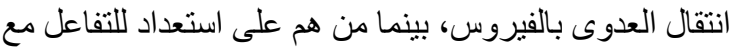

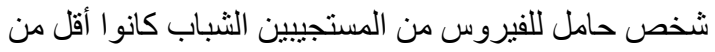
و واحد من بين كل خمسة أفر اد.

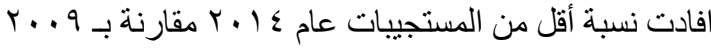

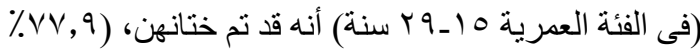

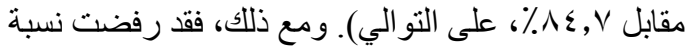

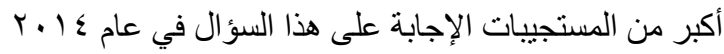

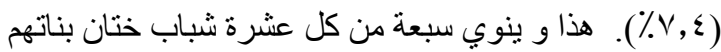




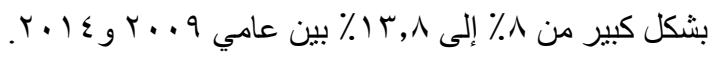

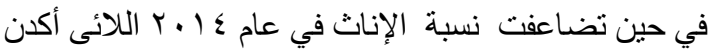

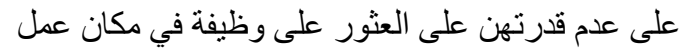

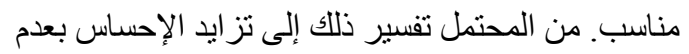

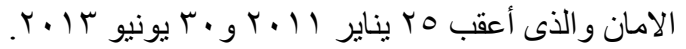

على الرغم من عدم الاستقر ار السباسي و الاقتصادي

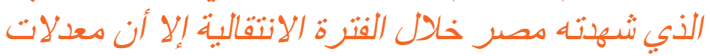

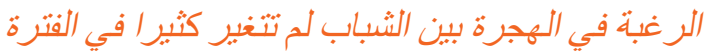

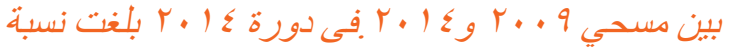

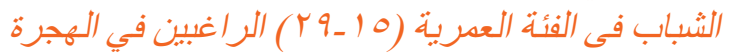

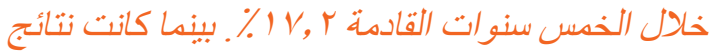

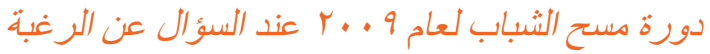

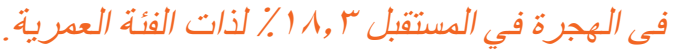

الثباب الذكور فى الفئة العمرية (10 ـ9 ب) كانو ا أكثر رغبة

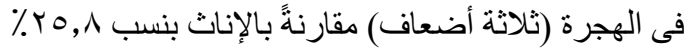

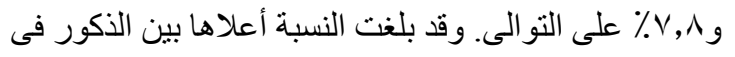

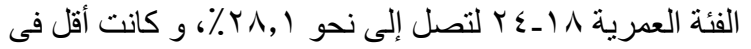

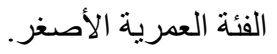

تزداد نسبة الر اغبين فى الهجرة من الثباب الذكور فى الفئة

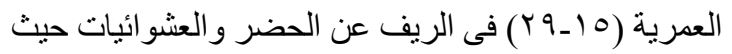

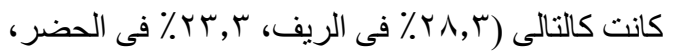

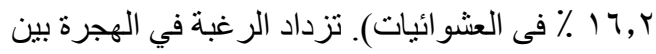

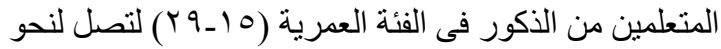

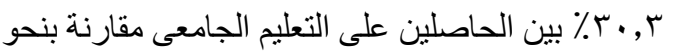

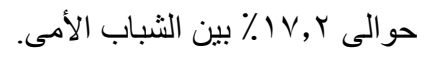
تمثل العو امل الاقتصادية أحد أهم الأسباب التي تدفع الثباب

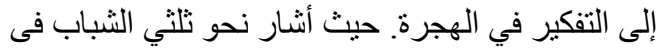

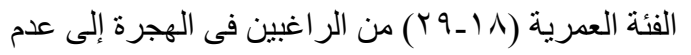

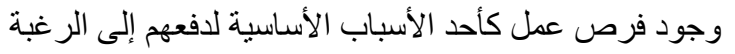

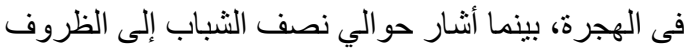

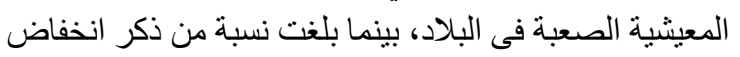

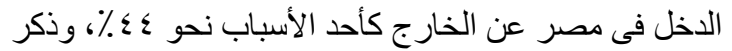

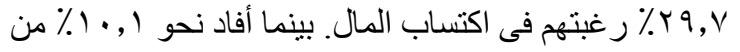
الثباب أن الظروف الأمنية و السياسية للبلاد هى التى تدفعهم التهال

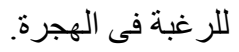

الثّوظّف

تدهورت ظروف عمل الشباب خلال الفترة الانتقالية،

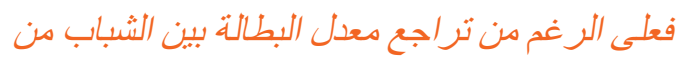

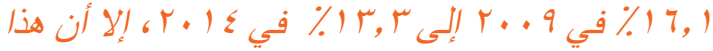
التر اجع لم بصاحبه زيادة في مستويات تثغيل الثيل الثباب.

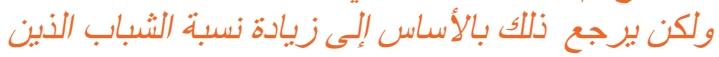

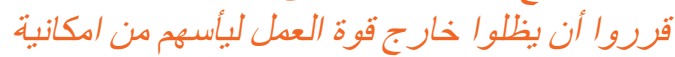
الحصول على فرصة عدل مناسبة.

انخفضت نسبة المشاركة في قوة العمل بين الثباب بشكل

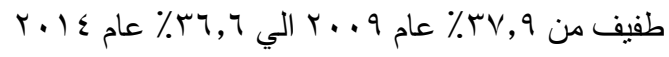
وكذللك انخفضت نسبة المشاركة في قوة العمل بين الثباب

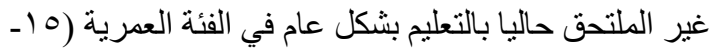

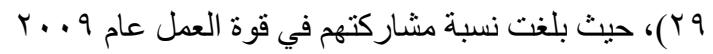

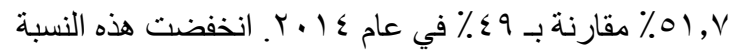

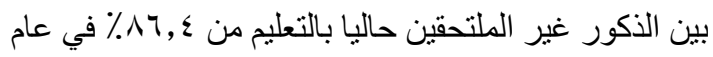

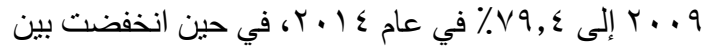

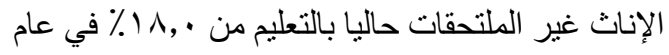

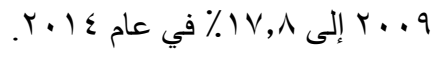

ماز ال عدد كبير من الثباب مرتبط بعمل غير رسمي (بدون

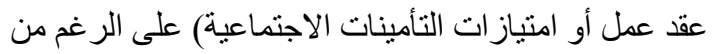

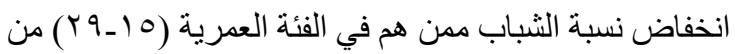

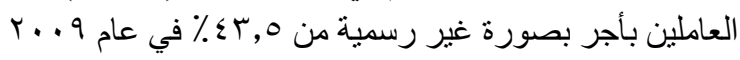

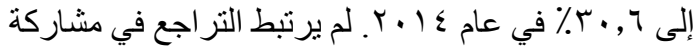

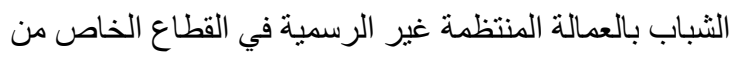

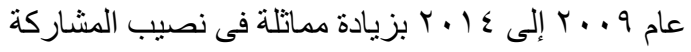

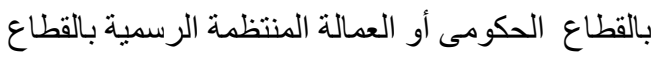

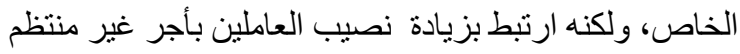

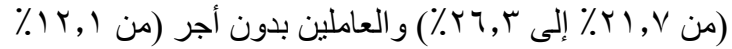

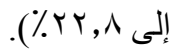

تم رصد زيادة في الاعتماد على ريادة الأعمال كحل بديل

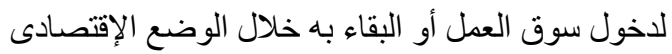
الصعب أثناء الفترة الانتقالية.

زادت نسبة الثباب فى الفئة العمرية (10 ـ9 ب ) أصحاب

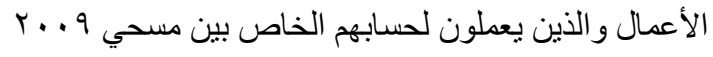

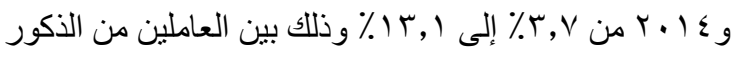

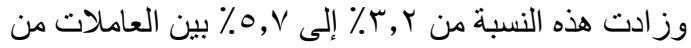

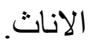

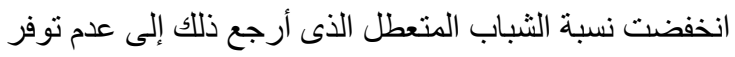

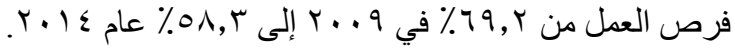

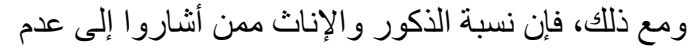

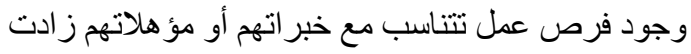




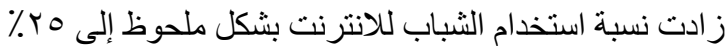

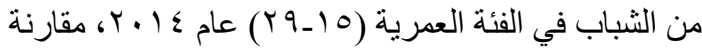

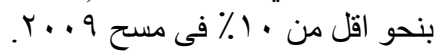

تم سؤ ال الثباب لتحديد اثثين من أهم القضايا المستقبلية التى تلى

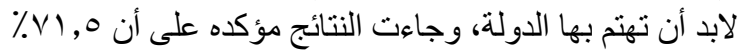

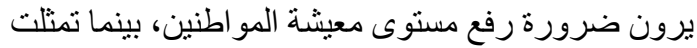

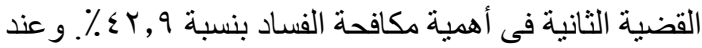

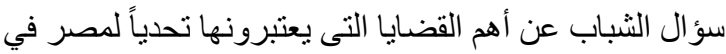

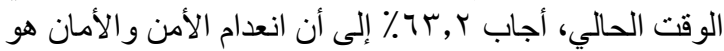

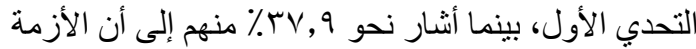

الاقتصادية تُعد ثانى تحدي لمصر حاليا.

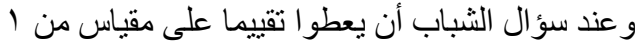

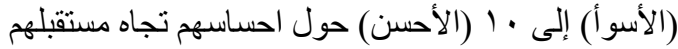

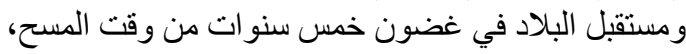
أظهرت النتائج ان الشباب متفائل إلى حد ما تجاه المستقبل.

آراء وتوجهات الشباب حول أدوار النوع الإجتماعى

تشبر بيانات المسح أن توجهات النوع الاجتماعي بشكل

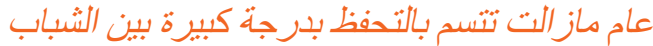

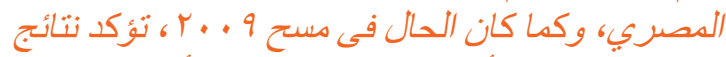

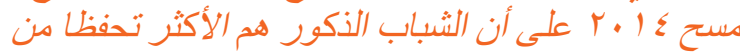
نظر ائهم من الإناث.

وكثفت النتائج عن نوجه مزيد من الثباب نحو المساو اة بين

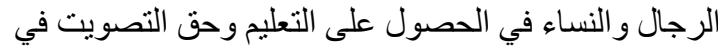

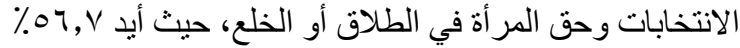

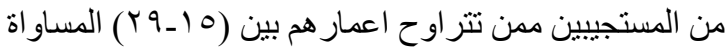

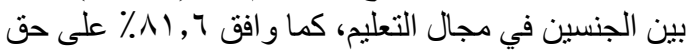

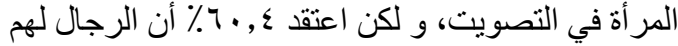
الأولوية فى التوظف عندما تقل الوظائف.

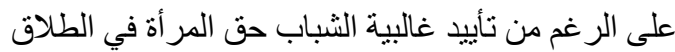

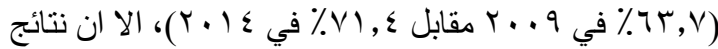
المسح تثير إلى أن المرأة المطلقة لا يُنظر اليها بشكل إيجابي

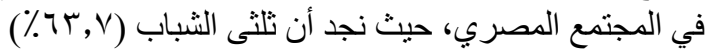

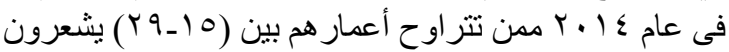
بأن مجتمعهم لا يحترم المر أة المطلقة.
الزواج وتكوين أسرة

أظهرت بيانات المسح أن نسبة كبيرة من الثباب الذكور

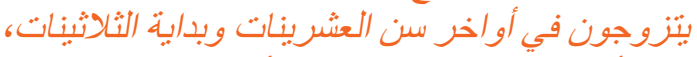

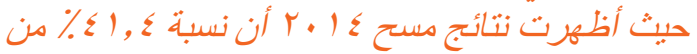

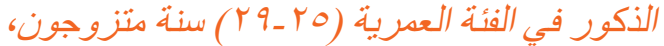

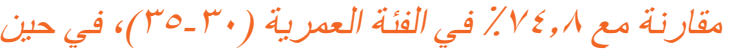

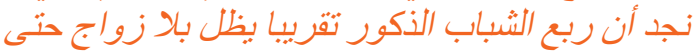

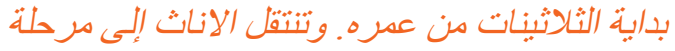

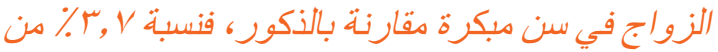

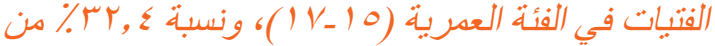

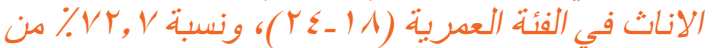

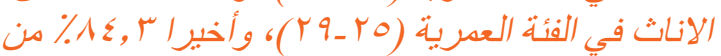

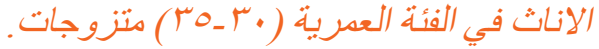

ماز الت الفتيات في المناطق الريفية تواجه خطر الزواج

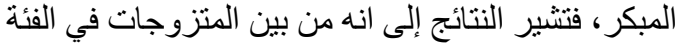

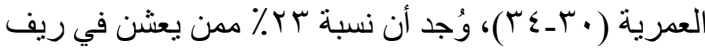

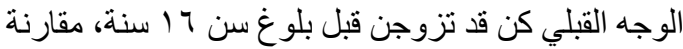

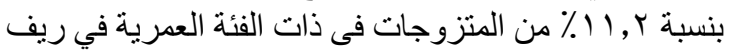

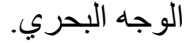

أثشارت البيانات عام 9 . . ب إلى أن الثباب غير المتزوج

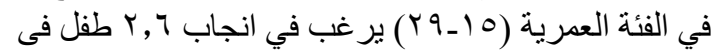

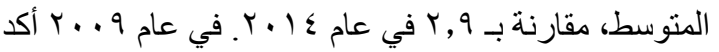

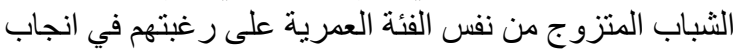

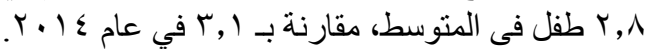

\section{المشاركتة المدنبية والسبياسية}

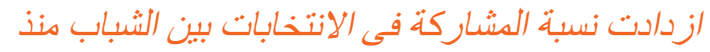

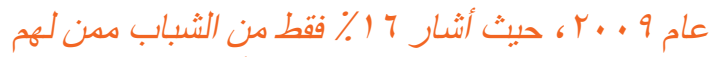

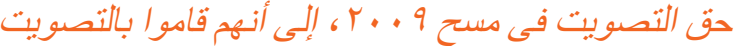
في السابق. وقد زادت معدلات الاقبال على الانتخابات

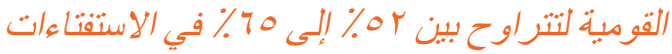

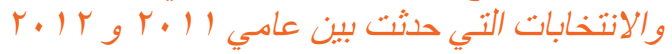

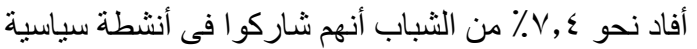

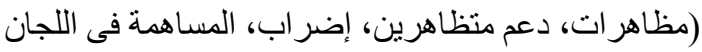

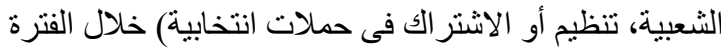

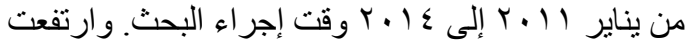

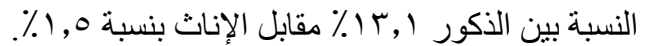

لاتز ال معدلات مشاركة الثباب في الأنشطة التطو عية

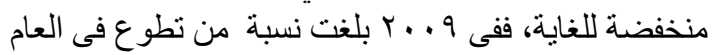

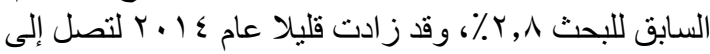

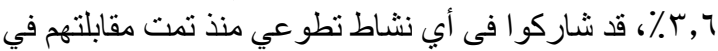
$r+.9$ 
حرماناً، فان سياسات لتعزيز المساو اة في الفرص لجميع الثباب تُعد وسيلة أكثر استدامة وبعيدة المدى لتغيير مستقبل التربل

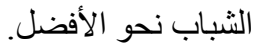

وفي النهاية، يعرض مسح النشء و الثباب في عـ الـ ب و لأول

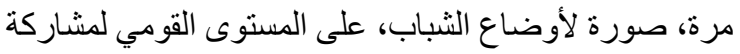

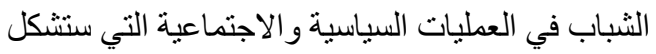

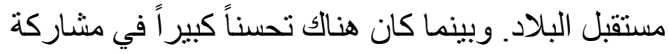

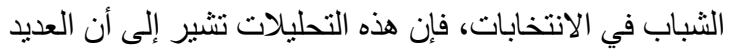

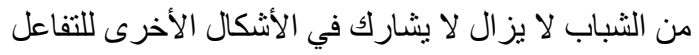

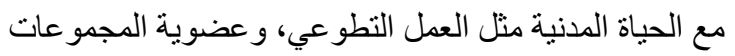

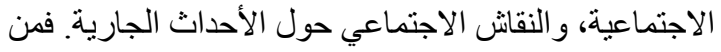

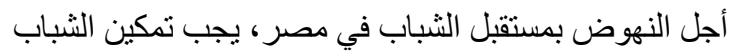

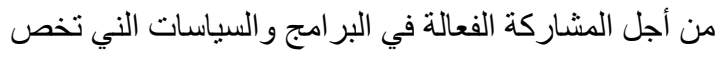

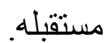

رانيه رشدي

الباحث الرئيسى رئل

مايا سيفيردنج

الباحث الإسنشارى ميفير
للأسف هناك نسبة كبيرة من الثباب تبرر العنف ضد المر أة

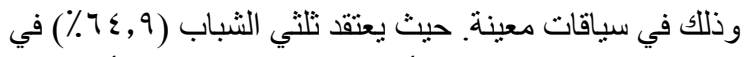

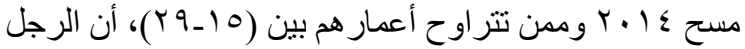

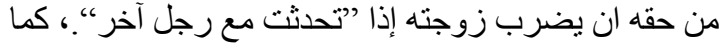

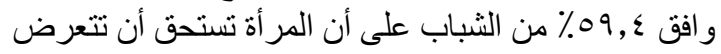

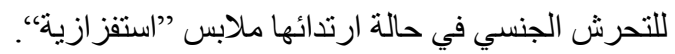

\section{ملاحظات ختامية وتوصيات}

يتمثل الهدف الرئيسي لمسح النشء و الثباب لعام ع ا ـ ب في

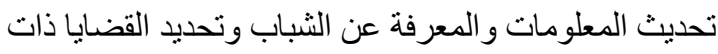

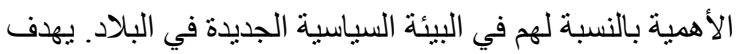

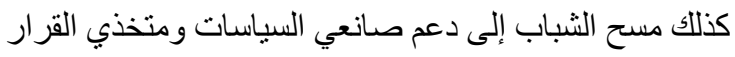

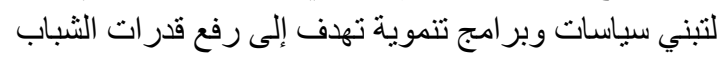

المصري وتمكينه من تحقيق آماله وطموحاته في مستقبل

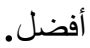

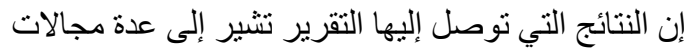

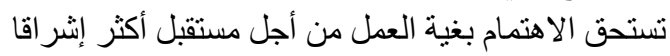

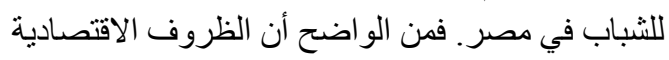

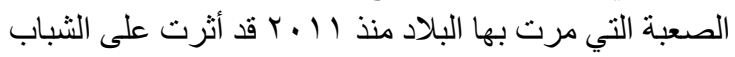

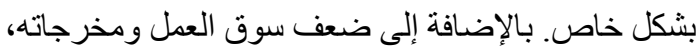

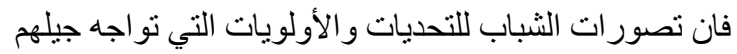

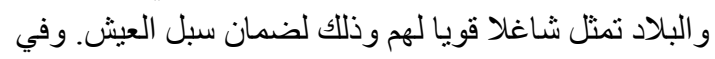

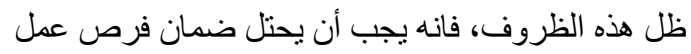

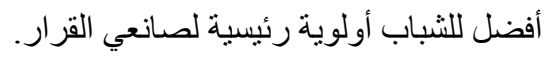

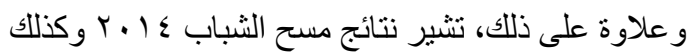

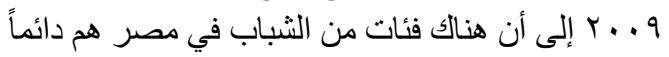

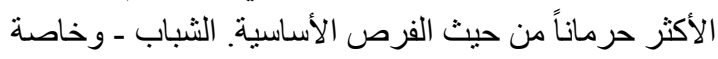

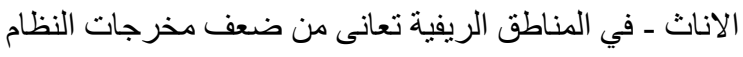

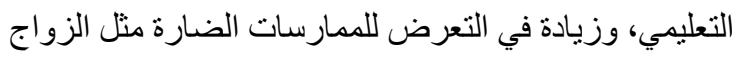

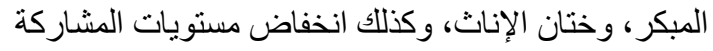

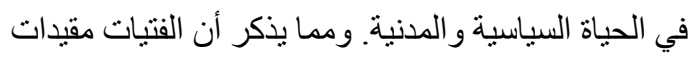

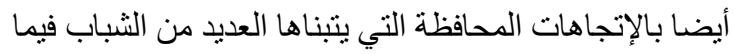

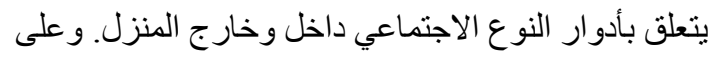
الرغم من أن بر امج التنمية تقوم حاليا باستهداف السكان النيان الأكثر 


$$
\begin{aligned}
& \text { | فول مست النشء و الشباب } \\
& \text { رانبه رثدي }
\end{aligned}
$$

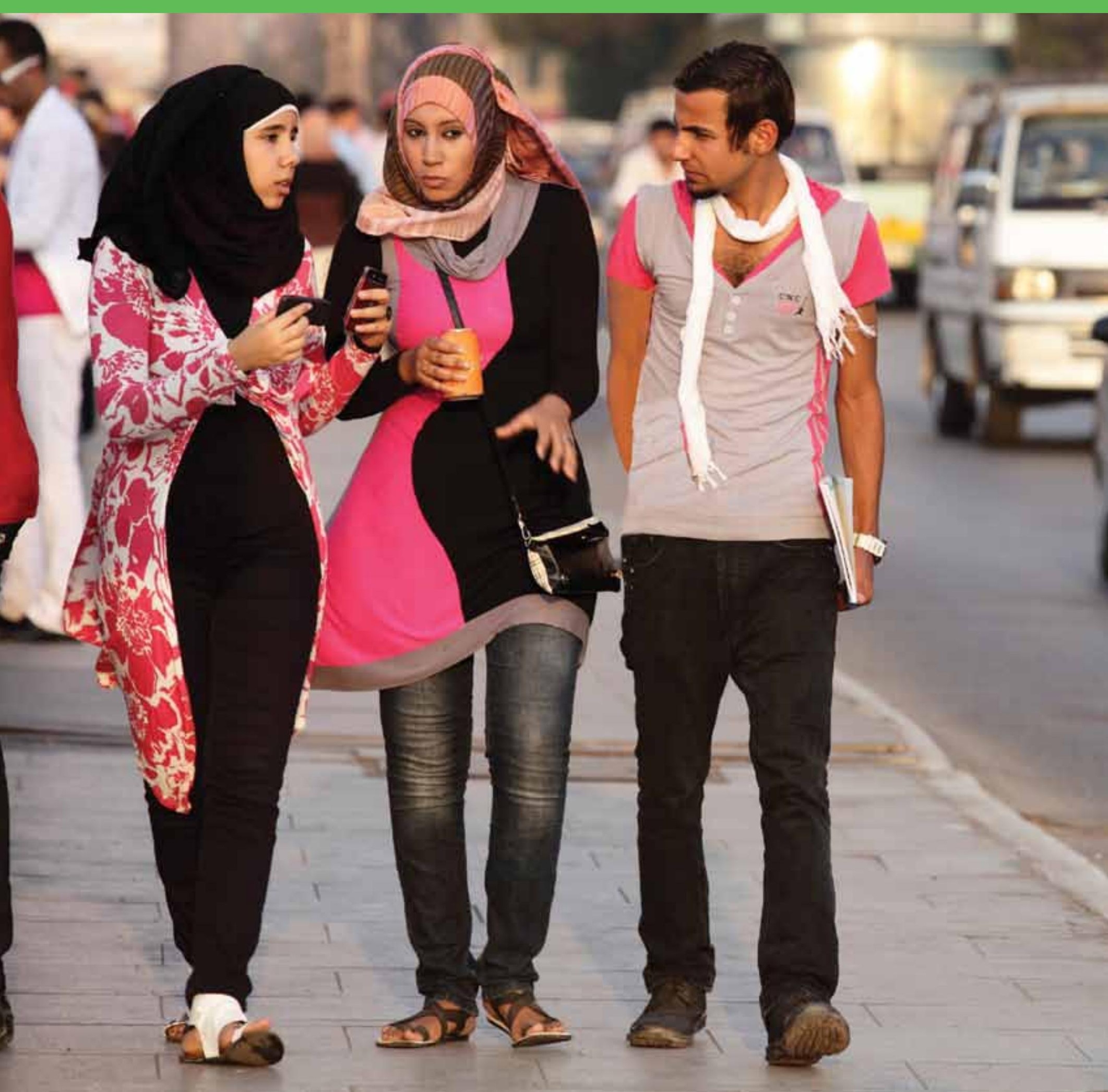




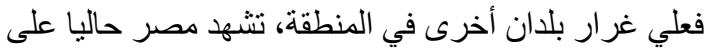

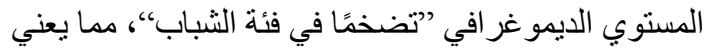

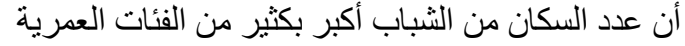
الأخرى. و على الرغم من ارتفاع أعداد المتعلمين تعليمًا عاليًا

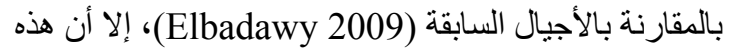
الفئة الثابة ما تز ال تناضل لتحال لتحقيق الاستقر ار الاقتصادي.

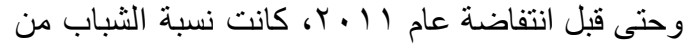
إجمالى العاطلين عن العمل على مستوي الدولة يقدر بحو الي .9 ٪ (UNDP and INP 2010).

ولذلك فمن الأهية بمكان السؤال عن كيف يتعامل الثباب

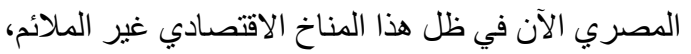

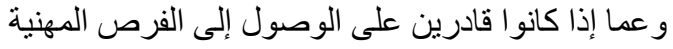

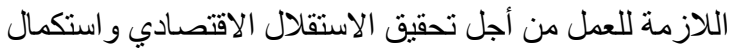

التحولات الرئيسية في الحياة كالزواج الاجي وتكوين أسرة. وفي الإني

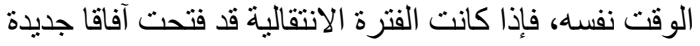

للثباب في المجالات الأخرى من الحياة، أبرز ها تعميق الأنيق

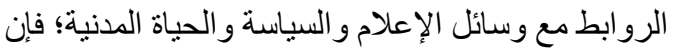
الأسئلة المتعلقة بتشغيل الشباب و المشاركة المدنية في هذا

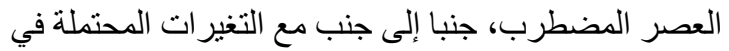

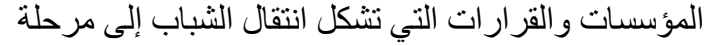
الرشد، كالصحة و الحصول على الرعاية الصحية، ونوعية التوالية

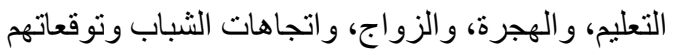
الخاصة بالحياة، كل هذه الأسئلة هو ما يسعى هذا التقرير التئي إلى التى فهم أفضل لها.

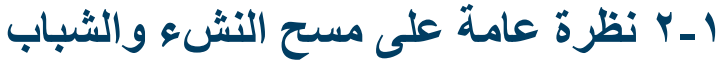

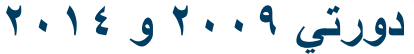

تم إجر اء الدورة الأولى لمسح النشء و الثباب في مصر

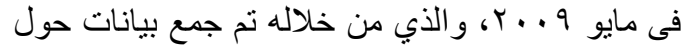

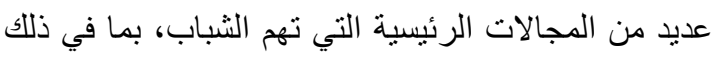

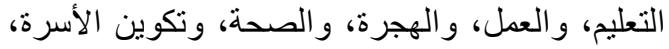

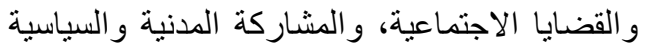
(Population Council 2010) وللتعرف على كيفية تعامل الثباب المصري خلال الفترة الانتقالية بعد الثورة

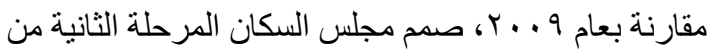

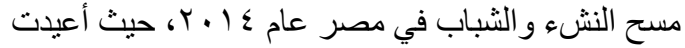

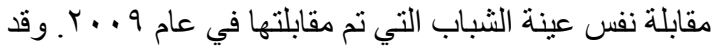

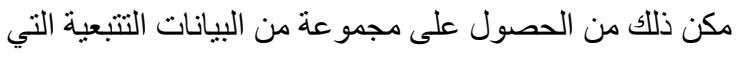

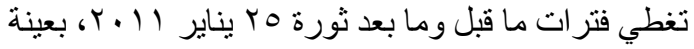

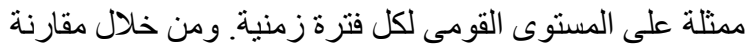

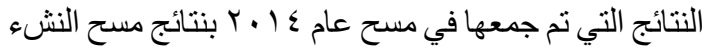

\section{لق كانت فترة السنو ات الخمس التي مرت منذ مسح مجلس \\ السكان للنشء و الشباب في مصر عام 9 . . T (SYPE)

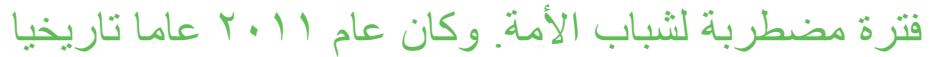 \\ للثباب المصري، حيث قام الثباب من جميع أنحاء البلاد بدور نشط في ثورة الخامس والعشرين من يناير.}

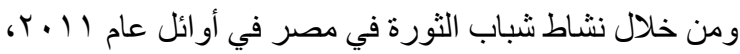

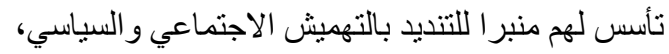

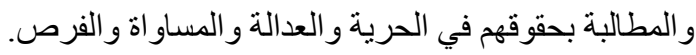

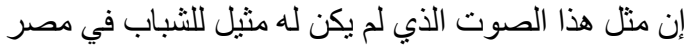

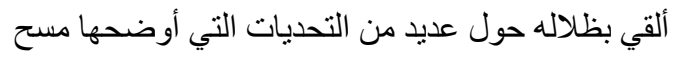

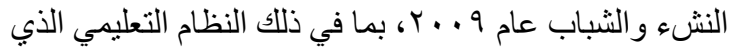

لا يستجيب لاحتباجات الثباب، وظروف العمل الصعبة،

و انخفاض مشاركة الثباب المدنية و السياسية، والبيئة

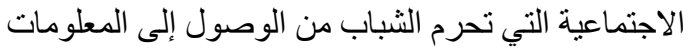
الأساسية حول انتقالهم إلى مرحلة الرشد.

\section{ا ـ ا مصر ما بعد الثروة}

لقد شهدت مصر عديد من التقلبات السياسية و التغييرات في

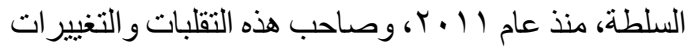
اضطر ابات مدنية واحتجاجات مستمرة شكلت جل الأحداث

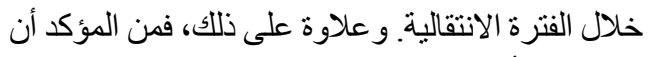

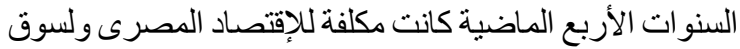

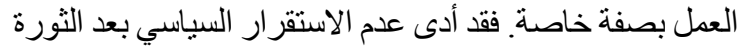

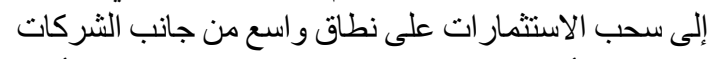

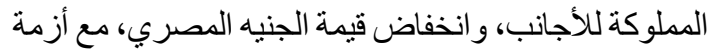
ديون تلوح في الأفق و التي لانز ال الدولة المصرية تكافح

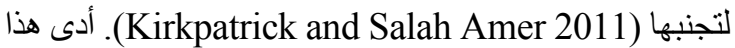

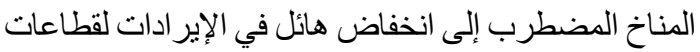

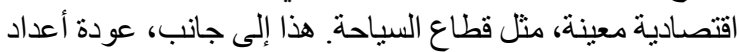

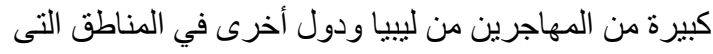

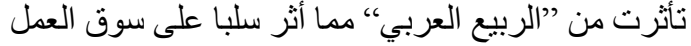

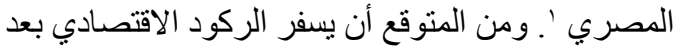

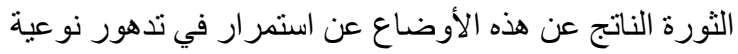

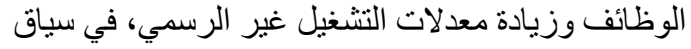

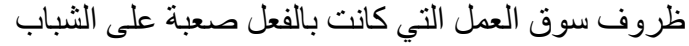

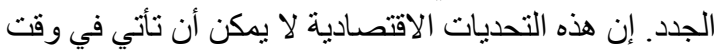

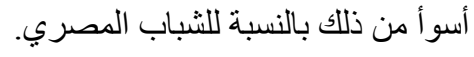

ا ب تم تغطية هذا التباطؤ الذي حدث للاقتصاد المصري بعد الثورة على نطاق واسع

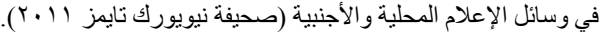




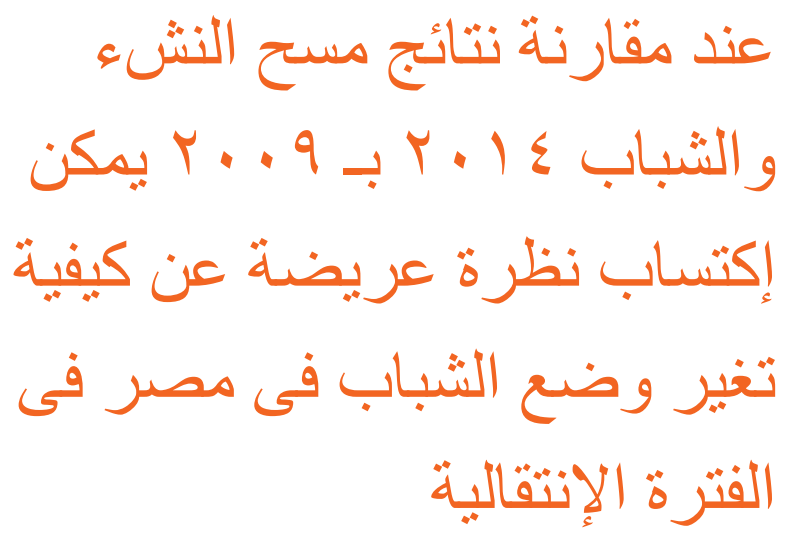

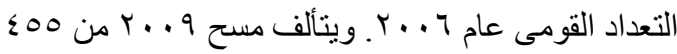

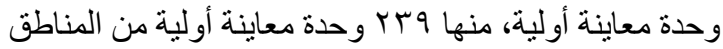

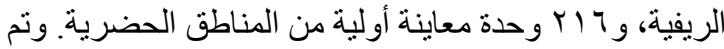

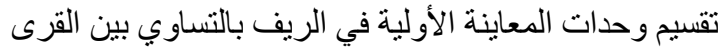

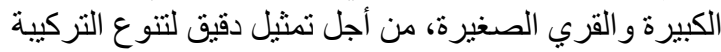

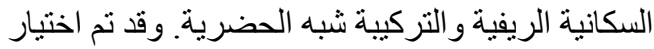

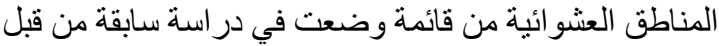

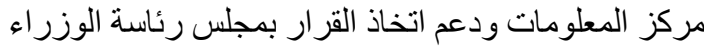

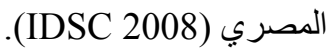

وقد أجريت عملية جمع بيانات مسح النشء و الثنباب في مصر

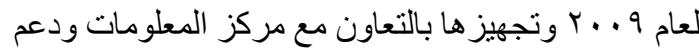

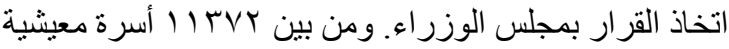

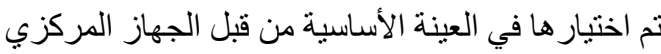

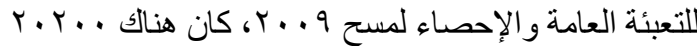
من الثباب المؤ هلين للمشاركة في المسح، وباستخدام تقنية Kish grid إجمالي المشاركين المحتملين. وفي المجمل، أجريت المقابلات

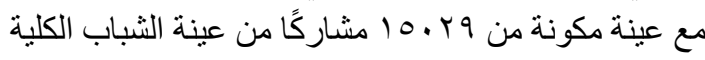

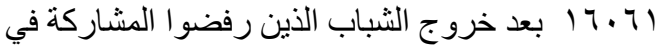
التطبيق أو الذين لم يكونو ا موجودين في فترة جمع البئ البيانات

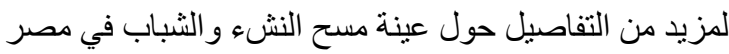

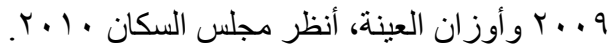

كانت عينة مسح النشء و الثباب عام ع | ـ ب هي نفس عينة

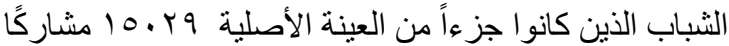

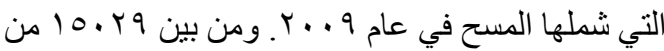

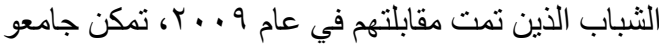

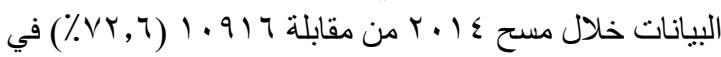

و الثباب في مصر عام 9 ، . ب، أمكننا الحصول على رؤية موسعة حول الطرق التي تغير بها الثباب في مصر خلال الفترة

الانتقالية. ويقدم هذا الفصل الاستهلالي وصفًا لتصميم عينة

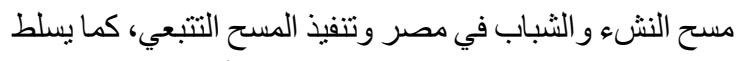
الضوء على خصائص الخلفية الاجتماعية الأساسية للثباب الذين الذين

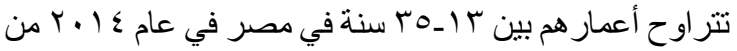

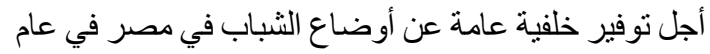

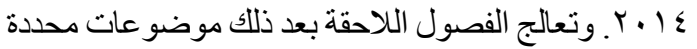

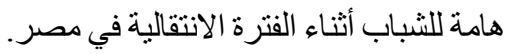

\section{ا _r تصمم المسح وإجراعات تثقيذه}

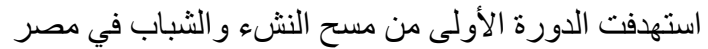

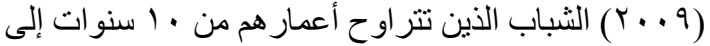

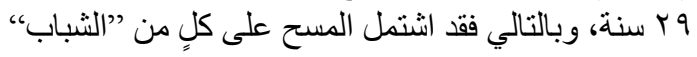
و "المر اهقين“، وكان اختيار فريق المسح لهذه الفئة العمرية

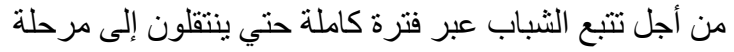

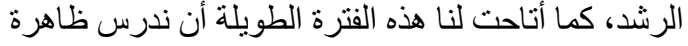

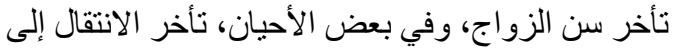

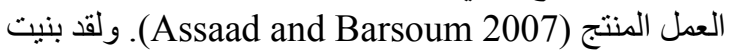

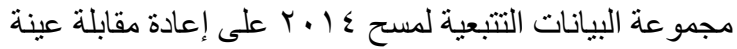

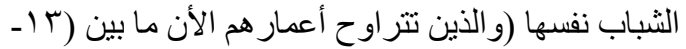

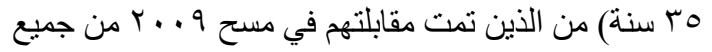

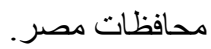

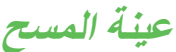

يُعد الثرح الموجز لتصميم عينة الدورة السابقة من مسح

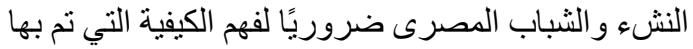

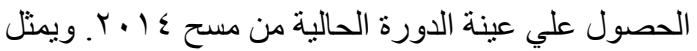

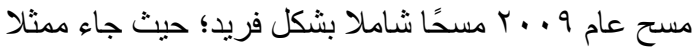

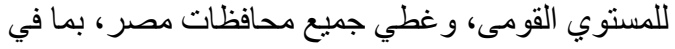

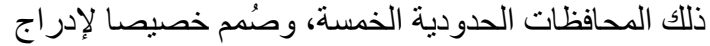

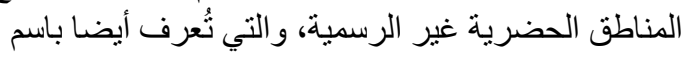

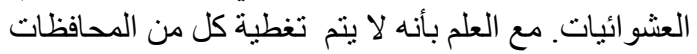

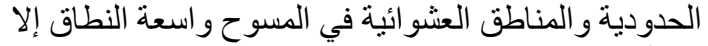

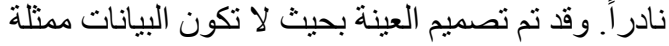

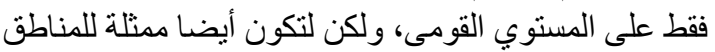

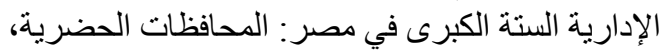

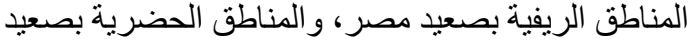

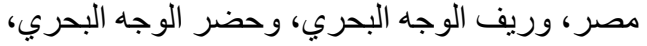

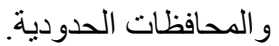

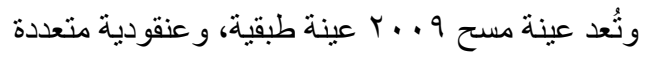
المر احل. وقد تقرر أخذ العينات باستخدام وحدات المعائة العينة الأولية (PSUs) المستمدة من العينة الرئيسية التي يقدمها لإنيا

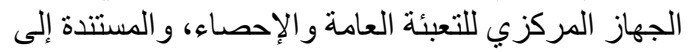




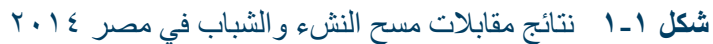

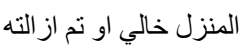

$(r, \%)$

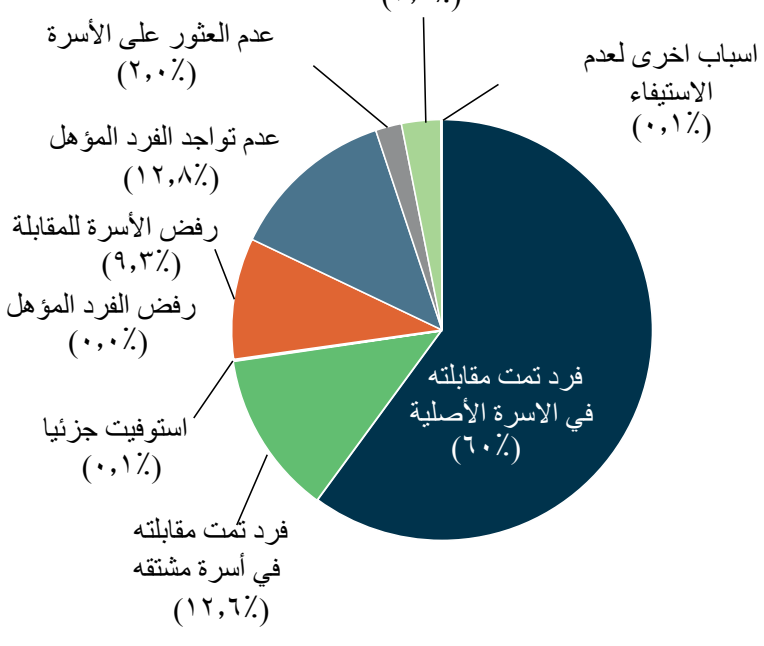

ولقد تضمن مسح 9 . . ب ثلاثة استبيانات: استبيان الأسرة المعيشية، واستبيان فردي يركز على المستجيب، واستبيان

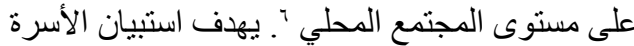
المعيشية إلي تقييم الخصائص الديمو غر افية والاجتماعية

ـالاقتصادية لأسرة المبحوث، وتم تطبيق هذا القسم من الاستبيان مع رب الأسرة أو مع أحد البالغين في الأسرة التي لمني تم مقابلتها.

ويتكون الاستبيان الفردي في مسح 9 ×. . من ستة نسخ مصدمة خصيصا لمختلف الفئات العدرية وللجنسين وهي علي النحو التالي: الذكور في الفئة العمرية من • 1 ــ اسنة،

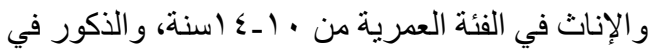

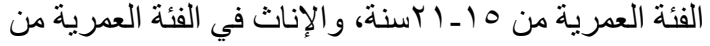

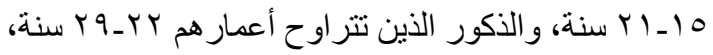

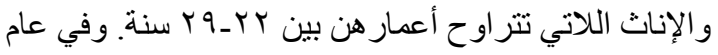

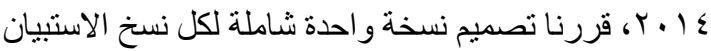

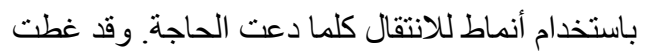

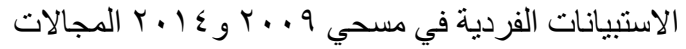
الرئيسية التالية: التعليم و العمل وتكوين الأسرة، و الصحة، و الهجرة، والمشاركة المدنية و السياسية.

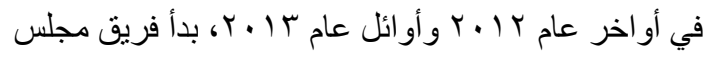

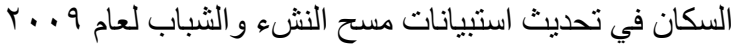
الخاصة باستبيان الأسرة المعيشية و الاستبيان الفردي وذللك من

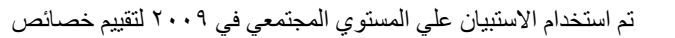

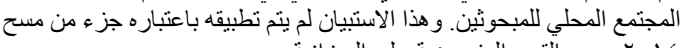

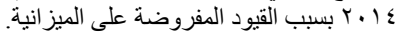

الفئة العمرية ؟ ـ ـهب سنة ؟. وقد بُذل كل جهذ ممكن من خلال

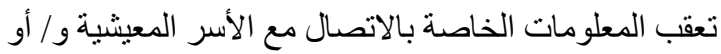

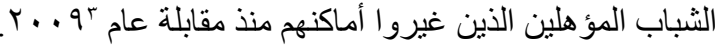

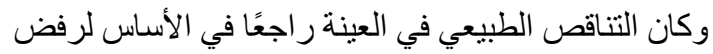

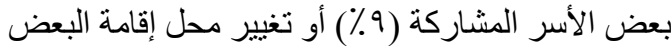

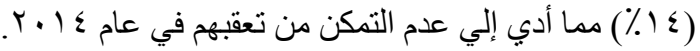

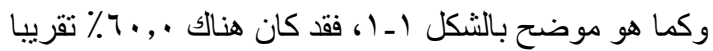

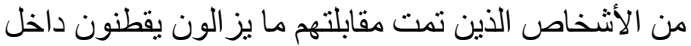

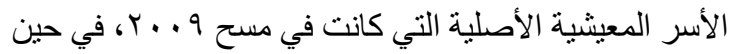

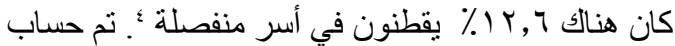
أوزان احتمالية عدم الاستجابة حتي تتخلاءم مع عينة مسح

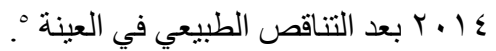

تصعيم الاستنبان

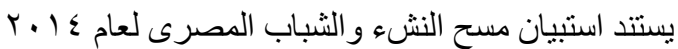
في المقام الأول على مسح 9 ×. . ب، و الذي تم تطويره و إعداده باستخدام بيانات كيفية جُمعت من خلال المناقتشات الجماعية البؤرية و المقابلات مع الثباب والتي حددت القضايا ذات الأهمية للشباب. وبالإضافة إلى ذلك، قام فريق المجلس

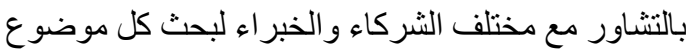
من الموضو عات التي يغطيها المسح وأنهي قر اءات مكثفة

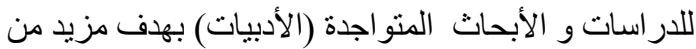

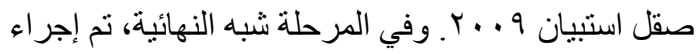
در اسة استطلاعية على عينة مختارة من وحدات المعاينة

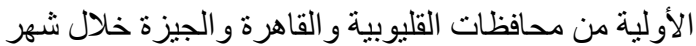

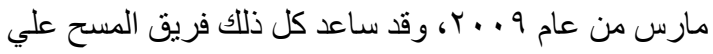
صقل الأداة قبل البدء في جمع البيانات على المستوى القومى.

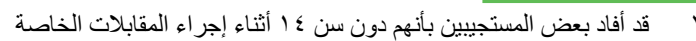

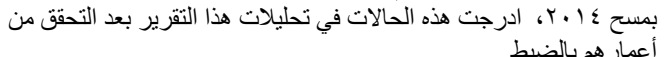

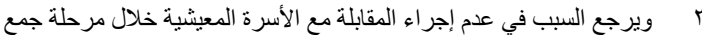

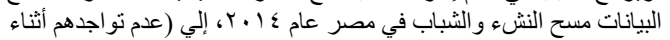

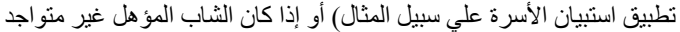

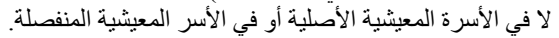

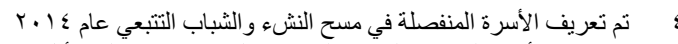

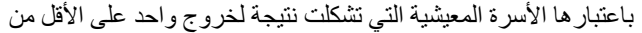

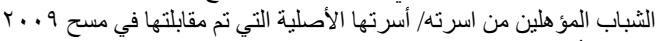
وتشكيل أسرة جديدة بعد مقابلة عام 9 ج. . r.

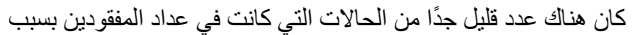

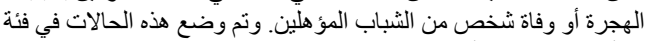

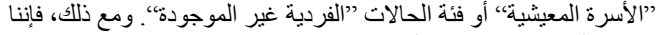

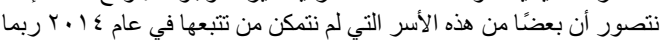

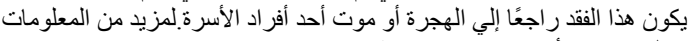
حول حساب الأوز ان يرجى مر اجعة (Roushdy 2015). 


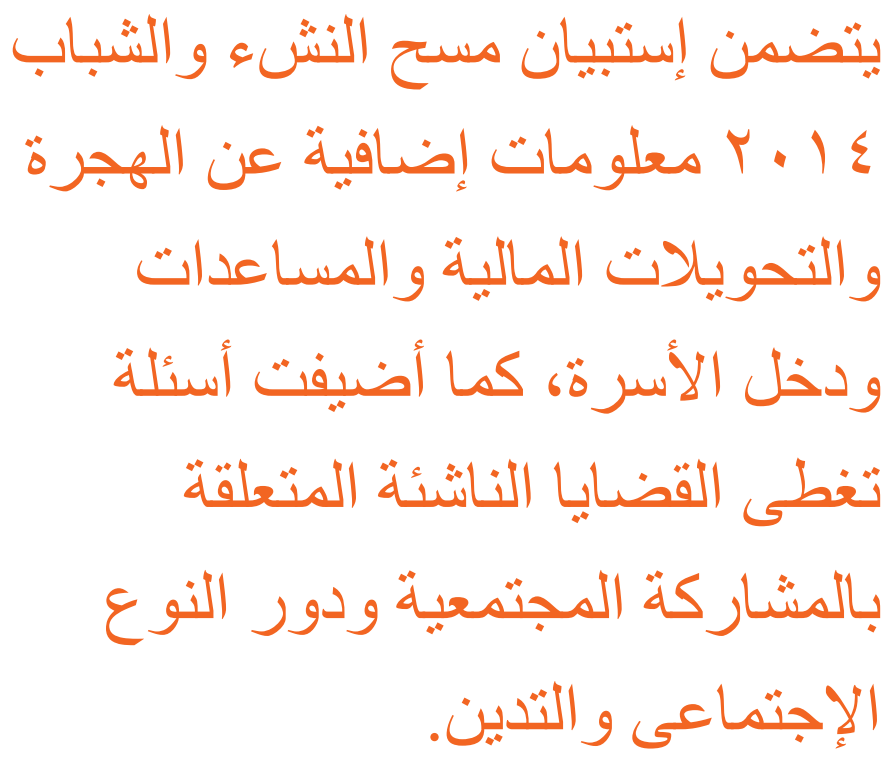

وفي أو ائل شهر يونيو من عام با ا ـ ج، أجرى فريق المسح

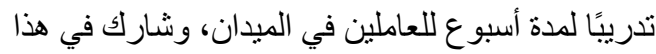
التدريب نحو 11 ألتربًا من القائمين بالمقابلات و المشرفين

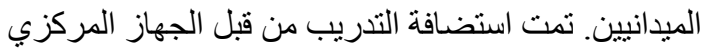

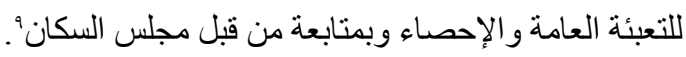

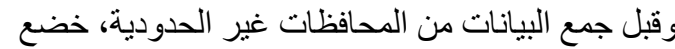

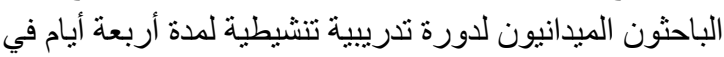

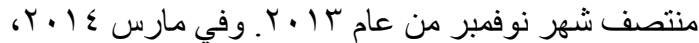

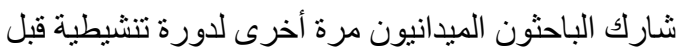
إجر اء العمل الميداني في هذه المحافظات.

اكتمل جمع البيانات تحت الإدارة المباشرة من الجهاز

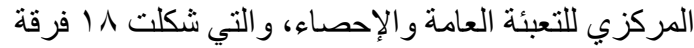

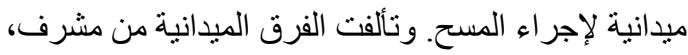

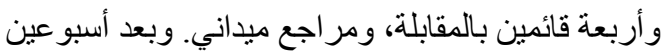

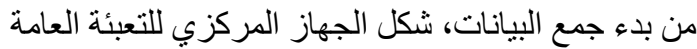

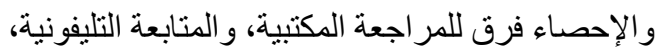

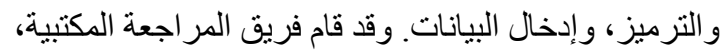

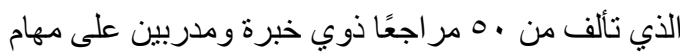

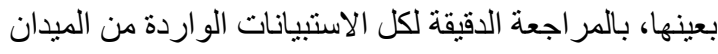
لضمان أن هذه الاستبيانات لا تحتوي علي بيانات مفقودة أو الو الون بيانات غير منطقية وأنها اتبعت أنماط الإحالة بشكل لانيات صحيح.

9 وفي أثناء التدريب تم مناقشة كل سؤ ال من أسئلة الاستبيان الفردي واستبيان

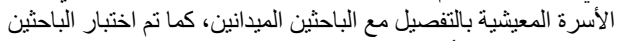

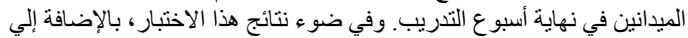

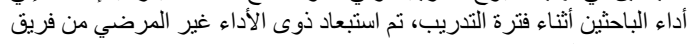

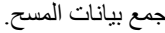

خلال التثاور مع عديد من الثركاء ومع من تكرر استخدامهم

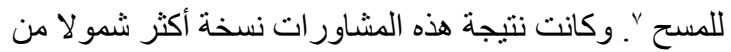
هذين الاستبيانين. ويتضمن استبيان الأسرة المعيشية في المستح

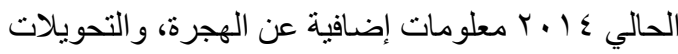
المالية، ودخل الأسرة و المساعدات المختلفة. كما أضيفت أيضا

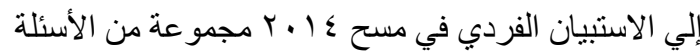

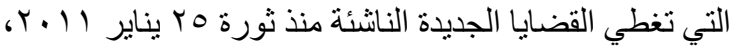

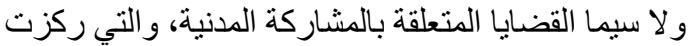

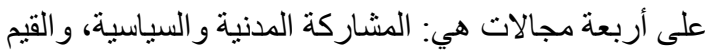
المجتمعية، واتجاهات الأدوار بين الجنسين، و التدين. أما فيما يتعلق بالصحة، و العنف، و المخاطر ، و السلامة فقد تم تحديثها

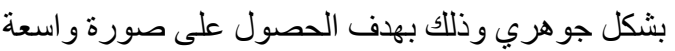

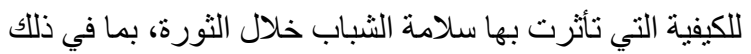

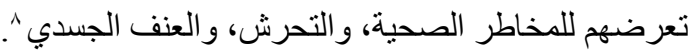

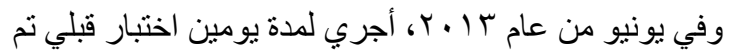

خلاله تطبيق استبيان الأسرة المعيشية الكامل و الاستبيانات

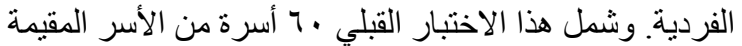

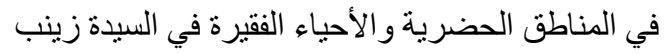

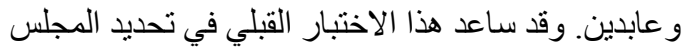
للمدة الزمنية المتوقعة للمقابلة الكاملة وتحديد الأسئلة الإشكالية

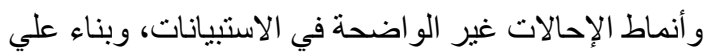
نتائج هذا الاختبار القبلي جرى تعديل لكل ذللك.

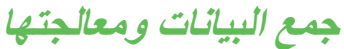

أجريت عملية جمع البيانات الخاصة بمسح النشء و الثباب

المصرى ع ( ـ ب بالتعاون مع الجهاز المركزي للتعبئة

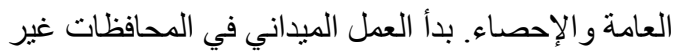

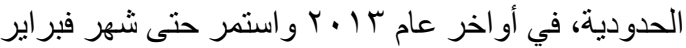

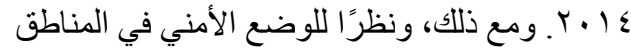

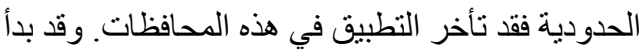

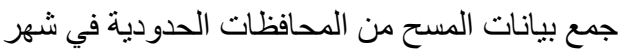

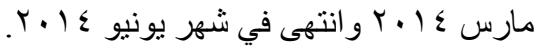

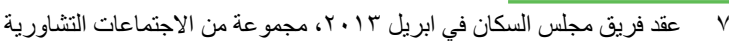

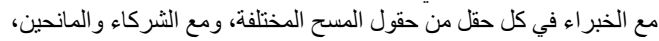

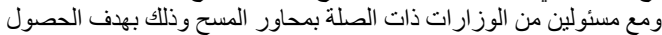

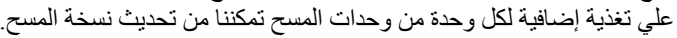
وكان لهذه الاجتماعات بالغ الأثر في تحسين تصميم الاستيبان

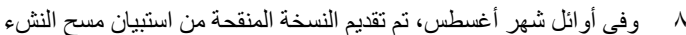

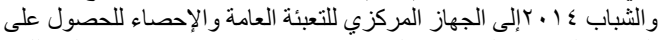

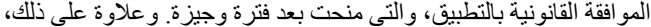

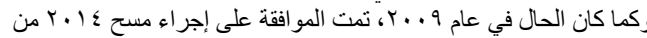

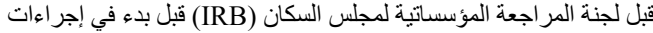

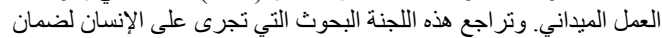

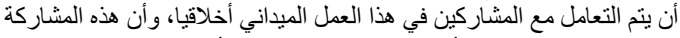

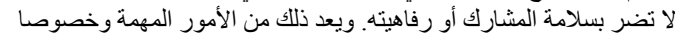
عندما ينطوي البحث على در اسة القصر ، كما هو الحال مع مسح النش الثر و الثباب 
أعمار هم ما بين 10 و و r سنة ". و أصبحت العينة التي كانت

صغيرة السن في مسح 9 . . ب ، و التي كانت تقع في الفئة العمرية من • ـ ـ ا سنة، أصبحت الأن أكبر سنًا، كما أصبح

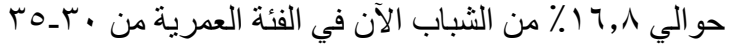
سنة وهي الفئة التي كانت خارج نطاق تغطية مسح 9 . . ب.

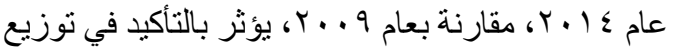

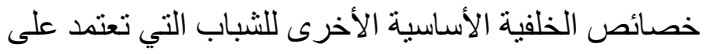
العمر، مثل مستوى التعليم و المشاركة في سوق العمل.

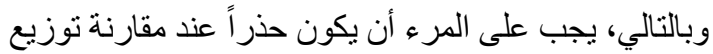
الثباب وفقًا لخصائص الخلفية الأساسية، حتى في أوساط أنسا

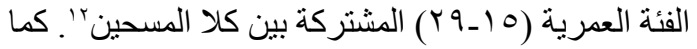
قد يرتبط التقدم في عمر عينة المسح أيضا بتغيرات سلوكية ومخرجات اتجاهية، مثل الإقبال على السلوكيات الصحية الخطرة، و الاتجاهات نحو الأدوار بين الجنسين، و علاقات الثباب مع أسر هم ومع مجتمعاتهم المحلية. ومن ثم، فيجب علينا أن نتوخى الحذر عند مقارنة نتائج مسح 9 × . . ب بنتائج مسح ع ا ـ ب. ولهذا السبب، استخدم المؤلفون في كتابة هذا التقرير مجمو عة منتو عة من منهجيات المقارنة بين نتائج على الفئة العمرية (0 ـ ـ Y))، و هي الفئة العمرية المشتركة

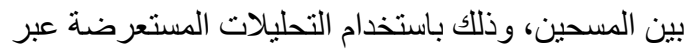
جولتي المسح. وفي تحليلات أخري، أعتمد المؤلفون على ودئ بلى البعد التتبعي لفحص التغير في النتائج بين نفس المجمو عة ولة من الثباب مع تقدمهم في العمر، على سبيل المثال نتبع مسار التغير في سوق العمل أو في الحالة الزو اجية. إن هذا التغيير في توزيع الثباب حسب الفئة العمرية في

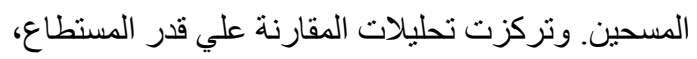

تم إبلاغ فريق المتابعة التليفونية بالأخطاء التي تم تحديدها،

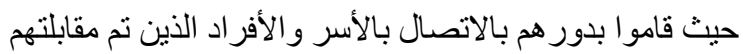
بهدف جمع المعلومات الصحيحة. و إذا ما حدد فريق المتابعة أن هناك تضارب في الإجابة بين الاستبيان وردود الأسرة عبر الهاتف، وهذا ما حدث في حالات قليلة جدا، نم إرسال الاستبيان لفريق مر اقبة الجودة لمزيد من التحقيق.

وبعد مر اجعة جميع الاستبيانات، قام فريق ترميز البيانات بالجهاز المركزي و المكون من الاستيان 10 فرد بتكويد فرئ ترميز الأسئلة

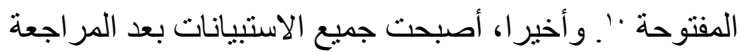

و الترميز جاهزة لإدخال البيانات. وباستخدام واجهة إدخال

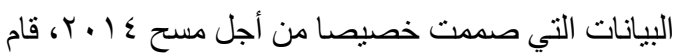
فريق الإدخال بإدخال البيانات. و أستلم مجلس السكان شريط

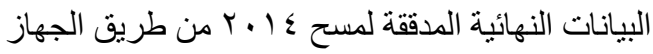
المركزي في أو اخر شهر سبتمبر ع ا ـ آ.

\section{ـ ـ خصائص الشباب في ع 1 .}

تُعد فترة الخمس سنوات في عمر عينة المسح ما بين الجولة

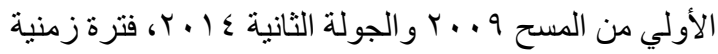
يمكن أن تتضمن العديد من التغيير ات في حياة الذين هم في خضم عملية الانتقال إلى مرحلة الرشد. وفي هذا القسم سوف نقوم بتحديث خصائص الخلفية الاجتماعية للشباب في عام

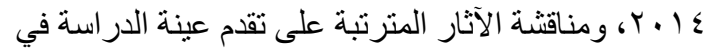
العمر عبر التحليل في الفصول اللاحقة.

أدي الارتفاع في معدلات الخصوبة الذي شهدته فترة الثمانيات، مصحوبًا بانخفاض في معدل وفيات الأطفال، إلي تحول ديمغر افي ملحوظ في مصر مسببًا ”تضخم في شريحة

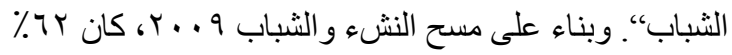

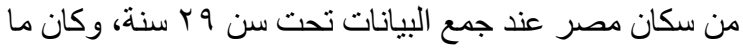
يقرب من · ع ٪ ممن ثتر اوح أعمار هم ما بين · ا و وج سنة.

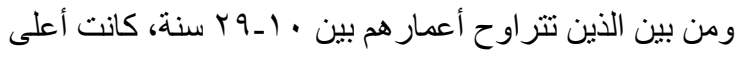

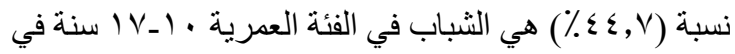

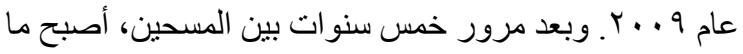

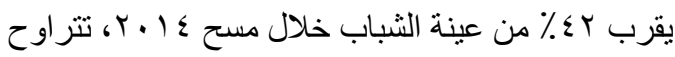

11 ولمزيد من المناقثة حول تضخم شريحة الثباب وتأثير ها علي سوق العمل أنظر: (Assaad and Krafft 2015)

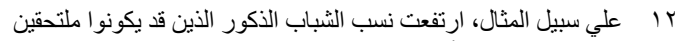

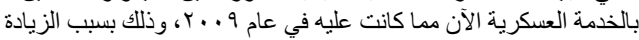

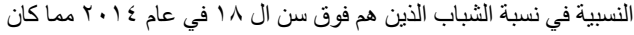

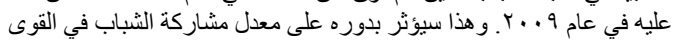

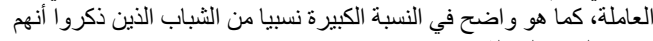

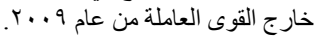

. 1 في هذه الخطوة، استخدم الفريق الأكواد التي وضعها الجهاز المركزي، فيما

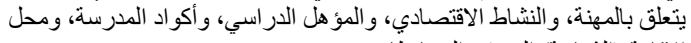
الإقامة (الثياخة/ الحي) والمحافظات 
الفصول الثمانية لهذا التقرير تتناول بالدر اسة و التحليل النتائج

التفصيلية لبيانات مسح النشء و الثباب. وقد تم استخدام كلا دورني المسح لانتاج هذا التقرير ، وفي مناسبات عديدة تم

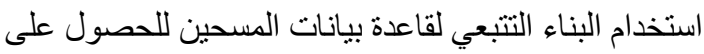
مقارنات وتصور ات لوضع الثباب قبل وبعد فترني المسح

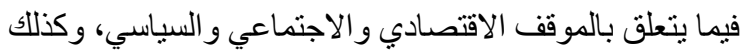
الحالة الصحية للثباب خلال هذه الفترة الحرجة من تاريخ

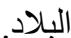

يهذف هذا التقرير الى تحديد القضايا ذات الأهمية للشباب في

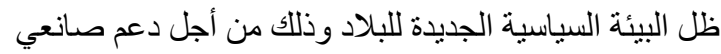

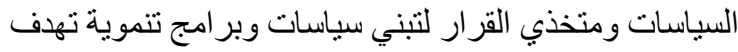
الى رفع قدرات الثباب المصري.
ويعرض الجدول Iـ ا الخصائص الديمو غر افية الأساسية لعينة

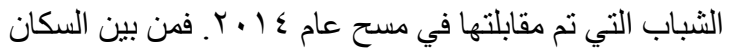

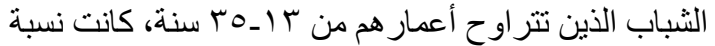

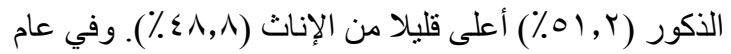

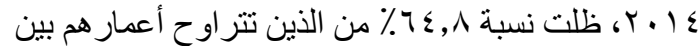

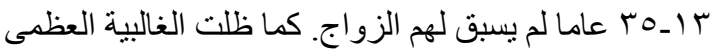

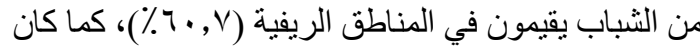

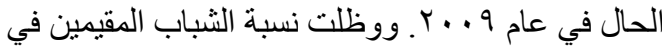

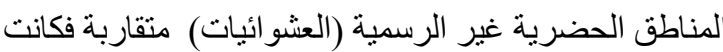

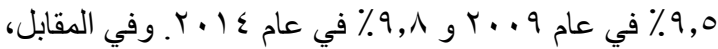
لوحظ انخفاض في نسبة الثباب في المناطق الحضرية

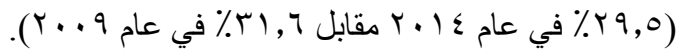

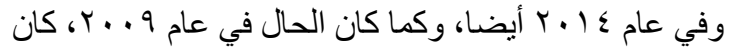

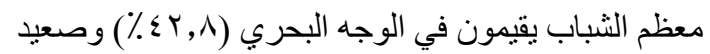

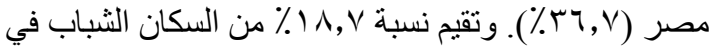

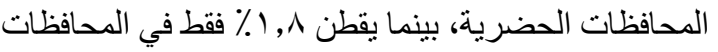

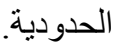

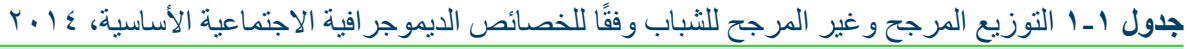

\begin{tabular}{|c|c|c|c|}
\hline العدد غير المرجح & العدد المرجح & النسبة المرجحة" & الخصائص \\
\hline & & & النوع \\
\hline$(0, r+4)$ & $(0,0 \wedge 7)$ & $01, Y$ & ذكر \\
\hline \multirow{2}{*}{$(r, 1 \cdot r)$} & $(0, r r \cdot)$ & $\varepsilon \wedge, \wedge$ & أنثى \\
\hline & & & العمر \\
\hline$(r, 197)$ & $(Y, Y Y V)$ & $r_{\cdot}, \varepsilon$ & IV-IT \\
\hline$(\varepsilon, 101)$ & $(\varepsilon, \Gamma 11)$ & rq,० & $r \leq-11$ \\
\hline$(r, 07 \varepsilon)$ & $\left.(r, 0)^{\prime}\right)$ & rtr, & rq-ro \\
\hline \multirow[t]{2}{*}{$(1,991)$} & $(1, \wedge r v)$ & 17,1 & ro-r. \\
\hline & & & الحالة الزواجية \\
\hline$(7, \Gamma, T)$ & $(V, \cdot V Y)$ & $7 \varepsilon, \wedge$ & لم يسبق له الزواج \\
\hline \multirow[t]{2}{*}{$(\Sigma, 095)$} & $(r, \wedge r \varepsilon)$ & ro,r & سبق له الزواج \\
\hline & & & المنطقة \\
\hline$(r, \cdot T \varepsilon)$ & $(r, \cdot \leq r)$ & $i \wedge, v$ & محافظات حضرية \\
\hline$(1, r \backslash \vee)$ & $(1, Y T r)$ & 11,7 & حضر الوجه البحري \\
\hline$(r, \leqslant r \checkmark)$ & $(r, \varepsilon \cdot \vee)$ & $r, r$ & ريف الوجه البحري \\
\hline$(7 r q)$ & $(\wedge \vee \wedge)$ & $\wedge$, & حضر الوجه القبلي \\
\hline$(r, T Y l)$ & $(r, \mid r v)$ & $r \wedge, \gamma$ & ريف الوجه القبلي \\
\hline \multirow[t]{2}{*}{$(90 r)$} & $(199)$ & $1, \wedge$ & المحافظات الحدودية \\
\hline & & & محل الإقامة ريف ـ حضر \\
\hline$(r, \Gamma) \varepsilon)$ & $(r, Y Y \backslash)$ & rq,० & حضر \\
\hline$(7,0,7)$ & $(7, T Y T)$ & $7, \mathrm{~V}$ & ريف \\
\hline$(1, \cdot 99)$ & $(1, \cdot V Y)$ & $9, \wedge$ & مناطق عشو ائية \\
\hline$(1 \cdot 917)$ & $(1 \cdot 917)$ & $1 \cdots$, & الإجمالي \\
\hline
\end{tabular}

* النسب المرجحة التي يتم تناولها خلال التقرير لتعكس مجتمع الثباب، بينما تعكس الأعداد والنسب غير المرجحة عينة الدراسة. 


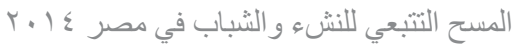

Assaad, Ragui and Ghada Barsoum. 2007. Youth Exclusion in Egypt: In Search of "Second Chances." Middle East Youth Initiative Working Paper, No. 2. Dubai: Wolfensohn Center for Development, Dubai School of Government, United Arab Emirates.

Assaad, Ragui and Caroline Krafft. 2015. “The Evolution of Labor Supply and Unemployment in the Egyptian Economy: 1998 -2012," in R. Assaad and C. Krafft (eds.), The Egyptian Labor Market in an Era of Revolution. Oxford, UK: Oxford University Press, pp. 1-26.

Elbadawy, Asmaa. 2009. “Education at a glance: Selected indicators based on the Egypt labor market surveys of 1988, 1998 and 2006," in Ragui Assaad (ed.), Egypt Labor Market: Revisited. Cairo: American University in Cairo Press, pp 117-155.

Kirkpatrick, David D. and Dina Salah Amer. 2011. "Egypt's Economy Slows to a Crawl; Revolt Is Tested." New York Times, 11 July. http://www.nytimes. com/2011/06/10/world/middleeast/10egypt. html?emc=eta1.\&_r=0.

Population Council. 2010. The Survey of Young People in Egypt: Final Report. Cairo: Population Council, Egypt.

Roushdy, Rania. 2015. “Who Attrite during Political Transitions: Analysis of the Survey of Young People Attrition Weights," Population Council Working Paper Series. Cairo: Population Council, Egypt (forthcoming).

United Nations Development Program and the Institute of National Planning, Egypt. 2010. Egypt Human Development Report 2010: Youth in Egypt: Building our Future. Cairo: UNDP. 


\section{الحالة الصحية الثشباب المصري في عام ع الم ب المعرفة والآجباهات والسيلوكيات}

سارة اسماعيل • نهالة عبد التواب • لبلي شبرة

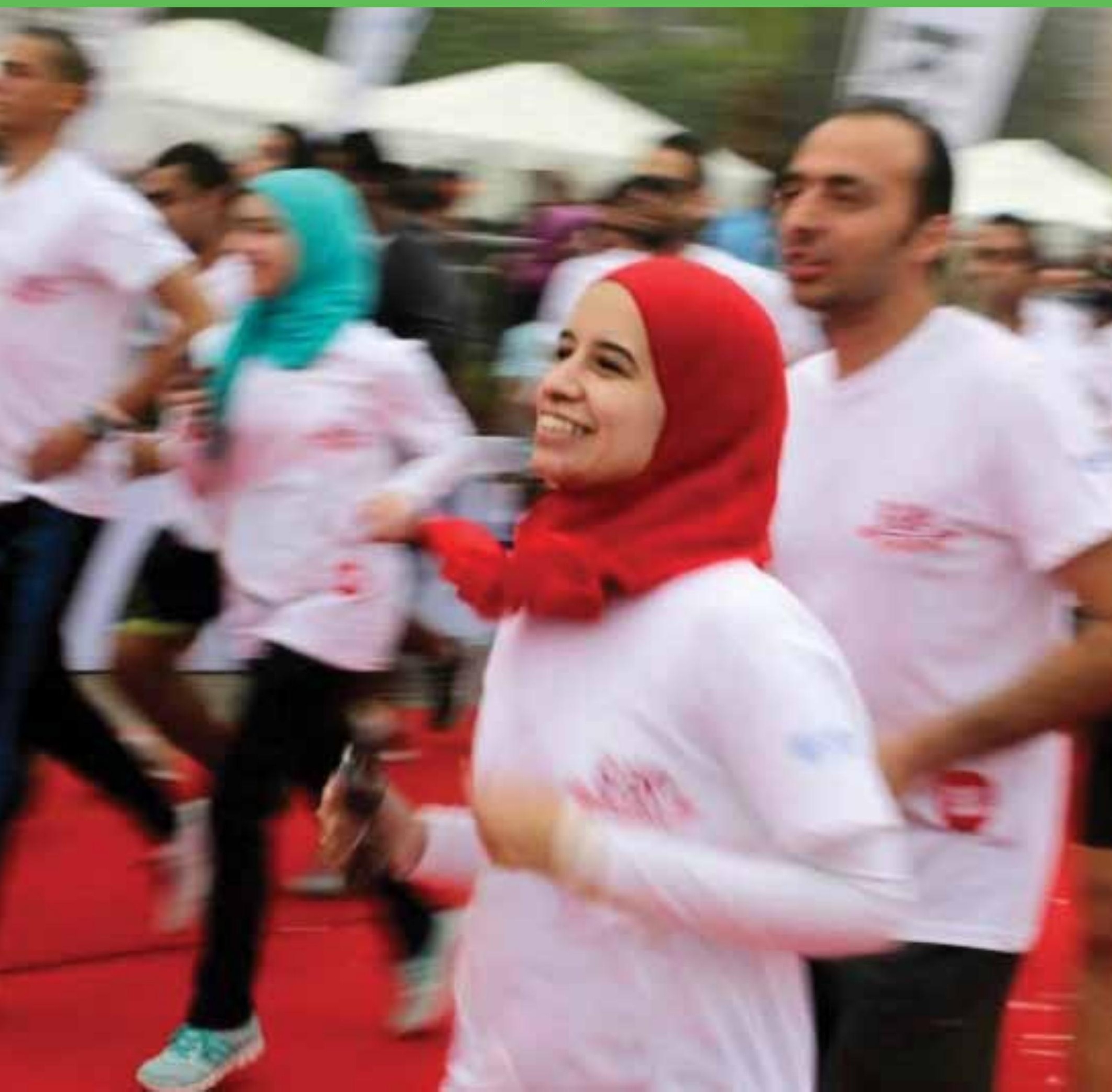


الإنجابية. وقد أضيفت بضعة أسئلة في عام ع ا ـ ب لقياس معرفة الأنماط المختلفة لانتقال فيروس نقص المناعة الإنة البشري|

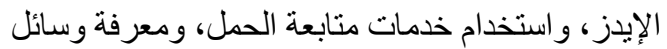

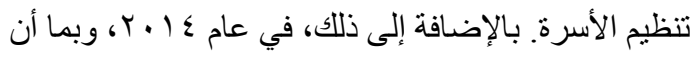
مجمو عات الثباب المدرجة ضمن عينة المسح قد أصبحت الأفي

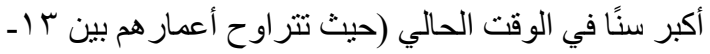

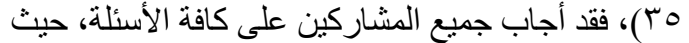
لا توجد أب أسئلة يمكن أن تعتبر غير لائقة أو غير مناسبة الأبنا

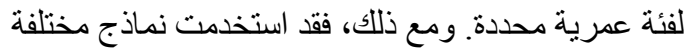
للمشاركين من الذكور و الإناث، وفقا لما تقتضيه الحاجة.

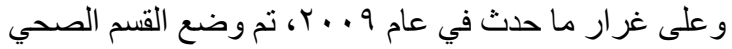

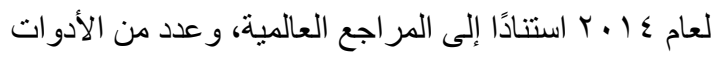

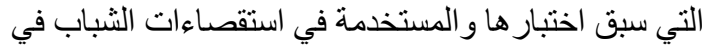

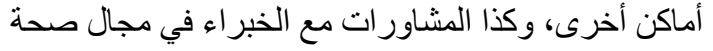

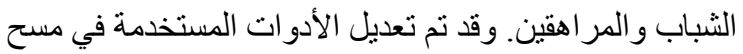

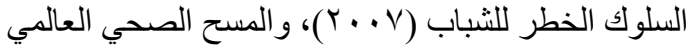

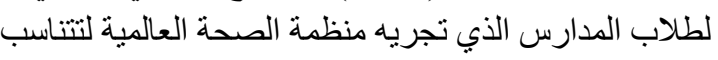

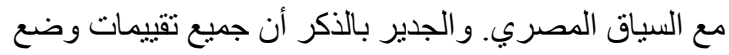

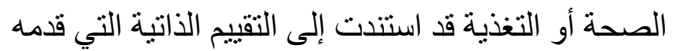
المشاركون، دون إجر اء فحص جسدي أو اختبار ات معملية الفية الفية

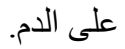

\section{Y _ Y إمكانية الحصول على الرعاية الصحية}

إن قدرة الثباب على الحصول على الرعاية الصحية عندما

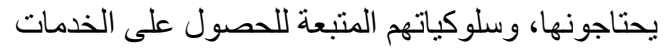

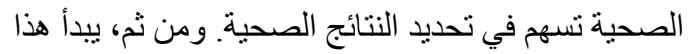

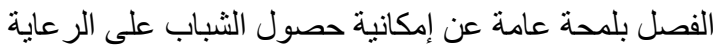

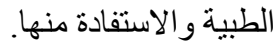

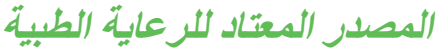

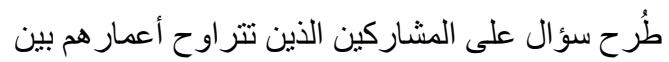

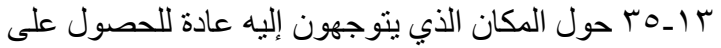

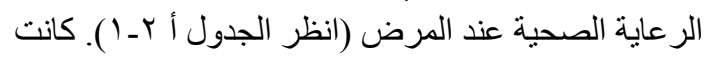

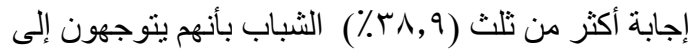

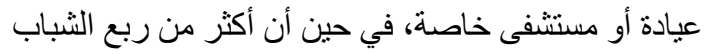

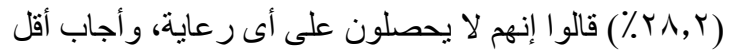

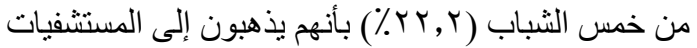
الحكو مية.

وكانت هنالك العديد من الاختلافات في المصدر المعتاد

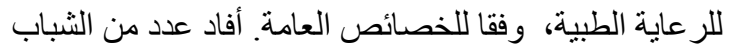

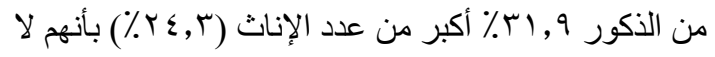

تنعكس صحة الثباب وتنميتهم انعكاسًا كبيرًا على سلامتهم في الحاضر و المستقبل على السواء، فضلاً عن تأثير ها على صحة أطفالهم في المستقبل. وبالإضافة إلى ذللك، تؤثر الامور الصحية على التحولات الأخرى في حياة الثباب، بما فيها التعليم، و العمل، وتكوين الأسرة، و المشاركة المدنية. ويحظى الثباب الذين يتمتعون بصحة جيدة بقدرة أكبر على النجاح في إتمام تعليمهم، وممارسة ونة حياة منتجة، وتقديم مساهمة إيجابية لأسر هم ومجتمعاتهم

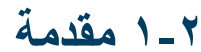

قد تكون لثورتي مب يناير و • بَ يونيو وما صاحبهما من

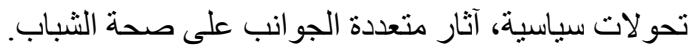

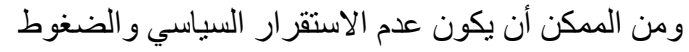

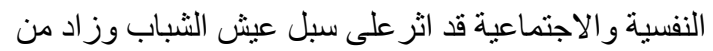

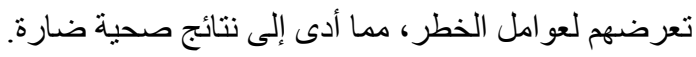

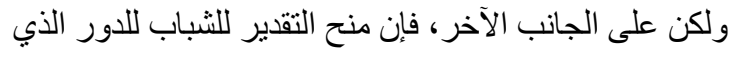

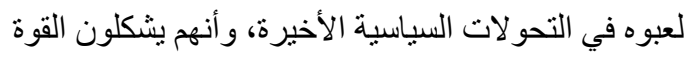

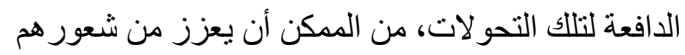

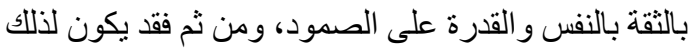

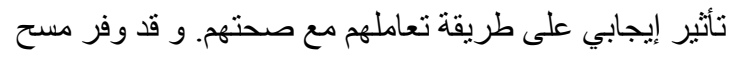

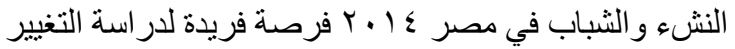

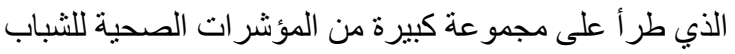
خلال الفترة الانتقالية في مصر عرة كبرة

ويقام هذا الفصل لمحة عامة عن معرفة واتجاهات وسلوكيات

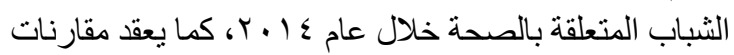

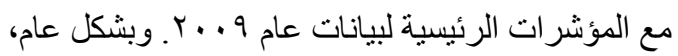

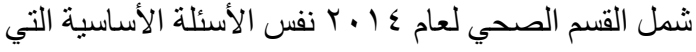

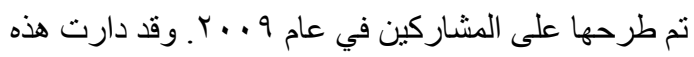

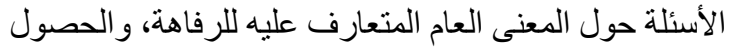

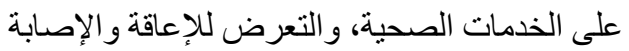

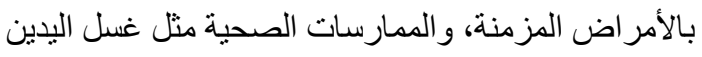

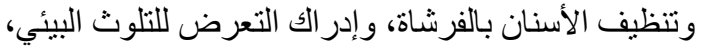

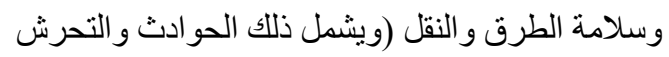

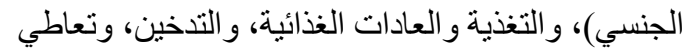
الكحول، و المخدرات، و الصحة العقلية و النفسية، و الصحة التُخة 
تثأثر صحة الثباب بالظروف الإجتماعية و الإقتصادية و السياسية، حيث تثأثز بمدى تو افر الخدمات الصحية و التعرض للأخطار منثل التلوث و الضغوط النفسية، وكذلك تثنأثر انماط الحباة الصحيةٌ مثنّ

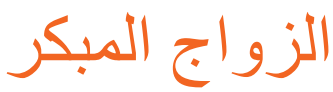

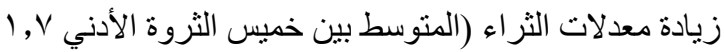

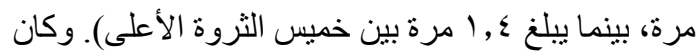

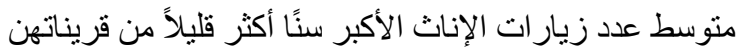

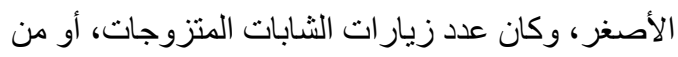

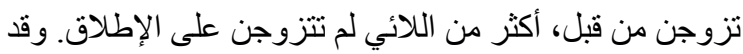

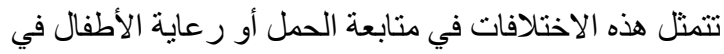

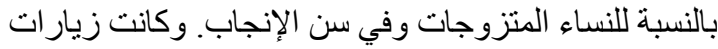
الثباب الذين يسكنون المحافظات الحدودية للمر افق الصحية وكية الصنات أقل من الثباب في سائر المناطق.

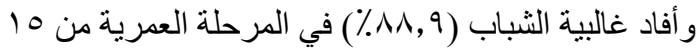
إلى 9 و عامًا الذين نوجهو اللحصول على الرعاية الصحية

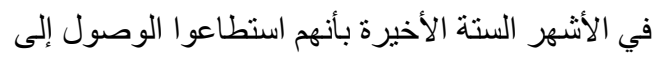

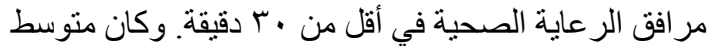

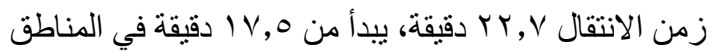
الحضرية في صعيد مصر ، ليصل إلى الى

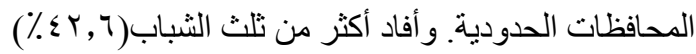

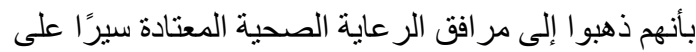

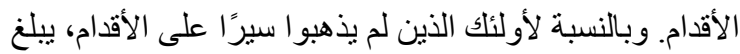

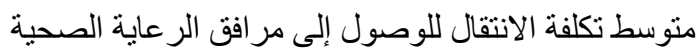

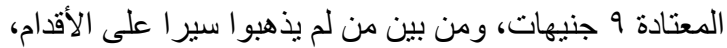

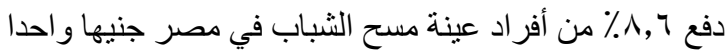

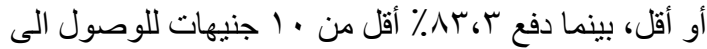
مصادر الرعاية الصحية المعتادة.
يحصلون على الرعاية الصحية. ومن ناحية أخرى، أفاد عدد

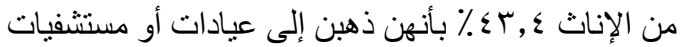

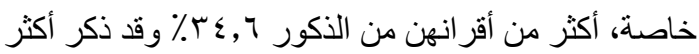
من نصف المشاركين في الاسنطلاع و القاطنين في المحافظات

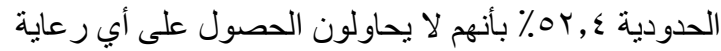
طبية مقارنة بنحو ربع المشاركين من سكان المحافظات الحضرية VYr\%. وبالمثل، زادت نسبة المشاركين الأميين

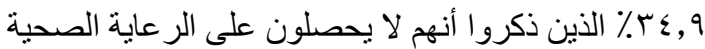
عند الثعور بالمرض عمن يجيدون القراءة والكتابة، أو الذين حصلو ا على قسط أكبر من التعليم.

ولعقد مقارنة مع عينة المسح لعام 9 . . ب ، درسنا البيانات التي قدمها الثباب من عمر 10 إلى 9 ب سنة في كلا المسحين.

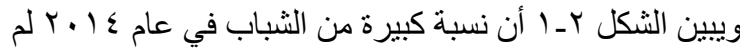

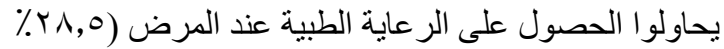

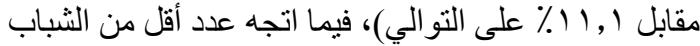

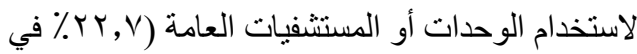

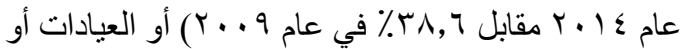

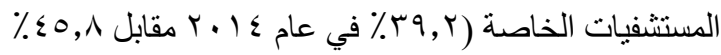

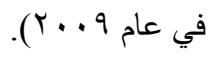

ومن ضمن الثباب فى الفئة العمرية ب ا ـــ الذين أفادو ا بأنهم

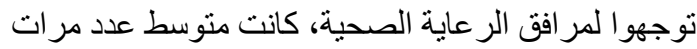
زيارة الذكور حو الي ؟ّ, إيارة خلال الأشهر الستة الماضية،

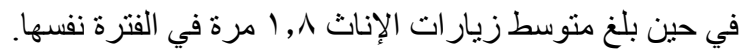

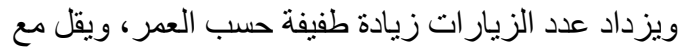

الثكل r ـ 1 مكان الحصول على الرعاية الطبية للمستجيبين

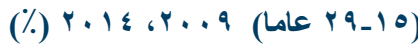

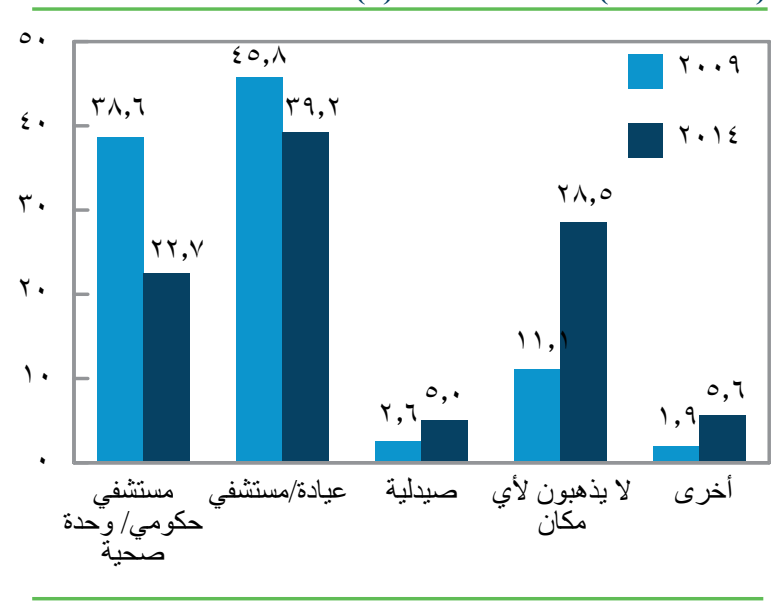


r Y r التقييم الذاتي للصحة والتقارير الخاصة بالأمر اض الَّزمنة والإعاقة

طلب النموذج الصحي لمسح الثباب في مصر من جميع المشاركين إجر اء تقييم ذاتي لحالتهم الصحية الحالية. وبشكل عام، أجاب المشاركون جميعًا بأنهم يشعرون بأن حالتهم

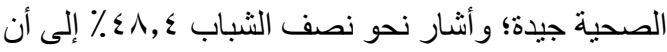

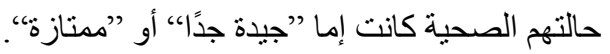

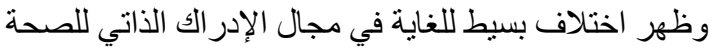

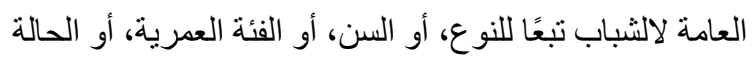

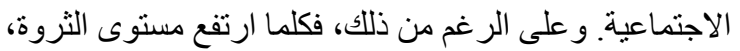

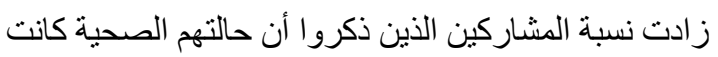

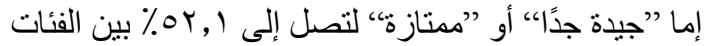

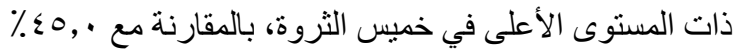

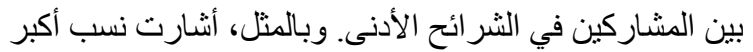

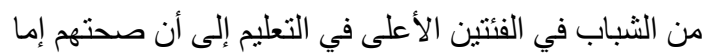

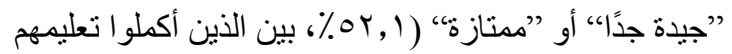

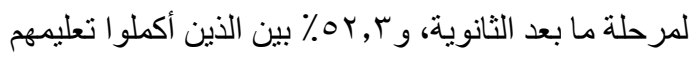

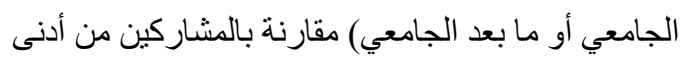

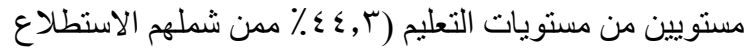
من الأميين، و 7 > ؛ ٪ ممن يسنطيعون القر اءة و الكتابة فقط).

ويوضح الثكل _ r التقييم الذاتي للحالة الصحية للثباب من

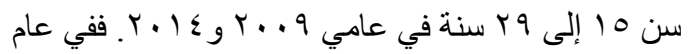

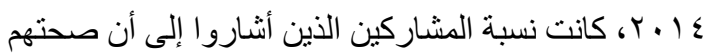

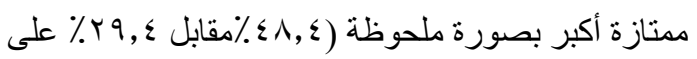

الشكل r r r التقييم الذاتي للحالة الصحية للمستجيبين

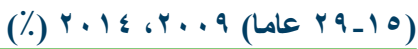

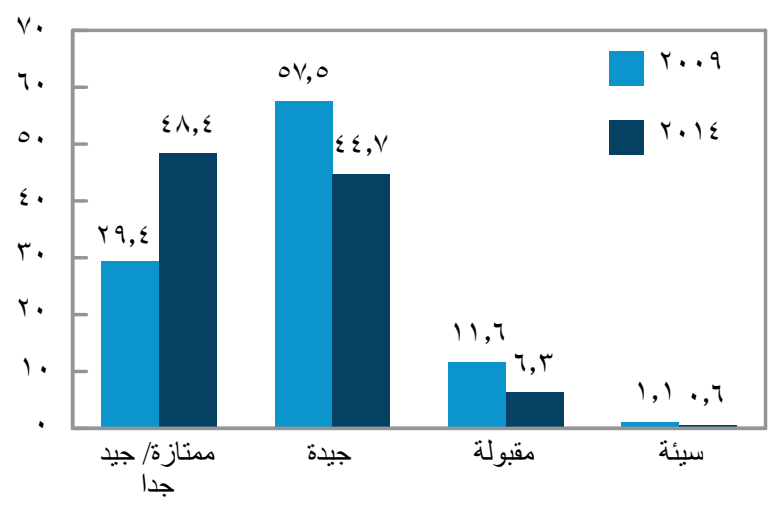

الثعلاج ومصروفُات الثدواء

بالنسبة للثباب الذين تتراوح أعمار هم بين س ا و وهر عائا

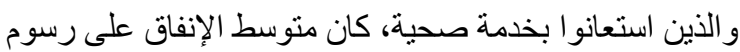
الفحص للحصول على الرعاية الطبية خلال الزيارة الأخيرة

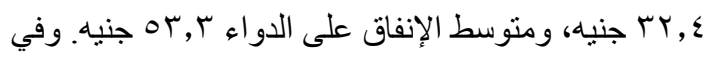

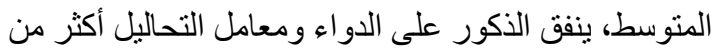

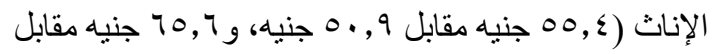

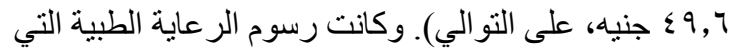

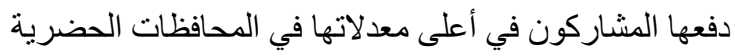

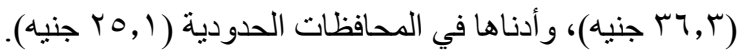

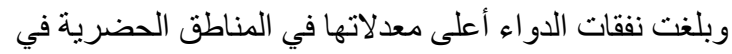

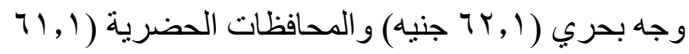
جنيه) و أدناها في المناطق الريفية بصعيد مصر (1) (0, ؛ جنبه).

وكما هو منوقع، ازدادت الرسوم ونفقات الدواء مع زيادة

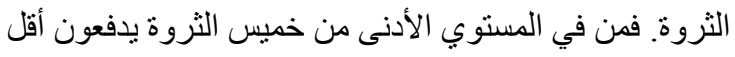

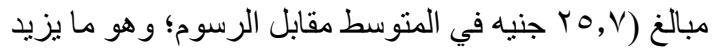

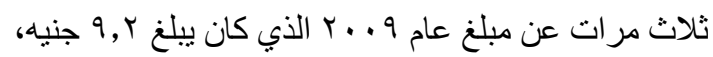

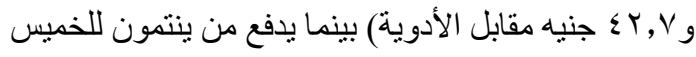

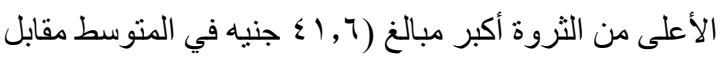

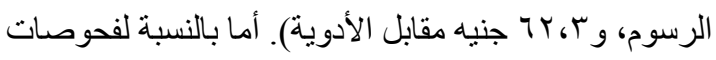

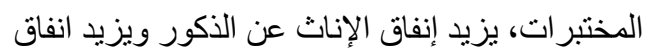
المشاركين في المسح في المناطق الحضرية.

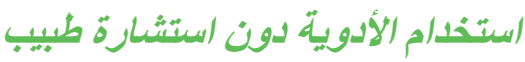
قد يؤدي تناول الأدوية دون وصفة طبية إلى الاستخدام غير

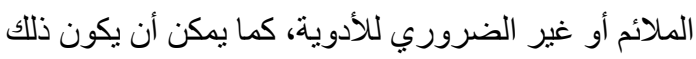

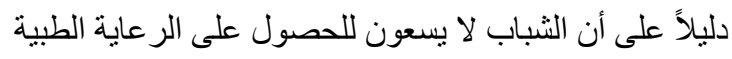

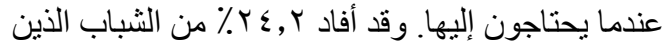

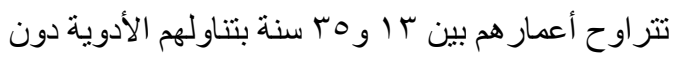

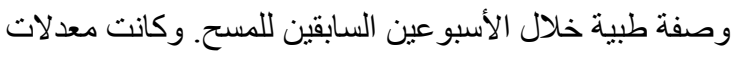

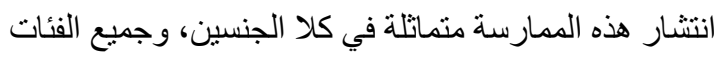

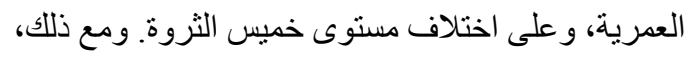

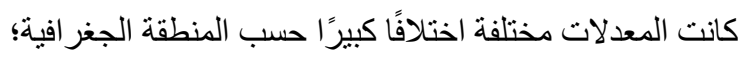

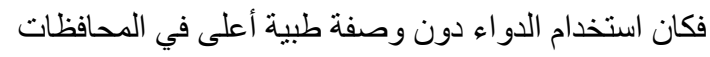

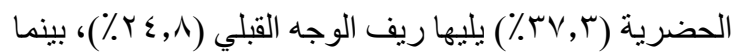
كان أدنى استخدام في المناطق الحضرية في وجه بحرى (لبه .(\%17,v) 
الثكل r-ب نسبة الثباب الذين يستخدمون فرشاة الأسنان

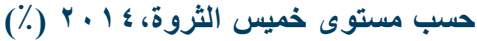

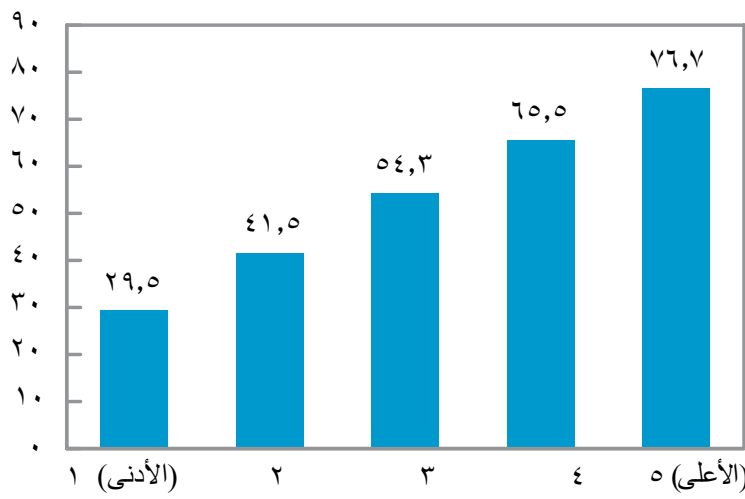

\section{بـ الصحة و البيئة}

وسئل المشاركون في المسح ممن نتر اوح أعمار هم بين سب أ ـ

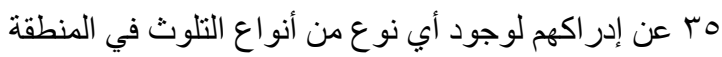

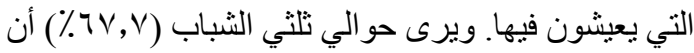
البيئة حولهم ملوثة. ويزداد إدر الك وجود التلوث مع ارتفاع

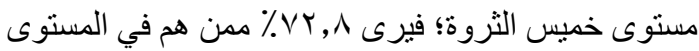

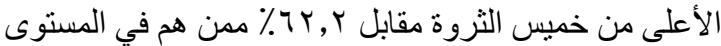

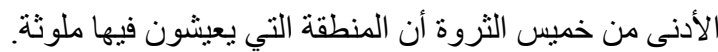

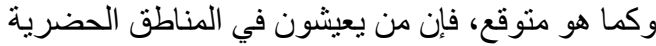

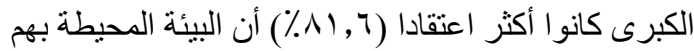
ملوثة، ومن يعيشون في المحافظات الحدودية كانوا أقل اعتقادا

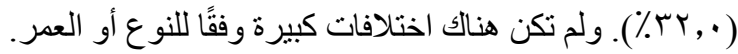

و وارتفعت نسبة الثباب الذين تتر اوح أعمار هم بين (10 _9 Y)

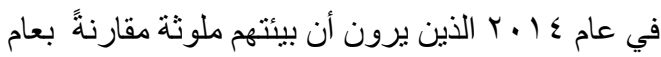

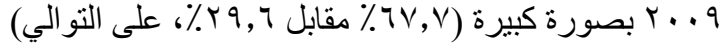

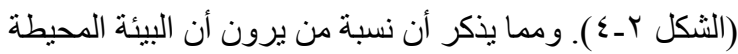

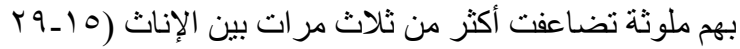

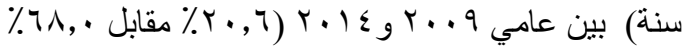

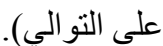

ويرى الثباب أن هناك مجمو عة من المخاطر الصحية البيئية

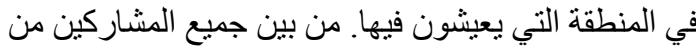

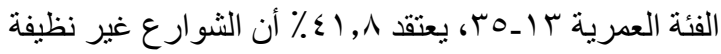

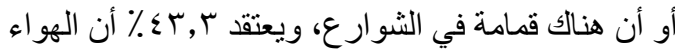

التو الي)، في حين أن نسبة أقل مقارنة بعام 9 . . ب أنشارو ا

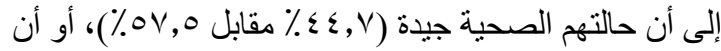

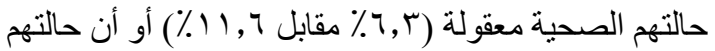
الصحية سيئة (7, • \% مقابل 1, 1\%).

\section{الأمراض المزئنة والإعاقِّة}

أفاد حو الي ربع المشاركين في مسح الثباب في مصر من الفئة

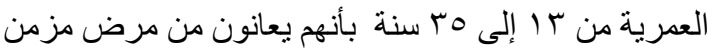

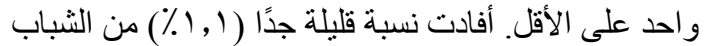

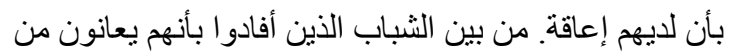

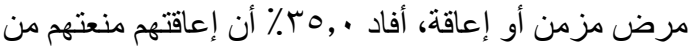

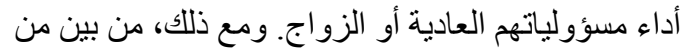

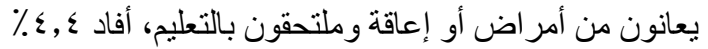

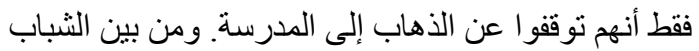

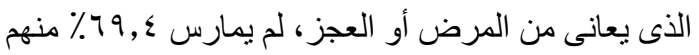

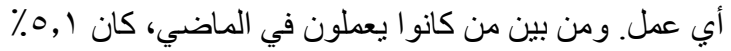

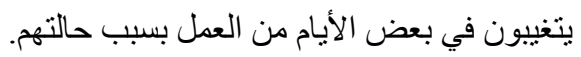

\section{ب _ع الممارسيات الصحية}

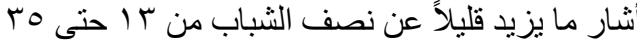
عامًا (7, § \% \%) إلى أنهم ينظفون أسنانهم بالفرشاة ومعجون

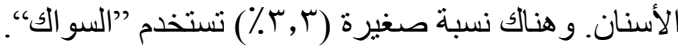

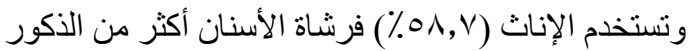

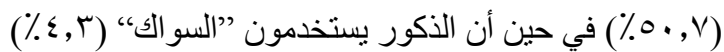

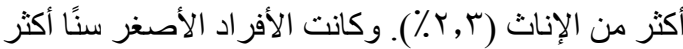

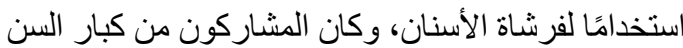

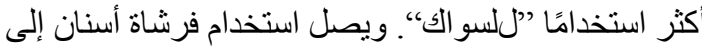

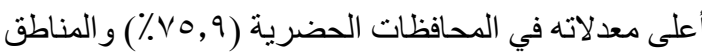

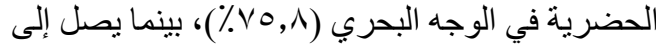

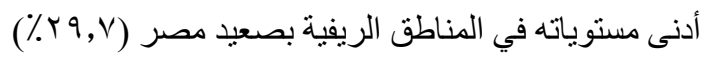

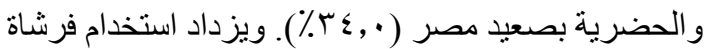

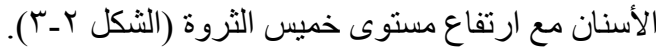

و أفاد حو الي , •^^٪ من الثباب أنهم يغسلون أيديهم بالصابون

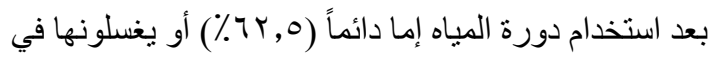
كثير من الأحيان (T,Vl\%). وكما هو منوقع، تزداد معدلات

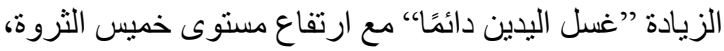

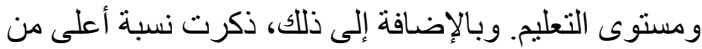

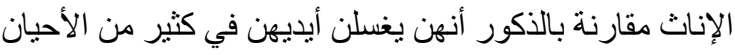

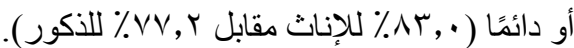


وردًا على سؤال حول وجود أثر معين من التلوث البيئي على الثى

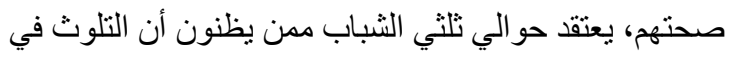

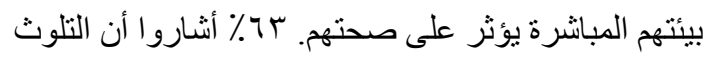

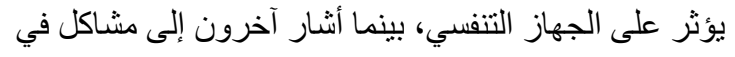

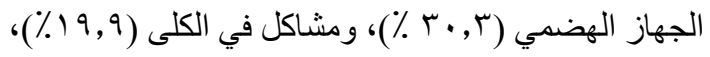

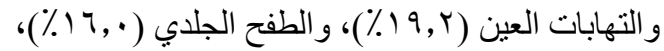

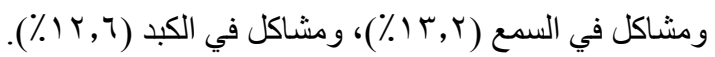

علي الرغم من التقارير الذاتية الا ان نسبة عالية من الثباب

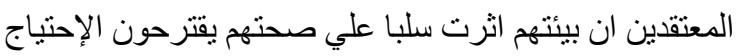

إلى سياسات عامة تحد مدى التلوث و المخاطر البيئية.

\section{Y ـ ا التعرض لمخاطر الإصابات والعنف}

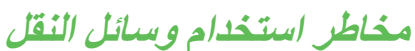

وطُلب من المشاركين في مسح الثباب في مصر الذين تنز اوح

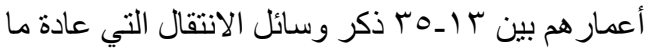

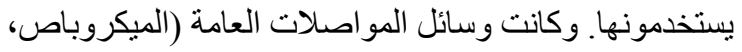

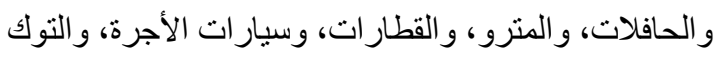
توك، و الثاحنات، والعربات الكارو) هي الوسائل الأكثر

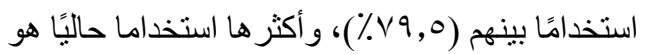
الميكروباص (90, \% \%). وتستخدم وسائل المو اصلات الخاصة ولخة

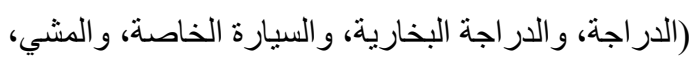

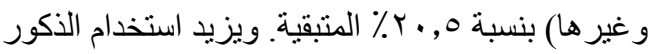

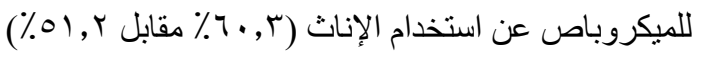

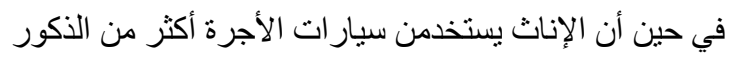

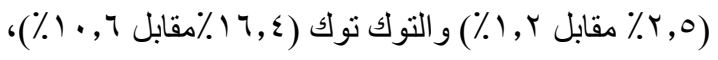

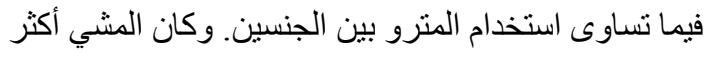

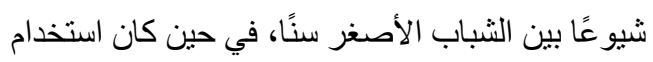
الميكروباص أكثر شيو عًا بين الثباب الأكبر سنًا.

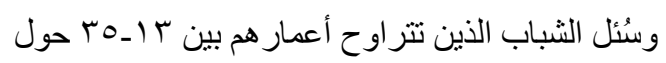
أكثر المخاطر التي يو اجهونها في الثشارع (وليس في وسائل

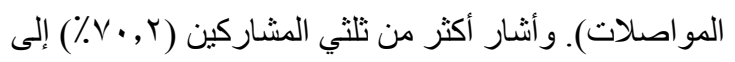

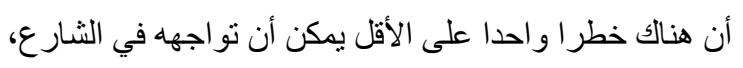

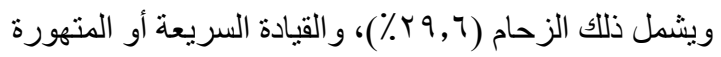

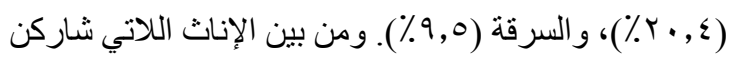

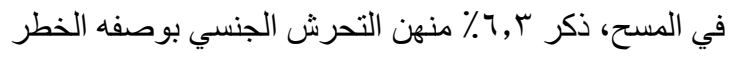

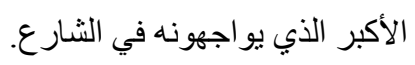

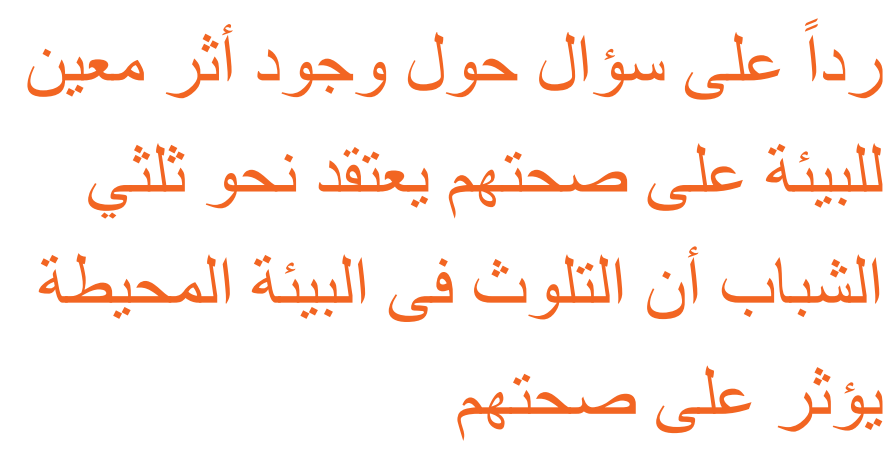

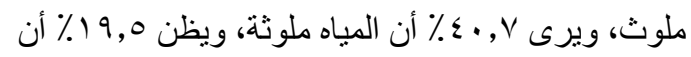

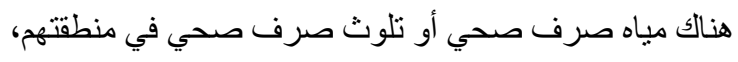

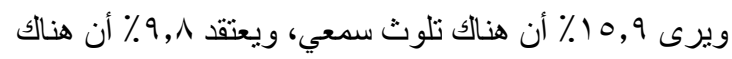
تلوث ناجم عن استخدام المبيدات الحشرية.

وسُئل من شملهم المسح الذين أنشاروا إلى أن بيئتهم المبانشرة

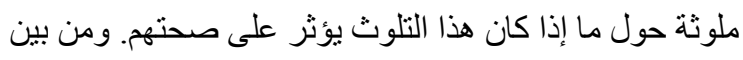

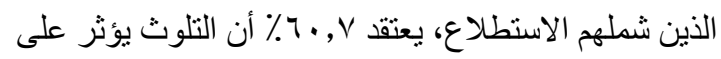

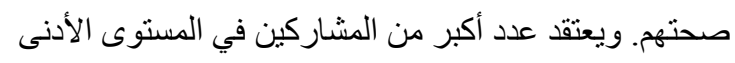

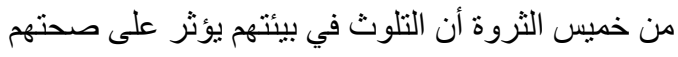

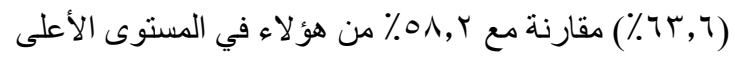

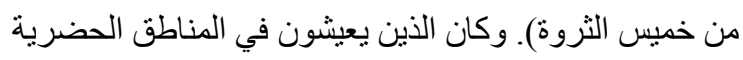

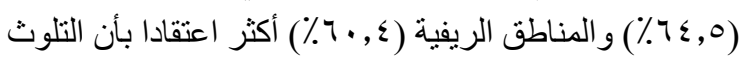

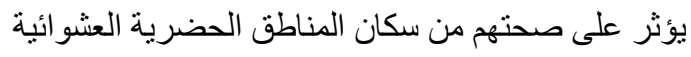

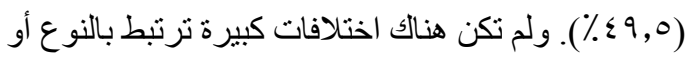
العمر. (- n

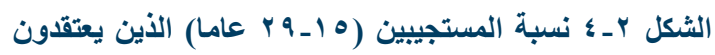
أن البيئة ملوثة

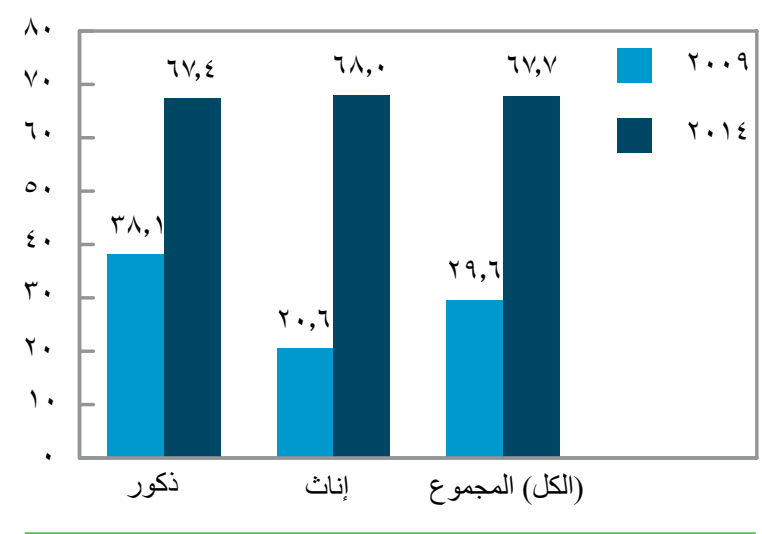




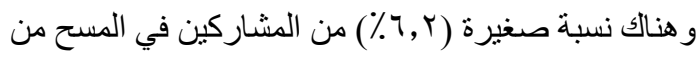

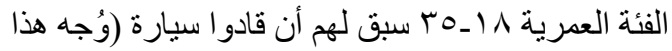

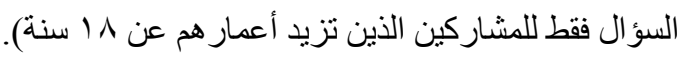

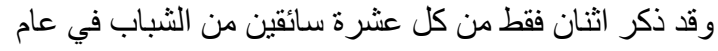

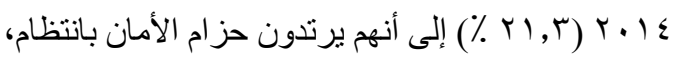

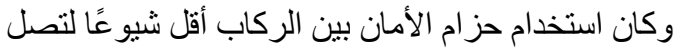

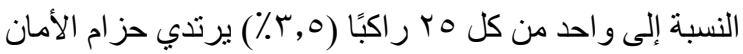
في مقاعد الركاب.

وقد انخفض معدل استخدام حز ام الأمان بين السائقين و الركاب

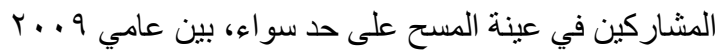

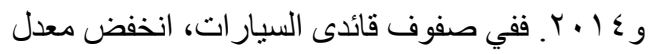

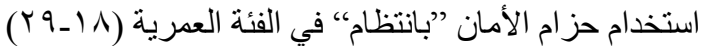

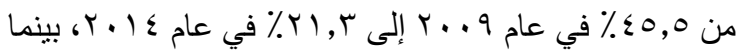

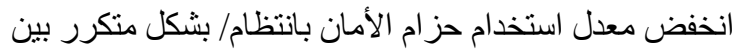

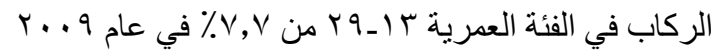

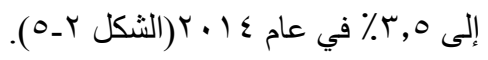

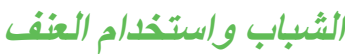

ولما كان العنف أحد عو امل الخطورة الرئيسية للفئة العمرية

الثشابة الو اقعة ضمن نطاق المسح (Krug et al. 2002)،

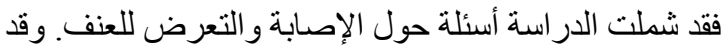

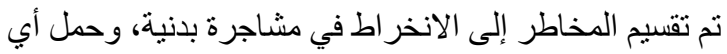

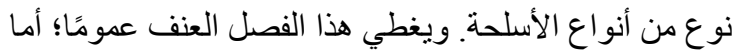

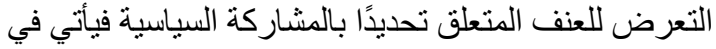

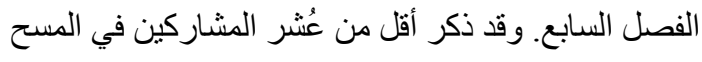

ومن بين الشباب الذين غالبًا ما يستخدمون وسائل المو اصلات

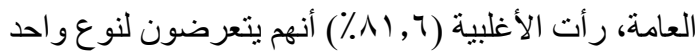

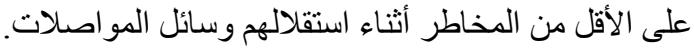

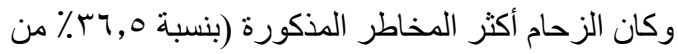

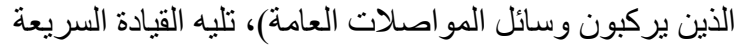

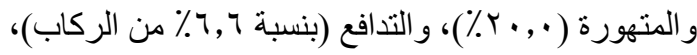

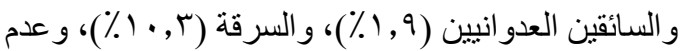
وجود ما يكفي من الوقت للصعود و النزول من وسائل

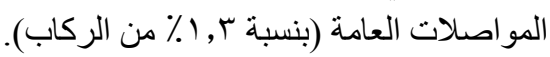

بمقارنة الإحساس بالمخاطر في الثوار ع وفي وسائل

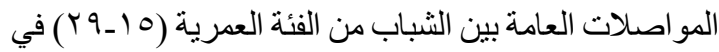

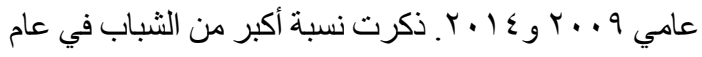

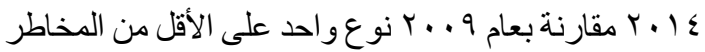

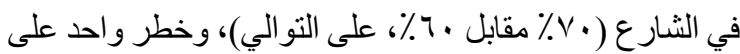

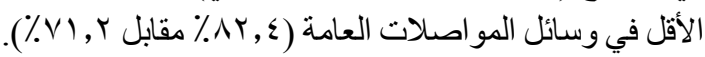

$$
\begin{aligned}
& \text { تـابيز السلامة في قيادة أو ركوب الدراجات أو الو }
\end{aligned}
$$

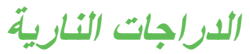

أثارت غالبية الثباب من مستخدمي الدراجات بوصفها وسيلة انتقالهم الأساسية إلى أنهم لا يستخدمون الخوذة الوقائية

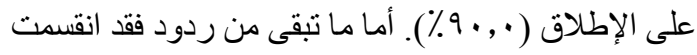

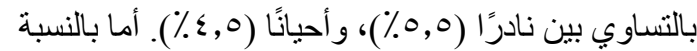

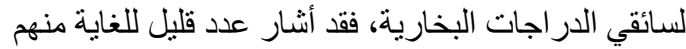

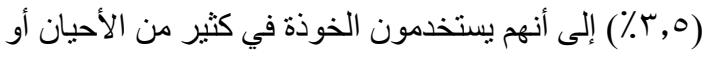

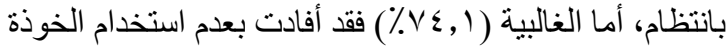

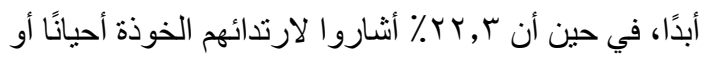
نادرًا.

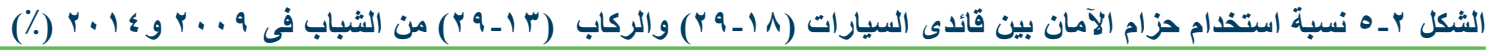

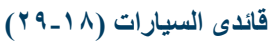

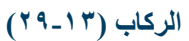
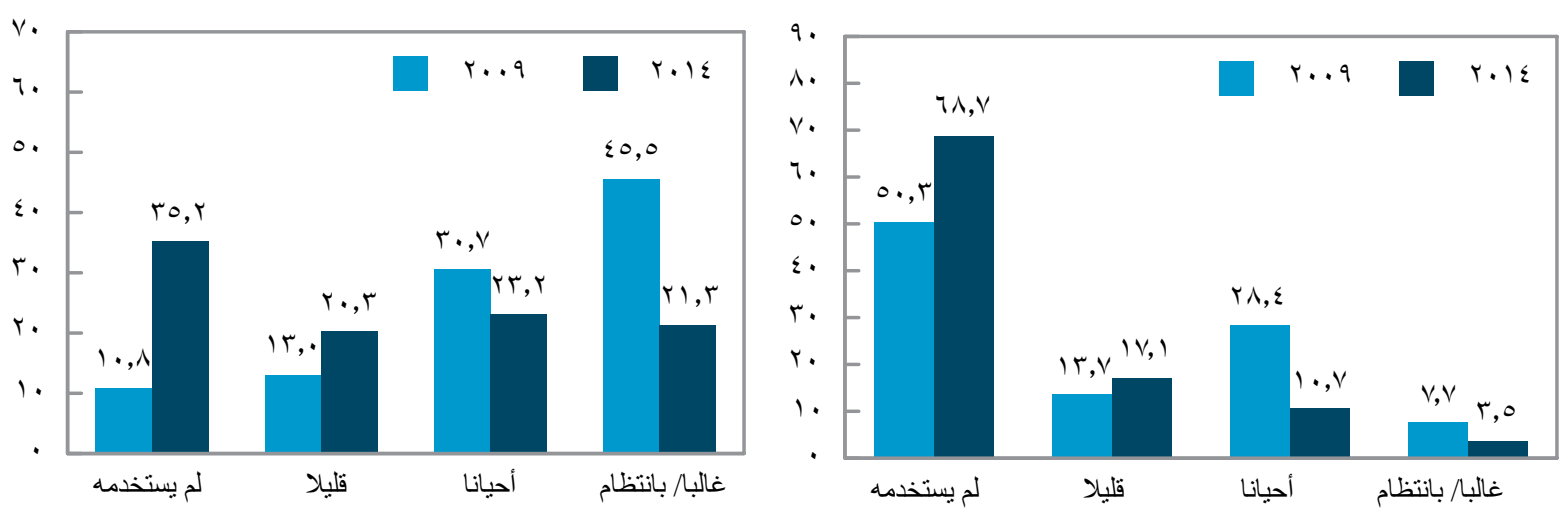


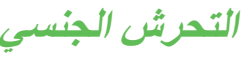

سُئلت الإناث في الفئة العمرية ب ا ـهب حول تعرضهن للتحرش الجنسي خلال الأشهر الستة الماضية. و أفادت أكثر

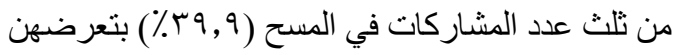

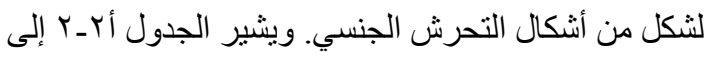

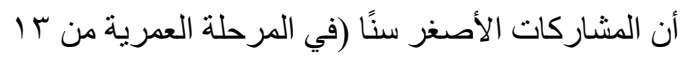
وحتى V V سنة) كن أكثر عرضة للتحرش الجنسي من الفئات العمرية الأكبر. وكانت حو ادث التحرش الجنسي أكثر حدوثا في المناطق الحضرية العشوائية (7, ( 7\%٪)، وفي المحافظات الحضرية (r, ror) و المناطق الحضرية بصعيد مصر

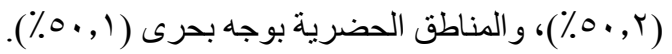

وعن نوع التحرش الجنسي، أفادت 7, , ؟ ٪ منهن أن شخصًا ما قد ألقى على مسامعهن تعليقًا خادشا للحياء أو غير مناسب،

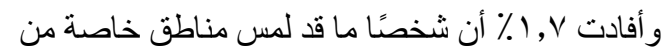
أجسامهن، فيما ذكرت أقل من واحد في المائة منهن أن شخصًا ما جعلهن يلمسن أجز اء خاصة من جسمه، أو كثف لهن عن جزء خاص من جسده، أو عانقها أو قبلها بطريقة جنسية، ولم تذكر أي من المشاركات في الاستطلاع تعرضها جناهي لمحاولة |غتصاب.

وكان المتحرشون في الأغلب من الغرباء كما جاء في تقارير

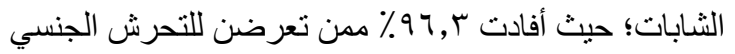

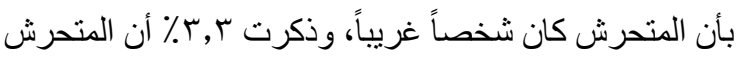

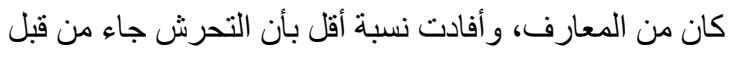

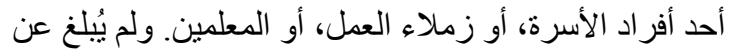

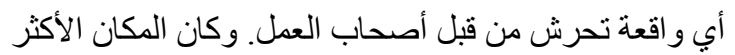

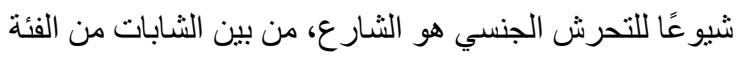

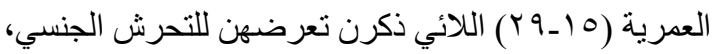

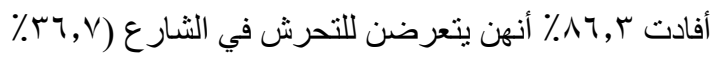

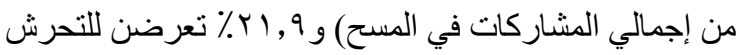

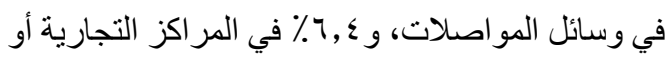

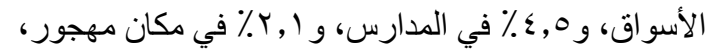

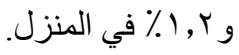

وقد ذكر حو الي ثلث عدد الإناث ( •, هץ\%) في الفئة العمرية

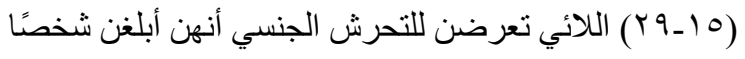

r, r\% بأنهم قد إنخرطو ا في مشاجرة بدنية خلال الأشهر

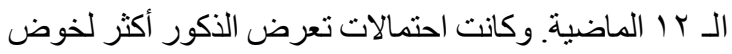

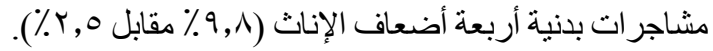
ولم تكن هنالك اختلافات كبيرة تنتعلق بالسن أو مستوى خميس

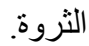

ذكرت نسبة صغيرة للغاية (7, r٪\%) من المشاركين في المسح

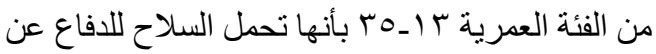

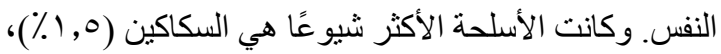

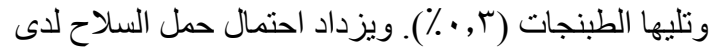

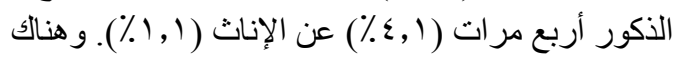

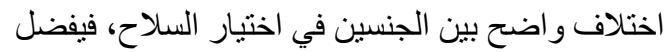

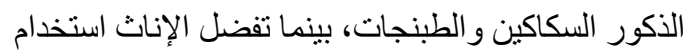

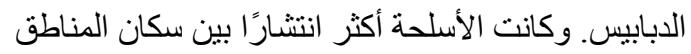

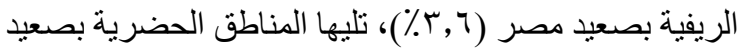

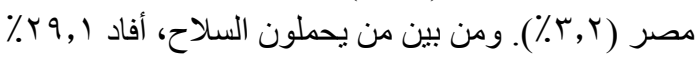

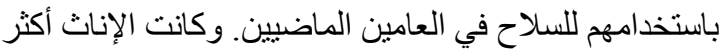

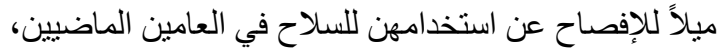

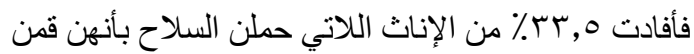

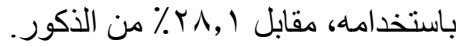

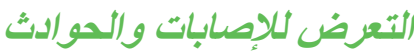

تشكل الإصابات، مثلها في ذلك مثل العنف، مشكلة صحية خطيرة تؤثر على الثباب بصفة خاصة (Peden et al. 2008). و وغالبًا

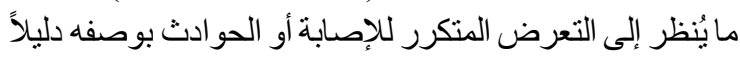

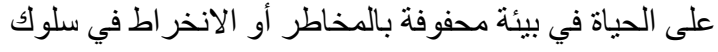

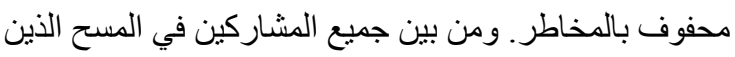

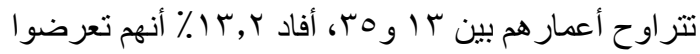

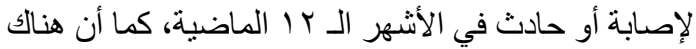

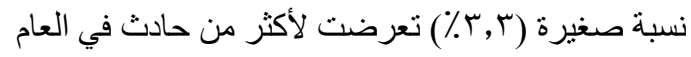

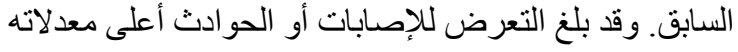

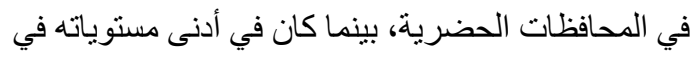

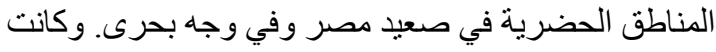

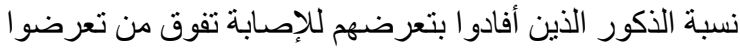

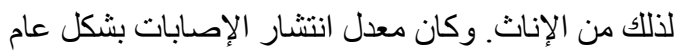
منماتل في مختلف الأعمار و على اختلاف مستوى خميس الإن

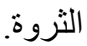

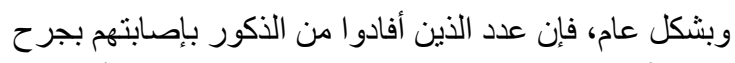

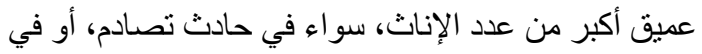

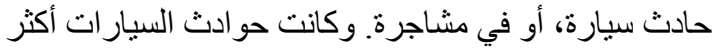
شيوعًا في المحافظات الحضرية منها في سائر المناطق. و أفادت الإناث بتعرضهن الدئ لحروق أكثر مقارنًة بالذكور،

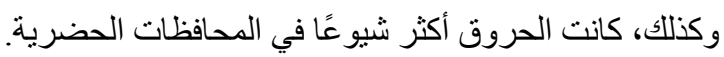




\section{أكثر من ثلث الإناث المستجيبات فى}

الفئة العمرية بر ـــ تعرضن لأحد

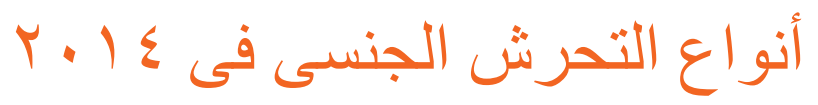

V-r التخذية، والعادات الغذائية، والنشاط

يتناول هذا القسم العادات الغذائية للمشاركين في مسح الثباب

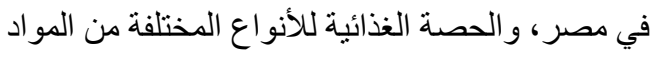

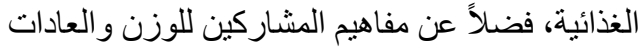

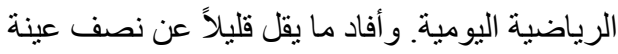

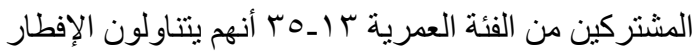

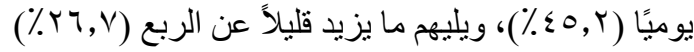

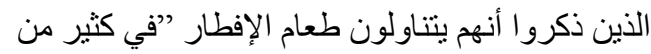

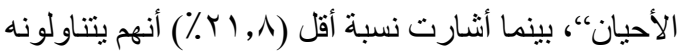

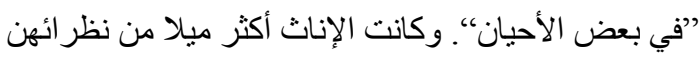

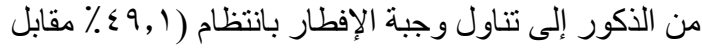

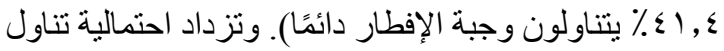

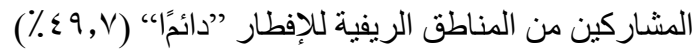

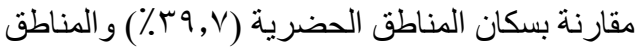

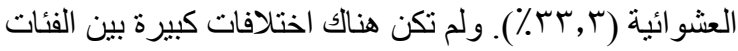

العمرية أو المستويات المختلفة من خميس الثروة.

كما تم توجيه سؤال إلى المشاركين في الاسنطلاع عن

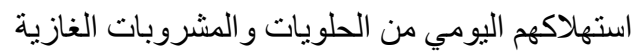
و الوجبات الخفيفة و الوجبات السريعة، وتنبين أن نسبة كبيرة

من الثباب يتبعون بعض العادات الغذائية غير الصحية.

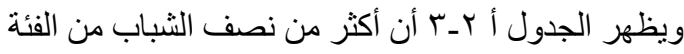

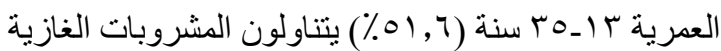

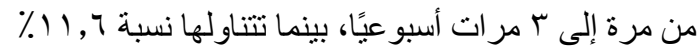

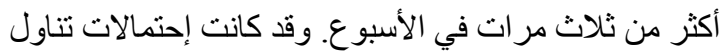

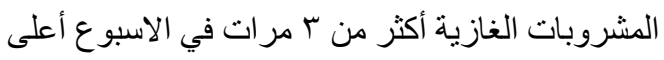

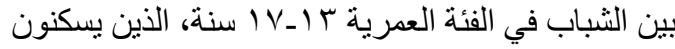

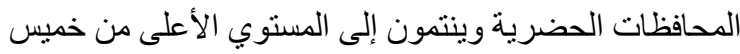

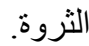

آخر عن تجربتهن. وكانت الإناث الأصغر سنًا أكثر احتمالا

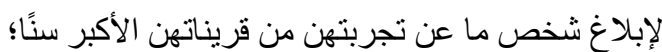

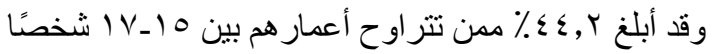

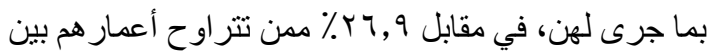

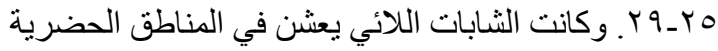

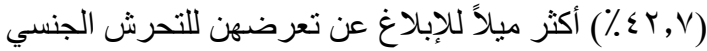

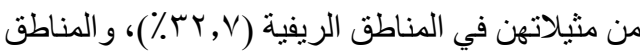

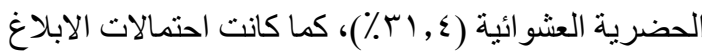

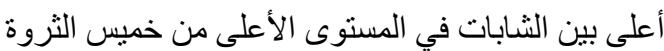

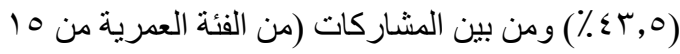

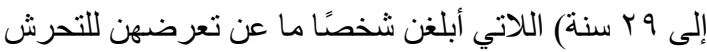

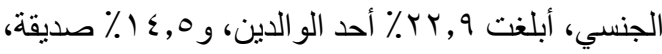

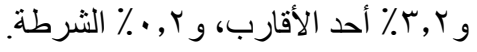

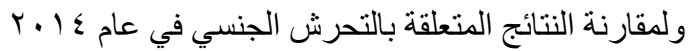

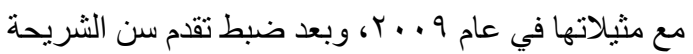

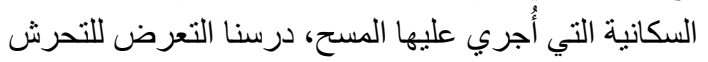

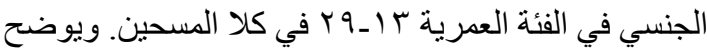

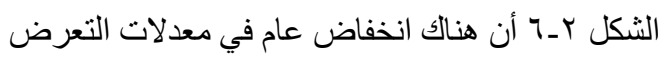

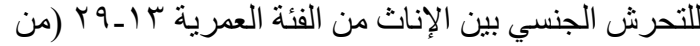

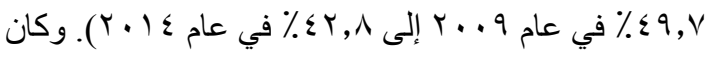

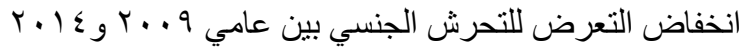

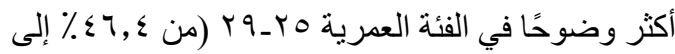

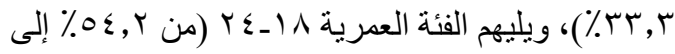

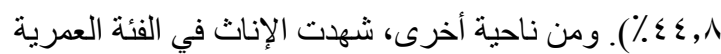

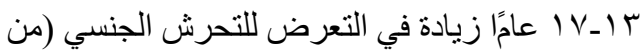

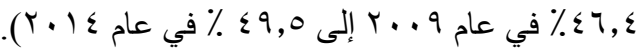

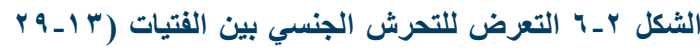

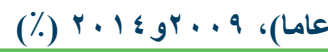

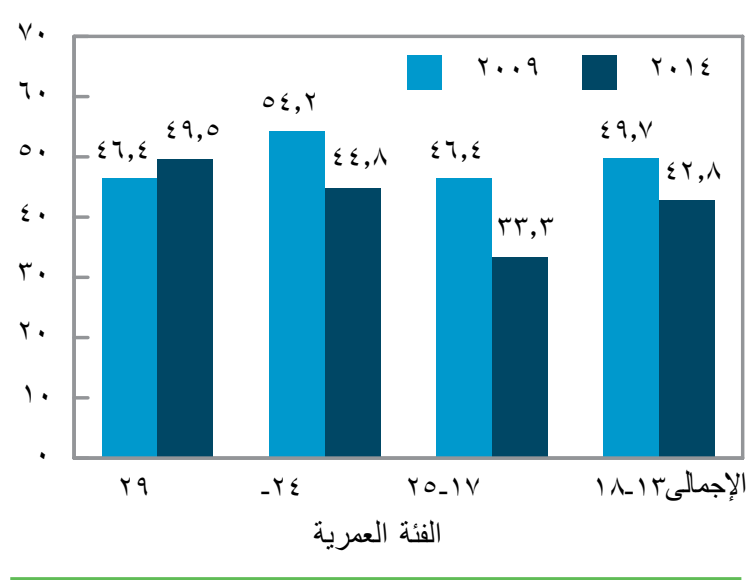


الدر اسي، وخاصة وجبة الإفطار ، مهمة للتنمية المعرفية

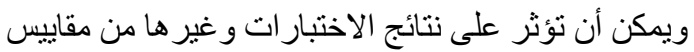

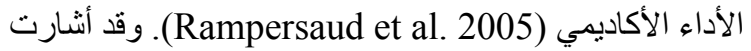

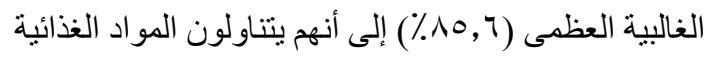

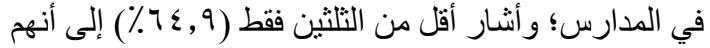

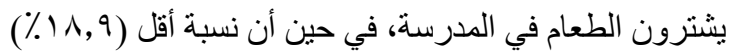

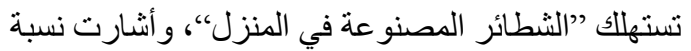
مئوية صغيرة جدًا إلى "الوجبة المدرسية"، (9, 1\%).

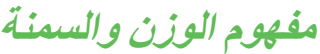

أفاد حو الي ثلاثة أرباع المشتركين في الاستطلاع من الفئة

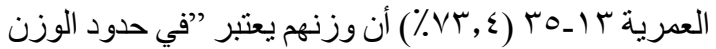

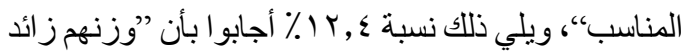

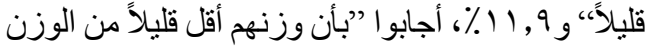

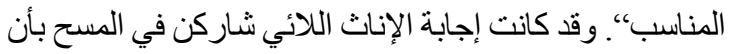

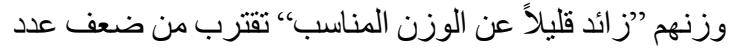

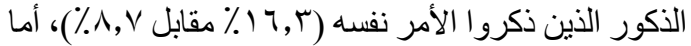

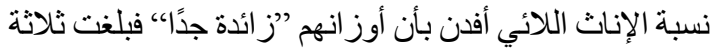

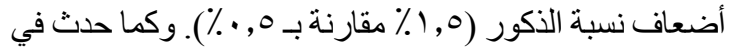

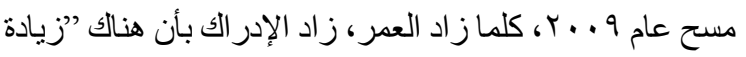
قليلة في الوزن، كذلك، حيث كانت تلاك هي إجابة أكبر الثرائح سنًا في الفئة العمرية موضوع المستح وتمثل 9 ه 1 ٪، بينما كانت

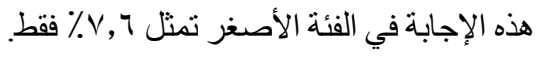

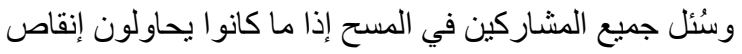

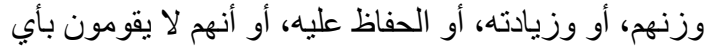

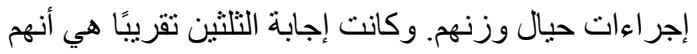

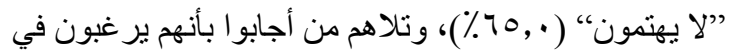

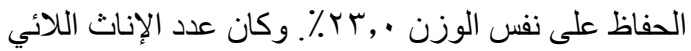

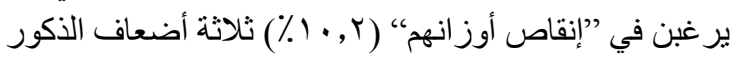

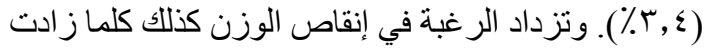

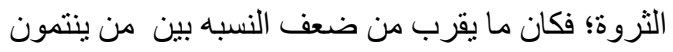

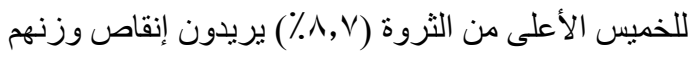

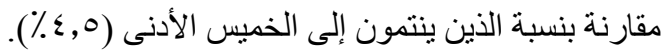

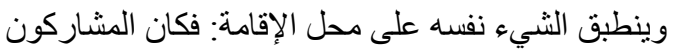
سكان المناطق الحضرية الذين برغبون فئون في إنقاص وزنهم ألكثر

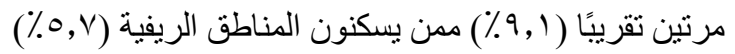

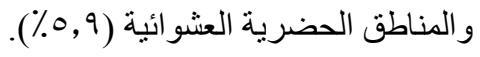

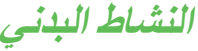

وشملت الدر اسة مجمو عة من الأسئلة تتناول الأنشطة البدنية

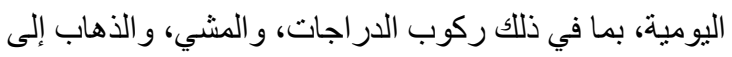
صالة الألعاب الرياضية، ولعب الرياضة، أو العمل البدني في

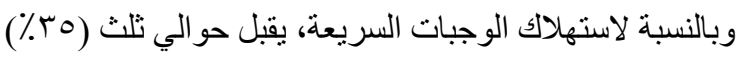

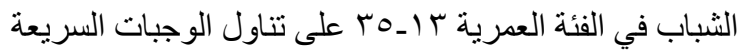

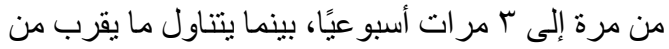

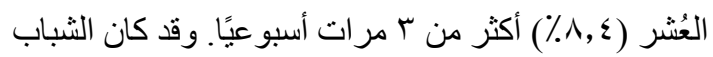

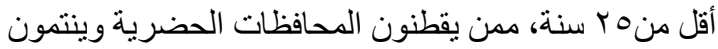

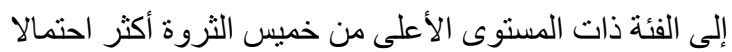

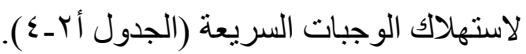

و هناك من الأدلة التي تشير إلى أن النظام الغذائي الذي يتضمن تناول كميات كبيرة من الملح، خصوصئا في البلدان النامية وذات الخات

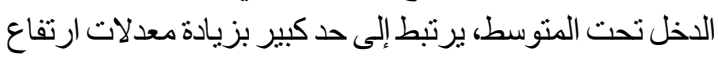

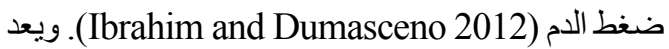
ارتفاع ضغط الدم أحد الأسباب الرئيسية للإصابة بأمر اض اض

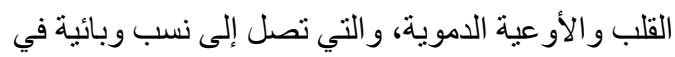

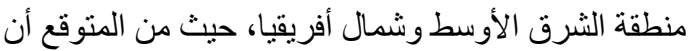

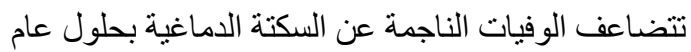

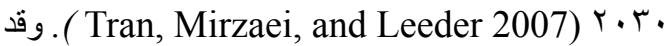
سُئل المشاركون في المسح عن تناولهم للملح ومدى تفضيلهم

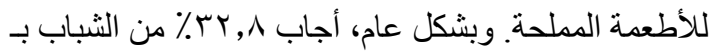
"نعم" على هذا السؤال. وكانت إحتمالات تفضيل الأكل الأكثر التر

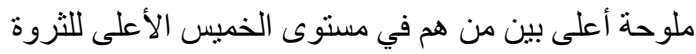

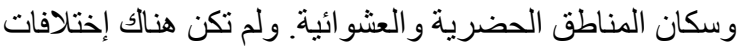

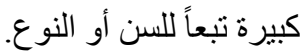

وسُئل المشاركون في المسح عن نوع الخبز الذي يتناولونه في المعتاد. و أثشار المشاركون في المستوى الأعلى من الأن الثن

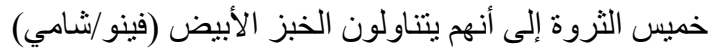

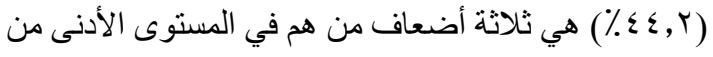

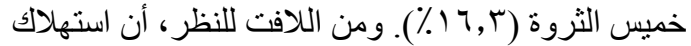

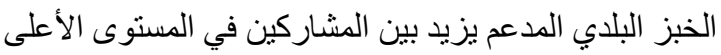

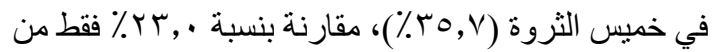

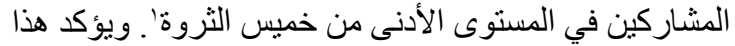

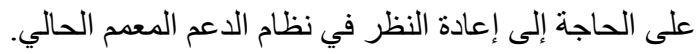

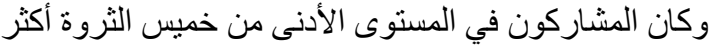

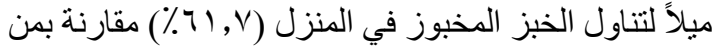

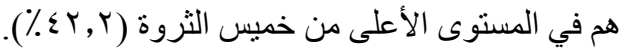

في نهاية القسم الخاص بالتغذية توجد بعض الأسئلة

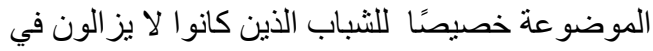

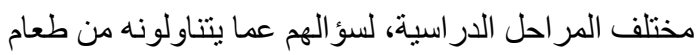
في المدرسة. وقد أظهرت الأبحاث أن التغذية أثناء اليوم

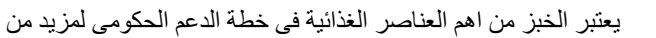

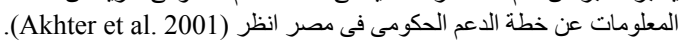




\section{ب_ r تعاطي التبغ والكحوليات والمخدرات}

في بداية الاستبيان نتناول الأسئلة قضية التدخين و عادات

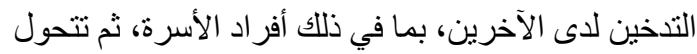

للسؤال عن عادات التدخين الخاصة بالمشارك في المسح. وكان الأساس المنطقي لهذا التسلسل هو الحصول على بيانات تقريبية في حالة عدم رغبة المشارك في إعطاء إجابة تتعلق به فه الهابه شخصيًا في هذه القضايا الحساسة. وقد تم استخدام نفس التقنية للاستفسار عن تعاطي المخدر ات و الكحوليات.

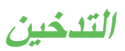

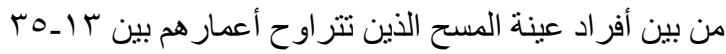

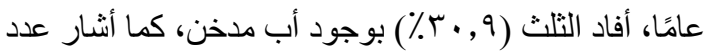

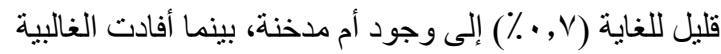

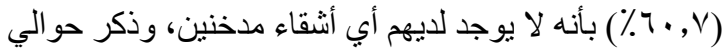

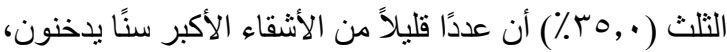

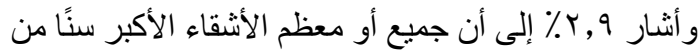

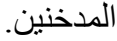

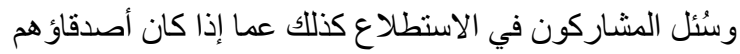

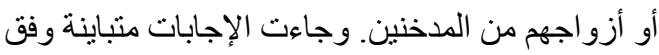

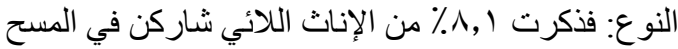

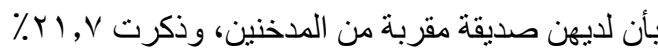

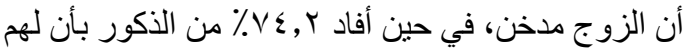

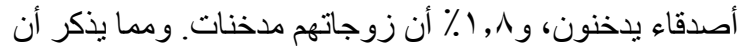

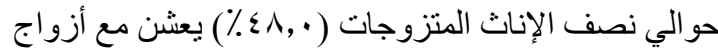

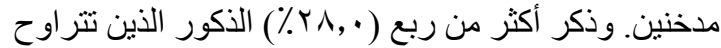

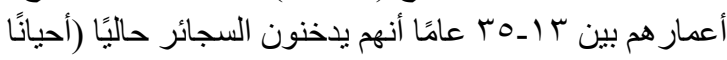

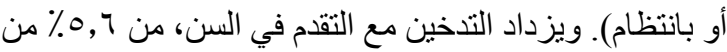

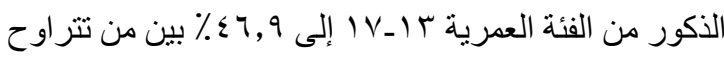

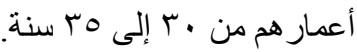

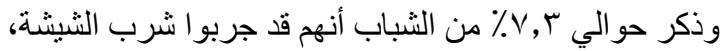
وقال 0, ؟\% إنهم يدخنون الثشيشة بانتظام، في حين أشنار

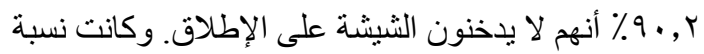

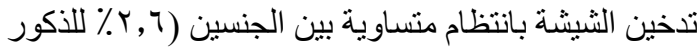

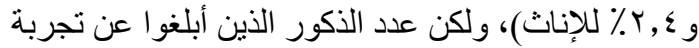

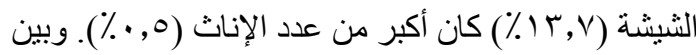
صفوف الذكور، كان تدخين الثيشة بانتظام أكثر انتشارًا في الني

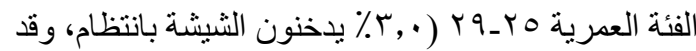

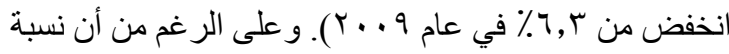

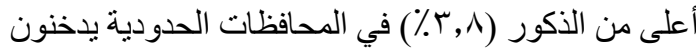
الثيشة بانتظام، أكثر من نظر ائهم في سائر المناطق (حيث
العمل. ويبين الجدول أ بـ ـ أن ما يقرب من نصف الثباب من

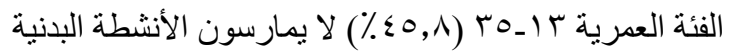

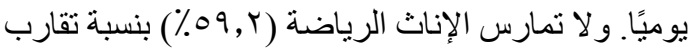

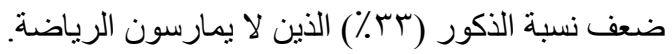

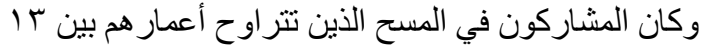

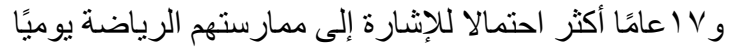

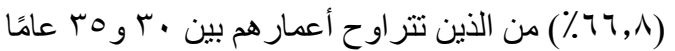

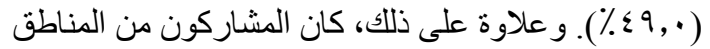

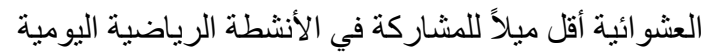

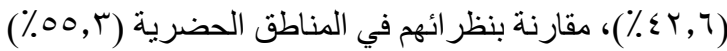
أو الريفية (7, 00\%). ولم تختلف المشاركة في الأنشطة الرياضية اليومية كثيرًا وفق مستوى الثروة أو التعليه.

وكانت الإجابة الأكثر شيو عًا بين أولئك الذين يمارسون

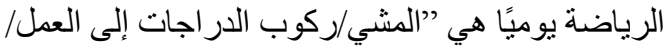

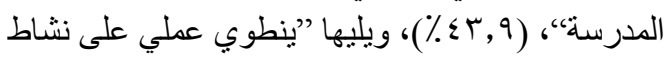

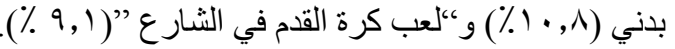

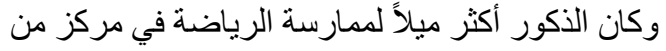

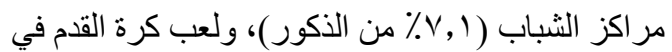

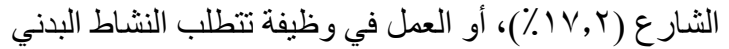

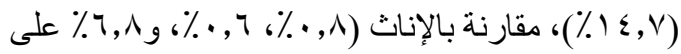

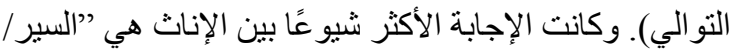

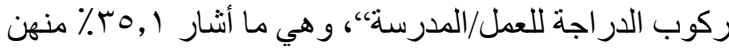
أنهن يمارسنها يوميًا.

وقد عُقدت مقارنة بين ممارسة الأنشطة الرياضية يوميًا بين

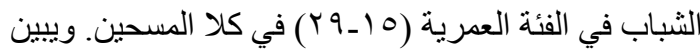
الشكل Y Y ا انخفاض المشاركة في ممارسة الأنشطة الرياضية

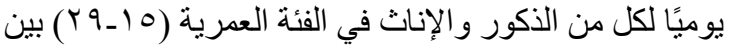

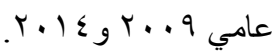

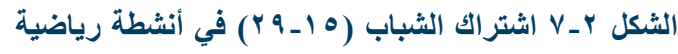

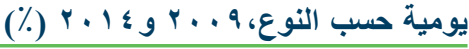

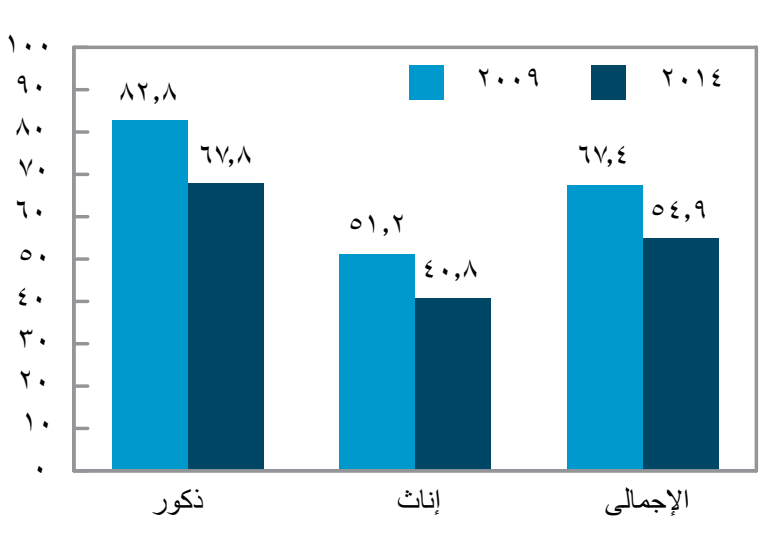




\section{Y ـ الصحة التفسية والتنمية الاجتماعية}

استخدمت الدراسة استبيان التقارير الذاتية (SRQ-20 )، الذي

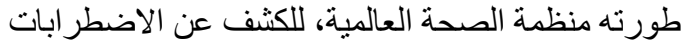

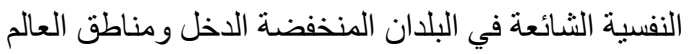

النامي (Beusenberg and Orley 1994). ويشمل الاستبيان مجمو عة من عشرين سؤ الاً إجابتها نعم/لا، وتكون

نتيجة المشارك هي مجموع عدد الأسئلة التي أجاب عنها ب "نعم". وقد تم تصميم هذه الأداة بحيث تُشير زيادة درجة الابنة المشارك إلى احتمالية إصابته باضطر اب نفسي. ويجب الإدة التحقق

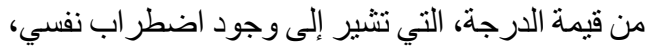

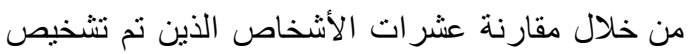

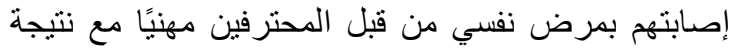

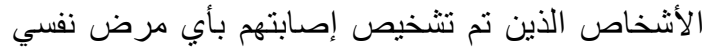

.(Beusenberg and Orley 1994)

وقد أسفرت مر اجعة الدر اسات المنشورة باستخدام استبيان

العشرين سؤ ال في مصر عن در اسة واحدة فقط، و التي التي

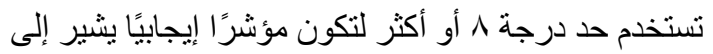
وجود اضطر اب نفسي (Vizcarra et al. 2004). وقد أكد (Rahman et al.2005) درجة 9 أو أكثر هي النتيجة الصحيحة. وفي الأردن، استخدم نتيجة تساوي حد 7 درجات وفي الاد

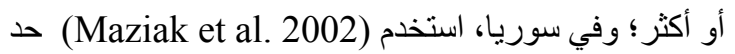

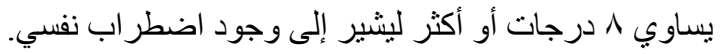

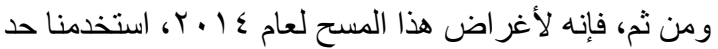

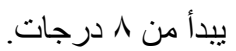

ومن بين أفر اد عينة المسح، كان منوسط عدد الإجابات

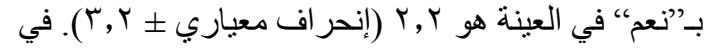

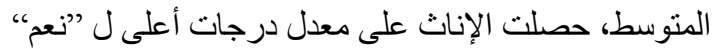

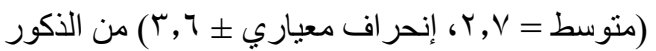

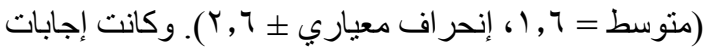

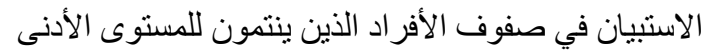

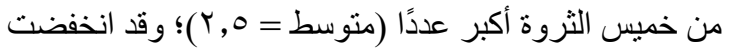

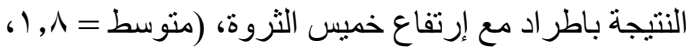

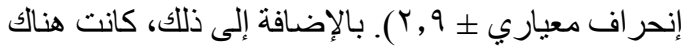
اختلافات طفيفة في درجات الاستبيان عند توزيعها وفق محل

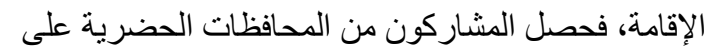

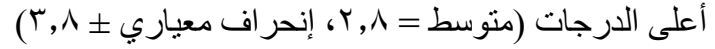
ويليهم سكان المناطق الريفية بصعيد مصر (منوسط = ع, ؟ ب،

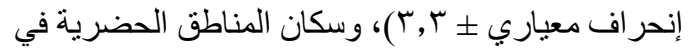

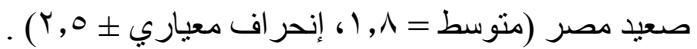

تبلغ النسبة في جميع المناطق الأخرى أقل من ^, ؟\%)، وكانت

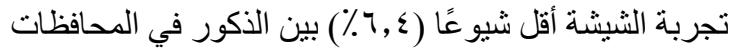

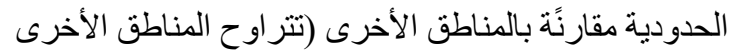
بين ع , 11\% إلى 1,7 (\%).

\section{تعاطي الكحوليات والمندرات}

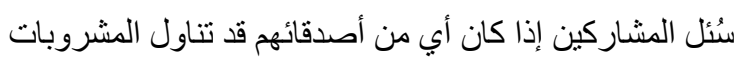

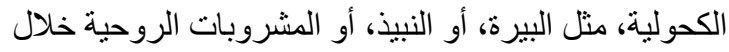

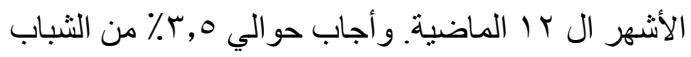

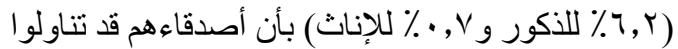

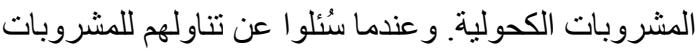

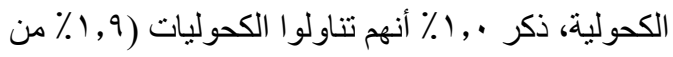

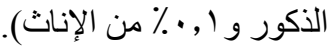

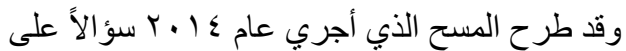

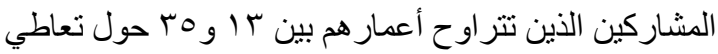

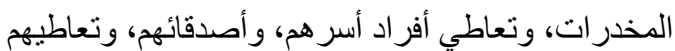

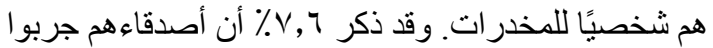

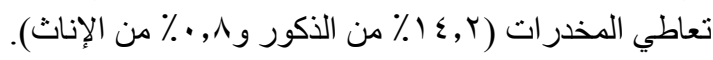

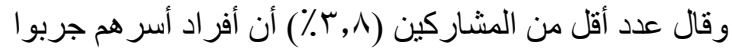

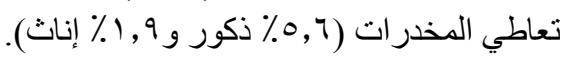

و أفاد عدد ضئيل للغاية (9 , 1\%) من المشاركين بالمسح الذين

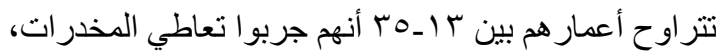

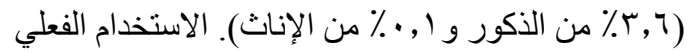

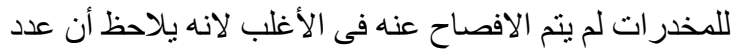
أكثر من المشاركين ذكروا ان افر اد اسر هم و اصدقائهم جربوا

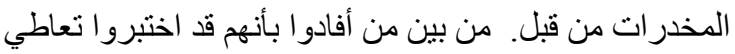

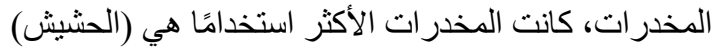

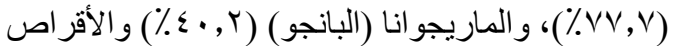
.$(\% \cdot, \wedge)$

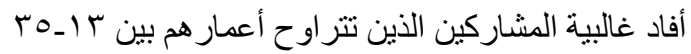

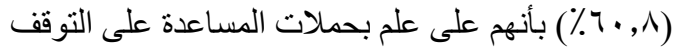

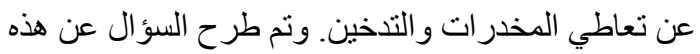

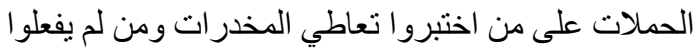

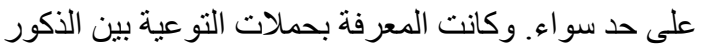

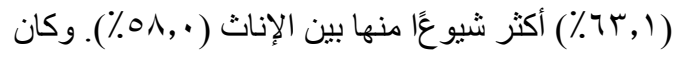

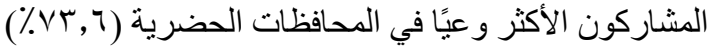

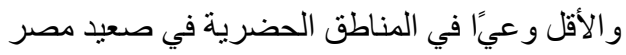

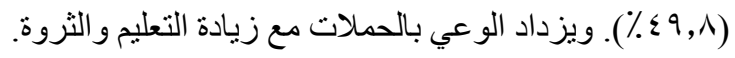

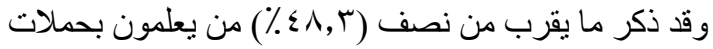

مكافحة المخدرات أنهم بعتقدون أن هذه الحملات ناجحة. 


\section{أكثز من نصف المستحبيبن صدمو

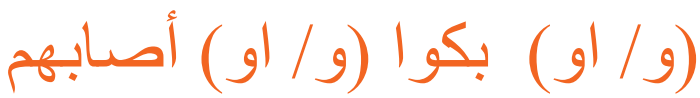 الخو فن عند البلو}

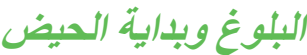

شهدت جميع الإناث اللاتي شاركن في المسح تقريبًا بدء وكاء

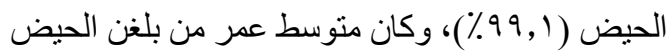

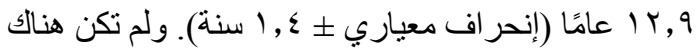

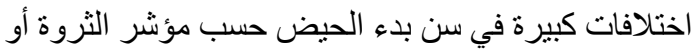

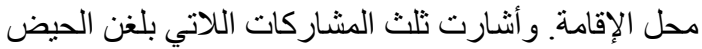
(\%rr,V)

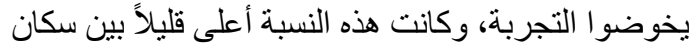

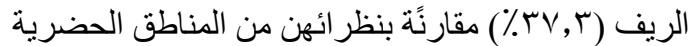

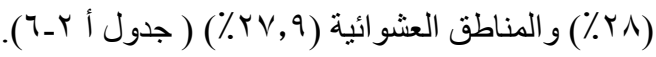

وقد أصيبت نصف الفتيات (r, 101\%) بالصدمة، وبكين، و /أو

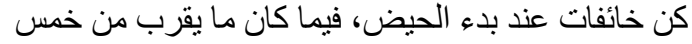

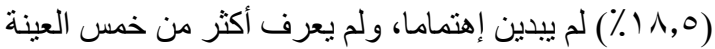

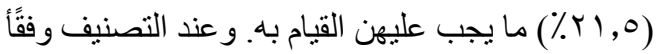
للتعليم، لم تكن هناك اختلافات كبيرة في رد الفعل إز اء بداية باتية

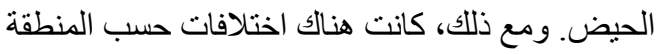
السكنية، فأجابت المشاركات من حضر صعيد مصر بأنهات

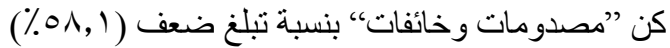

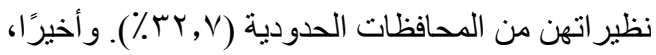

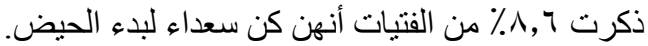

و أفادت غالبية الإناث المشاركات بأنهن يستخدمن الفوط

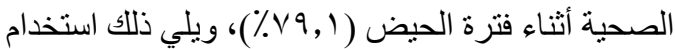

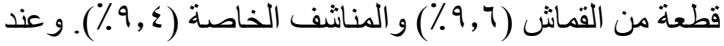
فحص هذه المسألة حسب المنطقة، كانت الإجابات مختلفة اختلافًا كبيرًا؛ فاستخدام الفوط الصحية هو الأكثر شيوعًا

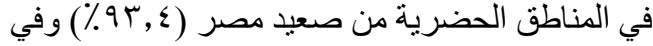

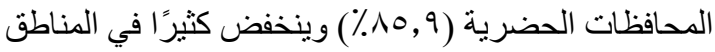

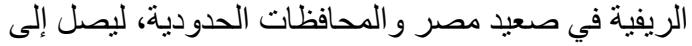

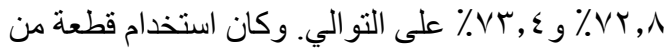

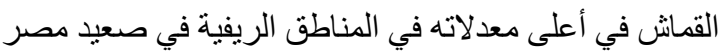

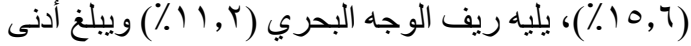

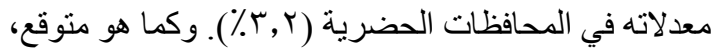

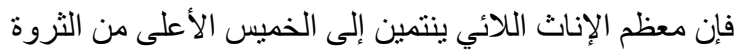

وباستخدام حد مؤشر درجات 1 أو أكثر ليدل على الاضطراب

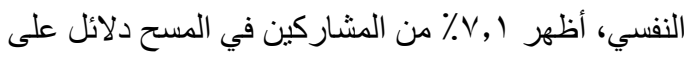

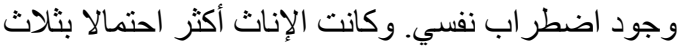

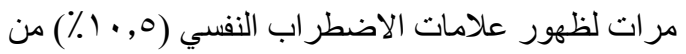

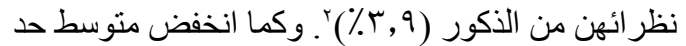

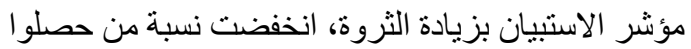
على درجات تساوي ^ أو أكثر إلى حد كبير مع زيادة الثنروة الثنان. وقد سجل الثباب الذين ينتمون إلى الخميس الأدنى من الثئي الثروة

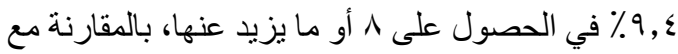

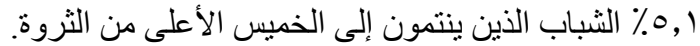

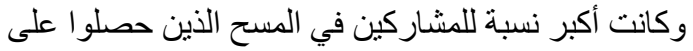
نتيجة في الاستبيان تساوي ^ أو نزيد عنها من المنان المحافظات الحضرية (r, r ( ٪) ويليها المشاركون من المناطق الريفية

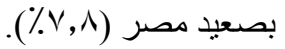

وسُئل المشاركون في المسح كذللك عما إذا كان لديهم تاريخ

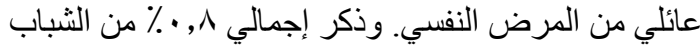

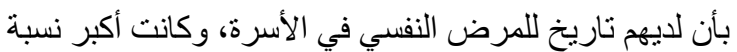

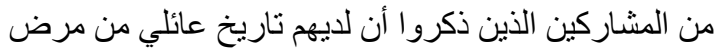

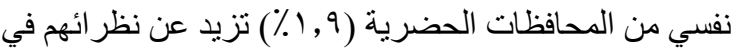

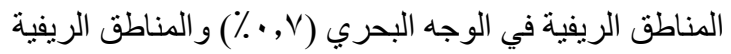

بصعيد مصر (†, • \%)، و هي المناطق التي احتلت المركز

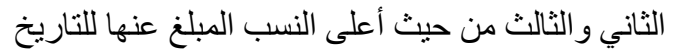

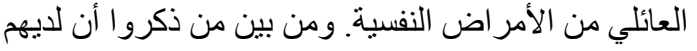

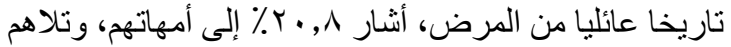

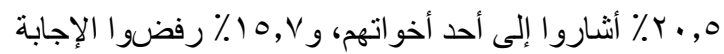

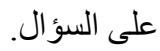

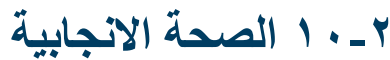

يتألف قسم الصحة الإنجابية من المسح من سلسلة من الأسئلة

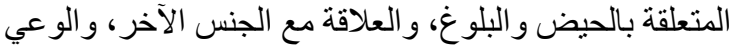

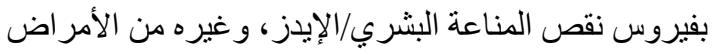

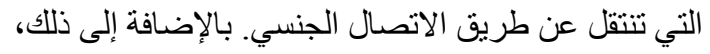

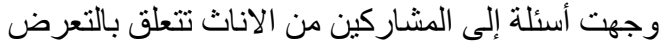

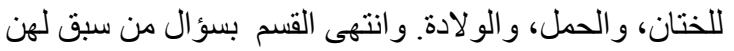
الزواج حول معرفتهم بوسائل تنظيم الأسرة وكيفية استخدامها.

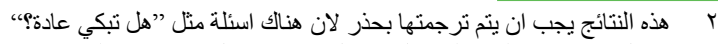
و"هل تخاف بسهولةب، التي يقل احتمال اجابتها بشكل ايجابى من الثباب.
} 


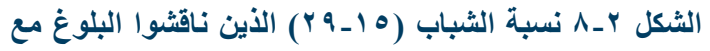

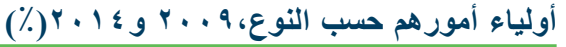

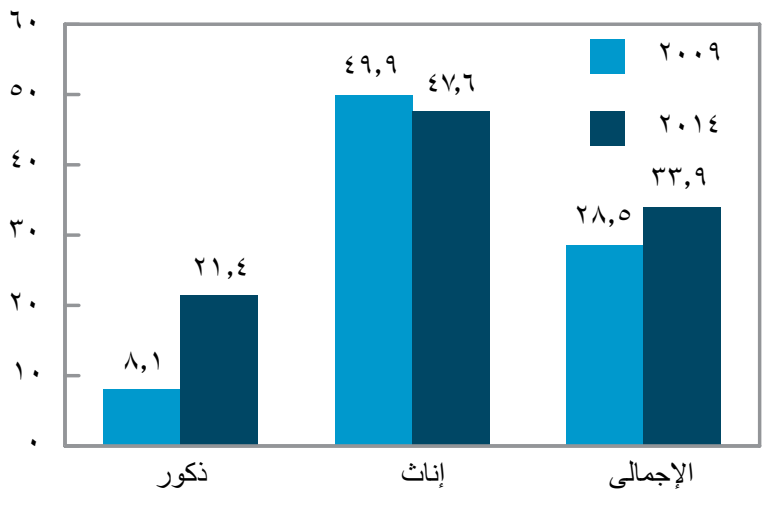

و عن آرائهج بخصوص العمر المناسب، إذا كان هنالك عمر

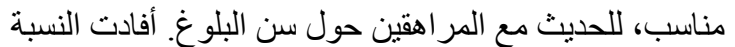

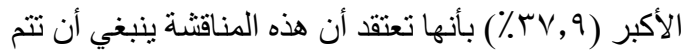

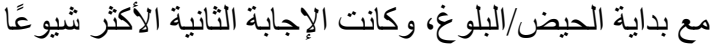

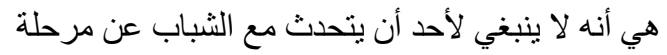

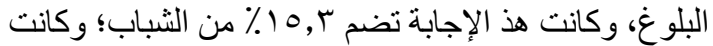

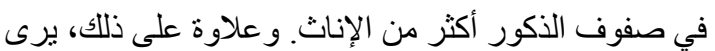

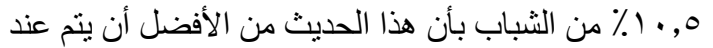

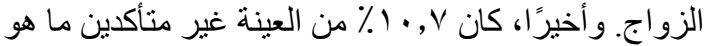

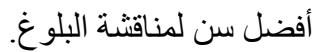

وسُئل الثباب أيضًا عن المصدر الرئيسي لمعلوماتهم حول البلوغ. وكان أكثر مصدر للحصول على المعلومات هو

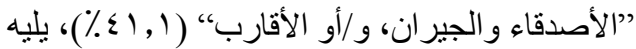

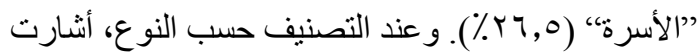

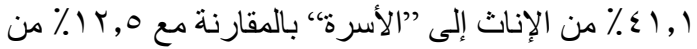

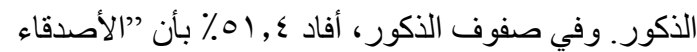
و الجيران، و /أو أقارب،، هم المصدر الرئيسي للمعلومات

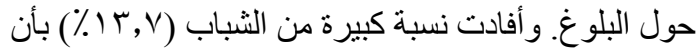

المصدر الرئيسي للمعلومات هو الأفلام و السينما. و عند

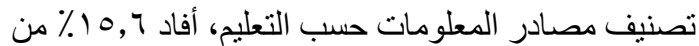
أصحاب التعليم الجامعي بأن المصدر الرئيسي للمعلومات بالنسبة إليهم هو المناهج الدراسية، وهو أكبر نسبه من بين

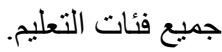

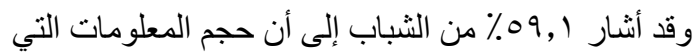

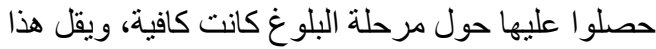

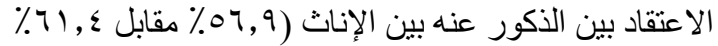

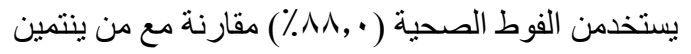

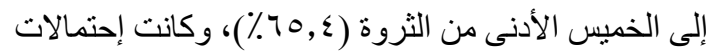

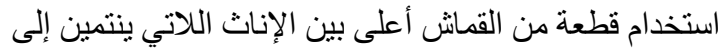
الخميس الأدنى ( • , (Y\%) مقارنة باللاتي ينتمين إلى المستوى الإنى

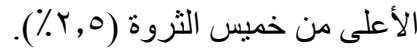

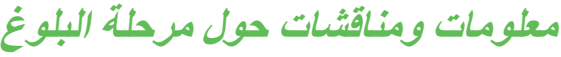

تضمن مسح عام \& 1 • ب سلسلة من الأسئلة وجهت للشباب

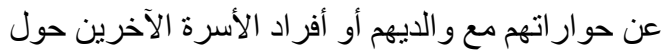
البلوغ و النمو، وتم طر ح هذه الأسئلة على جميع المشاركين.

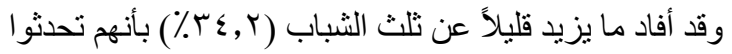

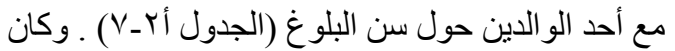
الفارق الأبرز بين المجمو عات المختلفة الشباب حسب النو النوع؛ فنسبة الإناث المشاركات اللاتي تحدثن مع أحد أفر اد الأسرة

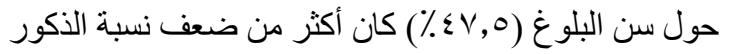

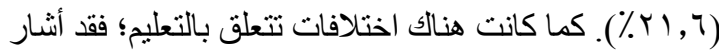

rV, 9

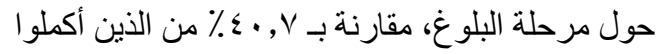
تعليمهم الجامعي.

وكان المشاركون من المحافظات الحدودية و المحافظات

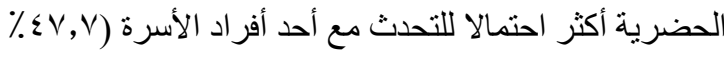

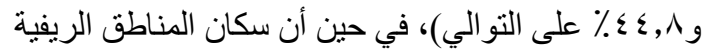

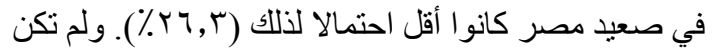
هناك اختلافات كبيرة حسب الفئة العمرية. و عند التصنيف

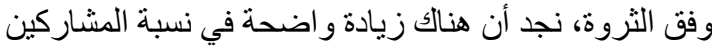

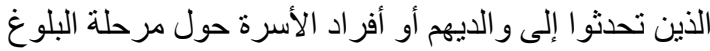

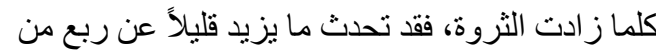

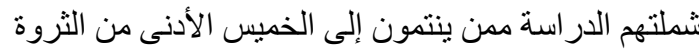

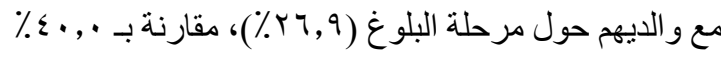
ممن ينتمون إلى الخميس الأعلى من الثروة.

ويبين الثكل Y_ Y أن هناك عددًا أكبر من المشاركين الذين

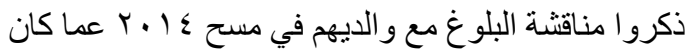

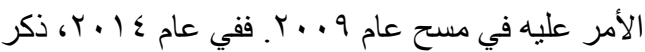

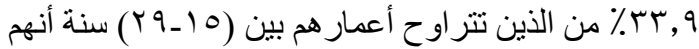

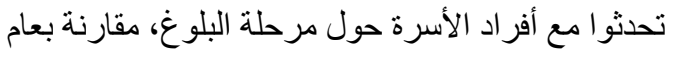

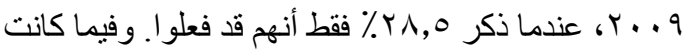

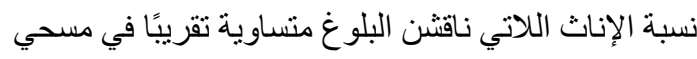

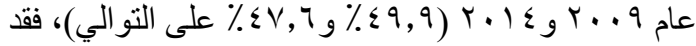

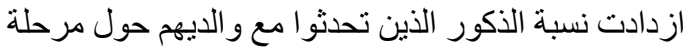

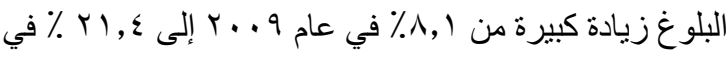


مقابل ^, 1 (\%). و علاوة على ذللك، كانت احتمالات الاجابة

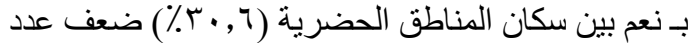

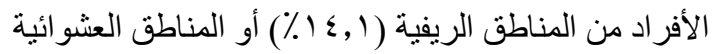

\section{معرفة فبروس نقص المناعة البشري/الإبإز وغيره

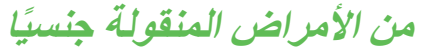

سُئل المشاركون في الدر اسة عما إذا كانوا قد سمعو ا عن المن

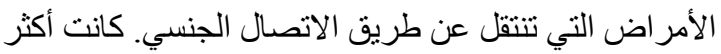

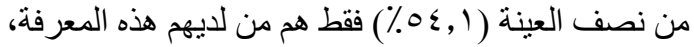

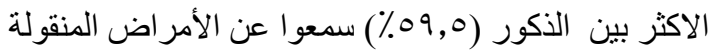

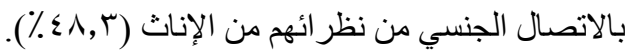
وازدادت معرفة الأمر اض المنقولة بالاتصال الجنسي مع الآناك

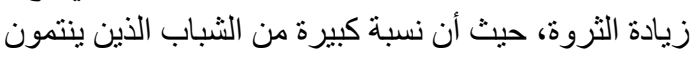

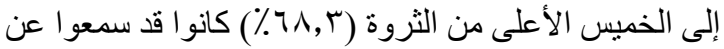

الأمر اض المنقولة جنسيًا مقارنة بمن بينتمون إلى الخئل الخميس

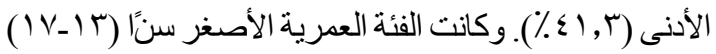

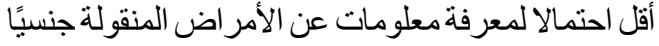

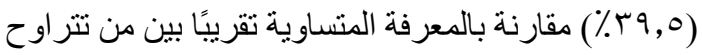

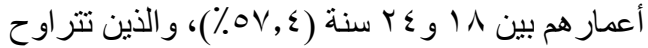

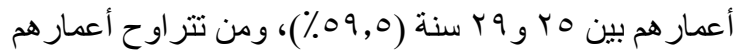

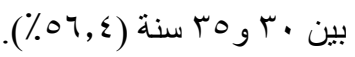

و على غرار الفئة العمرية، كلما زاد المستوى التعليمي

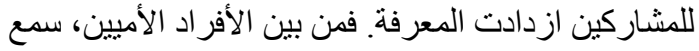

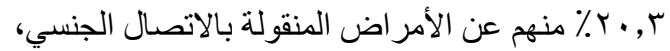

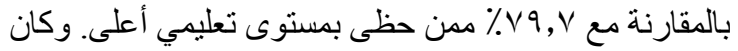

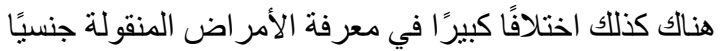

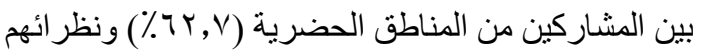

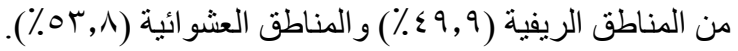

و عندما تُليت قائمة بالأمر اض المنقولة جنسيًا على الذين الأنيا

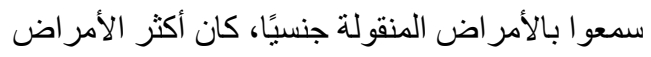

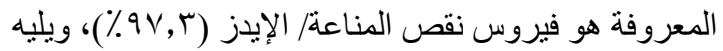

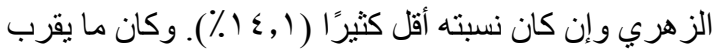

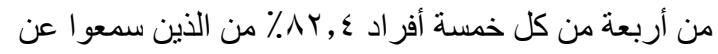

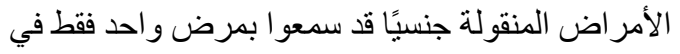

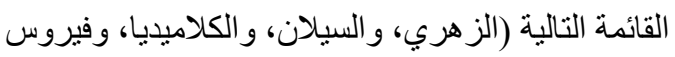

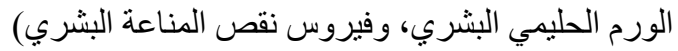

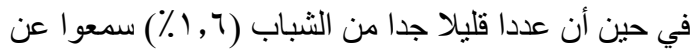

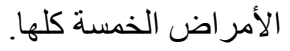

وسُئل المشاركون الذين أثناروا إلى أنهم لم بسمعوا عن أية

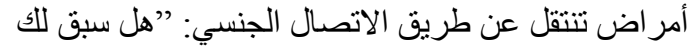

على التو الي). و عمومًا، كلما زاد سن المشاركين، زاد رضاهم عن المعلومات التي حصلو ا عليها، وكانت الفئات الأصغر

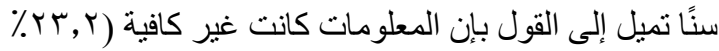

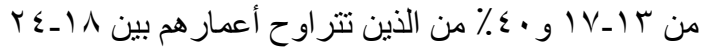

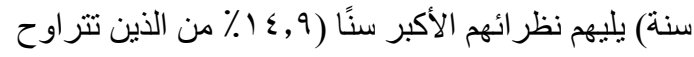

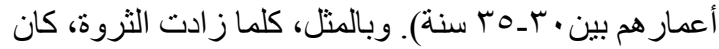

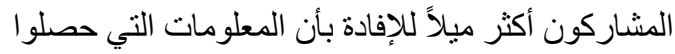

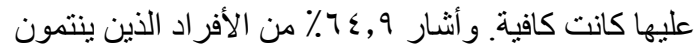

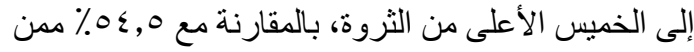

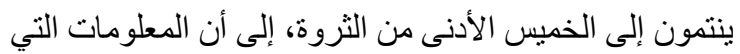
حصلو ا عليها عن البلوغ كانت كافية.

\section{العلاقُات مع الهنبس الآخر}

وكان من المقرر للمسح أن يسأل عن العلاقات الجنسية

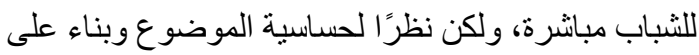

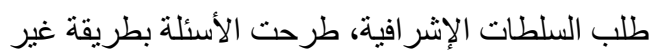
مبانشرة، أبي أنها كانت في شكل استفسار عن العلاقات مع الأنط

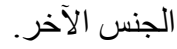

سُئل جميع المشاركين حول إذا ما كانو ا يعرفون فتبات أو شباب من نفس الفئة العمرية لهم علاقات مع الجنس الآخر.

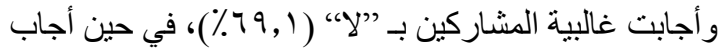

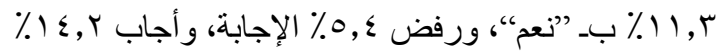

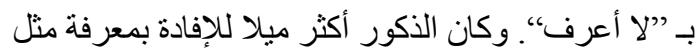

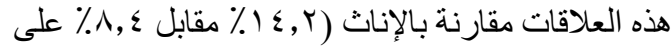

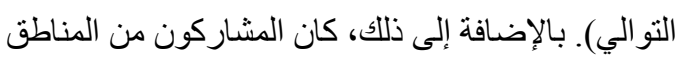

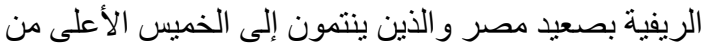
الثروة أكثر احتمالا لتقرير معرفتهم بمثل هذه العلاقات.

و أشارت النسبة الأعلى من المشاركين (ז, بـء) بأن الثباب

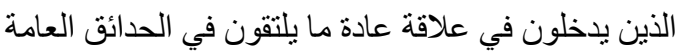

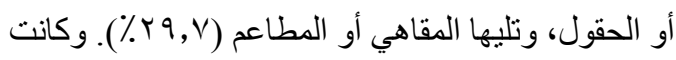

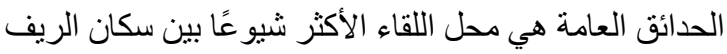

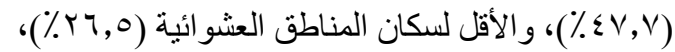

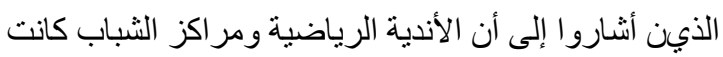

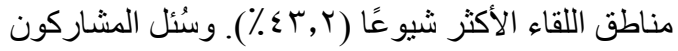

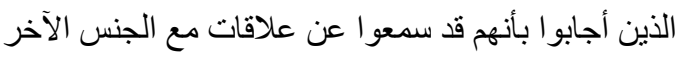

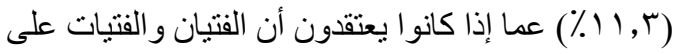

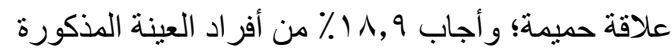

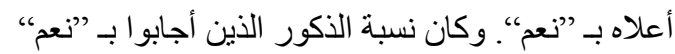

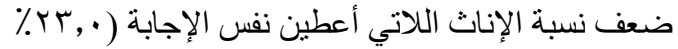




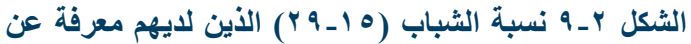

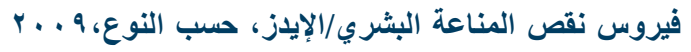
(\%) $r+1 \leq g$

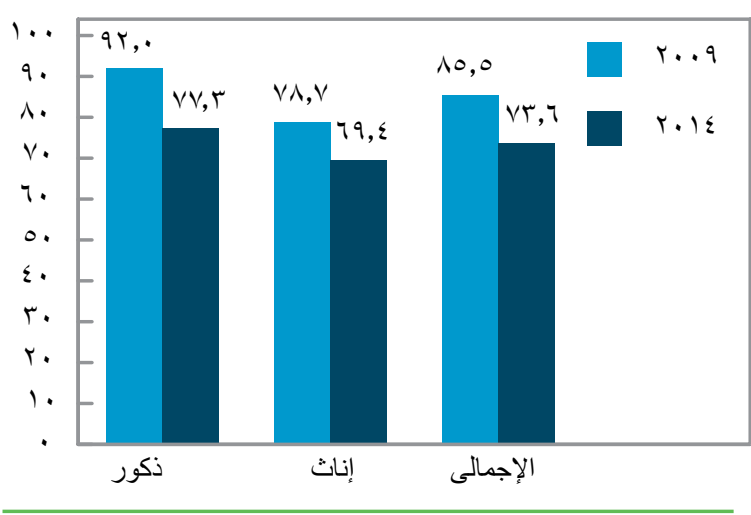

الثباب (؟,^^\%) إلى نقل الدم بوصفه وسيلة من وسائل انتقال فيروس نقص المناعة البشري، فضلاً عن مشاركة

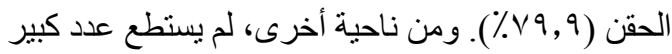

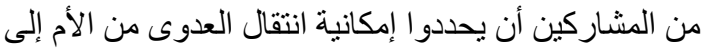

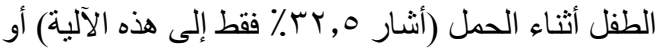

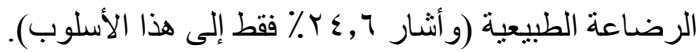

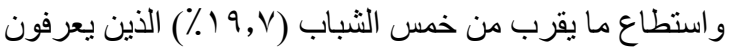
فيروس نقص المناعة البشري/الإيدز أن ينترفوا على جميع

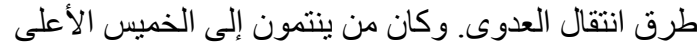

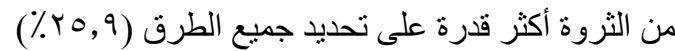

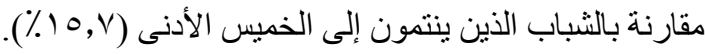

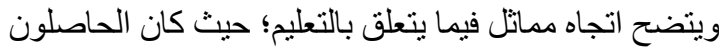
على أكبر قسط من التعليم (التعليم الجامعي وما بعده) على بلى لإنى

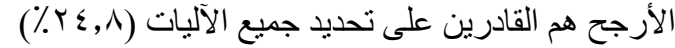

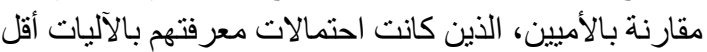
. $(\% 10,9)$

وأخطأ العديد من المشاركين بإجابتهم بأن هناك طرق معينة

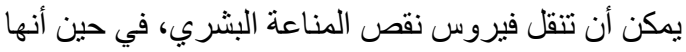

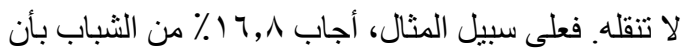

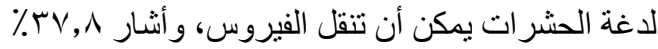
بأنهم لا يعرفون ما إذا كان هذا من طرق انتهر انتقال العدوى.

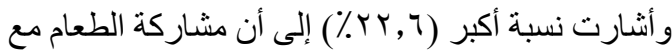

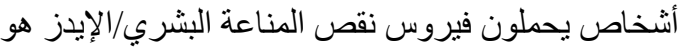

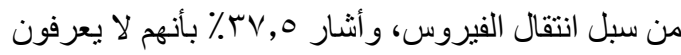

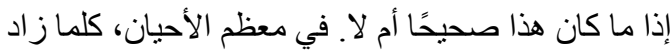

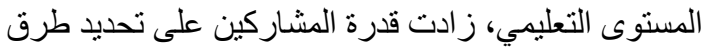
انتقال فيروس نقص المناعة البشري بشكل صحيح. ورأشارت

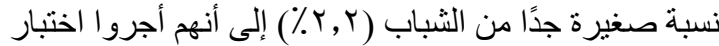
فيروس نقص المناعة البشري/الإيدز في وقت سابق.

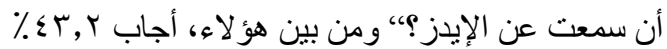

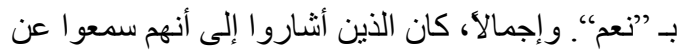

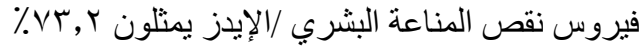

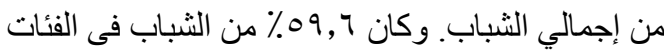

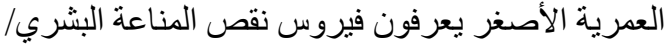

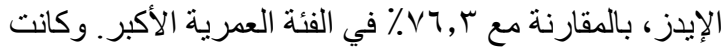

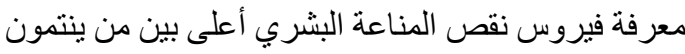

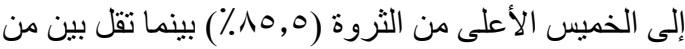

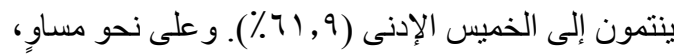
كانت احتمالية معرفة الفئة الأقل تعليمًا بفيروس نقص الإلى ولى المناعة

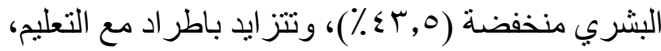

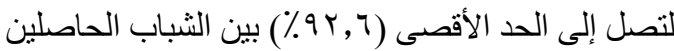

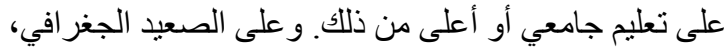
تتز ايد احتمالية معرفة المشاركين من المحافظات الحضرية اعلية

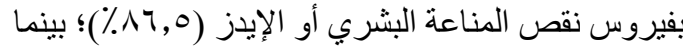

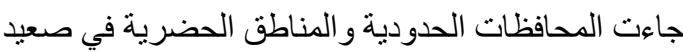

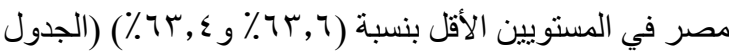
( (N-Y)

ومما يذكر أن نسبة المعرفة بفيروس نقص المناعة البشري/

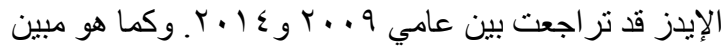

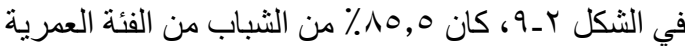

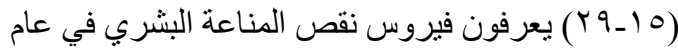

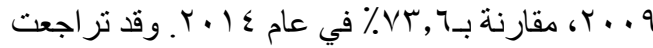

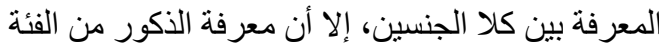

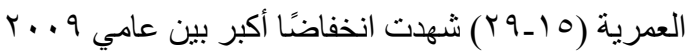

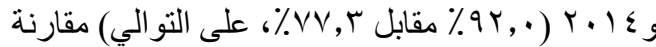

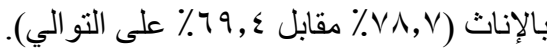

وعن مصادر المعلومات المتوفرة لديهم عن فيروس نقص

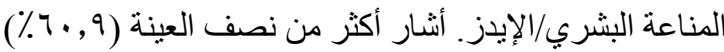

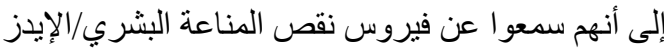

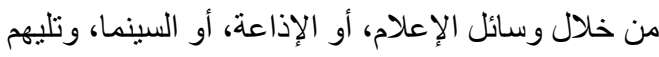

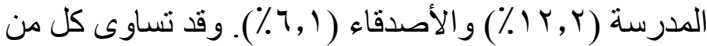
الذكور و الإناث المشاركين في ذكر المدرسة بوصفها مصدرًا للمعلومات، ولكن نسبة الذكور الذين أشناروا إلى الأصدقاء

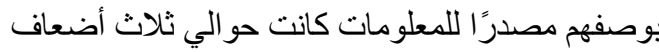

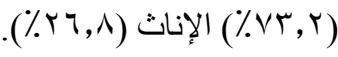

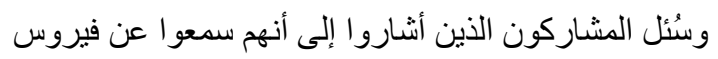
نقص المناعة البشري/الإيدز عن ثماني طرق (ستة منها كانت صحيحة و اثنتين غير صحيحتين) يمكن أن تنقل الفيروس.

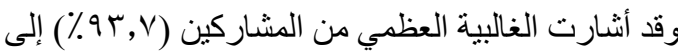
العلاقات الجنسية بوصفها وسيلة لنقل فيروس نقص المناعة البشري/الإيدز . و علاوة على ذلك، أشارت نسبة كبيرة من 
من الأميات أنهن خضعن للختان، مقارنة بـ 0, 1 \% في صفوف خريجي الجامعات (الجدول أب_9)

وكلما تقدم العمر، زادت نسبة من أفدن بأنهن خضعن لعملية الختان. وكانت احتمالات ختان الإناث في الفئة العمرية

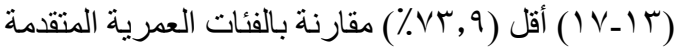

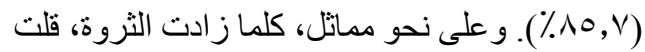

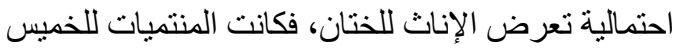
الأدنى من الثروة أكثر إحتمالا للتعرض للختان (r.人V,Y\%) مقارنة بالفتيات المنتميات للخميس الأعلى من الثروة الخيز $(\% \vee, r)$

وعقدت مقارنة بين انتشار ختان الإناث بين الثابات في الفئة

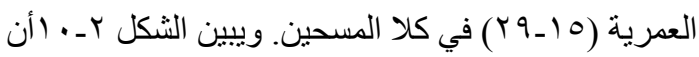

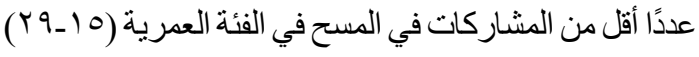

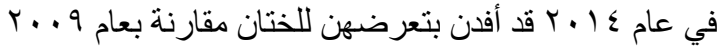

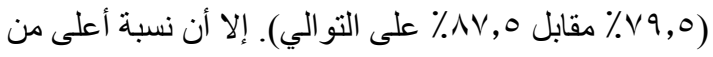

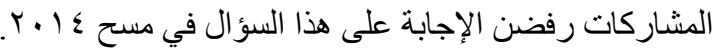
وتناقش الأسباب المحتملة لهذه الزيادة في ختام هذا الفصل. وكان متوسط سن الختان بين الإناث المشاركات في المسح

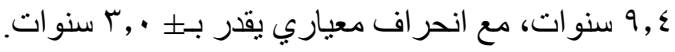
ويتم إجراء ختان الإناث في سن أصغر في المناطق الحضرية من صعيد مصر ( • V, سنوات،

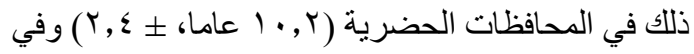

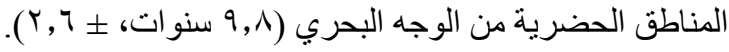
ولم يكن هنالك اختلاف في السن عند الختان حسب مؤشر

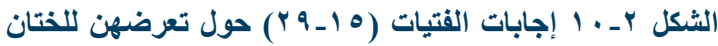

(\%) $r+1 \leqslant g, r q q$

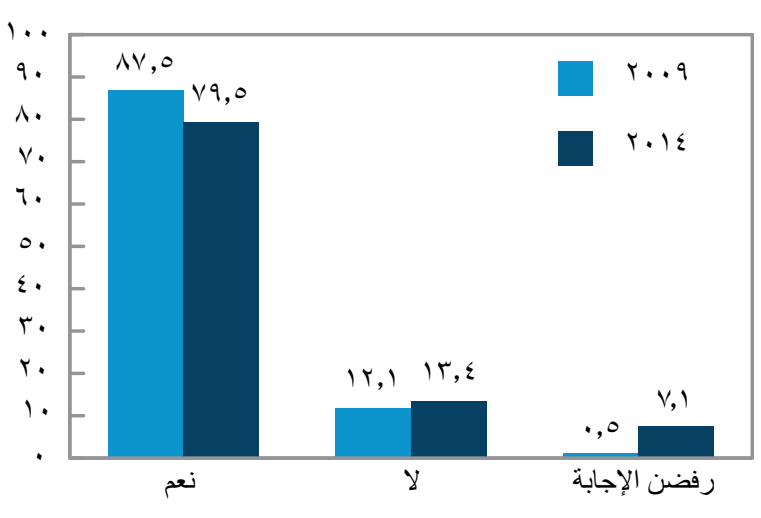

وسُئل المشاركون عن استعدادهم للتفاعل (من خلال

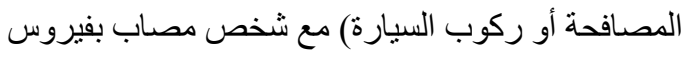

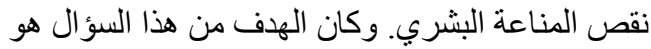

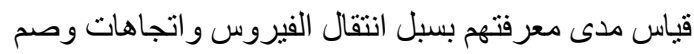

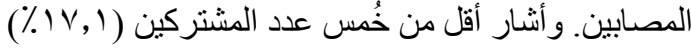
إلى أنهم مستعدون للتفاعل مع شخص مصناب، وقد

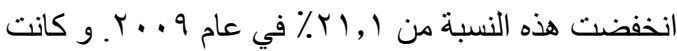

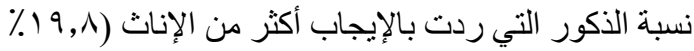
مقارنة بـر, ب (\%). وكانت النسبة بين المشاركين الأميين

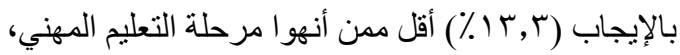

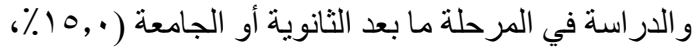

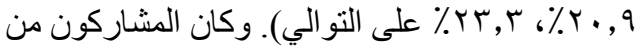
المناطق الحضرية العشوائية أكثر احتمالا بقليل للرد بالإيجاب الرئي

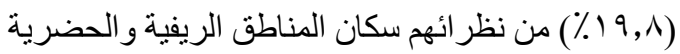

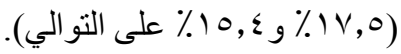

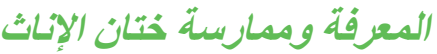

إن تشويه الأعضاء التناسلية للإناث/ختان الإناث هو الإزالة

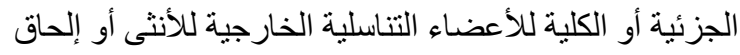

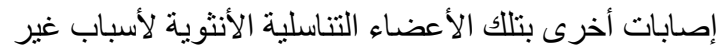
طبية (UNICEF 2010) وقد سُئل جميع المشاركين في المسح عما إذا كانو ا قد سمعو ا عن ختان الإناث (الختان أو الطهارة)، و أشار غالبية الشباب ( • , 9.

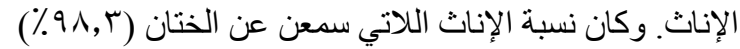

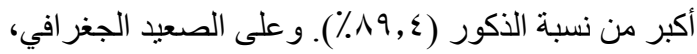

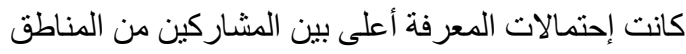

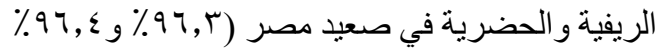
على التوالي) مقارنة بالمشاركين من ريف الوجه البحري

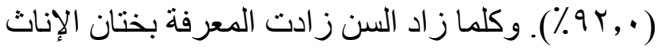

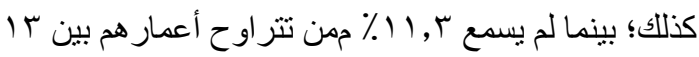

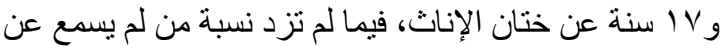

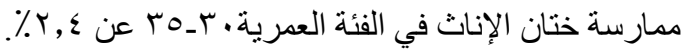

وسئلت جميع الإناث في الفئة العمرية ب ا ـهـ اللاتي أشرن

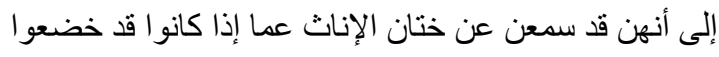

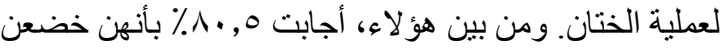

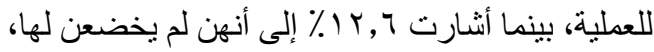
ورفضت • ₹\% الإجابة على السؤال. كان الختان أكثر شيوعًا

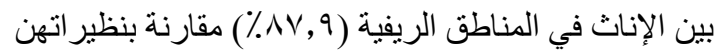

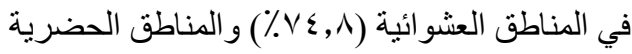

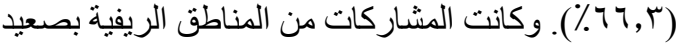

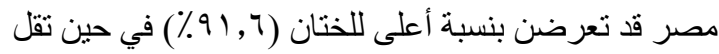

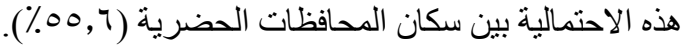

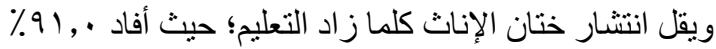


و عند التقييم حسب المنطقة، أفاد ؟, • ^ ٪ من سكان مدن

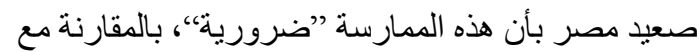

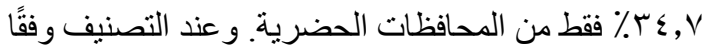

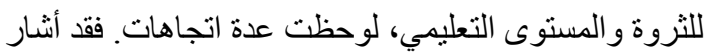
أكثر من ثلاثة أرباع المشاركين الأميين إلى أن ختان الفيان الإناث

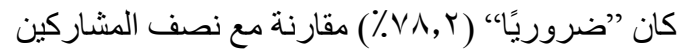

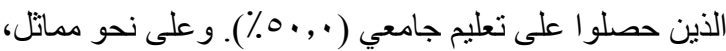

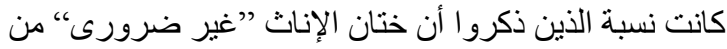

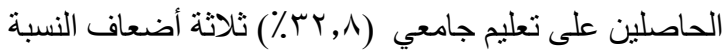
بين الأميين (1, 1 (1\%). وذكر نصف عدد المشاركين الذين

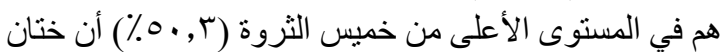

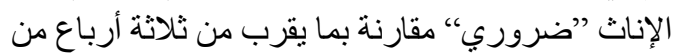

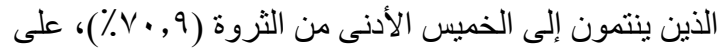

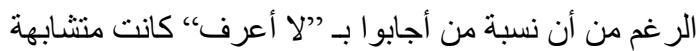

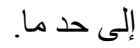

و عقدت مقارنة لاتجاهات المشاركين في المسحين من الفئة

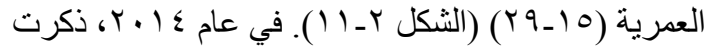

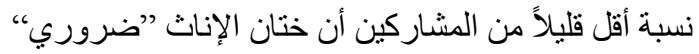

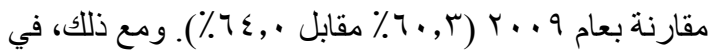

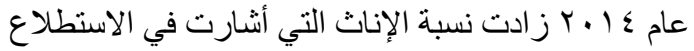

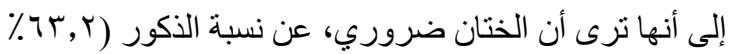

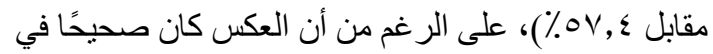

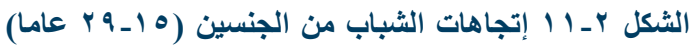

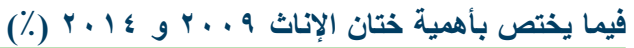

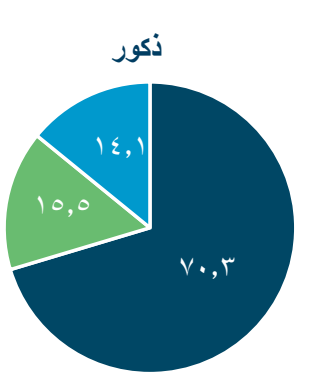

מת מס

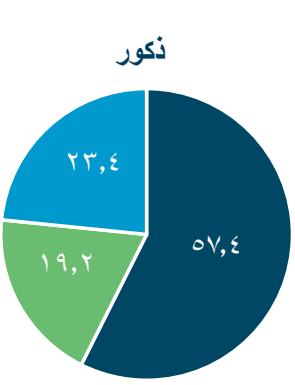

$r+.9$

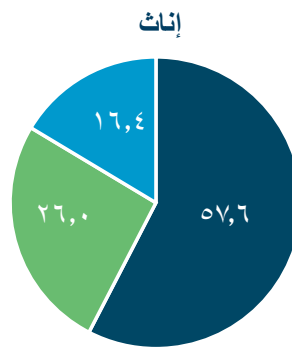

ل ألا ل أعرف

r. I $\varepsilon$

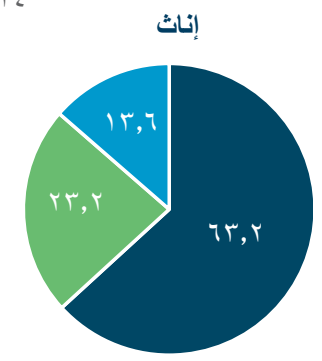

الثروة. وقد تكون هذه النتائج أقل قليلاً، إلا أنها تنفت مع كل

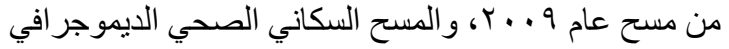

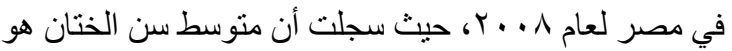

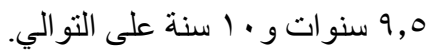

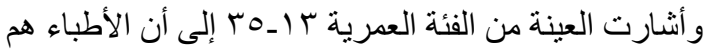

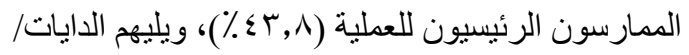

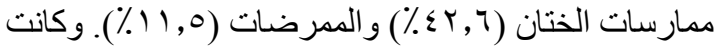

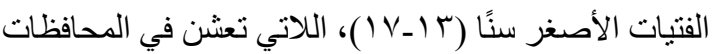

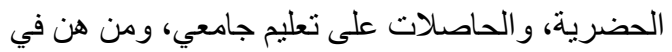

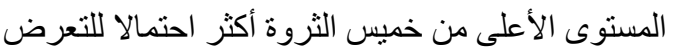
للختان على يد طبيب مقارنة بغير هن من الفنيات.

وذكر ما يقرب من ثلثي المثاركين في المسح من الإناث

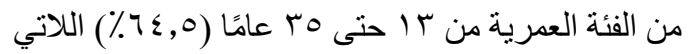

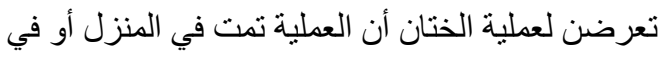

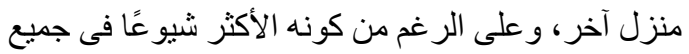

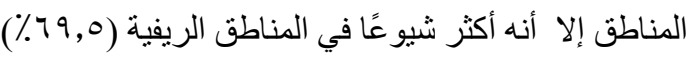

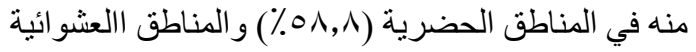

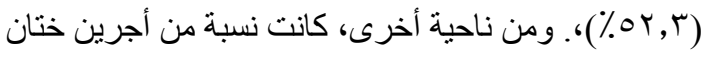

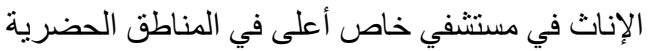

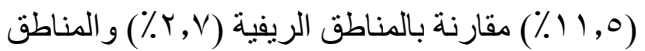

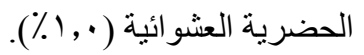

إنجاهات الثرأي حول الغتّان

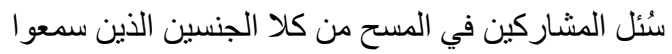
عن ختان الإناث سلسلة من الأسئلة للتعرف على ملى مو اقفهر

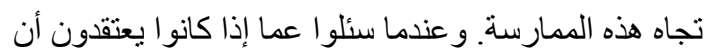

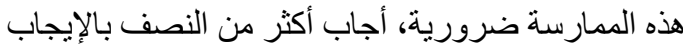

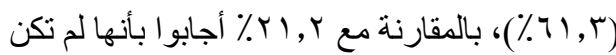

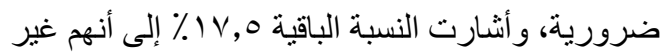

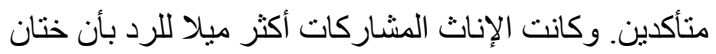

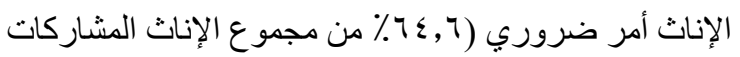

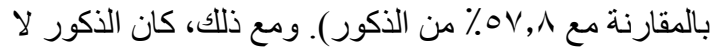

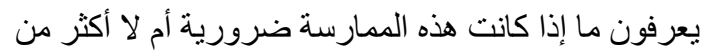

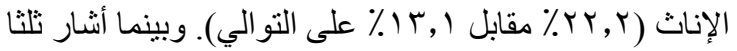

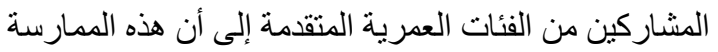

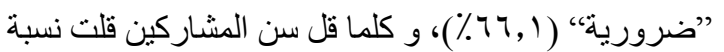

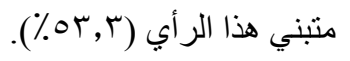


ومن بين الإناث المتزوجات، ذكرت 0, 1 ٪ منهن أنها

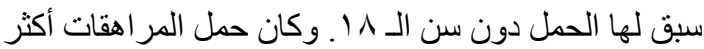

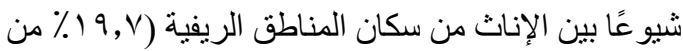
جميع حالات الحمل كانت بين المر اهقات) أكثر من مثنيلاتها

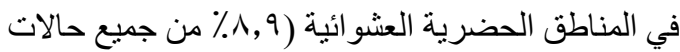
الحمل) و( , ,^٪) في المناطق الحضرية. و وعلى نحو مساوٍ ،

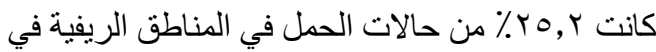

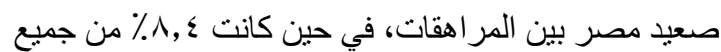

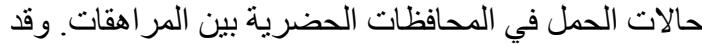

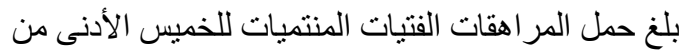

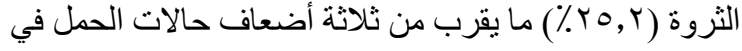

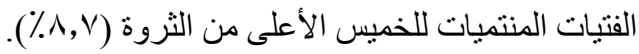

ومن بين الإناث اللائى سبق لهن الزواج و ذوكرن أنه سبق لهن أهن

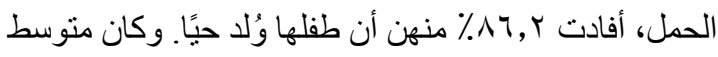

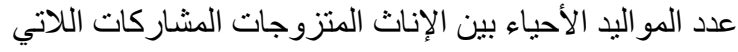

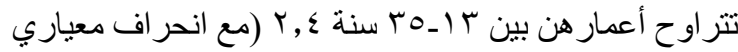

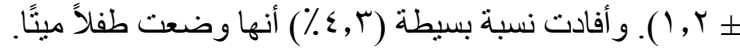

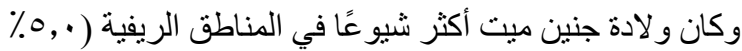

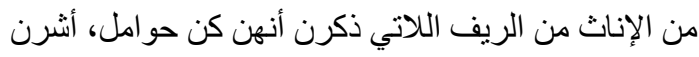

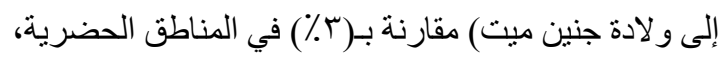

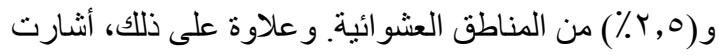

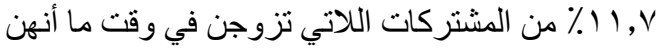

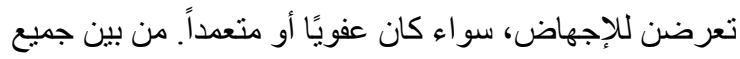

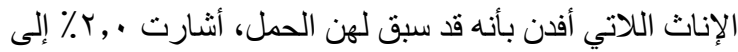
أنهن مررن بعملية إجهاض متعدد في وقت ما.

وذكر أكثر من أربعة أخماس ممن أثرن إلى أنه سبق

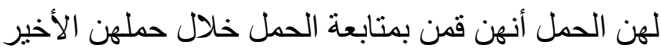

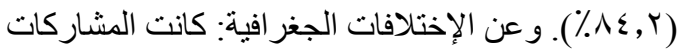

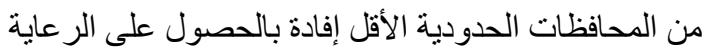

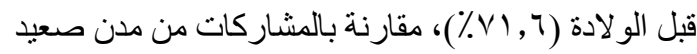

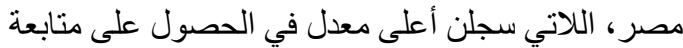

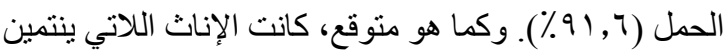

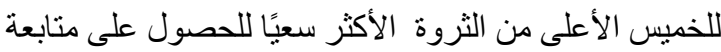

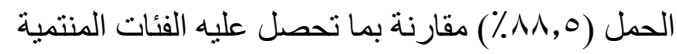

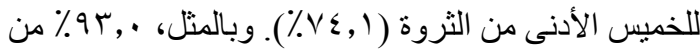

الإناث الحاصلات على تعليم جامعي سعين إلى الحصول متابعة للحمل، مقارنة بـ 9, ؟ ٪\% من نظر ائهن من الأميات.

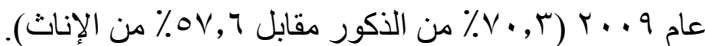
ومن ناحية أخرى، زادت نسبة الذكور الذين لا يعرفون ما إذا لإنا

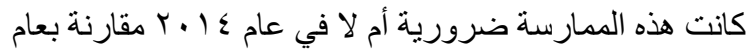

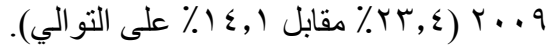

و عندما سُئلو ا عن سبب اعتقادهم بأن ختان الإناث أمر

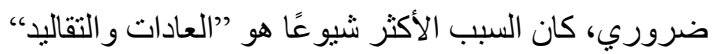

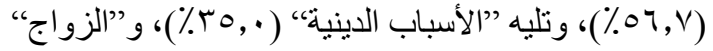

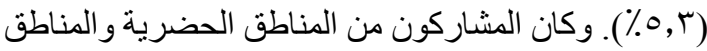

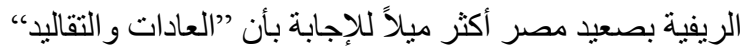

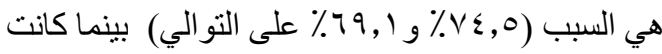

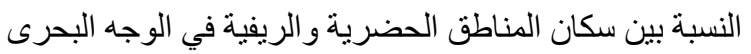

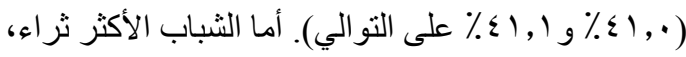

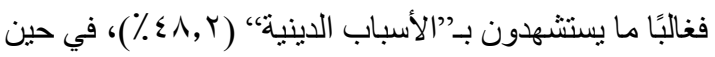

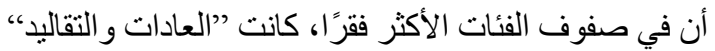

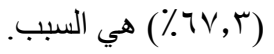

و عند سؤ الهم عما إذا كانو اسيجرون عملية الختان لبناتهم في المستقبل، أجاب سبعة من بين كل عشرة شملهم البحث بـ "نعم"، وجاءت النسب متساوية إلى حد ما بين الذكور

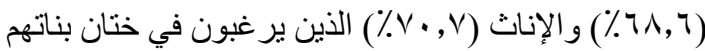

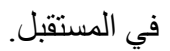

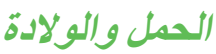
بطرح هذا القسم من فصل الصحة مجمو عة من الأسئلة التي

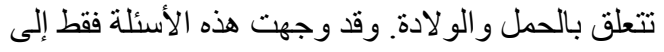

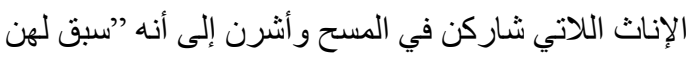

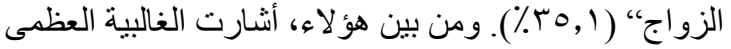

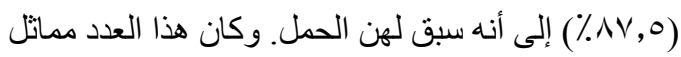

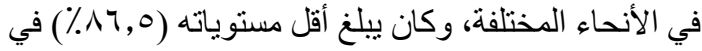

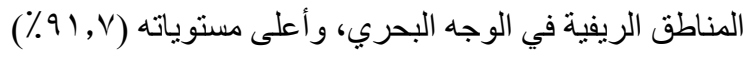
في المحافظات الحضرية. وكما هو منوقع، كانت أعلى نسب التباته

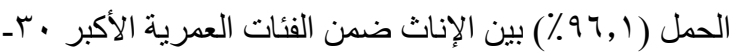

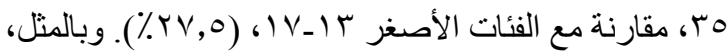

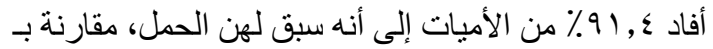

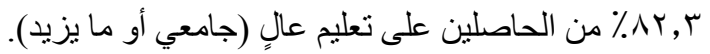
و أثشار عدد من الإناث المتزوجات اللاتي هن في المستوى لالئ

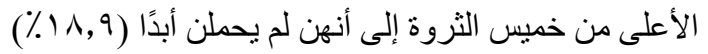
و هو ضعف هؤلاء الذين ينتمون إلى الخميس الأدنى ( •,9٪). 


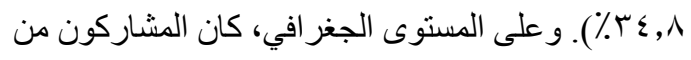

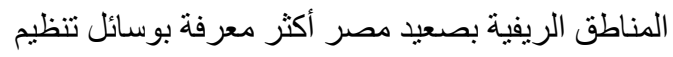

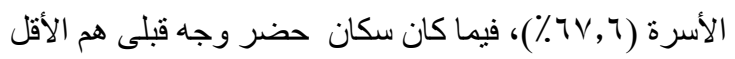

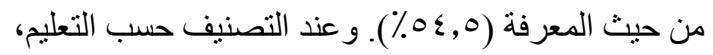

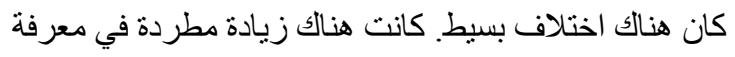

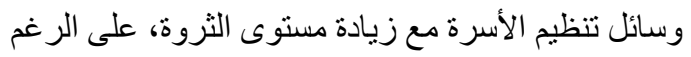

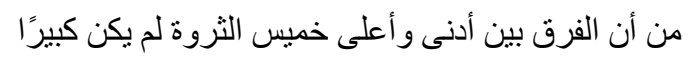

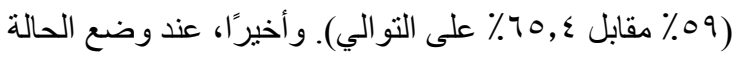

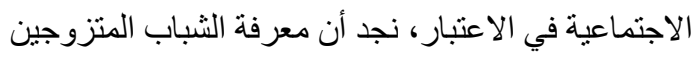

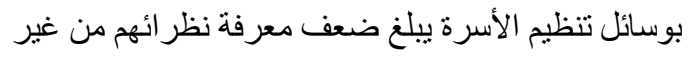

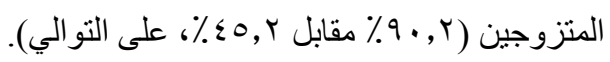

وكانت وسيلة تنظيم الأسرة الأكثر معرفة بين جميع المشاركين

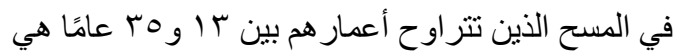

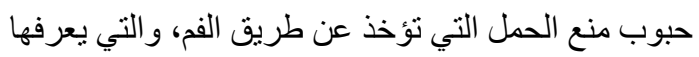

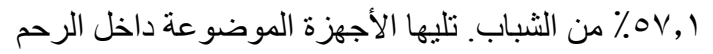

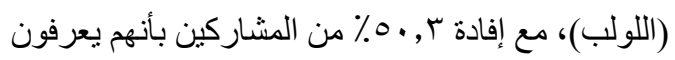

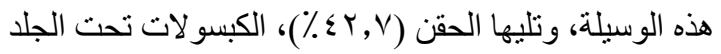

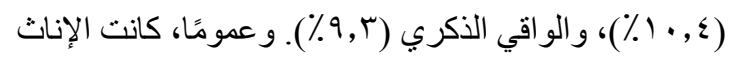

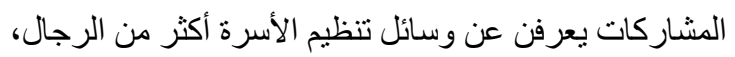

باستثناء الو اقي الذكري (الثكل r r r I ).

وفيما يتعلق بمصادر المعلومات المتعلقة بوسائل تنظيم الأسرة،

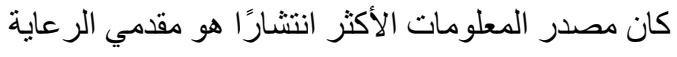

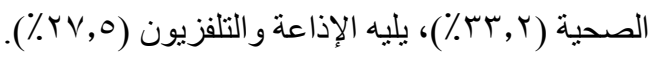

و أشارت الغالبية العظمى من الإناث (1, إب^٪) إلى أن الو لادة

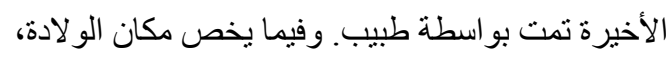

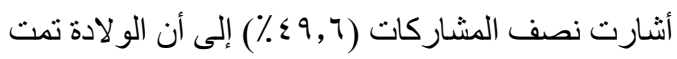

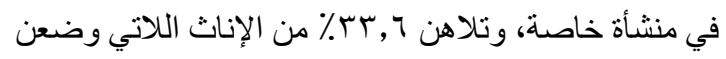

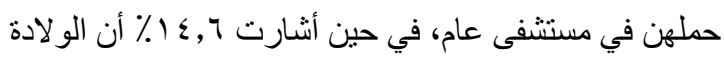

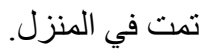

و أثنارت حو الى ثلث المشار كات (0, ب \%) إلى أنهن خضعن

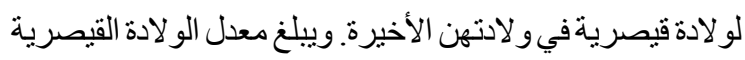

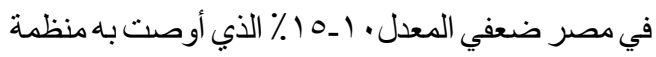
الصحة العالمية (1985 فorld Health Organization ). و عند إجر اء التحليل علي المستوى الجغر افي، أفادت نصف

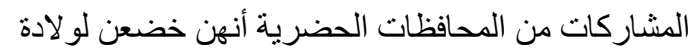

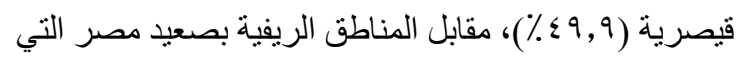

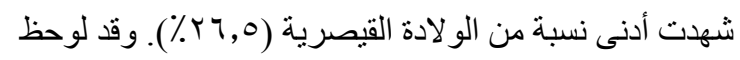

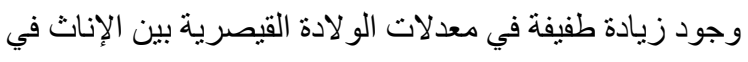

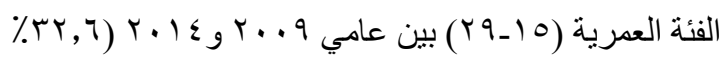

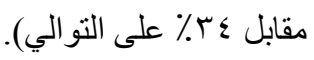
وسائل ثنطظمبم الأسبرة

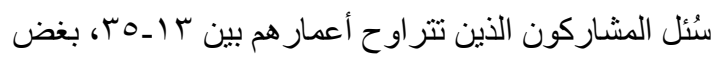

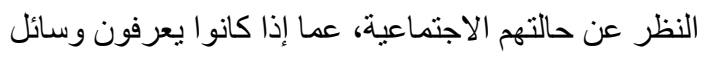

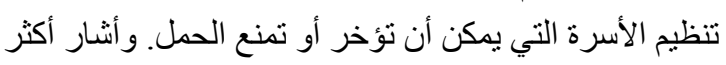

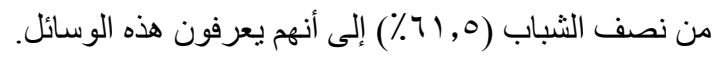

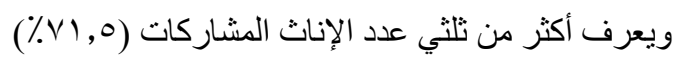

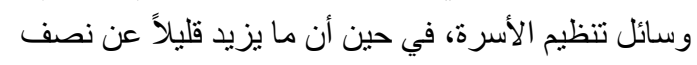

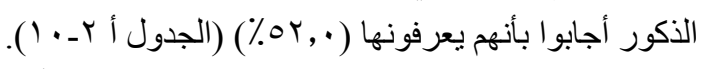

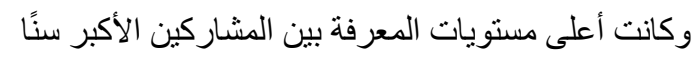

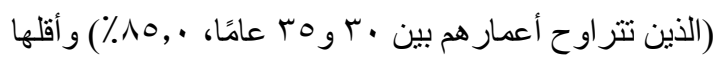

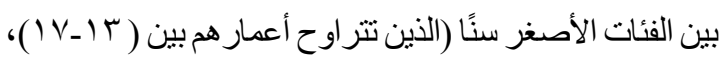

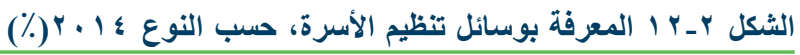

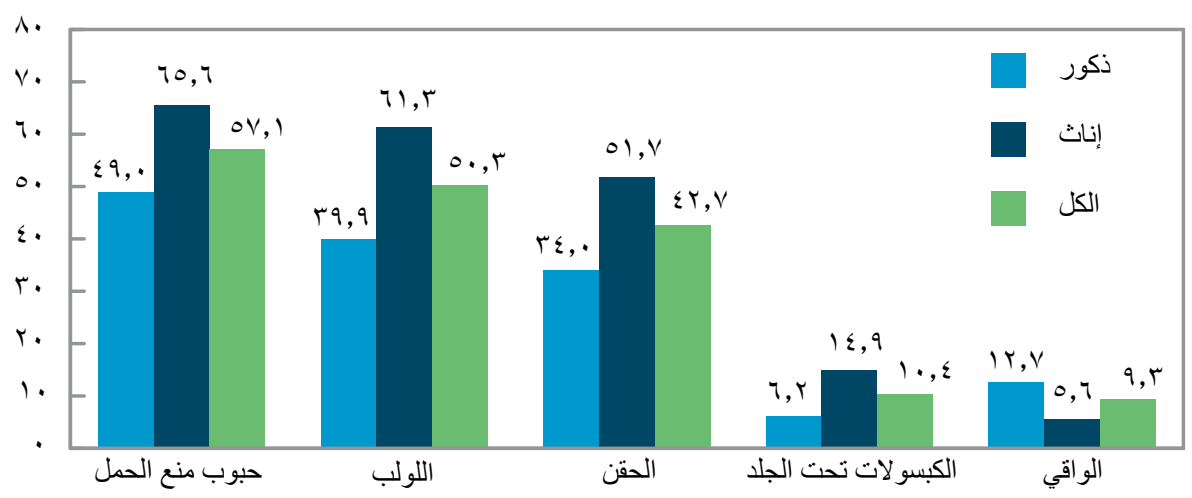




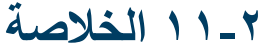

ثُلقي أسئلة قسم الصحة لمسح النشء و الثباب في مصر لعام

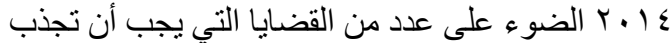

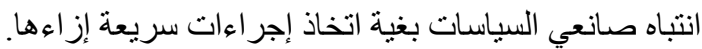

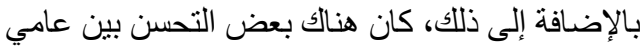

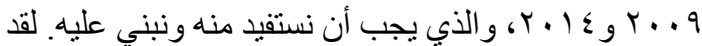

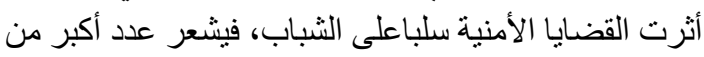

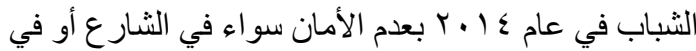

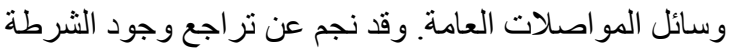

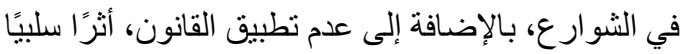

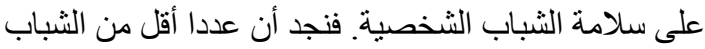

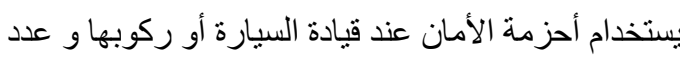

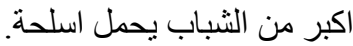

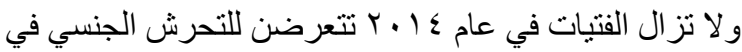

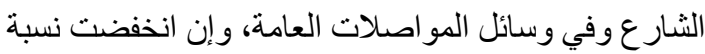

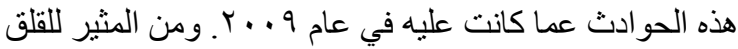

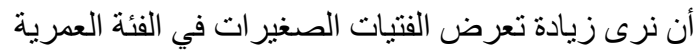

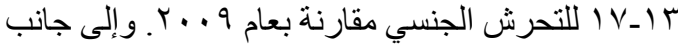

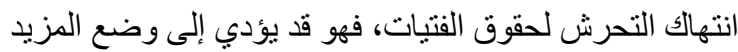
من القيود على حركة الفتيات ومشاركتهن في المجالات فئل العامة.

إن العادات الغذائية السائدة بين الثباب، إلى جانب عدم الثبان

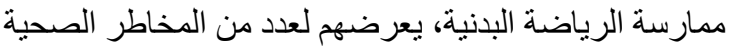

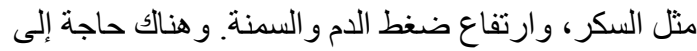
تنظيم حملات تو عية لتنقيف الثباب و أولياء أمور هم حول

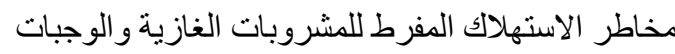
السريعة. وقد تعود المشاركة المحدودة للفتيات الصغير الصنات الصنات

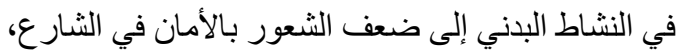

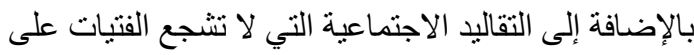

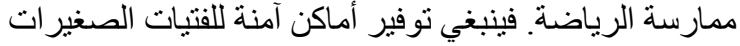

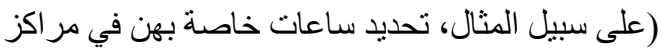

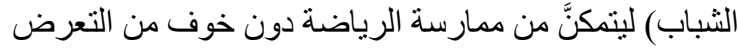

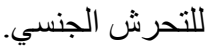

لقد تحسنت مناقثة الآباء و الأمهات للتغيير ات المصاحبة

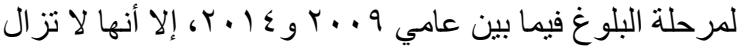

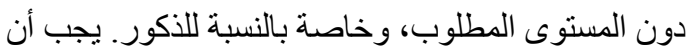

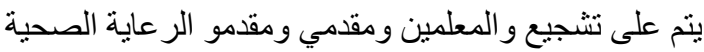

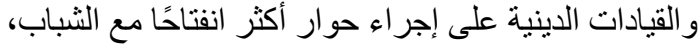

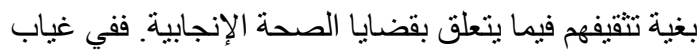

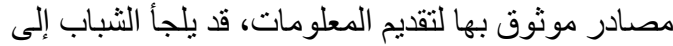

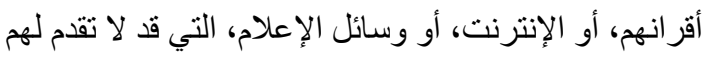

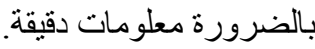

وفي القسم الأخير من فصل الصحة، طُلب من جميع

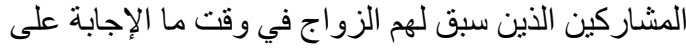

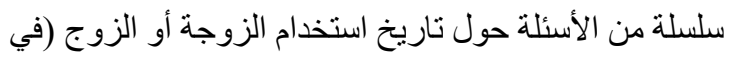

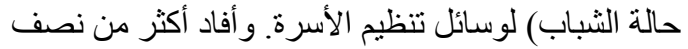

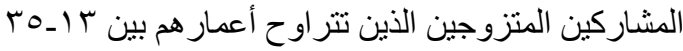
(أنهم (أو الزوج) قد استخدمو ا وسائل تنظيم الأسرة

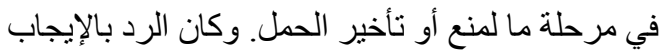

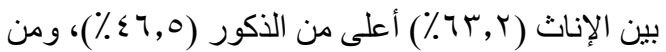

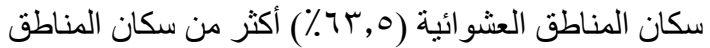

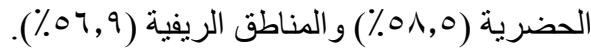

ومن الجدير بالذكر أن عدد المشاركين الذين أنشاروا إلى الى

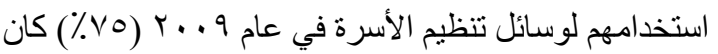

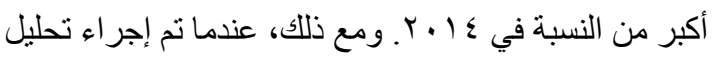

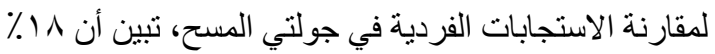

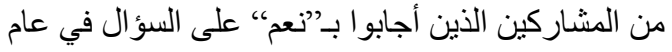

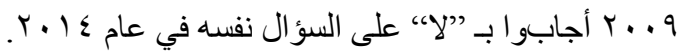
ويمكن أن يُعزى هذا التناقض إلى عدم تذكر هم لذلك بدقة، أو أو الهو سوء فهمهم للسؤال في أي من الجولتين.

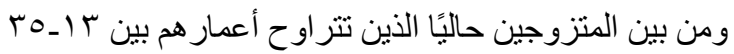

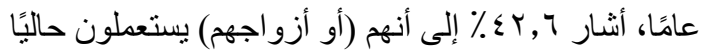
وسائل تنظيم الأسرة. ويبدو الاستخدام الحالي في أقل معدلاته إنها

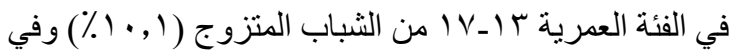

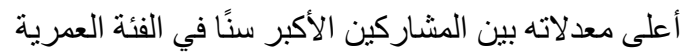

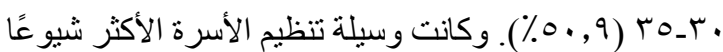

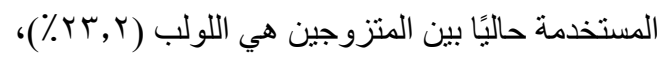

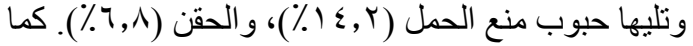

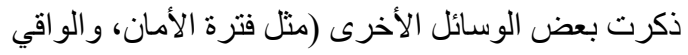

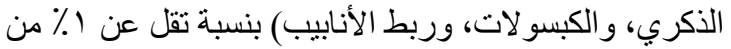

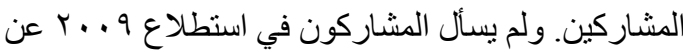
وسائل تنظيم الأسرة التي كانو ا بستخدمو ها في ذلك الوقت التهات

وسُئل الأفر اد المتزوجين المشاركين في المسح الذين أثشاروا

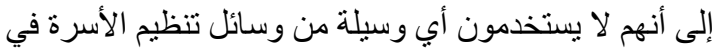
الوقت الر اهن إذا كانوا (أو أزواجهم) ينوون استخدام وسائل

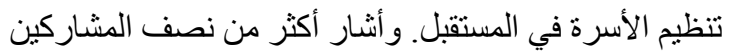

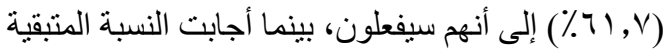

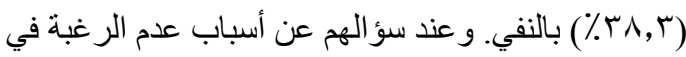

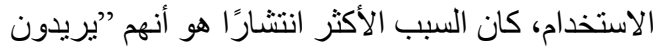

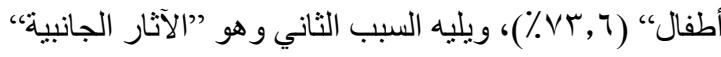
لوسائل تنظيم الأسرة (10,0) (1\%). 


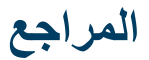

Beusenberg, M., Orley, J. A User's Guide to the SelfReporting Questionnaire (SRQ). World Health Organization:

Division of Mental Health. 1994.

Daradkeh, T. K., Alawan, A., Al Ma'aitah, R., \& Otoom, S. A. (2006). "Psychiatric morbidity and its sociodemographic

correlates among women in Irbid, Jordan." Eastern Mediterranean Health Journal 12 (S 2): S107-S117.

Gail C. Rampersaud, Mark A. Pereira, Beverly L. Girard, Judi Adams, Jordan D. Metzl, Breakfast Habits, Nutritional

Status, Body Weight, and Academic Performance in Children and Adolescents, Journal of the American

Dietetic Association, Volume 105, Issue 5, May 2005, Pages 743-760.

M Mohsen Ibrahim, Albertino Damasceno, Hypertension in developing countries, The Lancet, Volume 380, Issue

9841, 11-17 August 2012, Pages 611-619.

Maziak, W. et al. "Socio-demographic correlates of psychiatric morbidity among low income women in Aleppo,

Syria." Social Science \& Medicine, 2002, 54:1419-27.

Rahman, A., lqbal, Z., Lovel, H., and Shah, M.A. (2005).

"Screening for postnatal depression in the developing world:

A comparison of the WHO Self-Reporting Questionnaire (SRQ-20) and the Edinburgh Postnatal Depression

Screen (EPDS)." Journal of Pakistan Psychiatric Society 2: 69-72.

Peden, M. et al. (eds.) (2008). World Report On Child Injury Prevention. Geneva: World Health Organization.

Downloaded 23 November 2010 from:

http://whalibdoc.who.int/publications/2008/9789241563574_eng.pdf

Tran, Jackie, Masoud Mirzaei, and Stephen Leeder. "Hypertension: its prevalence and population-attributable

fraction for mortality from stroke in the Middle East and North Africa." Circulation. Vol. 122. No. 2. Page

530

UNICEF. The Dynamics of Social Change: Towards the Abandonment of Female Genital Mutilation/Cutting in Five

African Countries. October, 2010.

Vizcarra, B., Hassan, F., Hunter, W. M., Muñoz, S. R., Ramiro, L., and De Paula, C. S. "Partner violence as a risk factor

for mental health among women from communities in the Philippines, Egypt, Chile, and India." Injury

Control and Safety Promotion 11 (2):2004. 125-129.

World Health Organization. 1985. “Appropriate technology for birth," Lancet 2(8452): 436-437

World Health Organization. 1985. "Appropriate technology for birth," Lancet 2(8452): 436-437.
يمتلك الثباب، وخاصة الفتيات، معرفة محدودة بفيروس نقص المناعة البشري وطرق انتقاله، وحتى هذا القدر الضئيل

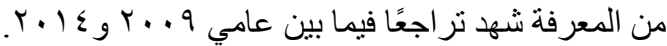

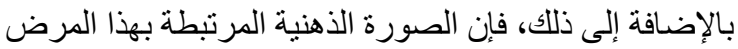
سائد بشكل منذر، حيث أبدى أقل من و احد من كل خمسة إنه

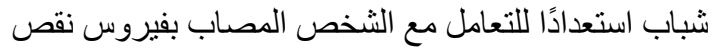
المناعة البشري. ومع وجود مثل هذه المستويات المنخفضة من من مئن

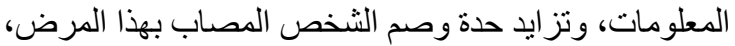
قد لا يتمكن الثباب من حماية أنفسهم أو أزو اجهم أو ذريتهم الثهاب المستقبلية من الإصـابة بفيروس نقص المناعة البشري.

و لا تز ال قضية ختان الإناث مثيرة للقلق، على الرغم من أن

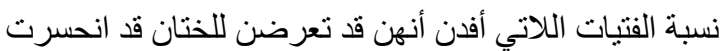

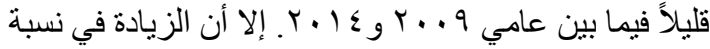

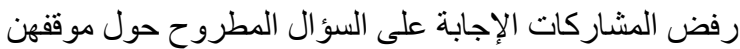

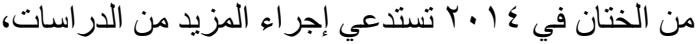
حيث يمكن أن يشبر ذلك إلى وجود تتاقضات فكرية إزاء هذه التهاء

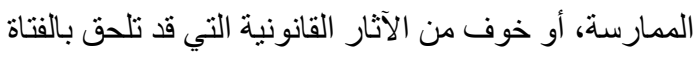

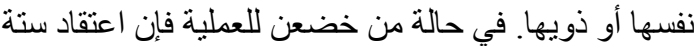

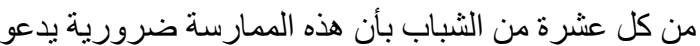

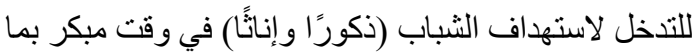
يسمح بمساعدتهم وحثهم على التأمل في معتقداتهم الخاصة التها

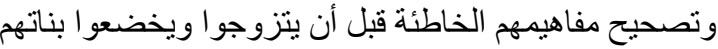

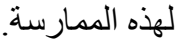

و على الرغم من زيادة الوعي بوسائل تنظيم الأسرة بقدر يبدو

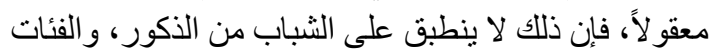

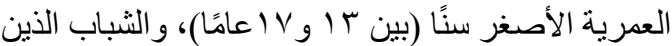

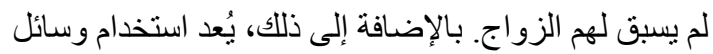

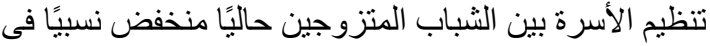

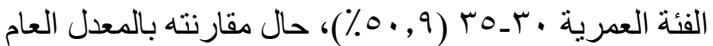

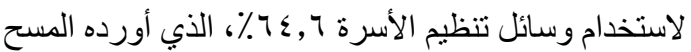

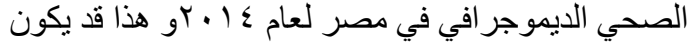

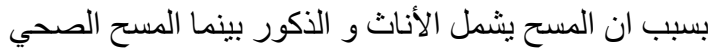

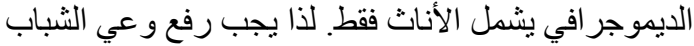

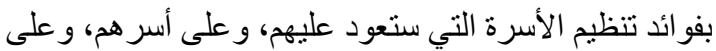

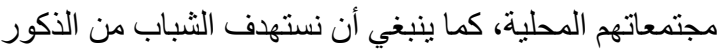

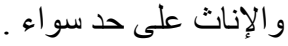

وختامًا، فقد أظهر مسح الثباب في مصر لعام ع ( ـ ع عددًا

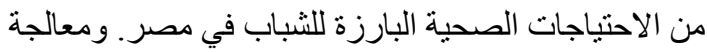
تللك الاحتباجات الصحية بستوجب تدخل قطاعات متعددة تثمل

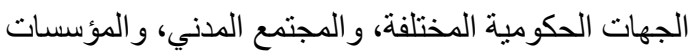
الدينية، ووسائل الإعلام، فضلاً عن أولياء الأمور ـ و الأهم من الكن ذللك، يجب أن تشرك تلك التدخلات الثباب أنفسهح لتمكنه من الأل الته هن

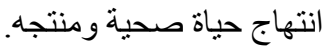




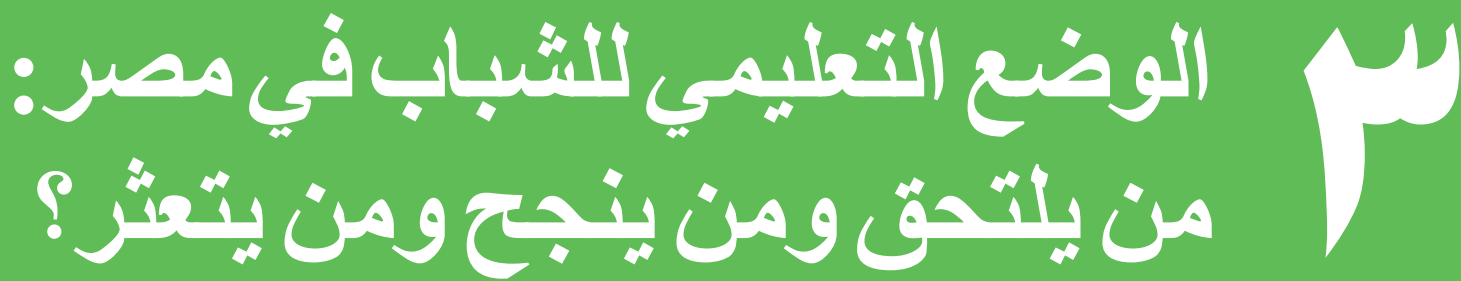

كارولين كر افت

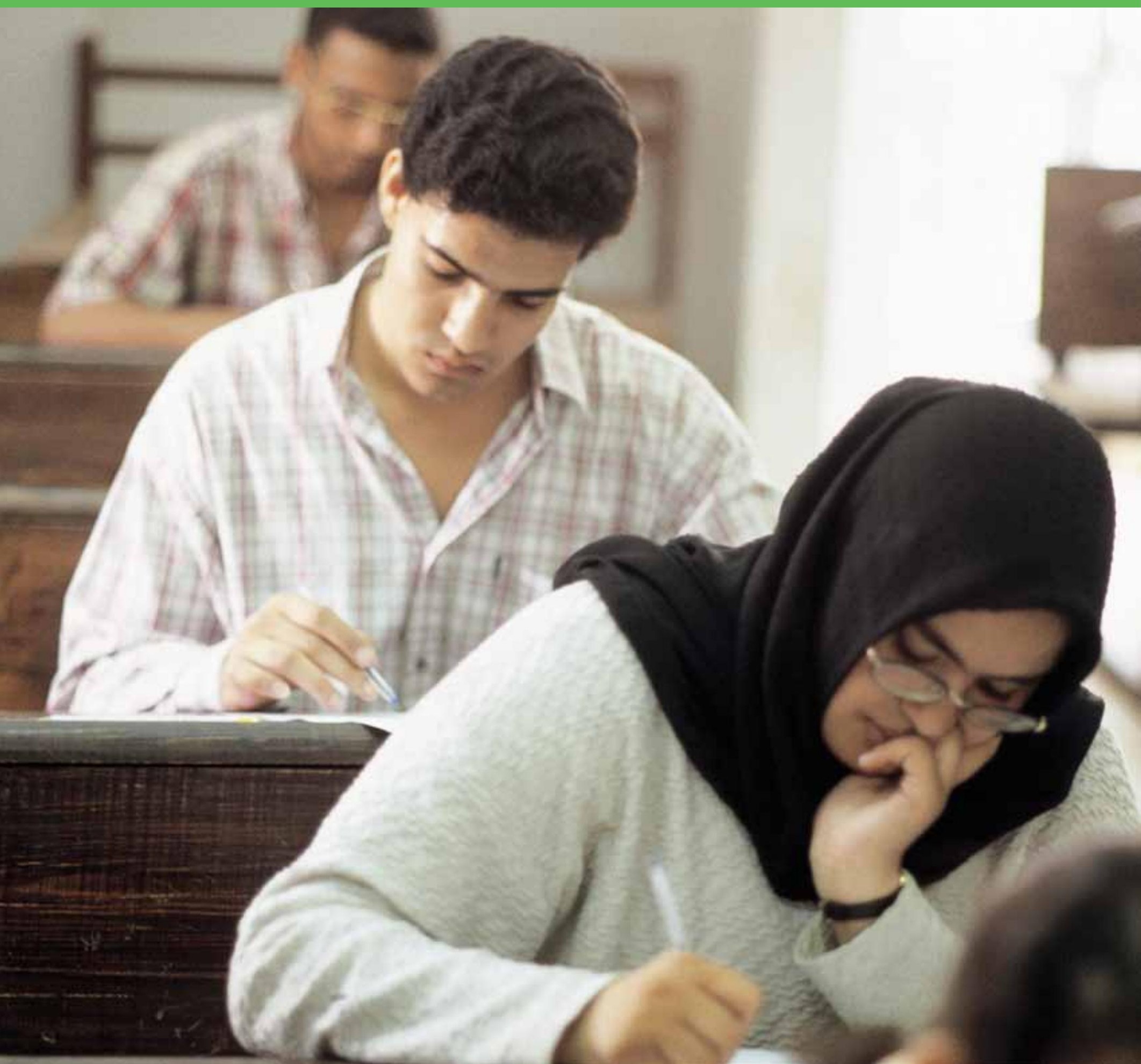


بالمدارس. وتتكون المرحلة الابتدائية من ستة صفوف'،

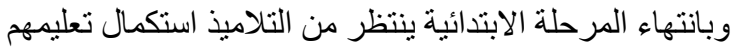
لنلاث سنوات أخرى إضافية بالتعليم الإعدادي.

وبنهاية المدرسة الإعدادية ووفقًا للارجات التي أحرزها

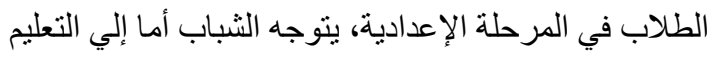
الثانوي العام أو التعليم الثانوي الفني. ويعتبر مسار الثانوية الثانية

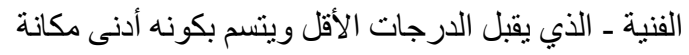
ـ مرحلة منتهية دائمًا على الرغم من استمر ار عدد فليل من

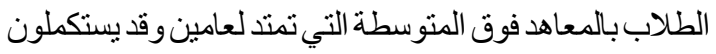

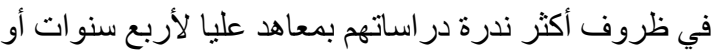

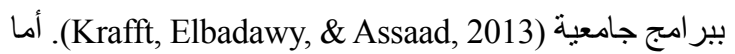
مسار التعليم الثانوي العام فيعطي ملتحقيه ضمانة غبر مباثرة

لاستكمال در استهم في الجامعة. وتستغرق بر امج الثانوية

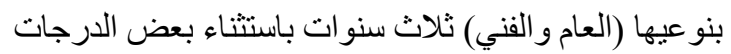
الثانوية الفنية التي تستغرق خمس سنو اتوات. وتحدد نتائج

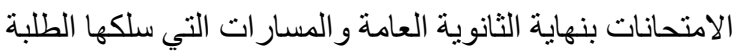

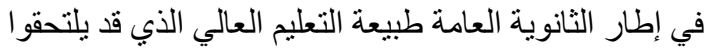

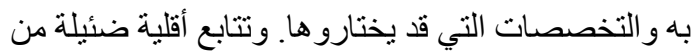

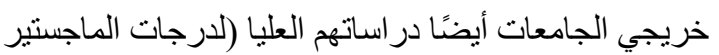

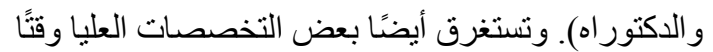

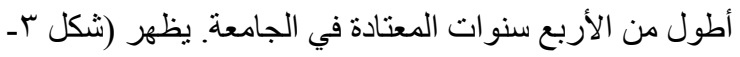
(1) السبل المتوقعة التي قد يسلكها التلاميذ عند التحاقهم بالنظام

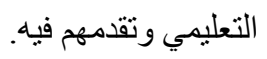

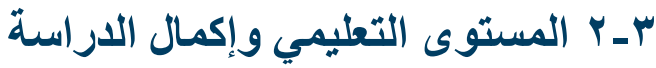

ونظرًا لأن سن المشاركين في مسح النشء و الشباب أصبح أكبر الآن، ومن ثم يكون بمقدورنا أن نتعرف على المستوى

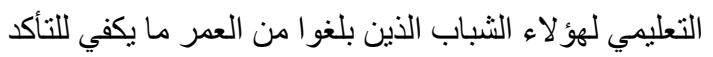

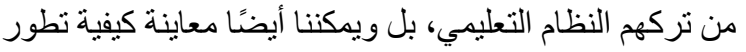
المستوى التعليمي بمرور الوقت، وذللك كله بسبب وجود شبعاب

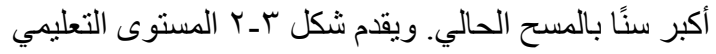

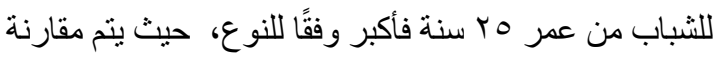

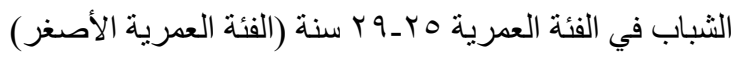
بالثباب فى الفئة العمرية . ـــ سنة (الفئة العمرية الأكبر)

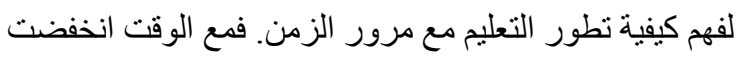

يلعب التعليم دوراً محورياً في تشكيل التنمية البشرية و الفرص المتوفرة للثباب فى مصر بالإضافة إلى التنمية الإقتصادية و الاجتماعية للبلد بأسر ها. ومن المهم فهم التقدم الذى حدث فى التعليم فى مصر و التحديات التى ومى ونى تو اجهه و السياسات المدكنة لتخطى هذه التحديات

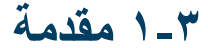

يضمن الدستور المصري للثباب الحق في التعليم المجاني،

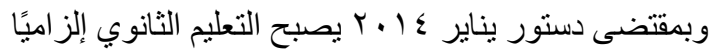

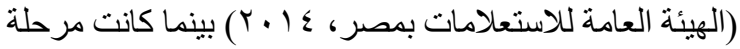
التعليم الأساسي (الابتدائية و الإعدادية) هي الإلز امية فيما سبق.

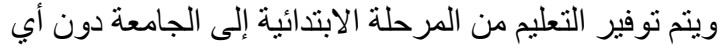
مصاريف في الوقت الذي لا يتوفر فيه التعليم قبل الابتدائي

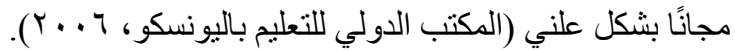

ولقد خصص الدستور للإنفاق القومي على التعليم نسبة لا لإنيا تقل عن ء ٪ من صافي الدخل القومي، على أن تزيد تدريجيًا في ضوء زيادة منوسط الانفاق العالمي على التعليم (الهيئة

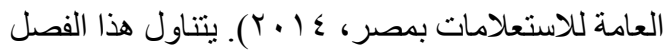

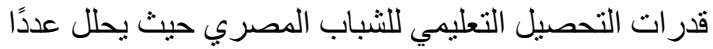

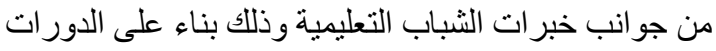

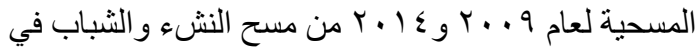

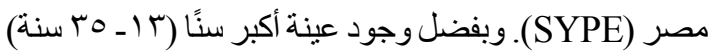

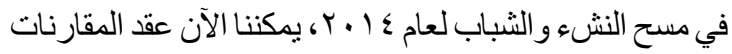
بين الفئات العمرية للثباب الذي استكملو ا تحصيلهم العلمي باستخدام هذه المسح.

يلتحق معظم النشء بنظام التعليم المصري في المرحلة

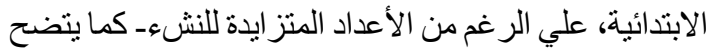

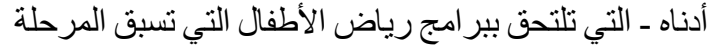
الابتدائية. ويعتبر سن السادسة هو السن المحدد للالتحاق

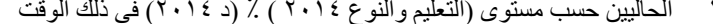

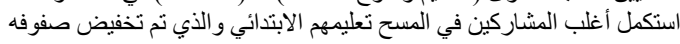

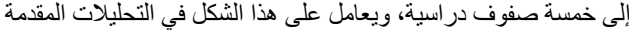

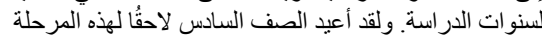




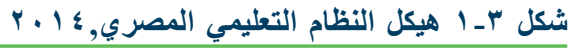

معاهد فوق متوسطة

سنتان

معاهد عليا

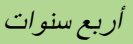

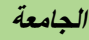

أربع سنوات الجات

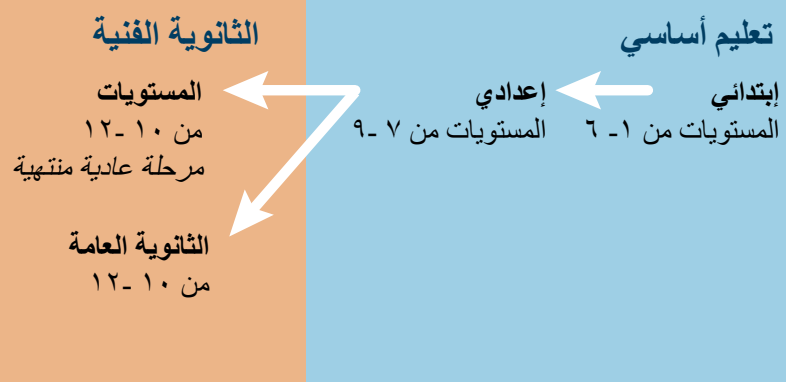

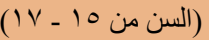

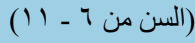

ملحوظة: تعتبر الأعمار الموجودة بين الأقواس هي المثالية بافتر اض الالتحاق بالمرحلة التعليمية في الوقت المثلي ودون تكرار أي من الصفوف الدراسية.

تعليم إعدادي، دون أي تغير عبر الفئات العمرية، انخفضت

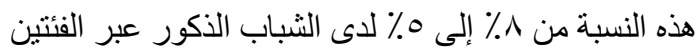
العمريتين. ونظرًا لندرة اعتبار بالثانوية العامة شهادة نهائية،

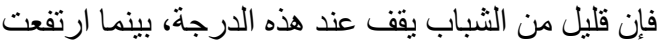

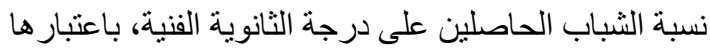

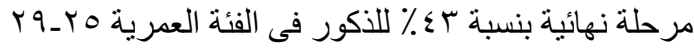

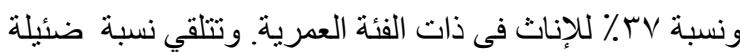

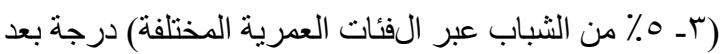

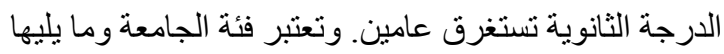

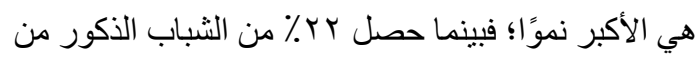

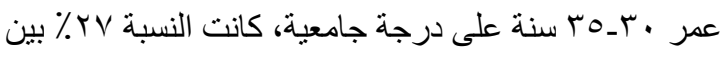

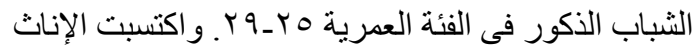

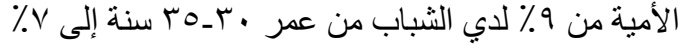

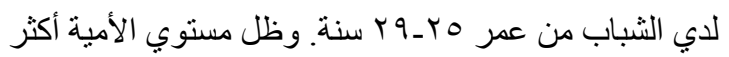

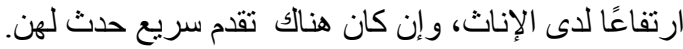

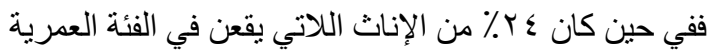

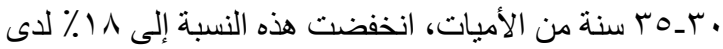

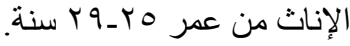

وتتر اوح نسبة الثباب الحاصل على التعليم الابتدائي فقط بين

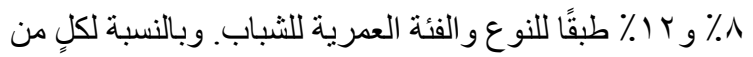
الذكور و الإناث تناقصت نسبة الحاصلين منهم على التعليم الابتدائي فقط عبر مرور الزمن حيث ارتفع مستو اهم التعليمي.

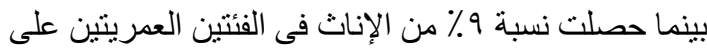

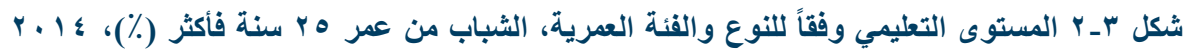

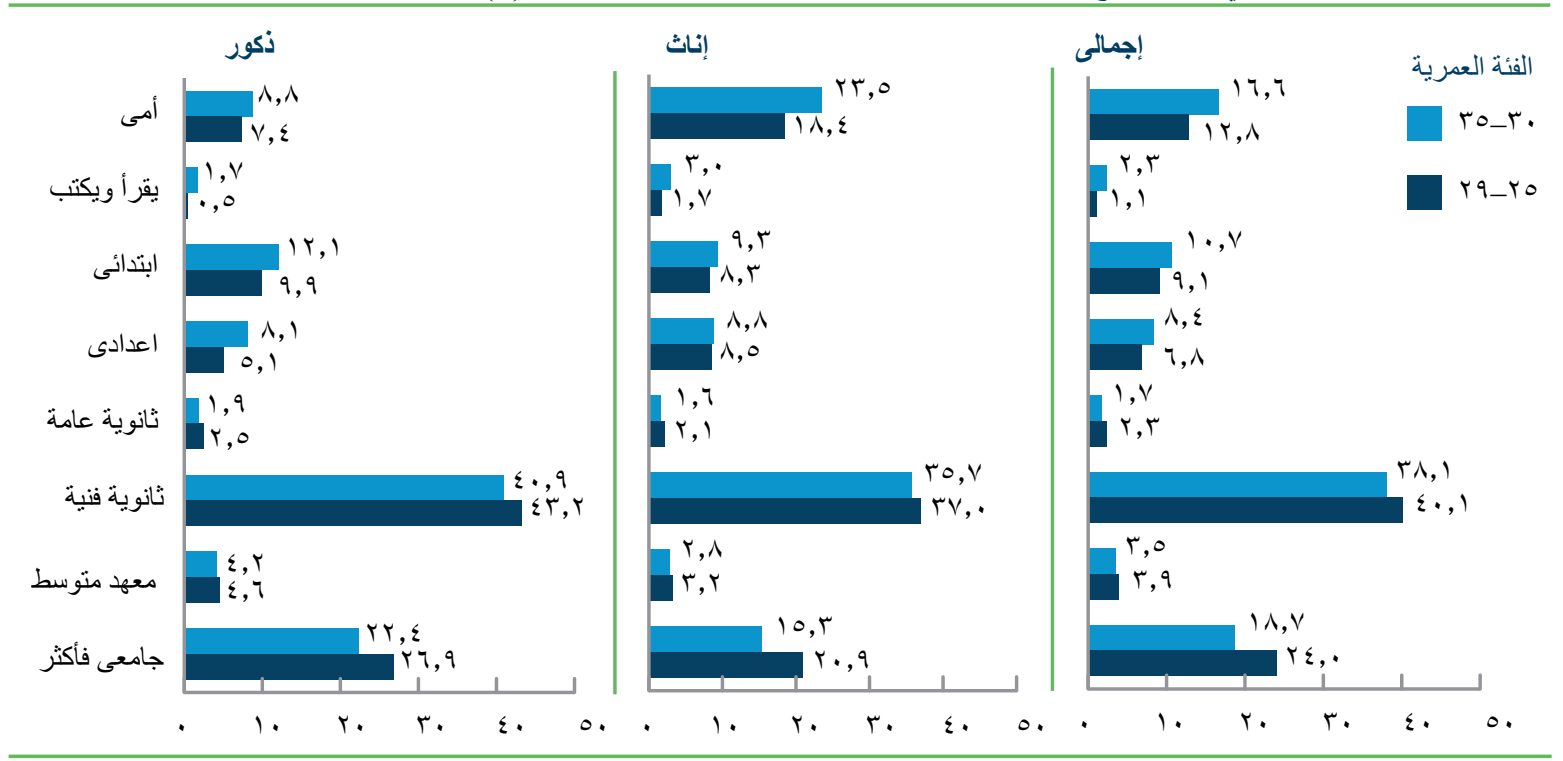




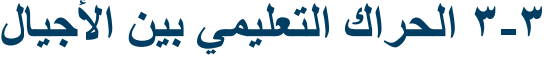

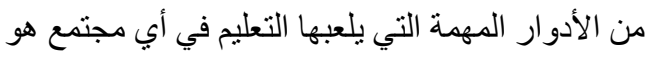

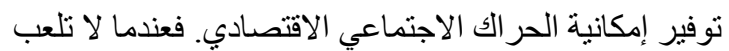

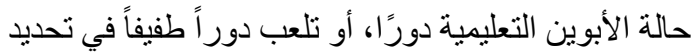
مستقبل الأطفال، فإن ذلك يعد علامة علي الحرّة الحر الك الاجتماعي

الاقتصادي أو علامة علي تساوي الفرص للجميع. ويعد هذا

الحراك أمر اً هاماً من منظور العدالة الاجتماعية ومن أجل الجل

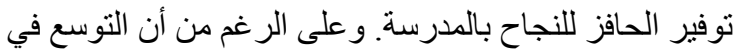

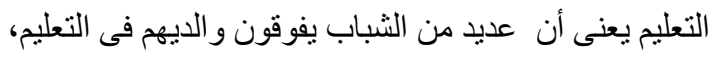

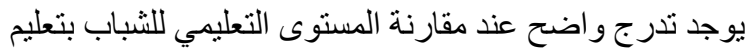

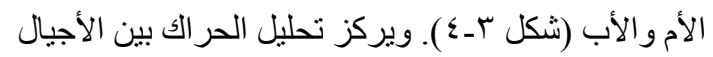

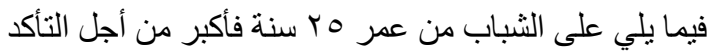
من أن الثباب استكملوا المرحلة التعليمية النهائيةً.

نحو ربع الذين يولودن لأباء أميين يصبحون هم أنفسهم أميين،

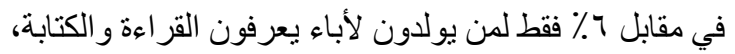

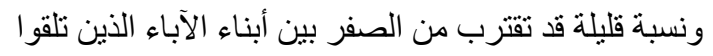

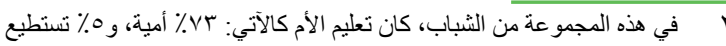

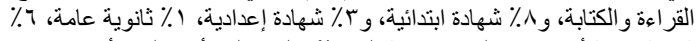

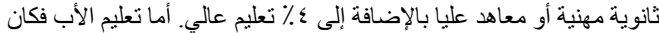

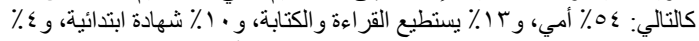

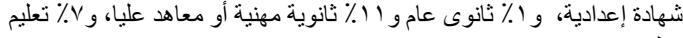

إضافة كبيرة؛ فقد ارتفعت نسبة من حصلن على درجة جامعية

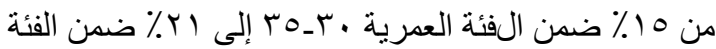

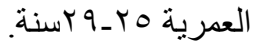

ولفهم التقدم الذي يتم إحر ازه في كل مرحلة در اسية، يعتمد

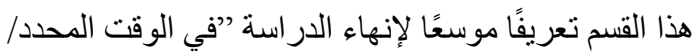

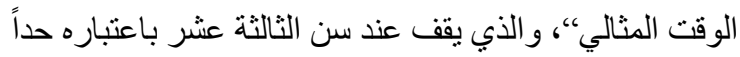

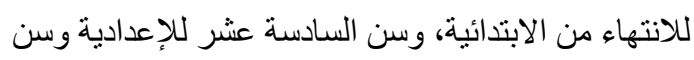

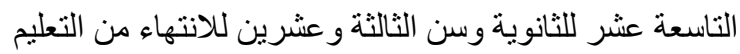

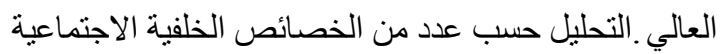

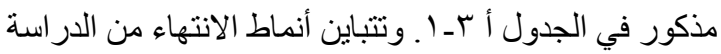

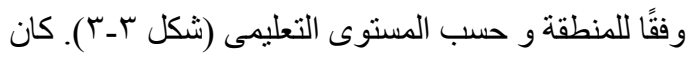

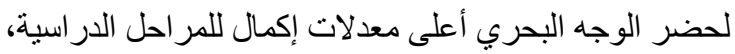

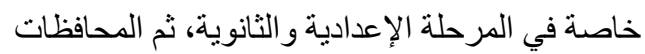

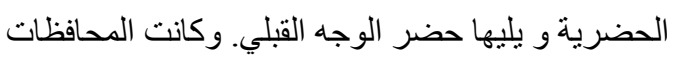
الحدودية هي الأدنى في معدلات إكمال الدر استة الابتدائية

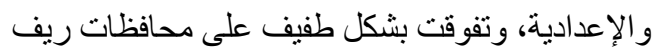

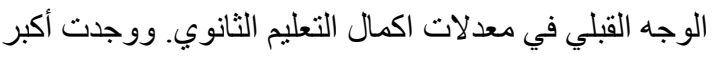

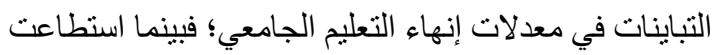

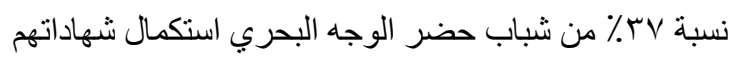

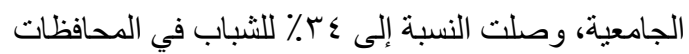

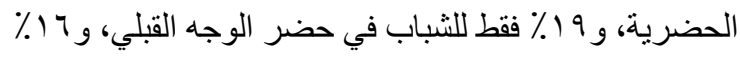
في ريف الوجه البحري و ه 1\% للشباب بالمحافظات الحدودية،

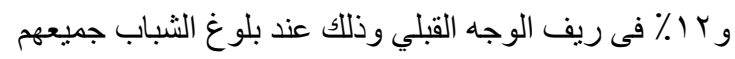

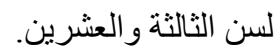

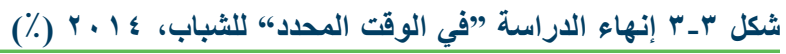

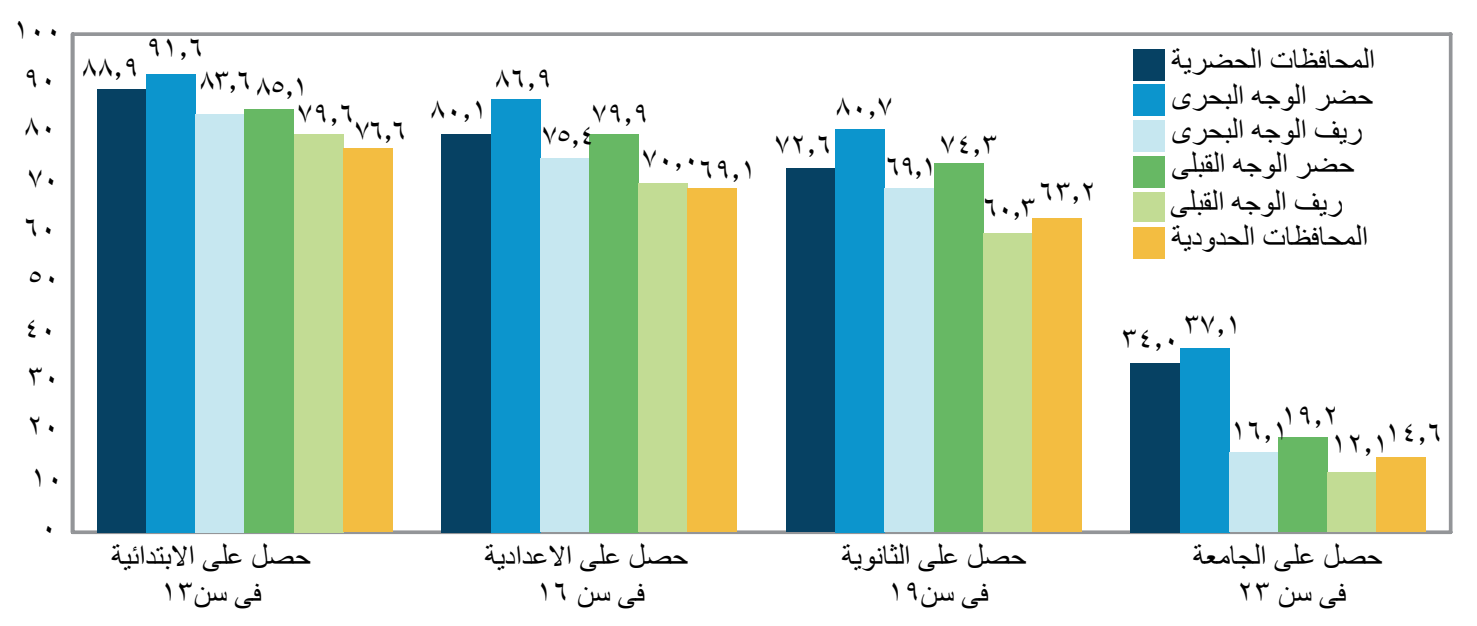

ملحوظة: إنهاء الدر اسة (استكمالها) يشمل كافة الثباب و لا يشترط دخول مسنوى دراسي معين. 

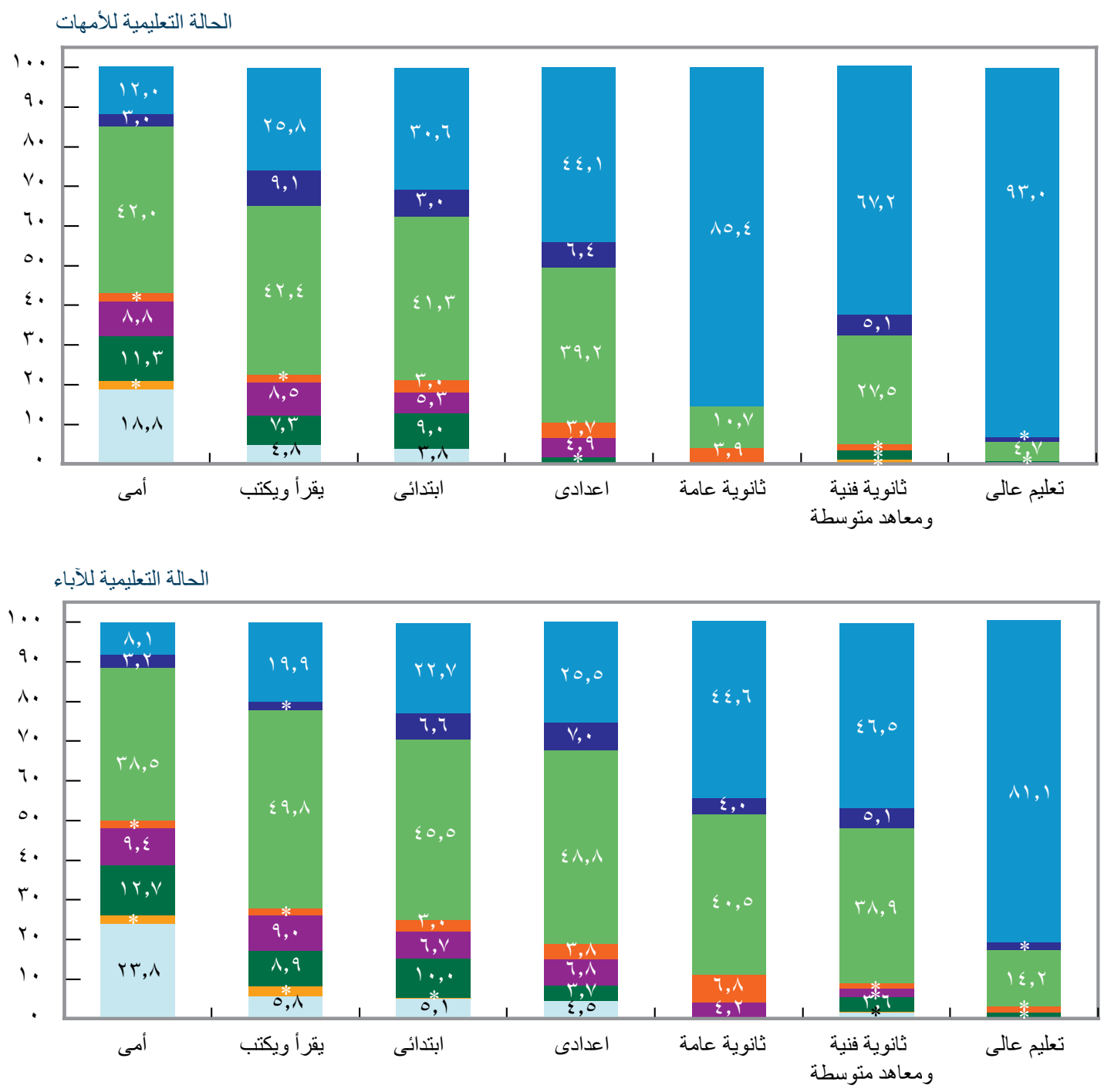

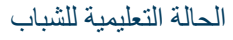

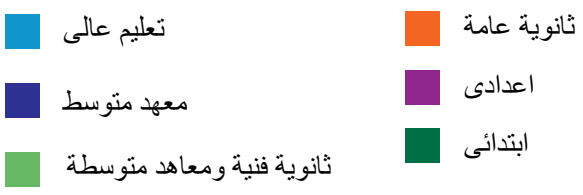

تجاه التعليم العالي. أما الثباب من أعلى درجات السلم

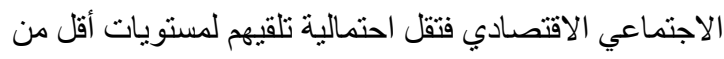

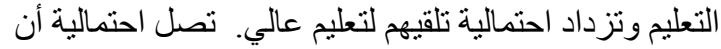

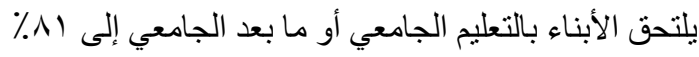
عندما يحصل الآباء على تعليم عالي.
مر احل عليا من التعليم. لقد تلقى ربع آخر من الثباب أبناء

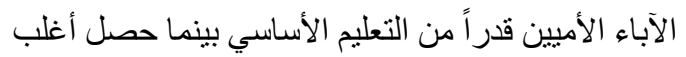

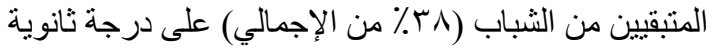

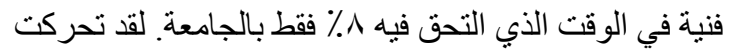

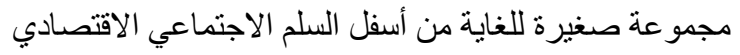


شكل بـ ه نسبة من لم يلتحق مطلقاً بالمدارس حسب النوع

والمناطق (\%)،

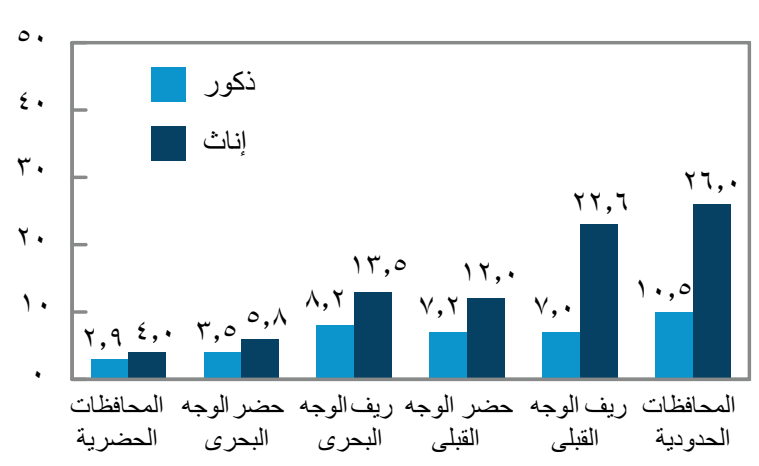

الشباب من الريف، خاصة الإناث، و شباب محافظات الوجه القبلى و المحافظات الحدودية هم الأكثر احتمالا لعدم الإلتحاق

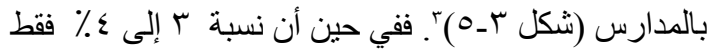

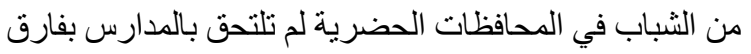
ضئيل بين الذكور (r\%) و الإناث (ع)\%)، بلغت نسبة الثباب من الذكور الذين لم يلتحقو ا بالمدارس إلى قرابة V__٪ في المناطق الريفية المختلفة، مع وجود فجوة واسعة بين الذكور و الإناث، فقد بلغت نسبة الفتيات اللاتي لم يلتحقن بالمدارس

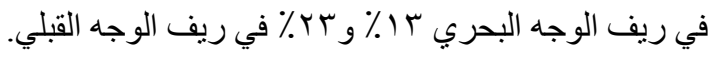

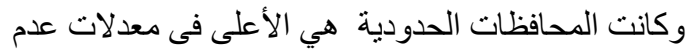

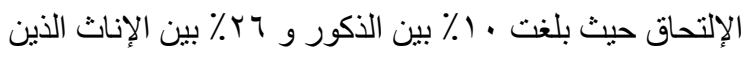

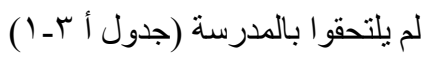

بالإضـافة إلى الاختلافات الكبيرة بين المناطق المختلفة، هناك اختلافات جوهرية فيما يتعلق بفرص عدم الالتحاق بالمدارس الإس الإس

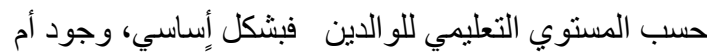

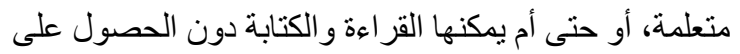

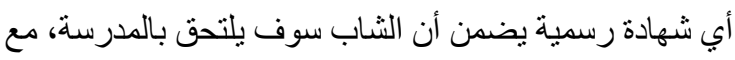

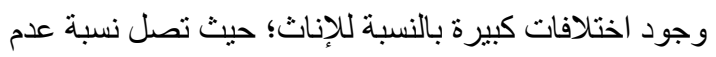

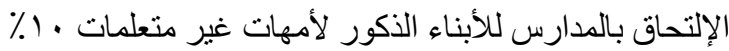

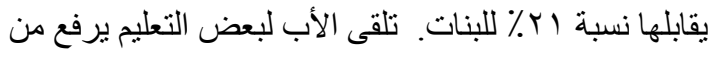
فرص الإلتحاق بالتعليم (انظر، جدول أ س_r).

r ب تعتبر منطقة ومحل الإقامة في هذا الفصل هي محل الإقامة الحالية (وقت الإقل

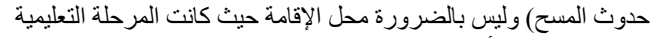

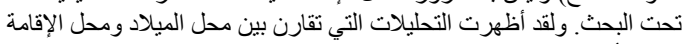

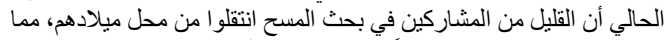

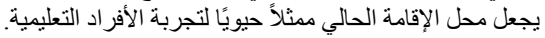

وتظهر حدة الاختلافات بين الأجيال عند النظر إلى تعليم

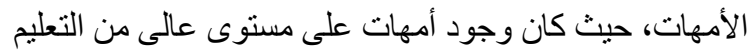

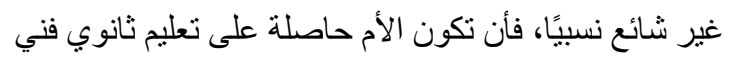

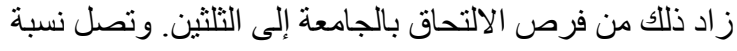

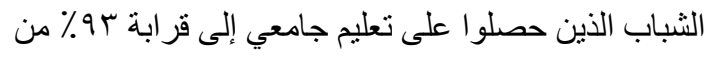

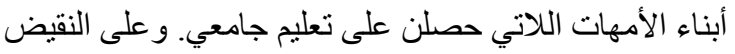

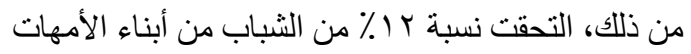

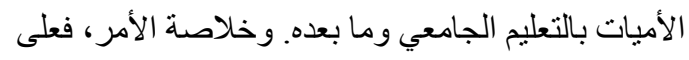

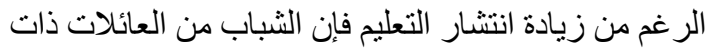

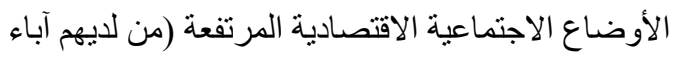

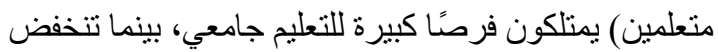

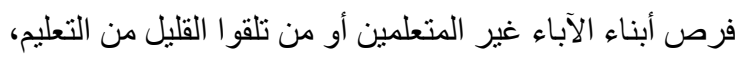

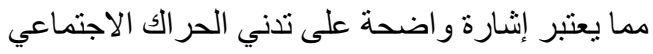
الاقتصادي في المجتمع المصري.

\section{ץ_ـ أنماط الالتحاق بالمدرسة}

ما زالت عملية إلحاق النشء بالمدرسة هي التحدي الأساسي

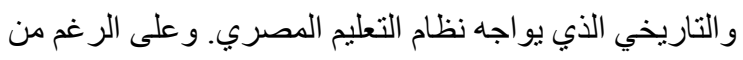

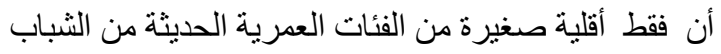

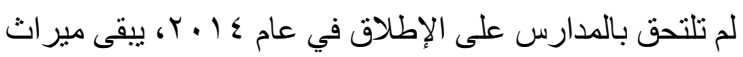

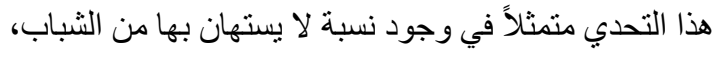

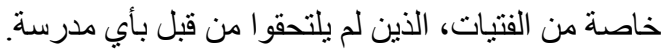

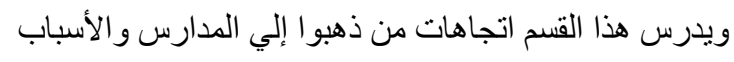
التي دفعت الثباب إلى عدم الالتحاق بالمدارس مع مقار التي المدارنة الثباب من الخلفيات المختلفة.

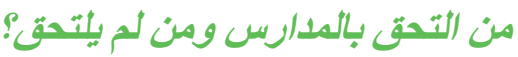

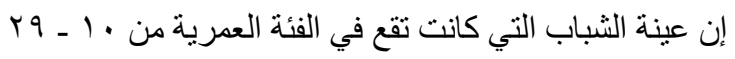

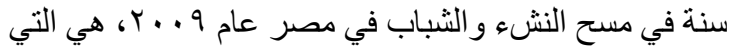

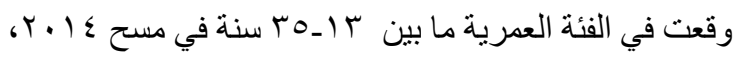

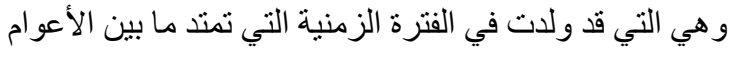

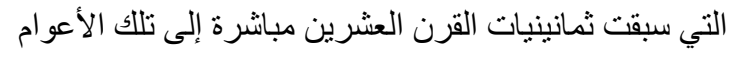

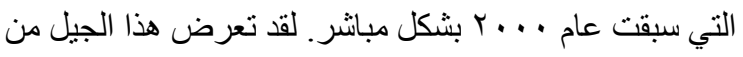

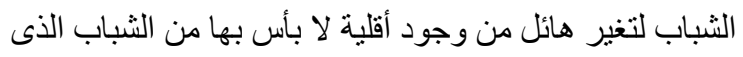

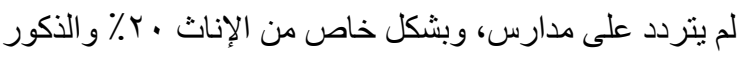

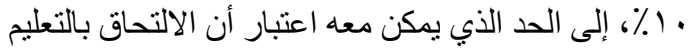

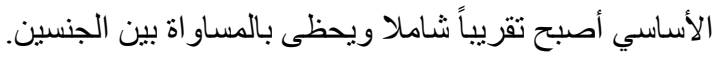

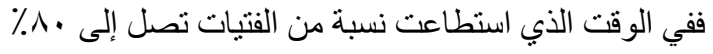

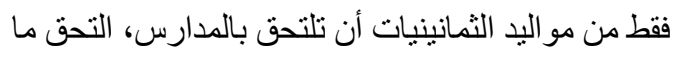

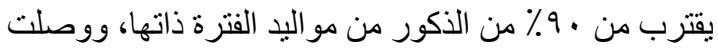

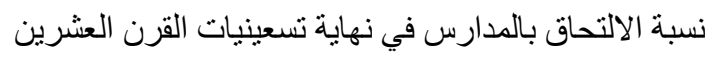

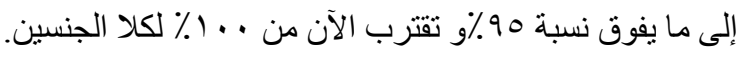


عدم قدرة الأسرة على تحمل تكاليف التعليم كان فى المركز الأول من العن

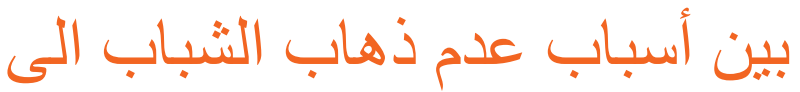
| - مالمدرسة

النتائج الهامة بالجدول. تشير النتائج أن عدم قدرة المنزل

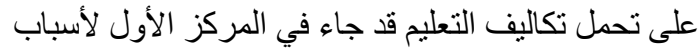
عدم تمكن الثباب من الذهاب إلي المدرسة (و هو السبب الذي الذي

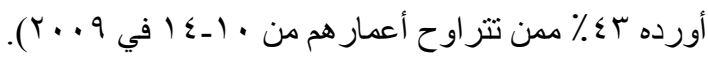

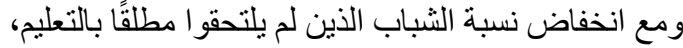

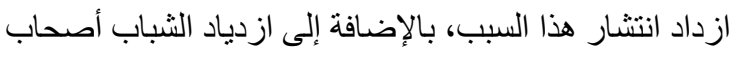

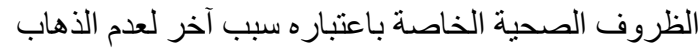

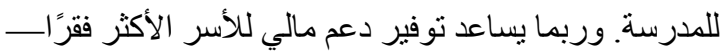

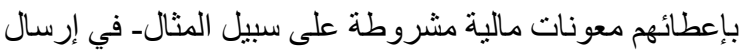
أبنائهم للمدارس على تخفيض نسبة من يتخلفون عن الذهاب

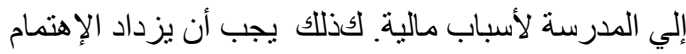

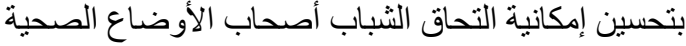

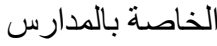

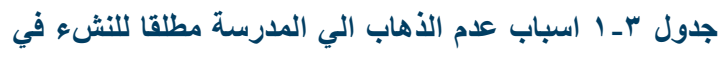

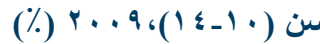

\begin{tabular}{|c|c|}
\hline$\leqslant r, q$ & لاسرة لا تستطيع تعليم او لادهم \\
\hline$r \vee, \Lambda$ & لو الدين ر افضين \\
\hline $19, r$ & الصحة \\
\hline$\wedge, 1$ & يجب ان اعمل \\
\hline$\wedge, 1$ & العادات و التقاليد \\
\hline $0, v$ & ' ل اريد ان اتعلم \\
\hline $0, r$ & الاب لا يو افق \\
\hline$r, 0$ & مساعدة في اعمال الوحدة المعيشية \\
\hline$r, \varepsilon$ & ساعدة الاسرة في العمل \\
\hline 1,9 & المدرسة بعيدة جدا \\
\hline $1, \cdot$ & لا توجد مدرسة \\
\hline $1, \cdot$ & لا يوجد شهادة ميلاد \\
\hline$\cdot$, & 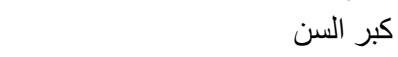 \\
\hline$\cdot, \cdot$ & ل المدرسة ذكور \\
\hline$\cdot, \cdot$ & الزواج \\
\hline
\end{tabular}

ملحوظة: قد يذكر المشارك أكثر من سبب. طبقاً لمسح النشء و الثباب

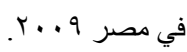

نسبة صغيرة نسبيا من الأفو اج الجديدة لم تلتحق بالتعليم و لكن

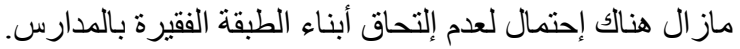

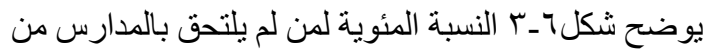

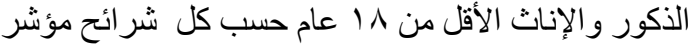

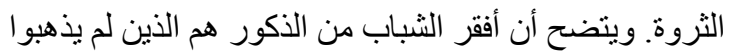
إلى المدرسة (9٪) وتمثل هذه المجموعة أكبر الفجوات بين

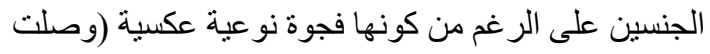

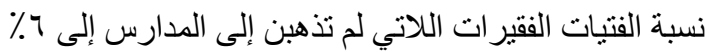

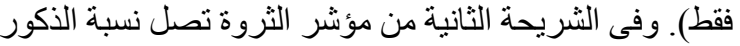

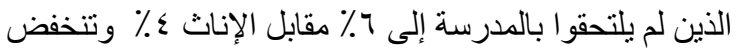

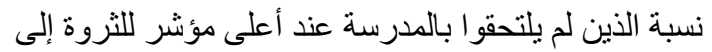

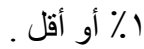

\section{لماذا لم بلتّحق بعض الشباب بالمدارس؟}

قد تقف عديد من المعوقات أمام التحاق الثباب بالمدارس. فكل

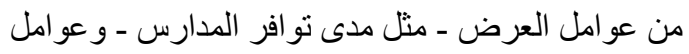

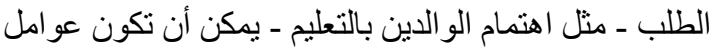

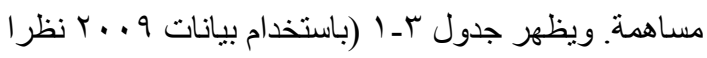

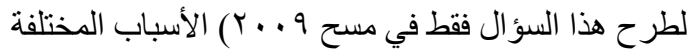
التي أوردها الشباب لعدم التحاقهم بالددارس مطلقًا، وذللك

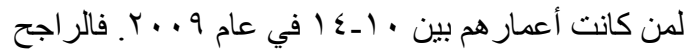

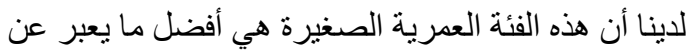

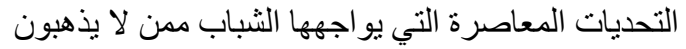

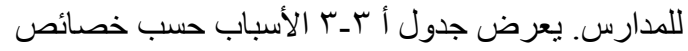
الخلفية الاجتماعية، عبر الأفواج العمرية، وسنناقش هنا بعض الإبل

شكل r-ـ نسبة الثباب تحت سن 1 ا الذين لم يلتحقوا

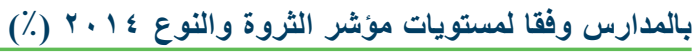

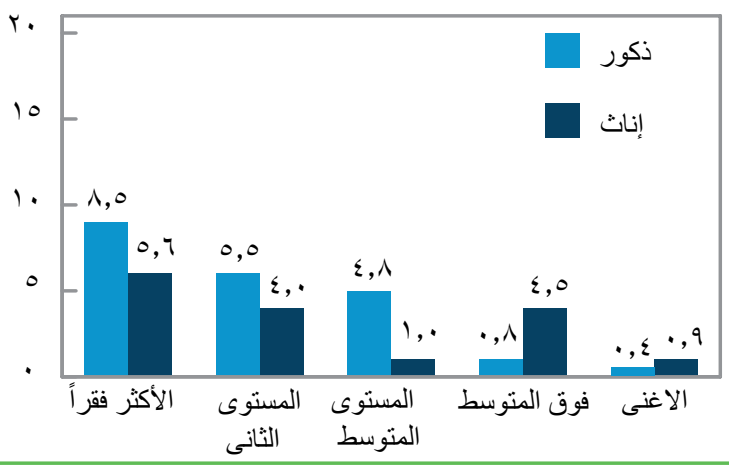


شكل Y_ مخرجات التعلم ونتائج حضور فصول محو الامية

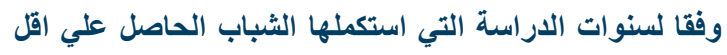

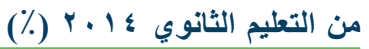

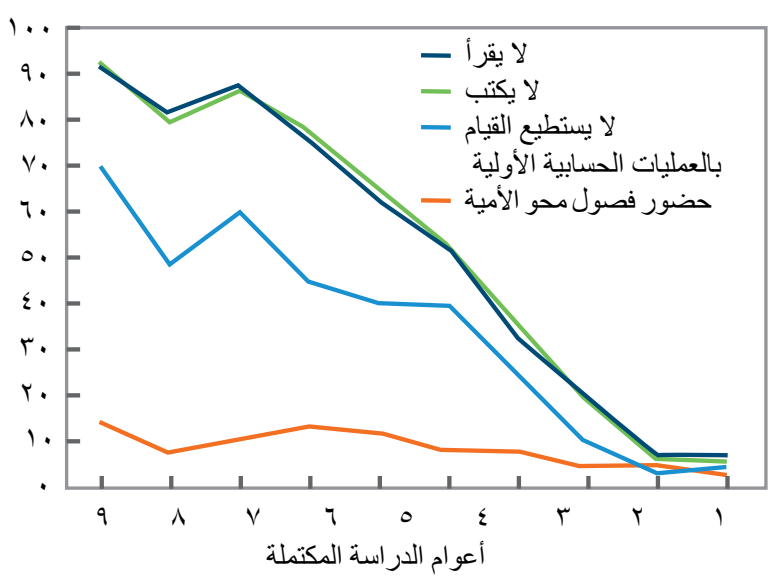

بناءاً على عدد السنوات الدراسية مع الأخذ فى الإعتبار أن البعض كان فى الإنى نظام الإبتدائية لخمس سنوات و البعض الآخر ست الآن سنوات.

ومن الجدير بالملاحظة أن القليل من الثباب يلتحق بفصول

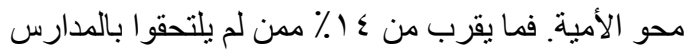

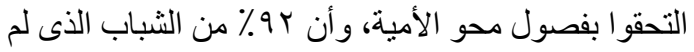

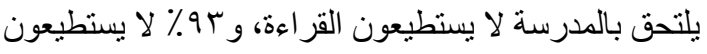
الكتابة و • \\% لا يستطيعون إجر اء العمليات الحسابية البسيطة.

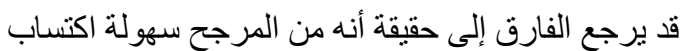

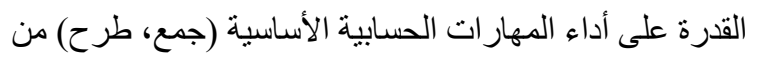

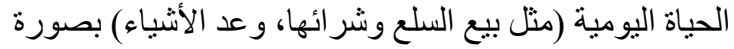

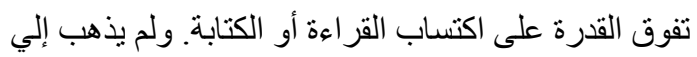

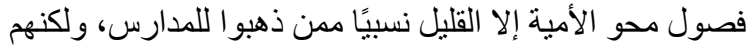

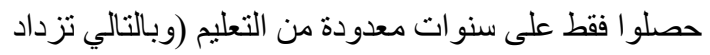

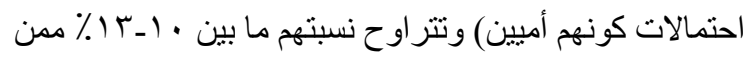

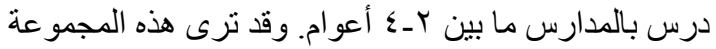

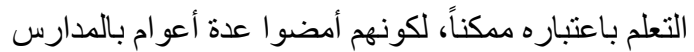

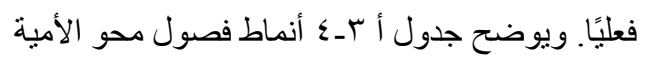

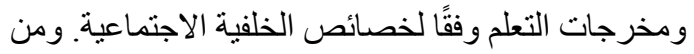
الجدير بالذكر أن نسبة مشاركة من تلقى قدر محدود من التعليم

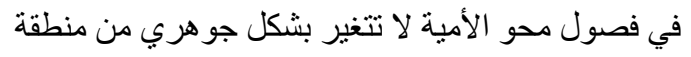
لأخرى على الرغم من تنوع مستويات الأمية.
وشكلت عدم رغبة الو الدين في إرسال أبنائهم للمدارس عائقاً

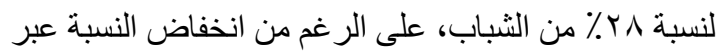
الزمن. عدم مو افقة الأب و،“العادات و التقاليد، عو امل تتضاءل التهال

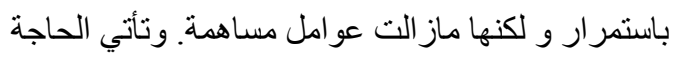

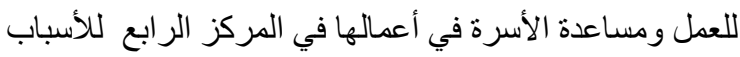
الأكثر شيوعًا و المساهمة في عدم الذهاب إلي المدرسة، الأهي

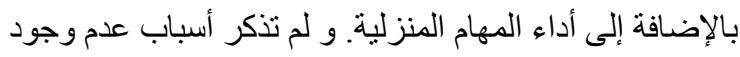

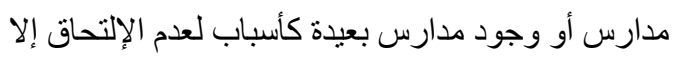

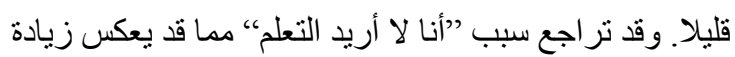
ملحوظة في إدارك ضرورة التعليم وقيمته، ولم ترد عو امل لئل مثل الزواج، وكبر السن، ونوع المدرس سوى مر ات قلائل.

إختلفت أسباب عدم الإلتحاق بالمدارس كثيرًا حسب النوع،

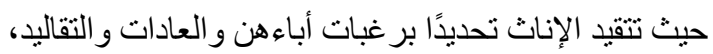

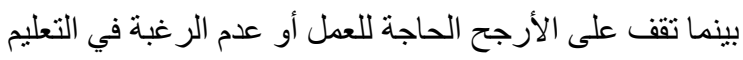

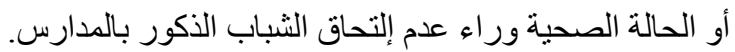

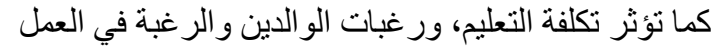

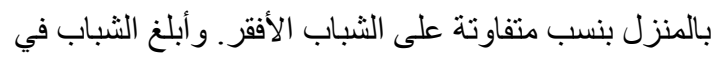
المستويات الثلاثة الدنيا لمؤشر الثروة عن وجود أسباب متعددة لعدم الإلتحاق، مما يوحي بضرورة معالجة عدد من المعوقات من أجل إلحاق الثباب الأكثر فقرًا بالمدارس.

\section{بـ خبرات الثباب مع فصول محو الأمية}

تبقى مشكلة أمية الثباب من المشكلات المزمنة في مصر،

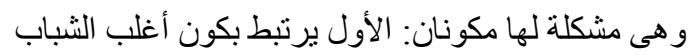

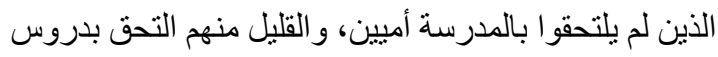

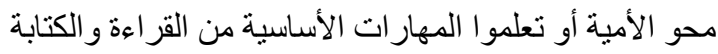
و الحساب و التي قد تتيح لهم فرصاً اقتصادية واجتماعية هامة:

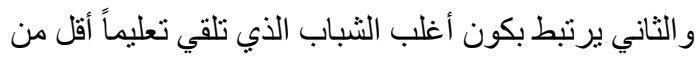

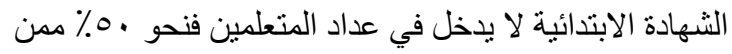

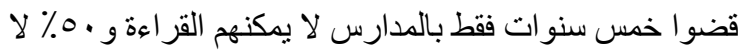
يستطيعون الكتابة و •ـ ٪ لا يستطيعون أداء العمليات الحسابية

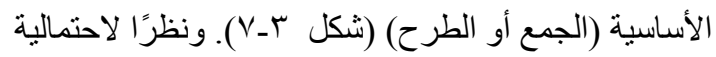
تسرب الثباب من المدارس بسبب عدم قدرتهم على مو اكبة الطبر

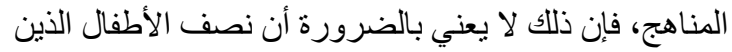

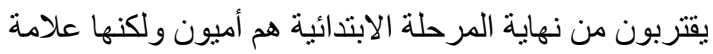
مثيرة للقق فيما يتعلق بجودة النظام التعليمى. 
شكل ץ_^ نسب الطلاب المستمرين في المدرسة وفقا للنوع ,

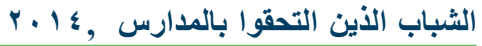

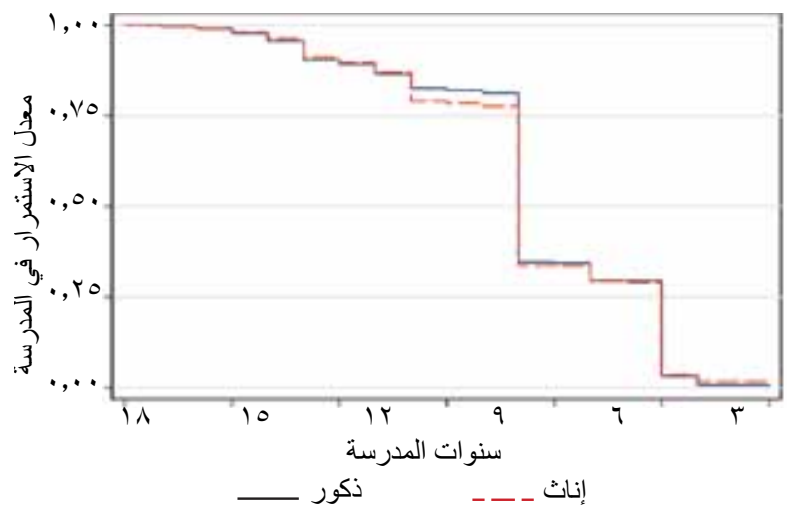

ملحوظة: جرت التقدير ات وفقا لأسلوب كابلان- مايير من أجل الإعتداد

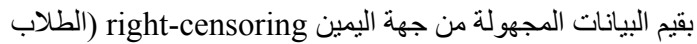

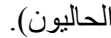

طفيفاً في عملية الاستمر ار في التعليم حتى الثانوية ضمن

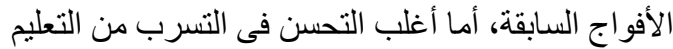

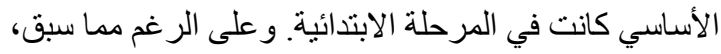

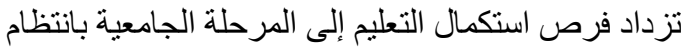

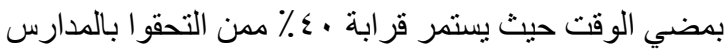

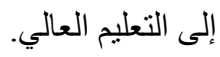

اختلفت مسار ات الثباب ممن ذهبو ا إلي المدرسة سواء فيما يتعلق بالتسرب من التعليم خلال أي مستوى أو في استكمال

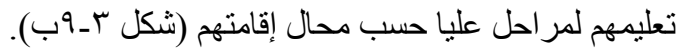
ففي ريف الوجه القبلى لا يو اجه الثباب فقط فرصاً مندنية في الالتحاق بالمدرسة، ولكن من بين أولئك الذين التحقو التها بالمدرسة، تتسرب نسبة أكبر من التعليم أثناء أي مرحلة التئ

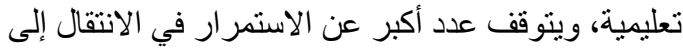
المر احل اللاحقة من الدراسة. ذللك في الوقت الذبة الذي يتسم فيه

الثباب من حضر الوجه البحري باستمر ار هم في شنى التى

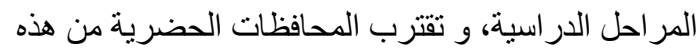

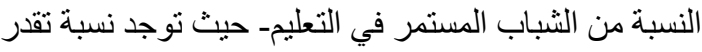

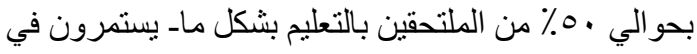

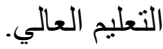

يظل العديد من الثباب الذى التحق بفصول محو الأمية أمي.

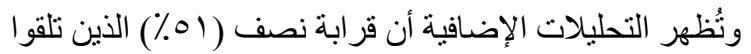

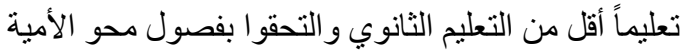

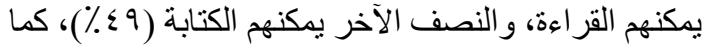

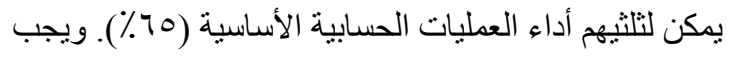

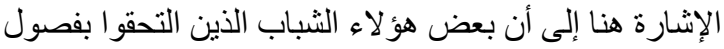

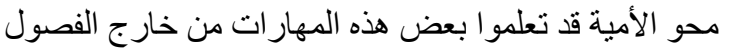

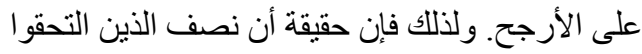

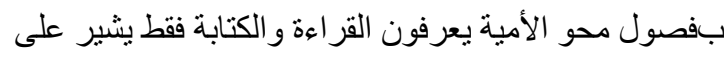

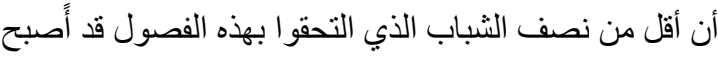

متعلمًا بفضلها.

\section{بـ ـ متى يغادر الطلاب التعليم؟}

بمجرد أن يلتحق الثباب من الجنسين بالنظام التعليمي،

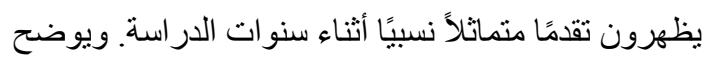

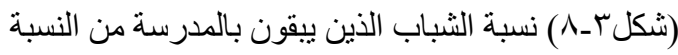

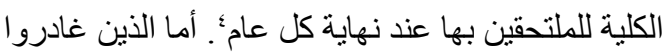

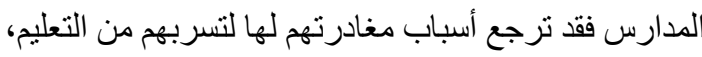

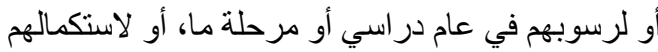

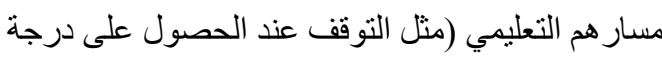

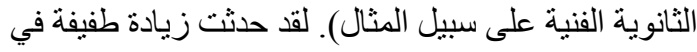
احتمال استكمال الثباب من الذكور لتعليمهر حتى الثانوية

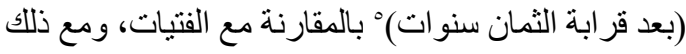

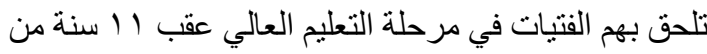

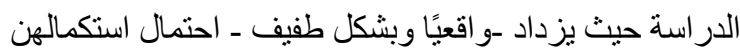
لار اساتهن حتى مرحلة الدر اسات العليا.

لم تتحسن فقط نسب الالتحاق بالمدارس بمضي الوقت، ولكن

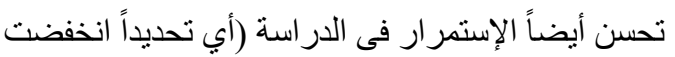

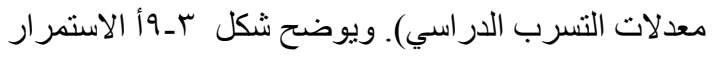

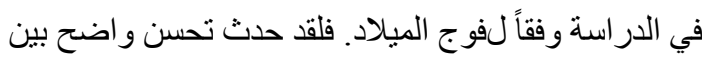

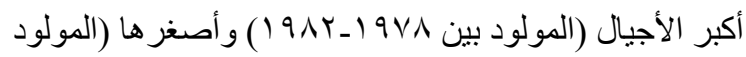

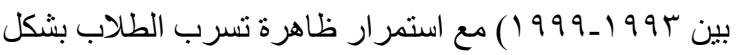

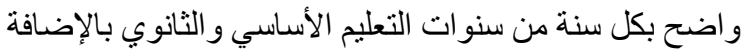

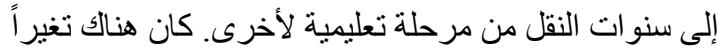

ع نظرًا لوجود عدد من الطلاب الحاليين بيانات مسح النشء و الثباب في مصر ،

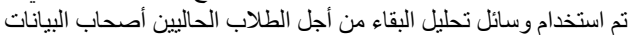

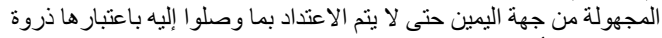
تعليمهم مع الأخذ في الاعتبار وصول لهم للمستوى لاند الحالي.

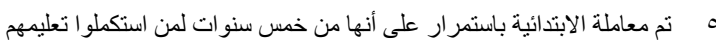

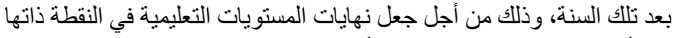

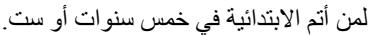


تظهر الفروق الكبيرة في إمكانية التسرب من التعليم عند

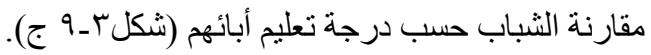

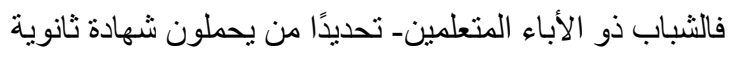

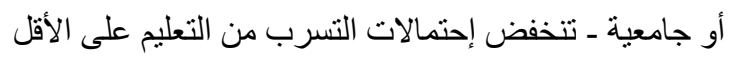

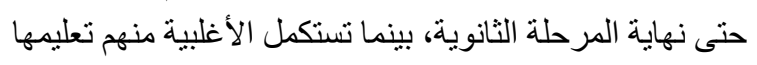
حتى الجامعة. أما الثباب ذو الأباء الأميين فيرتفع إحتمال

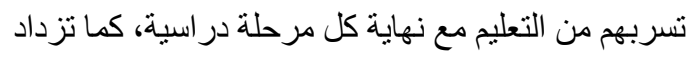
نسب تسربهم في سنو ات النقل على النقيض من من أبناء الأباء

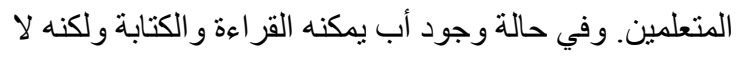

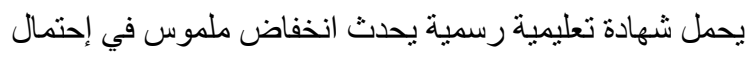
التسرب من التعليم. وبشكل عام، إن الثباب يو اجهون فرصئا

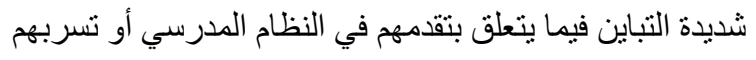

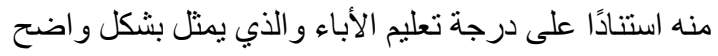

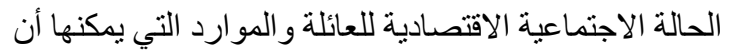

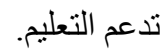

سُسٔل جميع الطلبة ممن تركو ا المدرسة فى عينة مسح النشء

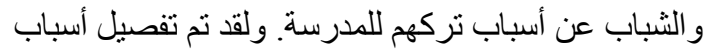

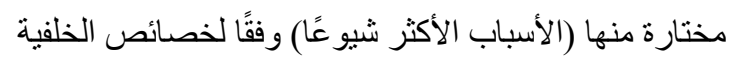

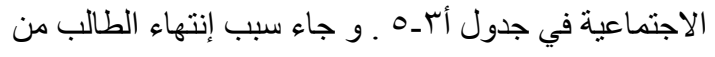

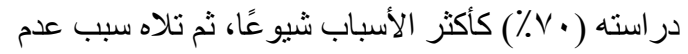

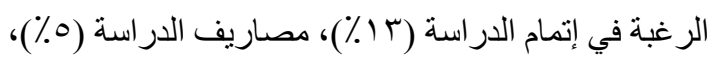

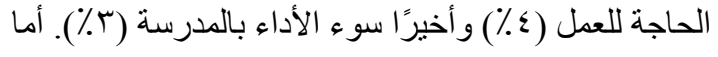

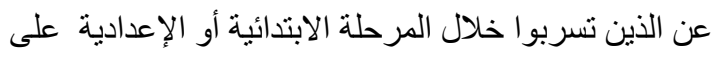

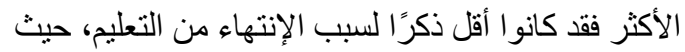

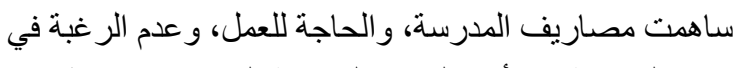

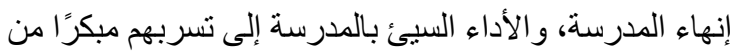
التعليم.

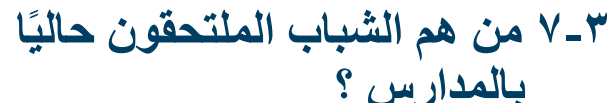

يعتمد عدد من التحليلات في القسم التالى (وخلال المتبقي من التباء

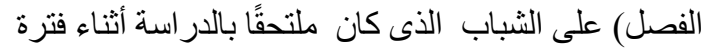

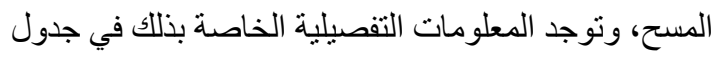

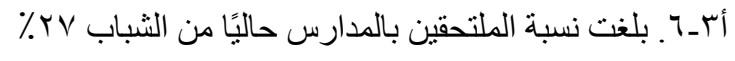

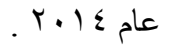

شكل بــ نسب الطلاب المستمرين في المدرسة وفقا لسنوات

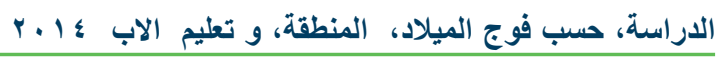
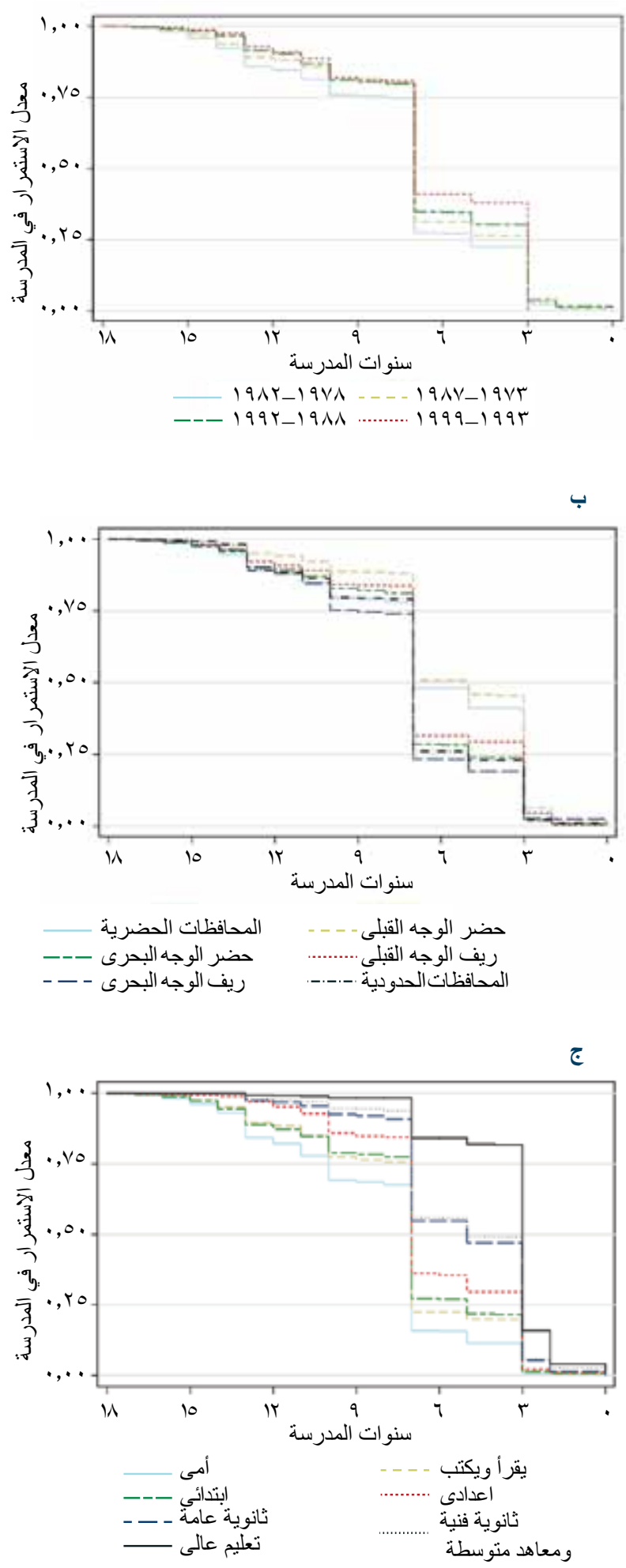

ملحوظة: جرت التقدير ات وفقا لأسلوب كابلان- مايير من أجل الإعتداد بقيم البيانات المجهولة من جهة اليمين right-censoring (الطلاب الحاليون). 
ذكر • ؟ من الطلبة أن المدرسين دائما ما بطلبون حفظ المعلومات عن ظهر قلب، بينما ذكر / 1 1 فقط أنهح دائما يتم تشجيعهم على تكوين و جهات نظر هم

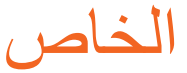

الثُاباب

بلغت نسبة الطلاب الذين تغييو ا عن المدرسة ليوم أو لعدة أيام

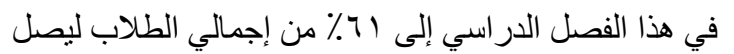

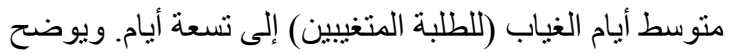

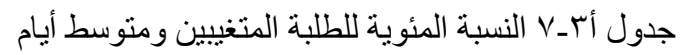

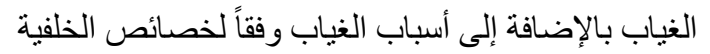

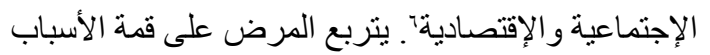

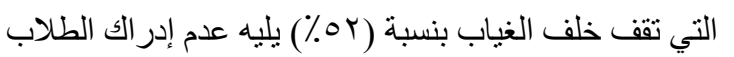

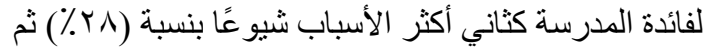

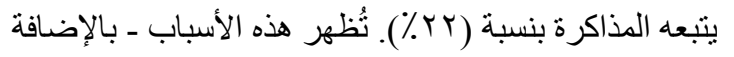

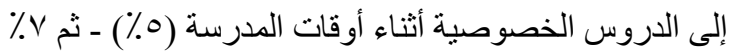

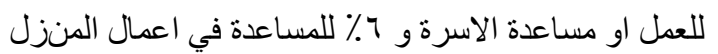

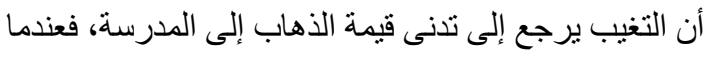

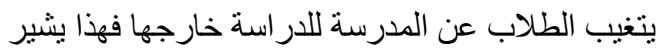

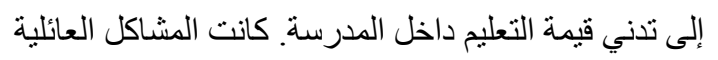

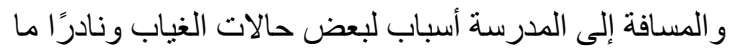

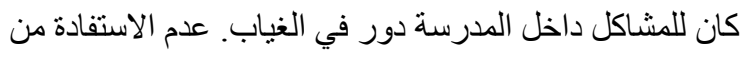

7 الجبب التعامل مع مستوى الغياب بحذر نظر ال لاختلاف الوقت من منطقة لأخرى

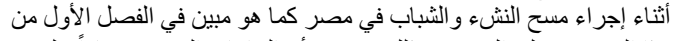

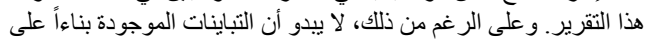

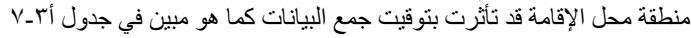

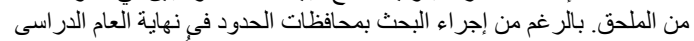

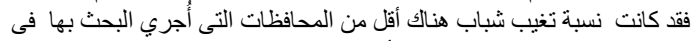
منتصف العام الدراسى. ولكن عدد أيام تغيب هؤ لاء طلبة المحافظات الحئ الحدودية كان أكثر قليلا.
جدول r-r توزيع الطلبة الحاليين وفقا للمستوى التعليمى

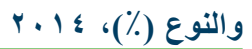

\begin{tabular}{|c|c|c|}
\hline اناث & ذكور & \\
\hline$\cdot, r$ & $\cdot, 7$ & ملتحق بالابتدائية \\
\hline $1 \wedge, \Sigma$ & $1 \wedge, \mathrm{V}$ & ملتحق بالاعدادية \\
\hline$r \wedge, \varepsilon$ & YI, & ملتحق بالثانوية العامة \\
\hline$r r, q$ & r.,. & ملتحق بلثانوية الفنية \\
\hline$r, \cdot$ & 1,1 & ملتحق بالمعاهد المتوسطة \\
\hline$r v, 1$ & $r \uparrow, r$ & ملتحق بالتعليم الجامعي فأعلي \\
\hline $1 \cdots$, & $1 \cdots$, & الاجمالي \\
\hline
\end{tabular}

ويوضح جدول r_r ت توزيع المر احل التعليمية وفقا للنوع.

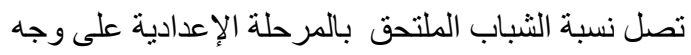

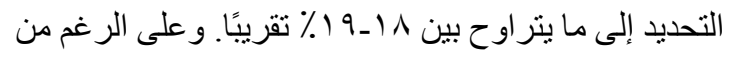

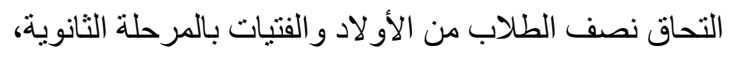

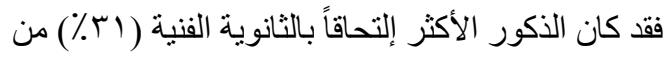

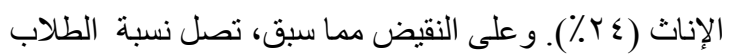

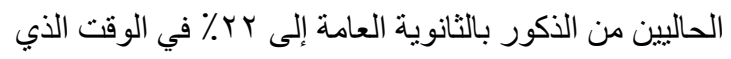

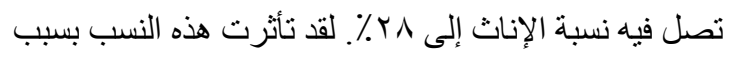

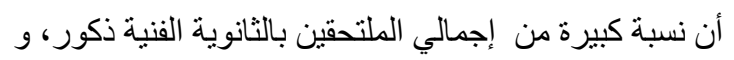

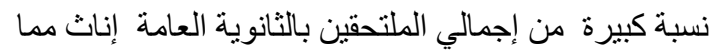
يثير إلى إمكانية تفوق نسبة الإناث على الذكور بين الطلبة الجامعيين فى المستقبل.

\section{ب-1 التعثر في الاراسة}

يتناول هذا القسم قضيتان محوريتان في إطار النظام التعليمي

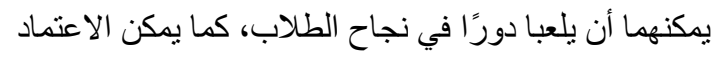

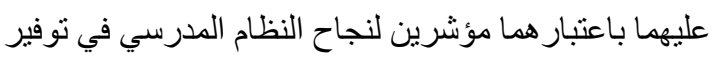

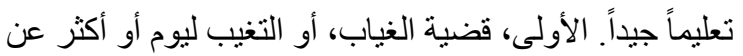

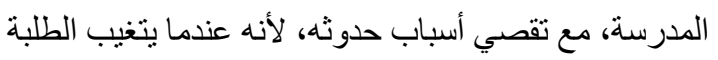

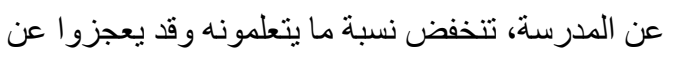

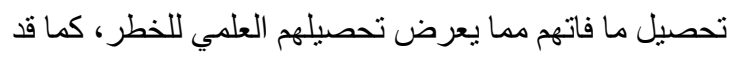

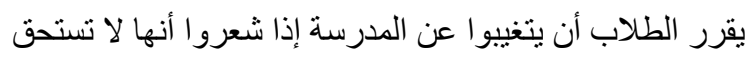

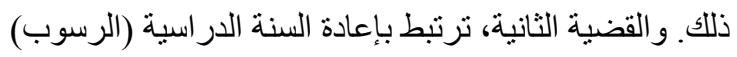

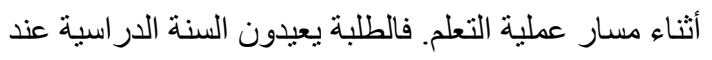

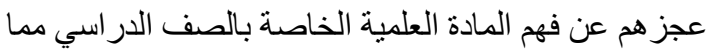
يعد عرضًا من أعر اض مشاكل الجودة و عدم الكفاءة بالتعليم لعني

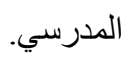


صحيح على الإطلاق. وفيما يتعلق بالمساو اة في معاملة بين

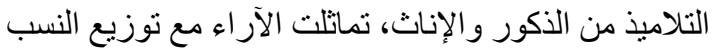

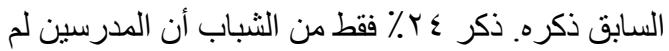

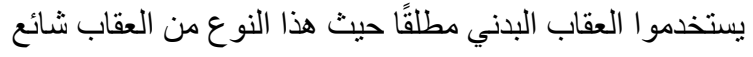

$$
\text { في المدارس.(شكل r- • (1) }
$$

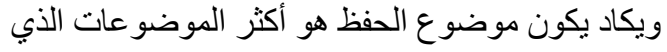

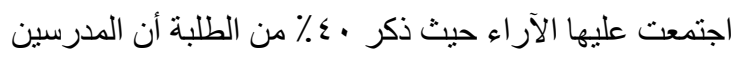

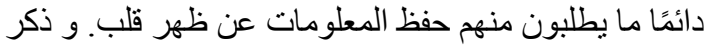

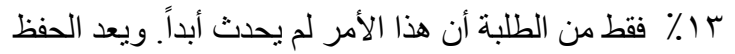

إحدى المشكلات الخطيرة بجودة التعليم التي تو اجه المنطقة

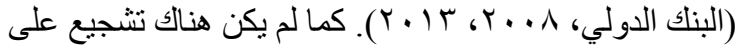
التفكير الناقد، فقد ذكر /1 (1 فقط من إجمالي الطلبة أنه دائًًا ما

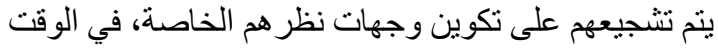

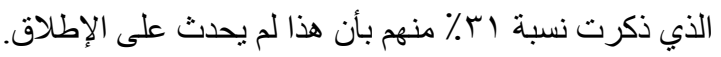

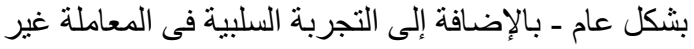

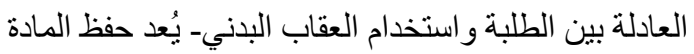
العلمية غيبًا هو السائد مع ندرة الاعتماد على التفكير الناقد.

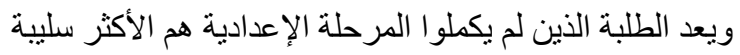

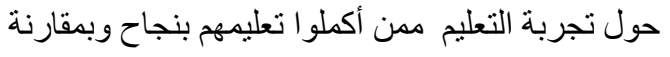

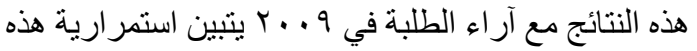
التحديات التي تو اجه النظام التعليمي.

\section{منشآت المدربسة}

وُجه للطلاب الذين يدرسون حاليًا أيضًا عددا من الأسئلة حول

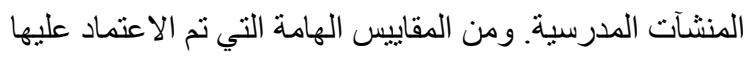

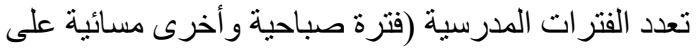

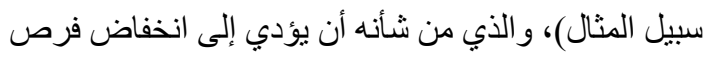

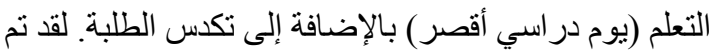

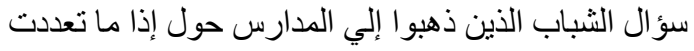

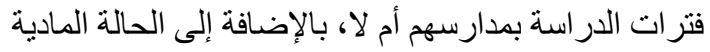

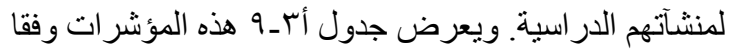

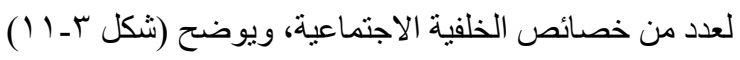
بعض هذه النتائج وفقاً لمحل الإقامة. لقد ظهرت اختلافاتهات جغر افية جو هرية تشير بشكل و اضح إلى عدم تساوى البنية التعليمية أو الصيانة بين المناطق المختلفة بمصر. انتشر تعدد

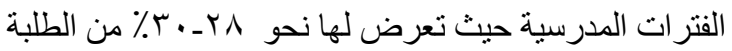

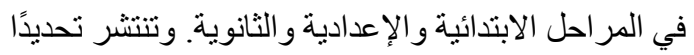

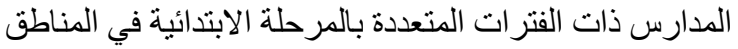
الحضرية، تتبعها المناطق الريفية، ثم مناطق العشو ائيات.

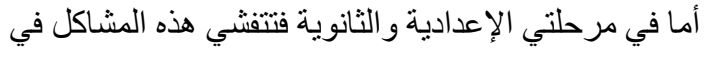

الدرسة بالأخص كان سببًا منتشرًا في المرحلة الثانوية، بينما كانت الدر اسة و الدروس الخصوصية الأكثر شيو عاً فى مرحلة

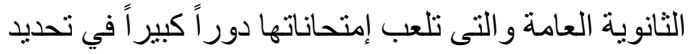
الجامعة التي قد يدخلها الطلاب.

\section{إعادة الصفوف اللاراسياة}

إعادة السنة الدر اسية أمر شائع في مصر خاصة في المرحلة الإعدادية و الجامعية. فبينما أفاد بـ من الملتحقين بالنظام

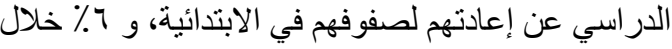

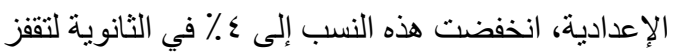

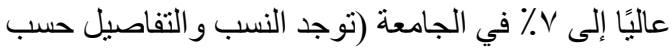
خصائص الخلفية الاجتماعية و الاقتصادية في جدول أبــــ).

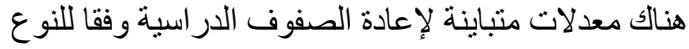

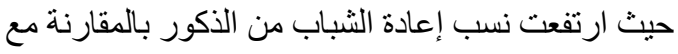

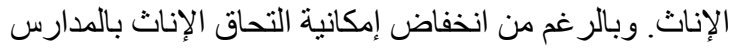
فى الماضى فلقد استطعن تحقيق نجاحات أكبر أثناء تقدمهم في النظام التعليمى. ولقد ارتفعت إحتمالات الإعادة بين الإنين

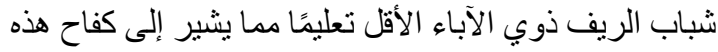
المجمو عات للنجاح في المدارس و الذي قد يحتاج دعمًا إضافيًا.

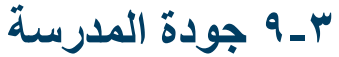

جودة المدرسة هو أحد المفاهيم المعقدة ومتعددة الأبعاد، فهناك طرق متنو عة لقياس جودة المدرسة في إطار كل من المدخلات (مثل حجم الفصول)، أو المخرجات (مثل التعلم أو نتائج الامتحانات) أو الآراء (درجة رضا الثباب عن الدراسة).

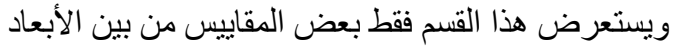

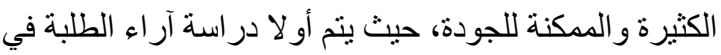
تجربتهم المدرسية ثم يتم در اسة جودة المنثأة المدرسية (من المناه وجهة نظر الطلبة).

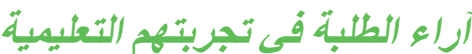

سُُنل الثباب الذين ذهبوا إلي المدرسة (أو الطلاب الحاليين)

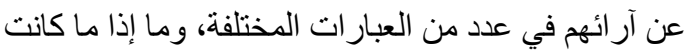
العبارة في رأي الثباب لم تحدث من قبل أو تحدث بين الحين

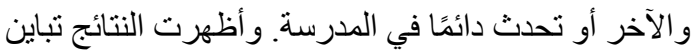

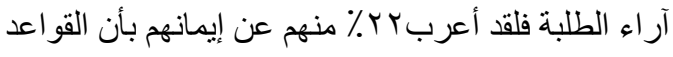

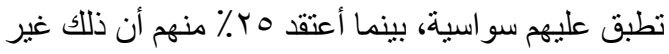




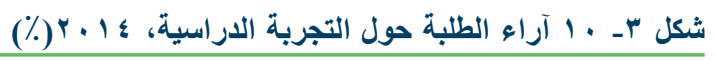

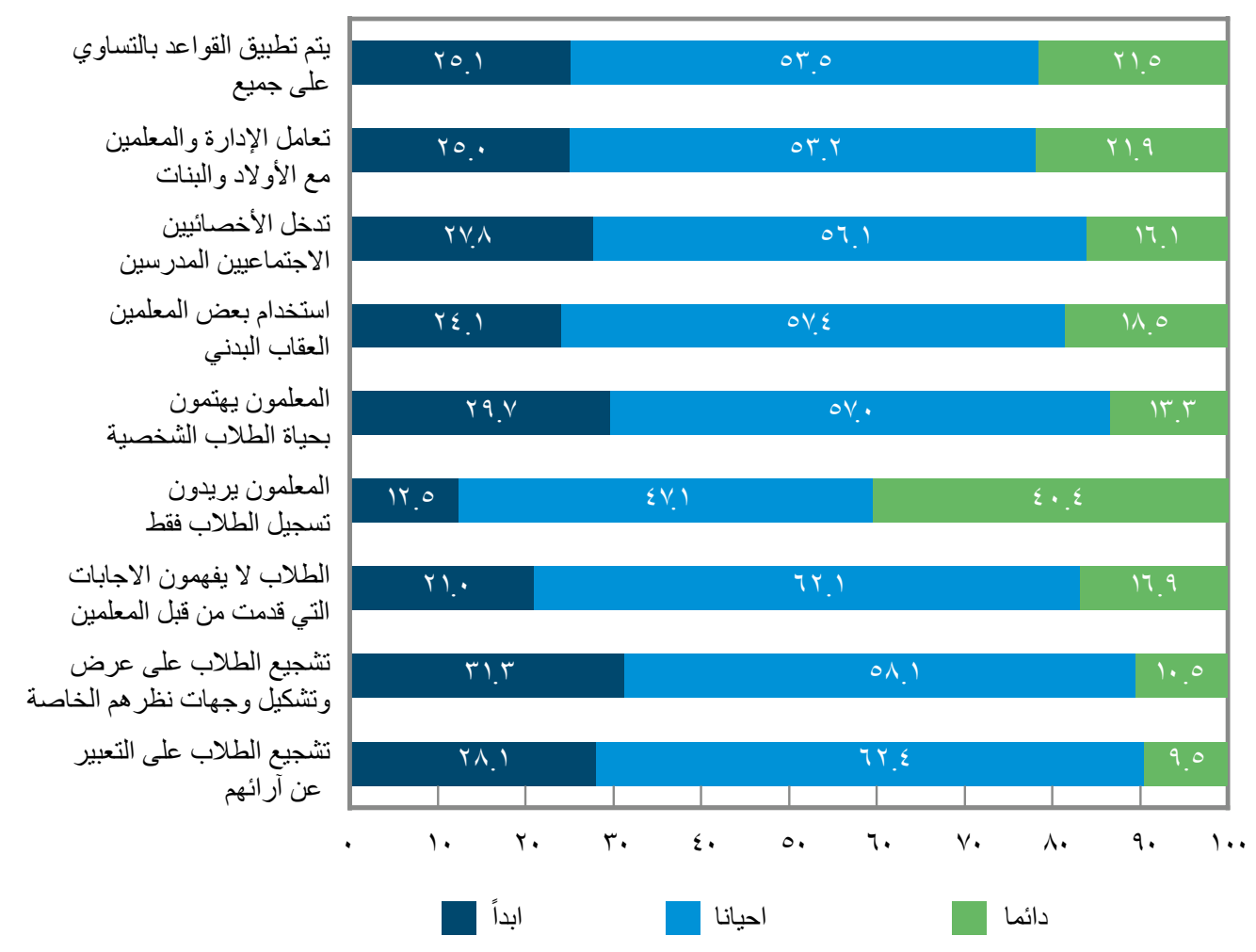

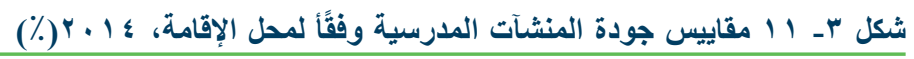

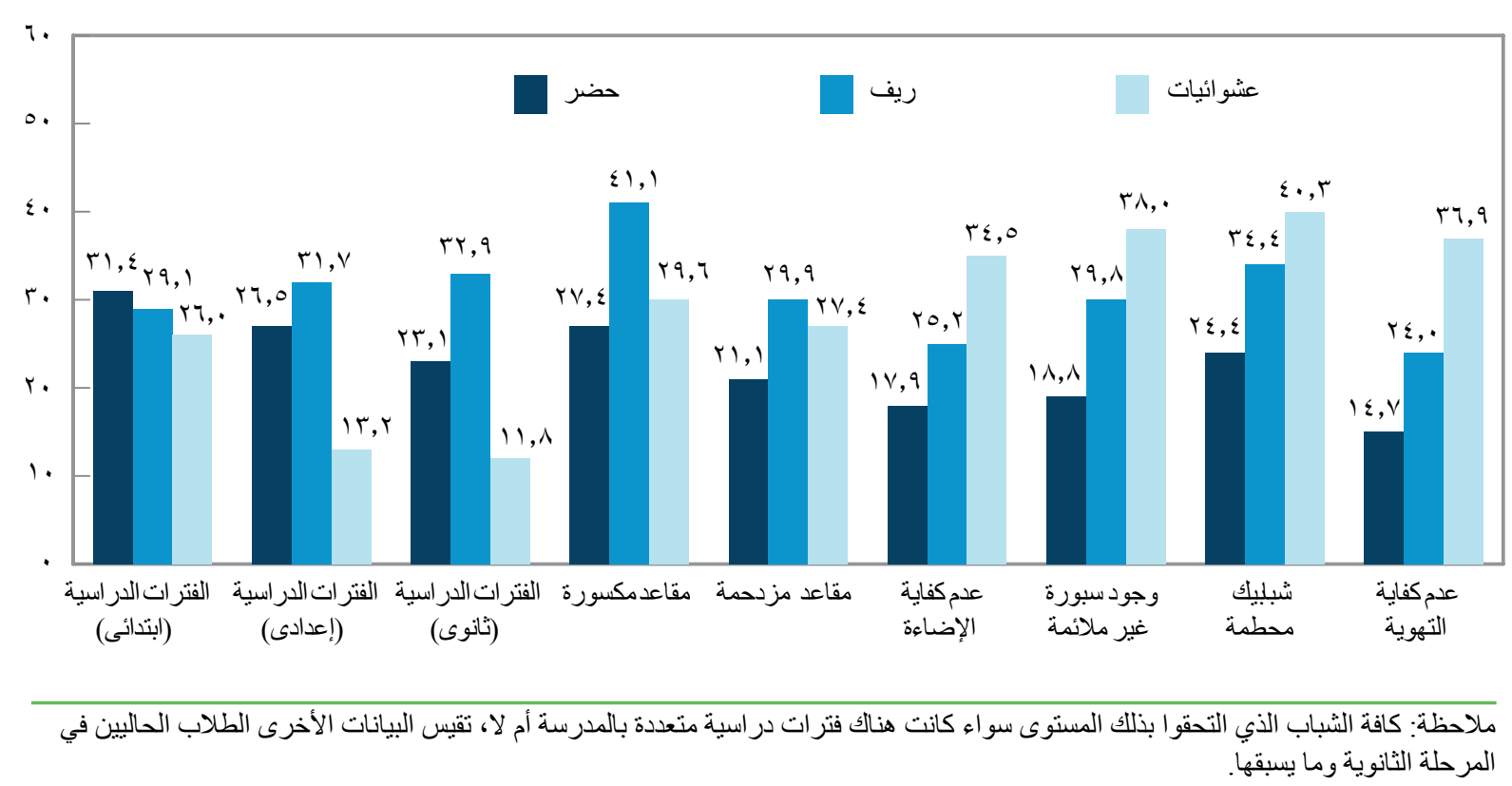


وفي ضوء عدم كفاية معايير الجودة بالمدارس، قد تمد الأسر

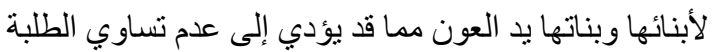
علميًا لأن مقدار المساعدة بعتمد على موارد الآباء وتعليمه.

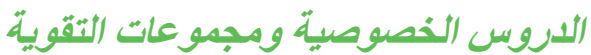
يوجد في مصر نوعان من الدروس الخارجية هما: الدروس

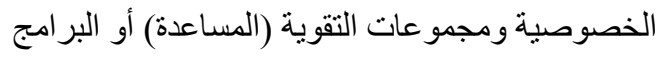

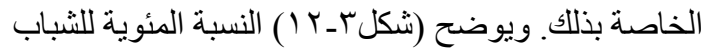

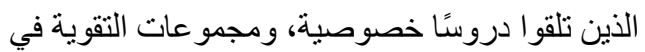

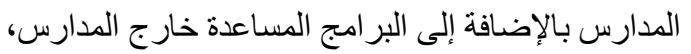

و النسبة التي لا تتلقى أبٍ مما سبق بكل الإحل مرحلة در اسية.

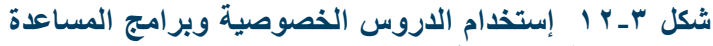

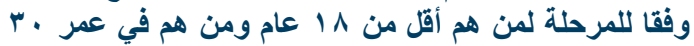

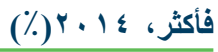

ابتدائى (ابن

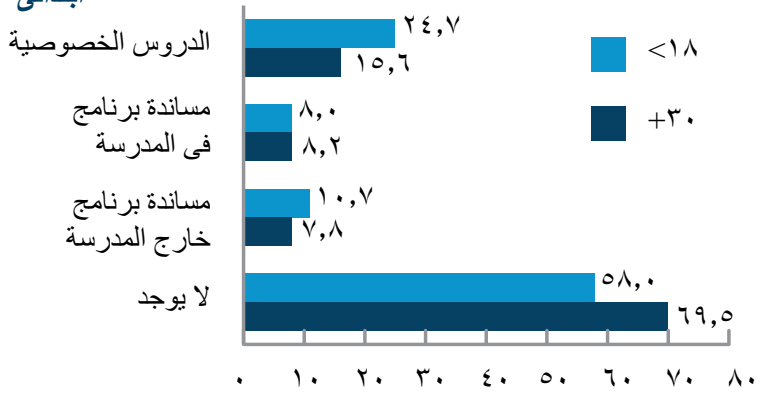

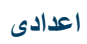

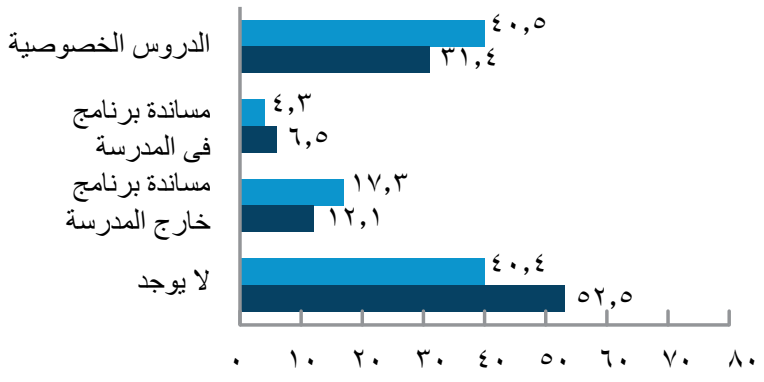

ثنانوى

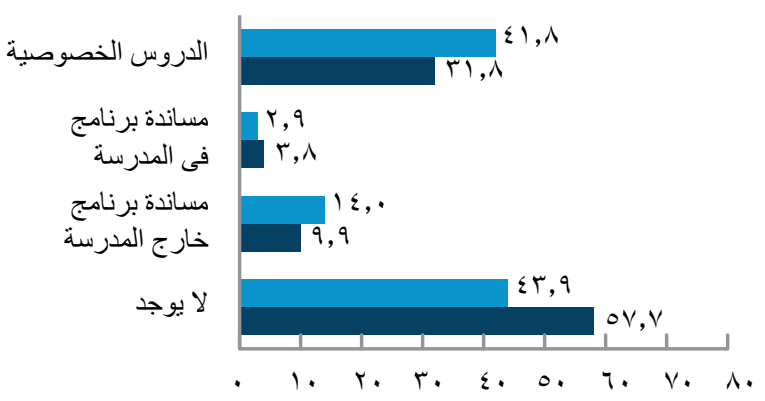

ملحوظة: بناء على آر اء كافة الثباب الذى ذهب إلى المدرسةّ.
الهناطق الريفية، ثم تليها المناطق الحضرية بالإضافة إلى

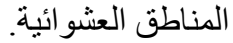

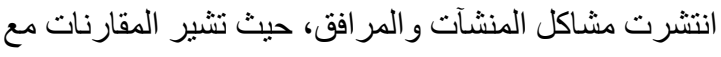

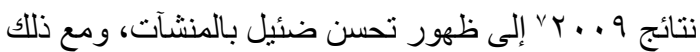

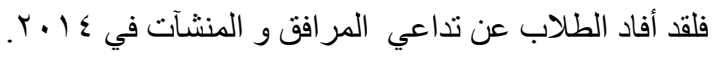

ففي ذللك العام، ذكر ب؟\%٪ من الطلبة وجود مقاعد محطمة،

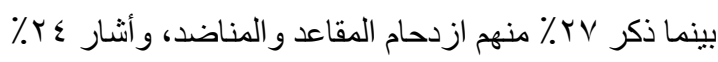

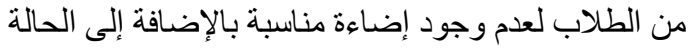

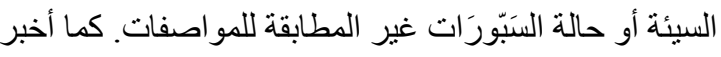

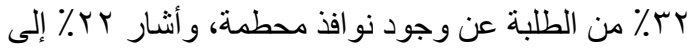

$$
\text { عدم كفاءة نظم التهوية. }
$$

و على الرغم من أن تلك النتائج تفيد بوجود نسبة لا بستهان

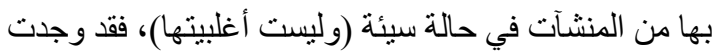

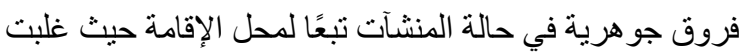

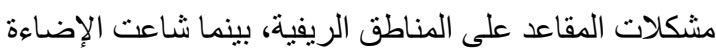

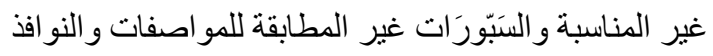

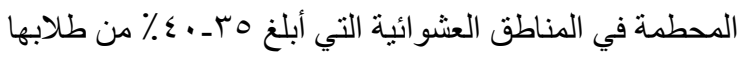

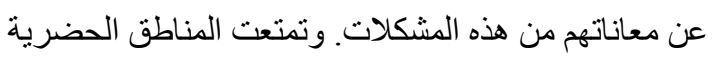

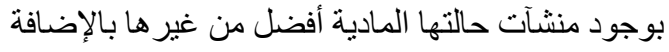

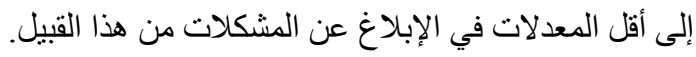

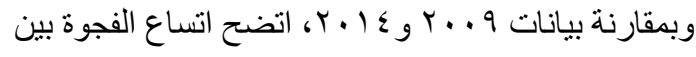

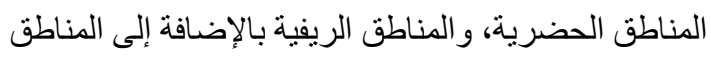

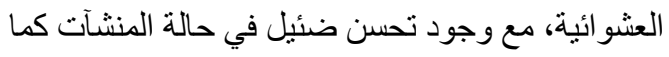

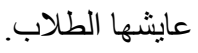

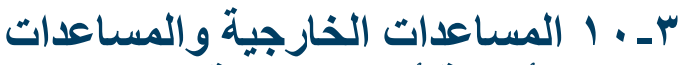 الأسرية أثناء الار استة}

من المفترض أن يكون التعليم داخل الفصل كافيًا كمًا وكيفًا

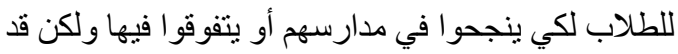

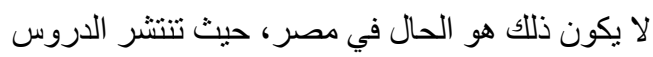

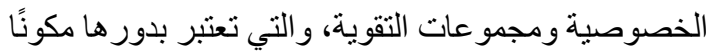

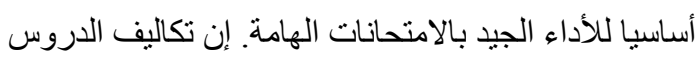

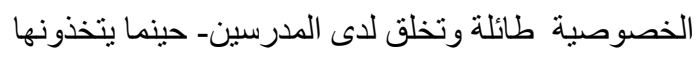

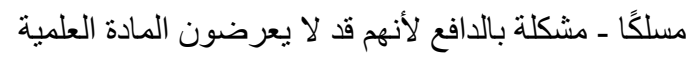

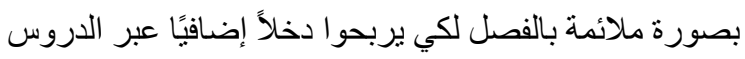
الخصوصية (Assaad, \& Levison,2009; Ille 2015) .(Assaad \& Krafft, 2015; Elbadawy, Ahlburg V آراء الطلاب الذين تسربوا من التعليم قبل التحاقهم بالمرحلة الإعدادية هم أكثر 


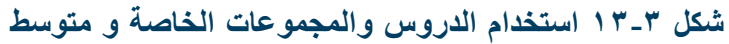

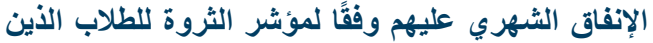

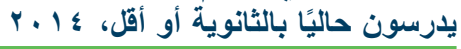

نسب إستخدام الاروس و المجموعات الخاصة

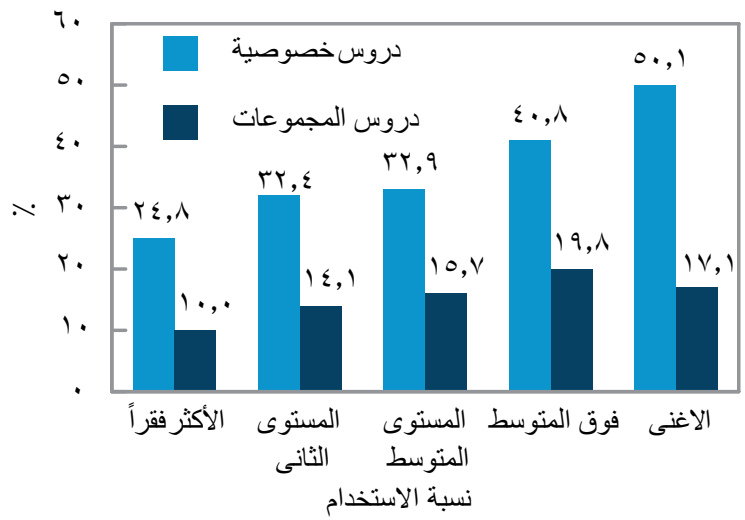

متوسط الإنفاق الشهرى

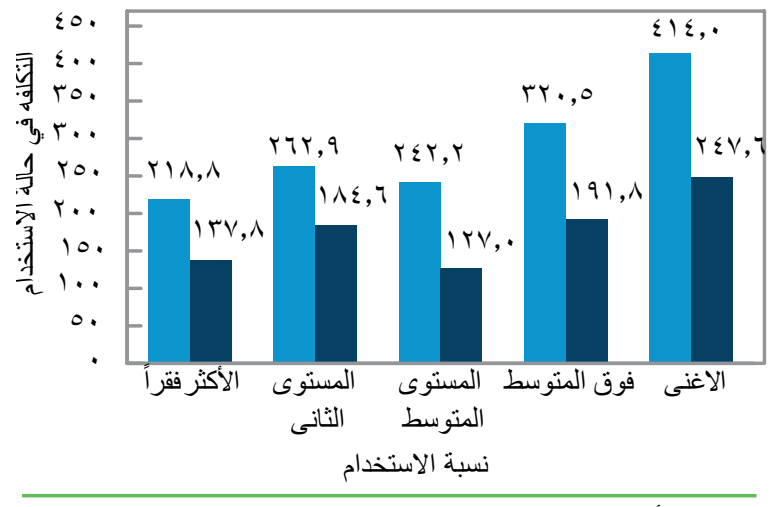

الدو لار الأمريكى يوازى Y,Y جنيه مصرى فى يونيو 10

المساعداتث العائلية"

تتصاعد فرص الطلبة في تلقي الدعم من عائلاتهم مع زيادة

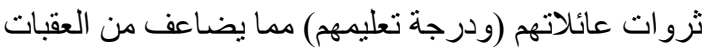

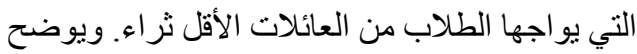

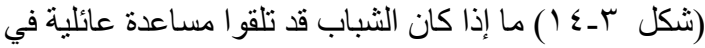

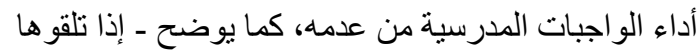
بالفعل- مصادر المساعدة (الذي يحتمل تعددها). وبينما تلقى

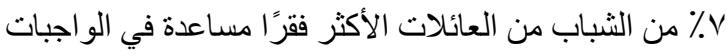

الدرسية، تلقى ؟ب٪ من الثباب المنحدرين من العائلات الثرية جدًا المساعدة. وازدادت احتمالية تلقى الطلبة المساعدة

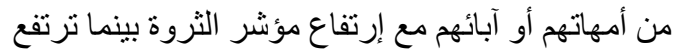

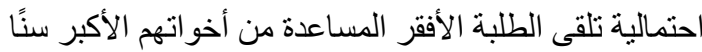

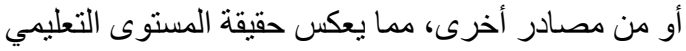

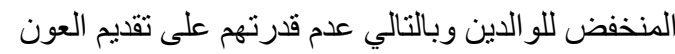
لأبنائهم في الو اجبات المدرسية.
و هنا يجب ملاحظة أن بعض الطلاب يتلقون أشكالاً متعددة من الدروس الخصوصية. التفاصيل بالأرقام وفقا لعدد من

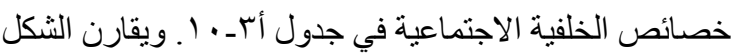

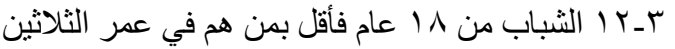

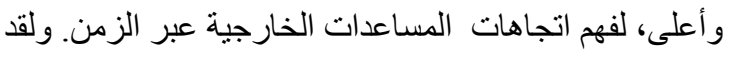
أوضحت النتائج انتشار الدروس الخصوصية، كما انخفضت التضات

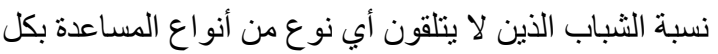

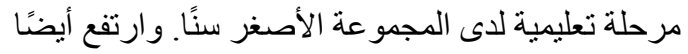

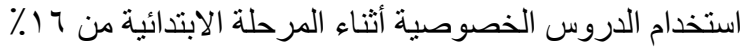

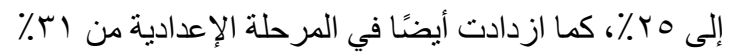

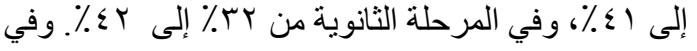

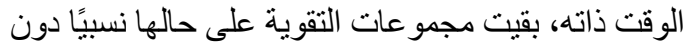

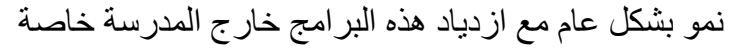

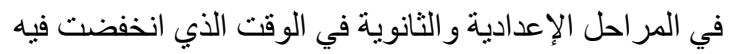

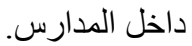

ويرتبط استخدام الدروس الخصوصية ارتباطًا وثيقًا بالخلفية الاجتماعية الاقتصادية للأسر المصرية، فتزداد احتمالية تلقي التئية

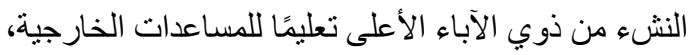

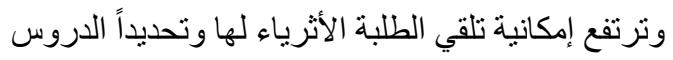

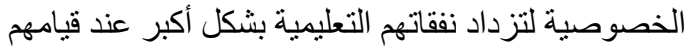

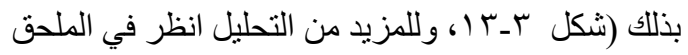

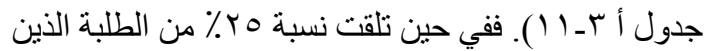

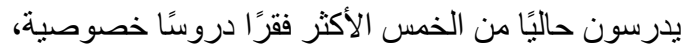

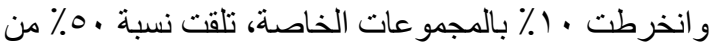

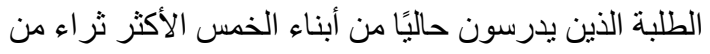
أصحاب الثروة دروسًا خصوصية و V ا ٪ مجمو عات خاصة. ويتضاعف بذللك متوسط الإنفاق الثهري على المساعدات

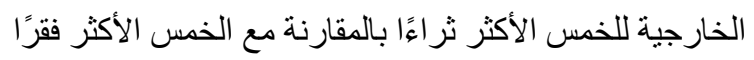

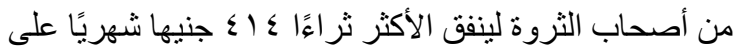

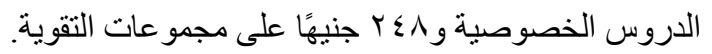

تلقى §ه٪ من الطلبة الذبن تلقو ا دروساً خاصة دروسًا مع معلم

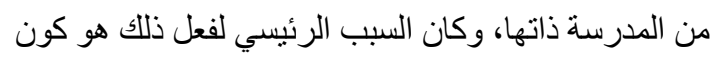

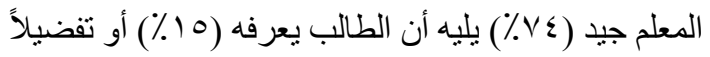

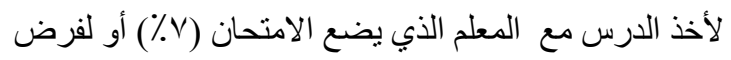

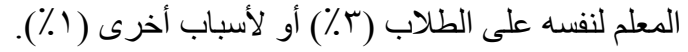

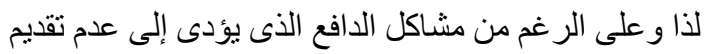
المدرسين لتعليم مناسب داخل المدرسة، لا يعتقد الطلبة غالبًا أنهم مجبرون على تلقي دروساً خاصة على أيدي معلميهر. 
شكل سـ ع ا المساعدة بالواجبات المدرسية ومصدرها (إذا تم تلقيها بالفعل) وفقا لمؤشر توزيع الثروة بالنسبة للطلاب الذين يدرسون

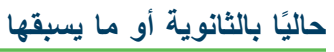

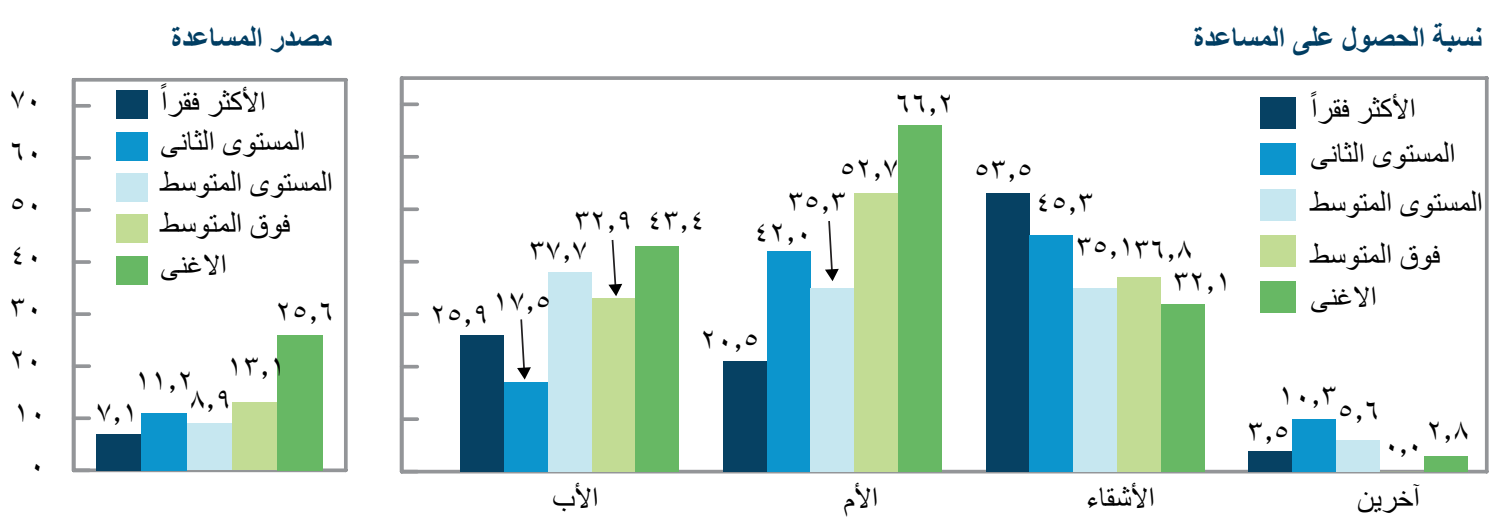

El-Kogali \& Krafft 2015 ;World Bank ) الخاصة .(2012

يظهر الحرص على التعليم قبل الدرسي بين أبناء الآباء

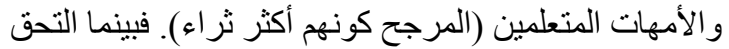

فقط r 1 ٪ من الثباب ذوي الأمهات الأميات بالتعليم قبل

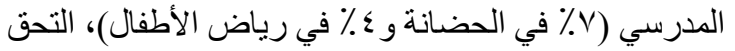

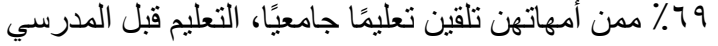

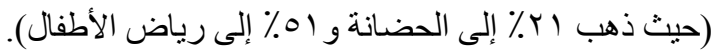

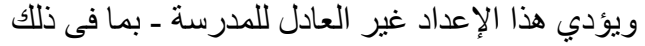
الاستثمار الحكومى غير العادل ـ إلى الإسهام في إحداث تبادين لاحق في النظام التعليمي.

$$
\text { النّطبم الثانوي الفني }
$$

تعتبر شهادة الثانوية الفنية أكثر المستويات التعليمية شيوعًا

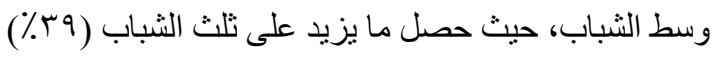

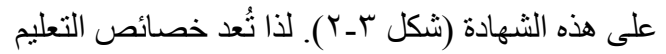
الثانوي الفني ذات أهمية خاصة للثباب و الاقتصاد المصري.

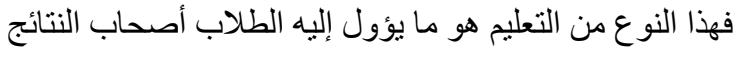

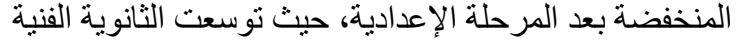

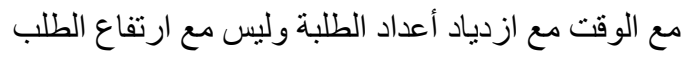

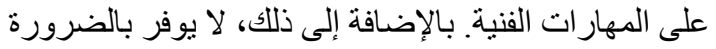

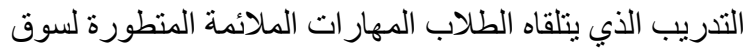
(Krafft 2013 ) (UNDP \&Institute of National Planning 2010 ) (2007World Bank). ويصف شكل r-7 ا تخصصات

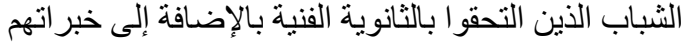

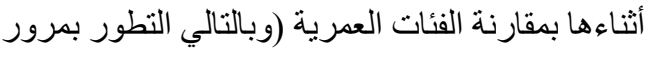

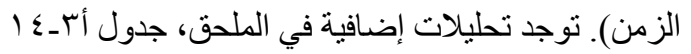

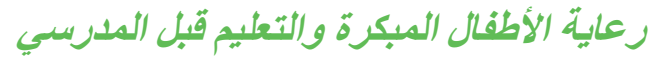
إن الطفولة المبكرة هي أهم مرحلة فى النمو. فحين يلتحق الأطفال بدور رعاية الطفولة المبكرة (ECCE) أو رياض الفرال

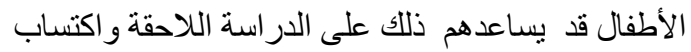

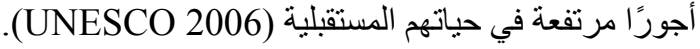

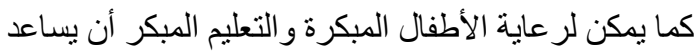

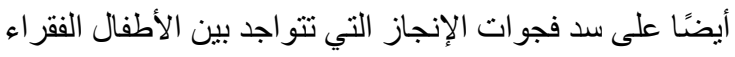

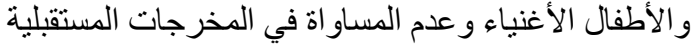

Checchi and Van de werfhorst 2014 ; Jung) Hasan 2014 \& (. و على الر غم من زيادة نسبة المتلقين

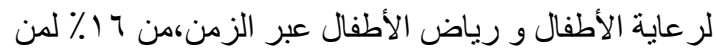

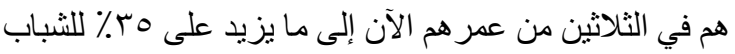

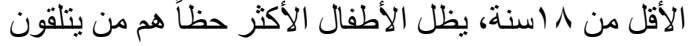

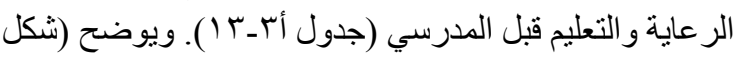

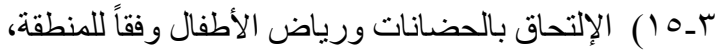

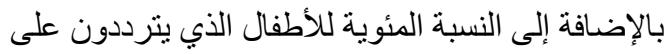

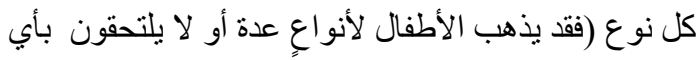

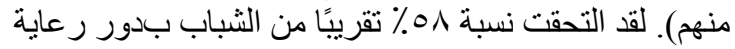

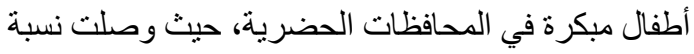

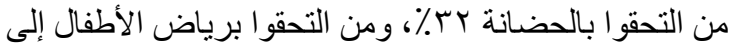

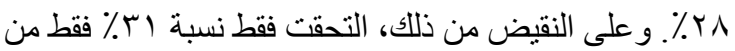

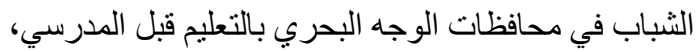

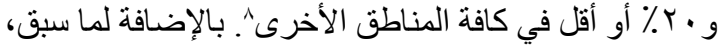

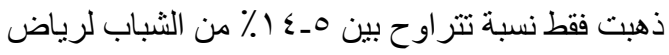

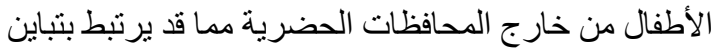

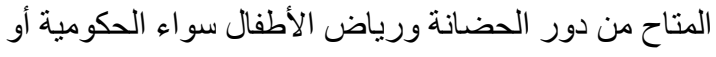

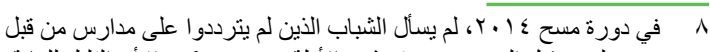

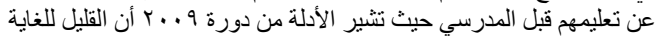

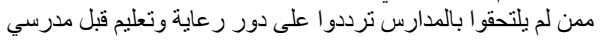

(Krafft 2015) 
الثهادة الثانوية الفنية هى الأكثر شيو عا بين الثباب فى مصر ومن ثم فإن تحسين التعليم المهنى ضرورة لملائمة متطلبات سوق العمل لـذذا التعليم

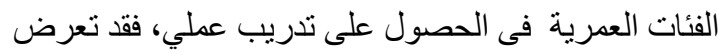

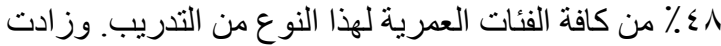

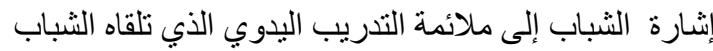

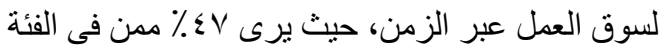

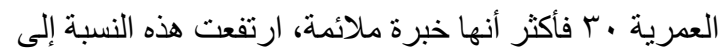

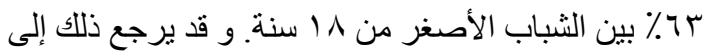

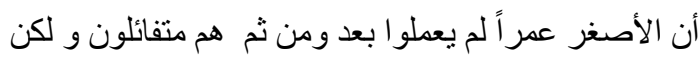

شكل بـ ا ا التخصص والخبرة في لثانوية الفنية وفقًا

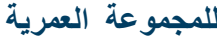

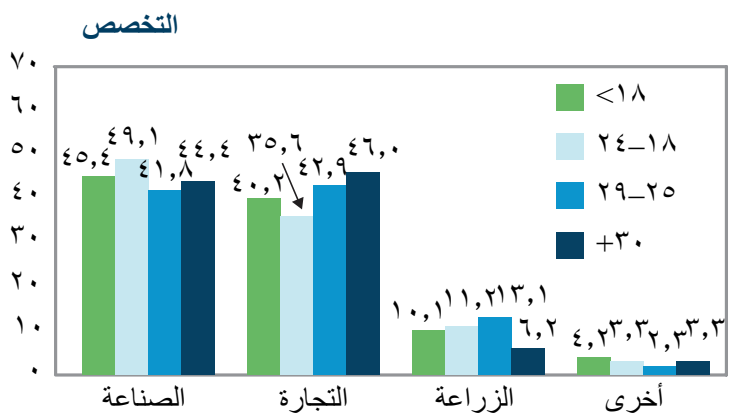

أهمية التطليم المهنى

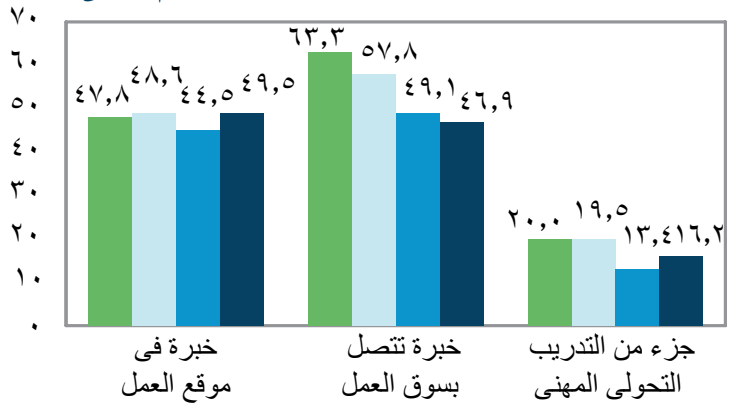

ملاحظة: بناءاً على كافة الثباب الذين التحقو ا بلثانوية الفنية من قبل.
شكل rــ ه ا رعاية الأطفال والتعليم قبل المدرسي (ونوعل)

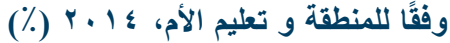
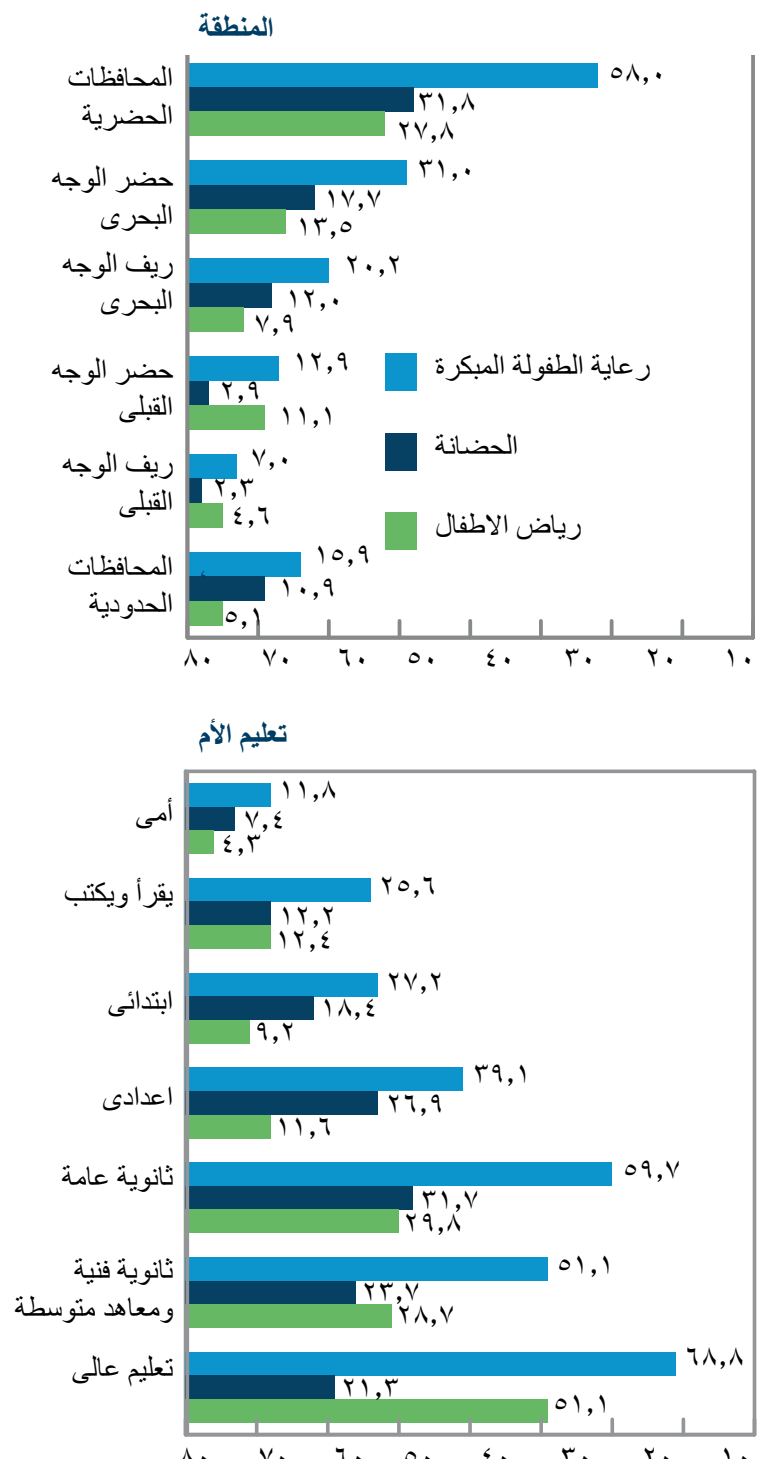

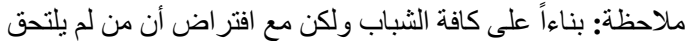

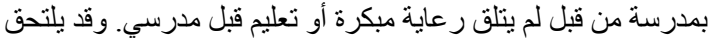
الأطفال بأنو اع متعددة من رعاية الأطفال و التعليم قبل الدذرسي.

كان هناك تغير اً طفيفاً في تخصصات الثباب في التعليم الفني

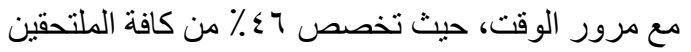
بهذا التعليم في المسار الصناعي، و •ـ ٪ في التجاري

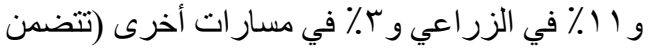

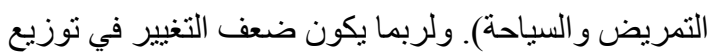
التخصصات مؤشرًا لعدم استجابة التنريب الذي تربات توفره الثانوية

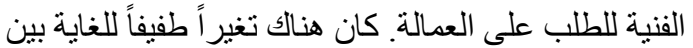


باحتر ام مع الطلبة. و على الرغم من تنوع خبر ات الجودة في

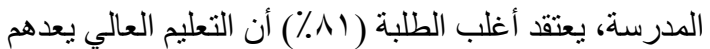

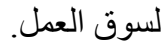

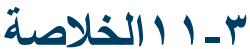

استطاعت مصر تحقيق تقدم كبير عبر العقود العديدة الأخيرة في ضمان التحاق الثباب بالمدارس. ويقترب التعليم الابتدائي من الثمول الكامل على الرغم من وجود مجمو عة صغيرة

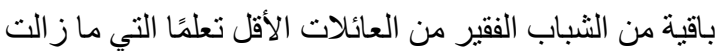
لا يمكنها الالتحاق بالمدارس. وبشكل متز ايد، فإن التحدي القائم لمصر سيكون ضمان نجاح الأطفال وتعلمهم في المدارس. فقد أشارت نتائج هذا الفصل إلى أن مصر ماز الن ال أمامها

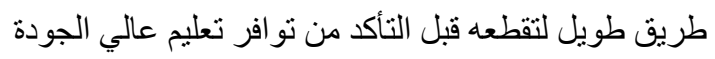
لكافة أطفالها. ونظل الإشكالية بمناهج التعليم، التي تؤكد على تلى تلى الحفظ عن ظهر قلب، بدلا من التأكيد من التفكير الناقد، والتي

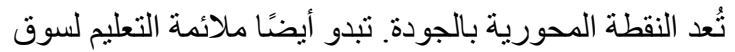

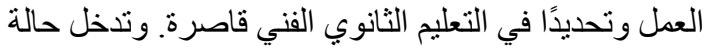

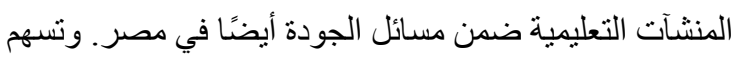

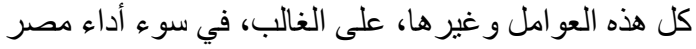

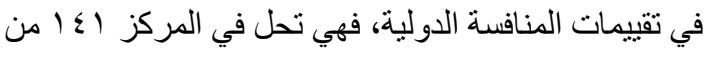

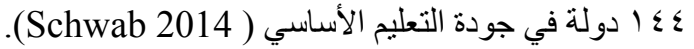
وتؤدي الجودة المتدنية للتعليم في المدارس إلى الحاجة إلى الى دروس خصوصية إضافية، ولمساعدة الأسرة وهي المسائل التي تساهم في وجود فرص غير منساوية أمام الثباب في

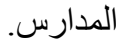

يعتبر النظام التعليمي في صورته اليُّلى مؤسسة توفر للطلاب فرصًا متساوية للنجاح، و على الرغم من ذلك فللشباب خبر التهات مختلفة في النظام التعليمي، ومخرجات تعليمية مختلفة بناء

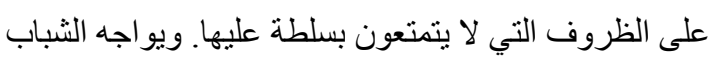
فرصًا غير متساوية في الدخول للمدارس وفي النجاح استنادا

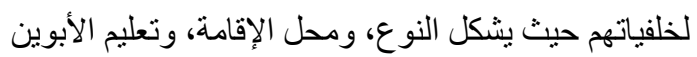

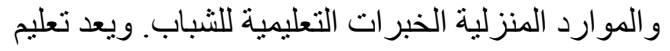

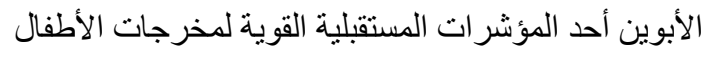

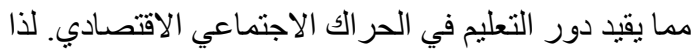

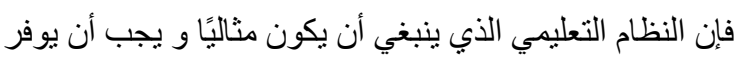

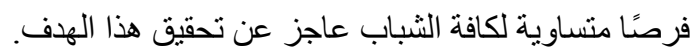

لا يدركون مدى ملائمة التدريب لسوق العمل. توسع البرنامج المصري لتحسين التدريب المهني إلى حد ما بمرور الوقت؛

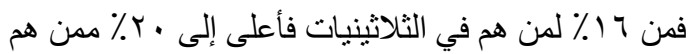
أصغر من \1 ا ـ بشكل عام، لقد حدثت بعض التطور ات الطفيفة

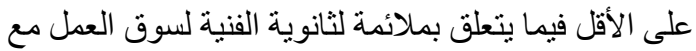

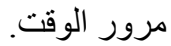

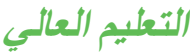

تصل نسبة المصريين الحاصلين علي مؤهل جامعي إلى قر ابة

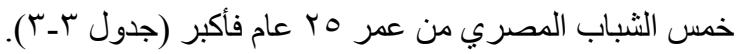

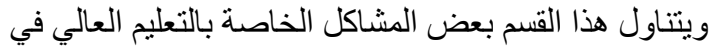

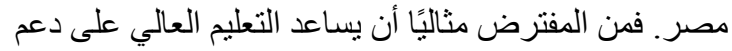

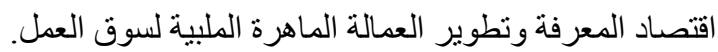

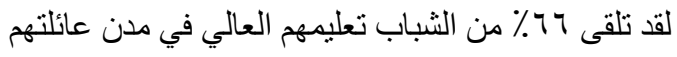

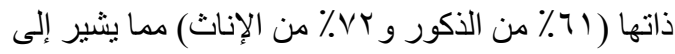
ارتباط التعليم العالي المتاح في أغلب الأحيان بمدينة الإقامة.

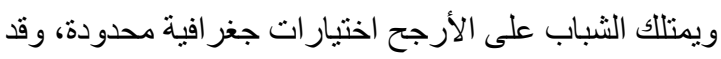
لا يسنطيعون أن يختاروا الكليات في ضوء درجاتهم، حيث

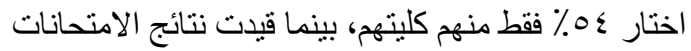
نتائج المتبقين. ولقد تتوعت خبر ات الطلاب في إطار التعليم العالي حيث ذكر حو الي نصفهم (rع ٪) أن أساتذتهم يحثونهم على التفاعل بالمشاركة في مناقثة الموضو عات المتعلقة

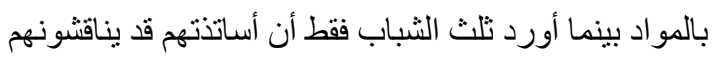

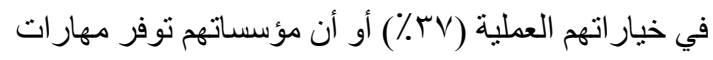

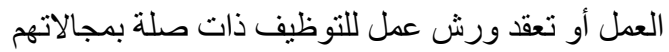

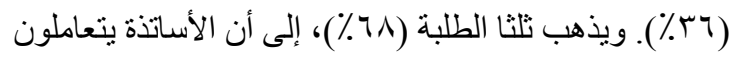

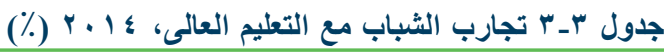

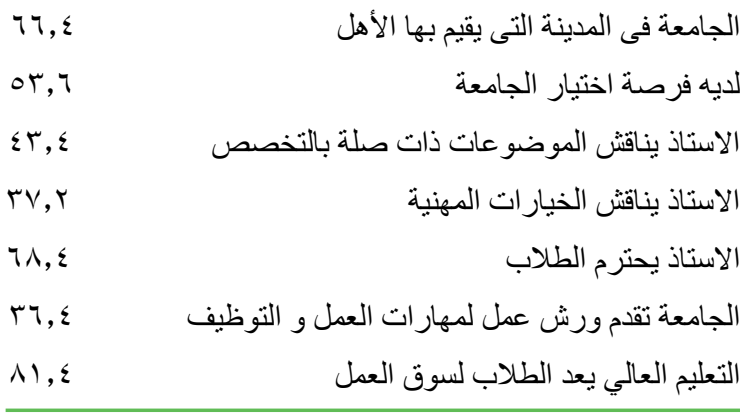
ملاحظة: يشمل كافة الطلاب الذين سبق لهم الإلتحاق بالتعليم العالي 


$$
\text { الوضع التعليمي للشباب في مصر : من يلتحق ومن ينجح ومن يتعثر؟ }
$$

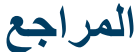

Assaad, R. and C. Krafft. 2015. “Is Free Basic Education in Egypt a Reality or a Myth?" Egyptian Center for Economic Studies (ECES) Working Paper No. 179. Cairo: ECES.

Checchi, D. and H.G. van de Werfhorst. 2014. "Educational Policies and Income Inequality." IZA Discussion Paper Series No. 8222. Bonn: IZA.

Egypt State Information Service. 2014. "Constitution of The Arab Republic of Egypt" (English Translation). Retrieved from http://www.sis.gov.eg/Newvr/ Dustor-en001.pdf.

El-Kogali, S., and C. Krafft 2015. Expanding Opportunities for the Next Generation: Early Childhood Development in the Middle East and North Africa. Washington, DC: World Bank.

Elbadawy, A., D. Ahlburg, R. Assaad, and D. Levison. 2009. "Private and Group Tutoring in Egypt: Where Is the Gender Inequality?" Paper Presented at the XXVI IUSSP International Population Conference. Marrakech, Morocco.

Ille, S. 2015. "Contrived Private Tutoring in Egypt: Quality Education in a Deadlock between Low Income, Status and Motivation." Egyptian Center for Economic Studies Working Paper No. 178. Cairo: ECES.

Jung, H. and A. Hasan. 2014. "The Impact of Early Childhood Education on Early Achievement Gaps: Evidence from the Indonesia Early Childhood Education and Development (ECED) Project." World Bank Policy Research Working Paper No. 6794. Washington, DC: World Bank.

Krafft, C. 2013. "Is School the Best Route to Skills: Returns to Vocational School and Vocational Skills in Egypt." Minnesota Population Center Working Paper Series No. 2013-09. Minneapolis, MN: Minnesota Population Center.

- - - 2015. "Increasing educational attainment in Egypt: The impact of early childhood care and education," Economics of Education Review 46: 127-143.

Krafft, C., A. Elbadawy, and R. Assaad. 2013. "Access within the higher education system: Evidence for more inequality of opportunity," in A. Elbadawy (ed.), Is There Equality of Opportunity under Free Higher Education in Egypt? (Arabic). Cairo: Population Council.

Schwab, K. 2014. The Global Competitiveness Report: 2014-2015. Geneva: World Economic Forum.

Shahine, G. 2003. "A system for Sisyphus," Al-Ahram Weekly Issue No. 648. Cairo: Al-Ahram. http://weekly. ahram.org.eg/2003/648/eg6.htm. Retrieval date: March 2015.

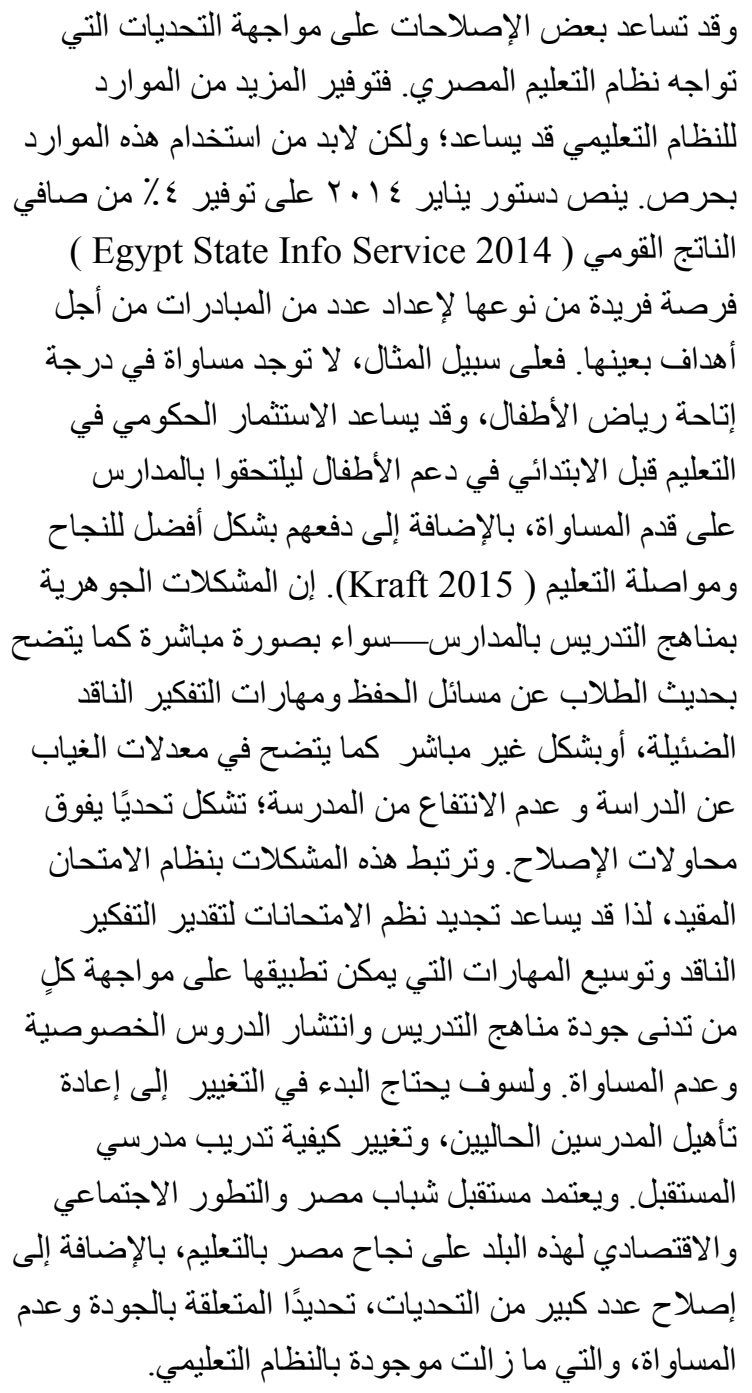


المسح التتبعي للنشء و الثباب في مصر ؟ ا.ب

UNDP and Institute of National Planning. 2010. Egypt Human Development Report 2010. Cairo: UNDP and INP.

UNESCO. 2006. Education For All Global Monitoring Report 2007: Strong Foundations: Early Childhood Care and Education. Paris: UNESCO.

UNESCO International Bureau of Education. 2006. Egypt: Early Childhood Care and Education (ECCE) Programmes. Country Profile Prepared for the Education for All Global Monitoring Report 2007. Geneva: UNESCO IBE

World Bank. 2002. Arab Republic of Egypt Strategic Options for Early Childhood Education. Washington, DC: World Bank.

- - - 2007. Youth--An Undervalued Asset: Towards a New Agenda in the Middle East and North Africa: Progress, Challenges and Way Forward. Washington, DC: World Bank.

- - -2008. The Road Not Traveled: Education Reform in the Middle East and North Africa. Washington, DC: World Bank.

- - . 2013. Jobs for Shared Prosperity: Time for Action in the Middle East and North Africa. Washington, DC: World Bank. 


\section{مخرجات سوق عمل الثباب في فترة الاتحول}

رانبه رشدي • ايريني سلو انبيس

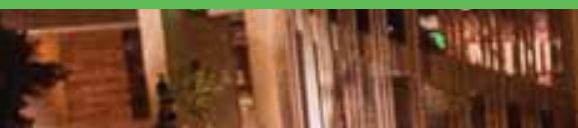 \\ $*^{3}+$ tolliaria}

$\Rightarrow$

i.

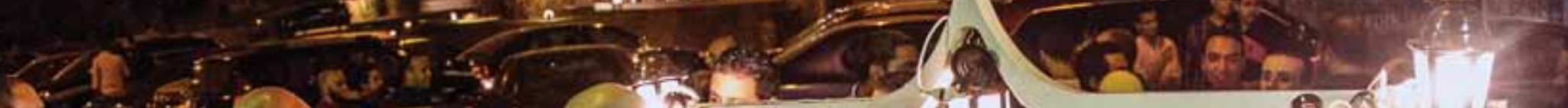

mist

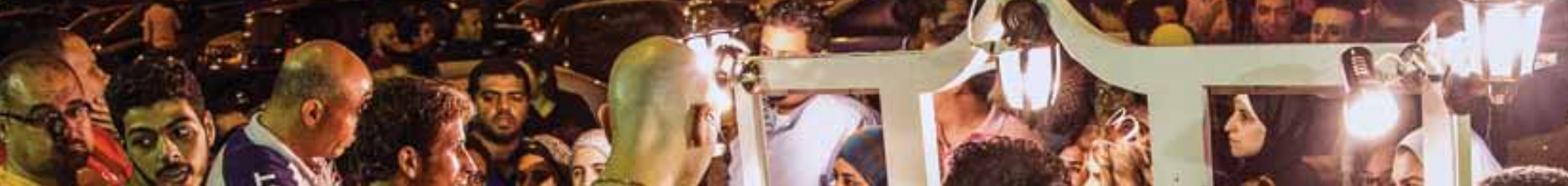

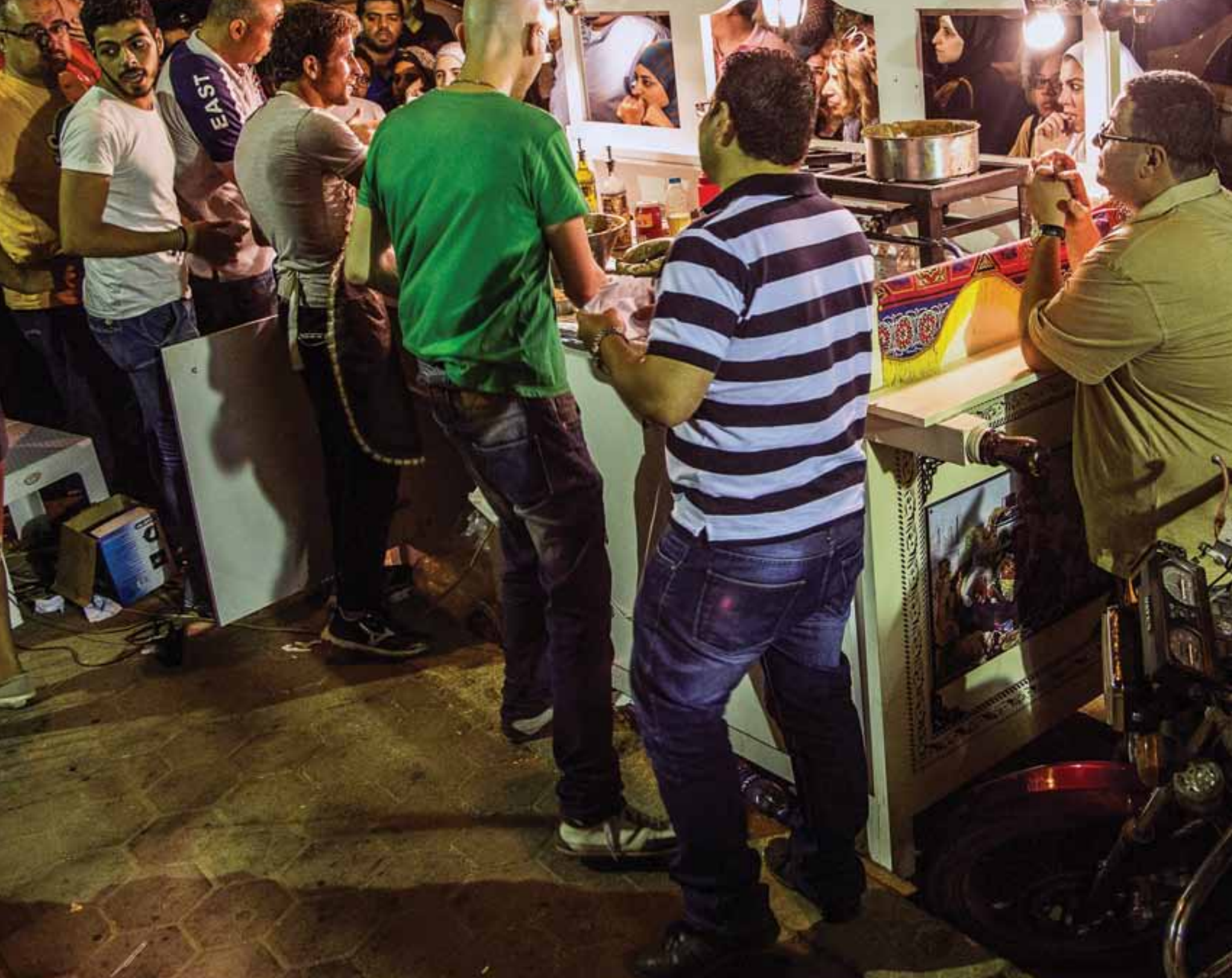


ويحاول هذا الفصل استخدام بيانات التوظيف المُحدثة التي يقدمها مسح النشء و الثباب في مصر من أجل تقديم تحليل

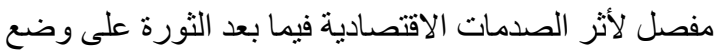

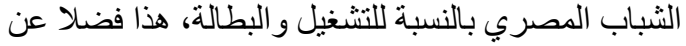
تحليل الكيفية التي أثرت بها الثورة علي حالة العمل المنتظم و الرسمي بين شباب العاملين. ونحن نركز هنا على تعريف

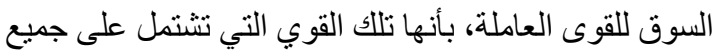
الأفر اد المنخرطين في النشاط الاقتصادي لأغر اض تبادل العمل مقابل أجر أو الذين يبحثون عن عمل. كما اعتمدنا أيضا علي التعريف القياسي الذي وضعته منظمة العمل الدولية (ILO)

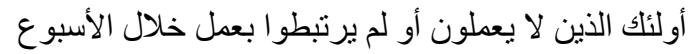

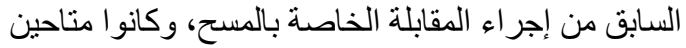

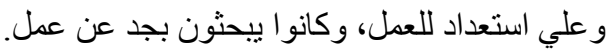

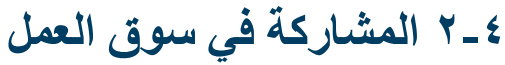

وفقًا لنتائج مسح ع ا ـ ب، انخفضت بشكل طفيف معدلات مشاركة الثباب الذين تتر اوح أعمار هم بين (10 ـ و ب) سنة

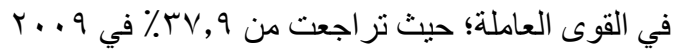

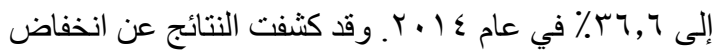

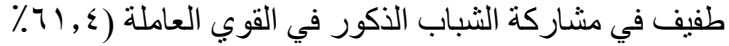

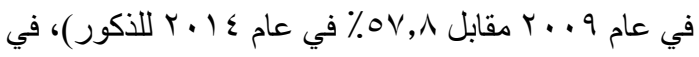

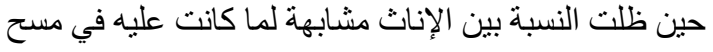

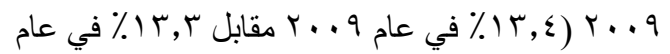

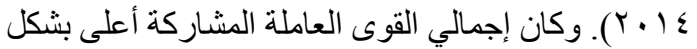

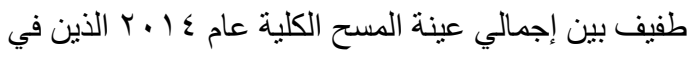

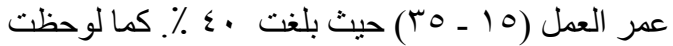

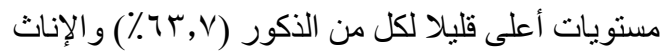

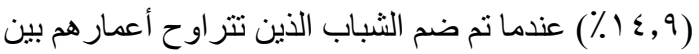

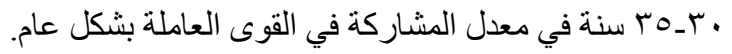

ونظرًا لأن هناك كثير من الثباب لا يز الون في التعليم، فسوف

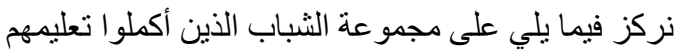

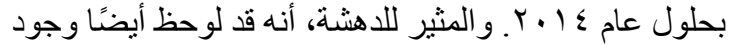

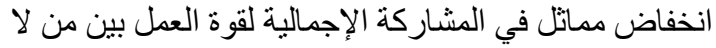

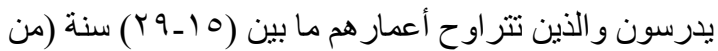

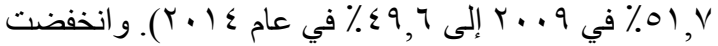

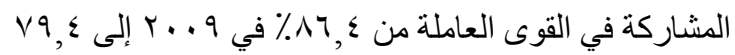
\% في عام ع ا ـ ب بين الثباب الذكور من غير الدارسين،

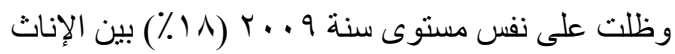

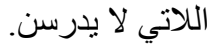

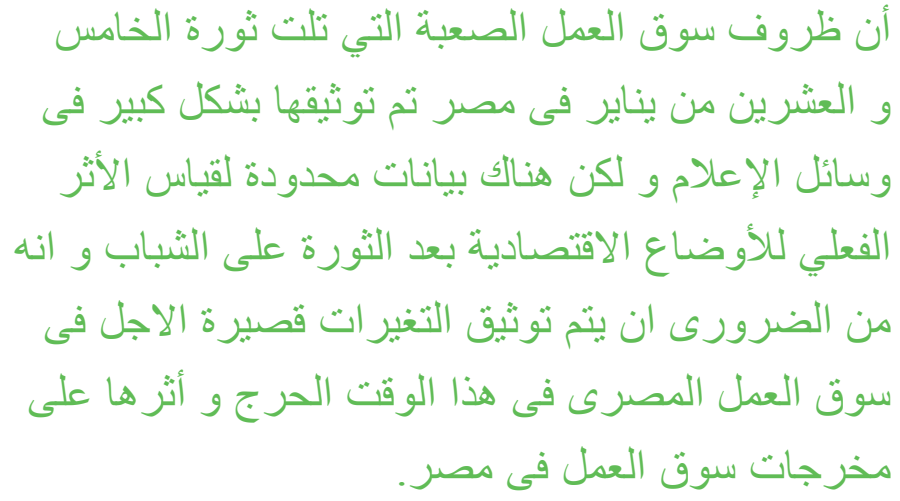

ع ا مقدمة

ولقد أوضحت الأدلة الدولية التاريخية أن هناك عدة عو امل

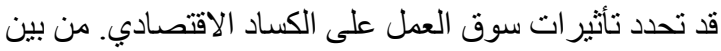
تللك العوامل حجم الكساد الاقتصادي، ودور مؤسسات سوق العمل الحالية، وطبيعة الاستجابة السياسية (Verick 2010).

ويمكن أيضًا ملاحظة أثار الصدمات الاقتصادية المرتبطة

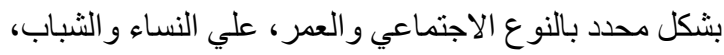

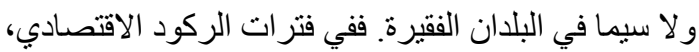

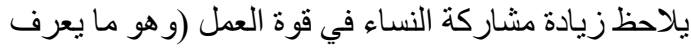
بتأثثير العمالة الإضافية) أو انسحابهن من قوة العمل (ما يسمى فئر

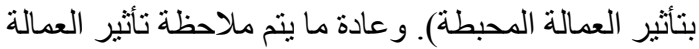

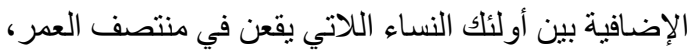

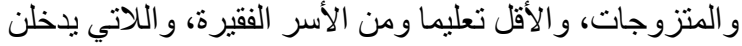

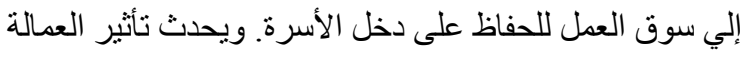
المحبطة، في المقام الأول، بين الثباب، المتعلمين تعليما عاليا، وبين النساء غير المتزوجات اللاتي يعطلن في قطاع الخدمات .'(World Bank 2009; Roushdy and Gadallah 2012)

ف فعلى سبيل الثثال، خلال أزمة الديون بأمريكا اللاتينية في أو ائل الثمانينيات

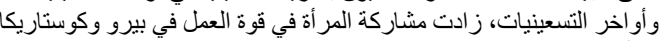

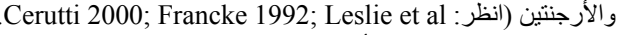

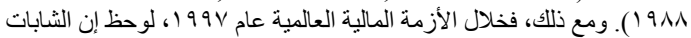

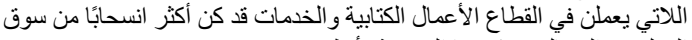

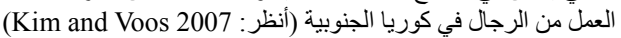


انخفضث معدلات مشار كة الذكور حسب جمبع مستويات التعليم باستثناء التعليم الثانوى بين الثباب الذى لا بدرس حالبا، وفى المقابل ز ادث مثنار كة الإناث فى في قوة العمل بين الأميات و الحاصلات على الثّهادة الابتدائبة و الثانوبة
ويعرض (الجدول ع ـ 1 ) معدلات مشاركة الثباب ممن لا

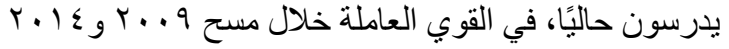

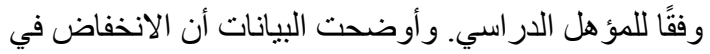
معدلات مشاركة الذكور في قوة العمل كان شاملا لجميع

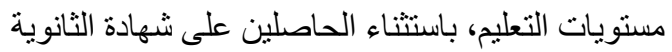
العامة. وفي المقابل، زادت مشاركة المر أة في قوة العمل بين

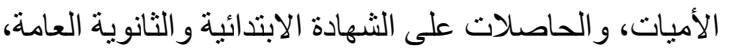

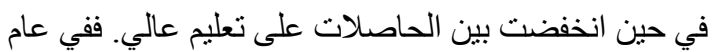

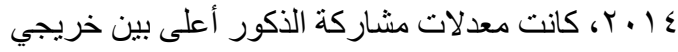

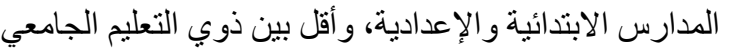
وما بعده و الأميين. أما بالنسبة للإناث، فكانت المشاركة

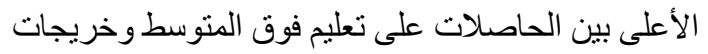
الجامعات، و أقل لدي من حصلن على الثهادة الابندائية

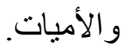

وكثفت النتائج في عام \& 1 ـ ب عن وجود علاقة طردية بين

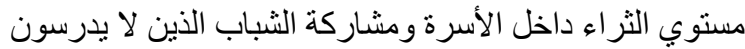

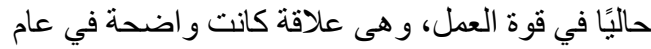

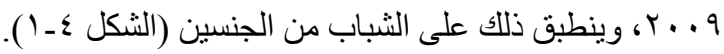

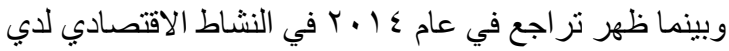

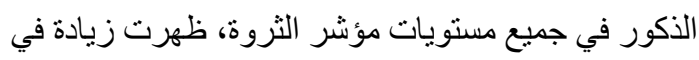
مشاركة الإناث ممن في المستوي الأدنى من الثروة و المستوي

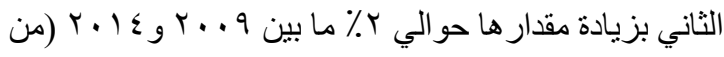

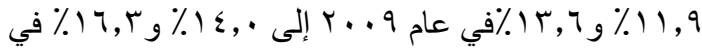

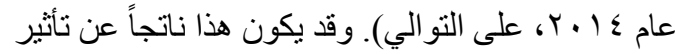

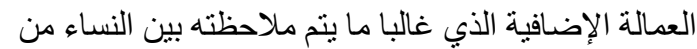
الأسر الفقيرة اللاتي يدخلن إلي سوق العمل خلال فترات
وكما هو متوقع أن الانخفاض الملحوظ في مشاركة الذكور في

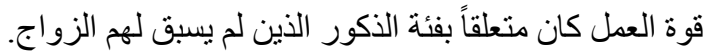
حيث شهدت فئة الثباب من الذكور الذين لم يسبق لهم الزواج

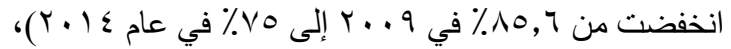

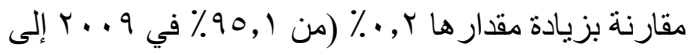

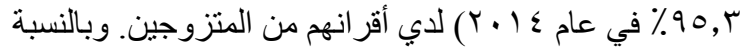

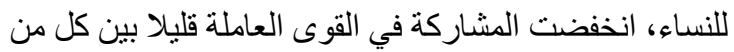

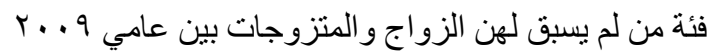

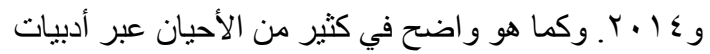

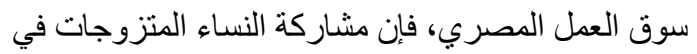

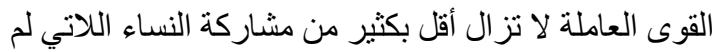

يسبق لهن الزواج (Assaad and El-Hamidi 2009).

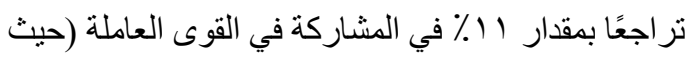

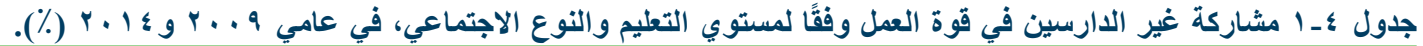

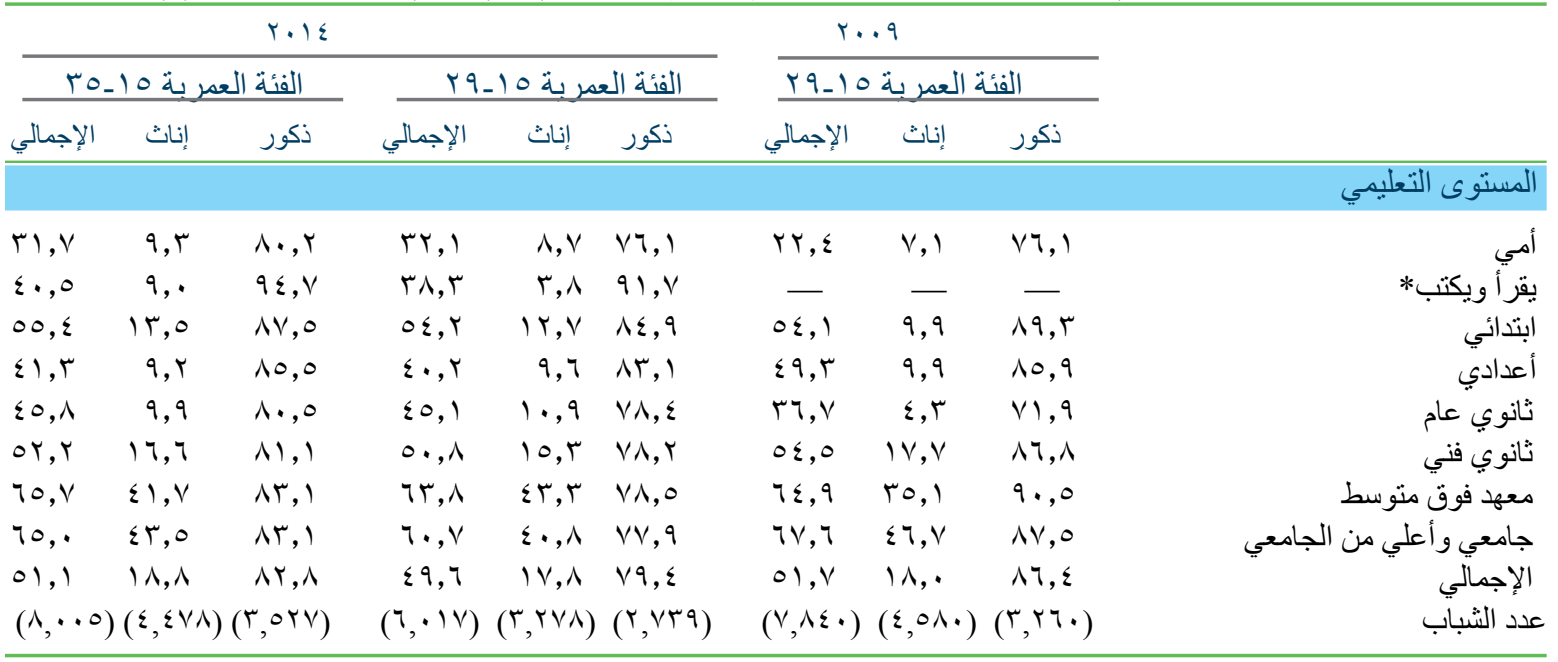

*لم يتضمن هذا الجدول معدلات غير الدارسين الذين يعرفون القر اءة و الكتابة في عام 9 . . ب نظر الصغر حجم العينة. 


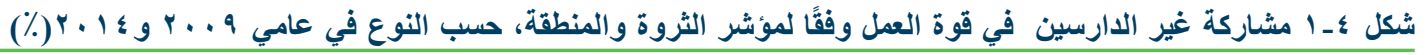

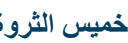

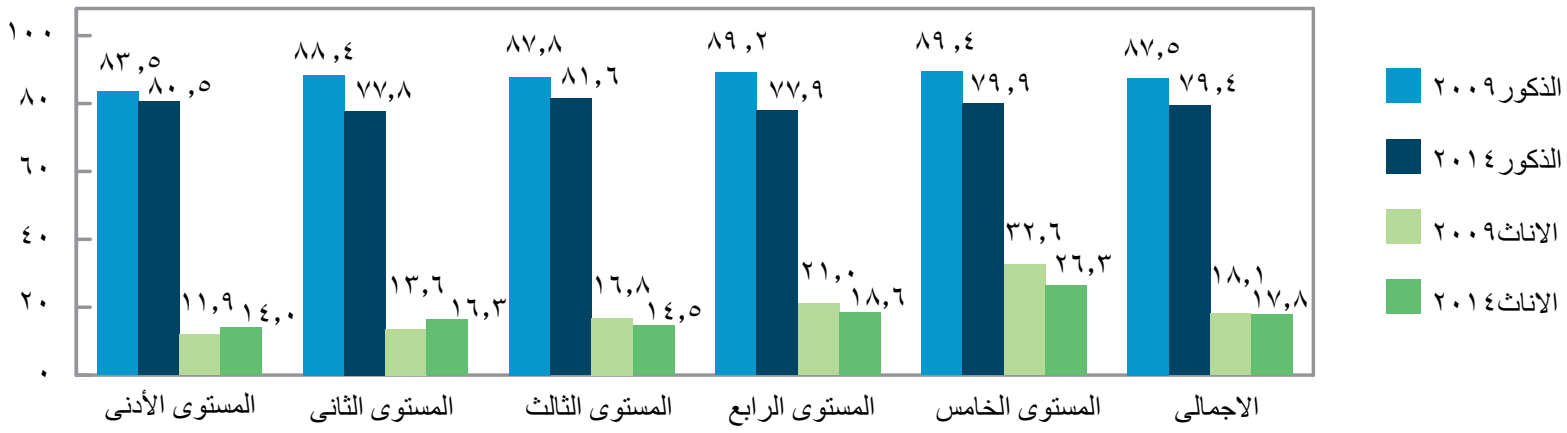

المنطقة

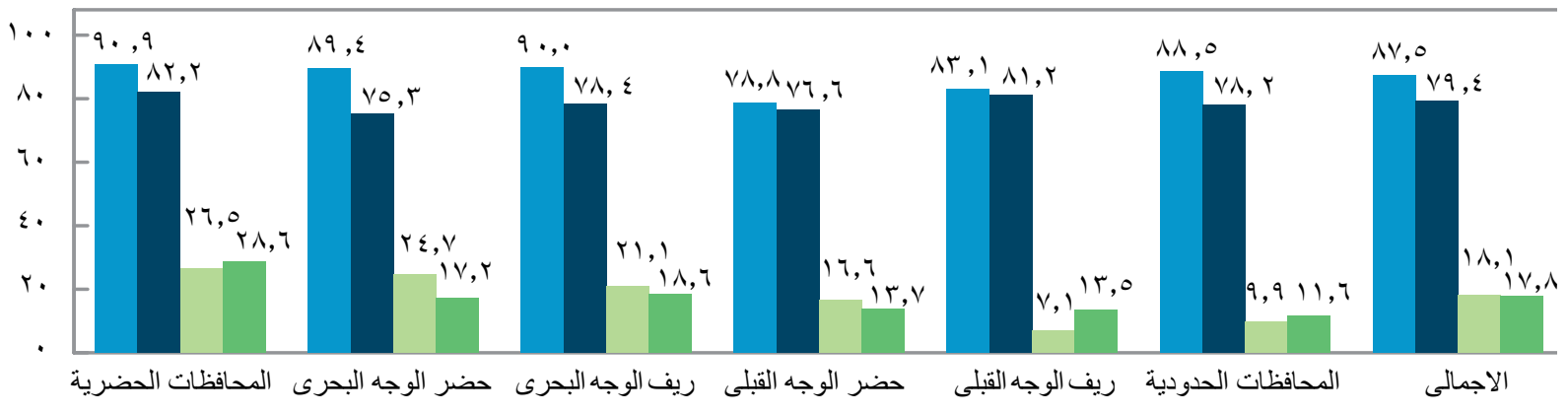

علي مستوي المحافظات الحضرية. وكان الانخفاض في نسبة مشاركة الثباب من الذكور (الذين تنر اوح أعمار هم ما بين الانئ

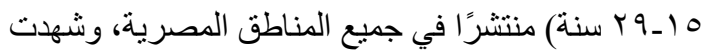

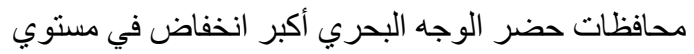

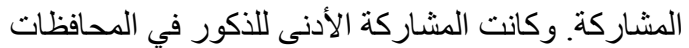

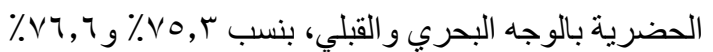
على التوالي.

و عموماً، كان الثباب في الفئة العمرية (10 ـ 9 Y) سنة و الذين

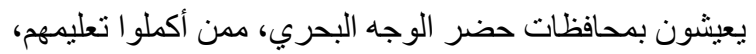

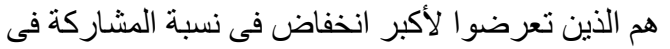

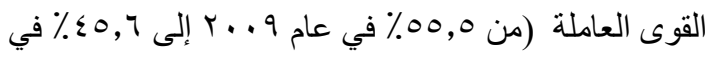

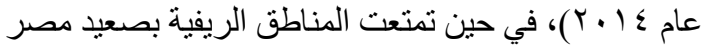

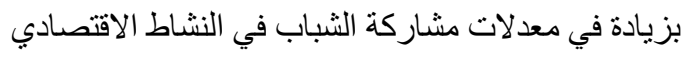

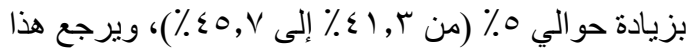

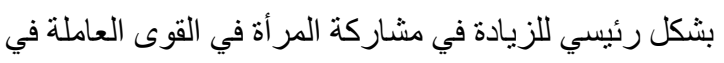

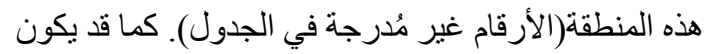

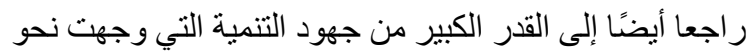

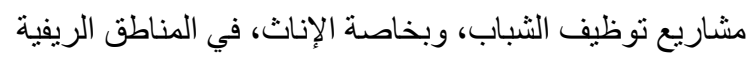

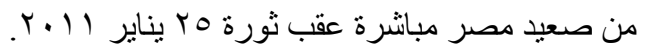

الركود الاقتصادي للحفاظ على دخل الأسرة. و قد نم ملاحظة

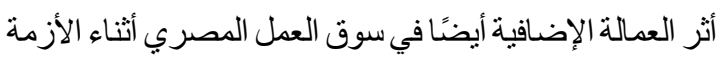
المالية العالمية أنظر: (Roushdy and Gadallah 2012).

و علاوة على ذللك، كان هناك تباين، على مستوي المنطقة، في التغييرات التي تم ملاحظتها في معدل مشاركة الثباب

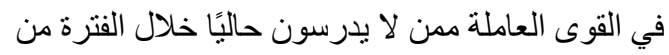

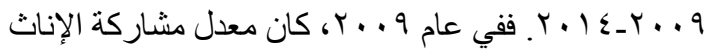

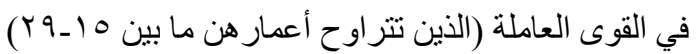

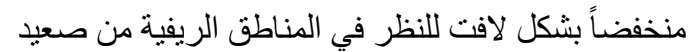

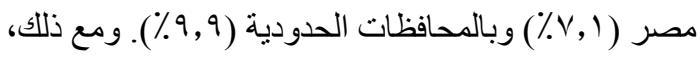

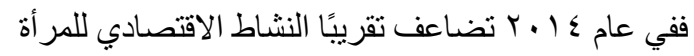

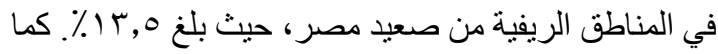

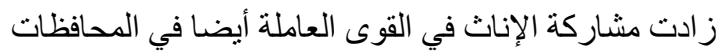

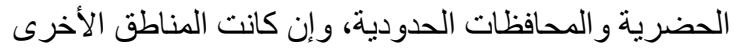

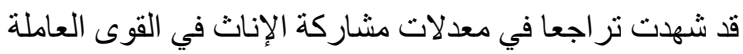

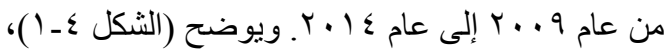

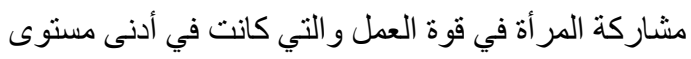

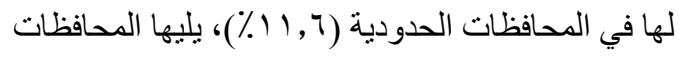

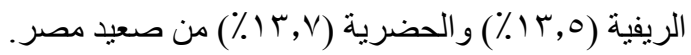
و لا يز ال شباب الإناث هن الناشطات اقتصادياً على الأرجح 
ومن أجل ضبط التغير في التوزيع العمري للشباب بين دورتي مسح النشء و الثباب في مصر ، نقام في (الثكل ع ـ-Y) بيانات

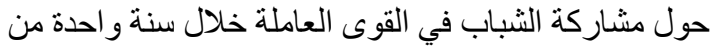

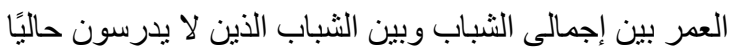

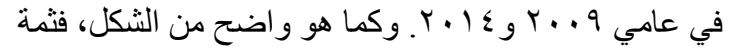

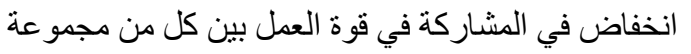
الثباب ممن لا يدرسون حاليًا و إجمالى الثباب (في الفئة الثئة

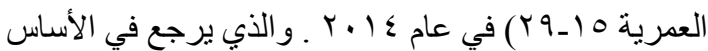

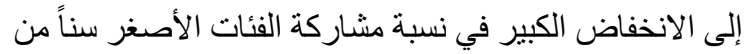

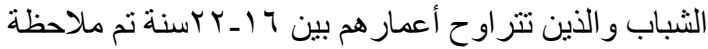

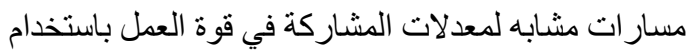
تعريف موسع للبطالة، و الذي يشمل إضافة العاطلين المحبطين

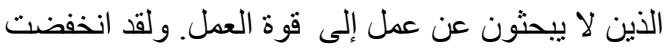

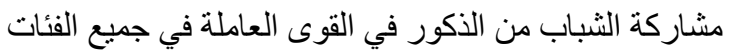

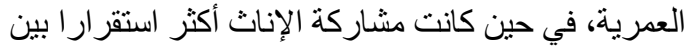

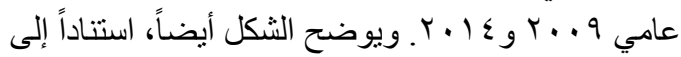

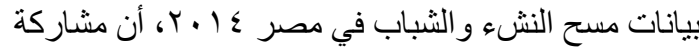

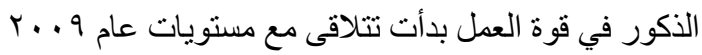

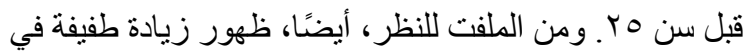
مشاركة المر أة بعد سن ·r سنة بالمقارنة بالأعمار الأصغر. كما لوحظ انخفاض في مشاركة الثباب في القوى العاملة في وخي

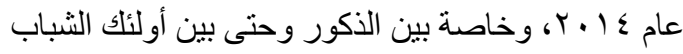

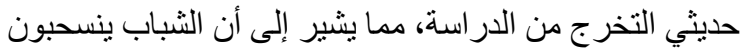

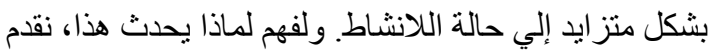

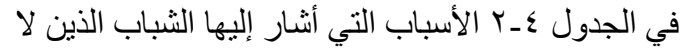

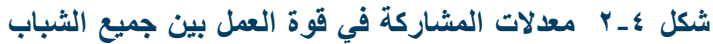

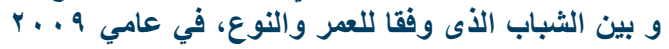

و
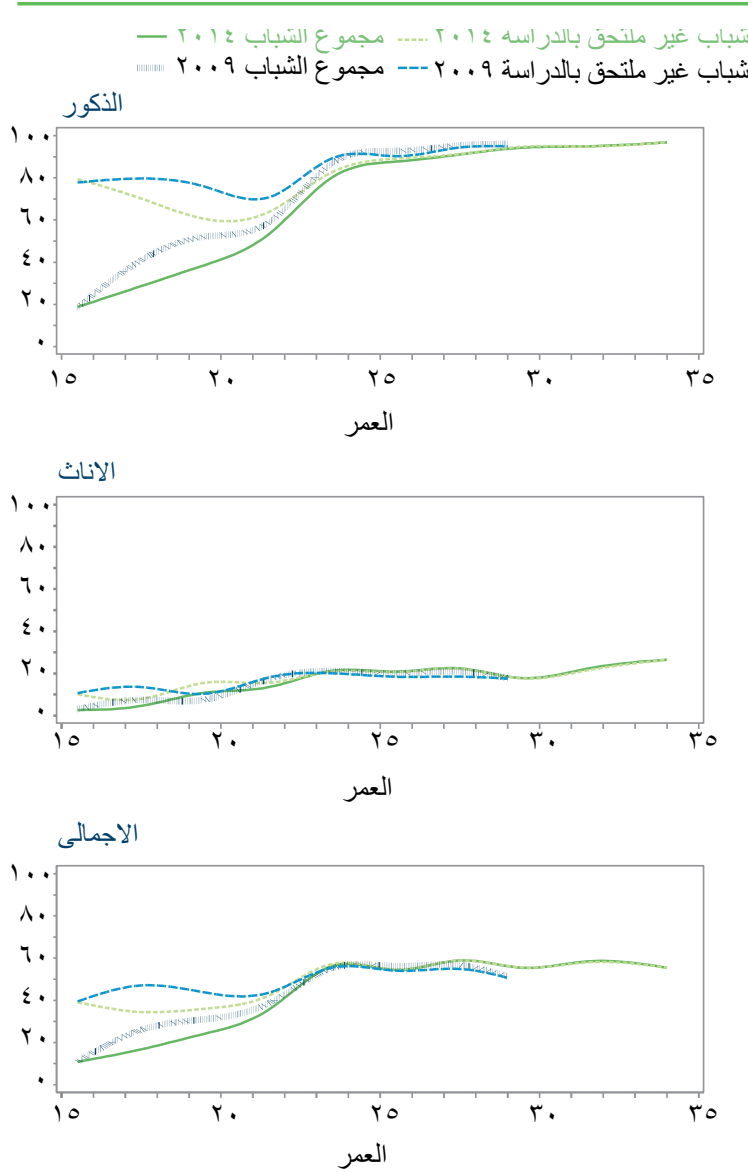

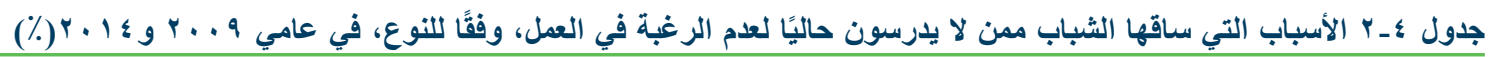

\begin{tabular}{|c|c|c|c|c|c|c|}
\hline \multicolumn{3}{|c|}{$r \cdot 1 \leqslant$} & \multicolumn{3}{|c|}{ r.. q } & \\
\hline 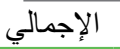 & إناث & ذكور & 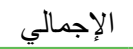 & 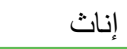 & ذ ذكور & \\
\hline & & & & & & أسباب عدم الرغبة في العمل \\
\hline $0 ., 0$ & 71,9 & $r, V$ & $\Delta r, q$ & 94,9 & $\cdot, \cdot$ & 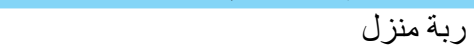 \\
\hline$r, \cdot$ & $r, \cdot$ & $r, \cdot$ & $\varepsilon, \varepsilon$ & $r, 0$ & Ir,r & لا أرغب في العمل* \\
\hline$\cdot, \mathrm{V}$ & $\cdot, 1$ & $r,$. & 1,. & $\cdot, r$ & $\vee, \varepsilon$ & إعاقة مؤقتة \\
\hline 1, & $\cdot, 0$ & $r, \varepsilon$ & r, & $\cdot, \wedge$ & ir,o & إعاقة دائم \\
\hline$\cdot$, & $\cdot, \cdot$ & $\cdot, r$ & $\cdot$, & $\cdot, \cdot$ & $\cdot, r$ & إنجازة بدون أجر للدة عام على الأقل \\
\hline$\cdot r$ & $\cdot, \cdot$ & $1, r$ & $\cdot, r$ & $\cdot, \cdot$ & $r, r$ & أخطط للسفر / عمل في الخارج أو الهجرة \\
\hline$r_{1,1}$ & 10,9 & $\varepsilon r, q$ & 0,1 & $r, \cdot$ & $r \cdot, \cdot$ & لا يوجد فرصة عمل مناسبة \\
\hline $1 T, V$ & 17,0 & $r, \cdot$ & - & - & - & رفض الأب/الزوج \\
\hline $9, \varepsilon$ & 1,7 & $\leqslant r, \cdot$ & $\varepsilon, \varepsilon$ & $\cdot, 7$ & $r_{0, r}$ & آخري \\
\hline$(r, 11 \cdot)$ & $(r, T Y \lambda)$ & $(\varepsilon \wedge r)$ & $(\Gamma, 907)$ & $(\Gamma, T T V)$ & $(Y \wedge 9)$ & عدد الثباب \\
\hline
\end{tabular}

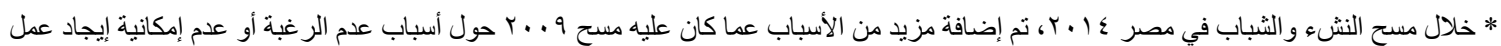

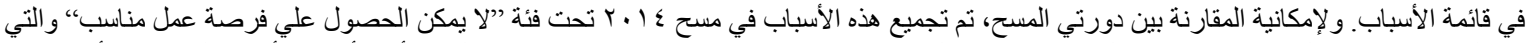

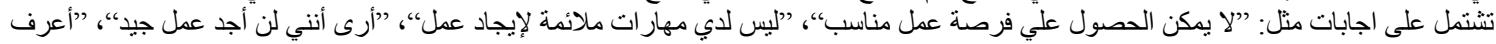

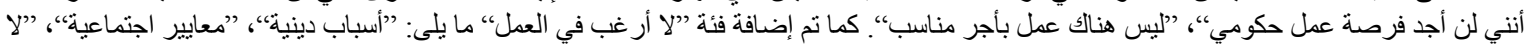

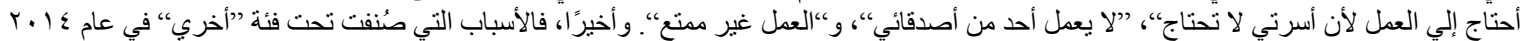




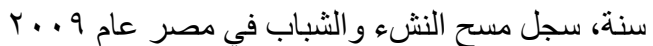

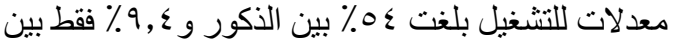
الإناث في نفس الفئة العدرية. ووفقا لمسح النشء و الثباب في مصر لعام ع ا • Y، فقد استمر هذا الاتجاه السلبي إلى أبعد مما سبق، فكان معدل التشغيل الاجمالي للثباب في الفئة العمرية

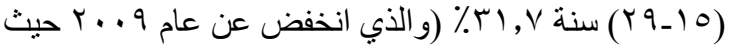

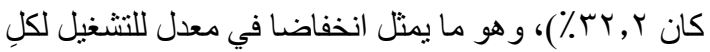

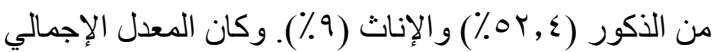
للتشغيل لكل المستجيبين في مسح النشء و الثباب في مصر

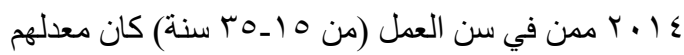

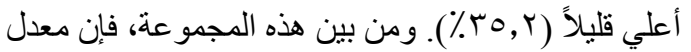

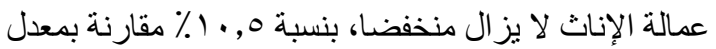

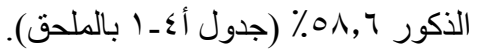

\section{الاختلاف بين الجنسين في نوع العمل}

وبالتركيز على هيكل التثغيل بين الثباب من الجنسين في الفئة

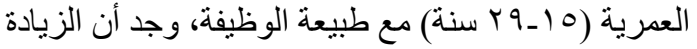

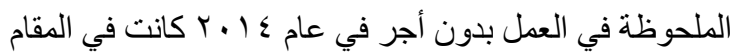
الأول بسبب الزيادة المطردة في حصة العمل لدي الأسرة بدون

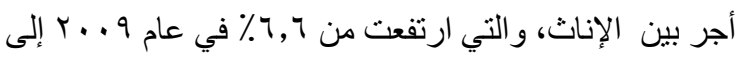

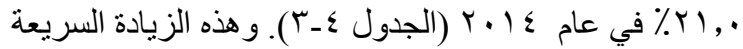

في عمل المر أة بدون أجر قد تكون ناتجة عن أثر العمالة

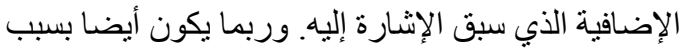
التوسع في مشاريع توظيف الثباب في مرحلة ما بعد مب بيناير المذكور أعلاه، وخاصة للثباب من الإناث في المناطق الريفية

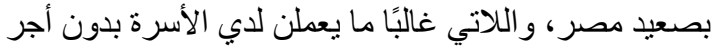

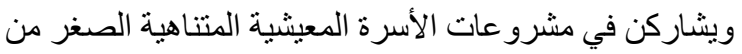

$$
\text { اجل الحفاظ علي دخل ثابت للأسرة. }
$$

كماز ادت نسبة الثباب من الذكور و الإناث من أصحاب العمل أو العاملين لحسابهم الخاص عبر دورتي المسح، لتصل إلى لى لى

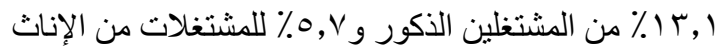

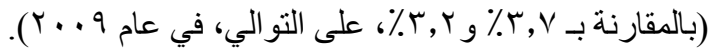

يدرسون حاليًا لعدم رغبتهم في العمل (وبالتالي فهم حتى لا

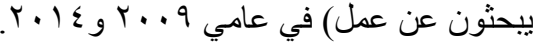

على الرغم من أن نسبة الثباب الذين أفادو ا بعدم رغبتهم في

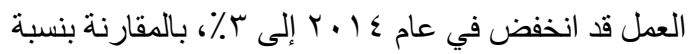

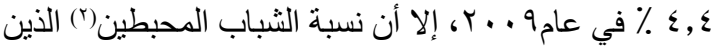
لا يريدون أن يعملوا بسبب عدم توفر فرصة عمل مناسبة قد إندابل

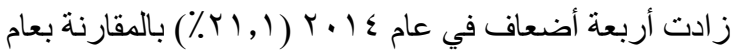

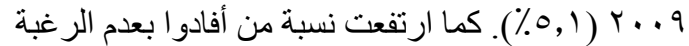

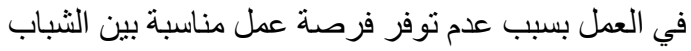

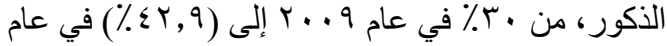

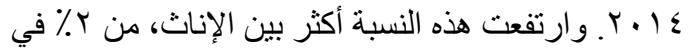

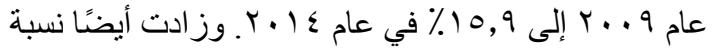

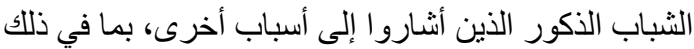

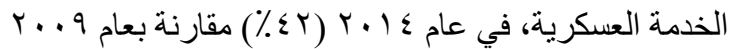

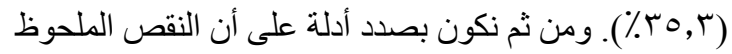

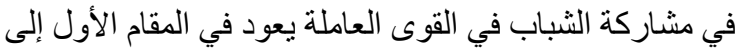

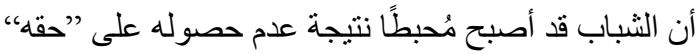

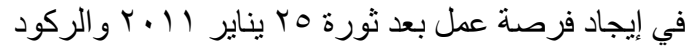
الاقتصادي الذي أعقبها.

كما يوفر الجدول (ع بـ دليل على أن الثقافة و المعايير

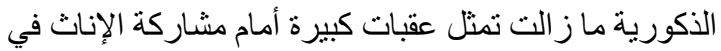

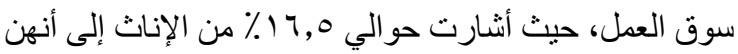
لا ير غبن في العمل نظر الرفض آبائهن أو أزواجهن.

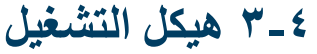

رصد مسح النشء و الثباب في مصر معدل التشغيل بين

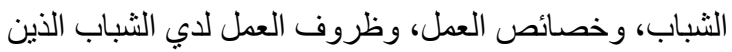

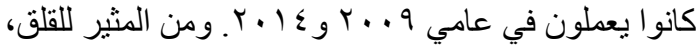

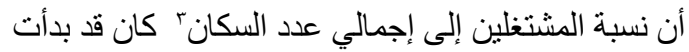

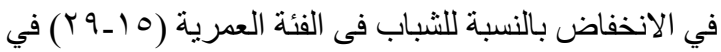

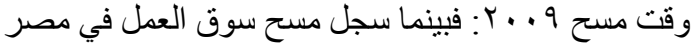

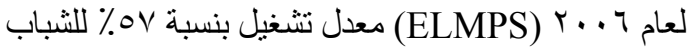

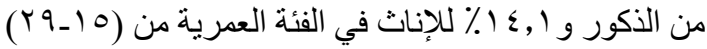

نوعني "بالإحباط" هنا أن الشاب/الثابة لم يعد لديد/لديها الر غبة في العمل لأن

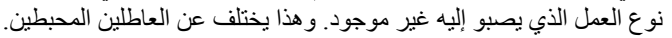

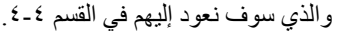

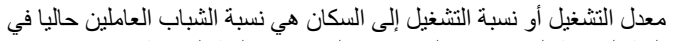

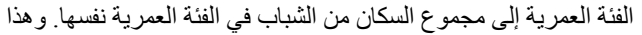

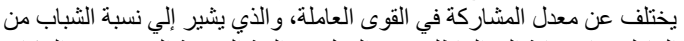
العاملين بالإضافة إلى العاطلين عن العمل في الفئة العمرية إلى مجموع الئل السكان من الثباب في الفئة العمرية نفسها. 


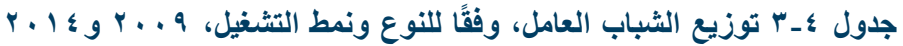

\begin{tabular}{|c|c|c|c|c|c|c|c|c|c|}
\hline \multicolumn{6}{|c|}{$r+1 \leqslant$} & \multirow{2}{*}{\multicolumn{3}{|c|}{ 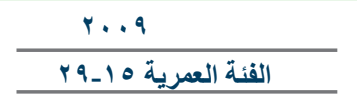 }} & \multirow[b]{3}{*}{ 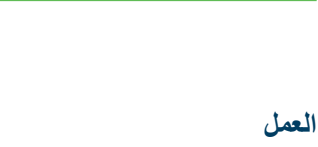 } \\
\hline \multicolumn{3}{|c|}{ الفئة العمرية ه 1 إهب } & \multicolumn{3}{|c|}{ الفئة العمرية ه 1 _q r } & & & & \\
\hline الإجمالي & 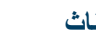 & ذكور & الإجمالي & إناث & ذكور & الإجمالي & إناث & 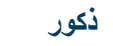 & \\
\hline & & & & & & & & & العمل بأجر \\
\hline 17,7 & $r_{0, \varepsilon}$ & $1 T, \varepsilon$ & $1 \pi, 7$ & rq,० & 11,1 & $1 r, 9$ & $r v, T$ & $1 \cdot, \cdot$ & قطاع عام \\
\hline $\mathrm{v}, \Lambda$ & $1 \cdot, r$ & $\vee, \varepsilon$ & $7, \wedge$ & $1 \cdot, 9$ & 7,1 & $\wedge, \vee$ & Ir,r & $\wedge, 1$ & خاص رسمي بأجر منتظم \\
\hline rA, r & ri,0 & rq,० & $r \cdot, r$ & rצ, & r), & $\varepsilon r, 0$ & rT, & $\varepsilon 0, r$ & خاص غير رسمي بأجر منتظم \\
\hline$r \leq, 1$ & 7,1 & $r V, r$ & $r \uparrow, r$ & 7,9 & rq, r & YI,, & 7,9 & $r \varepsilon, r$ & بأجر غير منتظم \\
\hline$\vee \neg, \wedge$ & VT,r & $V \vee, \varepsilon$ & $V V, r$ & $\vee r, \varepsilon$ & $\checkmark V, \Lambda$ & $\wedge \vee, q$ & $q \cdot, r$ & $\Lambda V, 0$ & إجمالي من يعمل بأجر \\
\hline & & & & & & & & & العمل بدون أجر \\
\hline $9, \cdot$ & $1 \wedge, 7$ & $v, r$ & $1 \cdot, v$ & r), & 9,1 & $\wedge, 0$ & 7,7 & $\wedge, \wedge$ & يعمل لاي الأسرة بدون أجر \\
\hline$\uparrow, \wedge$ & $r, r$ & $\mathrm{v}, \mathrm{T}$ & 0,9 & $r, r$ & $\uparrow, \varepsilon$ & 1,1 & $\cdot, 0$ & $1, r$ & صاحب عمل \\
\hline$\vee, \varepsilon$ & $\uparrow, \cdot$ & $\mathrm{v}, \mathrm{T}$ & $T, Y$ & r,o & $\uparrow, V$ & r,o & $r, V$ & $r, 0$ & يعمل لحسابه الخاص \\
\hline $\begin{array}{l}(r, r O \cdot) \\
r, r\end{array}$ & $\begin{array}{l}r \uparrow, \wedge \\
(0 \leq \vee)\end{array}$ & $\begin{array}{l}r, r, T \\
(r, \wedge \cdot r)\end{array}$ & $\begin{array}{c}r Y, \wedge \\
(r, \varepsilon r r)\end{array}$ & $\begin{array}{l}\text { (4ד, } \\
(r+4)(\end{array}$ & $\begin{array}{l}r, r, r \\
r, \cdot V O)\end{array}$ & $\begin{array}{c}\mid r, 1 \\
(r, \mid V T)\end{array}$ & $\begin{array}{l}9,1 \\
(00 \cdot)\end{array}$ & $\begin{array}{c}M, O \\
(r, T Y T)\end{array}$ & عدد الثنباب من بعمل بدون أجر \\
\hline
\end{tabular}

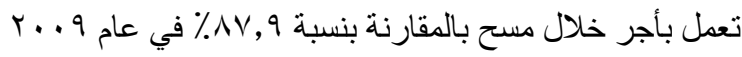

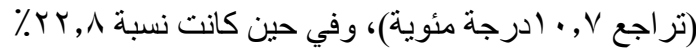

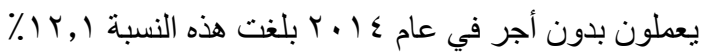

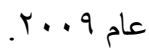

وقد لوحظ أيضاً انخفاض جو هري في نسبة الثباب العاملين بأجربشكل منتظم وغير رسمي بالقطاع الخاص. وبشكل

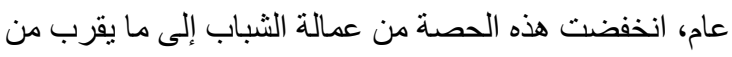

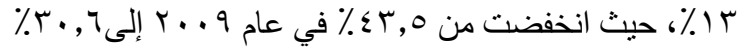

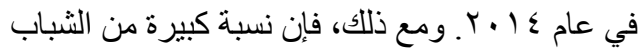

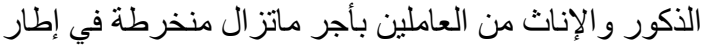
العمل غير الرسمي، بدون عقود عمل أو خدمات التأمينات الأنيات الاجتماعية. ولم يو اكب الانخفاض الملحوظ في في مشاركة

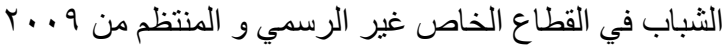

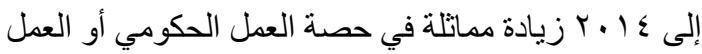

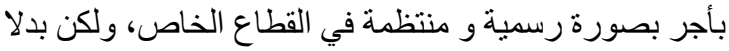
من ذلك كانت هناك زيادة في حصة العمل بأجر غير المنتظم

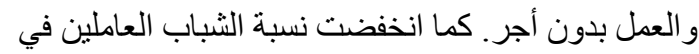

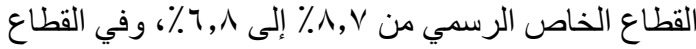

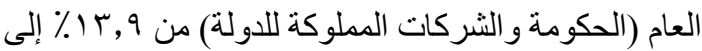

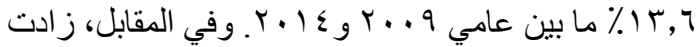

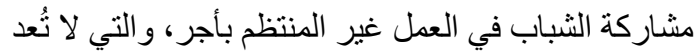

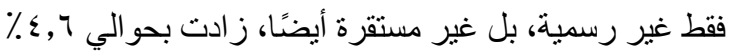

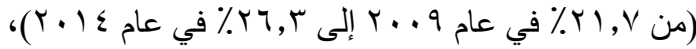

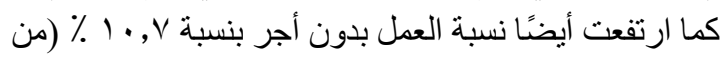

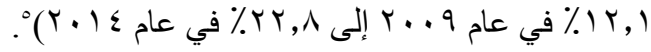

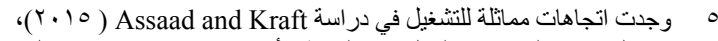

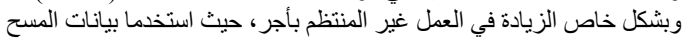

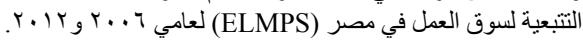

و تشير هذه النتائج إلى أن أكثر الثباب بدأوا يتحولون إلى ريادة

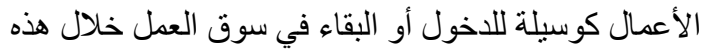

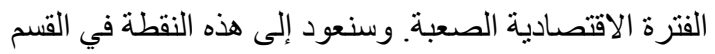

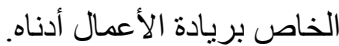

و على نحو مماثل لعام 9 . . ب، كانت النساء أكثر دخو لاً للعمل بالقطاع الحكومي من نظر ائهن من الرجال. ومع ذللك، فقد

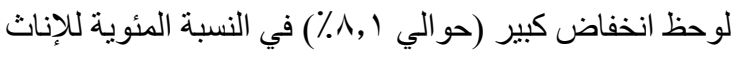

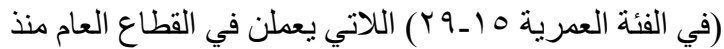

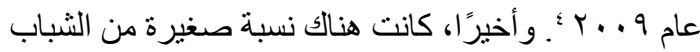

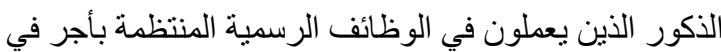

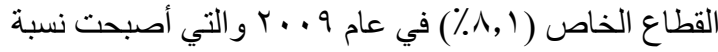

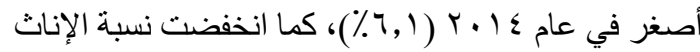

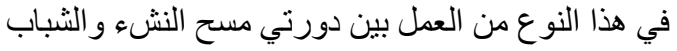

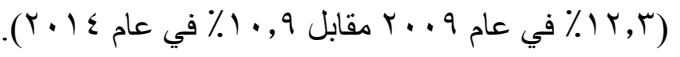

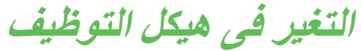

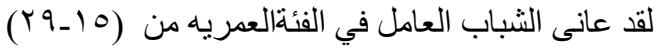

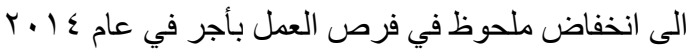

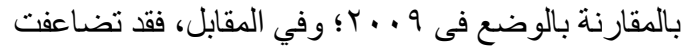

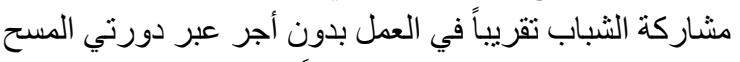

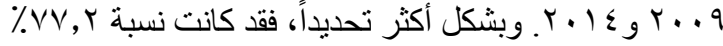

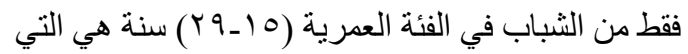

ع وقد يكون ذلك لتأثثر أفو اج العمرية، وهو ما يعني أن الوظائف الحكومية

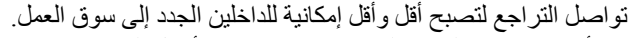

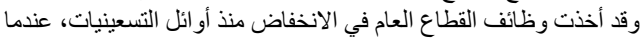

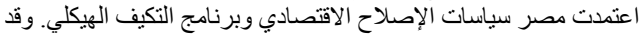

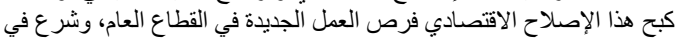

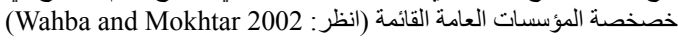


من ثلث النساء المشتغلات ( •,०\%٪) يعملن في هذه الأشكال من النشاط الاقتصادي، بالمقارنة بنسبة r , ٪\% فقط من الثباب

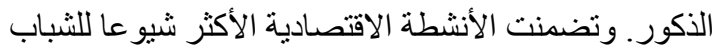

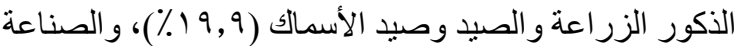

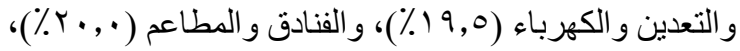

$$
\text { و البناء (19,1). (19). }
$$

وكما هو متوقع، ونظر اللزيادة في حصة الشباب الذين يعملون

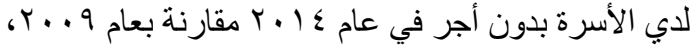
ارتفعت حصة المر أة العاملة في قطاع الزر اعة و الصيد وصيد

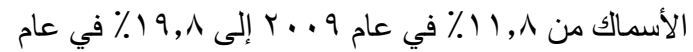

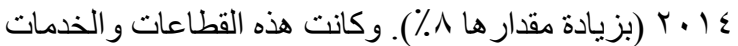
العامة هما فقط القطاعين الوحيدين اللذين شهدا زيادة في النسبة بين الإناث. أما بالنسبة للذكور، فكانت القطاعات التي شهدت حصة منز ايدة هي الفنادق وتجارة الجملة و المطاعم و البناء وقطاعات الخدمات العامة. ويعرض (الثكل عــ؟ النشاط الاقتصادي لجميع العاملين فى الفئة العمرية (0 ـ ـ هب) بمسح ع ا . ب يلاحظ وجود هيكل مماثل للنشاط الاقتصادي.

خصائص العمل

ويوضح (الجدول ع ــ)، زيادة نسبة الشباب المشتغلين في

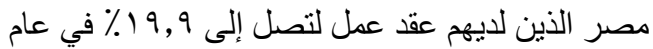

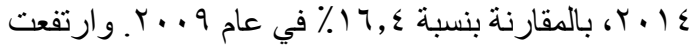
نسب الذين لديهم عقود عمل لكل من كل الذكور و الإناث
على الرغم من ان الثباب من الأكور و الإناث كانو ا متساوينين فى حصولثه

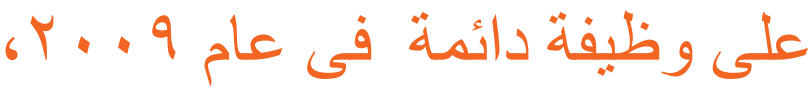
إلا أن النسبة الذين لديهم وظيفة دائمة

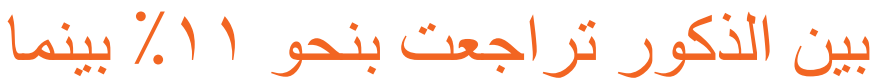

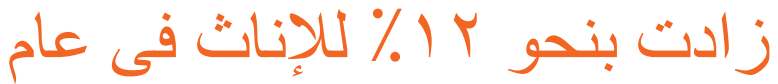

ويوضح (الثكل عــ") قطاعات النشاط الاقتصادي للشباب الذكور و الإناث في الفئة العمرية 10 ـ ـ ب سنة الذين كانوا

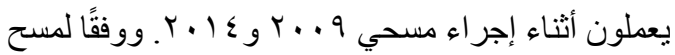

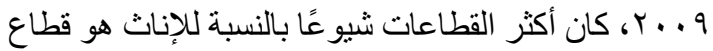
الخذمات العامة (بما في ذلك الإدارة العامة، و التعليم، و الر عاية

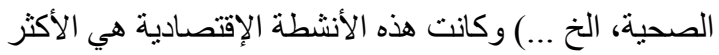

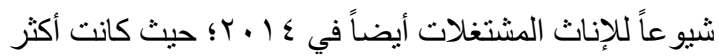

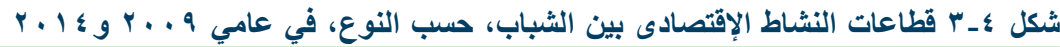

$r \ldots q$

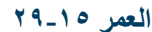

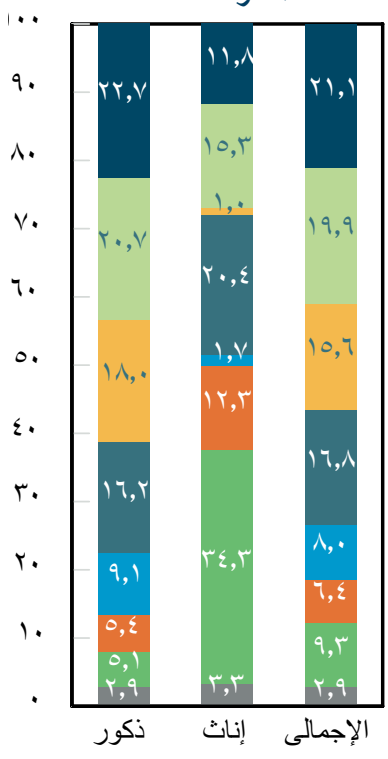

r. I $\leq$

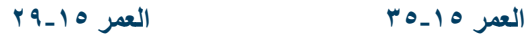

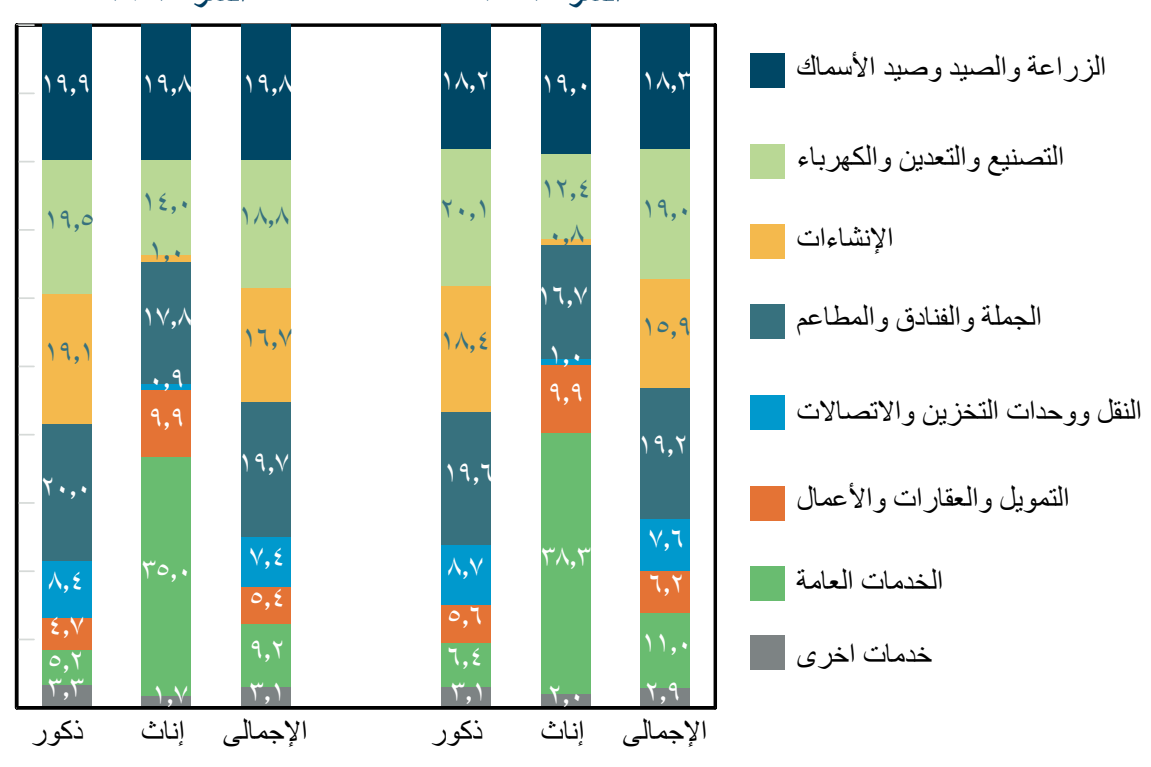




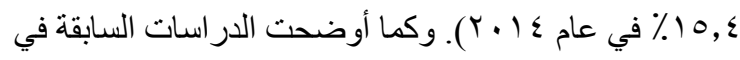
تفسير هذا الفرف بين الجنسين فيما يتعلق بالحصول علي عقد

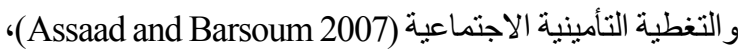
فإن ذلك يرجع أساسا إلى حقيقة أن المر أة في كثير من الأحيان

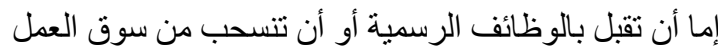
(أي تخرج من قوة العمل).

أما عن الاستقر ار الوظيفي، فعلى الرغم من أن شباب الذكور

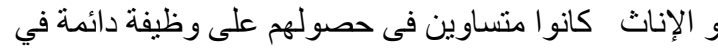

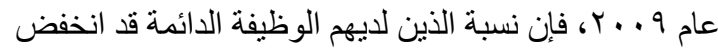

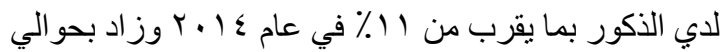
r 1 لدي الإناث. وفي المقابل، زادت نسبة الذكور العاملين

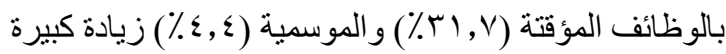

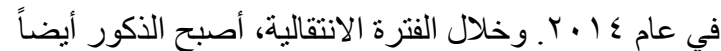

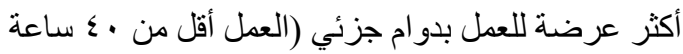

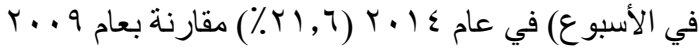

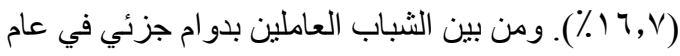

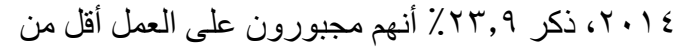

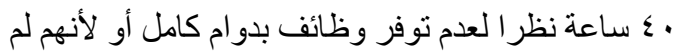

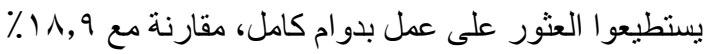

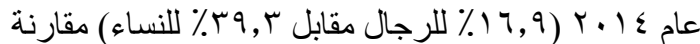

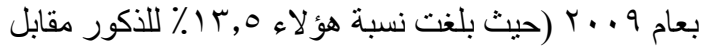

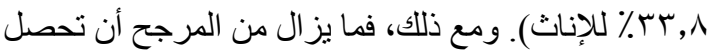
الإناث المشتخلات على عقد عمل مقارنة بنظر ائهن من الذكور في عام ع ا • ب. فقد كان حو الي ثلثي العاملين في القطاع العام من الذكور والإناث لديهم عقود؛ ومع ذلك، كانت احتمالية حصول الإناث على عقد في القطاع الخاص أكثر من الضعف ولى عإِ

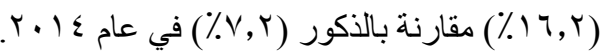

وبالمثل، فقد ارتفعت نسبة المشتغلين من الثباب الذين

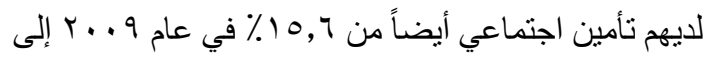

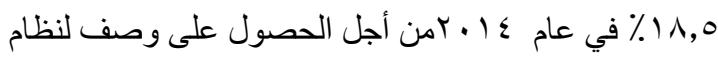
التأمين الاجتماعي و الزمن الذي يستغرقه الثباب من أجل الحصول على التأمين الاجتماعي في سوق العمل المصري أنظر :(Roushdy and Selwaness 2014). ولم تحافظ المر أة العاملة فقط على ميزة إمكانية حصولها على التأمينات

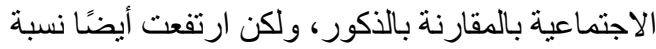

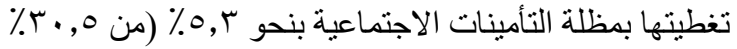

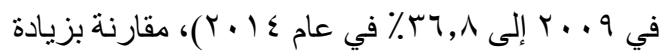

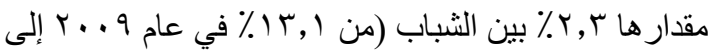

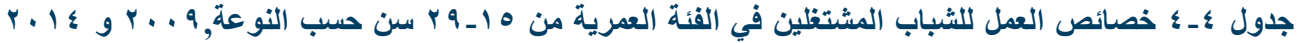

\begin{tabular}{|c|c|c|c|c|c|c|}
\hline \multicolumn{3}{|c|}{$r \cdot 1 \leq$} & \multicolumn{3}{|c|}{$r \ldots q$} & \multirow[b]{3}{*}{ خصائص الوظيفة الرسمية } \\
\hline الإجمالي & إناث & ذاكور & الإجمالي & إناث & ذكور & \\
\hline & & & & & & \\
\hline 19,9 & rq,r & 17,9 & $17, \varepsilon$ & & $1 \pi, 0$ & العقد \\
\hline \multirow{2}{*}{11,0} & & $10, \varepsilon$ & 10,7 & $r \cdot, 0$ & $1 \pi, 1$ & التأمينات الاجتماعية \\
\hline & & & & & & الاستقرار الوظيفي \\
\hline$\leq \neg, r$ & $\uparrow \wedge, 1$ & $\leqslant r, q$ & $0 \leqslant, 1$ & 07,0 & ד, & 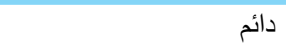 \\
\hline$V \leqslant, \varepsilon$ & ov, q & $\vee \wedge, \varepsilon$ & $\vee 9,7$ & $0 \wedge, 0$ & Ar,r & 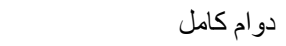 \\
\hline ro,, & $\varepsilon r, 1$ & $r_{1,7}$ & $r_{\cdot}, \varepsilon$ & $\leqslant 1,0$ & $17, \mathrm{~V}$ & دوام جزئي \\
\hline$r \cdot, q$ & $r_{\cdot}, \cdot$ & ri,. & $r_{1}, 9$ & $r \varepsilon, 7$ & 19,1 & مؤقت \\
\hline$\varepsilon, r$ & $r, v$ & $\varepsilon, \varepsilon$ & 1,1 & $r, r$ & 1,0 & موسمي \\
\hline$r \wedge, T$ & $\Lambda, r$ & r,, $\mathrm{V}$ & $r, r$ & $0, V$ & ro,. & عرضي \\
\hline \multirow[t]{2}{*}{$r 9,0$} & $\langle 1, \wedge$ & $r \cdot, \Lambda$ & $\leqslant 9, \varepsilon$ & $\varepsilon r, r$ & $0 ., 7$ & يتطلب العمل مهارة \\
\hline & & & & & & كيف تتعلم مهارة؟ \\
\hline Ir, & $r q, 1$ & $9, r$ & $1 \leq$, & $r \varepsilon, T$ & 11,1 & التعليم النظامي \\
\hline $1 \leqslant, \cdot$ & $r r, \cdot$ & $1 T, \cdot$ & $r \wedge, \uparrow$ & $\leqslant 0, \cdot$ & rч, & تدريب مهني \\
\hline$\varepsilon 1, \wedge$ & $1 \cdot, v$ & $\leq 0, r$ & rq, r & 0,7 & $\varepsilon r, q$ & تدريب لاى أسطى \\
\hline $19, \varepsilon$ & $10, v$ & 19,9 & $r, \cdot$ & 1,1 & $r, r$ & التدريب أثناء العمل \\
\hline 11,9 & $11, \varepsilon$ & 11,9 & $11, \cdot$ & $7, \wedge$ & 11,0 & الأسرة/ التدريب الذاتي \\
\hline$\cdot, \wedge$ & $\cdot, \cdot$ & $\cdot, 9$ & $\varepsilon, r$ & 7,9 & $r, q$ & أخرى \\
\hline$(Y, \varepsilon \leqslant V)$ & (r) & $(r, \cdot \wedge 0)$ & $(\Gamma, I \vee T)$ & $(00 \cdot)$ & $(r, T Y T)$ & عدد الشباب \\
\hline
\end{tabular}


بين أرباب العمل في مصر لتكون بديلا عن ضعف مستوى التدريب المقدم للثباب خلال التعليم الرسمي ’.

\section{ظطروف العمل}

ويعرض (الجدول أ ع _ ب) خصائص إضـافية عن ظروف العمل الخاصة بالثباب المشتغلين. وكما هو الحال في عام

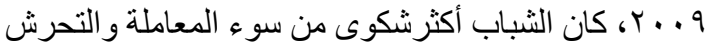
في القطاع الخاص منها في القطاع العام، وينطبق ذلك على منى الثباب من كلا الجنسين. ومع ذلك، فإنه من المثير للاهتمام أن نلاحظ أنه لا يوجد فرق جو هري بين الجنسين في تجربة المعاملة القاسية من جانب المشرفين سواء في القطاع العام

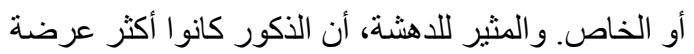

للمعاناة من المضايقات والتحرش من الإناث. وكما ذكر

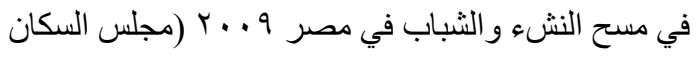

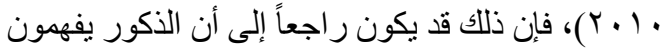
مصطلح "التحرش" بشكل مختلف عن الإناث. فهم قد يعتقدون أن التحرش يعني الخناقات أو الجدال أو هو جزء من سوء لإلتات

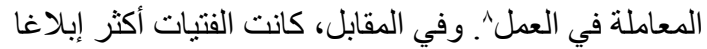
عن التحرش أثناء التنقل اليومي. وقد يكون ذللك راجعًا إلى إلى إنى

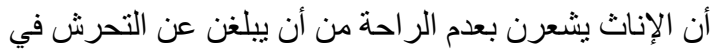

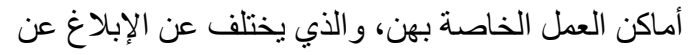
التحرش في الأماكن العامة مثل في الثار ع أو المو اصلات.

كما كان الثباب من الجنسين أكثر عرضة للشكوى من ساعات العمل الطويلة، وزيادة عبء العمل، وظروف العمل الخطرة في القطاع الخاص على نحو أكثر من القطاع العام. و أيضاً، على غرار 9 . . r، فماز ال أغلبية الذكور والإناث يشتكون

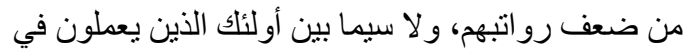

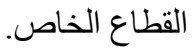

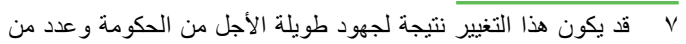

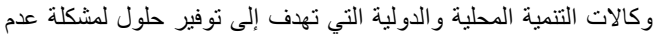

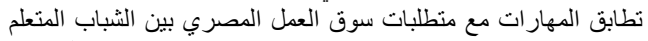

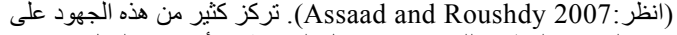

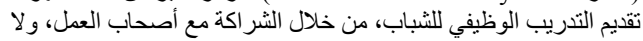

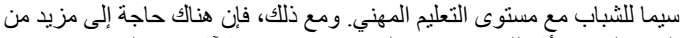

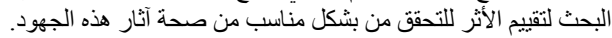

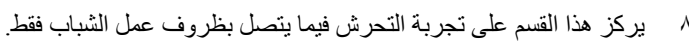
ولمزيد من المعلومات حول تجربة النحرش بين جميع الإناث، انظر الفصل بلفيل

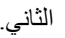

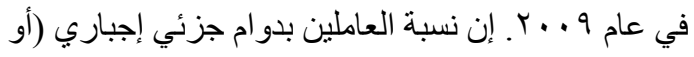

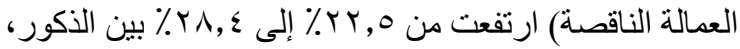

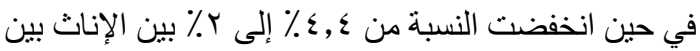

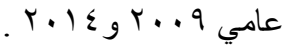

ويوفر ذلك دليلاً على أن الوظائف المستقرة للأكور قد

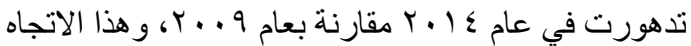
يتميز بنقص فرص الحصول على وظيفة دائمة، مع وجود تز ايد في الوظائف المؤقتة والموسمية، والاجبار على العمل بدوام جزئي'.

وبالإضافة إلى الاستقر ار الوظيفي وحالة العمل الرسمي، فقد

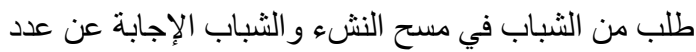
من الأسئلة التي تتعلق بما إذا كان عملهم يتطلب مهارة خاصة

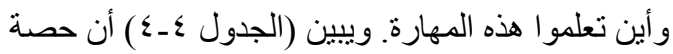
الشباب الذين تتطلب وظيفتهم مهارة خاصة قد انخفضت إلى ولى حد كبير في عام ع | • ب بين كل من الذكور و الإناث، ولكن لا يز ال الذكور أكثر عرضة للمشاركة في وظيفة تنطلب مهارة

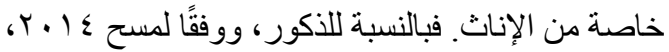

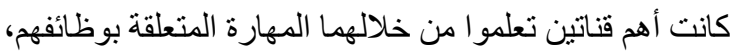

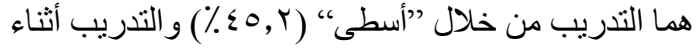

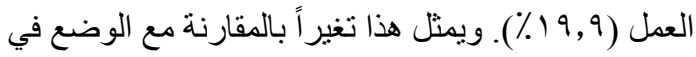

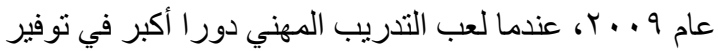

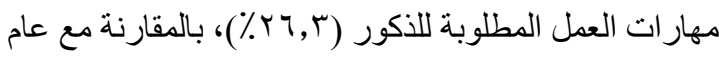
.$(\%, \cdot) r \cdot 1 \varepsilon$

واختلفت قنوات التدريب للإناث؛ فقد أوردن أنهن قد حصلن علي تدريبهن في المقام الأول من خلال نظام التعليم ( , وب\%)

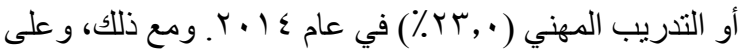
غرار الرجال، فقد انخفضت النسبة المئوية للنساء في الإفادة باكتساب المهار ات من خلال التدريب المهني بمقدار النصف

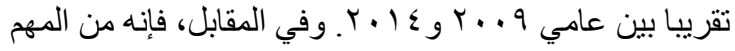
أن نلاحظ هنا أن نسبة الشباب الذين تعلمو ا مهارة وظائفهم من

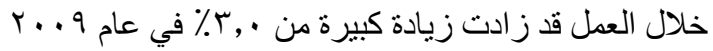

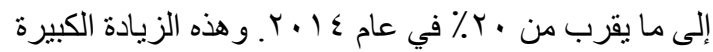
لوحظت لاى الذكور و الإناث على حد السو اء. وربما يكون هذا مؤشر ا على أن ثقافة تقديم التدريب المهني قد بدأت في التوسع

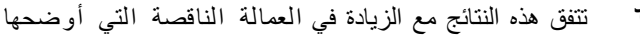

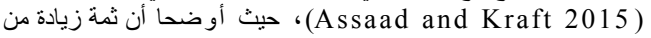

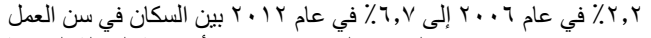

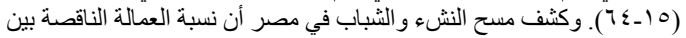

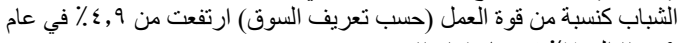


شكل ع ـ ـ معدلات بطالة الشباب، حسب العمر والنوع، مسحي

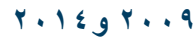
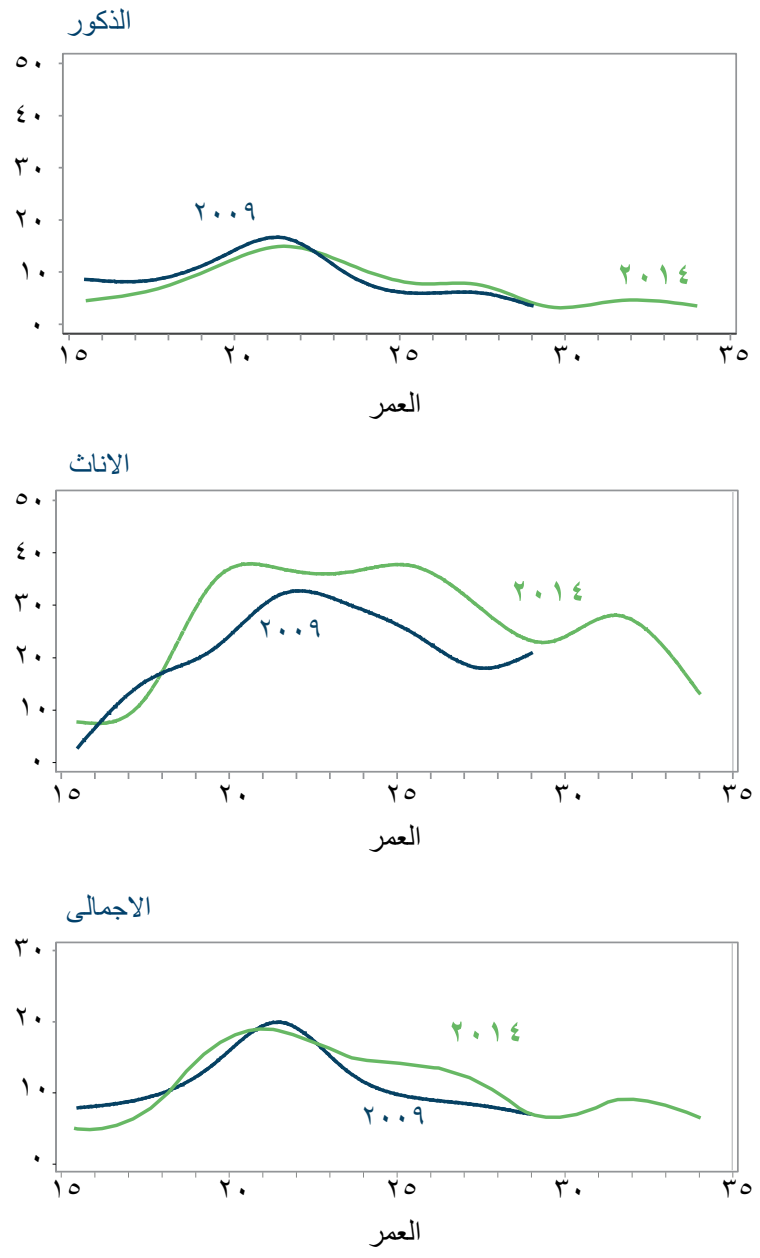

يوضح (الثكل ع ــ ) أن البطالة تظل هي المشكلة الحقيقة

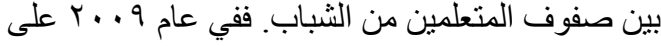
سبيل المثال، كانت معدلات البطالة أعلى بين الثباب الذين الذين

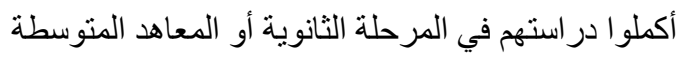

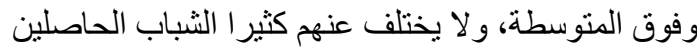

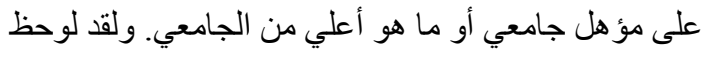

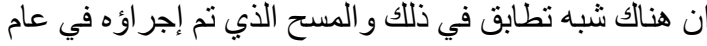

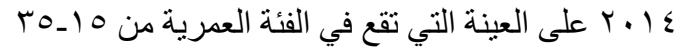

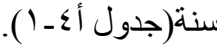

\section{أسباب ألبطانلة}

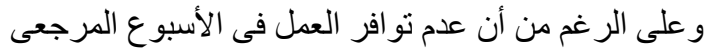

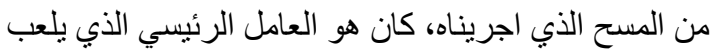

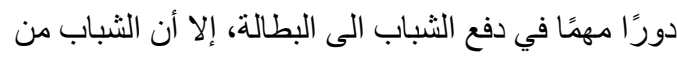

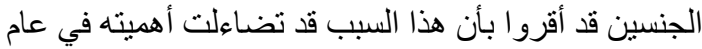

ع - ع البطالة

باستخدام تعريف السوق لمفهوم البطالة، نجد أن بطالة الثباب

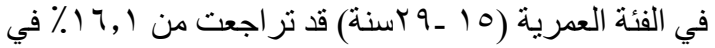

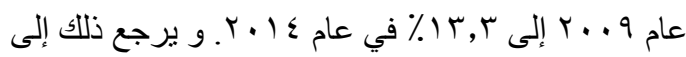

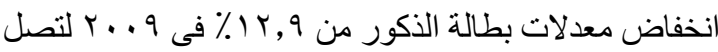

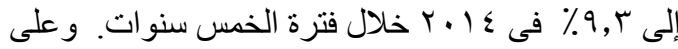

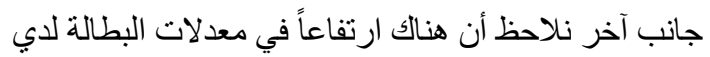

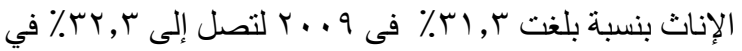

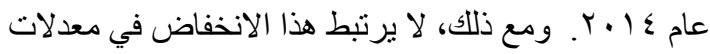

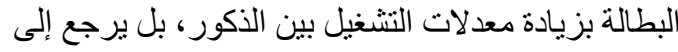

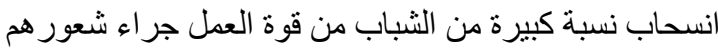

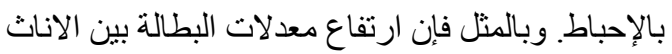

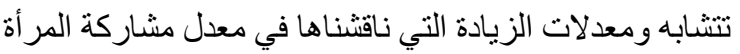

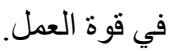

انخفض معدل البطالة بالمفهوم الموسع، و الذي يضم كلا من الثباب العاطلين المحبطين و غير الجادين في البحث عن عمل،

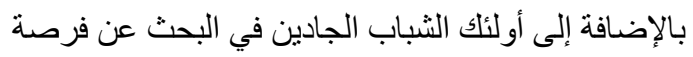

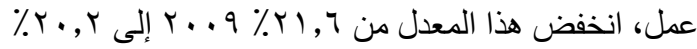

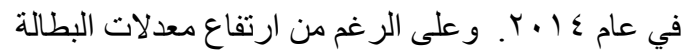

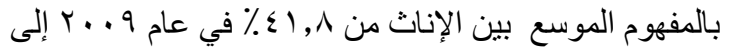

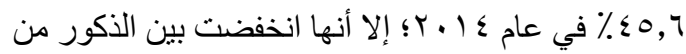

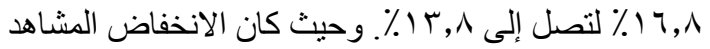

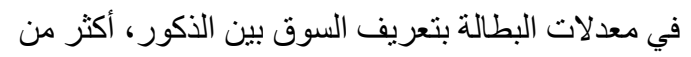

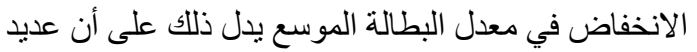

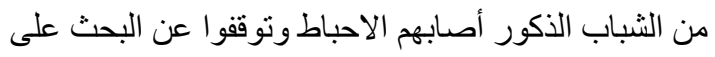

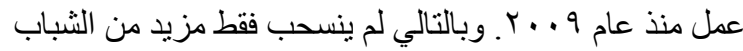

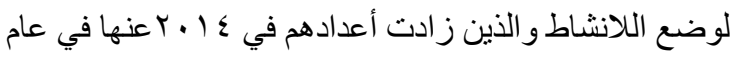

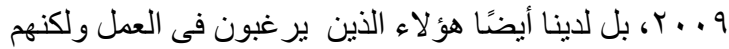
يميلون إلى التوقف عن البحث.

وقد أوضح تتاول قضية البطالة بتعريف السوق طبقا للعمر أن

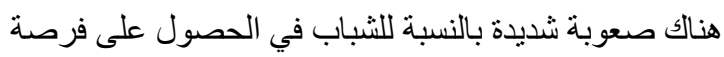

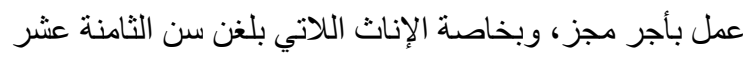

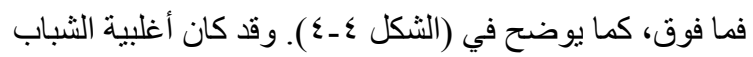

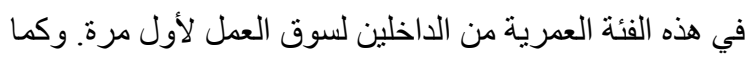

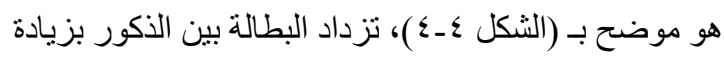

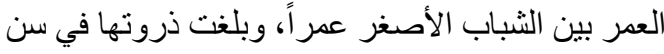

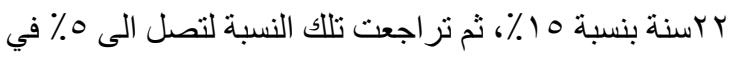
عمر ^^ سنة، وفى المقابل لذللك نجد زيادة في معدلات البطالة

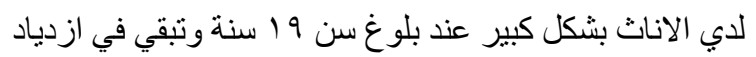

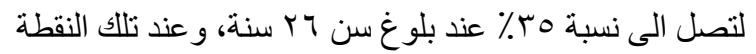

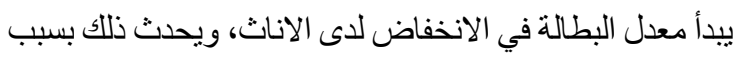
مغادرة العديد من النساء سوق العمل نتيجة للزو اجو الإنجاب. 


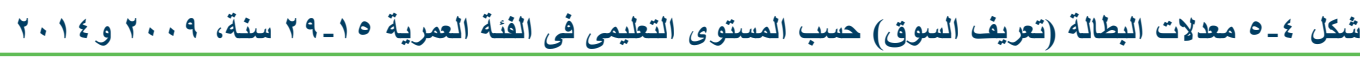
r.. q
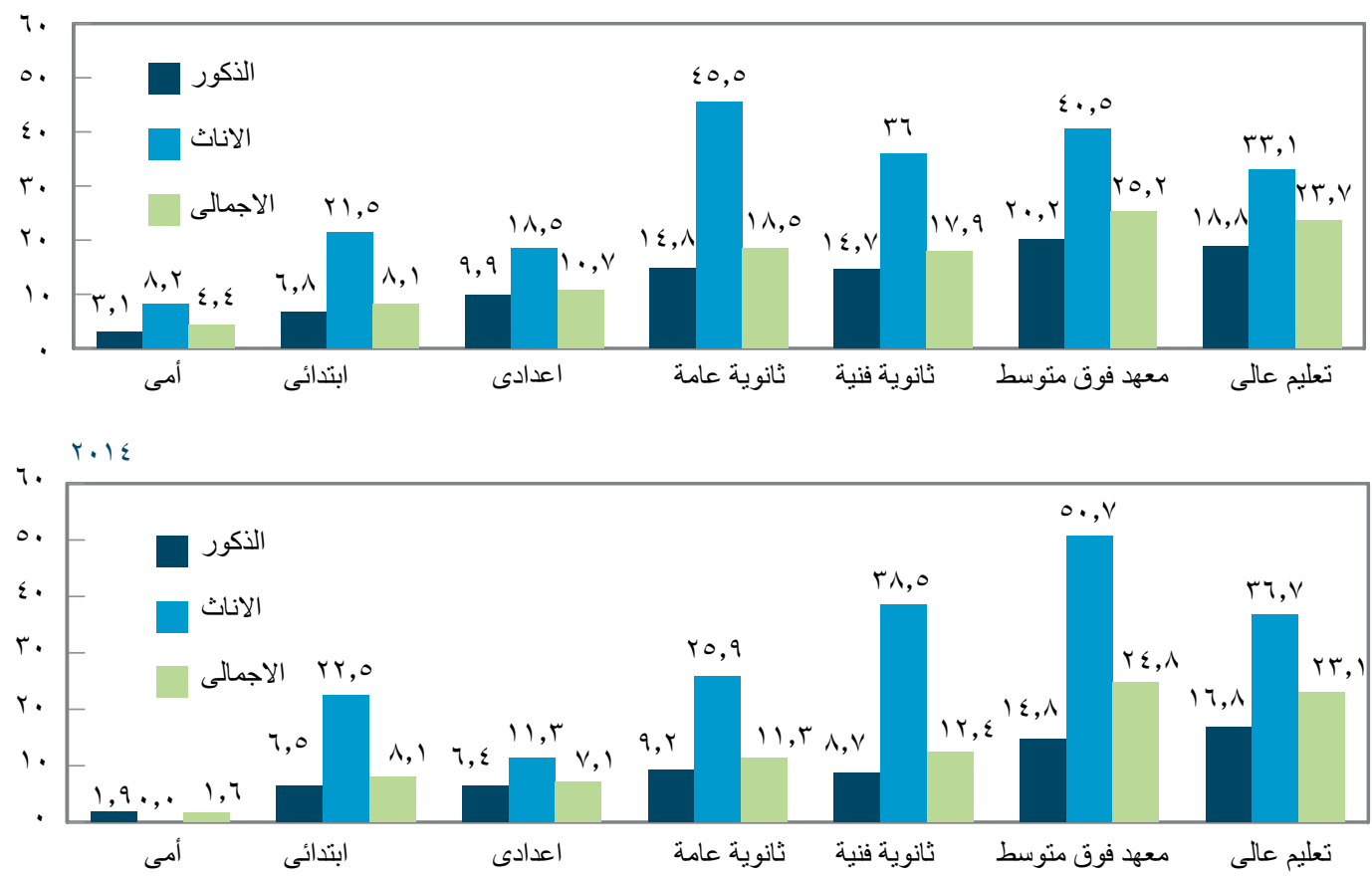

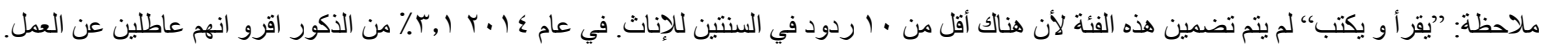

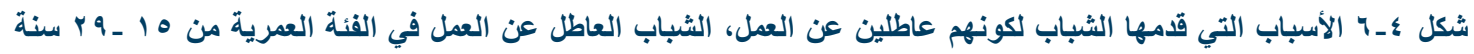

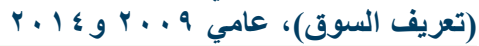

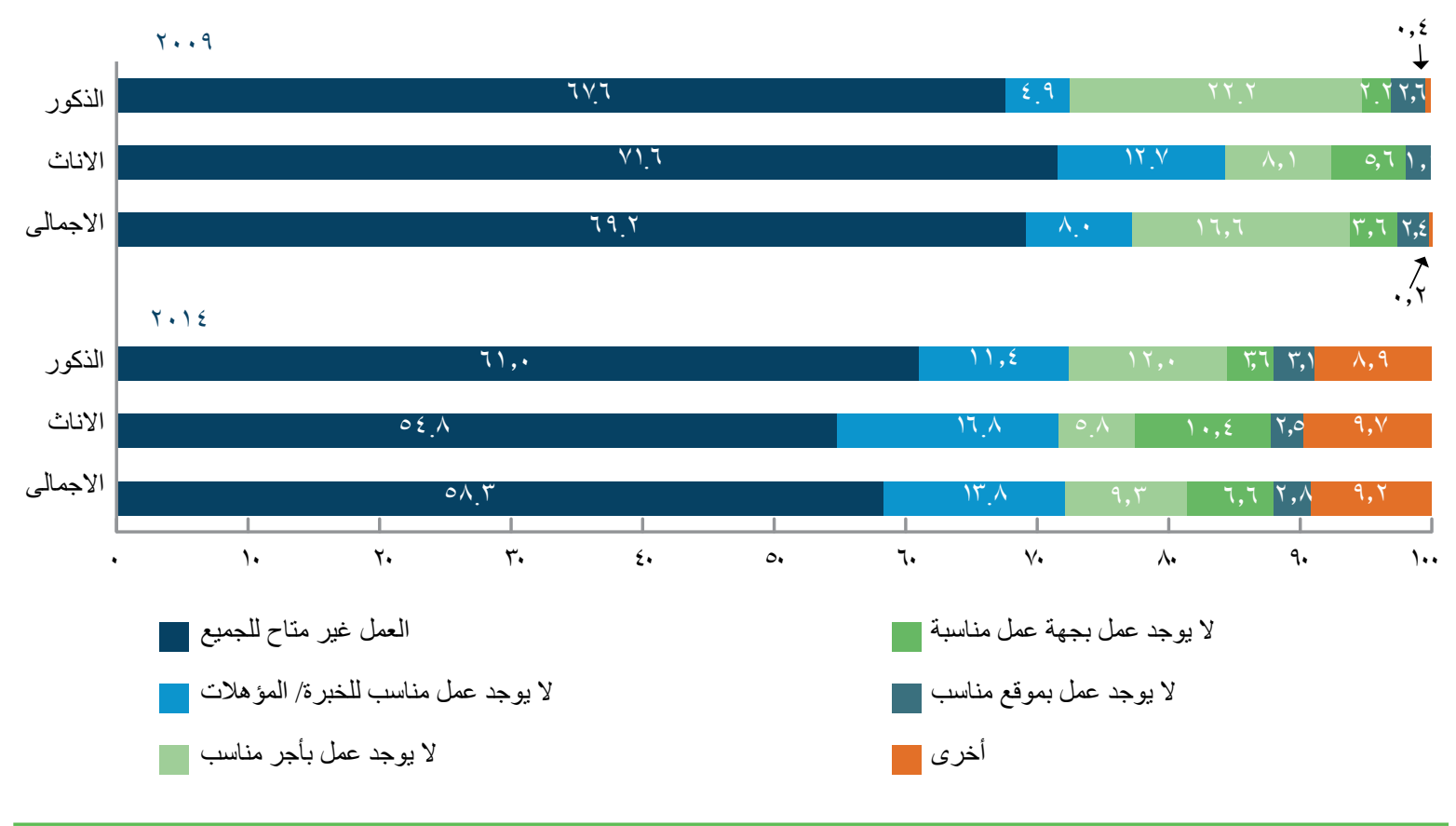




\section{بلغت نسبة الثُباب العاطل الذى أبلغ} أنه سجل فى مكاتب توظيف خاصة

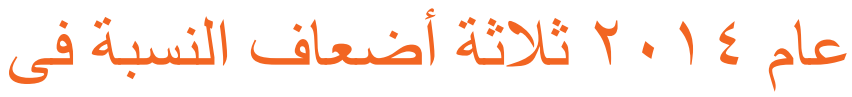
$r \cdot . q$

\section{البحث عن وظيقة}

تغيرت أساليب الثباب العاطلين عن العمل في البحث عن

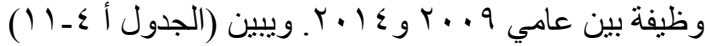

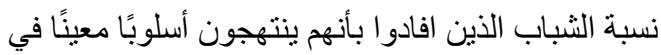
البحث عن العمل من بين فئة الثباب العاطلين عن العمل و وقا للتعريف الموسع. ففي عام 9 . . ب، جاء سؤال الأصدقاء و الأقارب عند البحث عن عمل على رأس قائمة الطرق التي يتبعونها في البحث، وجاء إرسال طلب وظيفة و الاستفسار في مكان العمل نفسه في المرتبة الثانية باعتباره أسلوب من الأ فن

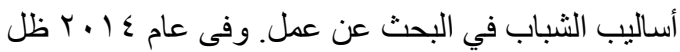
سؤال الاصدقاء والأقارب هو الأسلوب الأكثر استخداما في عام أني

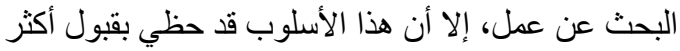

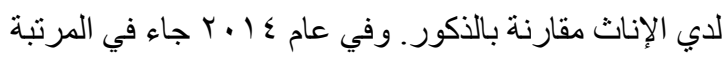

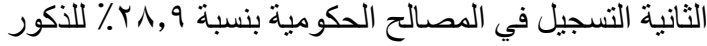

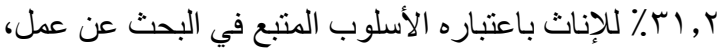

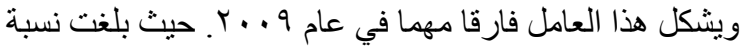
العاطلين الذين سجلو ا في مصالح حكومية فقط ع , 9 ٪ للذكور

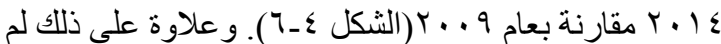
تشر الإناث إلى نفس السبب الذي أشنار إليه الذكور؛ بل على على عانى

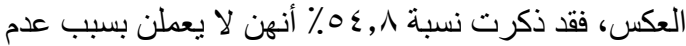
توفر العمل مقارنة بالذكور الذين بلغت نسبتهم آ٪\% في عام

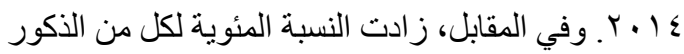
و الإناث الذين ذكروا عدم العثور على وظائف تتناسب مع

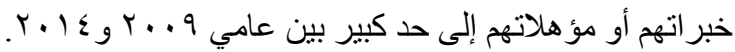
وكانت نسبة الإناث اللاتي ذكرن عدم عثور هن على ولى وظيفة في مكان عمل مناسب ץ اضعاف نسبة الذكور الذين ذكروا ذللك في عام ع ا ـ ب. وقد يرجع ذللك إلى تز ايد الإحساس بانعدام

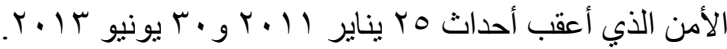

ويركز (جدول \& ــ) فقط على الثباب العاطلين عن العمل

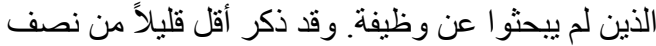

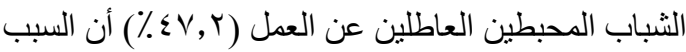

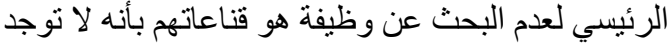

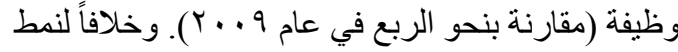

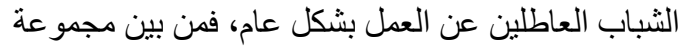
الثباب المحبطين العاطلين عن العمل، تظل الإناث أكثر الثر عرضة لتقرير انعدام فرص العمل من أقرانهن الذكور (ror\%

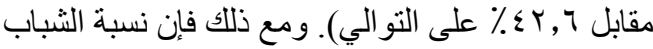

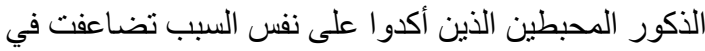

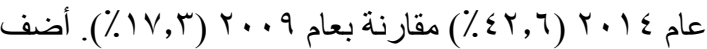

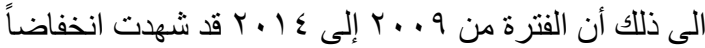
في نسبة هؤ لاء المحبطين العاطلين عن العمل و الذين ذكروا

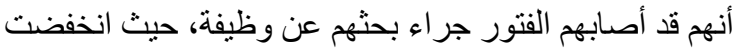

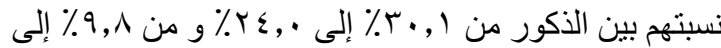

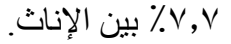

جدول ع ـه الأسباب التي قدمها الثباب لعزوفه عن البحث عن عمل، الثباب العاطل المحبط في الفئة العمرية من ه 1 ـ ب سنة،

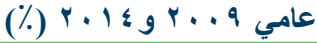

\begin{tabular}{|c|c|c|c|c|c|c|}
\hline \multicolumn{3}{|c|}{$r \cdot 1 \varepsilon$} & \multicolumn{3}{|c|}{$r+a q$} & \\
\hline الإجمالي & إناث & ذكور & الإجمالي & إناث & ذكور & \\
\hline$\varepsilon \vee, r$ & or,. & $\varepsilon r, T$ & ro,o & $r \leqslant, q$ & IV,r & نعتقد أنه لا توجد فرص عمل \\
\hline $17, \cdot$ & $\mathrm{v}, \mathrm{V}$ & $r \varepsilon, \cdot$ & $r \cdot, V$ & $9, \wedge$ & $r \cdot, l$ & تعبت من البحث عن وظائف \\
\hline$\cdot, r$ & $\cdot, 7$ & $\cdot, \cdot$ & $\cdot r$ & $\cdot, 7$ & $\cdot, \cdot$ & أصحاب العمل يفضلون الذكور عن الإناث في التوظيف \\
\hline $\mathrm{v}, \cdot$ & ᄉ, 0 & 0,7 & $19, \mathrm{~V}$ & IV,V & ri, r & لا أعرف وسيلة فعالة للبحث عن وظيفة \\
\hline$\cdot, \varepsilon$ & $\cdot, \cdot$ & $\cdot, \mathrm{V}$ & r,l & $r, \mathrm{~V}$ & $\cdot, \wedge$ & انتظر توظيف وزر اة القوى العاملة \\
\hline $0, v$ & $\vee, \varepsilon$ & $\varepsilon, r$ & - & - & - & لا يوجد وظائف حكومية \\
\hline r,o & $\cdot, 9$ & $\varepsilon, \cdot$ & $\cdot, 9$ & 1,9 & $\cdot, \cdot$ & ليس لدي مهارة / التدريب المطلوب \\
\hline 0,0 & $r, \mathrm{~V}$ & $v, r$ & $11, r$ & Ir, & $1 \cdot, r$ & لا يوجد وظيفة مناسبة \\
\hline- & - & - & r, & 1,9 & 0,1 & عدم وجود اتصالات \\
\hline $10, \varepsilon$ & $19, r$ & $11, \mathrm{~V}$ & 17,1 & IV,. & $10, r$ & 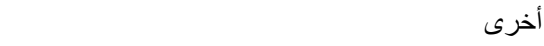 \\
\hline$(Y Y M)$ & $(11 \mathrm{~V})$ & $(1 \cdot 7)$ & $(Y \circ V)$ & $(1+7)$ & $(1 Y 1)$ & عدد الثباب العاطلين عن العمل المحبطين \\
\hline
\end{tabular}


الخاص، ويعمل لدي الأسرة بدون أجر، و العاطلين عن العمل

الذين يبحثّون بجد عن وظيفة، و العاطلين عن العمل و لا

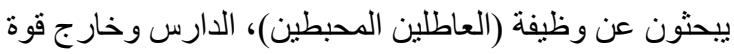
العمل، لا يدرس وخارج قوة العمل، خارج القوة البشرية تعني ان الشخص اكبر من 10 سنة و لا ير غب في العمل لكونه معاق اعاقة مزمنة.

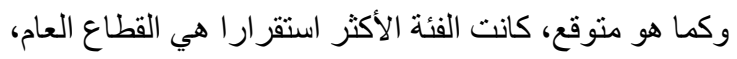

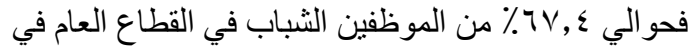

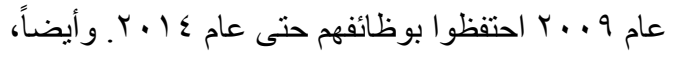
ظلت نسبة ^, \٪\% من أولئك الذين لا يدرسون وخارج قوة

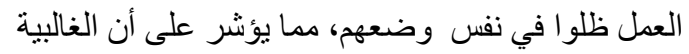

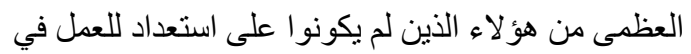

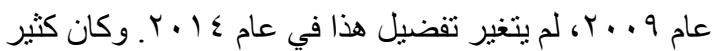

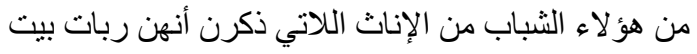

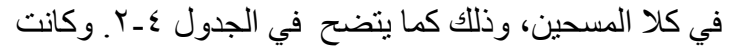

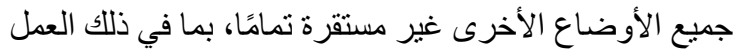

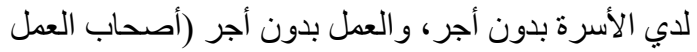

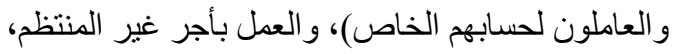

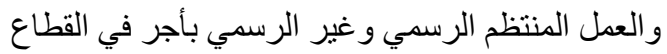

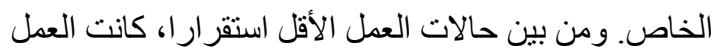

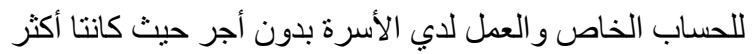

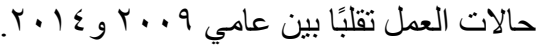

بينما بلغت 0, ـ ץ \% للإناث. وربما يرجع ذلك إلى الإعلان

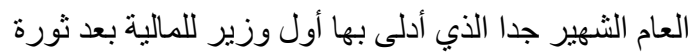

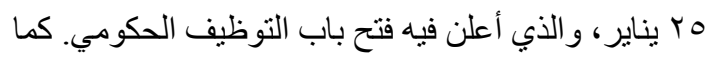

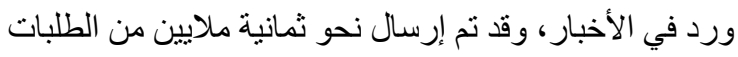

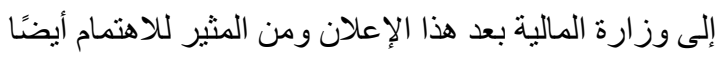

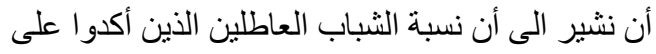

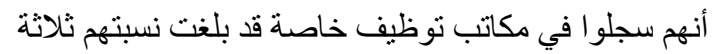

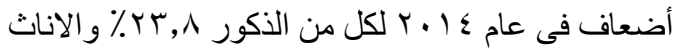

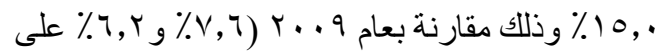
التو الي).

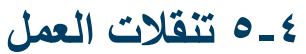

من أجل مزيد من التحليل لما حدث في وضع الثباب المصري

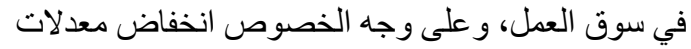

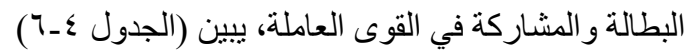

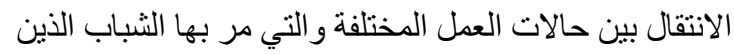

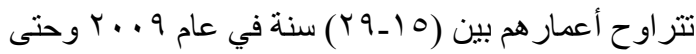

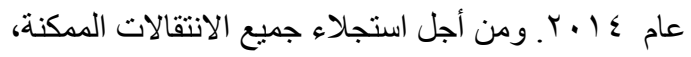

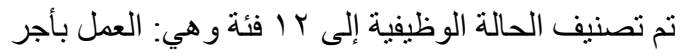

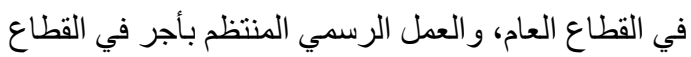

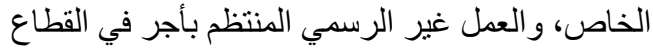

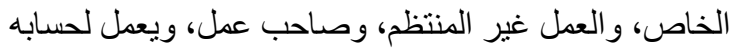

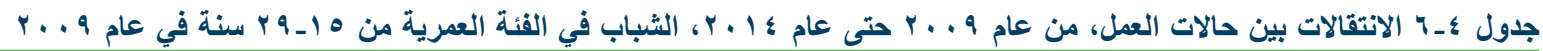

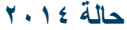

\begin{tabular}{|c|c|c|c|c|c|c|c|c|c|c|c|c|c|}
\hline الإجمالي & القوى البشرية & عاطل عث عن لا عمل & عن عندل عمل & ليس طالب & خارج فوة & 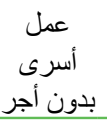 & لحسابه & صمل & أجور غبرة & غاص غير رسمي & خاصي & العام & حالة 9 . . . \\
\hline $1 \cdots$, & $\cdot, \cdot$ & $r, \cdot$ & $r, \Lambda$ & $\wedge, \wedge$ & 1,0 & $\cdot, \varepsilon$ & 1,1 & $\varepsilon, 1$ & $r, 0$ & $\varepsilon, 1$ & $r, \varepsilon$ & $T \vee, \varepsilon$ & قطاع عام \\
\hline $1 \ldots$, & $\cdot, \mathrm{V}$ & $1, V$ & $r, \Lambda$ & $\mathrm{V}, \mathrm{T}$ & r,q & 1,1 & $r,$. & $\Lambda, \vee$ & 0,7 & 11,0 & $r q, r$ & $1 \wedge, 1$ & خاص رسمي \\
\hline $1 \cdots$, & $\cdot, r$ & 1,9 & $\varepsilon, 7$ & Ir,A & $1, r$ & $1, \wedge$ & $\vee, \wedge$ & $v, 1$ & $19, r$ & $r \cdot, q$ & $7, r$ & $7, \varepsilon$ & خاص غير رسمي \\
\hline $1 \cdots$, & $\cdot, r$ & $r, T$ & $r, q$ & 11,9 & 1,7 & $\varepsilon, 7$ & $\wedge, 7$ & $v, r$ & $\lceil\wedge, \wedge$ & $r \cdot, 0$ & $\varepsilon, \cdot$ & $v, 1$ & أجور غير منتظمة \\
\hline $1 \cdots$, & $\cdot, \cdot$ & $\cdot, \cdot$ & 0,7 & $\varepsilon, \varepsilon$ & $\cdot, \cdot$ & $\varepsilon, 1$ & $\varepsilon, 0$ & rq, & $1 \pi, 7$ & $r V, r$ & $1 \cdot, r$ & $r, v$ & صاحب عمل \\
\hline $1 \cdots$, & $\cdot, \cdot$ & $\varepsilon, \wedge$ & 1,7 & 11,0 & r,q & $\Gamma, \Lambda$ & $1 \pi, 7$ & $\uparrow, \wedge$ & $r, T$ & $M, \varepsilon$ & $r, \tau$ & $1 \cdot, 0$ & يعمل لحسابه الخاص \\
\hline $1 \cdots$, & $\cdot, \cdot$ & $\varepsilon, r$ & 7,7 & $1 Y, 7$ & $r, T$ & Ir,r & $9, \vee$ & $\curlywedge, \varepsilon$ & $r \cdot, r$ & $17, r$ & $r, q$ & $\varepsilon, \cdot$ & عمل أسري بدون أجر \\
\hline $1 \cdots$, & $\cdot, r$ & $0, r$ & $9, r$ & 促 & ro,. & r,q & $1, r$ & $1, \wedge$ & $\uparrow, \cdot$ & $\vee, \wedge$ & $r, l$ & $\varepsilon, r$ & طالب خارج قوة العمل \\
\hline $1 \cdots$, & $\cdot, r$ & r, ६ & $\varepsilon, 1$ & vo, & $\cdot, 0$ & $r, \cdot$ & 1,7 & 1,1 & r,q & r, $\_$ & $\cdot, \mathrm{V}$ & $r, r$ & ليس طالب وخار ج لقوة العمل \\
\hline $1 \ldots$ & $\cdot, \wedge$ & $\varepsilon, r$ & $9, \varepsilon$ & $r V, \Lambda$ & $\cdot, \wedge$ & r,o & $\varepsilon, 7$ & $r, \cdot$ & $1 \cdot, \varepsilon$ & $19,$. & $\vee, \cdot$ & $1 \cdot, \varepsilon$ & عاطل يبحث عن عمل \\
\hline $1 \cdots$ & $\cdot, r$ & $r, v$ & $\wedge, 9$ & r, & $1, r$ & $\varepsilon, r$ & r, & $0, \cdot$ & $1 \wedge, 7$ & $17,$. & $r, \mathrm{~V}$ & $\varepsilon, \varepsilon$ & عاطل لا يبحث عن عمل \\
\hline $1 \cdots$, & $r_{0, v}$ & $\cdot, \cdot$ & $r, r$ & rr, & $\cdot, \cdot$ & $1 \cdot, 1$ & $\cdot, \cdot$ & $0, v$ & $1, r$ & $r, \wedge$ & $\cdot, \cdot$ & $\wedge, 7$ & خارج القوى البشرية \\
\hline $1 \ldots$ & $\cdot, 0$ & $r, \tau$ & 7, & rq,r & $v, v$ & r,l & $r, \varepsilon$ & $r, 0$ & 9,9 & 11,1 & $r, \mathrm{v}$ & $v, 0$ & الإجمالي \\
\hline$(\mathrm{V}, \mathrm{V} 00)$ & $(Y \uparrow)$ & $(Y V V)$ & $(\varepsilon r \varepsilon)$ & $(r, \Sigma \Lambda T)$ & $(007)$ & $($ (YYT) & $($ Yo. $)$ & $(Y \leq \wedge)$ & $(7 \cdots)$ & $(\wedge) \curlyvee)$ & (וד) & $(0 \wedge r)$ & عدد الثباب \\
\hline
\end{tabular}




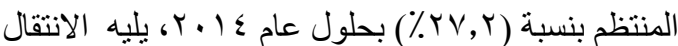

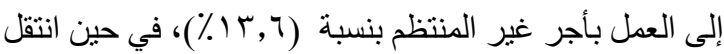

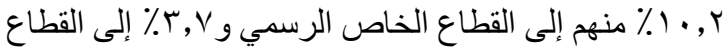

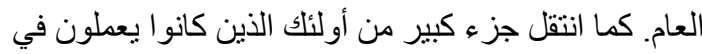
القطاع الخاص بأجر بشكل منتظم ولكن غير رسمي القي في عام

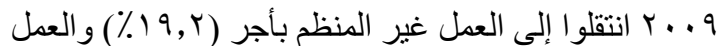

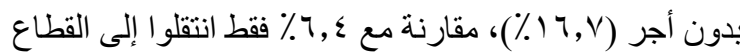

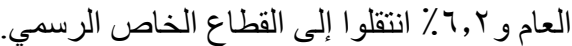

وعلاوة على ذللك، احتفظت نسبة تقدر بأقل من • بـ من الثباب الذين كانو ا يعملون في القطاع الخاص المناص النتظم الرسمي

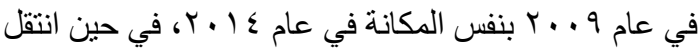

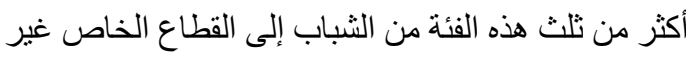

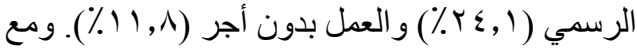

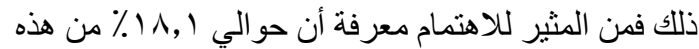

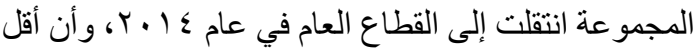

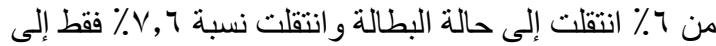

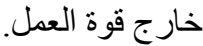

وبالتالي، فقد كان انخفاض مشاركة الثباب في قوة العمل

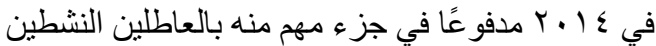

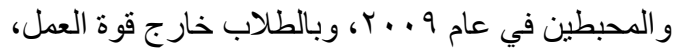
وبالثباب العاملين لحسابهم الخاص و الذي أدي بذوره إلي

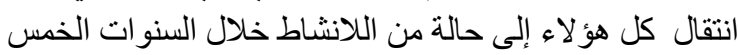

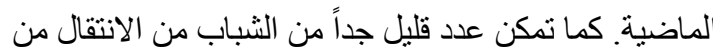
قطاعات الأجور غير الرسمية وقطاع العمل بدون أجر إلى الى الثيل قطاع العمل العام و إلى القطاع الخاص الرسية الرسمي بين مسحي

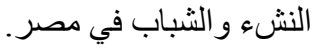

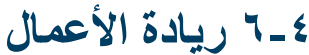

نظرًا لأحوال السوق المتعثرة في مصر بعد ثورة الخامس

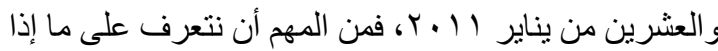
كان في استطاعة الثباب خلق فرص عمل لأنفسه من خلال اقامة مشرو عات في تللك الفترة. أنشارت النتائج إلى انخفاض

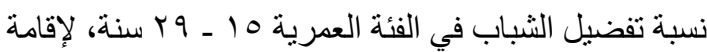

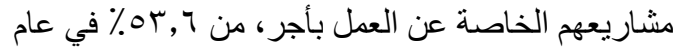

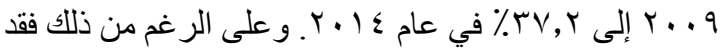

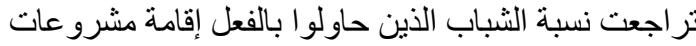

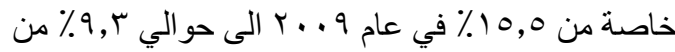

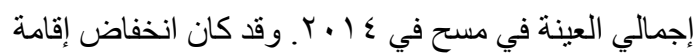
المشرو عات الخاصة لاي الثباب الذكور أسر ع منه لابي

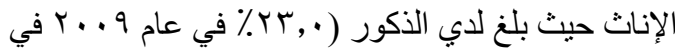

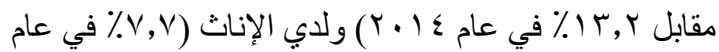

و احتفظت نسبة هب\% فقط من الثباب، الذين كانو طلابًا

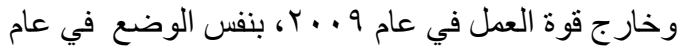

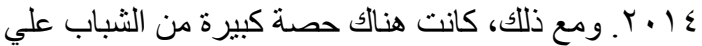

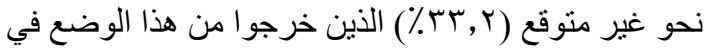

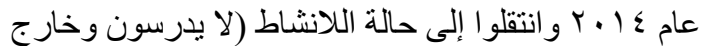

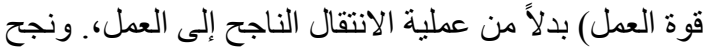

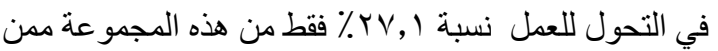

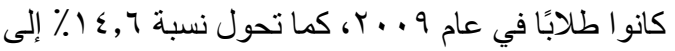

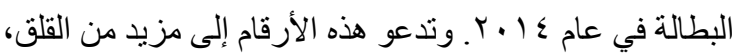

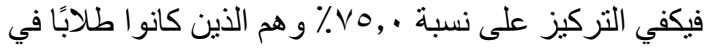

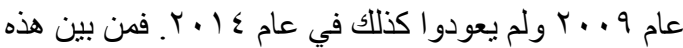

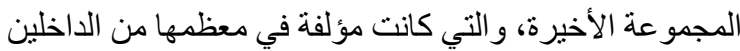
الجدد إلى سوق العمل، تمكنت فقط نسبة >, ٪\% من العثور

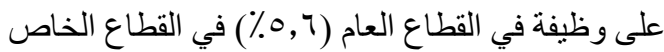

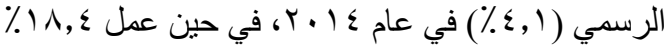

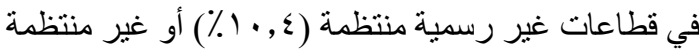

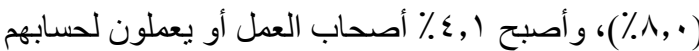

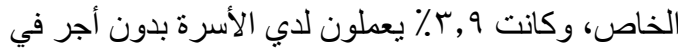

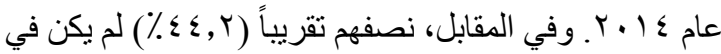

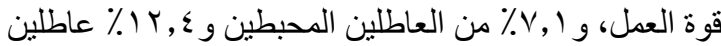

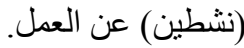

ومن النتائج الأخرى التي تدق ناقوس الخطر هي وجود العبا

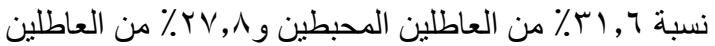

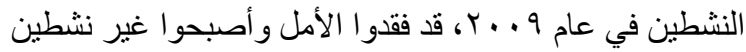
(خار ج الدراسة وخارج قوة العمل). بالإضافة إلى ذللك، فقد

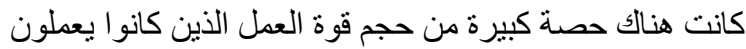

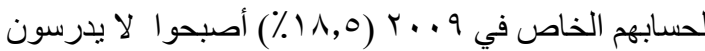

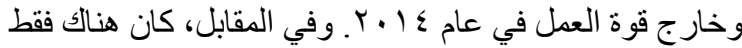
أكثر قليلا من نصف الثباب العاطلين عن العمل من المحبطين

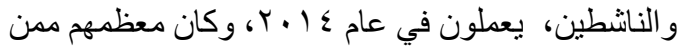
انتهى بهم المطاف في قطاعات الأجور الخاصة غير الركان الرسمية المنتظمة أو غير المنتظمة. ومن بين العاطلين النشطين

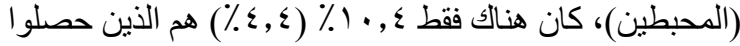

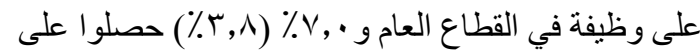

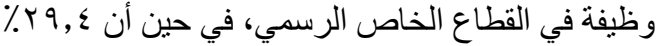

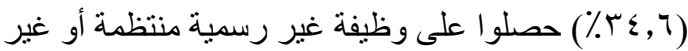

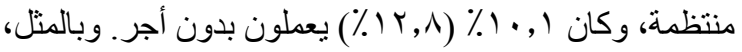

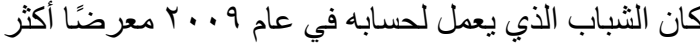

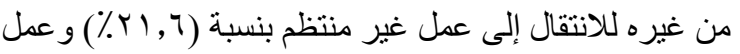

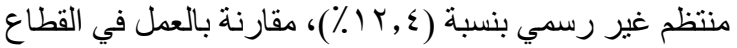

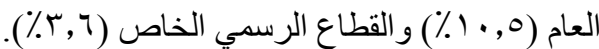

وكان الثباب أصحاب العمل في عام 9 . . ب الأكثر ترجيحاً فى الإنتقال إلى العمل بأجر في القطاع الخاص غير الرعاب الرسي 


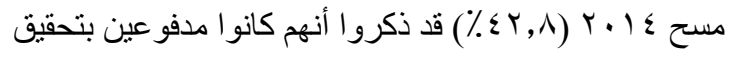

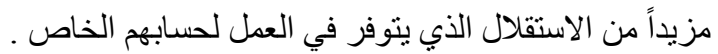

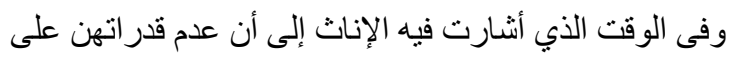

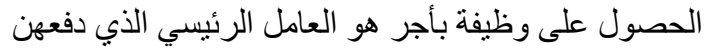

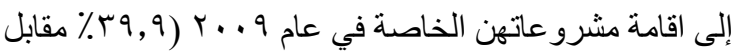

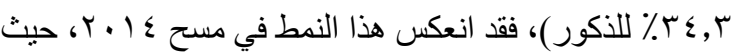

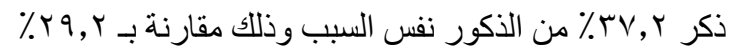

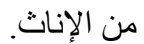

ومن حيث معوقات ريادة الأعمال كما كثف عنها الثباب في

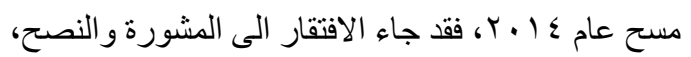

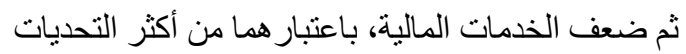

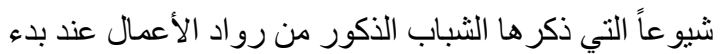

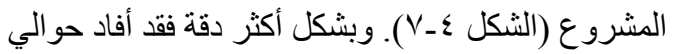

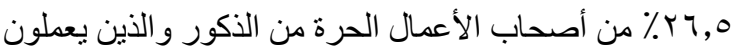

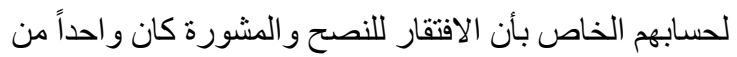

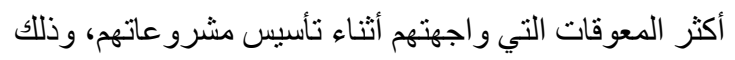

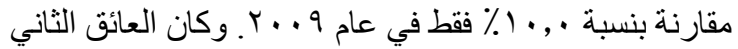

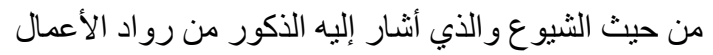

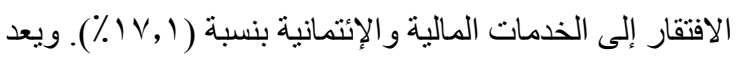

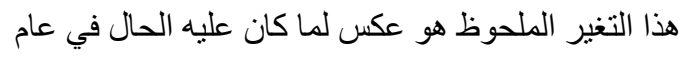

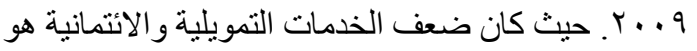

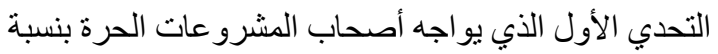
(r, (T\%). كما ظل غياب المعلومات التجارية عند الإناث

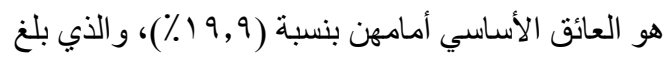

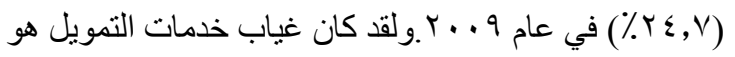

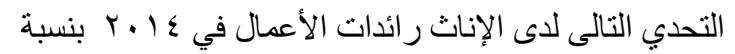
.(\%) 1 , $)$

أما بالنسبة لمصادر التمويل التي يستخدمها الثباب الذين

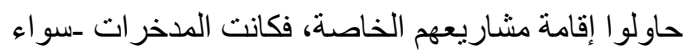

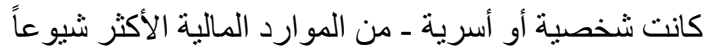

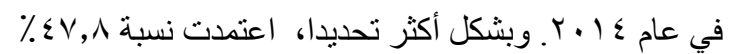

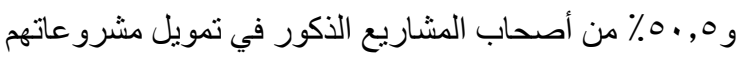

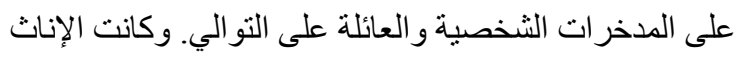

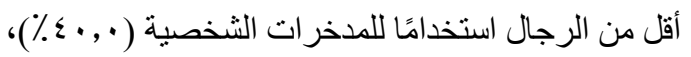
في حين كانت منلها مثل الذكور تعتمد على مدخر ات الأسرة

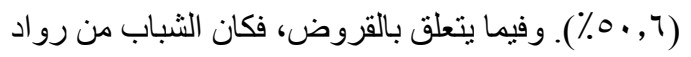

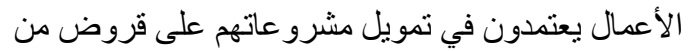

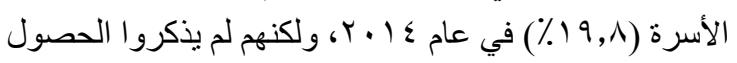

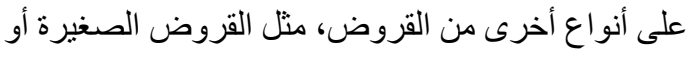

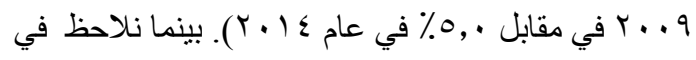

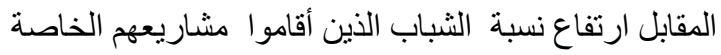

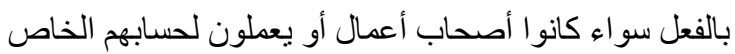

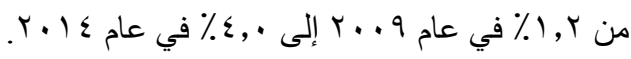

ولقد تثابهت الأسباب التي دفعت الثباب الذين بدأو ا بالفعل

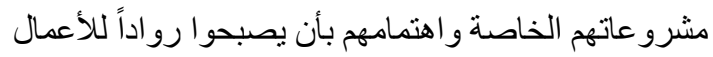

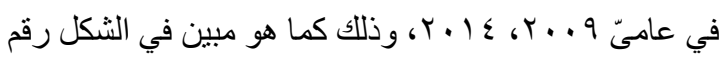

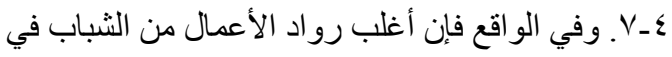

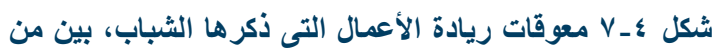

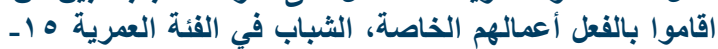

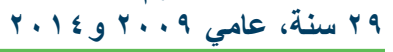

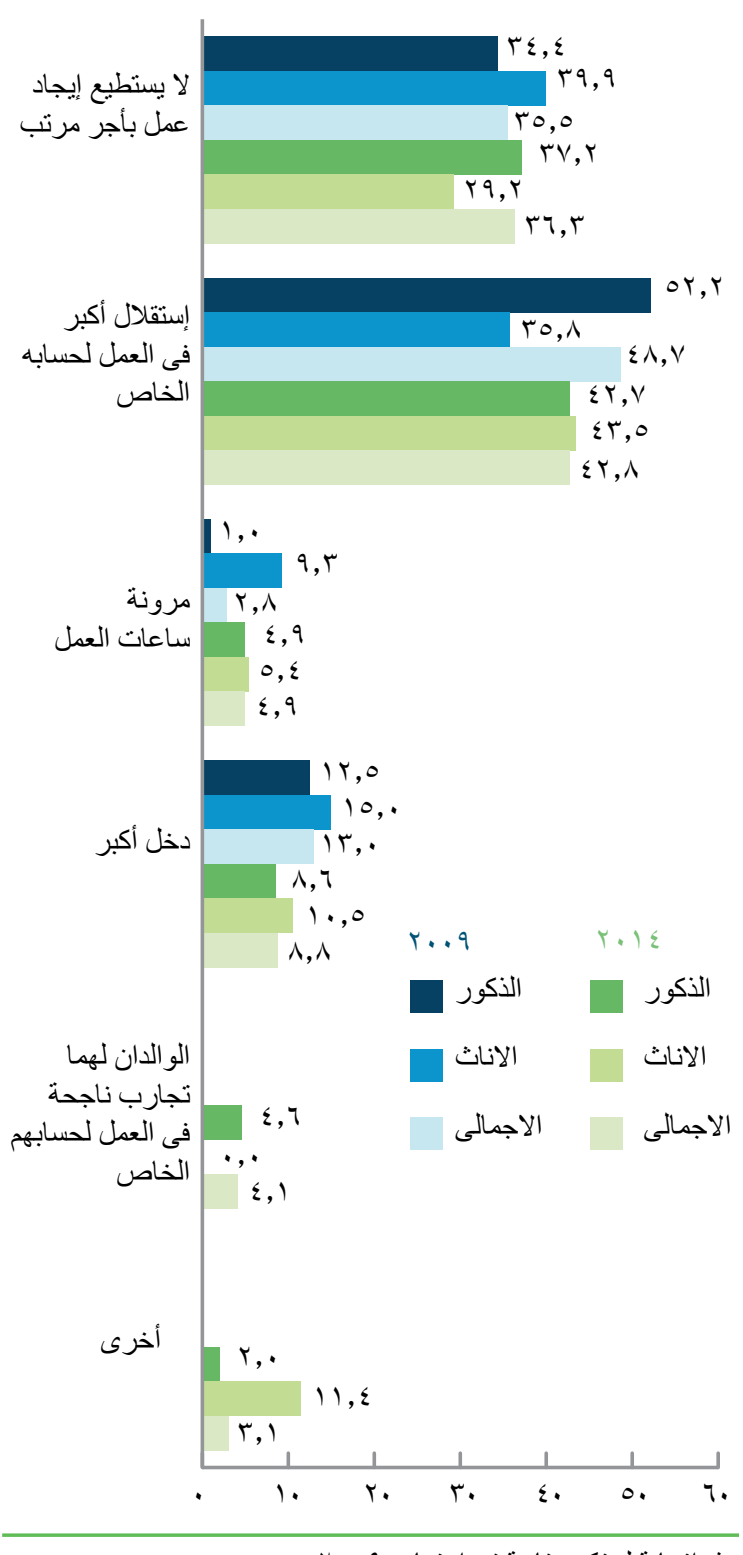

هذه افجابة لم تكن متاحة فى إستمارة 9 . . ب 


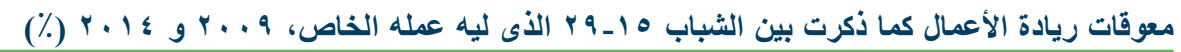

\begin{tabular}{|c|c|c|c|c|c|c|}
\hline \multicolumn{2}{|c|}{ 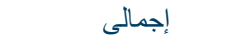 } & \multicolumn{2}{|r|}{ إناث } & \multicolumn{2}{|c|}{ 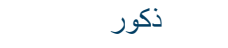 } & \\
\hline$r+1 \leq$ & r.. q & $r \cdot 1 \leq$ & $r \ldots q$ & $r \cdot 1 \leqslant$ & $r \ldots q$ & \\
\hline $1 \leq$, & $1 \leq, 9$ & 19,9 & $r \leqslant, V$ & Ir, & Ir, r & المعلومات المتعلقة بالمال/الأعمال \\
\hline ir, & $10, \varepsilon$ & IT,O & 11,9 & $1 \%, \varepsilon$ & $17, r$ & 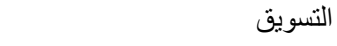 \\
\hline 17,9 & rq,. & $1 \leq, \wedge$ & r), & $1 \mathrm{~V}, 1$ & $r, r$ & 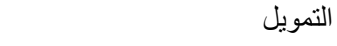 \\
\hline 1,9 & $1, \varepsilon$ & $\cdot, \cdot$ & $\cdot, \cdot$ & $r, r$ & $1, v$ & العمال المحاسبية \\
\hline $1, \cdot$ & $\varepsilon, 0$ & $0, \cdot$ & $\cdot, \cdot$ & $\cdot, 0$ & $0, v$ & الأعمال القانونية \\
\hline$r \leq, T$ & $9, \wedge$ & $1 \cdot, r$ & $9, r$ & r & $1 \cdot, \cdot$ & الخبرة و النصح و الإرشاد \\
\hline $1, v$ & $r, \mathrm{~V}$ & $9, \wedge$ & $0, V$ & $\cdot, 7$ & 1,9 & التدريب على الإدارة \\
\hline$\varepsilon, 7$ & $\cdot, \mathrm{V}$ & $\cdot, \cdot$ & $\cdot, \cdot$ & $0, r$ & $\cdot, 9$ & التدريب على المهار ات \\
\hline 1,1 & 1,1 & $\cdot, \cdot$ & $\cdot, \cdot$ & $1, r$ & $r, r$ & الحصول على التكنولوجيا \\
\hline r, $\varepsilon$ & $r, \cdot$ & 7,1 & $7, r$ & $r, \cdot$ & $r, 1$ & تطوير المنتجات \\
\hline$r, \cdot$ & r,, & $\cdot, \cdot$ & $\cdot, \cdot$ & $r, r$ & $r, v$ & الحصول على المر افق \\
\hline- & $\Lambda, r$ & - & $\wedge, \vee$ & - & $\wedge, 1$ & إيجاد شريك \\
\hline $1 \cdot, \varepsilon$ & - & 9,1 & - & $1 \cdot, 1$ & - & لا شيء \\
\hline$\vee, \varepsilon$ & $r, 0$ & IT, & $\mid r, 1$ & 7,7 & 1,1 & أخرى \\
\hline$(1+7)$ & $(I K Y)$ & $(19)$ & $\left(r^{\prime}\right)$ & $(11 \mathrm{~V})$ & (91) & 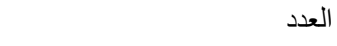 \\
\hline
\end{tabular}

- = = خيار الرد لم يكن متو افر في سنة المسح.

في نسب الثباب الذين أصبحو ا محبطين وخرجوا من القوى

العاملة.

تعرض الثباب كل من الاناث و الذكور، الى انخفاض فى نسبة

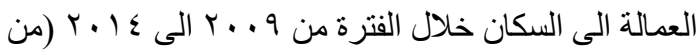

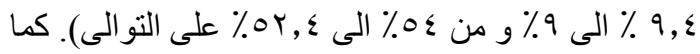
انخفضت حصة العمل في الحكومة و العمل بأجر بثكل رسمي أو غير رسمي في القطاع الخاص. ويبدو أن ذللك قد دفع عديد

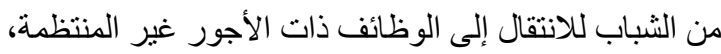
وهو الثكل الأكثر عرضة للتشغيل.

من ناحية ايجابية, تم ملاحظة الاثار المترتبة على زيادة

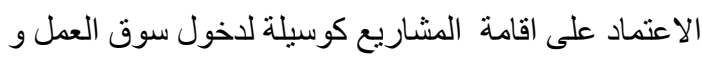

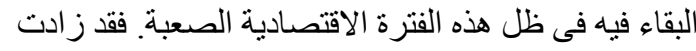
نسبة الثباب الذين يعملون لحسابهم و اصحاب العمل خلال

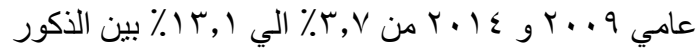

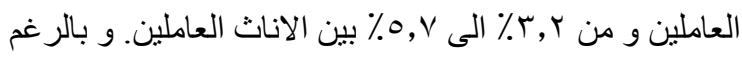

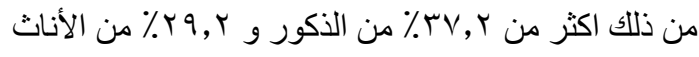
ابلغوا ان عدم امكانية حصولهم على عمل هو السبب الرئيسي لأقامة مشرو عات خاصة بهم.

علاوة على ذللك فقد انخفضت نسبة الشباب الذين يعزون سبب

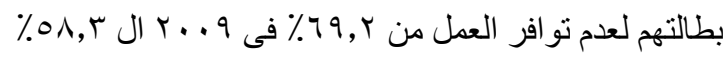

القروض المصرفية. و لا تز ال الحاجة إلى تطوير خدمات مالية كافية ومشجعة للترويج لإقامة المشرو عات في أوساط

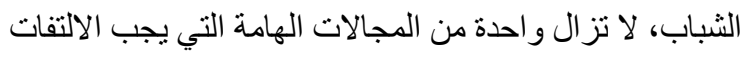

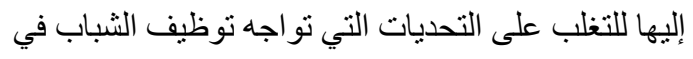
مصر (انظر: 2012 Sieverding) (الأرقام غير مُدرجة في توفي (الجدول).

\section{ع V V الخلاصة}

يستخدم هذا الفصل البيانات الثرية التي يقدمها مسح النشء

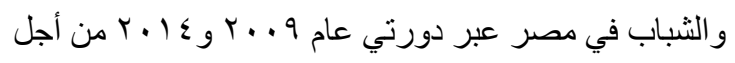
تحديث حالة المعرفة الخاصة بنواتج سوق العمل بين الثباب

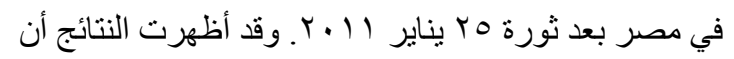

ظروف سوق عمل الثباب قد تدهورت في عهد الثورة.

إن البحث السريع في معدل البطالة وحدها قد يؤدي إلى

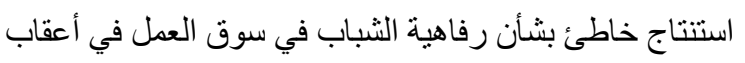

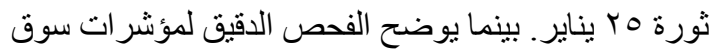
العمل الأخرى أن تدهور نو اتج سوق عمل الثباب قد تفاقمت

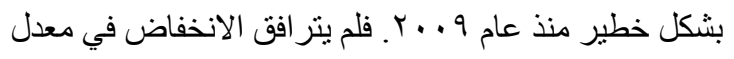
البطالة مع زيادة في فرص العمل، بل كان راجعًا إلى الزيادة 


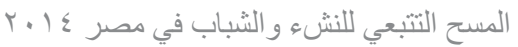

prepared for the International Center for Research on Women Seminar on Weathering Economic Crises: Women's Responses to the Recession in Latin America, Washington, DC, August 11.

Kim, Haejin and Paula B. Voos. 2007. "The Korean economic crisis and working women," Journal of Contemporary Asia 37(2): 190-208.

Leslie, Joanne, Margaret Lycette, and Mayra Buvinic. 1988. "Weathering Economic Crises: The Crucial Role of Women in Health," in Health, Nutrition and Economic Crises: Approaches to Policy in the Third World, David E. Bell and Michael R. Reich (eds.), Dover, MA.: Auburn House Publishing Company, pp. 307-348.

Mokhtar, May, and Jackeline Wahba. 2002. "Informalization of Labor in Egypt," in The Egyptian Labor Market in an Era of Reform Economy: Egypt in the 1990s, Assaad R. (ed.). Cairo: The American University in Cairo Press, Cairo, Egypt, pp. 131-157.

Population Council. 2010. The Survey of Young People in Egypt: Final Report. Cairo: Population Council, Egypt.

Roushdy, Rania and May Gadallah. 2012. "Informality and Labor Market Dynamics during Economic Downturns: Evidence from Egypt." Gender and Work in the MENA Region Working Paper Series, No. 26, Cairo: Population Council, Egypt.

Roushdy, Rania and Irene Selwaness. 2014. "Duration to Coverage: Dynamics of Access to Social Security in the Egyptian Labor Market in the 1998-2012 Period," Economic Research Forum (ERF) Working Papers No. 836, Cairo: ERF, Egypt

Sieverding, Maia. 2012. "Youth Perspectives on Entrepreneurship in Egypt: Barriers to Entrepreneurship as a Means to Combat Youth Unemployment," Policy Brief Series, No. 5. Cairo: Population Council, Egypt.

Verick, S. 2010. "Unraveling the Impact of the Global Financial Crisis on the South African Labor Market." Employment Working Paper no. 48. Geneva: International Labour Office.

World Bank. 2009. How Should Labor Market Policy Respond to the Financial Crisis? Washington, D.C.: World Bank, HD and PREM Labor Market Teams, April.

$$
\begin{aligned}
& \text { فى ع ا ـ ب. ولكن زادت نسبة كلا من الذكور و الاناث الذين } \\
& \text { يرجعون سبب بطالتهم الى عدم وجود عمل ملائم لقدر اتهم و }
\end{aligned}
$$

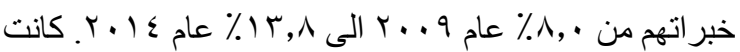

$$
\begin{aligned}
& \text { شباب الاناث الاتى ابلغن عدم وجد عمل بمكان عمل مناسب } \\
& \text { كان ضعفى عدد الذكور. و هذا من الممكن ان يكون راجع } \\
& \text { لعدم الاحساس بالأمان بعد ثورة هب يناير. }
\end{aligned}
$$

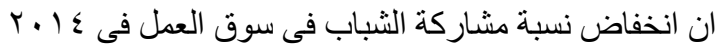
يرجع الي نسبة الطلاب فى 9 . . ب خارج قوة العمل(r, rr\%) و العاطلين النشطين (T, آץ\%) و العاطلين المحبطين

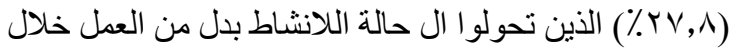
الخمس سنو ات الماضية.

يقدم هذا الفصل أدلة على أن تعديلات سوق العمل خلال

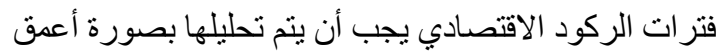

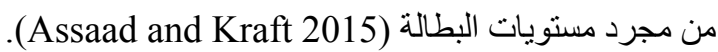
وأن الزيادة في نسب الثباب المحبطين وصعوبة الانتقال إلى مع معاد العمل الرسمي بأجر بيرهن على ظروف لعن عمل غير مستقرة تو اجهها الأجيال الثابة بعد الثورة المصرية.

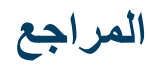

Assaad, Ragui and Caroline Krafft. 2015. “The Evolution of Labor Supply and Unemployment in the Egyptian Economy: 1998 -2012," in The Egyptian Labor Market in an Era of Revolution, R. Assaad and C. Krafft (eds.). Oxford, UK: Oxford University Press, pp. 1 -26.

Assaad, Ragui and Ghada Barsoum. 2007. "Youth Exclusion in Egypt: In Search of 'Second Chances.'” Middle East Youth Initiative Working Paper, No.2. Washington, DC: Publisher?

Assaad, Ragui and Fatma El-Hamidi. 2009. "Women in the Egyptian labor market," in The Egyptian Labor Market Revisited, Ragui Assaad (ed.). Cairo: American University in Cairo Press, pp. 217-257.

Assaad, Ragui and Rania Roushdy. 2007. "Poverty and the Labor Market in Egypt: A Review of Developments in the 1998-2006 period," Background Paper for Arab Republic of Egypt: Poverty Assessment Update. Cairo: The World Bank.

Cerutti, Marcela. 2000. “Economic reform, structural adjustment, and female labor force participation in Buenos Aires, Argentina," World Development 28 (5): 879-891.

Francke, Marfil. 1992. "Women and the Labor Market in Lima, Peru: Weathering Economic Crisis." Paper 


$$
\text { المصير الخطلة: ثضير ثطلعات الثباب }
$$

دافني بابو تشاكي • جاكلين و هبه

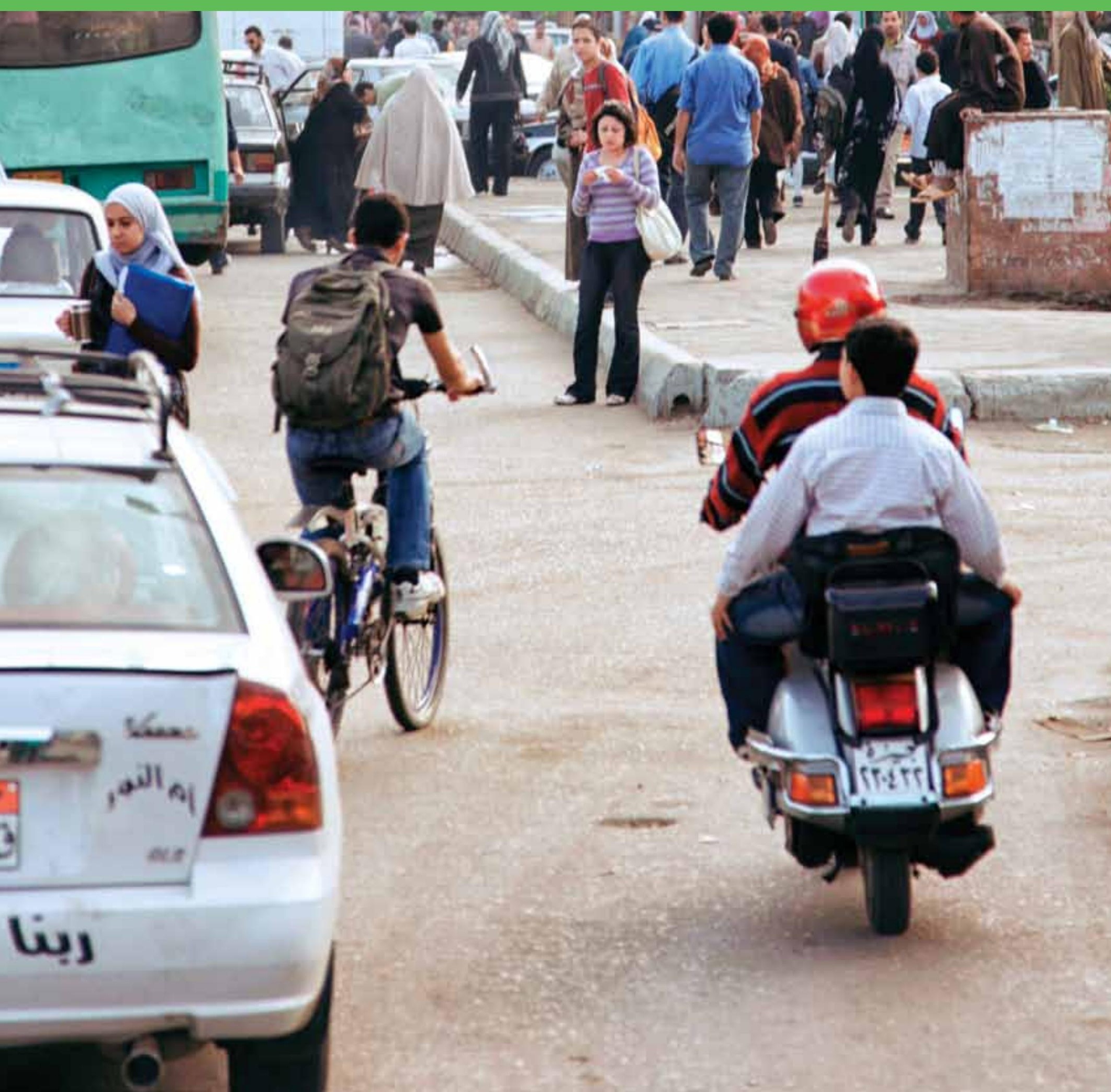


قدمت البيانات التفصيلية التي تم جمعها على مسنوى قومي في

مسح النشء و الثباب لعام 9 . . r حول الرغبة في الهجرة، للباحثين فرصة فريدة من نوعها لدر اسة الهجرة المحتملة ونية الثباب المصري في الهجرة.و بعد ه سنوات سمحت البيانات

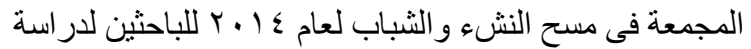

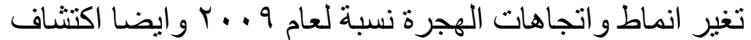

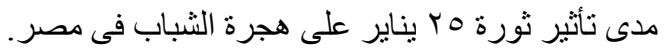
وجد (Elbadawy 2010) أن الثبكات الاجتماعية للشباب كانت عاملًا رئيسيًا في تطور تطلعاتهم للهجرة. بالإضافة

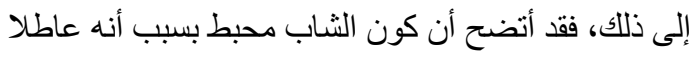

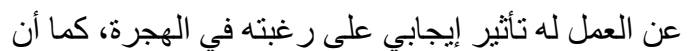
الأشخاص الأكثر ثر اءً أكثر ميلًا لاختبار الدول الغربية

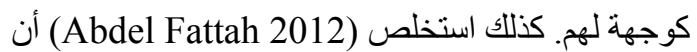
شبكة علاقات المهاجر و الاعتقاد بأن الحصول على وظيفة في الخارج سوف يكون الحل الجوهري لمشكلاته (خاصة

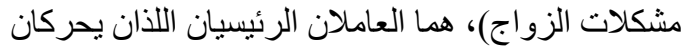

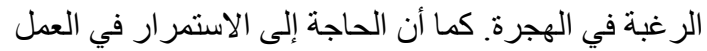

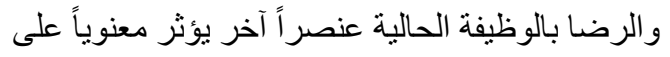
احتمال التفكير فى الهجرة. ومن ناحية أخرى، درس كل من الترطية (Elbadawy, Said, and Wahba 2013) بين النية في الهجرة و الاستثمار في التعليم. أجرت منظمة الهجرة الدولية در اسة استقصائية حول الرغبة

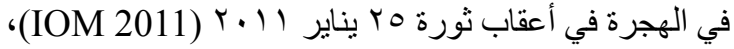

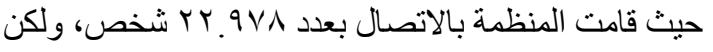

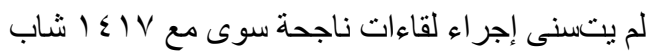

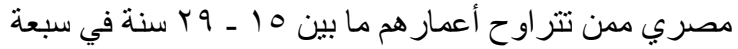

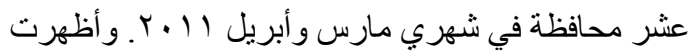
تللك الدر اسة أن • Vo من الثباب الذين تمت مقابلتهم يتطلع للهجرة، ولم يتضح ما اذا كان السبب ور اء هذه النسبة المرتفعة هو العينة أو نوقيت الاسنطلاع، خاصة و أن اسنطلاعات سابقة

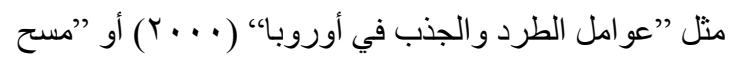

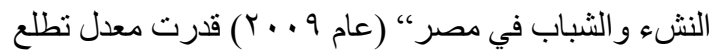
الثباب للهجرة بنحو • •\% فقط.

ومن المهم أن ندرك أن تو افر الرغبة في الهجرة لا تعني بالضرورة الهجرة الفعلية، فالعقبات القانونية و القيود المالية، بجانب معوقات أخرى، تحد من فرص وقدرة المهاجرين
تعتبر الهجرة محل نقاش مهم لصانعي السياسات وذللك للنتائج الاقتصادية و الأجتماعية و الثقافية النابعة من التحركات الكبيرة عبر الحدود الدولية ويعد قياس نية الثباب للهجرة فى مصر موضوع مهم للغاية وذللك لانه غني بالمعلومات عن المحددات المحتملة للهجرة و انماطها.

\section{ــ 1 مقدمة}

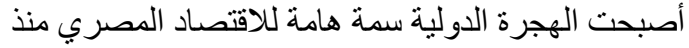

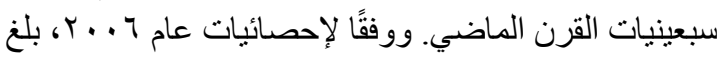

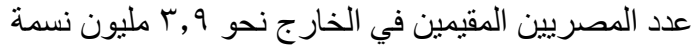

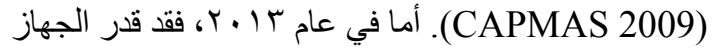
المركزي للتعبئة العامة و الإحصاء عددهم بحو الي 1 مليون المان نسمة (Sabry 2012). علاوة على ذللك، فقد أظهرت النتائج

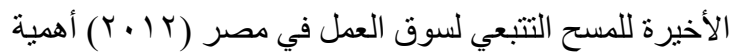
الهجرة الدولية باعتبار ها العمود الفقري للاقتصاد المصري؛

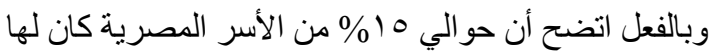

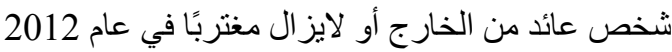

(Wahba 2015)

ورغم أن هناك أدبيات مُسهية حول العو امل التي تؤُثر على

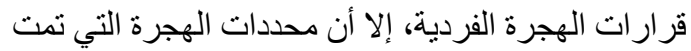

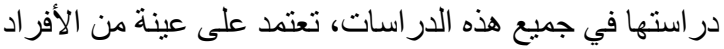

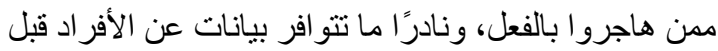
الهجرة. ومن ثم، تركز بعض الدر اسات على على النية في الهجرة

بدلًا من الهجرة الفعلية وذللك للوقوف على بلى عو المل الهُ الهرة

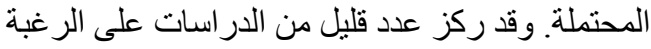

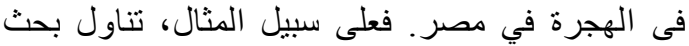
(Zohry 2006)

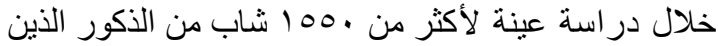

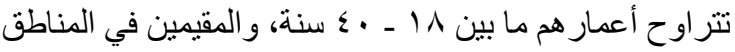
ذات النسب الأعلى للهجرة في محافظتي القاهرة و الإسكندرية، وفي أربع محافظات فى الوجه البحري و اثنتين في صعيد

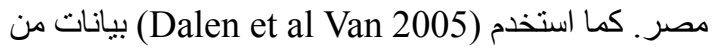
دول متعددة لار اسة محددات و آليات الهجرة الدولية إلى كلى

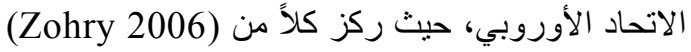

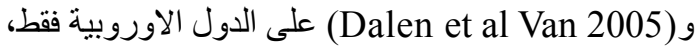
في حين أن الغالبية العظمى من المصريين يهاجرون إلى دول

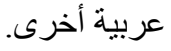




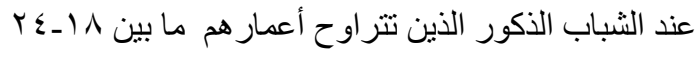

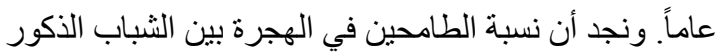

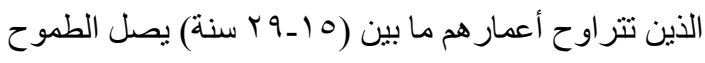

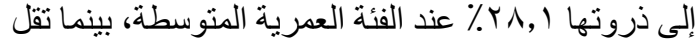

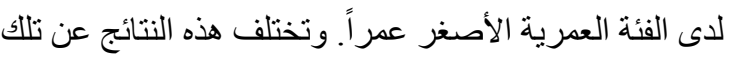

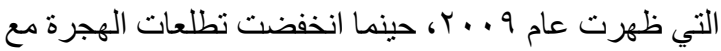

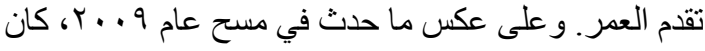
الثباب الذكور غير المتزوج الذين تتراو حـ أعمار هم ما بين

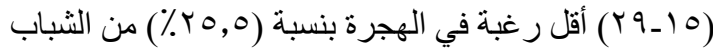

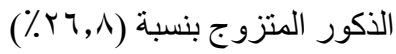

كان الذكور الذين تتر اوح أعمار هم ما بين (10 ـ 9 ؟ ب) في

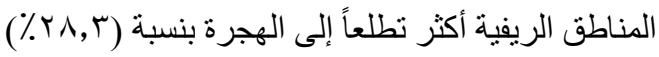

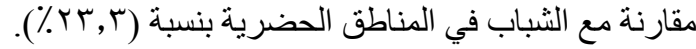
ومع ذللك، كان الذكور الذين يسكنون في المناطق العشو ائية

الشكل هـ 1 تطلعات الهجرة على المدى البعيد بين الثباب حسب

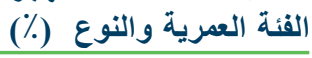

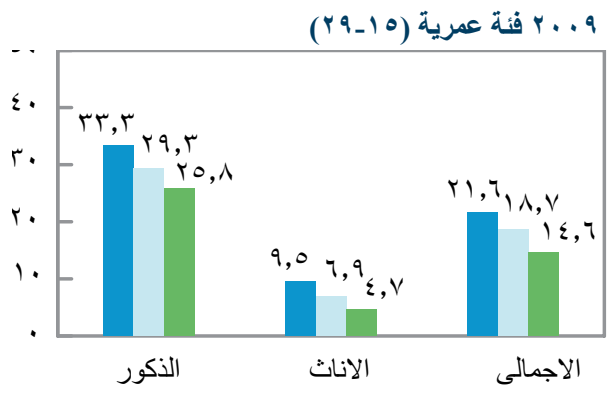

الفئة عمرية

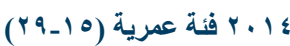

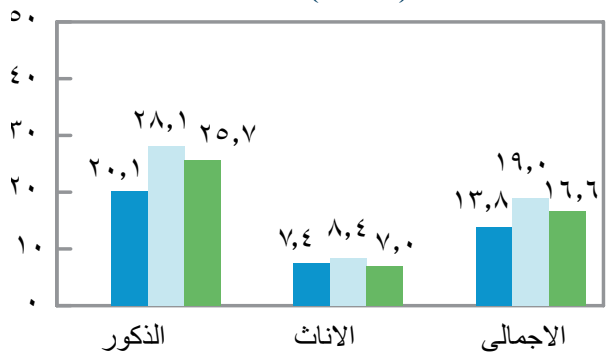

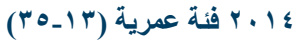

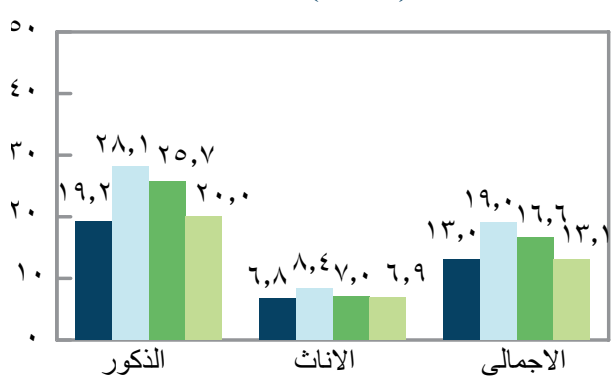

المحتملين من أجل تحقيق طموحاتهم (انظر على سبيل المثال

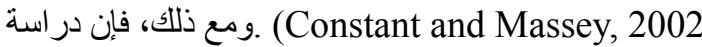
الرغبة في الهجرة لا تز ال هامة لمساعدتنا على فهم المحددات

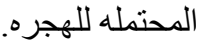

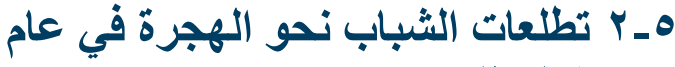 $r$. Is \\ التطلعات نحو الهجرة على المدى البعبا}

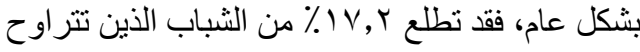

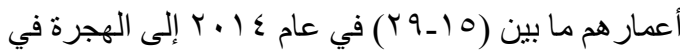
غضون الأعو ام الخمس المقبلة، وهو ما سنشير إليه بالتطلعات

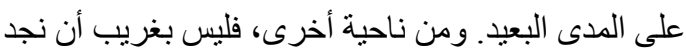
نسبة المنطلعين إلى الهجرة على المدى القريب أقل 9 ,^٪؛

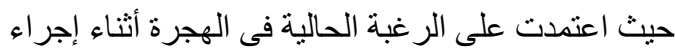

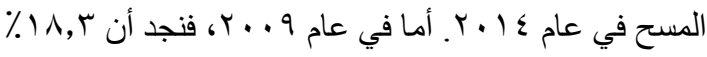

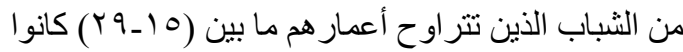

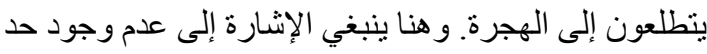

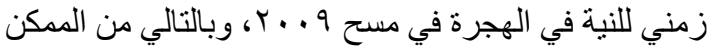
أن تشير الإجابات إلى التطلعات الحالية، أو القريبة أو البعيدة

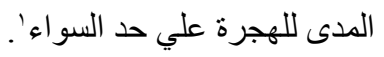

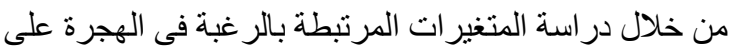

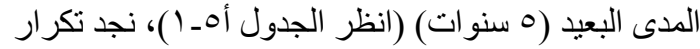

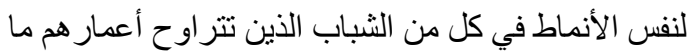

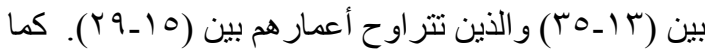

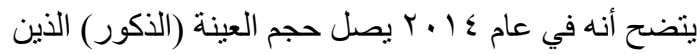

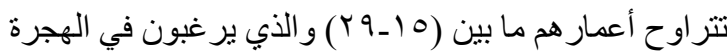

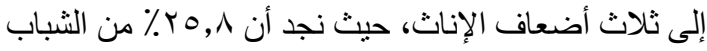

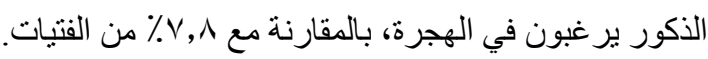

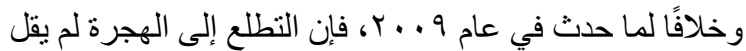

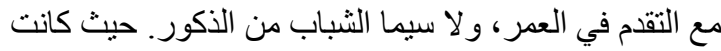

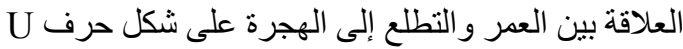

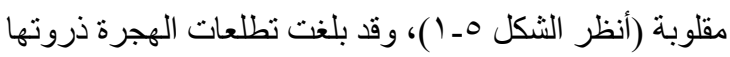

( ) هناك فرق مهم هو أن السؤ ال حول التطلع الى الهجرة كان مختلفا قليلا في كلا

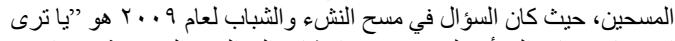

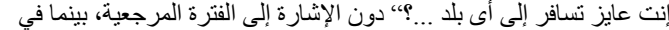

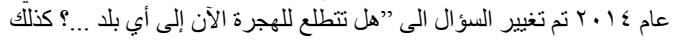

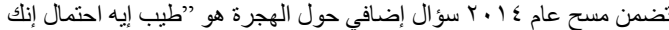

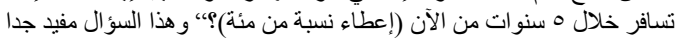

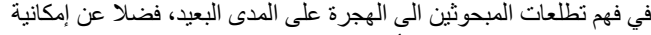

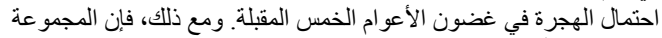

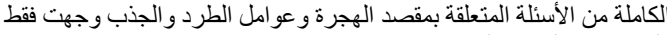
لأولئك الذنين أجابو أبأهم يتطلعون إلى الهجرة الآن. 


\section{التطلعات الى الهجرة على المدى القريب}

عند النظر إلى خصائص أولئك الذين يطحون في الهجرة

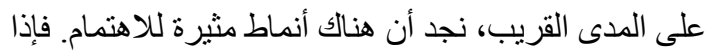

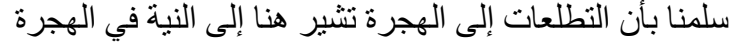

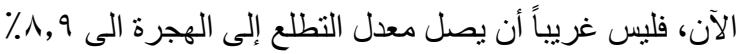

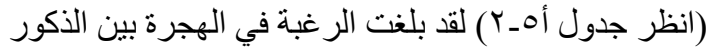

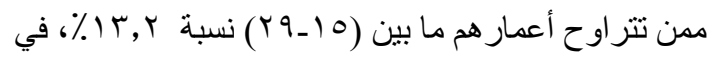

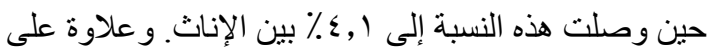
ذللك، فإن النية في الهجرة إلى الغرب كانت ه, 1 ٪ فقط، بينما

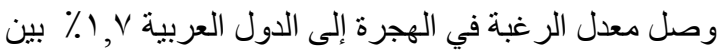
الثباب من (10 _9 Y) عاما. ومن الجدير بالذكر أن تطلعات

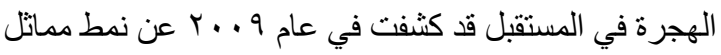
من التفضيل، حيث أوضحت أن ץ, ـ ا ٪ من الثباب يفضلون

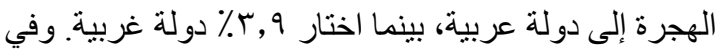

كلا الاستطلاعين، كان تفضيل الدول العربية يصل أربعة

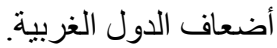

كما لوحظ وجود أنماط مماثلة فيما يتعلق بتطلعات الثباب على المدى القريب في ضو ضو متغير ات العمر و التعليم و الحالة الاجتماعية و الثروة و الوضع الوظيفي للشباب في الفئات

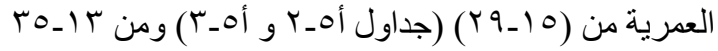

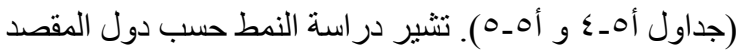

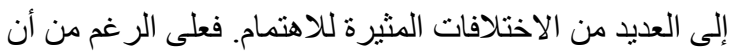

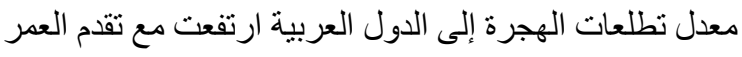
بين الذكور ، إلا أنها انخفضت بالنسبة للاول الغربية مع التقدم

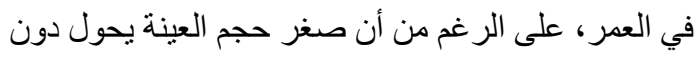

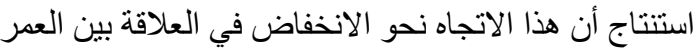

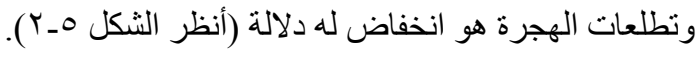

الثكل ه_r بلدان المقصد للهجرة (الدول العربية والدول

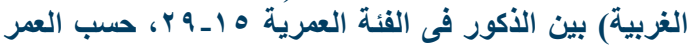

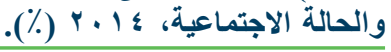

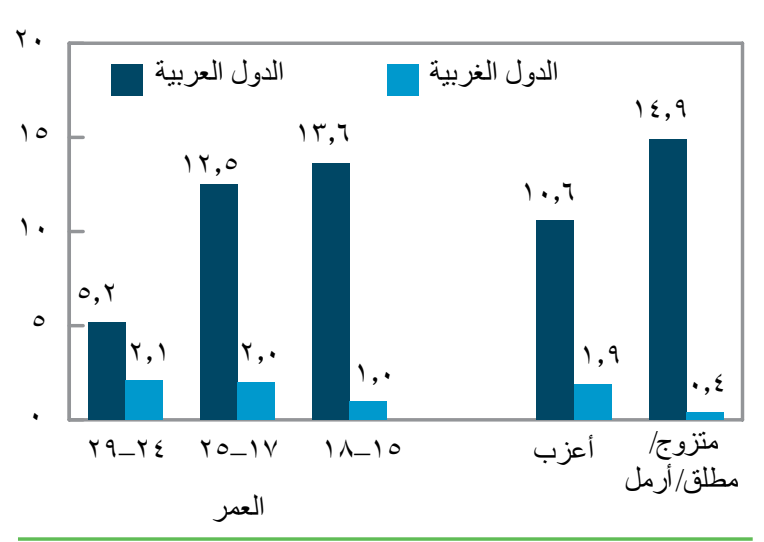

كانت هنالك زيادة و اضحة في الرغبة و هي الهجرة مع ارتفاع مؤشر الثروة، 9 . . T، حيث لم يكن هنالك علاقة إيجابية و اضحة بين الثراء

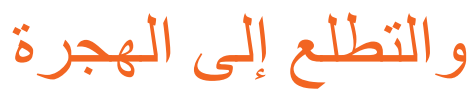

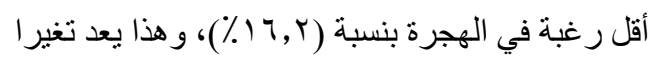

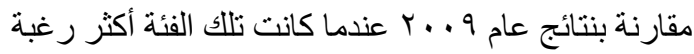

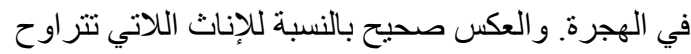

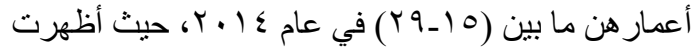

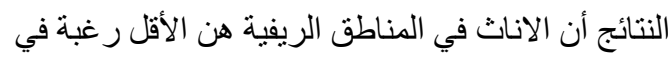

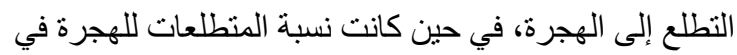
المناطق الحضرية و العشو ائية أعلى. فئ.

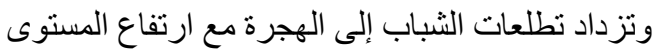

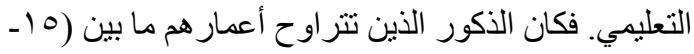

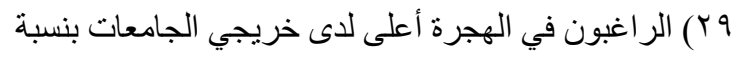

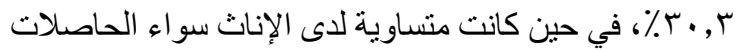
على الثانوية العامة أو خريجات الجامعة بنسبة (7 آ (0 1\%). وبشكل عام، كانت أنماط تطلعات الهجرة لدي المتعلمين

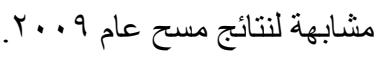

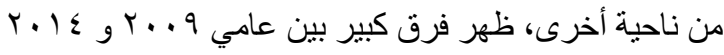

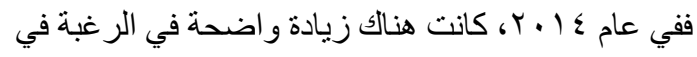

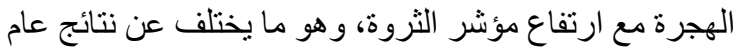

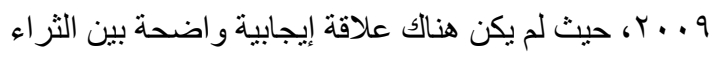

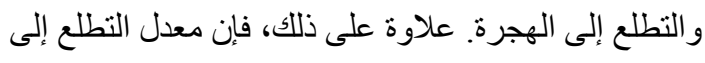

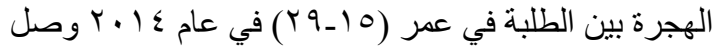

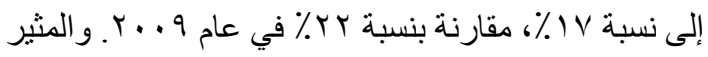

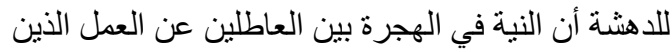

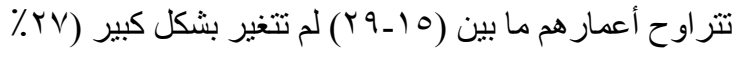

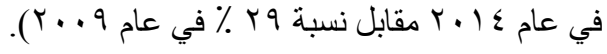




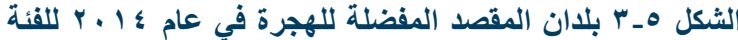

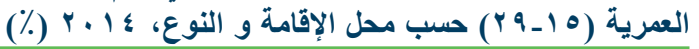

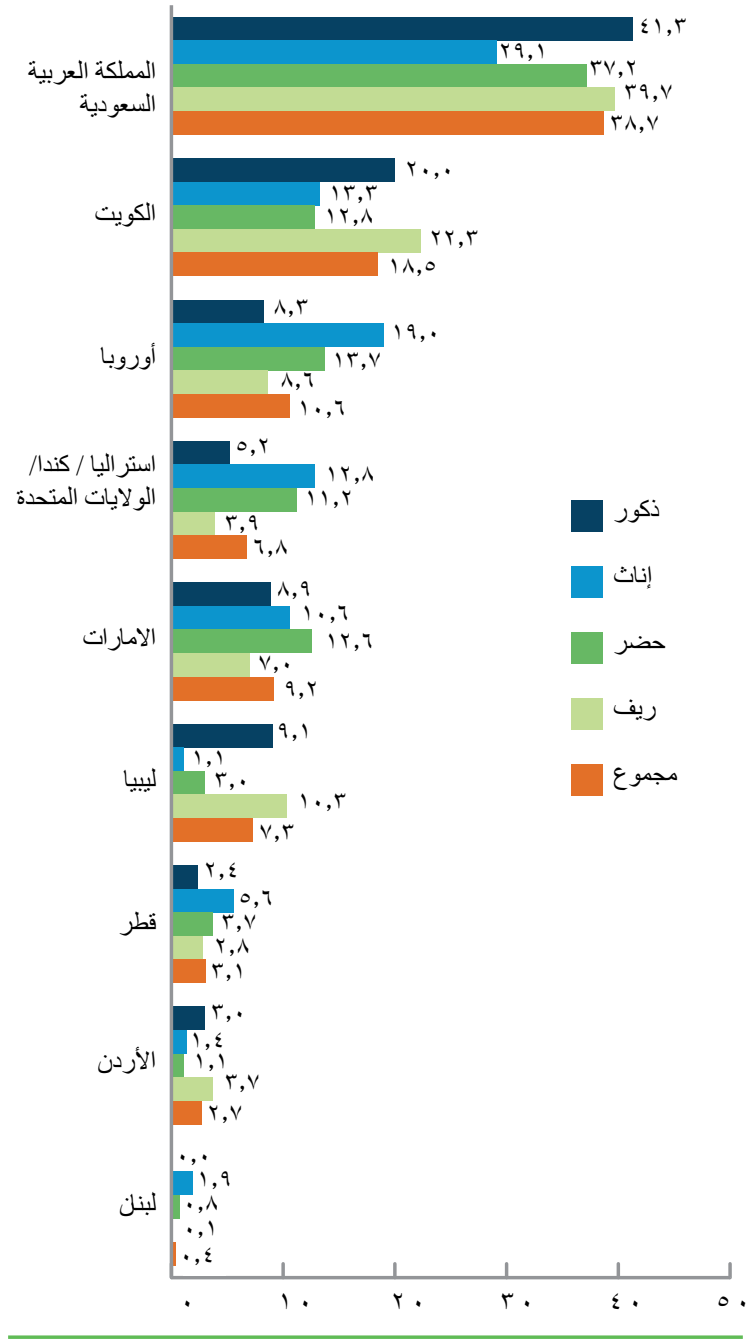

اعتقد ·, ـ ـ ٪ من الثباب أن الدخل في مصر أقل من الخارج،

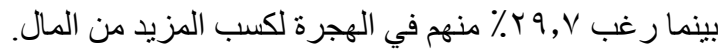

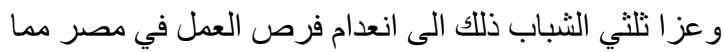
دفعهم للتطلع إلى الهجرة. وكانت الظروف المعيشية السيئة

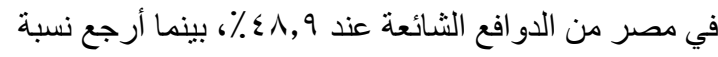

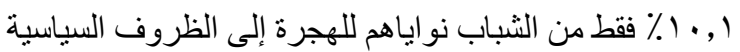

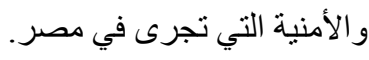

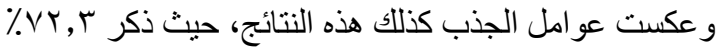

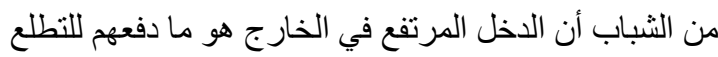
إلى الهجرة، كما كان الادخار من أجل الزواج سببا آخر وراء

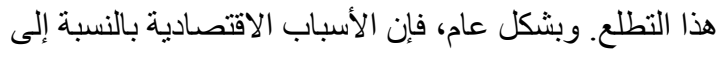

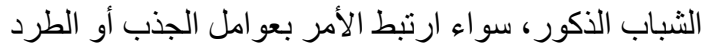

و على نفس المنوال، نجد أن الذكور المتزوجين يظهرون رغبة أعلى في الهجرة إلى الدول العربية مقارنة بأولئك الذين لم

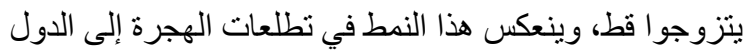
الغربية وساد نفس النمط فى 9 . . ب. و أخيراً، نجد أن تطلعات

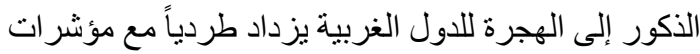
الثروة، و لكن ليس للاول العربية.

\section{بلدان المقصد التحى بتطلع الشباب اليى الهجرة اليها

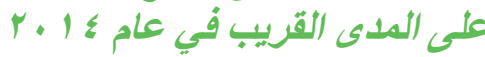

تختلف الاتجاهات المفضلة للهجرة على المدى القريب لدى

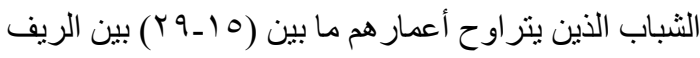

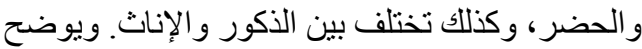

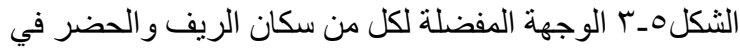

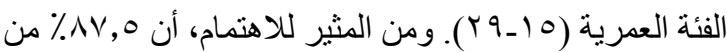

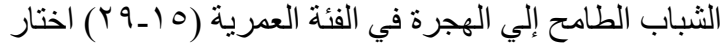

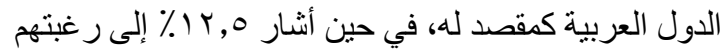
في الهجرة إلى الدول الغربية. و علاوة على ذلك، فقد أوضح

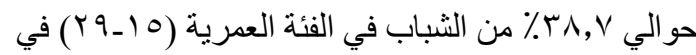
كل من الريف والحضر رغبته في الهجرة إلى المملكة العربية

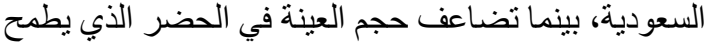

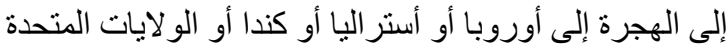

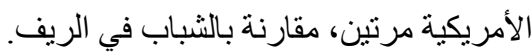

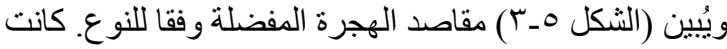
المملكة العربية السعودية الوجهة الأكثر تفضيلًا بين الر اغبين

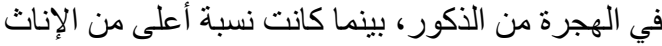

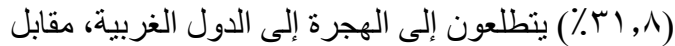

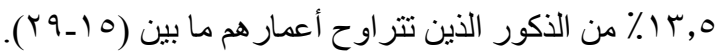
وقد لوحظ وجود أنماط مماثلة بين الثباب الذين في الفئة الفئ

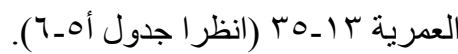

\section{أسباب نطلع الشباب إلى الهجرة}

ذكرت الغالبية العظمى من الثباب (بنسبة ،, ب9\%) من الذين

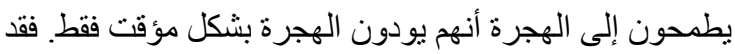

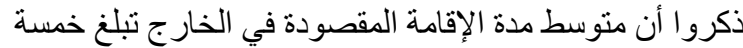

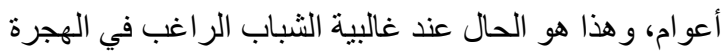

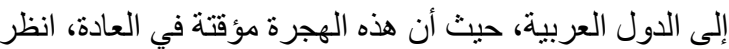

على سبيل المثال(Wahba 2015).

ويلخص جدول هـ ا الأسباب الرئيسية ور اء تطلعات الثباب

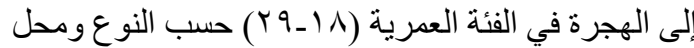

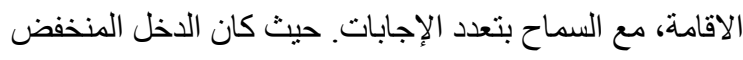

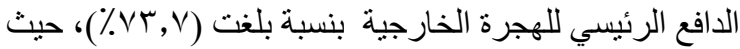




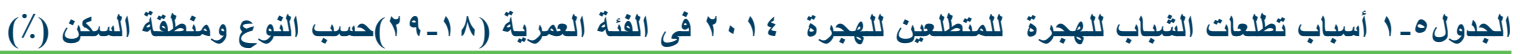

\begin{tabular}{|c|c|c|c|c|c|c|c|c|c|}
\hline \multicolumn{3}{|c|}{ الإجمالي } & \multicolumn{3}{|c|}{ إناث } & \multicolumn{3}{|c|}{ ذكور } & \multirow[b]{3}{*}{ عوامل الطرد } \\
\hline الإجمالي & ريف | ريف & حضر & | إجمالي & ريف & حضر & الإجمالي & ريف & حضر & \\
\hline & & & & & & & & & \\
\hline 70,7 & $\uparrow,$. & Tr, & $\varepsilon v, 0$ & $\varepsilon १, १$ & $\varepsilon \varepsilon, \wedge$ & 79,9 & $v 1,0$ & $T V, 1$ & عدم وجود فرص العمل متاحة في مصر \\
\hline$\varepsilon \varepsilon$, & $\leqslant 0,0$ & $\varepsilon 1, v$ & $r, \uparrow$ & $r q, 1$ & $r \varepsilon, r$ & $\leq 7,9$ & $\varepsilon \wedge, \vee$ & $\varepsilon r, q$ & الدخل في مصر أقل من الخارج \\
\hline$\varepsilon \wedge, q$ & $\varepsilon \wedge, q$ & $\varepsilon \wedge, q$ & $\varepsilon r, r$ & $r v, Y$ & $\varepsilon \vee, r$ & $0 ., \varepsilon$ & $01,$. & $\varepsilon 9, \varepsilon$ & الظروف المعيشية السيئة في مصر \\
\hline$\varepsilon, 1$ & $r, r$ & $0, \S$ & $\wedge, \vee$ & $\varepsilon, \vee$ & 1,1 & $r, \cdot$ & $r, \cdot$ & $r, \cdot$ & للهروب من الضغوط العائليّة والمتاعب \\
\hline$r, 0$ & $r, \Lambda$ & $r, \cdot$ & $1 \cdot, r$ & $11, \mathrm{~V}$ & $\wedge, 0$ & $\cdot, \mathrm{V}$ & 1,1 & $\cdot, \cdot$ & مر افقة العائلة \\
\hline iv,. & $19,$. & $1 r, \lambda$ & $1 \cdot, r$ & $9, \vee$ & 11,1 & 11,0 & $r \cdot, \Lambda$ & $1 \varepsilon, 7$ & لمساعدة عائلتي \\
\hline$\cdot, \wedge$ & $\cdot, \mathrm{V}$ & $\cdot, 9$ & $r, \cdot$ & $r, 0$ & $1, \varepsilon$ &., 0 & .,r & $\cdot, \wedge$ & لا أعلم \\
\hline $4, Y$ & $r, \uparrow$ & 11,9 & $19, r$ & Kr, & $r 4,4$ & $r, r$ & $\cdot, \mathrm{V}$ & $v, \varepsilon$ & عدم وجود فرص لاكتساب المعلومات والخبرات \\
\hline$r q, v$ & $r q, \wedge$ & $r q, 7$ & 17,1 & $1 \leqslant, 0$ & $19, \varepsilon$ & rr, & $r, \Lambda$ & rr, & للحصول على المال \\
\hline $1 ., 1$ & $9, \cdot$ & 11,9 & 14,1 & $1 \cdot, \lambda$ & $10, \mathrm{~V}$ & $१, \varepsilon$ & $\wedge, 7$ & $1 \cdot, v$ & الظروف السياسية والأمنية في مصر \\
\hline $1, \mathrm{v}$ & $\cdot, \wedge$ & $r, r$ & $y, \tau$ & $\varepsilon, q$ & $1 ., 0$ & $\cdot$, & $\cdot, \cdot$ & $1, \cdot$ & آخري \\
\hline 070 & $r \varepsilon \varepsilon$ & rrI & $1 \cdot v$ & 07 & 01 & $\varepsilon 01$ & rM & 179 & حجم الَعينة \\
\hline & & & & & & & & & عوامل الجذب \\
\hline 9,7 & $\wedge, \vee$ & 11,1 & $19, \varepsilon$ & $1 \leqslant, 7$ & $r \leqslant, T$ & $v, r$ & $v, 7$ & $\mathrm{v}, \cdot$ & رؤية دول أخرى \\
\hline$v, q$ & ఛ, & $1, ., 1$ & 11,7 & $1 \cdot, r$ & Ir, & $v, 1$ & 0,9 & 9,1 & أريد أن أعيش في الخارج \\
\hline$r, r$ & ఛ, & 7,7 & 11,1 & 9,7 & Ir,Y & 0,1 & $0, r$ & $\varepsilon, \wedge$ & لدي أقارب / أصدقاء هناك \\
\hline$\varepsilon, q$ & $\varepsilon, 1$ & 7,1 & $r, \mathrm{~V}$ & $\cdot, \cdot$ & $\mathrm{v}, \mathrm{v}$ & 0,1 & $\leq, q$ & 0,1 & لاي عرض عمل هناك \\
\hline $\mathrm{r}, \mathrm{O}$ & $\varepsilon, 7$ & 11,9 & $r \varepsilon, 0$ & 19,0 & $r q, 9$ & $r, 0$ & $1, v$ & 7,0 & يمكنتي الدر اسة بها \\
\hline$V Y, r$ & $v r, v$ & $v \cdot, r$ & 00,9 & $0 \leqslant, V$ & $O V, r$ & $V 4, Y$ & $Y Y, \varepsilon$ & $v \varepsilon, 1$ & الدخل أعلى في الخارج مما عليه في مصر \\
\hline$\varepsilon 1, \wedge$ & $\varepsilon \varepsilon, r$ & $r \wedge, r$ & $v, l$ & ૫, ६ & $v, q$ & $0 .,$. & 01,0 & $\varepsilon \vee, \varepsilon$ & لتوفير المال للزواج \\
\hline $1 \cdot, r$ & $0, \varepsilon$ & $i v, \Lambda$ & $r v, r$ & $r,$. & $r \varepsilon, r$ & $T, Y$ & $r, r$ & $I_{1}, q$ & لتحسين معرفتي \\
\hline$r, q$ & $r, 0$ & $r, \varepsilon$ & $\Lambda, r$ & $1 ., r$ & ד,r & 1,7 & $1,$. & $r, T$ & لم شمل الأسرة \\
\hline $\begin{array}{c}1,7 \\
(070)\end{array}$ & $\begin{array}{l}1,9 \\
(, 46)\end{array}$ & $\begin{array}{l}1, r \\
G, 1\end{array}$ & $r, q$ & r,V & $r, \cdot$ & $\begin{array}{l}1, r \\
(\leq 0 \wedge)\end{array}$ & l,A & , & آخري لَّينة \\
\hline$(070)$ & $(\Gamma \leq \varepsilon)$ & $(Y Y)$ & $(1 \cdot v)$ & $(07)$ & $(01)$ & $(\Sigma 0 \wedge)$ & $(\curlyvee \wedge \wedge)$ & $(179)$ & حجم العينة \\
\hline
\end{tabular}

فإن أعلى معدلات الر غبة في الهجرة كانت لاى هؤلاء غير الو اثقين في المستقبل. و هكذا، وبشكل عام، يبدو أن عدم الرضا لإنا

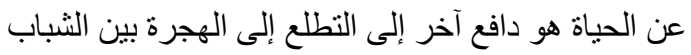

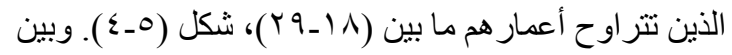

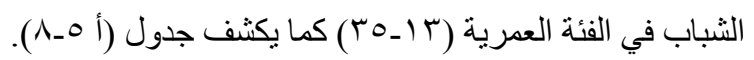

\section{مصادر المعلومات والثشبكات الإنهاعياّة}

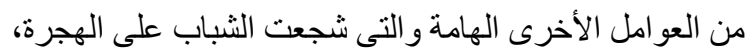

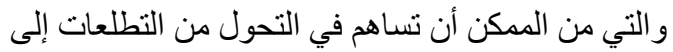

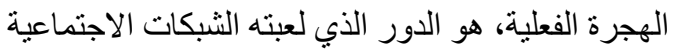

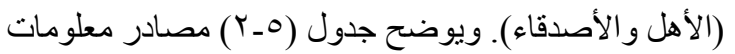

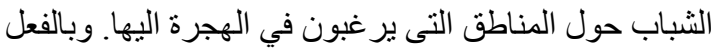

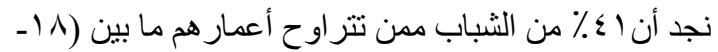

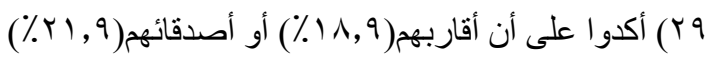

أهم من الأسباب السياسية أو الاستثمار في رأس المال البشري

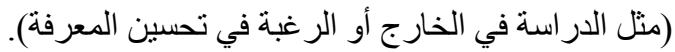

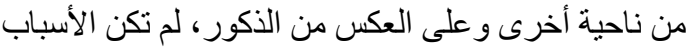

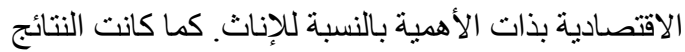

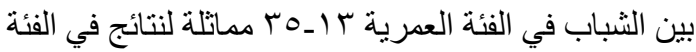

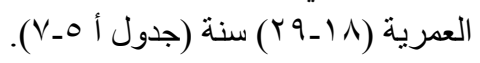

وبما أن ما يقرب من نصف الثباب يعتقدون أن الظروف المعيشية السيئة هي الدافع ور اء رغبتهم في الهجرة، يقدم شكل

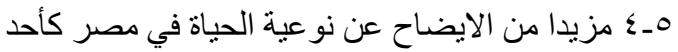

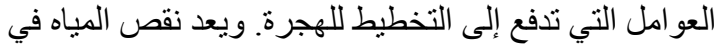

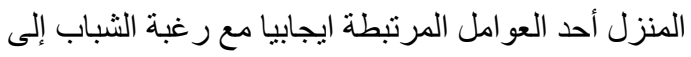

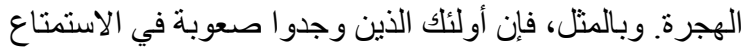

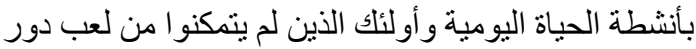

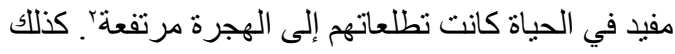




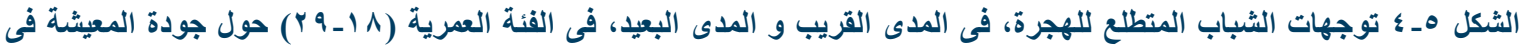

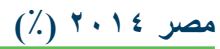
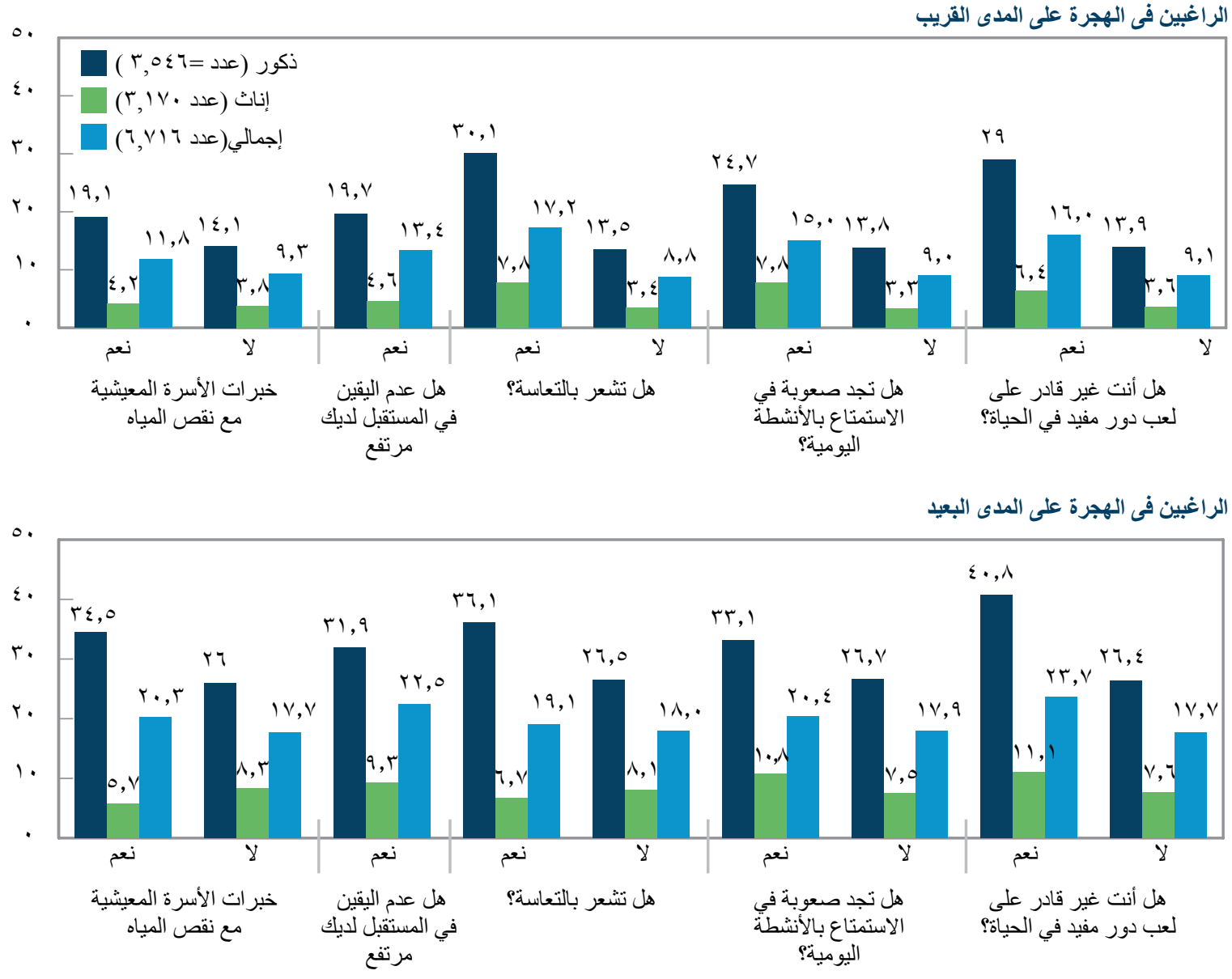

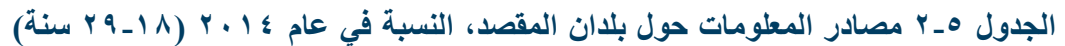

\begin{tabular}{|c|c|c|c|c|c|c|c|c|c|}
\hline \multicolumn{3}{|c|}{ أى مقصد } & \multicolumn{3}{|c|}{ البلدان الغربية } & \multicolumn{3}{|c|}{ البلان العربية } & \\
\hline الإجمالي & ريف & حضر & الإجمالي & ريف & حضر & الإجمالي & ريف & حضر & \\
\hline 11,9 & $r \cdot, r$ & $17, r$ & $17, v$ & $r_{1, r}$ & Ir, 9 & $19, \varepsilon$ & $r \cdot, \Lambda$ & 17,9 & أقارب بالخارج \\
\hline $10,$. & $I r, \wedge$ & IV,. & 7,1 & $\varepsilon, 1$ & $\vee, \wedge$ & 17,7 & $1 \leqslant, \wedge$ & 19,9 & أقارب في مصر \\
\hline$r_{1}, 9$ & $r \leq, 1$ & $1 \wedge, \varepsilon$ & $i v, \wedge$ & $19, v$ & $17, r$ & $r r, \cdot$ & ro,. & 19,0 & الأصدقاء المصريين في الخارج \\
\hline$r, r$ & rtr, & $r_{\bullet}, \varepsilon$ & $\mid v, 1$ & $r \leqslant, \Lambda$ & $1 \cdot, 9$ & $r, \Lambda$ & $r r, \varepsilon$ & r), & أصدقاء في مصر \\
\hline 7,0 & $r, \tau$ & $1 \cdot, 9$ & $r \leqslant, \varepsilon$ & IV,V & rq, १ & $r, \varepsilon$ & 1,7 & \urcorner,$\varepsilon$ & الإنترنت \\
\hline$\cdot, \varepsilon$ & $\cdot, 7$ & $\cdot, \cdot$ & - & - & - & $\cdot, 0$ & $\cdot, \vee$ & $\cdot, \cdot$ & الحكومات \\
\hline$\varepsilon, r$ & $\varepsilon, 1$ & $\varepsilon, 0$ & $\uparrow, V$ & $\uparrow, V$ & $\uparrow, \wedge$ & $r, \wedge$ & $r, v$ & $\varepsilon, \cdot$ & قر اءات عامة \\
\hline 9,0 & $\wedge, r$ & $11, \varepsilon$ & $1 \cdot, r$ & 0,1 & $1 \leqslant, \cdot$ & 9,1 & $\Lambda, r$ & $1 \cdot, 7$ & وسائل الإعلام (تلفزيون، راديو، صحف) \\
\hline$\cdot, r$ & $\cdot, r$ & $\cdot, r$ & - & - & - & $\cdot, r$ & $\cdot, r$ & $\cdot, \varepsilon$ & السفار ات / القنصليات \\
\hline $1, r$ & $1, \varepsilon$ & $\cdot, 9$ & $\cdot, \wedge$ & $\cdot, \cdot$ & 1,0 & $1, r$ & 1,7 & $\cdot, 7$ & أخرى \\
\hline$(070)$ & $(\Gamma \leq \varepsilon)$ & $($ (YY) & $(\wedge \vee)$ & $(r q)$ & $(\varepsilon \wedge)$ & $(\Sigma T V)$ & $($ (१৭) & $(17 \wedge)$ & 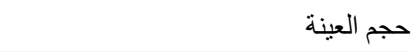 \\
\hline
\end{tabular}


جدول هـ ؛ : المساعدة التى يتوقعها الثباب الطامح في الهجرة لعام

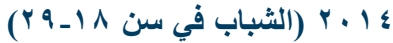

\begin{tabular}{|c|c|c|c|}
\hline اي بلد & البلان الغربية & البلان العربية & \\
\hline$Y Y, Y$ & $r V, r$ & $r V, r$ & اقارب فى الخارج \\
\hline$\leqslant 9,7$ & 07,9 & $\varepsilon \wedge, \varepsilon$ & اقارب فى الداخل \\
\hline $1 ., 0$ & 9,1 & $1 \cdot, \wedge$ & اصدقاء مصريين بالخارج \\
\hline$\uparrow, \varepsilon$ & $\varepsilon, q$ & $\uparrow, V$ & اصدقاء فى مصر \\
\hline$r, \Lambda$ & - & $r, r$ & سماسرة الهجرة \\
\hline$r, o$ & $r, \cdot$ & $r, \Lambda$ & اخرون \\
\hline$(Y \leqslant 1)$ & $\left(\Gamma^{\prime}\right)$ & $(Y \cdot Y)$ & \\
\hline
\end{tabular}

القناة الرئيسية، كما يتضح أن نسبة ^ر, ؟\% فقط من الثباب الذين

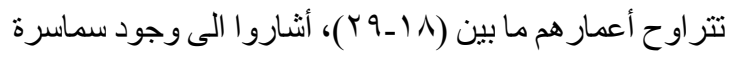

أو وكلاء الهجرة ممن يساعدون الثباب على الهجرة و إيجاد

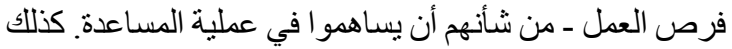

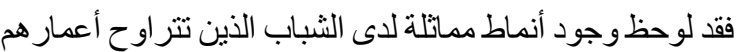
ما بين (T ـ ـ ب) من حيث الاعتماد على الثبكات الاجتماعية للمساعدة في عملية الهجرة (جدول أ هـ • (1).

الخلاصة أنه من أبرز عو امل الطرد التي تدفع الثباب للهجرة

هي محدودية فرص العمل وسو ء الأحوال المعيشية، بينما كانت أهم عوامل الجذب هي الأجور الأعلى في الخارج

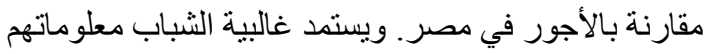
عن البلدان المفضلة للهجرة من عائلاتهم و أصدقائهم الذين كانو ا بعيشون في الخارج. و لاتز ال المملكة العربية السعودية الوجهة الأكثر تفضيلاً بين الثباب. وتنتشابه هذه النتائج إلى حد كبير مع النتائج ما توصلت إليها منظمة الهجرة الدولية في عام التئ

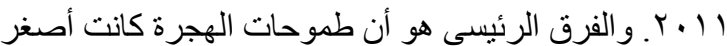
بكثير من مسح منظمة الهجرة الدولية أو مسح النشء و الثنباب

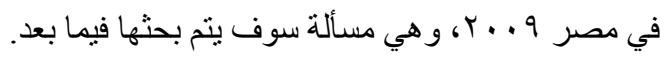

\section{هـr التغيرات في التطلع الى الهجرة: $r \cdot 1 \leqslant g, r . q$}

يبحث هذا القسم التغير في مسار ات التطلع إلى الهجرة بين

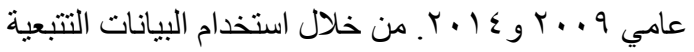
لمسح النشء و الثباب في مصر ، حيث نركز في البداية على من التي

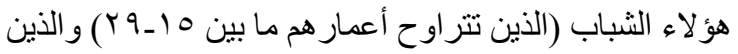

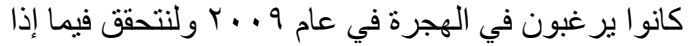

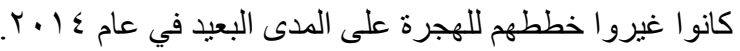

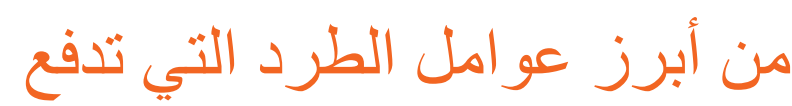

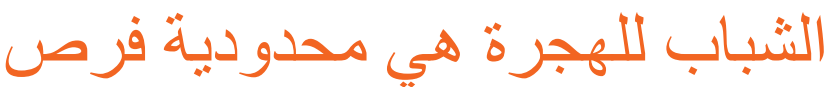
العمل و سوع الأحو ال المعيشّبة، بينها كانث أهم عو امل الجذب هي الأجور

$$
\begin{aligned}
& \text { الأعلى في الخار ج مقار نه بالأجور } \\
& \sin
\end{aligned}
$$

في الخارج، كانوا هم المصدر الرئيسي للمعلومات. و أشتار

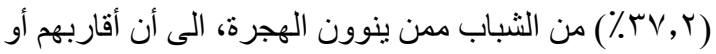

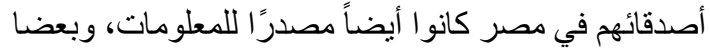
منهم كان من المهاجرين العائدين. وليس من المفاجئ أن عامل العمر لا يؤثر على تغيير نمط مصادر المعلومات حول مناطق

الهجرة (انظر جدول أ هـ9 ) لمن نتر اوح أعمار هم ما بين

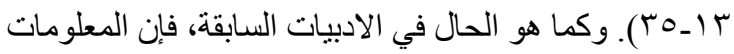

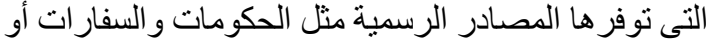
القتصليات للطامحين في الهجرة قليلة جداً.

ومع ذللك، هنالك اختلاف ملفت للنظر قد برز بين عامي

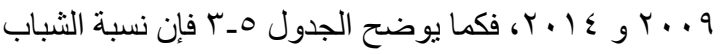
الذى يستخدم الانترنت في المناطق الحضرية للحصول على الى النى معلومات عن بلدان المقصد قد ازدادت إلى حد كبير.

وفيما يتعلق بالمساعدة التى يتوقعها الثباب الطامح في الهجرة

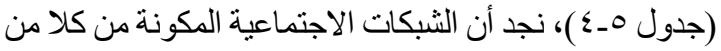
الأصدقاء و الأقارب سواء في داخل مصر أو خارجها، تُعد هى

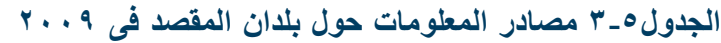

\begin{tabular}{|c|c|c|c|c|}
\hline الإجمالي & يف & & حضر & \\
\hline$r .1 \leqslant r \ldots q$ & $r .1 \leqslant$ & $r \ldots q$ & $r .1 \leqslant r \ldots q$ & \\
\hline$\vee \wedge, \cdot \quad \vee q, q$ & $\wedge, v$ & $\Lambda \varepsilon, q$ & $V Y, \cdot V Y, Y$ & أقارب/ أصدقاء \\
\hline$\uparrow, 0 \quad Y, V$ & $r, \tau$ & $1, \wedge$ & $1 \cdot, 9 \quad r, \Lambda$ & انترنت \\
\hline •, & ז, • & $\cdot, r$ & •, & الحكومات \\
\hline$\varepsilon, r \quad r, r$ & $\varepsilon, 1$ & 1,9 & $\varepsilon, 0 \quad r, \wedge$ & قر اءأل الاعلام \\
\hline $9,0 \quad 1 \leqslant, 0$ & $\wedge, r$ & $1 \cdot, v$ & $11, \leqslant \quad 19,7$ & (تليفزيون/ر اديو/صحف) \\
\hline $1,0 \quad \cdot, r$ & 1,7 & $\cdot$, , & I,r & أخرى \\
\hline$(070)($ I KY $)$ & $(\Gamma \leq \varepsilon)$ & $(799)$ & (YYI) (OYT) & مجم العينة \\
\hline
\end{tabular}

o 


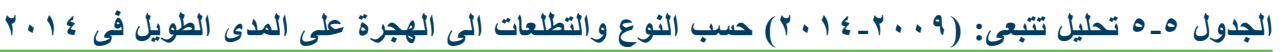

\begin{tabular}{|c|c|c|c|c|}
\hline حجم العين & حالات مفقودة & تطلعات الهجرة على الطويل ع ا ـ المد & لا توجد تطلعات للهجرة & \\
\hline & & & & الإجمالي \\
\hline$(1, V \leq 7)$ & $r_{1,7}$ & $1 \wedge, r$ & $0 ., r$ & تطلعات الهجرة 9 . . ب \\
\hline$(9, \cdot 90)$ & $r \wedge, \wedge$ & $9, \wedge$ & 71,0 & لا توجد تطلعات عام 9 × . T \\
\hline$(1 \cdot, \wedge \leq 1)$ & $(r, 17 \wedge)$ & $(1, Y \cdot \varepsilon)$ & $(7, \leqslant 79)$ & حجم العينة ل \\
\hline$(1, r \leq \varepsilon)$ & $r \cdot, v$ & $1 \wedge$, & $01, r$ & > تطلعات الى البلدان العربية و . . r \\
\hline \multirow[t]{2}{*}{$(r \wedge \vee)$} & ro,v & $19, \varepsilon$ & $\leqslant 0,0$ & > تطلعات الى البلدان الغربية 9 . . ب \\
\hline & & & & ذكور \\
\hline$(1$, ror $)$ & rq, \& & $r_{1}, \varepsilon$ & $\varepsilon 9, r$ & تطلعات الهجرة 9 . . ب \\
\hline$(\Gamma, \varepsilon \neg \varepsilon)$ & $r \wedge, 1$ & IV,V & $0 \leqslant, r$ & لا توجد تطلعات عام 9 ، . ب \\
\hline$(\varepsilon, \wedge \backslash\rceil)$ & $(1, r v \cdot)$ & $(9 \cdot 1)$ & $(Y, 0 \leq 0)$ & حجم العينة \\
\hline$(1, \cdot \times 1)$ & 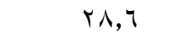 & $r \cdot, \Lambda$ & $0 ., 7$ & > تطلعات الى البلدان العربية 9 × . ب \\
\hline 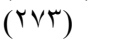 & rᄉ, & $v, \cdot$ & $0 \leqslant, Y$ & > تطلعات الى البلدان الغربية 9 × . ب \\
\hline & & & & إناث \\
\hline$($ (१ะ) & rq,1 & $v, 1$ & or,人 & تطلعات الهجرة 9 . . ب \\
\hline$(0,74)$ & $r q, r$ & $\varepsilon, 9$ & 70,9 & لا نوجد تطلعات عام 9 × . ب \\
\hline(\urcorner$, \cdot Y 0)$ & $(1, \vee 9 \wedge)$ & $(r \cdot r)$ & $(r, q \Gamma \leq)$ & حجم العينة \\
\hline$(Y \vee \leq)$ & rr,q & $r \leqslant, 1$ & $\varepsilon r, 1$ & > تطلعات الى البلدان العربية 9 × . ب \\
\hline$(114)$ & $\varepsilon \cdot, v$ & $\wedge, \cdot$ & $01, r$ & > تطلعات الى البلدان الغربية 9 × . ج \\
\hline
\end{tabular}

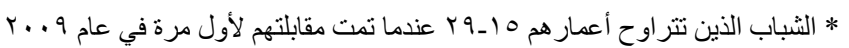

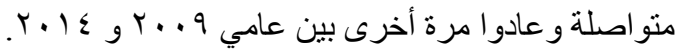

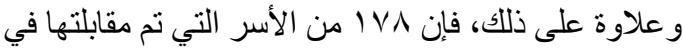

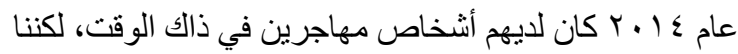
لا نعلم ما إذا كان لدى هؤلاء المهاجرين الحاليين تطلعات

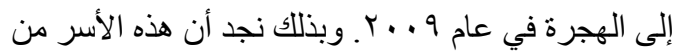

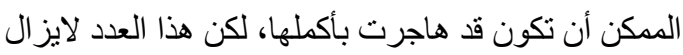

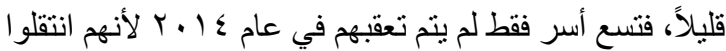

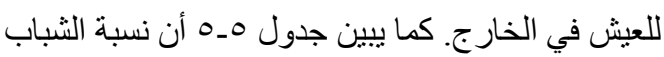

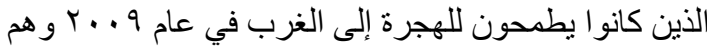

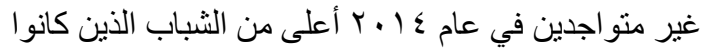

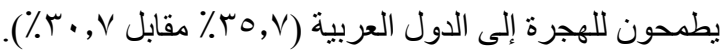

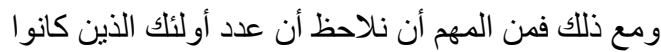
يطمحون للهجرة إلى الغرب صغير لئ.

علاوة على ذللك، فقد بحثنا عن أولئك الذين كانو ا يطمحون للهجرة في عام 9 . . ب و الذين لا يز الو ا يطمحون إلى الهجرة على المدى القصير في عام ع ا ـ ب وذلك للتحقق من التغيير في خطط الهجرة. وليس من المفاجئ، انه عند دراسة خطط

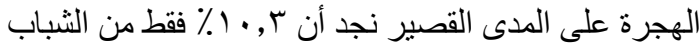

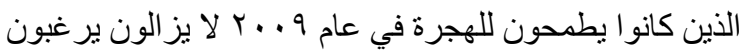

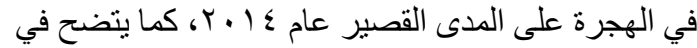

ويوضتح جدول 0_0 عدد ونسبة الشباب وفقاً لمستويات

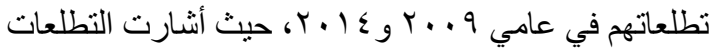
في عام 乏 ا ـ ب إلى الرغبة بعيدة المدى في الهجرة بالنسبة للشباب بما في هؤلاء الذين تعذر متابعتهم (أو غير متو اجدين)

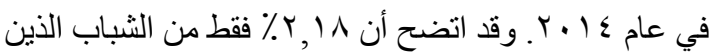

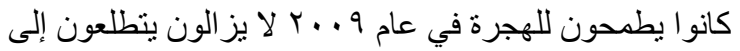

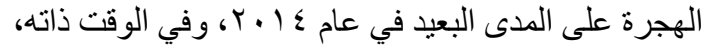

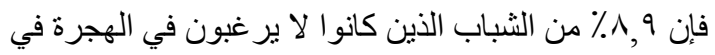
عام 9 . . ب قد تغيرت آر ائهم و أصبحو ا يتطلعون إلى الهجرة

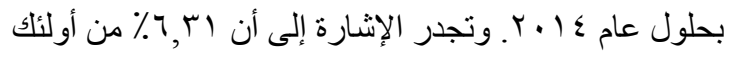

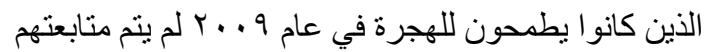
في عام ع 1 ـ ب بسبب عدم تو اجدهم، كذلك فإن نسبة مماتلة

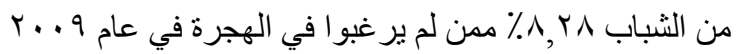
تعذر متابعتهم في عام ع ا ـ ب بسبب عدم تو اجدهم.

و لا يشير هذا الى احتمال أن يكون من تعذر متابعتهم في عام

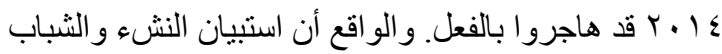

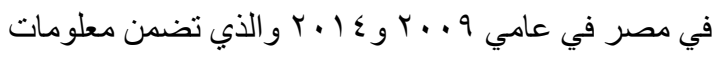
عن أفراد الأسرة الذين سافروا و عادو ا مرة أخرى ما بين

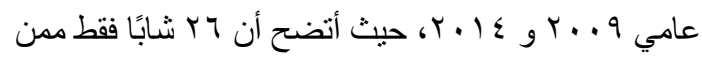

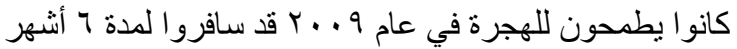


خلال الخمس أعوام القادمة، وكذلك الثباب الر اغبين في

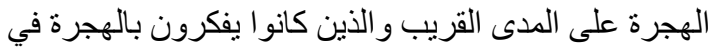

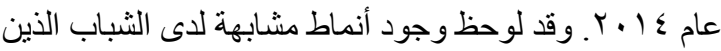

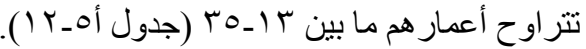

بشكل عام، يبدو أن الثورة كان لها تأثثير محدود على اتجاه

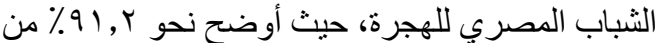

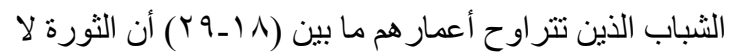
علاقة لها بر غبتهم في الهجرة، أما النسبة المنبقية فهي مقسمة بالتساوي بين هؤلاء الذين كانوا أكثر ميلا للهجرة بعد الثورة

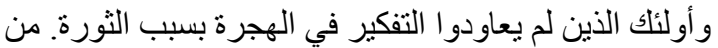
بين هؤ لاء الثباب الذكور الذين يخططون للهجرة على المدى

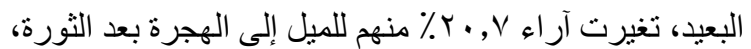

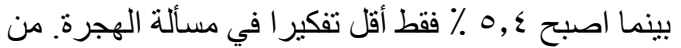

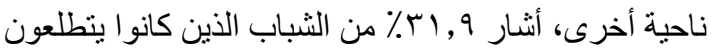
إلى الهجرة على الددى القريب إلى أن زيادة رغبتهم في الهجرة برجع إلى الثورة.

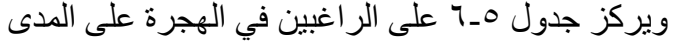

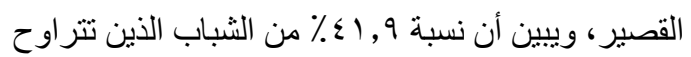

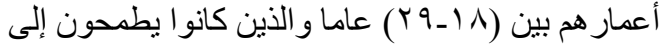

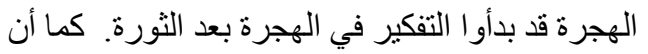

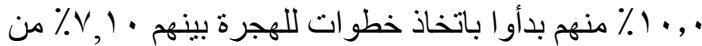

جدول أ هـ 11 ـ وبشكل عام، فليس من الضرورة أن تثير هذه

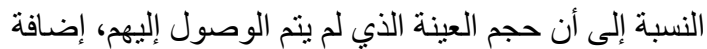

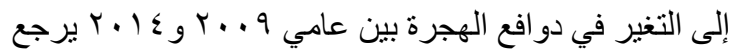

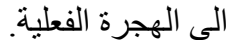

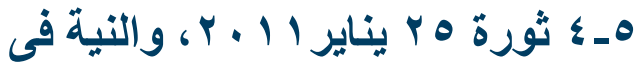 الخهمرة}

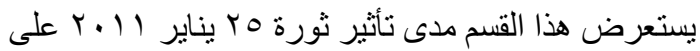
طموحات الهجرة لدى الثباب. رغم أنه من المتوقع أن يدفع

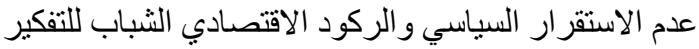

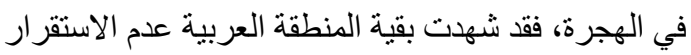

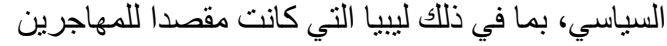

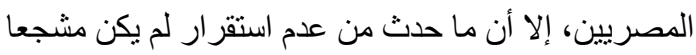

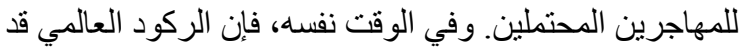

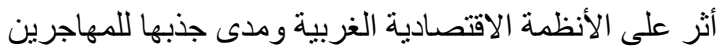
وذللك نتيجة ارتفاع معدلات البطالة و التقشف الاقتصادي.

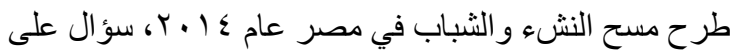

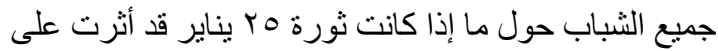

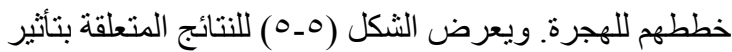

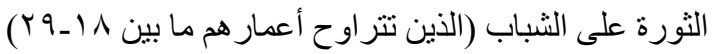
الطامحين إلى الهجرة على المدى البعيد والذين خططو اللهجرة

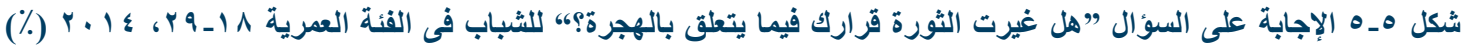

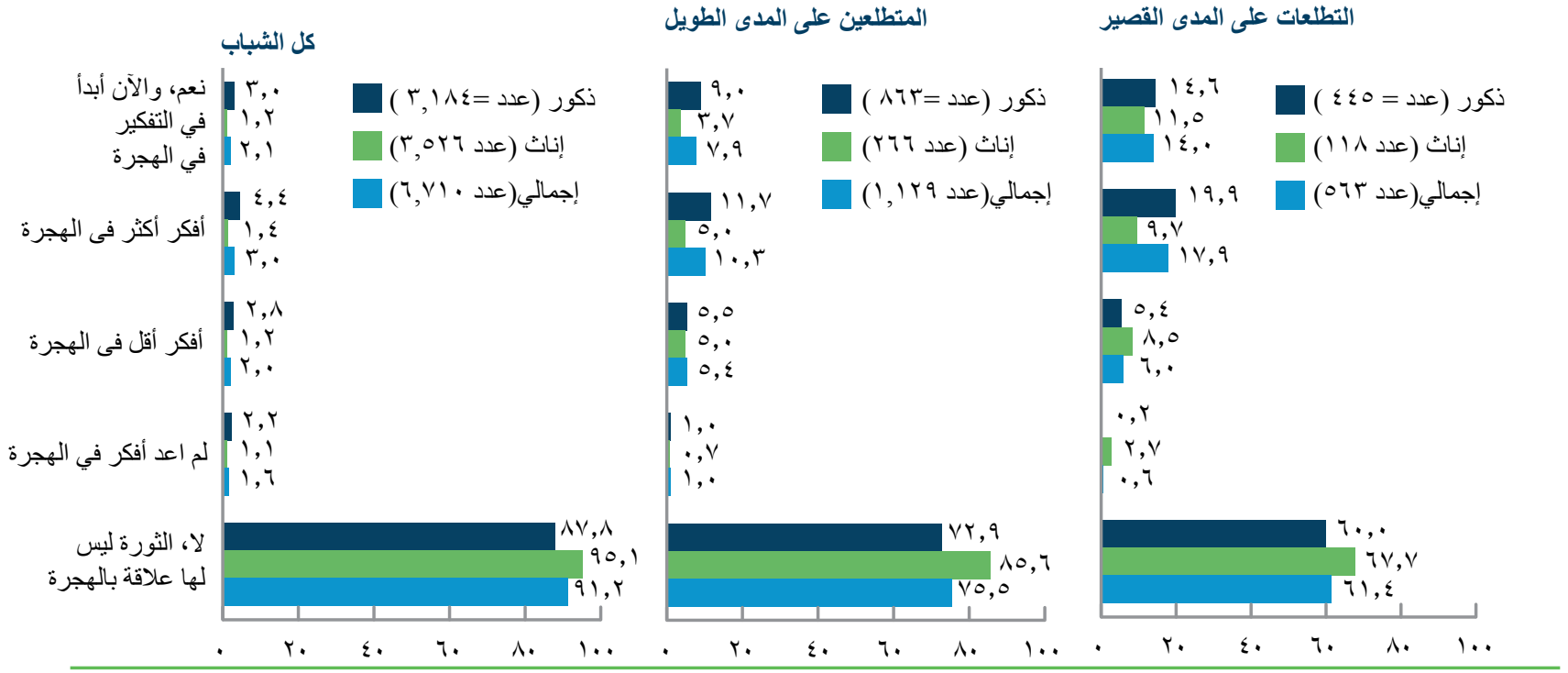

Total $(\mathrm{N})$ for all youth =6,710; $(\mathrm{N})$ for long-term =1,129; $(\mathrm{N})$ for short-term $=563$. 
هـه الخلاصة

تناول هذا الفصل تطلعات الهجرة بين الثباب المصري أثناء

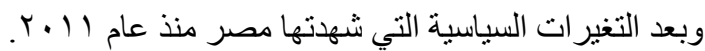

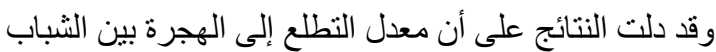

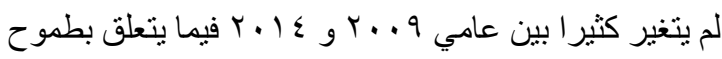
الشباب للهجرة في غضون خمسة أعو ام مقبلة. لكن بالنظر

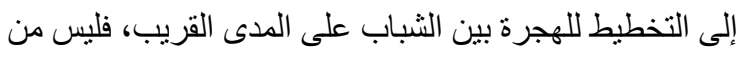

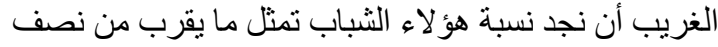
نسبة الثباب المنطلع إلى الهجرة على المدى البعيد في عام الثراه

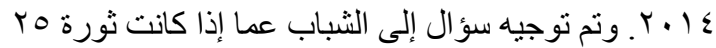

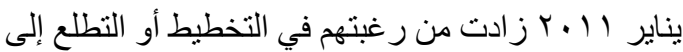

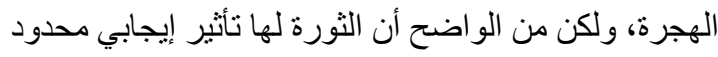

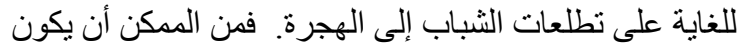

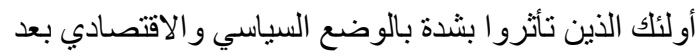

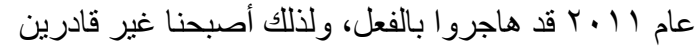

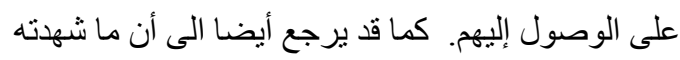

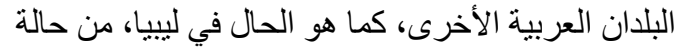

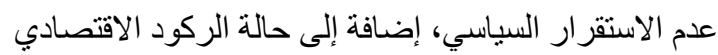

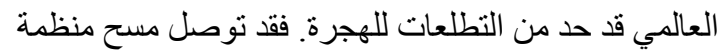

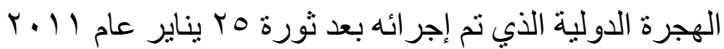

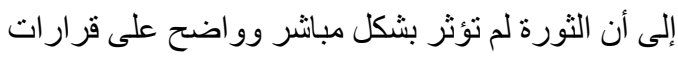
الشباب المصري نحو الهجرة.

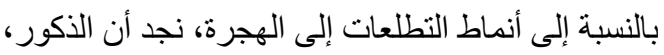

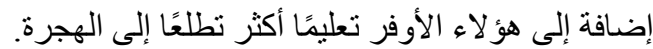

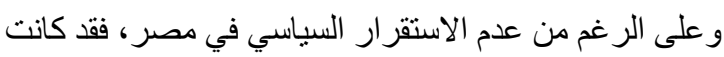
العوامل الاقتصادية هي المحرك الرئيسي للهجرة. كذللك

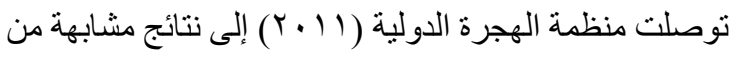
حيث أن نقص فرص العمل و الدخل المنخفض هما أول عاملين

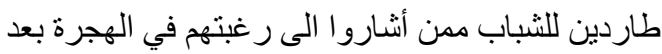

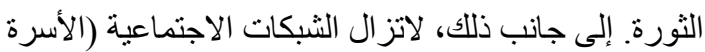

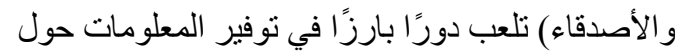

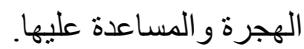

ومن المهم أن نلاحظ أن معظم تطلعات الهجرة لا تتحقق. في الو اقع، فالهجرة الفعلية تعتمد على عدة عو امل المل و وهي:

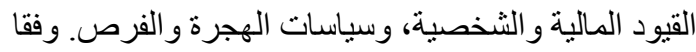

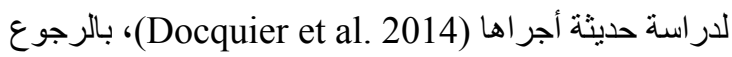
إلى ^ب ا دولة، فإن و احد من كل خمسة مهاجرين محتملين

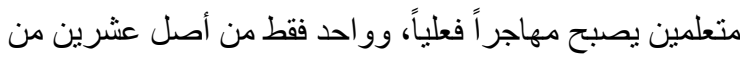

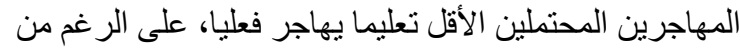
ذللك، فإن در اسة الرغبة في الهجرة هامة لفهم محددات الهجرة.

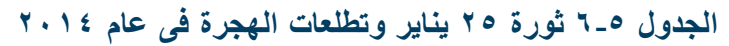

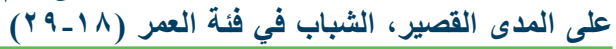

\begin{tabular}{|c|c|c|c|}
\hline إجمالي & إناث & ذكور & \\
\hline & & & في الهجرة بدأت التفكير \\
\hline $0 \wedge, 1$ & $7 \cdot, V$ & $O V, O$ & قبل الثورة \\
\hline$\leqslant 1,9$ & rq, & $\varepsilon r, 0$ & بعد الثورة \\
\hline 070 & $1 . v$ & $\varepsilon 01$ & جم العبنة \\
\hline
\end{tabular}

\begin{tabular}{|c|c|c|c|}
\hline & & & أم أنها مجذأ أي خطورات للهجرة \\
\hline $1 \cdot, \cdot$ & $\mathrm{v}, \cdot$ & $1 \cdot, \mathrm{V}$ & نعم، لقد بدأت في وضع خطط \\
\hline rq, & $19, \varepsilon$ & r, r & لم اضع أى خطط بعد \\
\hline \multirow{2}{*}{$7 \cdot, 9$} & $V_{T}, \mathrm{~V}$ & ov, 9 & لم افكر مطلقا \\
\hline & & & هل هاذ قرام أحد بالتأثير عليك \\
\hline $19, \varepsilon$ & r), & $1 \wedge, \wedge$ & نعم \\
\hline \multirow[t]{2}{*}{$\wedge \cdot, \uparrow$} & $\vee \wedge, r$ & $\wedge, r$ & $\gamma$ \\
\hline & & & عنى هم أكثر من اثروا \\
\hline$v, r$ & 7,9 & $v, r$ & و الدي في الخارج \\
\hline$\cdot, 7$ & $r, 7$ & $\cdot, \cdot$ & و الدتي في الخارج \\
\hline rт, 9 & 11,0 & r, & أقارب آخرين في الخارج \\
\hline rv,l & rr, $\varepsilon$ & 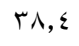 & الأصدقاء المصريون في الخارج \\
\hline $7, \varepsilon$ & 0,1 & 7,7 & و الدي في مصر \\
\hline$\cdot, \vee$ & $\cdot, \cdot$ & $\cdot, 9$ & و الدتي في مصر \\
\hline 0, & Tr, & $r, v$ & أقارب" آخرين في مصر \\
\hline $1 \cdot, 7$ & $11, \mathrm{~V}$ & $1 \cdot, r$ & أصدقاء في مصر \\
\hline r, 9 & 11,0 & $\cdot, 7$ & شريك الحياة الأجنبي (زوج/ زوجة) \\
\hline$\cdot, \vee$ & $\cdot, \cdot$ & $\cdot, 9$ & سماسرة الهجرة س س س س \\
\hline$\cdot, 9$ & $\cdot, \cdot$ & $1, r$ & صاحب العطل المحلي السابق / الحالي \\
\hline$\cdot, 9$ & $\varepsilon, 1$ & $\cdot, \cdot$ & مؤسسة تعليمية \\
\hline$(1 \cdot 7)$ & $(r+)$ & $(\wedge r)$ & حجم العينة \\
\hline
\end{tabular}

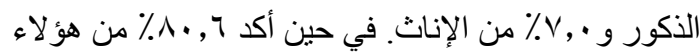

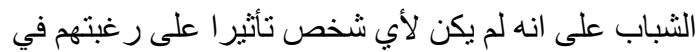

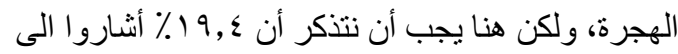

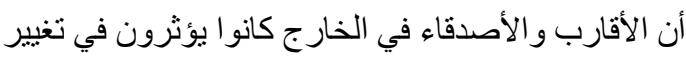

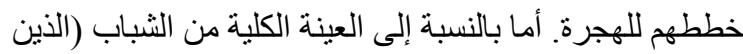

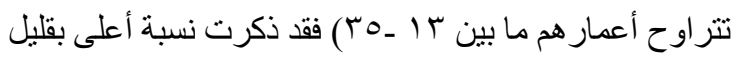

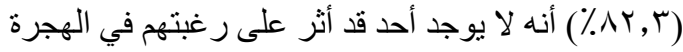

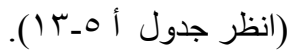


المسح التتبعي للنشء و الشباب في مصر ع ا ب r

Wahba, Jackline. 2015. “Through the keyhole: International migration in Egypt," in The Egyptian Labor Market in an Era of Revolution, R. Assaad and C. Krafft (eds.). Oxford: Oxford University Press, pp. 198 -217.

Van Dalen, Hendrik P., George Groenewold, and Tineke Fokkema. 2005. "The effect of remittances on emigration intentions in Egypt, Morocco, and Turkey," Population Studies: A Journal of Demography, 59(3): 375-392.

Zohry, Ayman. 2006. Attitudes of Egyptian Youth towards Migration to Europe. Cairo: IOM.

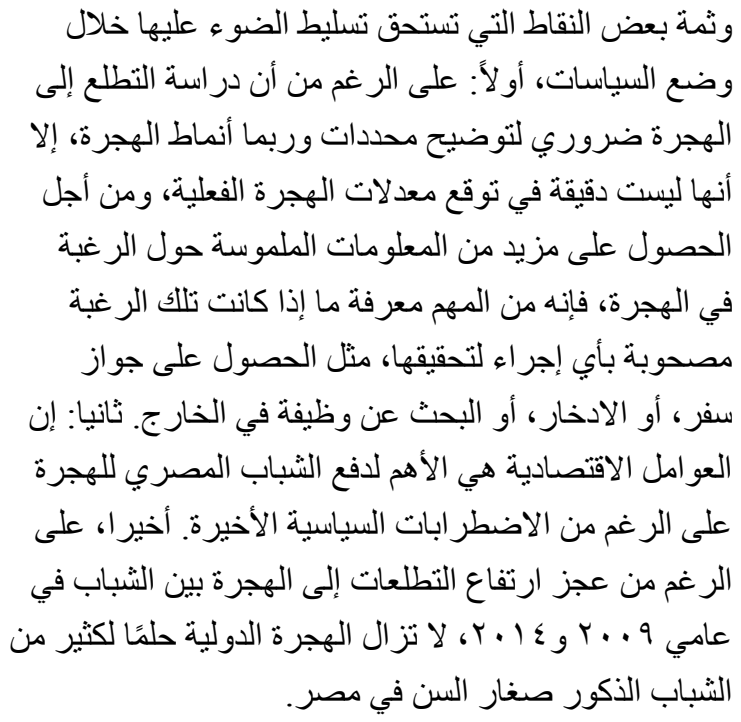

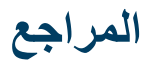

Abdel Fattah, D. 2012. "Satisfaction at the Workplace and Potential Migration among Egyptian Youths."

Paper submitted to Middle East Economic Association Meetings in Alexandria June 24-26.

CAPMAS. 2009. Housing and Population Census, 2006. Cairo: CAPMAS.

Constant, Amelie and Douglas S. Massey. 2002. "Return migration by German guestworkers: Neoclassical versus new economic theories," International Migration 40(4): 5-38.

Docquier, F. ,G. Peri. and I. Ruyssen. 2014. “The CrossCountry Determinants of Potential and Actual Migration" International Migration Review, 48: S37-S99.

Elbadawy, A. 2010. “Migration Aspirations among Young People in Egypt: Who Desires to Migrate and Why?" Economic Research Forum Conference paper, Antalya, Turkey.

Elbadawy, A., M. Said, and J. Wahba. 2013. "Migration Aspirations and Education among Youth in Egypt: Evidence from Survey of Young People, 2009" mimeo.

IOM. 2011. "Egypt after January 25: Survey of Youth Migration Intentions." Cairo: IOM.

Population Council, 2010. Survey of Young People in Egypt: Final Report. Cairo: Population Council, Egypt.

Sabry, Bassem. 2012. "A guide to Egypt's challenges: Overpopulation." Alahram online, 16 August. http:// english.ahram.org.eg/NewsContent/1/0/49602/ Egypt/Overpopulation.aspx. Accessed 20 January 2015. 


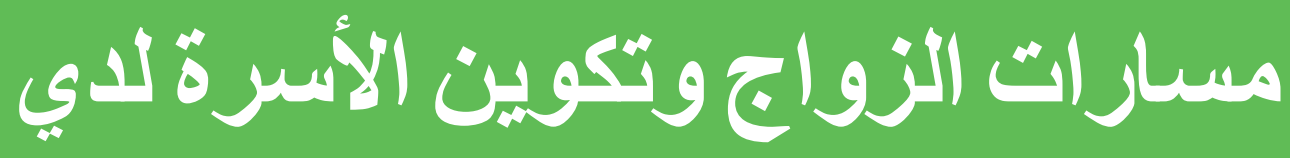

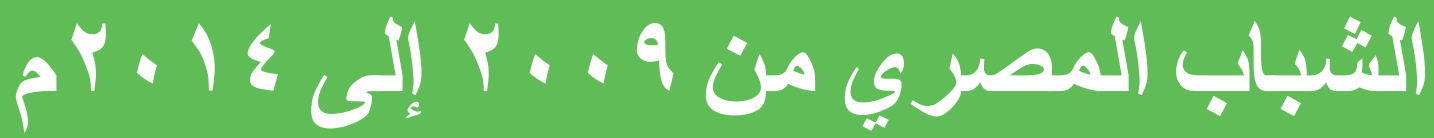

مايا سيفيردينج • أحمد رجب

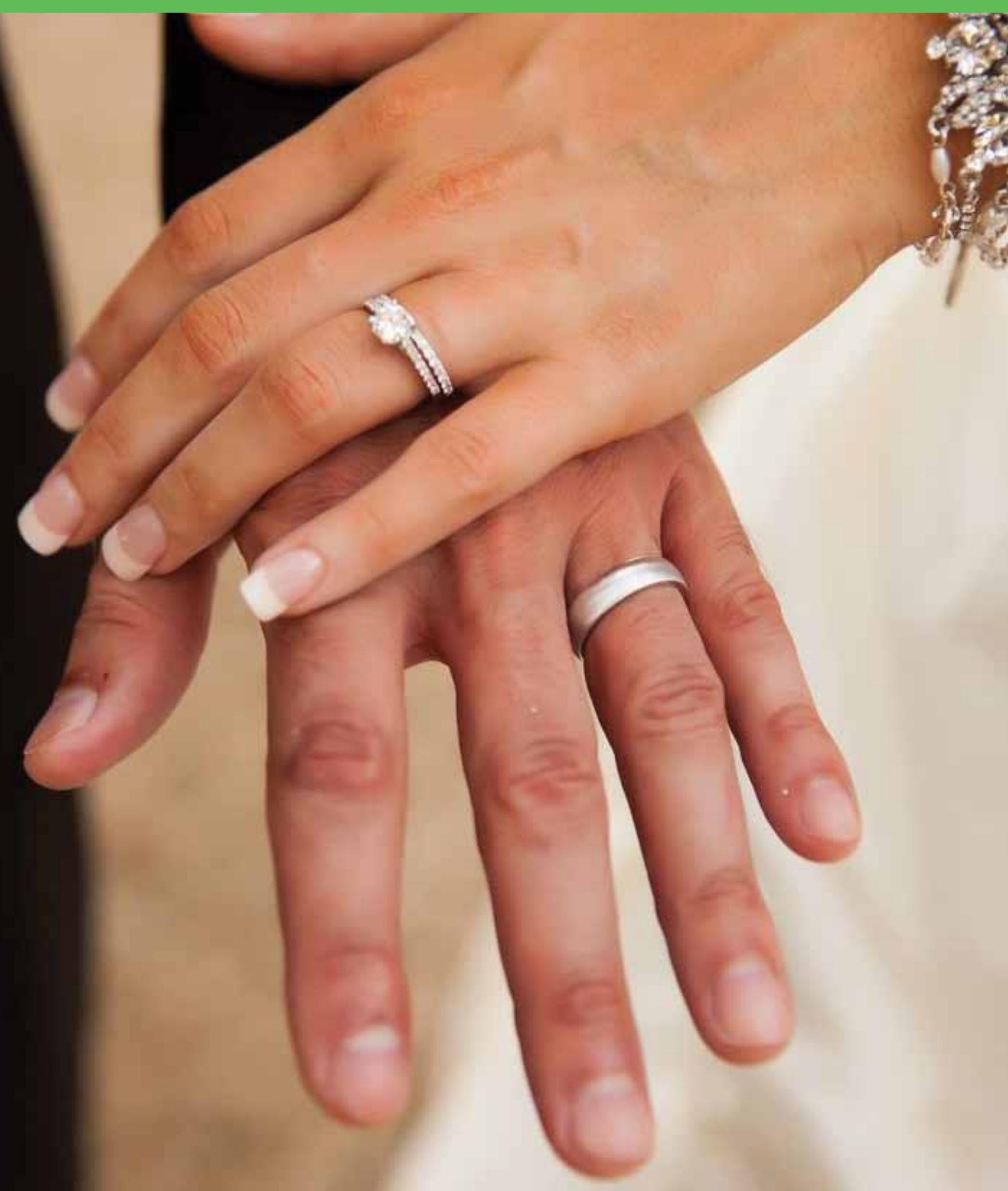




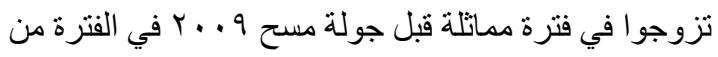

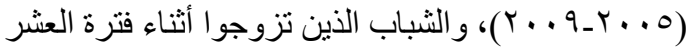

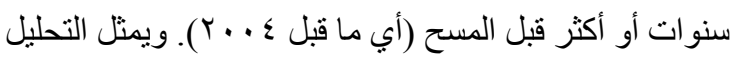

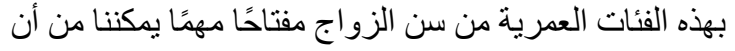
نفحص اتجاهات التحول في الزواج.

\section{Y_ ا الحالة الزواجية بين الشباب في عامي $r \cdot 1 \leq g r \cdot q$}

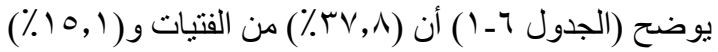
من الثباب في الفئة العمرية ما بين (10 ـ و ب) سنة كانوا

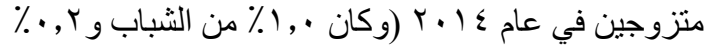

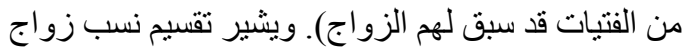

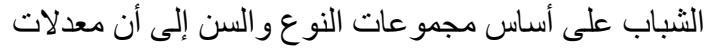

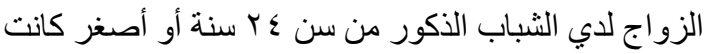

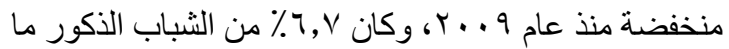

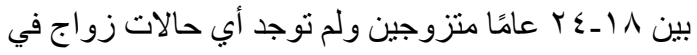

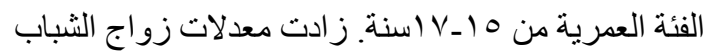

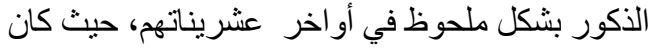

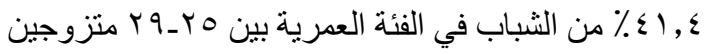

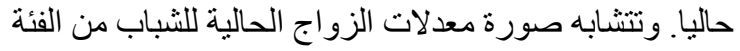

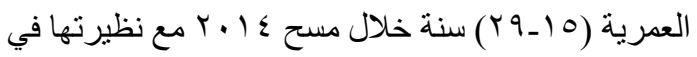

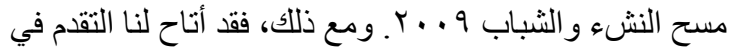

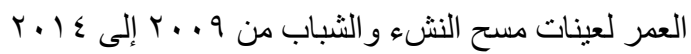

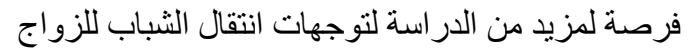
في الأعمار المتقدمة؛ فقد ارتفعت نسبة الرجال المتزوجين

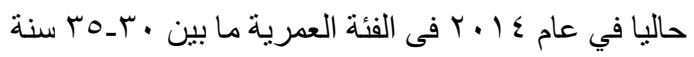

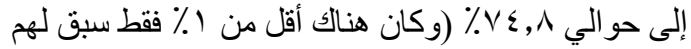

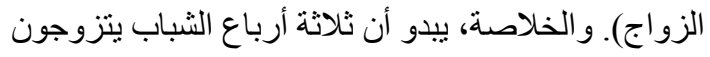

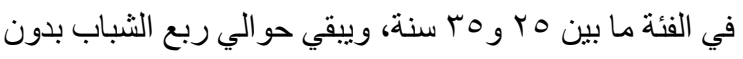
زواج بداية الثلاثينات من عمر هم.

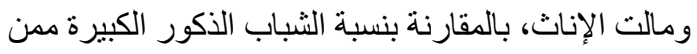

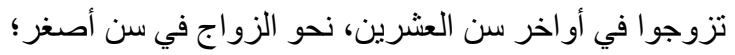

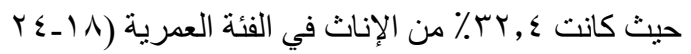

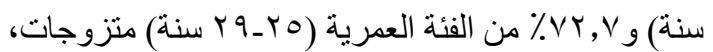

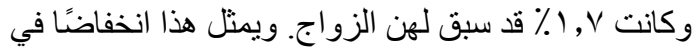

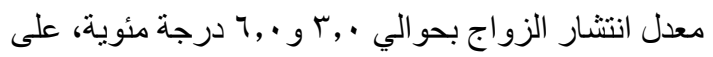

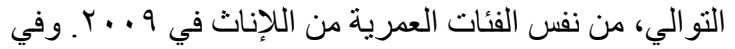
سياق منصل بانخفاض سن الزواج، لم تُعد الزيادة في معدل

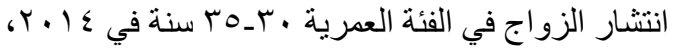

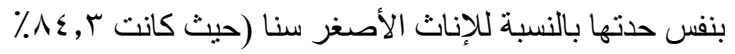

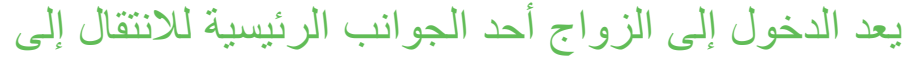
مرحلة الرشد، و علامة مهمة لهذه المرحلة في المجتمع المصري.و فى بعض المناطق، ينتظر الثباب فترة أطول حتى الزو اج لعدة أسباب. و على الرغم من ذلك إلا أن الفتيات فى مصر مازلن عرضة للزو اج المبكر بما له من من لهن أثنار سلبية ودخول مرحلة الرشد مبكر اً.

\section{7ـ 1 -}

يرجع تأخر سن الزواج بين الثباب، في جزء منها، إلى الزى

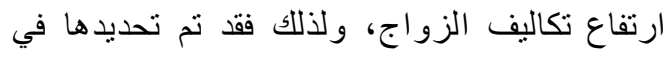

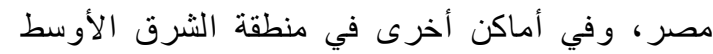

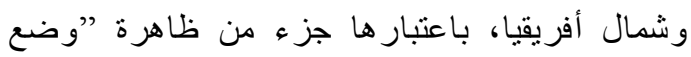
الانتظار “ waithood، أو توقف الانتقال الى مرحلة الرشد (Dhillon and Yousef 2009; Singerman 2007) وفي الوقت الذي يلقي فيه موضوع تأخير سن الزواج اهنماما

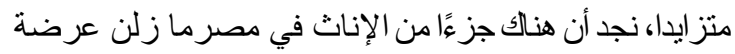

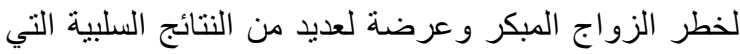

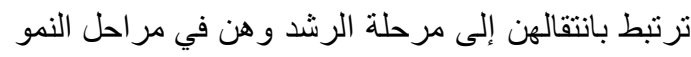

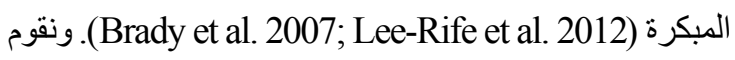

في هذا الفصل، بنحديث الوصف الخاص بانتقال الثباب

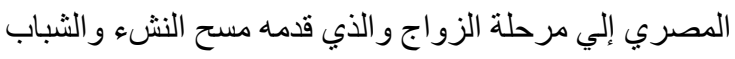

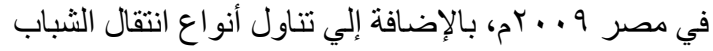

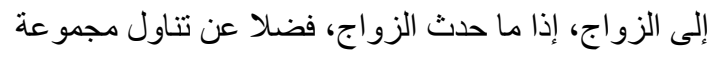

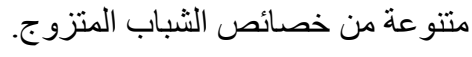

وتسمح لنا الفترة الزمنية لعينة مسح النشء و الثباب فى الثى

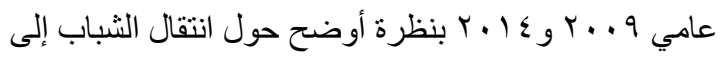

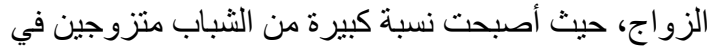

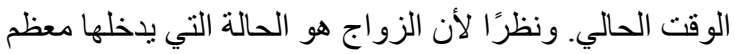

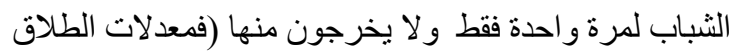

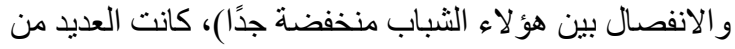

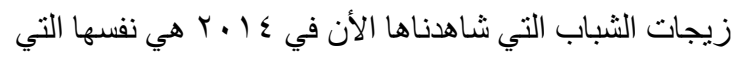

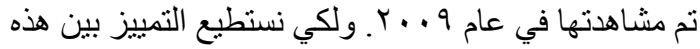

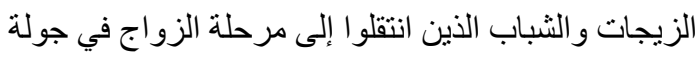

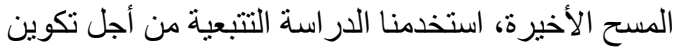

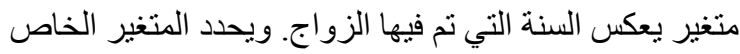

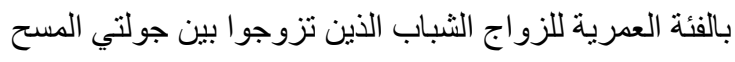

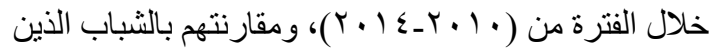


ومالت الإناث؛ بالمقارنهة بنسبة الثباب

الذكور الكبيرة مدن نزوجو أي

أو اخر سن العثرين، نحو الزو اج في

سن أصغر ؛ حيث: كانت ع, ؟r\% من

الإناث في الفئة العمربة ) 1 ( ـ ك سنة

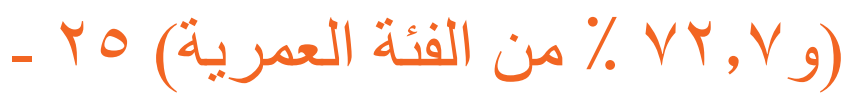

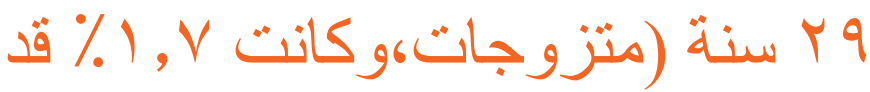
سبق لـن الزو اج

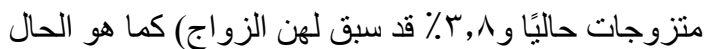

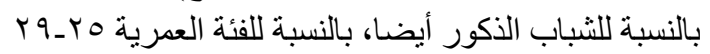
سنة. ويثير هذا أيضا إلى أن نسبة قليلة فقط من الإناث

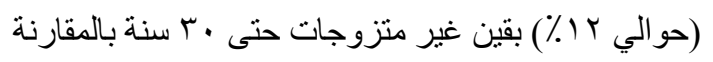

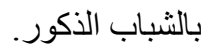

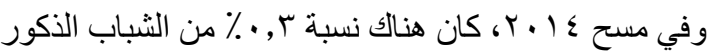

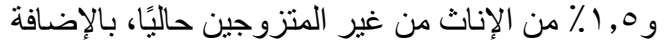

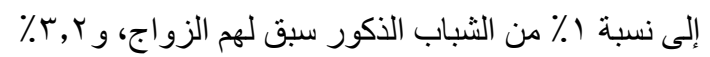

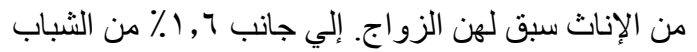

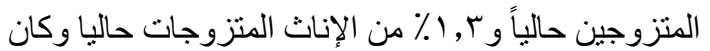

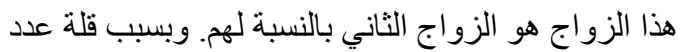

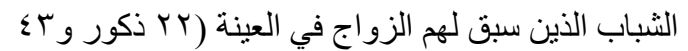
إناث) تم غض الطرف عن تحليلهم في بقية الفصل و التزركيز

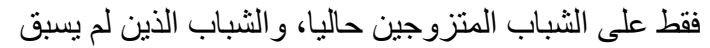

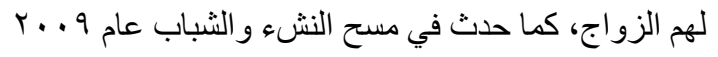
.(Population Council 2010)

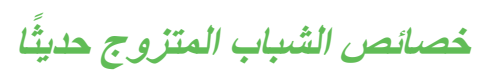
باستخدام جولتي مسح النشء و الثباب في مصر ، يمكننا فحص

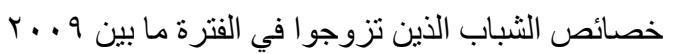

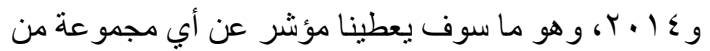
الثباب كانت أقرب للزواج في تلاك الفترة. لقد كان حو الي

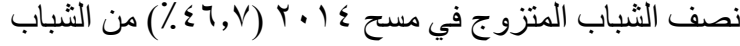

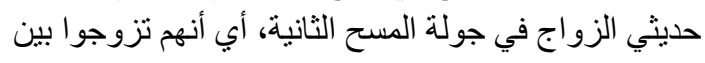

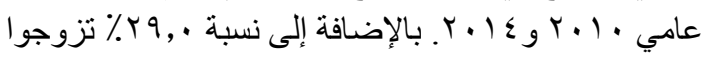

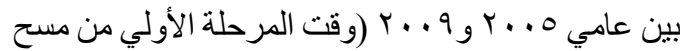

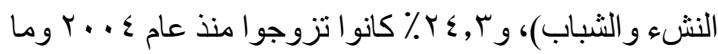

قبلها.

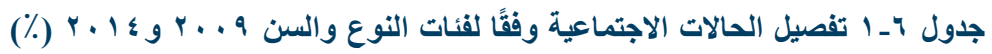

\begin{tabular}{|c|c|c|c|c|c|c|}
\hline \multicolumn{3}{|c|}{$r \cdot 1 \varepsilon$} & \multicolumn{3}{|c|}{$r \ldots q$} & \multirow[b]{2}{*}{ الفئة العمرية/ النوع } \\
\hline سبق لده/لها & متزوج & للم يسبق للهم & سبق لذه/لها & متزوج & له يسبق الزواج لهم & \\
\hline & & & & & & الثباب الذكور \\
\hline$\cdot, \cdot$ & $\cdot, \cdot$ & $99, \wedge$ & $\cdot, \cdot$ & $\cdot, \cdot$ & $1 \cdots$, & $1 V_{-10}$ \\
\hline$\cdot, 1$ & $\uparrow, \mathrm{V}$ & $9 \varphi, r$ & $\cdot, \cdot$ & $\varepsilon, 9$ & 90,1 & $r \leq-11$ \\
\hline . & $\varepsilon 1, \varepsilon$ & $0 \wedge, 1$ & $\cdot, r$ & $\leqslant 1,0$ & $0 \Lambda, Y$ & rq_ro \\
\hline$\cdot, \Lambda$ & $V \varepsilon, \wedge$ & $r \varepsilon, \varepsilon$ & - & - & - & ro_t. \\
\hline$\cdot, \mathrm{r}$ & 10,1 & $\Lambda \varepsilon, \nu$ & $\cdot, 1$ & $1 \pi, 1$ & $\Lambda \uparrow, \Lambda$ & إجمالي 10_9 Y \\
\hline$\cdot, \Gamma$ & $r \leqslant, \cdot$ & VT,Y & & & & إجمالي 10_0ب \\
\hline & & & & & & الإناث \\
\hline$\cdot, \Gamma$ & $r, \nu$ & $90, \wedge$ & $\cdot, \cdot$ & $r, r$ & १४, $\vee$ & $1 V_{-} 10$ \\
\hline$\cdot, 9$ & rr, $\varepsilon$ & $T r, \mathrm{~V}$ & 1,1 & $r_{0, r}$ & $T, v$ & $r \varepsilon_{-} \mid 1$ \\
\hline I,V & $V,, V$ & $r_{0, T}$ & $r, 0$ & $\mathrm{VA}, \mathrm{V}$ & $\mid \wedge, \wedge$ & rq-ro \\
\hline$r, \Lambda$ & $\lambda \varepsilon, r$ & 11,9 & - & - & - & ro-t. \\
\hline $1, \cdot$ & $r v, \Lambda$ & $T, r$ & $1, r$ & $\varepsilon \cdot, r$ & $0 \wedge, 0$ & إجمالي 0 _a r \\
\hline 1,0 & $\leq 0,1$ & $0 ., r$ & - & - & - & إجمالي 10_0 \\
\hline & & & & & & كل الثباب \\
\hline$\cdot, 7$ & rฯ,. & $V T, \varepsilon$ & $\cdot, \mathrm{V}$ & rฯ, ६ & $\mathrm{Vr}, \cdot$ & إجمالي 0 _qج \\
\hline$\cdot, 9$ & $r \varepsilon, r$ & $T, \cdot$ & - & - & - & إجمالي 10_0ب \\
\hline or & rVYo & OV^9 & vA & $r \leq 4$. & $v \leqslant r \wedge$ & عدد الثباب 10 _q \\
\hline$q 4$ & $\varepsilon 0 . v$ & $7.1 \mathrm{~V}$ & & & & عدد الثباب 10_0_r \\
\hline
\end{tabular}


النسبة الكبيرة بين الثباب الذكور والإناث المتزوجين، بين

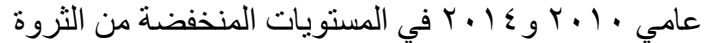

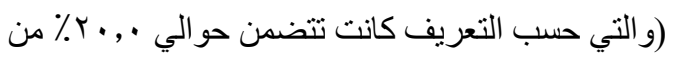
العينة الكلية). ومن المحتمل أن يكون ذللك مرتبطاً بالمستويات

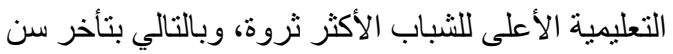

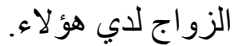

\section{צ_r السن عند الزواج والزواج المبكر}

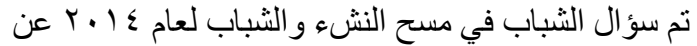

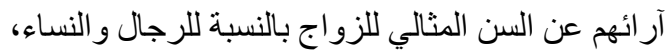

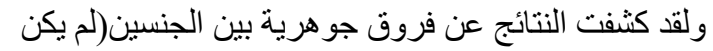

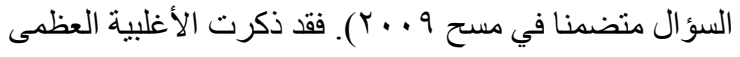

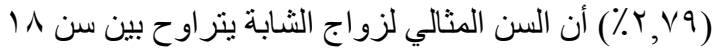

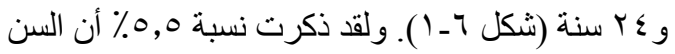

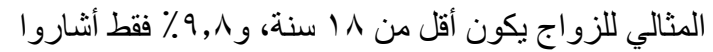

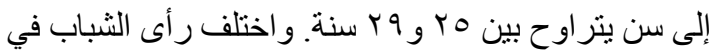

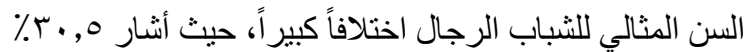

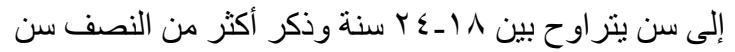

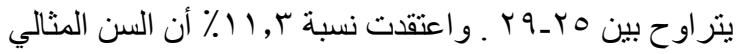

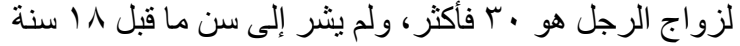
إلا أقل من اج اجن

ولقد اتفق وسيط العمر عند الزواج الفعلي بين الثباب من

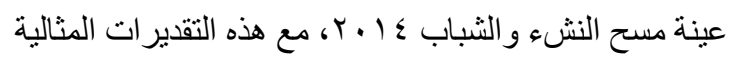

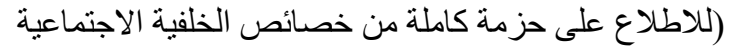

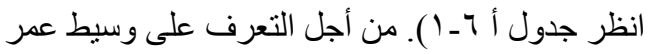

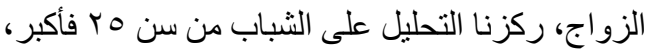
فالتقدير ات بالنسبة للشباب الأصغر يتوقع أن تكون متحيزة

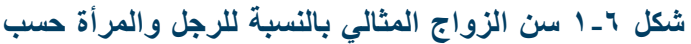

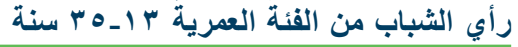

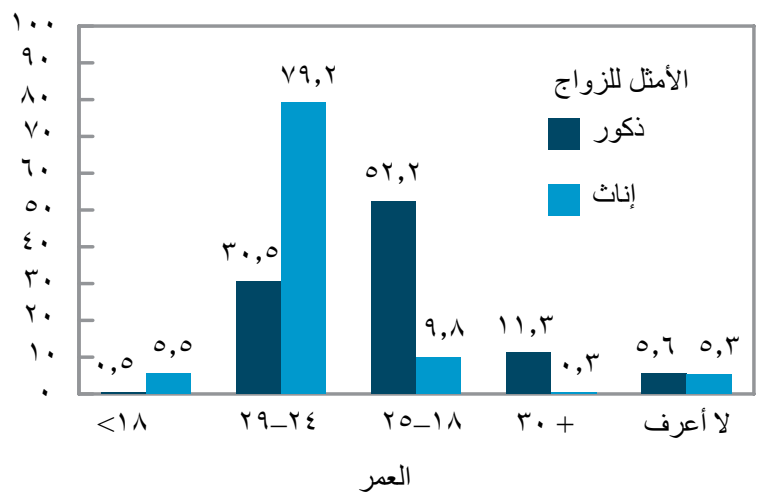

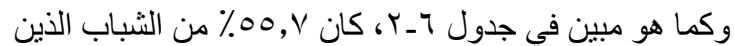

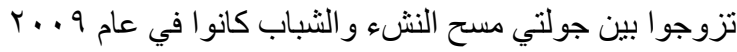

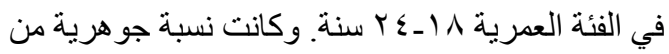

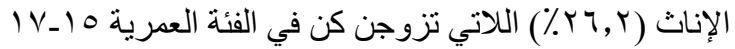

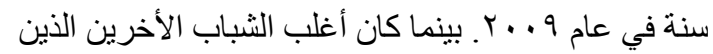

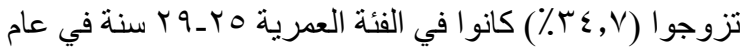

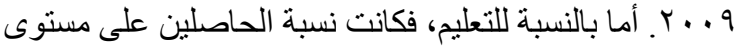

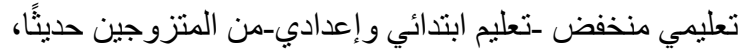

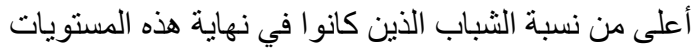

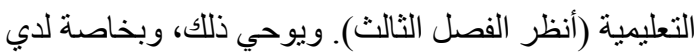

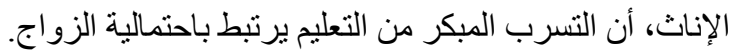

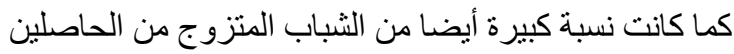
على التعليم الفني، وقد يرتبط ذللك بالنسبة الكبيرة من الثباب

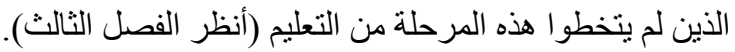

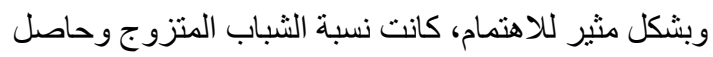

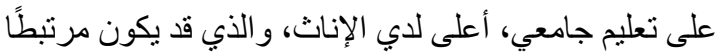
بتأخر منوسط سن الزواج عند الثباب الذكور. و أخير ا، كانت

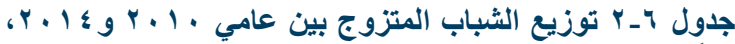

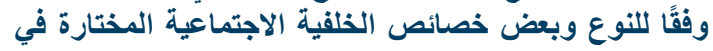

r... q

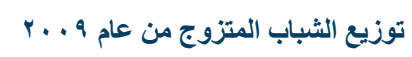

\begin{tabular}{|c|c|c|c|}
\hline إجمالي & إناث & ذكور & خصائص الخلفية \\
\hline & & & الفئة العمرية \\
\hline$\wedge, r$ & $10, r$ & $\cdot, \wedge$ & $1 \varepsilon_{-} 1$. \\
\hline $10, \mathrm{~V}$ & $r, r$ & $\varepsilon, r$ & $1 V_{-} 10$ \\
\hline $00, \mathrm{~V}$ & 01,0 & T., £ & $r \varepsilon_{-1} 11$ \\
\hline \multirow[t]{2}{*}{$r \cdot, r$} & $v, l$ & $r \varepsilon, v$ & rq_ro \\
\hline & & & المستوى التعليمى \\
\hline 7,9 & $9, \varepsilon$ & $\varepsilon, 1$ & أمي \\
\hline 1,7 & $r, 1$ & $\cdot, \cdot$ & يقر أ ويكتب \\
\hline $17, v$ & $r, r$ & $11, \varepsilon$ & ابتدائي \\
\hline $19, r$ & r & $1 \leqslant, V$ & إعدادي \\
\hline $1 \cdot, r$ & $11, r$ & q,r & ثانوي عام \\
\hline$r q, V$ & $r, r$ & $\Gamma \wedge, \uparrow$ & ثانوي فني \\
\hline$r, T$ & 1,0 & $r, q$ & معهد فوق متوسط \\
\hline \multirow[t]{2}{*}{ Ir, 9} & $\wedge, 1$ & $\mid \wedge, 1$ & جامعي وما فوق \\
\hline & & & مؤشر الثروة \\
\hline rr,o & $r_{0, r}$ & r),0 & الأدنى \\
\hline Y), & rY,V & $r \cdot, q$ & الثاني \\
\hline$r \uparrow, l$ & r & $r_{0, \Lambda}$ & الأوسط \\
\hline 17,7 & $10,$. & $1 \wedge, \varepsilon$ & الر ابع \\
\hline Ir,. & $1 \cdot, v$ & \& & الأعلى \\
\hline $1 \ldots$, & or, r & $\varepsilon \vee, \wedge$ & الإجمالي \\
\hline$r \cdot{ }_{10}$ & ro. & NTO & عدد الثباب \\
\hline
\end{tabular}


بين التعليم وسن الزو اج تكون أوضح بالنسبة للإناث صغار

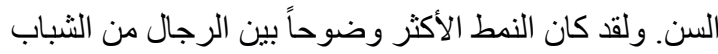

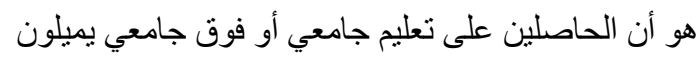
إلى الزواج في سن متأخرة أكثر من كل المستويات التعليمية التهبية الأخرى بوسيط عمر يبلغ مب سنة.

وقد أتضح بالنسبة للإناث أن وسيط عمر الزواج قد وصل

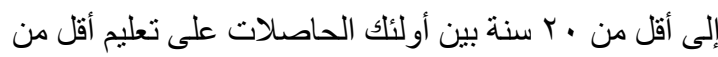

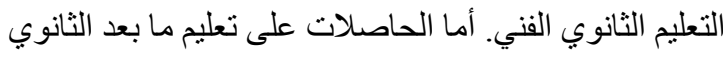

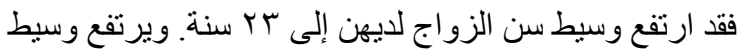

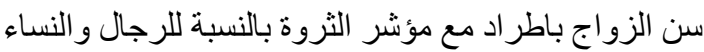

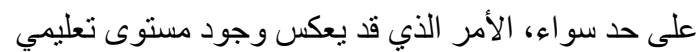
أكبر ، حيث يتوقع أن يكون الثباب الأكثر ثروة أكثر قدرة

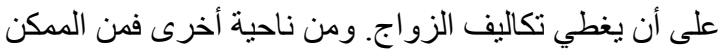

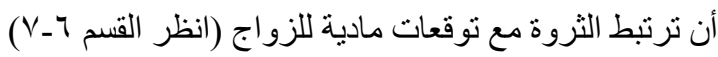
وييلغ وسيط عمر الزواج بين الثباب المتعطلين عن العمل فركل

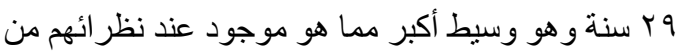

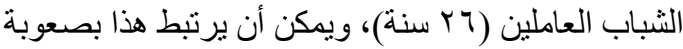
توفير النقود التي ينطلبها الزواج في حالة عدم وجود وظيفة.

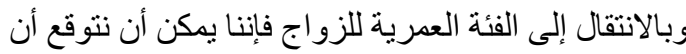

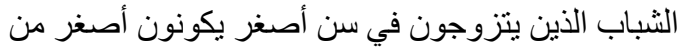

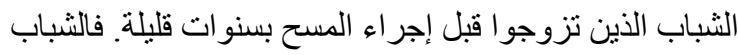

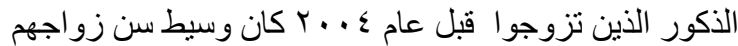

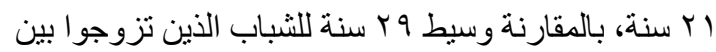

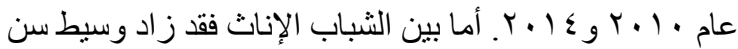

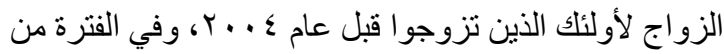

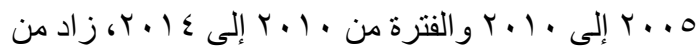

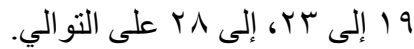

ولقد أتضح أن الزواج المبكر يؤثر تأثير اً بالغاً على صحة

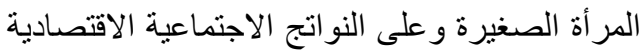
(Lee-Rife et al. 2012) سن الزواج، فإن الزواج المبكر في مصر يعد ظاهرة تتركز

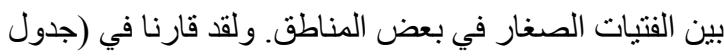

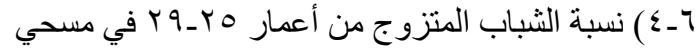

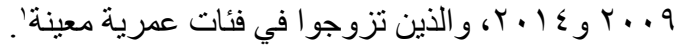
فبينما كانت المعدلات قبل السن القانونية وهي مل ا سنة

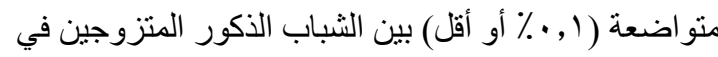

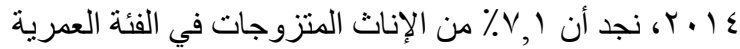

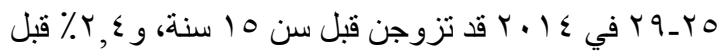

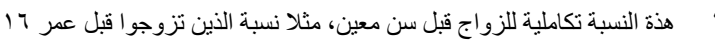
تشمل كذلك الذين نزوجو ا قبل سن 10 ـ حصرنا هذا التحليل في الفئة العمرية الأكبر.
للأقل. وحتى في هذه الأعمار الأكبر، من الأهمية بمكان أن

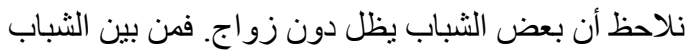

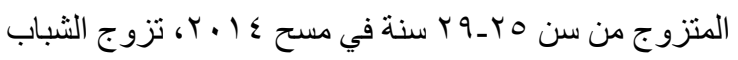
الذكور عند وسيط عمر ييلغ مo سنة وتزوجت الإناث عند

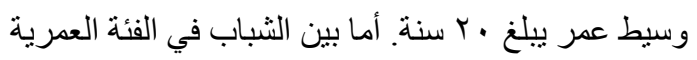

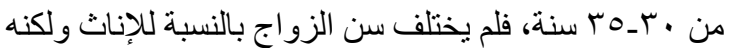

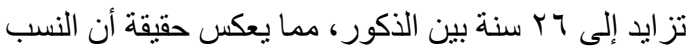
الأعلى من الثباب الذكور تظل غير متزوجة حتى سن أكبر.

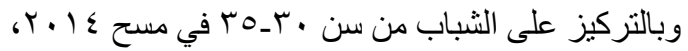

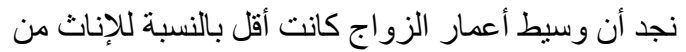

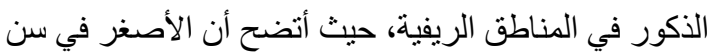

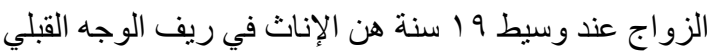

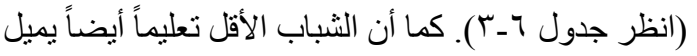
إلى الزواج في سن أصغر، هذا على الرغم من أن العلاقة الطئ

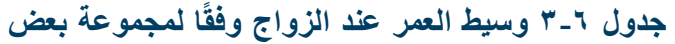

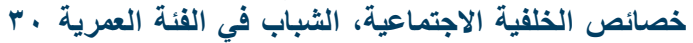

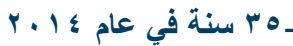

\begin{tabular}{|c|c|c|c|}
\hline إجمالي & إناث & ذكور & \\
\hline & & & المنطقة \\
\hline$r \varepsilon$ & r) & rV & محافظات حضرية \\
\hline rt & r) & rt & حضر الوجه البحري \\
\hline rr & $r$. & ז & ريف الوجه البحري \\
\hline Tr & r) & ro & حضر الوجه القبلي \\
\hline YI & 19 & ro & ريف الوجه القبلي \\
\hline \multirow[t]{2}{*}{ rr } & r) & ro & المحافظات الحدودية \\
\hline & & & المستوى التعليمى \\
\hline$r \cdot$ & 19 & $r \varepsilon$ & أمي \\
\hline 11 & 11 & $r \varepsilon$ & يقر أ ويكتب \\
\hline r) & 19 & ro & ابتدائي \\
\hline$r \cdot$ & 11 & rt & إعدادي \\
\hline$r \leq$ & 19 & rt & ثانوي عام \\
\hline rr & $r$. & ro & ثانوي فني \\
\hline$r \varepsilon$ & rt & ry & معهد فوق متوسط \\
\hline \multirow[t]{2}{*}{ ז } & rt & rᄉ & جامعي وما فوق \\
\hline & & & الحالة العملية \\
\hline ro & $r$. & Tד & يعمل \\
\hline r & r) & rq & عاطل \\
\hline r. & $r \cdot$ & ro & خارج قوة العمل \\
\hline & & & الفئة العمرية للزواج \\
\hline rq & rی & rq & $\varepsilon 1 \cdot r_{-} \cdot 1 \cdot r$ \\
\hline$r \leq$ & r & ro & $q \ldots r-0 . r r$ \\
\hline 19 & 19 & YI & ما قبل r . . ؛ \\
\hline rt & r. & YY & الإجمالي \\
\hline$|V T|$ & 1.10 & $7 \leqslant 7$ & عدد الثباب \\
\hline
\end{tabular}




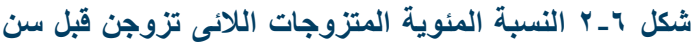

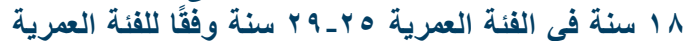

والمنطقة (\%)

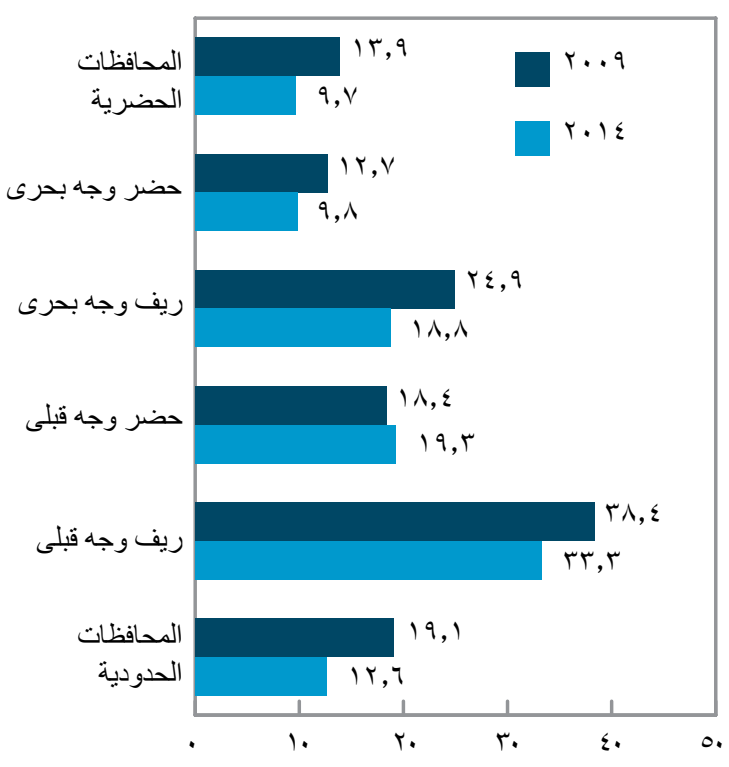

مرتفعة نسبياً بالمقارنة بنسبة الإناث الأميات في هذه الفئات

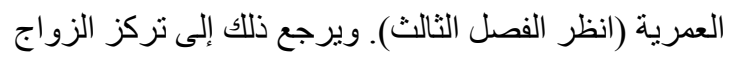
(المبكر للإناث في المناطق الريفية، حيث تنخفض المستويات التعليمية، ولكنه يكثف أيضاً الآثار الوقائية للتعليم فيما يتعلق بالزو اج، فالإناث اللائي تزوجن يملن إلى الاتسحاب من

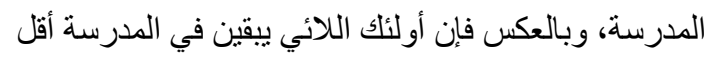
إحتمالا أن يتزوجن مبكراً( (Brady et al 2007).

\section{7ـ - خ خصائص الشباب المتزوج}

إن خصائص زواج الثباب قد يكون لها انعكاسات مهمة على إنى طبيعة العلاقة بينهما. ويصح ذلك بشكل خاص علي الإناث،

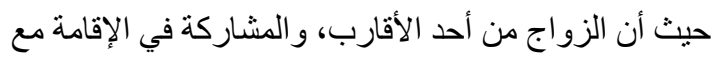
الأصهار، وفارق السن الكبير بين الإناث وأزو اجهن قد يكون

كل ذلك مصحوبًا بانخفاض استقلالية الإناث. وبالاعتماد ولاد على الفئات العمرية الجديدة للزو اج التي تم وضعها ما بين جولتي مسح النشء و الشباب في مصر ، يقوم هذا القسم بدر اسة مسار ات التغير في هذه العو امل لدي الثباب المتزوجين.
جدول جـ ـ الزواج المبكر وفقًا للنوع، الثباب في الفئة العمرية

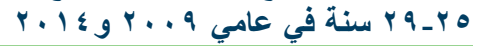

\begin{tabular}{|c|c|c|c|c|}
\hline \multicolumn{5}{|c|}{ الشباب في الفئة العمرية ه بـ ج سنة } \\
\hline \multicolumn{2}{|c|}{ 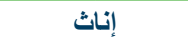 } & \multicolumn{2}{|c|}{ ذ ذكور } & ن الزواج قبل سن \\
\hline$r+1 \varepsilon$ & $r \ldots q$ & $r \cdot 1 \varepsilon$ & $r \ldots q$ & \\
\hline $1, v$ & $r, \tau$ & $\cdot, 1$ & $\cdot, 1$ & 10 \\
\hline$\varepsilon, r$ & $\Lambda, r$ & $\cdot, 1$ & $\cdot, 1$ & 17 \\
\hline$\langle 1,1$ & $r r, q$ & $\cdot, \vee$ & 1,9 & 11 \\
\hline$\leqslant 0,7$ & $\varepsilon \Lambda, r$ & $r, Y$ & $\vee, \wedge$ & $r$. \\
\hline
\end{tabular}

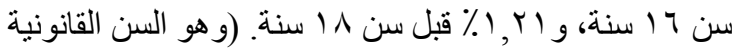

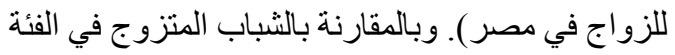

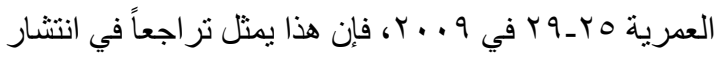

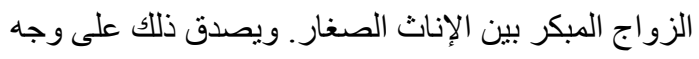

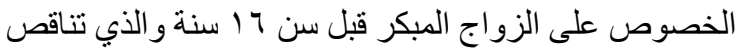

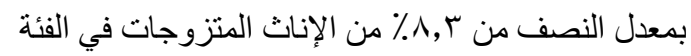

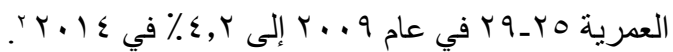
و إذا ما حاولنا أن نتقدم خطوة بأن نفصل هذه المعدلات للزواج

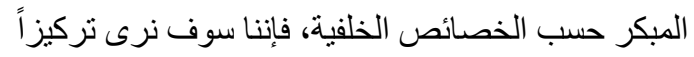

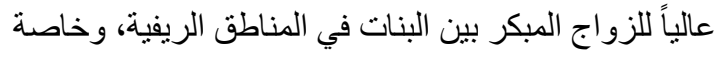

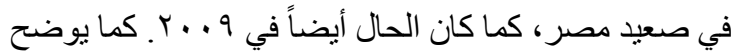

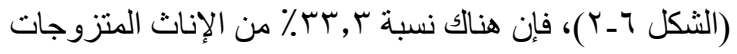

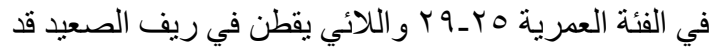

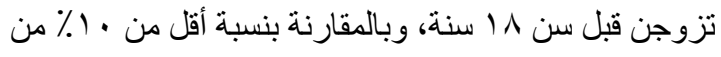

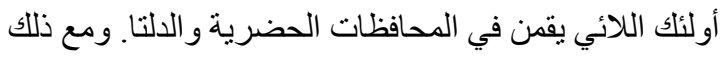

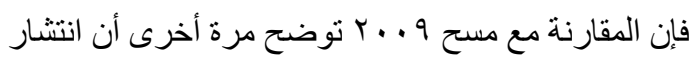

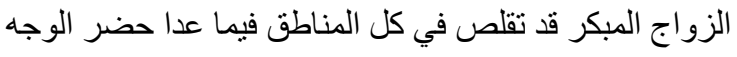

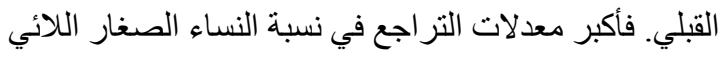

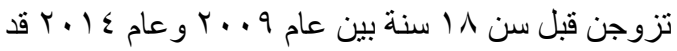

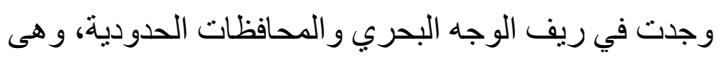
المناطق التي يسود فيها الزواج المبكر.

وبالإضافة إلى هذه التوجهات الإقليمية، فإن حو الي نصف

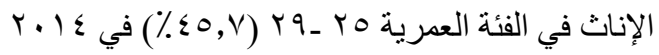

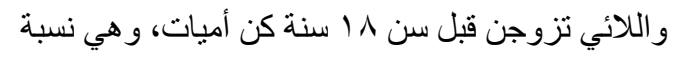

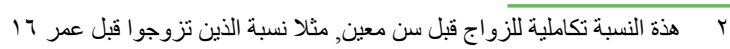

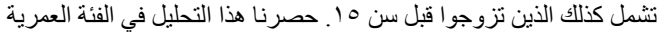


الريفية، حيث كان ما يقرب من ثلث الزيجات من الأقارب. كما

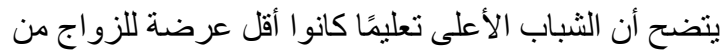
الأقارب، فمن بين الذين أكملوا الثهادة الجامعية كانت نسبة

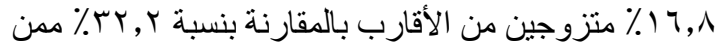

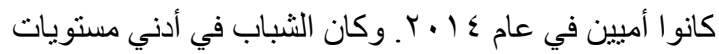

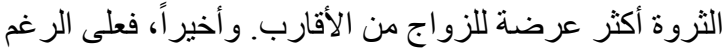

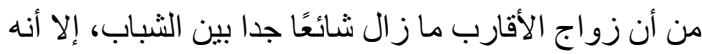

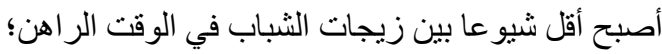

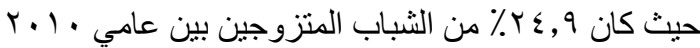

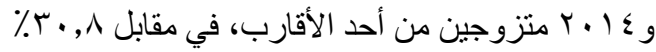

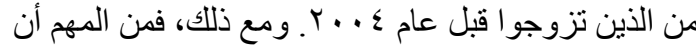

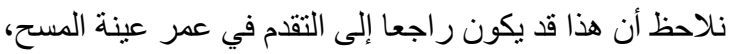
فالثباب الذين تزوجو ا وهم في سن صغيرة كانو ا أكثر احتمالا

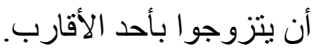

كان الزوج فى زيجات الثباب عام ع ا ـ r، أكبر من الزوجة

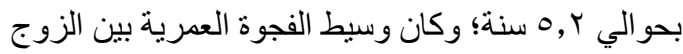
و الزوجة ه سنو ات بين الإناث المنزوجات و ـ سنو ات بين الزين الثباب الذكور المتزوجين. وكما هو مبين في الجدول Tــن،

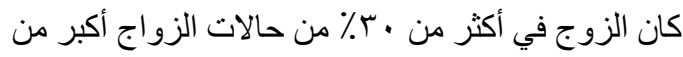

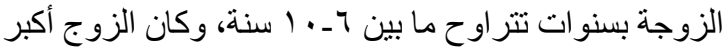

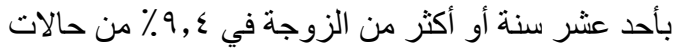
الزواج. وكانت فجوات السن الكبيرة بين الزوجين أكثر تو اترا

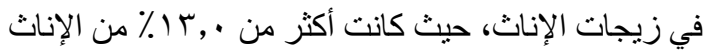

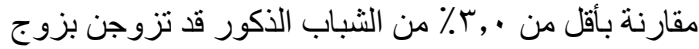

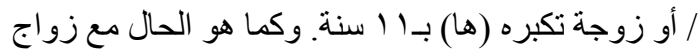

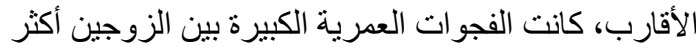
شيو عا بين الفتيات اللاتي تزوجن في سن صغيرة؛ حيث كان

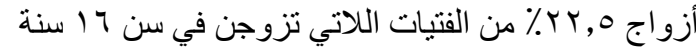

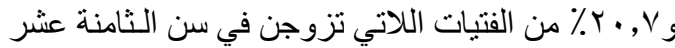
أكبر منهن بأحدي عشر عاما أو أكثر ، و. اما بالنسبة للمنطقة،

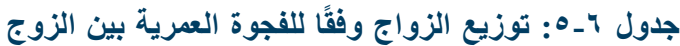

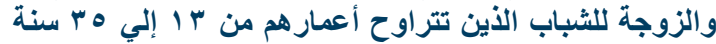

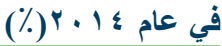

\begin{tabular}{|c|c|}
\hline$\%$ & \\
\hline$\varepsilon v, v$ & الزوج أكبر بـا ـ- سنة \\
\hline rr,o & الزوج أكبر بـ آ-. \\
\hline १, ६ & الزوج أكبر بـا 1 سنة فأكثر \\
\hline 0,9 & لا فارق فى السن \\
\hline$\varepsilon, 0$ & الزوجة أكبر \\
\hline
\end{tabular}

ومع مرور الوقت يتر اجع الزواج بين الأقارب، أو زواج القر ابة، بين الثباب من كلا الجنسين. وبشكل عام، تر اجعت

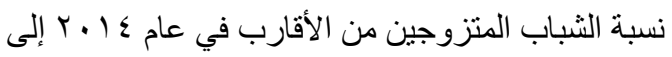

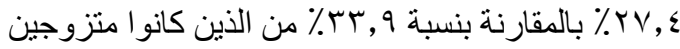

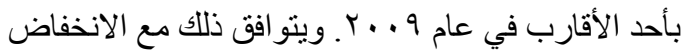

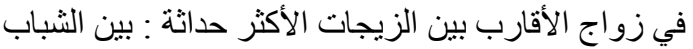

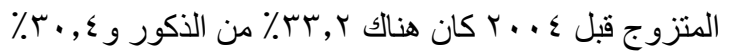

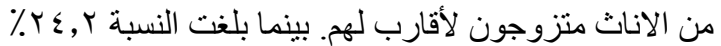

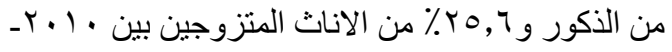

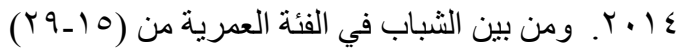

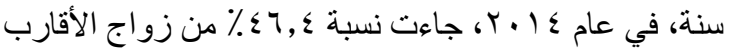

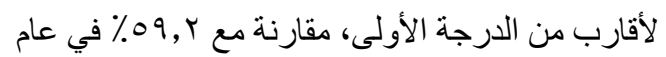

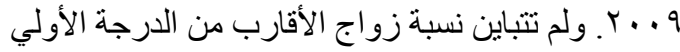

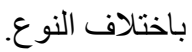
كان الزواج من الأقارب هو الأكثر شيو عا بين الفتبات اللاتي

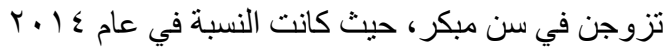

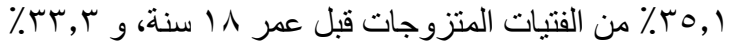
من الفتيات المتزوجات قبل سن 17 عاما. حسب المنطقة، كان

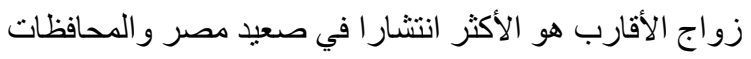

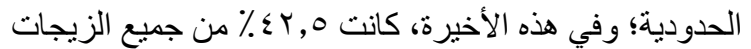

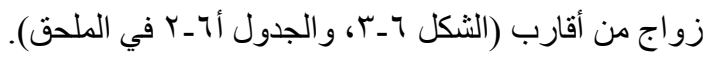
كما كان زواج الأقارب هو أيضا الأكثر شيو عا في المناطق

شكل צ-ب انتثار زواج الأقارب، وفقًا للمنطقة والنوع

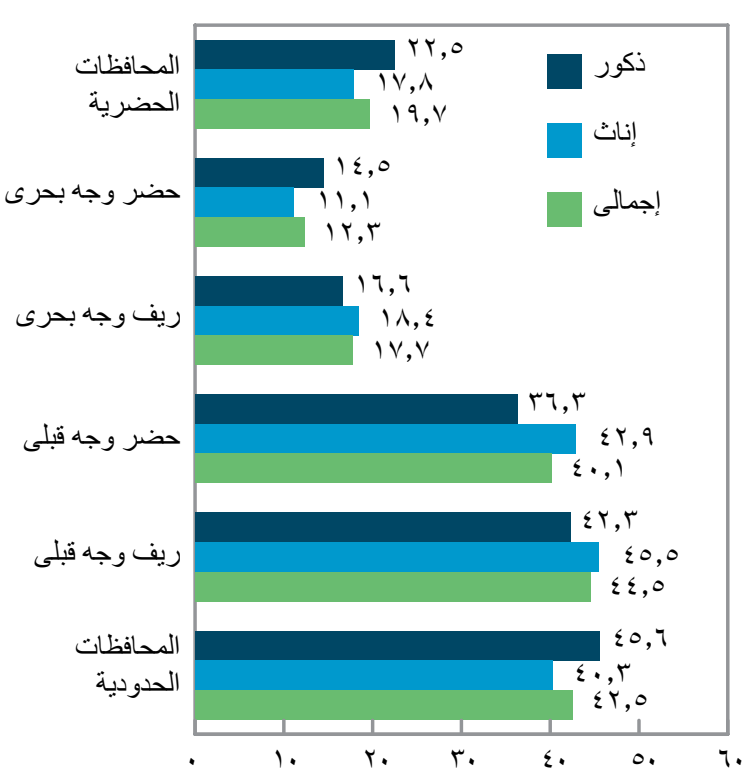




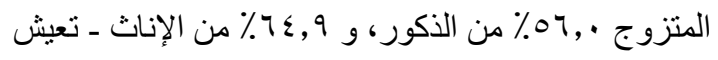

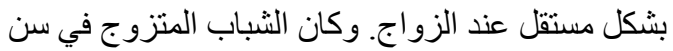

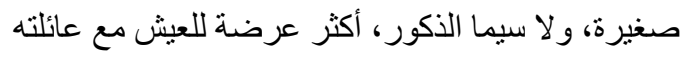

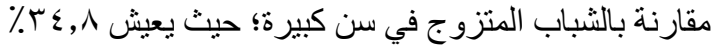

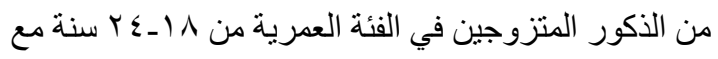

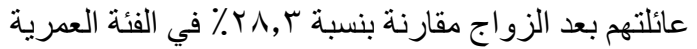

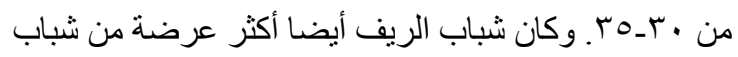

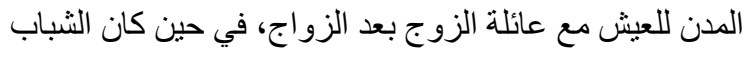

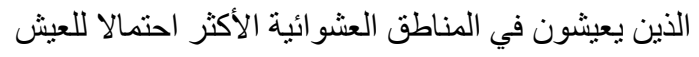

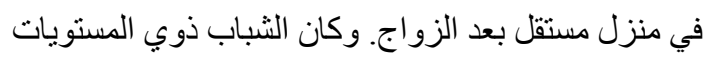

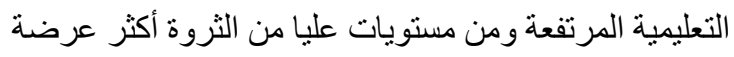

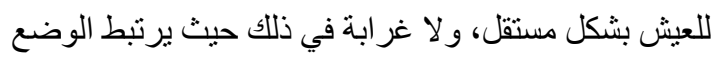

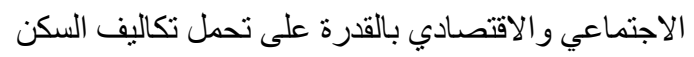

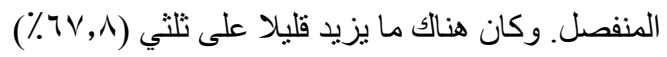

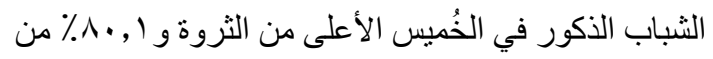
الإناث يعيشون بشكل مستقل عند الزواج الاجي من الترو

\section{7ـ ـ مقابلة واختيار شريك الحياة}

غالبا يحدث تتسيق الزواج بين الثباب عن طريق شبكة

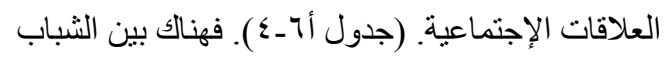

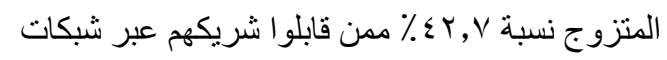

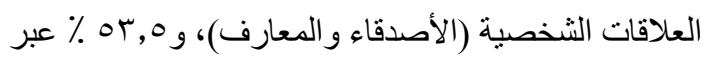

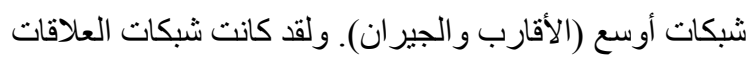

وكان شباب الريف أيضا أكثر عرضة

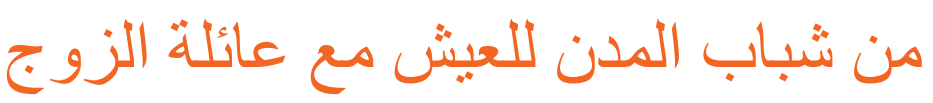
بعد الزواج، في حين كان الثباب الذين يعيشون في المناطق العثو ائية الأكثر احتمالا للعيش في منزل مستقل بعد

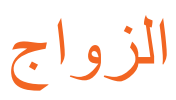

فقد وجد هذا الفارق العمري الكبير بين الزوجين في المناطق

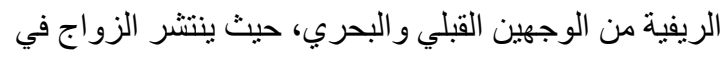

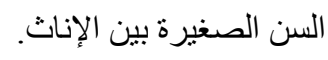

وتظهر بيانات مسح النشء و الثباب أن الزواج في مصر

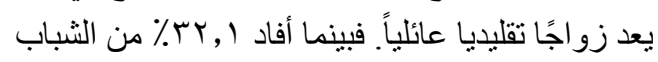

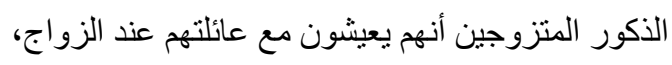

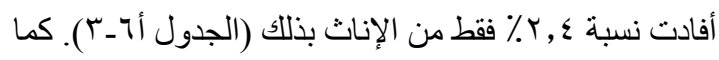

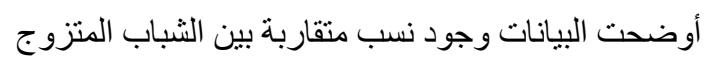

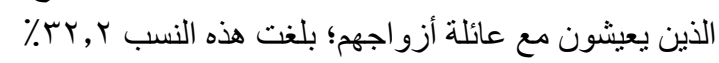

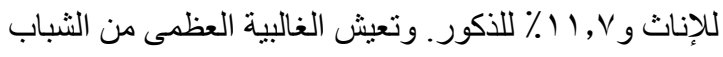

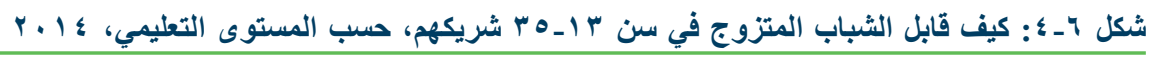

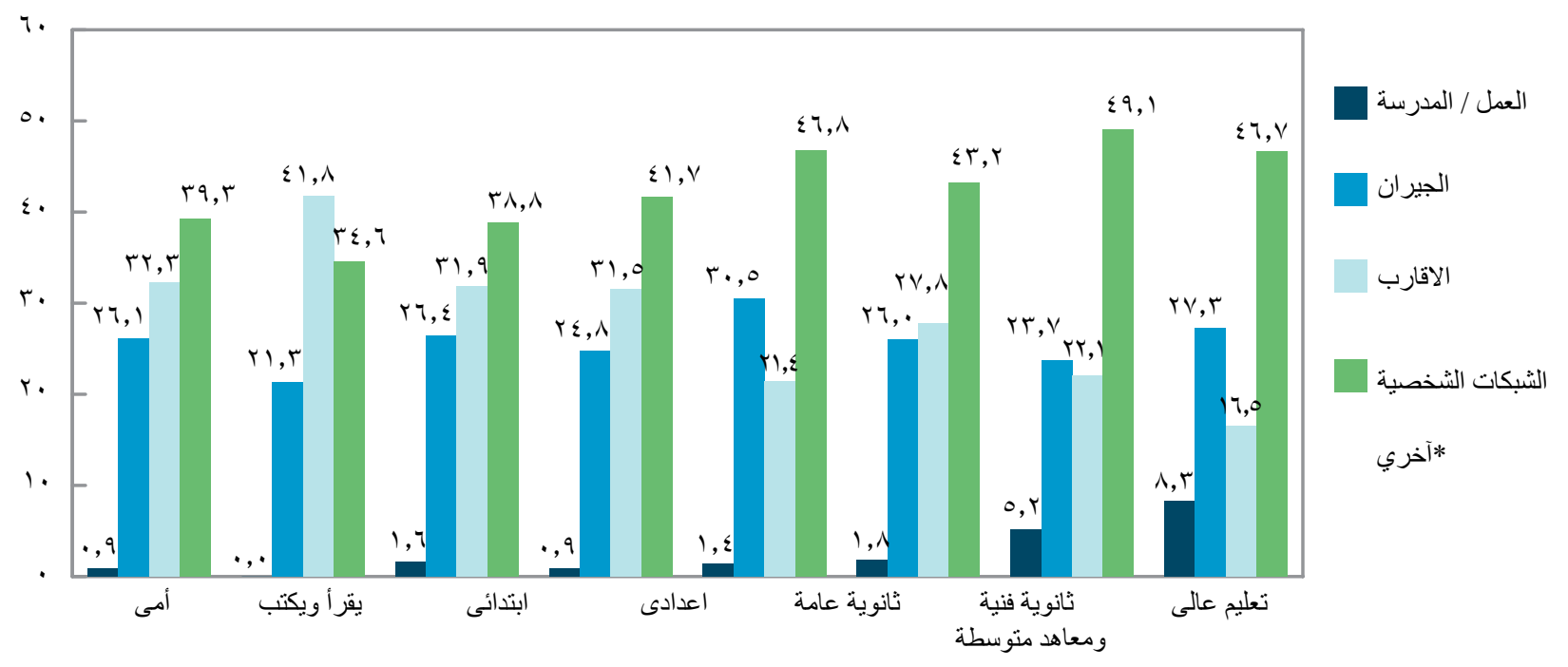

كانت النسبة فى أخرى أقل من ؟\% فى جميع مستويات التعليم عدا فى يقر أو يكتب كانت ؟ ؟ ؟٪ 


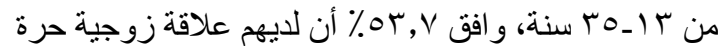

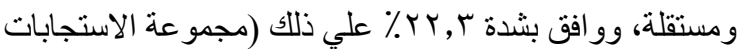

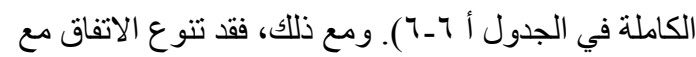
هذه العبارة بشكل كبير وفقًا لمستوى التعليم ومنطقة الإقامة، و الثروة. فعلى سبيل المثال، في حين أن ا, بr\% من الثباب

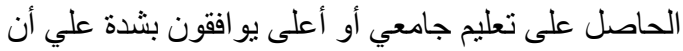

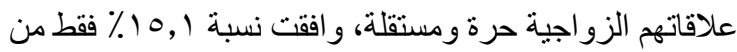

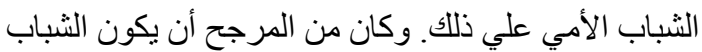
الأقل تعليمًا محايدين في استجابتهم على هذا السؤال.

وطُب من الثباب أيضا أن يجييو ا على سلسلة من العبار ات

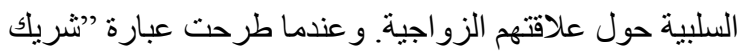

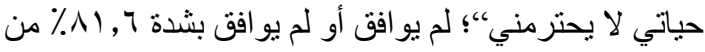

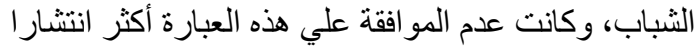

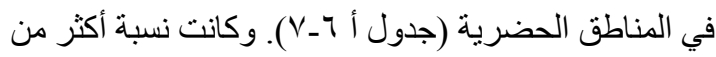

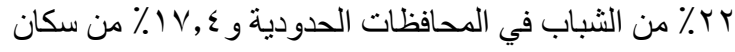
المناطق الحضرية غير الرسمية (العشو ائية) محايدة فيما يتعلق بهذه العبارة. و عندما طرحت عبارة أقوى وهي "شريك حياتي

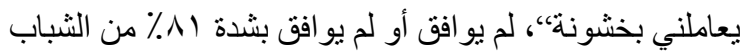

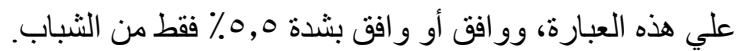

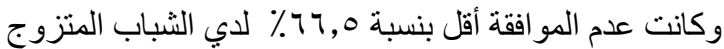

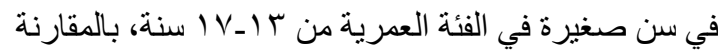

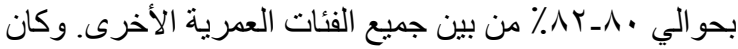

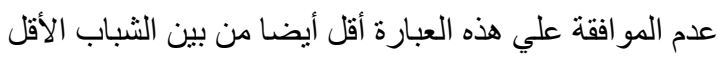

تعليمًا و الأكثر فقرًا.

و عندما سُئل الثباب المتزوجون في الفئة العمرية من

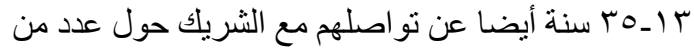

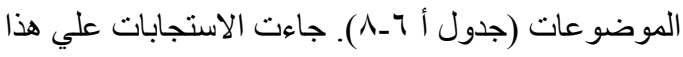

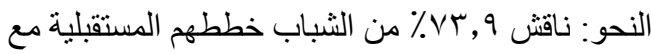

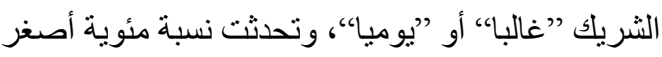

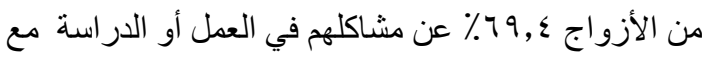

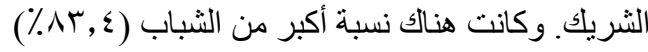
تتو اصل مع شريك الحياة حول كيفية تسير أمور حياتهم

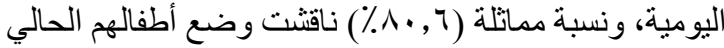

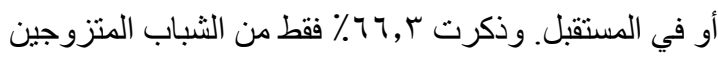

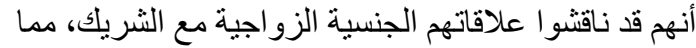

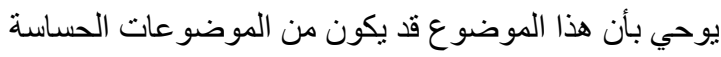

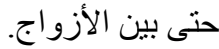

ومن المثير للاهتمام، أن الثباب الذكور كانوا بتقديرات تراوحت ما بين r_N درجة مئوية أكثر احتمالا لأن يقروا
الشخصية كانت أكثر انتشار اً بين الثباب الأكثر تعليماو غنى وقاطني المدن في لقاء الثريك بالمقارنة بشبكة الأقارب و التي

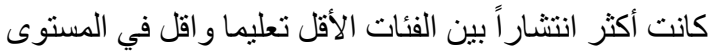
المادي وقاطني المناطق العشو ائية، بشكل خاص في الصعيد

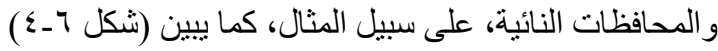

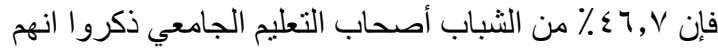

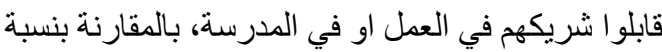

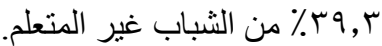

عندما تم سؤ ال عينة مسح النشء و الثباب عن من اتخذ القرار

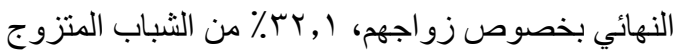

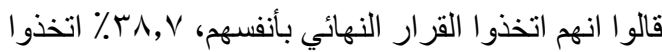

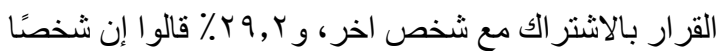
أخر قد انفرد باتخاذ هذا القرار بالنيابة عنهم (جدول أه, ؟).

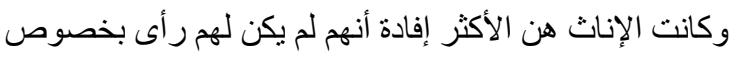

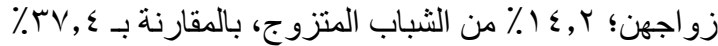

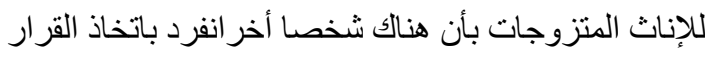

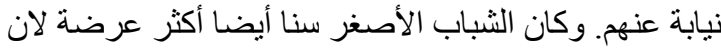

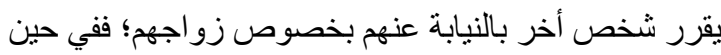

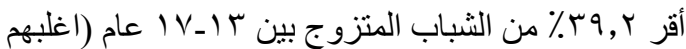

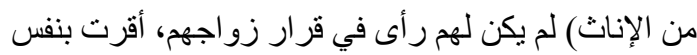

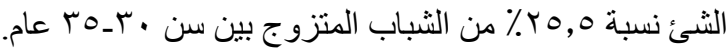

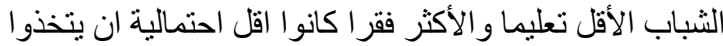

قرار زو اجهم بأنفسهم.

جدول 7 7 7: درجة المساهمة فى إتخاذ قرار الزواج (الفئة

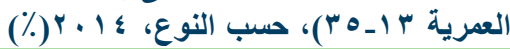

\begin{tabular}{|c|c|c|}
\hline 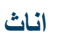 & 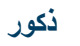 & إتخاذ القرار \\
\hline$r \cdot, r$ & $0 \leqslant, 1$ & بنفسى \\
\hline$r v, \varepsilon$ & $1 \leqslant, r$ & حد نانى \\
\hline$\varepsilon r, \varepsilon$ & $r, v$ & قرار مشترك مع الاهل \\
\hline
\end{tabular}

\section{צـ آنوعية (جودة) علاقات الثباب الزواجية}

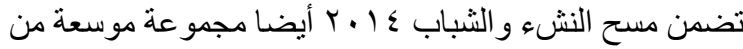

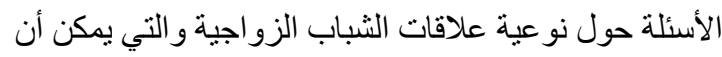
توفر نظرة إضافية للحياة الأسرية، والاستقلالية الشخصية بين الشين الثباب. وبشكل عام فمن بين الثباب المتزوج في الفئة العمرية 
تكاليف الأثاث، و الأجهزة المنزلية، و البضائع الأولية من

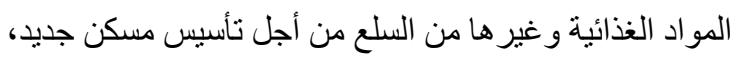

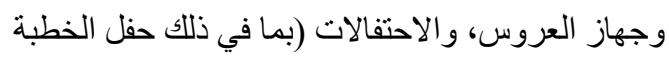

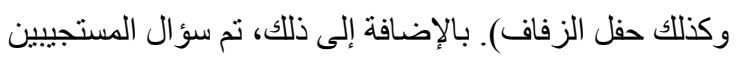

عن قيمة الثبكة، أو المجوهر ات التي تم تقديمها للعروس.

ومن الممكن أن تمنحنا مقارنة التوجهات في قيمة الثبكة

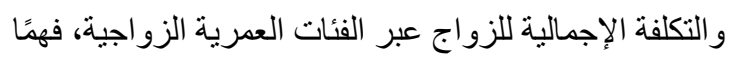

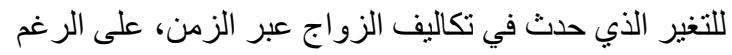

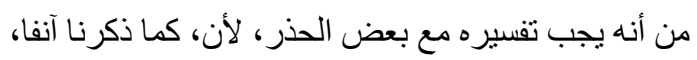
الثباب الذين تزوجو ا مؤخر ا كانو ا عادة أكبر سنًا وأكثر تعليمًا.

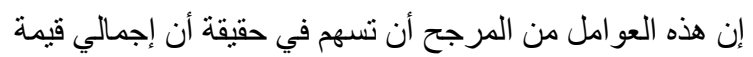

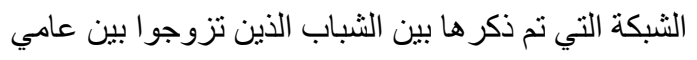

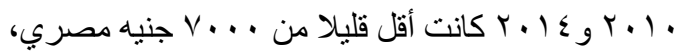

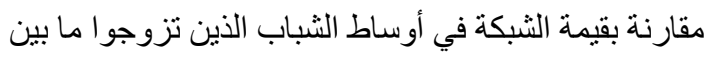

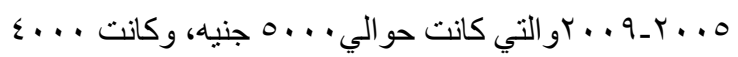

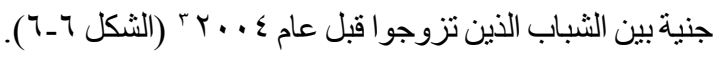
ومع ذللك، فمن الممكن أيضا أن يكون انخفاض قيمة الجنيه

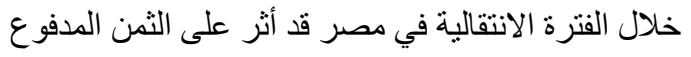

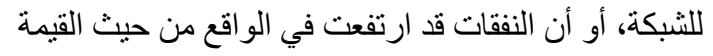

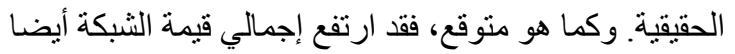

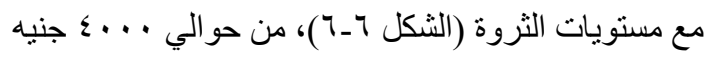

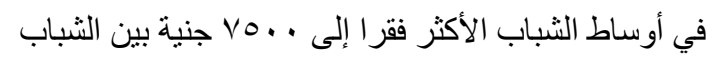

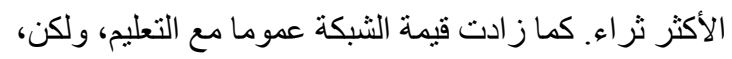

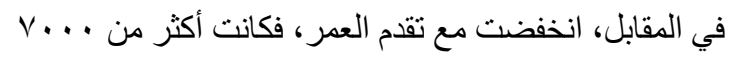

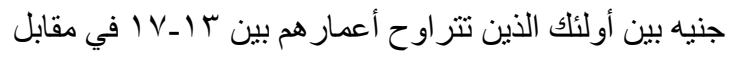

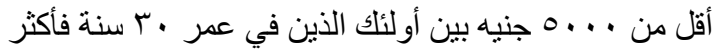

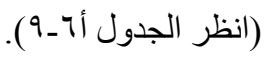

على غرار التوجهات في قيمة الثبكة، يظهر الثكل 7 ـ 7

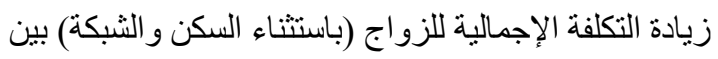

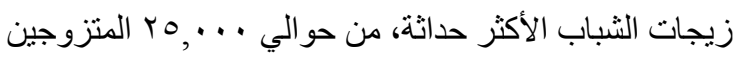

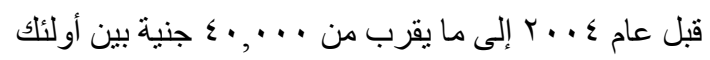

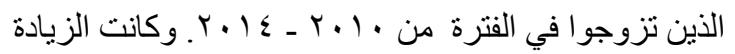

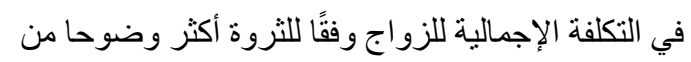

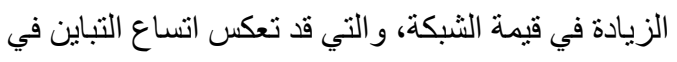

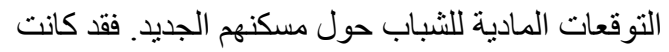

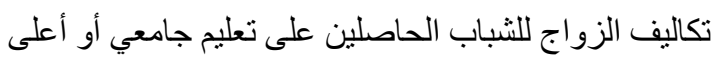

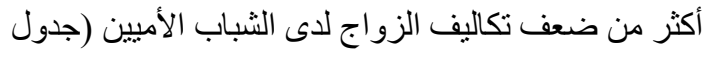

بأنهم يناقتشون كل هذه الموضو عات مع زوجاتهم أكثر مما

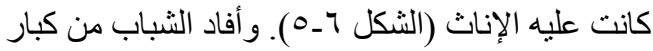
السن، و الأكثر تعليما، و الأكثر ثر اء أيضا بأنهم أكثر تكر ارًا

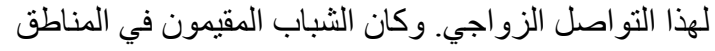

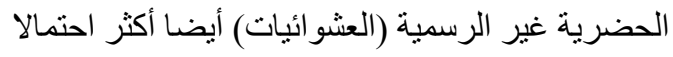

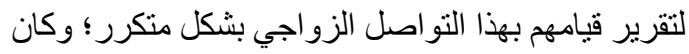

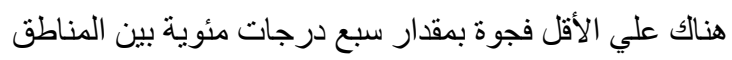

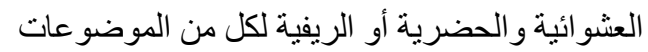
الاتصالات الزواجية الخمسة.

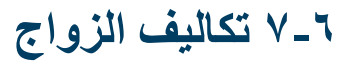

يعد ارتفاع تكلفة الزواج في مصر من الموضو عات التي

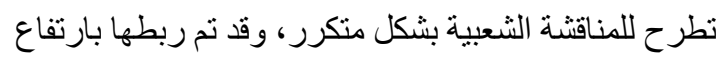
سن الزواج و الانتقالات المتعثرة إلى مرحلة الرشد (Singerman 2007; Dhillon and Yousef 2009) فيتوقع من الثباب في مصر أن يقوموا بتأسيس منزل مستقل

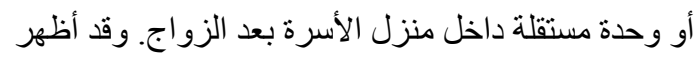

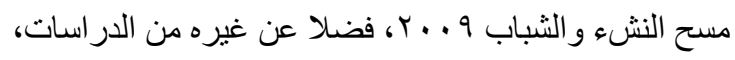

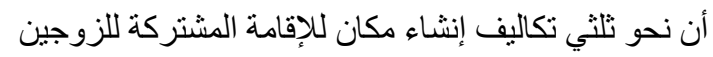

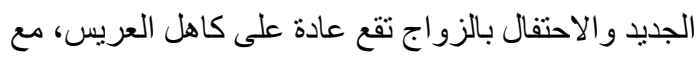

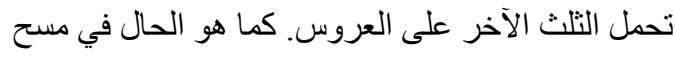

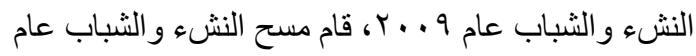

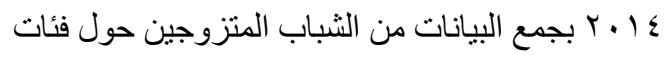
نفقات الزواج الرئيسية، باستنناء السكن. وشملت هذه الفئات التئن

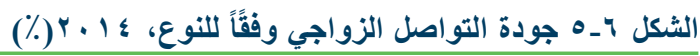

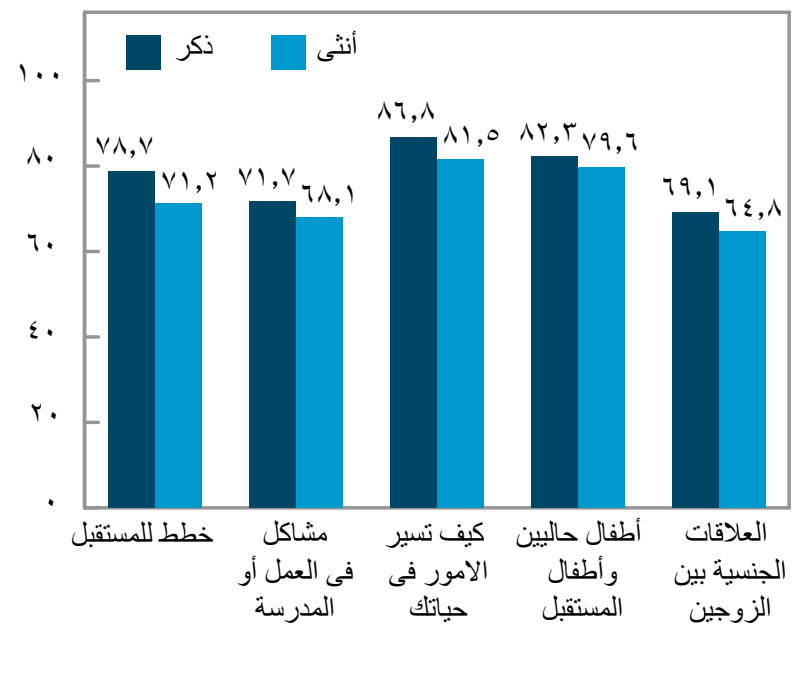


إدر اكا لمجمو عة من العو امل التي تمثل مشكلات بالمقارنة مع الثباب عام 9 . . ب. و على الرغم من أن النسبة المئوية

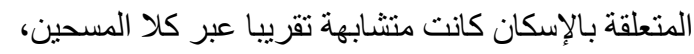

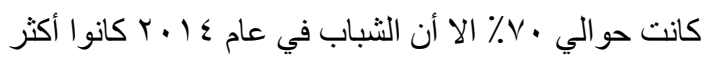

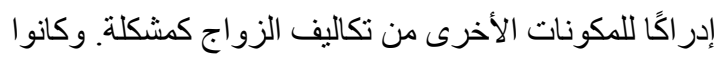

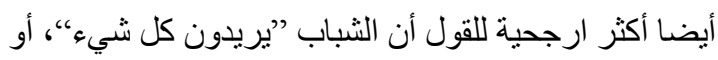

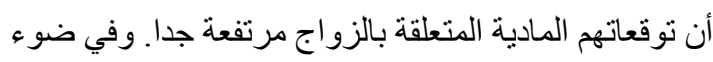

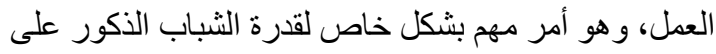

الادخار من أجل الزواج و التأسيس للزوجية، أثنارت نسبة

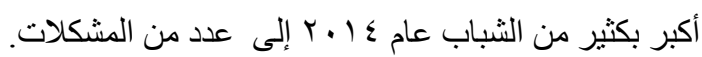

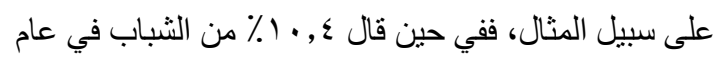

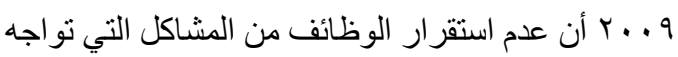

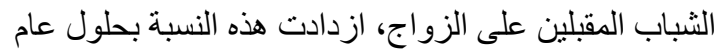

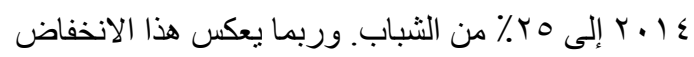

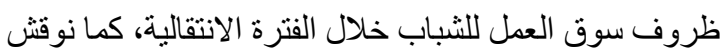

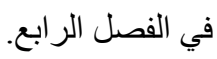

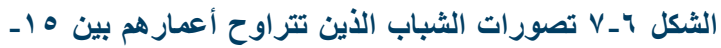

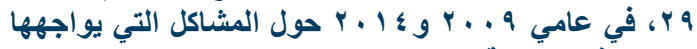
الشباب في محاولة الزواج (ب) و

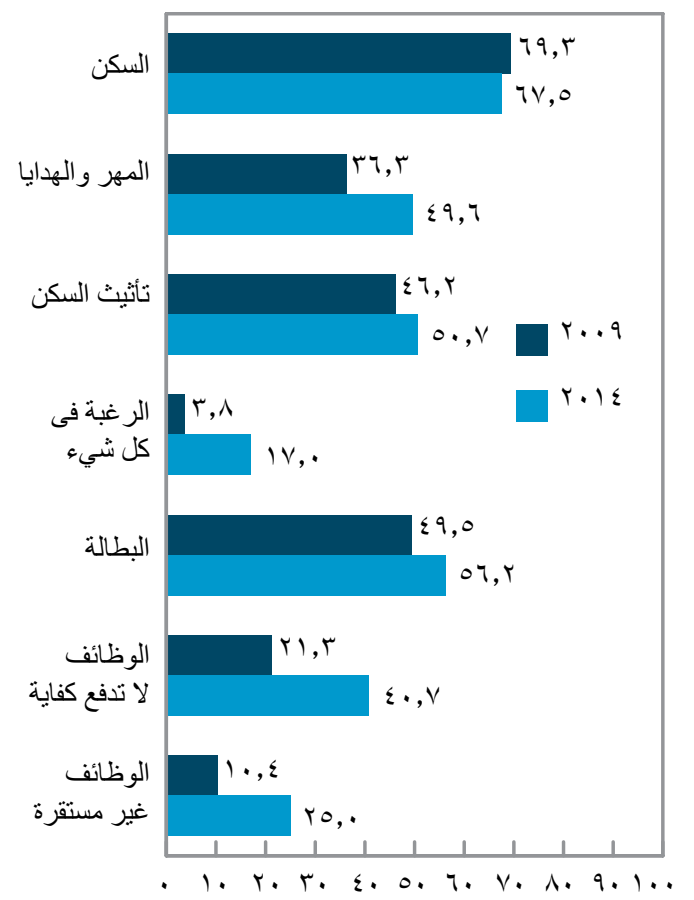

الثكل رقم 7 ـ 7 متوسط تكلفة شبكة العروس والتكلفة الاجمالية

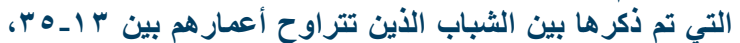
وفقًا للثروة وسنة الزواج لين التباب

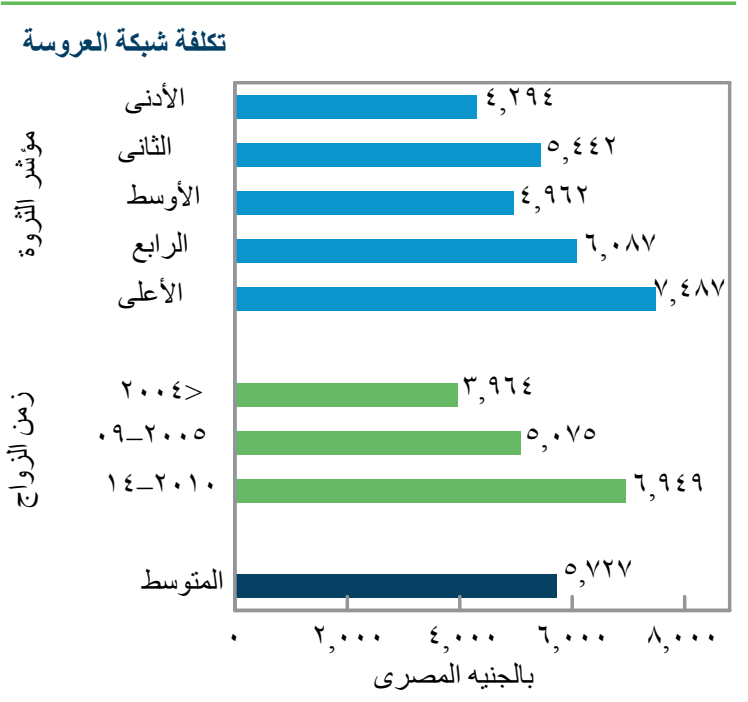
التكلفة الإجمالية للزواج

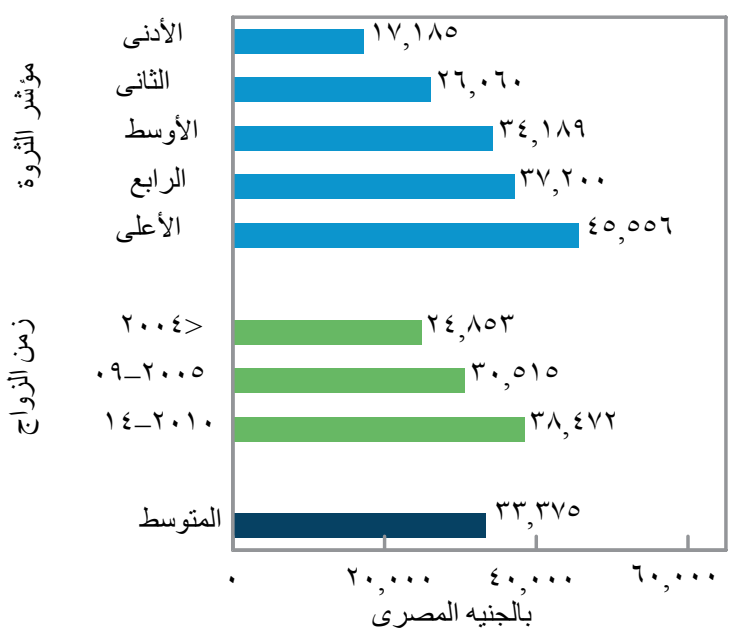

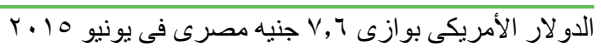

أ7 ـ9). ويتو افق هذا مع النتائج السابقة من أن الثباب المتعلم

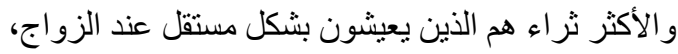
وبالتالي ينفقون المزيد على تأسيس إقامة منفصلة.

$$
\text { الثّصورات حول معوقات الزئواج }
$$

ونظر اللعبء الكبير الذي يمثله الادخار من أجل الزواج

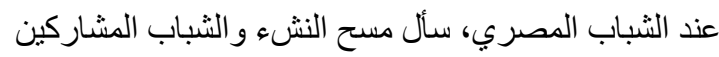

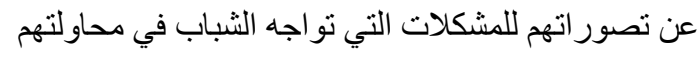

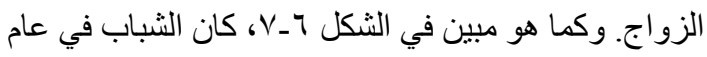

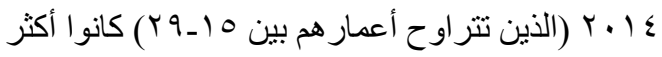




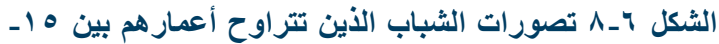

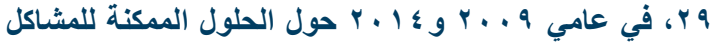

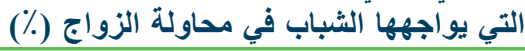

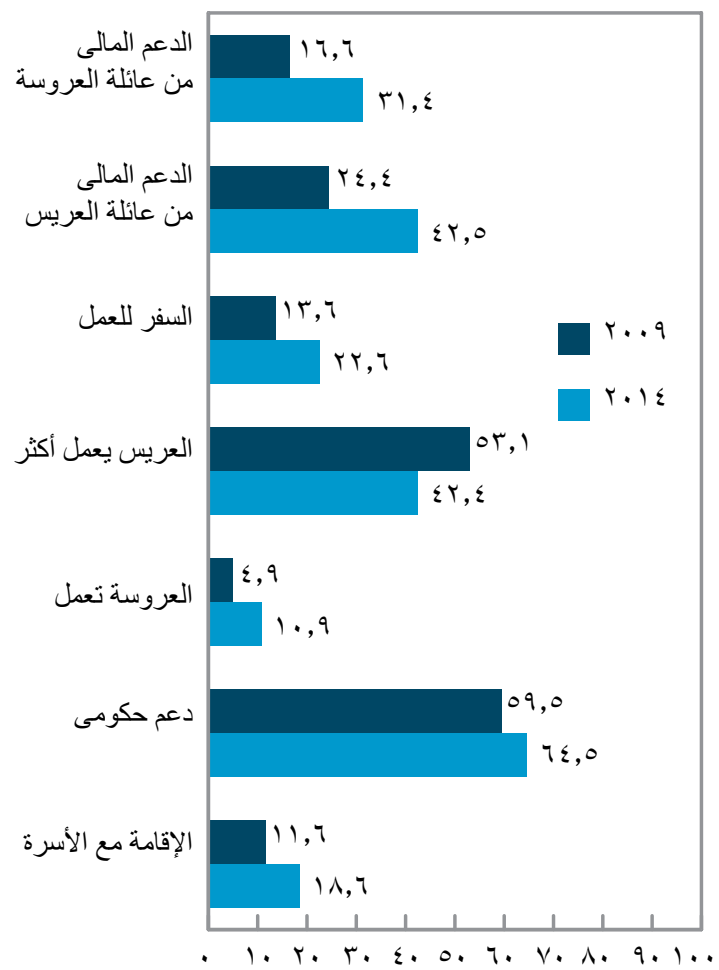

الشكل جـ أو عدد الأطفال المرغوب فيه بين الثباب المتزوجين

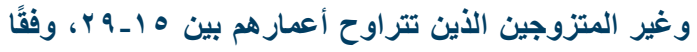

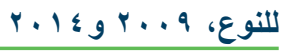

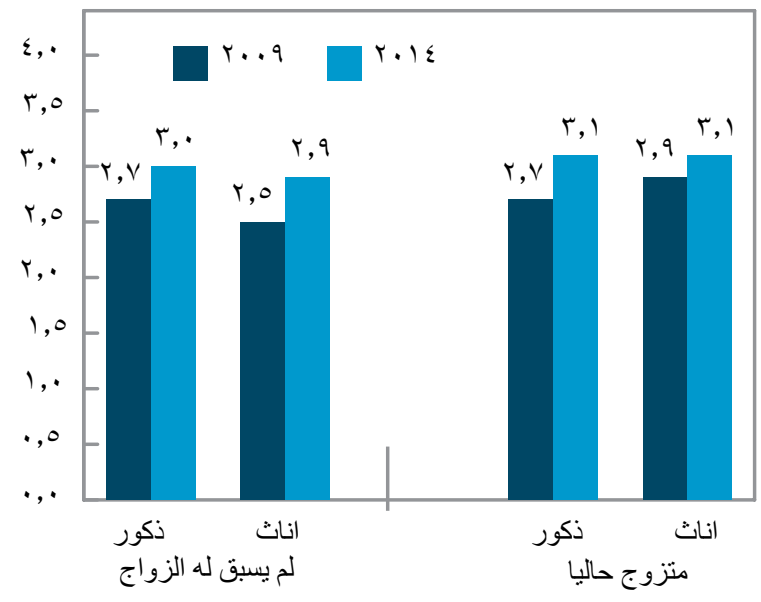

\section{ز ادت معدلات الخصوبة المطلوبة} لكل من الذكور و الإناثث باتساق عبر مستوبات الثروة. قد يؤدى هذا إلى آثار مهمة بالنسب لمعدلات الخصوبة في المستقبل

\section{الملول الثقترحة لمشاكل الثزواج}

وارتبط قلق الثباب الأكبر بالشكاتلات التي تو اجه الثباب

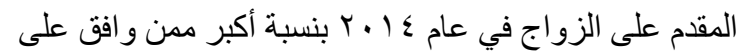

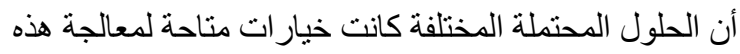

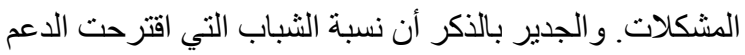

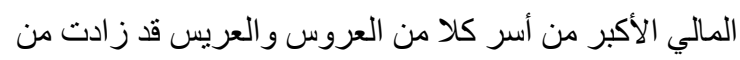

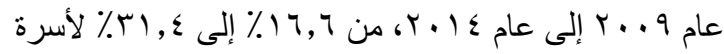

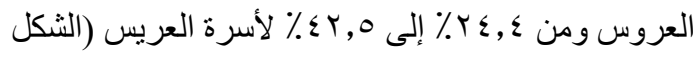

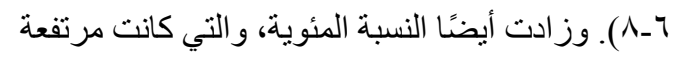

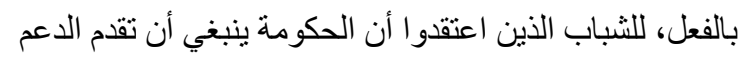

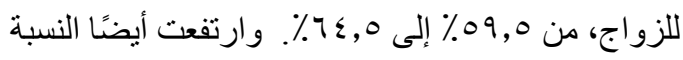

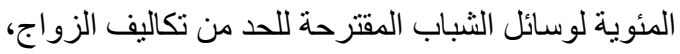
و هي التنازل عن بعض الأشياء والعيش مع الأسرة.

\section{1.}

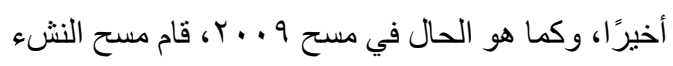
و الثباب ؛ ا ب ب بسؤ ال كل الثباب عن تصور هم لعدد الأطفال

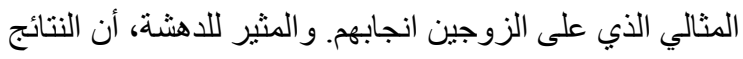

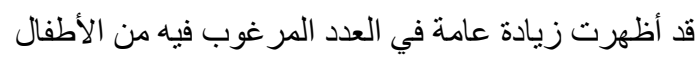

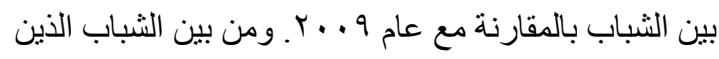

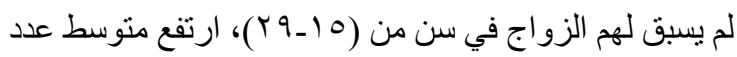

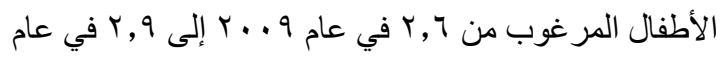

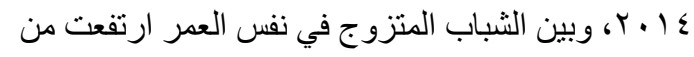

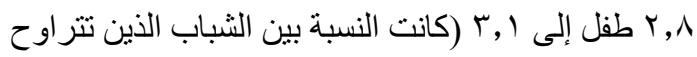

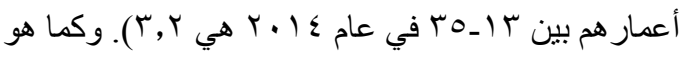

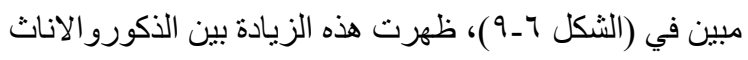
بغض النظر عن حالتها الزوجية 
وفي الوقت نفسه، هناك عدد من الثباب الأكثر تعليما،

وبخاصة الذكور، ينتقلون إلى الزواج بشكل منأخر نسبيا.

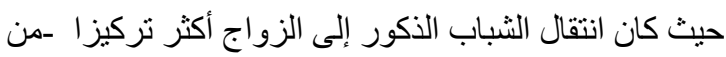

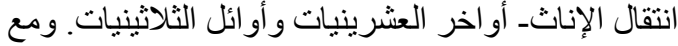

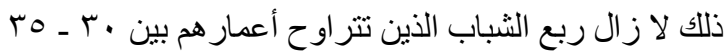
سنة غير متزوجين. إن الأهمية الاجتماعية للزو اج باعتباره

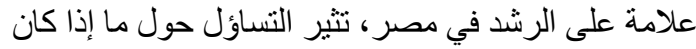

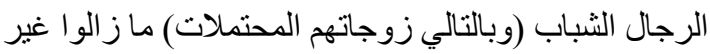

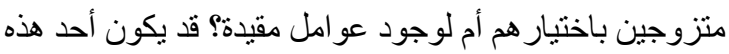

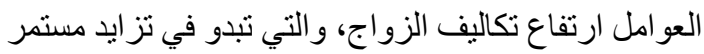
في الزيجات الحديثة (أو بين المجمو عات الفوات الفر عية من الثباب

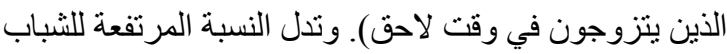

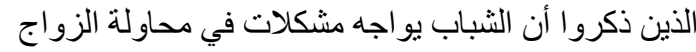

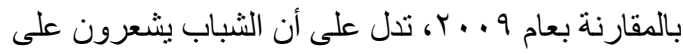
نحو متز ايد بضغط تكاليف الزواج تحت الظروف الاقتصادية

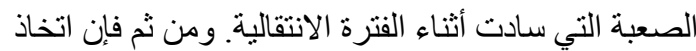

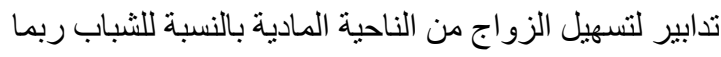
يكون بداية لضمان انتقال ناجح إلى مرحلة الرشد.

و أخير اً، فقد ارتفع عدد الأطفال الذين ير غب الثباب في إنجابه

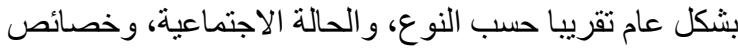

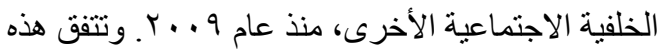
النتيجة المقلقة مع النتيجة الخاصة بانخفاض استخدام وسائل

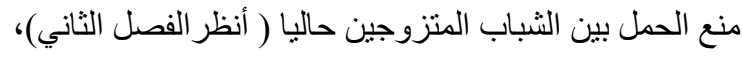

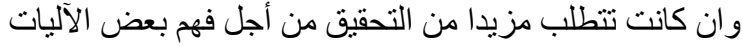

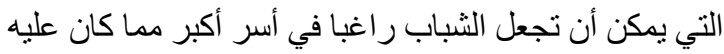

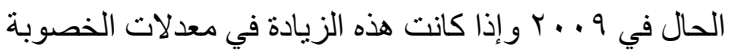

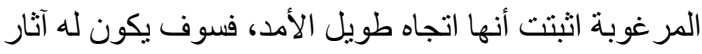
متتو عة من مؤشر ات التنمية الوطنية (انظر، على سبيل التيل المثال:

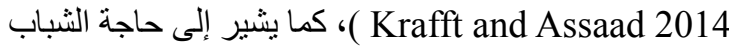
إلى تحسين فرص الحصول على التعليم و المعلومات المتعلقة

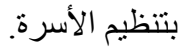

كانت الزيادة في العدد المرغوب فيه من الأطفال مثبتة أيضا عبر كل مستويات الثروة، ومستويات التعليم ومناطق الإقامة

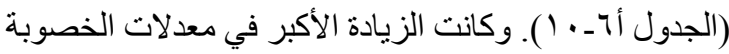

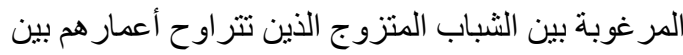

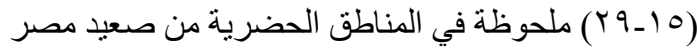

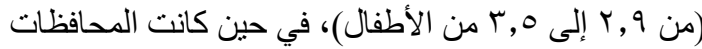

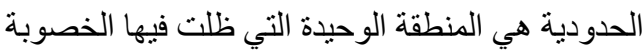
المطلوبة مستقرة. وارتفعت معدلات الخصوبة المر غوبة بين الثباب الذين لم يسبق لهم الزواج، بمقدار 0, • طفل في

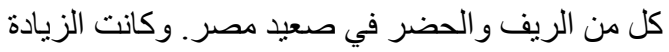
في معدلات الخصوبة المطلوبة منسقة تماما عبر مستويات الثروة، فكانت بمقار ץ, • ــ , · ط طفل بين الثباب المتزوجين، ونحو ا, · طفل للثباب الذين لم يسبق لهم الزو اج في معظم

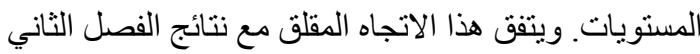
الخاصة بانخفاض انتشار وسائل منع الحمل بين النساء الإناث المتزوجات حاليا، ويمكن أن تكون لها آثار مهمة بالنسبة الثابة ل ل المدلات الخصوبة في المستقبل.

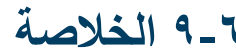

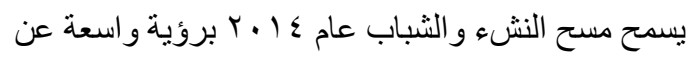
انتقال الثباب المصري إلى الزواج، وقد تقدمت عينة مسح

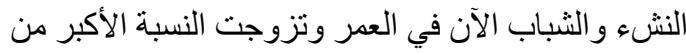
المشاركين. ويكثف التحليل في هذا الفصل عن أن الانتقال

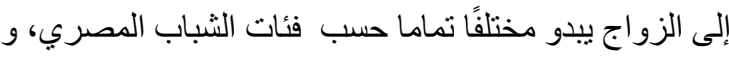

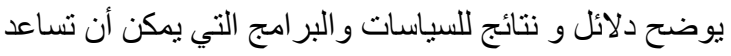

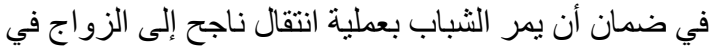
الوقت المناسب وللشخص الذي يختارونه.

و لا تزال الإناث في مصر عرضة لخطر الزواج المبكر،

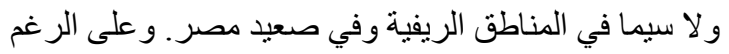

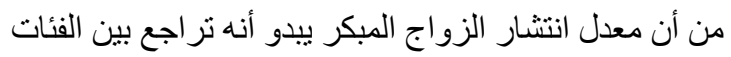

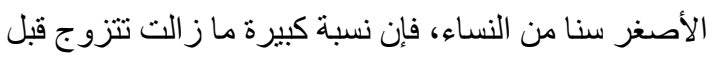

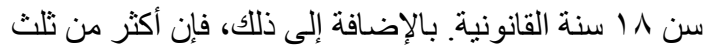

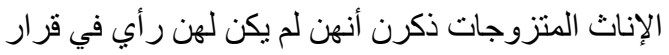

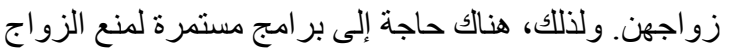

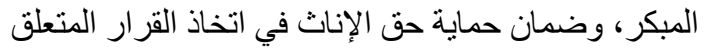

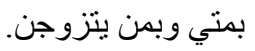


المسح التتبعي للنشء و الثباب في مصر ؟ ا.ب

Brady, Martha, Ragui Assaad, Barbara Ibrahim, Abeer Salem, and Rania Salem. 2007. “Providing New Opportunities to Adolescent Girls in Socially Conservative Settings: The Ishraq Program in Rural Upper Egypt." New York: Population Council.

Dhillon, Navtej and Tarik Yousef, eds. 2009. Generation in Waiting: The Unfulfilled Promise of Young People in the Middle East. Washington, DC: Brookings Institution Press.

Krafft, Caroline and Ragui Assaad. 2014. "Beware of the Echo: The Impending Return of Demographic Pressures in Egypt." Economic Research Forum Policy Perspective No. 12. Cairo: ERF.

Lee-Rife, Susan, Anju Malhotra, Ann Warner, and Allison McGonagle Glinski. 2012. “What works to prevent child marriage: A review of the evidence," Studies in Family Planning 43(4): 287-303.

Population Council. 2010. "Survey of Young People in Egypt." Cairo: Population Council.

Singerman, Diane. 2007. "The Economic Imperatives of Marriage: Emerging Practices and Identities among Youth in the Middle East." Middle East Youth Initiative Working Paper, No. 6. Washington, DC: Wolfensohn Center for Development and Dubai School of Government. 
لعام ع ا ـ ب فرصة فريدة للإجابة عن هذه الأسئلة

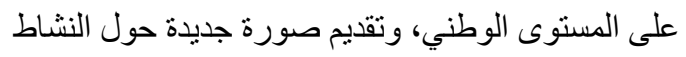

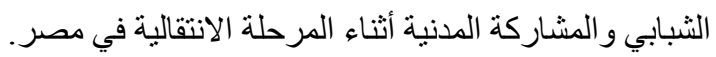

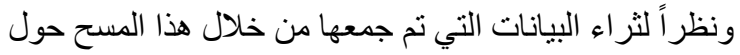

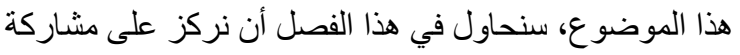

الثباب في الأحداث و العمليات السياسية، وفي الاحتجاجات

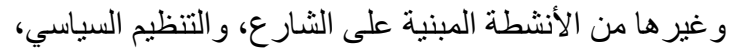

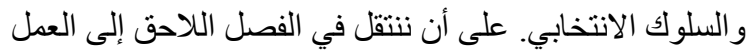
التطو عي و المشاركة بين الفئات الاجتماعية، فضلا عن الآراء الاجتماعية و السياسية للثباب حول عدد من الأحداث و القضايا

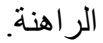

وبسبب التغير ات العديدة التي طر أت على الساحة السياسية

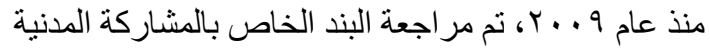

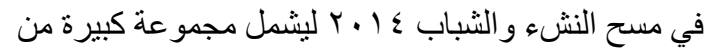
الأسئلة المتعلقة بالمشاركة المدنية، بما في ذلك المشاركة في

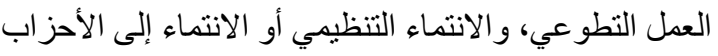

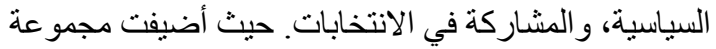

جديدة من الأسئلة حول المشاركة في الأحداث التي وقعت الاتش

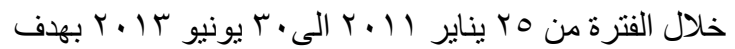

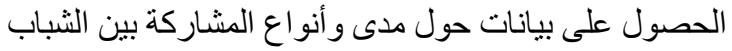

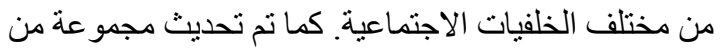
الأسئلة التي كانت موجو دة بمسح 9 . . ب ب، و المتعلقة باستخدام

وسائل الإعلام، في محاولة لقياس مدى استخدام الثباب التباب

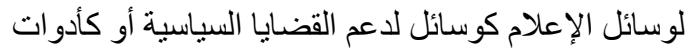
لحث المو اطنين على المشاركة.

\section{م_ م مشاركة الثباب في النشاط السبياسي

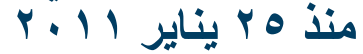

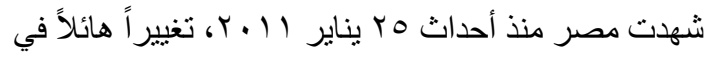
الطرق التي يطالب بها المو اطنون بحقو قهم السياسية ويعبرون

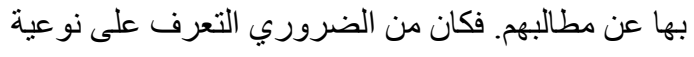
المجمو عات الثبابية التي شاركت بالفعل في الاحتجاجات،

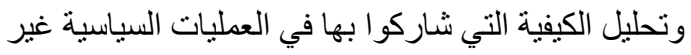
المستقرة خلال السنوات الثلاث الماضية، وذللك من أجل تسليط

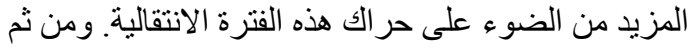

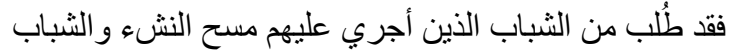
في ع ا ـ ب أن يوضحو ا مدى مشاركتهم في الاحتجاجات،

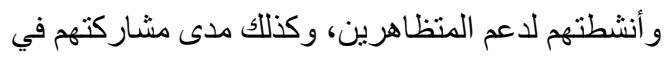
الإضر ابات وفي اللجان الشعبية، و المشاركة في أي شكل من

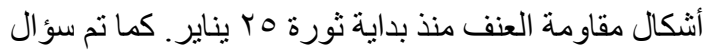

لقد أثارت الأيام الثمانية عشرة منذ بداية الخامس و العشرين

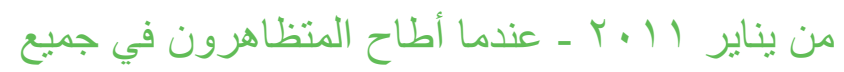
أنحاء البلاد بنظام الرئيس الاسبق حسنى مبارك ــ ـ اهتماماً جديداً بالثباب المصري عبر وسائل الإعلام، و المجتمع، و السياسة. فتم النظر إلى الثباب باعتبار هم العامل المحفز للثورة من خلال أنشطتهم السياسية العامة عبر الفضاء الافتر اضى و الو اقعي. استخدم الثباب وسائل التو اصل الاجتماعي، و الاحتجاجات في الشوارع، و اللجان الثعبية، وتقديم الخدمات الاجتماعية للمتظاهرين، و الأشكال الإبداعية ولية فى التعبير الفني للتعبير عن مظالمهح و الدعوة للتغبير.

\section{V ا}

كان الدور المحوري للشباب في اندلاع ثورة ه ب يناير مقنعًا

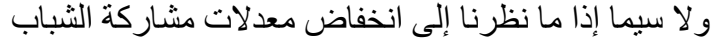

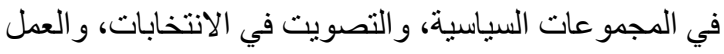
التطوعي فيما قبل تللك الفترة. ففي عام 9 . . ب، أشنارت

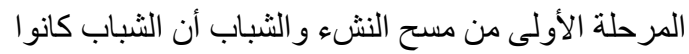

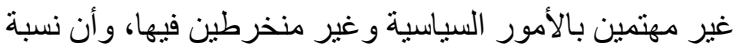

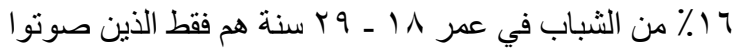

في الانتخابات السابقة، وينتمي أقل من و احد في المئة منهم

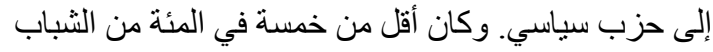

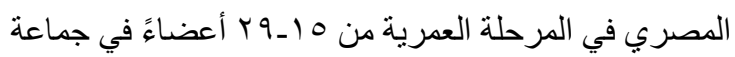

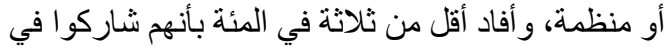

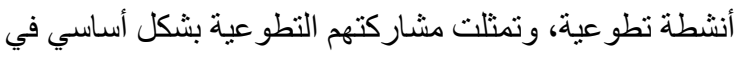
تقديم المساعدة للفقر اء (Population Council 2010).

ونظرًا لأنه لا تتو افر لدينا سوي بيانات قليلة حول مدي تمثيل مشاركة الثباب على الصعيد الوطني في ثورة هب يناير

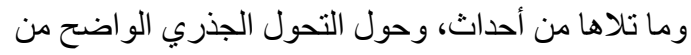

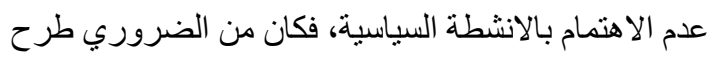

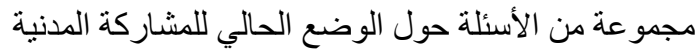

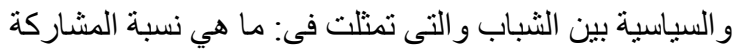

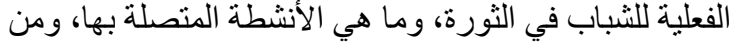

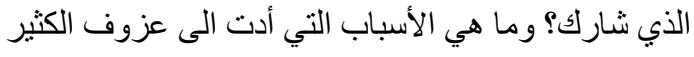
من الثباب عن المشاركة في الأحداث السياسية التي بدأت

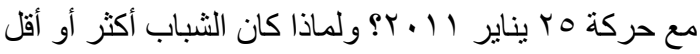
احتمالا للتصويت في الانتخابات و الاستفتاءات التي أجريت

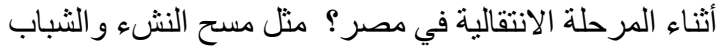




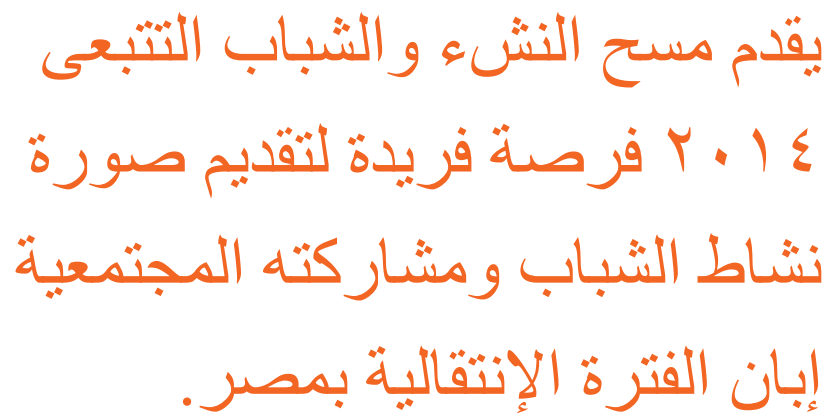

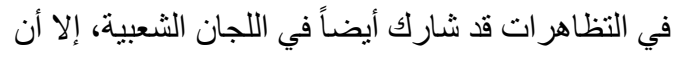

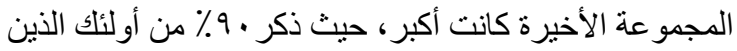

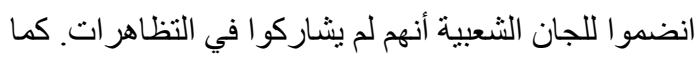

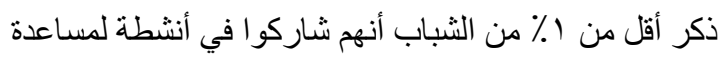

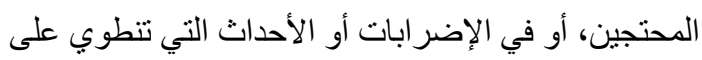

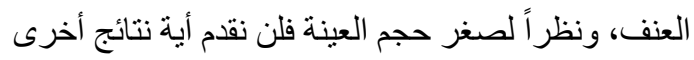
حول كل نوع من هذه الأنواع من النشاط.

إن فهم التركيبة الاجتماعية و الاقتصادية لأولئك الذين اشتركو ا في الاحتجاجات يمكن أن يساعد في كثف فا فا كان مسيطرًا

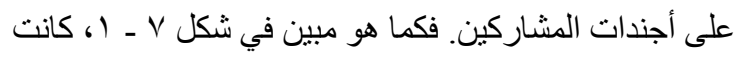

هنالك فجوة كبيرة بين الجنسين في المشاركة في الأنشطة

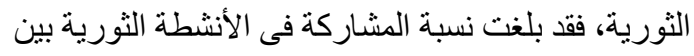

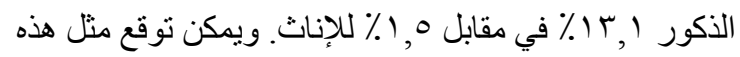

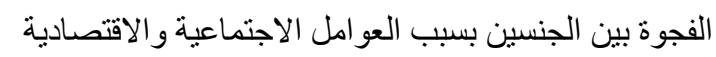
و السياسية والأمنية التي تُعيق النساء من المشاركة الكاملة

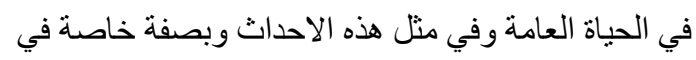

الشباب أيضًا عما إذا كانو ا قد شاركو ا في أي شكل من أشكال

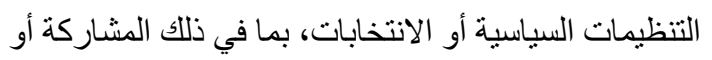

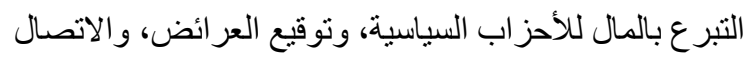
بالسياسين، أو المشاركة في الحملات الانتخابية.

و المثير للاهشة، أن نجد أن مستوي مشاركة الثباب في مثل

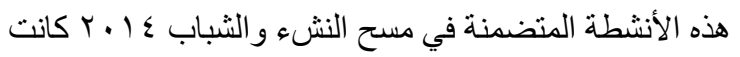

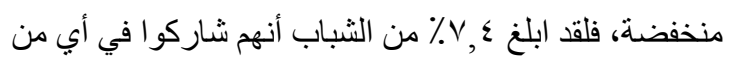

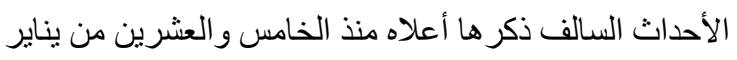

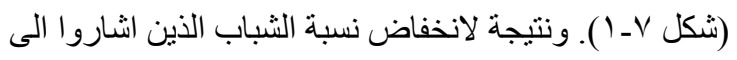

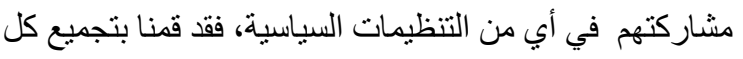

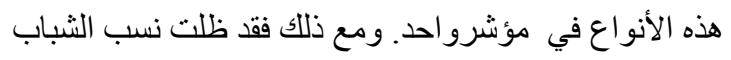

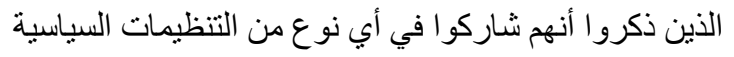

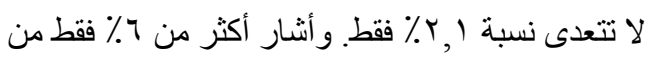

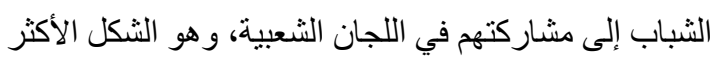

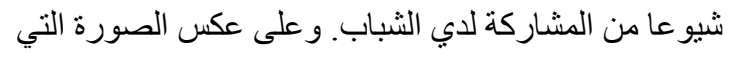

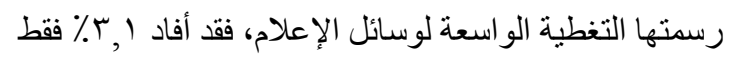

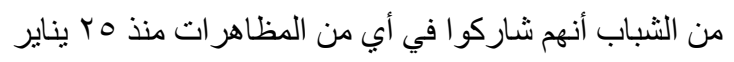

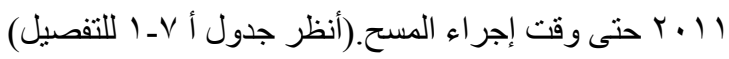

و على الرغم من أن غالبية الثباب لم يشاركو ا في أكثر من

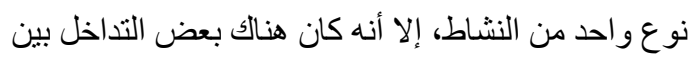
الثباب المشاركين في هذه الأشكال المختلفة من النشاط.

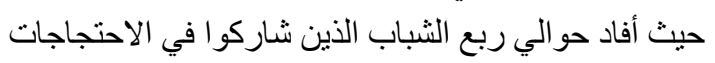

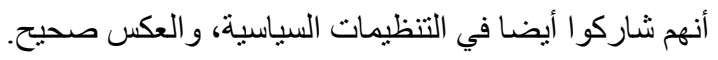

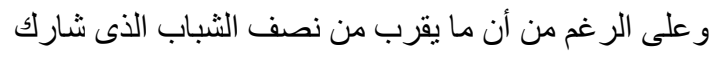

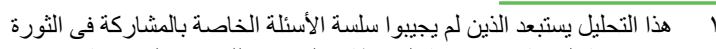

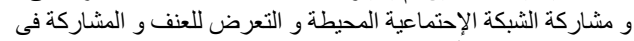

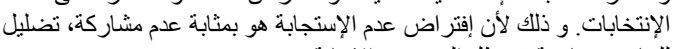
للنتائج و خاصة فى ظل التردد في الإجابة.

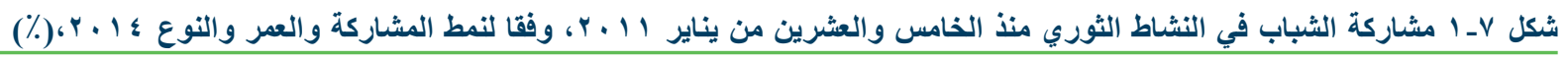

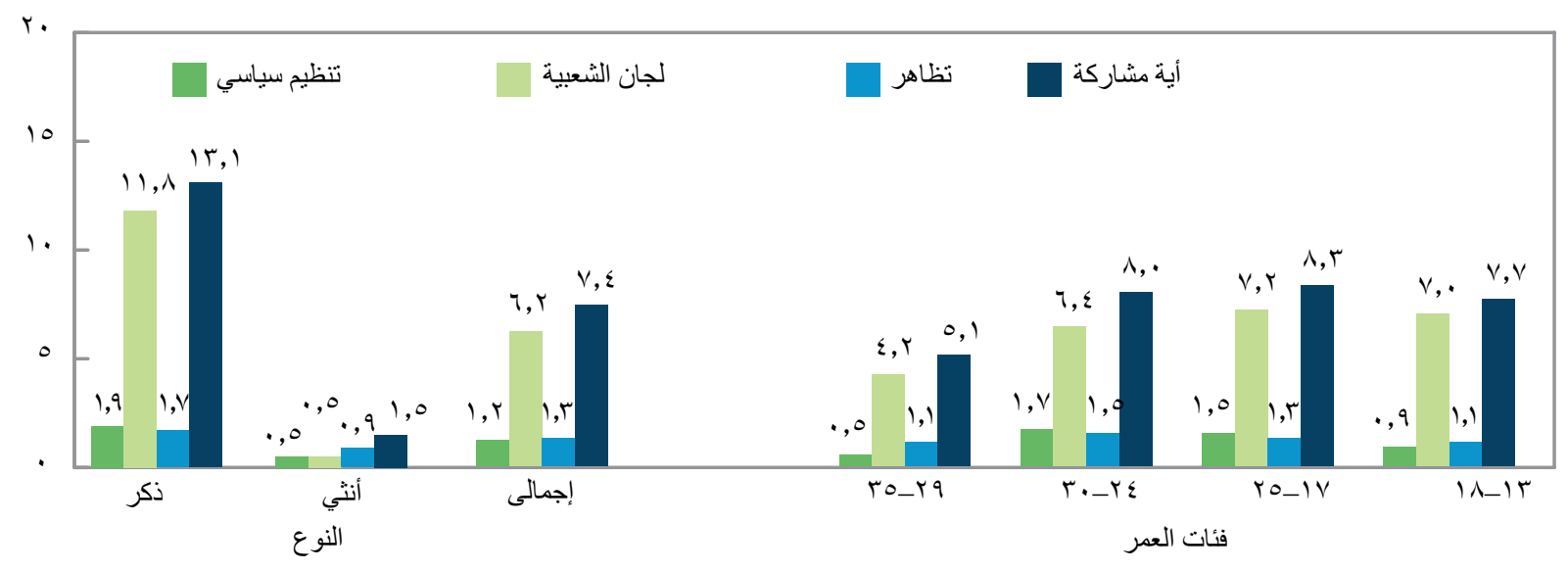


من الثباب في الريف، وما يقرب من ا ٪ من الثباب الذين يعيشون في المناطق العشو ائية. ويمكن تفسير هذه الفروق في كون التظاهر ات وأحداث العنف التي صاحبتها والتي أدت وندئ إلى تكوين اللجان الشعبية، قد تركزت بشكل أكبر في القاهرة والمناطق الحضرية الكبرى.

وقد كانت هنالك علاقة طردية بين المسنوى التعليمي للنباب واحتمال المشاركة في أي شكل من أشكال النشاط السياسي. فقد كان الشباب الأميون أقل مشاركة، حيث بلغت نسبة مشار كتهم T, Y\%، مقارنة مع أولئك الحاصلين على تعليم جامعي ومستوى

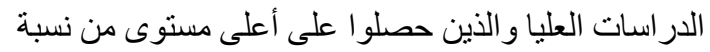

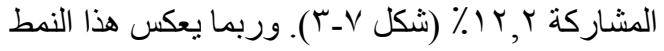

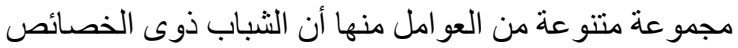

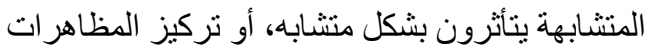
حول الجامعات، أو حقيقة أن سكان الحضر ، و الذين كانت معدلات المشاركة لديهم عالية، يمنلكون مستوى تعليمي أعلى الفى الفي (انظر الفصل ب). وبالمثل، كانت هناك علاقة إيجابية بين

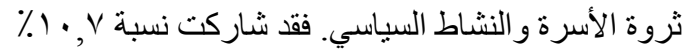
من الثباب في المستوي الأعلى للثروة (المستوي الخامس)

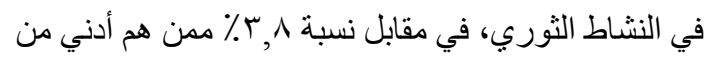
المستوي الخامس للثروة. وقد ظهرت العلاقة بين الثروة و المشاركة في جميع أنواع المشاركة التي تم قياسها. فعلى ونى

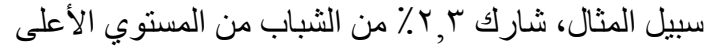

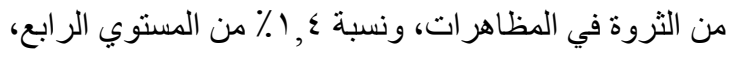
مقارنة مع نسبة ب, • ٪ فقط من المستوي الأدنى من الثروة.

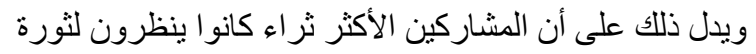

احتجاجات الشارع المفتوحة وما شابهها من أحداث، و إن كان ذلك يتناقض مع المناقشة الإعلامية الواسعة حول مشاركة الإناث الثابات في الاحتجاجات و غير ها من الاحداث. ووفئًا لتصنيف النوع، فقد أكد ^, 1 ( ٪ من الثباب الذكور أنهم كانوا جزءا من اللجان الشعبية، التي نظمت خلال الثمانية عشرة يوما لثورة عام | 1 ـ ب لحماية المنازل من ("البلطجية،")

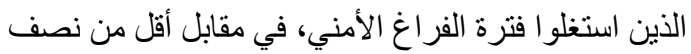
في المئة من الثابات. وكانت أعلى نسبة مشاركة من الثابات في أي نشاط واحد تتعلق بالتظاهر (9, • \%)، يليها المشاركة

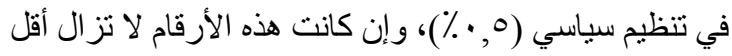
من معدلات مشاركة الشباب الذكور في نفس النشاط (فكانت

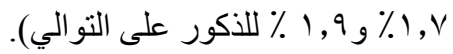
إلى جانب الفروق في معدلات المشاركة حسب النوع اختلفت المشاركة في النشاط الثوري، وفقا لمحل الإقامة؛ حيث شارك

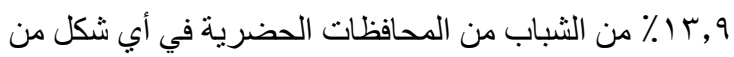

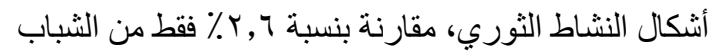

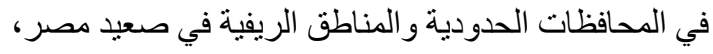
في حين بلغت اقل معدلات المشاركة و التى جاءت بنسبة

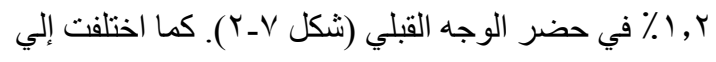
حد ما مشاركة الثباب في نوع النشاط تبعًا لمحل الإقامة. ففي حين كانت مشاركة الثباب في اللجان الثعبية أكثر شيو عا في المناطق الحضرية (r,9 ٪)، كانت أقل شيو عا في العشو ائيات

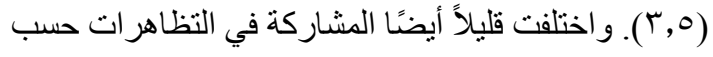
مكان الإقامة: قد أكد ·, ب٪ من الثباب المقيمين في المناطق

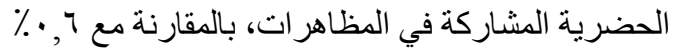

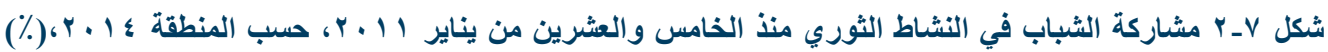

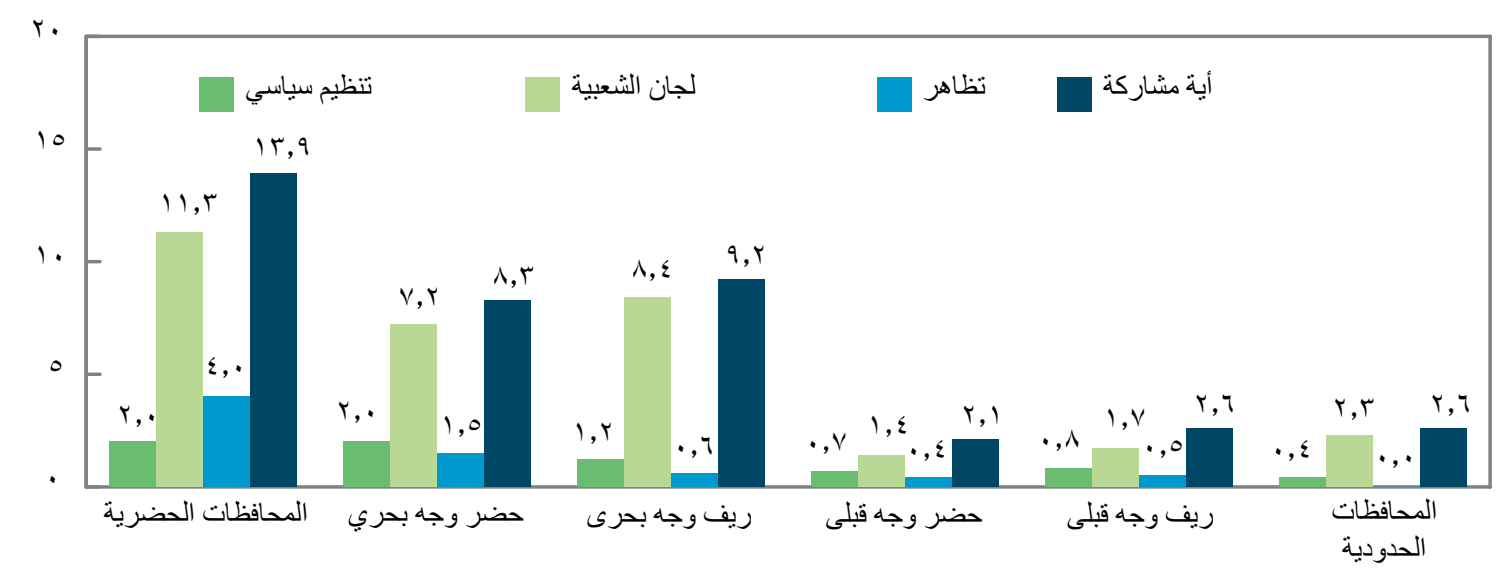




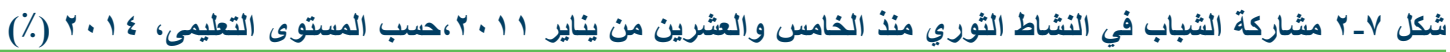

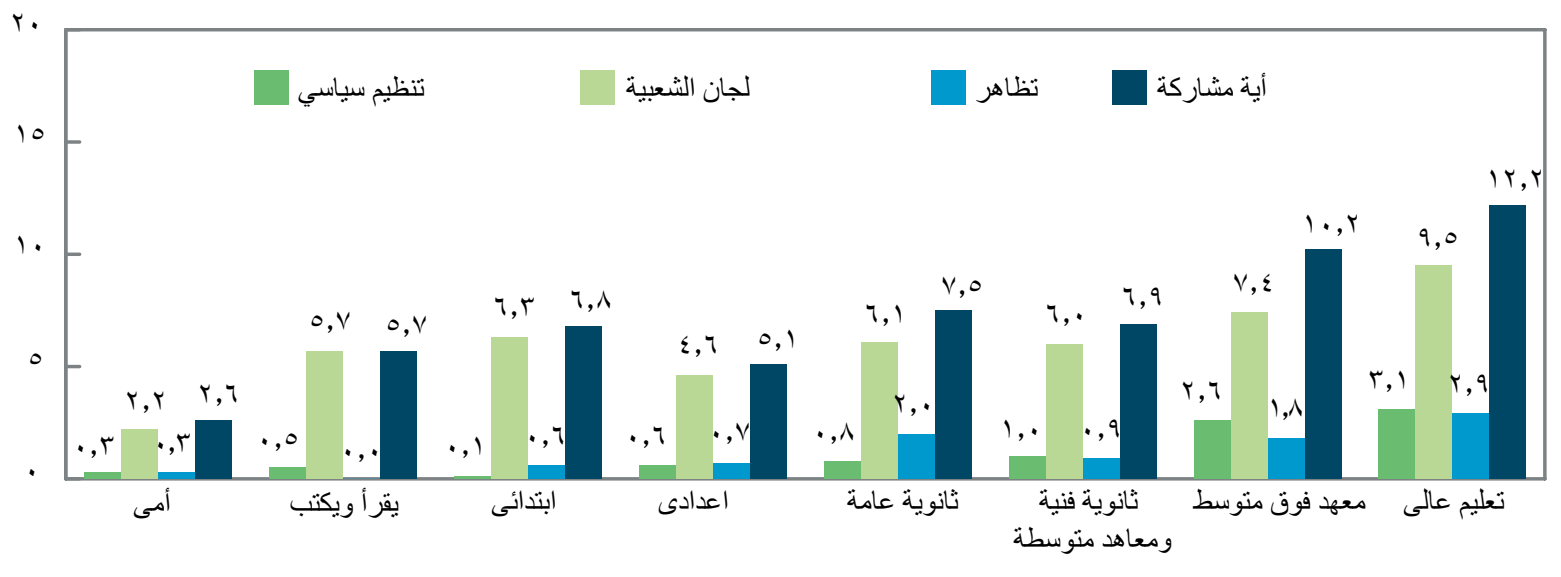

مسح النشه و الثباب ـ ا ـ Y، حيث تم جمع البيانات في أو اخر

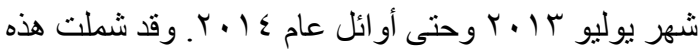
الفترة حملات على بعض الأحز اب السياسية، فضلا عن إقرار

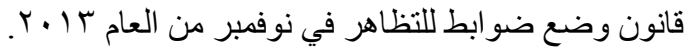
و على الرغم من التأكيد مر ار ا وتكر ار ا علي المشاركين في في

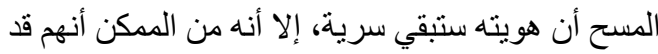
يكونو ا قد ترددو ا في الإبلاغ عن نشاطهم خلال هذه الفترة

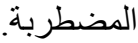

إن ما يدفعنا إلى الثكك في أن الثباب لم يفصحو ا عن نشاطهم الثوري هو ارتفاع معدلات المشاركة التي ذكرو ها لأناس آخرين في حياتهم. فقد طُلب من الثباب في مسح النشء الثاء و الثباب ك ا ـ ب أن يوضحو ا معدلات تكر ار مشاركة و الديهه،

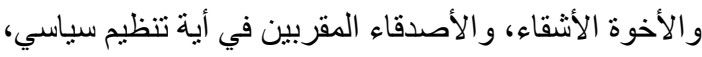

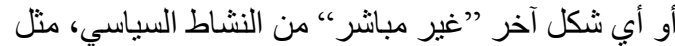

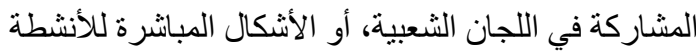
مثل الاعتصامات'. ففي حين كانت معدلات إقرار الثباب بمشاركتهم في أب من هذه الأنو اع من الأنشطة الثورية

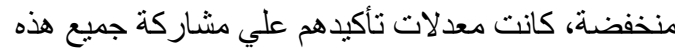

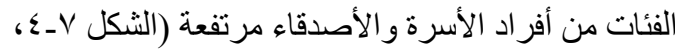

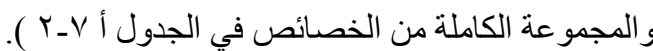

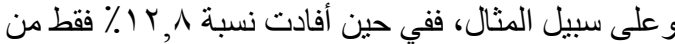

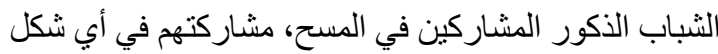

r بالنسبة لثبكات الثباب، تم تعريفها من خلال مسح النشء و الثباب بأنها الأشكال

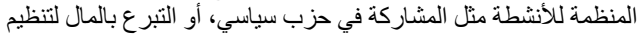

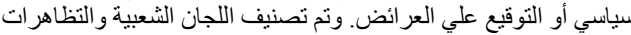

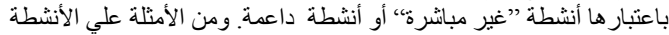

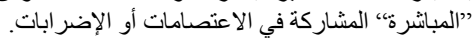

و يناير على أنها نضال من أجل الحقوق المدنية والسياسية وليست مجرد ثورة بسبب المظالم الاقتصادية.

وكان الثباب المتعطل عن العمل أكثر عرضة للمشاركة في (باري

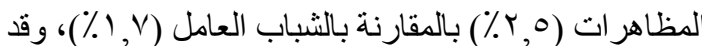

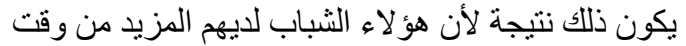

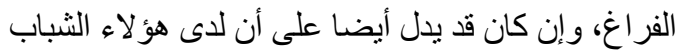

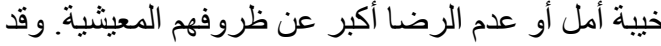

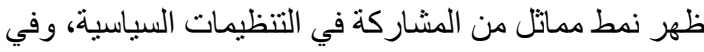
مساعدة المتظاهرين، وظهر بشكل مثير للاهتمام في المشاركة في الاعتصامات، على الرغم من أن هؤ لاء الثباب قد أفادوا

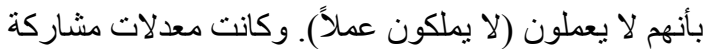

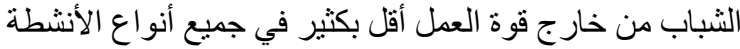

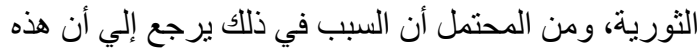

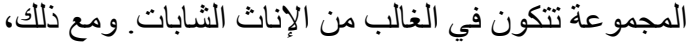

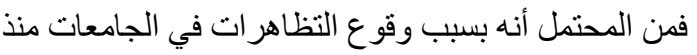

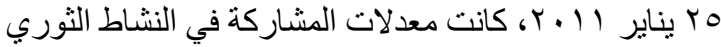

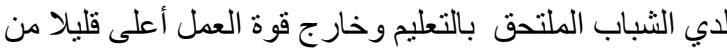

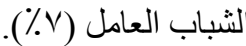

\section{V_V المشاركة في الثبكات الاجتماعية}

إن انخفاض معدلات المشاركة التي أفصح عنها الجيل الذي تم وصفه "بشباب الثورة"، تثير الدهشة تماما، وتؤدي إلى طرح

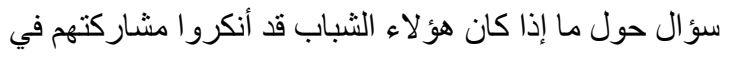
مثل هذه الأحداث الثورية بسبب المناخ الحساس من الناحية السياسية الذي تميزت به الفترة التي تم خلالها جمع بيانات 
شكل V_ه تقريز الشباب لمشاركة شبكاتهم الاجتماعية في

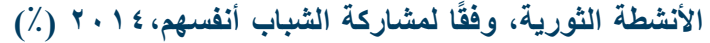
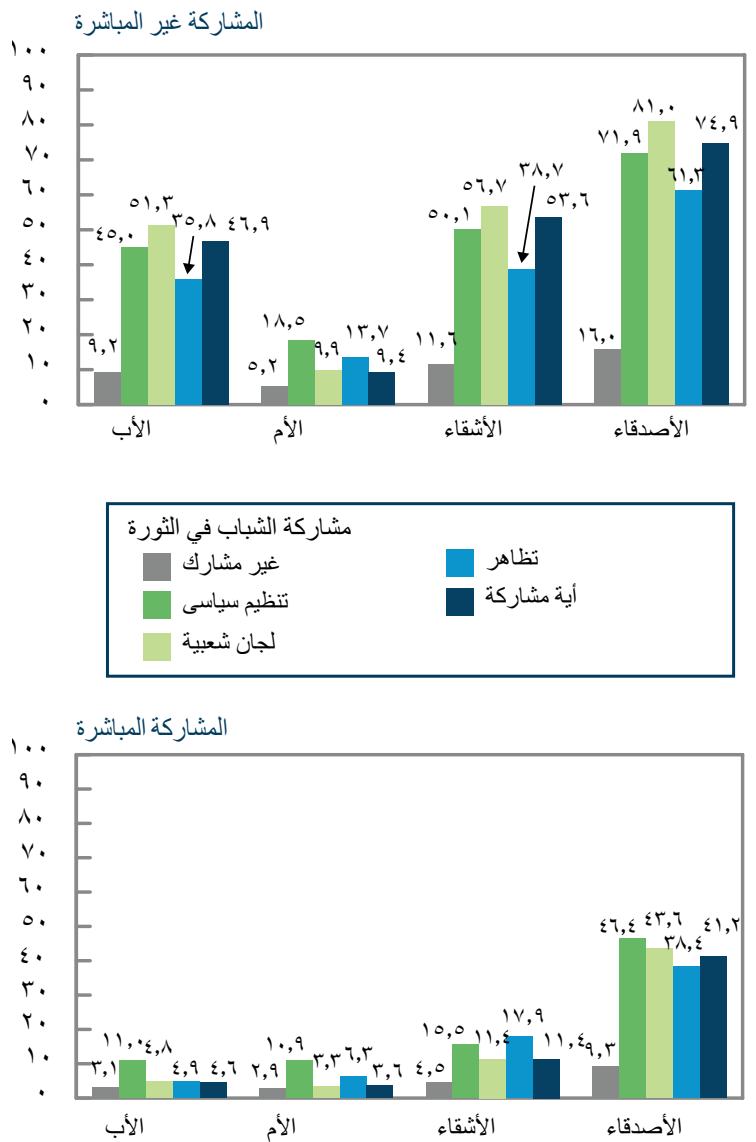

وتُظهر هذه البيانات أيضا التأثير الكبير للثبكات الاجتماعية

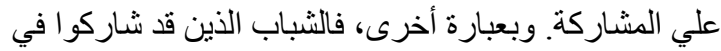

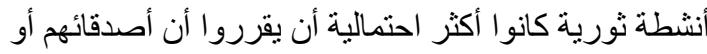

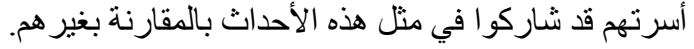

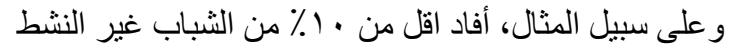
ثُريًا بأن أباءهم قد شاركو ا في بعض الأنشطة الثورية،

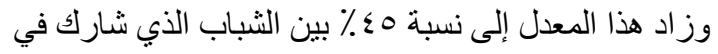

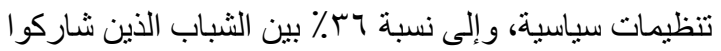

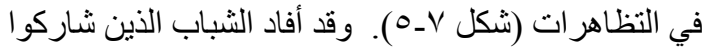

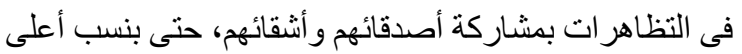

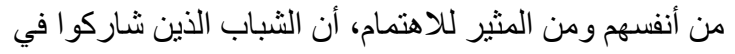

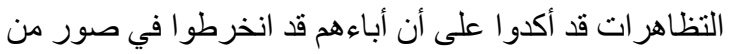

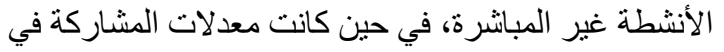

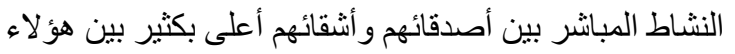
الشباب الذين أفادو ا بعدم مشاركتهم في التظاهر.
شكل V- ـ مشاركة الشباب و شبكاتهم الاجتماعية في أي نشاط

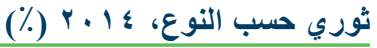

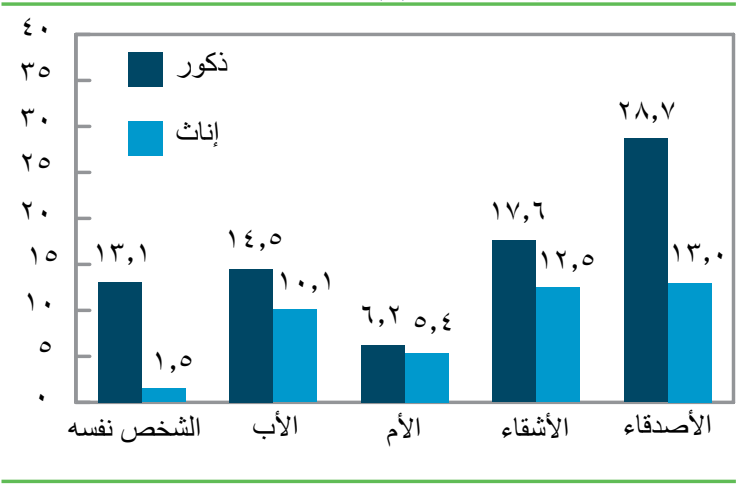

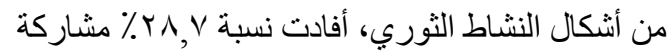

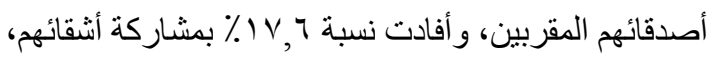

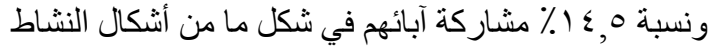

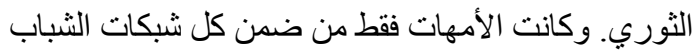
الاجتماعية الأقل مشاركة في الأنشطة الثورية، حيث الأن أفادت

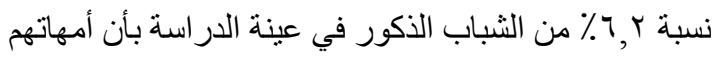

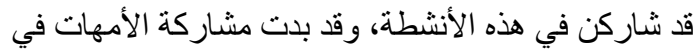
الأنشطة الثورية أقل من مشاركتهم هم أنفسهم. ولقد كانت هناك

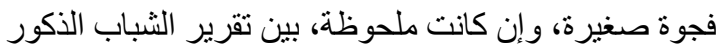
لمشاركة شبكاتهم الاجتماعية "في الأشكال المباشرة للأنشطة

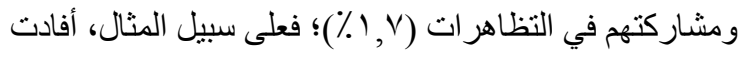

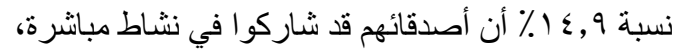

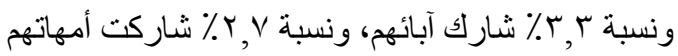

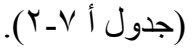

أما بالنسبة للإناث المشاركات في المسح، فعلى الرغم من أن

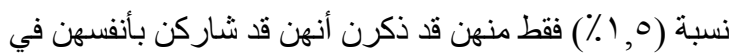

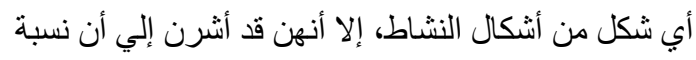

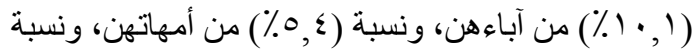

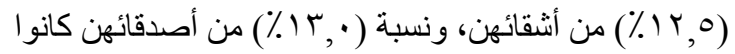

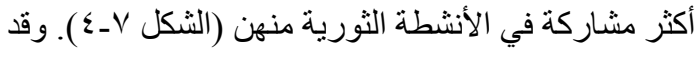
قررن أن شبكاتهن الاجتماعية كانت أكثر نشاطا بالمالمقارنة

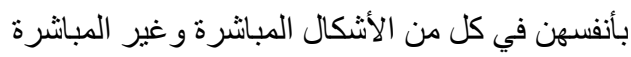
للمشاركة. حقبقة أن الثباب، عبر كل الخصائص الخلفية، قد الثدال

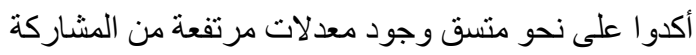

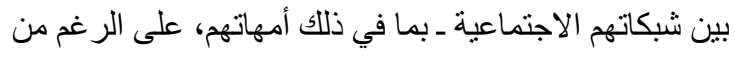

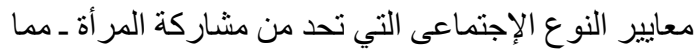

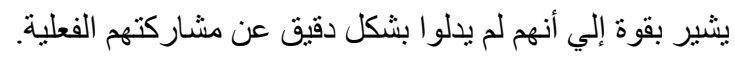

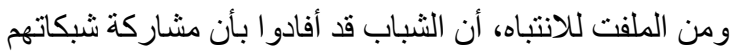

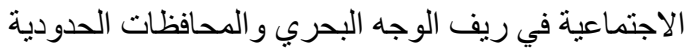
كانت كبيرة أيضا (جدول أ أ (Y-V). 
الحضرية أولياء أمور هم مسئولية عدم مشاركتهم، أشتارت

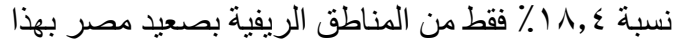

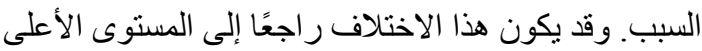
من النشاط الثوري في المحافظات الحضرية، مما يستدعي

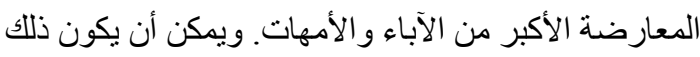

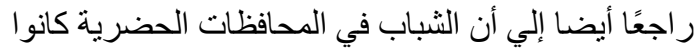

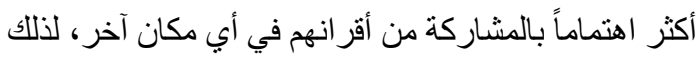

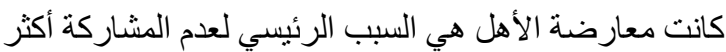

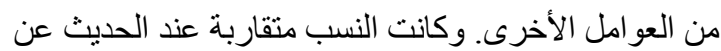

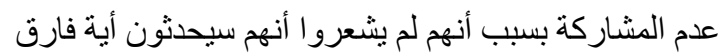

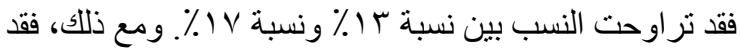
كان الشباب من صعيد مصر و المناطق الريفية أكثر إمكانية

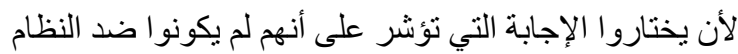

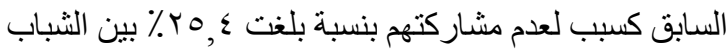

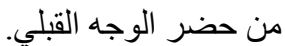

_ _ استخدام وسائل الاعلام كمصدر للمعلومات عن ثورة ه ب يناير.

يمكن لو عي المو اطنين بالأحداث الاجتماعية و الاقتصادية

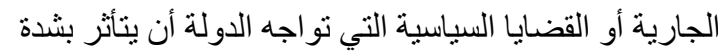

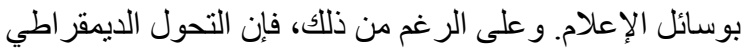

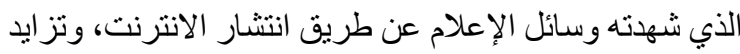

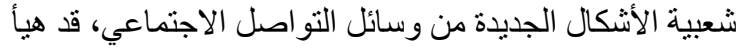

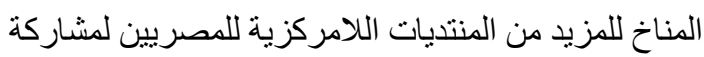
المعلومات ومناقثة الأحداث السياسية. وقد كان هناك تركيز

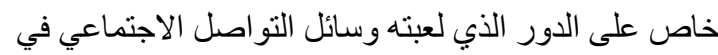

\section{_ - ع أسباب العزوف عن المشاركة}

بالر غم من احتمال عدم دقة تصريح الثباب حول مشاركتهم فى الأنشطة السياسية، إلا أن كثير من الثباب أشتار بالفعل

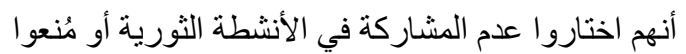

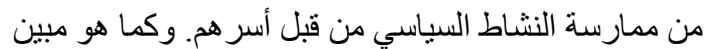

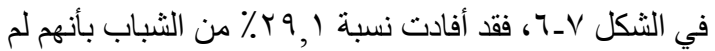

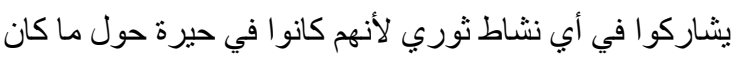

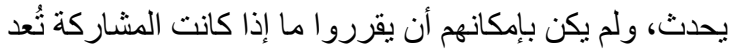

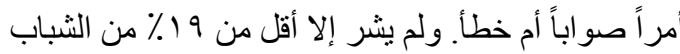

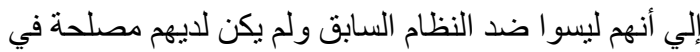

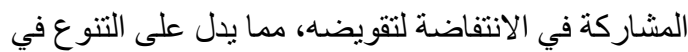

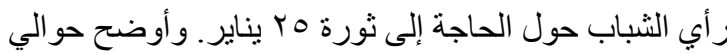

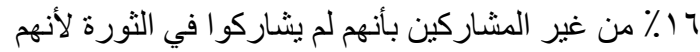

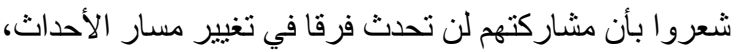
و أعطى 0, ؛ (\% أسباب أخرى.

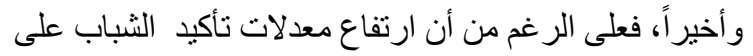

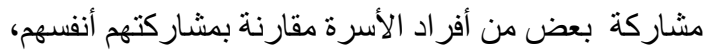

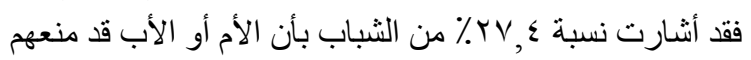

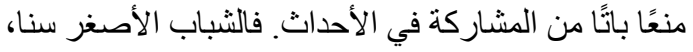

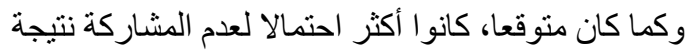

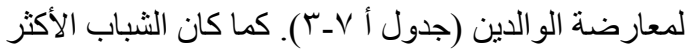

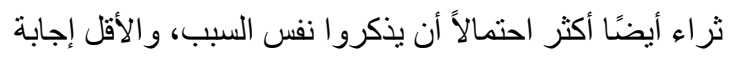

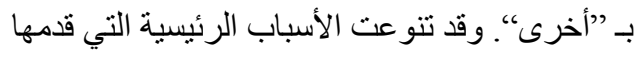
الثباب كأسباب لعدم المشاركة اعتمادًا على محل الإقامة. ففي

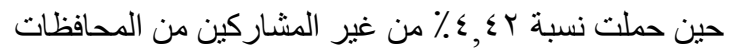

شكل V_r أسباب عزوف الشباب عن المشاركة في النشاط الثوري، حسب المناطق، ؛ 1 ـ r (\%) (مسموح بتعدد الإجابات)

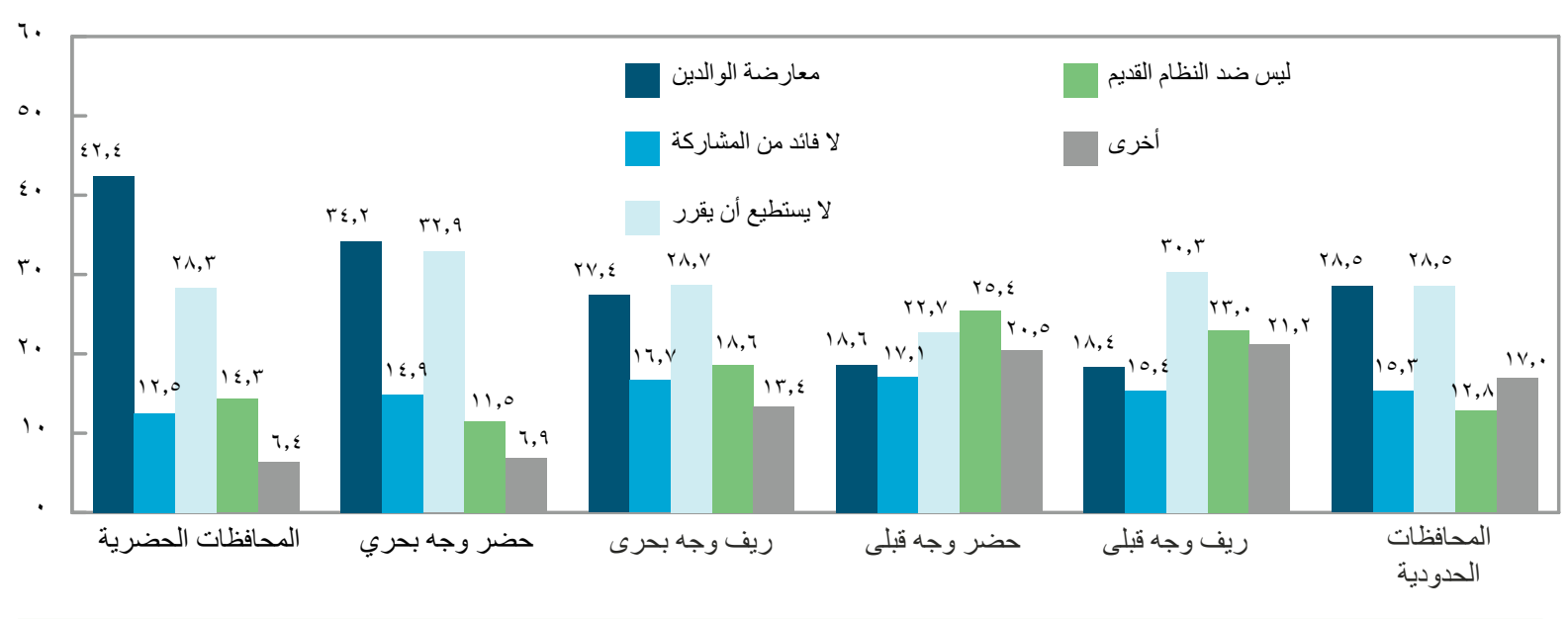


للمعلومات بالنسبة للثباب فيما يتعلق بالثورة بالإضافة

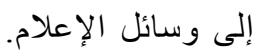

وقد ظهر اختلاف طفيف في ترتيب الثباب لأهمية المصادر

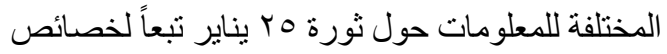

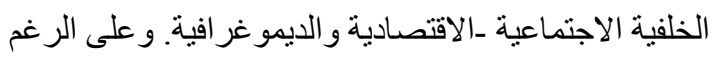

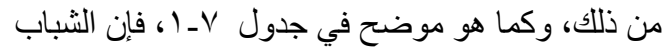

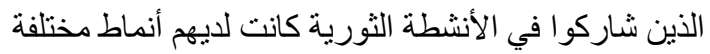

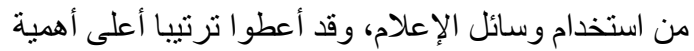

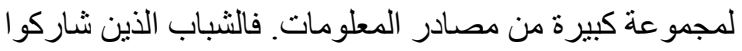

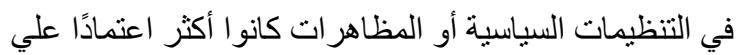

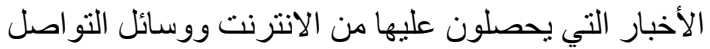

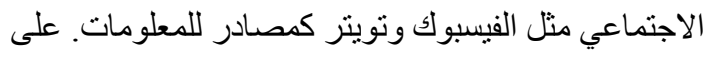
سبيل المثال، فإن الثباب الذين شاركو ا في المظاهر ات وات وفي

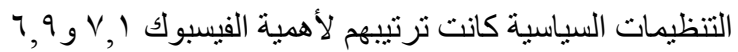

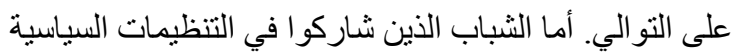

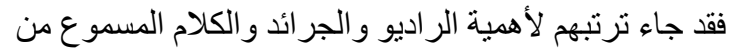

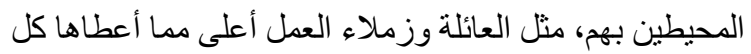
من الشباب عموماً و المتظاهرين خاصة.

\section{I التعرض للعنف}

عانت مصر معاناة شديدة عبر أكثر الاضطر ابات السياسية

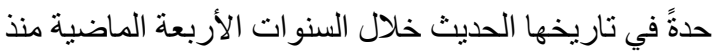

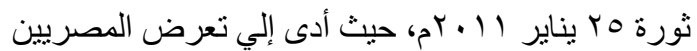
لمستويات جديدة من العنف سواء من خلال وسائل الإعلام أو أو إئ

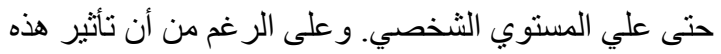
الاضطر ابات على الثباب غير معروف، فإن الخطوة الأولى لى الثى

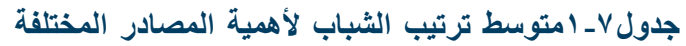

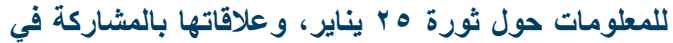

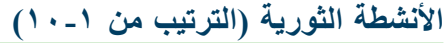

\begin{tabular}{|c|c|c|c|}
\hline متظاهرون & سياسيون & الشبابع & المصدر \\
\hline$v, r$ & $\Lambda, 1$ & $\Lambda, r$ & التليفزيون \\
\hline 7,7 & $v, 0$ & 0,7 & الأصدقاء/الأسرة \\
\hline$\varepsilon, q$ & 7,1 & $\varepsilon, V$ & الصحف \\
\hline$\varepsilon, 1$ & $0, \xi$ & $\varepsilon, V$ & الر اديو \\
\hline Т, ६ & $\mathrm{v}, \mathrm{l}$ & $\varepsilon, 0$ & أخبار الانترنت \\
\hline $\mathrm{v}, \mathrm{l}$ & 7,9 & $\varepsilon, \varepsilon$ & فيس بوك \\
\hline 0,0 & $0, v$ & $r, q$ & تويتز \\
\hline צ, & 0,9 & $r, q$ & العمل \\
\hline$\varepsilon, \cdot$ & $\varepsilon, 9$ & $r, 0$ & كتيبات \\
\hline$r, q$ & $\varepsilon, \wedge$ & $r, r$ & الاجتماعات \\
\hline$r, \wedge$ & $\varepsilon, \varepsilon$ & $r, r$ & الرسائل النصية \\
\hline$\varepsilon, r$ & $\varepsilon, 0$ & $r, r$ & الايميل \\
\hline
\end{tabular}

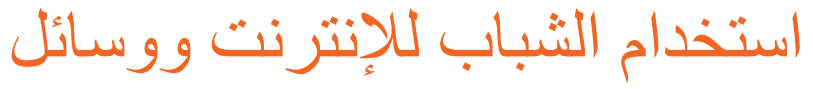

$$
\begin{aligned}
& \text { الإ علام قد تز ابد بشيكل كبير فى } \\
& \text { الخمس سنو اثن من أقل من ، } 1 \text { ٪ عام }
\end{aligned}
$$

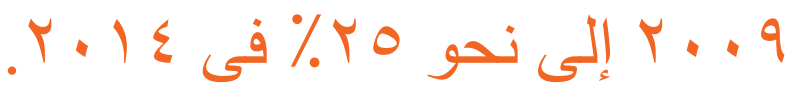

التشجيع على الثور ات التي حدثت في الثرق الأوسط وشمال

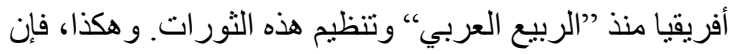

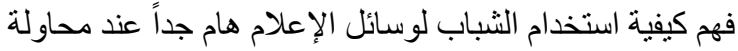

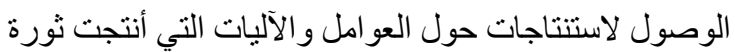
O ب يناير و غير ها من لحظات الحر الك السياسي.

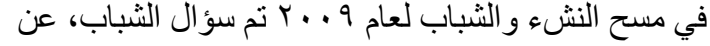

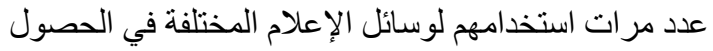

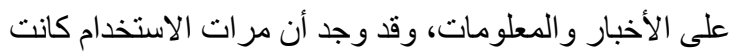

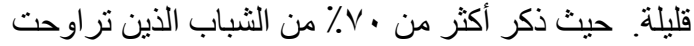

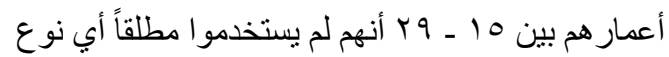

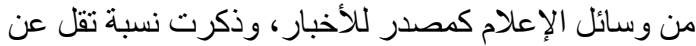

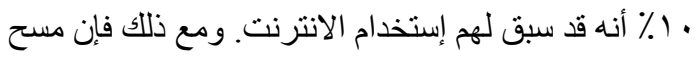

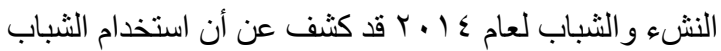

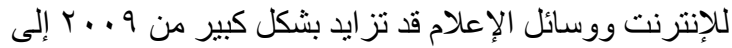

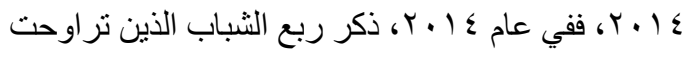

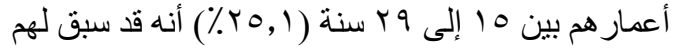

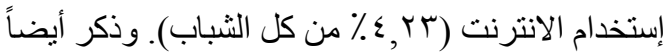

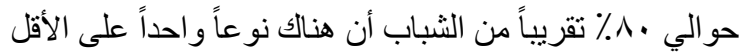

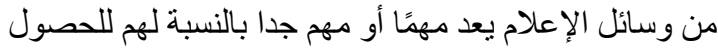
على معلومات حول ثورة بو ب يناير.

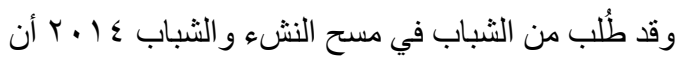
يقوموا بترتيب المصادر المختلفة للمعلومات حسب أهميتها

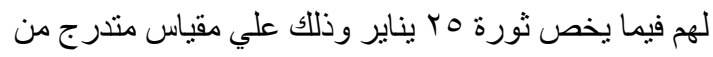

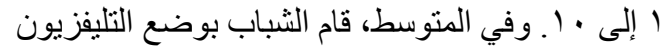

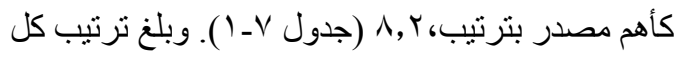

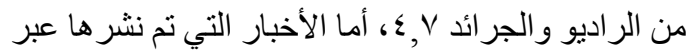

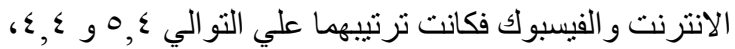

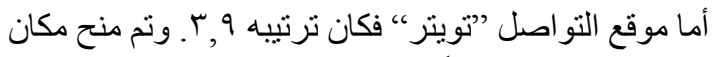

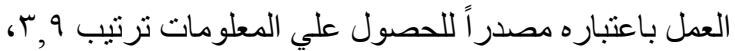

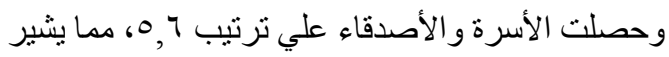

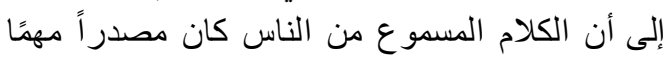




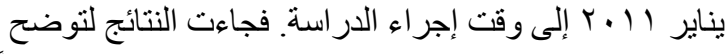

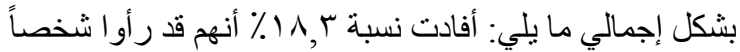

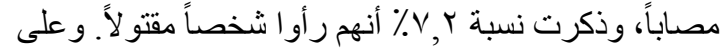

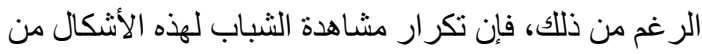

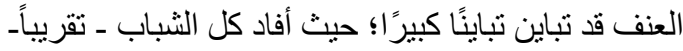

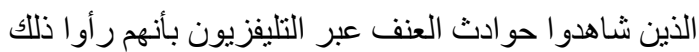

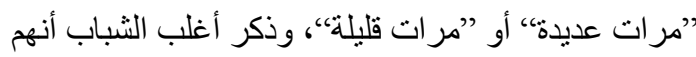

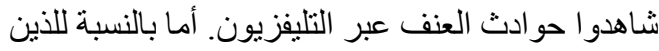

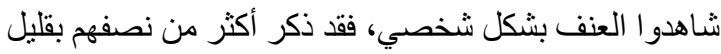

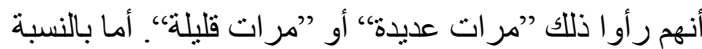

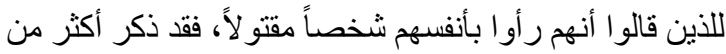

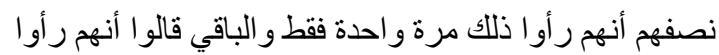
ذلك أكثر من مرة. ومرة أخرى، كان الذكور من الثباب، من الن النهائ
هي قياس تعرض الثباب بشكل مباثر وغبر مباثر للعنف أثناء

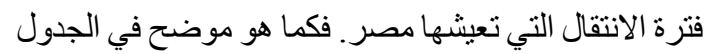

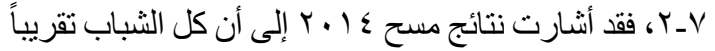

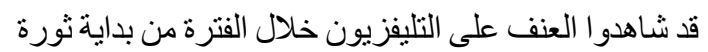

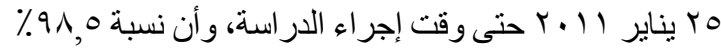

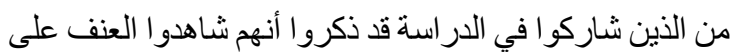

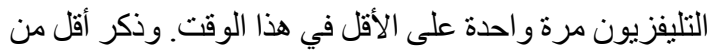

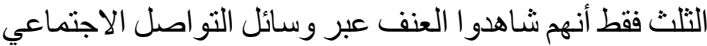
أثناء نفس الفترة. وقد أفاد الذكور من الثباب، و والذين تراوحت

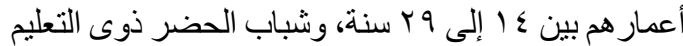
العالي، و أو لئك الذين جاءو ا من بيوت ثرية، بأنهم شاهدو العن العنف عبر وسائل التو اصل الاجتماعي.

وقد تم سؤال الثباب أيضاً عما إذا كانوا قد رأوا شخصاً

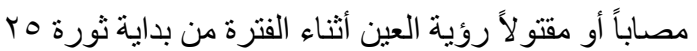

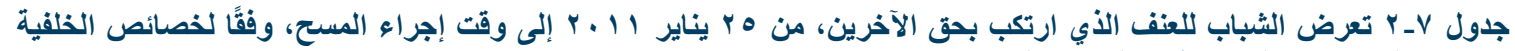

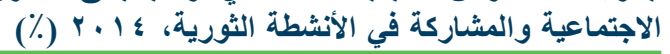

\begin{tabular}{|c|c|c|c|c|}
\hline روئة شخص مقتول & روئية شخص مصاب & وسائل التواصل & التليفزيون & \\
\hline & & & & النوع \\
\hline 9,7 & $r \leq, \cdot$ & $r v, \tau$ & $9 \wedge, \varepsilon$ & ذكر \\
\hline \multirow[t]{2}{*}{$\varepsilon, \vee$} & Ir,r & $r \leqslant, 0$ & 91,0 & أنثي \\
\hline & & & & القئة العمرية \\
\hline $0, r$ & $1 \leqslant, 9$ & rr,l & $9 \wedge, \wedge$ & $\mid V_{-1 T}$ \\
\hline$\wedge, \varepsilon$ & $r_{\cdot}, \cdot$ & $r \varepsilon, \wedge$ & $9 \wedge, \varepsilon$ & $r \varepsilon_{-} \mid 1$ \\
\hline$\checkmark, V$ & 11,9 & $r q, 7$ & $9 \wedge, r$ & rq_ro \\
\hline \multirow[t]{2}{*}{$7, \cdot$} & IV,r & $r \varepsilon,$. & $9 \wedge, r$ & ro_r. \\
\hline & & & & المحافظة \\
\hline $9, \cdot$ & $r, O$ & $0 \leqslant, 9$ & 99,1 & محافظات حضرية \\
\hline $1 \cdot, 9$ & rr,, & $r v, r$ & $99, \cdot$ & حضر الوجه البحري \\
\hline$\vee, \vee$ & $\mathrm{V}, \mathrm{V}$ & $r q, q$ & $q \vee, r$ & ريف الوجه البحري" \\
\hline$\varepsilon, \cdot$ & 7,1 & rT,O & 91,0 & حضر الوجه القبلي \\
\hline$\varepsilon, \cdot$ & $1 \cdot, r$ & $17, V$ & 99,1 & ريف الوجه القبلي \\
\hline \multirow[t]{2}{*}{$r \cdot, \wedge$} & $r q, 0$ & 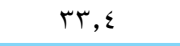 & $9 \wedge, r$ & محافظات الحدود \\
\hline & & & & التعليم \\
\hline$r, r$ & $\mathrm{v}, \mathrm{V}$ & $\wedge, \vee$ & 97,7 & أمي \\
\hline 1,9 & $1 \cdot, v$ & $\mathrm{~V}, \varepsilon$ & 99,1 & يقر أ ويكتب \\
\hline $7, r$ & $1 \leqslant, \Lambda$ & $10,$. & 91,0 & ابتدائي \\
\hline$\varepsilon, \wedge$ & 15,9 & $r \cdot, r$ & 99,1 & إعدادي \\
\hline$v, \cdot$ & $1 \wedge, \varepsilon$ & $\leqslant 0,9$ & $9 \wedge, 0$ & ثانوي عام \\
\hline$v, \cdot$ & IV,r & $r \leqslant, 0$ & १^, ₹ & ثانوي مهني \\
\hline 11,1 & $r \cdot, q$ & $\leq 7,0$ & 99,0 & فوق المتوسط \\
\hline $11,$. & $r V, V$ & $7 \cdot, \varepsilon$ & १^, $\vee$ & جامعي وفوق الجامعي \\
\hline & & & & مشاركة الثباب في الثورة \\
\hline $7, \mathrm{~V}$ & 17,9 & r^, $\Sigma$ & $9 \wedge, r$ & 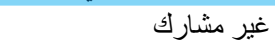 \\
\hline $1+, 1$ & $r_{0,9}$ & 70,1 & 99,9 & أية مشاركة \\
\hline rI,, & or, 9 & $\vee \wedge, 0$ & $1 \cdots$, & تتظيم سياسي \\
\hline $1+1$ & ד, Tr & 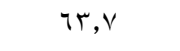 & 99,9 & لجان شعبية \\
\hline$r, \wedge$ & $T, 1$ & $\Lambda \cdot, 9$ & $1 \cdots$, & تظاهر \\
\hline$V, r$ & $1 \wedge, r$ & rI, r & 91,0 & الإجمالي \\
\hline$(1 \cdot, \wedge \wedge \wedge)$ & $(1 \cdot, \wedge 9 \cdot)$ & $(1 \cdot, \wedge \wedge 9)$ & $(1 \cdot, \wedge 9 \cdot)$ & 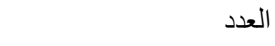 \\
\hline
\end{tabular}


أنهم تعرضو اللإساءة اللفظية فقد ذكروا أن ذلك قد حدث عند

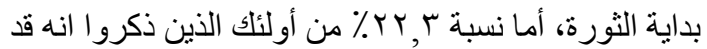

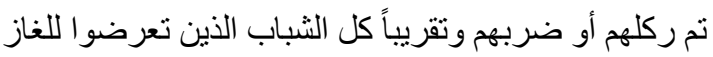

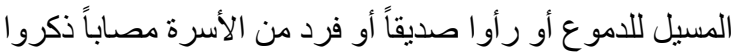

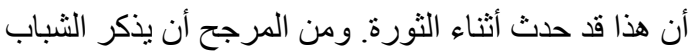

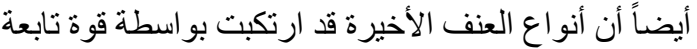

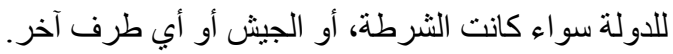

إن تلاك الإقرارات القليلة حول التعرض المباثر للعنف في التي

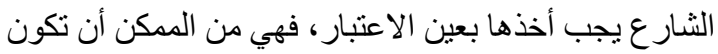

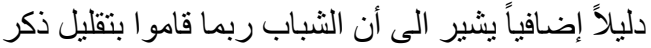

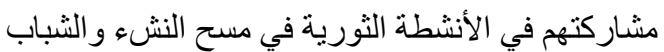

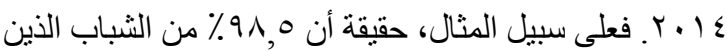
تعرضو اللغاز المُسيل للاموع ذكروا أن هذا حدث منذ الثورة

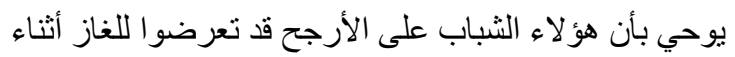

مظاهرة. و على الرغم من أنه من الممكن أن يكون هؤ لاء

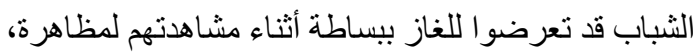

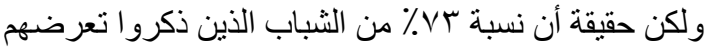

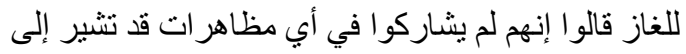

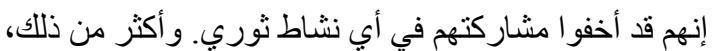
فالنسبة المرتفعة من الثباب الذين ذكروا أنهم قد رأوا بأنفسهم شخصاً قتل أو أصيب بالمقارنة بنسب ذكر مشاركتهم تبدو غير منسقة. إن هذا التناقض الكبير بين تللك الأرقام التي ذكرت

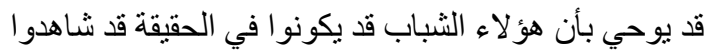
العنف أثناء تو اجدهم في المظاهر ات أو أب أحداث أخرى.

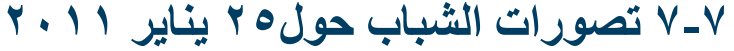

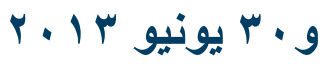

علي مدي السنو ات الأربعة الماضية حدث تغير في نظامين في مصر و هذا التغيير في الأنظمة لم يقم عن طريق الانتخابات:

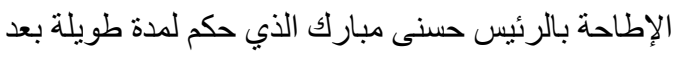

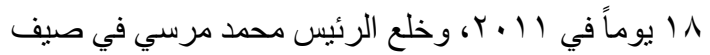

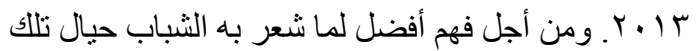

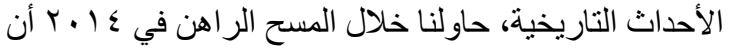

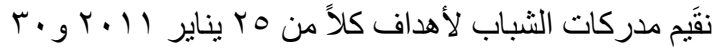

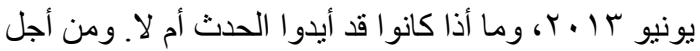

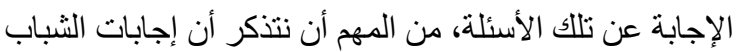

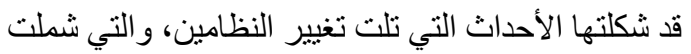
عدم الاستقرار السياسي و الكساد الاقتصادي. إن الإجابات

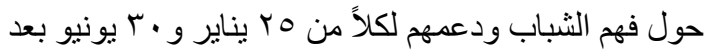

فئة منتصف العمر و الذين حصلو ا على تعليم عالي هم من

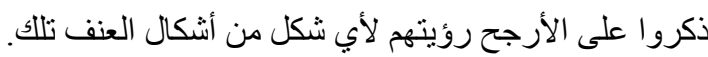

كما اختلف الثباب الذين ذكروا إنهم شاهدوا العنف رؤية

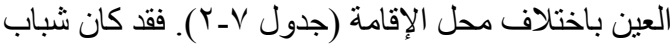
المحافظات الحدودية أعلى في مستوى مشاهدتهم للعنف، أفاد

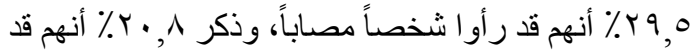

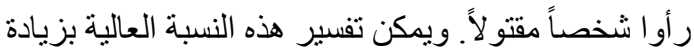

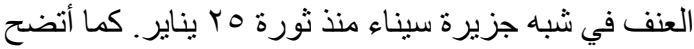

أيضًا أن الثباب في المحافظات الحضرية (حضر الوجها

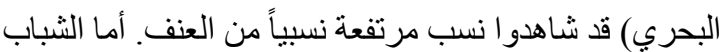

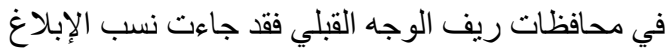
بمشاهدة عنف بأنفسهم منخفضة؛ حبث اشار •, ؛ ٪ منهم أنهم قد

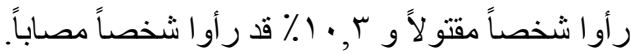
وتماثلا مع المعدلات المنخفضة في المشاركة في المظاهرات و غير ها من الأحداث، وفى المقابل من النتائج الدذكورة أعلاه،

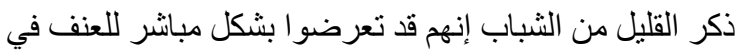

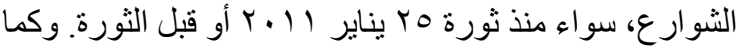

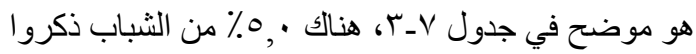

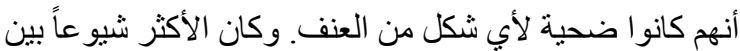

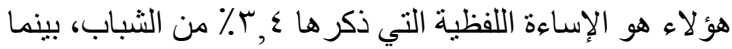

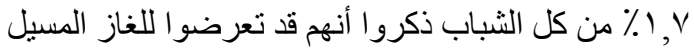

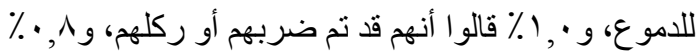

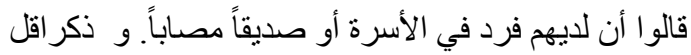

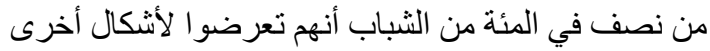

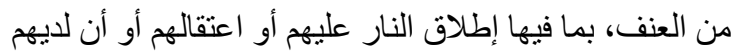

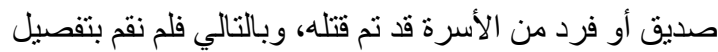
تللك الأرقام بشكل أكبر بسبب صغر حجم العنرة فينة.

و على الرغم من أن التعرض لأنو اع مختلفة من العنف كان

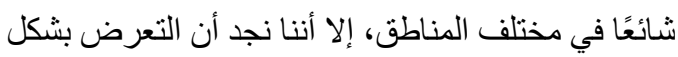

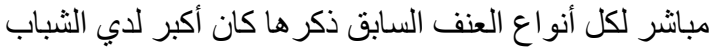

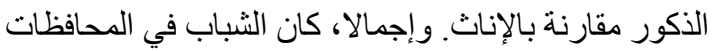

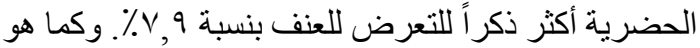

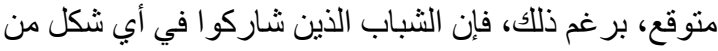

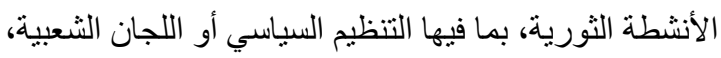

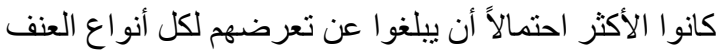

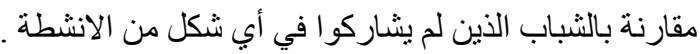

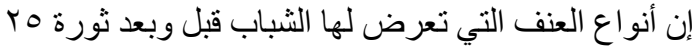

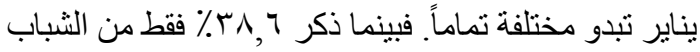


جدول V_r تجارب الشباب كضحايا للعنف، وفقًا لخصائص مختارة من الخلفية الاجتماعية، والمشاركة في النشاط الثوري، ووقت حدوث العنف.

\begin{tabular}{|c|c|c|c|c|c|}
\hline $\begin{array}{c}\text { إصابة صديق أو أحد أفرد } \\
\text { الأسرة }\end{array}$ & غلاز مُسيل & 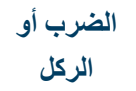 & الإسـاءة & أن أي شكل من العنف & \\
\hline & & & & & النوع \\
\hline $1, r$ & $r, r$ & 1,7 & $\varepsilon, \wedge$ & $\mathrm{V}, \mathrm{r}$ & ذكر \\
\hline$\cdot, r$ & $\cdot, \mathrm{V}$ & $\cdot, \varepsilon$ & 1,9 & $r, \tau$ & أنثي \\
\hline & & & & & الفئة العمرية \\
\hline$\cdot, r$ & $1, \cdot$ & 1,1 & $r, v$ & $\varepsilon, 0$ & $\left|V_{-}\right| T$ \\
\hline$\cdot, \mathrm{V}$ & $r, \cdot$ & 1,1 & r,o & 0,0 & $r \varepsilon_{-11}$ \\
\hline $1, r$ & 1,1 & $1, r$ & $r, \tau$ & $0, \varepsilon$ & rq- ro \\
\hline$\cdot, \wedge$ & 1,7 & $\cdot, 0$ & $r, r$ & $r, \Lambda$ & ro-r. \\
\hline & & & & & المنطقة \\
\hline$r, 1$ & $0, r$ & $\cdot, \mathrm{V}$ & $r, 1$ & $\vee, q$ & محافظات حضرية \\
\hline$\cdot, r$ & 1,1 & $\cdot, 0$ & $1, \cdot$ & 1,9 & حضر الوجه البحري \\
\hline$\cdot, \varepsilon$ & $\cdot, 9$ & $\cdot, \mathrm{V}$ & $r, \cdot$ & r,q & ريف الوجه البحري \\
\hline$\cdot, r$ & 1,0 & $\cdot, \wedge$ & $\varepsilon, V$ & $7, \cdot$ & حضر الوجه القبلي \\
\hline$\cdot, \varepsilon$ & $\cdot, 7$ & 1,1 & $\varepsilon, 7$ & $0, \varepsilon$ & ريف الوجه القبلي \\
\hline$r, \cdot$ & $\cdot, 7$ & $\cdot, \varepsilon$ & $1, r$ & $\varepsilon, 1$ & محافظات الحدود \\
\hline & & & & & مشاركة الثباب في الثورة \\
\hline$\cdot, r$ & $\cdot, \varepsilon$ & $\cdot, \wedge$ & $r, \wedge$ & r, & غير مشارك \\
\hline $7, \cdot$ & 18,1 & r, & $1 \cdot, 7$ & $r_{0, V}$ & أية مشاركة \\
\hline $1 T, \varepsilon$ & rт, l & $r, \varepsilon$ & $1 \pi, r$ & $r \Lambda, r$ & تنظيم سياسي \\
\hline 0,7 & IV,r & $r, \tau$ & 9,1 & $r \leqslant, 0$ & لجان شعبية \\
\hline 0,1 & ro, s & $0, \cdot$ & $1 \%, 7$ & $\varepsilon 1, \cdot$ & تظاهر \\
\hline$\cdot, \wedge$ & $1, \mathrm{~V}$ & $1, \cdot$ & $r, \varepsilon$ & $0, \cdot$ & الإجمالي \\
\hline$(1 \cdot,, \vee 94)$ & $\left(1 \cdot, Y_{Y}\right)$ & $(1 \cdot, \vee 9 \wedge)$ & $(1 \cdot, \wedge 9 \cdot)$ & $(1 \cdot, \wedge 9 \cdot)$ & العدد ا \\
\hline$(9 \wedge)$ & $(179)$ & $(9 r)$ & $($ (rY $)$ & $(0 \cdots)$ & إجمالي عدد المستجبين (من أجابو ا بنعم) \\
\hline 97,0 & $9 \wedge, 1$ & $r, r$ & rᄉ, & N/A & 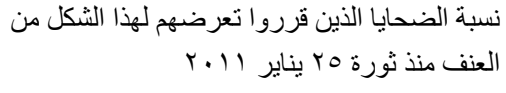 \\
\hline $0 \wedge, 0$ & $\uparrow \wedge, \varepsilon$ & $9, r$ & $\Lambda, r$ & N/A & ون نسبة الضحايا الذين قرروا تعرضهم لهذا الشكل \\
\hline
\end{tabular}

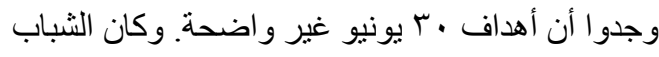

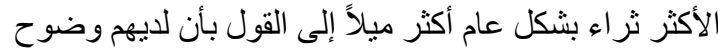

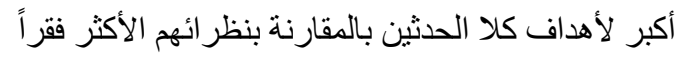

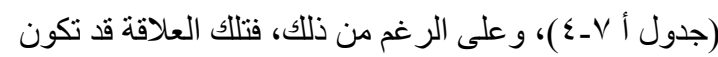

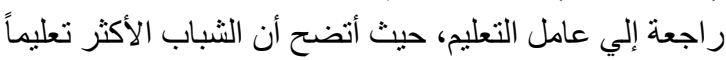

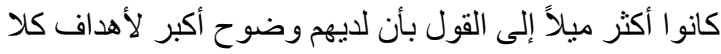

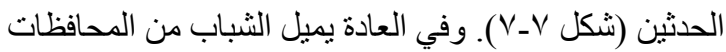

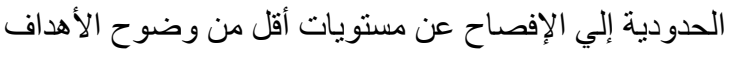
بالنسبة لكلا الحدثين. وكان الثباب الذكور أكثر ميلاً لذكر أن الأن

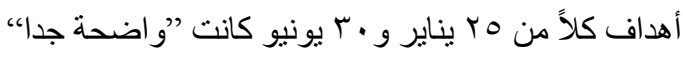
بالمقارنة بالإناث، اللاتي ذكرن أن أهداف الحدثين كانت

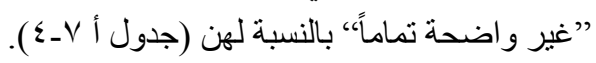

مضي سنتين، و عدة أشهر ، على التو الي، قد يكون مختلفاً عن

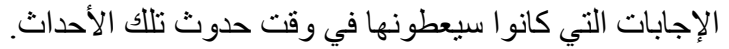

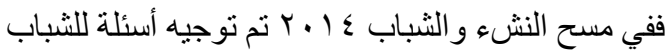

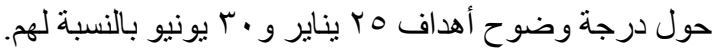

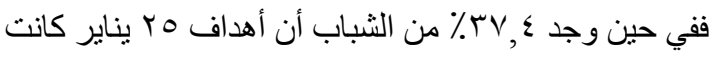

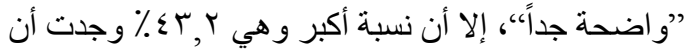

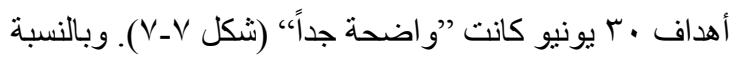

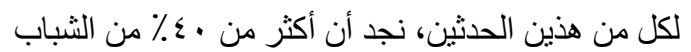

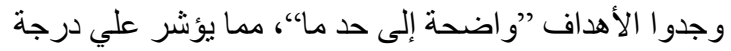

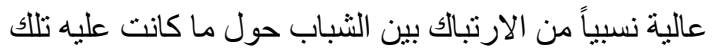

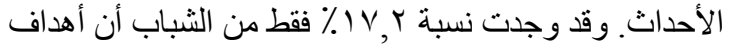

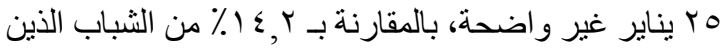




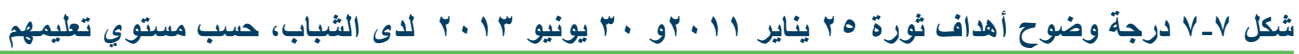

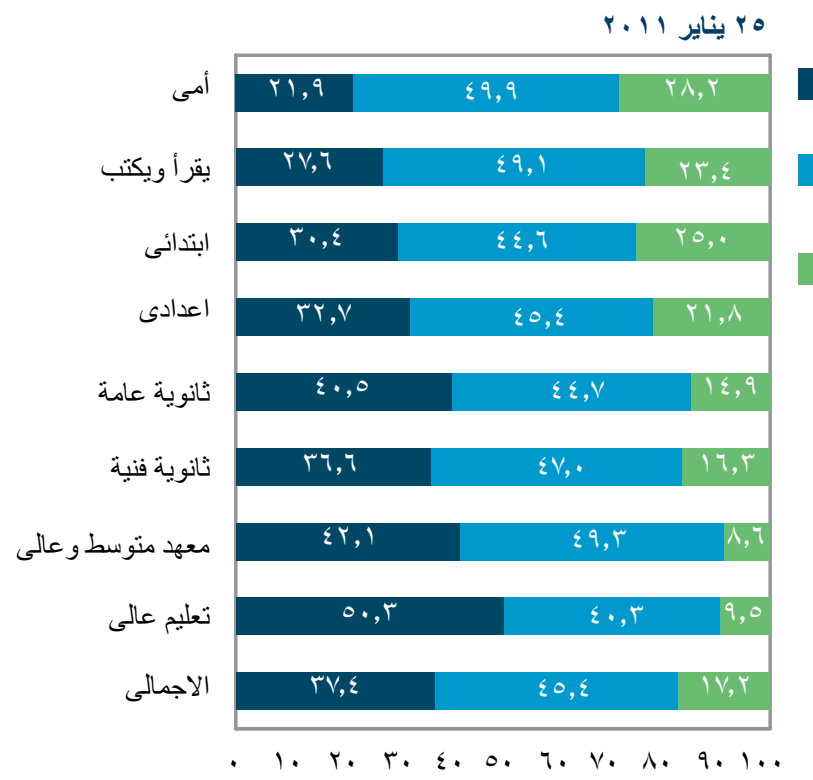

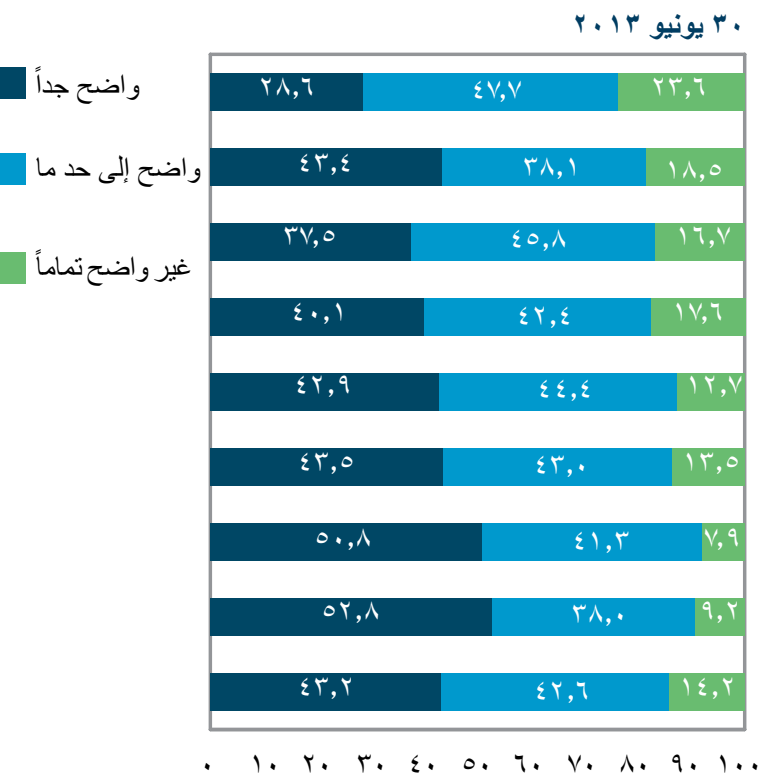

أن هؤ لاء المرشحين تم استبعادهم بعد ذلك من قبل المحكمة

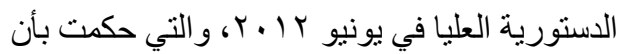

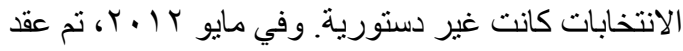

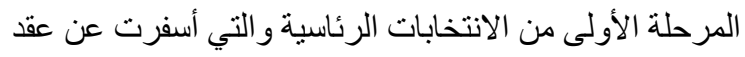

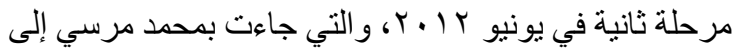

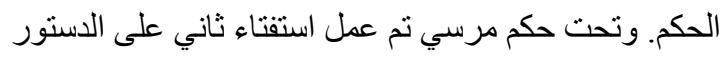

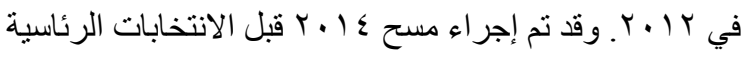

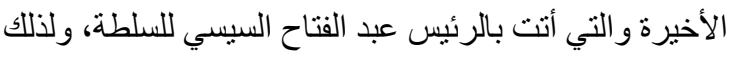
فإن البيانات حول مشاركة الثباب في تللك الاتنخابات الأخيرة

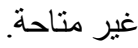

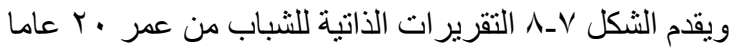

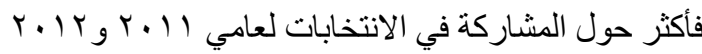

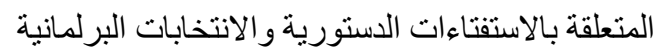

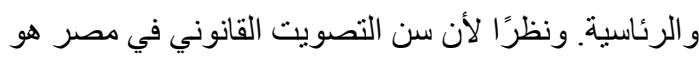

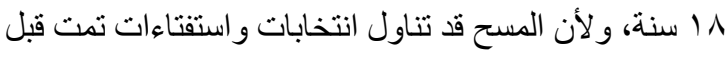

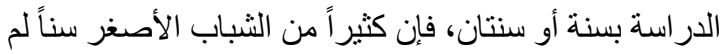

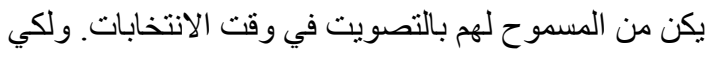

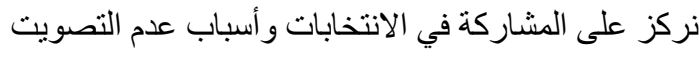

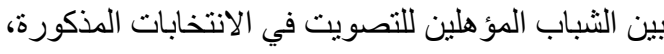

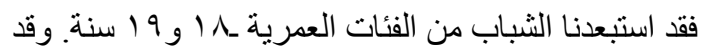

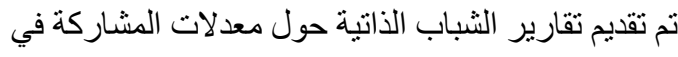
الانتخابات وفقًا لمختلف الخلفيات الاجتماعية و المشاركة فى لألى

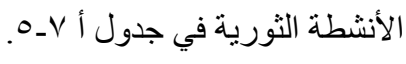

\section{A_V

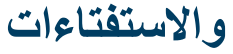

احتكر الحزب الوطني الديمقر اطي في ظل حكم مبارك، بشكل

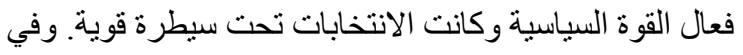

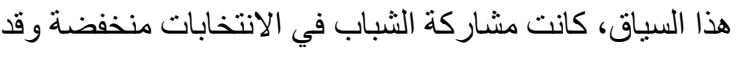

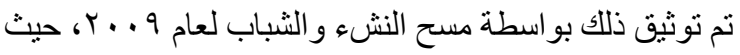

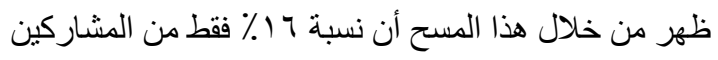

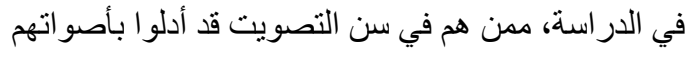

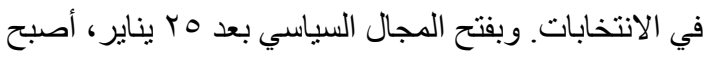

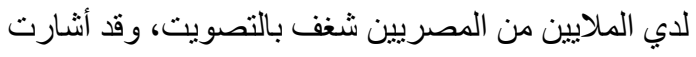

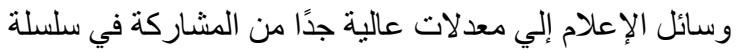

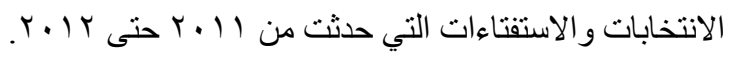

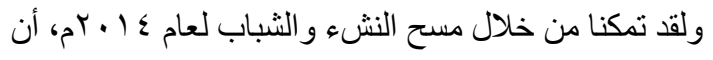

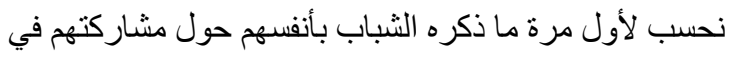
هذه الانتخابات، وفحص الاختلاف في معدلات المشاركة في الانتخابات لدي مجمو عات مختلفة من الثباب.

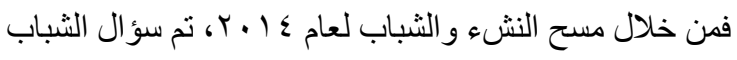

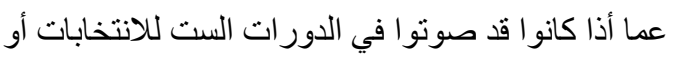

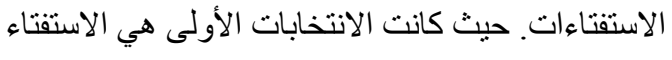

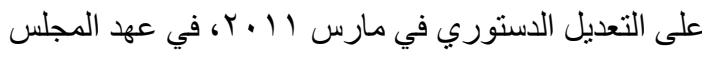

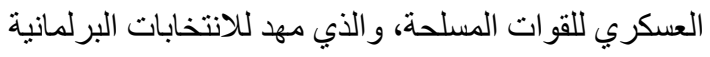

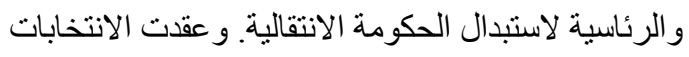

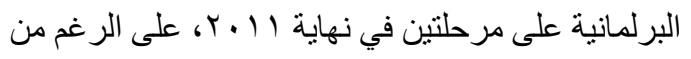




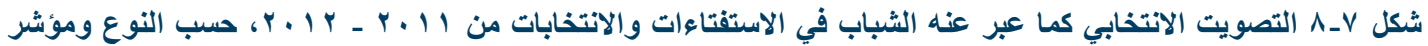

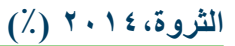

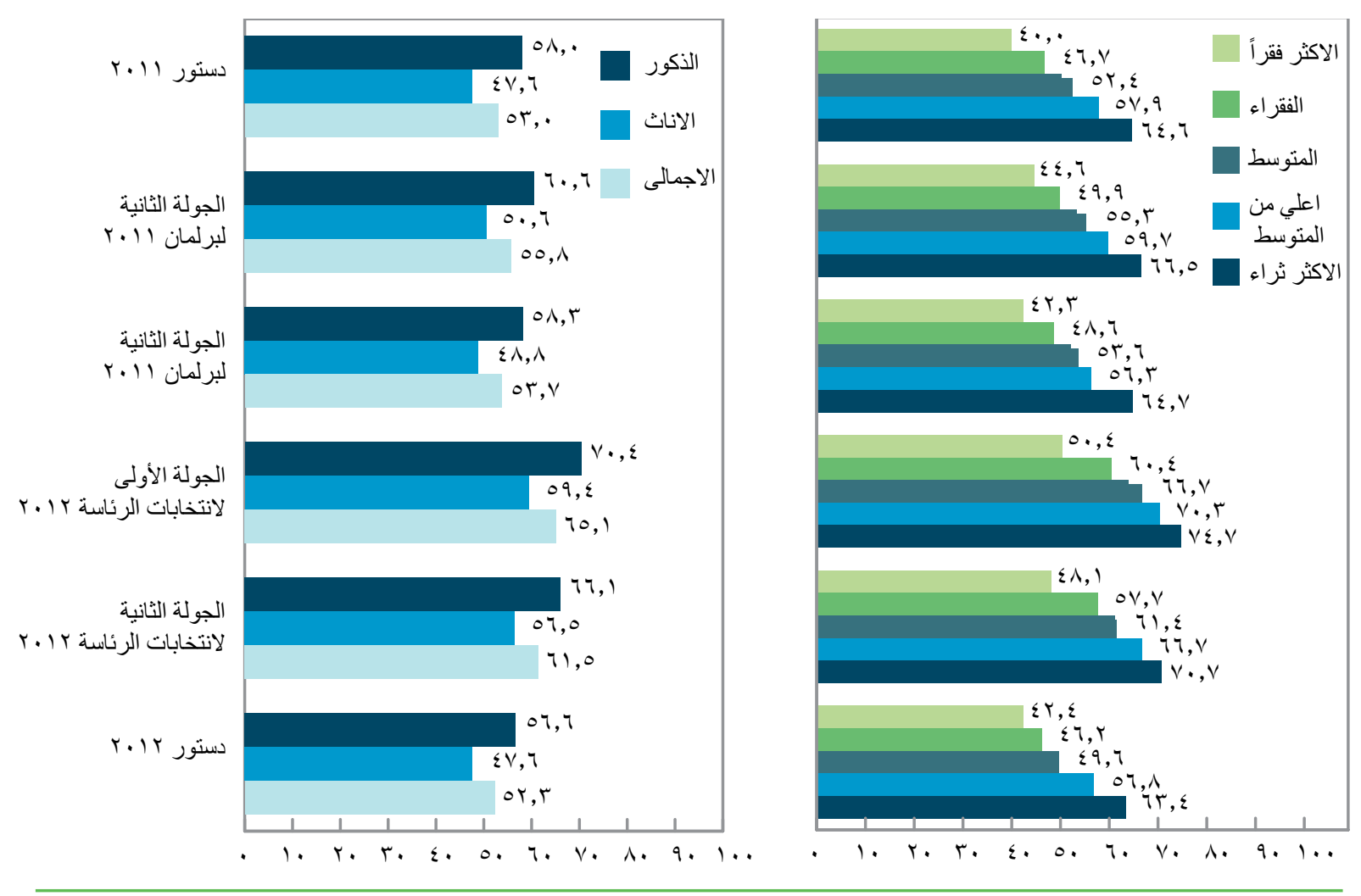

في الثباب المؤهلين للتصويت في محافظات الوجه القبلي

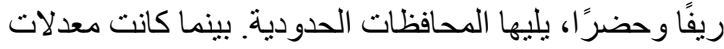

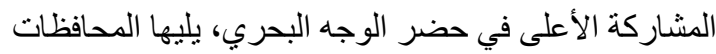

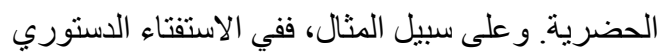

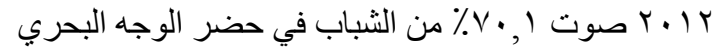

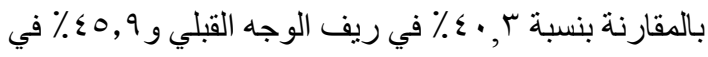
حضر الوجه القبلي.

وقد كانت معدلات المشاركة في الانتخابات دائماً أعلى بنسبة من 7 ـ 9 ٪ بين الثباب من سن • ب سن فما فوق بالمقارنة

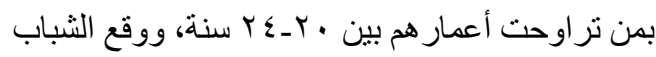
من سن 0r ـ ـ و في المنتصف. وفي المقابل، فإن الثباب المنزوج كان أكثر مشاركةً من نظرائهم غير المتزوجين في ولي كل الاستفتاءات و الانتخابات. و على الرغم من أن الحكومة

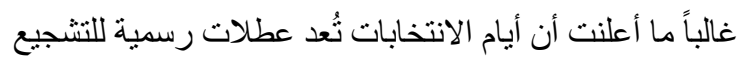

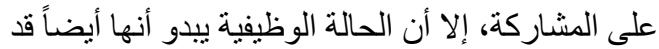

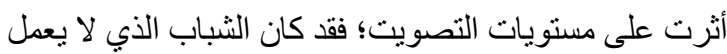
أعلى في معدلات المشاركة من الثباب الذي يعمل. وكانت

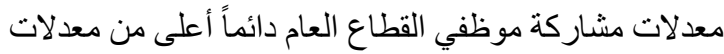

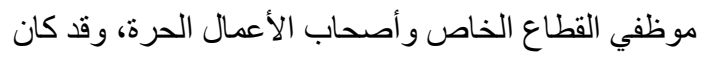

إن مشاركة الثباب في الانتخابات المحلية قد نز ايدت بشكل

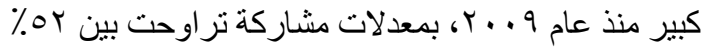
إلى 70\%. وكما هو منوقع، فإن مشاركة الشباب الأعلى

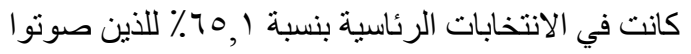

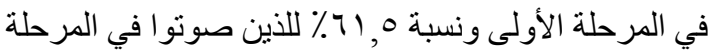

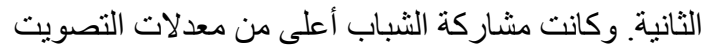

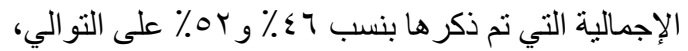

بالنسبة لهذين الانتخابين (Carter Center 2012). أما لـابه في الاستفتاءين على التعديلات الدستورية فقد كانت مشاركة الشباب هى الأقل وكانت نسبة كلاهما حو الي به ٪. لاستفتاء I I . Y و Y | . Y، فقد عكس انخفاض المشاركة الإجمالية بنسب إء٪ و rr\% على التوالي. ولكن كما هو موضتح من خلال هذه الأشكال كانت معدلات مشاركة الثباب لهن أعلى من معدلات المشاركة لبقية الثعب (Sabry 2012).

ولقد اختلف السلوك التصويتي لدى الثباب منذ هب بناير

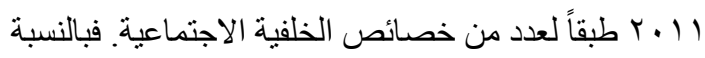
للإناث، كان معدل مشاركتهن أقل بنسبة ـ ـ ـ من الذكور

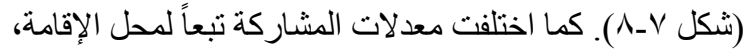
فقد وجدنا أن المشاركة في التصويت كانت أقل بشكل عام 


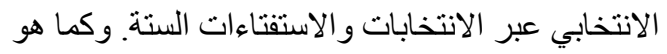

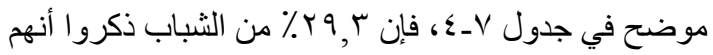

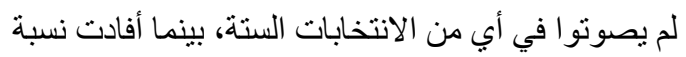

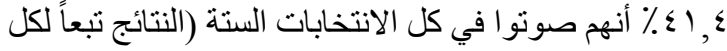

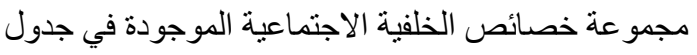

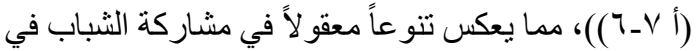

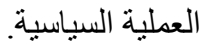

وقد جاءت أنماط عدم المشاركة في أي انتخاب منسقة مع ما

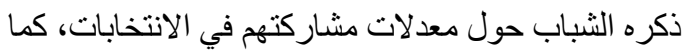

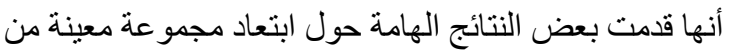

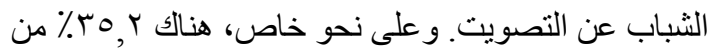

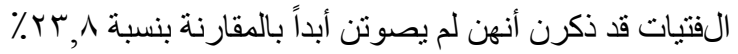

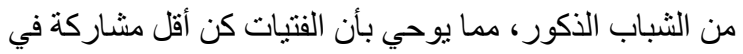

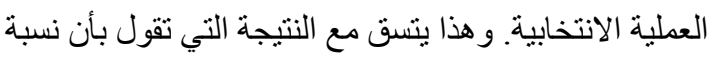

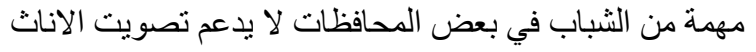

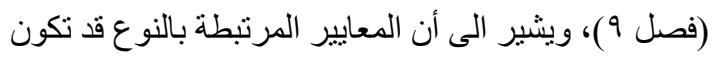

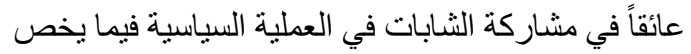

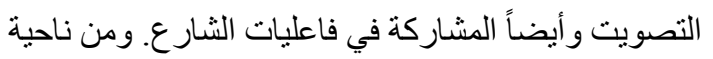

جدول V- ـ نسب الثباب الذين ذكروا أنهم لم يصوتوا أبداً

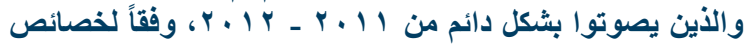

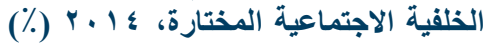

\begin{tabular}{|c|c|c|}
\hline يصوئمًات & لم يصدًات & \\
\hline & & النوع \\
\hline$\leqslant 0, \varepsilon$ & $r r, \wedge$ & ذكر \\
\hline$r v, 1$ & ro,r & أنثي \\
\hline & & المحافظة \\
\hline$\leqslant 0,0$ & $r r, 0$ & محافظات حضرية \\
\hline 09,9 & $1 \leqslant, \wedge$ & حضر الوجه البحري \\
\hline$\varepsilon r, \varepsilon$ & $r r, \wedge$ & ريف الوجه البحري \\
\hline$r v, r$ & $r r, \xi$ & حضر الوجه القبلي \\
\hline$r \cdot, q$ & $r \wedge, q$ & ريف الوجه القبلي \\
\hline$r \Lambda, r$ & $r \varepsilon$, & محافظات الحدود \\
\hline & & التعليم \\
\hline$r \cdot, r$ & $0 \leqslant, V$ & أمي - أمي \\
\hline$r, r$ & $r, 0$ & يقر أ ويكتب \\
\hline$r 1,0$ & $r V, \varepsilon$ & ابتدائي \\
\hline$r, r$ & $r \wedge, r$ & إعدادي \\
\hline$r v, 0$ & $r$ r, & ثانوي عام \\
\hline$\varepsilon \cdot, \wedge$ & $r q, 9$ & ثانوي مهني \\
\hline $0 \leqslant, r$ & $\mid v, A$ & فوق المتوسط \\
\hline or,, 0 & 17,7 & جامعي وفوق الجامعي \\
\hline$\leqslant 1, \varepsilon$ & $r, r q$ & الإجمالي \\
\hline
\end{tabular}

مشاركة الثباب في الانتخابات المحلية

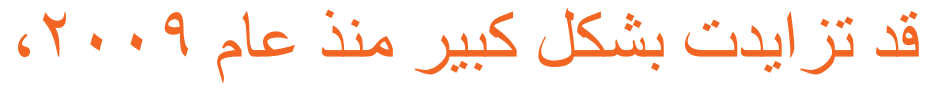

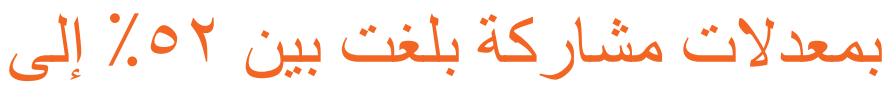
$\%$

العمال بدون أجر هم الأقل في معدلات المشاركة. وقد تكون تللك الأنماط من المشاركة في علافتها بالحالة الوظيفية متأثرة

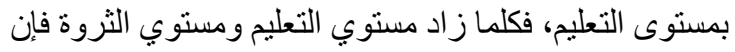
ذلك يرتبط بمعدلات أعلى في المشاركة في الانتخابات. فبينما

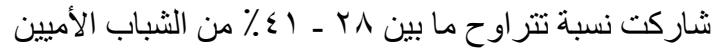

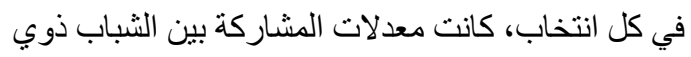

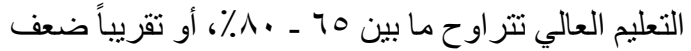

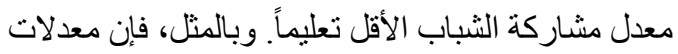

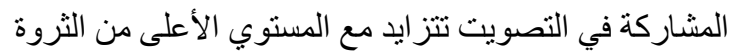

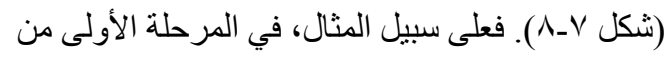

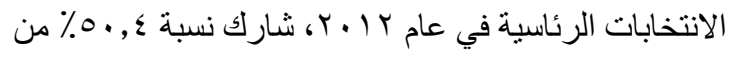
الثباب في الخمس الأدنى من الثروة في الانتخابات، بالمقارنة الثانة

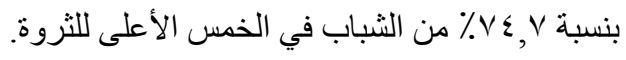

وتوضح نتائج المشاركة في الانتخابات أيضاً أن النشاط

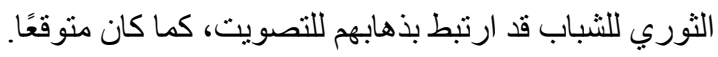

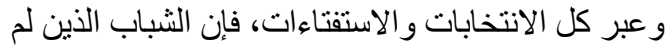

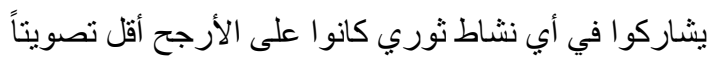

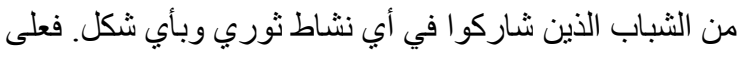

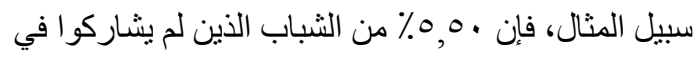

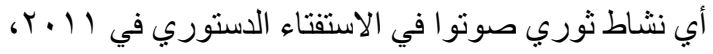

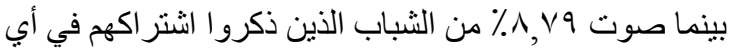

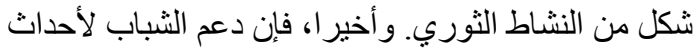

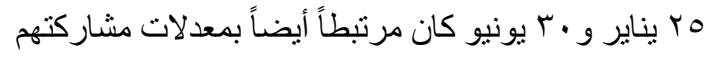

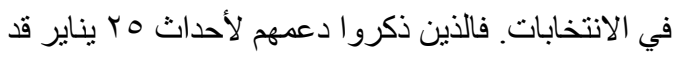

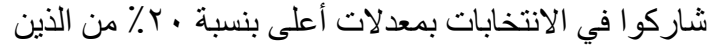

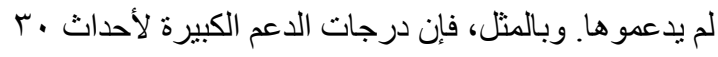
يونيو قد ارتبطت بمعدلات أكبر في المشاركة في الانتخابات.

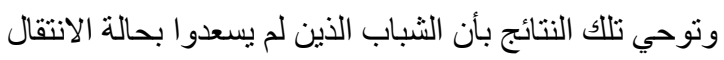

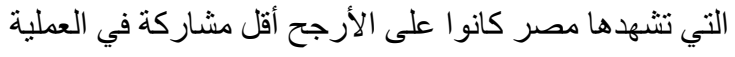
السياسية وفي ممارسة حقهم في التصويت.

أوضحت النتائج أن هناك مجمو عة من الثباب لم تتمكن من

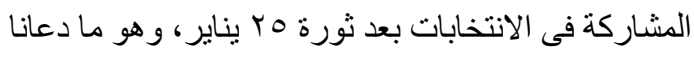
للقيام بتحليل إضافي حول استمر ار الثباب في الخروج 


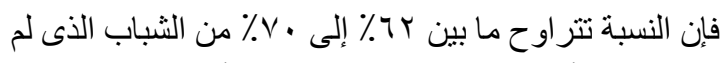

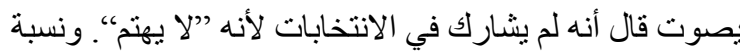

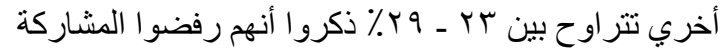

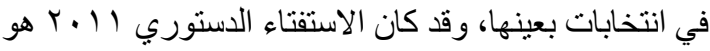

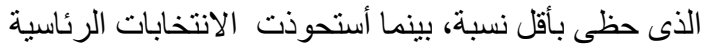

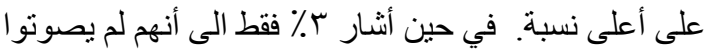

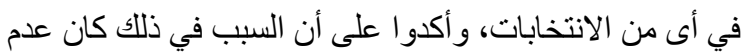

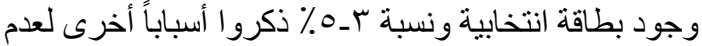

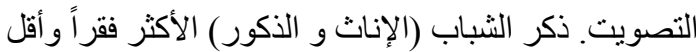

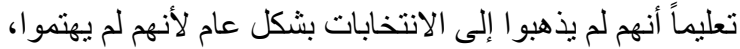

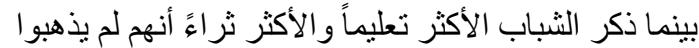
للتصويت لأنهم رفضوا المشار كة.

وأخير اً، قام المسح بطرح سؤ ال علي الثباب حول مدي

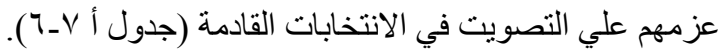

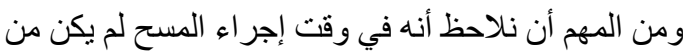

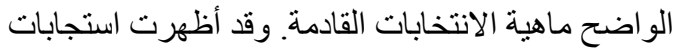

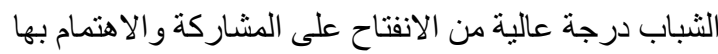

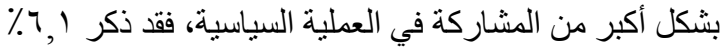

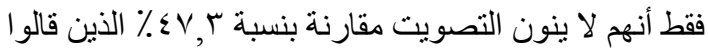

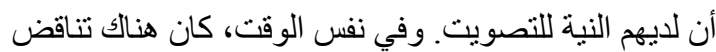

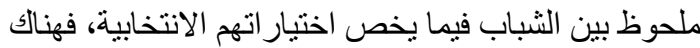

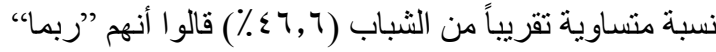

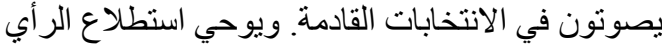

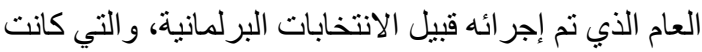

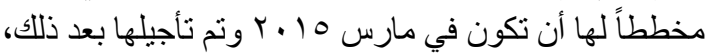
بأن الثباب بشكل عام ماز ال مهتم بمواصلة المشار إنساركة رسمياً

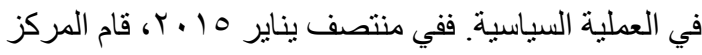
المصري لبحوث الر أي العام (بصيرة) بعمل استطلاع للر أبي

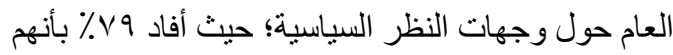

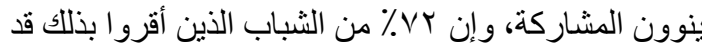

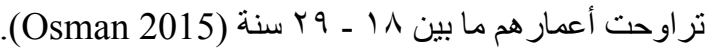

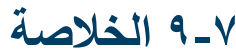

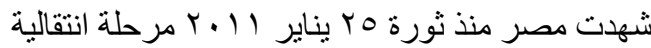

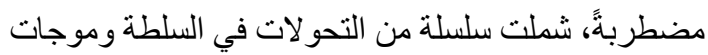
من الاضطر ابات المدنية و المظاهر ات. وخلال تلاتك الأحداث،

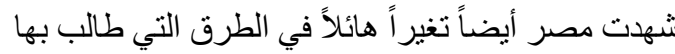

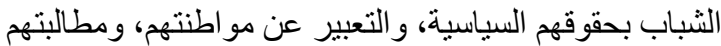

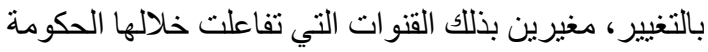

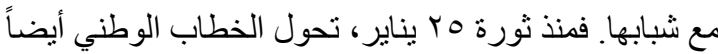

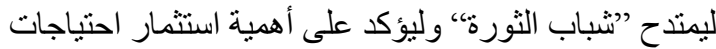

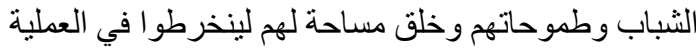

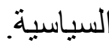

أخرى، وكما سوف يتم مناقشته فيما يلي، فإن الثابات قد ذكرن

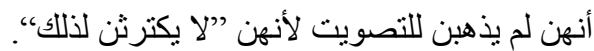

كان شباب الصعيد و المحافظات الحدودية أكثر ابلاغا أنهم لم يشاركو ا مطلقا في التصويت، إلي جانب ذوى المستويات الدنيا

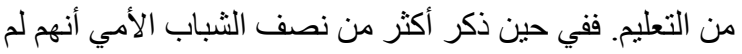

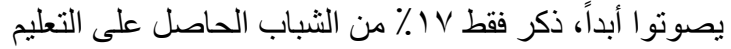

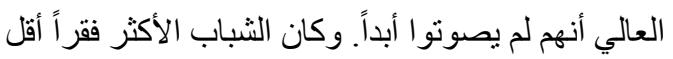

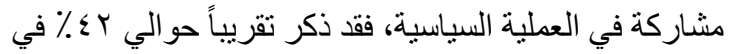

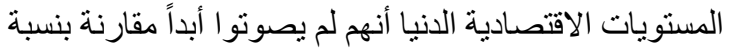
ا I \% من الثباب الذين يقعون في المستويات الاقتصادية العليا. و علي نفس وتيرة نتائج المشاركة في الانتخابات، كان الثباب

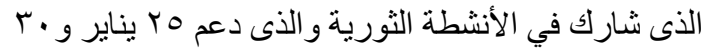

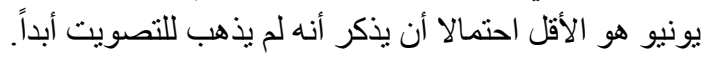

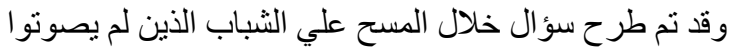

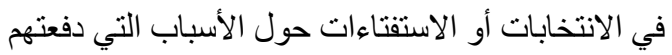

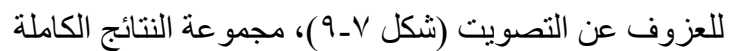

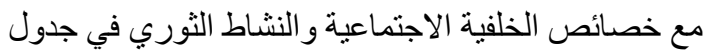

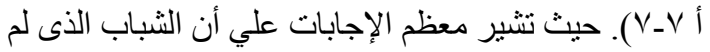

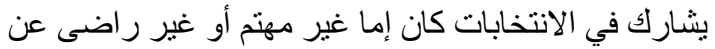

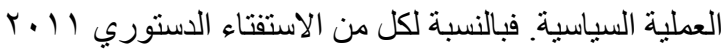

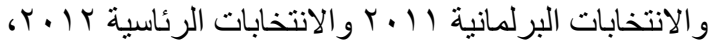

شكل Y Y Y أسباب عدم التصويت في الانتخابات الرئاسية

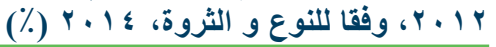

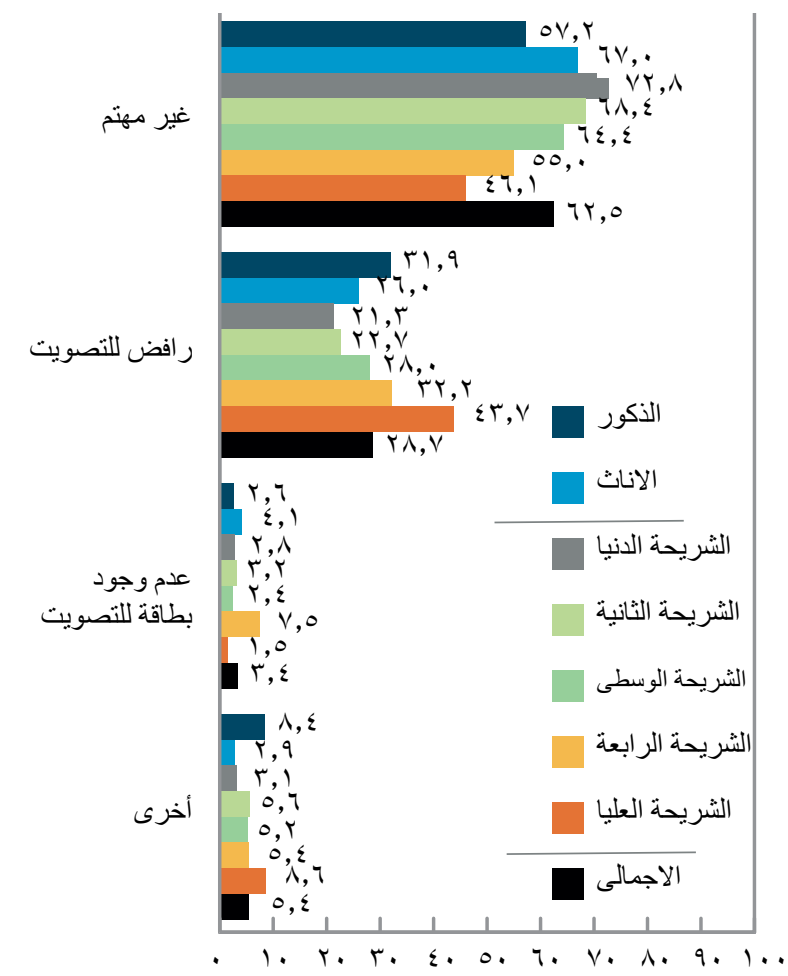


وفي الختام، فإن نتائج هذا المسح توحي بقدر أكبر من التنوع في الر أي بين الثباب حول ثورة ب ب يناير و الأحداث التالية لها

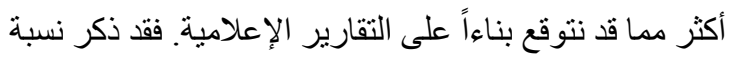

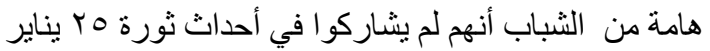
لارتباكهم حول أهدافهاأو لعدم كونهم ضد النظام القديم، وتللك

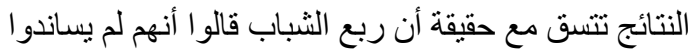

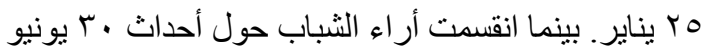

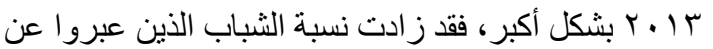
عدم وضوح الأهداف بالنسبة لهم و الدعم المختلط للأحداث.

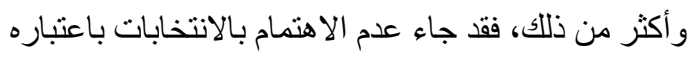

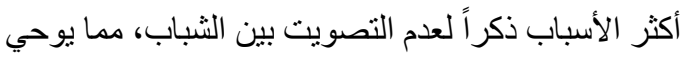
بأن الارتباك حول الأحداث أو معارضة الأبداث لأحداث التي شهدتها شو ارع مصر قد تؤدى إلى عزوف الثباب عن المشاركة

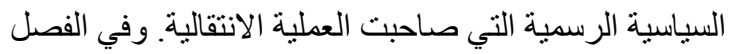

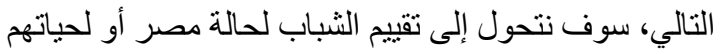
لكي نكتثف أكثر كيف يمكن أن يؤثر هذا التنوع في الر أي في لئي أحلامهم بالنسبة للمستقبل وفي انخر اطهم في أنشطة لتحسين

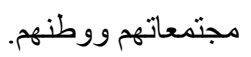

\section{المراجع}

Carter Center. 2012. "Presidential Election in Egypt: Final Report." Atlanta: The Carter Center. www.cartercenter. org/resources/pdfs/news/peace_publications/election_reports/egypt-final-presidential-elections-2012. pdf. Accessed 20 January 2015.

Dunne, Michele and Scott Williamson. 2014. "Egypt's Unprecedented Instability by the Numbers." Carnegie Endowment for International Peace, 24 March. www.carnegieendowment.org/2014/03/24/egypt-sunprecedented-instability-by-numbers/h5j3. Accessed 20 January 2015.

Mungin, Lateef. 2011. "Amnesty: Egypt far from justice over unrest that killed more than 800." CNN, 19 May. Accessed 20 January 2015.

Osman, Maged. 2015. "Political Conditions in Egypt: Press Release." Baseera. January. www.baseera.com. eg/pdf_poll_file_en/participation\%20in\%20parliamentary\%20elections-\%20En.pdf. Accessed 25 April 2015.

Population Council. 2010. Survey of Young People in Egypt Final Report. Cairo: Population Council.

Sabry, Bassem. 2012. "The meaning of Egypt's referendum," Al Monitor, 23 December. www.al-monitor.com/ pulse/originals/2014/01/egypt-referendum-constitution-evaluation.html. Accessed 20 January 2015.
وتقدم بيانات مسح النشء و الثباب ـ ا ـ ب صورة أكثر تعقيداً

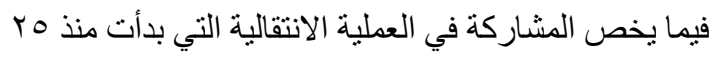

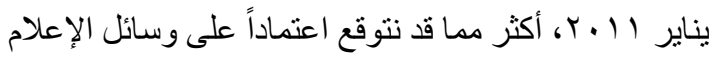

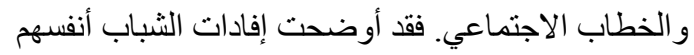

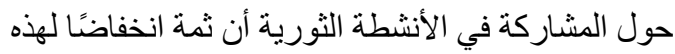

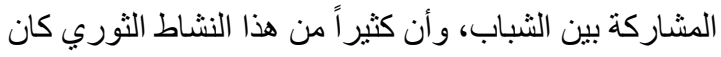

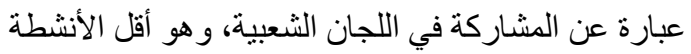

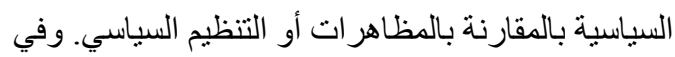

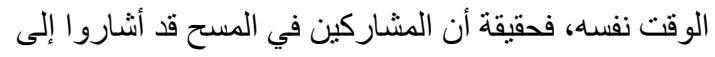
معدلات أعلى من المشاركة بالنسبة لأفر اد عائلتهم و أصدقائهم الماته

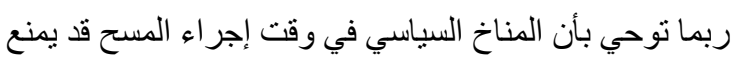

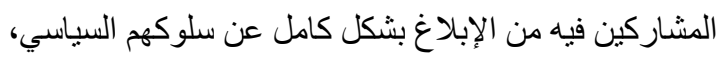

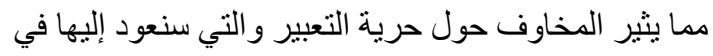

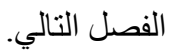

وقد وضحت البيانات التي تم جمعها من خلال المسح أن

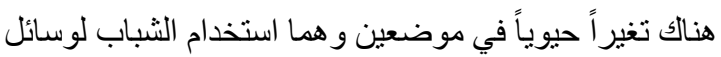

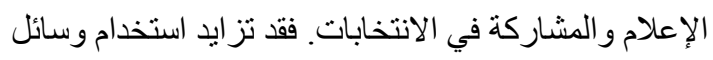

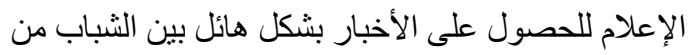

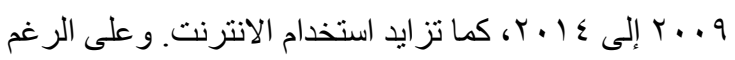

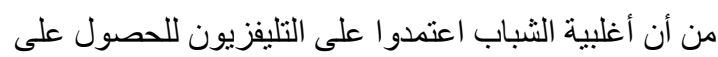

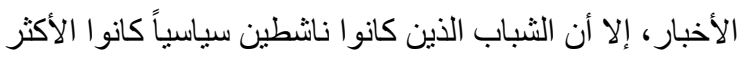

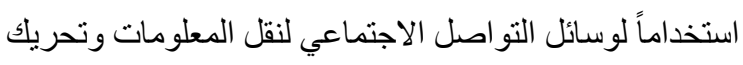

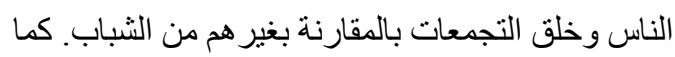

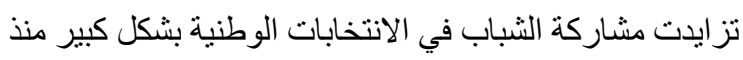

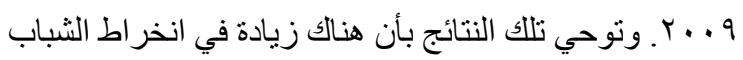

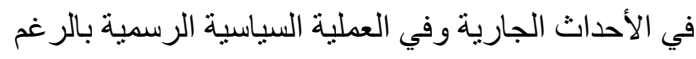

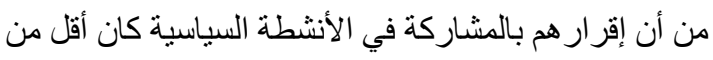
المنوقع.

ومع ذللك، فإن نتائج هذا المسح تثير عددا من المخاوف حول وجود مجمو عة فرعية من الثعب لم تنتأثر بالعملية السياسية

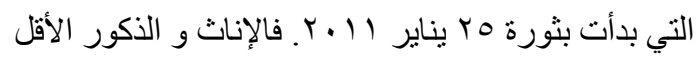

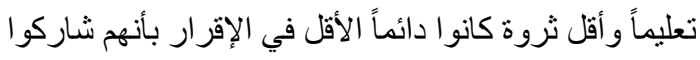

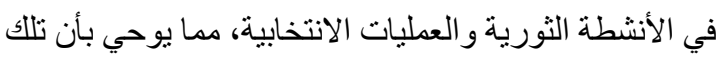

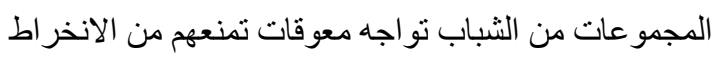

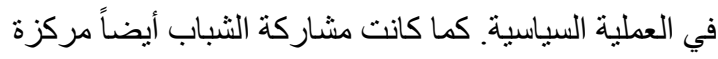

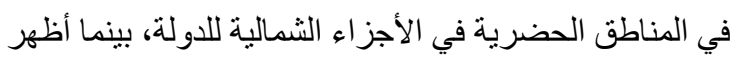

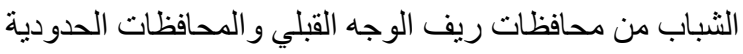

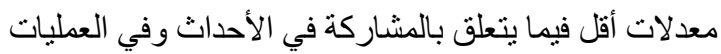

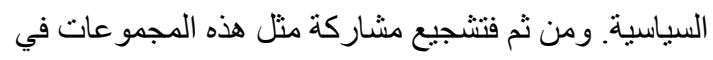
العملية السياسية هو المفتاح لخلق تحو لاً ديمقر اطياً حقيقياً. 
للأنظمة المصرية الثلاثة الأخيرة وفقًا لمجمو عة متتو عة من المؤشر ات المتعلقة بالديمقر اطية، و التنمية، وسيادة القانون. وسوف نناقش مشاركة الثباب في الأنشطة التطو عية منذ مستح

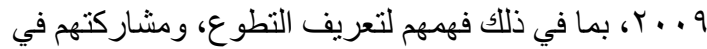

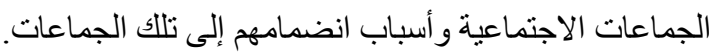

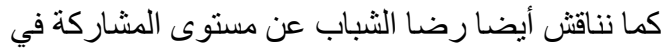
مجتمعاتهم المحلية بشكل موسع.

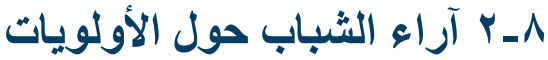 والتهديدات التي تواجه الدولة}

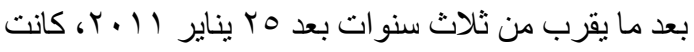
تقدير ات الثباب حول مدي نجاح الحركة الثورية و أهميتها المستمرة لمصر يشوبها الخلط الثنديد. فكما هو مبين في الثكل 1ـ ا ، فإن ما يقرب من نصف الثباب قد أيد أو أيد بشدة عبارة

أن مصر "في حاجة إلى إصلاح، ولكنها ليست في حاجة

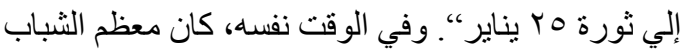
لا يعتقدون أن O Y يناير قد حققت الإصلاحات التي تحتاجها

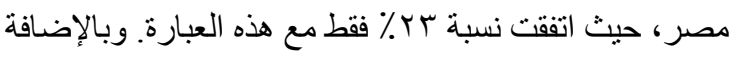
إلى ذللك، ففي حين وافق أكثر من نصف الثباب على أن ثورة

شكل ^ـــ ـ رأي الثباب حول مدي ضرورة ونجاح ثورة الخامس

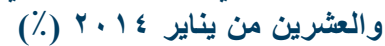

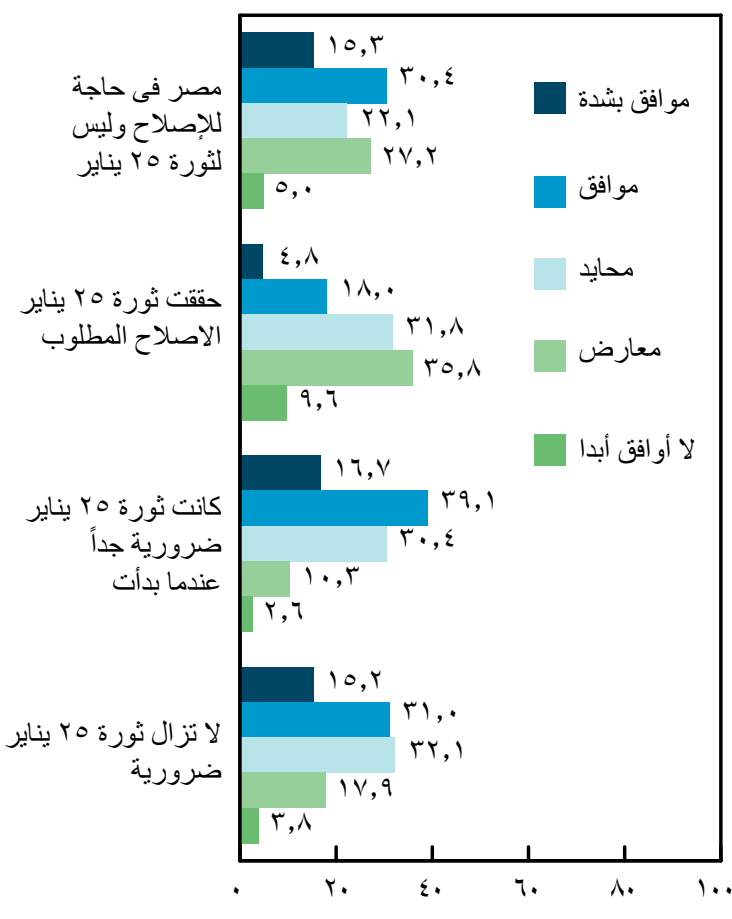

مما لاشك فيه أن آراء الثباب قد تأثرت بالتحو لات التي تمر بها مصر في هذه الفترة الحرجة من تاريخها، وتأثرت كذللك اهتمامهم بالمشاركة في تنمية وطنهم، هذه التحو لات تؤثر بشكل جلي علي توقعاتهم تجاه المستقبل و علي مشاركتهم لأقر انهم، ولمجتمعاتهم المحلية، ولوطنهم. وفي نفس الوقت، فإن تصور ات الثباب للكيفية التي تعبر بها مصر المرحلة الانتقالية وتأثير ها علي حباتهم لها آثار هامة علي انتقال هذا لفال

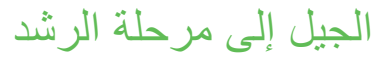

\section{1ـــ ا مقدمة}

تكون مشاركة الثباب الفاعلة في التغيير الاجتماعي والسباسي

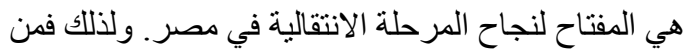

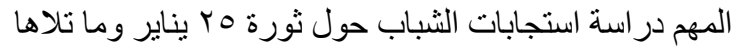

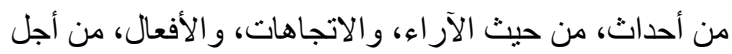
فهم أفضل لكيفية تثجيع مشار كتهم المدنية.

وفي هذا الفصل، سوف نقوم بدراسة آراء الثباب حول القضايا

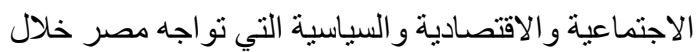

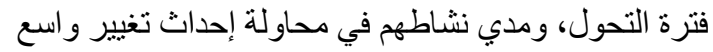

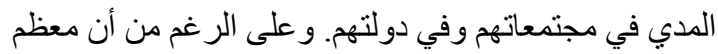

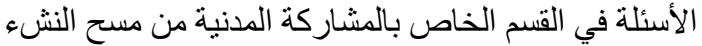

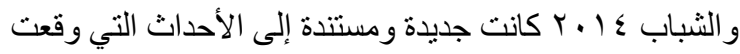

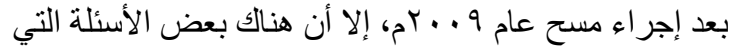

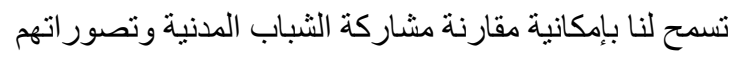
حول القيم الاجتماعية خلال المسحين.

وسوف نبدأ بآراء الثباب حول ماهية الأولويات التي يجب أن النا

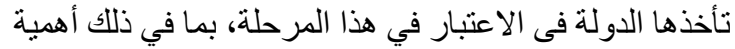

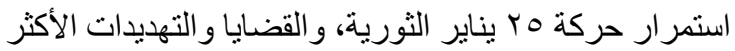

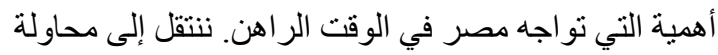

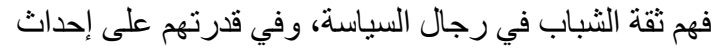
تغيير سياسي، كما نحاول أيضا أن نتعرف علي تقيبيم الثباب 
طغت الهموم الاقتصادية بشكل و اضح على الهموم السياسية فيما يتعلق بالتحسينات التي يود الثباب بأن تتم

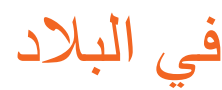

وفي ظل هذه الظروف، طغت الهموم الاقتصادية بشكل و اضح على الهموم السياسية فيما يتعلق بالتحسينات التي يود الثباب

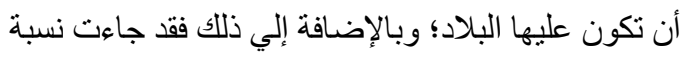
؟,9 ٪ من الثباب لتضع تحسين التعليم و الر عاية الصحية على الصى

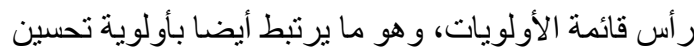
المستويات المعيشية وتأمين الاحتياجات الأساسية.

ووضعت نسبة تسعة في المئة من الثباب محاربة الفساد على كلى كائه

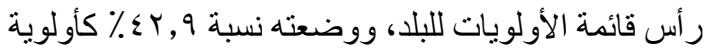
ثانية. ومع ذللك، فقد اعتقدت نسبة v, ٪\% فقط من الثباب أن

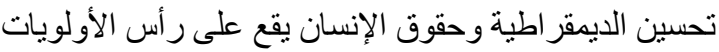

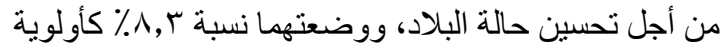

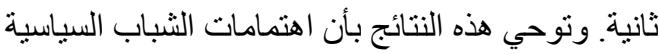

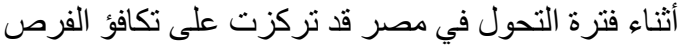
و الحاجة إلى الحد من الاستخدام الخاص للمو ارد العامة، و هو الأمر الذي يرتبط بالعودة مرة أخرى إلى حالة القلق الثديد

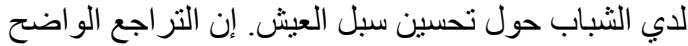

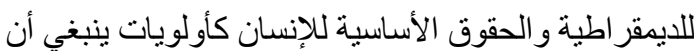
يؤخذ بعين الاعتبار في ضو ء ما قد يوحى به من استعداد الثباب للضغط على الحكومة لحماية حرياتهم و استقلالها خلال

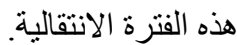

وأخير ا، جاء زيادة تأثير الدين على السياسة والقانون في المرتبة الدنيا من أولويات الثباب جاء كأولوية اولي بنسبة

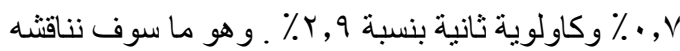
في القسم التالي، و الذي يؤكد علي وجود نمط عام في بيانات المسح يوحي بأن الثباب المصري، و ولا سيما في أعقاب العام فئ فئات المضطرب الذي قضاه الرئيس الأسبق مرسي في السلطة، قد ظهرت لديهم الثكوك حول الدور السياسي للاين.

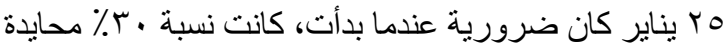
حول هذه النقطة، وكان رأي الثباب حول الحاجة الملحة

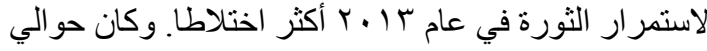

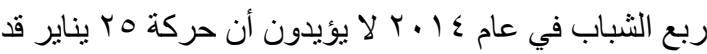
ظلت ضرورية، مقارنة بنسبة ب ا ٪ فقط الذين لم يو افقو ا علي أن الثورة كانت ضرورية عندما بدأت. ونتشير هذه النتائج

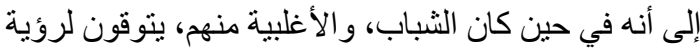

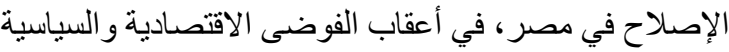

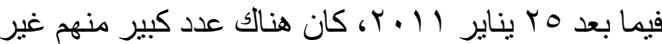
متأكد مما إذا كانت الثورة وسيلة فعالة لخلق هذا التغيير. و على النقيض من آر اء الثباب المختلطة حول أهمية استمر ار الثورة كحل لمشاكل مصر، كان ر أي الثباب حول الأولويتين

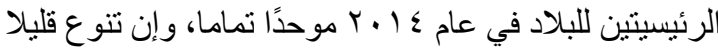
حسب خصائص الخلفية الاجتماعية. فقد ذكرت نسبة كبيرة

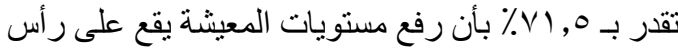

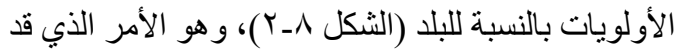

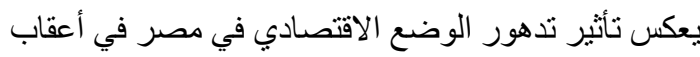

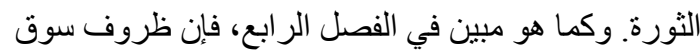

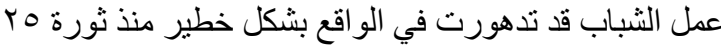
يناير، واستمر الثباب باعتبار هم الفئة الأكثر حرمانا في سوق العمل المصري من حيث معدلات البطالة، و الأجور، و والأمن والاستقر ار الوظيفي (Krafft and Assaad eds, 2015).

شكل ^_r r. رأي الثباب حول أثثين من الأولويات الكبرى للاولة، (\%) $r+1 \leq$

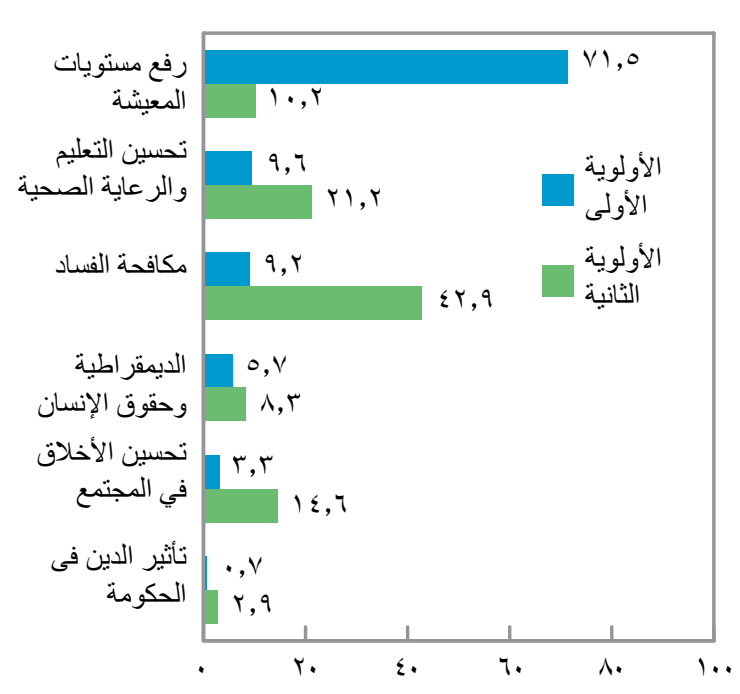




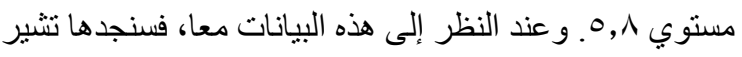

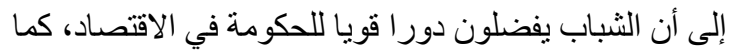

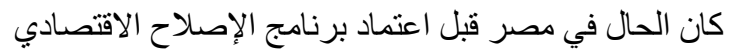
و الاصلاح الهيكلي في بدايات عام • 99 ام (Assaad 1997). أما رأي الثنباب في اثتين من كبرى التهديدات التي نو اجها

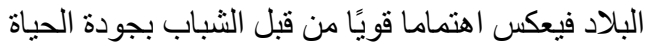

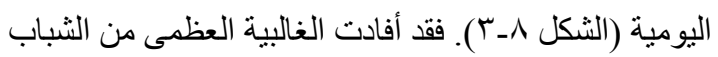

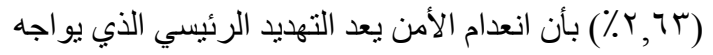

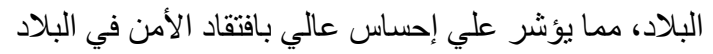

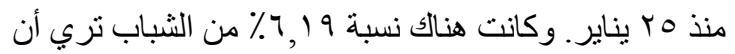

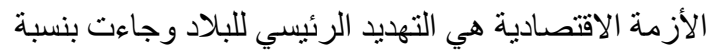

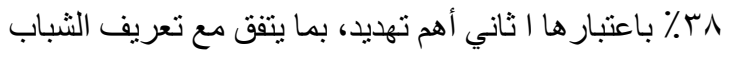
للقضايا المتعلقة بتحسين مستويات المعيشة كأولوية رئيسية

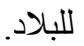

واعتبرت نسبة ضئيلة من الثباب أن تأثير وسائل الإعلام

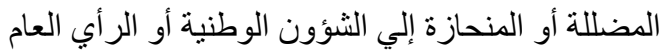

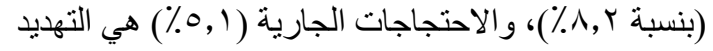

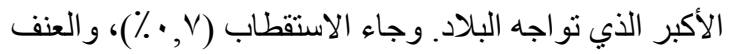
من قبل المتظاهرين (1, (\%)، واستمر ار وجود فلول نظام

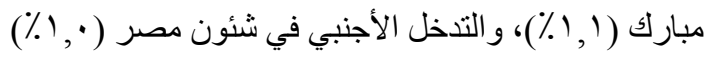

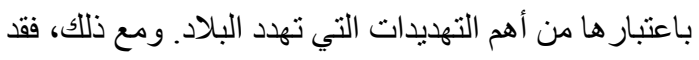

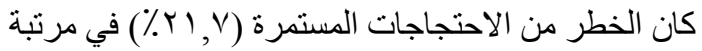

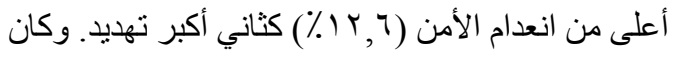

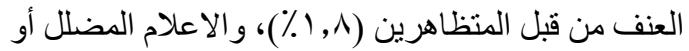

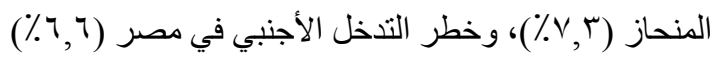

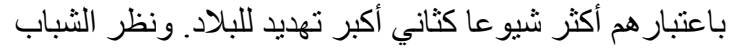
إلى الاستقطاب الذي يعاني منه المجنمع المصري التهري كأقل التهديدات التي تو اجه البلاد أهمية بشكل عام.

\section{A_r الآراء حول السياسة والنشاط السياسى}

جنباً إلى جنب مع قياس مثشاركة الثباب في التنظيم السياسى

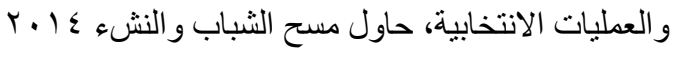
تقييم درجة الثقة فيما اذا كانو ا هم أنفسهم، ورجال السيال والسياسية،

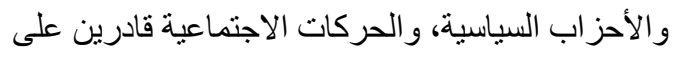

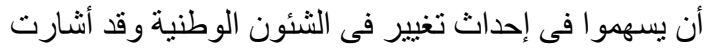

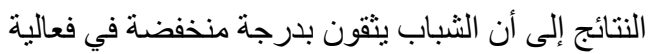

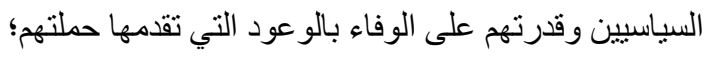

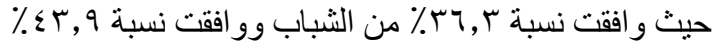

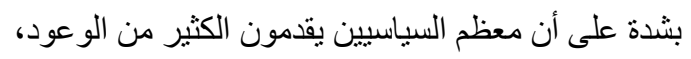

ونظر اً لتركيز الثباب على رفع مستويات المعيشة باعتبار ها

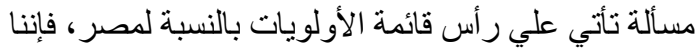

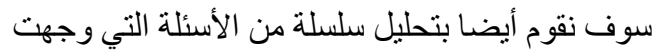
للشباب حول تقييم عدد من التصريحات المتعلقة بالسياسات

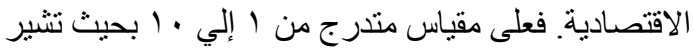

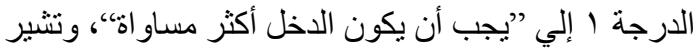

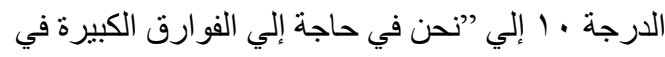

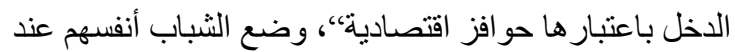

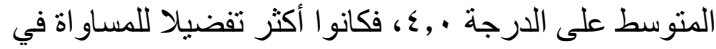

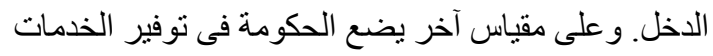

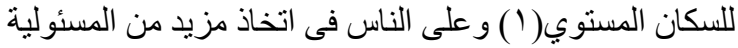

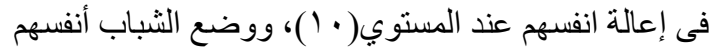

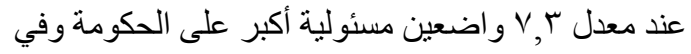

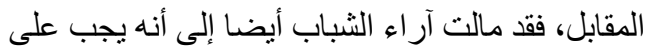

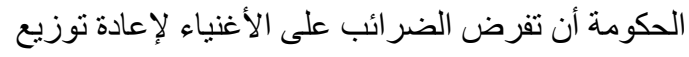
الاخل. و عند مقارنة بيانات الملكية الخاصة لقطاع الأعمال

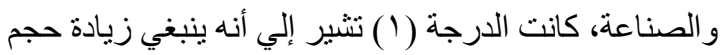
الملكية الخاصة لقطاع الأعمال و الصناعة، و الدرجة (ل) (1)

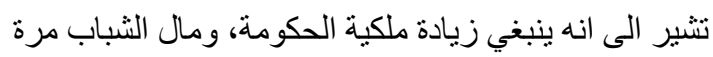

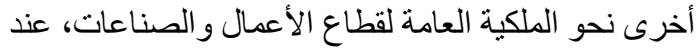

شكل ^_ ب رأي الثباب في أعلي ترتيبيين للتهديدات التي تواجه

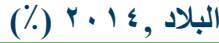

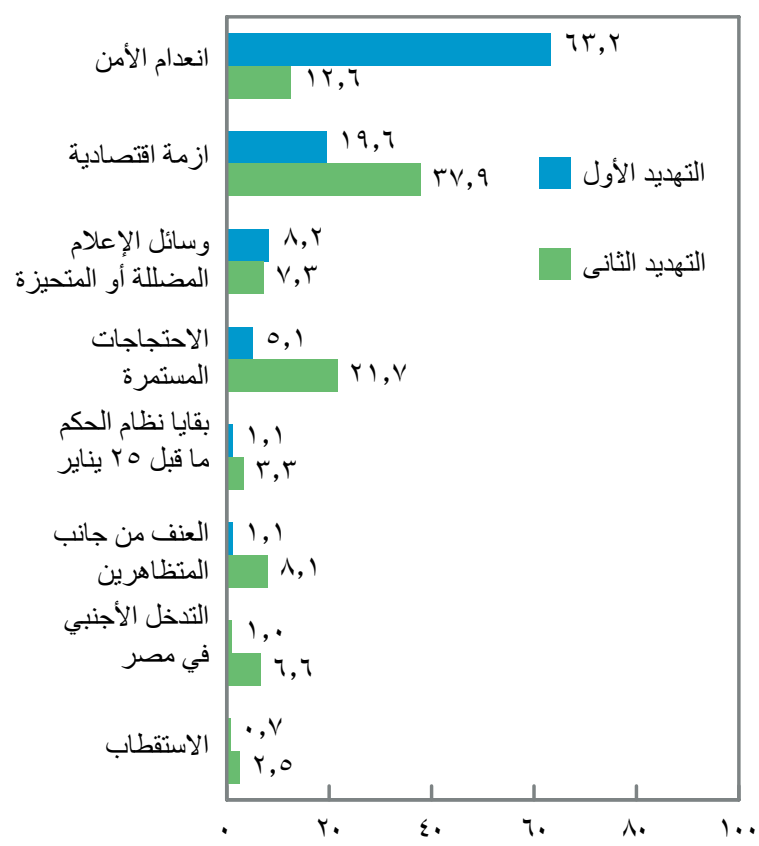


الممكن أن يكون لها تأثثر على السياسة العامة، وأيدت نسبة

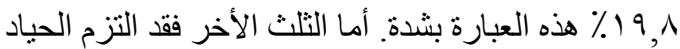

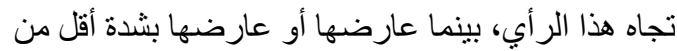
10\%. وتوحي هذه النتائج بأن الثباب بشكل عام كانوا اليجابيين تجاه قدرتهم على التأثر في التغيير السياسي. وقد يظهر ذلان التك جليا في نسب التصويت العالية بين الثباب في ع أ ـ ب مقارنة

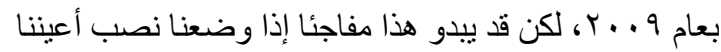
معدلات المشاركة الضعيفة في التنظيمات السياسية و التي

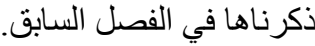

وقد أيدت نسبة كبيرة أيضا من الثباب قدرة الحركات الوطنية و الدولية على التأثير في شئون البلاد. و عندما تم سؤ ال الثباب عما إذا ما اتحد المصريون فهل سيكون لهم تأثير كبير على لئي

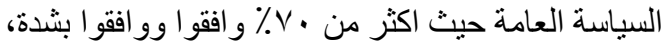

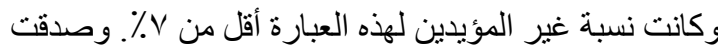
نسب مشابهة أيضا على تأثير الحركات الدولية على السياسات

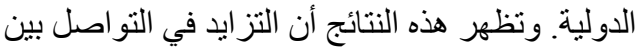
المو اطنين عن طريق وسائل الاتصسال وتأثير الربيع العربي

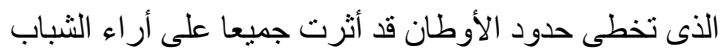
تجاه فاعلية الحركات العالمية في احداث تغيير ات سياسية. و إذا جمعنا هذا مع عدم ثقة الثباب في السياسيين نُظهر هذه النتائج أن الثباب لديهم ثقة كبيرة في الحركات الثعبية وقدرنها على التغيير في السياسة الوطنية و الدولية على حد سو اء بالمقارنة

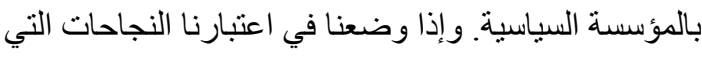

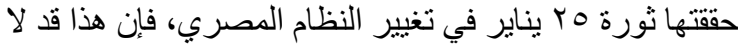

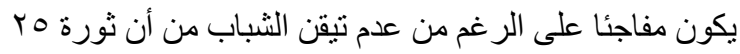
يناير قد حققت أغلب أهدافها.

\section{1_ ـ تقييم النظم السياسية الراهنة}

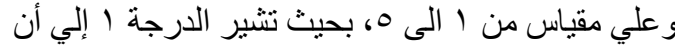

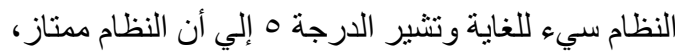

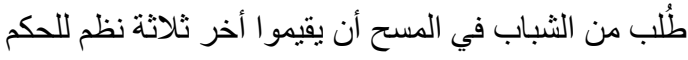

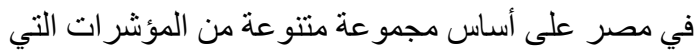
ترتبط بالديمقر اطية، والتمية، وسيادة القانون. وكانت النظم الثلاثة هي النظام قبل ب ب يناير برئاسة حسنى مبارك، و والنظام

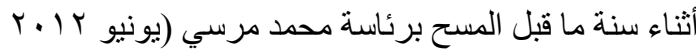

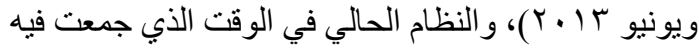

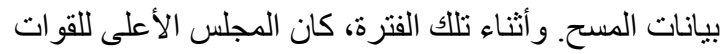
المسلحة، بقيادة اللواء عبد الفتاح السيسي عين عدلي منصور

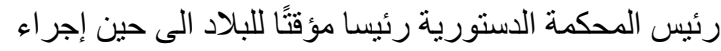

شكل ^ــ ـ رأي الثباب في السياسيين وفي قدرتهم علي التأثير

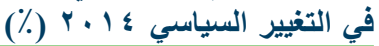

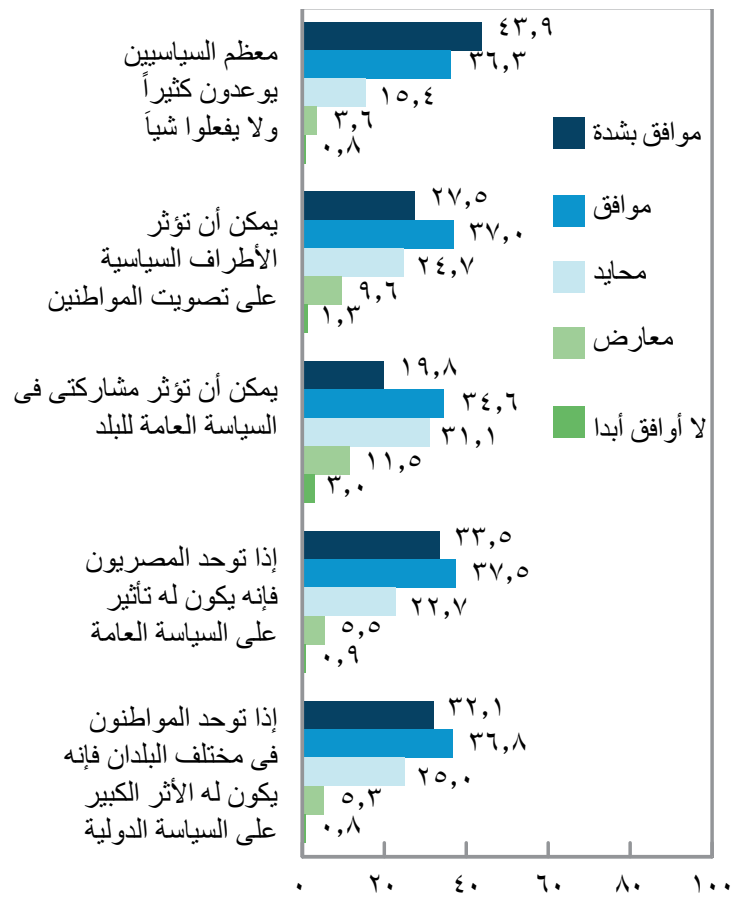

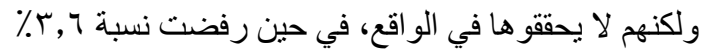

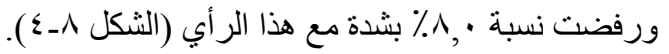
ومع ذللك فإن اغلبية الثباب آمنو ا أن الأحزاب السياسية كانت لديها القدرة على التأثثر في المواطنين وحثنه على التئ التصويت:

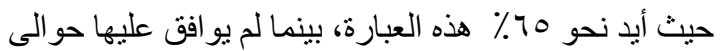
• 1\%. ومن منظور الثباب كانت لدى الأحز اب السياسية

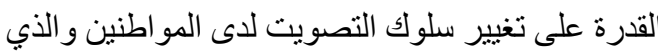
يكون قد تأثر بالانفتاح الذي حدث علي الساحة منذ الخامس

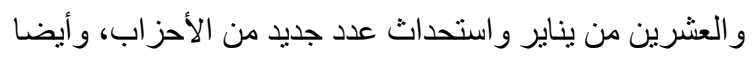
قد يكون متعلقا بالزيادة المفاجئة في مشاركة الثباب في العملية

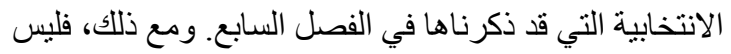

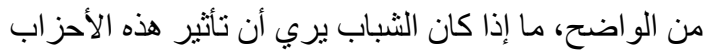
السياسية يعد تأثثرًا إيجابيا أم تأثثرًا سلبياً.

ولتقييم تقة الثباب في قدرتهم على أن يكونو ا فاعلين في

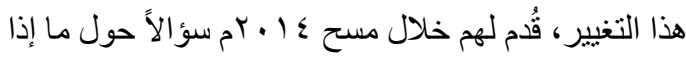
كانوا يشعرون بأن مشاركتهم السياسية من المكن أن تئثر

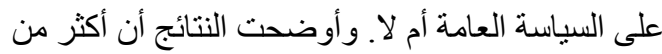

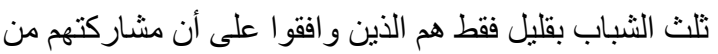


الثباب بأنه كان لديهح تأثير أكبر قليلاً على الحكومة أثناء حكم

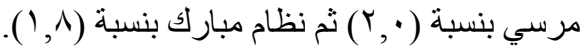

وفيما يخص الفساد وسيادة القانون، فإن النظام الحالي أيضاً قد فاق النظامين السابقين فيما يخص السيطرة على الفساد بنسبة

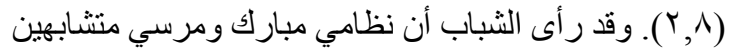

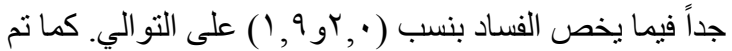

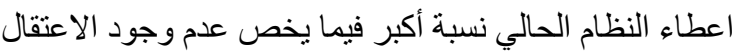

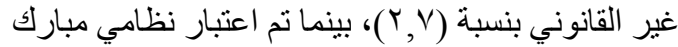

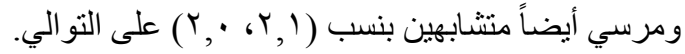
و أخير أ، تم سؤال الثباب أيضاً أن يقيمو ا حسب ر أيهم إلى أي

مدى كانت المحاكم بعيدة عن التأثير السياسي. فقي حين نم

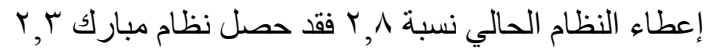

وفاق نظام مرسي في هذه النقطة.

وبالنظر إلى الأمن و الاقتصاد، وهما القضيتان اللتين اعتبرهما الثباب الأكثر أهمية في مصر في وقت المسح، فقد تم إعطاء

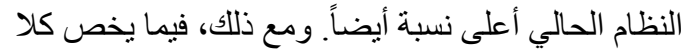
القضيتين فقد جاء نظام مبارك قبل نظام مرسي بثكل و اضيح

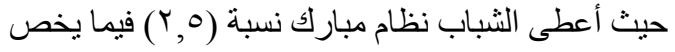
أولوية منع الجريمة و الحفاظ على النظام مقارنة بنظام مرسي

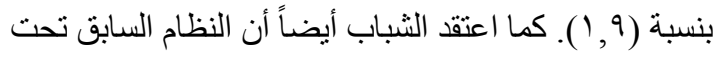

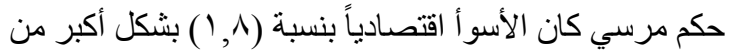

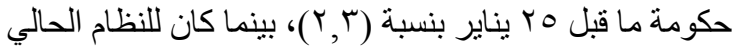

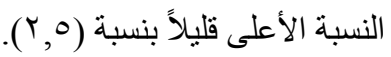

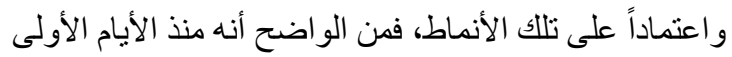

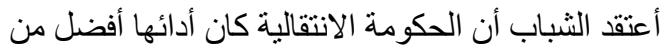

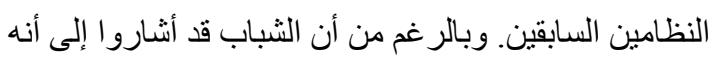

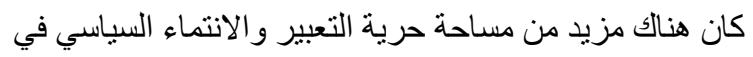

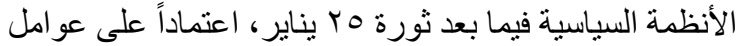

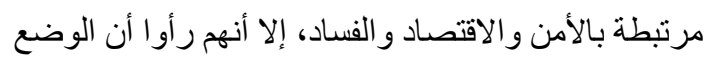
كان أسوا أحت حكم مرسي مقارنة بحكم مبارك قبل أن يتحسن التحن

في ظل الحكومة الانتقالية. ومع ذللك، فمن المهم أن نأخذ في الاعتبار، أن الثباب قد أعطو الأنظمة الثثلاثة عموماً نسب

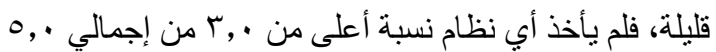

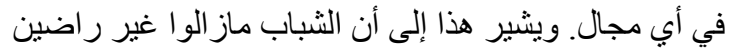

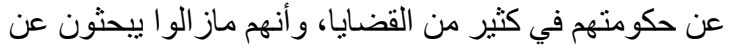

الانتخابات الرئاسية عام ـ ا ـ ب وقد تم تعيين السيسي رئيساً

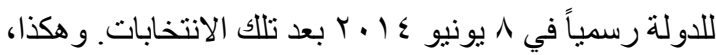

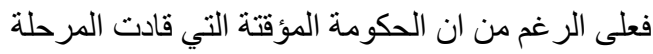
الانتقالية كانت وثيقة الصلة بالرئيس السيسي، إلا أن تقييم

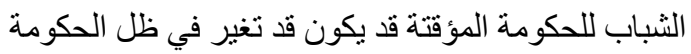

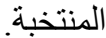

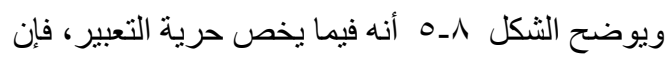
الثباب قد اعطو ا الحكومة الحالية أعلى نسبة وهي (Y, (Y ) يليها

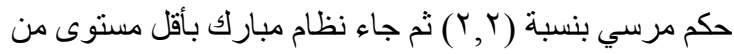

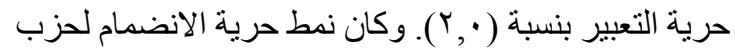

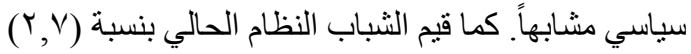
باعتباره أفضل من النظامين السابقين فيما يخص إعطاء المجال "للناس العاديين“، لكي يؤثروا على الحكومة. كما اعتقد

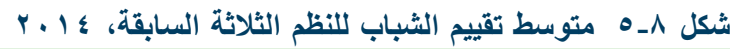

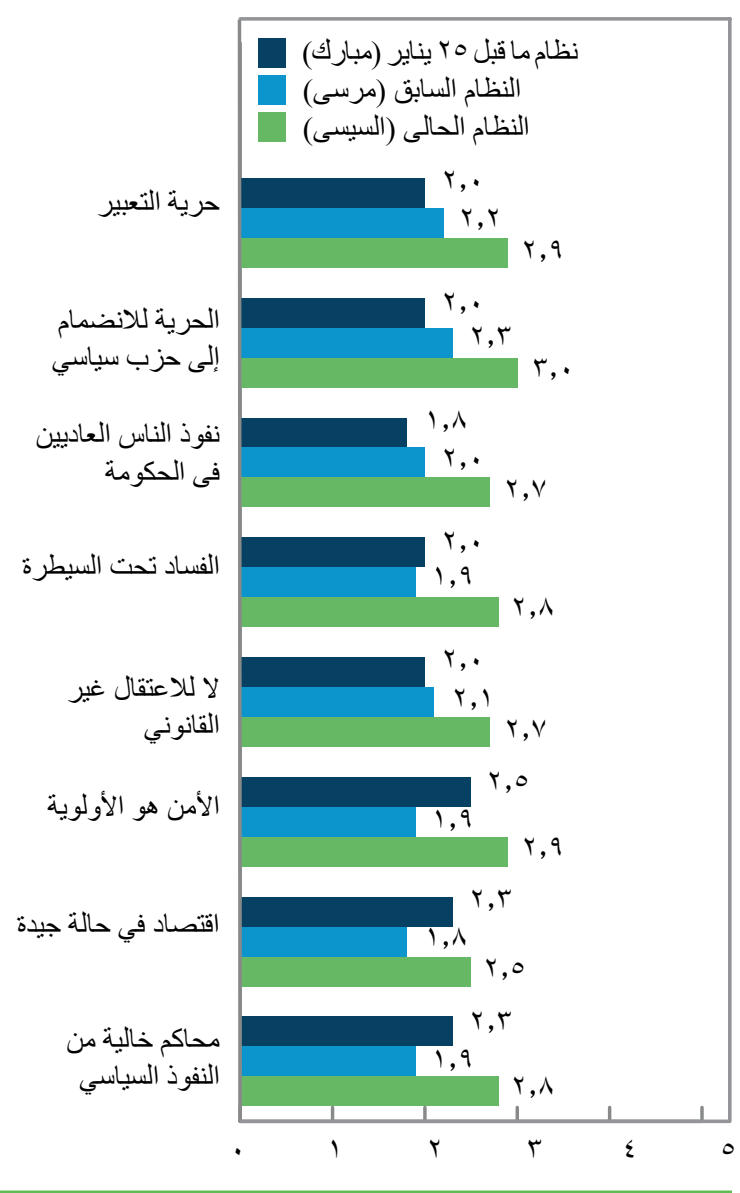


تشير النتائج إلى أن الثباب ماز الو ا غير راضين عن حكومتهم في كثير من القضايا، و أنهم ماز الوا ي يجثُون عن نظام أكثر انفتاحاً بسياسات

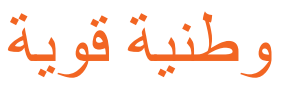

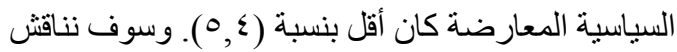
مسألة النقاش السياسي و الانفتاح على الآر اء السياسية للأخرين

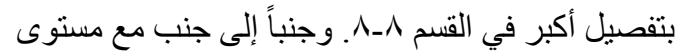

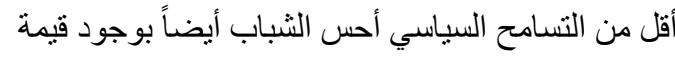

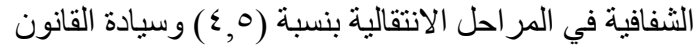

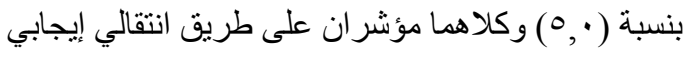

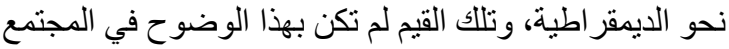

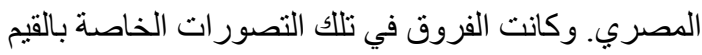
قليلة إلى حد ما عبر أغلب خصائص الخلفية الاجتماعية. وكان

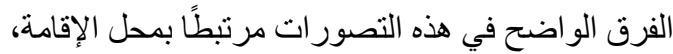
ولكنه تجاوز نقطة واحدة في المقياس في حالات قلبيلة فقط.

وكانت قيم العدل داخل مؤسسات العمل و العدل في توزيع

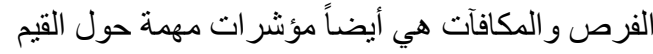
الاجتماعية؛ وقد تم معرفة وجهة نظر الثباب حول تلاك القيم من خلال المسح عن طريق طرح عديد من من الأسئلة المرتبطة

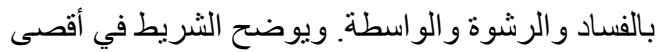

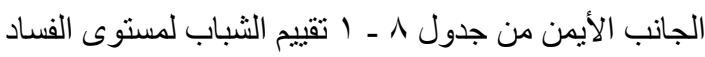

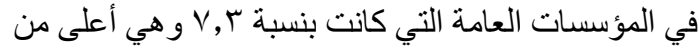

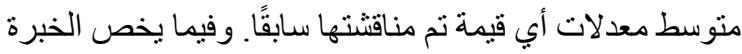

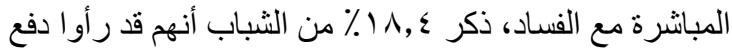
الرشوة في السنة الماضية.

كما رأى الثباب أيضاً أن الواسطة أو استخدام المعارف الثباف الثخصية و المجاملات للحصول على الوظائف، يعد شيئاً

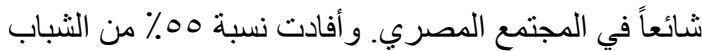
بأنه ”الى حد كبير“، يتم الحصول على الوظائف عن طريق

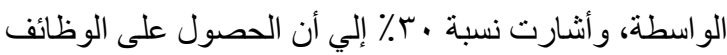

\section{^ــ تقبيم حالة القيم في المجتمع المصري}

لفهم كيفية زيادة انخر اط الثباب في التتمية و الحياة المدنية،

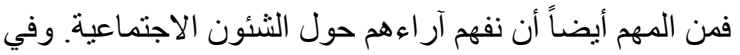

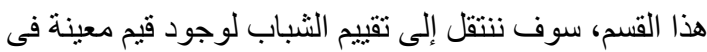
المجتمع المصري باستخدام مقياس من ا إلى • ( حول مدي لهابي

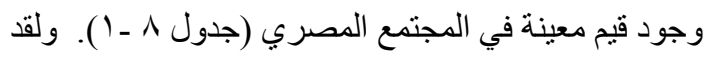
أوضحت البيانات أنه في المنوسط، قام الثباب بتقبيم أهمية الهية

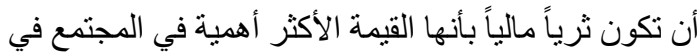
الوقت الر اهن بمعدل 1, 7 من · ل ـ كما أحس الثباب أيضاً

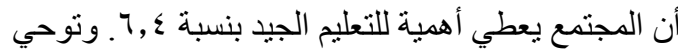
هاتان القيمتان بتأكيد الثباب على تأمين مستقبل مستقر ، مما قد يعكس حالة عدم الإحساس بالأمان الاقتصادي الذي يشعر

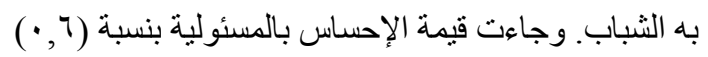

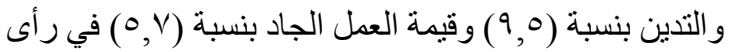
الثباب باعتبار ها قيم موجودة إلى حد ما في المجتمع.

وفيما يخص قيمة التسامح، أعطى المشاركون في المسح

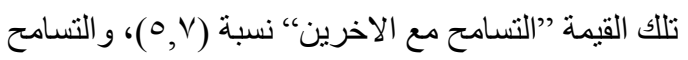
الديني نسبة (,, §). كما أعتقد الثباب أن التسامح تجاه الآراء

جدول ^ ــ امتوسط تقييم الثباب لحالة القيم الموجودة في

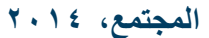

متوسط التقييم

\urcorner,$\wedge$

$7, \varepsilon$

ๆ, *

0,9

$0, V$

$\circ, \mathrm{V}$

0,0

أهمبة الثروة

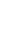

9 أهيبة التعليم الشعور بالمسؤولية

الإيمان الديني

العمل شاق

التسامح مع الآخرين

الاستقلال

o, $\varepsilon$

$0, v$

التسامح الديني

$\circ$, .

المساعدة المجتمعية

دور القانون

$\varepsilon, 9$

الادخار المالي

$\varepsilon, 0$

التسامح السياسي

$\varepsilon, 0$

شفافية التحول

تقنيم مستوى القساد 
توضح في المتوسط تحسناً طفيفاً للغاية في إدر الك أن هناك قيمًا

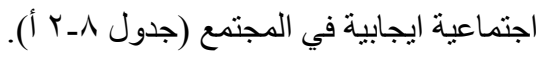

\section{ــ ـ دور الدين في السياسة والقانون والحياة الثخصية}

بصعود نظام مرسي وسقوطه و إعادة كتابة الدستور في عام

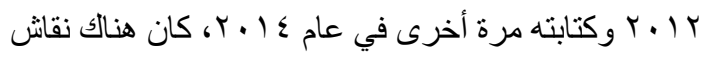

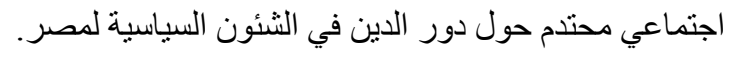

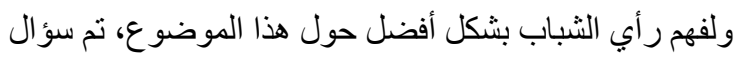
المشاركين في مسح عام ؟ ا ـ بم، سلسلة من الاسئلة المتعلقة بما ينبغي أن يكون عليه دور الدين في الحياة السياسية و العامة.

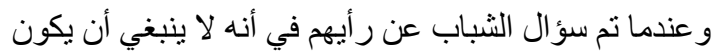

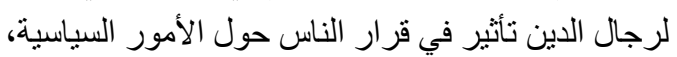

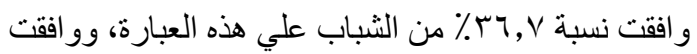

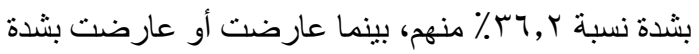

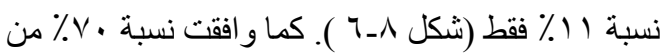

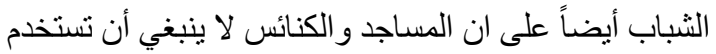

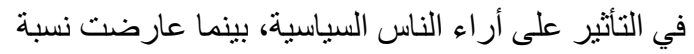

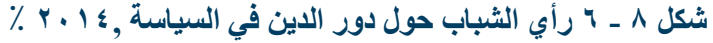

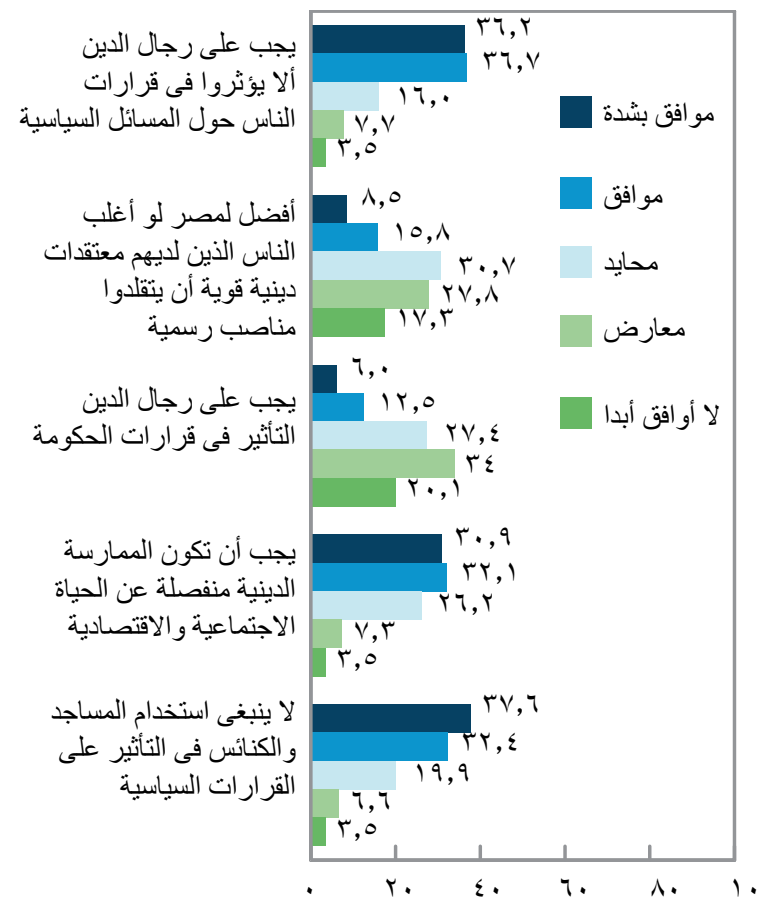

عن طريق الواسطة يحدث "احياناً،، و أوضحت نسبة ب٪ فقط

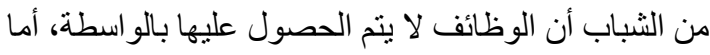

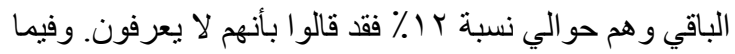

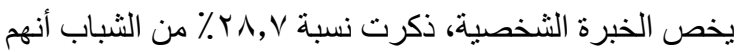
شاهدو ا استخدام الو اسطة أثناء السنة الماضية وحدها.(البيانات

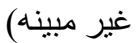

وربما بسبب تصور ات الثباب حول المستويات العالية من

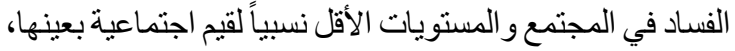
فإن الثباب قد عبرو ا عن مستويات منخفضة من الثقة العامة.

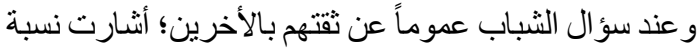

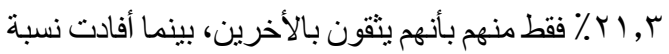

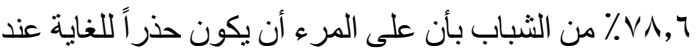

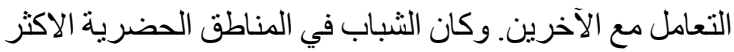

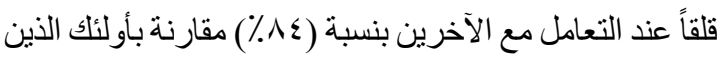
يعيشون في المناطق الريفية بنسبة (V^٪) و المناطق العشو ائية بنسبة ( • ٪\%)، وكانت الفروق محدودة وفقًا لخصائص الخلفية الاجتماعية الأخرى، بما فيها النوع و السن.

و على الرغم من المستوى المنخفض من الثقة، فإن الثباب

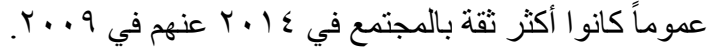

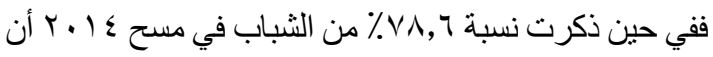

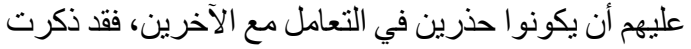

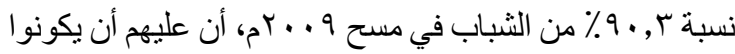

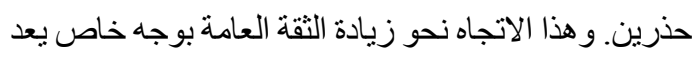

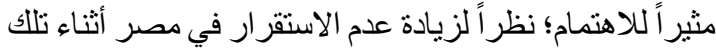

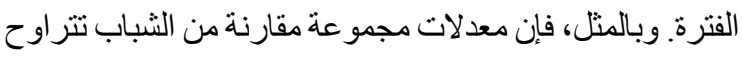

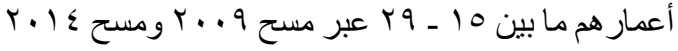

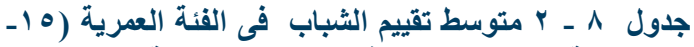

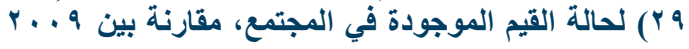
$r \cdot 1 \leqslant 9$

\begin{tabular}{|c|c|c|}
\hline r.l \{ & r...q & \\
\hline 7 & 0,1 & الثعور بالمسئولية \\
\hline $0, v$ & $0, v$ & العمل الثاق \\
\hline $0, v$ & $0, v$ & التنسامح مع الاخرين \\
\hline 0,9 & 0,1 & الايمان الديني \\
\hline $0, \varepsilon$ & 0,9 & الاستقلال \\
\hline$\varepsilon, 9$ & $\varepsilon, 9$ & الادخار المالي \\
\hline
\end{tabular}




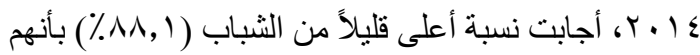

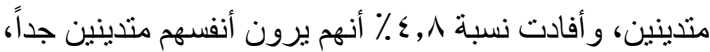

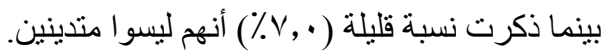

و عندما سُئل الثباب في مسح عام 9 . . Y، كم مرة يذهبون إلى المسجد أو الكنيسة، ذكر ثلثا الثباب تقريباً أنهم يذهبون أكثر من مرة واحدة يومياً. وقد نم تغيير السؤ ال في مسح عام لهي

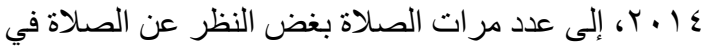

دور العبادة أو في المنزل، ولكن مع ذلك فقد تمت الإنشارة

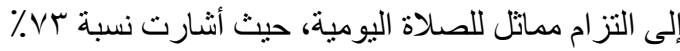

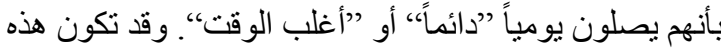

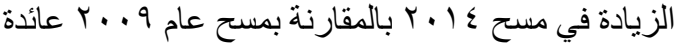
إلى التغيير الذي حدث في الكلمات المستخدمة، لأن كثيرًا من

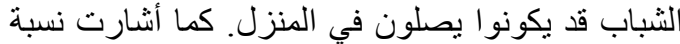

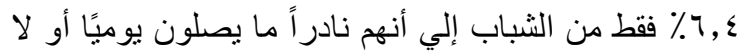

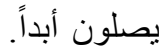

ولتقييم اعتماد الثباب على وسائل الإعلام الدينية، تم طرح

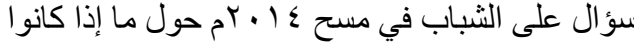

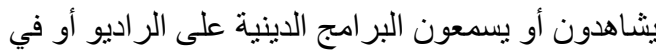
التليفزيون. وجاءت ممارسة الثباب متتو عة الى حد كبير :

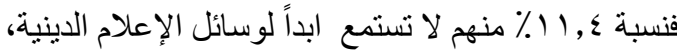

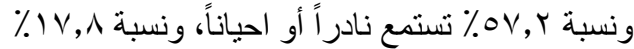

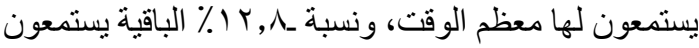

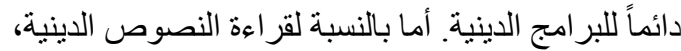

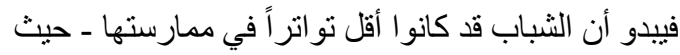
ذكرت نسبة ؟ ، ؟ ؛ أنهم لا يقر أون أبدا القرآن أو الإنجيل،

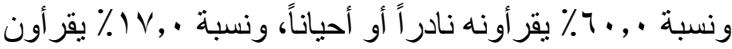

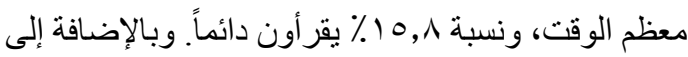

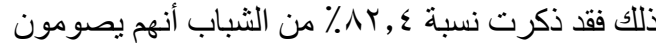

رمضان أو الوقت المخصص للصيام في المسيحية بشكل

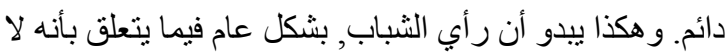

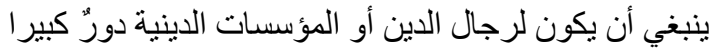

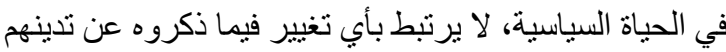

الثخصي؛ لأن معظمهم يرون أنفسهم متدينين ويمارسون

شعائر هم بانتظام الى حد ما. ـ ـ (البيانات غير مبينه)

\section{N_ التقاؤل تجاه المستقبل V_}

إن تقييمات الثباب حول حالة الدولة بعد ثورة ه يناير وما

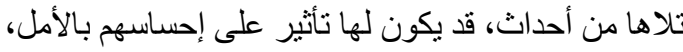

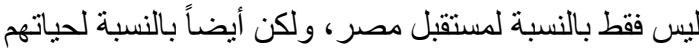

• 1\% فقط. وتشير تلك النتائج إلى أن أغلبية الثباب لا يؤيدون أن تقوم الثخصيات و المؤسسات الدينية بالتأثير على الآراء السياسية لأتباعها.

ومن ناحية أخرى، كان للشباب آر اء مختلفة حول ما أذا

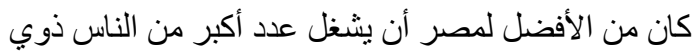

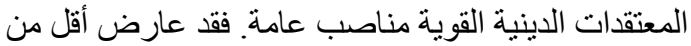

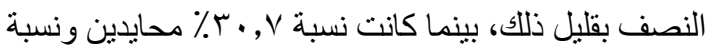
○\% \% تقريباً مؤيدين. وكان رأي الثباب حول أن يكون لرجال

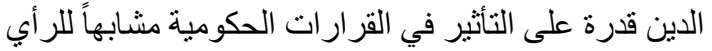

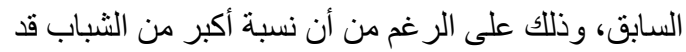
عارضوا هذه الفكرة. وتتناقض تلك النتائج مع نتائج أسئلة

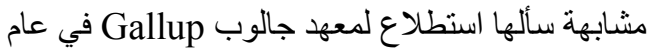

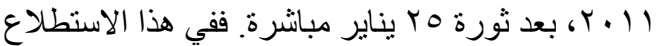

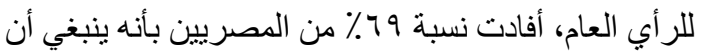
يقوم القادة الدينيون بنصح المسئولين حول كتابة التشريعات

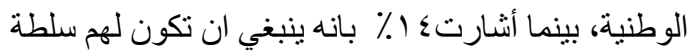

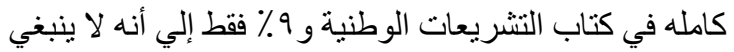

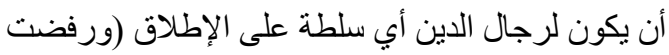
نسبة ^٪ السؤال أو قالو ا أنهم لا يعرفون) (Gallup 2014). وبالرغم من أن استفتاء جالوب قد تم بين الدصريين الذابن الذين في عمر 10 عاما فما فوق، ومن ثم فهو لا يقارن بشكل مبان بانش مع مسح ـ ا ـ بم، إلا أن هذا الفرق الكبير قد يوحي بأن الرأي

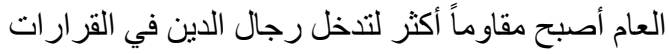

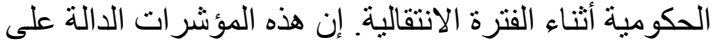

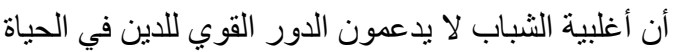

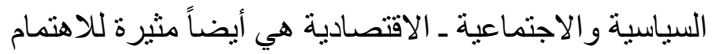

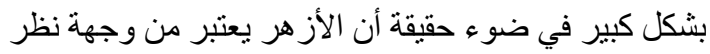
الكثير من المسلمين في العالم أعلى سلطة في الفكر الإسلامي

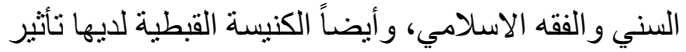

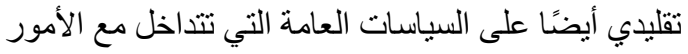
الدينية مثل قانون الأحو ال الثخصية.

وحتى يمكننا أن نقارن آراء الثباب حول دور الدين في الحياة السياسية والعامة، ننتقل إلى مجمو عة أخري من الأسئلة حول

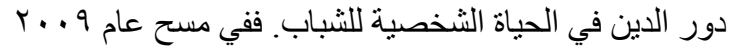

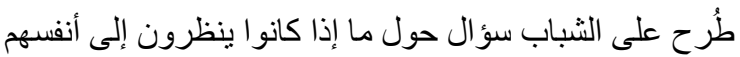

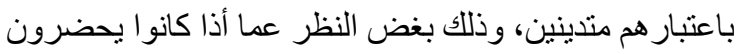
دروس دينية أم لا، وقد أجابت الأغلبية العظمي بنسبة ولغية

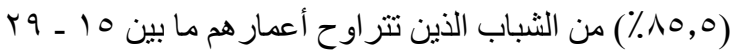

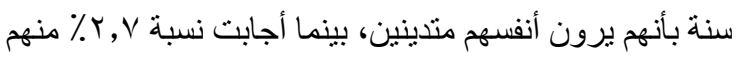

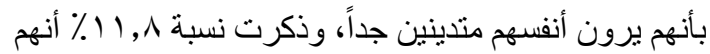
ليسو ا متدينين. و عندما سُئل الثباب نفس السؤ ال، في مسح 
قد ذكروا أيضاً أن أحداث الثورة ستؤثر سلبياً على مستقبلهه.

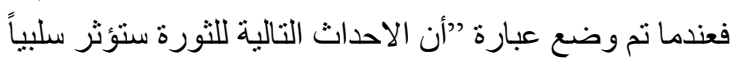

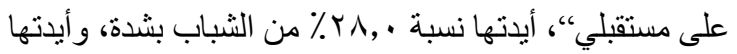

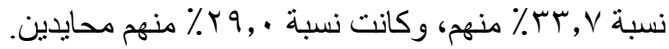

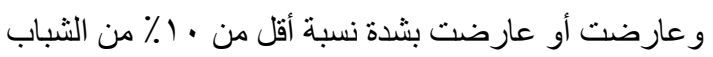
هذه العبارة. وكان الثباب من المحافظات الحضرية و المناطق

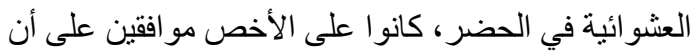

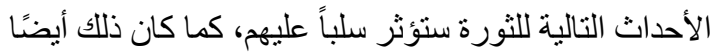

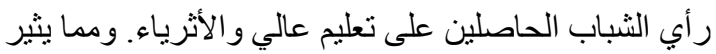

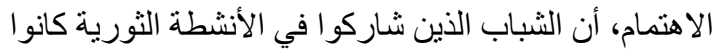

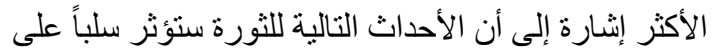

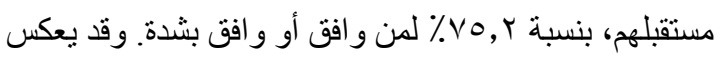

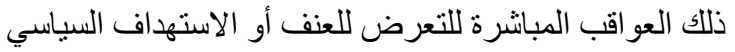

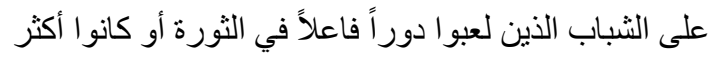
تثناؤماً وشعروا أن الثورة لم تحقق أهدافها.

تللك النتائج المتناقضة حول تفاؤل الثباب بالنسبة لمستقبلهم و إحساسهم بأن الثورة ستؤثر سلباً على حياتهم قد يفسره

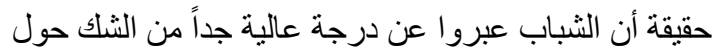

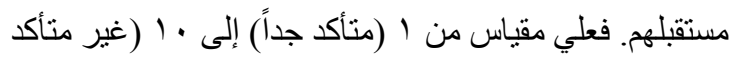

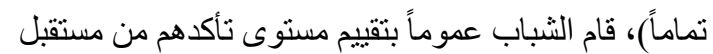

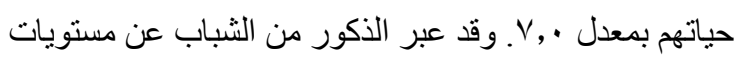

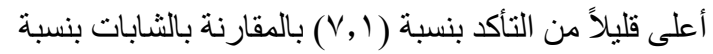

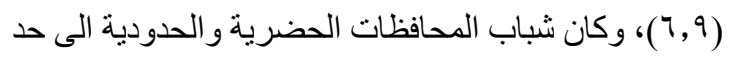

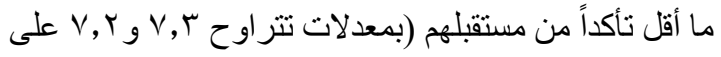

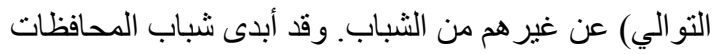
الحضرية وجه قبلى أعلى مستويات عن تأكدهم من حياتهم بنسبة (0, 7), بينما عبر جميع شباب باقى المحافظات بنسبة

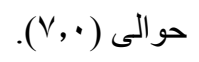

لقد كان يقين الثباب حول المستقبل مرتبطاً بالتعليم؛ فقد كان

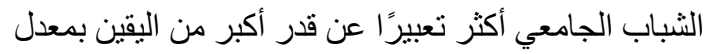

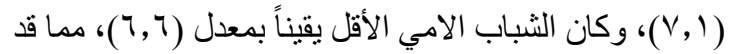

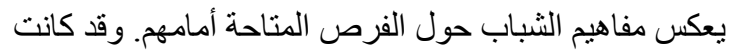

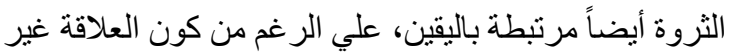

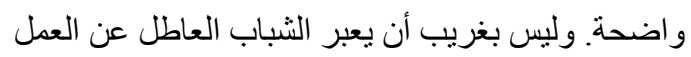

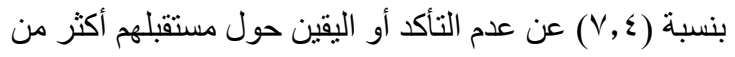

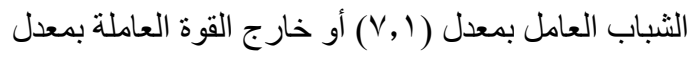

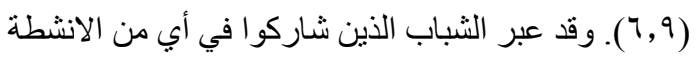

شكل V_N متوسط تقييم الشباب لحياتهم ولحالة الدولة أثناء

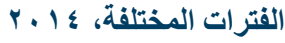

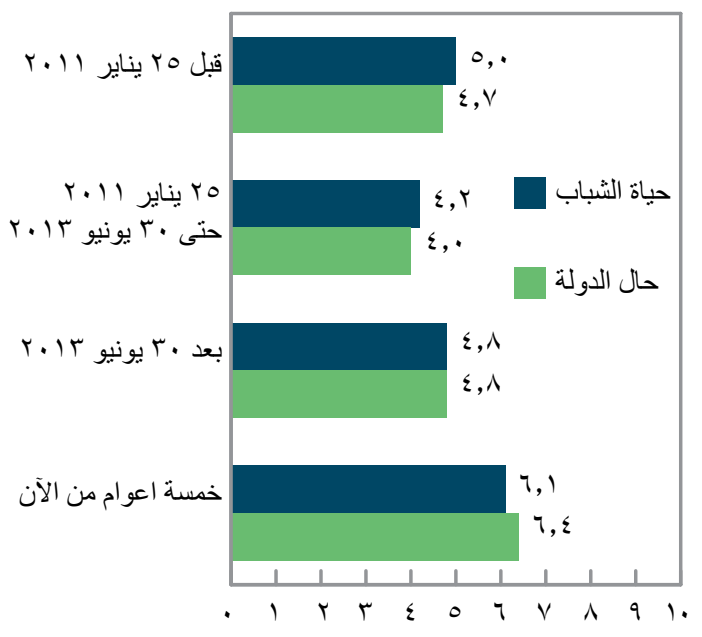

الثخصية. ومن ثم، فقد طُلب من الثباب في هذا المسح أن

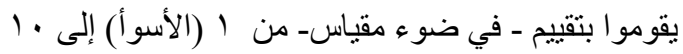

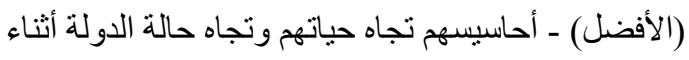

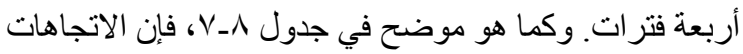

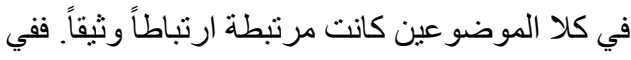

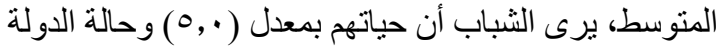

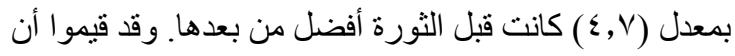

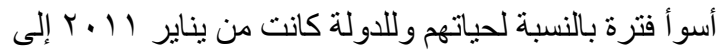

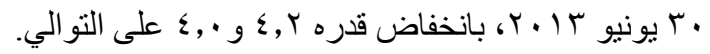

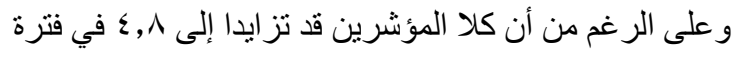

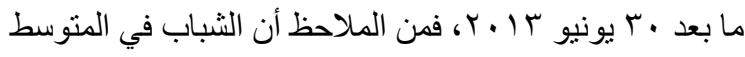

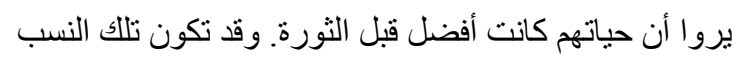

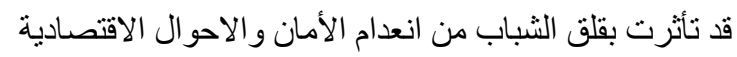
السيئة بعد الثورة، كما تم توضيحه في الأقسام السابقة.

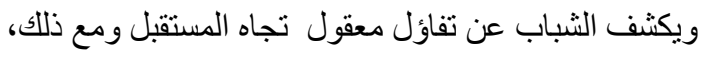

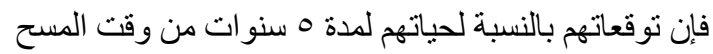

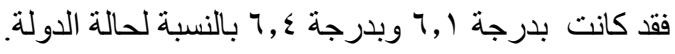
و على الرغم من مخاو فهم حول الأحو ال في مصر ألثاء أنثاء الفترة

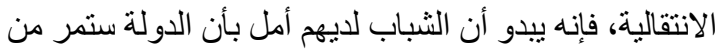

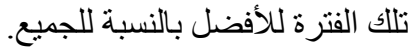

وبالر غم من أن الثباب قد عبروا عن تفاؤلهم حول مسار

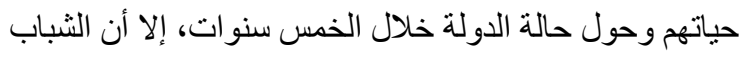


ويحلل جدول ^_ـ نسبة الثباب المشاركين بالعمل التطوعي خلال الوقت الذي ذكروا تطو عهم للعمل فيه (معدلات المشاركة علي جميع خصائص الخلفية الاجتماعية موجودة جدول أم ـ ( ). وقد كانت معدلات العمل التطوعي للفترة من

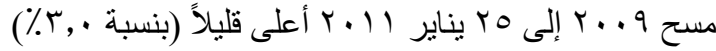

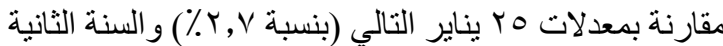
من الثورة (بنسبةم, r٪). و أكثر من ذللك، فإن كثير من الثباب

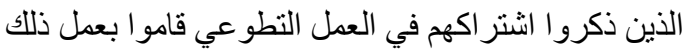
بشكل مستمر عبر الفترات الثلاث. وبعبارة أخرى، يبدو ان هنالك نسبة صغيرة من الثباب ملتزمين بالعمل التطوعي

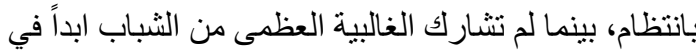
الانشطة التطو عية في اي من الفترات المذكورة. و هذه النتيجة تتناقض بشدة مع التصور المتعلق بالعمل التطوعي بين الشباب في الأشهر التالية لثورة هب بناير.

ويبدو أن دائرة الثباب الذين شاركو ا في الأنشطة التطو عية

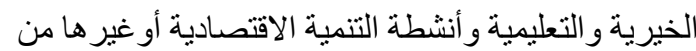
الأنشطة تتداخل مع مجمو عة الثباب الصغيرة الذين ذكروا

انهم شاركو ا في الأنشطة الثورية، و الذى تم تعريفهر هناب بالمشاركين في اى تنظيم سياسي أو فى الانشطة التي تحدث في الثوارع مثل المظاهر ات (انظر فصل V). وكانت نسبة العمل التطوعي بين الشباب الذين ذكروا مشاركتهم في
الثورية منذ هب يناير عن قدر أكبر من عدم اليقين بمعدل

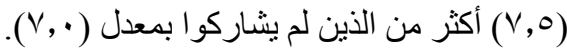

\section{1 _ـ_ المشاركة في العمل التطوعي والمجمو عات الاجتماعية}

كانت هناك بعد الأيام الثمانية عثر من ثورة يناير I 1 • Y ، تغطية إعلامية عريضة للشباب الذين انخرطوا في أنشطة لتحسين مجتمعاتهم وبيئته، مما أدى إلى خلق انطباع عام بأن مشاركة الشباب في العمل التطوعي و المجمو عات الاجتماعية

المنظمة قد تز ايد عن المستويات المنخفضة قبل الثورة.

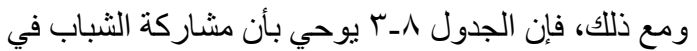

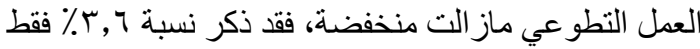

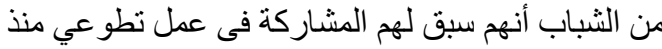

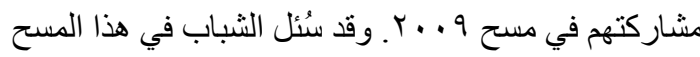
عن مشاركتهم في الأعمال التطو عية الخيرية، و التعليمية، وفي تتمية المجتمع، وجمع التبر عات وغير ها من الأنشطة التطو عية. لكن بسبب انخفاض المعدلات الإجمالية للأعمال التطو عية فإننا لن نذكر ها بالتفصيل تبعاً لنوع النشاط.

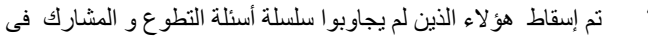

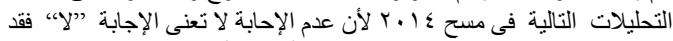
يكون هناك شباب متردد في الإجابة لبعض أسئلة الأنشطة.

جدول ^_ب الثباب المشاركين في الأعمال التطوعية حسب الفترة والنوع و و طبيعة المشاركة في الانشطة الثورية، ؛ 1 ـ ب(\%)

\begin{tabular}{|c|c|c|c|c|c|c|}
\hline \multicolumn{3}{|c|}{ 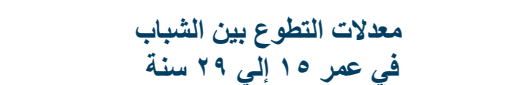 } & \multicolumn{3}{|c|}{ 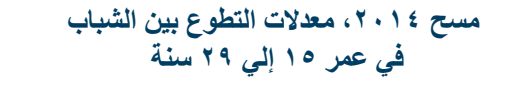 } & \\
\hline المستطو السابق في & 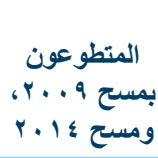 & 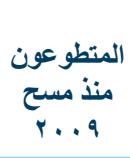 & فيما بعد الثورة & 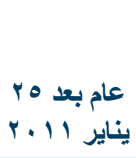 & 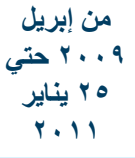 & \\
\hline & & & & & & النوع \\
\hline$\varepsilon, r$ & $\varepsilon, 0$ & $\varepsilon, 0$ & r, & $r, 0$ & $r, \Lambda$ & ذكر \\
\hline $1, r$ & $r, V$ & $r, \varepsilon$ & 1,9 & 1,1 & $r, r$ & أنثي \\
\hline & & & & & & مشاركة الشباب في الثورة \\
\hline & & $r, \varepsilon$ & 1,1 & $1, v$ & $r, \cdot$ & غير مشارك \\
\hline & & 17,0 & $1 \leqslant, r$ & $1 \leqslant$, & $1 \leqslant, 7$ & أية مشاركة \\
\hline & & $r \varepsilon, \varepsilon$ & 吾, & $r \cdot, v$ & $r q, r$ & تنظيم سياسي \\
\hline & & $17, r$ & $1 \leqslant$, & $1 r, 9$ & $1 \varepsilon, \varepsilon$ & لجان شعبية \\
\hline & & $19, r$ & $1 \wedge, \wedge$ & $i v, 0$ & IV,r & تظاهر \\
\hline$r, \wedge$ & $r, \uparrow$ & r,o & $r, \wedge$ & $r, v$ & r, & الإجمالي \\
\hline $1.9 \times 7$ & $v .11$ & $\Lambda \wedge \leqslant \varepsilon$ & $\Lambda \wedge \leqslant \varepsilon$ & $\Lambda \Lambda \leqslant \leqslant$ & $\Lambda \wedge \leqslant \varepsilon$ & العدد \\
\hline
\end{tabular}


الذين شاركو ا في العمل التطوعي هم الاكثر احتمالاً لاختبار

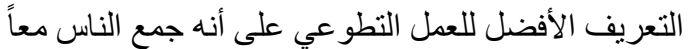

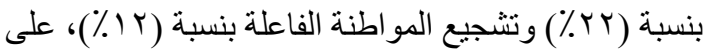

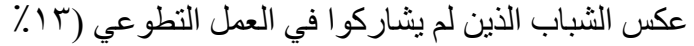

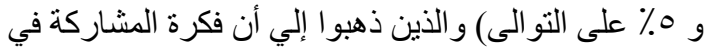
الانشطة التطو عية ممتدة لما ور اء الاعمال الخيرية.

وبالرغم من عدم سؤ ال الثباب الذين شاركو ا في العمل

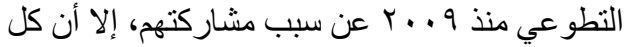

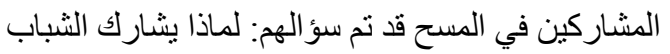

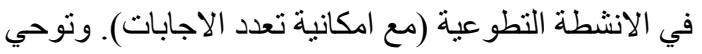

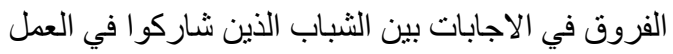

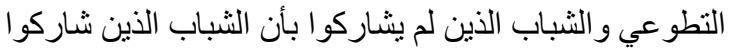

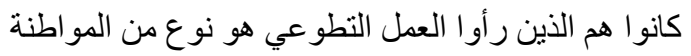

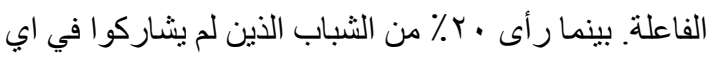
عمل تطو عي على الاطلاق انه "كون الفرد مواطناُ فاعلاً

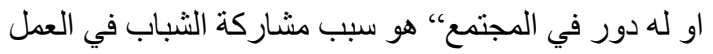

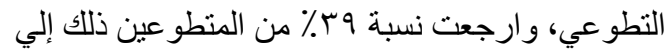

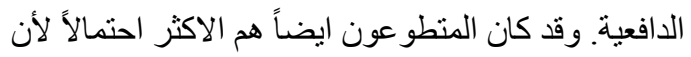

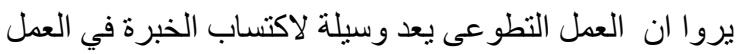

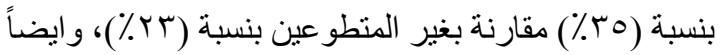

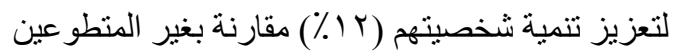

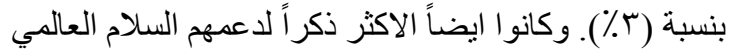

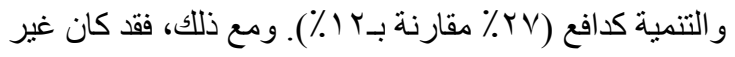
المنطو عين هم الاكثر احتمالاً لذكر مساعدة الاخرين بنسبة ولية

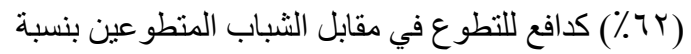

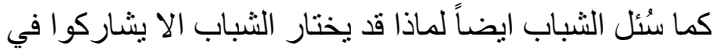

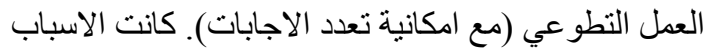

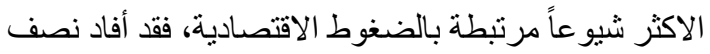

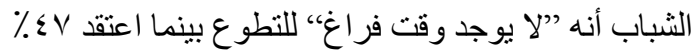

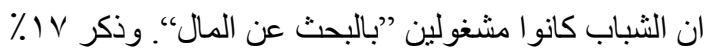

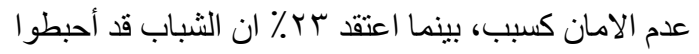
من قبل عائلاتهم. وقد تم اعتبار المعلومات القليلة المتوفرة

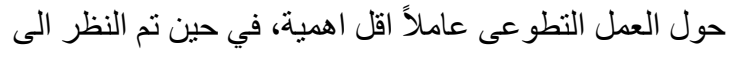

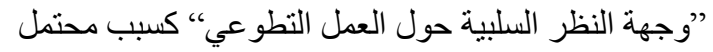

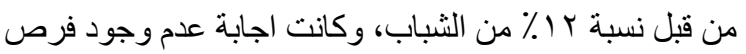
للتطوع موجودة بنسبة س ا ٪ و واجابة "لم يطلب مني احد ابداً

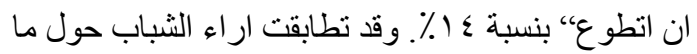

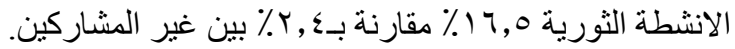

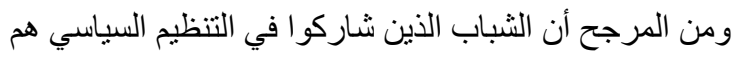

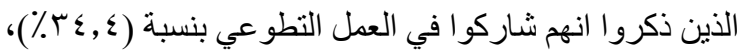

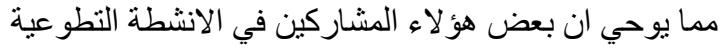
ربما كانو ا منظمين من قبل جماعاتهم او احز ابهم السياسية.

وقد كانت هناك فجوة نوعية فيما يتعلق بالأنشطة التطوعية،

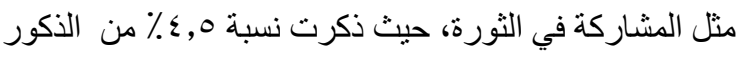

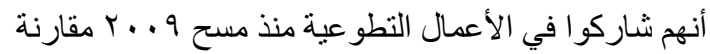

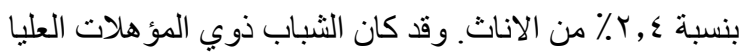

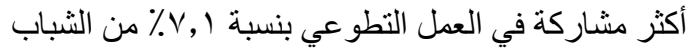

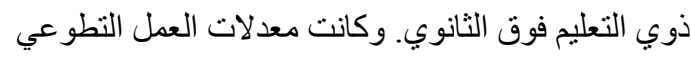
بين الثباب ذوي التعليم الأقل من الإعدادي أقل من نسبة ٪ ٪

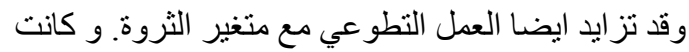

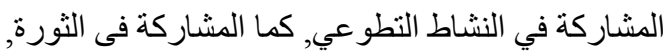
أكثر بين الثباب العاطلين عن العمل بنسبة (1, ؟٪) بالمقارنة

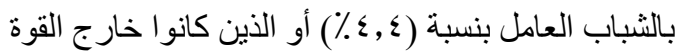

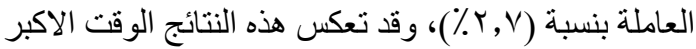

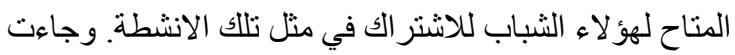

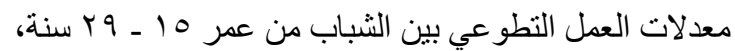

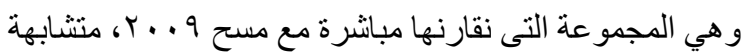

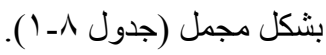

ولكي نفسر المعدلات المنخفضة و المثيرة للدهشة للمشاركة

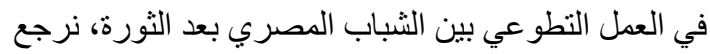

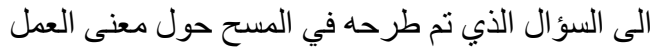

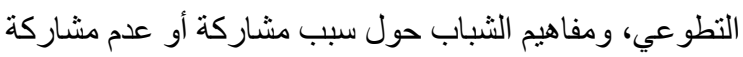

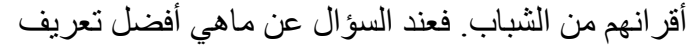

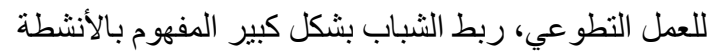

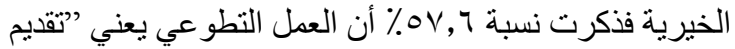

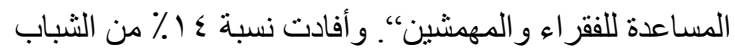

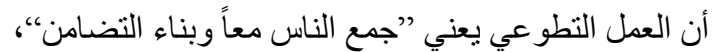

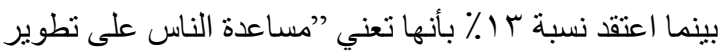

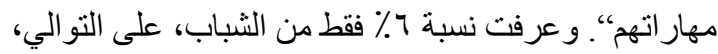

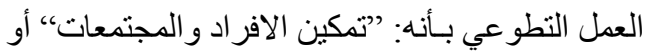

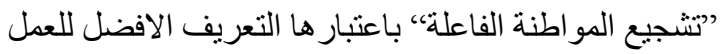

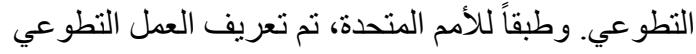

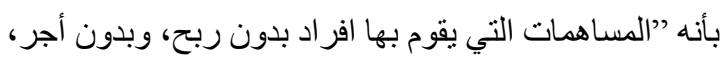
و لا تمثل مهنة لرفاهية الجيران و المجتمع ككل"، ـ و هو تعريف

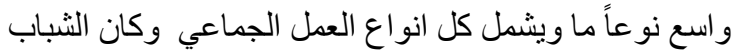


جدول ^ــ ـ مشاركة الشباب في المجموعات والجمعيات، حسب

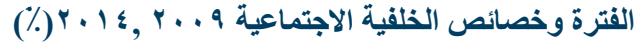

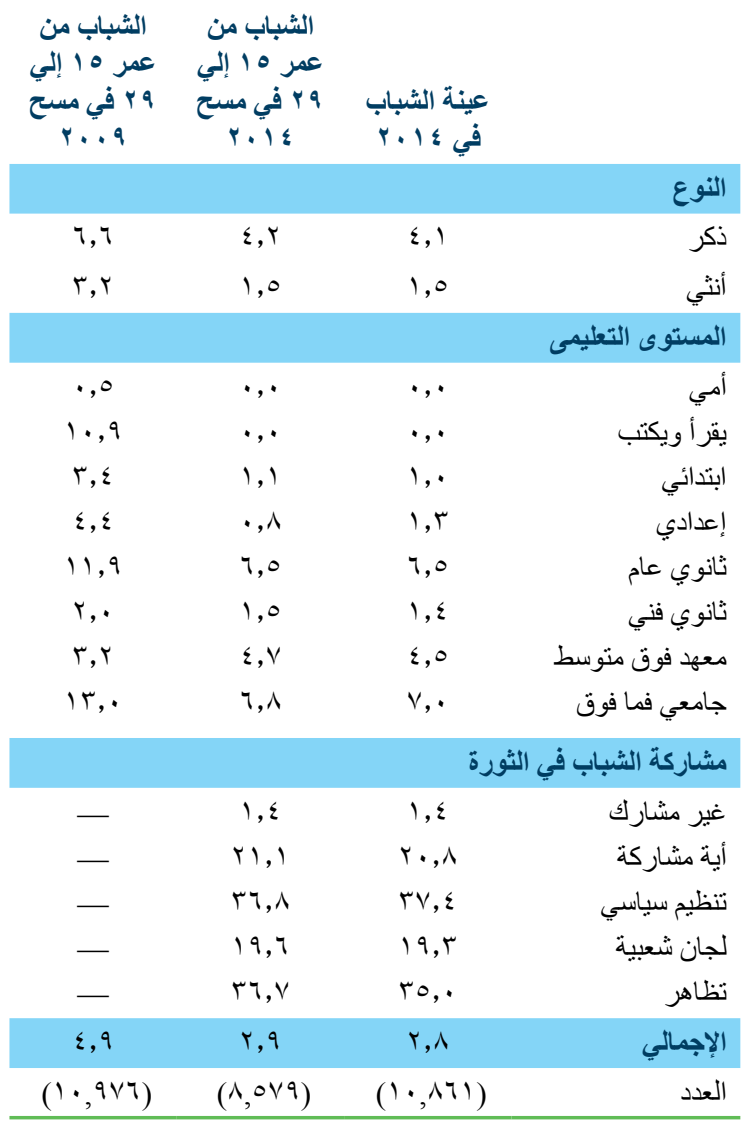

انهم اعضاء في احز اب او جمعيات سياسية كانت (r, • ٪)

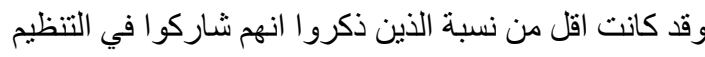

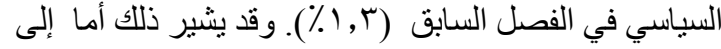

عدم اعتبار الثباب أنفسهم اعضاء رسميين فى جماعة ما

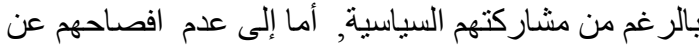

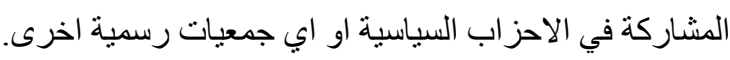

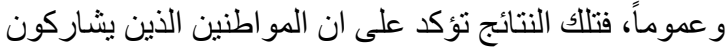

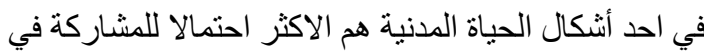
اى من أنثكالها أو أنشطتها الأخرى.

وقد تم سؤال الثباب الذين ذكروا انهم اعضاء في مجمو عة أو جمعية عن سبب اختيار هم لتلك المجمو عة. وقد اختلفت تللك

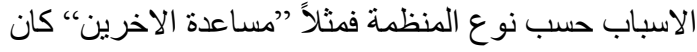

يمكن ان يشجعهم على التطوع (مع امكانية تعدد الاجابات)

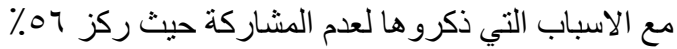

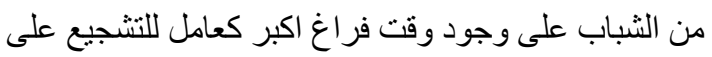
التطوع بينما ذكر \$ ٪ من الثباب عامل توفر المال.

وثمة شكل اخر من الانخر اط في الحباة المدنية وهو المشاركة في الجمعيات و النوادي الرسمية، سواء كان لديها اجندة

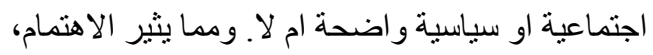

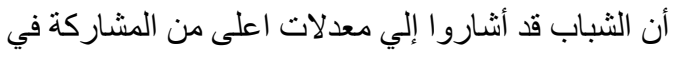

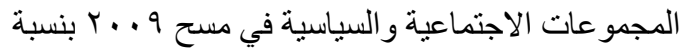

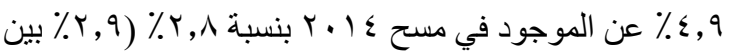

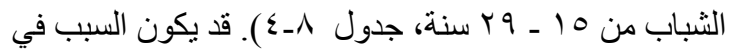

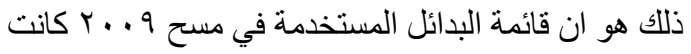
مختلفة عن تللك المستخدمة في مسح ـ ا ب ب و وإنها ذكرت بالاسم انو اع اخرى من المجمو عات بشكل فردي.

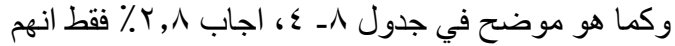

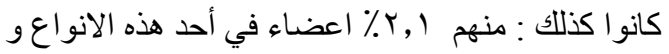

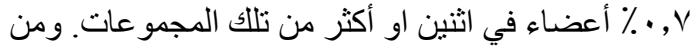

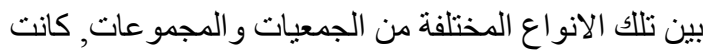

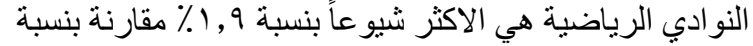
اقل من 1\% بالنسبة لكل الانواع الاخرى (المعدلات وفقًا لكل

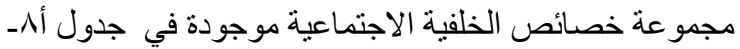

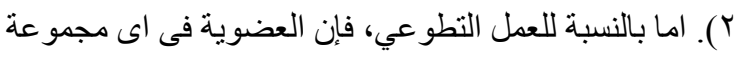

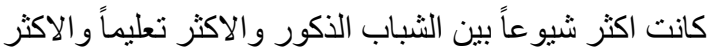

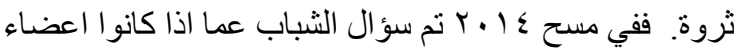

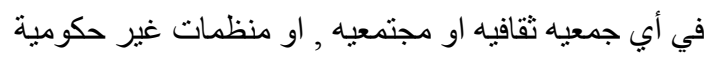

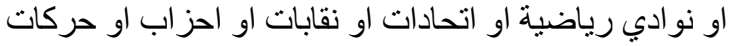
سياسية او جماعات غير رسمية وغير مسجلة .

وبالمثل، فإن عضوية أى مجمو عة كانت اكثر شيو عاً بشكل

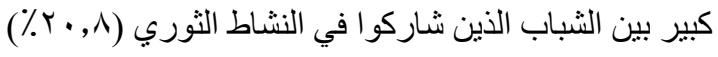

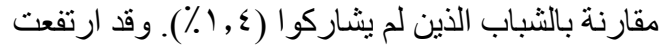

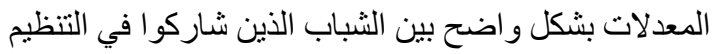

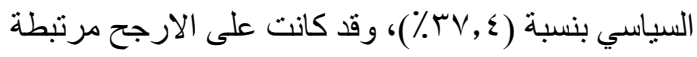

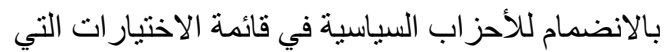

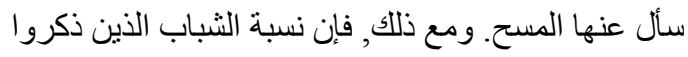

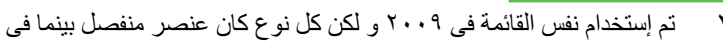

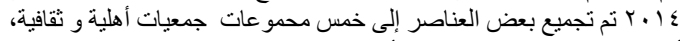

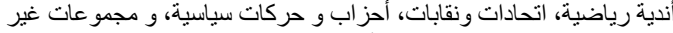
رسمية مع ذكر العناصر المختلفة كأمنلة. 
تصنع القوانين و السياسات في الدولة. وتظهر استجابة الثباب للعبار ات التى توضح انخر اطهم النشط في الاحداث الجارية

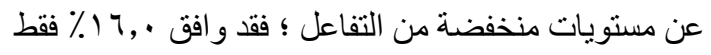

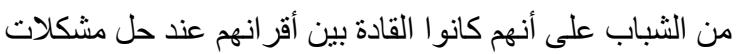

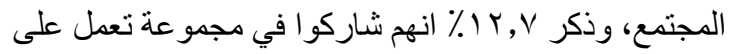

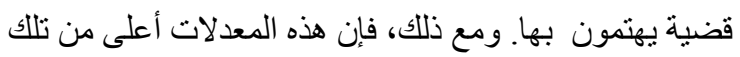
الموجودة في المشاركة في النشاط الثوري، و العمل التطوعي و الجماعات الاجتماعية مما يوحي بأن الثباب برون انفسهم منخرطين في مجتمعاتهم بطرق اقل رسمية.

و إلى جانب ثقتهم المنخفضة بشكل عام في فهمه للقضايا

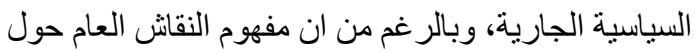
القضايا السياسية قد امتد وتوسع اثناء هذه الفترة المثيرة للنزاع، فإن الكثير من الثباب لا يبدو انهم يناقشون الامور

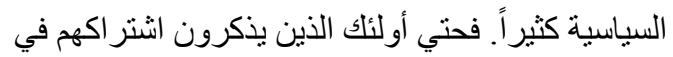

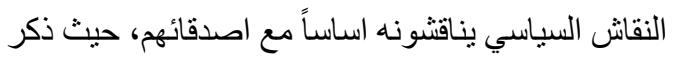
أكثر من • \% من الثباب انهم يناقشون القضايا السياسية مع

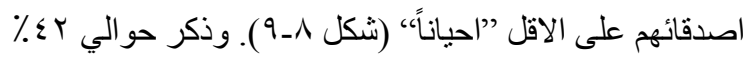
من الثباب انهم يناقثون القضايا السياسية على الاقل "احياناً، مع اخوتهم بينما كانوا اقل كلامأ في الامور السياسية مع ابائهم و امهاتهم.

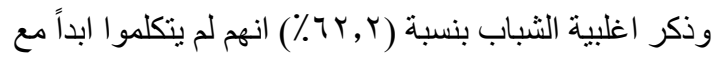

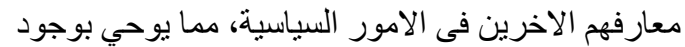

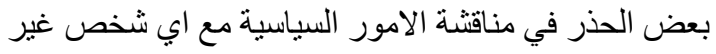

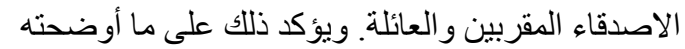
البيانات فى رأي الثباب حول الدرجة التى يمكن أن يؤثر بها النقاش السياسي على رأيهم أوعلى رأي الاخرين. فنسبة سبـ

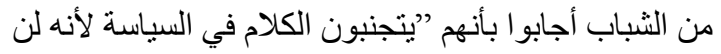

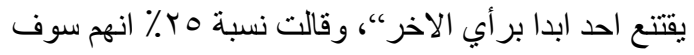

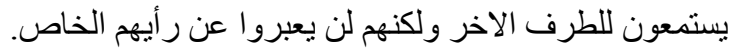
كما أثارت 1 ( ٪ فقط أنهم يحاولون اقناع الأخرين بر أيهم الخاص, و 1 (\% كان لديهم الاستعداد للاقتناع بر أي الاخرين.
السبب الاكثر ذكر اً بالنسبة للجماعات الخيرية و المجتمعية

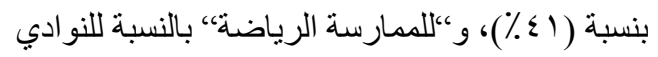

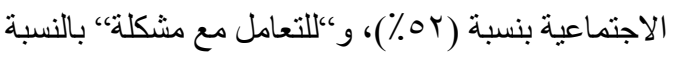

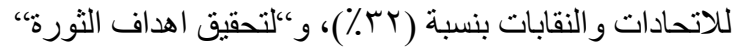

بالنسبة لعدد قليل من الثباب الذين ذكروا عضويتهم في

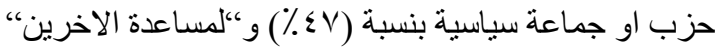

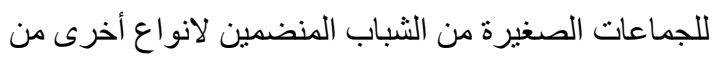

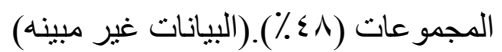

\section{ــ ـ المشاركة في النقاش الاجتماعي}

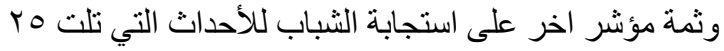

يناير 11 1 ـr و هو انخر اطهم في النقاش العام حول القضايا السياسية و الاجتماعية والاقتصادية التي تو اجه الدولة. وقد تم توضيح تصور ات الثباب حول مستوى انخر اطهم في الاحداث

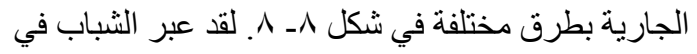
المتوسط عن درجة من الثقة في فهمه للقضايا السياسية الهامة في الدولة اعلى من فهمه لكيفية عمل القو انين و السياسات. فأكثر من · ب \% من الثباب و افقو ا او و افقو ا بشدة ان لديهح

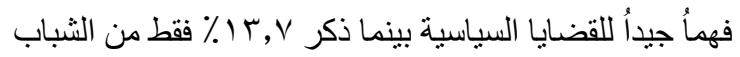

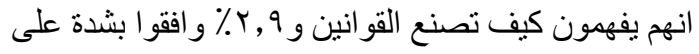
ذللك. ولقد شعر نصف الثباب تقريباً بأنهم لا بعرفون كيف

شكل ^_ـ تقييم الشباب لانخر اطهم في الاحداث الجارية وتنمية

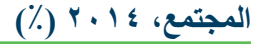

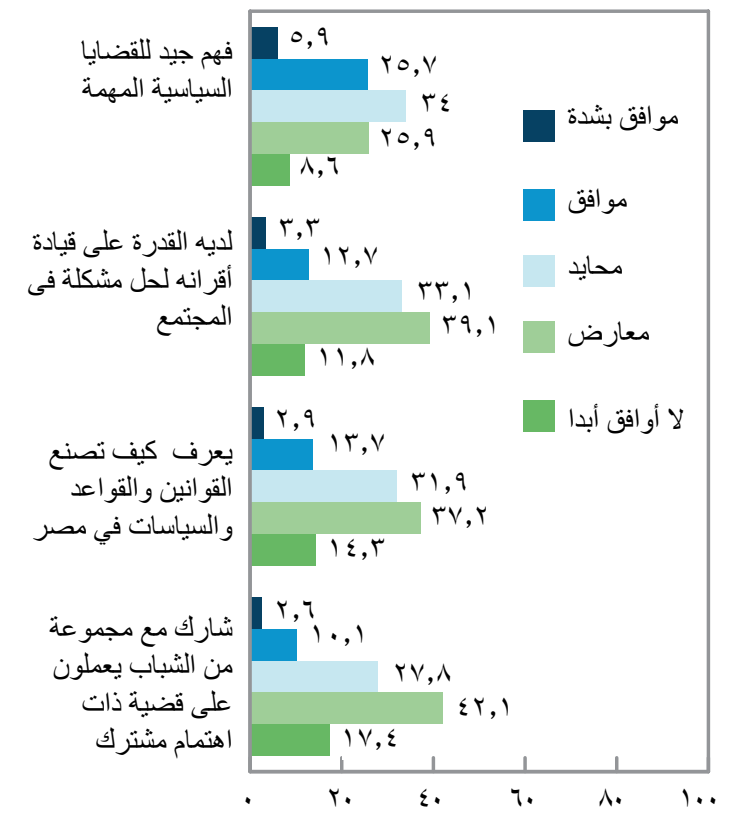


أنهم ونظر أ لعدم الاستقر ار الاقتصادي و الاجتماعي و السياسي

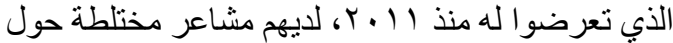

ما اذا كانت هذه الحركة ماز الت ضرورية او ما اذا كاندانت التاني الطريقة الاكثر فعالية لتحقيق الاصلاح. ومع ذللك، كان الثباب

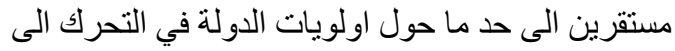
الامام و التى جاءت على رأسها الاستقر ار الاقتصادي وتحسين

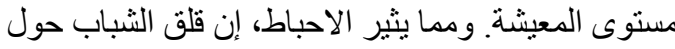

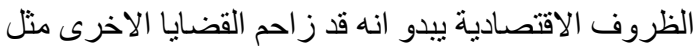
ضمان الديموقر اطية وحقوق الانسان، و قد اعترف الكثير

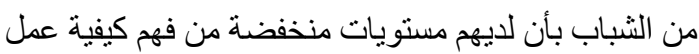
الجهاز السياسي و التشريعي، على الرغم من مناقثة الكثير من الاصلاحات وتطبيقها اثثاء هذه الفترة.

علاوة على ذللك و على الرغم من وجود نصور أن الثباب

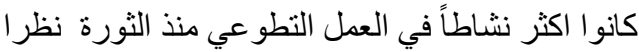
لاحساسهم بو اجب مساعدة واصلاح وطنهم، إلا ان بيانات

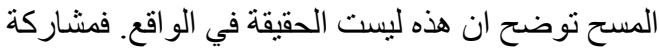
الثباب في العمل التطو عي قد ظلت ثابتة منذ 9 ـ . بـ، ومشاركتهم في المجمو عات الاجتماعية قد انخفضت بالفعل. و أكثر من ذلك، فإن الثباب الذين يشاركون وينخرطون بشكل ما فى الحياة المدنية هم الاكثر مشاركة فى الاشكال الأخرى

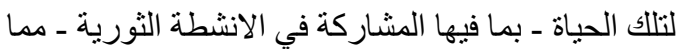
يبر هن على وجود عدد قليل من الثباب المنخرط في الحياة

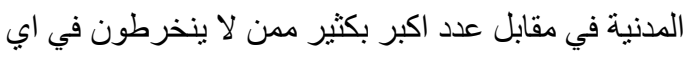

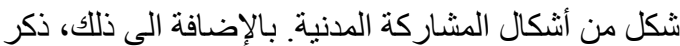
الثباب في المسح انهم في الحقيقة لا يتناقشون في السياسة كثير أ، و عندما يفعلون ذلك فأنهم يناقشونها مع اصدقائهم و أنثقائهم. اغلبية الثباب ذكروا ايضا انهم لا يتحدثون في

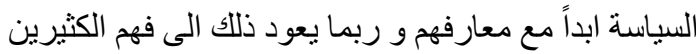
ان البيئة السياسية قد اصبحت استقطابية وان مستويات الثقة الاجتماعية بالإجمال منخفضة.

ان المستويات المنخفضة للمشاركة المدنية للثباب تعكس التباعد الثديد بين ما يعتقدون انه سيحدث التغيير في مصر

وبين افعالهم، مما يثير الكثير من القلق بالنسبة للمرحلة

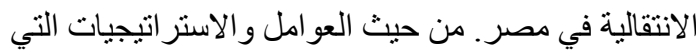
يعتقد الثباب بأنها ستحدث الاصلاح في مصر ، فإن ثقتهم قليلة في ان السياسيين سوف يوفون بو عودهم في احداث

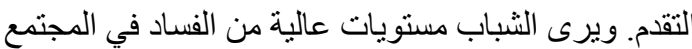
ومستويات منخفضة نسبياً لبعض القيم الاجتماعية بما فيها

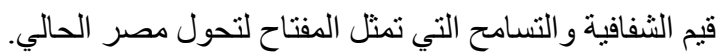

\section{مدى مناقثة الثباب للأحداث الجارية مع الآخرين، ؛ ا ب (\%).}

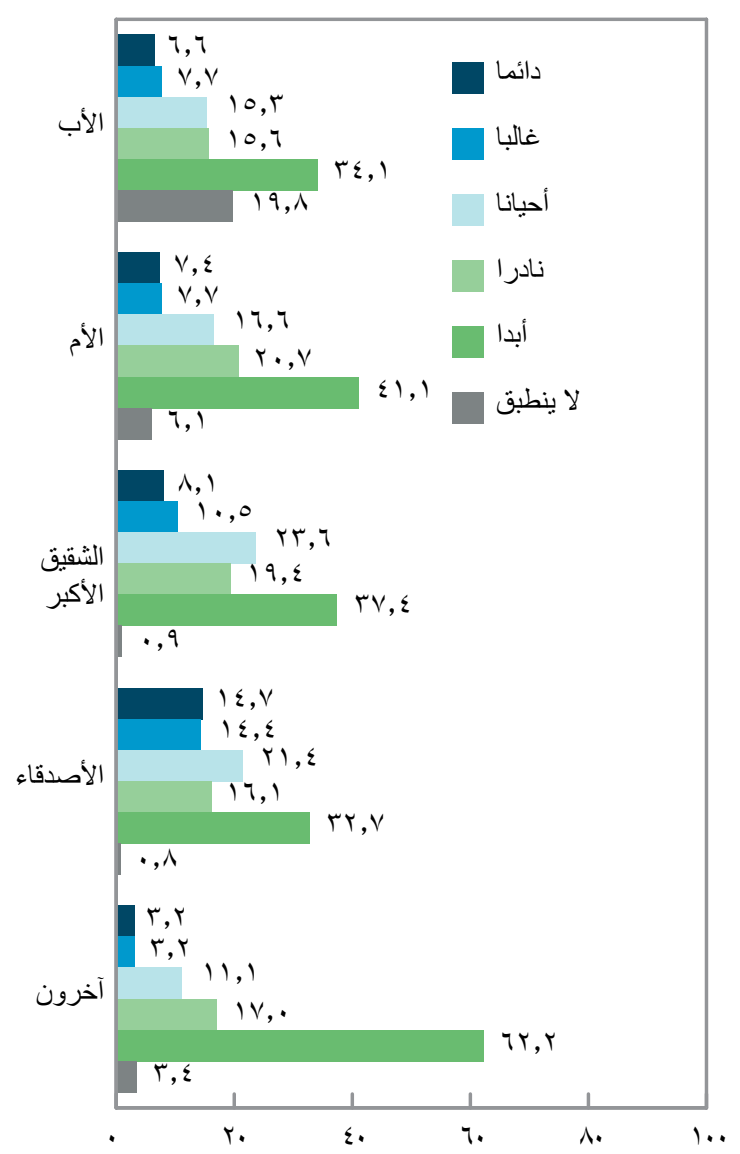

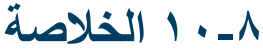

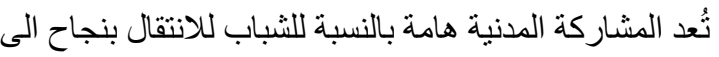
ادوار الناضجين الهادفة والتي عن طريقها يمكنهم المشاركة

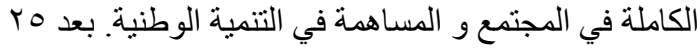

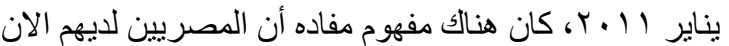
احساس اكبر بالو اجب لكي يكونو ا منخرطين في المشاركة المدنية وان يساعدو ا في تغيير اتجاه وطنهم. وقد حاول هذا الفصل ان يقدم فهماً اعمق للايناميكية المحيطة بالمشاركة

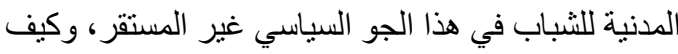
ان مشاركتهم قد تشكلت في هذه الفترة مقارنة بالمستويات

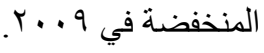

ولقد أوضحت نتائج المسح انه على الرغم من ان الثباب قد

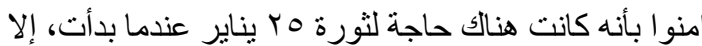


المسح التتبعي للنشء و الشباب في مصر ع ا ـ

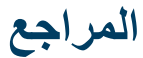

Assaad, Ragui. 1997. “The effects of public sector hiring and compensation policies on the Egyptian labor market." The World Bank Economic Review 11 (1): 85-118.

Assaad, Ragui and Caroline Krafft (eds.). 2015. The Egyptian Labor Market in an Era of Revolution. Oxford: Oxford University Press.

Corporation for National and Community Service. 2011. "Report Shows Majority of Americans Civically Engaged in their Communities." www.nationalservice. gov/newsroom/press-releases/2011/reportshows-majority-americans-civically-engaged-theircommunities. Accessed January 20, 2014.

Gallup. 2011. “Egypt from Tahrir to Transition: Egyptians on their Assets and Challenges and What Leaders Should Do about It." www.gallup.com/ poll/157046/egypt-tahrir-transition.aspx. Accessed January 20, 2014.

Korayem, Katima. 1997. "Egypt's Economic Reform and Structural Adjustment," The Egyptian Center for Economic Studies. www.eces.org.eg/Publication. aspx?ld=209. Accessed January 20, 2014.

United Nations. 1999. "International year of the volunteer 2001, background note," United Nations Volunteers, Bonn: UNV.

$$
\begin{aligned}
& \text { بالإضافة الى ذللك، عبر الثباب عن مستويات عالية من عدم } \\
& \text { الرضا عن اداء كل النظم الثناثة الاخيرة بالنسبة لمختلف } \\
& \text { القضايا الاقتصادية و السياسية والامنية. وفي المقابل، فإن } \\
& \text { حو الي • ٪ من المشاركين في المسح و افقو ا او و افقو ا بشدة }
\end{aligned}
$$

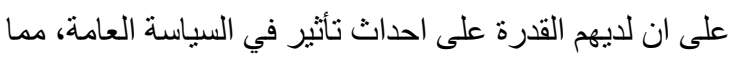

$$
\begin{aligned}
& \text { يثير الدهشة نظر اً للمعدلات المنخفضة في مشاركتهم الفعلية الفية } \\
& \text { في النشاط الثوري الذي تم ذكره في الفصل السابق و ايضاً } \\
& \text { المعدلات المنخفضة للعمل التطوعي و عضوية المجمو عات } \\
& \text { المذكورة في هذا الفصل. } \\
& \text { هنالك نتيجة و احدة مفعمة بالأمل وهي ان الثباب اظهروا قدراً } \\
& \text { من التفاؤل حول المستقبل، ويتوقعون تحسن حياتهم و مستوى } \\
& \text { أفضل للاولة فى خلال ه سنوات من وقت المسح مقارنة } \\
& \text { بتوقعاتهم قبل ه ب يناير ـ ومع ذلك، لكي نحقق هذه الرؤية } \\
& \text { الايجابية يجب ان يتم تعزيز مشاركة الثباب في الاحداث } \\
& \text { وفي النقاش السياسي والاجتماعي. بينما ينم اصلاح الهياكل }
\end{aligned}
$$

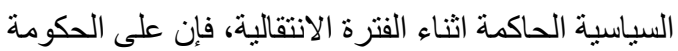

$$
\begin{aligned}
& \text { و المجتمع المدني تقديم طرق يمكن من خلالها سماع صوت } \\
& \text { الثباب بشكل هادف، وتلبية احتياجاتهم ومنحهم المساحة } \\
& \text { للمساهمة و المساعدة في تخطي التحديات التي تو اجهها الدولة. }
\end{aligned}
$$


و التحرش الجنسي - فقد تم تعديل صياغة الأسئلة في مسح

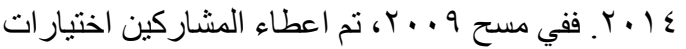

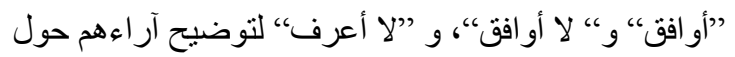

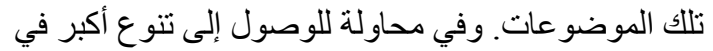

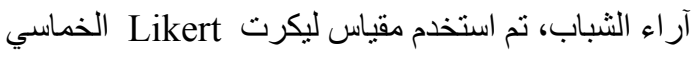

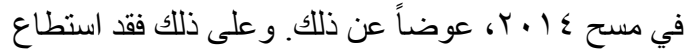

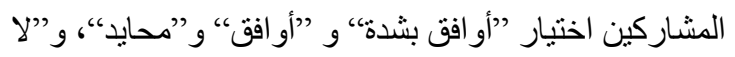

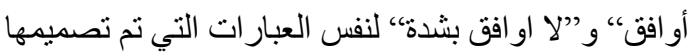
لقياس الاتجاهات الخاصة بالنوع الاجتماعي بين عينة sسح

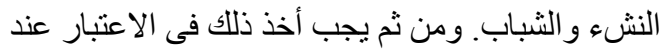

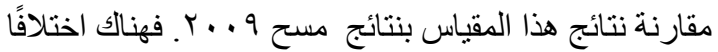

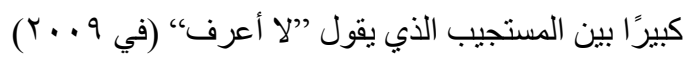

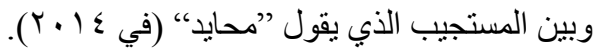

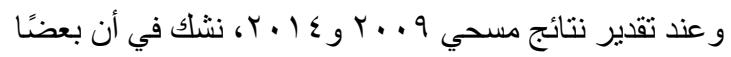

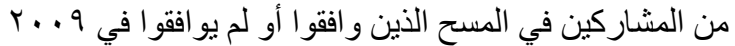

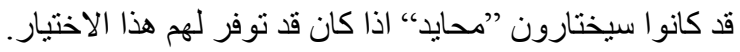

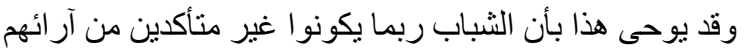

المتعلقة بمعايير النوع الاجتماعي و المساو اة بين النوعين،

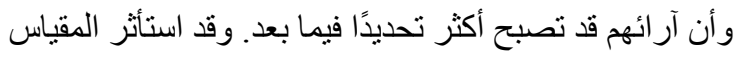

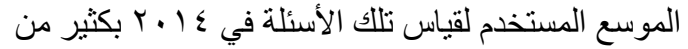
هذه التفاعلات. وفي مو اقف متعددة، ومن أجل تسهيل تفسير

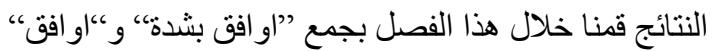

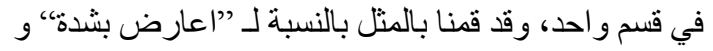

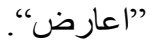

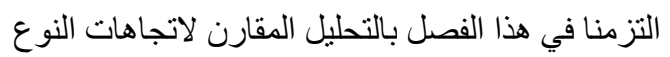
الاجتماعي التي لم تخضع لهذا الاستبيان المعدل. ويركز

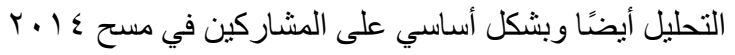

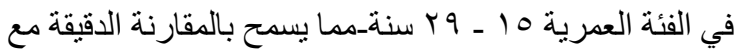

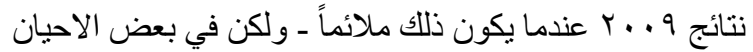

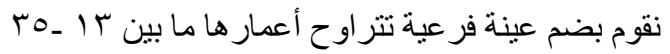

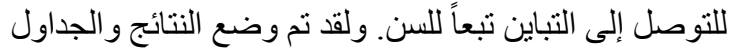

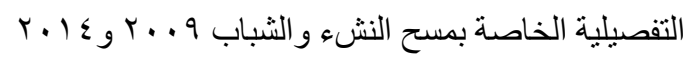
في الملحق، و التي تغطي المشاركين في مسح ع ا ـ ب الذين

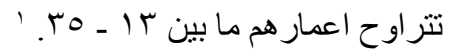

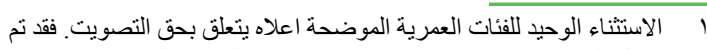

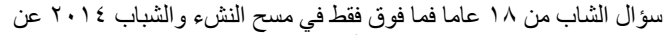

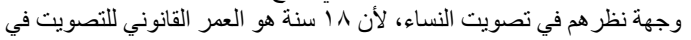

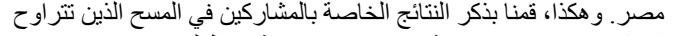

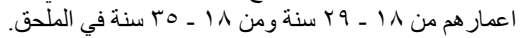

\section{توجهات المحتمع عن النوع لها آثنار مباشرة على مجالات

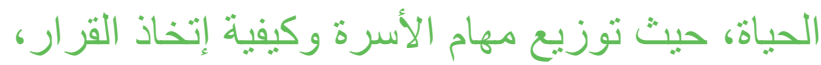 وتوازن القوى فى العلاقات الأسرية. هذه التوجهات تؤثر على الإناث من حيث حقها فى الطلاق و التعليم و العمل و المشاركة السياسية ، بل و خطر تعرضها للعنف.}

\section{9ـ 1 مقدمة}

قام مسح النشء و الثباب في مصر 9 ×. . ب بقياس اتجاهات

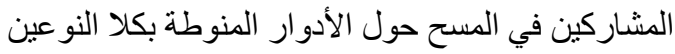

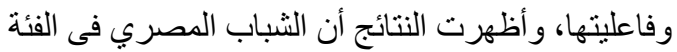

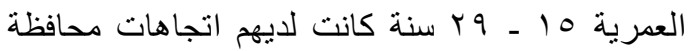

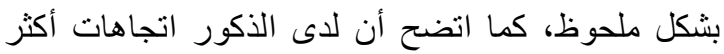

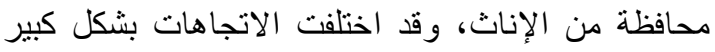

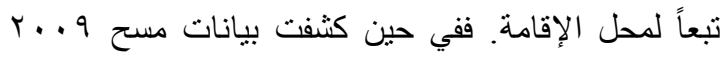

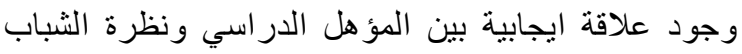

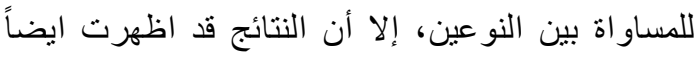

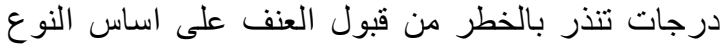

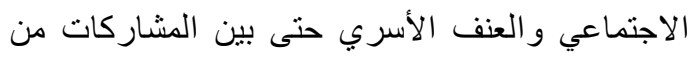
الاناث (El Kogali, Krafft ,and Sieverding 2011).

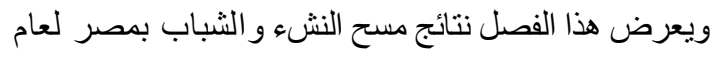

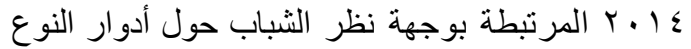

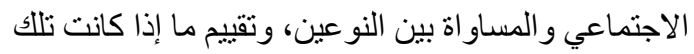

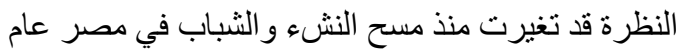

$$
.+9
$$

ولقد تضمن استبيان § ا ـ ب نفس الأسئلة المرتبطة بالنوع

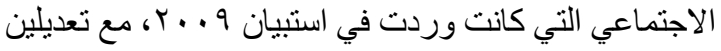

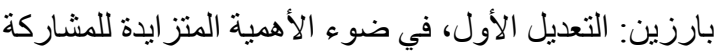

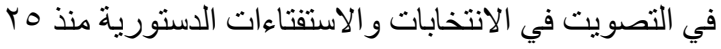

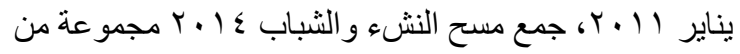
البيانات حول نظرة الثباب لتصويت المر أة. أما التعديل الثاني،

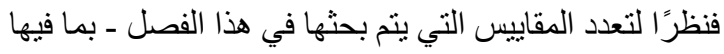
المقاييس المرتبطة بالنوع الاجتماعي، و الحصول على التعليه،

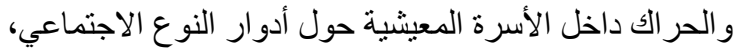




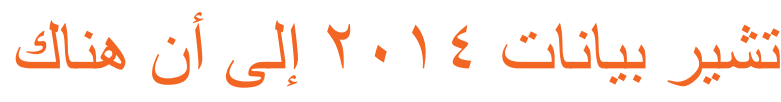
علاقة طردية بين المستوى التعليمي للشباب ودعمهم للمساو اة في الحصول على التعليم بالنسبة للأو لاد و البنات على السو اء.

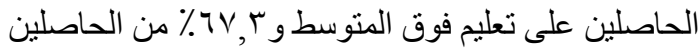
على التعليم الجامعي يعتقدون أن تعليم البنات هو بنفس أهمية

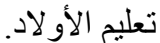

وتختلف الاتجاهات حول أهمية تعليم البنات بالمقارنة بتعليم

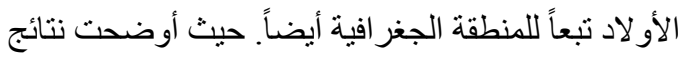

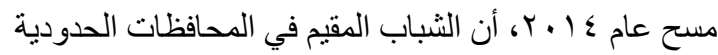

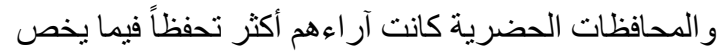

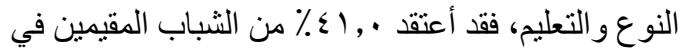

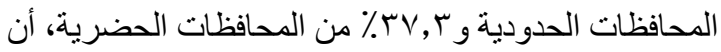

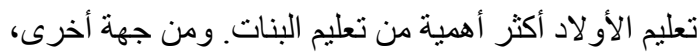

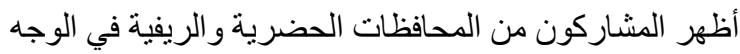

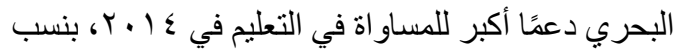

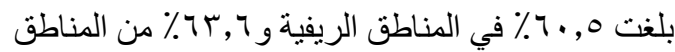

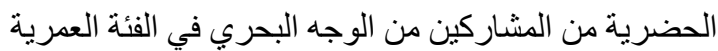

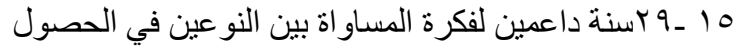

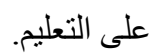

T_Y الحصول على التعليم، والتوظيف

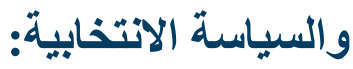

تعليم الأناث في مقابل الأكور

لمعرفة كيف ينظر الثباب المصري للمساو اة بين النو عين في

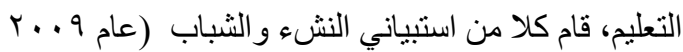

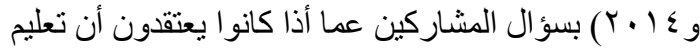

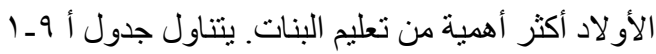

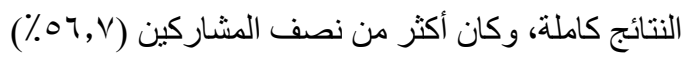

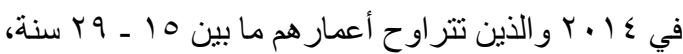
قد عارضوا فكرة أن تعليم الأو لاد أهم من تعليم البنات، بينما

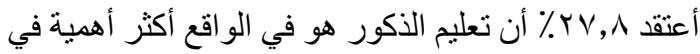

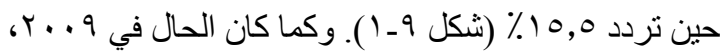

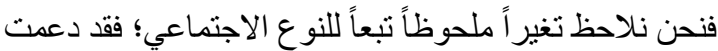

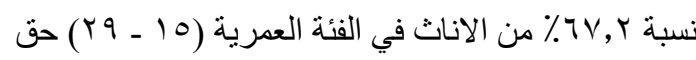

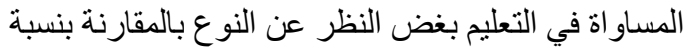

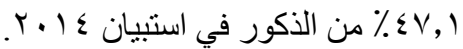

وتثير بيانات \& 1 ـ ب إلى أن هناك علاقة طردية بين المستوى

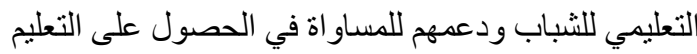

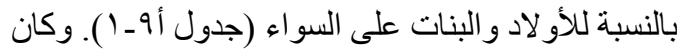
الثباب الذنين لم يحصلوا على أي قدر من التعليم (الأميين)

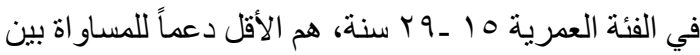

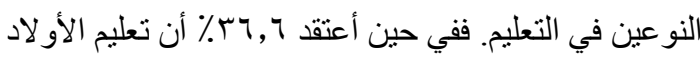

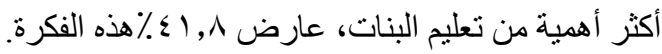

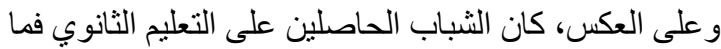

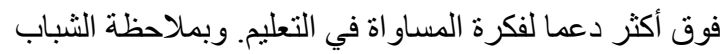

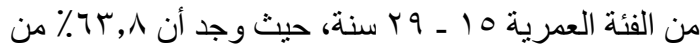

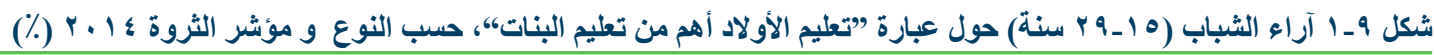

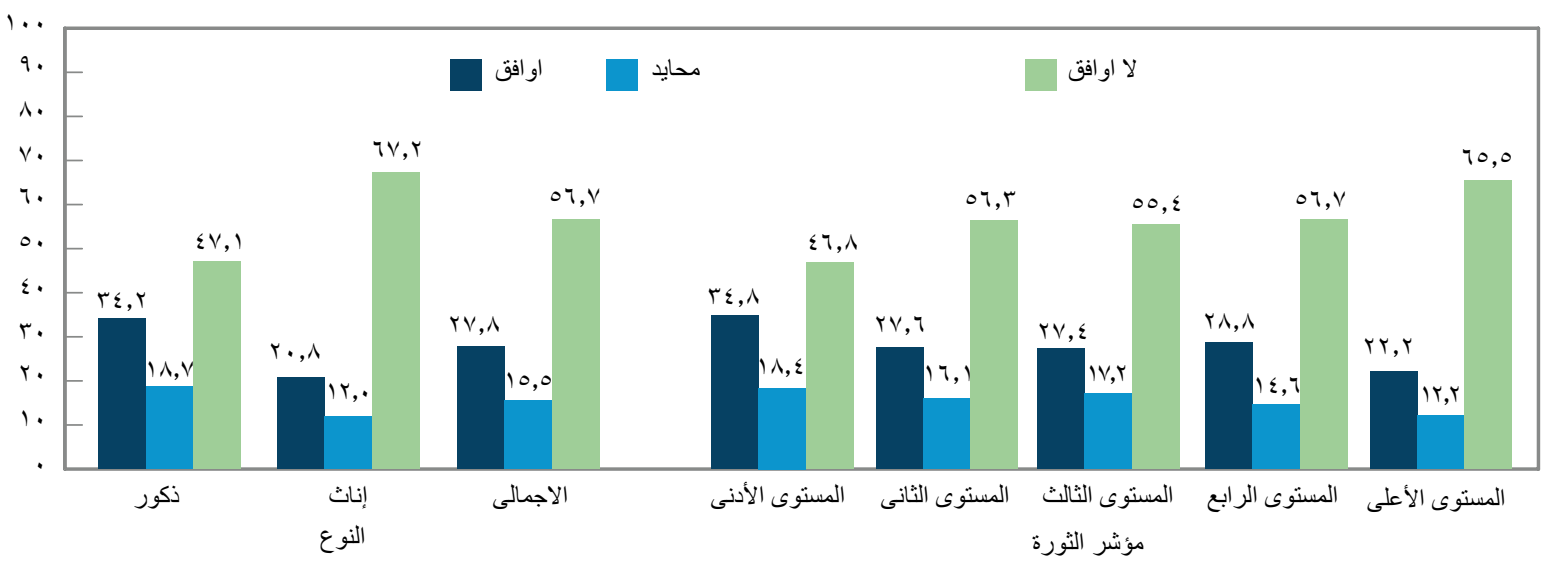




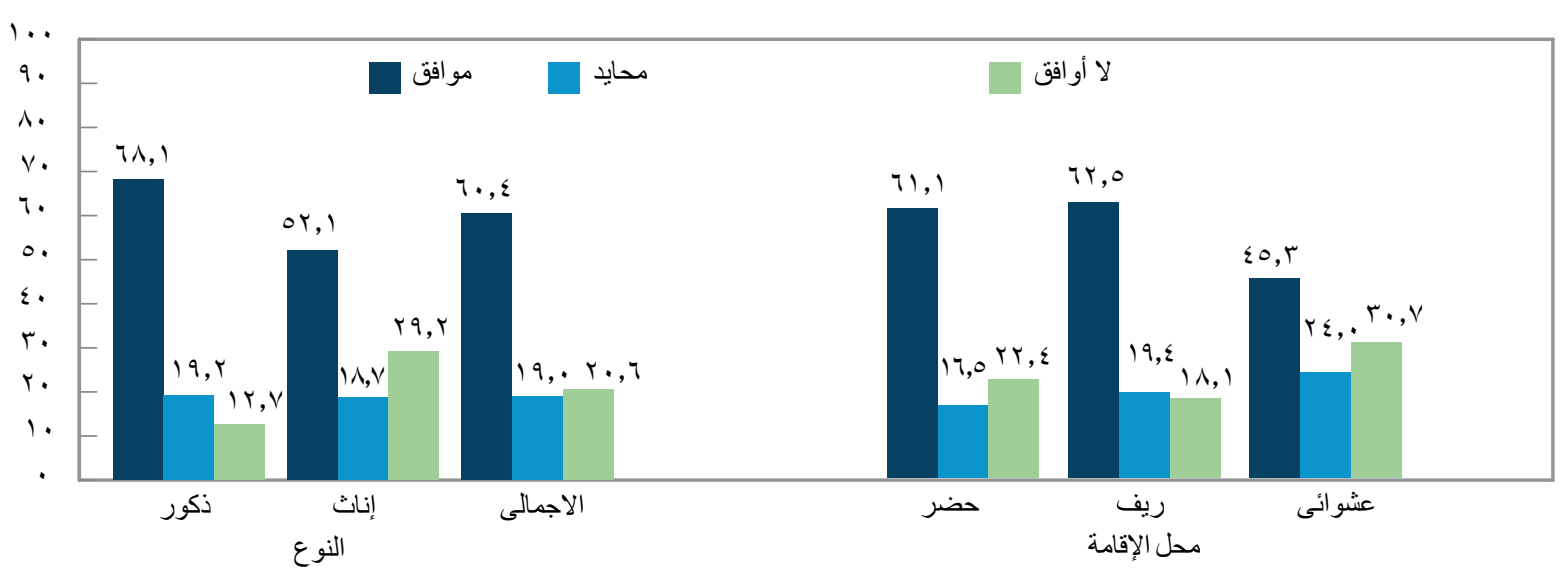

الرجال في كلا المسحين. ومع ذلك، نجد أن غالبية المشاركين

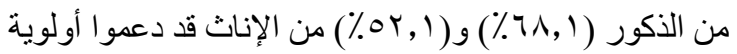

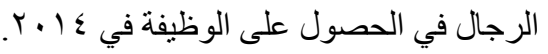

وكان دعم الثباب لأولوية الرجال في الحصول على عمل

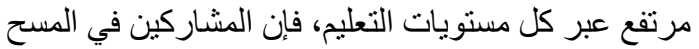

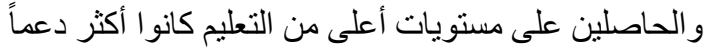

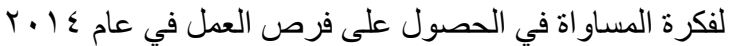

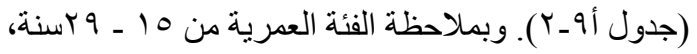
نجد أن المشاركين الحاصلين على تعليم ثانوي كانو ا أكثر

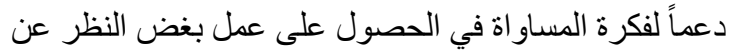

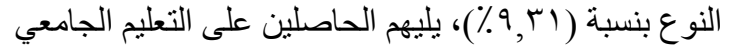

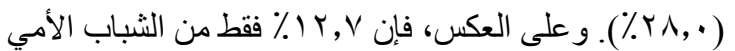

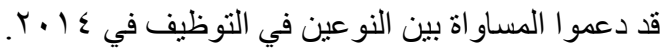

نلاحظ كذلك بعض الفروق في أراء الثباب تبعاً للمنطقة الجغر افية ومكان الإقامة (حضر /ريف). فالثباب في الفئة

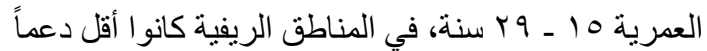

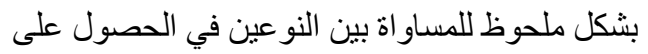
عمل، أكثر من أولئك الذين يعيشون في المناطق العشو ائية،

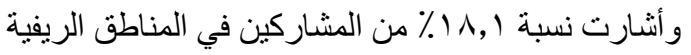

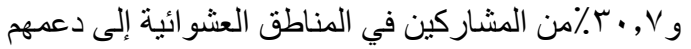

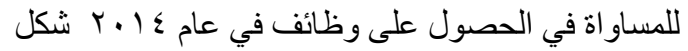

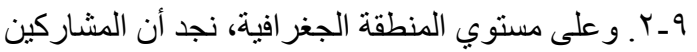

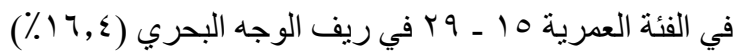
وفي المحافظات الحدودية (ع (0 1\%) كانو ا الأقل دعماً لفكرة المساو اة في فرص العمل. و على خلاف نظر ائهم الريفيين،

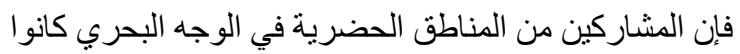

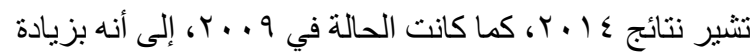
مستوي الثروة، يزداد دعم حق البنات في التعليم (شكل 9 ــ ( ).

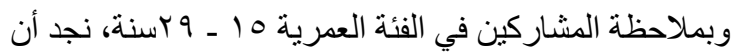
الثباب من الأسر الأقل ثروة كانوا الأكثر تحفظاً في آر ائهم

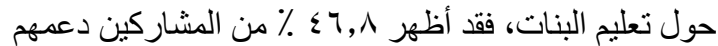

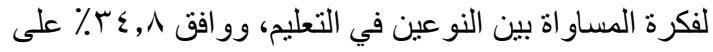

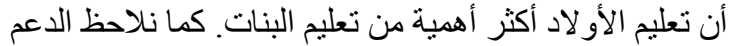

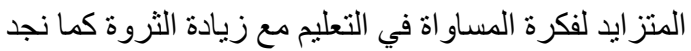

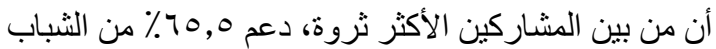

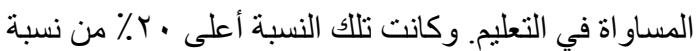

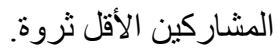

\section{أولويةّة التوظيف}

تم سؤ ال المشاركين في كلا المسحين عما إذا كانو ا يعتقدون أن للرجال الحق في الحصول على الوظائف أكثر من النساء عندما تقل فرص العمل المتاحة (لمعرفة كل النتائج، انظر

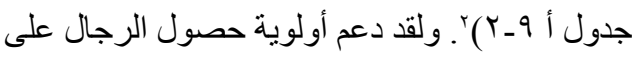
الوظائف نسبة ع , ـ 7 ٪ من بين الثباب في الفئة العمرية 10

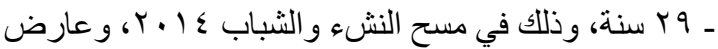

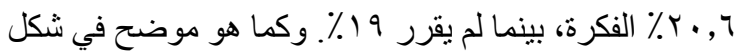
9_T، كانت الإناث المشاركات هن من نادين بالمساو اة بين

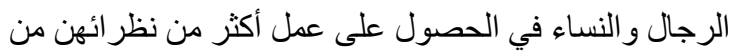

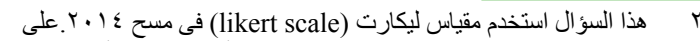

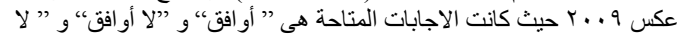

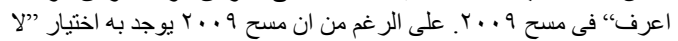

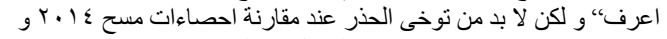

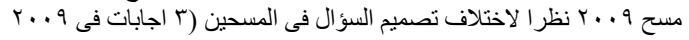

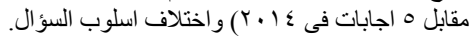




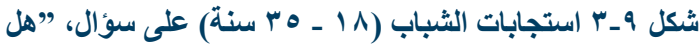

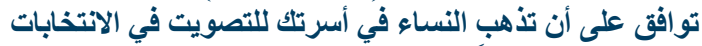

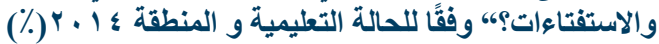

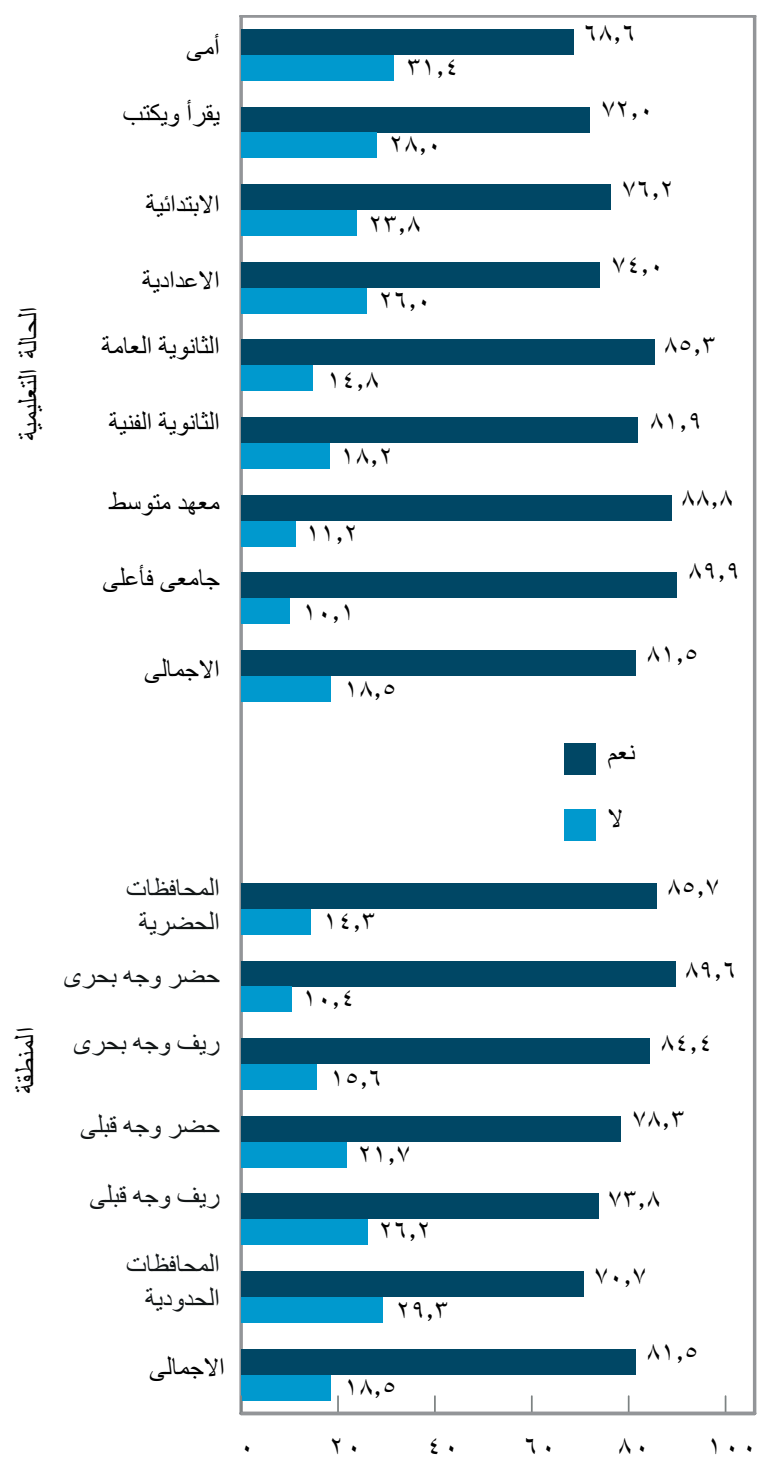

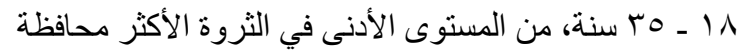

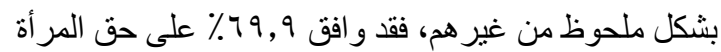

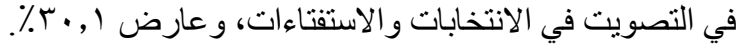

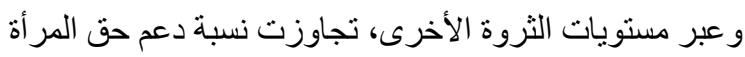
في التصويت أكثر من • ^٪ من المشاركين. ونلاحظ أن أكثر

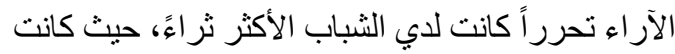

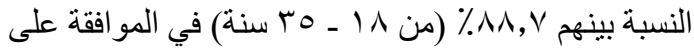
حق النساء من أفر اد الأسرة في التصويت.
الأكثر دعماً لفكرة المساو اة، بأكثر من الربع بقليل (7, ד ؟ \%) مؤكدين دعمهم للمساو اة في الحصول على عمل بغض النظر

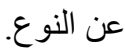

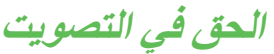

تم تعديل قسم المشاركة المدنية لمسح النشه و الثباب ـ ـ ـ r،

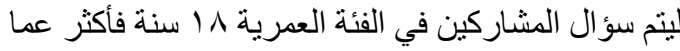
إذا كانو ا يعتقدون في وجوب السماح للنساء من قبل أسر هن

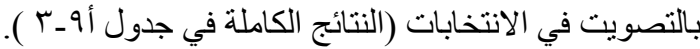

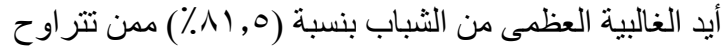

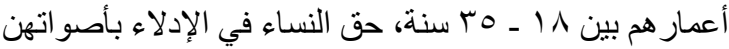

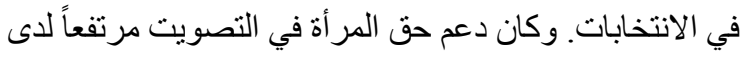

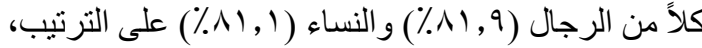

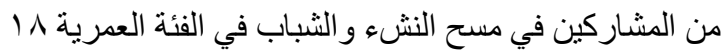

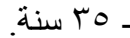

وكما هو موضح في شكل 9-ب، فإن غالبية الثباب في كل

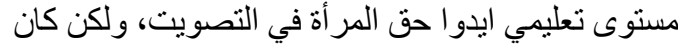

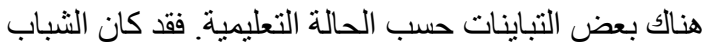

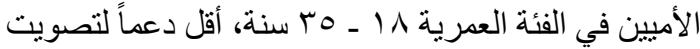

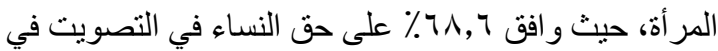
الانتخابات والاستفتاءات. وقد كان ذلك أقل ـ بـ من الثباب

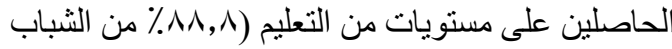

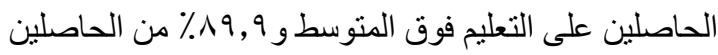
على التعليم الجامعي، و (r ,10\%) من الحاصلين على شهادة

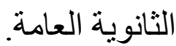

وبالنظر للمنطقة ومكان الإقامة، كان الثباب في الفئة

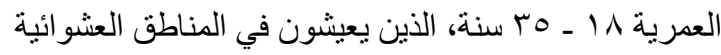
الأكثر دعماً لفكرة تصويت المر أة بنسبة (0, • 9\%)، يليهم

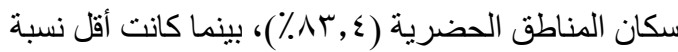

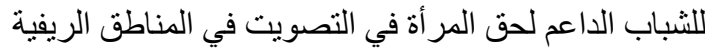

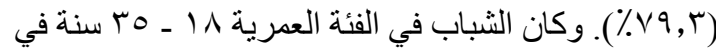
المحافظات الحدودية وريف الصعيد في الغالب هم الأقل دعماً

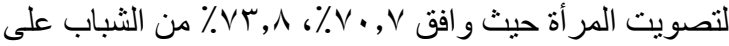

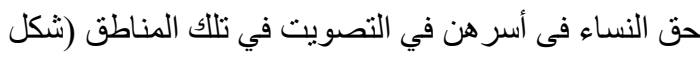

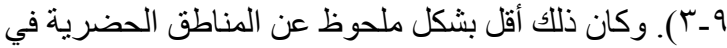

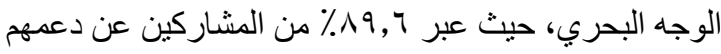

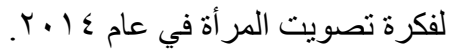
كما لوحظ وجود علاقة موجبة بين مستوى ثر اء الأسرة ودعم الثباب لتصويت المر أة. فقد كان الثباب في الفئة العمرية 


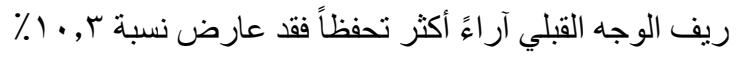

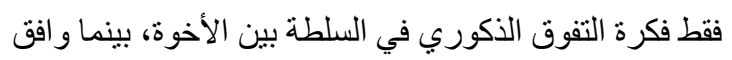

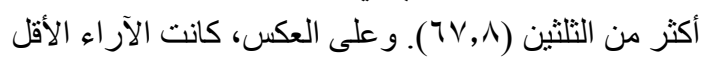

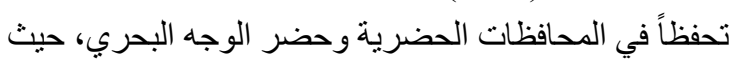

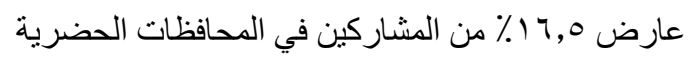

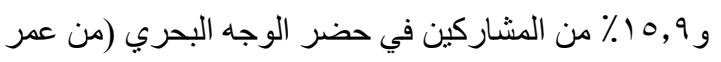
10 ـ و س سنة) على فكرة سلطة الأخ على أخته.

وظلت الآر اء محافظة بغض النظر عن الحالة التعليمية، على الرى

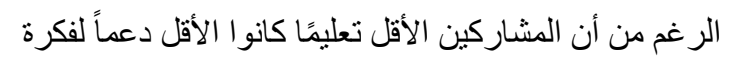

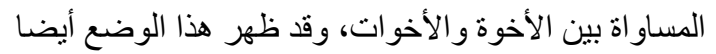

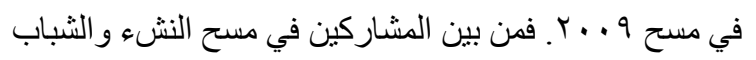

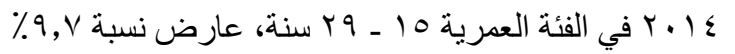
فقط من الثباب الأمي و 9٪ من الثباب الحاصلين على التعليم

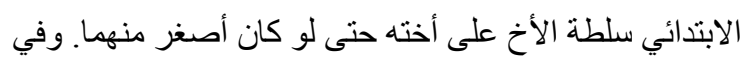

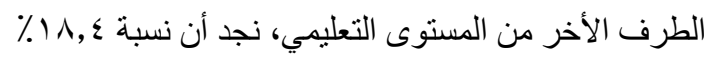

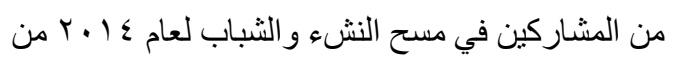

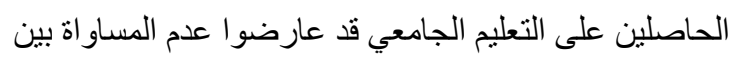

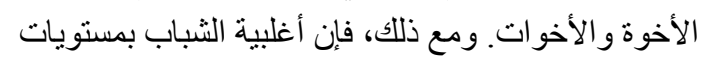

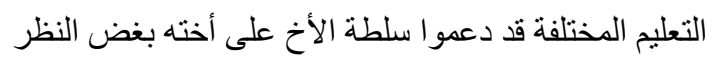

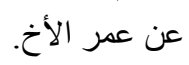

وكانت الآر اء المحافظة حول عدم المساواة بين الأخوة

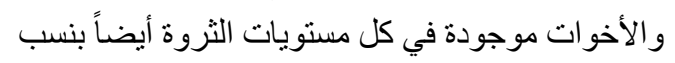
متفاوتة، على الرغم من أن هناك علاقة بين الثروة و وآراء

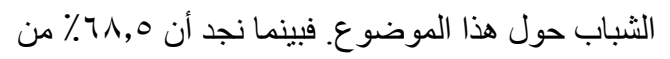

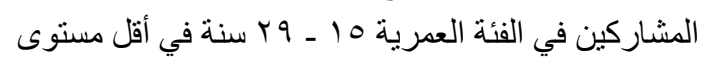

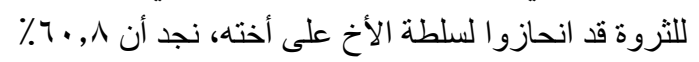

ـ_r الحرات فى الأسرة المعيشية

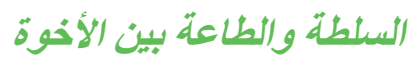

لكي ندرس بشكل أفضل الحر الك داخل الأسرة المعيشية حول

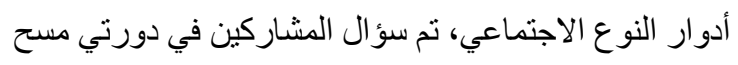

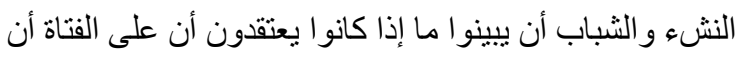

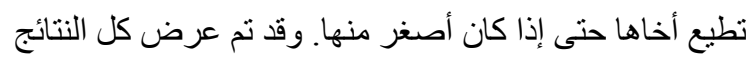

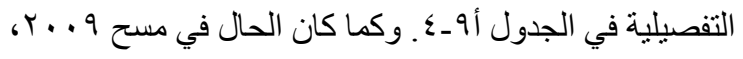

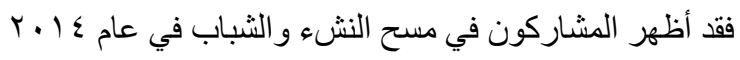

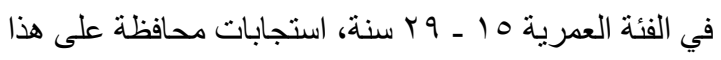

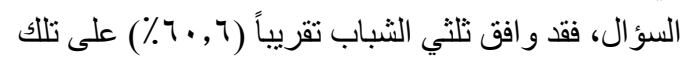

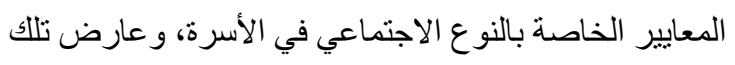

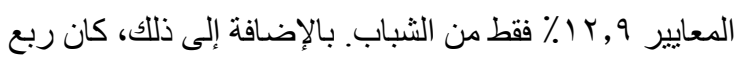

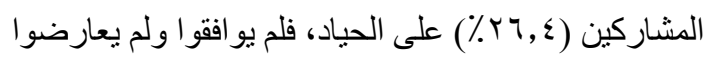

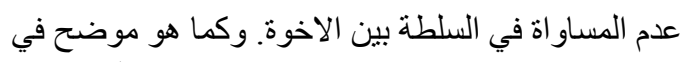

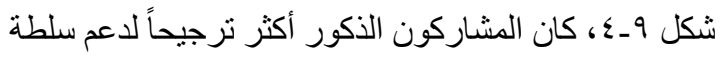

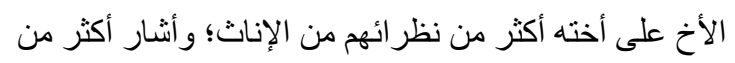

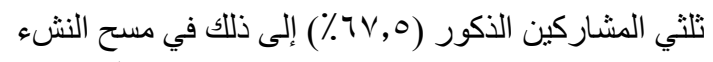

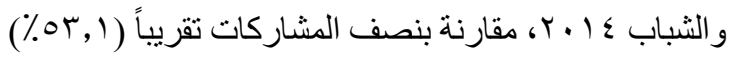

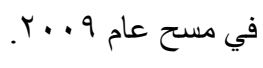

وفي حين كان دعم سلطة الأخ على أخو اته البنات مرتفعًا

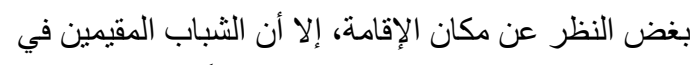

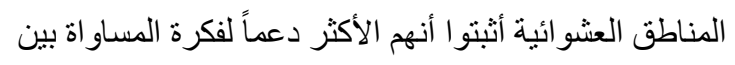

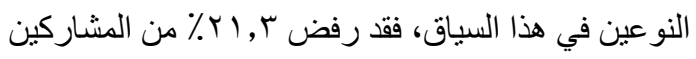

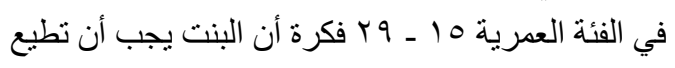

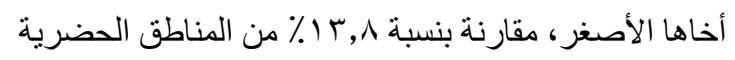

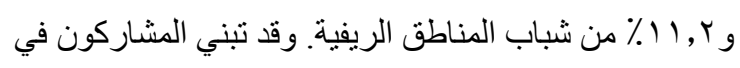

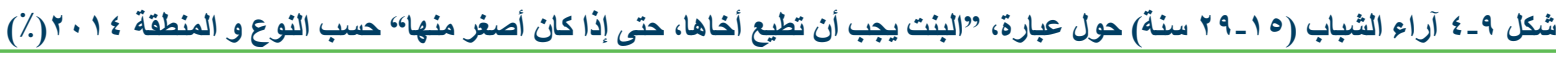

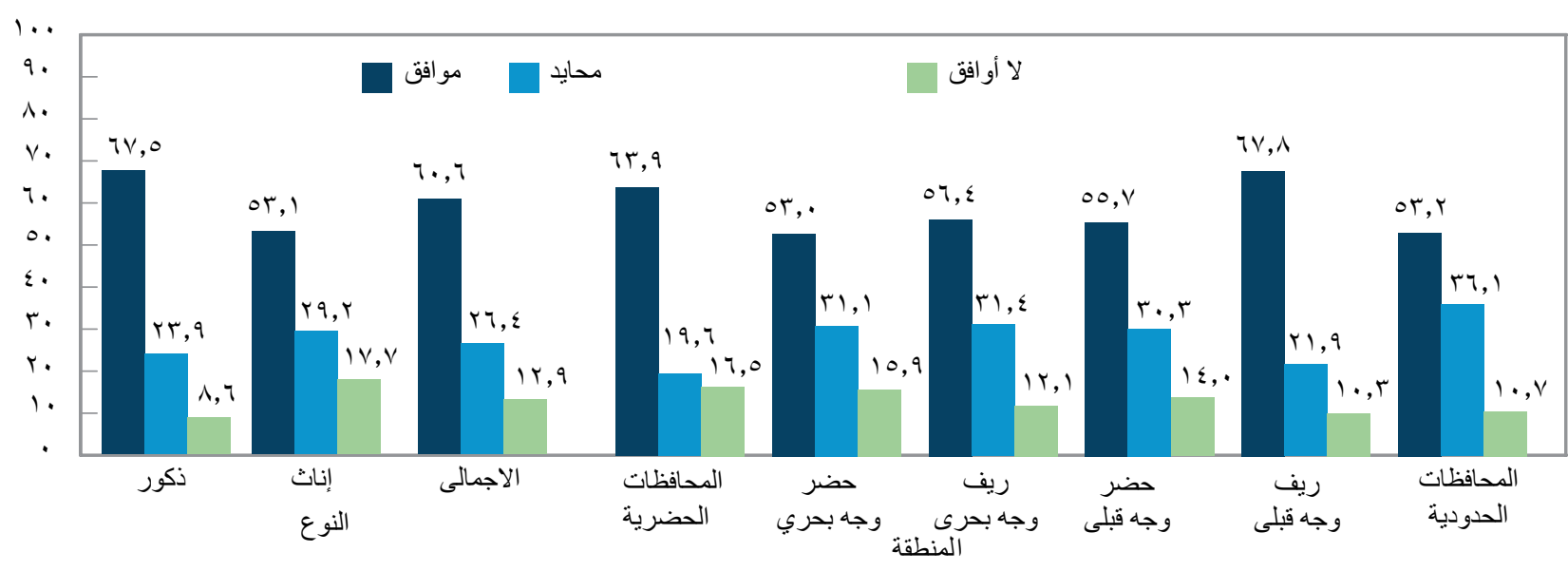




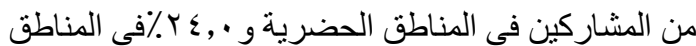
الريفية. ويختلف هذا عن نتائج مسح 9 9. . ب، حيث كان هنالك

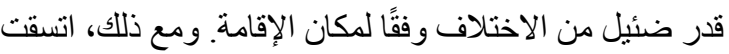
نتائج مسح ـ 1 ـ ب المتعلقة بتصور ات الثباب حول الأعباء المنزلية المرتبطة بالنوع الاجتماعي مع النتائج المتعلقة بالسلطة بين الأخوة والأخوات، حيث لاحظنا بالمثل آراء أكثر تحرراً بين الثباب في المناطق العشو ائية وآراء أكثر تحفظاً بين الثباب في المناطق الريفية.

و على مستوي المحافظات، فمرة أخرى تبني الثباب فى ريف الوجه القبلي و المحافظات الحدودية الآر اء الأكثر تحفظًاً.

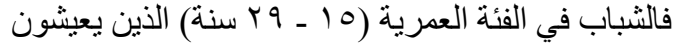
في ريف الوجه القبلي و الدحافظات الحدودية كانوا أقل دعماً لمساهمة الأولاد في الأعباء المنزلية بالتساوي مع البنات، فقد

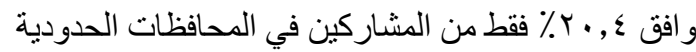

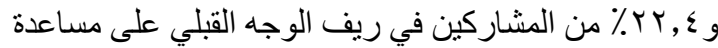

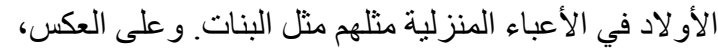
فإن المشاركين الذين يعيشون في المحافظات الحضرية كانوا

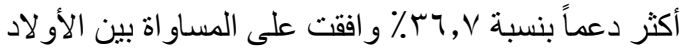

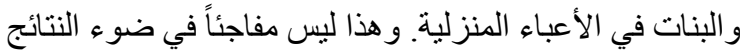

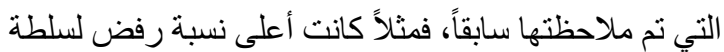
الأخ على أخوته البنات في المحافظات الحضرية .

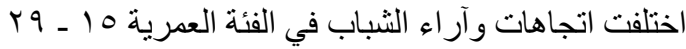

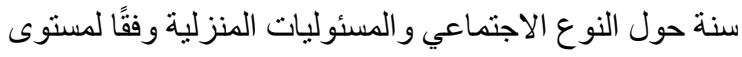
التعليم، ولكن لا يبدو أن هناك علاقة ارتباطية ثابتة بين

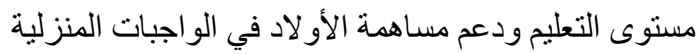

من المشاركين في المستوى الأوسط لمؤشر الثروة و 7,00٪ من المشاركين ذو المستوى الأعلى من مؤشر الثروة كانوا

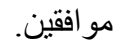

\section{النوع الاجتهاعي والواجبات المنزلية}

لكي نفهم أكثر آراء الثباب حول معايير النوع الاجتماعي

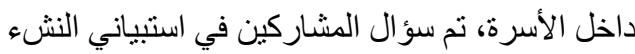

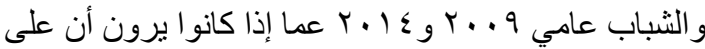

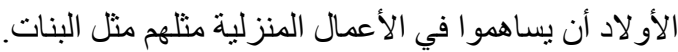
يعرض جدول أوــ البيانات التفصيلية حول هذا الدفهو .

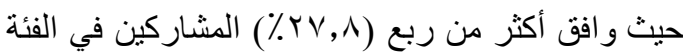

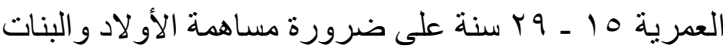

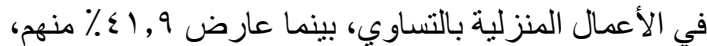

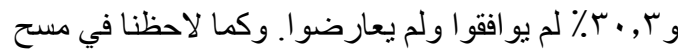

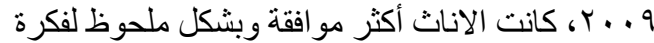
المساو اة بين البنات و الأو لاد في الأعمال المنزلية: حيث و افقت

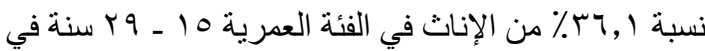

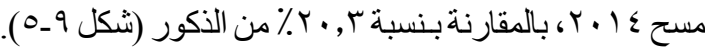

وبملاحظة النتائج وفقًا لمحل الإقامة، نلاحظ أن من بين

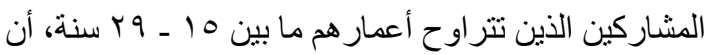

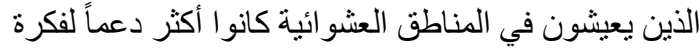

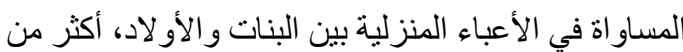

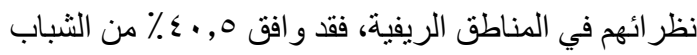

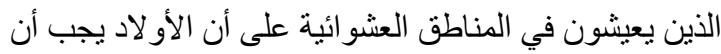

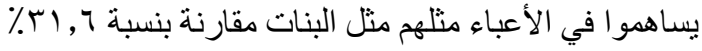

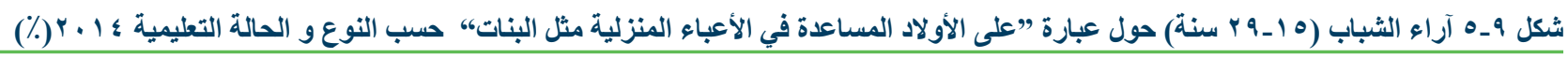

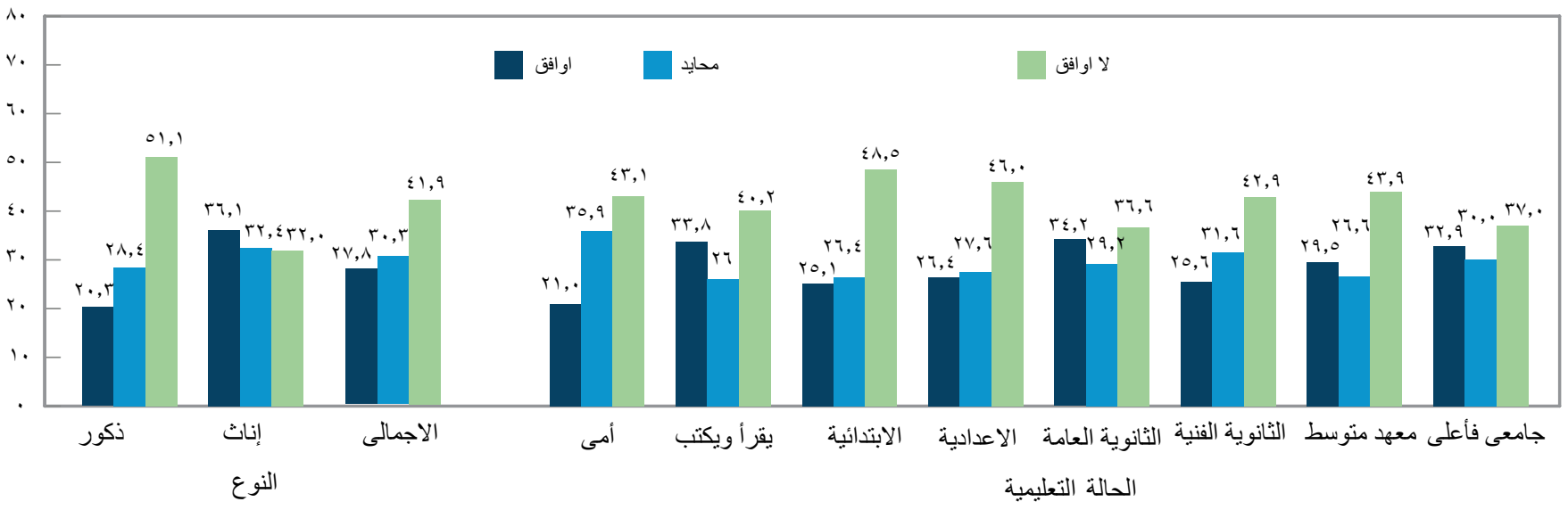




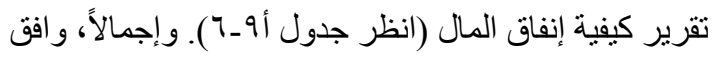

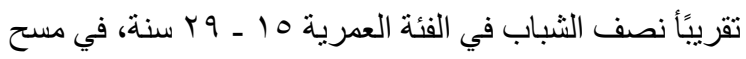

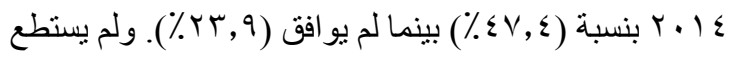

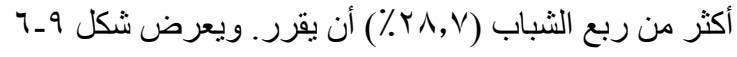

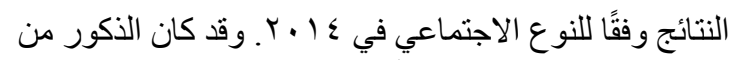

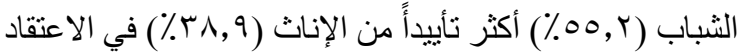

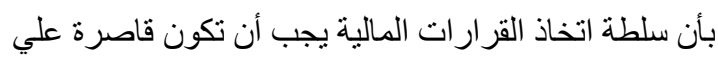

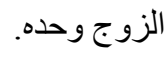

وقد وجد أكبر تاييد لسلطة الرجال على الإنفاق المنزلي في

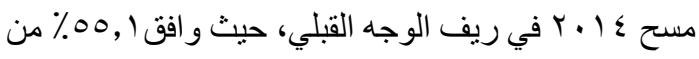

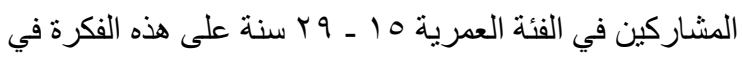

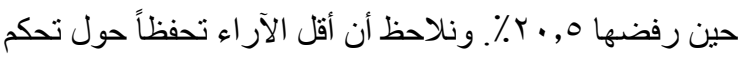

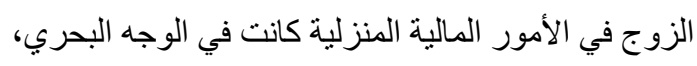

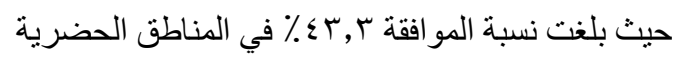

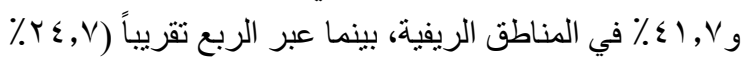

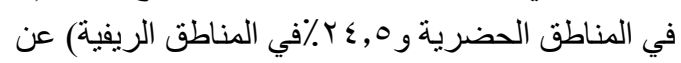
رفضهم لهذه الفكرة.

ونلاحظ أن هنالك تبايناً ملحوظاً ـ دون وجود ارنباط و اضح-

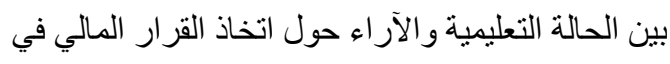

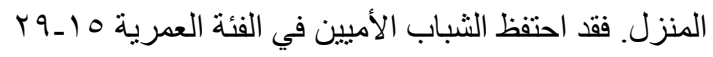

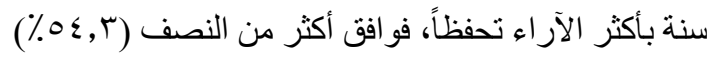

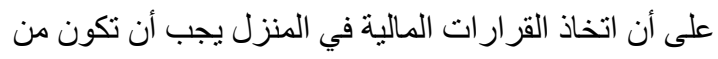

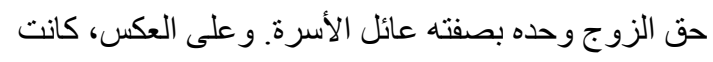

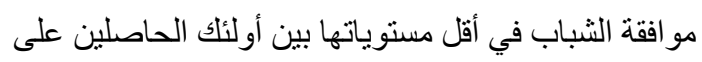

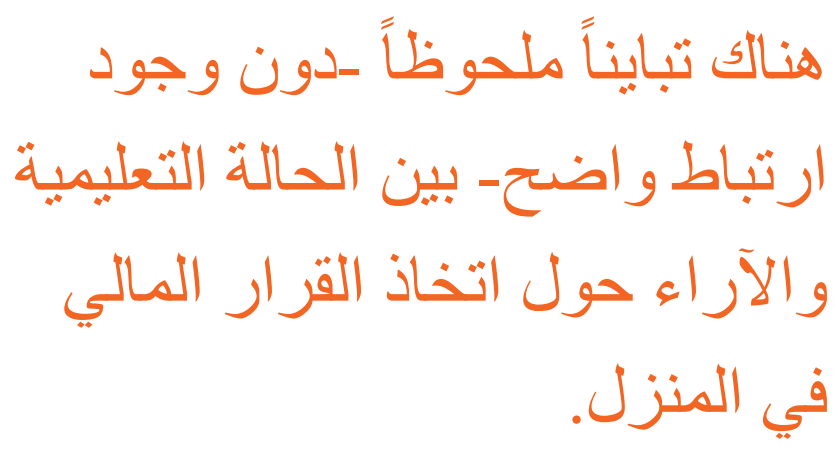

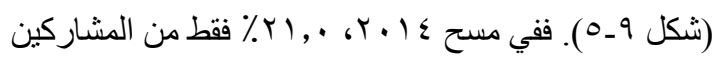

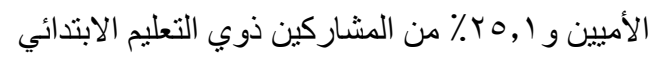

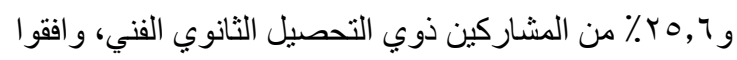

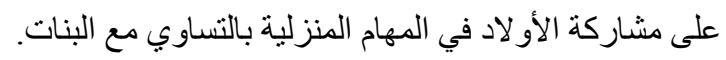

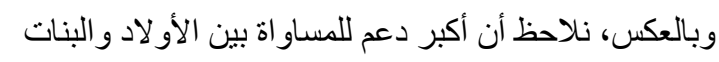

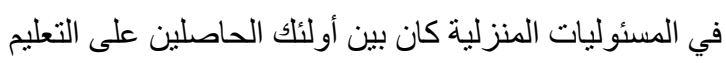

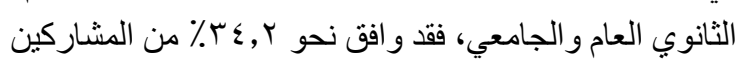

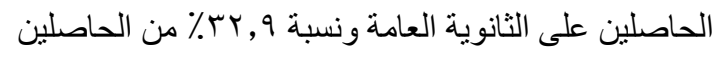

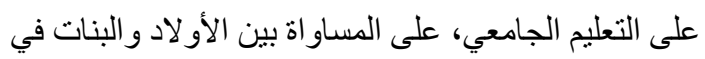
المساهمة في الأعمال المنزلية. انتخاذّ القرارات الهالية بين الأزواج لتقييم تصور ات الثباب حول سلطة اتخاذ القرارات المنزلية

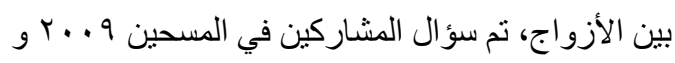

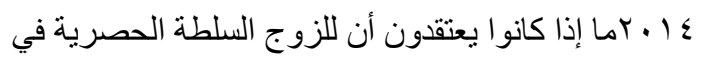

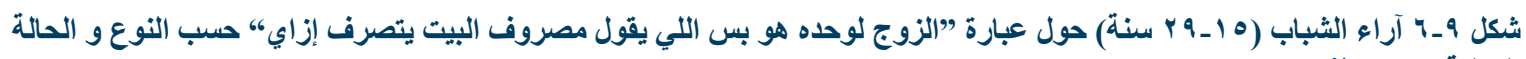

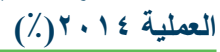

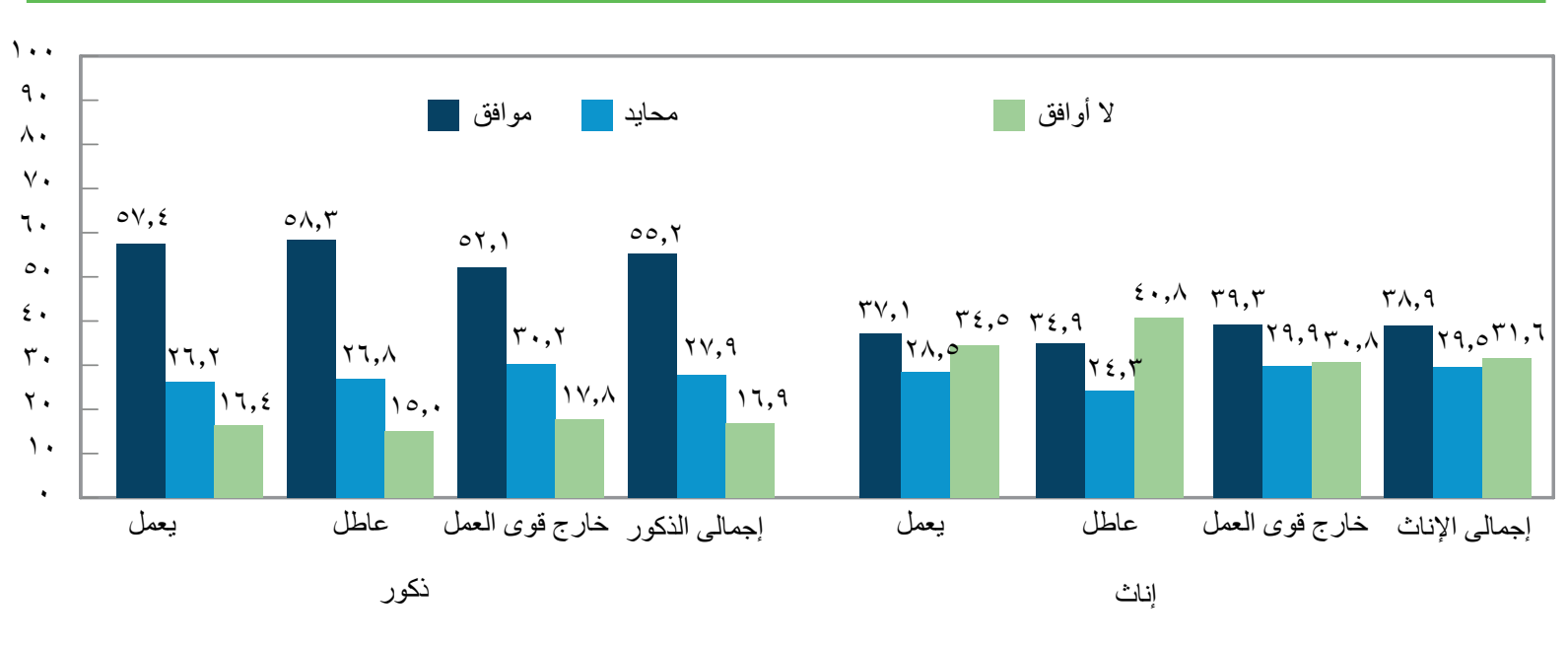




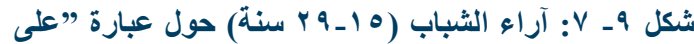
المرأة ان تأخذ إذن زوجها قبل القيام بأي شيء، حُه حسب النوع

(\%) $\%$. 1 \&

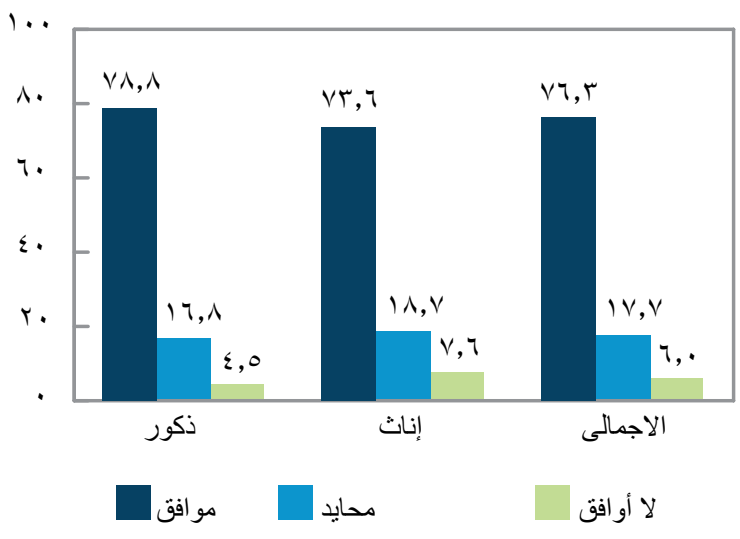

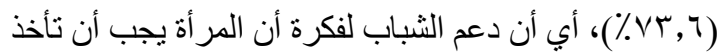

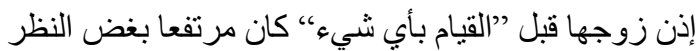

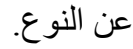

وكان هناك قليلاً من التباين في آراء الثباب حسب الحالة التعليمية، ولكن لم تكن هنالك علاقة و اضحة بين التعليم و الآر اء حول تللك المسألة. وفي الواقع، كان الثباب في الفي الفئة العمرية 10 ـ9 بنة الحاصلين على التعليم فوق المتوسط الأكثر

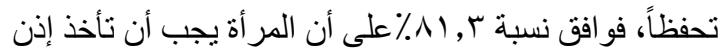

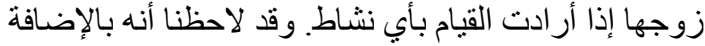

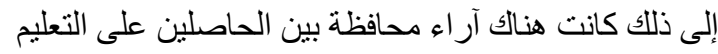

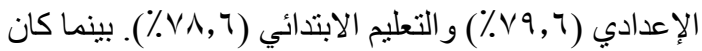

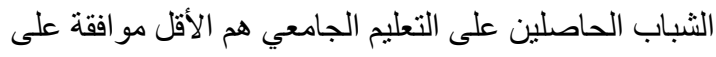

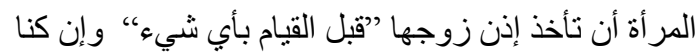

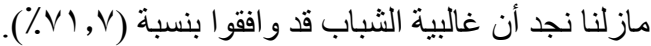

بتحليل نتائج مسح ع ا ـ ب تبعاً لمكان الإقامة، نلاحظ ان أكثر

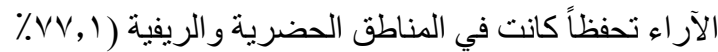

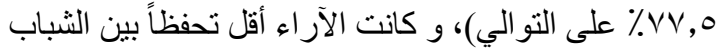

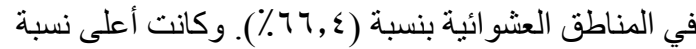

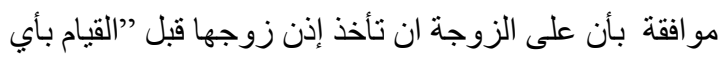

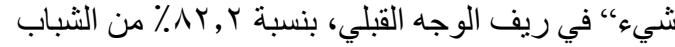
المشاركين في المسح. بينما كانت الموافقة أقل في ريف الوجات الوجه

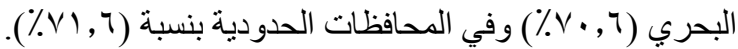

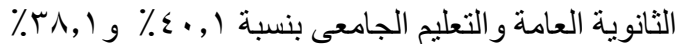

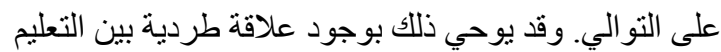
ووجهات نظر الثباب حول المساو اة في سلطة اتخاذ القرار ات اتل

المالية المنزلية بين الزوجين، كما نلاحظ ان هناك آراء

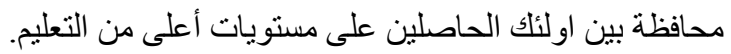

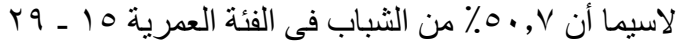

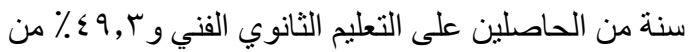

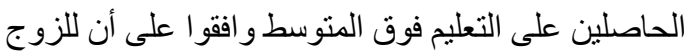

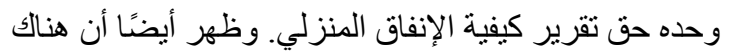

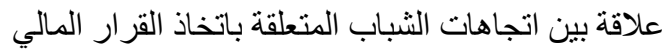

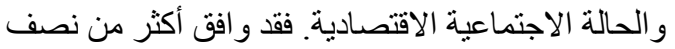

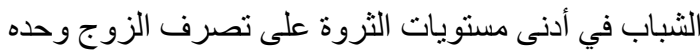
في الإنفاق المنزلي بنسبة (0, ؛ ٪) و العكس بالعكس، فقد و افق فقط ץ , • ؛ ٪ من الثباب في المستوى الأعلى من الثروة.

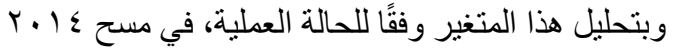

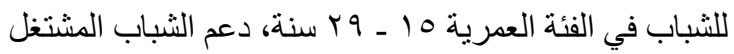
فكرة تحكم الزوج في القرار ات المالية المنزلية بنسبة

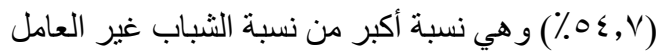

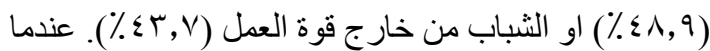

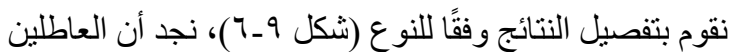
من الذكور في الفئة العمرية 10 ـ 9 ب سنة، كانوا أكثر دعماً، بدرجة قلبلة، لفكرة هيمنة الزوج على القرار ات المالية المنزلية

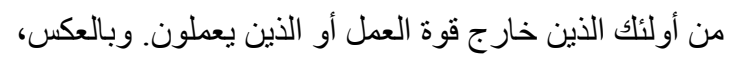

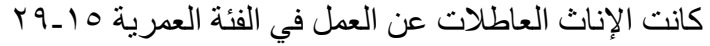

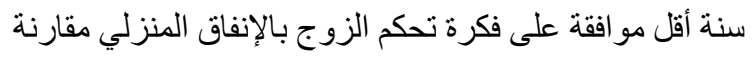
بنظير اتهن من الإنات العاملات أو خارج قوة العمل.

\section{الحصول على إذن من الزٔوج}

اهتم المؤشر الأخير الذي قام بتقييم اتجاهات الثباب حول

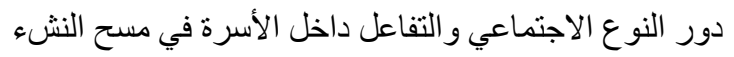

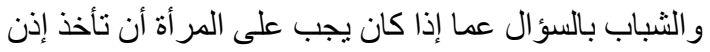

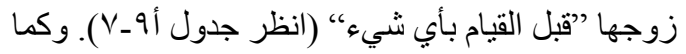

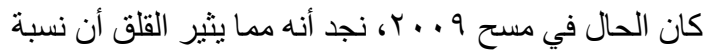

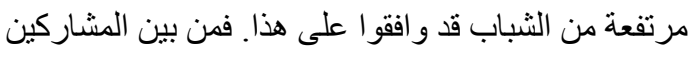

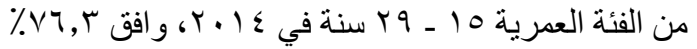

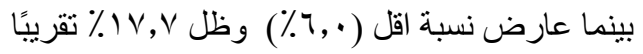

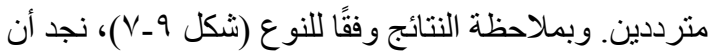

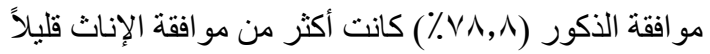




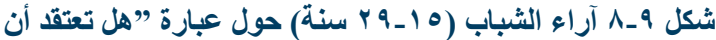

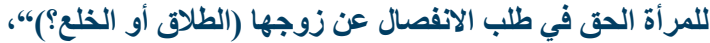

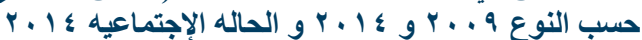

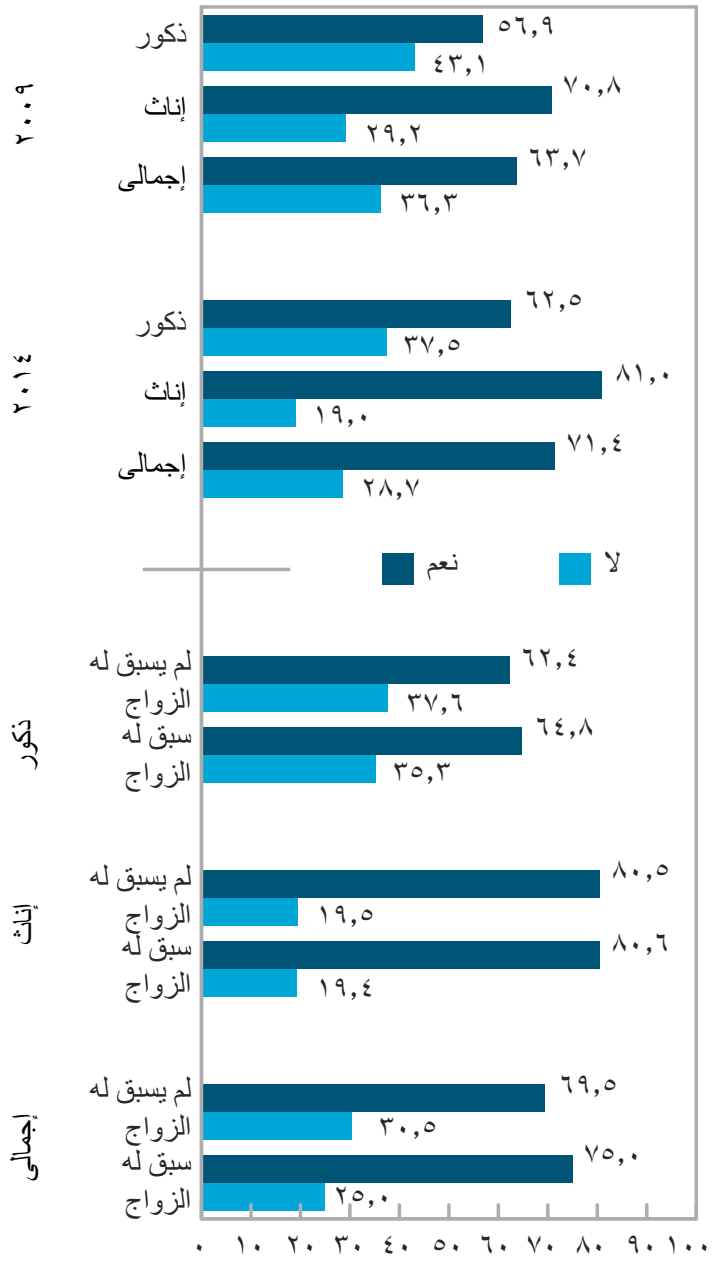

وقد اختلفت الاراء و الاتجاهات للشباب نحو حق المر أة في

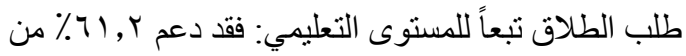

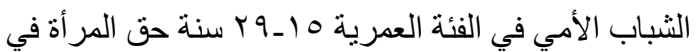
الطلاق، ومع زيادة المستوي التعليمي نجد زيادة ملحوظة في نسبة الدعم لحق المر أة في طلب الطلاق بين الثباب الثبا. فمن بين

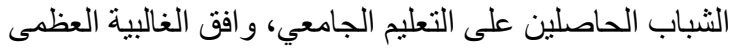

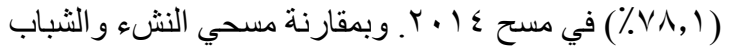

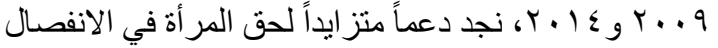
عن زوجها في كل مسنويات التعليم ما عدا الثنباب الحاصل الاصل على التعليم فوق المتوسط.
وبملاحظة آر اء الشباب في مسح ع ا ـ ب حول الحاجة إلى إذن

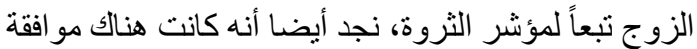
قوية في كل مستويات مؤشر الثروة، كما وجدنا أن هناك علاقة ضعيفة بين المستوى الاقتصادي للفرد و آر اء الثباب حول تلك آلكان المسألة. فالثباب الو اقع في أدني مسنويات الثروة الثيان كان الأكثر مو افقة على ذلك بنسبة (^, • •^٪)، ونجد أن نسبة المو افقة بين

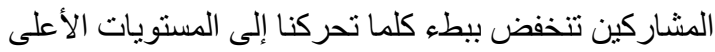
من الثروة. على الرغم من ذلك الارتباط الو اضح، ظلت موافقة الثباب مرتفعة بشكل مثير للقلق بين مستويات مؤشر الثروة الثرة الثران

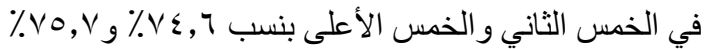

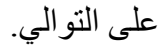

9 - ـ الطلاق حق المرأة في طلب الطلاق

سمح لنا استبيانا مسح النشء و الثباب 9 . . ب و ـ ا ـ ب بمقارنة آراء الثباب حول حق المر أة في الانفصال عن زوجها

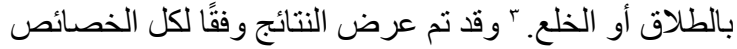

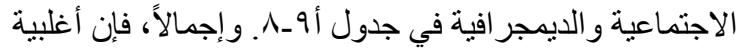

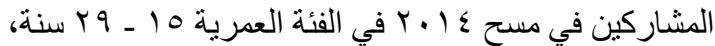
قد دعموا فكرة حق الزوجة في الانفصال عن زوجها بنسبة

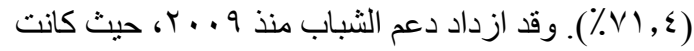

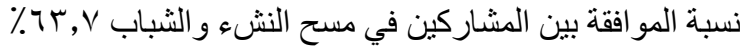

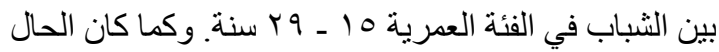
في مسح 9 . . T، كانت المشاركات من الإناث هن الأكثر دعماً

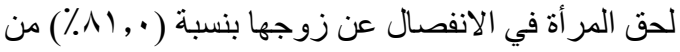

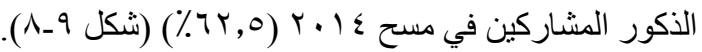

ومثل نتائج 9 . . T، كان الثباب الأكثر ثروة هم الأكثر دعماً لحق المر أة في الطلاق من الثباب الأقل ثروة. فأكثر من ثناثة

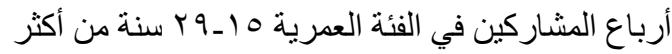

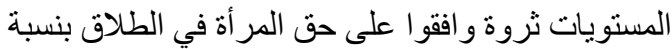

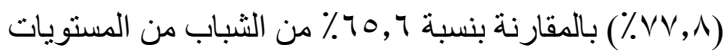
الأقل ثروة. وقد ازداد دعم الثباب لحق المر أة في الطلاق بين الثباب في كل مستويات الثروة ما بين مسحي النشء و الثنباب

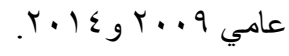

r ب مسرت التعديلات على قو انين الأحو ال الثخصية التي صدرت في يناير

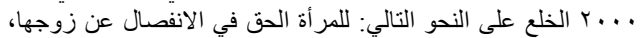

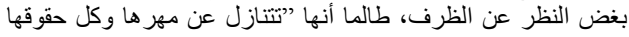
المالية"، (Sonneveld 2004). 
و إذا كان زوجها ”يعرف،“ه امر أة أخرى (ع ,97\%). بينما رأى المشاركين أن العنف المنزلي المتكرر هو من أهم أسباب

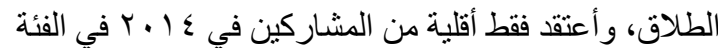

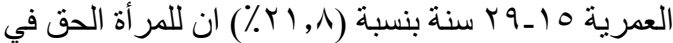

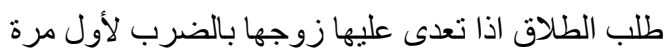

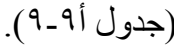

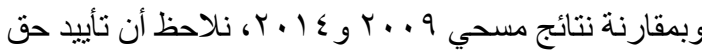
المر أة في طلب الطلاق قد ظل ثابتاً في كثير من الظروف التي

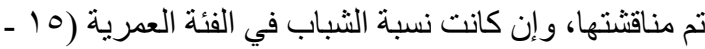

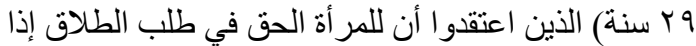

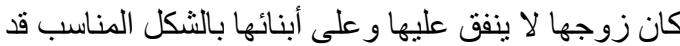

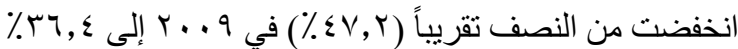

في ـ ا ـ Y. كما انخفضت أيضًا نسبة الثباب الذين اعتقدوا

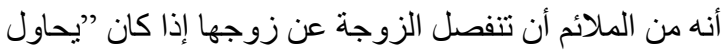

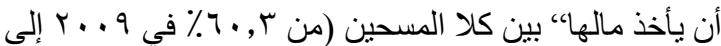

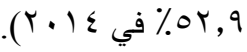

ويتناول (جدول أو ـ · ) في الملحق تصور ات الثباب حول

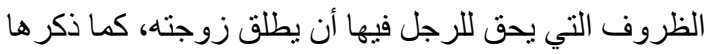
المشاركون في مسح النشء والثباب. وكان من أكثر الأسباب

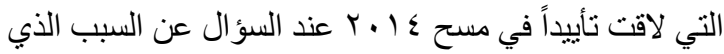
يجعل الرجل بطلق زوجته لاى الثباب في الفئة العمرية 10 ـ

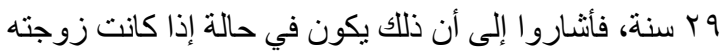
"تعرف، رجلاً آخر بنسبة (19\%)، أو إذا كان يكرهز زوجته

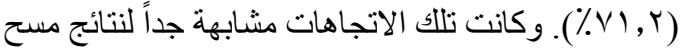

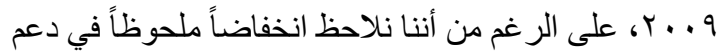

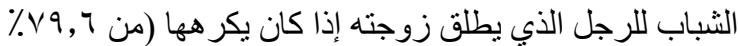

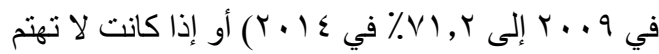

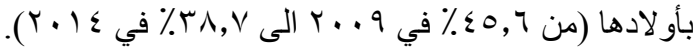

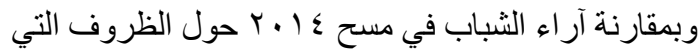
يحق فيها للرجل في مقابل المر أة أن بطلب الطلاق، نلاحظ أن

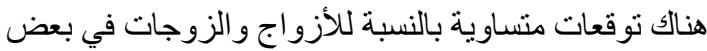

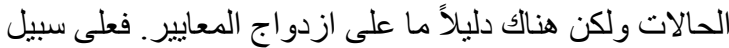

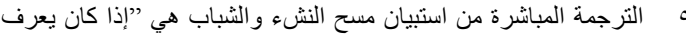

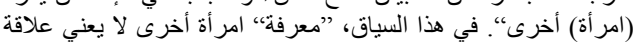
جنسية صريحة، و إن كان بعض المشاركين قد يفسرونها هكذا.

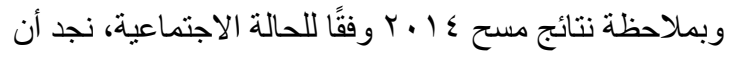

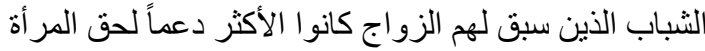

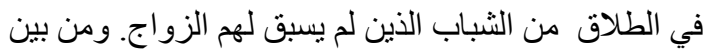

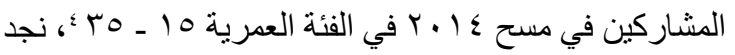

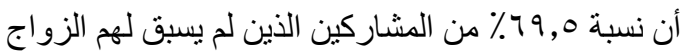

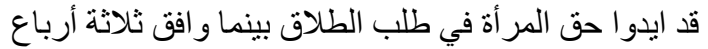

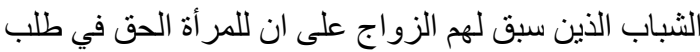

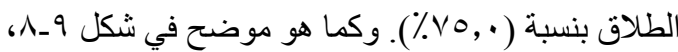
ايدت الإناث اللاتي سبق لهن الزواج حق المر أة في طلب

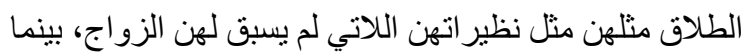
نلاحظ نسبة أعلى قليلاً في الدعم بين الثباب الذكور الذين

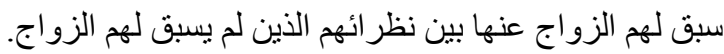
و على مستوى المناطق الجغر افية، نجد أن الثباب (10 ـ

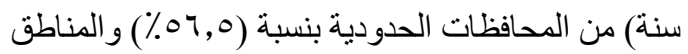
الحضرية في صعيد مصر بنسبة (9,90\%) كانو ا الأقل تأييداً

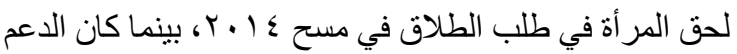

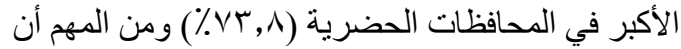
نلاحظ أن تأكيد الثباب لحق المر أة قد تز ايد بشكل ملحوظ في ريف الوجه القبلي، و هذه المنطقة من الدولة كانت تتمبز دائماً

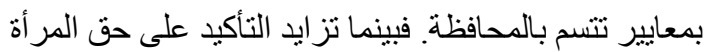

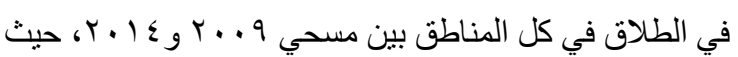

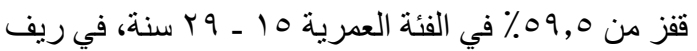

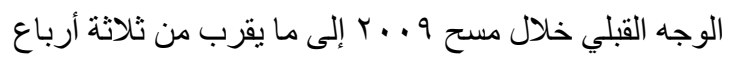

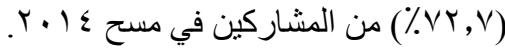
الثطروف الثي تشبرر الطلاق

في مسح النشء و الثباب طلب من الثباب أن يوضحوا الظروف التي يمكن للمر أة وللرجل أن يحق لهم طلب الطلاق.

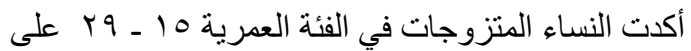

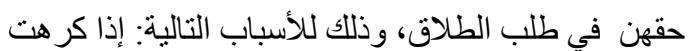
الزوجة زوجها (

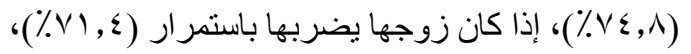

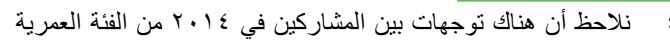

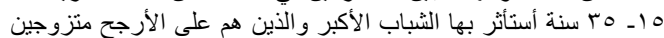

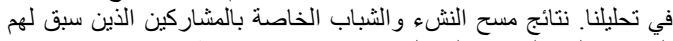

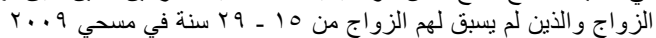

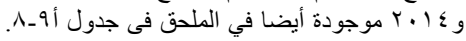




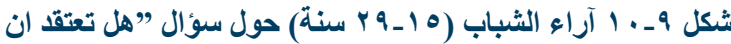
المجتمع ينظر للنساء المطلقات باحترام؟ حسب المستوى التعليمى

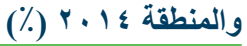

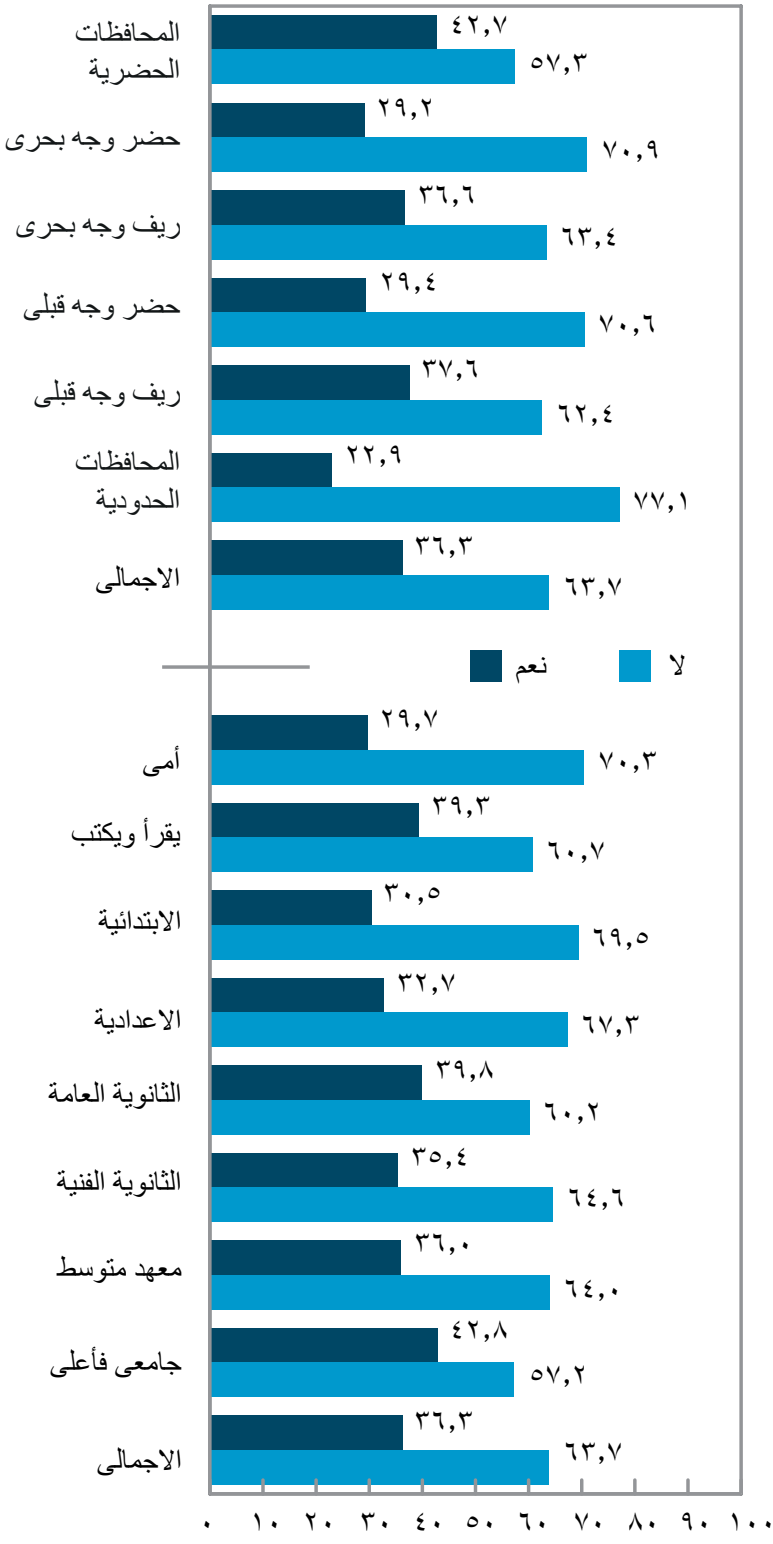

من الإناث) إلى أنهم لا بعتقدون أن المجتمع ينظر إلى النساء

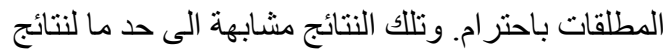

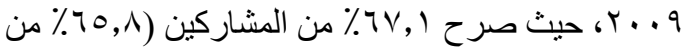

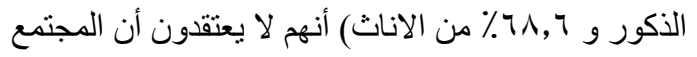
ينظر للنساء المطلقات باحتر ام.
المثال، و افق ما يقرب من ثلاثة أرباع الثباب في مسح النشء

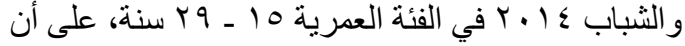

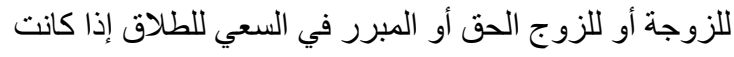

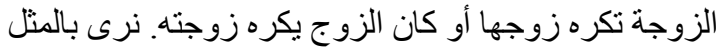

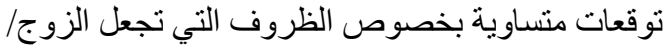
الزوجة يعاني من الخلل الجنسي أو لا يمكنه أن ينجب أطفال.

وتختلف التوقعات بشكل أكبر عندما نركز على الظرف

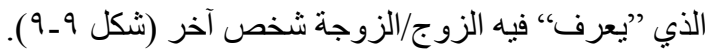

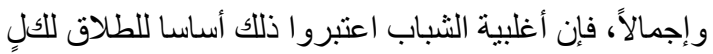

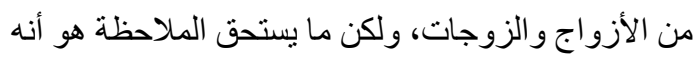

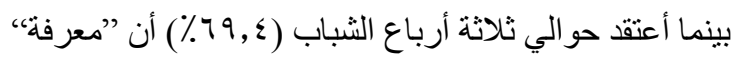

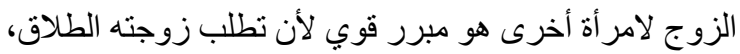

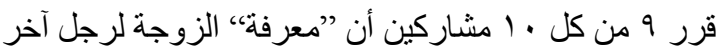
هو سبب أساسي لأن يطلقها زوجها.

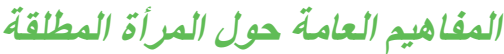

تشير نتائج مسح النشء و الثباب ـ 1 ـ ب إلى أن المر أة المطلقة

ما تز ال تحظى بنظرة غير ايجابية في المجتمع المصري

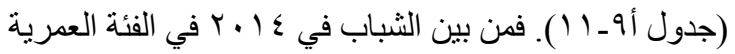

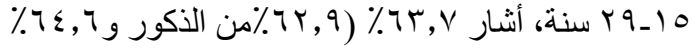

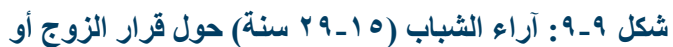

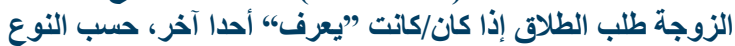
(\%) $)^{r}+1 \leqslant 9$

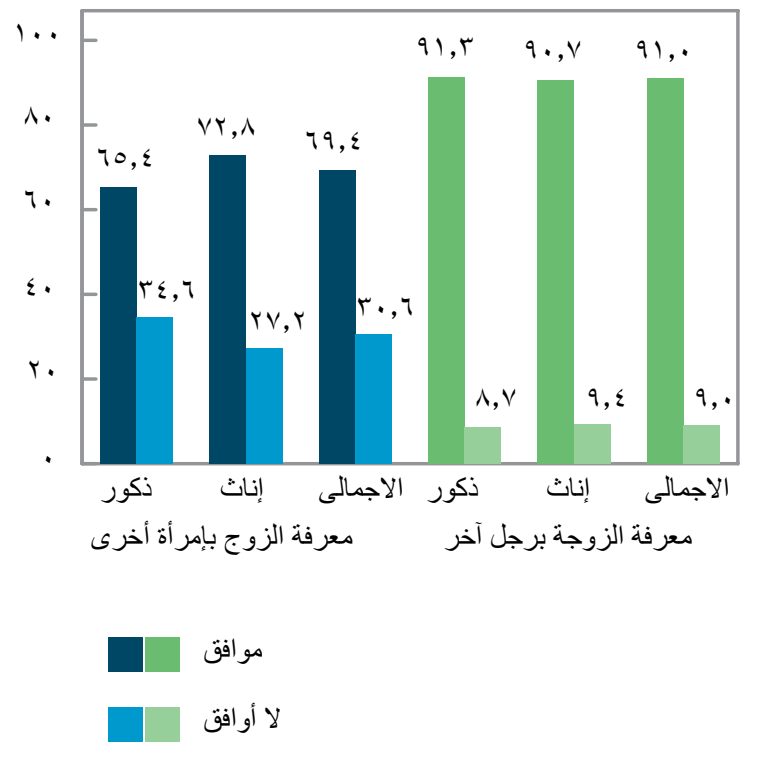


بينما كانت النسبة عالبة بشكل يثير

القلقَ، فإن دعم المشّار كبن لضرب

الزوجة ان "'تحدث الزوجة مع

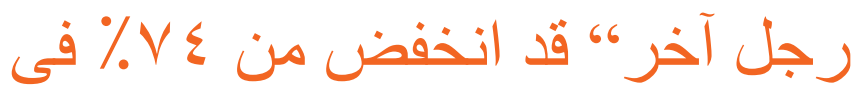

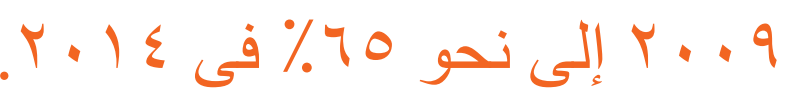

ـــ العنف القائم على النوع

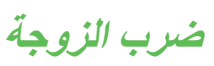

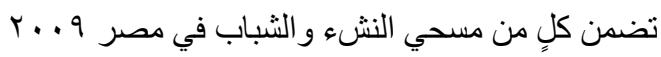

و ـ ا ـ ب آر اء المشاركين عن السياق الذي يمكن أن يبرر

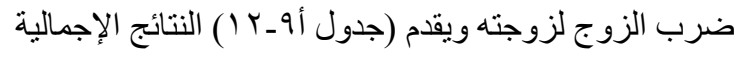

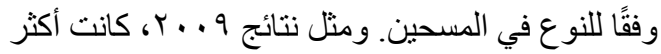

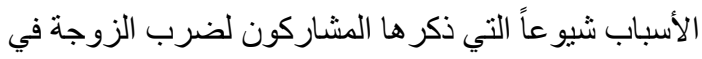

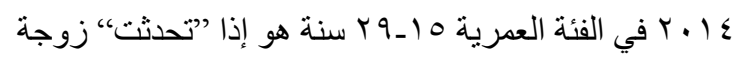

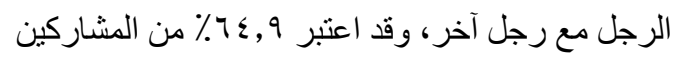

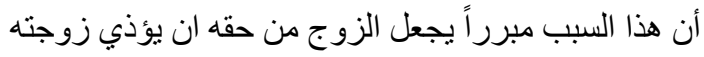

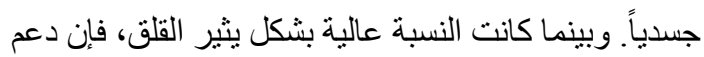

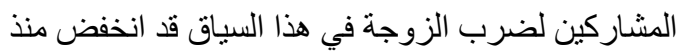

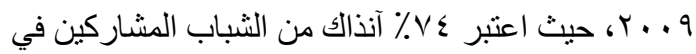

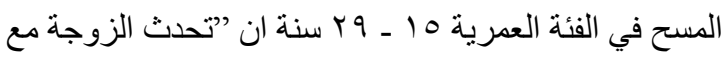

رجل آخر، مبرر يجعل الزوج يضربها.

وبالمقارنة بين مسحي 9 . . ب و ـ ا ـ ب، نلاحظ أن مو افقة

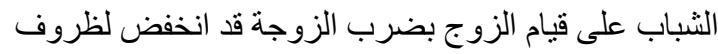

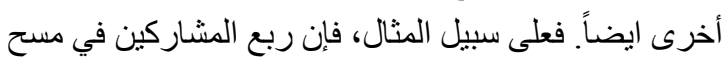

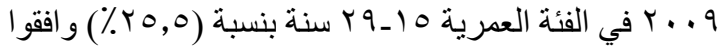

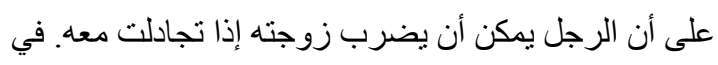

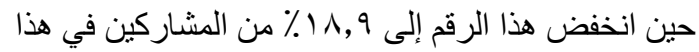

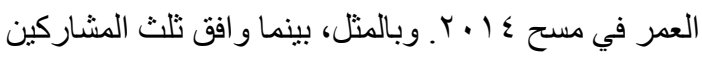

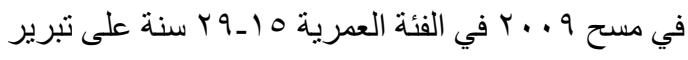

نلاحظ بعض الاختلاف تبعاً لمستوى التعليم (شكل 9 ـ • (). فيعتقد الثباب الحاصلين على التعليم الجامعي في الفئة

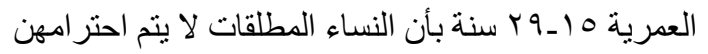

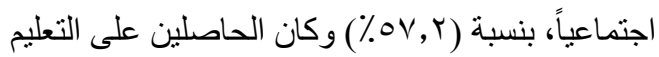

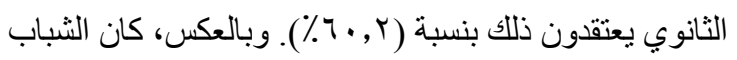

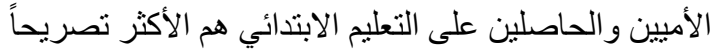

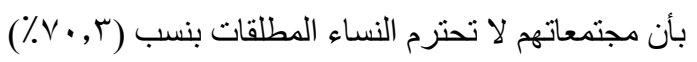

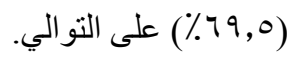

وباستعر اض النتائج التفصيلية للمسح في دورة ـ ا ـ ب تبعاً للمستويات المختلفة لمؤشر الثروة، نلاحظ أن هناك تبايناً

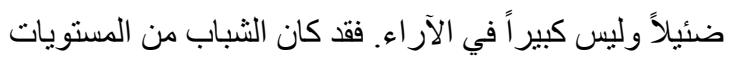

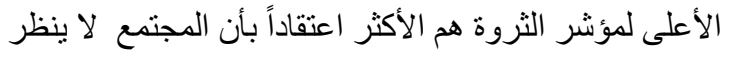

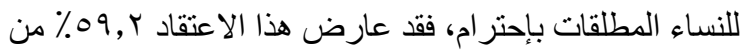

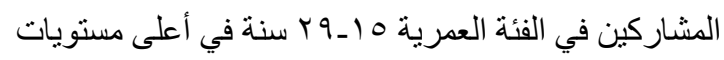

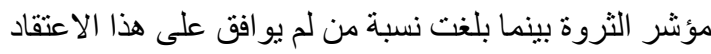

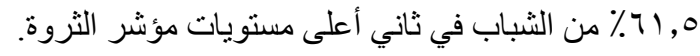
وكانت نسبة الثباب الذى يعتقد أن المجتمع لا يحترم النساء النقاء

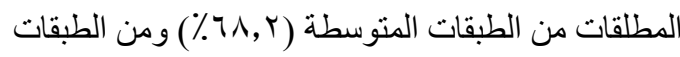

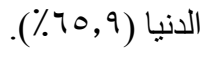

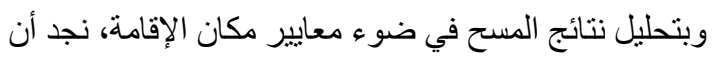

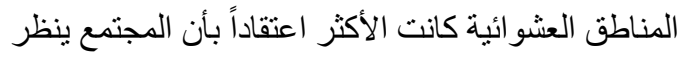

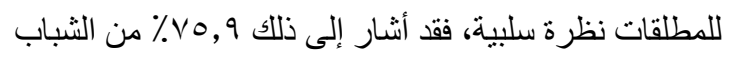

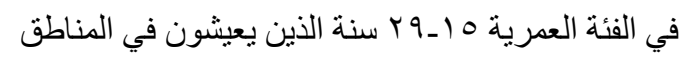

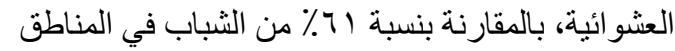

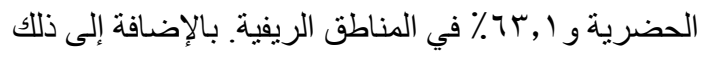

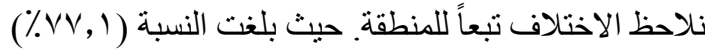

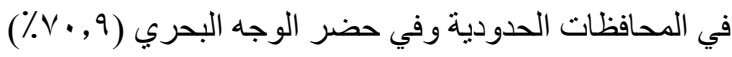

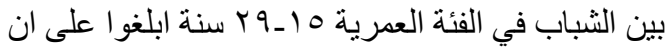
المجتمع لا يحترم المطلقات.

ومن ناحية أخرى، نجد نسبة الثباب في ريف الوجه القبلي

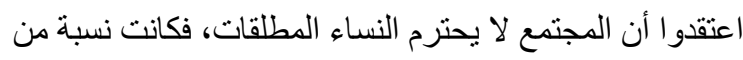

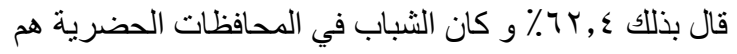

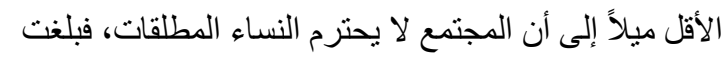

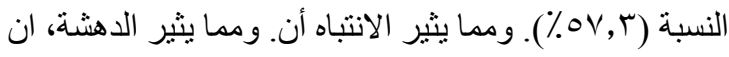

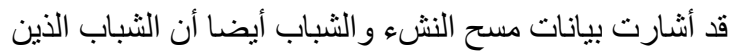

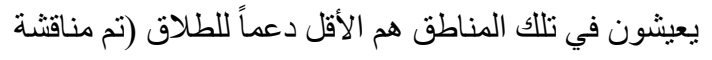
ذللك في القسم السابق). 


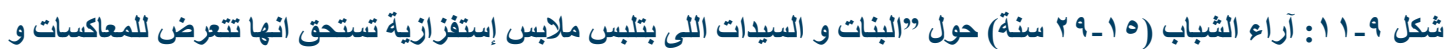

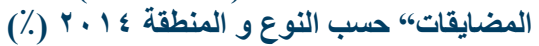

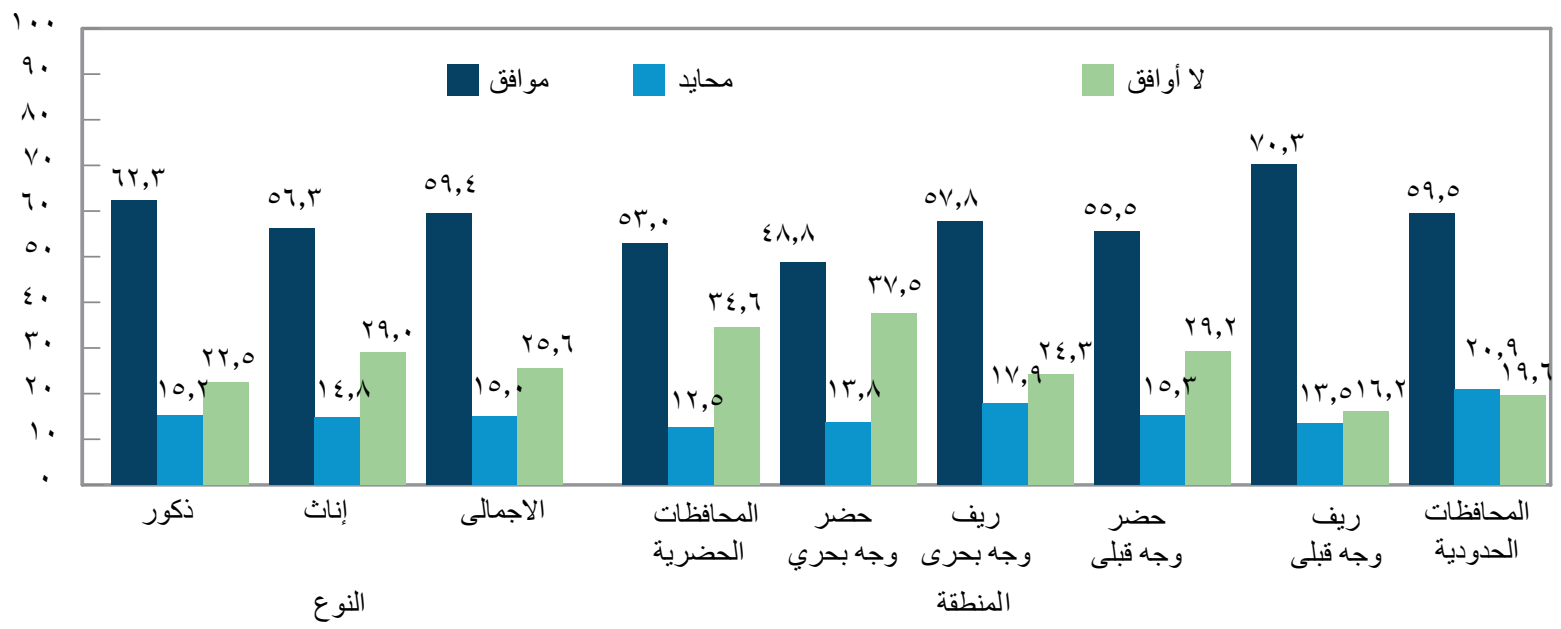

جدول أو_ـ (1). نجد أن غالبية المشاركين من الثباب في

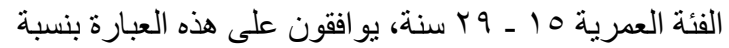

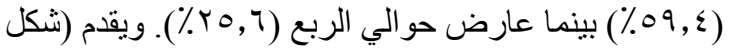

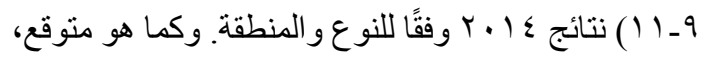

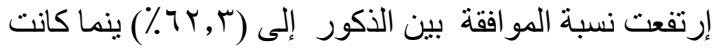

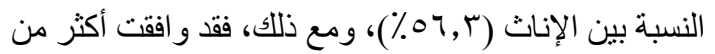

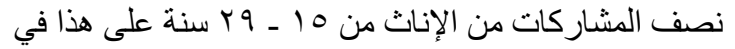
r..$\leq$

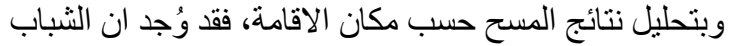

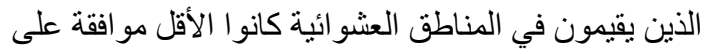

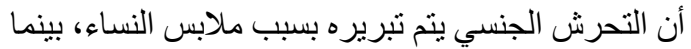

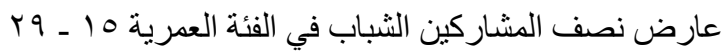

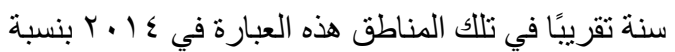

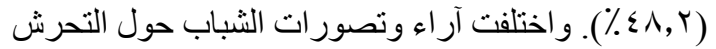
الجنسي بين الثباب الذين يعيشون في المناطق العشو الشورائية عنها بين الذين يعيشون في المناطق الحضرية (حيث عارض فقط

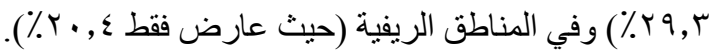

وبملاحظة النتائج وفقًا للمنطقة الجغر افية (شكل 9 ـ (1)، نجد

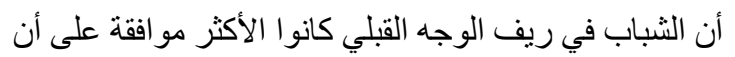

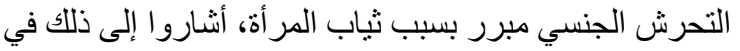

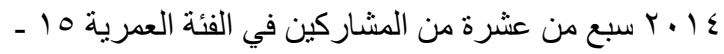

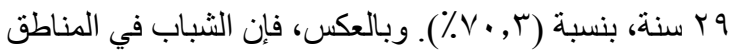
الحضرية في الوجه البحري كانوا الأقل مو افقة على لولى لوم النساء
ضرب الزوجة إذا أضاعت نقود زوجها بنسبة (بr\%)، كانت

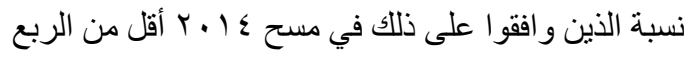
.$(\% r, \wedge)$

وكما كان الحال في مسح 9 . . ب، فإن الذكور كانوا أكثر

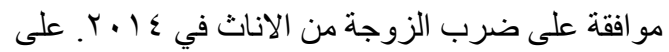

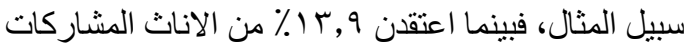

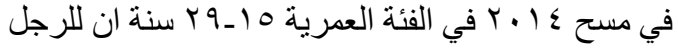

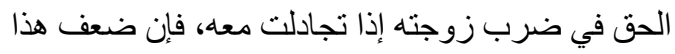

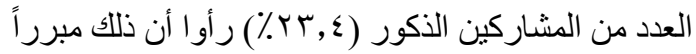

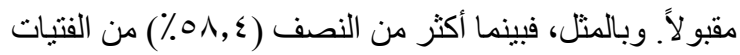

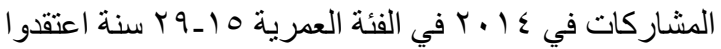

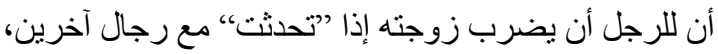

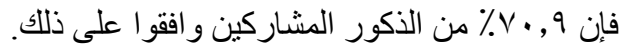

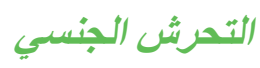

تم سؤال المشاركين في الاستبيان الخاص بمسح النشء

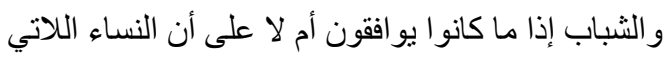

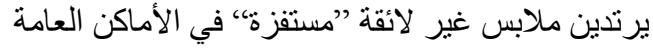

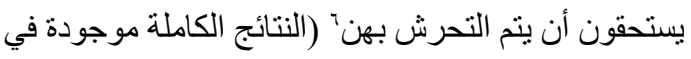

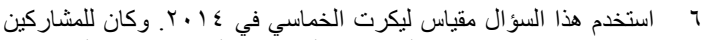

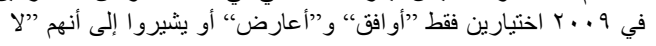


وقد اختلفت درجات التحفظ في اتجاهات الثباب نحو أدوار

النوع الاجتماعي حول مجالات واسعة تم بحثها في هذا

الفصل. فاختلفت اتجاهات الثباب إلى حد ما في المجال

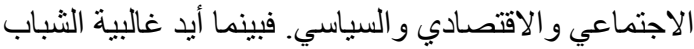

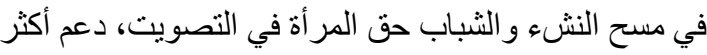
من نصف المشاركين المساو اة في الحصول على التعليم، إلا

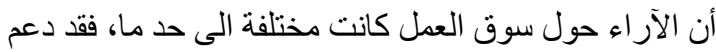
أغلبية المشاركين أولوية الرجال في الحصول على الوظائف.

و على الرغم من أن هناك مؤشر ات إيجابية حول المشاركة

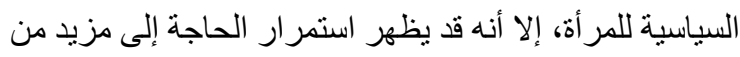

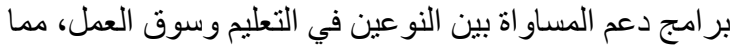

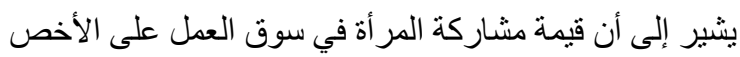
لا تلقى التقدير من كثير من الثباب.

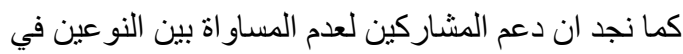

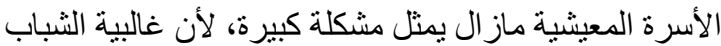

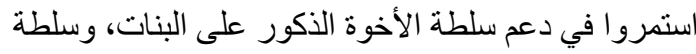

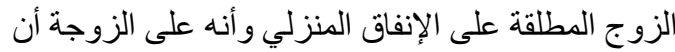

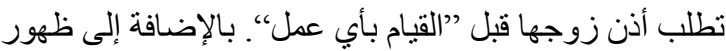
اعتماد الو اجبات المنزلية على النوع الاجتماعي، فنسبة كبيرة

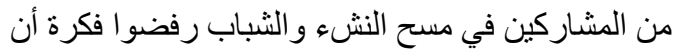
الأو لاد يجب أن يساهمو ا في الأعباء المنزلية منلهم مثل البنات.

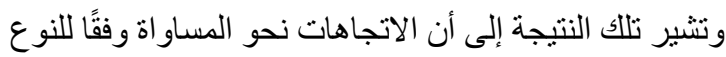

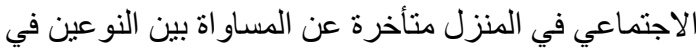
المجالات العامة، مما يشير الى أثنار سلبية في استقلال المرأة ألتا

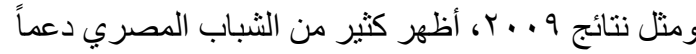

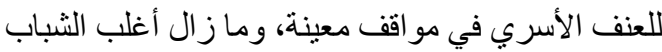

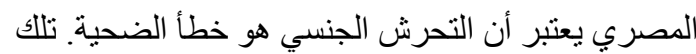

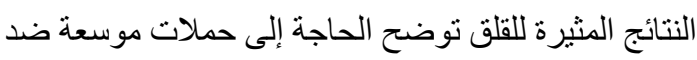
العنف القائم على النوع الاجتماعي داخل وخارج المنزل. و على الجانب الايجابي، فقد ألقى تحليلنا الضوء على الدعم

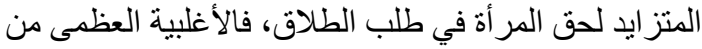

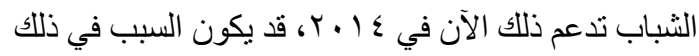
التغيير القانوني في مصر وتغير المعايير الاجتماعية أيضا.

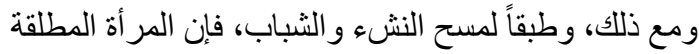
ماز الت تواجه التهميش الاجتماعي في المجتمعات المصرية،

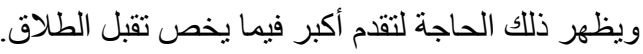
و أخير ا، و على الرغم من أن الآراء ماز الت محافظة إجمالا،
على التحرش الذي يعانون منه في الشوارع، فقد عارض أكثر

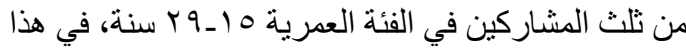
المنطقة فكرة أن ملابس النساء المستفزة في المناطق العامة

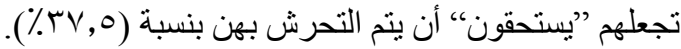

كان هناك بعض الاختلاف في آراء الثباب في الفئة العمرية

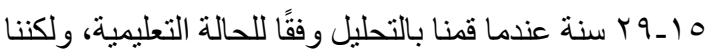
لا نجد ارتباطاً و اضحاً بين التعليم وتصور بات التهات الثباب حول التحرش الجنسي. فكان الحاصلين على التعليم الجامعي أقل

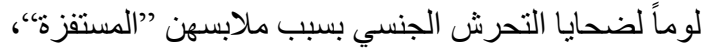

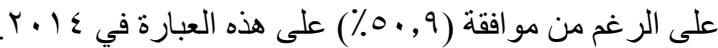

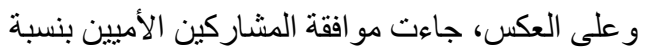

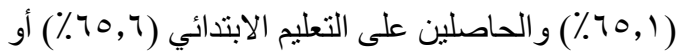

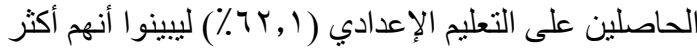

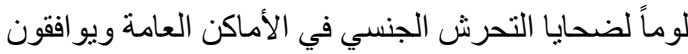

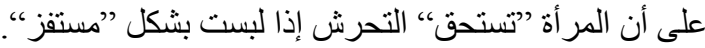

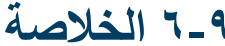

ظلت الاتجاهات المتعلقة بالنوع الاجتماعي بين المصريين

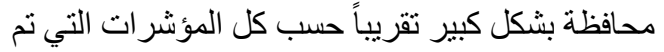
بحتها في هذا الفصل. وقد قام تحليلنا بإلقاء الضوء على عدئ عديد

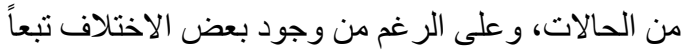

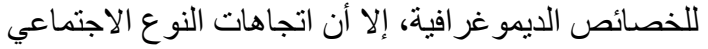

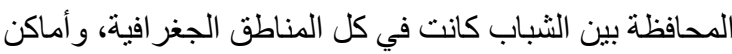
الإقامة و عبر مستويات الثروة و التعليه. وكما كان الحال في

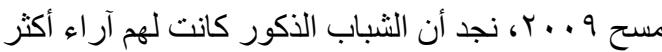

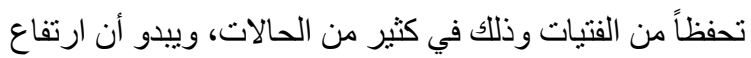

المستوى التعليمي للثباب يؤدي إلى آراء أكثر تحرراً فيما

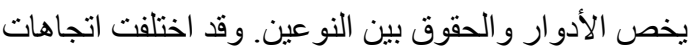
النوع الاجتماعي لاى الثباب بشكل ملحوظ تبعاً لمحل الاقامة.

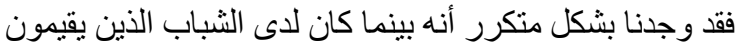

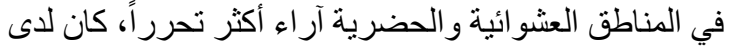

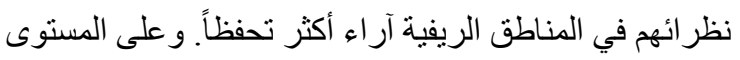

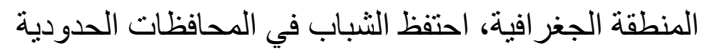
وريف الوجه القبلي بتصور ات متحفظة بشكل كبير حول أدوار

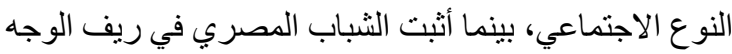
البحري أنهم الأكثر انفتاحاً على المساو اة بين النوعين. 
المسح التتبعي للنشء و الثباب في مصر ؟ ا.ب

فقد أدى مقياس ليكرت الخماسي لمعرفة التردد (و عدم اليقين)

الملحوظ الذي يشعر به كثير من الثباب تجاه الأسئلة المتعلقة

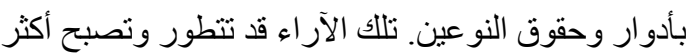

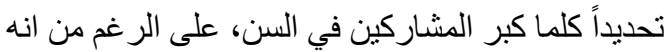

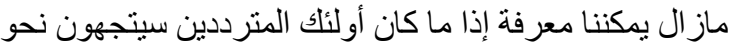

المساو اة بين النوعين أو سيكونون آراء أكثر تحفظاً.

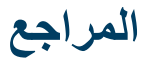

El-Kogali, Saffaa, Caroline Krafft, and Maia Sieverding. 2011. "Attitudes toward gender roles," Survey of Young People in Egypt, Final Report. Cairo: Population Council West Asia and North Africa Office.

Sonneveld, Nadia. 2004. "The implementation of the 'Khul Law' in Egyptian courts: Some preliminary results," Rechet van de Islam 21, pp. 21-35. 


\section{الملاحثق}

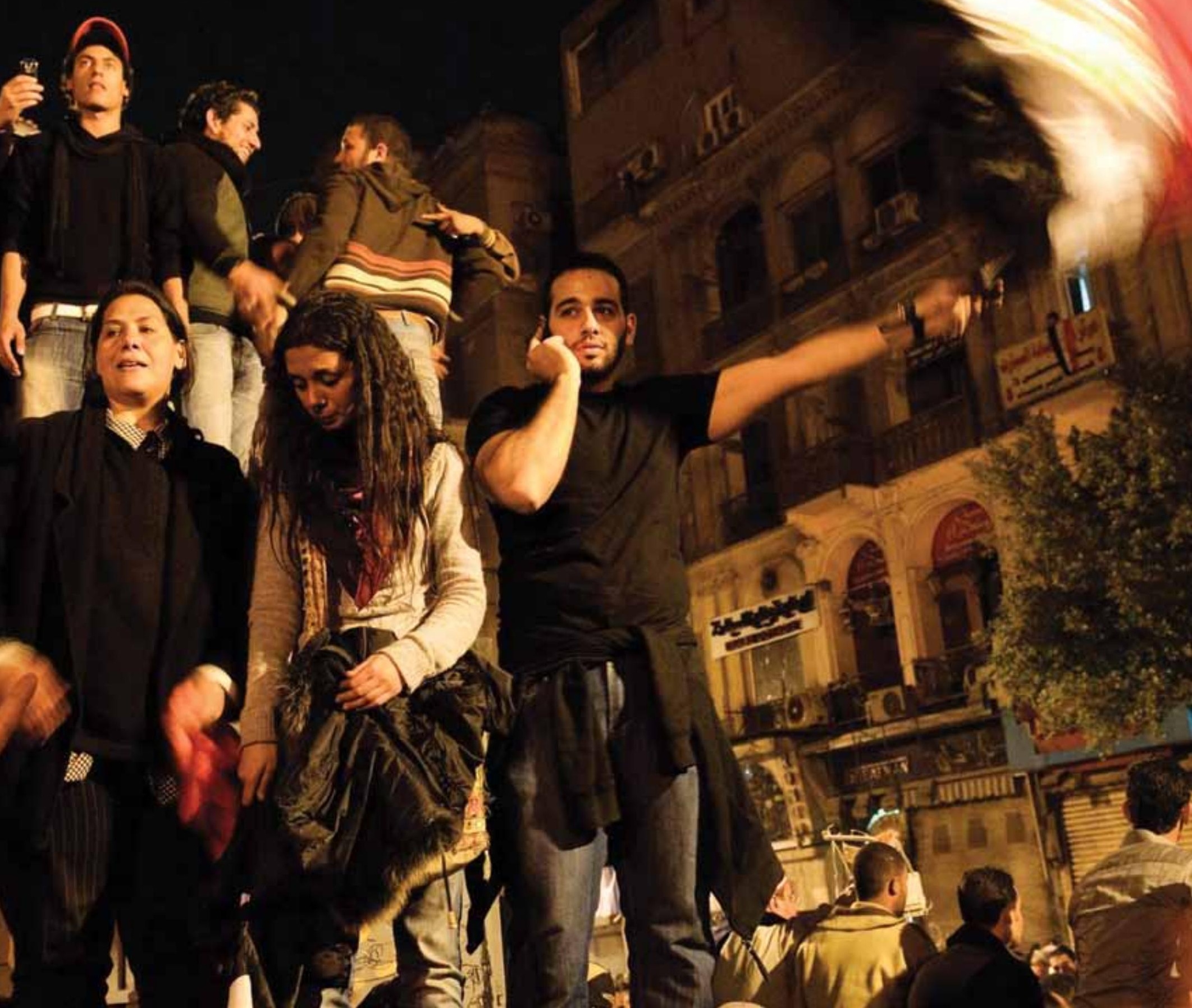



ماحق (أ)

$$
\text { الجداول }
$$





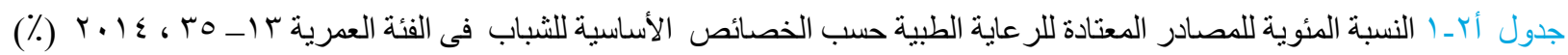

\begin{tabular}{|c|c|c|c|c|c|c|c|}
\hline المجموع & لأيذ مذب إلى ألى & أخرى & خؤسساتة & الصيدلية & مؤسسات & الصحين & \\
\hline & & & & & & & النوع \\
\hline $1 \cdots$, & ri, 9 & r,. & $r \varepsilon, T$ & $\uparrow, \cdot$ & $r \cdot, 0$ & 0,1 & 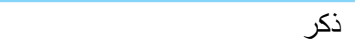 \\
\hline \multirow{2}{*}{$1 \cdots}$, & $r \varepsilon, r$ & $1, r$ & $\varepsilon r, \varepsilon$ & $\varepsilon, \cdot$ & $r \varepsilon, 1$ & $r, l$ & أنثى \\
\hline & & & & & & & الفئة العمرية \\
\hline $1 \ldots$, & 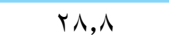 & 1,1 & (4, & $\varepsilon, 0$ & 19,9 & $\wedge, 9$ & $\left|V_{-}\right| r$ \\
\hline $1 \cdots$, & $r q, 1$ & $1, \varepsilon$ & $\varepsilon \cdot, r$ & $0, r$ & $r, \tau$ & $r, 0$ & $r \varepsilon-11$ \\
\hline $1 \cdots$, & $r V, r$ & 1,9 & $r q, q$ & $0, r$ & rr,l & $r, q$ & rq_ro \\
\hline \multirow[t]{2}{*}{$1 \cdots}$, & r & $1, \varepsilon$ & $r v, \wedge$ & $\varepsilon, \wedge$ & $r_{0, \varepsilon}$ & $r, \wedge$ & ro_r. \\
\hline & & & & & & & محل الأقامة \\
\hline $1 \ldots$, & $r \wedge, q$ & $r, Y$ & $r q, r$ & $r, 1$ & $r \cdot, V$ & 0,7 & حضر \\
\hline $1 \ldots$, & r & $1,$. & $r q, \wedge$ & 0,0 & ד, & ґ,^ & ريف \\
\hline \multirow[t]{2}{*}{$1 \ldots}$, & $r v, v$ & $r, 1$ & r., & $v, T$ & $\curlywedge \wedge, \wedge$ & $1, \varepsilon$ & مناطق عشو ائية \\
\hline & & & & & & & المنطقة \\
\hline $1 \cdots$, & $r v, \cdot$ & $r, r$ & $r v, v$ & $1, \wedge$ & $r T, V$ & 7,7 & محافظات حضرية \\
\hline $1 \cdots$, & $r \cdot, q$ & $1, r$ & $\leqslant 1,0$ & r,q & $19, r$ & $\varepsilon, 1$ & حضر الوجه البحري \\
\hline $1 \cdots$, & r & 1,1 & rq, r & $r, 1$ & $r \varepsilon, \varepsilon$ & $0, v$ & ريف الوجه البحري \\
\hline $1 \cdots$, & r^, 9 & $r, \uparrow$ & Tr,q & 11,9 & r & $\cdot, 0$ & حضر الوجه القبلي \\
\hline $1 \cdots$, & ro,r & $1, \cdot$ & $\varepsilon 1,1$ & $\wedge, r$ & r T,Y & 1,1 & ريف الوجه القبلي \\
\hline \multirow[t]{2}{*}{$1 \cdots}$, & or, \& & $\cdot, 7$ & 19,0 & $1, r$ & r & $r,$. & محافظات حدودية \\
\hline & & & & & & & المستوى التعليمي \\
\hline $1 \cdots$, & $r \varepsilon, q$ & $1, r$ & $r V, O$ & $\varepsilon, \wedge$ & $r \cdot, \varepsilon$ & 1,1 & أمي \\
\hline $1 \cdots$, & $r, r$ & $0, \cdot$ & $r \wedge, \wedge$ & $\vee, \varepsilon$ & $r_{0, T}$ & $\cdot, 9$ & يقرأ ويكتب \\
\hline $1 \cdots$, & $r v, O$ & $\cdot, 9$ & $r, r$ & $0,$. & $r \varepsilon, r$ & $1, r$ & إبتدائي \\
\hline $1 \cdots$, & $r \wedge, r$ & $1, r$ & & $0, \varepsilon$ & $r v, \varepsilon$ & $0, \varepsilon$ & إعدادي \\
\hline $1 \cdots$ & $r o, v$ & 1,1 & $\leq 7,1$ & r, & $1 \leqslant$, & 9,1 & ثنانوي عام \\
\hline $1 \cdots$ & $r v, q$ & 1,7 & rᄉ, & $0, v$ & rr, & $r, \varepsilon$ & ثانوي فني \\
\hline $1 \cdots$, & ro, & 1,9 & $\varepsilon r, r$ & $\mathrm{v}, \mathrm{v}$ & $\curlywedge \wedge, \varepsilon$ & $\varepsilon, \vee$ & فوق منوسط \\
\hline \multirow[t]{2}{*}{$\cdots}$, & r^, & $1, \wedge$ & $\varepsilon \wedge, 9$ & r, & Ir,T & $\varepsilon, 9$ & جامعي فأكثر \\
\hline & & & & & & & الحالة الوظيفية \\
\hline $1 \cdots$, & $r \wedge, \vee$ & 1,9 & $r v, 1$ & 7,9 & $r \cdot, V$ & $\varepsilon, \wedge$ & عامل بأجر \\
\hline $1 \cdots$ & rq, ₹ & 1,7 & ro, & $\uparrow, \wedge$ & $r \leqslant, 0$ & 1,9 & صاحب عمل / يعمل لحساب نفسه \\
\hline $1 \cdots$ & r^, & $\cdot, \mathrm{V}$ & $r, 1$ & $T, r$ & 4,9 & $1, r$ & يعمل لدى الأسرة بدون أجر \\
\hline $1 \cdots$, & r४, & $1, r$ & $\varepsilon \cdot, 1$ & $\varepsilon, \varepsilon$ & ץ & $1, \cdot$ & عاطل يبحث عن عمل \\
\hline $1 \cdots$, & $r v, \Lambda$ & $1, r$ & $r 9,7$ & $r, \wedge$ & หฺ, & $\cdot, 9$ & عاطل بدرس \\
\hline \multirow[t]{2}{*}{$1 \ldots$} & r^,l & 1,9 & $\varepsilon,, r$ & $\varepsilon, r$ & 10,1 & $9, r$ & عاطل لا يدرس \\
\hline & & & & & & & 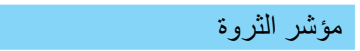 \\
\hline $1 \cdots$, & $\Gamma, \Lambda$ & $1, r$ & ro, 9 & 7,0 & rt, & r,r & الأدني \\
\hline $1 \cdots$, & r^, & $1, r$ & $r \varepsilon, 0$ & $\mathrm{v}, \mathrm{T}$ & $r_{0, r}$ & $r, r$ & 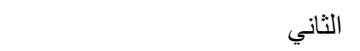 \\
\hline $1 \cdots$, & $r \varepsilon, T$ & $1, v$ & $r q, 7$ & 0,1 & $r \varepsilon, r$ & $\varepsilon, \wedge$ & الأوسط \\
\hline $1 \cdots$, & $r q, q$ & $1, r$ & $\varepsilon 1,0$ & r, & 19,1 & $\varepsilon, 7$ & 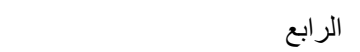 \\
\hline $1 \ldots$, & $r v, \cdot$ & $r, r$ & $0 ., r$ & $r, T$ & Ir,V & $0, r$ & الأعلى \\
\hline $1 \ldots$, & Y^,, & 1,7 & r^, 9 & $0, \cdot$ & YY, & $\varepsilon, 1$ & الإجمالى \\
\hline
\end{tabular}




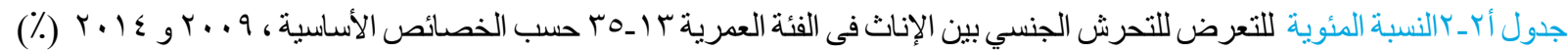

\begin{tabular}{|c|c|c|c|}
\hline 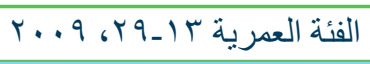 & 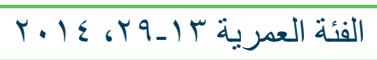 & 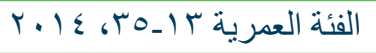 & الخصائص \\
\hline & & & الفئة العمرية \\
\hline$\leqslant \uparrow, \varepsilon$ & $\varepsilon 9,0$ & $\varepsilon 9,0$ & $\left|V_{-1}\right| r$ \\
\hline $0 \leqslant, r$ & $\varepsilon \varepsilon, \wedge$ & $\varepsilon \varepsilon, \wedge$ & $r \varepsilon_{-} \mid \wedge$ \\
\hline \multirow[t]{3}{*}{$\leqslant \uparrow, \varepsilon$} & rr,r & rr, & $r_{Q} r_{0}$ \\
\hline & & $r v, l$ & ro_r. \\
\hline & & & 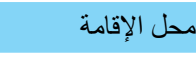 \\
\hline 71,9 & $0 ., r$ & $\varepsilon v, v$ & حضر \\
\hline$\varepsilon \cdot, q$ & $r_{0,1}$ & $r r, T$ & 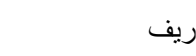 \\
\hline \multirow{2}{*}{ •, זr } & $70,$. & 71,7 & مناطق العشوائية \\
\hline & & & المنطقة \\
\hline Vr, & 07,0 & or,r & محافظات حضرية \\
\hline r & or,, & $0 ., 1$ & حضر وجه بحري \\
\hline or, 9 & ro, & $r+$, & ريف وجه بحري \\
\hline r & or, 1 & $0,, r$ & حضر وجه قبلي \\
\hline$r V, \varepsilon$ & r,o & rT, & ريف وجه قبلي \\
\hline \multirow[t]{2}{*}{ rv, q } & r., , & $r \wedge, 0$ & محافظات حدودية \\
\hline & & & المستوى التعليمي \\
\hline r৯, & $r r, O$ & rY, & أمي \\
\hline$r$ rer & ro, 9 & $r \cdot, l$ & 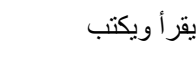 \\
\hline$\varepsilon 1, r$ & $r v, q$ & $r \leqslant, 0$ & إبتدائي \\
\hline $0 \leqslant$, & $\varepsilon r, 1$ & $\varepsilon 1, \varepsilon$ & إعدادي \\
\hline $79, r$ & $01, r$ & $0, \underline{\varepsilon}$ & 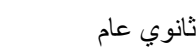 \\
\hline 01,9 & $\varepsilon r, 0$ & $r q, r$ & 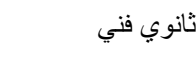 \\
\hline$T \leqslant, Y$ & 01,7 & $\varepsilon \wedge, 0$ & فوق متوسط \\
\hline \multirow[t]{2}{*}{77,7} & $\leq q, r$ & $\{\wedge, 0$ & جامعي فأكثر \\
\hline & & & مؤشر الثروة \\
\hline rr, r & $r \Lambda, \nu$ & ro,r & الأدني \\
\hline$\varepsilon \varepsilon, 1$ & $\varepsilon r, r$ & $\varepsilon \cdot, r$ & الثاني \\
\hline$\varepsilon v, 0$ & $\leq 7,1$ & $\varepsilon r, 1$ & الأوسط \\
\hline$\circ \wedge, \wedge$ & $\varepsilon 1,7$ & $r q, 1$ & الر ابع \\
\hline$T V, \Lambda$ & $\varepsilon r, v$ & $\varepsilon 1, \varepsilon$ & الأعلى \\
\hline$\varepsilon q, \vee$ & $\varepsilon r, \wedge$ & $r q, q$ & الاجمالي \\
\hline$(7, \wedge / 9)$ & $(\varepsilon, 7 r q)$ & $(0, \Delta r !)$ & حجم العينة \\
\hline
\end{tabular}




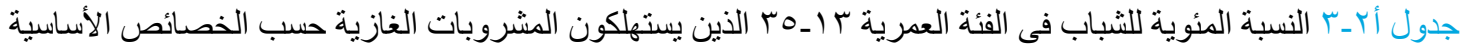

\begin{tabular}{|c|c|c|c|}
\hline \multicolumn{3}{|c|}{ إستهلاك المشروبات الغازية } & \multirow[b]{2}{*}{ الخصائص } \\
\hline r مر ات فأكثر & من ا_r مرات & أبدا & \\
\hline & & & الفئة العمرية \\
\hline 10,1 & or, \& & r & $\left|V_{-}\right| r$ \\
\hline Ir,r & or, 1 & $r \varepsilon, v$ & $r \varepsilon_{-11}$ \\
\hline$৭, \wedge$ & $0 ., v$ & r৭,० & rq_ro \\
\hline \multirow[t]{2}{*}{$\Lambda, r$} & $\varepsilon \vee, \varepsilon$ & $\varepsilon \varepsilon, r$ & ro_r. \\
\hline & & & النوع \\
\hline Ir,T & or, 9 & 促, & ذكر \\
\hline \multirow{2}{*}{$1 \cdot, 7$} & $\varepsilon q, r$ & $\varepsilon \cdot, r$ & أنتى \\
\hline & & & محل الأقامة \\
\hline 17,9 & $07, \varepsilon$ & YT,V & حضر \\
\hline $9, r$ & $\varepsilon \wedge, \uparrow$ & $\varepsilon r, r$ & ريف \\
\hline \multirow[t]{2}{*}{$1 \cdot, 1$} & 07,1 & q & مناطق عشو ائية \\
\hline & & & المنطقة \\
\hline 19,0 & $07, r$ & $r \varepsilon, r$ & محافظات حضرية \\
\hline $1 \leqslant, 1$ & $01, V$ & $r \varepsilon, r$ & حضر وجه بحري \\
\hline $1 \cdot, \varepsilon$ & $\varepsilon q, \vee$ & rq, १ & ريف وجه بحري \\
\hline$\vee, \wedge$ & $T r, V$ & $r q, 0$ & حضر وجه قبلي \\
\hline$\lambda, r$ & $\varepsilon \vee, v$ & $\varepsilon \varepsilon, r$ & ريف وجه قبلي \\
\hline \multirow[t]{2}{*}{$0, v$} & $0 ., 7$ & $\varepsilon r, r$ & محافظات حدودية \\
\hline & & & المستوى التعليمي \\
\hline$\varepsilon, r$ & $r q, \varepsilon$ & $07, r$ & أمي \\
\hline$r, \wedge$ & r.r., & $\leqslant r, q$ & يقر أويكتب \\
\hline$\vee, \wedge$ & $\leq 0,7$ & $\leq 4, v$ & إبتدائي \\
\hline $9, r$ & $\varepsilon 9, \wedge$ & $\varepsilon 1$, & إعدادي \\
\hline$r, \cdot$ & $00, r$ & $r T, V$ & ثانوي عام \\
\hline 9,0 & or,r & $r \wedge, r$ & ثانوي فني \\
\hline 17, & 00,9 & $r \wedge, l$ & فوق منوسط \\
\hline \multirow[t]{2}{*}{$i v, v$} & ov, T & $r \leqslant, V$ & جامعي فأكثر \\
\hline & & & مؤشر الثروة \\
\hline $0, \cdot$ & $\varepsilon \varepsilon, 1$ & $0 ., 9$ & الأدني \\
\hline $\mathrm{v}, \cdot$ & $0 ., 7$ & $\varepsilon r, \varepsilon$ & الثناني \\
\hline $11, r$ & $0 \leqslant, \varepsilon$ & $r \varepsilon, r$ & الأوسط \\
\hline ir, & $0 \leqslant, r$ & $r, v$ & الر ابع \\
\hline 19,1 & or, 9 & $r, r$ & الأعلى \\
\hline 11,7 & 01,7 & $r 4, \Lambda$ & الاجمالي \\
\hline$(1, r M T)$ & $(0,04 \varepsilon)$ & $(\varepsilon, 1+4)$ & حجم العينة \\
\hline
\end{tabular}




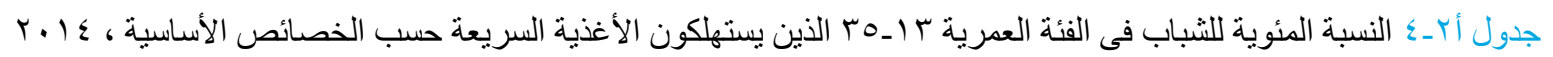

\begin{tabular}{|c|c|c|c|}
\hline \multirow[b]{2}{*}{ r مر ات فأكثر } & \multicolumn{2}{|l|}{ الأغذية السريعة } & \multirow[b]{2}{*}{ الخصائص } \\
\hline & من مرة إلى ؟ مرات & أبدا & \\
\hline & & & الفئة العمرية \\
\hline $1 \cdot, \cdot$ & ז צ & or,t & $\left|V_{-}\right| T$ \\
\hline 9,7 & r & $0 \leqslant, r$ & $r \varepsilon_{-1 \lambda}$ \\
\hline$T, V$ & ro,. & $0 \wedge, r$ & rq_ro \\
\hline \multirow[t]{2}{*}{7,1} & $r \cdot, 0$ & $\pi, 0$ & ro-r. \\
\hline & & & النوع \\
\hline $1 \cdot, 1$ & $\varepsilon 1,7$ & $\varepsilon \wedge, r$ & ذكر \\
\hline \multirow[t]{2}{*}{7,7} & $r \wedge, l$ & $70, \varepsilon$ & أنثى \\
\hline & & & محل الأقامة \\
\hline Kr,T & $\varepsilon r, r$ & $\varepsilon \varepsilon, r$ & حضر \\
\hline $7, \varepsilon$ & $r \cdot, \varepsilon$ & r & ريف \\
\hline \multirow{2}{*}{$\wedge, 0$} & $r_{\Lambda, \nu}$ & or,A & مناطق عشو ائية \\
\hline & & & المنطقة \\
\hline $10, r$ & $\varepsilon \uparrow$, & $r \wedge, \nu$ & محافظات حضرية \\
\hline $1 \cdot, r$ & $r v, v$ & or, 1 & حضر وجه بحري \\
\hline$v, 1$ & rr, & $r \cdot, r$ & ريف وجه بحري \\
\hline 0,1 & $r q, \varepsilon$ & 00,0 & حضر وجه قبلي \\
\hline $0, v$ & $r \wedge, r$ & 74,1 & ريف وجه قبلي \\
\hline \multirow[t]{2}{*}{$r, r$} & r1, 9 & 71,9 & محافظات حدودية \\
\hline & & & المستوى التعليمي \\
\hline$r, T$ & $r \mu,$. & $v \varepsilon, 0$ & أمي \\
\hline 1,1 & $r \varepsilon, r$ & $T \varepsilon, \wedge$ & يقر أويكتب \\
\hline T, & $r \wedge, r$ & 70,0 & إبتدائي \\
\hline$\Upsilon, \wedge$ & rq, १ & Tr, & إعدادي \\
\hline $1 \%, 0$ & $\varepsilon \cdot, 0$ & $\leq 0,9$ & ثانوي عام \\
\hline $\mathrm{v}, \cdot$ & $r r, v$ & $\Delta 9, r$ & ثانوي فني \\
\hline $1 \cdot, r$ & $\varepsilon r, 0$ & $\varepsilon V, r$ & فوق متوسط \\
\hline \multirow[t]{2}{*}{ Tr, } & $\varepsilon 0,7$ & $\varepsilon \cdot, \wedge$ & جامعي فأكثر \\
\hline & & & مؤشر الثروة \\
\hline $0, r$ & $r \varepsilon, V$ & $V \cdot, r$ & الأدني \\
\hline $0,$. & rr,V & Tr, & الثاني \\
\hline$\wedge, \varepsilon$ & $r_{0, v}$ & 00,9 & الأوسط \\
\hline $9, \varepsilon$ & $r q, \uparrow$ & 01, & الر ابع \\
\hline $1 T, 1$ & $\varepsilon \cdot, 7$ & $\leq \pi, r$ & الأعلى \\
\hline$\wedge, \varepsilon$ & ro,. & 07,7 & الاجمالي \\
\hline$(9.9)$ & $(\Gamma, \Upsilon \top \cdot)$ & $(\neg, r r \varepsilon)$ & حجم العينة \\
\hline
\end{tabular}


جدول أ _ـ النسبة المئوية للشباب الذين يمارسون أنشطة رياضية حسب الخصائص الأساسية

\begin{tabular}{|c|c|c|c|}
\hline 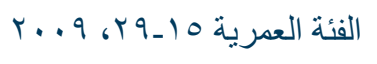 & 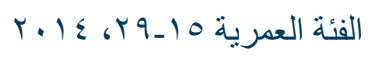 & 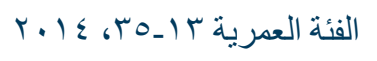 & الخصائص \\
\hline & & & الفئة العمرية \\
\hline$\Delta r, \cdot$ & 77,9 & $74, \wedge$ & $\left|V_{-}\right| r$ \\
\hline$T \varepsilon, V$ & or, 1 & or, 1 & $r \varepsilon_{-1 \wedge}$ \\
\hline \multirow[t]{3}{*}{$7, r$} & $\varepsilon \wedge, 9$ & $\varepsilon \wedge, q$ & rq_ro \\
\hline & & $\varepsilon १,$. & ro_r. \\
\hline & & & النوع \\
\hline$\wedge r, \wedge$ & $T V, \Lambda$ & $T V, \cdot$ & ذكر \\
\hline \multirow{2}{*}{$01, r$} & $\varepsilon \cdot, \wedge$ & $\varepsilon \cdot, \wedge$ & أنثى \\
\hline & & & 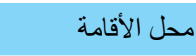 \\
\hline 79,0 & $07, r$ & $00, r$ & حضر \\
\hline $74, \cdot$ & 00,9 & 00,7 & 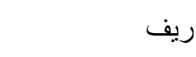 \\
\hline \multirow[t]{2}{*}{$T \Lambda, V$} & $\varepsilon \varepsilon, \varepsilon$ & $\varepsilon r, T$ & مناطق عشو ائية \\
\hline & & & المنطقة \\
\hline 79,0 & ov,o & 00,9 & محافظات حضرية \\
\hline$V r, O$ & $\varepsilon \uparrow, r$ & $\varepsilon \varepsilon, 7$ & حضر وجه بحري \\
\hline$V r, v$ & ov, q & $o v, 1$ & ريف وجه بحري \\
\hline r & 07,1 & 07,1 & حضر وجه قبلي \\
\hline 07,1 & $0 \leqslant, r$ & $0 \leqslant, r$ & ريف وجه قبلي \\
\hline \multirow[t]{2}{*}{09,0} & $\varepsilon \cdot, 0$ & ५৭, ६ & محافظات حدودية \\
\hline & & & المسنوى التعليمي \\
\hline$\leq 7, r$ & $\varepsilon r, \wedge$ & $\varepsilon \varepsilon, 1$ & أمي \\
\hline$\vee, \wedge$ & $\varepsilon q, r$ & $\leq 9,7$ & يقر أويكتب \\
\hline$v \leqslant, 7$ & $\varepsilon \wedge, \vee$ & $\leq १, 7$ & إبتدائي \\
\hline vo,r & or, 9 & 00,9 & إعدادي \\
\hline$v r, 0$ & 10,1 & 10,1 & ثانوي عام \\
\hline$T r, 0$ & $07, \mathrm{~V}$ & $00, r$ & ثانوي فني \\
\hline $7, V$ & $07, \varepsilon$ & $\infty 0,$. & فوق متوسط \\
\hline \multirow[t]{2}{*}{ Tr,q } & or,o & or, \& & جامعي فاكثر \\
\hline & & & مؤشر الثروة \\
\hline Tr,T & $0 \leqslant, 1$ & or,T & الأدني \\
\hline 9 & $0 \leqslant, Y$ & or, & الثاني \\
\hline 79,7 & or, v & $0 \leqslant$, & الأوسط \\
\hline $79, r$ & $07, r$ & $00, v$ & الر ابع \\
\hline$v_{\cdot}, \varepsilon$ & 07,1 & $0 \leqslant, 9$ & الأعلى \\
\hline$T V, \varepsilon$ & $0 \leqslant, 9$ & $0 \leqslant, Y$ & الاجمالي \\
\hline$(v, 11 \cdot)$ & $(\varepsilon, \varepsilon \wedge \cdot)$ & $(0,0 \vee \wedge)$ & حجم العينة \\
\hline
\end{tabular}




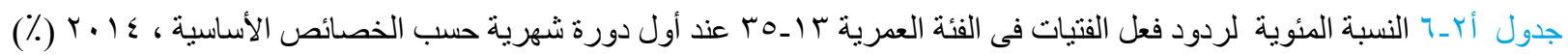

\begin{tabular}{|c|c|c|c|c|c|c|c|}
\hline الاجمالي & لا أعرف & أخرى & لا تدري ماذا تفعل & لا يختلف & سعيدة & خدمة / بكاء / & \\
\hline & & & & & & & الفئة العمرية \\
\hline $1 \ldots$, & $\cdot, \cdot$ & $\cdot, \cdot$ & $r \cdot, 0$ & $i \Lambda, V$ & $\wedge, \wedge$ & or,. & IV-IT \\
\hline $1 \ldots$, & $\cdot, \cdot$ & $\cdot, 1$ & $r, q$ & IV, $\varepsilon$ & $9, \cdot$ & $0 ., 0$ & $r \varepsilon_{-11}$ \\
\hline $1 \ldots$, & .,. &., 1 & $r, \varepsilon$ & $\backslash \Lambda, \varepsilon$ & $\wedge, q$ & $01, r$ & rq_ro \\
\hline \multirow[t]{2}{*}{$1 \ldots}$, & $\cdot, 1$ &., 1 & $19, v$ & $r \cdot, r$ & $v, r$ & or,t & ro_r. \\
\hline & & & & & & & محل الأقامة \\
\hline $1 \ldots$, & $\cdot, \cdot$ & $\cdot, 1$ & $r \cdot, r$ & $r \cdot, r$ & $9, \cdot$ & $0 ., 0$ & حضر \\
\hline $1 \ldots$ & $\cdot$, &., 1 & $r, Y$ & IV, & $v, 0$ & or, ६ & ريف \\
\hline \multirow[t]{2}{*}{$1 \ldots}$, & $\cdot, r$ & .,. & $|\Lambda|$, & $19, \wedge$ & $1 \leqslant, 0$ & $\varepsilon \vee, \varepsilon$ & مناطق عشو ائية \\
\hline & & & & & & & المنطقة \\
\hline $1 \ldots$, & $\cdot, \cdot$ &., 1 & 19,7 & ro, 1 & $\wedge, 7$ & $\leq 7, V$ & محافظات حضرية \\
\hline $1 \ldots$, & $\cdot, 1$ & , , & rr,. & $19, r$ & $\wedge, 9$ & $\varepsilon १, \wedge$ & حضر وجه بحري \\
\hline $1 \ldots$, & $\cdot, \cdot$ & , , & $r \cdot, \wedge$ & $\backslash \Lambda, \wedge$ & 9,1 & $01, \varepsilon$ & ريف وجه بحري \\
\hline $1 \ldots$, & $\cdot$, & .,. & 10,7 & 9,9 & $17, \varepsilon$ & $\Delta \lambda, 1$ & حضر وجه قبلي \\
\hline $1 \ldots$, & $\cdot$, & $\cdot, r$ & $r \varepsilon, Y$ & 10,7 & 0,7 & $0 \leqslant$, & ريف وجه قبلي \\
\hline \multirow[t]{2}{*}{$1 \ldots}$, & $\cdot$, & .,. & $r, \wedge$ & $r \cdot, r$ & $10, r$ & $r,, v$ & محافظات حدودية \\
\hline & & & & & & & المستوى التعليمي \\
\hline $1 \ldots$, & $\cdot, 1$ & $\cdot, \cdot$ & $19, \varepsilon$ & 19,1 & $\wedge, \uparrow$ & Or, r & 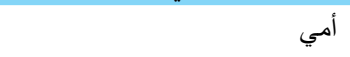 \\
\hline $1 \ldots$, & $\cdot, \cdot$ & ., & $i v, 0$ & $r \cdot, r$ & $11, v$ & $0 ., 7$ & يقرأ ويكتب \\
\hline $1 \ldots$, & $\cdot, \cdot$ & . r & $r, T$ & 17,7 & $\mathrm{v}, 0$ & $0 \leqslant,$. & إبتدائي \\
\hline $1 \ldots$, & $\cdot, \cdot$ & .,. & $r, 0$ & $1 \Lambda, T$ & $0, \wedge$ & $0 \leqslant, 1$ & إعدادي" \\
\hline $1 \ldots$, & $\cdot, \cdot$ & $\cdot, r$ & $r, r$ & $i v, v$ & $\Lambda, r$ & or, 1 & ثانوي عام \\
\hline $1 \ldots$, & $\cdot, \cdot$ & .,r & $r, v$ & 17,7 & $1 .,$. & 01,7 & ثانوي فني \\
\hline $1 \ldots$, & $\cdot, \cdot$ & $\cdot, \cdot$ & $r V, T$ & $1 T, \varepsilon$ & $\wedge, 9$ & $0 ., r$ & فوق متوسط \\
\hline \multirow[t]{2}{*}{$1 \ldots}$, & ., &., & $r, \wedge$ & $r, \wedge$ & $\wedge, \wedge$ & $\varepsilon \uparrow, V$ & جامعي فأكثر \\
\hline & & & & & & & الحالة الوظيفية \\
\hline $1 \ldots$, & $\cdot, \cdot$ & $\cdot, \cdot$ & $17, r$ & $r_{0,1}$ & 7,r & or,o & عامل بأجر \\
\hline $1 \ldots$, & $\cdot, \cdot$ & $1, \varepsilon$ & rr,q & $r$ r, & $r, 0$ & $\varepsilon १, 0$ & صاحب عمل / يعمل لصالح نفسه \\
\hline $1 \ldots$, & $\cdot, \cdot$ & $\cdot, \cdot$ & $i v$, & $r$ re, & $\varepsilon, 1$ & 00,0 & يعمل لحساب أسرته بدون أجر \\
\hline $1 \ldots$, & $\cdot, \cdot$ & ., ६ & $r 4, r$ & 19,9 & $\varepsilon, 9$ & $\varepsilon \wedge, \vee$ & عاطل يبحث عن عمل \\
\hline $1 \ldots$, & $\cdot, \cdot$ & $\cdot, 1$ & $\lceil, \wedge$ & $i v, 0$ & 9,1 & 01,7 & عاطل يدرس \\
\hline \multirow[t]{2}{*}{$1 \ldots}$, & $\cdot, \cdot$ & $\cdot$, & $r, \varepsilon$ & $1 \Lambda, 0$ & 9,7 & $0 ., 0$ & عاطل لا يدرس \\
\hline & & & & & & & مؤشر الثروة \\
\hline $1 \ldots$, & $\cdot, 1$ & $\cdot, r$ & $1 \wedge, 9$ & $1 \varepsilon, r$ & 9,1 & $o v, \varepsilon$ & الأدني \\
\hline $1 \ldots$, & $\cdot, \cdot$ & $\cdot$, & $r \varepsilon, \varepsilon$ & $v, v$ & $\Lambda, r$ & $\varepsilon q, \vee$ & الثناني \\
\hline $1 \ldots$, & $\cdot, \cdot$ & $\cdot, r$ & $r, \cdot$ & $|\Lambda|$, & $11, r$ & $\leqslant \Lambda, 0$ & الأوسط \\
\hline $1 \ldots$, & $\cdot, \cdot$ & ., & $r, r$ & $r \cdot, 0$ & $\wedge, 1$ & $0 ., r$ & الر ابع \\
\hline $1 \ldots$, &., & ., & $r \cdot, V$ & $r, \tau$ & $\mathrm{T}, \mathrm{V}$ & $01,$. & الأعلى \\
\hline $1 \ldots$, & ., &., 1 & $r 1,0$ & 11,0 & $\wedge, \uparrow$ & $01, r$ & الاجمالي \\
\hline
\end{tabular}


جدول أ V_ النسبة المئوية للثباب الذين ناقثوا البلوغ مع أولياء أمور هم حسب الخصائص الأساسية

\begin{tabular}{|c|c|c|c|}
\hline 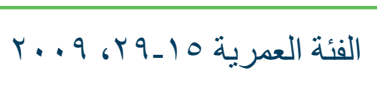 & 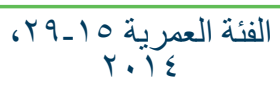 & 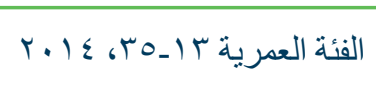 & الخصائص \\
\hline & & & الفئة العمرية \\
\hline$r v, t$ & $r \varepsilon, v$ & $r \varepsilon, q$ & $\left|V_{-}\right| r$ \\
\hline$r \wedge, \wedge$ & $r, v$ & rr,v & $r \varepsilon_{-} \mid \wedge$ \\
\hline \multirow[t]{3}{*}{$r \wedge, Y$} & rT, & ד, Tr & rq_ro \\
\hline & & $r_{0, r}$ & ro_r. \\
\hline & & & النوع \\
\hline$\wedge, 1$ & $r, \varepsilon$ & $r, r$ & ذكر \\
\hline \multirow[t]{2}{*}{$\varepsilon १, १$} & $\varepsilon Y, \tau$ & $\varepsilon \vee, 0$ & أنثى \\
\hline & & & محل الأقامة \\
\hline rr,v & $\varepsilon \cdot$, & $\varepsilon \cdot, r$ & حضر \\
\hline$r_{0,0}$ & $r q, v$ & $r \cdot, r$ & ريف \\
\hline \multirow[t]{2}{*}{ Tr, } & $\leqslant 1,0$ & $\varepsilon \cdot, q$ & مناطق عشو ائية \\
\hline & & & المنطقة \\
\hline$r \varepsilon, q$ & $\{0,0$ & $\varepsilon \varepsilon, \wedge$ & محافظات حضرية \\
\hline$r \cdot, 0$ & $r q, r$ & $r q, \wedge$ & حضر وجه بحري \\
\hline Y૫, \& & rr,A & ع \& & ريف وجه بحري \\
\hline$r q, \varepsilon$ & $r q, r$ & $r q, v$ & حضر وجه قبلي \\
\hline$r \leq, r$ & $r צ, r$ & $r, r$ & ريف وجه قبلي \\
\hline \multirow[t]{2}{*}{ rr, } & $\varepsilon \gamma, \wedge$ & $\varepsilon \vee, \vee$ & محافظات حدودية \\
\hline & & & 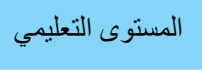 \\
\hline$r q, 0$ & Y૫, \& & $r v, q$ & أمي \\
\hline$r \wedge, 1$ & $r \varepsilon, \varepsilon$ & ru, r & يقرأ ويكتب \\
\hline$r \varepsilon, 1$ & $r q, r$ & $r_{1,0}$ & إبتدائي \\
\hline Yฯ,V & rY, & Tr,T & إعدادي \\
\hline rr, & $r q, r$ & $r q, r$ & ثانوي عام \\
\hline$r V, \Lambda$ & $r, r$ & $r_{1, V}$ & ثانوي فني \\
\hline Tr, & $\varepsilon \cdot, q$ & $\varepsilon \cdot, 0$ & فوق متوسط \\
\hline \multirow[t]{2}{*}{$r \varepsilon, \varepsilon$} & $\varepsilon \cdot, v$ & $\varepsilon \cdot, v$ & جامعي فأكثر \\
\hline & & & مؤشر الثروة \\
\hline$r_{1, q}$ & $r q, r$ & $r 7,9$ & الأدني \\
\hline Y૫, \& & $r q, 7$ & $r q, q$ & الثاني \\
\hline$r 4, \Lambda$ & $r, r$ & $r_{1,9}$ & الأوسط \\
\hline$\mu, r$ & $\varepsilon \cdot, 1$ & $\varepsilon \cdot, v$ & الر ابع \\
\hline 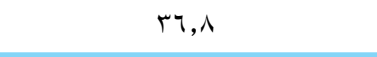 & $\varepsilon \cdot, r$ & $\varepsilon \cdot, \cdot$ & الأعلى \\
\hline$r \wedge, 0$ & $r r, q$ & $r \varepsilon, r$ & الاجمالي \\
\hline$(\Gamma, \varepsilon \Gamma \varepsilon)$ & $(r, \mid v 0)$ & $(\varepsilon, \cdot \leq \vee)$ & حجم العينة \\
\hline
\end{tabular}


جذول أب_N النسبة المئوية للثباب الذين يعرفون عن فيروس نقص المناعة البشري/ الإيدز حسب الخصائص الأساسية

\begin{tabular}{|c|c|c|c|}
\hline 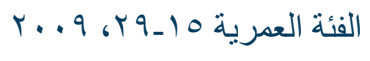 & 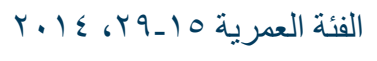 & 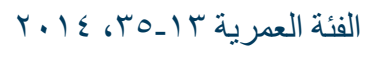 & الخصائص \\
\hline & & & الفئة العمرية \\
\hline$\Lambda \cdot, \uparrow$ & $T, 1$ & 09,7 & $\mid V_{-1}$ \\
\hline$\Lambda v, r$ & $v V, r$ & $v V, r$ & $r \leq-11$ \\
\hline \multirow[t]{3}{*}{$\wedge \uparrow, \varepsilon$} & $\vee 7,1$ & $v_{4}, 1$ & rq_ro \\
\hline & & $v_{4}, r$ & ro_t. \\
\hline & & & النوع \\
\hline $94, \cdot$ & $V v, r$ & $V \vee, \varepsilon$ & ذكر \\
\hline$\vee \wedge, \vee$ & $79, \varepsilon$ & $\uparrow \wedge, \wedge$ & أنثى \\
\hline & & & محل الأقامة \\
\hline 91,0 & $\Lambda, r$ & $\lambda \cdot, v$ & 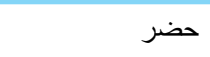 \\
\hline$\lambda, r$ & $v \cdot, v$ & $v \cdot, r$ & 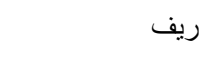 \\
\hline $91,$. & $M . r$ & $\uparrow, \vee$ & مناطق عشوائية \\
\hline & & & المنطقة \\
\hline 94,0 & $\wedge \uparrow, 0$ & $\Lambda \uparrow, 0$ & محافظات حضرية \\
\hline 94,1 & $v \varepsilon, r$ & $v \varepsilon, r$ & حضر وجه بحري \\
\hline$\Delta r, q$ & VY,Y & $v_{1, q}$ & ريف وجه بحري \\
\hline$\lambda v, q$ & $70, \varepsilon$ & \& & حضر وجه قبلي \\
\hline$\vee \wedge, 0$ & 79,7 & $\uparrow 1,9$ & ريف وجه قبلي \\
\hline$\vee q, r$ & $T \varepsilon, \varepsilon$ & ד, (זיד & محافظات حدودية \\
\hline & & & المستوى التعليمي \\
\hline$\varepsilon \uparrow$, & $\varepsilon 1, \wedge$ & $\varepsilon r, 0$ & أمي \\
\hline or, \& & or, \& & 07,7 & يقرأ ويكتب \\
\hline$V \varepsilon, \varepsilon$ & ov, & $0 \wedge, 7$ & إبتدائي \\
\hline$\wedge \uparrow, r$ & $09, r$ & ov, 9 & إعدادي \\
\hline qv,r & $\vee \wedge, 0$ & $\vee \wedge, q$ & ثانوي عام \\
\hline 9 १, ६ & $v_{0,0}$ & $\mathrm{~V}, \mathrm{~V}$ & ثانوي فني \\
\hline $9 \vee, 1$ & $q \cdot, v$ & $91, r$ & فوق متوسط \\
\hline $9 \vee, \wedge$ & qr, r & $9 Y, 7$ & جامعي فأكثر \\
\hline & & & مؤشر الثروة \\
\hline$V Y, q$ & $T, Y$ & 71,9 & الأدني \\
\hline$\wedge \cdot, \varepsilon$ & $v \cdot, 0$ & 79,9 & الثاني \\
\hline$\wedge \uparrow, r$ & $V Y, \varepsilon$ & $V Y, Y$ & الأوسط \\
\hline$q Y, V$ & $V r, Y$ & $V T, O$ & الر ابع \\
\hline 90,9 & $10, r$ & 10,0 & الأعلى \\
\hline 10,0 & $V r, T$ & $V r, Y$ & الاجمالي \\
\hline$(9, r r V)$ & $(\neg, r \cdot r)$ & $(\mathrm{V}, 9 \mathrm{Tr})$ & حجم العينة \\
\hline
\end{tabular}


جدول أب ـ 9 النسبة المئوية للفتيات المختنات حسب الخصائص الأساسية

\begin{tabular}{|c|c|c|c|}
\hline 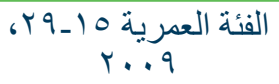 & 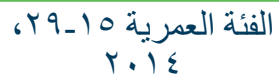 & 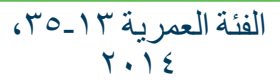 & الخصائص \\
\hline & & & الفئة العمرية \\
\hline$\wedge, \wedge$ & $v \varepsilon,$. & $v r, q$ & IV-IT \\
\hline$A V, \varepsilon$ & $v q, r$ & $v q, r$ & $r \varepsilon_{-} \mid \Lambda$ \\
\hline \multirow[t]{3}{*}{9 9., } & $\wedge \varepsilon, 1$ & $\Lambda \varepsilon, 1$ & rq_ro \\
\hline & & $\mathrm{N}_{0, \mathrm{~V}}$ & ro_r. \\
\hline & & & محل الأقامة \\
\hline$v_{0}, r$ & 70,1 & $\pi, r$ & حضر \\
\hline $9 \xi, \varepsilon$ & $N \mathrm{~V}, \mathrm{O}$ & $N Y, q$ & ريف \\
\hline \multirow[t]{2}{*}{$\wedge \varepsilon, 1$} & $v 1, q$ & $v \varepsilon, \wedge$ & مناطق عشو ائية \\
\hline & & & المنطقة \\
\hline$v, 0$ & or,r & 00,7 & محافظات حضرية \\
\hline A.,, 9 & $v 1, q$ & $v \varepsilon, 1$ & حضر وجه بحري \\
\hline $9 \varepsilon, Y$ & Ar, & $\Lambda \varepsilon, T$ & ريف وجه بحري \\
\hline $91, \varepsilon$ & $\wedge \mathrm{v}, \Lambda$ & $\wedge \wedge, \vee$ & حضر وجه قبلي \\
\hline$q \leqslant, q$ & 91,0 & 91,7 & ريف وجه قبلي \\
\hline \multirow[t]{2}{*}{$79, r$} & Vr, r & $V r, v$ & محافظات حدودية \\
\hline & & & المستوى التعليمي \\
\hline 90,7 & $91, \varepsilon$ & 91, , & أمي \\
\hline$q_{,, v}$ & $9 \cdot, \wedge$ & $\wedge \varepsilon, 1$ & يقر أويكتب \\
\hline 91,1 & 10,r & 10,9 & إبتدائي \\
\hline 10,7 & $\wedge \varepsilon, \varepsilon$ & $\Delta r,$. & إعدادي \\
\hline$v 1, v$ & 70,9 & $7 \pi$, & ثانوي عام \\
\hline 9 qr, & Nr,r & $\wedge r, \varepsilon$ & ثانوي فني \\
\hline $9 \cdot, 9$ & VY,O & $v_{0, v}$ & فوق متوسط \\
\hline \multirow[t]{2}{*}{$v_{0, \varepsilon}$} & $v_{1, \varepsilon}$ & $v 1,0$ & جامعي فأكثر \\
\hline & & & مؤشر الثروة \\
\hline 90,0 & $\wedge \uparrow, \uparrow$ & AV,, $\mathrm{r}$ & الأدني \\
\hline 90,1 & $\wedge r, \varepsilon$ & Ar,o & الثاني \\
\hline $9 \leqslant, \varepsilon$ & Ar,, & Ar, & الأوسط \\
\hline$\wedge \uparrow, \wedge$ & $v v, v$ & $\forall \wedge, q$ & الر ابع \\
\hline$\pi, 1$ & $v \cdot, r$ & $v, r$ & الأعلى \\
\hline$\Lambda Y, O$ & $v_{9,0}$ & A., 0 & الاجمالي \\
\hline$(0, \wedge r V)$ & $(\varepsilon, r \vee 0)$ & $(0, Y Y 0)$ & حجم العينة \\
\hline
\end{tabular}


جدول أب ـ ـ النسبة المئوية بين المستجيبين فى الفئة العمرية ب ا ـهـ الذين يعرفون وسائل تنظيم الأسرة حسب الخصائص الأساسية

\begin{tabular}{|c|c|c|c|c|c|c|}
\hline الو اقي & تحت الجلد & الحقن & اللولب & منع ألحمثل & يعلم عن الوسائل & الخصسائص \\
\hline & & & & & & الفئة العمرية \\
\hline$r, \varepsilon$ & $r, r$ & $r,$, & $r_{0, \varepsilon}$ & $r \varepsilon$, & $r \varepsilon, \wedge$ & $\left|V_{-}\right| r$ \\
\hline 9,0 & 9,1 & $r q, \wedge$ & $\leq \pi, r$ & or,A & $07,$. & $r \varepsilon_{-11}$ \\
\hline 11,0 & $1 \leqslant, \varepsilon$ & $0 \leqslant, Y$ & Tr, & 79,1 & $v r, q$ & $r_{\text {q_ro }}$ \\
\hline \multirow[t]{2}{*}{ Ir, } & $i v,$. & $\pi, 1$ & $V \varepsilon, \varepsilon$ & $\checkmark \wedge, Y$ & 10,. & ro_r. \\
\hline & & & & & & النوع \\
\hline $1 \%,$. & ז, & $r \varepsilon, v$ & $\varepsilon \cdot, \uparrow$ & $\varepsilon १, \vee$ & or,. & ذكر \\
\hline \multirow{2}{*}{$0, \wedge$} & $10, \varepsilon$ & or,. & $T, Y$ & $T V, \cdot$ & $v_{1}, 0$ & أنثى \\
\hline & & & & & & محل الأقامة \\
\hline IT,Y & 9,0 & rq,v & $\varepsilon \wedge, r$ & 04,0 & 09,9 & حضر \\
\hline$\Lambda, r$ & $1 \cdot, v$ & $\leq 0,0$ & or, 9 & $09, Y$ & $\pi$ & ريف \\
\hline \multirow[t]{2}{*}{$v, r$} & $1 \varepsilon, \varepsilon$ & $\varepsilon r, V$ & $01, \varepsilon$ & or,r & $0 \leqslant, 0$ & مناطق عشو ائية \\
\hline & & & & & & المنطقة \\
\hline IT,Y & $v, r$ & $r v, \tau$ & $\leq 9,1$ & ov, \& & 71,7 & محافظات حضرية \\
\hline $1 ., r$ & 11,1 & rq, & $0 ., 7$ & $0 \leqslant, r$ & : & حضر وجه بحري \\
\hline$v, v$ & $v, r$ & ו ג & $0 ., r$ & $0 \leqslant, r$ & 09,7 & ريف وجه بحري \\
\hline$\wedge, \wedge$ & $W, r$ & $\varepsilon \wedge, 9$ & $\varepsilon 7, r$ & or, 9 & $0 \leqslant, 0$ & حضر وجه قبلي \\
\hline$\wedge, \wedge$ & $1 \leqslant, \varepsilon$ & $0 \leqslant, 9$ & 07,1 & 10,7 & $T V, T$ & ريف وجه قبلي \\
\hline \multirow[t]{2}{*}{10,7} & $11,$. & $\varepsilon r, \uparrow$ & $\varepsilon \wedge, 1$ & $07, \mathrm{~V}$ & $09, r$ & محافظات حدودية \\
\hline & & & & & & المستوى التعليمي \\
\hline$\varepsilon, 7$ & $10, r$ & or,Y & $O V, Y$ & $T \leqslant, r$ & 79,1 & أمي \\
\hline$v, r$ & $1 \leqslant, V$ & $\varepsilon \wedge, 9$ & $T, r$ & vo, 1 & $\wedge \cdot, l$ & بقر أ ويكتب \\
\hline$\vee, \wedge$ & $v, 0$ & $\varepsilon r, r$ & or,r & $\Delta q, v$ & $\Delta ৭, \vee$ & إبتدائي \\
\hline 7,7 & $\wedge, \vee$ & $r v, r$ & $\varepsilon r, 0$ & $0 ., 1$ & Tr, & إعدادي \\
\hline 0,1 & 0,1 & $r 4, q$ & $r \varepsilon, T$ & $\varepsilon r, \varepsilon$ & $0 \leqslant, 1$ & ثانوي عام \\
\hline$\wedge, \vee$ & $1 ., 1$ & $\varepsilon \varepsilon, \varepsilon$ & or, 1 & $0 \wedge, 9$ & $T r, r$ & ثانوي فني \\
\hline 17,1 & 10,1 & or,r & 11,1 & Tצ, & $79, r$ & فوق متوسط \\
\hline \multirow[t]{2}{*}{$17, \varepsilon$} & $1 T, 7$ & $\varepsilon V, r$ & $07, \varepsilon$ & $\Upsilon 1, \wedge$ & $T \varepsilon, \wedge$ & جامعي فأكثر \\
\hline & & & & & & مؤشر الثروة \\
\hline $7, r$ & Ir,r & $\varepsilon \varepsilon$, & $\leqslant 7,0$ & 04,7 & $09, \cdot$ & الأدني \\
\hline $9, \cdot$ & $11,$. & $\varepsilon r, T$ & $\varepsilon q, \vee$ & 04,1 & $\Delta ৭, \varepsilon$ & الثاني \\
\hline$v, q$ & $1 ., 0$ & $\varepsilon 0, r$ & $0 \leqslant, V$ & $0 \wedge, 9$ & $T r, V$ & الأوسط \\
\hline 9,1 & $\wedge, \wedge$ & $\varepsilon \cdot, r$ & $\varepsilon q,$. & $07, V$ & $7 .,$. & الر ابع \\
\hline $1 \leqslant, 1$ & $1 \cdot, 9$ & $\leq 0,0$ & 00,9 & 7,7 & $70, \varepsilon$ & الأعلى \\
\hline 9,0 & $1 \cdot, v$ & $\varepsilon r, \tau$ & $01, \varepsilon$ & $0 \wedge, 1$ & 71,0 & الاجمالي \\
\hline$(1 \cdot, 917)$ & $(1 \cdot, 917)$ & $(1 \cdot, 917)$ & $(1 \cdot, 917)$ & $(1 \cdot 917)$ & $(1 \cdot, 9 \cdot r)$ & حجم العينة \\
\hline
\end{tabular}




\begin{tabular}{|c|c|c|c|c|}
\hline أنت الجامعة في سن سب & أتم الثانوية في سن 9 ا & أتم الاعدادية في سن 17 & أتم الابتدائية في سن سا & \\
\hline & & & & النوع \\
\hline$r, 1$ & $V r, r$ & $\vee q, r$ & $\Delta v, \uparrow$ & ذكر \\
\hline \multirow[t]{2}{*}{$19, r$} & $T \varepsilon, 0$ & $V r, r$ & $\wedge$, & أنثى \\
\hline & & & & 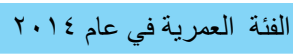 \\
\hline $\mathrm{n} / \mathrm{a}$ & $\mathrm{n} / \mathrm{a}$ & $\vee \wedge, \uparrow$ & 9 १, & 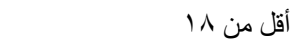 \\
\hline r & $V r, Y$ & $\wedge \cdot, 9$ & $\Lambda \wedge, r$ & $r \varepsilon_{-} \mid \wedge$ \\
\hline$r, r$ & 79, & $v \varepsilon, 1$ & $v \wedge, r$ & rq_ro \\
\hline \multirow[t]{2}{*}{$\backslash \mathrm{Y}, \Lambda$} & $71, \cdot$ & $7 r, 1$ & $V Y, r$ & 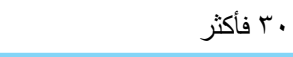 \\
\hline & & & & محل الأقامة \\
\hline 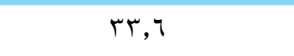 & $v_{0, \Lambda}$ & $\Delta r, r$ & $\wedge ৭, \varepsilon$ & حضر \\
\hline $1 \leqslant, 1$ & $T \leqslant, V$ & VY,O & $\wedge$, , & ريف - ت \\
\hline \multirow[t]{2}{*}{ ro, 9} & $V \varepsilon, r$ & $\wedge 1,9$ & $\Delta \vee, 0$ & مناطق عشو ائية \\
\hline & & & & المنطقة \\
\hline$r \varepsilon, \cdot$ & VY,T & $\wedge \cdot, 1$ & $\wedge \wedge, q$ & محافظات حضرية \\
\hline$r v, 1$ & $\Lambda \cdot, v$ & $\wedge 7,9$ & 91,7 & حضر وجه بحري \\
\hline 17,1 & 79,1 & $v_{0, \varepsilon}$ & $\wedge r, \uparrow$ & ريف وجه بحري \\
\hline $19, r$ & $v \varepsilon, r$ & $\vee q, q$ & 10,1 & حضر وجه قبلي \\
\hline $\mid r, 1$ & $r ., r$ & $v_{\cdot}, \cdot$ & $\vee १, 7$ & ريف وجه قبلي \\
\hline \multirow[t]{2}{*}{$1 \leqslant, 7$} & $T r, r$ & 79,1 & $v_{\imath, 1}$ & محافظات حدودية \\
\hline & & & & 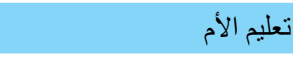 \\
\hline $11,$. & $0 \wedge, 9$ & $T V, r$ & $\mathrm{~V}, \mathrm{~V}$ & أمية \\
\hline$r \leqslant, r$ & $V Y, \varepsilon$ & $\Lambda r, v$ & $9 \cdot, \wedge$ & تقر أ وتكتب \\
\hline$r v, \Lambda$ & $\vee q, \varepsilon$ & $\wedge \varepsilon, \varepsilon$ & १५, ६ & إبتدائي \\
\hline$\varepsilon \cdot, r$ & $\Lambda, 0$ & $9 \cdot, \cdot$ & $q \vee, r$ & إعدادي \\
\hline$V_{7}, 0$ & $90, \varepsilon$ & 99,1 & $1, ., \cdot$ & ثانوي عام \\
\hline ov, q & 90,0 & q४, 1 & ११,। & ثانوي فني وما بعده \\
\hline \multirow[t]{2}{*}{$\Lambda \wedge, \vee$} & $99, \varepsilon$ & $99, \cdot$ & $99, \vee$ & جامعي فأكثر \\
\hline & & & & تعليم الأب \\
\hline$v, o$ & or,. & $7 \cdot, 0$ & $V u, r$ & أمي \\
\hline $1 v, q$ & $\vee \cdot, \wedge$ & $V v, \Lambda$ & $\Lambda_{T, V}$ & يقر أ ويكتب \\
\hline $19, \varepsilon$ & $v_{0, r}$ & $\lambda, r$ & $\wedge ৭, \varepsilon$ & إبتدائي \\
\hline$r v, q$ & $\wedge, \wedge$ & $\wedge 9, r$ & $97, Y$ & إعدادي \\
\hline$\varepsilon \varepsilon, \varepsilon$ & $\wedge \wedge, \cdot$ & 90,1 & $9 \wedge, 9$ & ثانوي عام \\
\hline$\varepsilon \varepsilon, V$ & 91,7 & $9 \leqslant, \varepsilon$ & $৭ \vee, \wedge$ & ثانوي فني وما بعده \\
\hline$v_{0, q}$ & $9 \wedge, r$ & $9 \wedge, \vee$ & 99,7 & جامعي فأكثر \\
\hline$r, r$ & 79, & $v_{7}, r$ & $\wedge \varepsilon, \varepsilon$ & الاجمالي \\
\hline$(0,70 \varepsilon)$ & $(\wedge, Y \circ Y)$ & $(1 \cdot, \cdot V Y)$ & $(1 \cdot, q \cdot v)$ & حجم العينة \\
\hline
\end{tabular}




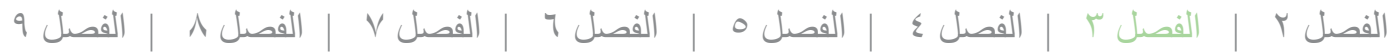

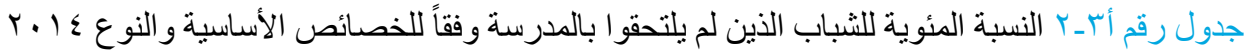

\begin{tabular}{|c|c|c|c|}
\hline الاجمالي & إناث & ذكور & \\
\hline & & & الفئة العمرية في عام ع ا ب r \\
\hline$r, 0$ & $r, 1$ & $\varepsilon$, & أقل من 11 ا \\
\hline$v, 1$ & 9,7 & $0, \cdot$ & $r \leq-11$ \\
\hline $\mid r, \Lambda$ & $r_{\cdot, \cdot}$ & $v, q$ & rq_ro \\
\hline \multirow[t]{2}{*}{ 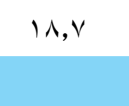 } & $r$ r & $1 \cdot, r$ & 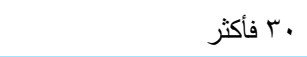 \\
\hline & & & محل الأقامة \\
\hline$\varepsilon, r$ & $0, \cdot$ & r, $\varepsilon$ & حضر \\
\hline$i r$, & $\curlywedge \curlywedge, \varepsilon$ & $v, v$ & ريف \\
\hline \multirow[t]{2}{*}{$\Lambda, r$} & $1 ., r$ & 7,1 & مناطق عشوائية \\
\hline & & & المنطقة \\
\hline r, £ & $\varepsilon, \cdot$ & r,q & محافظات حضرية \\
\hline$\varepsilon, v$ & $0, \wedge$ & $r, 0$ & حضر وجه بحري \\
\hline $1 \cdot, v$ & $1 \%, 0$ & $\lambda, r$ & ريف وجه بحري \\
\hline 9,0 & ir,. & $v, r$ & حضر وجه قبلي \\
\hline 10, & rY,T & $\mathrm{v}, \cdot$ & ريف وجه قبلي \\
\hline \multirow[t]{2}{*}{$1 \wedge}$, & r & $1 \cdot, 0$ & محافظات حدودية \\
\hline & & & تعليم الأم \\
\hline $10, \mathrm{~V}$ & rI, r & $1 \cdot, \cdot$ & أمية \\
\hline$r, \uparrow$ & $\varepsilon, r$ & r,q & تقر أ وتكتب \\
\hline 1,7 & $\cdot, v$ & $r, r$ & إبتدائي \\
\hline$\cdot, \varepsilon$ & $\cdot, \varepsilon$ & $\cdot, 0$ & إعدادي \\
\hline$\cdot, \cdot$ & $\cdot, \cdot$ & $\cdot, \cdot$ & ثانوي عام \\
\hline$\cdot, r$ & $\cdot, r$ & $\cdot, r$ & ثانوي فني وما بعده \\
\hline \multirow[t]{2}{*}{$\cdot, 1$} & $\cdot, r$ & $\cdot, \cdot$ & جامعي فأكثر \\
\hline & & & ت تعليم الأب \\
\hline$r \cdot, l$ & $r \uparrow, Y$ & $1 r, r$ & أمي \\
\hline 7,0 & 9,0 & $r, r$ & يقرأ ويكتب \\
\hline$r, r$ & $0, r$ & 1,0 & إبتدائي \\
\hline$r, r$ & $r, r$ & $r, r$ & إعدادي \\
\hline 1,1 & $r, T$ & $\cdot, \cdot$ & ثانوي عام \\
\hline$\cdot, 9$ & $\cdot, \wedge$ & $1, \cdot$ & ثانوي فني وما بعده \\
\hline$\cdot, \cdot$ & $\cdot, \cdot$ & $\cdot, \cdot$ & جامعي فأكثر \\
\hline 9,9 & Ir,v & $7, r$ & الاجمالي \\
\hline$(1 \cdot q \cdot v)$ & $(0, \wedge r v)$ & $(0, \cdot v \cdot)$ & حجم العينة \\
\hline
\end{tabular}




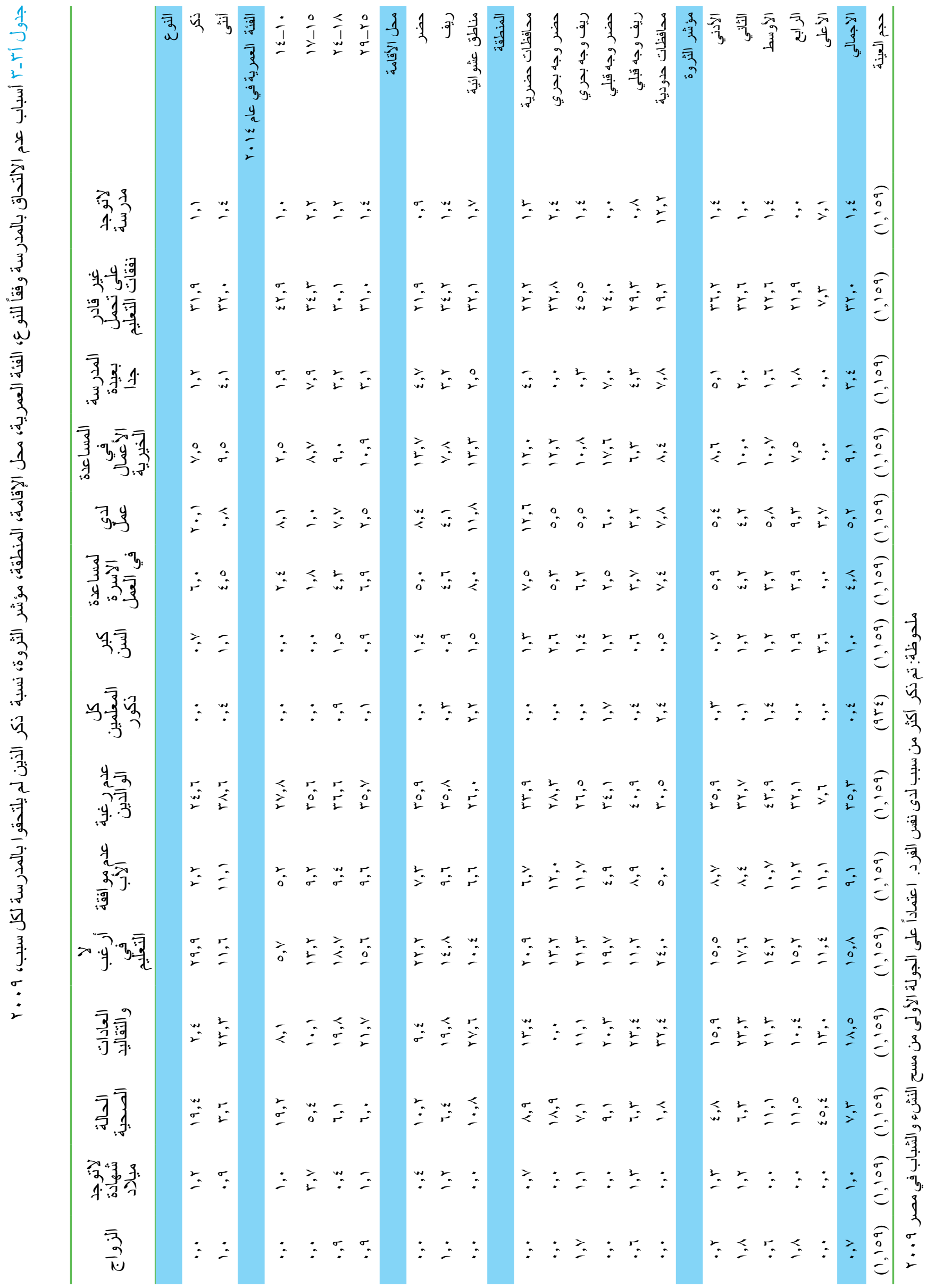


جذول أبـــ نسبة الثباب الحاصلين على تعليم أقل من الثانوي الذين التحقوا بفصول محو الأمية، أو الذين لا يستطيعون القراءة، أو الذين لا بيستطيعون

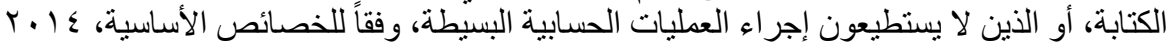

\begin{tabular}{|c|c|c|c|c|}
\hline 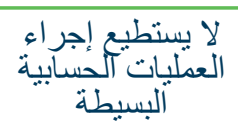 & لا يستطيع الكتابة & لا يستطيع القراءة & شارك في فصيول محو & \\
\hline & & & & النوع \\
\hline$r_{1, \cdot}$ & $\varepsilon 0, r$ & $\{0,1$ & 7,1 & ذكر \\
\hline$r_{\Lambda}, \varepsilon$ & or, 1 & 01,0 & $11, r$ & أنثى \\
\hline & & & & 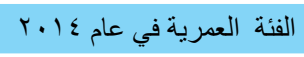 \\
\hline IV,r & $r r, l$ & $r$ r,o & $\varepsilon$, & أقل من 11 أ \\
\hline ro,v & $\varepsilon \wedge, \uparrow$ & $\varepsilon \wedge, r$ & $7, \mathrm{~V}$ & $r \varepsilon_{-11}$ \\
\hline$\leq 4,9$ & $\pi, \wedge$ & T4, & $1 r, 9$ & rq_ro \\
\hline$\varepsilon 0, v$ & 70,9 & $T \leq, \Gamma$ & $1 r, \wedge$ & • فأكثر \\
\hline & & & & محل الأقامة \\
\hline 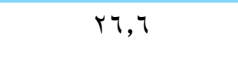 & $r \wedge, r$ & rN, 9 & $\Lambda, r$ & حضر \\
\hline$r q, r$ & or,o & or, 9 & $\wedge, 9$ & ريف \\
\hline$r \varepsilon, \varepsilon$ & $\varepsilon r, \varepsilon$ & $\varepsilon \cdot, r$ & $1 \cdot, \wedge$ & مناطق عشو ائية \\
\hline & & & & المنطقة \\
\hline$r \cdot, q$ & $r 4, r$ & ru, 9 & $9, \mathrm{~V}$ & محافظات حضرية \\
\hline$\curlyvee \wedge, \wedge$ & $r T, \Lambda$ & $r \cdot, v$ & $v, q$ & حضر وجه بحري \\
\hline$r v, \cdot$ & $01, \cdot$ & $\varepsilon १, १$ & $v, 1$ & ريف وجه بحري \\
\hline$r \leqslant, q$ & or,r & or, r & $v, q$ & حضر وجه قبلي \\
\hline$\varepsilon 1, r$ & $00, r$ & 00,1 & $1 \cdot, 0$ & ريف وجه قبلي \\
\hline ro,. & 00,1 & $00, \mathrm{~V}$ & $v, 1$ & محافظات حدودية \\
\hline & & & & تعليم الأم \\
\hline$\varepsilon \cdot, \cdot$ & 07,1 & $00, \varepsilon$ & $1 \cdot, 1$ & أمية \\
\hline ro,. & rr, & 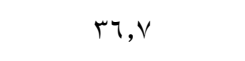 & $0, v$ & تقرا و وتكثب \\
\hline rr, & $r, \wedge$ & $r q, 7$ & $\varepsilon, \vee$ & إبتدائي \\
\hline$I \leqslant, V$ & 10,0 & 19,1 & 1,9 & إعدادي \\
\hline$r \cdot, r$ & $r \cdot, r$ & $r \cdot, v$ & $\cdot, \cdot$ & ثانوي عام \\
\hline $0, \cdot$ & $\mathrm{v}, \cdot$ & $\mathrm{v}, \wedge$ & $\varepsilon, \wedge$ & ثانوي فني وما بعده \\
\hline$\varepsilon, \wedge$ & 9,7 & Ir,O & $\wedge, r$ & جامعي فأكثر \\
\hline & & & & ت تعليم الأب \\
\hline$\varepsilon r, T$ & 09,0 & $\circ 9, \cdot$ & 9,0 & أمي \\
\hline$r 4, q$ & $\varepsilon \cdot, 7$ & $r q, \wedge$ & Ir,. & يقرأ ويكتب \\
\hline$r V, V$ & $r V, T$ & $r v, r$ & 9,1 & إبتدائي \\
\hline$i \Lambda, V$ & $r \Lambda, \vartheta$ & rч, & $\varepsilon, \vee$ & إعدادي \\
\hline $0, \varepsilon$ & $\wedge, 9$ & $0, \varepsilon$ & $r, 0$ & ثنانوي عام \\
\hline $1 \%, \varepsilon$ & 10,9 & iv,r & $\varepsilon, r$ & ثانوي فني وما بعده \\
\hline$\varepsilon, V$ & $\varepsilon, V$ & $r, q$ & $\varepsilon, 0$ & جامعي فأكثر \\
\hline & & & & الحالة التعليمية \\
\hline $79, \wedge$ & $9 \%, \cdot$ & QY, r & Ir,v & لا يوجد \\
\hline$r v, l$ & r , V & $\varepsilon 1,7$ & 10,0 & ماز ال في المرحلة الابتدائية \\
\hline 1,1 & $r, v$ & $\varepsilon, 9$ & $r, q$ & ماز ال في المرحلة الاعدادية \\
\hline$\varepsilon 1,0$ & $r, r$ & 09,7 & $9, \wedge$ & أنهى الابتدائية \\
\hline १, ६ & 10,0 & $1 \leqslant, \wedge$ & 7,1 & أنهى الاعدادية \\
\hline $9, \varepsilon$ & 10,0 & $1 \leqslant, \wedge$ & 7,1 & الاجمالي \\
\hline$(\Gamma, \Upsilon \mu \wedge)$ & $(\Gamma, T \Gamma \wedge)$ & $(\Gamma, T \Gamma \wedge)$ & $(\Gamma, T \Gamma \wedge)$ & حجم العينة \\
\hline
\end{tabular}




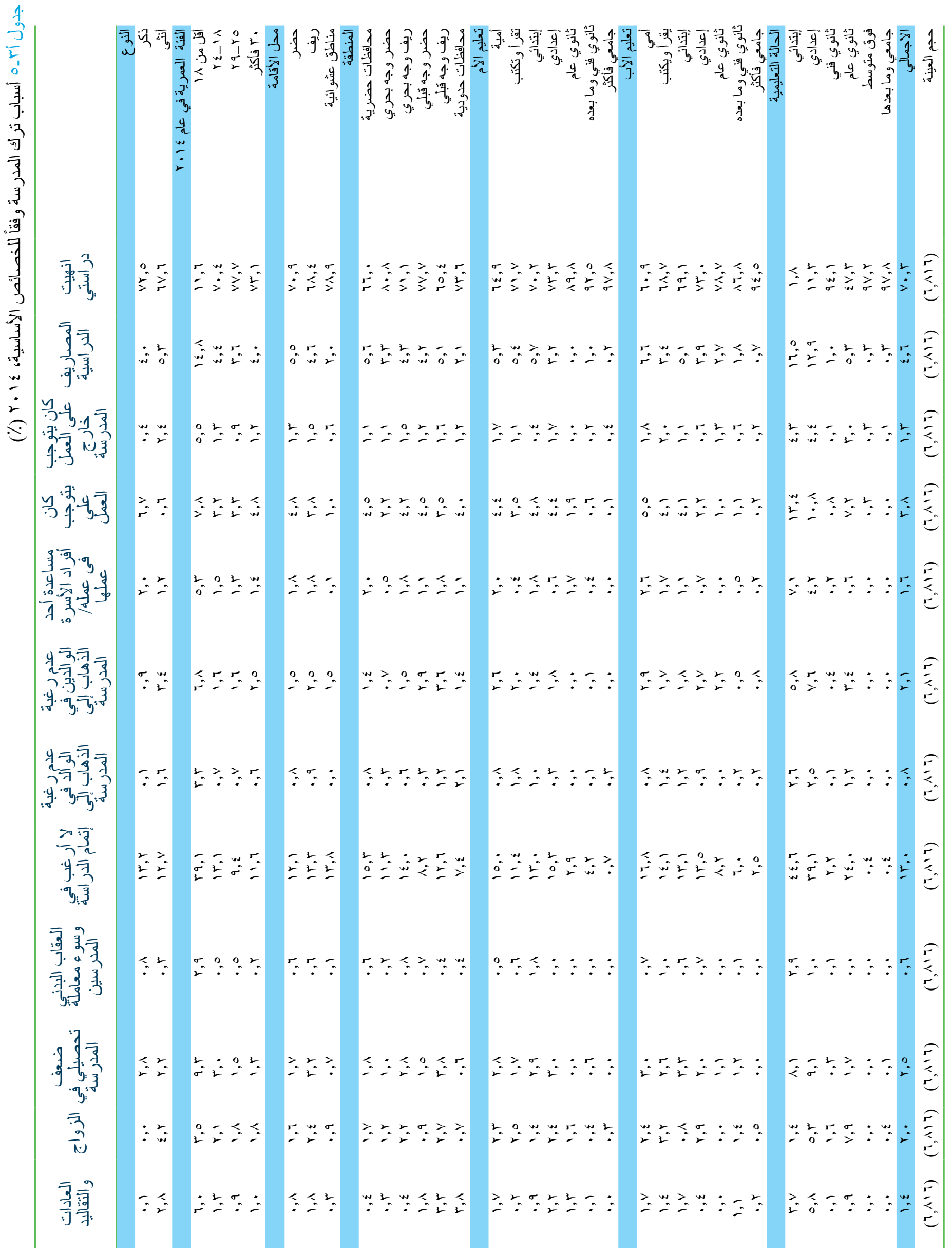


جدول أبـا7 توزيع المستوي التعليمي للطلاب الذين يدرسون حالياً طبقاً للخصائص الأساسية، ـ ا ب (٪)

\begin{tabular}{|c|c|c|c|c|c|c|c|}
\hline الاجمالي & جامعي وما & مالمتو فوق & ثانوي عام & ثانوي فني & الاعدادي & الابتدائي & \\
\hline & & & & & & & النوع \\
\hline $1 \cdots$, & rฯ, & 1,1 & $r^{1, \Lambda}$ & $\mu_{1}$, & $i \wedge, V$ & $\cdot, 7$ & ذكر \\
\hline \multirow[t]{2}{*}{$1 \cdots, \cdot$} & rv, I & $r, \cdot$ & $\gamma_{\Lambda}, \varepsilon$ & $r r, q$ & $1 \wedge, \varepsilon$ & $\cdot, r$ & أنثى \\
\hline & & & & & & & 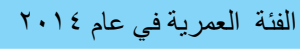 \\
\hline $1 \ldots$, & $\cdot, 9$ & $\cdot, 1$ & ro,, & $r r, q$ & $r q, \uparrow$ & $\cdot, 7$ & أقل من 11 \\
\hline $1 \ldots$, & $70, \xi$ & $\varepsilon, q$ & 9,7 & $1 \wedge, 7$ & 1,0 & $\cdot, \cdot$ & $r \varepsilon_{-1} \mid \Lambda$ \\
\hline $1 \ldots$, & $97, \wedge$ & $\cdot, \mathrm{V}$ & $\cdot, \cdot$ & $r, 0$ & $\cdot, \cdot$ & $\cdot, \cdot$ & rq-ro \\
\hline \multirow[t]{2}{*}{$1 \ldots}$, & $1 \ldots$, & $\cdot, \cdot$ & $\cdot, \cdot$ & $\cdot, \cdot$ & $\cdot, \cdot$ & $\cdot, \cdot$ & 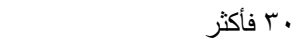 \\
\hline & & & & & & & محل الأقامة \\
\hline $1 \cdots, \cdot$ & rr, & $r, r$ & $r \wedge, q$ & $19, r$ & 10,7 & $\cdot, 0$ & حضر \\
\hline $1 \ldots$, & $r_{r,}$ & 1,9 & $r^{\prime}, \Lambda$ & $r, r$ & $r \cdot, v$ & • & ريف \\
\hline \multirow[t]{2}{*}{$1 \ldots}$, & $r \cdot, r$ & $1, \cdot$ & $r 9,1$ & $r \leqslant, 1$ & $10, \mathrm{~V}$ & $\cdot, \cdot$ & مناطق عشو ائية \\
\hline & & & & & & & المنطقة \\
\hline $1 \ldots$, & rr, & $r, \wedge$ & $r \wedge, q$ & $1 \curlywedge, \varepsilon$ & iv, & $\cdot, \wedge$ & محافظات حضرية \\
\hline $1 \ldots$, & $r 0,7$ & $1, r$ & 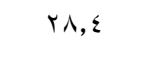 & $r_{\cdot, \cdot}$ & $1 \leqslant, 7$ & $\cdot, \cdot$ & حضر وجه بحري \\
\hline $1 \cdots$, & 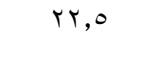 & $1, \mathrm{~V}$ & $r \leqslant, 0$ & $r \cdot, \Lambda$ & $r \cdot, r$ & $\cdot, r$ & ريف وجه بحري \\
\hline $1 \cdots$, & $r \cdot, \Lambda$ & 1,1 & $r \cdot, r$ & $r \leqslant, r$ & $1 r, 0$ & $\cdot, \cdot$ & حضر وجه قبلي \\
\hline $1 \ldots$, & $r, \uparrow$ & $r, \cdot$ & 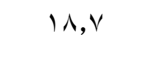 & ri, & $r, r$ & $\cdot, 7$ & ريف وجه قبلي \\
\hline \multirow[t]{2}{*}{$1 \ldots}$, & $r, \cdot$ & $\cdot, 9$ & $r, \cdot$ & $r, 0$ & $r, 0$ & $r, r$ & محافظات حدودية \\
\hline & & & & & & & تعليم الأم \\
\hline $1 \ldots$, & $i \Lambda, V$ & $r, \cdot$ & $17, r$ & $r q, v$ & $r, Y$ & $\cdot, 0$ & أمية \\
\hline $1 \cdots, \cdot$ & $r \cdot, v$ & $r_{,} \cdot$ & $Y V, \varepsilon$ & $r_{0, r}$ & $1 \varepsilon, V$ & $\cdot, \cdot$ & تقر أ وتكتب \\
\hline $1 \ldots$, & $r v, 0$ & $r, 1$ & $17, r$ & ri,v & $r \cdot, \lambda$ & $\cdot, V$ & إبتدائي \\
\hline $1 \ldots$, & $r, q$ & $r, r$ & $r \cdot, \cdot$ & $r r, r$ & $r \cdot, r$ & $\cdot, \wedge$ & إعدادي \\
\hline $1 \ldots, \cdot$ & $\varepsilon \cdot, \cdot$ & $\cdot, \cdot$ & $r \wedge, 7$ & $r \cdot, l$ & $11, r$ & $\cdot, \cdot$ & ثانوي عام \\
\hline $1 \ldots$, & ri,l & 1,0 & $r \varepsilon, r$ & $17, V$ & $17, r$ & $\cdot, r$ & ثانوي فني وما بعده \\
\hline \multirow[t]{2}{*}{$1 \ldots, \cdot$} & $\varepsilon r, \wedge$ & $1, r$ & $\varepsilon \cdot, \varepsilon$ & 0,7 & $\wedge, q$ & $\cdot, \cdot$ & جامعي فأكثر \\
\hline & & & & & & & تعليم الأب \\
\hline $1 \ldots$, & $I V, \varepsilon$ & $1, r$ & $1 \varepsilon, r$ & $\varepsilon \cdot$, & $r \uparrow, 0$ & , & أمي \\
\hline $1 \cdots, \cdot$ & $i v, v$ & $1, v$ & $r v, 1$ & $r \varepsilon, v$ & $1 \wedge,$. & $\cdot, 9$ & يقر أ ويكتب \\
\hline $1 \ldots$, & $r, 1$ & $r, 0$ & 10,9 & $\varepsilon \cdot, \wedge$ & $1 \wedge, 1$ &., 0 & إبتدائي \\
\hline $1 \cdots$, & 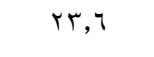 & $r, 0$ & $1 \varepsilon, \wedge$ & Tч, & $r), \Lambda$ & $\cdot, 9$ & إعدادي \\
\hline $1 \cdots, \cdot$ & $r_{0, .}$ & $0, \cdot$ & 9,9 & r , \& & Tr,T & $\cdot, \cdot$ & ثانوي عام \\
\hline $1 \cdots$, & $r V, \Lambda$ & $1, \wedge$ & $r, r$ & $r,, v$ & IV,r & $\cdot, r$ & ثانوي فني وما بعده \\
\hline $1 \cdots$, & $\varepsilon \varepsilon, 7$ & $1, \varepsilon$ & $\kappa_{\Lambda, \tau}$ & $v, 1$ & $\curlywedge, \varepsilon$ & $\cdot, \cdot$ & جامعي فأكثر \\
\hline $1 \cdots, \cdot$ & $r\urcorner, 7$ & 1,9 & $r \leqslant, q$ & $r V, V$ & $1 \wedge, 7$ & $\cdot, \varepsilon$ & الاجمالي \\
\hline$(r, \wedge \vee \cdot)$ & $(V \Gamma \varepsilon)$ & $(0 \leqslant)$ & $(V \Gamma \varepsilon)$ & $(\wedge \cdots)$ & (orv) & ('1) & حجم العينة \\
\hline
\end{tabular}


الفصل r | الفصل r | الفصل ع | الفصل 0 | الفصل 7 | الفصل V | الفصل م | الفصل 9

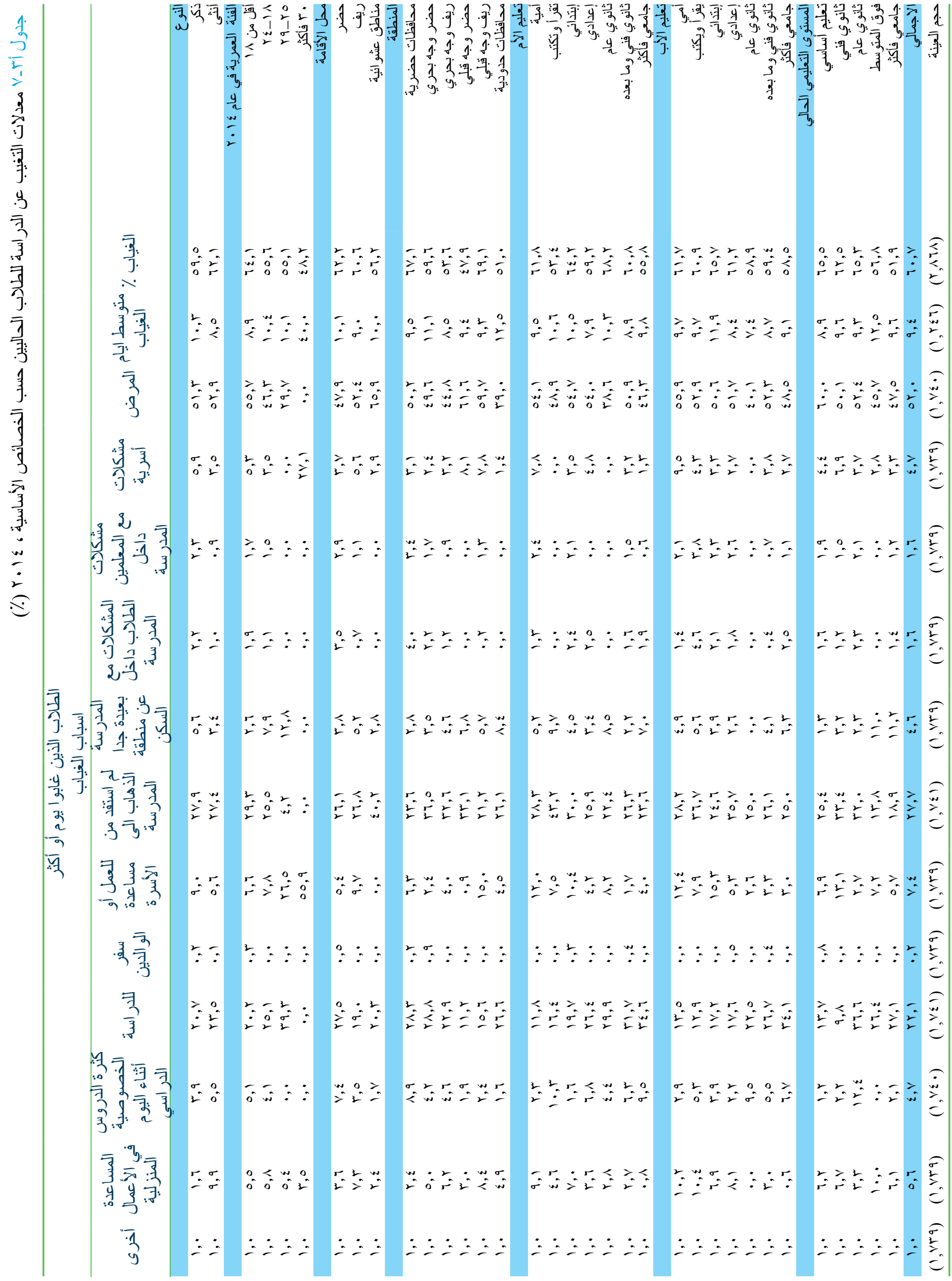




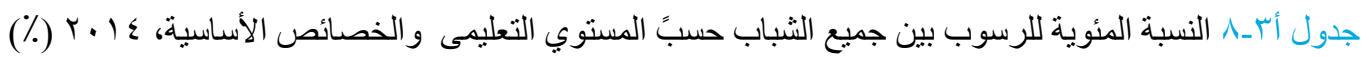

\begin{tabular}{|c|c|c|c|c|}
\hline الرسوب في الجامعة & الرسوب في المرحلة & الرسوب في المردلة & الرسوب في الابندائية & \\
\hline & & & & النوع \\
\hline $1 \cdot, 1$ & 0,0 & $v, 0$ & $r, q$ & ذكر \\
\hline \multirow[t]{2}{*}{$r, r$} & 1,9 & 0, & $r, \uparrow$ & أنثى \\
\hline & & & & 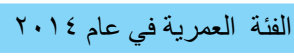 \\
\hline$\cdot, \cdot$ & $\cdot, \cdot$ & $r, v$ & $r, 0$ & 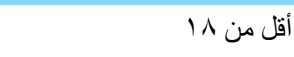 \\
\hline 0,0 & $\varepsilon, 0$ & $v, r$ & $r, \varepsilon$ & $r \varepsilon_{-1 \wedge}$ \\
\hline 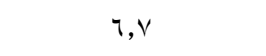 & r, ६ & Ү,. & $r, \cdot$ & rq-ro \\
\hline \multirow[t]{2}{*}{ १,६ } & $r, \cdot$ & $v, 1$ & $r, r$ & 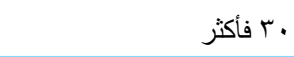 \\
\hline & & & & محل الأقامة \\
\hline 7,7 & $r, r$ & 0,1 & r,, $\mathrm{r}$ & حضر \\
\hline$\wedge, \wedge$ & $\varepsilon, 7$ & $\mathrm{v}, \mathrm{T}$ & $r, \gamma$ & ريف \\
\hline \multirow[t]{2}{*}{$r, r$} & $1, \varepsilon$ & r.o & r.o & مناطق عشو ائية \\
\hline & & & & المنطقة \\
\hline $9, r$ & $r, v$ & $0, r$ & $r, \wedge$ & محافظات حضرية \\
\hline $1, v$ & $1, r$ & $r, 0$ & 1,7 & حضر وجه بحري \\
\hline $0, v$ & $r, l$ & 0,0 & & ريف وجه بحري \\
\hline 1,1 & $r, \Lambda$ & $7, \cdot$ & $1, v$ & حضر وجه قبلي \\
\hline$i r, \Lambda$ & 7,7 & $1 ., 1$ & $\varepsilon$, & ريف وجه قبلي \\
\hline \multirow[t]{2}{*}{$1, \wedge$} & $r, \uparrow$ & $r, \cdot$ & $r, r$ & محافظات حدودية \\
\hline & & & & ت ت تعليم الأم \\
\hline $\mathrm{v}, \mathrm{v}$ & $\varepsilon, r$ & $\Lambda, \uparrow$ & $\varepsilon, r$ & أمية \\
\hline $0, r$ & $r, 1$ & $r, r$ & $\varepsilon$, & تقر أ وتكتب \\
\hline $9, \cdot$ & ד, & $0, v$ & $r, v$ & إبتدائي \\
\hline $1 \cdot, r$ & $r, r$ & 0,1 & $\cdot, 9$ & إعدادي \\
\hline$T, Y$ & 1,0 & $\cdot, \cdot$ & ., & ثانوي عام \\
\hline 0,7 & $r, 0$ & $r, \cdot$ & $\cdot, \wedge$ & ثانوي فني وما بعده \\
\hline \multirow[t]{2}{*}{$0, \cdot$} & 1,7 & $\cdot, 0$ & $\cdot, r$ & جامعي فأكثر \\
\hline & & & & تعليم الأب \\
\hline$T, r$ & $r, \wedge$ & $\wedge, \wedge$ & $\varepsilon, 7$ & أمي \\
\hline 0,7 & $\varepsilon, V$ & 7,0 & $\varepsilon$, & يقر أ ويكتب \\
\hline $11,$. & 0,0 & 9,7 & $\varepsilon, q$ & إبتدائي \\
\hline IV,r & $r, r$ & $0, v$ & $r, 0$ & إعدادي \\
\hline$r, T$ & $r, \wedge$ & $\varepsilon, \cdot$ & r.o & ثانوي عام \\
\hline 7,7 & $r, \cdot$ & $r, r$ & $1,$. & ثانوي فني وما بعده \\
\hline$\varepsilon, r$ & $r, 0$ & 1,1 & $\cdot, \wedge$ & جامعي فأكثر \\
\hline$\vee$, & $r, \wedge$ & $7, r$ & $r, r$ & الاجمالي \\
\hline$(1, \leqslant 79)$ & $(0, V \mu r)$ & $(\wedge, Y \circ r)$ & $(9,7 \vee \vee)$ & حجم العينة \\
\hline
\end{tabular}

ملحوظة: بناءا على الثباب الذين حضروا هذه المرحلة. 
جدول أب_9 مقاييس جودة المنشآت المدرسية طبقاً للخصائص الأساسية، ع ( ب (\%)

\begin{tabular}{|c|c|c|c|c|c|c|c|c|c|}
\hline تهولتية غيرة & مكسورة & وضبوح & إضلاءئمة غير & الزقداعدام & المكسورة & الثانوي & الاعدادي & الابتدائي & \\
\hline & & & & & & & & & النوع \\
\hline$r_{1, q}$ & $r \varepsilon, \wedge$ & $r \Lambda, T$ & $r \leqslant, 0$ & $r v, l$ & $\Gamma \wedge, \wedge$ & $r u, r$ & $r \Lambda, V$ & $r q, r$ & ذكر \\
\hline \multirow{2}{*}{ rr,q } & 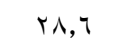 & $r_{0, T}$ & $r r,$. & ז & T, Tr & $r q, \cdot$ & $r V, T$ & $r q, \wedge$ & أنثى \\
\hline & & & & & & & & & محل الأقامة \\
\hline $1 \varepsilon, V$ & $r \varepsilon, \varepsilon$ & $\curlywedge \wedge, \wedge$ & $1 v, q$ & $r, 1$ & $r V, \varepsilon$ & $r r, l$ & $r \uparrow, 0$ & r & حضر \\
\hline$r \varepsilon$, & $r \varepsilon, \varepsilon$ & $r q, \wedge$ & ro,r & $r q, q$ & $\leqslant 1,1$ & rr,q & $r,, v$ & $r q, 1$ & ريف \\
\hline \multirow[t]{2}{*}{$m, q$} & $\varepsilon \cdot, r$ & rᄉ,. & $r \leqslant, 0$ & $r V, \varepsilon$ & $r q, \uparrow$ & $11, \wedge$ & Ir, r & ri, & مناطق عشو ائية \\
\hline & & & & & & & & & المنطقة \\
\hline $1 \varepsilon, 1$ & ro,r & iᄉ,. & 10,9 & $r \cdot, l$ & ז & ro,l & $r q, r$ & $r v, 0$ & محافظات حضرية \\
\hline$r r, \cdot$ & $r 1,9$ & $r q, \varepsilon$ & $r 4, r$ & $r \leqslant, 0$ & ro,. & $i v, \wedge$ & $r_{\cdot, \ell}$ & $r \cdot, l$ & حضر وجه بحري \\
\hline rฯ, & $r v, \varepsilon$ & rr, & $r v, \cdot$ & $r q, q$ & $r v, v$ & rT, O & rr, & $r q, r$ & ريف وجه بحري \\
\hline$r v, l$ & $r q, 0$ & $r_{0, Y}$ & r৯, & ro,r & $r_{1, \varepsilon}$ & $1 \leqslant, 7$ & $1 \leqslant, 7$ & $1 T, \varepsilon$ & حضر وجه قبلي \\
\hline$r_{1, r}$ & $r \cdot, q$ & $r v, l$ & $r r, \cdot$ & $r \cdot, r$ & $\varepsilon 0, \varepsilon$ & rr, q & r, & $r q, \varepsilon$ & ريف وجه قبلي \\
\hline \multirow[t]{2}{*}{$19, \varepsilon$} & $r v, r$ & ro,v & ro,. & 11,0 & $r, \wedge$ & $v, 0$ & Ir,T & Ir,T & محافظات حدودية \\
\hline & & & & & & & & & تعليم الأم \\
\hline$r \varepsilon, r$ & 促, & $r \cdot, q$ & $r V, O$ & $r \cdot, r$ & ५१,६ & $r, 9$ & $r \cdot, r$ & ri, 9 & أمية \\
\hline$r_{0,9}$ & $r q, 1$ & $r q, r$ & rq, & $r v, r$ & $\varepsilon \cdot, v$ & $r_{0, \xi}$ & $r, \tau$ & $r \wedge, \gamma$ & تقرا و تكتب \\
\hline$r \cdot, q$ & $r v$, & $r_{0, r}$ & ro,r & $r v, l$ & $\varepsilon 1, v$ & $r \cdot, \cdot$ & $r \cdot, r$ & $r \cdot, l$ & إبتدائي \\
\hline $1 \wedge, 7$ & $\varepsilon \cdot, r$ & $r \cdot, \wedge$ & $r, \tau$ & $r v, \cdot$ & $\uparrow, \wedge$ & $r r, \varepsilon$ & $r_{0,9}$ & $r q, \varepsilon$ & إعدادي \\
\hline $\mid v, 1$ & $10, v$ & $1 \cdot, 7$ & $\wedge, \varepsilon$ & $1 \cdot, 0$ & $11, \varepsilon$ & $1 r$, & $r \leq, q$ & $r v, O$ & ثانوي عام \\
\hline$r, Y, Y$ & $r \cdot, r$ & rq, & Yr,O & $r_{0, \varepsilon}$ & rr, r & r), & ro,r & $r_{0,9}$ & ثانوي فني وما بعده \\
\hline \multirow[t]{2}{*}{$10, r$} & 10,0 & $I_{Y, \Lambda}$ & $1 \cdot, r$ & $1 T, 4$ & 19,0 & $I T, V$ & $1 \leqslant, 9$ & 17,7 & جامعي فأكثر \\
\hline & & & & & & & & & تعليم الأب \\
\hline rr,, & $r r, \Lambda$ & $r \cdot, q$ & rA,, & rT, \& & r, r & ri, & $r \cdot, q$ & r1, q & 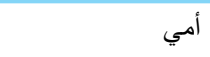 \\
\hline $1 \wedge, 7$ & $r v, 0$ & ro,. & $r V, \varepsilon$ & $r_{1,0}$ & $\varepsilon \wedge, 1$ & $r, 0$ & r৯,. & $r, 4$ & يقرأ ويكتب \\
\hline$r, \wedge$ & $r v, r$ & $r \wedge, \Lambda$ & $r_{0,1}$ & $r_{0,0}$ & $\leq 0, r$ & r & $\mu_{1, \varepsilon}$ & $r 1,9$ & إبتدائي \\
\hline$r \leqslant, q$ & $r, 1$ & $r \uparrow, 0$ & rr, r & $r r, q$ & ז, ז & ro,o & $Y \wedge, \vee$ & $r_{1, .}$ & إعدادي \\
\hline r., & $\uparrow_{\Lambda, \tau}$ & rA, 0 & r., 9 & ri,r & rv, & $r \cdot, r$ & $r \uparrow, \varepsilon$ & $r v, \Lambda$ & ثانوي عام \\
\hline$r \leqslant, r$ & rr, & rA, q & $r \varepsilon, r$ & $r V, O$ & ro,. & $r \varepsilon, 1$ & $r \uparrow, \varepsilon$ & $r v, \varepsilon$ & ثانوي فني وما بعده \\
\hline $\mid v, 1$ & 19,1 & 10,7 & $11, v$ & 17,7 & $r+$, & 15,9 & $19, \varepsilon$ & 19,1 & جامعي فأكثر \\
\hline$r, r$ & $r 1,9$ & $r V, r$ & $r r, \Lambda$ & $r v, \cdot$ & $r_{0, q}$ & $r v, 0$ & $r \wedge, r$ & $r 9,0$ & الاجمالي \\
\hline$(Y, .00)$ & $(r, .00)$ & $(r, .00)$ & $(r, .00)$ & $(Y, .00)$ & $(Y, .00)$ & $(V, Y \neg Y)$ & $(\wedge, \vee \wedge)$ & $(9,777)$ & حجم العينة \\
\hline
\end{tabular}

ملحوظة: أن هذه النسب تعتمد على كل الثباب الذين حضروا فى مستوي أو أكثر أثناء مر احل التعليم التى التحقو ابها، وكل المقاييس الأخرى للطلبة الذين يدرسون حالياً. 


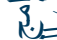

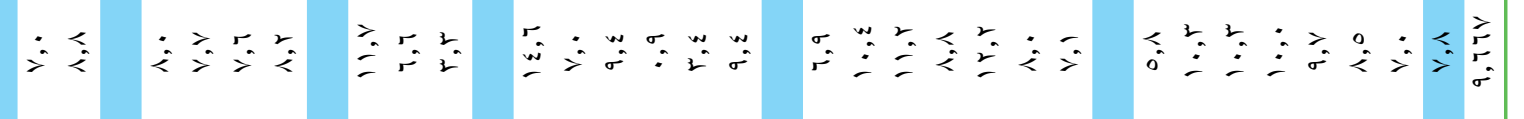

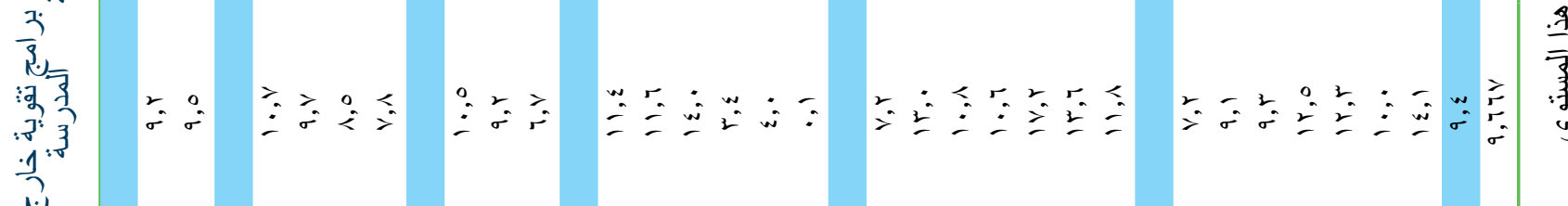

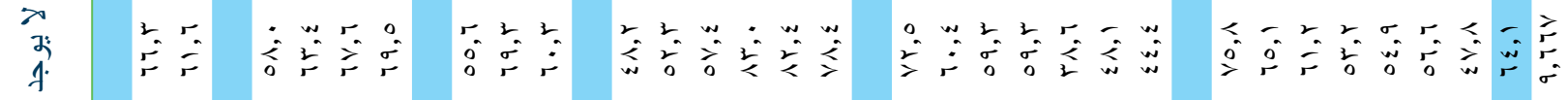

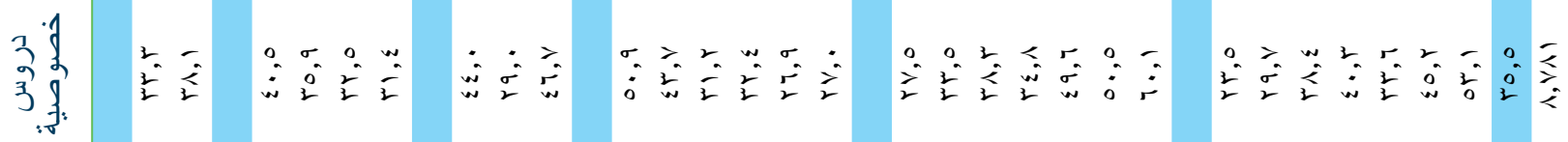

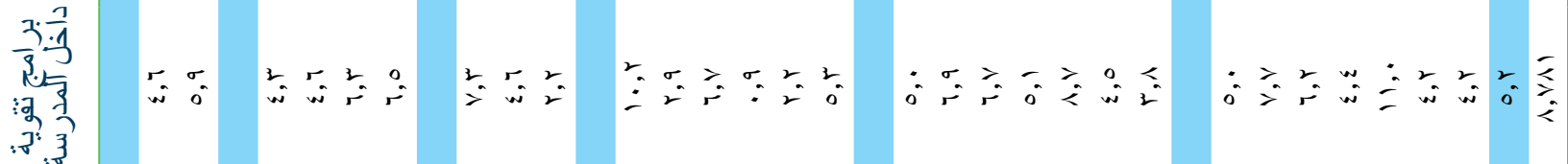
จ.

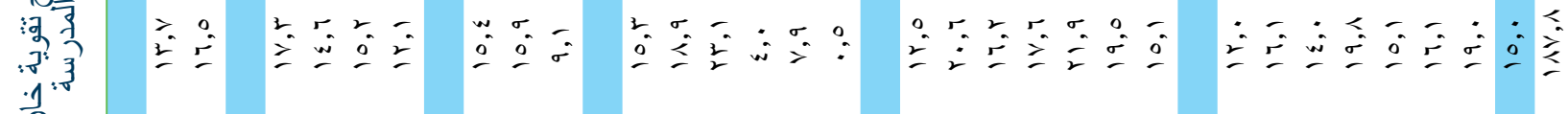

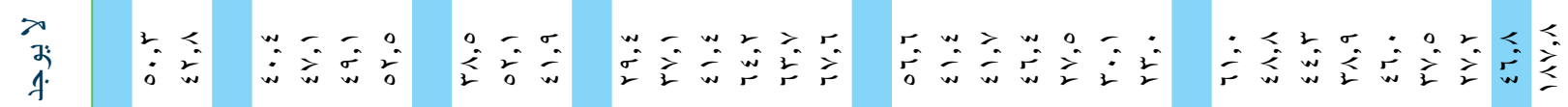
3
3
3

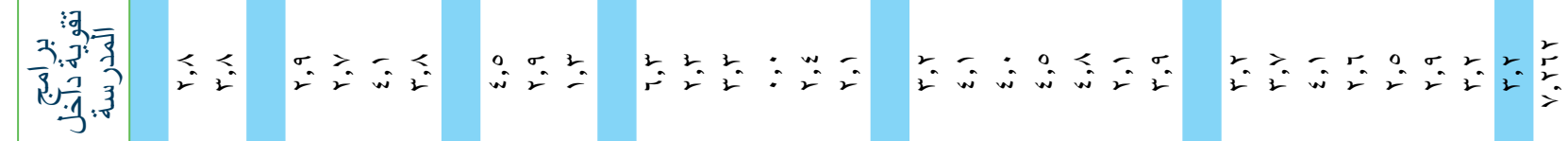




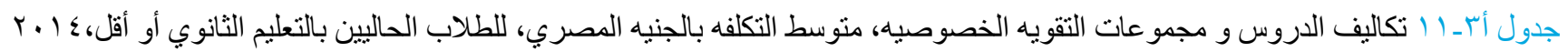

\begin{tabular}{|c|c|c|c|c|}
\hline \multicolumn{2}{|c|}{ مجمو عات التقوية } & \multicolumn{2}{|c|}{ الدروس الخصوصية } & \\
\hline \multirow[t]{2}{*}{ 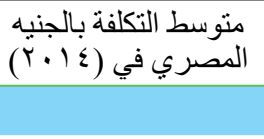 } & \multirow[t]{2}{*}{ النسبة المئوية } & \multirow[t]{2}{*}{ المصري في (ك التكلفة بالجنيه } & \multirow[t]{2}{*}{ النسبة المئوية } & \\
\hline & & & & النوع \\
\hline $179, r$ & $1+, 1$ & $r \cdot v, l$ & r, r & ذكر \\
\hline \multirow{2}{*}{$r \cdot r, T$} & $\backslash \wedge, \vee$ & rro,o & $\varepsilon \varepsilon, 0$ & أنتى \\
\hline & & & & محل الأقامة \\
\hline rrq,r & $1 \wedge, \wedge$ & $\varepsilon \cdot r, 0$ & $\leq 9, r$ & حضر \\
\hline $10 \Lambda, V$ & $10, r$ & r)१,० & rq,० & ريف \\
\hline \multirow[t]{2}{*}{ rrv,t } & $\wedge\urcorner$, & $\varepsilon r \varepsilon, \cdot$ & 01,1 & مناطق عشو ائية \\
\hline & & & & المنطقة \\
\hline$r 00, v$ & $r \cdot, r$ & $\varepsilon \leqslant \vee, r$ & $0 \leqslant, r$ & محافظات حضرية \\
\hline $197, \varepsilon$ & $r \cdot, r$ & एवा, & $\varepsilon r, q$ & حضر وجه بحري \\
\hline 149,9 & Y), & $r \cdot 0, v$ & Tr,T & ريف وجه بحري \\
\hline $110, \varepsilon$ & $r, v$ & r & $\leq 9, r$ & حضر وجه قبلي \\
\hline$r \leq V, \Lambda$ & $\wedge, 7$ & rrv, & rч, & ريف وجه قبلي \\
\hline \multirow[t]{2}{*}{191,7} & $r, 1$ & $r q \cdot, \wedge$ & rY, & محافظات حدودية \\
\hline & & & & تعليم الأم \\
\hline Irr, & $1 \cdot, r$ & ror,r & $r \leqslant, 0$ & أمية \\
\hline$M v, r$ & $r \varepsilon, r$ & $r \leq 1, \varepsilon$ & Tr,o & تقر أ وتكتب \\
\hline Irr,. & IV,r & ror, \& & r.,. & إبتدائي \\
\hline $11 \cdot, 9$ & $r \cdot, r$ & rTV,. & ro, & إعدادي \\
\hline $1 \varepsilon \cdot, r$ & rq, 9 & rol, 9 & 07,1 & ثانوي عام \\
\hline Yฯ, T & 19,7 & $r \cdot r, r$ & $\leq 9,9$ & ثانوي فني وما بعده \\
\hline \multirow[t]{2}{*}{ rVI, s } & 17,5 & $\{\Lambda 1, \varepsilon$ & $v \cdot, r$ & جامعي فأكثر \\
\hline & & & & تعليم الأب \\
\hline $10 .,$. & L & $r T \leq, 1$ & $r \cdot, r$ & أمي \\
\hline $179, v$ & $1 \%, \Lambda$ & ror,l & $r q, 1$ & يقر أويكتب \\
\hline IV.,r & Ir,^ & ए19,9 & $r q, r$ & إبندائي \\
\hline 110,0 & $10, r$ & $r \wedge \leq, r$ & $r \varepsilon, T$ & إعدادي \\
\hline$\wedge \wedge, 0$ & $9, \varepsilon$ & $r \nmid \wedge, r$ & rt, & ثانوي عام \\
\hline Y) 7,9 & IV,. & M10,. & $\varepsilon \wedge$, & ثانوي فني وما بعده \\
\hline \multirow[t]{2}{*}{ rrq, q } & $r, 7$ & $\varepsilon \cdot r, 0$ & $7 \cdot, \wedge$ & جامعي فأكثر \\
\hline & & & & مؤشر الثروة \\
\hline $1 r v, \lambda$ & $1 \cdot, \cdot$ & $r \backslash \Lambda, \Lambda$ & $r \leqslant, \wedge$ & الأدني \\
\hline $1 \wedge \leq, 7$ & $1 \leq, 1$ & rTr,q & 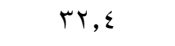 & الثاني \\
\hline Irv,. & $10, \mathrm{~V}$ & $r \leqslant r, r$ & r,$q$ & المتوسط \\
\hline 191,1 & 19,1 & rr., 0 & $\varepsilon \cdot, \wedge$ & 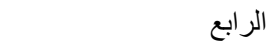 \\
\hline \multirow[t]{2}{*}{$r \leq V, T$} & $\mid v, 1$ & $\varepsilon 1 \varepsilon$, & $0 ., 1$ & الأعلى \\
\hline & & & & الحالة التعليمية \\
\hline IYA,. & $1 \wedge, \wedge$ & $19 \leq, r$ & ro, r & المرحلة الاعدادية \\
\hline 171,9 & $\wedge, \wedge$ & rrq, & $11, \wedge$ & مرحلة التعليم الفنى \\
\hline$r \leq \varepsilon, \varepsilon$ & YI, 1 & rNı, r & $T V, \Lambda$ & مرحلة التعليم الثنانوي العام \\
\hline$|\wedge \wedge|$, & $10, \mathrm{~V}$ & rIV,r & $r v, \varepsilon$ & الاجمالي \\
\hline$(Y ৭ \leq)$ & $(\vee \vee \vee)$ & $(r, \wedge \wedge)$ & $(r, \wedge r)$ & حجم العينة \\
\hline
\end{tabular}

ملحوظة: لم ينم الإشارة في الاحصاءات الحالية لتلاميذ المرحلة الابندائية نظراً لصغر حجة العينة (ن=اءع) 
جدول أبـ Y أنسبة المساعدة في الو اجبات المدرسية ومصدر المساعدة (في حال تلقي المساعدة)، للطلاب الذين يدرسون حالياً في المرحلة الثانوية

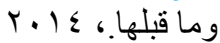

\begin{tabular}{|c|c|c|c|c|c|}
\hline \multicolumn{5}{|c|}{ الذين تلقو ا المساعدة } & \\
\hline شخصاعدة من & مساعدة من الإثقاء & مساعدة من الأم & مساعدة من & تلقي المساعدة & \\
\hline & & & & & النوع \\
\hline r,q & rq, १ & $\varepsilon v, q$ & $r v, \Lambda$ & Ir, & ذكر \\
\hline$r, \tau$ & $r \varepsilon, V$ & $07, Y$ & ( & $17, r$ & أنثى \\
\hline & & & & & محل الأقامة \\
\hline$\varepsilon, \wedge$ & $r, r$ & 71,1 & $r \varepsilon, 1$ & $19, \cdot$ & حضر \\
\hline r,q & $\varepsilon \vee, r$ & $\varepsilon 1, \wedge$ & $r v,$. & 11,7 & ريف \\
\hline$r, \xi$ & $0, \wedge$ & 79,1 & rr, & ir,t & مناطق عشو ائية \\
\hline & & & & & المنطقة \\
\hline$r, \cdot$ & ro,r & $0 \wedge, \wedge$ & $r \cdot, \uparrow$ & 11,0 & محافظات حضرية \\
\hline $0, r$ & $r \varepsilon$, & $\pi, V$ & $\leqslant 1,0$ & rt, & حضر وجه بحري \\
\hline$r, \cdot$ & ז & 01,9 & or, & Ir,V & ريف وجه بحري \\
\hline$v, r$ & $\varepsilon \varepsilon$, & Ni,r & rr, & $1,1,7$ & حضر وجه قبلي \\
\hline$r, \wedge$ & Tr, & $r v, r$ & $1 \leqslant, r$ & $1 \cdot, \varepsilon$ & ريف وجه قبلي \\
\hline $10, \varepsilon$ & $r_{0, T}$ & $0 \wedge, \varepsilon$ & $\{r, 1$ & $\neg, V$ & محافظات حدودية \\
\hline & & & & & تعليم الأم \\
\hline 7,7 & ov, T & $r \cdot, r$ & $r, r$ & 7,9 & أمية \\
\hline$\cdot, \cdot$ & $0 \leqslant, r$ & $\varepsilon r, \uparrow$ & rA, & Ir,V & تقر أ وتكتب \\
\hline$\cdot, \cdot$ & $T r, \varepsilon$ & $r_{1, r}$ & $r \varepsilon, T$ & 11,9 & إبندائي \\
\hline 19,9 & or, & $r q, 1$ & $r q, q$ & $1 \varepsilon, r$ & إعدادي \\
\hline $9, \varepsilon$ & $1 \wedge, 1$ & r & $0 \leqslant, r$ & $r \cdot, v$ & ثانوي عام \\
\hline$\cdot, \mathrm{V}$ & $r r, q$ & $v_{1, \cdot}$ & $\varepsilon 0, r$ & $19, r$ & ثانوي فني وما بعده \\
\hline$r, 1$ & $r \varepsilon, 0$ & $v \varepsilon, 1$ & $r v, r$ & rr,o & جامعي فأكثر \\
\hline & & & & & تعليم الأب \\
\hline $17, \varepsilon$ & 71,7 & rr,o & 11,0 & 0,1 & أمي \\
\hline,, & 00,0 & $11, \cdot$ & $\varepsilon \cdot, r$ & 7,0 & يقرأ ويكتب \\
\hline r,q & or,r & $r \cdot, \varepsilon$ & $11, r$ & $11,$. & إبندائي \\
\hline $9, \cdot$ & $\varepsilon 1, r$ & $\varepsilon \varepsilon, 0$ & Ir, & $11,$. & إعدادي \\
\hline$\cdot, \cdot$ & 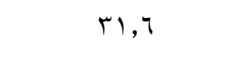 & $\wedge v, 1$ & 07,1 & rt, & ثانوي عام \\
\hline $1, \mathrm{~V}$ & rI, r & $T, r$ & rq, & $17, r$ & ثانوي فني وما بعده \\
\hline 1,0 & $r \Lambda, r$ & 07,7 & or, \& & rr,O & جامعي فأكثر \\
\hline & & & & & مؤشر الثروة \\
\hline$r, 0$ & or,o & $r_{\cdot, 0}$ & $r_{0,9}$ & $v, 1$ & الأدني \\
\hline $1 \cdot, r$ & $\varepsilon 0, r$ & $\varepsilon r$, & $i v, 0$ & $11, r$ & الثاني \\
\hline 0,7 & ro, & ro,r & $r v, v$ & $\wedge, q$ & المتوسط \\
\hline$\cdot, \cdot$ & r & or,, & Kr, q & $1 r, 1$ & 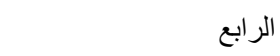 \\
\hline$r, \Lambda$ & rr, & $77, Y$ & $\varepsilon r, \varepsilon$ & ro,, & الأعلى \\
\hline & & & & & الحالة التعليمية \\
\hline$r, q$ & $r \wedge, q$ & $71, r$ & $r \leq, r$ & $17, Y$ & المرحلة الاعدادية \\
\hline$v, r$ & $\varepsilon \vee, 0$ & $\varepsilon r, r$ & 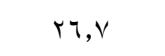 & 7,7 & مرحلة التعليم الفنى \\
\hline$r, \cdot$ & $r v, \Lambda$ & 01,0 & $r q, 0$ & $r \cdot, \cdot$ & مرحلة التعليم الثانوي العام \\
\hline$r, v$ & $r V, 1$ & Or, $\varepsilon$ & $r_{0, \varepsilon}$ & $1 \varepsilon$, & الاجمالي \\
\hline$($ (Yq) & $($ (Yq) & $($ (YYq) & $($ (YqQ) & $(r, .09)$ & حجم العينة \\
\hline
\end{tabular}

ملحوظة: لم يتم الإشارة في الاحصاءات الحالية لتلاميذ المرحلة الابتدائية نظر اً لصغر حجة العينة (ن=اء؟) 


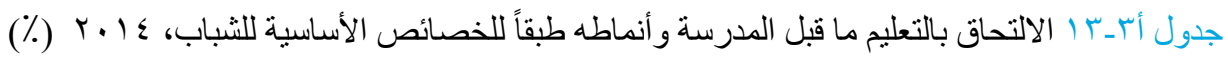

\begin{tabular}{|c|c|c|c|c|}
\hline أخري & الالتحاق برياض الإل & الالتحاق بالحضانة & التحق بالتعليم ما قبل & \\
\hline & & & & النوع \\
\hline$\cdot, r$ & $11, \varepsilon$ & $11, v$ & $r, 1$ & ذكر \\
\hline \multirow[t]{2}{*}{., 0} & $11, v$ & $1 \leqslant, 1$ & $r_{0,1}$ & أنثى \\
\hline & & & & 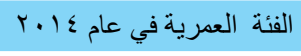 \\
\hline$\cdot, 0$ & $i v, r$ & $1 \wedge$, & $r \varepsilon, v$ & أقل من 11 ا \\
\hline$\cdot, \varepsilon$ & Kr, & $I_{,}, \Lambda$ & ro,. & $r \varepsilon_{-11}$ \\
\hline$\cdot, r$ & $\wedge, \cdot$ & $11,$. & $\lfloor\wedge, \wedge$ & rq-ro \\
\hline \multirow[t]{2}{*}{$\cdot, r$} & $v, \cdot$ & 9,1 & $17, r$ & 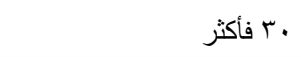 \\
\hline & & & & محل الأقامة \\
\hline$\cdot, \varepsilon$ & $r r, \Lambda$ & 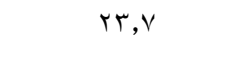 & $\varepsilon \uparrow, \varepsilon$ & حضر \\
\hline •, ६ & 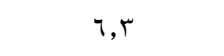 & $\vee, \varepsilon$ & $1 T, \Lambda$ & ريف \\
\hline \multirow[t]{2}{*}{$\cdot, 1$} & $v, r$ & $1 \leqslant, 1$ & $r \cdot, \uparrow$ & مناطق عشو ائية \\
\hline & & & & المنطقة \\
\hline$\cdot$, , & $r v, \Lambda$ & $r, \Lambda$ & o\, & محافظات حضرية \\
\hline$\cdot, \varepsilon$ & 17,0 & $i v, Y$ & r,. & حضر وجه بحري \\
\hline$\cdot, 0$ & $v, q$ & re, & $r \cdot, r$ & ريف وجه بحري \\
\hline , , & 11,1 & $r, q$ & $1 r, 9$ & حضر وجه قبلي \\
\hline$\cdot, r$ & $\varepsilon, \uparrow$ & $r, r$ & $\mathrm{v}, \cdot$ & ريف وجه قبلي \\
\hline \multirow[t]{2}{*}{$\cdot, r$} & 0,1 & $1 \cdot, 9$ & 10,9 & محافظات حدودية \\
\hline & & & & تعليم الأم \\
\hline$\cdot, \mathrm{r}$ & $\varepsilon, r$ & $v, \varepsilon$ & $11, \lambda$ & أمية - ا كية \\
\hline $1, r$ & $K_{t}, \varepsilon$ & $M, r$ & Yo,r & تقرا و وتكتب \\
\hline$\cdot, 0$ & $9, r$ & $1 \wedge, \varepsilon$ & $r v, r$ & إبندائي \\
\hline$\cdot, \wedge$ & 11,7 & $r 4,9$ & rq, & إعدادي \\
\hline$\cdot, \cdot$ & $r q, \wedge$ & $r, v$ & $\Delta ৭, \gamma$ & ثنانوي عام \\
\hline ., & $r \Lambda, r$ & 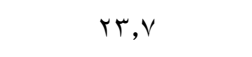 & 01,1 & ثانوي فني وما بعده \\
\hline \multirow[t]{2}{*}{$\cdot, r$} & 01,1 & $r, r$ & $\neg \lambda, \wedge$ & جامعي فأكثر \\
\hline & & & & تعليم الأب \\
\hline$\cdot, r$ & r, & I,r & $9, \wedge$ & أمي \\
\hline$\cdot, 9$ & $7, r$ & 1,0 & $i v, v$ & يقرأ ويكتب \\
\hline., 0 & $v, 1$ & $17, \varepsilon$ & $r r, 0$ & إبتدائي \\
\hline$\cdot, 7$ & $11, r$ & $r_{1,0}$ & Tr,T & إعدادي \\
\hline$\cdot, \cdot$ & $r, r$ & $1 \wedge, \wedge$ & $\varepsilon \wedge$, & ثانوي عام \\
\hline$\cdot, r$ & r,$\varepsilon$ & 19,9 & $\varepsilon \cdot, \cdot$ & ثانوي فني وما بعده \\
\hline$\cdot, 0$ & $r \wedge, \uparrow$ & $19, v$ & 07,0 & جامعي فأكثر \\
\hline$\cdot, \varepsilon$ & 11,0 & $I r, \Lambda$ & $r \leqslant, 1$ & الاجمالي \\
\hline$(1 \cdot, \wedge \wedge \vee)$ & $(1 \cdot, \wedge \wedge \vee)$ & $(1 \cdot, \wedge \wedge \vee)$ & $(1 \cdot, \wedge \vee)$ & حجم العينة \\
\hline
\end{tabular}

ملحوظة: تم الاعتماد على كل عينة الثباب، و إن كان قد استبعد منها هؤ لاء الذين لم يذهبوا أبداً إلى المدرسة ولم يلتحقو ا بالتعليم ما قبل المدرسي. هناك امكانية للالتحاق بأكثر من نمط في التعليم ما قبل المدرسي. 


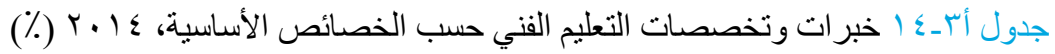

\begin{tabular}{|c|c|c|c|c|c|c|c|}
\hline \multicolumn{4}{|c|}{ التدريب الفنى على يد خبير } & \multicolumn{3}{|c|}{ التخصص } & \\
\hline التدريب المكثف & سوق العمل & علي أيدي & أخري & فنى زر اعي & فنى تجاري & صناعى & \\
\hline & & & & & & & النوع \\
\hline $1 \wedge, 7$ & $0 \leqslant, r$ & 01,0 & r,, & $1 \leqslant, 7$ & $r v, r$ & $07, Y$ & ذكر \\
\hline $17,$. & $00,$. & $\varepsilon r, 0$ & \&,7 & 0,7 & OV, $\varepsilon$ & rY, & أنتى \\
\hline & & & & & & & 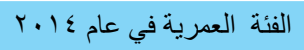 \\
\hline$r_{\cdot,, .}$ & Tr, & $\varepsilon \vee, \Lambda$ & $\varepsilon, r$ & $1,, 1$ & $\varepsilon, r$ & $\{0, \varepsilon$ & أقل من A 1 \\
\hline 19,0 & $o v, \Lambda$ & $\varepsilon \wedge, \uparrow$ & $r, r$ & $11, r$ & 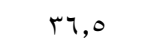 & $\leq 9,1$ & $r \varepsilon_{-11}$ \\
\hline $1 \%, \varepsilon$ & $\varepsilon 9,1$ & $\varepsilon \leqslant, 0$ & $r, r$ & $1+, 1$ & $\varepsilon r, q$ & $\varepsilon 1, \wedge$ & rq_ro \\
\hline $17, r$ & $\leq \uparrow, 9$ & $\varepsilon १, 0$ & $r, r$ & $7, r$ & $\varepsilon \uparrow$, & $\varepsilon \varepsilon, \varepsilon$ & فأكثر \\
\hline & & & & & & & محل الأقامة \\
\hline$r \leqslant, Y$ & 71,0 & $\leqslant १, 0$ & $0, \varepsilon$ & 7,1 & $r q, \wedge$ & $\varepsilon \wedge, \vee$ & 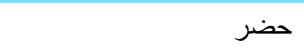 \\
\hline $1 \leqslant, 9$ & or, r & $\varepsilon \vee, \varepsilon$ & r, r & Ir, r & $r q, 0$ & $\varepsilon 0$, & ريف \\
\hline $1 \leqslant, 9$ & $\leqslant \wedge, q$ & $\varepsilon r, \Lambda$ & $r, 1$ & $T, r$ & $\varepsilon v, \cdot$ & $\varepsilon r, v$ & مناطق عشو ائية \\
\hline & & & & & & & المنطقة \\
\hline$r \cdot, r$ & $70, \mathrm{~V}$ & or, v & $\wedge, \wedge$ & $1, \wedge$ & $\varepsilon \cdot, \varepsilon$ & $\varepsilon 9,1$ & محافظات حضرية \\
\hline$i v, q$ & $\varepsilon r, 0$ & $01, \varepsilon$ & 1,9 & $\wedge, \uparrow$ & ro, & or, 9 & حضر وجه بحري \\
\hline $1 \leqslant, 1$ & $\leq 9,7$ & 01,9 & r,o & $9, \vee$ & ז & 01,0 & ريف وجه بحري \\
\hline 11,9 & 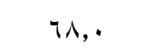 & r., r & 1,. & $11, r$ & or,o & ro,r & حضر وجه قبلي \\
\hline $10, \mathrm{~V}$ & $07, \mathrm{~V}$ & $\leqslant r, \cdot$ & r, & iv,o & $\varepsilon r, q$ & rч,o & ريف وجه قبلي \\
\hline $1 \Lambda, \varepsilon$ & $\varepsilon \varepsilon, \varepsilon$ & ov,r & r,o & $\mathrm{v}, \cdot$ & $r V, \Lambda$ & Tr,V & محافظات حدودية \\
\hline & & & & & & & ت تعليم الأم \\
\hline 10,7 & $0 \cdot, 1$ & $\varepsilon \leqslant, \varepsilon$ & $r, \varepsilon$ & Ir, & $\varepsilon \leqslant$, & $\varepsilon 1, \varepsilon$ & أمية \\
\hline $1 \leqslant$, & or, 1 & or,r & r, r & 7,1 & $r 4,9$ & $0 \leqslant, V$ & تقر أ وتكتب \\
\hline $1 \wedge$, & or, & or, 9 & $r, q$ & $1 \cdot, \varepsilon$ & $r_{V, \tau}$ & $\{\wedge, 1$ & إبتدائي \\
\hline$r \uparrow, \Lambda$ & 79,9 & or,r & $r, v$ & $\mathrm{v}, 1$ & $r q, 1$ & $r, r$ & إعدادي \\
\hline $17, r$ & $09, r$ & $r \varepsilon, \wedge$ & $r, q$ & 11,7 & $\varepsilon 1, \wedge$ & $\varepsilon r, v$ & ثانوي عام \\
\hline$r \leqslant, 1$ & Tr, & $0 \leqslant, r$ & $7, r$ & ?, & $r \cdot, r$ & ov, $\varepsilon$ & ثانوي فني وما بعده \\
\hline M,ג & 07, & $\pi, \cdot$ & 11,0 & $\vee, q$ & $r_{0,4}$ & 00,1 & جامعي فأكثر \\
\hline & & & & & & & تعليم الأب \\
\hline $1 \%, 9$ & $0 ., 0$ & $\varepsilon r, r$ & r, r & 11,1 & $\leq \uparrow, r$ & $r q, v$ & أمي \\
\hline 10,1 & 01,0 & $\{\wedge, 1$ & r, & $\mid r, \Lambda$ & $\varepsilon 1,1$ & $\varepsilon r, q$ & يقر أويكتب \\
\hline 19,1 & $o v, \varepsilon$ & $01, \cdot$ & $\varepsilon, 1$ & $1 \cdot, \wedge$ & $r \varepsilon, \varepsilon$ & $0 \cdot, \wedge$ & إبتدائي \\
\hline 17,0 & $07, \mathrm{~V}$ & $\varepsilon v, \cdot$ & $r, 0$ & $1 \cdot, r$ & ro,. & $01, r$ & إعدادي \\
\hline$r V, \Lambda$ & $01, \varepsilon$ & 07,0 & 7,9 & 9,7 & $r \varepsilon, \uparrow$ & $\{\wedge, \wedge$ & ثانوي عام \\
\hline rr, $\varepsilon$ & $\uparrow \cdot, \cdot$ & or, 9 & $r, \wedge$ & T,V & rч, ६ & or, 1 & ثانوي فني وما بعده \\
\hline$r \cdot, q$ & 09,0 & $00, \varepsilon$ & $\wedge, 1$ & $q, r$ & $r \wedge, q$ & or, & جامعي فأكثر \\
\hline & & & & & & & الحالة الوظيفية \\
\hline$i v, 0$ & 00,1 & $\varepsilon \varepsilon$, & $r, \cdot$ & $\wedge, r$ & $\varepsilon v, \uparrow$ & $\varepsilon 1,$. & y \\
\hline$i v, r$ & or, 9 & or, r & $r, \varepsilon$ & $1 \leqslant, Y$ & $r q, \cdot$ & or, r & نعم \\
\hline IV,o & $0 \leqslant, 0$ & $\varepsilon v, 7$ & $r, r$ & $1 \cdot, 7$ & $\varepsilon \cdot, r$ & $\leqslant 0,9$ & الاجمالي \\
\hline$(\varepsilon, r \leqslant r)$ & $(Y, 101)$ & $(\varepsilon, r \varepsilon r)$ & $(\varepsilon, r \leqslant \curlyvee)$ & $(\varepsilon, r \leqslant r)$ & $(\varepsilon, r \leqslant r)$ & $(\varepsilon, r \leqslant r)$ & حجم العينة \\
\hline
\end{tabular}

ملحوظة: اعنماداً على كل الثباب الذين سبق لهم الالتحاق بالتعليم الفني. 


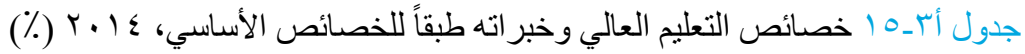

\begin{tabular}{|c|c|c|c|c|c|c|c|}
\hline "يعد للبوق العالي & والين التبادمبذ & 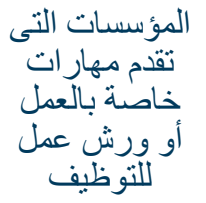 & 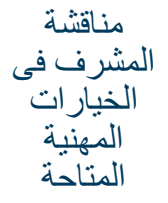 & المشرف فناقتة في & المؤستسة & المدينة & \\
\hline & & & & & & & النوع \\
\hline$\lambda_{\cdot, 0}$ & $74, r$ & $r v, 1$ & $r q, 9$ & $\varepsilon r, \varepsilon$ & or, 1 & 71,0 & ذكر \\
\hline \multirow[t]{2}{*}{$\Delta r, \varepsilon$} & $v_{1}, \cdot$ & ro, & $r v, T$ & $\varepsilon \varepsilon, 7$ & $0 \leqslant, Y$ & VY, & أنثى \\
\hline & & & & & & & الفئة العمرية في عام ع ا ـ r \\
\hline$\wedge r, q$ & $\uparrow \wedge, \vee$ & $r v, 0$ & rA, & $\leq 0,1$ & $0 \leqslant, 0$ & $77, r$ & $r \varepsilon-11$ \\
\hline$V \wedge, 0$ & TV,. & $r \varepsilon, v$ & $r_{0,7}$ & $r q, v$ & $01, V$ & $70, r$ & rq_ro \\
\hline \multirow[t]{2}{*}{$\mathrm{VA,}}$, & $v_{\cdot, l}$ & $r \leqslant, 0$ & rV, r & $\varepsilon r, r$ & or, 1 & $79, \varepsilon$ & 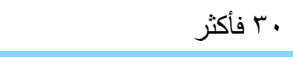 \\
\hline & & & & & & & محل الأقامة \\
\hline$\wedge \cdot, \varepsilon$ & $77, \cdot$ & $r_{0,9}$ & rی, 9 & $\varepsilon r, r$ & $07, r$ & $V Y, \varepsilon$ & حضر \\
\hline$\lambda \cdot, r$ & $\vee \cdot, \wedge$ & $r v, q$ & ч & $\varepsilon \vee, \wedge$ & Or, r & 7,4 & ريف \\
\hline \multirow{2}{*}{$\wedge q, r$} & $\uparrow \curlywedge, V$ & $r, \Lambda$ & rT, & ri,o & $\varepsilon \wedge, 0$ & $T \leqslant, 0$ & مناطق عشوائية \\
\hline & & & & & & & المنطقة \\
\hline$\wedge 1, r$ & 70,0 & $r \varepsilon, \wedge$ & $r+1$ & $r q, \wedge$ & $\circ \wedge$, & Ar,r & محافظات حضرية \\
\hline Ar,o & $v_{0, v}$ & $\varepsilon \cdot, \vee$ & $\leqslant 1,9$ & $\varepsilon r, r$ & or,. & $r, r$ & حضر وجه بحري \\
\hline$\vee १, \wedge$ & $V Y, \Lambda$ & $\varepsilon r, r$ & $\varepsilon \varepsilon, r$ & or, r & $0 \leqslant$, & $71, r$ & ريف وجه بحري \\
\hline$\wedge \varepsilon, r$ & $\leq 7,0$ & $r \cdot, 0$ & $r \cdot, r$ & $r, r$ & $\leq \uparrow, 9$ & $07, \mathrm{~V}$ & حضر وجه قبلي \\
\hline$\lambda_{., 0}$ & $T V, \Lambda$ & $r \cdot, l$ & ro,r & $r q, v$ & $\varepsilon १, 0$ & $7,$, & ريف وجه قبلي \\
\hline 91,1 & $\wedge \varepsilon$, & $0 \wedge, 0$ & $10, \varepsilon$ & $7 \wedge, q$ & 01,9 & $\varepsilon r, V$ & محافظات حدودية \\
\hline $1 \Lambda, \varepsilon$ & & & & & & & تعليم الأم \\
\hline$\vee \wedge, \wedge$ & 79, & $r \varepsilon, \wedge$ & ع £ & \&r,r & $\varepsilon \gamma, 0$ & $T$ T, & أمية \\
\hline$T V, V$ & TI, & $\varepsilon \cdot, \varepsilon$ & rv, & $\leq \neg, r$ & $\varepsilon 0, v$ & $o v, \Lambda$ & تقر أ وتكتب \\
\hline$\Lambda, r$ & 79,9 & $r \varepsilon, \varepsilon$ & $r, r$ & $\varepsilon \cdot, q$ & $0 ., r$ & $T V, 0$ & إبتدائي \\
\hline Ar,r & 79,9 & $\varepsilon r, Y$ & $r_{0, \Lambda}$ & $r \Lambda, 1$ & $0 \leqslant, 9$ & $7 \lambda, 9$ & إعدادي \\
\hline$\lambda_{\cdot}, \mathrm{V}$ & $r, r$ & m, & $r \varepsilon, r$ & $r q, r$ & or, r & vi, r & ثانوي عام \\
\hline$\wedge r, \wedge$ & 71,0 & r., & $r q, q$ & $\varepsilon r, 0$ & 00,9 & $7 \wedge, 9$ & ثانوي فني وما بعده \\
\hline \multirow[t]{2}{*}{$\wedge v, l$} & גד, & $r_{\wedge, \nu}$ & $\varepsilon r, q$ & $\varepsilon \vee, 0$ & $T \Lambda, r$ & $v \cdot, 0$ & جامعي فأكثر \\
\hline & & & & & & & تعليم الأب \\
\hline $\mathrm{V} \wedge, \varepsilon$ & 77,1 & $r 9,0$ & $\Gamma \cdot, \wedge$ & $r q, 1$ & $\leq 4,1$ & $7 \cdot, \wedge$ & أمي \\
\hline vo, & $\vee q, 7$ & $\varepsilon r, \varepsilon$ & $\varepsilon r, q$ & or,r & $\varepsilon \vee, \varepsilon$ & ov, 1 & يقرأ ويكتب \\
\hline$\wedge 1, \wedge$ & $V r, \Lambda$ & $r_{0, T}$ & ro,r & $\varepsilon \cdot, 0$ & $0 ., v$ & $v \vee, r$ & إبندائي \\
\hline ᄉ., \& & VY,. & $\varepsilon r, r$ & $\Upsilon_{\Lambda}, \varepsilon$ & $\varepsilon 1, \wedge$ & Tr, & ז., & إعدادي \\
\hline$v_{0},$. & $T \leqslant, 0$ & m, & $r, r$ & rr, r & $O Y, \lambda$ & גi, r & ثانوي عام \\
\hline Vq,r & Tצ, & ro,. & $r_{0, \varepsilon}$ & $\varepsilon r, \uparrow$ & $0,, \wedge$ & $10, Y$ & ثانوي فني وما بعده \\
\hline \multirow[t]{2}{*}{$\wedge \wedge}$, & 70,9 & $r q, 7$ & $\varepsilon r, \cdot$ & $\varepsilon \vee, 0$ & $T \leqslant, \varepsilon$ & $\Upsilon \lambda, 0$ & جامعي فأكثر \\
\hline & & & & & & & الحالة الوظيفية \\
\hline$\Lambda 1, r$ & $7 \Lambda, 0$ & $r_{0, V}$ & $r 4,9$ & $\leqslant r, q$ & $0 \leqslant, 0$ & 70,9 & ע \\
\hline$\wedge, 1$ & $\uparrow \Lambda, r$ & $r v, v$ & $r v, \Lambda$ & $\varepsilon \leqslant, \varepsilon$ & or, 1 & $T V, r$ & نعم \\
\hline$\wedge 1, \varepsilon$ & $\uparrow \wedge, \varepsilon$ & זч, & $r v, r$ & $\varepsilon r, \varepsilon$ & or,t & $77, \varepsilon$ & الاجمالي \\
\hline$(Y, Y \circ 7)$ & $(Y, Y \circ 0)$ & $(Y, Y \circ 0)$ & $(Y, Y \circ 0)$ & $(Y, Y \circ \Sigma)$ & $(Y, Y \circ 0)$ & $(Y, Y 00)$ & حجم العينة \\
\hline
\end{tabular}

ملحوظة: تم استبعاد الفئة العمرية أصغر من /1 سنة نظر اً لصغر حجم العينة. اعتماداً على العينة الكلية للشباب الذين التحقوا بالتعليم العالي. 


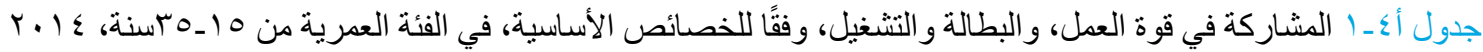

\begin{tabular}{|c|c|c|c|c|c|c|c|c|c|}
\hline \multicolumn{3}{|c|}{ 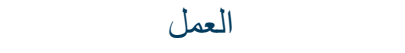 } & \multicolumn{3}{|c|}{ البطالة (التعريف المعتاد) } & \multicolumn{3}{|c|}{ مشاركة القوى العاملة } & \multirow{2}{*}{ الخصائص } \\
\hline الإجمالي & إناث & ذكور & الإجمالي & إناث & ذكور & الإجمالي & إناث & ذكور & \\
\hline & & & & & & & & & الفئة العمرية \\
\hline 11,0 & $r, 0$ & $r \cdot, r$ & $\varepsilon, Y$ & $v, 1$ & $\varepsilon, \varepsilon$ & Ir,. & $r, Y$ & ri,r & $1 V_{-10}$ \\
\hline$r \cdot, \cdot$ & $\wedge, q$ & $\varepsilon \wedge, r$ & $17, Y$ & $r \varepsilon, r$ & Ir,r & $r 0, \Lambda$ & 1r, & $00,$. & $r \varepsilon_{-} \mid \Lambda$ \\
\hline$\varepsilon 9, \vee$ & $1 \leqslant, 1$ & $\wedge r, q$ & $11, \mathrm{~V}$ & rr,, & $\mathrm{v}, \cdot$ & $07, r$ & $r_{1}, \cdot$ & $9 \cdot, r$ & rq_ro \\
\hline \multirow[t]{2}{*}{ Or,r } & iv,. & 91,7 & $\mathrm{v}, \mathrm{O}$ & 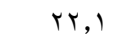 & $r, v$ & $07, \varepsilon$ & $r, q$ & 90,1 & $+r$. \\
\hline & & & & & & & & & محل الإقامة \\
\hline ru,v & $1 \leqslant$, & ov,r & $1 Y, 9$ & $r \leqslant, V$ & $9, \wedge$ & $\varepsilon r, 1$ & $1 \wedge, 7$ & $T r, 0$ & حضر \\
\hline ro,r & $9, \varepsilon$ & 7,1 & 11,7 & $r_{1, q}$ & $v, 0$ & $\varepsilon \cdot$, & $1 r, \lambda$ & 10, & ريف \\
\hline \multirow[t]{2}{*}{$r \cdot, r$} & $v, 0$ & ד, & $1 \cdot, 1$ & $r \mu, \Lambda$ & $0, \varepsilon$ & $r \mu, v$ & $11, r$ & 07,7 & مناطق عشو ائية \\
\hline & & & & & & & & & المنطقة \\
\hline$r \wedge, \wedge$ & 17,0 & $0 \wedge, Y$ & Ir,q & $r, \wedge$ & $1 \cdot, r$ & $\varepsilon \varepsilon, 0$ & $r, r$ & $10, \varepsilon$ & محافظات حضرية \\
\hline$r \cdot, q$ & $1 \cdot, \cdot$ & 01,7 & $1 r, \wedge$ & ri,. & १, ६ & $r 0, \Lambda$ & $1 \leqslant, 0$ & 07,9 & حضر وجه بحري \\
\hline$r \varepsilon, v$ & $9, \cdot$ & ov, T & $1 \leqslant, 7$ & $r_{\Lambda}, \varepsilon$ & $9, \vee$ & $\varepsilon \cdot, 7$ & $1 \leqslant, 7$ & Tr,A & ريف وجه بحري \\
\hline rT,. & 7,7 & $o v, 1$ & $\wedge, 1$ & $r \varepsilon, r$ & $\varepsilon$, & rч,. & $1 \cdot, \cdot$ & $r, r$ & حضر وجه قبلي \\
\hline$r 0,9$ & $9, \wedge$ & A & $\wedge, 0$ & $r_{0, .}$ & 0,1 & $r q, r$ & ir, & 77,1 & ريف وجه قبلي \\
\hline \multirow[t]{2}{*}{ ro,. } & 7,1 & Ir, & $11, r$ & $r q, 7$ & $v, r$ & rq, ६ & $1 ., 1$ & $T V, \cdot$ & محافظات حدودية \\
\hline & & & & & & & & & المستوى التعليمي \\
\hline$r \cdot, q$ & $9, \cdot$ & $\mathrm{VA,r}$ & r,o & $r, q$ & $r, \varepsilon$ & rI,V & $9, r$ & $\lambda \cdot, r$ & أمي \\
\hline$r q, 9$ & $9, \cdot$ & 9 १, १ & $1, v$ & $\cdot, \cdot$ & 1,9 & $\varepsilon \cdot, 0$ & $9, \cdot$ & $q \leqslant, V$ & يقرأ ويكتب \\
\hline $01, r$ & $1 \cdot, 7$ & Nr, r & $\mathrm{v}$, & rl,. & $0, r$ & 00,1 & $1 \%, 0$ & $\wedge \uparrow, \wedge$ & إبتدائي \\
\hline$r, r$ & $V, r$ & $\circ 9,$. & 7,0 & 11,0 & $0, v$ & rr, & $\lambda, r$ & $T r, 0$ & إعدادي \\
\hline 9,7 & $1, \wedge$ & IN,r & $9, \varepsilon$ & $r \varepsilon, 1$ & $v, 0$ & $1 \cdot, 7$ & $r, r$ & $19, \wedge$ & ثانوي عام \\
\hline$r q, 1$ & $\wedge, 7$ & Tr, & 11,0 & $r v, v$ & $v, r$ & $\varepsilon \varepsilon, r$ & $1 r, \Lambda$ & $7 \wedge, 1$ & ثانوي فني \\
\hline$\varepsilon \cdot, 7$ & 17,9 & $0 \wedge, r$ & $r \cdot, \wedge$ & $\{\uparrow, \uparrow$ & 11,7 & $01, r$ & $r,, v$ & 70,9 & فوق متوسط \\
\hline \multirow[t]{2}{*}{$r_{0,1}$} & $r_{\cdot}, \varepsilon$ & $\varepsilon \wedge, \wedge$ & 19,0 & r.,. & $1 \leqslant, r$ & $\varepsilon \varepsilon, r$ & $r 9,0$ & ov,. & جامعي فأكثر \\
\hline & & & & & & & & & الحالة الزواجية \\
\hline$r Y, \Lambda$ & $1 \cdot, \varepsilon$ & $\varepsilon V, \varepsilon$ & $1 \leqslant, Y$ & r.,o & $1 \cdot, 9$ & $r_{\Lambda}, r$ & $10, r$ & or, r & أعزب \\
\hline \multirow[t]{2}{*}{ r१,० } & $1 \cdot, 7$ & 9 १Y, & $\wedge, \varepsilon$ & $r v, \varepsilon$ & $r, 1$ & $\varepsilon r, 1$ & $1 \leqslant, 7$ & 90,7 & متزوج \\
\hline & & & & & & & & & مؤشر الثروة \\
\hline$r v, l$ & $1 \cdot, \cdot$ & $T \leqslant, \varepsilon$ & $\wedge, \wedge$ & rY,V & $T, Y$ & $\varepsilon \cdot, v$ & ir,. & $\uparrow \Lambda, V$ & الأدني \\
\hline ґ৯,. & $1 \cdot, 0$ & $T \leqslant, \varepsilon$ & $\wedge, \Upsilon$ & $r \varepsilon, \varepsilon$ & 0,0 & $\leqslant 1,0$ & $1 r, \Lambda$ & $i, 1$ & الثاني \\
\hline$r \leqslant, 0$ & $9, r$ & $09, r$ & Ir,. & $r v, 0$ & 9,1 & $r q, r$ & Ir,V & 10,1 & الأوسط \\
\hline$r r, o$ & $\wedge, \varepsilon$ & 04,1 & $1 \leqslant, \varepsilon$ & $\varepsilon 1, r$ & $\wedge, \wedge$ & $r q, 1$ & $1 \leqslant, r$ & 71,0 & الر ابع \\
\hline$r r, o$ & $1 r, \Lambda$ & $01, r$ & $10, r$ & $r \cdot, l$ & $1 \cdot, 7$ & $r q, 0$ & 19,1 & $o v, r$ & الأعلى \\
\hline$r 0, r$ & $1 \cdot, 0$ & $0 \wedge, 7$ & 11,9 & $r 9,0$ & $\wedge, \cdot$ & $\varepsilon \cdot, \cdot$ & $1 \leqslant, 9$ & $\pi, v$ & الإجمالي \\
\hline$(1 \cdot, \pi r)$ & $(0,7 \lambda \cdot)$ & $(\leqslant, q \leqslant 1)$ & $\left(1 \cdot, 7 r^{\prime}\right)$ & $(0,7 \lambda \cdot)$ & $(\Sigma, 9 \leqslant 1)$ & $\left(1 \cdot, \pi r^{\prime}\right)$ & $(0,7 \lambda \cdot)$ & $(\xi, 9 \leqslant 1)$ & العدد \\
\hline
\end{tabular}




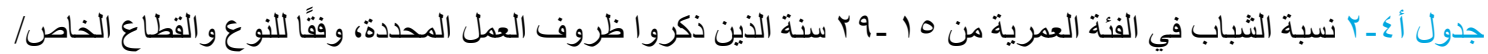

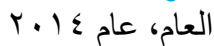

\begin{tabular}{|c|c|c|c|c|c|c|}
\hline \multicolumn{2}{|c|}{ الإجمالي } & \multicolumn{2}{|c|}{ إناث } & \multicolumn{2}{|c|}{ ذكور } & \\
\hline خاص & عام & خاص & عام & خاص & عام & \\
\hline & & & & & & هل تعاني من أي مما يلي \\
\hline 11,7 & $7, r$ & $৭, \vee$ & $7, \cdot$ & 11,1 & 7,0 & المعاملة القاسية من الددير (ة) \\
\hline$\lambda r, r$ & $r, \varepsilon$ & $i r, r$ & 7,9 & $9 r, r$ & $\varepsilon 1, \wedge$ & طول ساعات العمل \\
\hline$v r, v$ & $V Y, 1$ & or, r & 91,9 & $\wedge r$, & $\cdot r, r$ & انخفاض الأجور \\
\hline$\varepsilon r, 1$ & 0,0 & $7, r$ & $\varepsilon, 7$ & or, r & 7, & عدم وجود إجازة سنوية مدفو عة الأجر \\
\hline or, , & $\varepsilon, \varepsilon$ & $91, r$ & $\varepsilon, \wedge$ & $\pi$, & $\varepsilon, r$ & عدم وجود إجازة مرضية ددفو عة الأجر \\
\hline$\wedge, \wedge$ & 7,1 & $\cdot 1,9$ & $\varepsilon, \wedge$ & $v, q$ & $v, 7$ & عدم وجود إجازة رعاية طفل مدفو عة الأجر \\
\hline 94,1 & $v, \varepsilon$ & $9 r, 0$ & $11, \varepsilon$ & 94,1 & $\cdot r_{,} \cdot$ & عبء العمل \\
\hline$r, 7$ & $r, 1$ & 11,7 & $\cdot 1, r$ & $r, \wedge$ & $\varepsilon 1, \varepsilon$ & طول وقت التنقل للعمل \\
\hline$v, v$ & $7, \varepsilon$ & $\wedge, 9$ & $r, q$ & $v, 0$ & $v, 0$ & مضايقات / تحرش من الزملاء / الدير \\
\hline$r, 7$ & $\cdot, \cdot$ & $\cdot$ & $\because \cdot$ & r,q & $\cdot$, & التحرش من الزملاء / المدير \\
\hline$r, r$ & $\varepsilon, \gamma$ & $.1,0$ & $1, r$ & $r_{1}, \varepsilon$ & $7, \varepsilon$ & مضايقات / تحرش من الزبائن / العملاء \\
\hline$r, 7$ & 1,9 & $\cdot, \varepsilon$ & $\cdot \cdot$ & $r, \tau$ & $\varepsilon, r$ & التحرش من الزبائن / العملاء \\
\hline$r, \cdot$ & $v, 0$ & $r, 0$ & 1,1 & $\varepsilon 1, r$ & $\cdot 1, \varepsilon$ & ظروف العمل الخطرة \\
\hline$r, 7$ & 1,1 & $r, \wedge$ & $1, r$ & $r$, & $\cdot, 9$ & التحرش أثناء التنقل \\
\hline $0, V$ & $1, \varepsilon$ & $r, r$ & $\cdot \cdot$ & 7, & $r, \cdot$ & الأجور لم تدفع بعد الانتهاء من المهمة \\
\hline $0, v$ & $1, r$ & $r, r$ & $\cdot, \wedge$ & 7, & $1, \varepsilon$ & الأجور لم تحدد في بدابة العمل \\
\hline$r, q$ & $1, r$ & $r, r$ & $\cdot$, & $r, q$ & 1,7 & 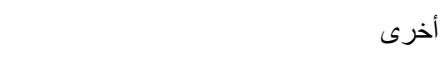 \\
\hline$(\ulcorner, \wedge \uparrow)$ & $(\Gamma+1)$ & $(T M V)$ & $(1$ ro) & $(\wedge \leq q, 1)$ & $($ (YT) & عدد من الثباب العاملين \\
\hline
\end{tabular}

جدول أ عـ ب أساليب الثباب في البحث عن عمل: النسبة المئوية لإستخدام الأساليب المذكورة، التعريف الموسع للبطالة، $r .1 \leq, r . .9$

\begin{tabular}{|c|c|c|c|c|c|c|}
\hline \multicolumn{3}{|c|}{$r \cdot 1 \leq$} & \multicolumn{3}{|c|}{ r...q } & \\
\hline 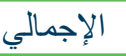 & إناث & ذكور & الإجمالي & إناث & ذكور & \\
\hline 91,9 & 01, & $r r, \wedge$ & $v_{,}$, & $7, r$ & $\mathrm{v}, \mathrm{T}$ & التسجيل في مكتب العمل \\
\hline $94, q$ & $1 \pi, r$ & Ar, $q$ & $r, \wedge$ & $\cdot r, 0$ & $9, \S$ & التسجيل في مكتب حكومي \\
\hline$v_{1}, \cdot$ & $\wedge, \varepsilon$ & $7, \cdot$ & $v_{1}, \cdot$ & Ar,o & $9, \varepsilon$ & دخلت مسابقة وظيفة حكومية \\
\hline$\Lambda, r$ & $\cdot r, r$ & $7, V$ & or,, 7 & $\varepsilon r, \varepsilon$ & $\pi, 0$ & أرسلت طلب وظيفة \\
\hline$r 1,9$ & $r, \wedge$ & 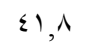 & $v_{1}, 1$ & $\wedge, \varepsilon$ & $r r, \wedge$ & سألت في مكان العمل \\
\hline \multirow[t]{2}{*}{$r, r$} & $r, r$ & $r, \varepsilon$ & $\cdot, 9$ & 1, & $\cdot, \wedge$ & تم الإعلان عنها في الصحف \\
\hline & & & $9, r$ & $7, r$ & $11, \varepsilon$ & قدمت في الوظائف المعلن عنها في الصحف \\
\hline$r, 1$ & $11, \varepsilon$ & $r^{\prime},{ }^{\prime}$ & - & - & & قدمت في الوظائف المعلن عنها في الصحف / الإنترنت* \\
\hline 0, & $\varepsilon, r$ & 0,7 & - & - & - & سجلت على الانترنت في مكتب العطل* \\
\hline $9 r, r$ & $\leqslant r, r$ & $r r, q$ & $r r, \wedge$ & ir, & $\cdot \varepsilon, 7$ & سؤ ال الأصدقاء أو الأقارب للمساعدة \\
\hline 11,7 & $7, r$ & $r, \cdot$ & $r_{1}, \varepsilon$ & $\varepsilon, r$ & $v, v$ & الإتصال بصاحب العمل \\
\hline $0, r$ & $\cdot$, & $9, r$ & $r, 0$ & . & $\varepsilon, 1$ & 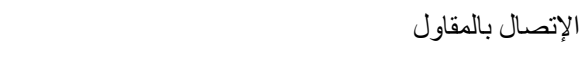 \\
\hline$r, 7$ & $\cdot$, & $\varepsilon, \uparrow$ & 1,7 & . & $r, r$ & انتظرت في أماكن تجمع العمال \\
\hline$r_{,}$, & $\cdot$, & $r, \wedge$ & $1, r$ & $\cdot, 7$ & 1,7 & بحثت عن المشرو عات الخاصة (الأرض و المعدات) \\
\hline $1, r$ & $\cdot, \cdot$ & $r, r$ & $\cdot, \wedge$ & 1,1 & $\cdot, \mathrm{V}$ & رتبت للحصول على تمويل لمشرو ع خاص \\
\hline$v, 0$ & $7, \varepsilon$ & $\wedge, 0$ & $\wedge r, q$ & $\varepsilon r, 1$ & $v \varepsilon$, & استخدام التليفون في أي من الطرق المذكورة أعلاه \\
\hline$o r, y$ & 01,9 & $r r, 0$ & $\pi, r$ & $\cdot r, \varepsilon$ & $0 \leqslant, 1$ & استخدام الهاتف الححمول في أي من الطرق الدذكورة أعلاه \\
\hline דr & .r & Trt & $11 \mathrm{~V}$ & זr & IAT & الثباب العاطلين عن العمل (التعريف الموسع) \\
\hline
\end{tabular}




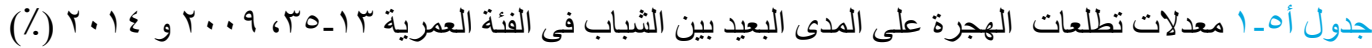

\begin{tabular}{|c|c|c|c|c|c|c|c|c|c|}
\hline \multicolumn{3}{|c|}{ 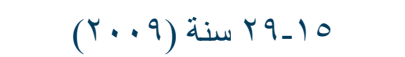 } & \multicolumn{3}{|c|}{ 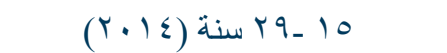 } & \multicolumn{3}{|c|}{ 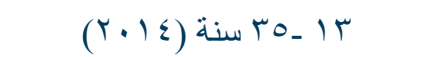 } & \\
\hline الإجمالى & إناث & ذ كور & الإجمالى & إناث & ذكور & الإجمالى & إناث & ذ & \\
\hline & & & & & & & & & الفئة العمرية \\
\hline - & - & - & - & - & - & 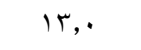 & 7,1 & $19, r$ & $\left|V_{-}\right| r$ \\
\hline$r, r$ & 9,0 & $r r, r$ & 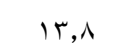 & $\mathrm{v}, \varepsilon$ & $r \cdot, l$ & - & - & - & $1 v_{-10}$ \\
\hline $1 \wedge, v$ & 7,9 & $r q, r$ & 19, & $\wedge, \varepsilon$ & rA,, & 19, & $\wedge, \varepsilon$ & rA,, & $r \varepsilon_{-1 \wedge}$ \\
\hline $1 \leqslant, 7$ & $\varepsilon, \vee$ & ro, & 17,7 & $\mathrm{v}, \cdot$ & $r_{0, V}$ & 17,7 & $\mathrm{v}, \cdot$ & ro,v & rq_ro \\
\hline - & - & - & - & - & - & 1,1 & 7,9 & $r \cdot, \cdot$ & $r \varepsilon_{-} r$. \\
\hline & & & & & & & & & محل الأقامة \\
\hline$i v, r$ & $\wedge, 9$ & $r_{0, \varepsilon}$ & $17, r$ & $\wedge, 1$ & $r, r$ & $10, v$ & $\mathrm{v}, \mathrm{v}$ & $r r, q$ & حضر \\
\hline $1 \wedge, r$ & $0, r$ & $r \cdot, v$ & $i n, r$ & $v, r$ & $r \wedge, r$ & 17,9 & $\mathrm{v}, \cdot$ & ז & ريف \\
\hline 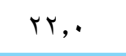 & $9, \vee$ & $r \varepsilon, V$ & $1 Y, q$ & $9, \vee$ & $17, r$ & ir, & 9,9 & $17, v$ & مناطق عشو ائية \\
\hline & & & & & & & & & المنطقة \\
\hline 17,9 & $\wedge, q$ & $r \varepsilon, r$ & 17,7 & $1 \cdot, r$ & rr, r & $17, r$ & $9, \wedge$ & rr, & محافظات حضرية \\
\hline $19, \varepsilon$ & $v, q$ & $r 1,0$ & $17, r$ & 9,9 & $r, 0$ & 17,1 & $1 \cdot, \cdot$ & $r$ r.o & حضر وجه بحري \\
\hline $1 \Lambda, r$ & 0,1 & $r \cdot, r$ & 11,9 & $0, v$ & $r \cdot, \cdot$ & $|v|$, & $0,$. & $r \Lambda, r$ & ريف وجه بحري \\
\hline$r, \wedge$ & $11, v$ & rr, & Ir,. & $r, r$ & $r \cdot, r$ & $1 ., 0$ & $r, T$ & $1 \wedge$, & حضر وجه قبلي \\
\hline 11,0 & 0,7 & $r, r$ & $\mid v, \wedge$ & $\wedge, \wedge$ & Tצ, & $17, \wedge$ & $9, \cdot$ & $r \leqslant, \Lambda$ & ريف وجه قبلي \\
\hline $11, r$ & $\varepsilon, 0$ & iv,o & $1 \%,$. & $v, r$ & 11,0 & Ir, r & $7, \cdot$ & $r \cdot, r$ & محافظات حدودية \\
\hline & & & & & & & & & المستوي التعليمي \\
\hline 0,1 & $1, r$ & $r_{1}$, & $\wedge, 1$ & $r, r$ & $I V, r$ & $\wedge$, & $\varepsilon$, & 17,0 & أمي \\
\hline$\varepsilon, \wedge$ & ., & $1 ., 9$ & $1, v$ & $\cdot, 7$ & $r, o$ & $\varepsilon, v$ & $r, r$ & $v, 1$ & يقر أويكتب \\
\hline 10,7 & $0, r$ & $r \varepsilon, \varepsilon$ & $I V, r$ & $0, r$ & $r_{0, \Lambda}$ & $10, r$ & $\varepsilon, 9$ & $r r, \varepsilon$ & إبتدائي \\
\hline $19, r$ & $\uparrow, \wedge$ & $r q, \wedge$ & $1 r, 0$ & $\varepsilon, 1$ & $r \varepsilon, r$ & Ir,O & $\varepsilon, \wedge$ & $r_{1,0}$ & إعدادي \\
\hline$r,, 1$ & Kr, & $r q, 1$ & 10,1 & $1 .,$. & rr, r & 17,1 & 9,7 & $r, r$ & ثانوي عام \\
\hline 19,7 & $0, \wedge$ & $r 1,9$ & IV,V & $7, \cdot$ & rצ,o & 17,7 & 0,9 & ro, 1 & ثانوي فني \\
\hline 19,9 & 9,9 & $r \wedge, \varepsilon$ & 10, & $\Lambda, r$ & $r_{\cdot, \cdot}$ & $1 \leqslant, 0$ & $\vee, \wedge$ & 19,7 & فوق متوسط \\
\hline rr,O & $\mid r, \varepsilon$ & Tr,O & $r$ r., & 10,7 & $r \cdot, r$ & rr, & $10, r$ & $r \cdot, \cdot$ & جامعي فأكثر \\
\hline & & & & & & & & & الحالة الزواجية \\
\hline r, r & $\wedge, 9$ & $r \cdot, q$ & $\backslash \wedge, \wedge$ & $\wedge, 0$ & $r_{0,0}$ & $1 \wedge, r$ & $\Lambda, r$ & ro, & أعزب \\
\hline$v, q$ & $\varepsilon, 1$ & $19, \varepsilon$ & Ir,V & $7, V$ & r & Ir,r & 7,7 & $r, \Lambda$ & متزوج \\
\hline & & & & & & & & & مؤشر الثروة \\
\hline IV, & $r, \tau$ & $r \cdot, \varepsilon$ & Ir, r & $r, \tau$ & $r \cdot, l$ & 11,1 & $r, r$ & $\mid \Lambda, V$ & الأدني \\
\hline 10,1 & $0, r$ & $r_{0,9}$ & $10, r$ & 0,9 & $r r, \wedge$ & $1 \leqslant, 1$ & $7, r$ & $r, \wedge$ & الثاني \\
\hline$\curlywedge \wedge, \wedge$ & $0, r$ & $r \cdot, \wedge$ & $1 V, T$ & $\wedge, \vee$ & rצ, & iv, & $\Lambda, \uparrow$ & $r_{0, \varepsilon}$ & الأوسط \\
\hline$r \cdot, r$ & $\wedge, q$ & $r, 1$ & $i v, q$ & $\wedge, \varepsilon$ & $r_{0, \Lambda}$ & iv, & $\wedge, \cdot$ & ro, 1 & الر ابع \\
\hline 19,9 & $11, \wedge$ & $r_{\Lambda}, \varepsilon$ & $r, v$ & $11, \varepsilon$ & $r \cdot, q$ & $r \cdot, \wedge$ & $1 \cdot, 7$ & $r \cdot, l$ & الأعلى \\
\hline & & & & & & & & & الحالة الوظيفية \\
\hline$r_{0,7}$ & $1 \cdot, \cdot$ & $r \wedge, r$ & $r \leqslant, T$ & $11, r$ & r & Yr,T & $1 \cdot, r$ & $r \varepsilon, Y$ & يعمل \\
\hline$r q, \varepsilon$ & 10,7 & $r V, r$ & $r v, \varepsilon$ & $9, \varepsilon$ & $r q, 0$ & $r v, r$ & $1 \cdot, r$ & $r q, q$ & متعطل \\
\hline$\wedge, 1$ & $r, r$ & $r \varepsilon, \varepsilon$ & $\mid r, \Lambda$ & $v, \varepsilon$ & $r, q$ & $11, \wedge$ & $v, \cdot$ & rY,r & خارج قوة العمل \\
\hline rr, & Ir, & $r \cdot, \cdot$ & 17,0 & $11,$. & $r, r$ & $10, v$ & $1 \cdot, r$ & r.,. & بدرس حاليا \\
\hline $1 \wedge, r$ & 7,9 & $r q, \varepsilon$ & $I V, Y$ & $v, \wedge$ & $r 0, \Lambda$ & $17, r$ & $v, 0$ & $r \varepsilon, 0$ & إجمالي النسبة \\
\hline$(1 \cdot, \wedge \varepsilon 1)$ & $(0, r Y \wedge)$ & $(0,01 \pi)$ & $(\wedge, T Y T)$ & $(\xi, \Sigma \vee\urcorner)$ & $(\varepsilon, 1 \leqslant \vee)$ & $(1 \cdot, 917)$ & $(0, \wedge \leq \Gamma)$ & $(0, \cdot V T)$ & العدد \\
\hline
\end{tabular}




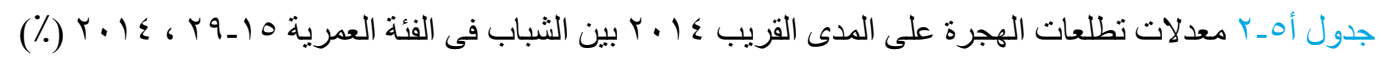

\begin{tabular}{|c|c|c|c|c|c|c|c|c|c|}
\hline & الاجمالى & & & إناث & & & ذكور & & \\
\hline أى مقصد & الغربيةن & العربيةن & أى مقصد & الغربيةن & العربية & أى مقصد & الغربية & العربية & \\
\hline & & & & & & & & & الفئة العمرية \\
\hline $7, \cdot$ & $r, 1$ & $r, \tau$ & $\varepsilon, 7$ & $r, r$ & $r, 1$ & $v, 0$ & r,l & $0, r$ & $1 V-10$ \\
\hline $1 .,$. & $i, v$ & $\wedge, 1$ & $\varepsilon, 0$ & 1,0 & $r, q$ & $1 \leqslant, 7$ & $r,$. & Ir,O & $r \varepsilon_{-11}$ \\
\hline 9,1 & $\cdot, v$ & $\Lambda, r$ & $r, \wedge$ & $\cdot, \varepsilon$ & $r, \varepsilon$ & $10,$. & $1, \cdot$ & $1 \%, 4$ & rq_ro \\
\hline & & & & & & & & & محل الأقامة \\
\hline $1 ., 1$ & $r, V$ & $\mathrm{v}, 1$ & 7,0 & $r, 0$ & $r, \wedge$ & IT, & $r, \Lambda$ & $1 \cdot, 1$ & حضر \\
\hline$\wedge, \vee$ & 1,1 & $v, 0$ & $r, 1$ & $\cdot, \wedge$ & $r, r$ & $i r, v$ & $1, r$ & $\mid r, \varepsilon$ & ريف \\
\hline ᄀ, & $\cdot, 9$ & $\varepsilon, v$ & $r, r$ & $\cdot, 7$ & 1,7 & $9, \vee$ & $1, r$ & $v, q$ & مناطق عشوائية \\
\hline & & & & & & & & & المنطقة \\
\hline $11, r$ & $r, r$ & $V, T$ & $\wedge, \vee$ & $r, 1$ & $0, \cdot$ & $1 T, T$ & $r, r$ & 9,9 & محافظات حضرية \\
\hline$\vee, q$ & $1, v$ & $0, v$ & $r, r$ & 1,1 & 1,0 & $\mid r, 1$ & $r, \varepsilon$ & 9,9 & حضر وجه بحري \\
\hline १,६ & l,r & $\wedge, 1$ & $r, r$ & $\cdot, v$ & $r,$. & 10,1 & $1, v$ & $\mid r, \varepsilon$ & ريف وجه بحري \\
\hline$\uparrow, \wedge$ & 1,1 & $0, v$ & $r, r$ & $1, r$ & $r_{,} \cdot$ & $1 ., 1$ & $\cdot, \wedge$ & $9, r$ & حضر وجه قبلي \\
\hline$\wedge, 1$ & $\cdot, 9$ & $\mathrm{v}, \cdot$ & $r, \tau$ & $1,$. & $r, 0$ & Ir,o & $\cdot, \wedge$ & 11,0 & ريف وجه قبلي \\
\hline$r, \wedge$ & $\cdot, 1$ & $r, \varepsilon$ & $1, r$ & $\cdot, \cdot$ & $1, r$ & $\varepsilon, r$ & $\cdot, r$ & $r, o$ & محافظات حدودية \\
\hline & & & & & & & & & المستوي التعليمي \\
\hline$r, r$ & $\cdot, 1$ & $r, 1$ & 1,1 & $\cdot, \cdot$ & 1,1 & $V, r$ & $\cdot, \varepsilon$ & $7, \wedge$ & أمي \\
\hline 0,7 & $\cdot, \cdot$ & 0,7 & $1, \varepsilon$ & $\cdot$, & $1, \varepsilon$ & ir,. & $\cdot, \cdot$ & ir,. & يقر أويكتب \\
\hline $9, \varepsilon$ & •, ६ & $\wedge, \wedge$ & ., & $\cdot, \cdot$ & $\cdot, \cdot$ & $17, r$ & $\cdot, v$ & $10, r$ & إبندائي \\
\hline 0,1 & $\cdot, \wedge$ & $\varepsilon$, & $1,$. & $\cdot, \cdot$ & $\cdot, 9$ & $9, \wedge$ & $1, v$ & $v, v$ & إعدادي \\
\hline$\wedge, 1$ & $r, \cdot$ & $\varepsilon, 0$ & 7,7 & $r, \wedge$ & $r, 1$ & $9, \vee v$ & $r, r$ & $v, 1$ & ثنانوي عام \\
\hline $9, \cdot$ & $1, \cdot$ & $\wedge, \cdot$ & r.o & , & $1, \wedge$ & $1 r, 9$ & $1, r$ & Ir,Y & ثانوي فني \\
\hline $1 T, 0$ & $r, \varepsilon$ & 11,1 & $9, \wedge$ & $r, Y$ & $v, 1$ & $17, r$ & $r, 1$ & $1 \leqslant, 1$ & فوق متوسط \\
\hline $1 Y, \varepsilon$ & r, & $9, \cdot$ & $9, \varepsilon$ & $r, \cdot$ & T,r & $10,$. & $r, r$ & $11, \varepsilon$ & جامعي فأكثر \\
\hline & & & & & & & & & الحالة الزواجية \\
\hline $9, v$ & 1,9 & $v, 0$ & $0, \cdot$ & 1,9 & r.q & $\mid r, \Lambda$ & 1,9 & 1,4 & أعزب \\
\hline 7,0 & •, ६ & 0,9 & $r, 0$ & •, ६ & $r, 1$ & 10,1 & $\cdot, \varepsilon$ & $1 \leqslant, 9$ & متزوج \\
\hline & & & & & & & & & مؤشر الثروة \\
\hline$V, r$ & , & $7, r$ & $r, 1$ & $\cdot, \mathrm{V}$ & 1,0 & Ir,. & $\cdot, 7$ & $1 \cdot, \wedge$ & الأدني \\
\hline$\gamma, 0$ & $1, \cdot$ & T,r & $r, \wedge$ & $\cdot, 9$ & $1, v$ & 11,9 & $1, r$ & $1 ., 0$ & الثاني \\
\hline$\wedge, 1$ & $1, \varepsilon$ & 7,7 & $r, 1$ & $1, \cdot$ & $1, \lambda$ & $1+, 1$ & $1, v$ & $11, \varepsilon$ & الأوسط \\
\hline$\wedge, \uparrow$ & $1, \wedge$ & 7,7 & $r, 1$ & l,r & $1, \wedge$ & r.r & $r, r$ & $1,, v$ & الر ابع \\
\hline Ir. & $r, 0$ & $9, r$ & $\Lambda, r$ & r.o & 0,0 & $10, \varepsilon$ & $r, \varepsilon$ & Ir,Y & الأعلى \\
\hline & & & & & & & & & الحالة الوظيفية \\
\hline $1 \leqslant, \cdot$ & $1, \cdot$ & IT,Y & $\mathrm{v}, \cdot$ & 1,1 & 0,9 & 10,1 & $1, \cdot$ & $1 \%, \Lambda$ & يعمل \\
\hline$r_{\cdot}, \varepsilon$ & ץ, & 17,1 & $9, r$ & $r, \varepsilon$ & $7, \wedge$ & $r v, q$ & $\varepsilon, 1$ & $r r, \varepsilon$ & متعطل \\
\hline $0, \varepsilon$ & 1,7 & $r, \tau$ & $r, 0$ & $1, r$ & $r, 1$ & 9,1 & $r, r$ & 7,7 & خارج قوة العمل \\
\hline $\mathrm{V}, \varepsilon$ & r,. & $\varepsilon, r$ & $\gamma, \varepsilon$ & $r, r$ & ५, q & $\gamma, \varepsilon$ & $r, \wedge$ & $\varepsilon, \varepsilon$ & يدرس حاليا \\
\hline$\wedge, 9$ & 1,0 & $v, 1$ & $\varepsilon, 1$ & $1, r$ & $r, T$ & $I T, Y$ & $1, v$ & $11, r$ & إجمالي النسبة \\
\hline$(741)$ & $(1 Y 7)$ & $(0,9)$ & $(170)$ & (07) & $(1 \cdot r)$ & $(017)$ & $(\mathrm{v} \cdot)$ & $(\varepsilon$ (ะ) & العدد \\
\hline
\end{tabular}




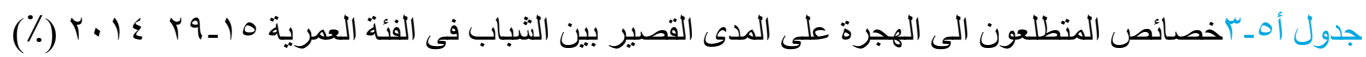

\begin{tabular}{|c|c|c|c|c|c|c|}
\hline \multicolumn{2}{|c|}{ الاجمالى } & \multicolumn{2}{|c|}{ 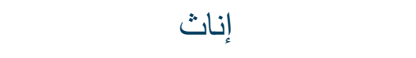 } & \multicolumn{2}{|c|}{ ذ ذكور } & \\
\hline البلدان الغربية & البلدان العربية & البلدان الغربية & البلدان العربية & البلدان الغربية & البلدان العربية & \\
\hline & & & & & & الفئة العمرية \\
\hline ro,. & $7 \cdot, \cdot$ & $\leq 7,9$ & $\varepsilon \leqslant, 0$ & $r V, \Lambda$ & $79, \varepsilon$ & $1 V_{-10}$ \\
\hline IV,o & 1,1 & rr, & $7 \leqslant, 9$ & $1 T, \varepsilon$ & $10, \varepsilon$ & $r \varepsilon_{-11}$ \\
\hline \multirow[t]{2}{*}{$v, 7$} & 19,9 & $1 \pi, 7$ & $\wedge \uparrow, \Sigma$ & 7,0 & $9 \cdot, 7$ & rq_ro \\
\hline & & & & & & محل الأقامة \\
\hline$r 7,0$ & $v_{\cdot}, \varepsilon$ & rᄉ, $q$ & ov, $q$ & r), & $v_{0,9}$ & حضر \\
\hline Ir, & $\wedge т, \vee$ & $r v, r$ & $v \cdot, v$ & 9,1 & $\wedge 9,9$ & ريف \\
\hline \multirow[t]{2}{*}{$1 \varepsilon, \varepsilon$} & $V V, 1$ & 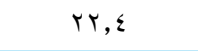 & $\pi, r$ & $\mid r, 1$ & $\wedge, V$ & مناطق عشو ائية \\
\hline & & & & & & المنطقة \\
\hline 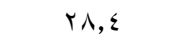 & $T V, \varepsilon$ & ro, 9 & ov,o & $r \leq, Y$ & $V r, 1$ & محافظات حضرية \\
\hline YI, 9 & $V Y, Y$ & $\leqslant 1, \varepsilon$ & $0 \wedge, 7$ & $\curlywedge \wedge, \cdot$ & $v_{0, \varepsilon}$ & حضر وجه بحري \\
\hline Ir, & $\wedge \uparrow, \varepsilon$ & $r_{0, \Lambda}$ & $V \varepsilon, Y$ & $11, \varepsilon$ & $\wedge \wedge, r$ & ريف وجه بحري \\
\hline 10,7 & $\wedge \varepsilon, \varepsilon$ & $\varepsilon \cdot, 1$ & 09,9 & $\Lambda, r$ & $91, \wedge$ & حضر وجه قبلي \\
\hline 11,1 & $\wedge т, \wedge$ & 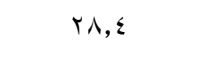 & $\uparrow \wedge$, & $T, Y$ & $q r, r$ & ريف وجه قبلي \\
\hline \multirow[t]{2}{*}{$\varepsilon, V$} & $\wedge 7,1$ & $\cdot, \cdot$ & $1 \cdots$ & $7, \cdot$ & $\wedge r, \Sigma$ & محافظات حدودية \\
\hline & & & & & & المستوي التعليمي \\
\hline$\varepsilon, r$ & $90, V$ & $\cdot, \cdot$ & $1 \cdots$, & 0,0 & $9 \leqslant, 0$ & أمي \\
\hline$\cdot, \cdot$ & $1 \cdots$, & $\cdot, \cdot$ & $\cdots$, & $\cdot, \cdot$ & $\cdots$, & يقر أ ويكتب \\
\hline$\varepsilon, \varepsilon$ & $q \mu, \varepsilon$ & na & na & $\varepsilon, \varepsilon$ & $q \pi, \varepsilon$ & إبتدائي \\
\hline $10, v$ & $\vee q,$. & $\cdot, \cdot$ & $\wedge \wedge, \wedge$ & $\mathrm{V}, \varepsilon$ & $\vee v, q$ & إعدادي \\
\hline$r v, 0$ & $00, r$ & ०^, & M,V & $r, I$ & $V Y, q$ & ثانوي عام \\
\hline $1 \cdot, 0$ & $\wedge \wedge, \uparrow$ & YT, & $V_{1}, 9$ & $\wedge, \vee$ & $9 \cdot, 9$ & ثانوي فني \\
\hline iv,o & $A Y, 0$ & $r v, \varepsilon$ & $V Y, T$ & $1 \pi, 1$ & $\wedge 7, q$ & فوق متوسط \\
\hline \multirow[t]{2}{*}{$r_{0,1}$} & $V Y, O$ & rr,. & $T V, Y$ & $r, r$ & $v_{0,0}$ & جامعي فأكثر \\
\hline & & & & & & الحالة الزواجية \\
\hline$r \cdot, \cdot$ & $\vee \wedge, \cdot$ & r^,r & $0 \wedge, r$ & $10, r$ & Ar,l & أعزب \\
\hline \multirow[t]{2}{*}{$0, v$} & $9 \cdot, \wedge$ & $1 \leq, r$ & $\wedge,, \wedge$ & $r, 0$ & $q \leq, r$ & منزوج \\
\hline & & & & & & مؤشر الثروة \\
\hline$\wedge, 9$ & $\wedge v$, & r., & 71,9 & $0, r$ & $9 \cdot, \cdot$ & الأدني \\
\hline $1 \%, 9$ & Ar,o & r., & $T, Y$ & 9,9 & $\wedge \wedge, \varepsilon$ & الثاني \\
\hline 17,9 & $\wedge, \varepsilon$ & Tr, & $0 \wedge, 7$ & Ir, & $\wedge т, \wedge$ & الأوسط \\
\hline$r \cdot, q$ & $V 7,9$ & $r q, 0$ & ov, $q$ & IV,r & $\wedge \cdot, 7$ & الر ابع \\
\hline \multirow[t]{2}{*}{$r \cdot, T$} & $\checkmark V, \wedge$ & $r \cdot, T$ & $T V, T$ & 10,9 & $\Delta r, v$ & الأعلى \\
\hline & & & & & & الحالة الوظيفية \\
\hline$v, \varepsilon$ & $9 \cdot, 9$ & 10,1 & $\Lambda \varepsilon, r$ & $7, \wedge$ & $91, \varepsilon$ & يعمل \\
\hline $17, v$ & $\wedge r, l$ & $r O, V$ & $V \varepsilon, r$ & $1 \varepsilon, V$ & $\wedge r, q$ & متعطل \\
\hline$r q, \wedge$ & 77,9 & T & $\circ \wedge, \vee$ & $r \varepsilon, \wedge$ & $V Y, q$ & خارج قوة العمل \\
\hline$\varepsilon \cdot, v$ & $07, Y$ & $\varepsilon r, \tau$ & or, r & $r v, q$ & $7 \cdot, \cdot$ & يدرس حاليا \\
\hline IV,r & $\wedge \cdot, \uparrow$ & rY, & $7 \varepsilon, 1$ & $1 r, 9$ & $\wedge 0, r$ & إجمالي النسبة \\
\hline$(1 \times 7)$ & (orq) & $(07)$ & $(1 \cdot r)$ & $(v \cdot)$ & $(\varepsilon r \uparrow)$ & 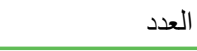 \\
\hline
\end{tabular}




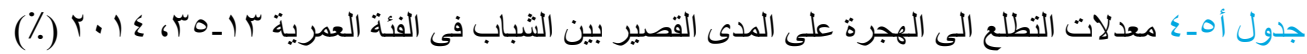

\begin{tabular}{|c|c|c|c|c|c|c|c|c|c|}
\hline \multicolumn{3}{|c|}{ الاجمالى } & \multicolumn{3}{|c|}{ إناث } & \multicolumn{3}{|c|}{ ذكور } & \\
\hline أى مقصد & الغربية & العربية & أى مقصد & الغربية & العربية & أى مقصد & الغربية & العربية & \\
\hline & & & & & & & & & الفئة العمرية \\
\hline 0,1 & 1,9 & $r, \varepsilon$ & $r, q$ & 1,1 & $1, v$ & $V, r$ & $r, \cdot$ & 0,1 & $\mid v-I T$ \\
\hline $1 \cdot, \cdot$ & $1, \mathrm{~V}$ & $\wedge, 1$ & $\varepsilon, 0$ & 1,0 & $r, q$ & $1 \leqslant, 7$ & $r, \cdot$ & Ir,o & $r \varepsilon_{-} \mid \lambda$ \\
\hline 9,1 & $\cdot, V$ & $\Lambda, r$ & $r, \wedge$ & •, ६ & $r, \xi$ & $10,$. & $1,$. & $1 \%, 4$ & $r q_{-} r_{0}$ \\
\hline$T, Y$ & $\cdot, \wedge$ & $0, r$ & $r, 1$ &., 0 & 1,7 & $1 ., 9$ & $1, r$ & $q, r$ & ro_r. \\
\hline & & & & & & & & & محل الأقامة \\
\hline 9,9 & r,o & $\mathrm{v}, \cdot$ & $0, \mathrm{~V}$ & $r, 1$ & r, & $I T, V$ & $r, \wedge$ & $1 \cdot, r$ & حضر \\
\hline$v, q$ & $\cdot, 9$ & 7,9 & $r, \Lambda$ & $\cdot, v$ & $r, \cdot$ & $I r, \Lambda$ & 1,1 & 11,7 & ريف \\
\hline 0,0 & $\cdot, \wedge$ & $\varepsilon, \varepsilon$ & $r, r$ & $\cdot, 0$ & $1, \varepsilon$ & $\wedge, \wedge$ & $1, \cdot$ & $\vee, \varepsilon$ & مناطق عشو ائية \\
\hline & & & & & & & & & المنطقة \\
\hline $11,$. & $r, \cdot$ & $v, 0$ & $v, T$ & $r, T$ & $\varepsilon, 0$ & $1 \leqslant, 1$ & $r, r$ & $1 \cdot, r$ & محافظات حضرية \\
\hline$v, r$ & 1,7 & $0, \varepsilon$ & $r, r$ & $\cdot, 9$ & $1, \varepsilon$ & $M, r$ & $r, r$ & $9, r$ & حضر وجه بحري \\
\hline$\wedge, 0$ & $1, \cdot$ & $v, \varepsilon$ & $r, r$ & $\cdot, 7$ & $1, v$ & $1 \leqslant, 1$ & 1,0 & Kr, & ريف وجه بحري \\
\hline$\uparrow, \varepsilon$ & $\cdot, 9$ & $0, \S$ & $r, \uparrow$ & 1,1 & 1,7 & 9,9 & $\cdot, v$ & $\wedge, q$ & حضر وجه قبلي \\
\hline$\gamma, \varepsilon$ & $\cdot, \wedge$ & 7,0 & $r, \varepsilon$ & $\cdot, 9$ & $r, \varepsilon$ & 11,7 & $\cdot, v$ & $1 \cdot, v$ & ريف وجه قبلي \\
\hline$r, v$ &., 1 & $r, \xi$ & $1, \cdot$ & $\cdot, \cdot$ & $1, \cdot$ & $\varepsilon, \varepsilon$ & $\cdot, r$ & $r, \Lambda$ & محافظات حدودية \\
\hline & & & & & & & & & المستوي التعليمي \\
\hline$r, r$ & $\cdot, r$ & $r, 0$ & $\cdot, \wedge$ & $\cdot, \cdot$ & $\cdot, \wedge$ & $7, V$ & •, & 7,1 & أمي \\
\hline$r, \wedge$ & $\cdot, \cdot$ & $\ulcorner, \wedge$ & 1,7 & $\cdot, \cdot$ & 1,7 & $v, v$ & $\cdot, \cdot$ & $v, v$ & يقر أويكتب \\
\hline$\wedge, \wedge$ & , & $\wedge, 1$ & •, ६ & $\cdot, r$ & $\cdot, r$ & $10, r$ & $\cdot, \wedge$ & $1 \varepsilon, r$ & إيتدائي \\
\hline $0, \cdot$ & ., & $\varepsilon$, & l,r & $\cdot, \cdot$ & 1,1 & $9, r$ & $1, \varepsilon$ & $\gamma, \varepsilon$ & إعدادي \\
\hline$\wedge, \cdot$ & r,l & $\varepsilon, \varepsilon$ & $\uparrow, \varepsilon$ & $r, \wedge$ & $r, \cdot$ & $9, \wedge$ & $r, r$ & $v, 1$ & ثانوي عام \\
\hline$\Lambda, r$ & $\cdot, \wedge$ & $\vee, \varepsilon$ & $r, r$ & $\cdot, 7$ & 1,7 & $1 \%$, & $1, \cdot$ & 11,9 & ثانوي فني \\
\hline $1 r, 1$ & $r, \varepsilon$ & $1 \cdot, v$ & $\wedge, 7$ & $r, r$ & $7, \varepsilon$ & 17,0 & r.o & $1 \leqslant$, & فوق متوسط \\
\hline Ir,Y & r,q & $\wedge, 9$ & $\wedge, \vee$ & $r, V$ & $7, \cdot$ & $10, r$ & $r, r$ & 11,0 & جامعي فأكثر \\
\hline & & & & & & & & & الحالة الزواجية \\
\hline $9, r$ & 1,9 & $v, r$ & $\varepsilon, V$ & 1,1 & $r, Y$ & Ir,O & 1,9 & $1 \cdot, \varepsilon$ & أعزب \\
\hline $7, r$ &., 0 & 0,0 & $r, r$ & $\cdot, r$ & 1,9 & $1 r, r$ & $\cdot, \mathrm{v}$ & Ir,. & متزوج \\
\hline & & & & & & & & & مؤشر الثروة \\
\hline 7,0 & $\cdot, 0$ & $0, v$ & I,V &., 0 & $1, r$ & $11, \varepsilon$ &., 0 & $1 \cdot, r$ & الأدني \\
\hline 7,9 & $\cdot, 9$ & $0, \wedge$ & $r, \wedge$ & $\cdot, \wedge$ & 1,9 & $1 \cdot, \wedge$ & $1, \cdot$ & 9,7 & الثاني \\
\hline$\vee, \varepsilon$ & l,r & $7, \cdot$ & $r, Y$ & $\cdot, \wedge$ & 1,7 & Ir,. & $1, v$ & $1 \cdot, r$ & الأوسط \\
\hline$\Lambda, r$ & 1,7 & 7,0 & $r, r$ & $1, \cdot$ & 1,7 & $1 \%, 0$ & $r, r$ & $11,$. & الر ابع \\
\hline $11, r$ & $r, r$ & $\wedge, \wedge$ & $v, r$ & $r, r$ & $\varepsilon, q$ & $10,$. & $r, r$ & Ir,r & الأعلى \\
\hline & & & & & & & & & الحالة الوظيفية \\
\hline$M, V$ & $1, \cdot$ & $11, r$ & $7, r$ & $\cdot, 9$ & $0, r$ & $1 T, V$ & 1,1 & $M, \varepsilon$ & يعطل \\
\hline$r_{\cdot, \cdot}$ & $r, r$ & $17, \varepsilon$ & 9,1 & $r, \wedge$ & $7, r$ & $r \wedge, l$ & $r, \tau$ & $r r, \lambda$ & متعطل \\
\hline$\varepsilon, 9$ & 1, ६ & $r, r$ & $r, \cdot$ & 1,1 & $1, \wedge$ & १,. & $r, r$ & 7,7 & خارج قوة العمل \\
\hline 7,9 & $r, \Lambda$ & $r, q$ & 7,7 & $r, q$ & $r, 0$ & $v, 1$ & $r, Y$ & $\varepsilon, r$ & يدرس حاليا \\
\hline$\Lambda, r$ & $1, \varepsilon$ & $7, V$ & $r, r$ & 1,1 & $r, r$ & IT,V & 1,7 & $1 \cdot, \wedge$ & إجمالي النسبة \\
\hline$(\vee \vee \cdot)$ & $(1 \leqslant 1)$ & $(7 r \cdot)$ & $(\curlywedge \wedge \wedge)$ & (7) & $(|Y|)$ & $(T \cdot Y)$ & $(\wedge \cdot)$ & $(0.9)$ & العدد \\
\hline
\end{tabular}




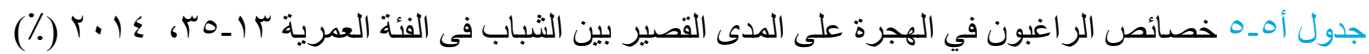

\begin{tabular}{|c|c|c|c|c|c|c|}
\hline \multicolumn{2}{|c|}{ الاجمالى } & \multicolumn{2}{|c|}{ إناث } & \multicolumn{2}{|c|}{ ذكور } & \\
\hline البلدان الغربية & البلدان العربية & البلدان الغربية & البلدان العربية & البلدان الغربية & البلدان العربية & \\
\hline & & & & & & الفئة العمرية \\
\hline$r \varepsilon, r$ & 71,1 & $\leq 7,9$ & $\varepsilon \varepsilon, 0$ & $r V, r$ & $v \cdot, r$ & $\left|V_{-}\right| T$ \\
\hline IV,o & $\wedge 1,1$ & Tr,T & $7 \leqslant, 9$ & $1 \Gamma, \varepsilon$ & $10, \varepsilon$ & $r \varepsilon_{-} \mid \Lambda$ \\
\hline$v, r$ & $\wedge १, q$ & $1 \%, 7$ & $\Lambda_{\uparrow}, \varepsilon$ & 7,0 & $9 \cdot, 7$ & rq-ro \\
\hline$v, 7$ & $\wedge q, q$ & 1T, & $\Lambda \uparrow, \varepsilon$ & 7,0 & $9 \cdot, 7$ & ro_r. \\
\hline & & & & & & محل الأقامة \\
\hline$r_{0, \varepsilon}$ & $v \cdot, q$ & $r v, v$ & 09,0 & $r \cdot, \wedge$ & vo,r & حضر \\
\hline 11,7 & AV,, & 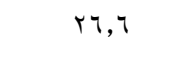 & $v 1,7$ & $\Lambda, 0$ & $9 \cdot, 0$ & ريف \\
\hline $1 T, 7$ & $v q, r$ & $r, \cdot$ & ד, דיד & $11, \mathrm{~V}$ & $\Delta r, r$ & مناطق عشو ائية \\
\hline & & & & & & المنطقة \\
\hline$r v, \cdot$ & $7 \lambda, 7$ & $r \varepsilon, v$ & $09, \varepsilon$ & $r, r$ & $V r, 1$ & محافظات حضرية \\
\hline$r, \cdot$ & $\mathrm{Vr}, \mathrm{r}$ & $r q, 1$ & $7 \cdot, 9$ & $19,$. & vo,r & حضر وجه بحري \\
\hline$M, r$ & Av, & $r_{0, \varepsilon}$ & $V \varepsilon, T$ & $1 \cdot, r$ & $\wedge 9$, & ريف وجه بحري \\
\hline $1 T, 7$ & $\wedge \varepsilon, r$ & $\varepsilon \cdot, 1$ & 09,9 & 7,9 & $q \cdot, r$ & حضر وجه قبلي \\
\hline 11,1 & $\wedge v, 1$ & $r v, 0$ & 79,0 & 7,1 & $q r, \varepsilon$ & ريف وجه قبلي \\
\hline$r, q$ & $\wedge \wedge, 0$ & $\cdot, \cdot$ & $1 \ldots$, & $\varepsilon, V$ & ᄉ , & محافظات حدودية \\
\hline & & & & & & المستوي التعليمي \\
\hline 7,0 & 94,0 & $\cdot, \cdot$ & $1 \ldots$, & $\Lambda, r$ & 91,1 & أمي \\
\hline$\cdot, \cdot$ & $1 \cdots$, & $\cdot, \cdot$ & $1 \cdots$, & $\cdot, \cdot$ & $1 \ldots$, & يقرأ ويكتب \\
\hline $7, \varepsilon$ & 91,9 & $0 \wedge, 1$ & $\varepsilon 1,9$ & $0, \varepsilon$ & 94,9 & إبتدائي \\
\hline $1 r, q$ & $\wedge, r$ & $\cdot, \cdot$ & 94,0 & $1 \leqslant, 9$ & $v q, 0$ & إعدادي \\
\hline rı, & 00,1 & $0 \wedge, 9$ & $r_{1, \cdot}$ & $r r, \wedge$ & $V Y, O$ & ثانوي عام \\
\hline $1 \cdot, \cdot$ & $\wedge \wedge, q$ & $r_{0, r}$ & $v \cdot, \varepsilon$ & $v, q$ & 91,0 & ثانوي فني \\
\hline $1 \Lambda, r$ & $\wedge, \wedge$ & $r_{0, r}$ & $V \varepsilon, \varepsilon$ & $10, r$ & $\wedge \varepsilon, \vee$ & فوق متوسط \\
\hline$r \leqslant, 1$ & $V r, \cdot$ & $r \cdot, 0$ & $\uparrow \wedge, \wedge$ & $r, \cdot$ & vo,. & جامعي فأكثر \\
\hline & & & & & & الحالة الزواجية \\
\hline 19,9 & $\vee \wedge, r$ & $\lceil\Lambda, 0$ & $0 \wedge, r$ & $10, r$ & NT,r & أعزب \\
\hline$v, v$ & $\wedge \wedge, 1$ & $1 \leqslant, 7$ & $\Lambda r, O$ & 0,7 & 19,9 & متزوج \\
\hline & & & & & & مؤشر الثروة \\
\hline $\mathrm{v}, \mathrm{v}$ & $\wedge \mathrm{V}, \mathrm{T}$ & $r q, 0$ & $v \cdot, 0$ & $\varepsilon, 0$ & $9 \cdot, r$ & الأدني \\
\hline $1 r, \varepsilon$ & $\wedge \varepsilon, r$ & $\curlyvee \wedge, \wedge$ & 10,7 & 9,0 & $\wedge 9$, & الثاني \\
\hline $\mid v, 1$ & $\wedge 1,0$ & $r \cdot, \varepsilon$ & T) & $1 \leqslant, 1$ & 10,9 & الأوسط \\
\hline $19, v$ & $\mathrm{v} \wedge, \varepsilon$ & m,r & $71, \varepsilon$ & $17, \lambda$ & $\wedge, \varepsilon$ & الر ابع \\
\hline$r \cdot, r$ & $v v, \varepsilon$ & $r, r$ & $T V, 1$ & $10, r$ & 11,9 & الأعلى \\
\hline & & & & & & الحالة الوظيفية \\
\hline$\Lambda, r$ & $\wedge १, \uparrow$ & $1 \leqslant, \wedge$ & $10, r$ & $v, v$ & $9 \cdot, \cdot$ & يعمل \\
\hline $17, \varepsilon$ & $\wedge, \mathrm{V}$ & ru,r & $\uparrow \wedge, \wedge$ & $I r, \Lambda$ & $\lambda \leq, 9$ & متعطل \\
\hline$r \wedge, q$ & $T \Lambda, 1$ & ro, \{ & $r \cdot r$ & $r \varepsilon, r$ & $V \Psi, V$ & خارج قوة العمل \\
\hline$\varepsilon \cdot, 0$ & $07, \varepsilon$ & $\varepsilon \Gamma, \uparrow$ & or, r & $r V, \Lambda$ & $7, r$ & يدرس حاليا \\
\hline 17,7 & A.,, 9 & $r, r$ & 70,0 & Ir,V & 10,. & إجمالي النسبة \\
\hline$(1 \leqslant 1)$ & $(\pi+\cdot)$ & (7) & $(|K|)$ & $(\wedge \cdot)$ & $(0.9)$ & العدد \\
\hline
\end{tabular}




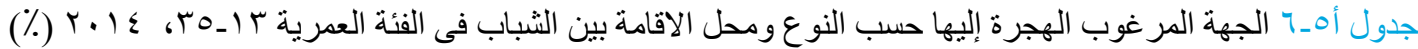

\begin{tabular}{|c|c|c|c|c|c|}
\hline \multirow[b]{2}{*}{ الاجمالى } & \multicolumn{2}{|c|}{ النوع } & \multicolumn{2}{|c|}{ محل الاقامة } & \\
\hline & اناث & ذكور & ريف & حضر & \\
\hline$\varepsilon \cdot, r$ & $r, 1$ & $\varepsilon r, V$ & $\varepsilon r, 1$ & $r v, T$ & المملكة العربية السعودية \\
\hline$w, q$ & $i r$, & $19, r$ & $r \cdot, r$ & $1 \leqslant, 1$ & الكويت ل \\
\hline $9,$. & $1 \cdot, r$ & $\Lambda, \mathrm{V}$ & $\mathrm{v}, 1$ & $11, v$ & الامارات \\
\hline 7,7 & $1, \varepsilon$ & $\Lambda,$. & 9,0 & r,o & ليبيا \\
\hline$r, r$ & $0, \cdot$ & $r, \mathrm{r}$ & $r, 0$ & $\varepsilon, 1$ & 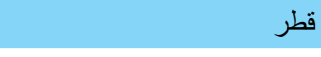 \\
\hline$r, r$ & $r, r$ & $r, \varepsilon$ & $\varepsilon, 0$ & $1, \varepsilon$ & الاردن \\
\hline$\cdot, \varepsilon$ & I,V & $\cdot, \cdot$ & $\cdot, 1$ & $\cdot, \mathrm{V}$ & 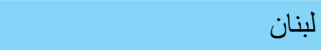 \\
\hline $1 \cdot, \varepsilon$ & IA,V & $\wedge, 1$ & $\Lambda, r$ & $1 T, r$ & 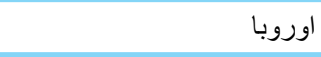 \\
\hline 7,7 & 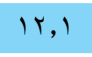 & 0,1 & $r, \tau$ & $1 \cdot, 4$ & استر اليا/ كندا/ الو لايات المتحدة \\
\hline$(\vee \vee \cdot)$ & $(17 V)$ & (TזT) & $(£ 09)$ & (1) & (العدد) \\
\hline
\end{tabular}

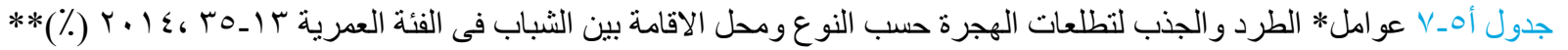

\begin{tabular}{|c|c|c|c|c|c|c|c|c|c|}
\hline \multicolumn{3}{|c|}{ 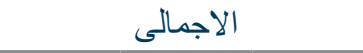 } & \multicolumn{3}{|c|}{ إناث } & \multicolumn{3}{|c|}{ ذكور } & \multirow[b]{3}{*}{ عوامل الطرد } \\
\hline 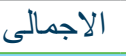 & ريف & حضر & 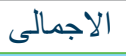 & ريف & حضر & 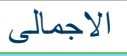 & ريف & حضر & \\
\hline & & & & & & & & & \\
\hline $7, r$ & $7 \pi, \pi$ & Oᄉ,. & $\varepsilon 0,1$ & 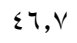 & $\varepsilon 0$, & $70, \Sigma$ & $T V, 1$ & $T, Y$ & عدم وجود فرص العمل المتاحة في مصر \\
\hline$\varepsilon r, \gamma$ & $\varepsilon 0, \varepsilon$ & $r_{\Lambda, q}$ & $\Upsilon_{\curlywedge}, \varepsilon$ & M, & rч, & $\leqslant \uparrow, 0$ & $\varepsilon \wedge, \varepsilon$ & $\varepsilon r, 0$ & الدخل في مصر أقل من الخارج \\
\hline$\varepsilon \wedge,$. & $\leqslant 9,0$ & $\leq 7,1$ & rq, r & $r V, \varepsilon$ & $\varepsilon \cdot, q$ & $0 ., \varepsilon$ & or,. & $\varepsilon \vee, q$ & الظروف المبيشية السيئة في مصر \\
\hline$\varepsilon, q$ & $\varepsilon, 1$ & 7, & $\wedge, \vee$ & 7,0 & $1 \cdot, v$ & $r, q$ & $r, \tau$ & $\varepsilon, r$ & لللهروب من الضغوط العائلية و المتاعب \\
\hline$r, r$ & r,. & $1, \varepsilon$ & 9,1 & ir,r & 0,1 & $\cdot, 0$ & $\cdot, \wedge$ & $\cdot, \cdot$ & مر افقة العائلة \\
\hline $10, r$ & $17, \mathrm{~V}$ & 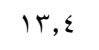 & $\vee, q$ & $9, r$ & $\uparrow, V$ & lv,r & $M, r$ & 10,1 & لمساعدة عائلتي \\
\hline $1, r$ & $\cdot, 0$ & $r, \varepsilon$ & $\varepsilon, \wedge$ & 1,1 & $\vee, T$ & $\cdot, \varepsilon$ & $\cdot, r$ & $\cdot, 7$ & ل ل أعلم \\
\hline $7, \varepsilon$ & $r, \varepsilon$ & 11,9 & $17, v$ & $1 \cdot, \cdot$ & $r$ r,A & $r, \uparrow$ & $\cdot, \wedge$ & $v, q$ & عدم وجو فرص لاكتساب المعلومات والخبرات \\
\hline$r \cdot, l$ & $r_{r, \cdot}$ & $r v, T$ & $i v, q$ & $17, \varepsilon$ & $19, r$ & $r \mu, \varepsilon$ & ro,r & $r \cdot, r$ & للحصول على المال \\
\hline $9, \wedge$ & $1 \cdot, \cdot$ & 9,0 & Ir, & Ir, & ir,. & 9,1 & 9,0 & $\wedge, 0$ & الظروف السياسية و الأمنية في مصر \\
\hline$r, 1$ & $1, \wedge$ & $r, T$ & $\vee, \varepsilon$ & $v, r$ & $\mathrm{v}, 1$ & $\cdot, \mathrm{v}$ & $\cdot, 7$ & $1, \cdot$ & 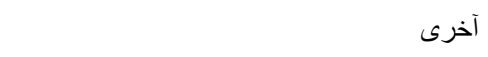 \\
\hline$(\vee \vee \cdot)$ & $(\varepsilon 09)$ & $(r+1)$ & $(17 V)$ & $(\wedge \cdot)$ & $(\wedge \vee)$ & $(T r 4)$ & $($ (rq $)$ & $(T \leq \varepsilon)$ & (العدد) \\
\hline & & & & & & & & & عوامل الجذب \\
\hline 1,1 & 9,7 & $10, \mathrm{~V}$ & r & $i v, \lambda$ & $r \varepsilon, 1$ & $\Lambda, r$ & $\mathrm{v}, q$ & 9,1 & روية دول أخرى \\
\hline$\vee, \wedge$ & $7, r$ & 9,9 & $11, r$ & $9, \vee$ & $\mid r, \Lambda$ & 7,9 & 0,7 & $\wedge, 9$ & 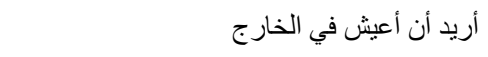 \\
\hline $7, Y$ & $v, 1$ & $7, r$ & 9,7 & $1 \cdot, 1$ & $\wedge, 0$ & 0,9 & ד, ז & $0, \varepsilon$ & ل ل لدي أقارب / أصدقاء هناك \\
\hline $0, \varepsilon$ & $\varepsilon, v$ & $7, r$ & $r, \wedge$ & $\cdot, \cdot$ & $0, \Sigma$ & 7,1 & $0, \mathrm{~V}$ & $7, \mathrm{~V}$ & لدي عرض عمل هناك \\
\hline$\wedge, 0$ & $0, \varepsilon$ & $i r, v$ & $r \uparrow, \varepsilon$ & $r r, r$ & $r q, r$ & $r, v$ & $1, v$ & $\uparrow, \wedge$ & يمكني الدراسة بها \\
\hline 79,7 & 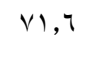 & $77, \mathrm{~V}$ & $\varepsilon \wedge, \vee$ & $0 ., 1$ & $\leq \uparrow, V$ & $v_{0, r}$ & $\mathrm{v}_{1}, \cdot$ & $v r, q$ & الدخل العالي في الخارج مما كان عليه في مصر \\
\hline$r+\wedge$ & $\varepsilon, \wedge$ & $r q, \wedge$ & 7,1 & $\uparrow, \mathrm{V}$ & 0,0 & $\leqslant 0$, & $\varepsilon q, r$ & $r_{\Lambda, 0}$ & 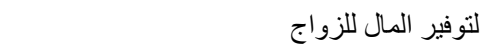 \\
\hline 9,9 & 7,0 & $1 \varepsilon, 0$ & re, & $r, 1$ & $r+r$ & 7,7 & $r, \varepsilon$ & $11, \varepsilon$ & لتحسين معرفتي \\
\hline r.o & $r, \varepsilon$ & r.o & $\mathrm{v}, \varepsilon$ & $1 \cdot, \varepsilon$ & $\varepsilon, 0$ & $1, r$ & $\cdot, \wedge$ & $1, \wedge$ & 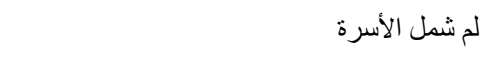 \\
\hline$r, r$ & $r,$. & $r, \varepsilon$ & $r, r$ & $r, \cdot$ & $r, 0$ & $r, l$ & $r,$. & $r, r$ & آخرى \\
\hline$(\vee ৭ \cdot)$ & $(\{09)$ & (Tr) & $(17 V)$ & $(\wedge \cdot)$ & $(\wedge \vee)$ & (TKT) & $($ (YYq) & $(Y \leq \varepsilon)$ & (العدد) \\
\hline
\end{tabular}




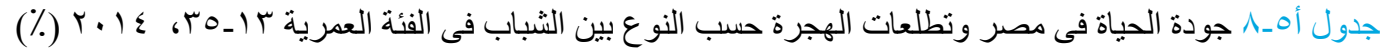

\begin{tabular}{|c|c|c|c|c|c|c|}
\hline \multicolumn{3}{|c|}{ نسبة تطلعات الهجرة على المدى الطويل } & \multicolumn{3}{|c|}{ نسبة تطلعات الهجرة على المدى القصبر } & \multirow[b]{3}{*}{ ملك الأسرة المعيشية أراضى زر اعية (فى المناطق الريفية) } \\
\hline 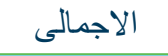 & اناث & ذكور & 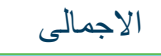 & 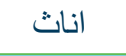 & ذكور & \\
\hline & & & & & & \\
\hline 19,9 & $1 \cdot, 0$ & $r V, \cdot$ & 7,9 & r, 9 & $1 \cdot, \cdot$ & 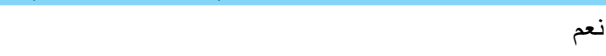 \\
\hline 10,9 & Ү,. & rฯ, ६ & $\wedge, r$ & $r, \wedge$ & $1 \leqslant$, & $y$ \\
\hline \multirow[t]{2}{*}{(\urcorner$, \leqslant 97)$} & $(r, 190)$ & $(r, r \cdot \bullet)$ & (\urcorner$, \leqslant 97)$ & $(r, 190)$ & $(r, r \cdot l)$ & حجم العينة فى المناطق الريفية \\
\hline & & & & & & خبرات الأسرة المعيشية مع نقص المياه \\
\hline IV,Y & 0,1 & $r q, 9$ & $9, \varepsilon$ & r, ६ & 10,0 & نعم \\
\hline \multirow[t]{2}{*}{17,} & $\mathrm{v}, q$ & 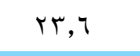 & $\wedge, \cdot$ & $r, \uparrow$ & ir, r & y \\
\hline & & & & & & عدم اليقين نحو المستقبل \\
\hline $11, \varepsilon$ & r,q & $i v, Y$ & v,r & $r, \Lambda$ & $1 \cdot, 9$ & | ا منخفض \\
\hline $1 \leqslant, \wedge$ & $v, r$ & $r$ rel & 7,1 & 1,9 & $1 \cdot, 7$ & r \\
\hline $10, \varepsilon$ & $v, 0$ & re,r & $\mathrm{v}, \mathrm{v}$ & $r, v$ & $11, \mathrm{v}$ & r \\
\hline $19, r$ & $9, \vee$ & $r \Lambda, \vee$ & $9, r$ & $\varepsilon, \wedge$ & |r, & $\varepsilon$ \\
\hline \multirow[t]{2}{*}{$1 \wedge, 7$} & $v, 1$ & rA,, & $1 \cdot, \wedge$ & $r, \varepsilon$ & iv, & م مرتفع \\
\hline & & & & & & هل تشعر بالتعاسة: \\
\hline 17,9 & 7,7 & r, & $1 \leqslant, 1$ & ᄀ,r & ro,. & نعم \\
\hline \multirow[t]{2}{*}{17,1} & $v, r$ & $r$ r,$q$ & $\mathrm{v}, \mathrm{r}$ & $r, r$ & 11,7 & $y$ \\
\hline & & & & & & هل تجد صعوبة فى الاستمتاع بالأنشطة اليوميةج \\
\hline 19,1 & $9, \mathrm{~V}$ & rr, & $11, \mathrm{v}$ & 7,0 & 19,1 & نعم \\
\hline \multirow[t]{2}{*}{10,9} & $V, r$ & $r r, \Lambda$ & $\checkmark, \wedge$ & $r, 1$ & ir,i & y \\
\hline & & & & & & هل انت غير قادر على لعب دور مفيد فى الحياة؟ \\
\hline r, & $1 \cdot, 0$ & rV, & 1r, & 0,0 & $r \varepsilon, 9$ & نعم \\
\hline \multirow[t]{2}{*}{10,9} & $\gamma, r$ & $r r, \Lambda$ & $\vee, q$ & $r, \varepsilon$ & ir,. & $y$ \\
\hline & & & & & & هل تشعر بأنك لا قيمة لك؟ \\
\hline $1 \%, 7$ & $0, v$ & $r \varepsilon, r$ & 9,7 & $\varepsilon, V$ & $17, r$ & نعم \\
\hline $17, \varepsilon$ & $v, T$ & $r \varepsilon, T$ & $\Lambda, r$ & $r, 0$ & Ir,O & y \\
\hline $17, r$ & $v, 0$ & $r \leqslant, 0$ & $\Lambda, r$ & $r, \tau$ & Ir,V & اجمالى الثباب \\
\hline$(1 \cdot, q \cdot v)$ & $(0, r$ YO $)$ & $(0,0 \wedge r)$ & $(1 \cdot, q \cdot \vee)$ & $(0, r$ ro $)$ & $(0,0 \wedge r)$ & 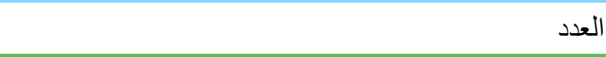 \\
\hline
\end{tabular}




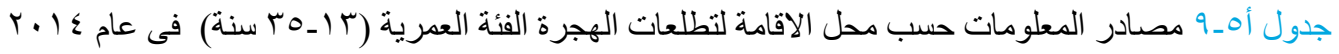

\begin{tabular}{|c|c|c|c|c|c|c|c|c|c|}
\hline & أى مقصد & & & 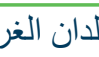 & & & ل بلدان العر & & \\
\hline الاجمالى & ريف & حضر & الاجمالى & ريف & حضر & الاجمالى & ريف & حضر & \\
\hline $1 \wedge, \varepsilon$ & $r_{\cdot}, \mathrm{v}$ & $10, \varepsilon$ & $\mathrm{IV}, \varepsilon$ & $r \cdot, V$ & 10,1 & 11,9 & $r \cdot, \Lambda$ & 10,1 & أقارب بالخارج \\
\hline $1 \leqslant, \wedge$ & $10,$. & $1 \leqslant, 0$ & $\varepsilon, q$ & $\varepsilon, r$ & $0, \varepsilon$ & $1 v, 1$ & $17, \varepsilon$ & $1 \Lambda, \varepsilon$ & أقارب في مصر \\
\hline$r, 1$ & 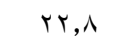 & $\curlywedge \wedge, \wedge$ & 10,1 & $1 \leqslant, 9$ & $17, \varepsilon$ & rr,q & $r \xi, r$ & $r \cdot, r$ & الأصدقاء الدصريين في الخارج \\
\hline$r \cdot, \Lambda$ & rr,o & $1 \wedge, \varepsilon$ & 10,0 & $r_{1, \varepsilon}$ & $11, r$ & $\lceil, \wedge$ & $r r, \cdot$ & 19,9 & أصدقاء في مصر \\
\hline$\wedge, 0$ & $\varepsilon, V$ & $I r, \Lambda$ & $r \uparrow, r$ & $r \cdot, \Lambda$ & $r \cdot, l$ & $\varepsilon$, & $r, r$ & 7,9 & الإلترنت \\
\hline$\cdot, 7$ & $\cdot, \wedge$ & $\cdot, r$ & $\cdot, \uparrow$ & $1, \varepsilon$ & $\cdot, \cdot$ & , & $\cdot, \wedge$ & $\cdot, r$ & الحكومات \\
\hline$r, v$ & r,q & $r, r$ & $0, r$ & $0, \wedge$ & $\varepsilon, q$ & $r, r$ & $r, 0$ & $r, \cdot$ & قر قراءات عامة \\
\hline $1 \cdot, 0$ & $\wedge, 1$ & $1 \%, \Lambda$ & Ir,T & 9,1 & $10,$. & $9, \wedge$ & $\mathrm{v}, \mathrm{v}$ & $1 r, r$ & صحف) الإعلام (تلفزيون، راديو، \\
\hline$\cdot, r$ & $\cdot, r$ & $\cdot, r$ & $\cdot, \cdot$ & $\cdot, \cdot$ & $\cdot, \cdot$ & $\cdot, r$ & $\cdot, r$ & $\cdot, r$ & السفار ات / القنصليات \\
\hline 1,0 & $1, r$ & $1, v$ & 1,1 & $1, \mathrm{~V}$ & $1, \wedge$ & $1, \varepsilon$ & $1, r$ & 1,7 & آخرى \\
\hline$(\vee \vee \cdot)$ & $(\varepsilon 09)$ & ( ) & $(1 \leqslant 1)$ & (ov) & $(\wedge \varepsilon)$ & $(7 r \cdot)$ & $($ ( १६) & $($ (Tז & العدد \\
\hline
\end{tabular}

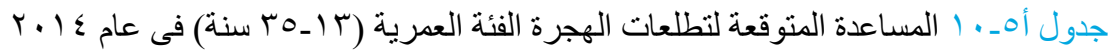

\begin{tabular}{|c|c|c|c|}
\hline أى مقصد & البلدان الغربية & البلدان العربية & \\
\hline r, 9 & $r q, \wedge$ & $r \uparrow, \varepsilon$ & أقارب في الخارج \\
\hline 01,1 & $07,$. & $0 ., r$ & أقارب في مصر \\
\hline 9,9 & $v, r$ & $1 \cdot, \varepsilon$ & الأصدقاء المصريين في الخارج \\
\hline ૫, ६ & $r, \cdot$ & $7, \mathrm{~V}$ & أصدقاء في مصر \\
\hline$r, r$ & $\cdot, \cdot$ & $r, q$ & سماسرة الهجرة \\
\hline$\cdot, 0$ & $1, r$ & $\cdot, r$ & قتصلية \\
\hline$r, q$ & $r, v$ & $r, \cdot$ & آخرى \\
\hline$(\Gamma r \cdot)$ & $(74)$ & $(Y \Upsilon \varepsilon)$ & 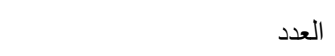 \\
\hline
\end{tabular}




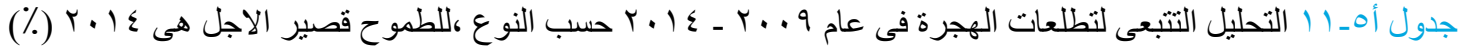

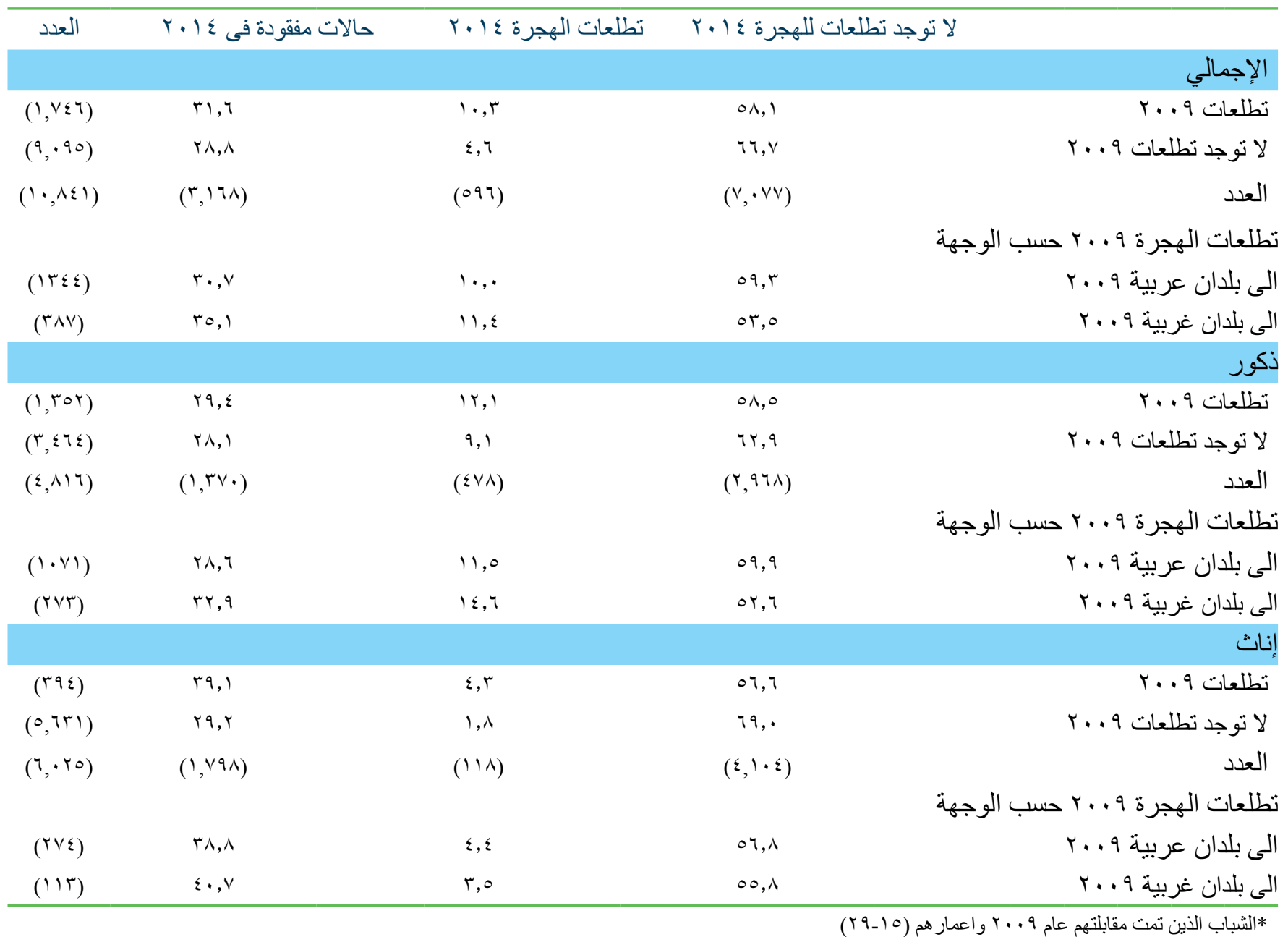

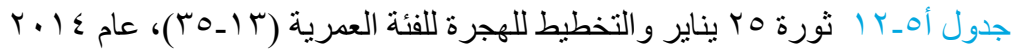

\begin{tabular}{|c|c|c|c|c|c|c|c|c|c|}
\hline \multicolumn{3}{|c|}{ ج. تطلعات القهرة على المدى } & \multicolumn{4}{|c|}{ ب. تطلعات الطجيلة على المدى } & \multicolumn{2}{|c|}{ 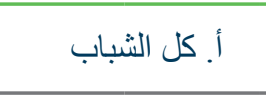 } & \\
\hline 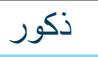 & اناث & الاجمالى & ذكور & 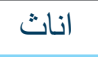 & 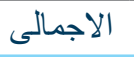 & ذكور & 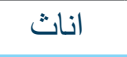 & 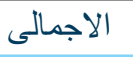 & \\
\hline & & & & & & & & & يتعلق بالهجرة ألثورة غيرت قرارك فيما \\
\hline Ir,Y & $1 \cdot, \wedge$ & Ir, & 7,0 & $r, r$ & $\mathrm{v}, \mathrm{o}$ & $1, v$ & $1, \cdot$ & $r, r$ & نعم، والآن أبدأ في التفكير في الهجرة \\
\hline $1 \wedge, 1$ & 11,1 & $r_{\cdot, \cdot}$ & $9, \wedge$ & $0, £$ & 11,1 & $r, v$ & 1,0 & $r, q$ & أفكر أكثر فى الهجرة \\
\hline$\checkmark, \cdot$ & $7, \cdot$ & т,. & $\varepsilon, q$ & $\ulcorner, \wedge$ & $0, r$ & $1, \wedge$ & 1,1 & $r, \varepsilon$ & أفكر أقل فى الهجرة \\
\hline$\cdot, 0$ & $1, \wedge$ & $\cdot, 1$ & 1,1 & $\cdot, v$ & $1, r$ & 1,7 & $1, r$ & 1,9 & لم اعد أفكر في الهجرة \\
\hline$i r, Y$ & $v_{\cdot}, \varepsilon$ & $\neg \cdot, Y$ & Vv, T & $\wedge \uparrow, \wedge$ & $v_{0, .}$ & QY, r & $90, r$ & $\wedge 9, \varepsilon$ & لا، الثورة ليس لها علاقة بالهجرة \\
\hline$(\vee \wedge \curlywedge)$ & $(1 \wedge 4)$ & $($ (.r) & $(1,701)$ & $(\& Y T)$ & $(1, Y Y \wedge)$ & $(1 \cdot, 190)$ & $(0, \wedge r r)$ & $(0, \cdot 7 r)$ & 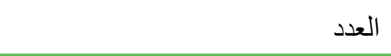 \\
\hline
\end{tabular}




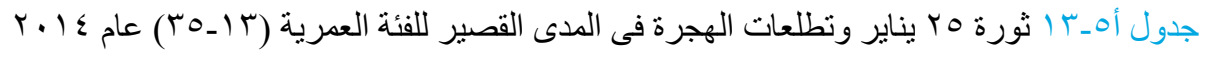

\begin{tabular}{|c|c|c|c|}
\hline 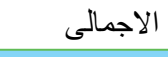 & & 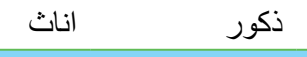 & \\
\hline & & & منذ متى بدأتم التفكير في الهجرة؟ \\
\hline 09,1 & ז'ז & ov, q & 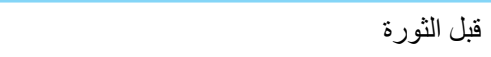 \\
\hline$\varepsilon \cdot, 9$ & r & $\varepsilon r, r$ & 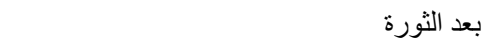 \\
\hline \multirow[t]{2}{*}{$(\vee \wedge ৭)$} & $(17 V)$ & $($ TrY) & 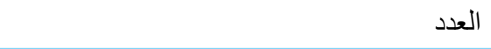 \\
\hline & & & هل تتخذ أي خطو ات للهجرة أم أنها مجرد فكرة؟ \\
\hline $1 \cdot, 0$ & $r, \wedge$ & 11,0 & نعم، لقد بدأت في وضع خطط \\
\hline$r V, r$ & 19,1 & $r q, r$ & لم اضع أى خطط بعد \\
\hline \multirow[t]{2}{*}{$\pi, r$} & $V r, \varepsilon$ & $09, r$ & لم افكر مطلقا \\
\hline & & & هل قام أحد بالتأثير عليك لإتخاذ قرار الهجرة \\
\hline $\mathrm{v}, \mathrm{v}$ & 10,1 & lA,r & نعم \\
\hline \multirow[t]{2}{*}{$\Delta r, r$} & $\wedge \varepsilon, r$ & $\wedge, \wedge$ & ע \\
\hline & & & من هم أكثر من اثروا على قر ارك بالهجرة: \\
\hline 7,0 & 9,7 & $0, \wedge$ & 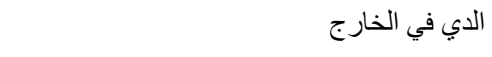 \\
\hline$\cdot, \varepsilon$ & $r, \varepsilon$ & $\cdot, \cdot$ & 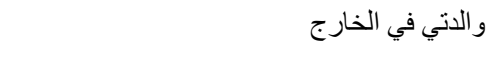 \\
\hline rı, & $1 \cdot, \varepsilon$ & rq, 9 & 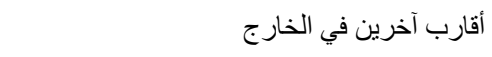 \\
\hline$\varepsilon \cdot, 1$ & rt, & $\leqslant 1,9$ & الأصدقاء المصريين في الخارج \\
\hline $0, r$ & $0, r$ & $0, r$ & و الدي في مصر \\
\hline$\cdot, 7$ & $\cdot, \cdot$ & $\cdot, \mathrm{V}$ & و الدتي في مصر \\
\hline $0, v$ & Ir,r & $\varepsilon, 1$ & أقارب آخرين في مصر \\
\hline $1 \cdot, 0$ & $1 \cdot, 7$ & $1 \cdot, \varepsilon$ & أصدقاء في مصر \\
\hline r,q & $1 \%, 0$ & $\cdot, \varepsilon$ & القرين الأجنبى \\
\hline$\cdot, 7$ & $\cdot, \cdot$ & $\cdot, \mathrm{V}$ & سماسرة الهجرة \\
\hline$\cdot, \mathrm{v}$ & $\cdot, \cdot$ & $\cdot, 9$ & صاحب العمل المحلي السابق / الحالي \\
\hline$\cdot, \mathrm{V}$ & $r, v$ & $\cdot, \cdot$ & مؤسسة تعليمية \\
\hline$(1+4)$ & $\left(\Upsilon^{\top}\right)$ & $(11 \cdot)$ & 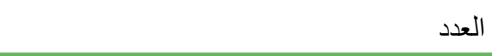 \\
\hline
\end{tabular}




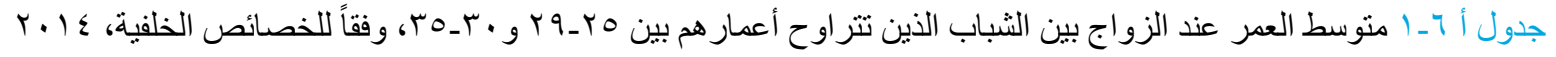

\begin{tabular}{|c|c|c|c|c|c|c|}
\hline \multicolumn{3}{|c|}{ الثباب في الفئة العمرية ـــــــ } & \multicolumn{3}{|c|}{ الثباب في الفئة العمرية هب_qج } & \multirow[b]{3}{*}{ المنطقة } \\
\hline 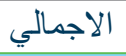 & اناث & 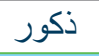 & 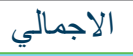 & اناث & ذكور & \\
\hline & & & & & & \\
\hline$r \varepsilon$ & r) & rV & r & r) & ro & محافظات حضرية \\
\hline r & r) & rq & rr & r) & ro & حضر وجه بحري \\
\hline Yr & $r$. & T & rr & r. & ro & ريف وجه بحري \\
\hline r & r) & ro & $r \varepsilon$ & ri & ד ז & حضر وجه قبلي \\
\hline r) & 19 & ro & r & 19 & $r \varepsilon$ & ريف وجه قبلي \\
\hline \multirow[t]{2}{*}{ r } & r) & ro & r & r. & $r \varepsilon$ & محافظات حدودية \\
\hline & & & & & & محل الاقامة \\
\hline$r \varepsilon$ & r) & $r V$ & r & ri & ro & 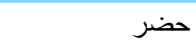 \\
\hline r) & 19 & ro & r) & 19 & $r \varepsilon$ & ريف \\
\hline \multirow[t]{2}{*}{ rt } & r. & ro & rr & r & $r \varepsilon$ & مناطق عشو ائية \\
\hline & & & & & & المستوي التعليمي \\
\hline r. & 19 & $r \varepsilon$ & 19 & 11 & $r \varepsilon$ & أمي \\
\hline 11 & 11 & $r \varepsilon$ & $r$. & 19 & ro & يقر أ ويكتب \\
\hline r) & 19 & ro & r) & 11 & $r \varepsilon$ & إبتدائي \\
\hline$r$. & 11 & rr & r) & $r$. & $r \varepsilon$ & إعدادي \\
\hline$r \varepsilon$ & 19 & rT & rr & $r$. & $r \varepsilon$ & ثانوي عام \\
\hline rr & r. & ro & rr & r. & ro & ثانوي فني \\
\hline$r \varepsilon$ & r & ז & r & $r$. & ז & فوق منوسط \\
\hline \multirow[t]{2}{*}{ YT } & r & rA & $r \varepsilon$ & r & ro & جامعي فأكثر \\
\hline & & & & & & الحالة الوظيفية \\
\hline ro & r. & rT & $r \varepsilon$ & r) & ro & يعمل \\
\hline r & rI & rq & rI & 19 & ro & لا يعطل \\
\hline \multirow[t]{2}{*}{$r}$. & $r$. & ro & $r$. & $r$. & ro & خارج قوة العمل \\
\hline & & & & & & مؤشر الثروة \\
\hline$r$. & 19 & $r \varepsilon$ & $r$. & 19 & $r \varepsilon$ & الأدني \\
\hline rr & $r$. & ro & rr & $r$. & $r \varepsilon$ & الثاني \\
\hline rr & $r$. & ro & rI & $r$. & ro & الأوسط \\
\hline rr & $r$. & rT & r & $r$. & ro & الر ابع \\
\hline \multirow[t]{2}{*}{$r \varepsilon$} & rr & rV & $r \varepsilon$ & rr & ro & الأعلى \\
\hline & & & & & & الفوج \\
\hline rq & rA & rq & $r \varepsilon$ & r & ro & $\left.r \cdot 1 \leqslant-r_{+}\right)$. \\
\hline$r \varepsilon$ & r & ro & $r$. & 19 & rr & $r \ldots q-r \ldots o$ \\
\hline 19 & 19 & ri & iv & iv & 19 & قبل عام ع . . r \\
\hline rY & $r$. & rY & rY & $r$. & ro & الاجمالي \\
\hline$(1, \mathrm{~V} / \mathrm{l})$ & $(1, \cdot 10)$ & $(7 \leq 7)$ & $(1, Y \Gamma I)$ & $(1,1 \vee 7)$ & $(000)$ & حجم العينة \\
\hline
\end{tabular}




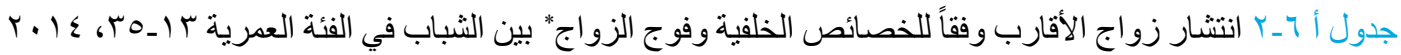

\begin{tabular}{|c|c|c|c|}
\hline الاجمالي & اناث & ذكور & \\
\hline & & & الفئة العمرية \\
\hline TM, r & $r_{v}, 1$ & $\cdot, \cdot$ & $V_{-} \mid T$ \\
\hline$r q, q$ & $r \Lambda, \Lambda$ & $r \varepsilon, r$ & $r \varepsilon_{-} \mid \lambda$ \\
\hline$r_{0, r}$ & $r v, 1$ & $r r, 0$ & rq_ro \\
\hline \multirow[t]{2}{*}{$r V, r$} & $r \wedge, 1$ & $r, 1$ & ro_r. \\
\hline & & & المنطقة \\
\hline $19, v$ & $Y v, \lambda$ & $r r, 0$ & محافظات حضرية \\
\hline Ir,r & 11,1 & $1 \leqslant, 0$ & حضر وجه بحري \\
\hline $\mid v, v$ & $1 \wedge, \varepsilon$ & 17,7 & ريف وجه بحري \\
\hline$\varepsilon \cdot, 1$ & $\varepsilon r, q$ & ri, r & حضر وجه قبلي \\
\hline$\varepsilon \leqslant, 0$ & $\leq 0,0$ & $\varepsilon r, r$ & ريف وجه قبلي \\
\hline \multirow{2}{*}{$r, 0$} & $\varepsilon \cdot, r$ & $\varepsilon 0,7$ & محافظات حدودية \\
\hline & & & محل الاقامة \\
\hline$r, \cdot$. & $r, r$ & $r, r$ & حضر \\
\hline$r \cdot, r$ & 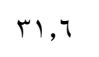 & $r v, r$ & ريف \\
\hline \multirow[t]{2}{*}{ rr, r } & $r \cdot, l$ & $r_{0, \lambda}$ & مناطق عشو ائية \\
\hline & & & المستوي التعليمي \\
\hline rY, r & $r r,$. & $r q,$. & أمي \\
\hline$\varepsilon 1, \wedge$ & $\varepsilon 1,0$ & $\varepsilon r, Y$ & يقرأ ويكتب \\
\hline$\Gamma, \Lambda$ & ri, & $r, \lambda$ & إبندائي \\
\hline$r_{1, \varepsilon}$ & $r \varepsilon, \wedge$ & $r, \cdot$ & إعدادي \\
\hline$r, \varepsilon$ & $r, \cdot$ & $r, r$ & ثنانوي عام \\
\hline r৯,. & $r V, r$ & $r_{\Lambda, Y}$ & ثانوي فني \\
\hline$r, Y$ & $i v, v$ & $r v, \lambda$ & فوق متوسط \\
\hline \multirow[t]{2}{*}{$17, \wedge$} & $i v, r$ & 17,1 & جامعي فأكثر \\
\hline & & & الحالة الوظيفية \\
\hline$r q, q$ & 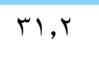 & $r_{0, q}$ & بعمل \\
\hline IV,T & $10, \varepsilon$ & $r, r$ & لا يعمل \\
\hline \multirow[t]{2}{*}{ rA,O } & $r \Lambda, \varepsilon$ & $r, \tau$ & خارج قوة العمل \\
\hline & & & مؤشر الثروة \\
\hline$r$ & $r v, \varepsilon$ & rr,q & الأدني \\
\hline r & rr, r & $r q, r$ & الثاني \\
\hline$r v, \Lambda$ & $r V, r$ & $r \wedge, q$ & الأوسط \\
\hline$r \varepsilon, \wedge$ & $r_{0, r}$ & $r, \varepsilon$ & الر ابع \\
\hline \multirow[t]{2}{*}{19,1} & 19,7 & $\mid \wedge, r$ & الأعلى \\
\hline & & & الفوج \\
\hline$r \varepsilon, q$ & $r_{0,4}$ & $r \varepsilon, r$ & $r \cdot 1 \leq-r \cdot 1$. \\
\hline 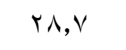 & $r q, r$ & $r V, 0$ & $r \ldots q-r \ldots o$ \\
\hline$r \cdot, \wedge$ & $\Gamma_{\cdot}, \varepsilon$ & rT, & قبل عام ع . . r \\
\hline$r V, \varepsilon$ & $r \wedge, r$ & rฯ, & الاجمالي \\
\hline$(1, r r \cdot)$ & $(90 \varepsilon)$ & (דיז) & حجم العينة \\
\hline
\end{tabular}

* فوج الزواج: تتبع الحالة الاجتماعية لمجمو عة من المستهوفين في فترات زمنية محددة. 


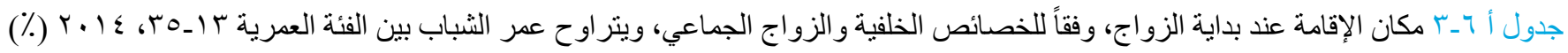

\begin{tabular}{|c|c|c|c|c|c|c|c|c|}
\hline \multicolumn{2}{|c|}{ يعيشون مستقلين } & \multicolumn{2}{|c|}{ مع حد تاني } & \multicolumn{2}{|c|}{ مع أسرة الزوج/الزوجة } & \multicolumn{2}{|c|}{ مع أسرته/أسرتها } & \multirow[b]{3}{*}{ الفئة العمرية } \\
\hline \multirow[t]{2}{*}{ اناث } & ذكور & اناث & ذكور & اناث & ذكور & اناث & ذ ذكور & \\
\hline & & & & & & & & \\
\hline$T Y, \varepsilon$ & & $\cdot, \cdot$ & & $r, 1$ & & $\varepsilon, 7$ & & $\left|V_{-}\right| T$ \\
\hline Tו,O & 00,1 & $\cdot, \varepsilon$ & ., & $r \cdot, \wedge$ & १,६ & $r, \varepsilon$ & $r \varepsilon, \wedge$ & $r \varepsilon_{-1 \Lambda}$ \\
\hline Tr, & or,A & $\cdot, \varepsilon$ & . r & Tr, & $11,$. & $r, 1$ & ro, 9 & rq_ro \\
\hline \multirow[t]{2}{*}{70,7} & $0 \wedge, v$ & $\cdot, \wedge$ & $\cdot, 1$ & re, & ir,q & 1,7 & $r \Lambda, r$ & ro_r. \\
\hline & & & & & & & & المنطقة \\
\hline$v \wedge, r$ & $T V,$. & $\cdot, 0$ & $\cdot, r$ & $17, r$ & $1 \cdot, v$ & $\varepsilon, 9$ & $r, \cdot$ & محافظات حضرية \\
\hline$\wedge \vee, q$ & $v \varepsilon, v$ & $\cdot, r$ & , , & 11,1 & $11, \varepsilon$ & $\cdot, \wedge$ & $1 \%, 9$ & حضر وجه بحري \\
\hline$T V, \Lambda$ & $\Delta \wedge, \wedge$ & $\cdot, \wedge$ & • ६ & rq, & ir,l & $1, \wedge$ & $r \wedge, r$ & ريف وجه بحري \\
\hline rn,1 & $\varepsilon \cdot, \wedge$ & $1, r$ & .,. & $r \cdot, r$ & $0, \wedge$ & $\cdot, 0$ & or, \& & حضر وجه قبلي \\
\hline$\varepsilon v, r$ & $\varepsilon r$, & ., r & .,. & $\leq 9, \wedge$ & $1 \leqslant, r$ & $r, \wedge$ & $\varepsilon r, \wedge$ & ريف وجه قبلي \\
\hline \multirow[t]{2}{*}{$v \varepsilon, 1$} & or,Y & $\cdot, \mathrm{v}$ & .,. & $r, r$ & $\mathrm{r}, \mathrm{V}$ & $r, 0$ & $\varepsilon \cdot, 7$ & محافظات حدودية \\
\hline & & & & & & & & محل الاقامة \\
\hline$v_{0,0}$ & $09, \mathrm{~V}$ & $\cdot, r$ & •,, & $r \cdot, 0$ & $1 \cdot, r$ & $r, v$ & $r q, 9$ & حضر \\
\hline $0 \wedge, 1$ & 01,9 & $\cdot, 0$ & ., r & $r q, r$ & $\mid r, \Lambda$ & $r, r$ & ro, & ريف \\
\hline \multirow[t]{2}{*}{$\wedge 9, r$} & VY,r & $1,$. & .,. & $q, r$ & $9, \cdot$ & $\cdot, 7$ & IA,V & مناطق عشو ائية \\
\hline & & & & & & & & المستوي التعليمي \\
\hline $1 \ldots$, & $r v, \gamma$ & or,. &., 0 & $\cdot, V$ & ir,. & $\varepsilon \varepsilon, \varepsilon$ & $\varepsilon \wedge, \vee$ & أمي \\
\hline 09,1 & $\varepsilon r, Y$ & $\cdot, \cdot$ & .,. & $r q, \wedge$ & ir, r & $1, r$ & $\varepsilon \varepsilon, r$ & يقر أ ويكتب \\
\hline ov, q & $\leq 9,9$ & $\cdot, \mathrm{v}$ & .,. & rq,. & $i r, v$ & $r, \varepsilon$ & rד, & إبتدائي \\
\hline or,. & $07, \mathrm{~V}$ & $\cdot, \mathrm{V}$ & .,. & $\varepsilon r, Y$ & $1 \%, \varepsilon$ & $r, v$ & $r q, q$ & إعدادي \\
\hline vr,l & $\varepsilon 1,7$ & $\cdot, \cdot$ & .,. & $r \varepsilon, V$ & $1 \%, 0$ & $r, r$ & $\varepsilon \varepsilon, q$ & ثانوي عام \\
\hline$r \Lambda, r$ & $00, \wedge$ & ., \& & $\cdot, r$ & rq, r & Ir,v & $r,$. & $r_{1, \varepsilon}$ & ثانوي فني \\
\hline ᄉı,. & $v \cdot, o$ & $\cdot, \cdot$ & .,. & Kr,o & ir, r & 1,0 & $17, r$ & فوق منوسط \\
\hline \multirow[t]{2}{*}{$\wedge \varepsilon, \gamma$} & $T V, r$ & $\cdot, \varepsilon$ & •, ६ & $1 \pi$, & 7,0 & $r,$. & $r_{0,9}$ & جامعي فأكثر \\
\hline & & & & & & & & الحالة الوظيفية \\
\hline$T V, V$ & ov,. & $\cdot, 0$ & $\cdot, 1$ & $r \wedge, \vee$ & Ir,. & $r, r$ & ri,. & بعمل \\
\hline VY,O & $r_{V}, 0$ & $\cdot, \cdot$ & $\varepsilon, 7$ & ץ & $\varepsilon, v$ & 1,1 & or,r & لا يعمل \\
\hline \multirow[t]{2}{*}{$T \varepsilon, Y$} & $\varepsilon \wedge, \wedge$ & $\cdot, 0$ & .,. & rr,q & $11, r$ & $r, \varepsilon$ & $\varepsilon \cdot$, & خارج قوة العمل \\
\hline & & & & & & & & مؤشر الثروة \\
\hline$\varepsilon \Lambda, \varepsilon$ & $\varepsilon 1$, & 1,1 & $\cdot, r$ & $\varepsilon \wedge, \uparrow$ & $10, r$ & 1,9 & $\varepsilon r, 0$ & الأدني \\
\hline $0 \wedge, 7$ & $\varepsilon \varepsilon, r$ & $\cdot, r$ & ., & $r v, 0$ & 11,1 & ז, & $\varepsilon \varepsilon, Y$ & الثاني \\
\hline $10, \mathrm{~V}$ & $o v, 1$ & •, & . r & $r, r$ & Ir,r & $r, \varepsilon$ & $r \cdot, \varepsilon$ & الأوسط \\
\hline $79, \varepsilon$ & Tr,r & $\cdot, r$ & $\cdot, \varepsilon$ & $r \wedge, r$ & 11,7 & $r, r$ & $r \varepsilon, Y$ & الر ابع \\
\hline$\lambda_{\cdot, l}$ & $T V, \Lambda$ & .,r & .,. & $\mid v, \Lambda$ & $9, \mathrm{~V}$ & 1,9 & rr,o & الأعلى \\
\hline $7 \varepsilon, 9$ & 07, &., 0 & $\cdot, r$ & rY, & $11, v$ & $r, \varepsilon$ & rr, & الاجمالي \\
\hline$(r, l \cdot \wedge)$ & $(A \Gamma \varepsilon)$ & $(10)$ & $(r)$ & (97.) & $(1 \leqslant r)$ & $(79)$ & $(r V \cdot)$ & حجم العينة \\
\hline
\end{tabular}




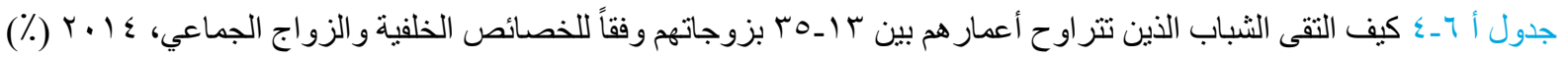

\begin{tabular}{|c|c|c|c|c|c|}
\hline آخر & الشخصبكات & الأقارب & الجير ان & المدرسل / العمل & \\
\hline & & & & & النوع \\
\hline$\cdot, \wedge$ & rq, ६ & ro,A & ri,. & $r, \cdot$ & ذكر \\
\hline \multirow[t]{2}{*}{1,0} & $\varepsilon \leqslant, 0$ & $r \Lambda, r$ & $r$ r, & r,o & أنثى \\
\hline & & & & & الفئة العمرية \\
\hline$r, T$ & $r \xi, \varepsilon$ & & $r_{0,0}$ & $1, r$ & $\left|V_{-}\right| r$ \\
\hline 1,1 & $\{1, \varepsilon$ & $r q, q$ & $r_{0, T}$ & $r, l$ & $r \varepsilon_{-} \mid \Lambda$ \\
\hline $1, r$ & $\varepsilon r, r$ & ro,o & $r \uparrow, V$ & $r, \varepsilon$ & rq_ro \\
\hline \multirow[t]{2}{*}{ I,r } & & $r v, 1$ & $r_{0, V}$ & $r, \varepsilon$ & ro_r. \\
\hline & & & & & المنطقة \\
\hline$\cdot, V$ & $\varepsilon r, r$ & $19, \mathrm{~V}$ & rI, r & $0, r$ & محافظات حضرية \\
\hline $1, r$ & $O V, \Lambda$ & IT, r & $r r, \wedge$ & $0, \cdot$ & حضر وجه بحري \\
\hline 1,1 & $\varepsilon \wedge, r$ & $1 V, 7$ & $r \cdot, \varepsilon$ & 1,9 & ريف وجه بحري \\
\hline$\cdot, \varepsilon$ & $\leqslant 1,9$ & $\varepsilon \cdot, 1$ & 10, & $r, T$ & حضر وجه قبلي \\
\hline 1,1 & $r 1,9$ & $\varepsilon \varepsilon, r$ & ru, & 1,0 & ريف وجه قبلي \\
\hline \multirow[t]{2}{*}{$\cdot, r$} & $r צ, r$ & $\{r, O$ & rq,q & $1, r$ & محافظات حدودية \\
\hline & & & & & محل الاقامة \\
\hline$\cdot, 9$ & $\varepsilon r, \cdot$ & rr, & rq, 1 & $0, \cdot$ & حضر \\
\hline 1,0 & $\varepsilon \cdot, 7$ & $r \cdot, \cdot$ & $r 4, r$ & $1, v$ & ريف \\
\hline \multirow[t]{2}{*}{$\cdot, \varepsilon$} & $07, Y$ & rr, & $\mid v, \lambda$ & $r, o$ & مناطق عشو ائية \\
\hline & & & & & المستوي التعليمي \\
\hline 1,0 & $r q, r$ & rr, & זч, & $\cdot, 9$ & أمي \\
\hline$r, \varepsilon$ & $r \varepsilon, \tau$ & $\varepsilon 1, \wedge$ & $r, r$ & $\cdot, \cdot$ & يقرأ ويكتب \\
\hline $1, \varepsilon$ & $r \wedge, \wedge$ & $r, q$ & $r \Upsilon, \varepsilon$ & 1,7 & إبتدائي \\
\hline $1, r$ & $\varepsilon 1, v$ & $r_{1,0}$ & $r \varepsilon, \wedge$ & $\cdot, 9$ & إعدادي \\
\hline$\cdot, \cdot$ & $\varepsilon \uparrow, \wedge$ & Y, \& & $r \cdot, 0$ & $1, \varepsilon$ & ثانوي عام \\
\hline $1, r$ & $\varepsilon r, r$ & $r v, A$ & זч,. & $1, \lambda$ & ثانوي فني \\
\hline$\cdot, \cdot$ & $\leq 9,1$ & rr, & $r r, v$ & $0, r$ & فوق متوسط \\
\hline \multirow[t]{2}{*}{$1, r$} & $\sum \uparrow, \vee$ & 17,0 & $r v, r$ & $\Lambda, r$ & جامعي فأكثر \\
\hline & & & & & الحالة الوظيفية \\
\hline$\cdot, \wedge$ & $r q, 9$ & $r \uparrow, \uparrow$ & $r \wedge, \Upsilon$ & $\varepsilon, 1$ & يعمل \\
\hline$r, \tau$ & $\varepsilon v, q$ & $1 V, T$ & $\lceil\wedge, \wedge$ & $r, \cdot$ & لا يعمل \\
\hline \multirow[t]{2}{*}{ l, } & $\varepsilon \varepsilon, r$ & $r \Lambda, 0$ & $r \leqslant, 1$ & $1, v$ & خارج قوة العمل \\
\hline & & & & & مؤشر الثروة \\
\hline $1, \varepsilon$ & ri,. & rฯ, ६ & $r \varepsilon, T$ & 1,7 & الأدني \\
\hline $1, \cdot$ & $r \wedge, \varepsilon$ & r1,0 & $r v, V$ & 1,0 & الثاني \\
\hline $1, \cdot$ & $\varepsilon \varepsilon, 1$ & $r v, \Lambda$ & $r \leqslant, T$ & $r, 0$ & الأوسط \\
\hline $1, r$ & $\varepsilon r, 0$ & $r \leqslant, V$ & $r V, T$ & $r, q$ & الر ابع \\
\hline 1,0 & $\varepsilon 9, \wedge$ & $1 \Lambda, V$ & ro,T & $\varepsilon, \varepsilon$ & الأعلى \\
\hline $1, r$ & $\varepsilon r, Y$ & $r V, \varepsilon$ & 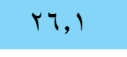 & T,V & الاجمالي \\
\hline$(7 \cdot)$ & $(r, \cdot 11)$ & $(1, r 9 \wedge)$ & $(1, r r \varepsilon)$ & $(11 \vee)$ & حجم العينة \\
\hline
\end{tabular}




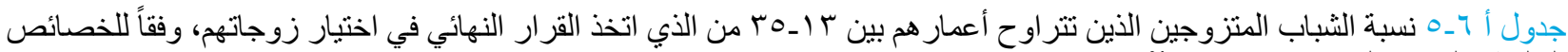

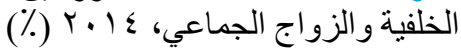

\begin{tabular}{|c|c|c|c|}
\hline قرار مشترك مع الأهل & 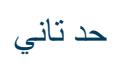 & بنفسي & \\
\hline & & & النوع \\
\hline YI,V & $1 \leqslant, r$ & $0 \leqslant, 1$ & ذكر \\
\hline \multirow[t]{2}{*}{$\varepsilon r, \varepsilon$} & $r v, \varepsilon$ & $r \cdot, r$ & أنثى \\
\hline & & & الفئة العمرية \\
\hline$r \leqslant, 0$ & $r q, r$ & ru, & $\mid V_{-1 T}$ \\
\hline rq, ६ & $r \varepsilon, \uparrow$ & $r 4,1$ & $r \varepsilon_{-11}$ \\
\hline$r \Lambda, r$ & $r q, \cdot$ & $r, \wedge$ & rq_ro \\
\hline \multirow[t]{2}{*}{$r q,}$. & $r_{0,0}$ & ro,o & ro_r. \\
\hline & & & المنطقة \\
\hline$r_{0, r}$ & $1 \varepsilon, 1$ & $0 ., v$ & محافظات حضرية \\
\hline$\varepsilon \leqslant, \varepsilon$ & $r q, r$ & r.,. & حضر وجه بحري \\
\hline rr,v & rr,o & N & ريف وجه بحري \\
\hline Tr,r & $1 \wedge$, & 11,9 & حضر وجه قبلي \\
\hline r৭, ६ & $r_{0, \varepsilon}$ & $r_{0, r}$ & ريف وجه قبلي \\
\hline \multirow[t]{2}{*}{$r_{0, \lambda}$} & $r, 1$ & $r, 1$ & محافظات حدودية \\
\hline & & & محل الاقامة \\
\hline$r q, r$ & IV,r & $\varepsilon r, \xi$ & حضر \\
\hline r r & qr,q & $r q, \wedge$ & ريف \\
\hline \multirow[t]{2}{*}{ or, v } & $r_{0, \Lambda}$ & $r_{\cdot}, \varepsilon$ & مناطق عشو ائية \\
\hline & & & المستوي التعليمي \\
\hline r.,. & $\varepsilon 1, r$ & Yr,A & أمي \\
\hline$\varepsilon 1, v$ & $r \cdot, 0$ & $r V, \Lambda$ & يقرا و يكتب \\
\hline Tr, & $r \cdot, 0$ & די, & إبتدائي \\
\hline ro,A & r ז, & $r \cdot, q$ & إعدادي \\
\hline$\mu_{\mu, \varepsilon}$ & $r \wedge, r$ & $r v, q$ & ثانوي عام \\
\hline$\{1, \varepsilon$ & r৯,. & $r \cdot, r$ & ثانوي فني \\
\hline$\varepsilon \cdot, \varepsilon$ & $r r, 0$ & Tr, & فوق متوسط \\
\hline \multirow[t]{2}{*}{$r q, v$} & $1 \wedge, 0$ & $\varepsilon 1, \wedge$ & جامعي فأكثر \\
\hline & & & الحالة الوظيفية \\
\hline rr, & $i v, \varepsilon$ & $0 ., 0$ & يعمل \\
\hline$\varepsilon \varepsilon, V$ & $r q, r$ & r., & لا يعمل \\
\hline \multirow[t]{2}{*}{$\varepsilon r, \wedge$} & $r v, r$ & $r_{\cdot, \cdot,}$ & خارج قوة العمل \\
\hline & & & مؤشر الثروة \\
\hline rq, ६ & ro, 1 & $r_{0,0}$ & الأدني \\
\hline$r q, \wedge$ & $r q, r$ & $r \cdot, 0$ & الثاني \\
\hline$r_{V}, 0$ & $r \cdot, v$ & $r, \wedge$ & الأوسط \\
\hline r., & $r \wedge, 1$ & $r_{0, \Lambda}$ & الر ابع \\
\hline$\varepsilon, 0$ & $r r, \Lambda$ & $r_{0, v}$ & الأعلى \\
\hline$\lceil\wedge, \nu$ & $r q, r$ & rr, & الاجمالي \\
\hline$(1, \wedge \mid \wedge)$ & $(1, \leqslant \leqslant T)$ & $(1, \leqslant 09)$ & حجم العينة \\
\hline
\end{tabular}




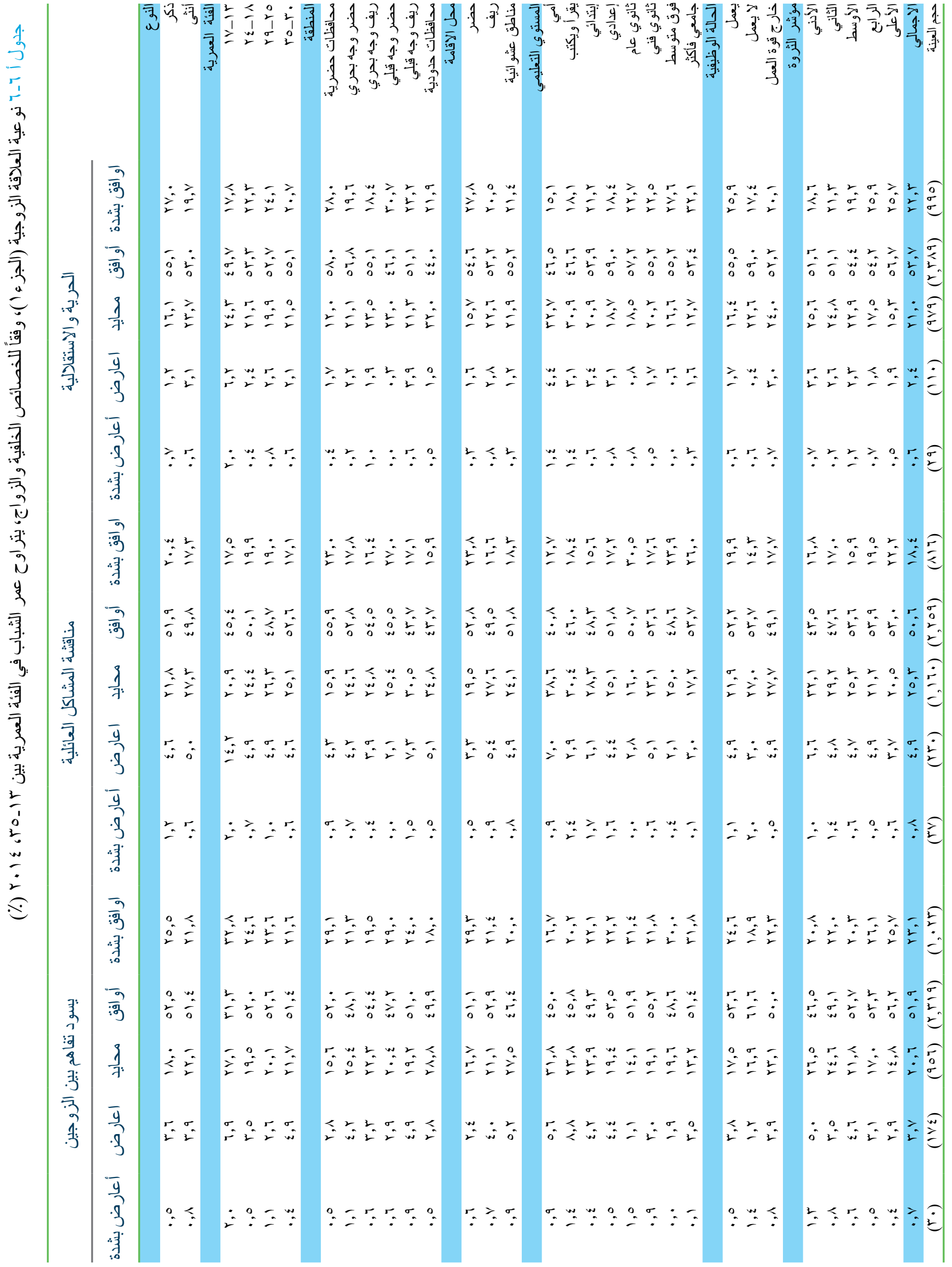




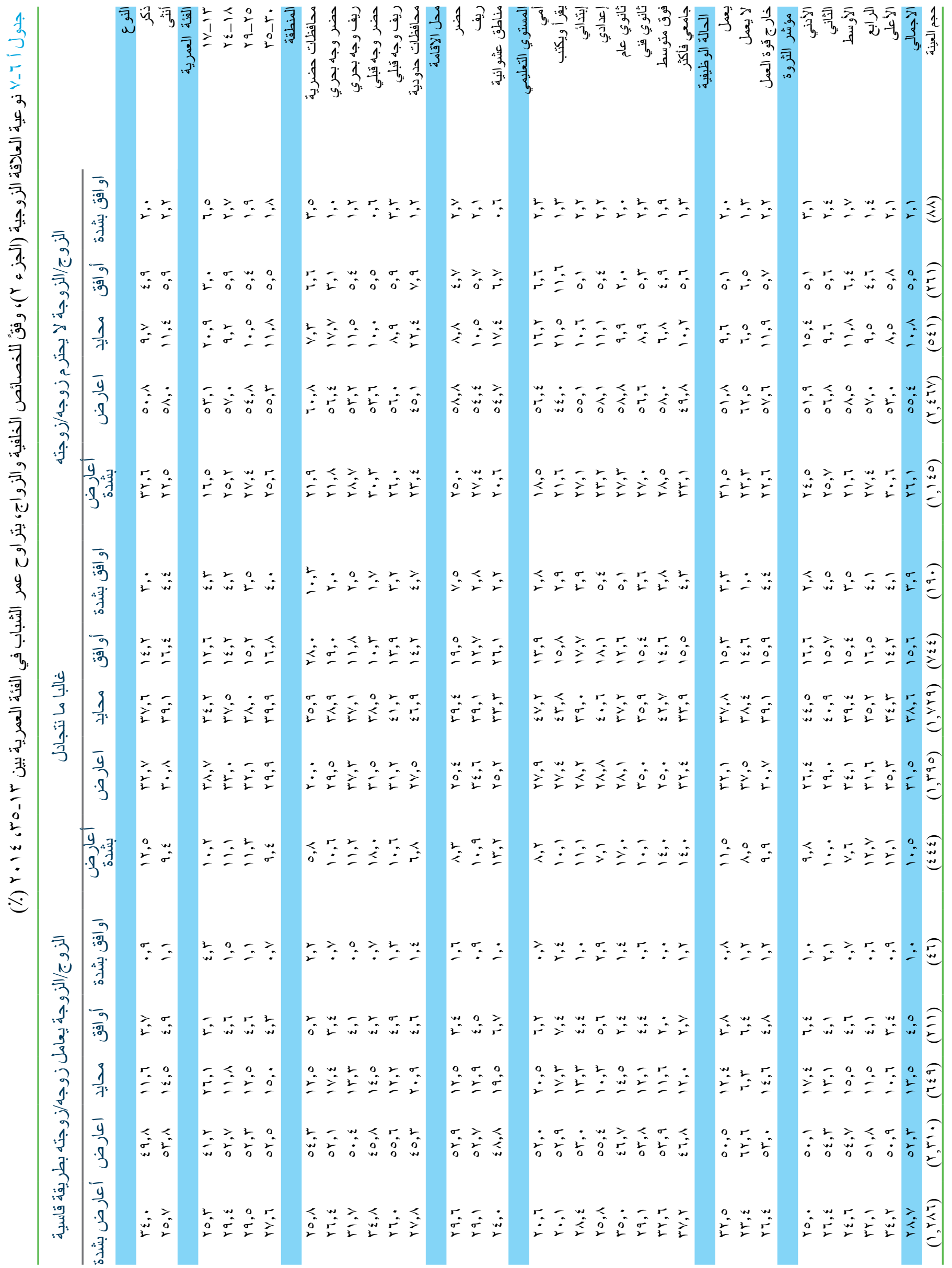




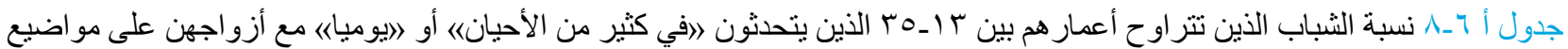

\begin{tabular}{|c|c|c|c|c|c|}
\hline بين الزوجة الحميمية & مناقتشة أحوال الأطفال & كيف تسير & مشـاكل في العمل أو اسي & خطط المستقبل & \\
\hline & & & & & النوع \\
\hline 79,1 & $\Delta r, r$ & $\wedge \uparrow, \wedge$ & vi,v & $\vee \wedge, \vee$ & ذكر \\
\hline \multirow[t]{2}{*}{$T \leqslant, \wedge$} & $\vee q, 7$ & $\wedge, 0$ & 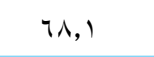 & vi,r & أنثى \\
\hline & & & & & الفئة العمرية \\
\hline (T, ז & $V Y, \Lambda$ & $v_{0, q}$ & 09,7 & 71,9 & IV-IT \\
\hline $79, \varepsilon$ & v৭, 1 & $\wedge r, \wedge$ & $T V, \varepsilon$ & $v \leqslant, v$ & $r \varepsilon_{-} \mid \Lambda$ \\
\hline$T V, 1$ & $\lambda \cdot, 9$ & $\wedge \varepsilon, r$ & $\uparrow \wedge, \wedge$ & $V Y, V$ & rq_ro \\
\hline \multirow{2}{*}{$T \varepsilon}$, & $\wedge, r$ & Ar,l & $v_{1}, \varepsilon$ & $v \leqslant, 9$ & ro_r. \\
\hline & & & & & المنطقة \\
\hline$T 4, Y$ & $\Lambda_{\cdot}, \mathrm{T}$ & NT,r & $V Y, \varepsilon$ & $V T, O$ & محافظات حضرية \\
\hline$V r, O$ & $\wedge, \uparrow$ & $q_{\cdot, \cdot}$ & $\wedge \uparrow, \uparrow$ & $\lambda v, v$ & حضر وجه بحري \\
\hline$T \leqslant, q$ & $\wedge r, \wedge$ & $10, r$ & $v, v$ & $V Y, T$ & ريف وجه بحري \\
\hline$V r, V$ & $\checkmark V, O$ & $v v, 0$ & 79,0 & vฯ, & حضر وجه قبلي \\
\hline ד, & $v_{0,0}$ & $\mathrm{v} \wedge, 0$ & $0 \wedge, 7$ & $T \varepsilon$, & ريف وجه قبلي \\
\hline \multirow[t]{2}{*}{$v i, t$} & $\Delta r, 0$ & 10,7 & $\vee \wedge, \wedge$ & $\lambda_{\cdot,, l}$ & محافظات حدودية \\
\hline & & & & & محل الاقامة \\
\hline $74, \wedge$ & $v_{q, \cdot}$ & $\Delta r, v$ & $\vee, \wedge$ & Vr,T & حضر \\
\hline$T \leqslant, r$ & $\vee १, 0$ & Ar, r & 70,9 & $v 1,0$ & ريف \\
\hline \multirow[t]{2}{*}{ vq,. } & 91,1 & $q_{\cdot, v}, v$ & $\wedge \vee, o$ & 91,0 & مناطق عشوائية \\
\hline & & & & & المستوي التعليمي \\
\hline $07, r$ & $V r, T$ & $v \varepsilon, 1$ & $\pi, r$ & $4 r, 9$ & أمي \\
\hline 7,1 & $\vee \neg, r$ & $\vee १, \wedge$ & $79, \cdot$ & $\vee \uparrow, \wedge$ & يقرأ ويكتب \\
\hline 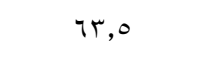 & vq,r & ᄉ , r & $\pi, \Lambda$ & $10,$. & إبتدائي \\
\hline Tr,o & $v \vee, r$ & $\wedge 1,0$ & Tr,o & $77, V$ & إعدادي \\
\hline$v_{0,1}$ & $\wedge \vee$, & $10, \varepsilon$ & $V Y, q$ & $\lambda_{\cdot,, 0}$ & ثانوي عام \\
\hline $7 \lambda, 0$ & $\wedge r, \wedge$ & $\wedge \varepsilon, \varepsilon$ & vi,. & Vฯ,, & ثانوي فني \\
\hline $70,$. & $\wedge, \varepsilon$ & $\wedge \wedge, 0$ & $V Y, r$ & $\wedge 1,0$ & فوق متوسط \\
\hline \multirow[t]{2}{*}{$V \varepsilon, r$} & $\Lambda \varepsilon, 1$ & $\wedge \wedge, \varepsilon$ & $\vee ৭, \wedge$ & $\lambda \varepsilon, \Gamma$ & جامعي فأكثر \\
\hline & & & & & الحالة الوظيفية \\
\hline $7 \wedge, 9$ & $\Lambda r, \varepsilon$ & $\Lambda_{T}, \mathrm{~V}$ & $V r, \varepsilon$ & $\vee \wedge, \vee$ & يعمل \\
\hline 71,7 & $\wedge \varepsilon, r$ & $\wedge \wedge, 0$ & 77,0 & $v \wedge, 0$ & لا يعمل \\
\hline \multirow[t]{2}{*}{$7 \leqslant, 9$} & vq,. & $\Lambda_{\cdot}, \mathrm{v}$ & IT, & $v \cdot, r$ & خارج قوة العمل \\
\hline & & & & & مؤشر الثروة \\
\hline $0 \leqslant, 9$ & VY,T & $V v, \varepsilon$ & $O V, r$ & $7, \cdot$ & الأدني \\
\hline 77,0 & $\vee q, v$ & $\Delta r, 0$ & 70,1 & $v_{\cdot}, \cdot$ & الثاني \\
\hline$v \cdot, r$ & $\Delta r, r$ & $\wedge \varepsilon$, & Vr,r & $\vee \wedge, 0$ & الأوسط \\
\hline $79, r$ & Nr,r & 10,r & $V r, T$ & $v \wedge, 0$ & الر ابع \\
\hline $79, r$ & $\wedge r, \wedge$ & $\wedge_{T, T}$ & vo,l & $v q, r$ & الأعلى \\
\hline $77, r$ & $\wedge \cdot, 7$ & $\wedge r, \varepsilon$ & $79, \varepsilon$ & $V r, q$ & الاجمالي \\
\hline$(r, \cdot r r)$ & $(r, \pi 4 \pi)$ & $(\ulcorner, Y \wedge \vee)$ & $(r, \wedge r)$ & $(r, r \circ \varepsilon)$ & حجم العينة \\
\hline
\end{tabular}


جدول أ أ ـا متوسط تكلفة الثبكة و التكلفة الإجمالية للزو اج، وفقاً للخصائص الخلفية، و الزواج، ينر اوح عمر الثباب في الفئة العمرية بين r.

\begin{tabular}{|c|c|c|}
\hline التكلفة الاجمالية للزواج & الشبكة & \\
\hline & & النوع \\
\hline$r r, q 1$. & 0,991 & ذكر \\
\hline \multirow[t]{2}{*}{$r_{r}, \varepsilon l}$. & $0,01 r$ & أنثى \\
\hline & & الفئة العمرية \\
\hline ro,09r & $v, r T v$ & IV-IT \\
\hline$r q, r \leq \Lambda$ & $7,9 \wedge \leq$ & $r \varepsilon_{-} \mid \wedge$ \\
\hline$r r, \varepsilon \wedge \varepsilon$ & $0, Y \cdot 0$ & rq-ro \\
\hline \multirow{2}{*}{$r \cdot, r q \varepsilon$} & $\varepsilon, 10$ & • فأكثر \\
\hline & & المنطقة \\
\hline$\varepsilon r, q \leqslant r$ & $\varepsilon, \cdot r$ & محافظات حضرية \\
\hline$\varepsilon 7, \cdot \wedge 9$ & 7,194 & حضر وجه بحري \\
\hline rq, r. & $0, £ \cdots$ & ريف وجه بحري \\
\hline$r \cdot, \leqslant \leqslant V$ & 0,947 & حضر وجه قبلي \\
\hline \multirow[t]{2}{*}{$r \cdot, \cdot \cdot v$} & 7,109 & ريف وجه قبلي \\
\hline & & 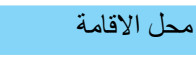 \\
\hline$r q, q \cdot 1$ & $0, \cdot r r$ & حضر \\
\hline \multirow{2}{*}{$r \cdot, o v V$} & $T, \cdot \leqslant r$ & ريف \\
\hline & & المستوي التعليمي \\
\hline$r, r \cdot \varepsilon$ & $\varepsilon, T \vee \wedge$ & أمي \\
\hline$r, T \wedge \varepsilon$ & 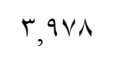 & يقر أ ويكتب \\
\hline$r_{0, T r}$ & $\varepsilon, Y V Y$ & إبتدائي \\
\hline$r \cdot$, VAr & 0,011 & إعدادي \\
\hline$r \wedge, \wedge \vee\urcorner \tau$ & $7,1.0$ & ثانوي عام \\
\hline rr, VTr & 0,071 & ثانوي فني \\
\hline ч৭, Ат. & $T, Y \cdot V$ & فوق منوسط \\
\hline \multirow[t]{2}{*}{$01, \leq \leq \varepsilon$} & $\wedge, r \circ \Lambda$ & جامعي فاكثر \\
\hline & & الحالة الوظيفية \\
\hline$r r, r \cdot \Lambda$ & $7, \cdot T V$ & يعمل \\
\hline$r q, 417$ & $0,71 \leq$ & لا يعمل \\
\hline \multirow[t]{2}{*}{$r r, 0 \leqslant q$} & $0,0 . \varepsilon$ & خارج قوة العمل \\
\hline & & مؤشر الثروة \\
\hline $1 V, 110$ & $\varepsilon, r q \varepsilon$ & الأدني \\
\hline$r q, \cdot 7$. & $0, \leqslant \leqslant r$ & الثناني \\
\hline$r \leqslant, 1 \wedge 9$ & $\varepsilon, 97 r$ & الأوسط \\
\hline$r v, r \ldots$ & \urcorner,$\cdot \wedge V$ & 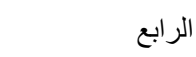 \\
\hline \multirow[t]{2}{*}{0,007} & $V,\{\lambda v$ & الأعلى - الى \\
\hline & & الفوج \\
\hline$r \wedge, \varepsilon V r$ & $7,9 \leq 9$ & $\left.r \cdot 1 \leqslant-r_{+}\right)$. \\
\hline$r \cdot, 010$ & $0, \cdot v_{0}$ & $r \ldots q_{-} \ldots .$. \\
\hline$r \varepsilon, 10 r$ & r,qтะ & قبل عام ع ... F \\
\hline rT, rVo & $0, Y Y V$ & الاجمالي \\
\hline$(\Gamma, \Upsilon \wedge 0)$ & $(\varepsilon, \vee \backslash \vee)$ & حجم العينة \\
\hline
\end{tabular}




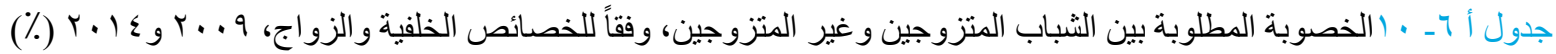

\begin{tabular}{|c|c|c|c|c|c|c|}
\hline & متزوج حاليا & & & لم يسبق له الزو اج & & \\
\hline 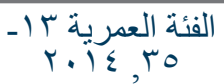 & 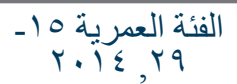 & 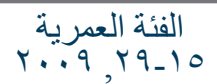 & 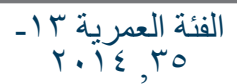 & 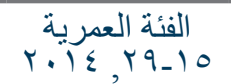 & الفئة العمرية و 10... & \\
\hline & & & & & & النوع \\
\hline$r, r$ & $r, 1$ & $r, V$ & $r,$. & $r,$. & $r, V$ & ذكر \\
\hline$r, r$ & $r, l$ & r,q & r,q & r,q & $r, 0$ & أنثى \\
\hline & & & & & & الفئة العمرية \\
\hline$r, r$ & - & - & $r, q$ & - & - & IV-IT \\
\hline- & $r, r$ & $r, \varepsilon$ & - & r,q & $r, \uparrow$ & $1 V_{-10}$ \\
\hline r,. & $r,$. & $r, \wedge$ & r,. & $r,$. & $r, V$ & $r \varepsilon_{-} \mid \lambda$ \\
\hline$r, r$ & $r, r$ & $r, q$ & r,q & $r, q$ & $r, T$ & rq_ro \\
\hline$r, r$ & - & - & $r,$. & - & - & 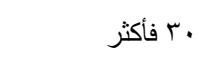 \\
\hline & & & & & & المنطقة \\
\hline$r, Y$ & $r, Y$ & $r, 0$ & $r, \uparrow$ & $r, T$ & $r, 0$ & محافظات حضرية \\
\hline$r, \cdot$ & $r, q$ & $r, \uparrow$ & $r, r$ & $r, Y$ & r,o & حضر وجه بحري \\
\hline$r, \cdot$ & r,q & $r, \gamma$ & $r, \mathrm{r}$ & $\curlyvee, \wedge$ & $r, T$ & ريف وجه بحري \\
\hline$r, \uparrow$ & $r, 0$ & $r, q$ & $r, r$ & $r, r$ & $r, \wedge$ & حضر وجه قبلي \\
\hline 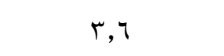 & $r, 0$ & $r, r$ & r, & r, & $r, q$ & ريف وجه قبلي \\
\hline$r, r$ & $r, r$ & $r, r$ & $r, q$ & $r, q$ & $r, \cdot$ & محافظات حدودية \\
\hline & & & & & & محل الاقامة \\
\hline$r, q$ & r,q & $r, T$ & $r, \mathrm{r}$ & $r, Y$ & r,o & حضر \\
\hline r & $r, r$ & $r, q$ & $r, \cdot$ & $r, 1$ & $r, v$ & ريف \\
\hline$r, 1$ & $r, 1$ & $r, Y$ & $r, q$ & $r, q$ & $r, 0$ & مناطق عشو ائية \\
\hline & & & & & & المستوي التعليمي \\
\hline$r, \uparrow$ & $r, \varepsilon$ & $r, r$ & $r, r$ & $r, r$ & r, 9 & أمي \\
\hline r r & $r, 1$ & $r, \cdot$ & $r, \wedge$ & $r, q$ & $r, \xi$ & يقرأ ويكتب \\
\hline$r, r$ & $r, r$ & $r, \wedge$ & r,. & $r, \cdot$ & $r, r$ & إبتدائي \\
\hline$r, r$ & $r, 1$ & $r,$. & $r,$. & $r, \cdot$ & $r, r$ & إعدادي \\
\hline$r, l$ & $r, 1$ & $r, q$ & $r, v$ & $r, V$ & $r, 0$ & ثانوي عام \\
\hline$r, 1$ & $r, 1$ & $r, v$ & $r,$. & $r, \cdot$ & $r, v$ & ثانوي فني \\
\hline$r, l$ & $r, 1$ & $r, Y$ & $r, \wedge$ & $r, \wedge$ & $r, T$ & فوق متوسط \\
\hline$r, q$ & $r, q$ & $r, \uparrow$ & $r, \wedge$ & $r, \Lambda$ & $r, 0$ & جامعي فأكثر \\
\hline & & & & & & الحالة الوظيفية \\
\hline$r, r$ & $r, 1$ & $r, V$ & $r, \cdot$ & $r, \cdot$ & $r, Y$ & يعمل \\
\hline$r, q$ & $r, \wedge$ & $r, \uparrow$ & $r, \wedge$ & $r, \wedge$ & $r, r$ & لا يعمل \\
\hline$r, r$ & $r, r$ & $r, q$ & $r, q$ & $r, q$ & $r, T$ & خارج قوة العمل \\
\hline & & & & & & مؤشر الثروة \\
\hline r,o & $r, \varepsilon$ & r,l & r, r & $r, r$ & $r, \wedge$ & الأدني \\
\hline$r, r$ & $r, r$ & $r, q$ & $r, l$ & $r, l$ & $r, r$ & الثاني \\
\hline$r, r$ & $r, r$ & $r, q$ & $r, q$ & $r, q$ & $r, Y$ & الأوسط \\
\hline$r, l$ & $r, \cdot$ & $r, \uparrow$ & $\curlyvee, \wedge$ & $r, \wedge$ & $r, r$ & الر ابع \\
\hline$r, q$ & $r, q$ & $r, 0$ & $r, v$ & $r, v$ & $r, \varepsilon$ & الأعلى \\
\hline & & & & & & الفوج \\
\hline$r, \cdot$ & $r, \cdot$ & - & - & - & - & $\left.r \cdot 1 \leqslant-r_{\cdot}\right) \cdot$ \\
\hline$r, r$ & $r, r$ & - & - & - & - & $r \ldots q-r \ldots o$ \\
\hline$r, 0$ & $r, 0$ & - & - & - & - & قبل عام ع . . F \\
\hline$r, r$ & $r, 1$ & $r, \Lambda$ & $r, q$ & $r, q$ & $r, T$ & الاجمالي \\
\hline$(\varepsilon, 0.1)$ & $(Y, Y Y Y)$ & $(r, \Gamma ৭ \Sigma)$ & $(7, r \mid r)$ & $(0,19 \cdot)$ & $(\nu, Y \circ \wedge)$ & حجم العينة \\
\hline
\end{tabular}




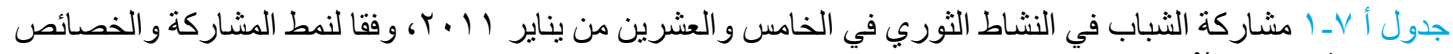

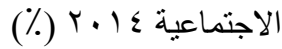

\begin{tabular}{|c|c|c|c|c|}
\hline تظاهر & لجان الشعبية & تنظيم سباسي & أية مشاركة & \\
\hline & & & & النوع \\
\hline $1, \mathrm{~V}$ & 11,1 & 1,9 & $1 r, 1$ & ذكر \\
\hline \multirow[t]{2}{*}{$\cdot, 9$} &., 0 & $\cdot, 0$ & 1,0 & أنثى \\
\hline & & & & الفئة العمرية \\
\hline 1,1 & $\varepsilon, r$ & $\cdot, 0$ & 0,1 & IV-IT \\
\hline 1,0 & $7, \xi$ & $1, v$ & $\wedge,$. & $r \varepsilon_{-} \mid \lambda$ \\
\hline $1, r$ & $v, r$ & 1,0 & $\Lambda, r$ & rq_ro \\
\hline \multirow[t]{2}{*}{1,1} & $\mathrm{v},$. & $\cdot, 9$ & $v, v$ & ro_r. \\
\hline & & & & المنطقة \\
\hline$\varepsilon, \cdot$ & $11, r$ & $r, \cdot$ & $1 r, 9$ & محافظات حضرية \\
\hline 1,0 & $V, r$ & $r, \cdot$ & $\Lambda, r$ & حضر وجه بحري \\
\hline . & $\wedge, \varepsilon$ & I,r & $q, r$ & ريف وجه بحري \\
\hline$\cdot, \varepsilon$ & $1, \varepsilon$ & $\cdot, \mathrm{V}$ & $r, l$ & حضر وجه قبلي \\
\hline$\cdot, 0$ & $1, v$ & $\cdot, \wedge$ & $r, T$ & ريف وجه قبلي \\
\hline \multirow[t]{2}{*}{$\cdot}$, & $r, r$ & ـ § & $r, T$ & محافظات حدودية \\
\hline & & & & محل الاقامة \\
\hline$r, \cdot$ & $9, r$ & 1,9 & $11, \varepsilon$ & حضر \\
\hline . & $0, r$ & $1,$. & ฯ,. & ريف \\
\hline \multirow[t]{2}{*}{., 9} & $r, 0$ & $\cdot, 9$ & $\varepsilon$, & مناطق عشوائية \\
\hline & & & & المستوي التعليمي \\
\hline$\cdot, r$ & $r, r$ & . r & $r, T$ & أمي \\
\hline$\cdot, \cdot$ & $0, v$ &., 0 & $0, v$ & يقر أ ويكتب \\
\hline$\cdot, 4$ & ז,r &., 1 & $\Upsilon, \wedge$ & إبتدائي \\
\hline$\cdot, \mathrm{V}$ & $\varepsilon, 7$ & •, & 0,1 & إعدادي \\
\hline$r,$. & 7,1 & $\cdot, \wedge$ & $\mathrm{v}, \mathrm{o}$ & ثانوي عام \\
\hline$\cdot, 9$ & १,. & $1, \cdot$ & 7,9 & ثانوي فني \\
\hline $1, \wedge$ & $\mathrm{v}, \varepsilon$ & $r, T$ & $1 ., r$ & فوق متوسط \\
\hline \multirow[t]{2}{*}{$r, q$} & 9,0 & $r, 1$ & Kr, r & جامعي فأكثر \\
\hline & & & & الحالة الزواجية \\
\hline 1,7 & $\checkmark, \cdot$ & 1,0 & $\Lambda, 0$ & أعزب \\
\hline \multirow[t]{2}{*}{$\cdot, \mathrm{V}$} & $\varepsilon, 9$ & $\cdot, \mathrm{V}$ & $0, \varepsilon$ & متزوج \\
\hline & & & & الحالة الوظيفية \\
\hline $1, V$ & 11,0 & 1,1 & $M, \Lambda$ & يعمل \\
\hline$r, 0$ & $11, v$ & $r, 0$ & 1r, & لا يعمل \\
\hline $1, \cdot$ & r,q & $\cdot, \wedge$ & $\varepsilon$, & خارج قوة العمل \\
\hline$\cdot, 0$ & 1,1 &., 0 & 1,9 & خارج قوة العمل و لا بدرس \\
\hline \multirow[t]{2}{*}{$1, \wedge$} & $0, \varepsilon$ & $1, r$ & $\mathrm{v}, \cdot$ & خارج قوة العمل ويدرس \\
\hline & & & & المهنة \\
\hline $1, r$ & $1 \cdot, v$ & $1, \wedge$ & $K, \varepsilon$ & يعمل بالقطاع العام \\
\hline $1, v$ & $11, r$ & ।,A & Kr, & يعمل بالقطاع الخاص \\
\hline $1, v$ & $1 \leqslant, \varepsilon$ & $r, \uparrow$ & $1 \leq, 9$ & يعمل لحسابه الخاص \\
\hline \multirow[t]{2}{*}{$r, \cdot$} & $1 \cdot, \varepsilon$ & $1, r$ & $11, v$ & يعمل بدون أجر \\
\hline & & & & مؤشر الثروة \\
\hline$\cdot, r$ & r, & $\cdot, \varepsilon$ & $r, \wedge$ & الأدني \\
\hline$\cdot, 9$ & $\varepsilon, 7$ & $\cdot, \mathrm{v}$ & $0, v$ & الثاني \\
\hline $1, r$ & $0, \Lambda$ & $\cdot, 9$ & $\uparrow, \wedge$ & الأوسط \\
\hline $1, \varepsilon$ & $\wedge$, & $1, \varepsilon$ & $q, r$ & 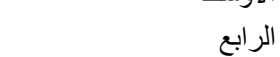 \\
\hline$r, r$ & $\wedge, \vee$ & $r, 0$ & $1 \cdot, \mathrm{v}$ & الأعلى \\
\hline $1, r$ & $7, Y$ & $1, r$ & $\mathrm{v}, \varepsilon$ & الاجمالي \\
\hline$(1 \cdot, \wedge 9 \cdot)$ & $(1 \cdot, \wedge 9 \cdot)$ & $(1 \cdot, \wedge 9 \cdot)$ & $(1 \cdot, \wedge 9 \cdot)$ & 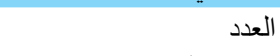 \\
\hline$(1+4)$ & $(71 \mathrm{~V})$ & $(I, T)$ & $(V \leq \varepsilon)$ & عدد من أجاب بنعم \\
\hline
\end{tabular}




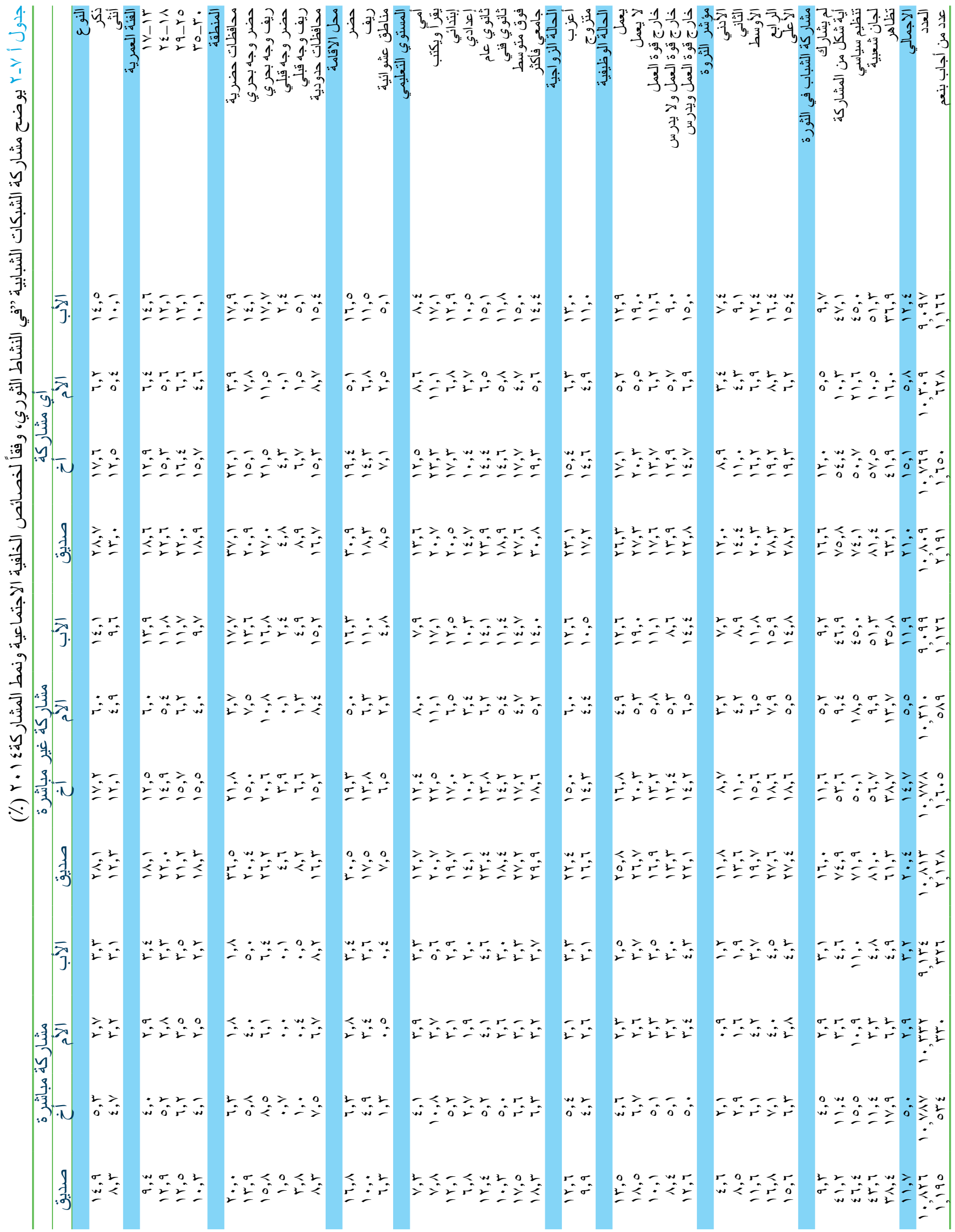




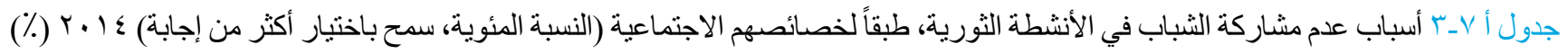

\begin{tabular}{|c|c|c|c|c|c|}
\hline أخرى & لست ضلد النظام & الصواب من أستطع تحدئ & مشار كتي لن تحدث & معارضة الو الدين & \\
\hline & & & & & النوع \\
\hline 1,0 & $19, r$ & $r \cdot, 0$ & 17,1 & 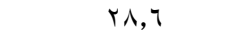 & ذكر \\
\hline \multirow{2}{*}{$1 \wedge, 1$} & $1 \Lambda, \varepsilon$ & $r v, V$ & $1 \leqslant, 1$ & Y T,r & أنثىى \\
\hline & & & & & الفئة العمرية \\
\hline $1 \varepsilon$ & 17,0 & ro,r & Ir,r & ro, & IV-IT \\
\hline IY,Y & $1 \lambda, r$ & $r q, r$ & $10, \varepsilon$ & $r \cdot, l$ & $r \leq-11$ \\
\hline $10, \varepsilon$ & $r_{., 0}$ & $r q, q$ & 17, & $r, T$ & rq-ro \\
\hline \multirow[t]{2}{*}{ iv, } & $r \cdot, q$ & M, & $|v|$, & iv,. & ro-r. \\
\hline & & & & & المنطقة \\
\hline $7, \varepsilon$ & $1 \leqslant, r$ & $r \Lambda, r$ & $1 Y, 0$ & $\varepsilon r, \varepsilon$ & محافظات حضرية \\
\hline 7,9 & 11,0 & rr, q & $1 \leqslant, 9$ & $r \leqslant, r$ & حضر وجه بحري \\
\hline $\mid r, \varepsilon$ & $1 \lambda, 7$ & $r \wedge\rangle$, & $17, V$ & TY, & ريف وجه بحري \\
\hline$r \cdot, 0$ & $r_{0, \varepsilon}$ & $r, Y$ & $\mid v, 1$ & $1 \Lambda, 7$ & حضر وجه قبلي \\
\hline rI, r & $r r, \cdot$ & $r \cdot, r$ & $10, \varepsilon$ & $1 \wedge, \varepsilon$ & ريف وجه قبلي \\
\hline \multirow[t]{2}{*}{$i v}$, & $\mid r, \Lambda$ & $r \wedge, 0$ & $10, r$ & rA,O & محافظات حدودية \\
\hline & & & & & محل الاقامة \\
\hline$\wedge, \wedge$ & 17,9 & 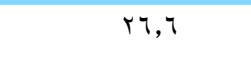 & Ir,A & rq, & حضر \\
\hline iv,r & $r_{\cdot,, \uparrow}$ & $r q, 0$ & 17, & $r,$. & ريف \\
\hline \multirow[t]{2}{*}{ Ir, 9} & ir, r & 足, & $\backslash \Lambda, V$ & $r, 0$ & مناطق عشو ائية \\
\hline & & & & & المستوي التعليمي \\
\hline rฯ, r & rr, r & $r \wedge, 0$ & $17, \varepsilon$ & $1 Y, q$ & أمي \\
\hline IV,r & $r \cdot, r$ & $r_{1, \Lambda}$ & $r, \tau$ & $1 Y, q$ & يقر أ ويكتب \\
\hline $1 \wedge, 9$ & 19,1 & $r \uparrow, \varepsilon$ & $\mid v, 1$ & ro,l & إبتدائي \\
\hline $\mid Y, \varepsilon$ & $19, r$ & $r V, \varepsilon$ & $17, r$ & $r \uparrow, 0$ & إعدادي \\
\hline 11,7 & 10,1 & $r V, \varepsilon$ & $1 \cdot, \mathrm{V}$ & $\lceil\Lambda, \varepsilon$ & ثانوي عام \\
\hline ir,. & $r 1,9$ & $r q, \wedge$ & $10, \mathrm{~V}$ & $r \varepsilon, r$ & ثانوي فني \\
\hline ir, & $10, \mathrm{~V}$ & $\lceil\Lambda, \varepsilon$ & $\mid r, \varepsilon$ & $r \varepsilon, 1$ & فوق متوسط \\
\hline \multirow[t]{2}{*}{$\wedge, \vee$} & 11,1 & $r_{1,0}$ & 10,1 & rv, & جامعي فأكثر \\
\hline & & & & & الحالة الزواجية \\
\hline $11, \mathrm{~V}$ & IV,V & $r V, V$ & 10,1 & $r r, l$ & أعزب \\
\hline \multirow[t]{2}{*}{$19, \varepsilon$} & $r \cdot, \wedge$ & $r_{1,0}$ & 10,9 & lv,r & متزوج /مطلق /أرمل \\
\hline & & & & & الحالة الوظيفية \\
\hline $1 \%, 0$ & 19,9 & $r \cdot, \wedge$ & 17,1 & $r \leqslant, 0$ & بعمل \\
\hline $1 \cdot, 1$ & 10, & $r_{0,7}$ & $1 \wedge, \wedge$ & $r V, O$ & لا يعمل \\
\hline $10, r$ & $1 \wedge, 0$ & $r v, v$ & $1 \leqslant, \varepsilon$ & $\curlyvee \wedge, \wedge$ & خارج قوة العمل \\
\hline$\lambda \Lambda, V$ & $r \cdot, r$ & $r \wedge, Y$ & 10,0 & rr, & خارج قوة العمل و لا يدرس \\
\hline \multirow[t]{2}{*}{$1,, \cdot$} & 17, & rt, r & $\mid r, \Lambda$ & $r q, r$ & خارج قوة العمل ويدرس \\
\hline & & & & & مؤشر الثروة \\
\hline$r \cdot, l$ & $1 \lambda, r$ & $r \cdot, \cdot$ & 17,1 & rI, r & الأدني \\
\hline $19, \varepsilon$ & $r r, \wedge$ & rA, r & $1 r, \Lambda$ & $r, 4$ & الثاني \\
\hline ir, & $\curlywedge \wedge, \wedge$ & $r \cdot, l$ & $10, \mathrm{~V}$ & $r$ & الأوسط \\
\hline $11,$. & $1 \wedge, r$ & $r \Lambda, \vee$ & $17, \wedge$ & $r \cdot, q$ & 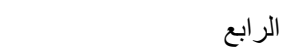 \\
\hline $9, \wedge$ & $17, r$ & r^,० & $1 \leqslant, 1$ & ro,A & الأعلى \\
\hline $1 \leqslant, 0$ & $\mid \wedge, \wedge$ & $r q, 1$ & $10, \varepsilon$ & $r V, \varepsilon$ & الاجمالي \\
\hline$(1 \cdot, 1 \leq 7)$ & $(1 \cdot, 1 \leq 7)$ & $(1 \cdot, 1 \leq 7)$ & $(1 \cdot, 1 \leq 7)$ & $(1 \cdot, 1 \leq 7)$ & العدد \\
\hline
\end{tabular}




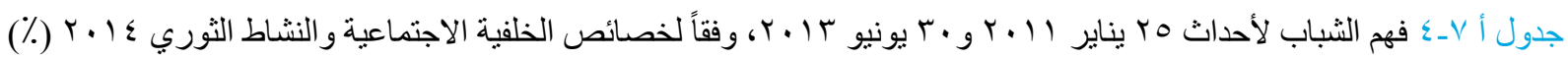

\begin{tabular}{|c|c|c|c|c|c|c|}
\hline \multicolumn{3}{|c|}{ أهداف • ب يونيو ץ| • T } & \multicolumn{3}{|c|}{ 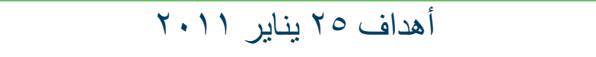 } & \\
\hline غير و اضماً & و اضدِ ما إلى & و اضحة جداً & غير واضحاً & و اضدِ ما إلىى & و اضحة جداً & \\
\hline & & & & & & النوع \\
\hline IT, & $\{1, \wedge$ & $\varepsilon 0, \wedge$ & 10,1 & $\leqslant 0,$. & $r q, r$ & ذكر \\
\hline 17, & $\varepsilon r, 0$ & $\varepsilon \cdot, 0$ & $i \Lambda, V$ & $\leq 0,9$ & $r_{0, \varepsilon}$ & أنثى \\
\hline & & & & & & الدنطقة \\
\hline $9, \wedge$ & $\varepsilon \leqslant, \varepsilon$ & $\varepsilon 0, \wedge$ & $1 \leqslant$, & $\{0, Y$ & $\varepsilon \cdot, r$ & محافظات حضرية \\
\hline 0,9 & $r_{\wedge, \Lambda}$ & $00, r$ & 17,7 & $r \wedge, \wedge$ & $\varepsilon \varepsilon, 7$ & حضر وجه بحري \\
\hline IY,. & $\varepsilon r, r$ & $\varepsilon \varepsilon, 7$ & $1 Y, 7$ & $\leq 9,7$ & $r, v$ & ريف وجه بحري \\
\hline 17,0 & $r_{\Lambda, \nu}$ & $\varepsilon \varepsilon, V$ & IV,Y & $r v, r$ & $\leq 0$, & حضر وجه قبلي \\
\hline$r, 1$ & $\varepsilon r, T$ & ro,r & $\curlywedge \wedge, \varepsilon$ & $\varepsilon 0, \varepsilon$ & ra,r & ريف وجه قبلي \\
\hline Ir, & or, \& & rT, & $r_{0,0}$ & $0 ., 1$ & $r \varepsilon, \varepsilon$ & محافظات حدودية \\
\hline & & & & & & المستوي التعليمي \\
\hline$r r, T$ & $\varepsilon \vee, v$ & $r \Lambda, \uparrow$ & $r \Lambda, r$ & $\varepsilon 9,9$ & r), & 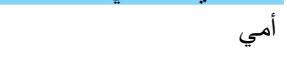 \\
\hline 11,0 & $r_{\Lambda}, 1$ & $\varepsilon \Gamma, \varepsilon$ & $r \mu, \varepsilon$ & $\varepsilon 9,1$ & $r V, T$ & يقر أويكتب \\
\hline $17, V$ & $\leq 0, \wedge$ & $r v, 0$ & ro,. & $\varepsilon \leqslant, 7$ & $r \cdot, \varepsilon$ & إبندائي \\
\hline $1 v, 7$ & $\varepsilon r, \varepsilon$ & $\varepsilon \cdot, 1$ & $r, \wedge$ & $\leq 0, \varepsilon$ & rr,v & إعدادي \\
\hline Ir,Y & $\varepsilon \varepsilon, \varepsilon$ & $\varepsilon r, q$ & $1 \leqslant, 9$ & $\varepsilon \varepsilon, V$ & $\varepsilon \cdot, 0$ & ثانوي عام \\
\hline $1 \%, 0$ & $\varepsilon r, \cdot$ & $\varepsilon r, 0$ & $17, r$ & $\varepsilon \vee, \cdot$ & 4 & ثنانوي فني \\
\hline$v, q$ & $\varepsilon 1, r$ & $0 \cdot, \wedge$ & $\wedge, 7$ & $\leq q, r$ & $\varepsilon r, 1$ & فوق منوسط \\
\hline $9, r$ & $r_{\Lambda}, \cdot$ & or, 1 & 9,0 & $\varepsilon \cdot, r$ & $0 ., r$ & جامعي فأكثر \\
\hline & & & & & & مؤشر الثروة \\
\hline ri,o & $\varepsilon r, \wedge$ & $r \leqslant, V$ & $r r, q$ & $\leq 7,1$ & $r_{1, \cdot}$ & 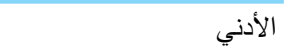 \\
\hline 11,0 & $r q, 0$ & $\varepsilon r, \cdot$ & 19,1 & $\varepsilon r, v$ & m, & 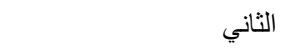 \\
\hline $11, \varepsilon$ & $\leqslant r, q$ & $\leq 0, v$ & 17,1 & $\varepsilon r, r$ & rq, 9 & الأوسط \\
\hline$৭, \wedge$ & $\leq \uparrow, \uparrow$ & $\varepsilon r, \uparrow$ & 10, & $\leq \uparrow, \wedge$ & $r \wedge, r$ & 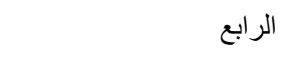 \\
\hline $1 \cdot, \mathrm{V}$ & $\varepsilon \cdot, v$ & $\varepsilon \wedge, \uparrow$ & $1 Y, T$ & $\varepsilon \vee, \cdot$ & $\varepsilon \cdot, \varepsilon$ & الأعلى \\
\hline & & & & & & مشاركة الثباب في الثورة \\
\hline $1 \leqslant, \varepsilon$ & $\varepsilon r, 1$ & $\varepsilon r, 0$ & $1 Y, T$ & $\varepsilon 0,1$ & $r v, r$ & لم يشارك \\
\hline $1 \cdot, \lambda$ & $r v, r$ & or,. & 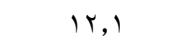 & $\varepsilon 9,7$ & $r \Lambda, r$ & أية شكل من المشاركة \\
\hline 10,7 & $r v, \varepsilon$ & 07,9 & $1 Y, 0$ & $r q, r$ & $0 \wedge, r$ & تنظيم سياسي \\
\hline $1, .0$ & $r q, 0$ & $0,, \cdot$ & Ir,o & or,y & $r \varepsilon, \wedge$ & لجان شعبية \\
\hline $1 \varepsilon, 7$ & $r \varepsilon, Y$ & $7, r$ & 1,1 & $r q, r$ & 09,7 & تظاهر \\
\hline $1 \leqslant, Y$ & $\leqslant r, T$ & $\varepsilon r, r$ & $I V, r$ & $\leq 0, \varepsilon$ & $r V, \varepsilon$ & الاجمالي \\
\hline & $(1 \cdot, \wedge \wedge)$ & & & $(1 \cdot, \wedge 9 \cdot)$ & & العدد - العد \\
\hline
\end{tabular}




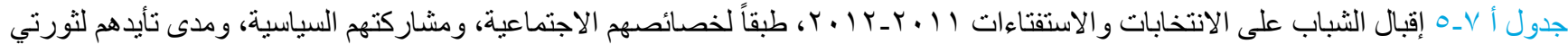

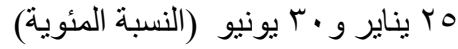

\begin{tabular}{|c|c|c|c|c|c|}
\hline استفتاء Y T T T & الالجئنخاباتة & 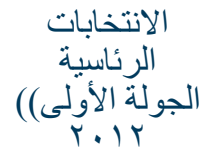 & 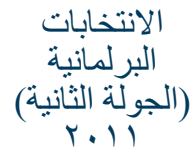 & (الجولة الأولىلى) & الاستفتاء ||| • ب \\
\hline
\end{tabular}

\begin{tabular}{|c|c|c|c|c|c|c|}
\hline & & & & & & النوع النوع \\
\hline 07,7 & 77,1 & $v_{0}, \varepsilon$ & $0 \wedge, \Gamma$ & $7 \cdot, 7$ & $0 \wedge, \cdot$ & ذكر ( ذا \\
\hline \multirow[t]{2}{*}{$\varepsilon \vee, \uparrow$} & 07,0 & $\Delta ৭, \xi$ & $\varepsilon \wedge, \wedge$ & $0 ., 7$ & $\varepsilon \vee, \tau$ & أنثى \\
\hline & & & & & & الفئة العمرية \\
\hline$\varepsilon 9, \cdot$ & ov, $q$ & $71, \mathrm{~V}$ & $\varepsilon 9,0$ & $01, \varepsilon$ & $\varepsilon \wedge, \vee$ & $r \varepsilon_{-}{ }^{\prime}$. \\
\hline or,, $\mathrm{r}$ & $T \leqslant$, & $T V, V$ & $00, \mathrm{~V}$ & $O V, v$ & 00,1 & rq- ro \\
\hline \multirow{2}{*}{$O V, r$} & $T \leqslant, 1$ & $i v, 1$ & O৯,. & $7 \cdot, \varepsilon$ & 07,1 & ro-r. \\
\hline & & & & & & المنطقة \\
\hline $7,$, & $T, r$ & $\uparrow,$. & $O V, r$ & $7 \cdot, \cdot$ & $7 \cdot, r$ & محافظات حضرية \\
\hline$v \cdot, l$ & A., l & $\wedge \cdot, \wedge$ & 79,9 & $V 1, \varepsilon$ & $V Y, V$ & حضر وجه بحري \\
\hline or, r & Tr,r & $u, r$ & $0 \leqslant, 1$ & ov,. & $0 \leqslant, r$ & ريف وجه بحري" \\
\hline$\leq 0,9$ & 7,7 & $T, r$ & Or, 1 & or,. & $\varepsilon \vee, \varepsilon$ & حضر وجه قبلي \\
\hline$\varepsilon \cdot, r$ & $01, \xi$ & $0 \xi, \varepsilon$ & $\varepsilon \varepsilon, 0$ & $\varepsilon 0, \wedge$ & rq, 9 & ريف وجه قبلي \\
\hline \multirow{2}{*}{$0 ., 1$} & $0 \wedge, 1$ & $0 \wedge, \varepsilon$ & Or,o & or, 1 & $01,$. & محافظات حدودية \\
\hline & & & & & & محل الاقامة \\
\hline 4 & $\pi, 0$ & $T, Y$ & $0 \leqslant, 9$ & ov,o & 07,1 & حضر \\
\hline$\varepsilon \vee, 1$ & ov, 7 & 7,7 & $\varepsilon 9,0$ & $01, V$ & $\varepsilon \vee, \varepsilon$ & ريف \\
\hline \multirow[t]{2}{*}{$79, r$} & $V Y, \Lambda$ & VI, Y & $v \varepsilon, 1$ & $V \varepsilon, r$ & $v r, q$ & مناطق عشو ائية \\
\hline & & & & & & إلمستوي التعليمي \\
\hline$r q, r$ & $\lceil\Lambda, \Lambda$ & $\varepsilon \cdot, \wedge$ & $r \cdot, 0$ & ru,r & r^,. & أمي \\
\hline$\varepsilon 1, \varepsilon$ & $07, r$ & $r, r$ & $\varepsilon \cdot$, & $\varepsilon \uparrow$, & $\varepsilon 1, \wedge$ & يقرًأ ويكتب \\
\hline$\varepsilon r,$. & or,. & $07, \Lambda$ & $\varepsilon r, \varepsilon$ & $\varepsilon \varepsilon, 1$ & $\varepsilon \cdot, \varepsilon$ & إبتدائي \\
\hline$\varepsilon r, \wedge$ & 01,1 & $0 \xi, r$ & $\varepsilon \varepsilon, q$ & $\{0, \wedge$ & $\varepsilon 1, V$ & إعدادي \\
\hline$\leqslant \uparrow, \varepsilon$ & $7 .,$. & 7,1 & $\varepsilon \wedge, r$ & Or,T & $\varepsilon 9, \cdot$ & ثانوي عام \\
\hline Or,o & $T, \varepsilon$ & r r r r & $0 \leqslant, 0$ & ov,. & or, & ثانوي فني \\
\hline $70, r$ & $V_{T}, \varepsilon$ & $v_{0, r}$ & ד, דו & $v \cdot, \cdot$ & $v_{\cdot},$. & فوق متوسط \\
\hline \multirow[t]{2}{*}{ 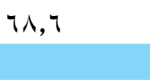 } & Vo,o & $\lambda_{0,}, 1$ & 79,1 & $v \cdot, v$ & $v_{\cdot},$. & جامعي فأكثر \\
\hline & & & & & & الحالة الزرواجية \\
\hline $01, r$ & $7 ., 0$ & $T \varepsilon, \Lambda$ & Or,O & $00, r$ & or,r & أعزب \\
\hline \multirow[t]{2}{*}{ \& } & $T r, 0$ & 70,0 & $0 \leqslant, q$ & $07, r$ & or,r & متزوج /مطلق /أرمل \\
\hline & & & & & & الحالة الوظيفية \\
\hline $0 \wedge, q$ & $\uparrow \Lambda, \uparrow$ & $V Y, \Lambda$ & $7 \cdot, \varepsilon$ & $T r, r$ & $7 \cdot, 1$ & 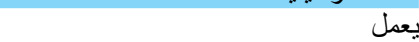 \\
\hline $7 \pi, r$ & $\mathrm{vr}, \mathrm{r}$ & $v_{4}, 0$ & ז & $\uparrow \Lambda, V$ & $T V, r$ & بعمل بالقطاع الحكومى /العام \\
\hline or, $\varepsilon$ & $T V, 1$ & $V Y, A$ & $09, r$ & $7 \cdot, \Lambda$ & $\Delta 9, \wedge$ & بعمل بالقطاع الخاص \\
\hline$T, \cdot$. & VY,O & $\mathrm{Vr}, \mathrm{.}$ & Tr,1 & 10,0 & $T, \cdot$ & بعمل لصسابه \\
\hline$\leq 0,7$ & $\Delta ৭, \wedge$ & r & $\leqslant 9,0$ & or,. & $\varepsilon \cdot, \cdot$ & ي بعمل بدون أجر \\
\hline $7, r$ & $79, r$ & $v_{0, r}$ & $T \leqslant, 1$ & $4 \pi, \Lambda$ & $T, r$ & عاطل \\
\hline$\leqslant 0, \varepsilon$ & $0 \leqslant, \xi$ & ov, 1 & ד & $\varepsilon \wedge, \vee$ & $\varepsilon 0,1$ & خارج قوة العمل \\
\hline$\varepsilon r, \gamma$ & or,. & $0 \leqslant, 7$ & $\varepsilon \varepsilon, 7$ & $\leq 7, \mathrm{~V}$ & $\varepsilon r, r$ & خارج قوة العمل و غير مقيد بالمدرسة \\
\hline \multirow[t]{2}{*}{$T \leqslant, 1$} & $v, \cdot$ & $v \varepsilon$, & $09, \wedge$ & $\pi$, & $7, r$ & خارج قوة العمل مقيد بالمدرسة \\
\hline & & & & & & مي مؤشر الثروة \\
\hline$\varepsilon r, \xi$ & $\varepsilon \wedge, 1$ & $0,, \xi$ & $\varepsilon r, r$ & $\varepsilon \varepsilon, 4$ & $\varepsilon \cdot, \cdot$ & الأدني \\
\hline$\varepsilon \pi, r$ & $o v, v$ & $r, \varepsilon$ & $\varepsilon \wedge, \uparrow$ & $\leq १, १$ & $\varepsilon \uparrow, V$ & الثاني \\
\hline$\varepsilon 9,7$ & $7, \varepsilon$ & $7 \pi, \mathrm{V}$ & דr, & $00, r$ & Or, \& & 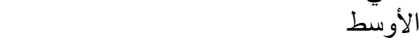 \\
\hline $07, \wedge$ & $7 \pi, \mathrm{V}$ & $v, r$ & $07, r$ & $\Delta ৭, v$ & ov, 9 & 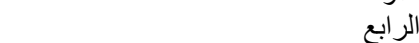 \\
\hline \multirow[t]{2}{*}{ צ ז } & $v \cdot, v$ & $v \varepsilon, v$ & $T \varepsilon, V$ & 77,0 & $T \leqslant, T$ & 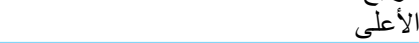 \\
\hline & & & & & & مشاركة الثباب في الثورة \\
\hline $0 ., \cdot$ & $09, \mathrm{~V}$ & r, & 01,7 & or, & $0 ., 0$ & 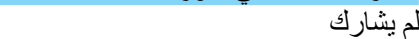 \\
\hline$V Y, T$ & $\Lambda, \mathrm{v}$ & $\Delta \uparrow, 0$ & VY,r & $\vee q, q$ & $\vee q, \wedge$ & أية شكل من المشاركة \\
\hline vฯ, 0 & $\lambda \varepsilon, \mathrm{V}$ & $\wedge \wedge, \uparrow$ & $\checkmark \wedge, 0$ & $\Delta r, v$ & $\wedge \varepsilon, r$ & 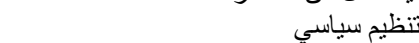 \\
\hline VY, & $\wedge, \wedge$ & $\wedge \uparrow, \Lambda$ & $\mathrm{vV}, \mathrm{v}$ & $\Lambda_{\cdot},$. & $\vee ৭, \wedge$ & لجان شعبية" \\
\hline \multirow[t]{2}{*}{ м५,. } & $\Lambda_{0}, \varepsilon$ & 91,7 & $\Lambda, 1$ & $\vee q, r$ & $10, \cdot$ & نظاهر \\
\hline & & & & & & الثباب المؤيد لثورتى ك o يناير و · يونيو \\
\hline$r \leqslant, \tau$ & 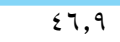 & $0 ., \varepsilon$ & $r \Lambda, r$ & $r q, \Lambda$ & $r \Lambda, r$ & غير مؤيد \\
\hline \multirow[t]{2}{*}{ Oᄉ,. } & $7 \pi, r$ & 79,9 & $0 \wedge, \wedge$ & $71, \cdot$ & $O V, \Lambda$ & هؤيد \\
\hline & & & & & & 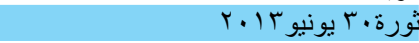 \\
\hline $07, \mathrm{~V}$ & 77,0 & $v \cdot, 1$ & $0 \wedge, \mathrm{V}$ & $7 \cdot, \varepsilon$ & $O V, r$ & 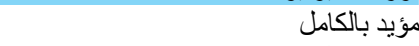 \\
\hline$\leqslant \vee, \Lambda$ & $0 \wedge, \varepsilon$ & Tr, $\varepsilon$ & $01, r$ & $0 \leqslant, 1$ & or,. & مؤيد بشكل جزئي \\
\hline$\varepsilon \vee, q$ & $0 r, q$ & 00,7 & $\varepsilon r, \tau$ & $\varepsilon 0, r$ & $\varepsilon r, r$ & 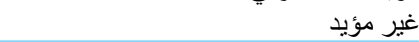 \\
\hline Or, r & 71,0 & 70,1 & or,v & 00,1 & or,. & الاجمالي - الاجي \\
\hline$(\mathrm{V}, \varepsilon \circ \wedge)$ & $(\vee, \leqslant \circ \wedge)$ & $\left(V^{\vee}, \leqslant 0 \wedge\right)$ & $(\mathrm{V}, \leqslant 0 \wedge)$ & $(v, \leqslant 0 \wedge)$ & $(\mathrm{V},\{0 \wedge)$ & 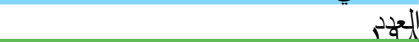 \\
\hline
\end{tabular}




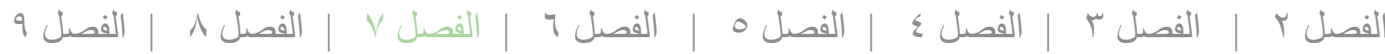

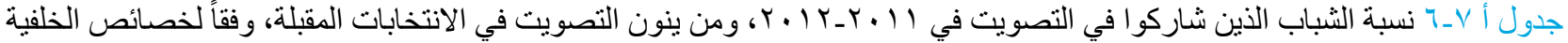
الاجتماعية و النشاط الثوري

\begin{tabular}{|c|c|c|c|c|c|}
\hline \multicolumn{3}{|c|}{ نسبة من ينون المشاركة في الانتخابات } & \multicolumn{2}{|c|}{ نسبة الذين لم يصوتون في الانتخابات و الاستفتاءات } & \\
\hline$y$ & | ربما & 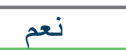 & يصوت دائماً & لم يصوت & \\
\hline & & & & & النوع \\
\hline $0, \mathrm{~V}$ & $\varepsilon r, \varepsilon$ & $0 ., 9$ & $\{0, \varepsilon$ & $r r, \Lambda$ & ذكر | ( ذكر \\
\hline 7,7 & $0 ., 1$ & $\varepsilon r, \varepsilon$ & $r_{V, 1}$ & ro,r & أنثي \\
\hline & & & & & الفئة العمرية \\
\hline 7,1 & $\varepsilon v, V$ & $\varepsilon \pi, r$ & r, $\mathrm{V}$ & rT,r & $r \varepsilon_{-} r$. \\
\hline$T, Y$ & $\leqslant \uparrow, \varepsilon$ & $\leqslant v, 0$ & $\varepsilon r, v$ & $r v,$. & rq_ ro \\
\hline$T, Y$ & $\{0,1$ & $\varepsilon \wedge, \vee$ & $\leq \pi,$. & $r V, O$ & ro-t. \\
\hline & & & & & المنطقة \\
\hline$\varepsilon, V$ & $\varepsilon 0, r$ & 0,1 & $\{0,0$ & $r \uparrow, 0$ & محافظات حضرية \\
\hline $0, r$ & ד & $\mathrm{r}, \mathrm{r}$ & $\circ 9,9$ & $1 \varepsilon, \wedge$ & حضر وجه بحري \\
\hline $7, \varepsilon$ & $\varepsilon r, r$ & $01, r$ & $\varepsilon r, \xi$ & $r \uparrow, \Lambda$ & ريف وجه بحري" \\
\hline$\varepsilon, q$ & 00,7 & $r q, 0$ & $r V, r$ & Tr, $\varepsilon$ & حضر وجه قبلي \\
\hline$\vee, \varepsilon$ & $0 \wedge, r$ & $\Gamma \varepsilon, \varepsilon$ & $r \cdot, q$ & $r \wedge, q$ & ريف وجه قبلي \\
\hline$\lambda, r$ & $\varepsilon v, 0$ & $\varepsilon \varepsilon, r$ & $r \Lambda, r$ & $r \leqslant,$. & محافظات حدودية \\
\hline & & & & & محل الاقامة \\
\hline $0, r$ & $\varepsilon v, \uparrow$ & $\sum V, r$ & $\varepsilon r, \varepsilon$ & $r V, r$ & حضر | ( حضر \\
\hline 7,9 & $\leqslant १, १$ & $\varepsilon r, r$ & $r 4,9$ & Tr, & ريف \\
\hline$\varepsilon$, & ro,r & $v \cdot, \Lambda$ & $T, r$ & 10,1 & مناطق عشو ائية \\
\hline & & & & & المستوي التعليمي \\
\hline$\wedge, \wedge$ & $77, \varepsilon$ & $r \varepsilon, V$ & $r \cdot, \tau$ & $0 \leqslant, V$ & \\
\hline$\wedge, 1$ & $\leqslant १, 0$ & $\varepsilon r, \xi$ & M, r & $\mu, 0$ & يقراً ويكتب \\
\hline$\wedge, \uparrow$ & or, r & $r \Lambda, 1$ & r,o & $r v, \varepsilon$ & إبتدائي \\
\hline $7, V$ & $07, r$ & rv, & Tr, T & $r \Lambda, r$ & إعدادي \\
\hline 0,7 & $\varepsilon १, 7$ & $\varepsilon \varepsilon, \wedge$ & $T V, O$ & Tr, \& & ثُانوي عَام \\
\hline $0, \varepsilon$ & $\{0, \lambda$ & $\varepsilon \wedge, q$ & $\varepsilon \cdot$, & $r q, q$ & ثنانوي فني \\
\hline$r, \varepsilon$ & $r_{\Lambda, 0}$ & $0 \wedge, 1$ & $0 \leqslant, r$ & $w, A$ & فوق متوسط \\
\hline $0, \varepsilon$ & r & $7, \mathrm{~V}$ & $O V, O$ & 17,7 & جامعي فأكثر \\
\hline & & & & & الحالة الزوراجية \\
\hline $7, \cdot$ & $\varepsilon \uparrow, \varepsilon$ & $\varepsilon V, \tau$ & $\varepsilon,, 1$ & $r q, 1$ & أعزب \\
\hline $7, Y$ & $\leqslant 7,9$ & $\leq 7,9$ & $\sum r, \lambda$ & $r q, \varepsilon$ & متزوج /مطلق /أرمل \\
\hline & & & & & الحالة الوظيفية \\
\hline $0, \varepsilon$ & $\xi 1, \Lambda$ & $O r, \Lambda$ & $\varepsilon \wedge, 1$ & $r, v$ & يعمل \\
\hline$\wedge, 1$ & 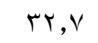 & $09, r$ & or,. & $19,$. & يعمل بالقطاع الحكومى /العام \\
\hline$\varepsilon, r$ & $\leqslant 0, \varepsilon$ & $0 ., r$ & $\varepsilon \neg, r$ & YY, & يُعمل بالقطاع الخاص \\
\hline ז, & $\Gamma \Lambda, \nu$ & $00, r$ & $01, \varepsilon$ & $19,$. & يعمل لحسابه \\
\hline$v, r$ & $\varepsilon \cdot, \Lambda$ & 01,9 & rr, q & T, & يعمل بدون أجر \\
\hline$r, \mathrm{~V}$ & $r q, \wedge$ & or,o & $\varepsilon \wedge, 0$ & $1 \Lambda, r$ & عاطل \\
\hline $\mathrm{v}, \mathrm{l}$ & $01, \mathrm{v}$ & $\varepsilon 1, r$ & $r \leqslant, v$ & $r V, r$ & خار ج قوة العمل \\
\hline $\mathrm{V}, \mathrm{r}$ & or, q & $r q,$. & Tr, & $\Gamma_{q, \varepsilon}^{\varepsilon}$ & خارج قوة العمل و غير مقيد بالمدرسة \\
\hline 7,9 & r ז,r & 07,1 & $0 ., r$ & $r, \wedge$ & خارج قوة العمل مقيد بالمدرسة \\
\hline & & & & & مؤشر الثروة \\
\hline 7,0 & $0 \Lambda, r$ & ro,r & T, & $\varepsilon r, 1$ & الأدنى \\
\hline $7, \mathrm{~V}$ & or, 1 & $\varepsilon, v$ & $r \leqslant, q$ & rr,o & الثاني \\
\hline $0, \mathrm{~V}$ & $\varepsilon v, \varepsilon$ & $\leq 7, q$ & $\varepsilon, r$ & $r \Lambda, r$ & الأوسطّ \\
\hline $7, \varepsilon$ & $\varepsilon,, \uparrow$ & or,. & $\varepsilon \varepsilon, r$ & $r \varepsilon,$. & 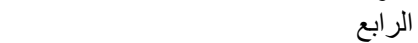 \\
\hline $0, \varepsilon$ & m, q & $o v, r$ & or, 1 & ri,. & 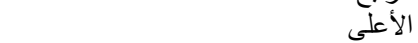 \\
\hline & & & & & مشار كة الثباب في الثورة \\
\hline $7, \xi$ & $\varepsilon \vee, q$ & $\{0, \uparrow$ & $r q, r$ & $r \cdot, q$ & 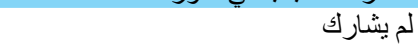 \\
\hline$r, \mathrm{~V}$ & r, 9 & $70, r$ & $7 \pi, 1$ & $1,, \mathrm{~V}$ & أية شكل من المشاركة \\
\hline$r, r$ & rY, & $79, \mathrm{~V}$ & $T V$, & $v, r$ & 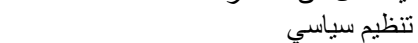 \\
\hline$r, \varepsilon$ & $\mathrm{r}, 9$ & $70, \mathrm{~V}$ & 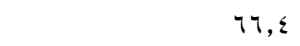 & $1 \cdot, 7$ & لجان شعبية \\
\hline$१, \varepsilon$ & 10,9 & $v \varepsilon, v$ & $T V,$. & 0,0 & تظاهر \\
\hline & & & & & الشباب المؤيد لثورتى ك به يناير و r. يونيو \\
\hline$\wedge, 1$ & $T \leqslant, \cdot$ & $r V, q$ & ro,r & $\varepsilon r, \lambda$ & غير مؤيد \\
\hline 0,0 & $\varepsilon \cdot, q$ & ד, & $\varepsilon \neg, V$ & $r \varepsilon, \Lambda$ & مؤيد \\
\hline & & & & & 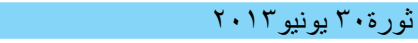 \\
\hline$r, q$ & $r 0, v$ & $7, \xi$ & $\varepsilon \pi, r$ & $r \leqslant, \Lambda$ & مؤيد بالكامل \\
\hline$\varepsilon, 1$ & $O v, v$ & $r \Lambda, r$ & $T V,$. & $r \cdot, r$ & مؤيد بشكل جزئي \\
\hline $17, \mathrm{~V}$ & 07,0 & $r \uparrow, \Lambda$ & ro, 9 & $\{, 0$ & غير مؤيد \\
\hline 7,1 & $\varepsilon \uparrow, \uparrow$ & $\varepsilon \vee, r$ & $\varepsilon, \varepsilon$ & $r q, r$ & الاجمالي \\
\hline$(1$ & & & $(\vee, \leqslant 0 \lambda)$ & $(\mathrm{V}, \leqslant 0 \wedge)$ & العدد \\
\hline
\end{tabular}


جدول أ V V أسباب عدم تصويت الثباب في الانتخابات أو الاستفتاء، وفقاً لخصائص الخلفية الاجتماعية و النشاط الثوري (تم استبعاد من هم أقل من 1)

\begin{tabular}{|c|c|c|c|c|c|c|c|c|c|c|c|c|}
\hline \multicolumn{4}{|c|}{ الانتخابات الرئاسية r I ب } & \multicolumn{4}{|c|}{ الانتخابات البرلمانية | 1 ، r } & \multicolumn{4}{|c|}{ الاستفتاء على الدستور (1 · r } & \\
\hline \multirow[t]{2}{*}{ أخرى } & تصبس لديث & للتصويت & ل لأ أهتم & 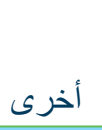 & تصبس لدي تبقي & للتصويت رافض & 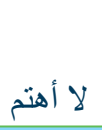 & أخرى & 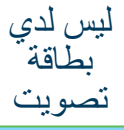 & للتصويت رافض & ل لا أهتم & \\
\hline & & & & & & & & & & & & النوع \\
\hline$\wedge, \varepsilon$ & $r, T$ & $r_{1,9}$ & $O V, r$ & $v, q$ & $r, r$ & $r_{0, \Lambda}$ & $7 \varepsilon, 1$ & 7,0 & 1,7 & $r_{0,1}$ & וד, & ذكر \\
\hline \multirow[t]{2}{*}{ r, 9} & $\varepsilon, 1$ & rq, & $T V, \cdot$ & $r, r$ & r, $\varepsilon$ & $r, \cdot$ & $v 1, \varepsilon$ & $r, 1$ & $r, v$ & $r \cdot, v$ & $V T, O$ & أنثى \\
\hline & & & & & & & & & & & & الفئة العمرية \\
\hline $7, r$ & $\varepsilon, 0$ & rı,V & $T r, 0$ & $7, Y$ & r,q & $r \varepsilon, Y$ & 70,1 & $\varepsilon, \wedge$ & $r, \varepsilon$ & $r, \wedge$ & 79, & $r \varepsilon-11$ \\
\hline 0,1 & $r, 1$ & rq, ₹ & Tr, \& & $0, \cdot$ & $1, \wedge$ & $r \leqslant, q$ & $\uparrow \wedge, \varepsilon$ & $r, \tau$ & 1,9 & $r t, v$ & $v \cdot, v$ & rq_ro \\
\hline \multirow[t]{2}{*}{$\varepsilon, 1$} & $r, r$ & r , , & 71,1 & $\varepsilon, 0$ & r, & $r, 0$ & $\vee 1, \lambda$ & $r, \mathrm{~V}$ & r,o & $r_{1, \varepsilon}$ & $V Y, \varepsilon$ & ro_r. \\
\hline & & & & & & & & & & & & المنطقة \\
\hline$r, \wedge$ & 1,9 & $\leq \vee, 1$ & $\varepsilon V, r$ & $r, \varepsilon$ & $r, \cdot$ & ґی, & ov, 1 & 1,7 & 1,7 & r & $7 \cdot, \cdot$ & محافظات حضرية \\
\hline$v, r$ & $1, \cdot$ & $r+q$ & $T V, V$ & 7,7 & $\cdot, \mathrm{V}$ & 11,7 & $V \varepsilon, r$ & $1 \cdot, \varepsilon$ & 1,1 & $1 \wedge, 1$ & $V \cdot, \varepsilon$ & حضر وجه بحري \\
\hline $\mathrm{T}, \mathrm{V}$ & r, r & $r \cdot, \tau$ & 09,0 & $\mathrm{v}, \wedge$ & r, r & $19, r$ & $v \cdot, v$ & $0, v$ & 1,9 & $r_{1, \cdot}$ & $v_{1}, 0$ & ريف وجه بحري \\
\hline$\cdot, \varepsilon$ & $r, r$ & Ir,V & $\Lambda \varepsilon, r$ & $1, \cdot$ & $r, 1$ & $r_{\cdot}, \tau$ & $v ч, r$ & 1,1 & $\cdot, 0$ & 17,1 & 11,0 & حضر وجه قبلي \\
\hline $7, Y$ & 0, & $r, r$ & $77, \mathrm{~V}$ & $0, v$ & $\varepsilon, 7$ & $r, \varepsilon$ & $T V, \varepsilon$ & r,^ & $\varepsilon, 9$ & $r \cdot, \varepsilon$ & $v_{1}, \cdot$ & ريف وجه قبلي \\
\hline \multirow[t]{2}{*}{$\varepsilon, 1$} & $r, r$ & $r \varepsilon, \cdot$ & $79, V$ & $r, v$ & 1,9 & 19,9 & $V \varepsilon, 7$ & r,r & 1,9 & $19, r$ & $V T, 0$ & محافظات حدودية \\
\hline & & & & & & & & & & & & المستوي التعليمي \\
\hline$r, r$ & 0,0 & $I V, r$ & $v_{0,1}$ & $r, 0$ & $\varepsilon, 9$ & $1 \leqslant, \varepsilon$ & $V V, Y$ & $r, \Lambda$ & r,q & 10,1 & $V Y, O$ & أمي \\
\hline$r, 1$ & $0, \varepsilon$ & 19,1 & V), T & $\cdot, \cdot$ & $\varepsilon$, & $M, \Lambda$ & Nr, & $\cdot, \cdot$ & $\varepsilon, 1$ & 11,9 & Nr,q & يقر أ ويكتب \\
\hline$\varepsilon, r$ & r,r & זч, & $T V, O$ & 0,1 & 1,9 & IV,r & $v_{0, V}$ & $\varepsilon, r$ & $r, \varepsilon$ & $r \cdot, T$ & $\vee r, \wedge$ & إبتدائي \\
\hline$r, \varepsilon$ & $\uparrow, \wedge$ & rq, r & ד, זיד & $r, \varepsilon$ & r, & r), r & 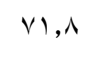 & $r, 1$ & $r, \varepsilon$ & $r \varepsilon, \cdot$ & $v \cdot, 0$ & إعدادي \\
\hline$r, \uparrow$ & $r, q$ & $\varepsilon \cdot, \wedge$ & 01,1 & $\varepsilon, 7$ & r,v & ro,r & 07,0 & $r, r$ & $1, \cdot$ & $r \wedge, r$ & $T V, V$ & ثانوي عام \\
\hline $\mathrm{v}, \mathrm{V}$ & $r, v$ & $r \uparrow, V$ & Tr,. & 7,0 & $r, r$ & $r \varepsilon, Y$ & $74, \wedge$ & $\varepsilon, \wedge$ & $r, V$ & $r, r$ & $V \cdot, \Sigma$ & ثانوي فني \\
\hline 11,9 & $\cdot, \cdot$ & $\varepsilon r, T$ & $\varepsilon \leqslant, 0$ & $1 ., 0$ & $\cdot, \cdot$ & 促, & $00, \mathrm{~V}$ & $V, r$ & $\cdot, \cdot$ & $r v, r$ & 00,1 & فوق منوسط \\
\hline \multirow[t]{2}{*}{$0, r$} & $r, \uparrow$ & $\leq 0,1$ & $\leq 7,1$ & 7,1 & $r, 0$ & ro,l & $07, r$ & $0, v$ & $1, v$ & r.,. & $7, V$ & جامعي فأكثر \\
\hline & & & & & & & & & & & & مؤشر الثروة \\
\hline$r, 1$ & $r, \wedge$ & r., & $V Y, \Lambda$ & r, & $r, r$ & Y),r & $V T, T$ & r,o & $r, \wedge$ & 19,7 & Vo,r & الأدني \\
\hline 0,7 & $r, r$ & Yr,V & $\uparrow \wedge, \varepsilon$ & $\varepsilon, 1$ & r, & $r \cdot, r$ & $V Y, V$ & $\varepsilon, 7$ & $r, \cdot$ & $r \cdot, l$ & VY,r & الثاني \\
\hline $0, r$ & $r, \varepsilon$ & r^,. & $T \leqslant, \varepsilon$ & $7, r$ & $r, \cdot$ & $r_{0, \varepsilon}$ & r., & $r, \varepsilon$ & $1, v$ & $r T, r$ & $v_{1, V}$ & الأوسط \\
\hline $0, \varepsilon$ & $v, 0$ & Tr, & $00, \cdot$ & $0, \varepsilon$ & 0,0 & $r \cdot, \tau$ & $7 \wedge, 0$ & $\varepsilon, V$ & $\varepsilon, 1$ & rT, r & $\curlyvee \wedge, \wedge$ & الر ابع \\
\hline$\wedge, \uparrow$ & 1,0 & $\varepsilon r, v$ & $\leq 7,1$ & $9, \cdot$ & 1,7 & Tr, & $07, Y$ & 7,1 & 1,1 & $r \cdot, \varepsilon$ & $71, V$ & الأعلى \\
\hline $0, \varepsilon$ & $r, \varepsilon$ & r^, $\vee$ & $T r, 0$ & $0, \varepsilon$ & $r, \wedge$ & $r r, \wedge$ & $7 \wedge, \cdot$ & $\varepsilon, r$ & $r, v$ & $r Y, \Lambda$ & $V \cdot, \Sigma$ & الاجمالي \\
\hline \multicolumn{4}{|c|}{$(\curlyvee, \wedge \cdots)$} & \multicolumn{4}{|c|}{$(r, \varepsilon \cdot 1)$} & \multicolumn{4}{|c|}{$(r, r 01)$} & العدد \\
\hline
\end{tabular}




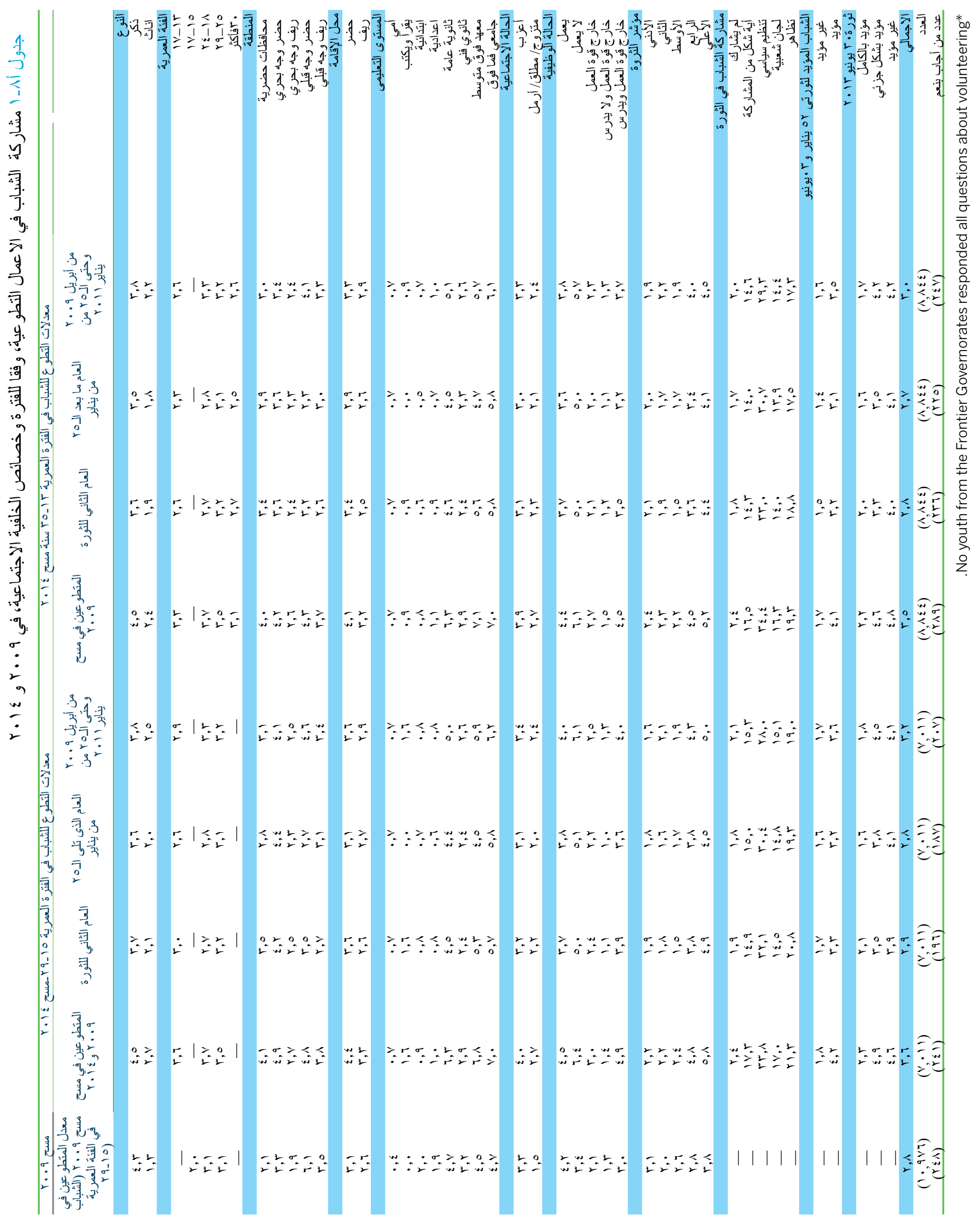




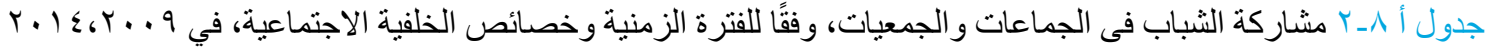

\begin{tabular}{|c|c|c|c|}
\hline 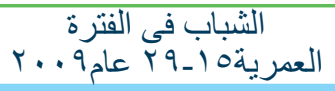 & 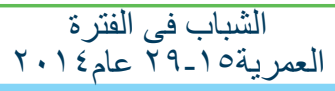 & 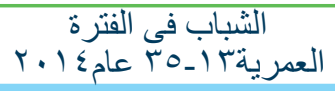 & \\
\hline & & & إلنوع \\
\hline $\begin{array}{l}7,4 \\
4,4\end{array}$ & $\varepsilon, Y$ & $\varepsilon, 1$ & ذأِكر \\
\hline$T, T$ & 1,0 & 1,0 & الفئَّى العمرية \\
\hline - & $r, r$ & $r, \Sigma$ & $\mid v-1 T$ \\
\hline ૫,乏 & - & - & $1 V_{-} 10$ \\
\hline$\{, \tau$ & $r, 1$ & $r, 1$ & $r \leq-11$ \\
\hline$\varepsilon, r$ & $r, r$ & $r, r$ & rq_ro \\
\hline - & - & $r, r$ & 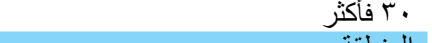 \\
\hline & & & المنطقة \\
\hline $1 \cdot, 7$ & $0, \Lambda$ & 0,1 & محافظات حضرية \\
\hline 0,7 & $r, 1$ & $r, \cdot$ & حضر وجه بحري \\
\hline$r, \varepsilon$ & $r, \uparrow$ & r,o & ريف وجه بحري \\
\hline$r, \Lambda$ & $\Gamma, \varepsilon$ & $r, \cdot$ & حضر وجه قبلي \\
\hline$r, \mathrm{~V}$ & $1, v$ & 1,7 & ريف وجه قبلي \\
\hline 1,9 & $r, q$ & $r, \Lambda$ & محافظات حدودية \\
\hline & & & محل الاقامة \\
\hline$\Lambda, \varepsilon$ & 0,0 & $0, \xi$ & حضر \\
\hline$r, 1$ & $r, 1$ & r, 1 & ريف \\
\hline$\varepsilon, \wedge$ & $\cdot, 1$ & $\cdot, 1$ & مناطق عشو ائية \\
\hline & & & المستوي التعليمي \\
\hline$\cdot, 0$ & $\cdot, \cdot$ & $\cdot, \cdot$ & أمي \\
\hline $1 \cdot, 9$ & $\cdot, \cdot$ & $\cdot, \cdot$ & يقرأ ويكتب \\
\hline$r, \varepsilon$ & 1,1 & $1, \cdot$ & إبتدائي \\
\hline$\varepsilon, \varepsilon$ & $\cdot, \wedge$ & $1, r$ & إعدادي \\
\hline 11,9 & 7,0 & 7,0 & ثانوي عام \\
\hline$r, \cdot$ & 1,0 & $1, \varepsilon$ & ثانوي فني \\
\hline$r, r$ & $\varepsilon, V$ & $\varepsilon, 0$ & فوق متوسط \\
\hline $1+,$. & $\uparrow, \Lambda$ & $\mathrm{v}, \cdot$ & جامعي فأكثر \\
\hline & & & الحالة الزواجية \\
\hline $7, Y$ & $\uparrow, \uparrow$ & $\Gamma, \uparrow$ & أعزب \\
\hline $1, \wedge$ & $1, r$ & $1, \varepsilon$ & متزوج \\
\hline & & & الحالة الوظيفية \\
\hline$\varepsilon, q$ & $r, r$ & $r, r$ & يعمل \\
\hline$\varepsilon, 0$ & 0,9 & $0, v$ & لا لا يعمل \\
\hline $0, \cdot$ & $\uparrow, \uparrow$ & ఛ,乏 & خارج قوة العمل \\
\hline $1, \varepsilon$ & $\cdot, \mathrm{v}$ & $\cdot, \mathrm{v}$ & خارج قوة العمل و لا يدرس \\
\hline 9,0 & $0, \cdot$ & $\varepsilon, 9$ & خارج قوة العمل ويدرس \\
\hline & & & مؤشر الثروة \\
\hline I,V & $\bullet, \wedge$ & $\because, 9$ & الأدني \\
\hline$r, \cdot$ & $1, \varepsilon$ & $1, \varepsilon$ & الثاني" \\
\hline r,V & $1, r$ & $1, r$ & الأوسط \\
\hline $0, \cdot$ & $r, 1$ & $r, \Lambda$ & الرابع \\
\hline $1 \leqslant, 7$ & $\vee, \cdot$ & $\vee, \cdot$ & 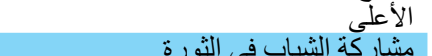 \\
\hline - & $1, \varepsilon$ & $1, \varepsilon$ & لم يشارك كسباب في التورن \\
\hline - & ri, & $r \cdot, \Lambda$ & أبِّ شكل من المشاركة \\
\hline - & $\uparrow, \Lambda$ & $r v, \xi$ & تنظيم سياسي \\
\hline - & 19,7 & $19, r$ & لجان شعبية \\
\hline - & r, $\mathrm{V}$ & ro,. & تظاهر \\
\hline & & & الشباب المؤيد لثورتى ك يناير و ×.يونيو \\
\hline - & 1,0 & re & غير مؤيد \\
\hline & 1,2 & & 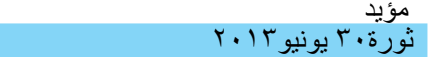 \\
\hline - & T,V & r,O & مؤيد بالكامل \\
\hline - & $r, 1$ & $r, r$ & مؤيد بشكل جزئي \\
\hline - & $r, r$ & $r, r$ & غير مؤيد \\
\hline$\varepsilon, 9$ & r,q & $r, \Lambda$ & 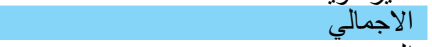 \\
\hline$(1 \cdot, 9 \vee 4)$ & $(\wedge, 0 \vee 9)$ & $(1 \cdot, \wedge T 1)$ & العدد \\
\hline$($ or $\varepsilon)$ & $(Y \leq \uparrow)$ & $($ (१৭) & عدد من أجاب بنعم \\
\hline
\end{tabular}




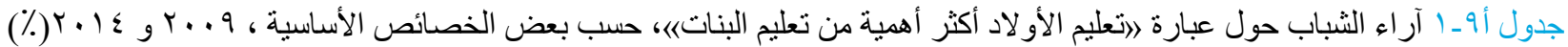

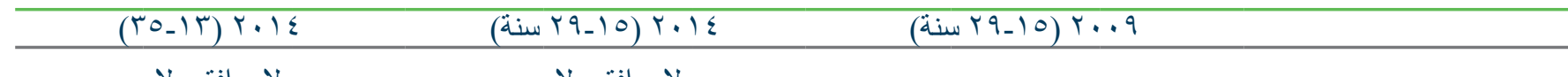

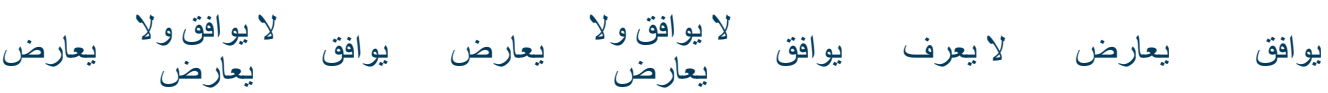

\begin{tabular}{|c|c|c|c|c|c|c|c|c|c|}
\hline & & & & & & & & & النوع \\
\hline$\leq 7,9$ & $1 \lambda, r$ & $r \varepsilon, q$ & $\varepsilon \vee, 1$ & $1 \wedge, v$ & $r \varepsilon, r$ & $\cdot, \mathrm{V}$ & $T \leqslant, \varepsilon$ & $r \leqslant, q$ & ذكر \\
\hline \multirow[t]{2}{*}{7} & $1 Y, 0$ & r), & $T V, r$ & Ir,. & $r \cdot, \wedge$ & $\cdot, 1$ & ᄉт,. & $1 T, \varepsilon$ & أنثى \\
\hline & & & & & & & & & المستوي التعليمي \\
\hline$\varepsilon r, r$ & $r \mid, \Lambda$ & ro,. & $\leqslant 1, \wedge$ & $r, Y$ & Tr, & $r, \varepsilon$ & $V \cdot, r$ & $r v, \varepsilon$ & أمي \\
\hline$r v, 0$ & rr,O & $\varepsilon \cdot, \cdot$ & r.,. & ז,ז & $r_{0, v}$ & $\mid v, 1$ & $V T, O$ & $9, \varepsilon$ & يقرأ ويكتب \\
\hline$\leqslant r, q$ & $1 \lambda, \wedge$ & $r \Lambda, r$ & $\varepsilon r, 0$ & 19, & $r_{\Lambda, 0}$ & $\cdot, \wedge$ & 79, & $r \cdot, r$ & إبتدائي \\
\hline $0 ., 7$ & $17, \varepsilon$ & $r+1$ & $\varepsilon \wedge, r$ & $\mid v, 1$ & $r \varepsilon, \tau$ & $\cdot, 7$ & $V r, \varepsilon$ & ri, & إعدادي \\
\hline $79, r$ & 11,1 & 11,9 & 79,1 & Ir, r & 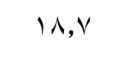 & $\cdot, \varepsilon$ & 1), & 11,7 & ثانوي عام \\
\hline $07, \varepsilon$ & 10,9 & $r v, V$ & 07,1 & 17,1 & $r v, \Lambda$ & $\cdot, r$ & $v_{0, \varepsilon}$ & $r \varepsilon, r$ & ثانوي فني \\
\hline $7 \cdot, \wedge$ & $I r, r$ & rq, & N ג & 11,7 & $r \leqslant, T$ & $\cdot, r$ & $\vee 1, \wedge$ & $r v, q$ & فوق متوسط \\
\hline \multirow[t]{2}{*}{$77, r$} & $11,$. & $r, \wedge$ & $T V, r$ & 11,0 & $r, r$ & $\cdot, r$ & $\wedge r, \wedge$ & 17, & جامعي فأكثر \\
\hline & & & & & & & & & المنطقة \\
\hline 01,0 & $1 \cdot, 7$ & $r v, q$ & or,o & $1 \cdot, 1$ & $r v, r$ & $\cdot, V$ & $V \varepsilon, \Lambda$ & $r \leqslant, 0$ & محافظات حضرية \\
\hline$T r, r$ & $1 \leqslant, \varepsilon$ & $r, r$ & ד, זד & $10, r$ & $r, r$ & $1, \cdot$ & $\Lambda_{4}, r$ & $M, \Lambda$ & حضر وجه بحري \\
\hline $7 ., 9$ & 11,0 & $r \cdot, r$ & $7 ., 0$ & $\curlywedge \wedge, \wedge$ & $r \cdot, r$ & $\cdot, \wedge$ & $\vee \wedge, \varepsilon$ & $r \cdot, \Lambda$ & ريف وجه بحري \\
\hline 07,1 & IA,V & $r \leqslant, 0$ & $09, \wedge$ & IV,V & $r r, O$ & $\cdot$, & $v \cdot, r$ & $r \wedge, \wedge$ & حضر وجه قبلي \\
\hline or,. & $1 \varepsilon, r$ & $r,, v$ & or, 9 & $1 \leqslant, 0$ & Tr, & $\cdot, \varepsilon$ & TV, & rr,o & ريف وجه قبلي \\
\hline \multirow[t]{2}{*}{$r V, \wedge$} & $r_{,}, \cdot$ & $\varepsilon 1, r$ & $r_{\Lambda}, \cdot$ & $r, 1$ & $\varepsilon 1$, & $\cdot, \cdot$ & $V_{T}, \varepsilon$ & rT,T & محافظات حدودية \\
\hline & & & & & & & & & محل الاقامة \\
\hline $0 \leqslant, 0$ & $I r, \Lambda$ & ri,v & $00, \wedge$ & $I T, V$ & $r \cdot, 0$ & $\cdot, \wedge$ & $V V, r$ & $r 1,9$ & حضر \\
\hline $07, \mathrm{~V}$ & 17,0 & rฯ, & $07, \varepsilon$ & 17,1 & หq, q & $\cdot, 7$ & $V r, r$ & $r+, 1$ & ريف \\
\hline \multirow[t]{2}{*}{$0 \wedge, 9$} & Ir, r & $r V, \Lambda$ & 71,0 & $1 T, 1$ & ro,o & $\cdot, \varepsilon$ & vy, & rr,O & مناطق عشو ائية \\
\hline & & & & & & & & & مؤشر الثروة \\
\hline$\varepsilon v, 1$ & $1 \wedge, \varepsilon$ & $r \varepsilon, T$ & $\varepsilon \uparrow, \wedge$ & $1 \wedge, \varepsilon$ & $r \varepsilon, \wedge$ & $\cdot, 9$ & $79, \mathrm{~V}$ & $r q, 0$ & الأدني \\
\hline $0 \leqslant, 1$ & $17, r$ & $r \wedge, \wedge$ & $07, r$ & 17,1 & $r V, T$ & $\cdot, V$ & $V r, 1$ & $r v, r$ & الثاني \\
\hline 00,1 & 17,9 & rA,. & $00, \varepsilon$ & IV,r & $r V, \varepsilon$ & 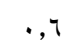 & $V r, \Lambda$ & $r_{0, V}$ & الأوسط \\
\hline 07,1 & $1 \leqslant, 0$ & $r q, \varepsilon$ & $07, \mathrm{~V}$ & $1 \leqslant, 7$ & $\lceil\wedge, \wedge$ & $\cdot, \varepsilon$ & $\checkmark v, \Lambda$ & $r, \wedge$ & الر ابع \\
\hline \multirow[t]{2}{*}{70,9} & $11, \wedge$ & rr, r & 70,0 & Ir, r & rr, r & $\cdot, 9$ & $\Delta r, 1$ & iv,. & الأعلى \\
\hline & & & & & & & & & الفئة العمرية \\
\hline ०१, ६ & $1 \leqslant$, & $r \uparrow, Y$ & $09, V$ & $1 \%, \Lambda$ & $r \uparrow, 0$ & $\cdot, 9$ & vo, 1 & $r \varepsilon, \cdot$ & $1 V_{-10}$ \\
\hline $07, \mathrm{~V}$ & 10,1 & $r v, 0$ & $07, \mathrm{~V}$ & 10,1 & $r V, O$ & •, & $V \varepsilon, r$ & $r_{0, r}$ & $r \leq-11$ \\
\hline $0 \leqslant, r$ & $17, r$ & $r 9,0$ & $0 \leqslant, r$ & $17, r$ & $r q, 0$ & $\cdot, 7$ & $V Y, r$ & $r T, Y$ & rq_ro \\
\hline \multirow[t]{2}{*}{$0 \leqslant, r$} & 10, & $r \cdot, v$ & - & - & - & - & - & - & ro_r. \\
\hline & & & & & & & & & الحالة الزواجية \\
\hline 04,1 & 10,7 & $r \wedge, r$ & $07, r$ & $10, \mathrm{~V}$ & rA,. & $\cdot, \wedge$ & VY, q & rฯ, \& & أعزب \\
\hline \multirow[t]{2}{*}{$07, \mathrm{~V}$} & 10,1 & $r \wedge, r$ & $o v, v$ & 10, & $r v, r$ & $\cdot, \varepsilon$ & $\lambda \cdot, r$ & $19, r$ & متزوج \\
\hline & & & & & & & & & الحالة الوظيفية \\
\hline $0 .,$. & 17,2 & $r$ r. & $0 ., \cdot$ & $1 v, 0$ & $r r, 0$ & $\cdot, \varepsilon$ & Tr, & $r \mu, \varepsilon$ & يعمل \\
\hline 71,0 & Ir, r & rצ, r & $\pi, \cdot$ & $11, r$ & $r v, \Lambda$ & $\cdot, \uparrow$ & $v_{0, \varepsilon}$ & $r \varepsilon_{,}$, & لا يعمل \\
\hline ०१, ६ & $1 \leqslant, 9$ & $r_{0, r}$ & $09, V$ & $1 \leqslant, \wedge$ & $r_{0,0}$ & $\cdot, \wedge$ & $\vee \vee, \varepsilon$ & 19,1 & خارجقوة العمل \\
\hline $07, r$ & $10, \varepsilon$ & $r \wedge, r$ & $07, \mathrm{~V}$ & 10,0 & $r V, \Lambda$ & $\cdot, V$ & vo,. & $r \varepsilon, \varepsilon$ & الاجمالي \\
\hline(\urcorner$, \wedge \wedge \vee)$ & $(1,7 V \cdot)$ & $(r, I \leq \vee)$ & $(\varepsilon, \wedge \varepsilon \wedge)$ & $(1, r \mid T)$ & $(r,\{0 r)$ & $(7 \wedge)$ & $(\wedge, \varepsilon \Gamma T)$ & $(r, \leq q १)$ & العدد \\
\hline
\end{tabular}


جدول أو ب آراء الثباب حول عبارة 》عندما تقل فرص العمل، فإن الأولوية يجب أن تكون للرجال وليس للإناث)، حسب بعض الخصائص

\begin{tabular}{|c|c|c|c|c|c|c|c|c|c|}
\hline \multicolumn{3}{|c|}{$\left(r_{0} \mid r\right) r \cdot 1 \varepsilon$} & \multicolumn{3}{|c|}{ 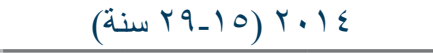 } & \multicolumn{3}{|c|}{ 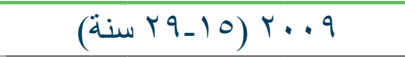 } & \\
\hline لا يعرف & بعارض & يو افق & لا بعرف & يعارض & يو افق & لا يعرف & بعارض & يو افق & \\
\hline & & & & & & & & & النوع \\
\hline$M, \Lambda$ & 19,1 & $\uparrow, 1$ & IT,V & $19, r$ & $\uparrow \wedge, 1$ & $\cdot, 9$ & $7, r$ & $94, \Lambda$ & ذكر \\
\hline 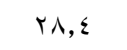 & $i \Lambda, v$ & or,. & $r q, r$ & $\curlywedge \wedge, \vee$ & or, 1 & 0,0 & $1 r, 4$ & $\wedge \cdot, q$ & أنثى \\
\hline & & & & & & & & & المستوي التعليمي \\
\hline $1 \%, q$ & $r \varepsilon, \cdot$ & Tr, & IT,V & $r, T$ & $T \leqslant, V$ & $r, \varepsilon$ & $9, r$ & $\wedge \wedge, r$ & أمي \\
\hline $1 \cdot, \cdot$ & rr, & $T V, q$ & $\cdot, 0$ & $r_{0, r}$ & $V r, q$ & $0, \cdot$ & $0, r$ & $\wedge ৭, \vee$ & يقر أ ويكتب \\
\hline$M, T$ & 10,9 & $v_{1,0}$ & $M, \varepsilon$ & 17,1 & $v 1,0$ & $r, r$ & $9, r$ & $\wedge \wedge, 0$ & إبتدائي \\
\hline $1 v, 9$ & $1 \wedge$, & $T \leqslant, 1$ & $10, \varepsilon$ & $1 \wedge, r$ & r & $r, r$ & 9,7 & $\Delta v, r$ & إعدادي \\
\hline ri, r & we. & 01,1 & $r 1,9$ & $i v, r$ & $0 ., 1$ & $0, r$ & $1 \cdot, r$ & $\wedge \varepsilon, \varepsilon$ & ثانوي عام \\
\hline$\curlywedge \wedge, \wedge$ & 19,1 & $T$ & $\lfloor, \wedge$ & $19, \varepsilon$ & $7, \wedge$ & $r, r$ & 9,9 & $\wedge$, & ثانوي فني \\
\hline$r \cdot, l$ & $1 \wedge, r$ & 7,7 & $r, \cdot$ & $1 \wedge, r$ & $\circ 9, \mathrm{~V}$ & $\ulcorner, \wedge$ & 0,9 & $q \cdot, r$ & فوق متوسط \\
\hline$r V, T$ & $1 \Lambda, \wedge$ & or, & rA, & 19, & or,. & 0,1 & ir,. & Nr,q & جامعي فأكثر \\
\hline & & & & & & & & & الهنطقة \\
\hline r., \& & Ir,r & $T V, \varepsilon$ & $r \cdot, q$ & Ir, & 74,1 & $r, r$ & $11,$. & $\Lambda \uparrow, v$ & محافظات حضرية \\
\hline$r, Y$ & $r \cdot, r$ & or,, & $r, 4$ & $r, r$ & 01,1 & $7, \cdot$ & Kr,T & $\Lambda, \varepsilon$ & حضر وجه بحري \\
\hline 17,0 & $r \varepsilon, 7$ & $0 \wedge, 9$ & $17, \varepsilon$ & $r \leqslant, T$ & $\circ 9, \cdot$ & $\varepsilon, \cdot$ & Ir,q & $\Delta r, 1$ & ريف وجه بحري \\
\hline rA, $\varepsilon$ & $r o, \lambda$ & $\varepsilon 0, \wedge$ & $r q, q$ & rr, & $\varepsilon \varepsilon, 1$ & r.o & $\mathrm{v}, \cdot$ & $9 \cdot, 0$ & حضر وجه قبلي \\
\hline$r_{\cdot, \ell}$ & $1 \leqslant$, & $10, \mathrm{~V}$ & $r \cdot, r$ & $1 T, \Lambda$ & $77, \cdot$ & 1,9 & $\varepsilon, 9$ & qr, & ريف وجه قبلي \\
\hline $1 \leqslant, r$ & ro, & $7 \cdot, 7$ & $10, \varepsilon$ & $r \leqslant, q$ & $09, V$ & 1,1 & $v, q$ & $9 \cdot, \varepsilon$ & محافظات حدودية \\
\hline & & & & & & & & & محل الاقامة \\
\hline$r 1,9$ & 17 & $T r, 1$ & rr, & 17,0 & 71,1 & $r, \wedge$ & $1 \cdot, r$ & ᄉ५, 9 & حضر \\
\hline $1 \wedge, r$ & 19,7 & $T, Y$ & $\mid \wedge, 1$ & $19, \varepsilon$ & $T r, 0$ & $r, \cdot$ & $9, r$ & $\Lambda v, v$ & ريف \\
\hline$r q, 0$ & $r, r$ & $\varepsilon \vee, r$ & $r \cdot, v$ & $r \varepsilon$, & $\varepsilon 0, r$ & 0, & 11,0 & یr,o & مناطق عشو ائية \\
\hline & & & & & & & & & مؤشر الثروة \\
\hline $10, \mathrm{~V}$ & $19, \varepsilon$ & $7 \leqslant, 9$ & 10,0 & $19, r$ & $70, r$ & $r, \varepsilon$ & $\mathrm{v}, \Lambda$ & $\wedge 9,9$ & الأدني \\
\hline$r \cdot, \uparrow$ & $1 \wedge, \wedge$ & $7 \cdot, 0$ & $r, \cdot$ & 19,1 & 09,9 & $r, v$ & १, ६ & NV, $q$ & الثاني \\
\hline$r, r$ & $1 \Lambda, V$ & $09, \mathrm{~V}$ & $r, q$ & $1 \wedge, \wedge$ & $09, \varepsilon$ & $r, q$ & $\Lambda, \vee$ & $\wedge \wedge, \varepsilon$ & الأوسط \\
\hline $19, \varepsilon$ & $1 \Lambda, \varepsilon$ & Tr, & 19,1 & 11,0 & $7, V$ & $r, \varepsilon$ & 11,7 & 10, & الر ابع \\
\hline$r \mu, \Lambda$ & $19, r$ & ov, & $r r, \Lambda$ & $19, r$ & ov,. & $\varepsilon, 0$ & Ir,. & Nr,o & الأعلى \\
\hline & & & & & & & & & الفئة العمرية \\
\hline$r r, q$ & 11,0 & $o v, Y$ & $r r, O$ & 11,1 & $0 \wedge, \varepsilon$ & r,q & $9, v$ & $\Lambda \uparrow, \varepsilon$ & $1 V_{-10}$ \\
\hline$r \cdot, r$ & $19, \varepsilon$ & $T, \varepsilon$ & $r \cdot, r$ & $19, \varepsilon$ & $7, \varepsilon$ & $r, 1$ & $৭, \wedge$ & $\wedge v, l$ & $r \varepsilon_{-1 \wedge}$ \\
\hline $19,$. & $19,$. & Tr, & 19, & $19,$. & Tr, & $r, v$ & $1 \cdot, \cdot$ & NV,r & rq_ro \\
\hline 11,0 & $1 \Lambda, r$ & Tr, & - & - & - & - & - & - & ro_r. \\
\hline & & & & & & & & & الحالة الزواجية \\
\hline YI, \& & $19, r$ & $09, r$ & $r, r$ & $19, r$ & 09,0 & $r, r$ & $9, r$ & $\Lambda \mathrm{V}, \varepsilon$ & أعزب \\
\hline $1 \wedge, 7$ & $1 \wedge, 1$ & \& \& & 11,9 & $1 \wedge, r$ & Tr, 9 & $r, v$ & $11, r$ & ᄉт, 1 & متزوج \\
\hline & & & & & & & & & الحالة الوظيفية \\
\hline 10,9 & $i v, 0$ & 74,7 & 10,1 & IV,T & $74, V$ & I,V & $v, r$ & $91,$. & يعمل \\
\hline $1 \wedge, \varepsilon$ & $1 \Lambda, r$ & צ & 17,7 & $\mid \wedge, 1$ & $70, r$ & $\varepsilon, \cdot$ & 9,0 & 14,7 & لا يعمل \\
\hline$r, 1$ & $19, v$ & $O V, r$ & $r, r$ & $19, V$ & ov, & $r, \Lambda$ & $11, r$ & 10, & خارجقوة العمل \\
\hline$r \cdot, \varepsilon$ & 11,9 & $7 \cdot, V$ & $r_{\cdot, T}$ & $19,$. & $7 \cdot, \varepsilon$ & $r, r$ & $9, \wedge$ & $\wedge v_{,}$ & الاجمالي \\
\hline$(r, 17 r)$ & $(Y, \cdot T \varepsilon)$ & $(7, T \vee V)$ & $(1, Y \Gamma \wedge)$ & $(1,7 \leqslant 1)$ & $(0, r r \varepsilon)$ & $(\Gamma Y \varepsilon)$ & $(1, \mid Y v)$ & $(9, \leqslant \wedge \curlywedge)$ & العدد \\
\hline
\end{tabular}




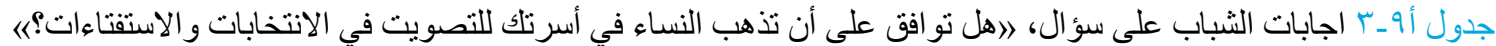

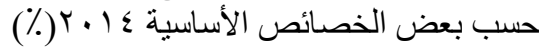

\begin{tabular}{|c|c|c|c|c|}
\hline \multicolumn{2}{|c|}{ 11 _هب سنة } & \multicolumn{2}{|c|}{ 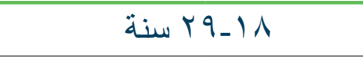 } & \\
\hline \multirow[t]{2}{*}{$\gamma$} & نعم & $\gamma$ & نعم & \\
\hline & & & & لنوع \\
\hline $\mid \Lambda, 1$ & $\wedge 1, q$ & $1 v, q$ & NT, & كر \\
\hline \multirow[t]{2}{*}{$19,}$. & $\wedge 1,1$ & $19,$. & $\wedge,$. & نثى \\
\hline & & & & لمستوي التعليمي \\
\hline$\Gamma, \varepsilon$ & $\uparrow, \uparrow$ & 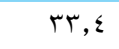 & 74,7 & مي \\
\hline r^,. & $V Y, \cdot$ & r & ז & قر أ ويكتب \\
\hline r & $V 4, r$ & $r \varepsilon, r$ & $v_{0, \lambda}$ & بندائي \\
\hline rצ, & $V \varepsilon$, & $r \uparrow, 0$ & $V r, O$ & عدادي \\
\hline $1 \varepsilon, \wedge$ & 10,r & 10,1 & $\Lambda \varepsilon, r$ & لانوي عام \\
\hline$M, Y$ & $\wedge 1,9$ & IN,r & $\wedge, \mathrm{V}$ & تانوي فني \\
\hline $11, r$ & $\wedge \wedge, \wedge$ & $1 \cdot, \lambda$ & $19, r$ & وق متوسط \\
\hline \multirow{2}{*}{$1 \cdot, 1$} & $\wedge 9,9$ & $q, \vee$ & $q \cdot, r$ & جامعي فأكثر \\
\hline & & & & لمنطقة \\
\hline $1 \leqslant, r$ & $10, \mathrm{~V}$ & $1 \leqslant, r$ & $10, \mathrm{~V}$ & حافظات حضرية \\
\hline $1 \cdot, \varepsilon$ & 19,7 & $1,, \cdot$ & $q_{\cdot, \cdot}$ & مضر وجه بحري \\
\hline 10,7 & $\wedge \leqslant, \varepsilon$ & 10, & 10, & ريف وجه بحري \\
\hline Y), & $\vee \wedge, r$ & rr, & $\vee \wedge, \cdot$ & مضر وجه قبلي \\
\hline$r 4, r$ & $V r, \Lambda$ & $r q, r$ & $V r, \Lambda$ & ريف وجه قبلي \\
\hline \multirow[t]{2}{*}{$r q, r$} & $v \cdot, v$ & $\lceil\Lambda, \varepsilon$ & $v 1, r$ & حافظات حدودية \\
\hline & & & & حل الاقامة \\
\hline 17,7 & Ar, \& & 17,7 & AT, & مضر \\
\hline$r_{\cdot}, q$ & $v q, 1$ & $r \cdot, v$ & $v q, r$ & ريف \\
\hline \multirow[t]{2}{*}{$1 ., 1$} & $9 \cdot, \cdot$ & 9,0 & $9 ., 0$ & ناطق عشو ائية \\
\hline & & & & ؤشر الثروة \\
\hline$r \cdot, l$ & 79,9 & $r, 1$ & $\uparrow \wedge, q$ & لالادني \\
\hline$r_{\cdot, r}$ & $v_{q, \varepsilon}$ & 19,9 & $\lambda_{\cdot,}, 1$ & ل الثاني \\
\hline$\curlywedge \wedge, \varepsilon$ & $\Lambda, \uparrow$ & IA,r & $\wedge,, \wedge$ & لأوسط \\
\hline $1 \leqslant, \varepsilon$ & $\wedge_{0,1}$ & 10,1 & $\wedge \varepsilon, q$ & لر لرابع \\
\hline \multirow[t]{2}{*}{$11, r$} & $\wedge \wedge, \vee$ & $1 \cdot, \lambda$ & $\wedge q, r$ & لأعلى \\
\hline & & & & لفئة العمرية \\
\hline $\mid \wedge, 1$ & $\wedge 1,9$ & $\mid \wedge, 1$ & $\wedge 1,9$ & $r \leq-11$ \\
\hline $19,$. & $\wedge 1,1$ & $19,$. & $\wedge, 1$ & rq_ro \\
\hline \multirow[t]{2}{*}{$1 \wedge, 9$} & $\wedge 1,1$ & & - & ro_r. \\
\hline & & & & لحالة الزواجية \\
\hline IA,Y & $\wedge 1, \wedge$ & $1 \Lambda, r$ & $\wedge, \mathrm{V}$ & عزب \\
\hline \multirow[t]{2}{*}{$1 \wedge, \wedge$} & $\wedge, r$ & $1 \wedge, 7$ & $\wedge 1, \varepsilon$ & كتزوج \\
\hline & & & & لحالة الوظيفية \\
\hline $1 \wedge, 1$ & Ar,. & $\mid \wedge, 1$ & $\wedge 1,9$ & be \\
\hline $1, .7$ & $\wedge १, \varepsilon$ & $1 ., 0$ & 19,0 & لا يعمل \\
\hline $19, v$ & $\Lambda \cdot, \varepsilon$ & $19, \varepsilon$ & $\lambda \cdot, 7$ & خارجقوة العمل \\
\hline 11,0 & 11,0 & $1 \wedge, \varepsilon$ & 11,7 & لاجمالي \\
\hline$(1,7 \leq 7)$ & $(V, \cdot Y V)$ & $(1, Y 07)$ & $(0, \leqslant \curlyvee \wedge)$ & لعدد \\
\hline
\end{tabular}




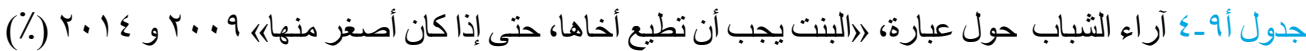

\begin{tabular}{|c|c|c|c|c|c|c|c|c|c|}
\hline \multicolumn{3}{|c|}{$\left(r 0_{-} \mid r\right) Y \cdot 1 \varepsilon$} & \multicolumn{3}{|c|}{ ع } & \multicolumn{3}{|c|}{ 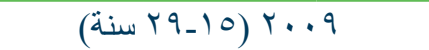 } & \\
\hline يعارض & لا يوارضق وضلا & يو افق & يعارض & لا يوارضق وضلا & يو افق ل & لا يعرف & يعارض & يو افق & \\
\hline & & & & & & & & & النوع \\
\hline$\wedge, \uparrow$ & $r r, q$ & $T Y, O$ & $\wedge, \uparrow$ & $r r, q$ & $T V, O$ & $\cdot, 0$ & $r \wedge, \Lambda$ & $v \cdot, \tau$ & ذكر \\
\hline IV,r & $r \wedge, q$ & or,q & $I V, V$ & $r q, r$ & or, 1 & 1,1 & $0 ., r$ & $\varepsilon \wedge, \vee$ & أنثى \\
\hline & & & & & & & & & المستوي التعليمي \\
\hline $9, \wedge$ & $r, r$ & $\circ ৭,$. & $৭, \vee$ & $M, r$ & 09,1 & $r, \varepsilon$ & $r \cdot, \wedge$ & 77,9 & أمي \\
\hline$v, v$ & $r v, l$ & 10,1 & $v, v$ & $r V, r$ & $T \varepsilon, 7$ & $i v, 1$ & $r q, r$ & or,o & يقر أ ويكتب \\
\hline$\wedge, 0$ & r, & $v_{\cdot}, \varepsilon$ & $9, \cdot$ & $r \cdot, 0$ & $v_{\cdot, r}$ & $\cdot, 9$ & $r \varepsilon, r$ & $7 \leqslant, 9$ & إبتدائي \\
\hline 11,1 & $r r, \varepsilon$ & 77,0 & $1 \cdot, 9$ & $r, r$ & 70,9 &., 0 & $\kappa_{\Lambda,}$ & 71,0 & إعدادي \\
\hline $1 \leqslant, 7$ & rA,, & ov, \{ & $1 \leqslant, \wedge$ & $r \wedge, r$ & ov,. & 1,1 & $\leqslant 7,9$ & or,. & ثانوي عام \\
\hline $11, v$ & $r \uparrow, \uparrow$ & $7, \lambda$ & $11, \varepsilon$ & rฯ, \& & $T Y, r$ & $\cdot, \mathrm{V}$ & $r v, v$ & 71,7 & ثانوي فني \\
\hline 17, & $r, q$ & 7,1 & $17, r$ & rr, & 7,1 & $\cdot$, & $\varepsilon r, 0$ & ov,o & فوق متوسط \\
\hline $1 \wedge, 1$ & rA, r & or, , & $1 \Lambda, \varepsilon$ & $r \wedge, 0$ & or,. & •, ६ & 01,1 & $\varepsilon \vee, \wedge$ & جامعي فأكثر \\
\hline & & & & & & & & & المنطقة \\
\hline $17, \varepsilon$ & 19,7 & $T \varepsilon$, & 17,0 & 19,7 & $7 r, 9$ & $1, \cdot$ & $\leqslant \uparrow, 0$ & or,o & محافظات حضرية \\
\hline $17,$. & $r \cdot, \cdot$ & $0 \leqslant$, & 10,9 & ri, & or,. & 1,1 & $\varepsilon \vee, \varepsilon$ & 01,0 & حضر وجه بحري \\
\hline $11, \varepsilon$ & ri,v & 07,9 & ir, & $r_{1, \varepsilon}$ & $07, \varepsilon$ & $\cdot, \wedge$ & $r_{0, \varepsilon}$ & ג, זד & ريف وجه بحري \\
\hline $1 \leqslant, 7$ & $r q, r$ & 00,1 & $1 \leqslant$, & $r \cdot, r$ & $00, v$ & •, £ & $\varepsilon \cdot, r$ & 09,0 & حضر وجه قبلي \\
\hline $1 \cdot, r$ & rr, & $T V, \Lambda$ & $1, ., r$ & $r 1, q$ & $T V, \Lambda$ &., 0 & $r \varepsilon, \varepsilon$ & $70, r$ & ريف وجه قبلي \\
\hline $11, \varepsilon$ & $r \varepsilon, \varepsilon$ & $0 \leqslant, r$ & $1 \cdot, v$ & rז, & or, r & $\varepsilon, r$ & $r \varepsilon, 1$ & 71,7 & محافظات حدودية \\
\hline & & & & & & & & & محل الاقامة \\
\hline $1 \leq, 1$ & ro,o & $7 ., 0$ & $1 \%, \Lambda$ & rq, r & $09, \wedge$ & $\cdot, 9$ & $\varepsilon 0, v$ & or, \& & حضر \\
\hline $1 \cdot, \lambda$ & $r V, I$ & $r, 1$ & $11, r$ & $r q, q$ & Tr,. & $\cdot, v$ & $r \leqslant, q$ & $T \leq, \varepsilon$ & ريف \\
\hline$r, 1$ & $r \varepsilon, r$ & $0 \leqslant, 7$ & $r, r$ & $r \varepsilon, Y$ & $0 \leqslant, 0$ & $1, r$ & $\varepsilon \varepsilon, r$ & $0 \leqslant, 0$ & مناطق عشو ائية \\
\hline & & & & & & & & & مؤشر الثروة \\
\hline $1 \cdot, r$ & rY, $\varepsilon$ & $T V, r$ & $1 \cdot, 1$ & $r, \varepsilon$ & 71,0 & $\cdot, 9$ & r T, T & $T V, 0$ & الأدني \\
\hline $11, \lambda$ & $r q, r$ & $0 \wedge, 9$ & $1 ., 9$ & $r \cdot, r$ & $0 \wedge, 0$ &., 0 & $r_{0, \varepsilon}$ & $T \leq, 1$ & الثناني \\
\hline 11,0 & וצ, & $T, v$ & $K_{,}, \varepsilon$ & $r \curlyvee, \wedge$ & $r \cdot, \lambda$ & $\cdot, 9$ & $\mu_{4, v}$ & Tr, & الأوسط \\
\hline$I r, r$ & $r \varepsilon, Y$ & $r, 1$ & $1 r, \wedge$ & $r \varepsilon, Y$ & 71,0 & ז, & $\varepsilon r, 1$ & $07, r$ & الر ابع \\
\hline $17, r$ & rA,, & 00,9 & 17,0 & $r v, q$ & 00,7 & l,r & $0 ., 1$ & $\varepsilon \vee, q$ & الأعلى \\
\hline & & & & & & & & & الفئة العمرية \\
\hline $1 \leq, 1$ & $r \leqslant, 0$ & $71, \varepsilon$ & $1 \varepsilon, r$ & $T \leqslant, 0$ & $T, r$ & $\cdot, \wedge$ & $r q, 1$ & $7 \cdot, 1$ & $1 V-10$ \\
\hline IT,Y & $r v,$. & $\bullet ৭, \wedge$ & Ir,r & $r v, \cdot$ & $\Delta 9, \wedge$ & $\cdot, 9$ & $r q, \cdot$ & $T \cdot, r$ & $r \leq-\mid \Lambda$ \\
\hline 11,0 & $r V,$. & 71,0 & 11,0 & $r v,$. & 71,0 & $\cdot, \wedge$ & ५ , q & $09, r$ & rq-ro \\
\hline Ir,. & $r 4, r$ & 71,9 & - & - & - & - & - & - & ro_r. \\
\hline & & & & & & & & & الحالة الزواجية \\
\hline $1 T, 7$ & $r \uparrow, \varepsilon$ & $7,$, & $1 \%, \varepsilon$ & rצ,O & 7,1 & $\cdot, 9$ & rی, r & $7 \cdot, 9$ & أعزب \\
\hline II,r & $r q, r$ & $T r, 0$ & 11,7 & $r \pi, r$ & Tr, & $\cdot, v$ & $\varepsilon 1, q$ & or, $\varepsilon$ & متزوج \\
\hline & & & & & & & & & الحالة الوظيفية \\
\hline $9, \vee$ & $r \leqslant, T$ & $10, \mathrm{~V}$ & 9,1 & ro,. & $7 \pi, \cdot$ & $\cdot, r$ & Mr,O & $T V, Y$ & يعمل \\
\hline $1 \cdot, 9$ & $r T, O$ & $70, \mathrm{~V}$ & Ir,r & $r, \cdot$ & $T T, V$ & $\cdot, 9$ & ro,v & o, & لا يعمل \\
\hline $1 \leqslant, 7$ & $r V, T$ & $o v, \lambda$ & $1 \leqslant, 9$ & $r V, T$ & $o v, 0$ & 1,1 & $\varepsilon r, 1$ & 00,1 & خارجقوة العمل \\
\hline$I Y, \Lambda$ & $r \uparrow, \varepsilon$ & $7 ., 9$ & Ir, 9 & Yฯ, \& & 7,7 & $\cdot, \wedge$ & $r q, r$ & 09,9 & الاجمالي \\
\hline$(1, \varepsilon Y r)$ & $(r, \wedge 94)$ & $(7,0 \wedge 7)$ & $(1,1 \leqslant r)$ & $(r, r \cdot l)$ & $(0,1 V \cdot)$ & $(117)$ & $(\xi, \varepsilon r \backslash)$ & $(7, \leqslant 00)$ & العدد \\
\hline
\end{tabular}




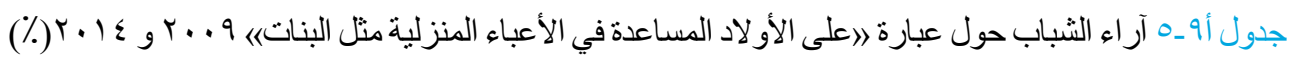

\begin{tabular}{|c|c|c|c|c|c|c|c|c|c|}
\hline \multicolumn{3}{|c|}{$\left.\left(T 0_{-}\right) T\right) Y \cdot 1 \varepsilon$} & \multicolumn{3}{|c|}{ 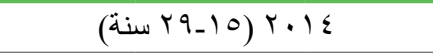 } & \multicolumn{3}{|c|}{ 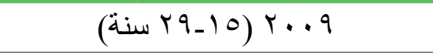 } & \\
\hline يعارض & لا يعارضق وضلا & يو افق & بعارض & لا يوارض وض لا & يو افق & لا يعرف & يعارض & يو افق & \\
\hline & & & & & & & & & النوع \\
\hline $01, \cdot$ & rA, r & $r \cdot, \wedge$ & $01, r$ & rA, \& & $r \cdot, r$ & $\cdot, 0$ & $V Y, O$ & $r v, 1$ & ذكر \\
\hline r,A & rt,A & $r_{0, \varepsilon}$ & 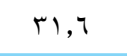 & Tr, & $r, 1$ & 1,1 & ov, 9 & «,, & أنثى \\
\hline & & & & & & & & & المستوي التعليمي \\
\hline$\varepsilon r, r$ & $r_{0, \varepsilon}$ & rr, & $\leq r, 1$ & $r_{0,9}$ & r.,. & $r, \varepsilon$ & $T r, \Lambda$ & $r \varepsilon, \wedge$ & أمي \\
\hline$\varepsilon r, 1$ & $r \cdot, \varepsilon$ & $r, T$ & $\varepsilon \cdot, r$ & rq, & $r r, \Lambda$ & $i v, 1$ & 09,0 & $r r, \varepsilon$ & يقر أويكتب \\
\hline$\varepsilon \wedge, \uparrow$ & r ז,O & $r \leq, q$ & $\varepsilon \wedge, 0$ & זד, & $r_{0,1}$ & $\cdot, v$ & 77,9 & $r$ r, & إبتدائي \\
\hline$\varepsilon r, v$ & $r V, O$ & $r \wedge, \wedge$ & $\leqslant 7$, & $r v, T$ & rฯ, & $\cdot, 7$ & 70,0 & (r), & إعدادي \\
\hline$r v, \varepsilon$ & $r q,$. & ז & T & $r q, r$ & $r \varepsilon, r$ & $\cdot, \varepsilon$ & (ז, & $r+, 1$ & ثانوي عام \\
\hline$\varepsilon r, \uparrow$ & $r 1,9$ & $r_{0, T}$ & $\varepsilon r, q$ & r & $r_{0, r}$ &., 0 & $74, \mathrm{~V}$ & $r, \wedge$ & ثانوي فني \\
\hline$\varepsilon r, 0$ & $r q, r$ & $r \Lambda, r$ & $\varepsilon r, q$ & ז & $r q, 0$ & $\cdot, \cdot$ & 79,1 & r.,. & فوق متوسط \\
\hline 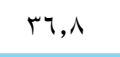 & $r \cdot, l$ & rT, & TV, & $r \cdot, \cdot$ & rr, q & $\cdot, \wedge$ & Tr, r & $r \uparrow, \Lambda$ & جامعي فأكثر \\
\hline & & & & & & & & & المنطقة \\
\hline$\varepsilon \cdot, 0$ & rr, $q$ & r & $\varepsilon \cdot, \uparrow$ & rY,T & 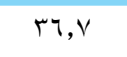 & $\cdot, 9$ & $\uparrow, \uparrow$ & $r \cdot, 0$ & محافظات حضرية \\
\hline$r \leqslant, \cdot$ & $r, r$ & $r r, v$ & $r_{0,1}$ & r., & rr, & 1,1 & זr, & ro, 9 & حضر وجه بحري \\
\hline$r q, \wedge$ & ro,. & $r_{0, r}$ & $\varepsilon \cdot, \cdot$ & $r \varepsilon, r$ & $r_{0, r}$ & $1,$. & $T \varepsilon$, & $r_{0,}$. & ريف وجه بحري \\
\hline$r v, r$ & rr, r & $r q, 0$ & rד,V & Tr, Tr & $r q, 7$ &., 0 & 11,. & $r_{\Lambda, 0}$ & حضر وجه قبلي \\
\hline$\varepsilon \wedge, \vee$ & 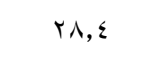 & $r, q$ & $\varepsilon \wedge, \wedge$ & $\lceil\wedge, \wedge$ & $r, \varepsilon$ & •, ६ & ז & rr, & ريف وجه قبلي \\
\hline$\varepsilon 1$, & $\lceil\wedge, \wedge$ & $r \cdot, r$ & $\varepsilon 1, r$ & $r \wedge, r$ & $r \cdot, \varepsilon$ & $\cdot, \cdot$ & $\Upsilon \wedge, \uparrow$ & $r 1,0$ & محافظات حدودية \\
\hline & & & & & & & & & محل الاقامة \\
\hline$\varepsilon \cdot, 0$ & $r A, r$ & $r_{1, \varepsilon}$ & $\varepsilon \cdot, r$ & $r \wedge, r$ & $r, 4$ & $\cdot, 9$ & $77, Y$ & rr,q & حضر \\
\hline$\varepsilon \varepsilon$, & ri, q & $r \leq, 1$ & $\varepsilon \varepsilon, r$ & rI, & $r \varepsilon$, & $\cdot, \vee$ & $70, r$ & $r \varepsilon, 1$ & ريف \\
\hline$r \cdot, r$ & $r \Lambda, \varepsilon$ & $\varepsilon 1, \varepsilon$ & $r, \wedge$ & $r v, V$ & $\varepsilon \cdot, 0$ & $\cdot, \wedge$ & ז & $\Gamma_{0, \Lambda}$ & مناطق عشو ائية \\
\hline & & & & & & & & & مؤشر الثروة \\
\hline$\varepsilon \vee, r$ & rA,, & $r \leqslant, V$ & $\varepsilon \wedge, \varepsilon$ & TV, & $r \varepsilon, 0$ & $\cdot, \wedge$ & 10,9 & r & الأدني \\
\hline$\varepsilon 1, \wedge$ & rT, & $r \leqslant, q$ & $\varepsilon 1$, & $r \varepsilon, 0$ & $r \leqslant, 0$ & •, £ & $T V, r$ & Tr, & الثاني \\
\hline$\varepsilon ., 1$ & $r, 1$ & $r \wedge, \Lambda$ & $\varepsilon \cdot, 0$ & $r, 1$ & 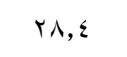 & $\cdot, \mathrm{V}$ & זיז & rr,q & الأوسط \\
\hline$\varepsilon 1, \varepsilon$ & $r q, r$ & rA, 9 & $\varepsilon r, r$ & $r q, r$ & YA,O & $\cdot, \mathrm{V}$ & $T \leqslant, 1$ & ro,r & الر ابع \\
\hline$r_{\Lambda, r}$ & $r \cdot, l$ & r & $\kappa_{\wedge, 0}$ & $r q, \varepsilon$ & $r, 1$ & l,r & $T r, \Lambda$ & זч,. & الأعلى \\
\hline & & & & & & & & & الفئة العمرية \\
\hline$\varepsilon r, \cdot$ & $r v, V$ & $r \cdot, r$ & $\varepsilon r, q$ & $r V, O$ & $r q, v$ & $\cdot, \mathrm{V}$ & ג ג & ro,o & $1 V_{-10}$ \\
\hline$\leqslant 1,9$ & $r \cdot, v$ & $r V, \varepsilon$ & $\leqslant 1,9$ & $r \cdot, v$ & $r v, \varepsilon$ & $\cdot, \mathrm{V}$ & TT, & rr, q & $r \varepsilon_{-} \mid \wedge$ \\
\hline$\leqslant 1,1$ & rI, & $r v, r$ & $\varepsilon 1,1$ & $r,, v$ & $r v, r$ & $\cdot, 9$ & $T \leqslant, \wedge$ & $r \varepsilon, \varepsilon$ & rq_ro \\
\hline$\varepsilon 1, r$ & $r, \tau$ & $r v, r$ & - & - & - & - & - & - & ro_r. \\
\hline & & & & & & & & & الحالة الزواجية \\
\hline$\varepsilon Y, \xi$ & $r q, r$ & $r v, q$ & $\varepsilon r, q$ & $r q, 7$ & $r V, T$ & $\cdot, \mathrm{V}$ & 77,1 & rr, & أعزب \\
\hline$\varepsilon \cdot, 1$ & r1, q & rı, & $r q, r$ & rr, r & YA, & $\cdot, \wedge$ & ז,זיד & ro, & متزوج \\
\hline & & & & & & & & & الحالة الوظيفية \\
\hline$\varepsilon \wedge, \wedge$ & $r \wedge, r$ & $r r, \cdot$ & $\varepsilon 9,9$ & rA, & $r, 1$ & $\cdot, r$ & $v \cdot, T$ & $r q, 1$ & يعمل \\
\hline$\varepsilon 0, r$ & $r q, r$ & $r_{0,0}$ & $\varepsilon \uparrow, r$ & rA, & ro,r & $\cdot, \wedge$ & $T, Y$ & rr,. & لا يعمل \\
\hline$r v, r$ & r,A & $r \cdot, q$ & $r V, T$ & r T, & $r \cdot, q$ & $1, \cdot$ & $T$ & r, & خارجقوة العمل \\
\hline$\leqslant 1,7$ & $r \cdot, 0$ & $r V, q$ & $\leqslant 1,9$ & $r \cdot, r$ & $r V, \Lambda$ & $\cdot, \wedge$ & $70, \varepsilon$ & rT,q & الاجمالي \\
\hline$(\varepsilon, \varepsilon \wedge \vee)$ & $(r, r \circ q)$ & $(\Gamma, .01)$ & $(r, \nabla \vee \varepsilon)$ & $(Y, T Y V)$ & $(r, \Sigma \mid r)$ & (Ar) & $(\vee, \cdot 99)$ & $(\Gamma, \wedge) \cdot)$ & العدد \\
\hline
\end{tabular}


جلول أو ـ آراء الثباب حول عبارة 》ا الزوج لوحده هو بس اللي يقول مصروف البيت يتصرف إزاي ) حسب بعض الخصائص الأساسية

(\%) $r+1 \leq, r+. q$

\begin{tabular}{|c|c|c|c|c|c|c|c|c|c|}
\hline \multicolumn{3}{|c|}{$\left(r \sigma_{-} / T\right) r \cdot \mid \varepsilon$} & \multicolumn{3}{|c|}{ ع r. } & \multicolumn{3}{|c|}{ 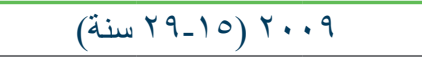 } & \\
\hline يعارض & لا يوارضق وضلا & يو افق & يعارض & لا يوارضق وضلا & يو افق & لا يعرف & يعارض & يو افق & \\
\hline & & & & & & & & & النوع \\
\hline 17,9 & $r V, \Lambda$ & $00, r$ & 17,9 & $r v, q$ & $00, r$ & •, ६ & $\Gamma_{\Lambda, \nu}$ & $7 \cdot, 9$ & ذكر \\
\hline$r_{1, \varepsilon}$ & $r q, r$ & $r q, \varepsilon$ & $r, \uparrow$ & $r 9,0$ & rı, q & $1, r$ & 7,7 & $r v, l$ & أنثى \\
\hline & & & & & & & & & المستوي التعليمي \\
\hline IV,r & $r 9,1$ & or,t & $1 V, 0$ & YA,, & $0 \leqslant, r$ & $r, 1$ & $\varepsilon \cdot, \cdot$ & Oᄉ,. & أمي \\
\hline $1 \%, q$ & $r_{1, r}$ & $0 \leqslant, \Lambda$ & $1 \leqslant, 1$ & ז & $09, r$ & $\mid v, 1$ & $T r, \Lambda$ & $r_{\cdot, \cdot}$ & يقرأ ويكتب \\
\hline 17,1 & $r q, 7$ & or,t & $i v, v$ & $r q, r$ & or, 1 & $1, r$ & $\varepsilon r, r$ & 00,7 & إبتدائي \\
\hline$r, 0$ & $r v, r$ & $\leq q, r$ & $r, \wedge$ & $r \wedge, 1$ & $\leq 9,1$ & $\cdot, \wedge$ & $\varepsilon \wedge, r$ & $01, \cdot$ & إعدادي \\
\hline$r_{1,9}$ & $r, 0$ & $\varepsilon 1,7$ & rr, & $r \rightarrow, q$ & $\varepsilon$, & $\cdot, \wedge$ & 00,7 & $\varepsilon r, r$ & ثانوي عام \\
\hline$r_{1,9}$ & rA, r & $\varepsilon 9, \wedge$ & $r_{\cdot, r}$ & $r \wedge, \gamma$ & $0 ., \mathrm{V}$ & $\cdot, 0$ & $0 ., \mathrm{V}$ & $\varepsilon \wedge, \wedge$ & ثانوي فني \\
\hline$r r, Y$ & $r v, \varepsilon$ & $\varepsilon \wedge, q$ & $r r, \Lambda$ & $r v, \cdot$ & $\varepsilon 9, r$ & $\cdot$, & ov, $\varepsilon$ & $\varepsilon r, Y$ & فوق متوسط \\
\hline$r, r$ & $r q, \wedge$ & $r \wedge, \wedge$ & M, & $r \cdot, r$ & rA,, & •, £ & $7, r$ & 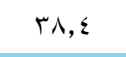 & جامعي فاكثر \\
\hline & & & & & & & & & المنطقة \\
\hline rA, 9 & $r \leqslant, r$ & $\leq 7,9$ & $r q, r$ & $r r, q$ & $\varepsilon \vee$, & $1, \varepsilon$ & $O Y, O$ & $\{1,1$ & محافظات حضرية \\
\hline$r \leqslant, 0$ & $r \cdot, \wedge$ & $\varepsilon \varepsilon, V$ & $r \leqslant, V$ & rr, & $\varepsilon r, r$ & $\cdot, \wedge$ & $00, r$ & $\varepsilon \varepsilon$, & حضر وجه بحري \\
\hline$r \varepsilon, 1$ & $r \varepsilon$, & $\leqslant 1,9$ & $r \leq, 0$ & ג ג & $\varepsilon 1, v$ & $\cdot, 9$ & $\leq 7,0$ & or,, & ريف وجه بحري \\
\hline$r \leqslant, q$ & $r v, l$ & $\varepsilon \wedge$, & $r, \Lambda$ & $r q, 1$ & $\varepsilon \wedge, r$ &., 0 & $0 ., 0$ & $\leq 9,1$ & حضر وجه قبلي \\
\hline$r \cdot, r$ & $r \varepsilon, r$ & $00, r$ & $r \cdot, 0$ & $r \varepsilon, \varepsilon$ & 00,1 & •, ६ & $\leq 0, r$ & $0 \leqslant, r$ & ريف وجه قبلي \\
\hline 17, & $r v, 1$ & $\varepsilon \vee$, & 17,0 & r ז r & $\varepsilon Y, r$ & 1,1 & $\varepsilon \wedge, 1$ & $0 ., \wedge$ & محافظات حدودية \\
\hline & & & & & & & & & محل الاقامة \\
\hline rq, & $r \wedge, r$ & $\{0, v$ & $r_{0,9}$ & $r \Lambda, T$ & $\{0,0$ & l,r & $07,$. & $\varepsilon r, Y$ & حضر \\
\hline$r, r$ & $r q, \varepsilon$ & $\varepsilon \wedge, r$ & rr,O & $r q, r$ & $\varepsilon \wedge, r$ & $\cdot, \vee$ & $\leq 0,9$ & or, \& & ريف \\
\hline rA,, & rr, & $\varepsilon \wedge, \vee$ & $r 7,9$ & $r_{0,1}$ & $\varepsilon \wedge$, & $\cdot, \mathrm{V}$ & or, \& & $\leqslant \uparrow$, & مناطق عشو ائية \\
\hline & & & & & & & & & مؤشر الثروة \\
\hline $1 \wedge, V$ & $r V, O$ & or, , & $i v, 0$ & rA, & $0 \leqslant, 0$ & $\cdot, \wedge$ & $\varepsilon 1, r$ & $0 \wedge, 1$ & الأدني \\
\hline$r_{\cdot, r}$ & $r q, q$ & $\varepsilon 9, \varepsilon$ & $r, r$ & $r \cdot, \varepsilon$ & $\varepsilon \wedge, 0$ &., 0 & $\{0,1$ & $0 \leqslant, \varepsilon$ & الثناني \\
\hline Tr, & $r \wedge, \gamma$ & $\varepsilon v, v$ & $r r, \varepsilon$ & 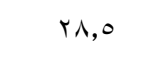 & $\varepsilon \wedge, r$ & 1,. & $\varepsilon \vee, r$ & 01,1 & الأوسط \\
\hline ro,. & $r V, r$ & $\varepsilon \vee, \Lambda$ & $r \leqslant, 0$ & $r V, T$ & $\varepsilon \wedge,$. & $\cdot, 9$ & $0 \leqslant, 0$ & $\varepsilon \varepsilon, V$ & الر ابع \\
\hline$r \cdot, \varepsilon$ & $r q,$. & $\varepsilon \cdot, 7$ & r.,. & $r \wedge, q$ & $\varepsilon \cdot, r$ & $1, r$ & $T r, \Lambda$ & rч,. & الأعلى \\
\hline & & & & & & & & & الفئة العمرية \\
\hline rq, & $r v, r$ & 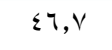 & $r \uparrow, V$ & $r 7, q$ & $\leqslant 7, \varepsilon$ & $1, r$ & $\varepsilon 9, \cdot$ & $\leq 9, \wedge$ & $1 V_{-10}$ \\
\hline$r r, \varepsilon$ & $r q, \wedge$ & $\leq \uparrow, \wedge$ & $r r, \varepsilon$ & $r q, \wedge$ & $\leq 4, \wedge$ & $\cdot, \wedge$ & $\varepsilon 9, \vee$ & $\varepsilon 9,7$ & $r \varepsilon_{-} \mid \wedge$ \\
\hline$r, Y$ & $r \wedge, 1$ & $\varepsilon q, r$ & $r, T$ & $r_{\wedge, 1}$ & $\varepsilon q, r$ & $\cdot, \mathrm{V}$ & $01,$. & $\varepsilon \wedge, r$ & rq_ro \\
\hline$r \leqslant, \wedge$ & $r V, \varepsilon$ & $\varepsilon Y, \Lambda$ & - & - & - & - & - & - & ro_r. \\
\hline & & & & & & & & & الحالة الزواجية \\
\hline$r r, \Lambda$ & $\Upsilon_{\Lambda}, \varepsilon$ & $\varepsilon v, q$ & $r r, \wedge$ & $\curlyvee \wedge, \varepsilon$ & $\varepsilon \vee, \wedge$ & 1,. & $\varepsilon \wedge, \varepsilon$ & $0 ., 7$ & أعزب \\
\hline$r \leqslant, \varepsilon$ & $\curlyvee \wedge, \wedge$ & $\leq \uparrow, \wedge$ & $r \varepsilon, r$ & $r q, \varepsilon$ & $\leq 4,0$ &., 0 & Tr, & $\leqslant 0,9$ & متزوج \\
\hline & & & & & & & & & الحالة الوظيفية \\
\hline 19,9 & $r \uparrow, \Lambda$ & or, \& & $1 \wedge, \wedge$ & $r 7,0$ & $0 \leqslant, V$ & $\cdot, r$ & $\varepsilon 1, r$ & $0 \wedge, 7$ & بعمل \\
\hline$r_{0,9}$ & 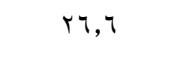 & $\varepsilon \gamma, 0$ & $r_{0, \varepsilon}$ & $r_{0, \Lambda}$ & $\varepsilon \wedge, q$ & $\cdot, 0$ & Or, r & $\varepsilon \vee, r$ & لا يعمل \\
\hline rq, & $r q, 7$ & $\varepsilon \varepsilon, r$ & $r, r$ & $r_{\cdot}, \cdot$ & $\varepsilon r, v$ & $1, r$ & $0 \leqslant, 1$ & $\varepsilon \varepsilon, V$ & خارج قوة العمل \\
\hline$r \varepsilon$, & $r \wedge, 0$ & $\varepsilon \vee, 0$ & $r r, q$ & $Y \wedge, Y$ & $\varepsilon v, \varepsilon$ & $\cdot, 9$ & $\leq 9,9$ & $\varepsilon q, r$ & الاجمالي \\
\hline$(Y, 70 \Sigma)$ & $(\Gamma, 1\rceil \wedge)$ & $(0, \wedge r)$ & $(Y, \cdot 9 \varepsilon)$ & $(r, 0,0)$ & $(\varepsilon,+1 \varepsilon)$ & $(1.1)$ & $(0,70 \cdot)$ & $(0, Y \leqslant 1)$ & العدد \\
\hline
\end{tabular}




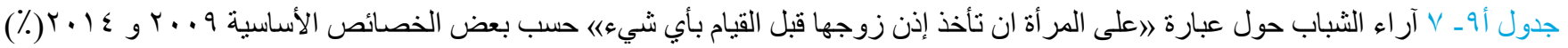

\begin{tabular}{|c|c|c|c|c|c|c|c|c|c|}
\hline \multicolumn{3}{|c|}{ 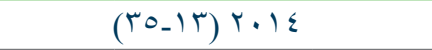 } & \multicolumn{3}{|c|}{ ع ب. r (10 (10 سنة) } & \multicolumn{3}{|c|}{ 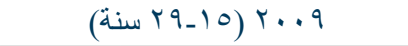 } & \\
\hline يعارض & لا يو افق و لا & يو افق & يعارض & لا يعارضق وضلا & يو افق & لا يعرف & يعارض & يو افق & \\
\hline & & & & & & & & & النوع \\
\hline$\varepsilon, \varepsilon$ & $1 v, 1$ & $\mathrm{VA,O}$ & $\varepsilon, 0$ & 17,1 & $\vee \wedge, \wedge$ & ., § & $1 \leqslant, 1$ & 10,0 & ذكر \\
\hline $\mathrm{v}, \varepsilon$ & $1 \wedge, 7$ & $v \varepsilon$, & $\mathrm{v}, \mathrm{T}$ & $i \wedge, \vee$ & $V r, T$ & $\cdot, 9$ & $r \leqslant, \wedge$ & $V \varepsilon, r$ & أنتى \\
\hline & & & & & & & & & المستوي التعليمي \\
\hline $0, r$ & 11,7 & $v_{4}, r$ & 0,7 & $i v, \Lambda$ & $\mathrm{V} \uparrow, \mathrm{V}$ & $r, 1$ & 17,1 & $\wedge, \wedge$ & أمي \\
\hline $7, \wedge$ & $r, Y, Y$ & $v \cdot, 0$ & $\varepsilon, r$ & rq, q & 71,9 & $\mid v, 1$ & $9, \vee$ & $V T, Y$ & يقر أ ويكتب \\
\hline$\varepsilon, \cdot$ & 17,7 & $v_{q, \varepsilon}$ & $\varepsilon, 7$ & $17, \lambda$ & $\vee \wedge, Y$ & $\cdot, 9$ & $i v, 1$ & $\Delta r, \cdot$ & إبتائي \\
\hline$\varepsilon, V$ & $17, Y$ & $\vee q, 1$ & $\varepsilon, \wedge$ & $10, \mathrm{~V}$ & $\vee ৭, 7$ & $\cdot, \varepsilon$ & 19,7 & $\lambda_{\cdot, \cdot}$ & إعدادي \\
\hline$v, v$ & $1 \wedge, r$ & $v \varepsilon$, & $v, 0$ & 11,0 & $v \varepsilon, 1$ & $\cdot, 7$ & rt,o & $V_{4}, \cdot$ & ثانوي عام \\
\hline 0,7 & lv,r & $V V, r$ & $0, r$ & IV,r & $v v, 0$ & $\cdot, r$ & $i v, v$ & $\Delta r, \cdot$ & ثانوي فني \\
\hline$r, \wedge$ & 10,0 & $\lambda \cdot, \vee \vee$ & $\varepsilon, 7$ & $1 \leqslant, 1$ & Ni,r & $\cdot, r$ & $r \cdot, l$ & $\vee q, 7$ & فوق متوسط \\
\hline$\wedge, \cdot$ & $r \cdot, l$ & $v 1, q$ & $\wedge, \varepsilon$ & $r \cdot, \cdot$ & vi, v & $\cdot, 0$ & $r \leqslant, q$ & $V \leqslant, V$ & جامعي فأكثر \\
\hline & & & & & & & & & المنطقة \\
\hline 7,1 & $1 \varepsilon, \varepsilon$ & $v 9,0$ & Ү, \& & $1 \leqslant, 0$ & $v q, 1$ & $1, \varepsilon$ & $r V, \varepsilon$ & $Y, Y$ & محافظات حضرية \\
\hline$v, r$ & rr,O & $V \cdot, r$ & $v, 0$ & $r r, \cdot$ & $v_{\cdot}, \mathrm{T}$ & $\cdot, 0$ & $r, 1$ & $V Y, \varepsilon$ & حضر وجه بحري \\
\hline $7, r$ & $r \cdot, \wedge$ & $V r, \cdot$ & $7, \varepsilon$ & $r \cdot, 0$ & $V r, r$ & $\cdot, 0$ & iv, & $\lambda r, 0$ & ريف وجه بحري \\
\hline$\wedge, 7$ & $r, r$ & $V \cdot, r$ & $\Lambda, r$ & $r, q$ & 79,1 &., 0 & $17, Y$ & $\lambda r, \varepsilon$ & حضر وجه قبلي \\
\hline$\varepsilon, r$ & $1 T, v$ & $\Delta, r$ & $\varepsilon, 1$ & $I T, V$ & $\Delta r, r$ & $\cdot, \varepsilon$ & $10, \mathrm{r}$ & $\Lambda \leqslant, 0$ & ريف وجه قبلي \\
\hline $0, \varepsilon$ & Yr, & $V Y, r$ & 7,1 & $r, r$ & VI, & $\cdot, 0$ & $19, V$ & $\vee \vee, \wedge$ & محافظات حدودية \\
\hline & & & & & & & & & محل الاقامة \\
\hline $0, v$ & WV,r & $V V, r$ & $0, \wedge$ & IV,r & $v v, 1$ & 1,1 & $r \leqslant, Y$ & $V \varepsilon, \wedge$ & حضر \\
\hline $0, r$ & iv,o & $V v, r$ & $0, r$ & WV,r & $V v, O$ & $\cdot, \varepsilon$ & $17, r$ & $\Lambda r, \varepsilon$ & ريف \\
\hline $1 \cdot, 9$ & $r, \wedge$ & $T V, r$ & $11, r$ & $r Y, \varepsilon$ & $77, \varepsilon$ & •, & Yr,, & $V v, r$ & مناطق عشو ائية \\
\hline & & & & & & & & & مؤشر الثروة \\
\hline$\varepsilon, r$ & 10,1 & $\Lambda_{\cdot,}$, & $r, v$ & 10,7 & $\wedge \cdot, \wedge$ & $\cdot, \wedge$ & $1 \leqslant, Y$ & $10, \cdot$ & الأدني \\
\hline 0,1 & $1 \wedge, \wedge$ & $v_{4}, 1$ & 0,7 & 11,9 & $v_{0, \varepsilon}$ & $\cdot, r$ & $1 v, 7$ & $\lambda r, l$ & الثاني \\
\hline $0, v$ & $19,$. & $v 0, r$ & I, & $1 \wedge, r$ & $v o, v$ & •, £ & $i v, 1$ & Ar,o & الأوسط \\
\hline $7, \varepsilon$ & $1 \wedge, 7$ & $v_{0,1}$ & 7,0 & $19,$. & $V \varepsilon, Y$ &., 0 & $r \cdot, r$ & $\vee q, r$ & الرابع \\
\hline$v, v$ & iv, & $v_{0, r}$ & $v, v$ & $17, V$ & $v_{0, v}$ & $1, \varepsilon$ & $r \Lambda, \uparrow$ & $v_{\cdot, l}$ & الأعلى \\
\hline & & & & & & & & & الفئة العمرية \\
\hline 0,0 & $1 \wedge, 1$ & Vฯ,r & 0,0 & IV,o & $v V, \cdot$ & $\cdot, 7$ & $r \cdot, r$ & $\vee q, r$ & $1 v_{-10}$ \\
\hline 7,1 & $W, \varepsilon$ & $V_{7,0}$ & 7,1 & $w, \varepsilon$ & $V_{Y}, 0$ & $\cdot, \mathrm{V}$ & 19,0 & $\vee \vee, \wedge$ & $r \varepsilon_{-1} \wedge$ \\
\hline $7, Y$ & $1 \wedge, r$ & $v_{0}, 0$ & $r, r$ & $1 \Lambda, r$ & vo,o & $\cdot, \mathrm{V}$ & $1 \lambda, r$ & $\wedge,, 1$ & rq_ro \\
\hline $0, \varepsilon$ & iv, v & $v_{7}, q$ & - & - & - & - & - & - & ro_r. \\
\hline & & & & & & & & & الحالة الزواجية \\
\hline $7, \cdot$ & $1 \Lambda, V$ & $v_{0, \varepsilon}$ & 0,9 & 11,0 & $v_{0, T}$ & $\cdot, \wedge$ & 19, & $\lambda \cdot, r$ & أعزب \\
\hline $0, \wedge$ & $17, r$ & $\mathrm{VA},$. & $7, r$ & 10,0 & $\forall \wedge, \varepsilon$ & $\cdot, r$ & $r \cdot, \varepsilon$ & $\vee q, r$ & متزوج \\
\hline & & & & & & & & & الحالة الوظيفية \\
\hline$\varepsilon, 1$ & iv, & $v \wedge, q$ & $r, v$ & 17,9 & $v_{9, \varepsilon}$ & $\cdot, r$ & 17,1 & $\wedge r, v$ & يعمل \\
\hline $0, r$ & $1 v, q$ & 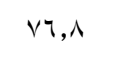 & 0,7 & $17, V$ & $v V, T$ & $\cdot, 1$ & $17, r$ & זr, & لا يعمل \\
\hline$v, \cdot$ & $1 \Lambda, r$ & $v \varepsilon, \wedge$ & $v, 1$ & $1 \Lambda, r$ & $v \varepsilon, v$ & $\cdot, 9$ & $r, r$ & $v v, \Lambda$ & خارجقوة العمل \\
\hline 0,9 & $\mathrm{i}, \mathrm{A}$ & $\vee 4, r$ & $7,$. & IV,V & $v 7, r$ & $\cdot, 7$ & $19, \varepsilon$ & $\Lambda_{\cdot, \cdot}$ & الاجمالي \\
\hline$(\Upsilon \wedge \uparrow)$ & $(1,9 Y 7)$ & $(\wedge, Y 9 Y)$ & $(009)$ & $(1,0.9)$ & $(7,0 \leqslant 0)$ & $\left(V^{\wedge}\right)$ & $(Y, Y, O)$ & $(\wedge, 799)$ & العدد \\
\hline
\end{tabular}


جدول أو_人 آر اء الثباب حول عبارة (هل تعتقد أن للمر أة الحق في طلب الانفصال عن زوجها (الطلاق أو الخع؟)) حسب بعض

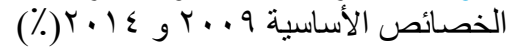

\begin{tabular}{|c|c|c|c|c|c|c|}
\hline \multicolumn{2}{|c|}{ (r. } & \multicolumn{2}{|c|}{ (10) Y. } & \multicolumn{2}{|c|}{ 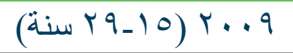 } & \\
\hline \multirow[t]{2}{*}{$y$} & 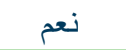 & y & 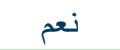 & $\gamma$ & 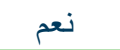 & \\
\hline & & & & & & النوع \\
\hline$r v, 1$ & $T r, q$ & $r v, 0$ & $T r, 0$ & $\varepsilon r, 1$ & 07,9 & ذكر \\
\hline \multirow[t]{2}{*}{19,0} & $\Lambda_{\cdot}, \mathrm{r}$ & $19,$. & $\wedge,$, & $r q, r$ & $v \cdot, \wedge$ & أنثى \\
\hline & & & & & & المستوي التعليمي \\
\hline$r v, \Lambda$ & $T r, r$ & $\lceil\wedge, \wedge$ & $71, r$ & $\leqslant 9,9$ & $0 ., 1$ & أمي - (2) \\
\hline rt, & $T V, \Lambda$ & rr,q & 77,1 & ґ , & $7, \varepsilon$ & يقرأ ويكتب \\
\hline rr,. & TV, & $r \varepsilon, \wedge$ & $70, r$ & $\varepsilon 1, r$ & $\Delta \wedge, \vee$ & إبتدائي \\
\hline$r \cdot, \cdot$ & $v_{\cdot}, \cdot$ & $r \cdot, \wedge$ & $79, r$ & $r v, v$ & Tr, & إعدادي \\
\hline rY, & $V V, T$ & rr,q & $v v, 1$ & $r_{\cdot}, \cdot$ & $v_{\cdot}, \cdot$ & ثانوي عام \\
\hline$r q, r$ & $v \cdot, v$ & $r \cdot, r$ & 79,1 & $r_{0,4}$ & $T \varepsilon, \varepsilon$ & ثانوي فني \\
\hline$r \varepsilon, r$ & $v_{0, v}$ & $r r, 0$ & $v_{4, T}$ & r), & $\vee q, \cdot$ & فوق متوسط \\
\hline \multirow[t]{2}{*}{$r, q$} & $v v, 1$ & $r, q$ & $\mathrm{v} \wedge, 1$ & ז ^ & $V r, r$ & جامعي فأكثر \\
\hline & & & & & & المنطقة \\
\hline ro,o & $V \varepsilon, 0$ & $r 4, r$ & $V r, \Lambda$ & $r \cdot, v$ & $79, r$ & محافظات حضرية \\
\hline$r \cdot, v$ & $79, r$ & $r q, \wedge$ & $V \cdot, r$ & ( ג & TT, & حضر وجه بحري \\
\hline rA, $)$ & $v 1,9$ & 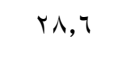 & $v_{1}, \varepsilon$ & M & $T r, 1$ & ريف وجه بحري \\
\hline ro, & $T \varepsilon, \varepsilon$ & $r \varepsilon, r$ & 70,9 & T,o & ס, ס & حضر وجه قبلي \\
\hline$r v, l$ & VY, q & $r v, r$ & $V Y, Y$ & $\varepsilon \cdot, 0$ & 09,0 & ريف وجه قبلي \\
\hline \multirow[t]{2}{*}{$\varepsilon r, \varepsilon$} & 07,7 & $\varepsilon r, 0$ & 07,0 & $\leq 9, \varepsilon$ & $0 ., 7$ & محافظات حدودية \\
\hline & & & & & & محل الاقامة \\
\hline$r \wedge, Y$ & $v, r$ & Y^, 9 & $v 1,1$ & Tr,T & $T \vee, \varepsilon$ & حضر \\
\hline$r v, q$ & $V Y, 1$ & $r \wedge, r$ & $v 1, v$ & $r \wedge, v$ & $7, r$ & ريف \\
\hline \multirow[t]{2}{*}{$r, \wedge$} & $r \Lambda, r$ & $r \cdot, r$ & $79, \vee$ & $r \varepsilon, \varepsilon$ & $70, \mathrm{~V}$ & مناطق عشو ائية \\
\hline & & & & & & مؤشر الثروة \\
\hline r & TT, & $r \varepsilon, \varepsilon$ & 70,7 & $\leq 0,0$ & $0 \leqslant, 0$ & الأدني \\
\hline$r \cdot, \cdot$ & $v_{\cdot}, \cdot$ & $r \cdot, l$ & 79,9 & $r q, 0$ & $7 ., 0$ & الثاني \\
\hline$r V, \Lambda$ & VY,Y & $r V, T$ & $V r, \varepsilon$ & $r 0, \wedge$ & $T \varepsilon, r$ & الأوسط \\
\hline$r \cdot, l$ & 79,9 & $r \cdot, \tau$ & $79, \varepsilon$ & $r \cdot, v$ & $79, r$ & الر ابع \\
\hline \multirow[t]{2}{*}{ rr, r } & $\checkmark v, \wedge$ & rr, & $\checkmark v, \wedge$ & $r q, \wedge$ & $V \cdot, r$ & الأعلى \\
\hline & & & & & & الفئة العمرية \\
\hline$r q, \wedge$ & $V \cdot, r$ & $r \cdot, \cdot$ & $v \cdot, 1$ & $r v, r$ & $T Y, V$ & $1 V-10$ \\
\hline$r \wedge, r$ & $\vee, \lambda$ & $r \Lambda, r$ & $v 1, \lambda$ & צ צ & ז,זד & $r \varepsilon_{-} \mid \wedge$ \\
\hline$r \wedge, r$ & $v, v$ & rA, r & $v_{1, v}$ & ro,r & $T \varepsilon, V$ & rq_ro \\
\hline \multirow[t]{2}{*}{$r v, r$} & VY, r & - & - & - & - & ro_r. \\
\hline & & & & & & الحالة الزواجية \\
\hline$r \cdot, \varepsilon$ & 79,7 & $r \cdot, \varepsilon$ & 79,7 & m,o & $\pi, 0$ & أعزب \\
\hline \multirow[t]{2}{*}{ ro,. } & vo,. & $r T, \Lambda$ & $v 4, r$ & ז,. & $T \varepsilon, 1$ & متزوج \\
\hline & & & & & & الحالة الوظيفية \\
\hline rY,. & in,. & rr,. & $T \lambda$, & $r \wedge, \wedge$ & $r, r$ & يعمل \\
\hline ro, \& & $V \varepsilon, 7$ & $r \leqslant, 0$ & $v_{0,0}$ & $r q, v$ & $r \cdot, r$ & لا يعمل \\
\hline$r$ r,A & Vr, r & $r v, r$ & $V Y, V$ & $r \varepsilon, v$ & $70, r$ & خارج قوة العمل \\
\hline$r \wedge, 0$ & $v 1,0$ & YA,,$\rangle$ & $v_{1}, \varepsilon$ & $r q, r$ & $T r, V$ & الاجمالي \\
\hline$(\Gamma, \wedge \varepsilon)$ & $(\mathrm{V}, \lambda r \cdot)$ & $(r,\{0 \cdot)$ & $(7,17 \pi)$ & $(\ulcorner, १ ৭ \vee)$ & $(7,994)$ & العدد \\
\hline
\end{tabular}




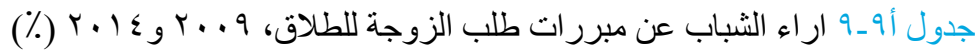

\begin{tabular}{|c|c|c|c|c|c|c|c|}
\hline \multicolumn{2}{|c|}{$\left(r_{-} / T\right) Y \cdot l \varepsilon$} & \multicolumn{2}{|c|}{ 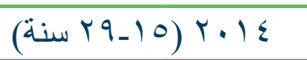 } & \multicolumn{3}{|c|}{ q . } & \multirow{3}{*}{ لو زوجها لم يحترم والديها او كبار عائلتها؟ } \\
\hline ע & 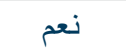 & $y$ & 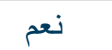 & لا يعرف & $y$ & 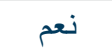 & \\
\hline & & & & & & & \\
\hline 07,9 & $\varepsilon r, 1$ & $07, r$ & $\varepsilon r, \wedge$ & $1, r$ & $\varepsilon \leqslant, \varepsilon$ & $0 \leqslant, r$ & ذكور \\
\hline 00,9 & $\varepsilon \leqslant, 1$ & $00, r$ & $\varepsilon \varepsilon, q$ & $\cdot, 9$ & $09, r$ & $\varepsilon,$, & إناث \\
\hline ه ₹ & ד, & $00, \mathrm{v}$ & $\varepsilon \varepsilon, \varepsilon$ & 1,1 & or, \& & $\leqslant \uparrow, 0$ & الكل \\
\hline \multirow[t]{2}{*}{$(\varepsilon, r \circ 9)$} & $(\Gamma, \leqslant 7))$ & $(r, r \wedge q)$ & $(r, Y Y \varepsilon)$ & $(\mathrm{V})$ & r,,$\vee v \vee)$ & $(r, 1 \leq \cdot)$ & العدد \\
\hline & & & & & & & لو زوجها لايحترم رايها وياخذه في الاعتبار \\
\hline$v 1, q$ & rA,, & Vr, r & $r V, Y$ & $1, r$ & $09, \cdot$ & r৭, & ذكور \\
\hline זיו & r q, q & 70,1 & $r \leqslant, r$ & $1, \cdot$ & $T V, Y$ & ri,r & إناث \\
\hline$T \Lambda, V$ & ri,r & $T \Lambda, \Lambda$ & r, r & 1,1 & $T, V$ & ro,l & الكل \\
\hline \multirow[t]{2}{*}{$(0,100)$} & $(r, 070)$ & $(\varepsilon, 1,1)$ & $(r, \cdot r)$ & $(\lambda r)$ & $(\varepsilon, 0 \leqslant \lambda)$ & $(r, r \neg r)$ & العدد \\
\hline & & & & & & & لو الزوج ضربها اول مرة او مد ايده عليها \\
\hline 11,0 & 11,0 & $\lambda r, 1$ & $1 v, q$ & $\cdot, \mathrm{V}$ & 1), & $1 \Lambda, r$ & ذكور \\
\hline vo,r & $r \leqslant, \Lambda$ & $v \varepsilon, q$ & ro, & •, & vo,r & $r \varepsilon, r$ & إناث \\
\hline $\mathrm{v} \wedge, \cdot$ & re, & $\vee \wedge, r$ & $r, \wedge$ & $\cdot, \mathrm{V}$ & $V Y, \Lambda$ & $r 1,0$ & الكل \\
\hline \multirow[t]{2}{*}{(\urcorner$, 1 \cdot \vee)$} & $(1, V \backslash T)$ & $(\varepsilon, \wedge) \cdot)$ & $(1, r \circ r)$ & (07) & $(0, \leqslant T 1)$ & $(1,0.7)$ & العدد \\
\hline & & & & & & & لو الزوج منعود يضربها او يمد ايده عليها \\
\hline$r \cdot, 0$ & 79,0 & $r \cdot, r$ & 79,1 & $\cdot, \uparrow$ & 19,9 & $\vee १, 0$ & ذكور \\
\hline$r V, 0$ & VY,O & $r v, r$ & VY,V & $\cdot, \Lambda$ & $r \wedge, 1$ & $v i, r$ & إناث \\
\hline$r \Lambda, \Lambda$ & $v, r$ & $r \Lambda, \uparrow$ & $v 1, \varepsilon$ & $\cdot, \mathrm{V}$ & $r \varepsilon, \varepsilon$ & vo,. & الكل \\
\hline \multirow[t]{2}{*}{$(r, r, q)$} & $(0,091)$ & $(1, Y \varepsilon \varepsilon)$ & $(\varepsilon, \varepsilon 19)$ & $(\varepsilon r)$ & $(1, Y \wedge 1)$ & $(0,179)$ & العدد \\
\hline & & & & & & & لو زوجها مش بيديها فلوس كفاية هي واو لادها \\
\hline$T, \mathrm{~V}$ & $r, r$ & $T \varepsilon, Y$ & $r 0,1$ & $\cdot, \uparrow$ & $\varepsilon \varepsilon, \uparrow$ & $0 \leqslant, \Lambda$ & ذكور \\
\hline T,0 & 4,0 & ו & r., 9 & $1, \cdot$ & $0 \Lambda, Y$ & $\varepsilon \cdot, \wedge$ & إناث \\
\hline ד, זוז & ז & ד,ץT & $\top_{4, \varepsilon}$ & $\cdot, \wedge$ & 01,9 & $\varepsilon Y, Y$ & الكل \\
\hline \multirow[t]{2}{*}{$(\varepsilon, 90 v)$} & $(r, \wedge T \Gamma)$ & $(r, \wedge ৭ \uparrow)$ & $(Y, Y Y \backslash)$ & (07) & $(r, Y \circ \varepsilon)$ & $(r, \wedge \wedge)$ & العدد \\
\hline & & & & & & & لو زوجها عاوز ياخد فلوسها او ممتلكاتها \\
\hline$\leqslant \uparrow, \cdot$ & $0 \varepsilon_{,}$, & $\varepsilon 0, \Lambda$ & $0 \leqslant, Y$ & $\cdot, \varepsilon$ & $r q, \uparrow$ & $v_{\cdot, \cdot} \cdot$ & ذكور \\
\hline$\varepsilon \Lambda, r$ & $01, v$ & $\varepsilon \Lambda, r$ & $01, v$ & $1, r$ & $\leq \uparrow, \uparrow$ & Or, r & إناث \\
\hline$\varepsilon \vee, r$ & Or,, $\mathrm{r}$ & $\varepsilon \vee, 1$ & Or,q & $\cdot, 9$ & $r \Lambda, \Lambda$ & $r, r$ & الكل \\
\hline \multirow[t]{2}{*}{$(r, \uparrow \wedge r)$} & $(\varepsilon, 1+\wedge)$ & $(r, \wedge 9 \cdot)$ & $(\Gamma, Y \vee \mu)$ & $(\mathrm{TV})$ & $(r, \wedge r q)$ & $(\varepsilon, \cdot 97)$ & العدد \\
\hline & & & & & & & لو الزوج بيعرف واحدة تانية \\
\hline ro,. & $70, \cdot$ & $r \leqslant, \tau$ & $70, \varepsilon$ & $\cdot, 7$ & $r Y, q$ & $v 1,0$ & ذكور \\
\hline rV,q & VY, & $r V, r$ & VY,A & $1,$. & $r, 1$ & $v \vee, q$ & إناث \\
\hline$r, 1$ & 71,9 & $r \cdot, \tau$ & $79, \varepsilon$ & $\cdot, \wedge$ & $r \leqslant, Y$ & vo,. & الكل \\
\hline \multirow[t]{2}{*}{$(r, r \vee r)$} & $(0, \leq \leqslant v)$ & $\left(1, \lambda r_{0}\right)$ & $(\varepsilon, \Gamma r \wedge)$ & $(00)$ & $(1, v \cdot 1)$ & $(0, Y M V)$ & العدد \\
\hline & & & & & & & لو الزوج تزوج عليها \\
\hline rT, & $T V, 1$ & rT,r & $74, V$ & $\cdot, \mathrm{V}$ & $\varepsilon r, r$ & 07,1 & ذكور \\
\hline $19,$. & $\wedge,$. & 11,0 & $\wedge 1,7$ & 1,0 & 19,1 & $v_{৭, \varepsilon}$ & إناث \\
\hline ro,r & $v \varepsilon, v$ & ro,r & $V \varepsilon, \Lambda$ & $1, r$ & $r \cdot, l$ & $\uparrow \wedge, \wedge$ & الكل \\
\hline \multirow[t]{2}{*}{$(1, \wedge \leqslant r)$} & $(0,9 \vee \wedge)$ & $(1, \leqslant \leqslant \cdot)$ & $(\varepsilon, V Y T)$ & (^) & $(r, \cdot 0 \cdot)$ & $(\varepsilon, \Lambda T r)$ & العدد \\
\hline & & & & & & & لو هي بنكر هـ \\
\hline rT, r & $\vee \uparrow, \wedge$ & $r+r$ & $\mathrm{~V}, \mathrm{~V}$ & $\cdot, 7$ & $I Y, V$ & $\Lambda \uparrow, \mathrm{V}$ & ذكور \\
\hline$r \cdot, \Lambda$ & v৭,r & $r \cdot, \Lambda$ & v৭,r & $1, r$ & $17, \mathrm{~V}$ & $\Delta r,$. & إناث \\
\hline 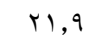 & $V A, r$ & $r, q$ & $\checkmark \wedge, 1$ & $1,$. & $1 \leqslant, 9$ & $\Lambda \varepsilon, r$ & الكل \\
\hline \multirow[t]{2}{*}{$(1,0 \wedge \varepsilon)$} & $(7, r+\uparrow)$ & $(1, Y 01)$ & $(\varepsilon, q \backslash r)$ & (79) & $(1,1,7)$ & $(0, \vee 9 \wedge)$ & العدد \\
\hline & & & & & & & لو الزوج ما بيخلفش عيال \\
\hline $0 ., \mathrm{V}$ & $\varepsilon q, r$ & $0 \cdot, \varepsilon$ & $\sum १, \uparrow$ & $r, 1$ & $0 \leqslant, 1$ & $\varepsilon r, \Lambda$ & ذكور \\
\hline 09,0 & $\varepsilon \cdot, 0$ & $09, r$ & $\varepsilon \cdot, v$ & $0,$. & 09,1 & $r_{0,9}$ & إناث \\
\hline 00,0 & $\varepsilon \varepsilon, 0$ & $00, r$ & $\varepsilon \varepsilon, \wedge$ & $\varepsilon, 1$ & 07,1 & $r q, 1$ & الكل \\
\hline \multirow[t]{2}{*}{$(\varepsilon, \varepsilon \Gamma \varepsilon)$} & $(\Gamma, \Gamma \wedge \uparrow)$ & $(\ulcorner, \xi \vee \uparrow)$ & $(r, T \wedge V)$ & $(Y \vee Y)$ & $(\varepsilon, \cdot 79)$ & $(Y, T \leqslant V)$ & العدد \\
\hline & & & & & & & اذا كان الزوج يعاني من أي مشكلة جنسية \\
\hline$\varepsilon 1$, & $09, \cdot$ & $\varepsilon \cdot, 0$ & 09,0 & $\varepsilon$, & $r, r$ & $v \leqslant, v$ & ذكور \\
\hline $0 ., 0$ & $\leqslant 9,0$ & $0 ., \varepsilon$ & $\varepsilon १, \uparrow$ & $\wedge,$. & $\varepsilon \wedge, \Lambda$ & $\varepsilon r, r$ & إناث \\
\hline$\sum \pi, r$ & or,A & $\leq 0,9$ & $0 \leqslant, 1$ & T,Y & $r 4, r$ & $o v, t$ & الكل \\
\hline$(\Gamma, 79 \varepsilon)$ & $(\xi, \mid Y \uparrow)$ & $(r, \wedge q \cdot)$ & $(\Gamma, Y \vee \Gamma)$ & $(\varepsilon r 0)$ & $(r, Y \leq r)$ & $(r, \lambda Y \uparrow)$ & العدد \\
\hline
\end{tabular}


الفصل r | الفصل ب | الفصل ع | الفصل 0 | الفصل 7 | الفصل V | الفصل م | الفصل

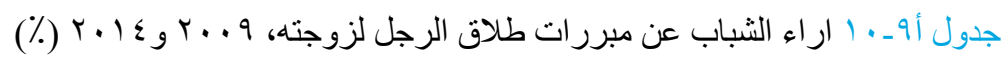

\begin{tabular}{|c|c|c|c|c|c|c|c|}
\hline \multicolumn{2}{|c|}{$\left(r 0_{-} / T\right) r \cdot 1 \varepsilon$} & \multicolumn{2}{|c|}{ (10) r. (10 } & \multicolumn{3}{|c|}{ q r r } & \\
\hline$y$ & نعم & $y$ & 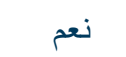 & ل لا يعرف & y & 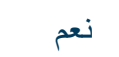 & \\
\hline & & & & & & & لو زوجته لم تحترم و الديه او كبار عائلته؟ \\
\hline$\varepsilon \cdot, 0$ & 09,0 & $\varepsilon \cdot, 0$ & 09,0 & 1,0 & rr, & Tा, \& & ذكور \\
\hline $01,$. & $\varepsilon q$, & $0 ., v$ & $\varepsilon q, r$ & $1, r$ & or, ६ & $\varepsilon\rceil, r$ & 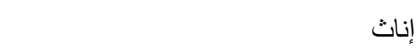 \\
\hline$\varepsilon 0,7$ & $0 \leqslant, \varepsilon$ & $\varepsilon 0, \varepsilon$ & $0 \leqslant, 7$ & $1, \varepsilon$ & $\varepsilon r, 1$ & 07,7 & 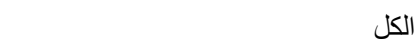 \\
\hline$(\varepsilon, q, q)$ & $(0,990)$ & $(r, \lambda r \cdot)$ & $(\xi, \vee \wedge r)$ & $(101)$ & $(\varepsilon, \wedge V \cdot)$ & $(0,9 \times 1)$ & العدد \\
\hline
\end{tabular}

لإناث
الكور زوجته لم تسمع كلامه (لو لم تطيعه)

إنكور

لو الزوجة مش واخذة بالها من الأو لاد كويس

ذكور

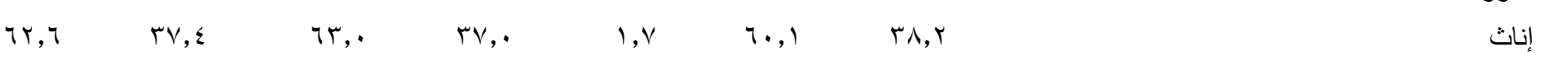

الكل

العدرد

\begin{tabular}{|c|c|c|c|c|c|c|c|}
\hline & & & & & & & لو عرفت راجل تاني \\
\hline$\wedge, \wedge$ & $91, r$ & $\wedge, \vee$ & $91, r$ & $\cdot, \wedge$ & Ir, r & $\wedge v$, & ذكور \\
\hline 9,1 & $9 ., 9$ & $१, \varepsilon$ & $9 \cdot, v$ & 1,0 & 10,9 & Ar,, & إناث \\
\hline $9, \cdot$ & 91, . & $9, \cdot$ & $91, \cdot$ & i,r & $1 \leqslant$, & $\wedge \varepsilon, q$ & الكل \\
\hline (१९५) & $(9,9 \cdot \wedge)$ & $($ (V৭r) & $(\vee, \wedge r \cdot)$ & $(1+\varepsilon)$ & $(1,077)$ & $(9$, Yq $)$ & 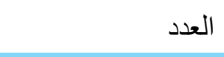 \\
\hline
\end{tabular}

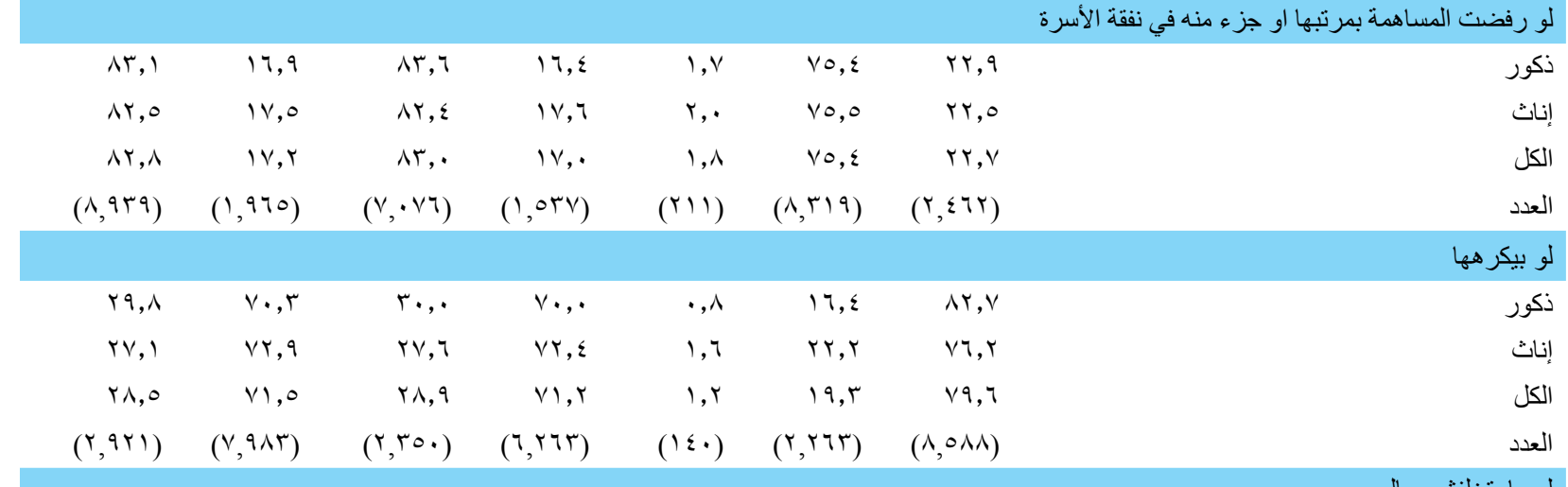

\begin{tabular}{|c|c|c|c|c|c|c|c|}
\hline & & & & & & & لو ما بتخلفش عبال \\
\hline 04,1 & $\varepsilon \varepsilon$, & 00,9 & $\varepsilon \varepsilon, 1$ & $r, 0$ & 09,1 & $r_{\Lambda, \varepsilon}$ & ذكور \\
\hline $0 \wedge, \wedge$ & $\varepsilon, r$ & $0 \wedge, \varepsilon$ & $\varepsilon 1, \uparrow$ & $\varepsilon, \wedge$ & $0 \wedge, \varepsilon$ & ז & إناث \\
\hline \multirow{3}{*}{$\begin{array}{c}O V, z \\
(T, Y \wedge V)\end{array}$} & $\varepsilon r, \uparrow$ & ov, 1 & $\varepsilon r, q$ & $r, \tau$ & $0 \wedge, Y$ & $r v, T$ & الكل \\
\hline & $(\varepsilon, \pi \backslash)$ & $(\varepsilon, 9 \leq 9)$ & $(r, T r \varepsilon)$ & $(\varepsilon, r)$ & $(T$, Orr $)$ & $(\varepsilon, \cdot \varepsilon \wedge)$ & 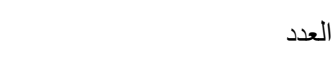 \\
\hline & & & & & & & اذا كانت تعاني من مشكلة جنسية \\
\hline$\leq 9,9$ & $0 ., 1$ & $\leq 9,9$ & $0 ., 1$ & $r, \mathrm{~V}$ & ro,o & $7 \cdot, 9$ & ذكور \\
\hline or,. & $\varepsilon \vee$, & or,A & $\varepsilon V, r$ & $\lambda, r$ & $\leq 9,1$ & $\leqslant r, T$ & إناث \\
\hline $01, \varepsilon$ & $\varepsilon \wedge, \uparrow$ & $01, r$ & $\varepsilon \wedge, \vee$ & 0,9 & $\varepsilon r, 1$ & 01,9 & الكل \\
\hline$(0, \pi r \varepsilon)$ & $(0, Y \Lambda \cdot)$ & $(\varepsilon, \varepsilon \pi r)$ & $(\varepsilon, 1 \wedge \cdot)$ & ( & $(\varepsilon, \wedge r \uparrow)$ & $(0,0$ Tr $)$ & 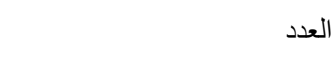 \\
\hline
\end{tabular}


الفصل r | الفصل r | الفصل ع | الفصل 0 | الفصل 7 | الفصل V | الفصل م | الفصل 9

جذول أو ـ ا آ آراء الثباب حول سؤال 》هل تعتقد ان المجتمع ينظر للنساء المطلقات باحتر ام؟) حسب بعض الخصائص الأساسية

(\%) r. $r \leqslant g r . . q$

\begin{tabular}{|c|c|c|c|c|c|c|}
\hline \multicolumn{2}{|c|}{$\left(r 0_{-} I T\right) r \cdot 1 \varepsilon$} & \multicolumn{2}{|c|}{ (10) r. } & \multicolumn{2}{|c|}{ 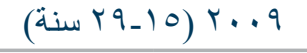 } & \\
\hline \multirow[t]{2}{*}{$y$} & نعم & $y$ & نعم & $y$ & نعم & \\
\hline & & & & & & النوع \\
\hline$\pi, \Lambda$ & $r V, r$ & $T r, q$ & $r v, 1$ & 70,1 & $r \varepsilon, r$ & ذكر \\
\hline \multirow[t]{2}{*}{$T \leqslant, \wedge$} & ro,r & $T \leqslant, 7$ & $r_{0, \varepsilon}$ & $\uparrow \wedge, \uparrow$ & $r_{1, \varepsilon}$ & أنثى \\
\hline & & & & & & المستوي التعليمي \\
\hline$\uparrow \wedge, \vee$ & $r, r$ & $v \cdot, r$ & $r q, r$ & $v 1,0$ & $r \Lambda, 0$ & أمي \\
\hline$\uparrow, \varepsilon$ & $r, 4$ & $7 \cdot, V$ & $r q, r$ & $1 \cdots$, & $\cdot, \cdot$ & يقر أويكتب \\
\hline $79, \varepsilon$ & $r \cdot, r$ & 79,0 & $r \cdot, 0$ & $v, \varepsilon$ & YA, & إبتدائي \\
\hline 77,7 & rT, & $T V, r$ & rr, & $77, \wedge$ & 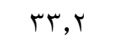 & إعدادي \\
\hline$\Delta 9, \wedge$ & $\varepsilon \cdot, r$ & $T \cdot, r$ & $r q, \wedge$ & 落, & rv, & ثانوي عام \\
\hline $10, \varepsilon$ & $r \varepsilon, v$ & $7 \leqslant, 7$ & $r_{0, \varepsilon}$ & $T V, T$ & rr,o & ثانوي فني \\
\hline $7 \cdot, 9$ & $r q, 1$ & $T \leqslant$, & $r_{4, \cdot}$ & $T r, 0$ & $r v, 0$ & فوق متوسط \\
\hline \multirow[t]{2}{*}{04,1} & $\varepsilon r, q$ & $o v, r$ & $\varepsilon r, \wedge$ & $T r, r$ & $r v, \Lambda$ & جامعي فأكثر \\
\hline & & & & & & المنطقة \\
\hline $07, Y$ & $\varepsilon r, \wedge$ & $o v, r$ & $\leq r, Y$ & (r, & $r \uparrow, v$ & محافظات حضرية \\
\hline 79,1 & $r \cdot, r$ & $v_{\cdot}, q$ & $r q, r$ & 70,9 & $r \varepsilon, 1$ & حضر وجه بحري \\
\hline (r, 9 & $r 4,1$ & Tr, & דצ, & $70, \mathrm{~V}$ & $r \varepsilon, r$ & ريف وجه بحري \\
\hline$v_{1}, q$ & $r \wedge, 1$ & $v \cdot, T$ & $r q, \varepsilon$ & $v_{\cdot,,}$ & $r_{\cdot}, \cdot$ & حضر وجه قبلي \\
\hline Tr, & $r v, l$ & $T r, \varepsilon$ & $r v, \tau$ & $\vee 1, \lambda$ & $r \Lambda, r$ & ريف وجه قبلي \\
\hline \multirow[t]{2}{*}{$v 4,4$} & $r r, \varepsilon$ & $v V, 1$ & rr,q & $T V, V$ & ru, r & محافظات حدودية \\
\hline & & & & & & محل الاقامة \\
\hline 09,9 & $\varepsilon \cdot, 1$ & $11, \cdot$ & $r q, 1$ & $7 \leqslant, 1$ & ro, 9 & حضر \\
\hline$\pi, V$ & $r \uparrow, \varepsilon$ & Tr, & rq, 9 & $\uparrow 1,0$ & $r, 4$ & ريف \\
\hline \multirow[t]{2}{*}{$v_{1},}$. & $r \varepsilon_{,}$ & $v_{0, q}$ & $r \leqslant, 1$ & $79, r$ & $r \cdot, v$ & مناطق عشو ائية \\
\hline & & & & & & مؤشر الثروة \\
\hline 77,1 & rT, q & 70,9 & $r \varepsilon, 1$ & $v_{1,0}$ & $r \Lambda, 0$ & الأدني \\
\hline 77, & $r \varepsilon, \cdot$ & $10,$. & ro,. & $79, \varepsilon$ & $r \cdot, v$ & الثاني \\
\hline$T V, 0$ & Tr,O & $T \Lambda, r$ & $r_{1, \Lambda}$ & $i \lambda, r$ & $r_{1, \nu}$ & الأوسط \\
\hline 71,7 & $r \wedge, \varepsilon$ & 71,0 & $r \Lambda, 0$ & $10,$. & ro,. & الر ابع \\
\hline \multirow[t]{2}{*}{$0 \wedge, \mathrm{V}$} & $\varepsilon 1, r$ & $09, r$ & $\varepsilon \cdot, \wedge$ & 11,. & ז৭,. & الأعلى \\
\hline & & & & & & الفئة العمرية \\
\hline Tr, & $r V, V$ & $T, Y$ & $r v, \Lambda$ & $T V, \cdot$ & rr,. & $1 V_{-10}$ \\
\hline$T \leqslant, r$ & ro,v & $T \leqslant, r$ & ro,v & $47, \wedge$ & rr, r & $r \varepsilon_{-} \mid \lambda$ \\
\hline 9ז, & $r ч, 1$ & Tr, & rq, & $\uparrow \wedge$, & rr,. & rq_ro \\
\hline \multirow[t]{2}{*}{$7 \varepsilon, 1$} & $r_{0, q}$ & - & - & - & - & ro_r. \\
\hline & & & & & & الحالة الزو اجية \\
\hline$T r, q$ & $r V, r$ & (r, & T4,q & 10,9 & $r \varepsilon, 1$ & أعزب \\
\hline \multirow[t]{2}{*}{$70, \varepsilon$} & $r \varepsilon, \tau$ & $10, \varepsilon$ & $r \varepsilon, T$ & $v \cdot, r$ & $r q, r$ & متزوج \\
\hline & & & & & & الحالة الوظيفية \\
\hline$T r, 0$ & $r v, 0$ & $T r, \Lambda$ & $r v, r$ & 77,1 & $r r, q$ & يعمل \\
\hline $70, r$ & $r \varepsilon, v$ & $T r, V$ & rฯ, \& & $7, \wedge$ & $r \wedge, r$ & لا يعمل \\
\hline$T \leq, r$ & ro,v & $T \leqslant, Y$ & $r 0, \Lambda$ & $i \Lambda, r$ & $r, \wedge$ & خارجقوة العمل \\
\hline$\pi r, v$ & $r \uparrow, r$ & $7 T, V$ & $r 7, r$ & $T V, 1$ & rr, q & الاجمالي \\
\hline$(v, 1 \cdot v)$ & $($ (,$\vee ৭ \vee)$ & $(0,7 \cdots)$ & $(r, \cdot 1 r)$ & $(v, r \circ v)$ & $(r, T r)$ & العدد \\
\hline
\end{tabular}




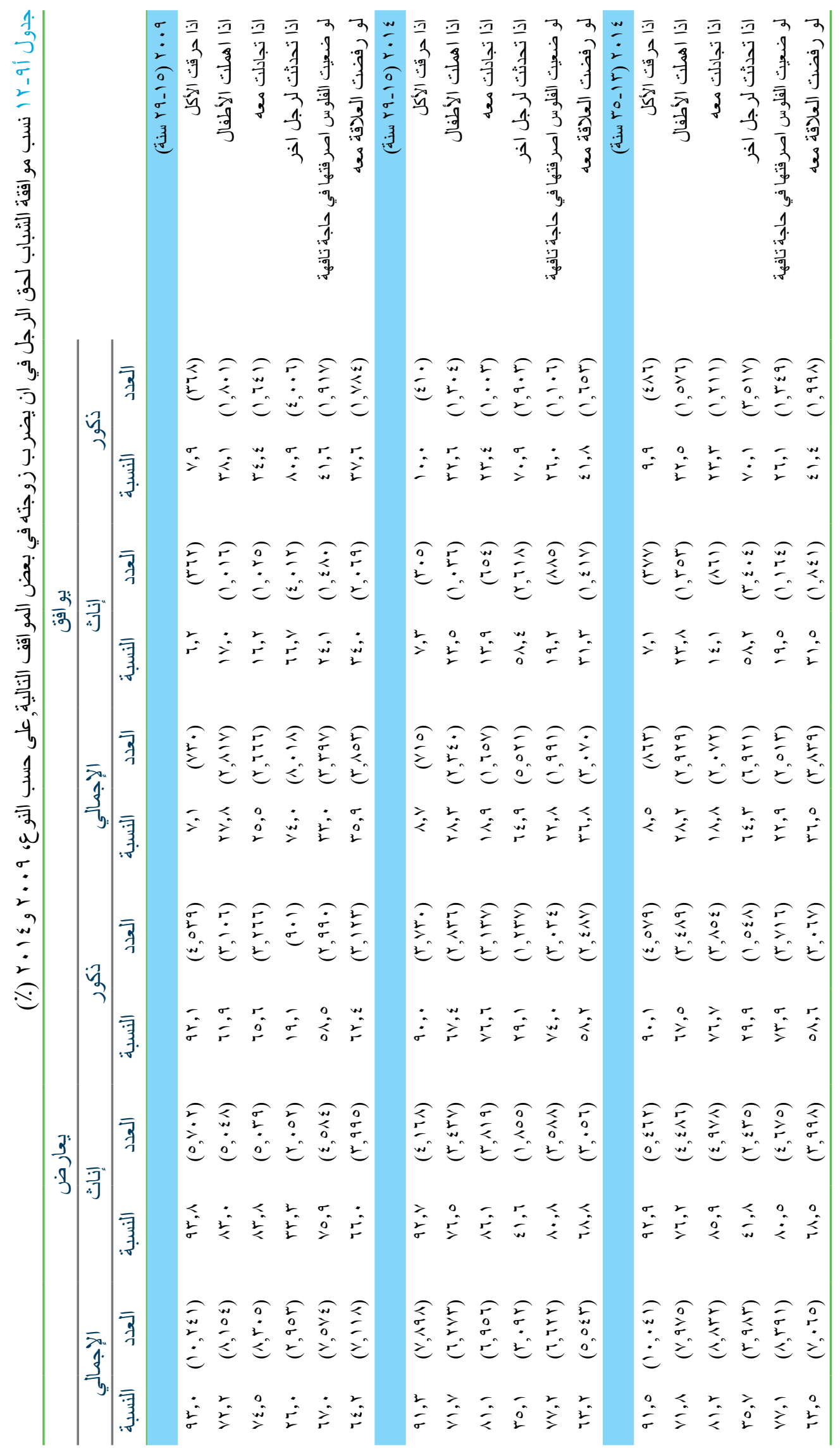




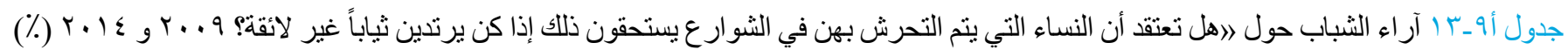

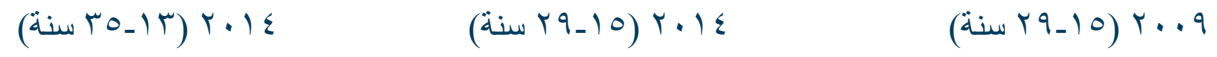

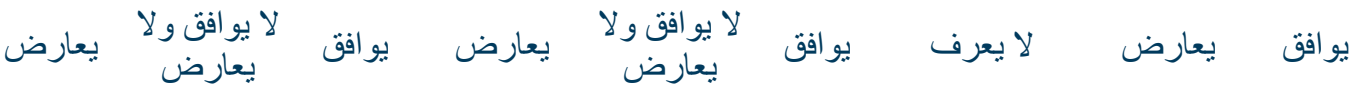

\begin{tabular}{|c|c|c|c|c|c|c|c|c|c|}
\hline & & & & & & & & & النوع \\
\hline$r, v$ & $10, r$ & $r, \cdot$ & $r, O$ & $10, r$ & $r, r$ & $\cdot, 0$ & $r \cdot, \cdot$ & $\vee q, 0$ & ذكر \\
\hline \multirow{2}{*}{$\curlyvee \wedge, \wedge$} & $10, r$ & 07,1 & $r q, \cdot$ & $1 \leqslant, \wedge$ & $07, r$ & $\cdot, \wedge$ & $r, Y$ & VY,O & أنثى \\
\hline & & & & & & & & & المستوي التعليمي \\
\hline$\lfloor\wedge, \wedge$ & $1 \wedge, \varepsilon$ & $\pi r, \Lambda$ & $1 v, q$ & IV,. & 70,1 & $r, r$ & $r \cdot, \Lambda$ & $v V, 1$ & أمي \\
\hline$r_{1, r}$ & $r 1,9$ & 07,9 & IV,O & $r \cdot, \varepsilon$ & or, 1 & $1 v, 1$ & $r,, v$ & $71, r$ & يقرأ ويكتب \\
\hline$r, \wedge$ & $I r, V$ & $T \leqslant, 0$ & $r, T$ & $1 T, 9$ & 70,7 & 1,1 & $r, \wedge$ & $v v, 1$ & إبتدائي \\
\hline$r, r$ & $10, \mathrm{~V}$ & 11,. & $r, \wedge$ & $10, r$ & $T, 1$ & $\cdot, 7$ & $r, 1$ & $v \vee, \varepsilon$ & إعدادي \\
\hline$r 4,7$ & 17,1 & $o v, r$ & $r 7, q$ & 10,9 & $O V, r$ & $\cdot, 7$ & $r \wedge, r$ & vi,r & ثانوي عام \\
\hline$r \varepsilon, \wedge$ & $i r, \wedge$ & $71, \varepsilon$ & $r \leqslant, \wedge$ & $1 \pi, 0$ & TI, V & $\cdot, 1$ & $r_{1, \Lambda}$ & $\vee \wedge, \cdot$ & ثانوي فني \\
\hline$r v, l$ & $1 \lambda, r$ & $0 \leqslant, Y$ & rq, 9 & 17,1 & ov, & $\cdot, \cdot$ & $r, r$ & $V v, V$ & فوق متوسط \\
\hline \multirow[t]{2}{*}{ rT, r } & 10,1 & 01,1 & $r, \wedge$ & $17, r$ & $0 ., 9$ & $\cdot, 7$ & $r q, 1$ & $v \cdot, r$ & جامعي فأكثر \\
\hline & & & & & & & & & المنطقة \\
\hline rT,V & IT,r & $0 \leqslant, \cdot$ & $r \varepsilon, \tau$ & Ir,O & or,. & $1, \cdot$ & r., & $T V, T$ & محافظات حضرية \\
\hline$r \Lambda, q$ & Tr, & $\varepsilon \vee, \wedge$ & $r v, 0$ & $\mid r, \wedge$ & $\varepsilon \wedge, \wedge$ & $\cdot, \wedge$ & $r r, \varepsilon$ & $v 0, \wedge$ & حضر وجه بحري \\
\hline$r r, \Lambda$ & $1 \wedge, \varepsilon$ & ov, v & $r \leqslant, r$ & $1 v, q$ & $o v, \lambda$ & $\cdot, \varepsilon$ & $r, \cdot$ & $V V, Y$ & ريف وجه بحري \\
\hline$r q, q$ & $10, \varepsilon$ & $0 \leqslant, Y$ & $r q, r$ & $10, r$ & 00,0 & $\cdot, 9$ & $19, r$ & $v q, q$ & حضر وجه قبلي \\
\hline $17, r$ & $1 \leq, 1$ & $79, \mathrm{~V}$ & $17, r$ & $1 T, 0$ & $v \cdot, r$ & $\cdot, 0$ & 19, & $\lambda_{\cdot, 0}$ & ريف وجه قبلي \\
\hline \multirow[t]{2}{*}{$1 \wedge, 7$} & $r, r$ & $7 \cdot, r$ & 19,7 & $r \cdot, q$ & 09,0 & i,r & $r \uparrow, \wedge$ & $v_{1}, q$ & محافظات حدودية \\
\hline & & & & & & & & & محل الاقامة \\
\hline$r 9,1$ & $1 \leqslant, \varepsilon$ & 00,1 & $r q, r$ & $1 \leqslant, 7$ & 07,1 & $1,$. & $r V, O$ & $v 1,0$ & حضر \\
\hline$r_{\cdot, r}$ & $17, \varepsilon$ & ع & $r \cdot, \varepsilon$ & 10,1 & $7 r, 9$ & $\cdot, 0$ & $r \cdot, r$ & $\vee \wedge, \wedge$ & ريف \\
\hline \multirow[t]{2}{*}{$\leq 7,9$} & $1 \cdot, v$ & $\{r, \xi$ & $\varepsilon \wedge, r$ & $11,$. & $\varepsilon \cdot, \lambda$ & $\cdot, \wedge$ & $r \varepsilon, \wedge$ & $V \varepsilon, \varepsilon$ & مناطق عشو ائية \\
\hline & & & & & & & & & مؤشر الثروة \\
\hline$r_{\cdot, \tau}$ & 17,7 & $T r, \Lambda$ & $r \cdot, r$ & $10, \mathrm{~V}$ & $T \leqslant$, & $1,$. & 19,1 & $\vee q, r$ & الأدني \\
\hline$r, r$ & $1 r, 9$ & 09,9 & rq, & $I T, V$ & $7 \cdot, r$ & $\cdot, \varepsilon$ & $r_{\cdot, r}$ & $v q, \cdot$ & الثاني \\
\hline$r \leqslant, r$ & $1 \varepsilon$, & II,V & $r \varepsilon, V$ & $I r, v$ & ד, & •, & $r \cdot, \wedge$ & $V \wedge, Y$ & الأوسط \\
\hline$r V, r$ & $10, \mathrm{~V}$ & ov, 1 & $r v, r$ & 10,1 & ov,, &., 0 & $r_{0, r}$ & $V \varepsilon, r$ & الر ابع \\
\hline \multirow[t]{2}{*}{$r \Lambda, q$} & 17, & 00,1 & $r \wedge, q$ & $17, \varepsilon$ & $0 \leqslant, \wedge$ & $\cdot, 9$ & $r, 1$ & $7 \wedge, \cdot$ & الأعلى \\
\hline & & & & & & & & & الفئة العمرية \\
\hline$r_{0, r}$ & 10,1 & $09, \cdot$ & $r_{0,1}$ & $10,$. & 09,9 & $\cdot, \wedge$ & $r, Y$ & vo,o & $1 V_{-} 10$ \\
\hline זч,. & $10, r$ & $\Delta \wedge, \vee$ & זч, & $10, r$ & O^, $\vee$ & $\cdot, v$ & $r, \wedge$ & $V_{7}, 0$ & $r \varepsilon_{-1 \wedge}$ \\
\hline$r_{0, r}$ & $1 \leqslant, r$ & $7 \cdot, r$ & ro,r & $1 \leqslant, r$ & $7 \cdot, r$ & $\cdot, 7$ & $r r, v$ & $v_{0, V}$ & rq_ro \\
\hline \multirow[t]{2}{*}{ ro,v } & 10,1 & 01,0 & - & - & - & - & - & - & ro_r. \\
\hline & & & & & & & & & الحالة الزواجية \\
\hline rฯ, & 10,1 & $o v, 1$ & $r \uparrow, r$ & 10,0 & $0 \wedge, \varepsilon$ & $\cdot, \wedge$ & $r r, v$ & $v_{0,0}$ & أعزب \\
\hline \multirow[t]{2}{*}{$r \leqslant, \varepsilon$} & $1 \leqslant, r$ & $71, \varepsilon$ & $r \varepsilon, r$ & 15,0 & $T, r$ & $\cdot, r$ & $r, r$ & $V V, \varepsilon$ & متزوج \\
\hline & & & & & & & & & الحالة الوظيفية \\
\hline rr, r & $1 \leqslant, V$ & זr, & r, & $1 \leqslant, \varepsilon$ & ז,זיד & $\cdot, r$ & YI, & $\vee \wedge, 1$ & يعمل \\
\hline$r v, r$ & $1 \%, 9$ & $0 \wedge, 9$ & $r_{0,0}$ & $1 \leqslant, V$ & $\circ 9, \wedge$ & $\cdot, \mathrm{V}$ & $r$ r, & $v_{7, \cdot}$ & لا بعمل \\
\hline$r v, \varepsilon$ & $10, \mathrm{~V}$ & 07,9 & $r v, r$ & $10, r$ & ov,o & $\cdot, 9$ & $r \leqslant, 1$ & vo,. & خارجقوة العمل \\
\hline$r_{0, V}$ & $10, r$ & 09,1 & $r_{0, T}$ & $10,$. & $09, \varepsilon$ & $\cdot, \mathrm{V}$ & $r, r$ & $V_{7,1}$ & الاجمالي \\
\hline$\left(Y_{8}^{Y} \vee \vee 0\right)$ & $(1,774)$ & $(7, \leqslant 7 T)$ & $(r, Y, Y)$ & $(1, r 90)$ & $(0,1 \cdot 7)$ & $(\wedge \varepsilon)$ & $(\Upsilon, T \Gamma \cdot)$ & $(\wedge, Y \vee \wedge)$ & العدد \\
\hline
\end{tabular}





\section{ملحق (ب)}

تقدير ات خطأ المعاينة

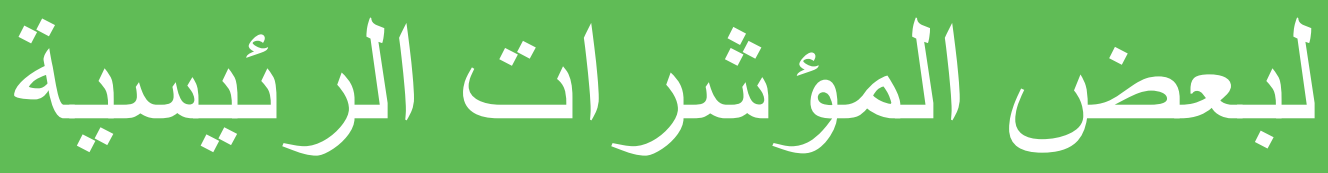

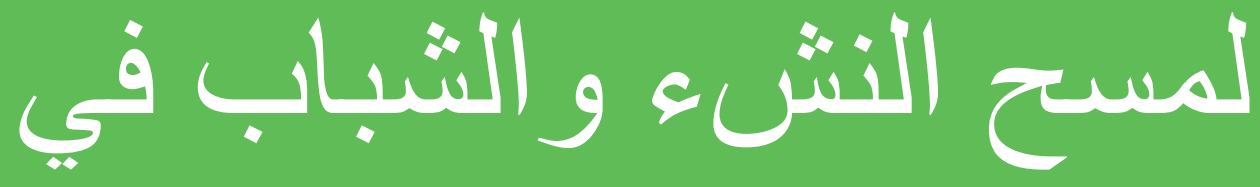

مصر ع المبح

محمد إسماعيل

علي راثد 



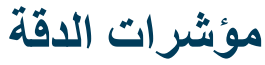 \\ مؤشر ات الدقة لتقدير ات المسح تضم ما يلى: \\ • خطأ المعاينة (و سبق شرحه) \\ - معامل الإختلاف \\ فترة الثقة

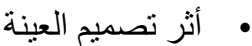 \\ معاهل الاختّناف}

و هو الخطأ المعياري النسبي، ويقاس كنسبة من خطأ المعاينة لتقدير معين إلي قيمة هذا التقدير. وكقاعدة بديهية، إذا تجاوزت قيمة فيمة معامل الإختلاف . r \% تقل موثوقية التقدير.

\section{(19)}

ينم استخدام فترة الثقة للتعبير عن عدم التأكد في تقدير ات المسح. حيث ينم توظيف خطأ المعاينة (الانحر اف المعياري) لتكوين فترة

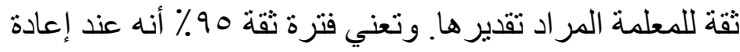
استخدام نفس طريقة المعاينة و حجم العينة المسحوبة لاختيار عينات

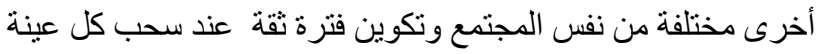

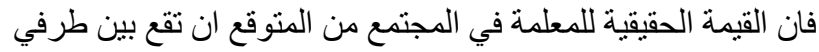
9 \% من فترات الثقة المكونة من كل هذه العينات.

بيد أنه عندما يكون الحد الأدنى لفترة الثقة سالب لمعلمة موجبة،

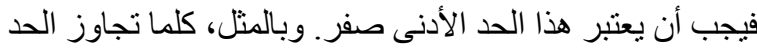

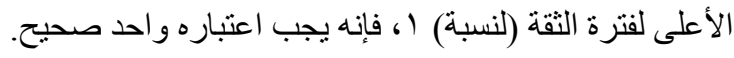

المقدمة

تعتمد دقة تقدير ات المسح على مدى التقارب بين تلك التقدير ات وبين قيمها الحقيقية على مستوى المجتمع. فالفرق بين تقديرات المستح

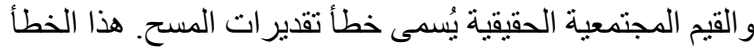
يعتبر مجموع كلا من خطأ المعاينة وخطأ لا يرجع للمعاينة.

يظهر خطأ المعاينة عندما لا يكون المجتمع بأكمله مُمثل فى المسح. عدا ذللك، كل الأخطاء الأخرى التى تظهر فى التقديرات ترجع

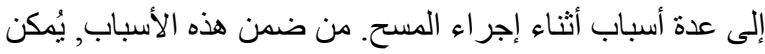
ذكرسو ع تحديد المجتمع المستهدف، مشاكل متعلقة بأسئلة الاستبيان,

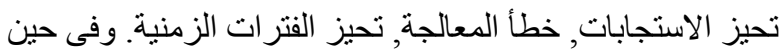
يتعذر قياس هذه الأخطاء التى لا ترجع للمعاينة، يمكن إحصائيا تقدير

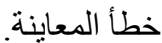

\section{تقدير خطأ المعاينة}

عادة، يستخدم الخطأ المعياري لقياس خطأ المعاينة (الجذر التربيعى

للتباين). فى حالة العينة العشو ائية البسيطة، طريقة حساب الخطأ

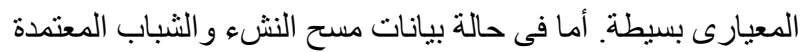
على التصميم العنقودى متعدد الطبقات، ينم استخدام معادلات أخرى. فقد أستُخدم STATA SVY من أجل حساب الخطأ المعيارى

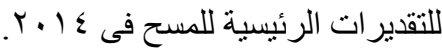


المستخدم لتقدير التباين بأنه التقاطع المشترك بين متغيري المكان (حضر وريف ومناطق عشو ائية)، و المناطق الجغر افية (محافظات

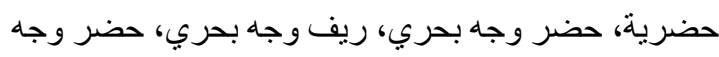

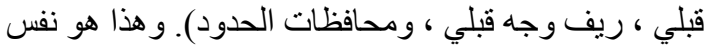

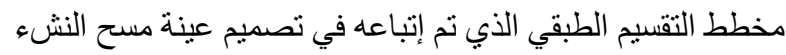

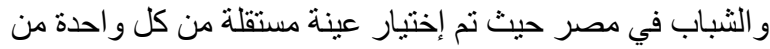

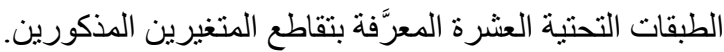
و الغرض من هذا التقسيم الطبقي هو خلق أكبر قدر ممكن من الطن الطبقات المتجانسة فيما يتعلق بمتغير ات المستح، ومن ثم الون الوصول إلى تقدير ات أكثر دقة للمسح.

وبالنظر الى مقاييس دقة المؤشر ات التي تم حسابها و عرضها في الجداول أدناه، فقد وُجدنا أن الأخطاء المعيارية للمؤشر ات التئر المختارة

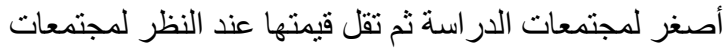

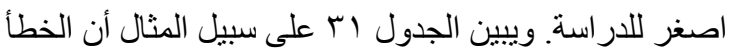
المعياري للنسبة المئوية للثباب الذكور المتزوجين في المناطق

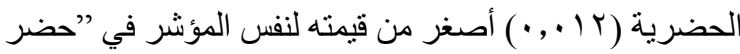

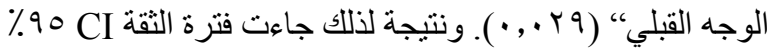

لمؤشر النسبة المئوية للشباب الذكور المتزوجين في المناطق

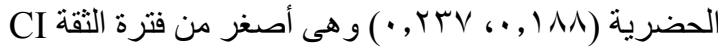

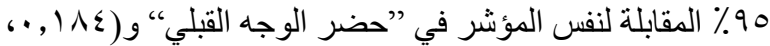
.$(\cdot, r 9 \vee$

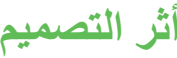

يعد أثر التصميم (DEFF) للعينة من المؤشر ات التي نقيس بها الى اي مدى يكون تصميم العينة الحالي أسو أ من تصميم العينة العشو ائية البسيطة (SRS). يتم تعريف أثر التصميم على أنه

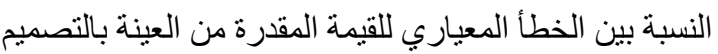
الحالي و الخطأ المعياري في حال لو تم اتباع تصميم العينة

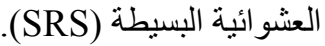

يُوضح أثر التصميم الكثير الى اي حد هناك كم من المعلومات المكتسبة (أو المفقودة) باستخدام تصميم العينة للار اسة الحالية

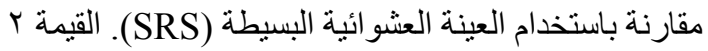

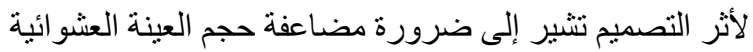

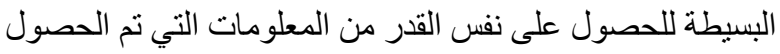

عليها من العينة الحالية. و القيمة الأثر التصميم (DEFF)

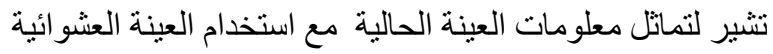
البسيطة (SRS).

أنر التصميم (DEFF) عادة أكبر من الواحد الصحيح. ومع ذللك،

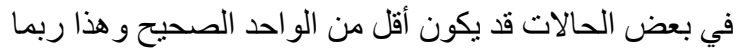

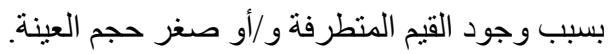

\section{دقة التثقير ات للمؤشرات الرئيسية لمسح

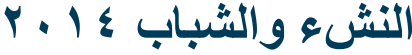

تم حساب الخطأ المعياري و غير ها من المقاييس الأخرى لدقة

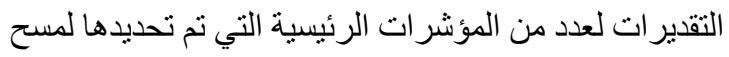

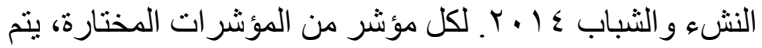

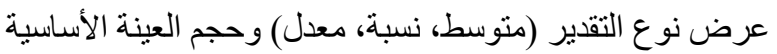
التي تم استخدامها لحسابه في الجدول أدناه.

لكل مؤشر من المؤشرات المختارة، فقد تم حساب التقدير ات

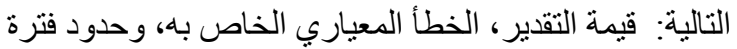

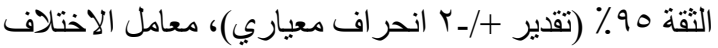
(CV=estimate/SE)

\section{Tables S1-S39 can be}

found online at:

popcouncil.org/SYPE2014

ومن الجدير بالذكر هنا أنه يتم تعريف متغير التقسيم الطبقي 


\begin{tabular}{|c|c|c|c|c|c|c|c|c|}
\hline \multirow[b]{2}{*}{ 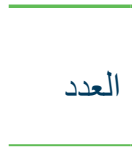 } & \multirow[b]{2}{*}{ أنثريم } & \multirow[b]{2}{*}{ 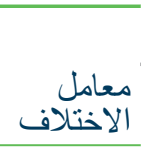 } & \multicolumn{2}{|c|}{ فترة ثقة 90\% } & \multirow[b]{2}{*}{ 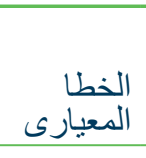 } & \multirow[b]{2}{*}{ المقدرة - المعلمة } & \multirow[b]{2}{*}{ المؤشر } & \multirow[b]{2}{*}{ 5 } \\
\hline & & & حد أعلى & حد أدنى & & & & \\
\hline $1 \cdot, \wedge \wedge 1$ & $r, \cdot \wedge$ & $\cdot, ., 17$ & $\cdot, \varepsilon \Gamma \varepsilon$ & $\cdot, \varepsilon \cdot V$ & $\cdot, \cdots v$ & $\cdot, \varepsilon \uparrow$. & معدل المشاركة في قوة العمل (التعريف الو اسع لقوة العمل) & 1 \\
\hline $1 \cdot, \wedge \wedge 1$ & $r, \cdot \leq 1$ & $\cdot, \cdot 1 \mathrm{~V}$ & $\cdot, \varepsilon \cdot \Gamma$ & $\cdot, \mathrm{MVV}$ & $\cdot, \cdots v$ & $\cdot, r q \cdot$ & معدل المشاركة في قوة العمل (بتعريف السوق لقوة العمل) & r \\
\hline$\varepsilon, 1 \wedge 9$ & r, Yrr & $\cdot, \cdot \leq 9$ & $\cdot, r \cdot$ & $\cdot, 170$ & $\cdot, \cdots 9$ & $\cdot$, וג & معدل البطالة (بالتعريف الواسع لقوة العمل) & r \\
\hline r, , & $1, V Y A$ & $\cdot, .01$ & 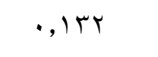 & $\cdot, 1 \cdot 0$ & $\cdot, \cdots v$ & $\cdot, 119$ & معدل البطالة (بتعريف السوق لقوة العمل) & $\varepsilon$ \\
\hline r, , & $1, V Y A$ & $\cdot, \cdots \wedge$ & $\cdot, \wedge 90$ & $\cdot, \wedge \uparrow \wedge$ & $\cdot, \cdots v$ & $\cdot, \wedge \wedge 1$ & نسبة العمالة إلى السكان (بتعريف السوق لقوة العمل) & $\circ$ \\
\hline$r, r v q$ & 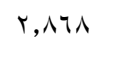 & $\cdot, \cdot 11$ & $\varepsilon \vee, \uparrow \ldots$ & $\leqslant 0,7 \ldots$ & $\cdot, 011$ & $\leq 7,7 \ldots$ & متوسط عدد ساعات العمل خلال الأسبوع المرجعي & 1 \\
\hline r, rлt & $1, r \cdot \Lambda$ & $\cdot, \cdot v \varepsilon$ & $1,90 \cdot, 0 \vee \wedge$ & $1,200,11 \wedge$ & IrT, & $V \cdot r, \wedge \wedge r)$ & المرجعية (بالجنيه) الثهري للعاملين بأجر خلال الثلاثة أثهر & v \\
\hline$r, r v q$ & $r, r \cdot r$ & $\cdot, \cdot 1 \leq$ & $\cdot, \vee \vee \wedge$ & $\cdot, \mathrm{V} r \mathrm{~N}$ & $\cdot, \cdot 11$ & $\cdot, \vee \vee 4$ & نسبة الأفر اد العاملين بأجر & $\wedge$ \\
\hline$r, r v r$ & $\varepsilon, Y \wedge 1$ & $\cdot, \cdot v_{0}$ & $\cdot, r \mid r$ & $\cdot, 101$ & $\cdot, \cdot 1 \leq$ & $\cdot, 110$ & نسبة الأفر اد العاملين بالزر اعة & 9 \\
\hline$r, r V t$ & Y,१Y & $\cdot, \cdot r_{Y}$ & $\cdot, 091$ & 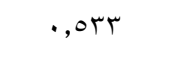 & $\cdot, \cdot 10$ & $\cdot, 07 r$ & نسبة الأفر اد العاملين بالصناعة & 1. \\
\hline$r, r v t$ & $r, r \cdot r$ & $\cdot, \cdot \leq \varepsilon$ & $\cdot$, rVo & $\cdot, r_{T}$ & $\cdot,+11$ & $\cdot$, ror & نسبة الأفر اد العاملين بقطاع الخدمات & 11 \\
\hline r, rی. & $1,7+$ & $\cdot, \cdot 1$ & $\cdot$, , $0 \mathrm{r}$ & $\cdot, \wedge r \cdot$ & $\cdot, \cdots \wedge$ & · & نسبة الأفر اد العاملين بالقطاع الخاص & it \\
\hline$r, r v q$ & $1,7 Y 1$ &., .04 & תד & 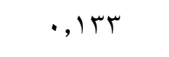 & $\cdot, \cdots \wedge$ & $\cdot, 1 \leq \wedge$ & نسبة الأفر اد العاملين لحسابهم الخاص و أصحاب الأعمال & ir \\
\hline$r, r \vee q$ & $r, \wedge \vee q$ &., $.9 r$ & $\cdot, 1 \cdot 1$ & $\cdot, \cdot v_{0}$ & $\cdot, \cdots \wedge$ & $\cdot, .9 r$ & نسبة الأفر اد العاملين لدى الأسرة بدون أجر & $1 \varepsilon$ \\
\hline $1 \cdot, 917$ & T,rTr & $\cdot, \cdot+4$ & $\cdot, r \cdot$ & $\cdot, I V T$ & $\cdot, \cdots v$ & $\cdot, 1 \wedge \vee$ & نسبة المتسربين من التعليم (قبل إكمال التعليم الأساسي 0 _- ب؟) & 10 \\
\hline $1 \cdot, 7 T_{1}$ & $r, T \leq T$ & $\cdot, \cdot \varepsilon$. & $\cdot, \mid A V$ & $\cdot, 17$ & $\cdot, \cdots v$ & $\cdot, I V T$ & نسبة الشباب الر اغبين في الهجرة (0 _0ـr) & 17 \\
\hline$\wedge, \vee Y \cdot$ & $1, \wedge \vee r$ & $\cdot, 11 r$ & $\cdot, \cdot r \cdot$ & $\cdot, \cdot 1 r$ & $\cdot, \cdots r$ & $\cdot, \cdot, \mathrm{V}$ & نسبة الثباب الذين هاجروا و عادوا (1 ( ـهץ) & iv \\
\hline $1 \cdot, \wedge \wedge 9$ & V,qY. & $\cdot, \cdot \leq 9$ & $\cdot$, Y०T & $\cdot, Y \backslash 1$ & $\cdot,+11$ & $\cdot, r T \leq$ & نسبة الثباب الذين يستخدمون الإنترنت & 11 \\
\hline $1 \cdot, \wedge 9$ & $r, \cdot 10$ & $\cdot, .9 \leq$ & $\cdot, \cdot \mathrm{rV}$ & $\cdot, \cdot$ ro & $\cdot, \cdots$ & $\cdot, \cdot r$ & نسبة الثباب المشاركين في الأنشطة التطو عية & 19 \\
\hline $1 \cdot, 917$ & $\varepsilon, .$, & $\cdot, 11 \pi$ & $\cdot$, . To & $\cdot, \cdot r r$ & $\cdot, \cdots r$ & $\cdot, \cdot r \wedge$ & نسبة الثباب المشاركين في مجمو عات تؤدي أنشطة إجتماعية & r. \\
\hline$\Lambda, \vee r$ & r,人זד & $\cdot, \cdot 10$ & $\cdot, 7 \times 1$ & $\cdot \operatorname{tr}$ & $\cdot, \cdot 1$ & $\cdot$, , tor & نسبة الشباب الذين أدلوا بصوتهم في أي إنتخابات (1 ـــم) & rI \\
\hline $1 \cdot, \wedge \wedge 1$ & $\varepsilon, \varepsilon \circ \wedge$ & $\cdot, 1 \leq \varepsilon$ & $\cdot, \cdot$ ro & $\cdot, \cdot 1 \leq$ & $\cdot, \cdots r$ & $\cdot, \cdot 19$ & نسبة المشتركين في نادي رياضي/مركز شباب & rt \\
\hline $1 \cdot, 9 \cdot \varepsilon$ & E,YTr & $\cdot, \cdot 4$ & $\cdot, r \cdot l$ & $\cdot$, Y74 & $\cdot, \cdots q$ & $\cdot$, tAr & نسبة الإتفاق على أن تعليم الأو لاد أكثر أهمية من تعليم الفتيات & r \\
\hline $1 \cdot, 9 \cdot \varepsilon$ & $\varepsilon, I V T$ &., $.1 r$ & $\cdot, \mathrm{VTr}$ & $\cdot, 791$ & $\cdot, \cdots 9$ & $\cdot, \times 10$ & نُبنة الإتفاق على أن المر أة لها الحق في طلب الطلاق (10 - & rs \\
\hline $1 \cdot, 9 \cdot \varepsilon$ & $7, Y V \leqslant$ & $\cdot, .0$ & $\cdot, r \cdot r$ &., $1 \vee$. & $\cdot, \cdots q$ & $\cdot, \mid \wedge \wedge$ & نسبة الإتفاق على أن للرجل الحق في ضرب زوجته إذا جادلته & ro \\
\hline $1 \cdot, 917$ & 1,919 & $\cdot, \cdots r$ & $\cdot, 99$. & $\cdot, 9 \wedge \varepsilon$ & $\cdot, \cdots r$ & $\cdot, 9 \wedge \vee$ & مُعدل عدم الاعاقة & rt \\
\hline $1 \cdot, 917$ & $0, \pi \uparrow$ & $\cdot, \cdot 1 r$ & $\cdot, \vee \vee \leq$ & $\cdot, \mathrm{V} r \mathrm{~V}$ & $\cdot, \cdot 1$ & $\cdot, \vee \circ 0$ & معدل عدم إنتشار الأمر اض المزمنة & rV \\
\hline $1 \cdot, 917$ & 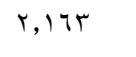 & $\cdot, \cdot r \cdot$ & $\cdot, 194$ & $\cdot,|v|$ & $\cdot, \cdots$ & $\cdot, 1 \wedge r$ & 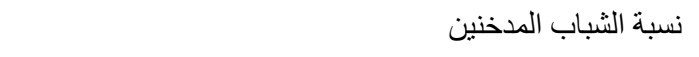 & rᄉ \\
\hline $1 \cdot, 917$ & $r, \cdot \leq r$ & $\cdot, 1$ Tro & $\cdot, \cdot 1 r$ & $\cdot, \cdots v$ & $\cdot, \cdots$ & $\cdot, \cdot 1$ & نسبة الثباب الذين تعاطو أو جربوا المخدرات & rq \\
\hline $0, \wedge \leq r$ & $\varepsilon, \varepsilon \neg \varepsilon$ & $\cdot, \cdot 1 \leq$ & $\cdot, \Lambda \mid r$ & $\cdot, \vee \vee \uparrow \wedge$ & $\cdot, \cdot 11$ & $\cdot, \vee \vee$ & نسبة الإناث اللاتي خضعن للختان & $r$. \\
\hline $1 \cdot, 9 \cdot 7$ & $r, r \cdot \Lambda$ & $\cdot, \cdot r$ & $\cdot, r 70$ & 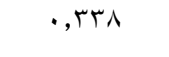 & $\cdot, \cdots v$ & $\cdot$, ror & 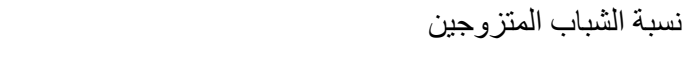 & M \\
\hline$\varepsilon, 09 \varepsilon$ & r,v^o & $\cdot, \cdot, 4$ & $\cdot, \leqslant 1 \Gamma$ & $\cdot$, , & $\cdot, \cdot 1 \leq$ & $\cdot$, ґی & نسبة الشباب المتزوجين ويعيشون مع و الديهح & rT \\
\hline $1 \cdot, 9 \cdot 7$ & $\uparrow, V \vee T$ & $\cdot, \cdots 9$ & $r, \cdot v \cdot$ & Y, 970 & $\cdot, \cdot r V$ & r,. IV & رأي الشباب في انجاب العدد المثالي من الأطفال & rt \\
\hline$\varepsilon, 09 \varepsilon$ & $r, v i$. &., .1 & T, זT & $r, 11 r$ & & $r, I V T$ & رأي الثباب المتزوجين في انجاب العدد المثالي من الأطفال & $r \varepsilon$ \\
\hline 1,90 & $r, .79$ & $\cdot, \cdot 11$ & $r, r \mid r$ & r,११५ &., .07 & $r, 1 \cdot r$ & رأي الثباب غير المتزوجين في انجاب العدد المثالي من الأطفال & ro \\
\hline $1, r 7 \leq$ & $1,0 \times 9$ &,,$\ldots$ & $r \leq, V T \leq$ & $r \&, r Y q$ & $\cdot, 111$ & $r \leqslant, 0$ & متوسط العمر عند الزواج الأول للشباب الذكور & Tr \\
\hline r, r tr & $r, l \leq r$ & $\cdot, \cdots \varepsilon$ & $r \cdot, 17 r$ & $19, \wedge r \mid$ & $\cdot, \cdot \wedge \varepsilon$ & $r \cdot, \cdots$ & منوسط العمر عند الزواج الأول للفتيات & rV \\
\hline r, trut & $1,91 \leqslant$ & $\cdot, \cdot \leq V$ & $\cdot, r+r$ & $\cdot, 194$ & $\cdot,+1$ & $\cdot, r \mid r$ & نسبة الإناث اللاتي تزوجن قبل سن ^| & ro \\
\hline $1 \cdot, 917$ & $0,9 \cdot 1$ & $\cdot, \cdot r_{1}$ & $\cdot, 07 \leqslant$ & $\cdot, 011$ & $\cdot, \cdot 1 \mathrm{~T}$ & $\cdot, 0 \leqslant 1$ & نسبة الثباب الذين يمارسون اي نشاط رياضي & 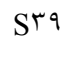 \\
\hline
\end{tabular}




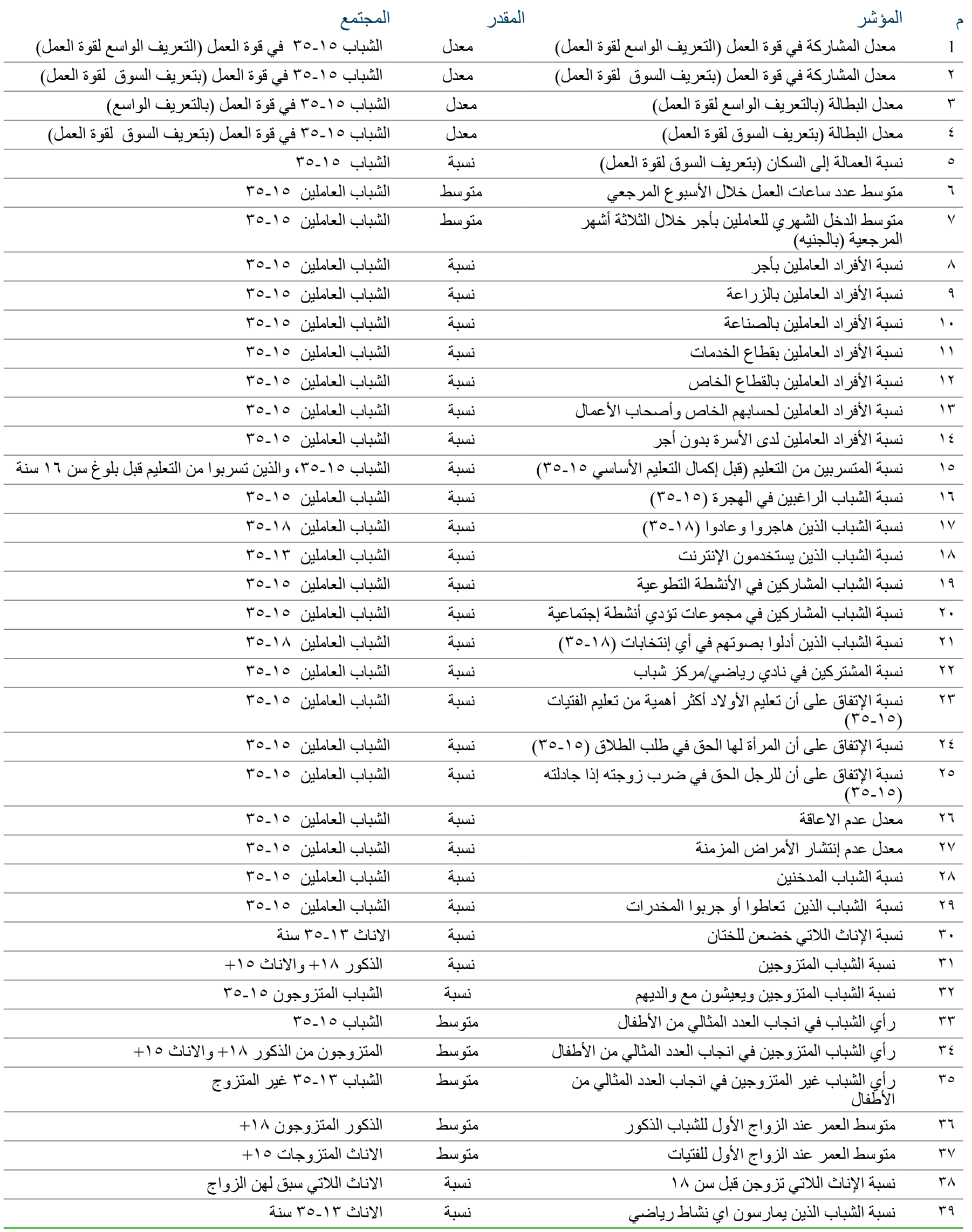





\section{Populatron is conveli}

Ideas. Evidence. Impact.

Population Council One Dag Hammarskjold Plaza

New York, NY 10017

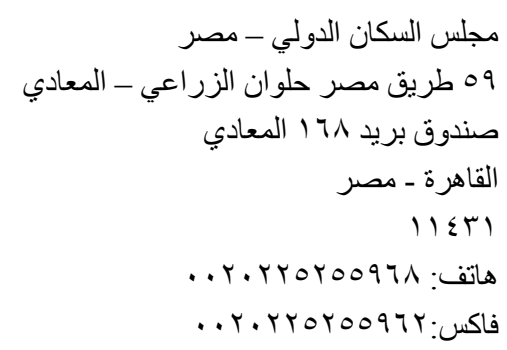

الموقع الالكتروني: www.popcouncil.org 